tesis doctoral 

LUIS ALBERT: RACIONALISMO EN LA CIUDAD DE VALENCIA. 1927/1936

doctorando MANUEL GIMÉNEZ RIBERA director JORGE LLOPIS VERDÚ 

a Mariví, Guillermo y Pablo, mi familia 

ABSTRACT (ESPAÑOL)

Uno de los primeros impulsos en la presente investigación, pasa por revisar el juicio superficial al que estaba sometida la producción arquitectónica valenciana de principios del siglo XX. Alejada de los centros germinales europeos, sucumbió relegada al bipolarizado debate nacional Madrid - Barcelona, sin alcanzar merecimientos para un agudo análisis arquitectónico. Aluzar semejante oclusión se infiere como objetivo.

Investigar fuentes, catalogar y sistematizar el grueso de la producción racionalista valenciana, constata el cambio en el gusto de los jóvenes arquitectos, como acercamiento a la modernidad. Resta concretar una coherencia doctrinal y el compromiso social preconizado por los maestros del Movimiento Moderno. Generalizar exhibe una clara falta de compromiso y, con el objeto de ausentar tal falta de atención, se escinde un autor, Luis Albert Ballesteros con la finalidad de contrastar su voluntad racionalista.

Redibujar planimetrías originales, recrear esquemas, perspectivas, detalles y procurar maquetas, resulta el método empleado. Recrear el análisis gráfico como herramienta a la profundidad del conocimiento, devuelve la mirada analítica a una producción individual. La metrópoli, referente aspiración de modernidad, dilucida el ámbito físico de este trabajo. Los albores de la arquitectura de Albert, un concurso Nacional para el Ateneo Mercantil de Valencia, marca el límite cronológico inferior. El superior, no admite argumentos disyuntivos, La Guerra Civil asume la frontera ineludible. 

Luis Albert destaca entre los promotores de la intención racionalista, en la capital levantina, inmersa en la trasnochada España de los años veinte y treinta. Sus aportaciones dejan evidencias de su espíritu trasgresor hacia las doctrinas academicistas e historicistas, su afán de renovación profesional y su sinceridad proyectual. Su proclamado camino de la verdad, ocupado en crear líneas puras y volúmenes armoniosos, en fomentar la utilidad de lo construido y acometer el espacio moderno, bien vale para procurar el pase a sus aportaciones edilicias en los catálogos de la arquitectura moderna.

\section{ABSTRACT (VALENCIÀ)}

Un dels primers impulsos en la present investigació, passa per revisar el judici superficial a què estava sotmesa la producció arquitectònica valenciana de principis del segle XX. Allunyada dels centres germinals europeus, va sucumbir relegada al bipolaritzat debat nacional Madrid Barcelona, sense assolir mereixements per a una aguda anàlisi arquitectònica. Enllumenar tal oclusió s'infereix com a objectiu.

Investigar fonts, catalogar i sistematitzar el gros de la producció racionalista valenciana, constata el canvi en el gust dels joves arquitectes, com a apropament a la modernitat. Resta concretar una coherència doctrinal i el compromís social preconitzat pels mestres del Moviment Modern. Generalitzar exhibeix una clara falta de compromís i, amb l'objecte d'absentar tal falta d'atenció, s'escindeix un autor, Luis Albert Ballesteros amb la finalitat de contrastar la seva voluntat racionalista. 

Redibuixar planimetries originals, recrear esquemes, perspectives, detalls i procurar maquetes, resulta el mètode emprat. Recrear l'anàlisi gràfica com a eina a la profunditat del coneixement, retorna la mirada analítica a una producció individual. La metròpoli, referent aspiració de modernitat, dilucida l'àmbit físic d'aquest treball. Els albors de l'arquitectura d'Albert, un concurs Nacional per al Ateneo Mercantil de València, marca el límit cronològic inferior. El superior, no admet arguments disjuntius, la Guerra Civil assumeix la frontera ineludible.

Luis Albert destaca entre els promotors de la intenció racionalista, a la capital llevantina, immersa en la Espanya dels anys vint i trenta. Les seves aportacions deixen evidències del seu esperit transgressor amb les doctrines academicistes i historicistes, el seu afany de renovació professional i la seua sinceritat projectual. El seu proclamat camí de la veritat, ocupat en crear línies pures i volums harmoniosos, a fomentar la utilitat del que construeix i escometre l'espai modern, bé val per a procurar el pas a les seves aportacions edilícies en els catàlegs de l'arquitectura moderna.

\section{ABSTRACT (ENGLISH)}

First one of the impulses in the present investigation, happens for checking the superficial judgment to which there was submitted the architectural Valencian production of beginning of the 20 th century. Removed from the initiation centers European, succumbed relegated to the bipolar argument, national discussion Madrid - Barcelona, without reaching merits for a sharp architectural analysis. To try light to similar occlusion appears as aim. 

To investigate sources, to catalogue and to systematize the thickness of the racionalist Valencian production, it states the change in the taste of the young architects, as approximation to the modernity. It remains to make concrete a doctrinal coherence and the social commitment praised by the teachers of the Modern Movement. To generalize exhibits a white of egg lacking in commitment and, in order such a lack of attention stays away, an author splits, Luis Albert Ballesteros with the purpose of confirming his racionalist determination.

To re-draw original mappings, to recreate schemes, perspectives, details and to shape models, it turns out to be the used method. To recreate the graphical analysis as tool to the depth of the knowledge, he returns the analytical look to an individual production. The metropolis, relating aspiration of modernity, explains the physical area of this work. The whiteness of Albert's architecture, a National Competition for the Ateneo Mercantil of Valencia, marks the chronological low limit. The Superior, does not admit disjunctive arguments, The Civil War assumes the unavoidable border.

Luis Albert stands out between the promoters of the racionalist intention, in the capital of Levante, immersed in the sleepless night spain of the twenties and thirties. His contributions leave evidences of his spirit trasgresor towards the doctrines historicist of the Academy, his zeal of professional renovation and his sincerity representation. His proclaimed way of the truth, occupied in creating pure lines and harmonious volumes, in promoting the usefulness of the constructed and attacking the modern space, well costs to try the pass to his contributions in the catalogues of the modern architecture. 

preámbulo METODOLOGÍA

introducción INTRODUCCIÓN URBANÍSTICA INTRODUCCIÓN ARQUITECTÓNICA BIOGRAFÍA

triada albertiana OBJETIVOS DEL PROYECTO HOSPITAL PROVINCIAL 



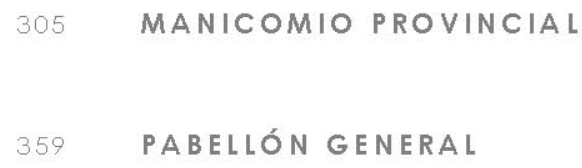





\section{MEMBRANA EXTERNA \\ 583 AZOTEA COLECTIVA \\ 587 INTENCIÓN MODERNA}

599 bibliografía

649 apéndice gráfico

OBRAS DEL PERIODO ANALIZADO

LISTADO PROJECTOS EN LA CIUDAD DE VALENCIA 
preámbulo 


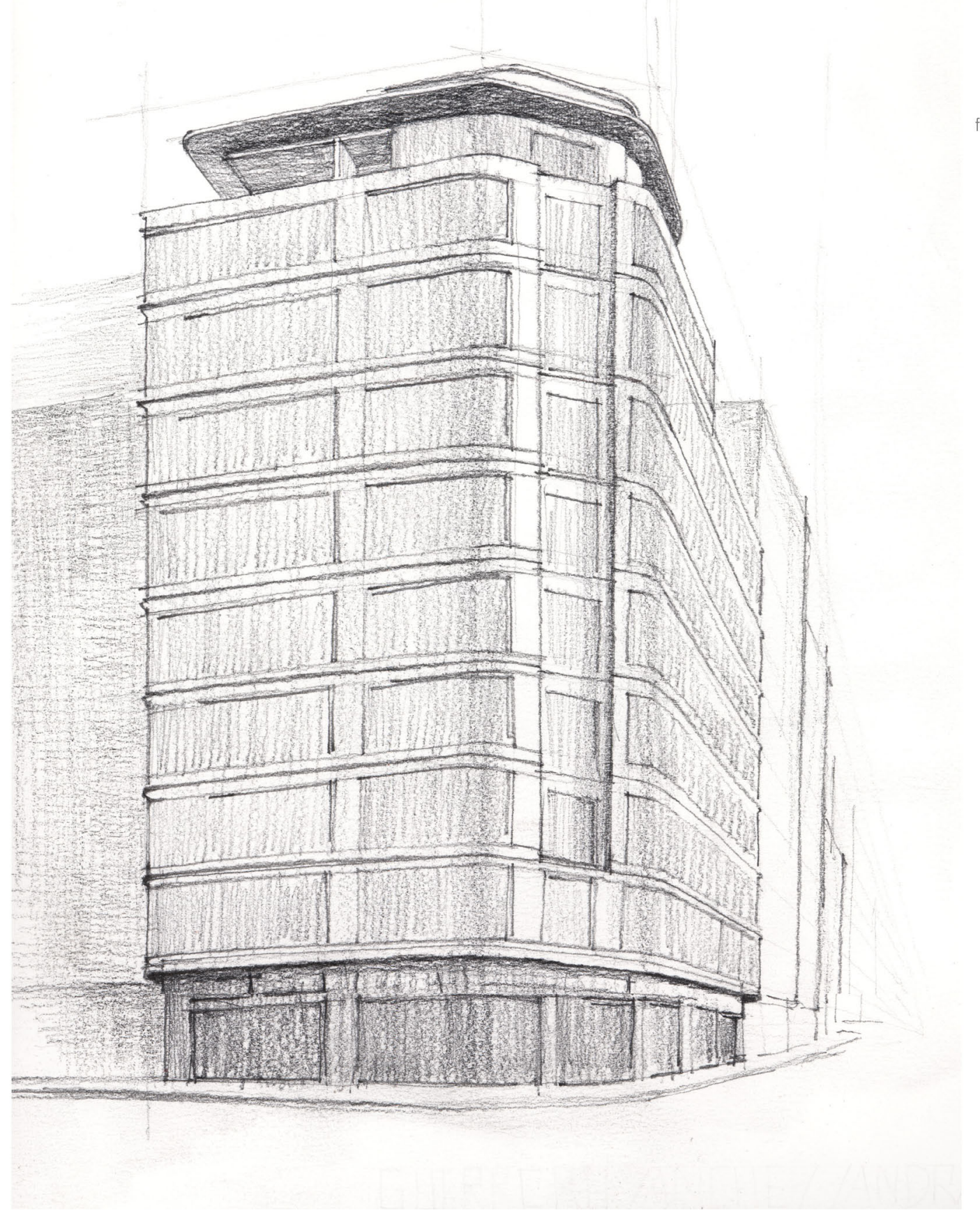

Ricard ROSO. Análisis formal edificio Llopis, c. San Vicente; dibujo propio del doctorando 
Dejaba indicado Umberto Eco, diferentes estados de convicción con los que enfrentarse a una tesis doctoral'. Aupaba esfuerzos investigadores, trabajo analítico e incluso esgrima sintáctica, en pos de titánicos logros personales. Al tiempo, planteaba bifurcaciones laborales, manteniendo la opción contraria, viajando hasta las antípodas en busca de logros ajenos $y$, sencillamente, empecinarse en transcribir, fusilar sin mayores empeños, plagiar bajo el amparo que descara la distancia. $Y$ sin otro cayado -no alcanza la semántica de báculo para contener físicamente a todas aquellas personas que ofrecieron su compañía-, emprendimos la singladura.

Al unísono, tronaba para mis adentros un académico fulgor casi relegado al ostracismo, una recóndita pasión formadora suscitada por el Movimiento Moderno. Reclamaba mi atención una reflexión -pospuesta a un profuso conocimiento- en cuanto al origen de mi atracción por la arquitectura, con mayúsculas, con sus inherentes imágenes confinadas en el fondo de la mochila del propio conocimiento (fig. 1), aguardando su evocación reflexiva a la hora de propiciar respuestas a mis cuestiones arquitectónicas. El radical compromiso de los grandes Maestros recobraba ímpetu. El racionalismo de sus iniciáticas propuestas, con sus formas en blanco y negro todavía epata la repercusión del color, aportando nuevos datos, dejando al descubierto arquitecturas referenciales tras visitarla in situ y contrastarlas con aquello memorizado en libros distraídos de gamas cromáticas-, sus paradigmáticos espacios materializados, sus convicciones y

1 ECO, Umberto. "Como escribir una tesis doctoral: Técnicas y procedimientos de estudio, investigación y escritura". 5² Edición. Geidisa. Barcelona, 1983. 


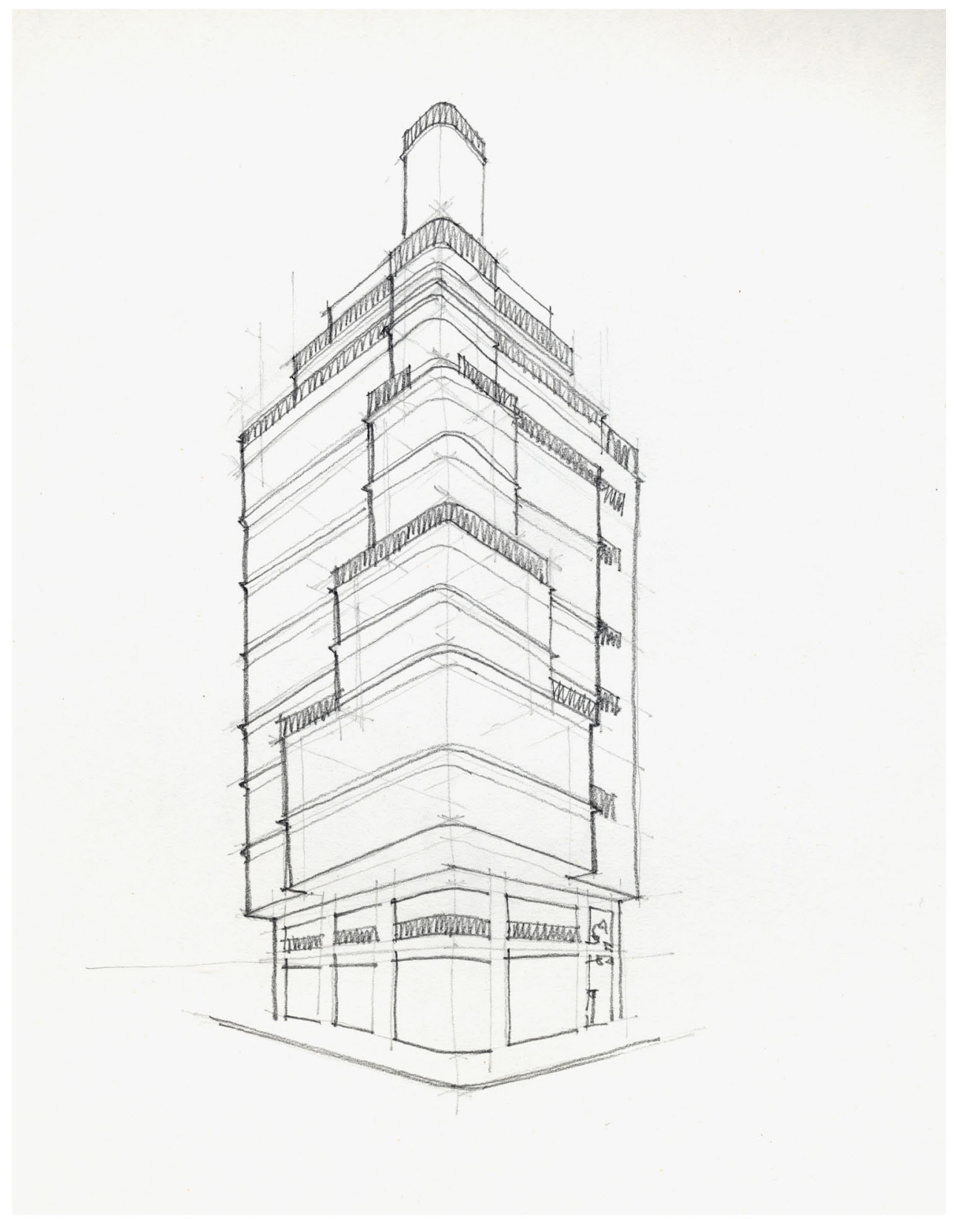


disciplina, su aureola de verdad universal y de ruptura hacia adelante, avivaron el interés por procurar un nuevo estudio sobre lo aprendido entonces. Y ahora, cuando más genuino se muestra criticar desde el conocimiento parcial, o denostar muy posiblemente desde la ignorancia supina todo lo que supuso de avance aquel moderno arranque de siglo, es cuando más sugestiona revisar nuestros principios, en oposición a soslayarlos. Habremos de escudriñar también aquellas corrientes arquitectónicas navegando en paralelo y sin las cuales tampoco se alcanzaría a comprender la repercusión acaecida.

Una época troyana que prestó erudición profesional y, a su vez adiestramiento social, habiendo de comprobarse la profundidad de sedimentación alcanzada. A los arquitectos en ciernes, supo imbuirles el irritante instinto de la insurrección, la sinceridad de sus convicciones. Estos respondieron mediante su espontáneo compromiso con el arte, con la cultura y, con un enconado espíritu de servicio -no únicamente por la arquitectura pretendida, también por quienes las debían disfrutar o, en su caso, padecerllevado por el orgullo de aquello que erigían, minuciosamente construido. Y con estos jóvenes profesionales avanzó, conjuntamente, la sociedad. Mirándose reflejada en las modernas arquitecturas que se exhibían en la metrópoli dispuesta a superar su pasado rústico, hasta llegar a la superación industrial, comercial y de servicio. Una modernidad que sentía indispensable su abrazo a la moda, a la cultura, al arte. La exposición Universal de Valencia, en 1909, relumbró como muestra de lo ambicionado. 


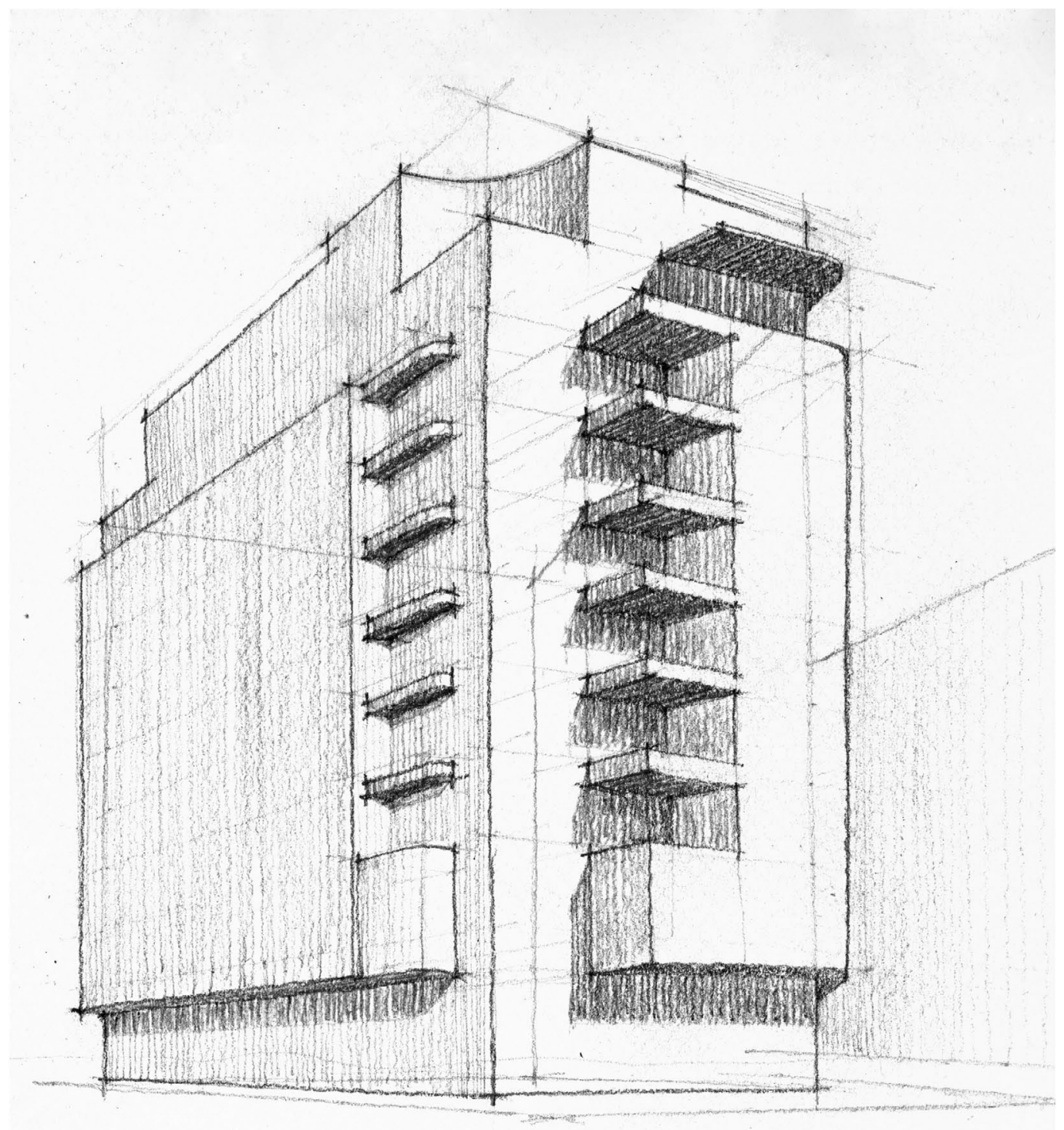

fig. 2 
Efectivamente, puede decirse que desde el punto de vista de la historia social del gusto, la modernidad, entendida como un sistema innovador de usos y costumbres cotidianas, si que afectó profundamente a la arquitectura valenciana de los años treinta. Desde ese mismo punto de vista la obra de arquitectos tan distintos entre sí como por ejemplo Goerlich, Gómez Davó, Pecourt y Rieta (fig. 2), puede entenderse como integrante de un mismo frente más o menos amplio, más o menos "moderno", pero, en el fondo, homogéneo ${ }^{2}$. Precisamente aquí reside el impulso a nuestro trabajo de investigación, firmemente convencidos de la necesidad de revisar el juicio superficial que lleva sometiendo a la arquitectura valenciana de principios de siglo $\mathrm{Xx}$.

Alejada como estaba, la producción edilicia levantina, de los centros germinales europeos, y relegada del debate nacional -bipolarizado por las urbes donde convergían las únicas escuelas de arquitectura- no alcanzaba ser merecedora de un agudo análisis arquitectónico. Toda una producción arquitectónica aglutinada en la evanescente homogeneidad, diluida por el manto de la uniformidad. Sin embargo, generalizar exhibe una clara falta de compromiso, una ausencia de atención y de estudio. Los arquitectos de la llamada "generación de 1925" -grupo bastante coherente, integrado por los arquitectos madrileños-, no supusieron lo mismo que la "generación del GATEPAC" -aparecerá pocos años después y, se verá nutrida en su mayor parte por arquitectos barceloneses- como tampoco resultaron equiparables el art déco con el racionalismo, y llegados a este punto,

2 LLORENS, Tomás. "Carta". Catálogo para la exposición realizada por el IVAM Centre Julio González, del 20 de enero al 5 de abril de 1998. "La ciudad moderna. Arquitectura racionalista en Valencia". Volumen I. pág. 31 


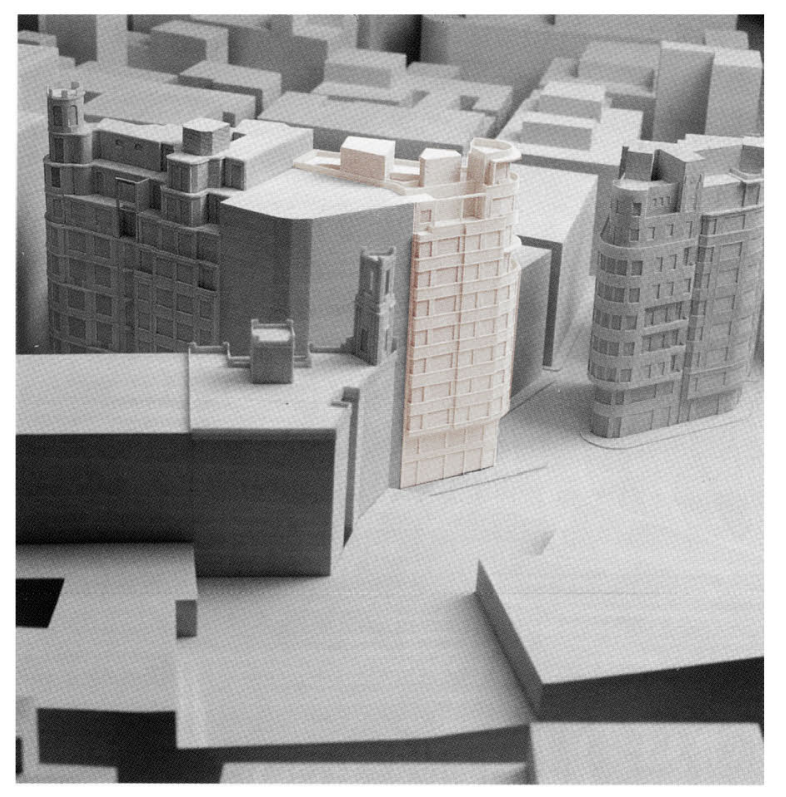

fig. 3 
tampoco las propuestas edilicias de Pecourt pueden asimilarse con la arquitectura de Goerlich.

No basta una constatación de cambios en el gusto, como acercamiento a la modernidad. La arquitectura, su análisis histórico, demanda concretar, además, otras cuestiones. La coherencia doctrinal, el compromiso social, la integridad e intención de aquello proyectado y erigido, requieren una investigación diferenciada, individualizada. Indagar en estos principios imprescindibles para llegar a rememorar e interpretar esa revolución moderna. 'Sin duda alguna, el Movimiento Moderno tenía un fundamento y una orientación'. ${ }^{3}$ Es más, creo que dilucidando el cumplimiento de sus axiomas, podremos aseverar la ortodoxia y el compromiso particular de la arquitectura valenciana, su grado de racionalismo más allá del juicio superficial.

Semejante despertar de conciencia, comenzó su andadura a través de nuevos enfoques -complementando renombrados autores y excelsas obras, también reconocidas, generalistas como summa Artis- propuestos por autores como Javier Pérez Rojas, Amadeo Serra Desfilis. Exposiciones consecuentes reforzaron la creencia de proseguir la senda, penetrar en las individualidades y sus condicionantes para revalorizar una arquitectura condenada al ostracismo, minusvalorada. Nunca permitiría olvidar la realizada por el IVAM (fig. 3) -Centre Julio González-, del 20 de enero al 5 de abril de 1998 bajo el epígrafe "La ciudad moderna. Arquitectura racionalista

${ }^{3}$ NORBERG-SCHULZ, Christian. "LOS PRINCIPIOS de la arquitectura MODERNA. Sobre Ia nueva tradición del siglo XX". Edición original: "Principles of Modern Architecture". Andreas Papadakis Publisher, Londres, 2000. Edición en español: Editorial Reverté, S.A. Barcelona, 2005. Prefacio, p.13 


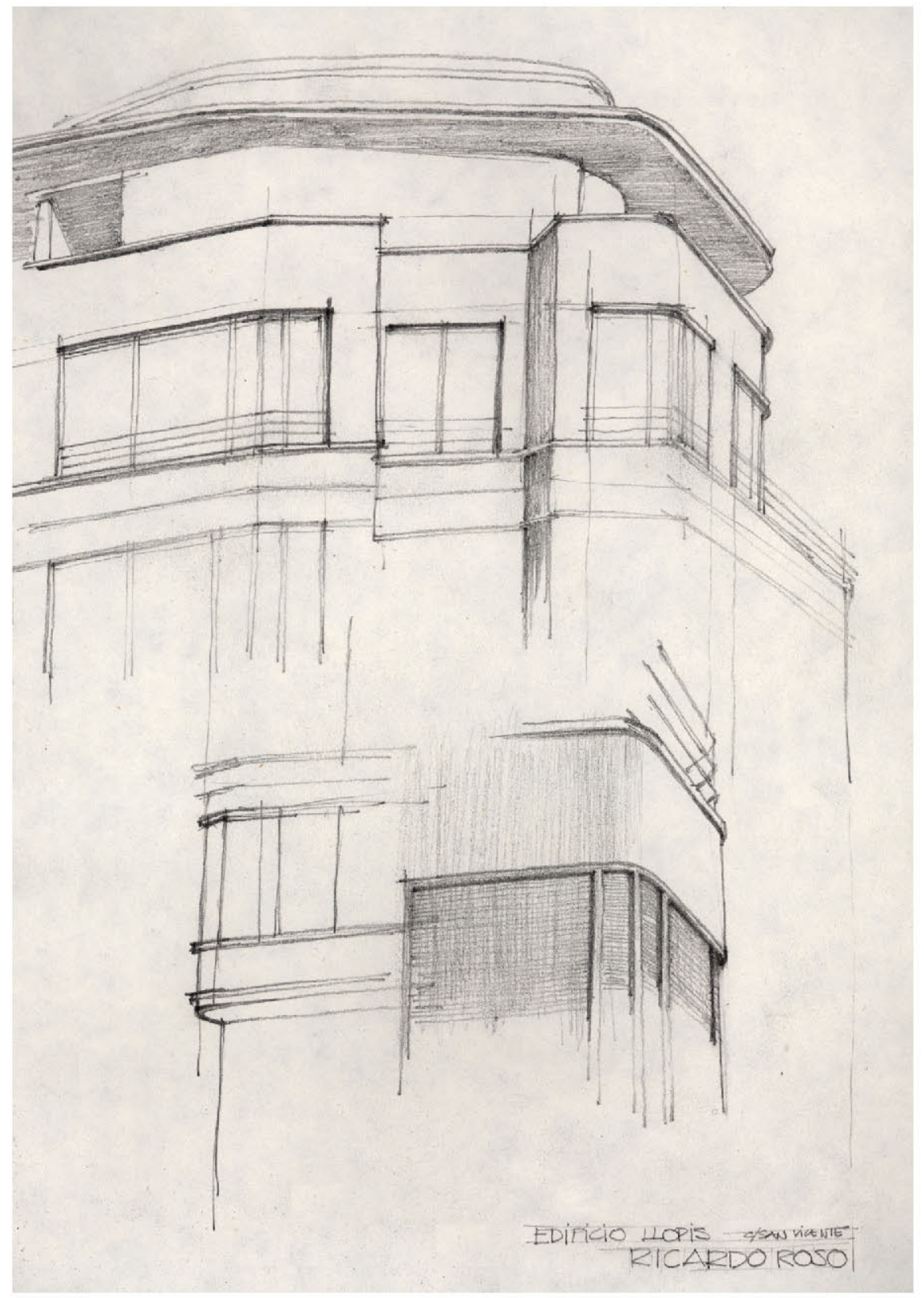

fig. 4 
en Valencia". Prosiguieron otras -Republica 70 anys Després: 1931-2001- y amanecieron artículos locales, estudios monográficos, tesis doctorales diferenciadoras sobre figuras contrastadas, clarividentes como la narrada por Marilda Azulay.

Muy probablemente, impelido por semejante compendio de circunstancias, acudía animoso al Archivo Histórico Municipal del Ayuntamiento de Valencia, diariamente, procurándome averiguaciones en aquella burbuja atemporal donde mezclaban expedientes edilicios de la capital levantina, conjuntamente con testimonios y monumentos funerarios. Comenzaba un trabajo de investigación recopilando todo atisbo de racionalidad, de modernidad a través de un infinito cosmos de fichas manuscritas, solicitudes y revisiones en evanescentes cajas -Policía Urbana o Ensanche-, intuyendo un camino impreciso, aventurando pasos hacia un arquitecto individual, una obra arquitectónica. Ricard Róso vino a ser mi primera decisión (fig. 4). Me distingue la oportunidad de haber gozado su estudio, en mi etapa de formación, como estudiante de arquitectura. Su avanzada edad no restaba lucidez a todos sus certeros comentarios, ni mucho menos paliaba su apasionamiento por el arte y la arquitectura. Yo coincidía, académicamente, con su nieto-compañero entonces de insomnes trabajos, hoy de ilusiones profesionales en el mismo despacho profesional- con sus enseres para proyectar, sus libros, revistas, esculturas... y asumí una deuda que intento ahora satisfacer. No obstante se malogró el posible acceso a la documentación original y descarrió el primer propósito en mi labor doctoral.

Casi de inmediato amaneció Luis Albert, calladamente y sin notificación. Haber reconocido entre tantos expedientes, y puesto autor a insignes 


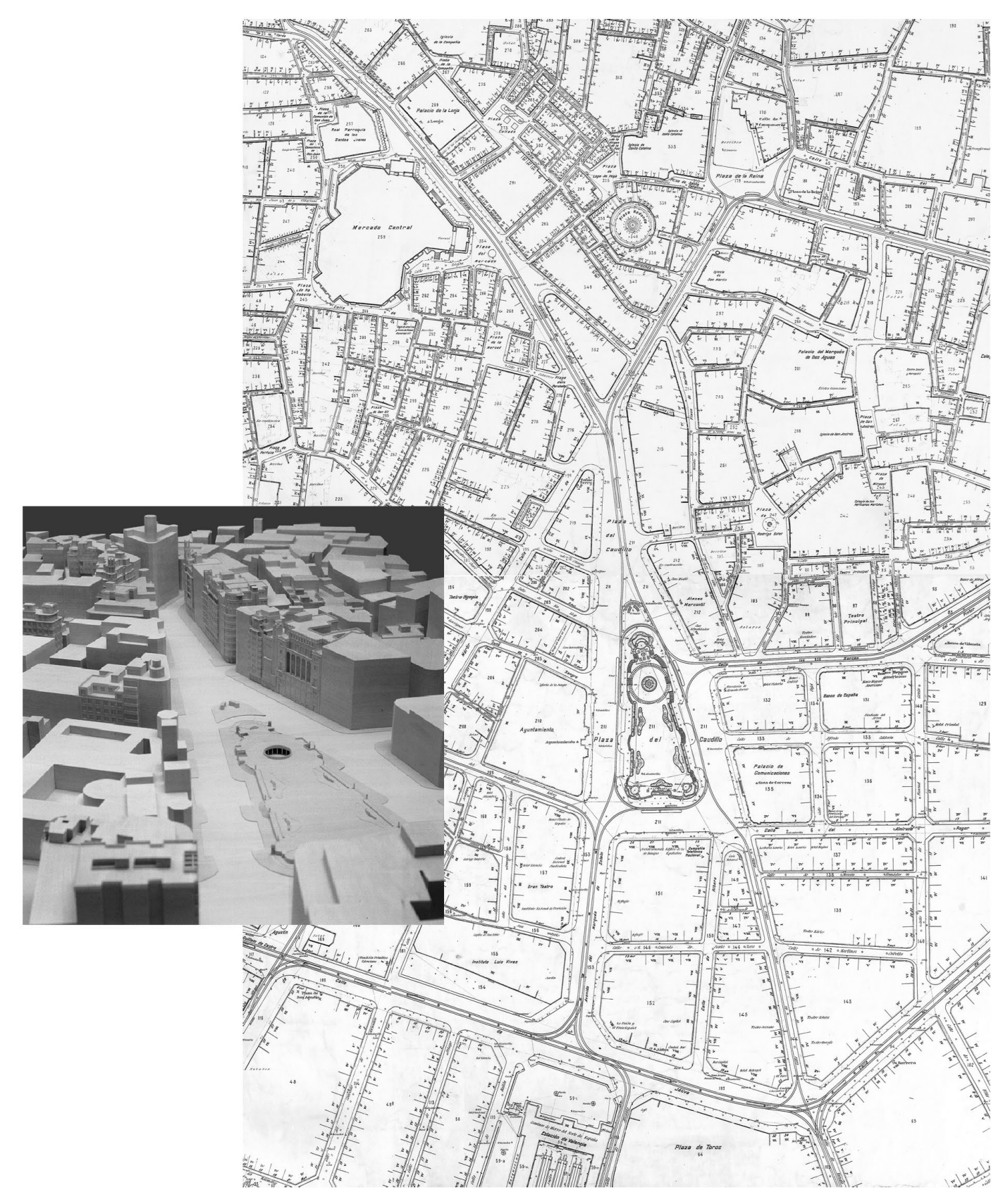


edificios, intuidos por la retina y almacenados en la mochila del conocimiento, me llevó a tamizar mis referentes. Luis Albert firmaba muchas de las obras de arquitectura capaces de hacernos levantar la mirada, en nuestro deambular peatonal por la metrópoli. Obras, una vez conocidas, capaces de anteceder rutas urbanas, predisponiendo una alerta mental, impidiendo pasar de largo sin aproximarse, observar atentamente y aprender. Podría decir, sin temor a la inexactitud, que aquellas obras emblemáticas tomaron la decisión, casi sin consultarme.

Sobrevenía el acercamiento a las fuentes de información. Alberto Peñín propició, no tan sólo su experiencia de haber comenzado a caminar profesionalmente en el estudio de Albert y acompañarlo hasta su deceso. Además insufló suficiente ánimo y amistad -así reza la dedicatoria de su libro ${ }^{4}$ guía y referente en mi trabajo- como para iniciar y proseguir hasta concluir. Hubo más alianzas, idénticamente desinteresadas, manantiales de conocimiento en su especialidad. Luis Perdigón aportó, a más de discernimiento, toda planimetría imaginable -fueron muchas las insospechadas y por el aluzadas- para transitar la urbe, observar su transformación y modernidad, para evocar cada arquitectura en su ámbito natalicio (fig. 5). Reconozco sus aportaciones y compromiso, conduciéndome de un artículo específico a un libro concreto. Lectura esclarecedora nunca faltó, al igual que tampoco negó distendidas disertaciones -nunca acaloradas, más siempre convencidas- sobre el Movimiento Moderno, sus ideales y compromiso, su gestación y sus corrientes antagonistas, coetáneas.

${ }_{4}$ PEÑÍN, Alberto. "Valencia. 1874-1959. Ciudad, arquitectura y arquitectos" Editorial: Escuela de Arquitectura de Valencia. Valencia, 1978. 


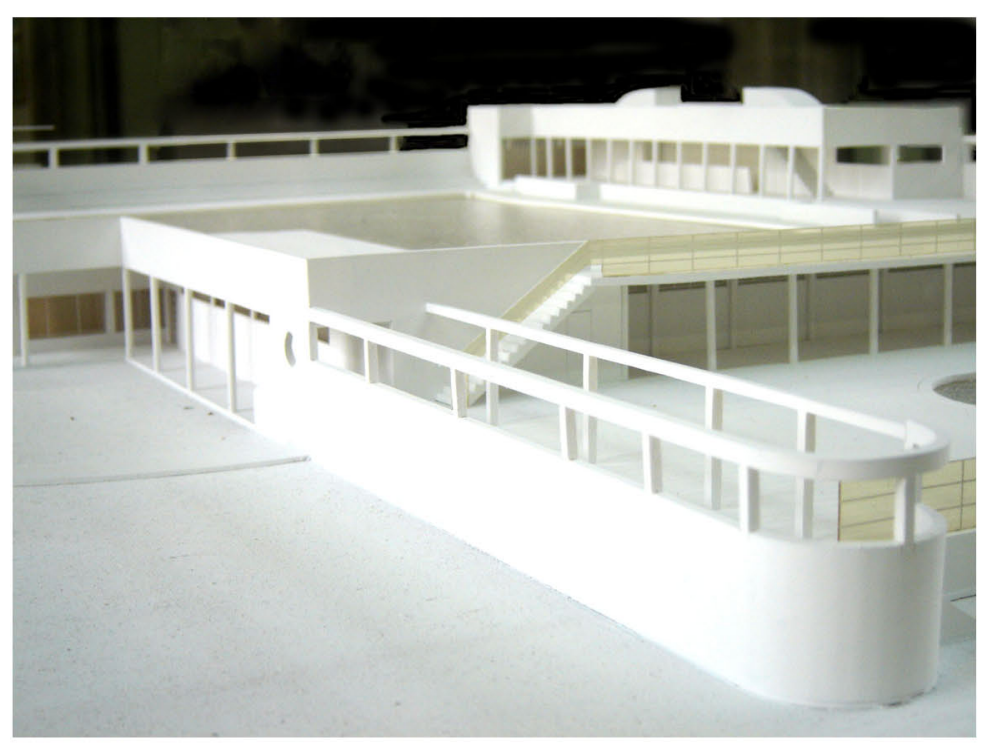

fig. 6 
Planteo pues, este trabajo, desde el agradecimiento a todos los que me acompañaron en su realización. Desde sus tribunas de saber, sus pedagógicos escritos, sus formidables aportaciones. Mucho se ha publicado y expuesto de aquel comprometido inicio de siglo. Mucho ha contribuido a nuestra formación aquella aportación racionalista de su arquitectura. Hora resulta, de aportar trabajo local que dilate el catálogo, con gratitud. Humildemente, continuar los pasos, el denodado esfuerzo de organizaciones como el DOCOMOMO por recuperar el patrimonio moderno y contrastar su influencia local.

Reconocimiento a una época troyana y a sus agentes arquitectónicos, sin los que no tendríamos la posibilidad de disfrutar la metrópoli por ellos incoada. Rendido homenaje, procurando evitar el olvido, la incomprensión y el desconocimiento público de la arquitectura moderna valenciana, en este caso de Luis Albert. Incultura histórica que, unida a desatadas ambiciones económicas, intereses especulativos, provocan puntuales ausencias (fig. 6). Arquitecturas ligadas a una ciudad como Valencia, que dejaron de existir, impunemente demolidas o mutiladas hasta hacerlas irreconocibles. Y aunque mal de muchos, tampoco sirvió de consuelo, la lectura de "Madrid. Arquitecturas perdidas. 1927-1986" nos anima en solidaria denuncia y denodado esfuerzo para concretar un catálogo donde entregar una serie de arquitecturas que contribuyeron a la renovación urbana y formal de las nuevas ciudades, consolidando su ciclo de modernidad.

5 AREA FERnÁndez, Antonio-VAQUERO GÓMEZ, José Angel-CASARIEGo CórdobA, Juan. Ediciones Pronaos S.A. 1995 


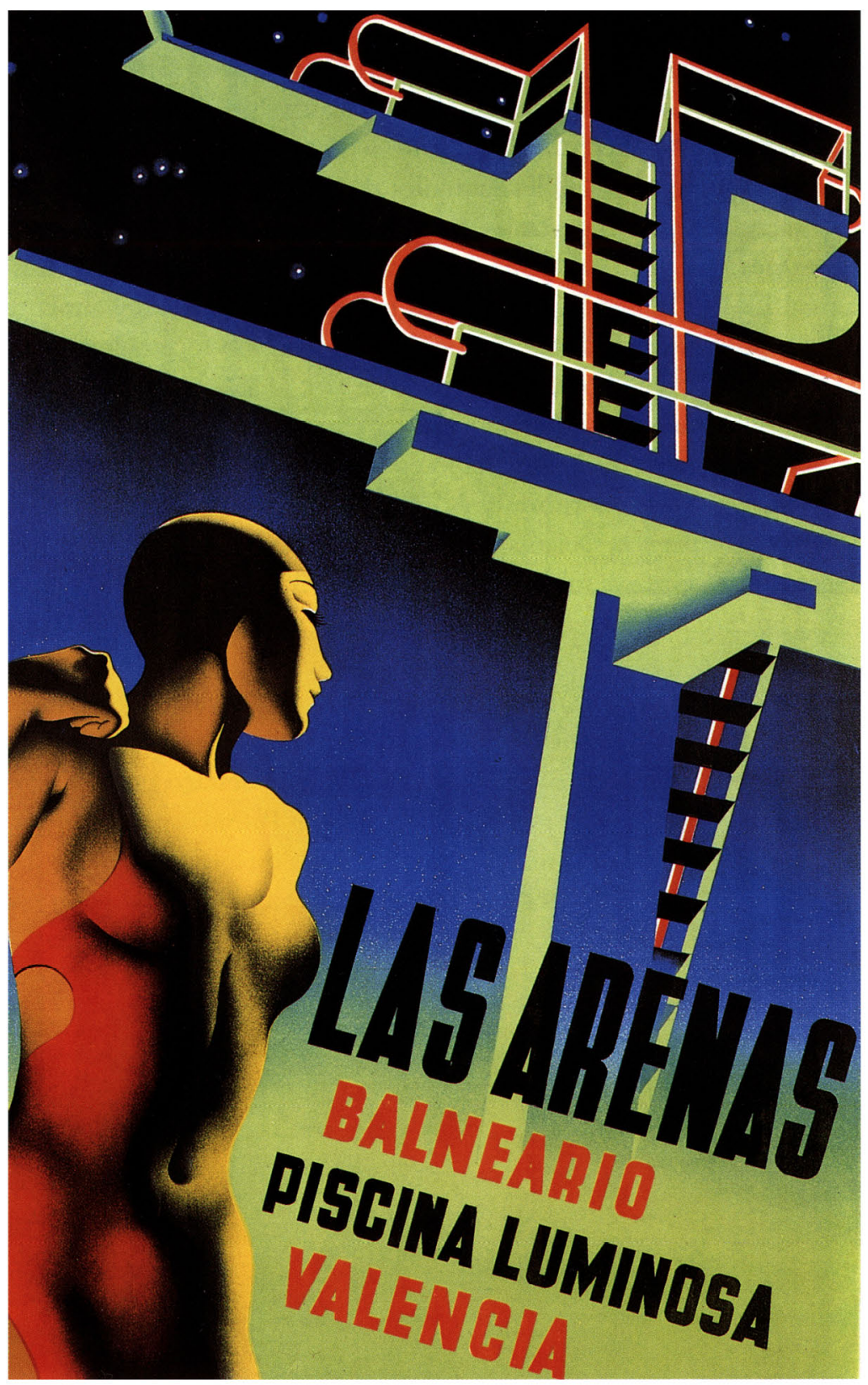

fig. 7 
Asoma ineludible la tarea de convenir límites eventuales para el período a investigar. De igual manera surge inevitable la imposición de circunscribir el ámbito físico, ubicar donde indagamos. En resumidas cuentas, urge delimitar fronteras temporales y acotar ámbitos de actuación.

Asumiendo prioritaria la tarea por delimitar fronteras temporales, manifestamos pues, que el propósito de esta tesis no galantea abarcar el global del Movimiento Moderno. Historiadores contrastados han debatido sus límites sin alcanzar acuerdo, excepción hecha en la premisa que niega el amanecer 'EX NOVO' de la vanguardia arquitectónica del siglo XX6. No entramos en estéril debate, salvo por introducir su reseña. Acatamos la sentenciada génesis de aquella revolución internacional, negada su independencia de la compleja realidad histórica, también del pasado doméstico y la cultura nativa. Es ahora y por menester de una visión de conjunto -emplazar temporalmente el periodo a investigar-, cuando nos surge imperativa la necesidad de revisarla acompañada de sus circunstancias y su máxima aspiración: finiquitar un momento histórico obsoleto, a la espera de un modelo arquitectónico acorde con el espíritu de modernidad (fig. 7), propio del recién inaugurado siglo.

Acompasadas por la necesidad de ruptura y corrección del rumbo, navegaron embrolladas, abundantes propuestas arquitectónicas obligadas a convenirse en el primer cuarto del siglo $x x$, apremiadas por finiquitar la

" Collins, Peter. "Los ideales de la arquitectura moderna; su evolución (1750-1950)". Editorial Gustavo Pili, S.A. Barcelona. Octubre de 1969. Prólogo a la edición española: de Solá-Morales Rubió, Ignacio. 

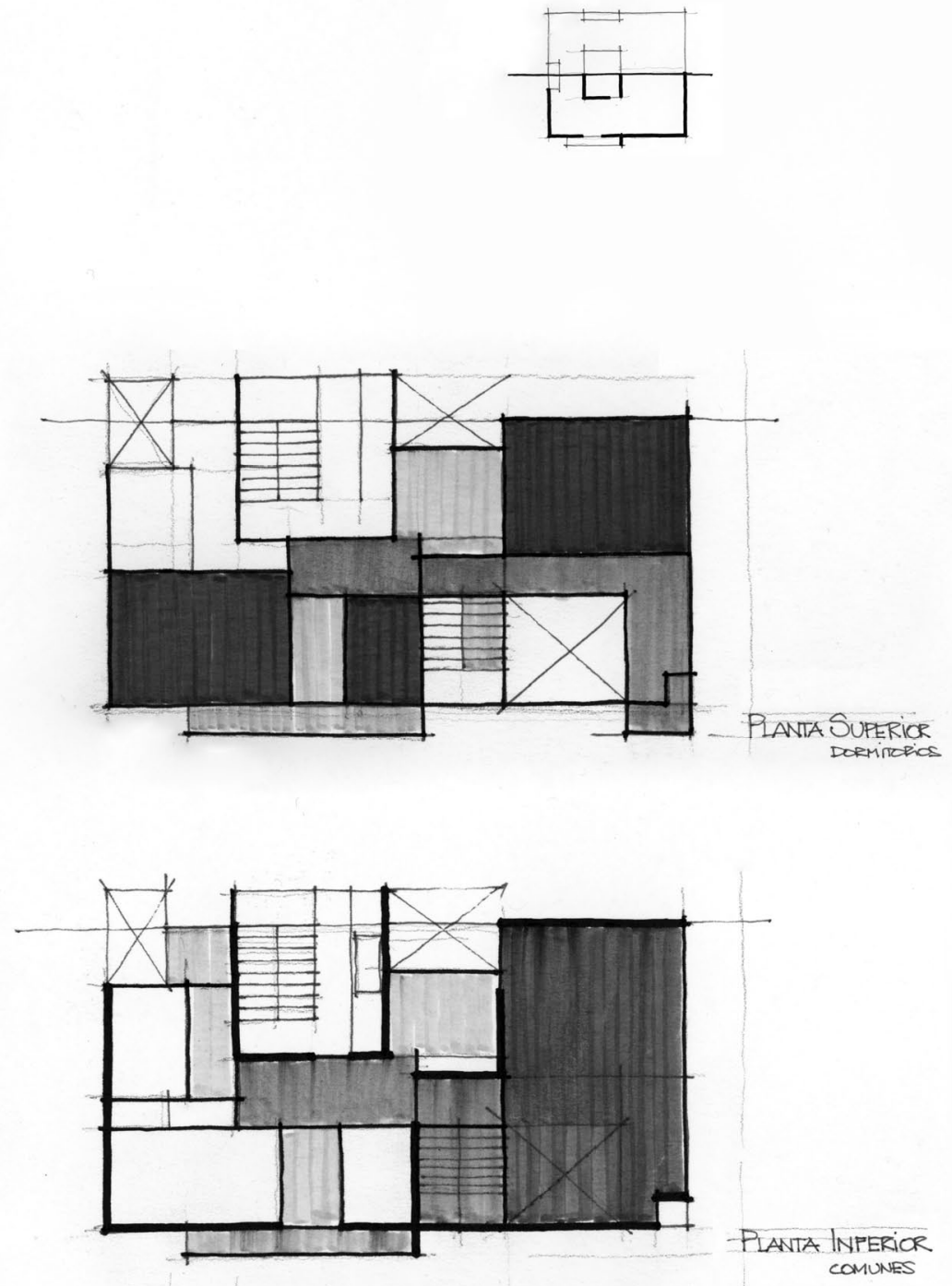
transición academicista, conminadas a disputarse el epílogo de los eclecticismos del XIX.

Declamaron la revolución arquitectónica, en aras de la anhelada modernidad, procurando hegemonía al funcionalismo. Esta renovación pluralista, culminó sintetizándose en el Estilo Internacional y, exegetas como Gropius, Le Corbusier o Mies van der Rohe fueron considerados paradigmas de la verdadera modernidad.7 Aunque cierta, esta revolución no resultó homogénea, no suscitó una firme coalición en torno a las vanguardias pioneras -escuela de Chicago, Sezession vienesa, futurismo italiano, escuela de Ámsterdam, expresionismo- hasta alcanzar el funcionalismo. Suscitó seguidores escrupulosos, y detractores combativos resguardados en la tradición académica. No obstante, una tercera vía, propuso integrar las otras, finalmente resultando la opción abundante. España accede con tardanza a semejante corriente progresista, y recoge de estas posturas dependiendo de la institución aleccionadora para sus profesionales, supeditada la elección, también, a las transformaciones económicas, sociales de la urbe que acoge sus trabajos.

No todos los cronistas patrios, parecen convencidos en convenir el arranque del Movimiento Moderno, en España. Tácitamente permanece ligado a tres obras capitales y dos grupos arquitectónicamente reconocidos, la generación del 25 madrileña y el GATEPAC. El momento pactado asoma por 1925, cuando concurrieron erigirse obras emblemáticas (fig. 8) de

7 CAPITEL, Antón. "Arquitectura europea y americana después de las vanguardias". SUMMA ARTIS. Historia General del Arte. Volumen XLI. Espasa Clape, S.A. Madrid, 1996. 


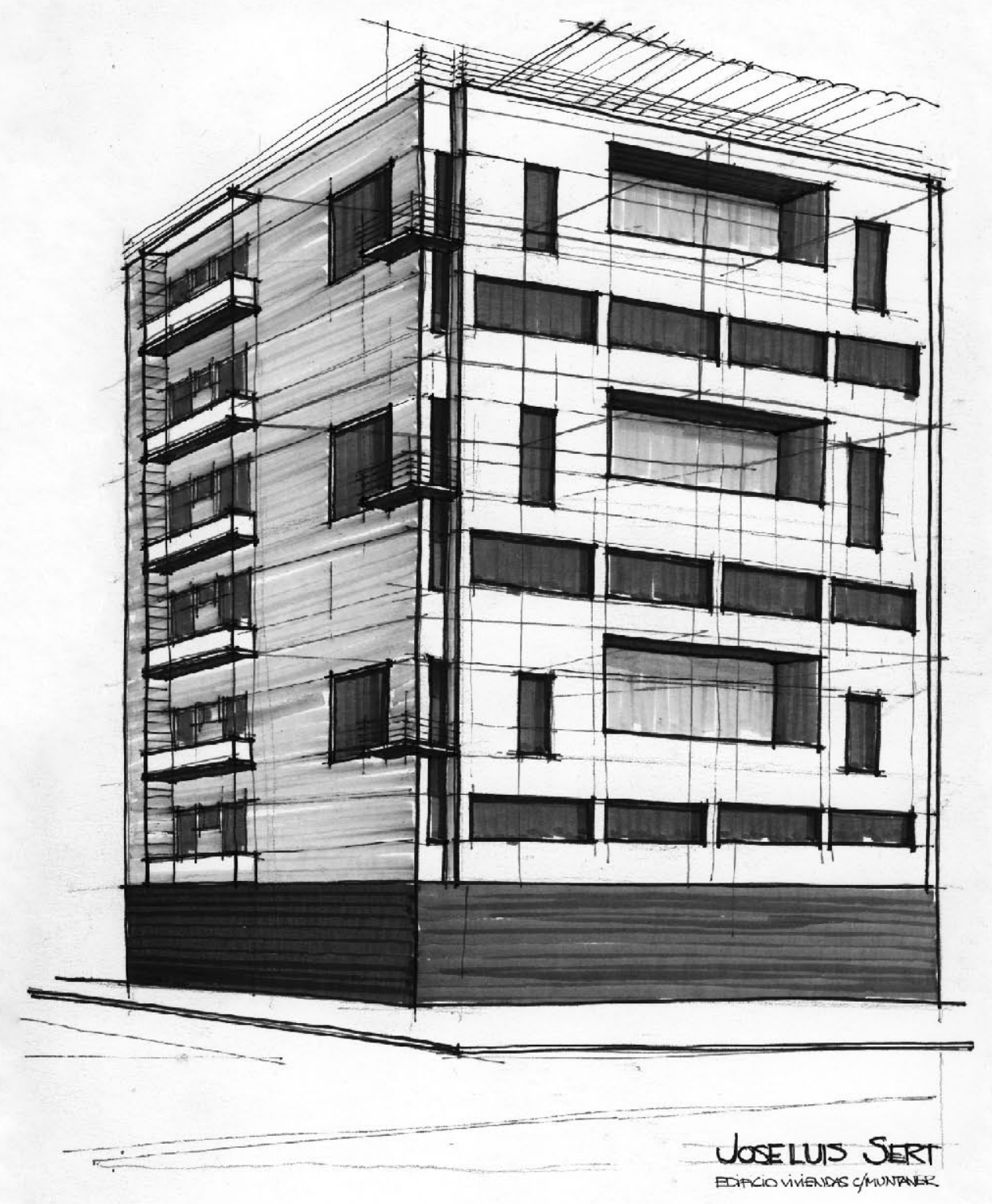

Josep LIuis SERT. Edificio de viviendas calle Muntaner. Barcelona, 1934; análisis formal del volumen construido; dibujo doctorando 
García Mercadal (el Rincón de Goya), Bergamín (la casa del marqués de Villora), y Fernández Shaw (la gasolinera de Porto Pi) probablemente iniciáticas y precursoras. Sin embargo, sería 1930 cuando tuvo lugar, en San Sebastián, la exposición de arquitectura y pintura moderna, verdadero punto de arranque del Grupo de Arquitectos y Técnicos Españoles para el Progreso de la Arquitectura Contemporánea. Ardua tarea supone concertar una fecha, siendo bastante más admisible y verazmente factible acotar décadas.

Valencia alcanzaría la sensación de progreso económico-social y cultural, instaurada como capital de la II República, aspirando a impulsar su espíritu moderno. Tampoco aquí, la renovación vanguardista-si acordamos que la hubo- surgiría de la nada. La Exposición Regional había sido festejada en Valencia en 1909, y se exhibió como una espléndida muestra del Eclecticismo arquitectónico. Emanaba cosmopolitismo e internacionalidad. Asomaba relevante hacia la modernidad de la urbe, la vida y la cultura ciudadana. Traslucía como compendio de estilos, aglutinando una aleación de motivos decorativos, una mezcolanza de ostentación y grandiosidad. Y precisamente en este exceso trovaría su consumación el Eclecticismo, abriendo la mano a nuevas corrientes arquitectónicas en espera de la revolución moderna. Europa daría por finalizada esta postura, con la aparición del Modernismo. "Frente a la valoración del Modernismo valenciano, la etapa siguiente no ha merecido, hasta fecha muy reciente similar difusión". Con esta frase el historiador Javier Pérez Rojas ${ }^{8}$, posicionaba la

8 PÉREZ ROJAS, Javier. "Formas de la ciudad moderna. Neobarrocos, Decós y Aerodinámicos". Catálogo de la exposición La ciudad moderna. Arquitectura racionalista en Valencia. IVAM Institut Valencià d'Art Modern, 1998; p. 7. 

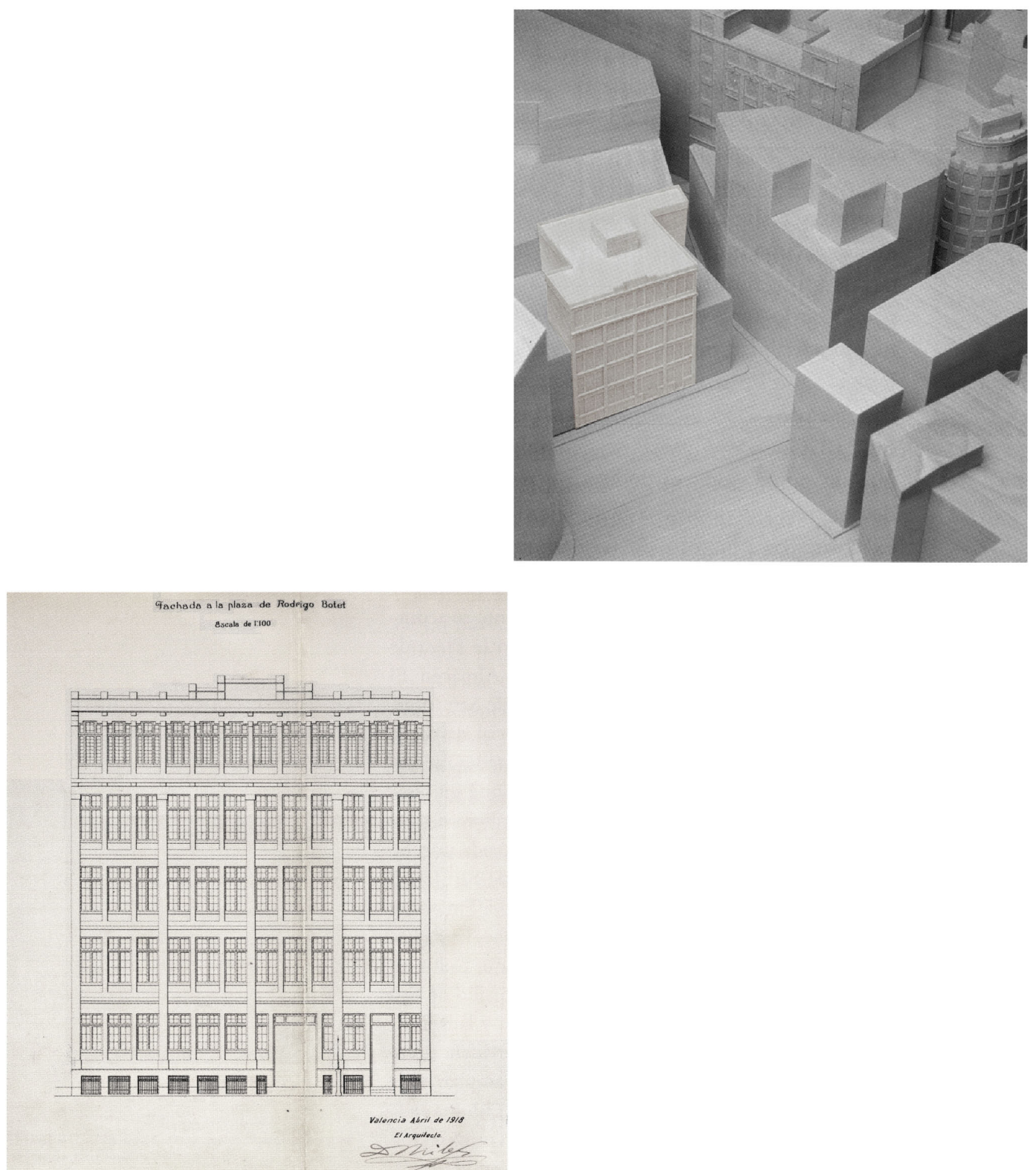

Demetrio RIVES. Almacenes para Ernesto Ferrer, plaza de Rodrigo Botet; exposición IVAM Fachada principal; Archivo Histórico Municipal de Valencia (AHMV) 
arquitectura acaecida en nuestra ciudad entre las décadas de los años veinte y treinta (fig. 9), apenas incluida en los manuales de la arquitectura española. Pero podemos afirmar que no navegaría en solitario, es más, su devenir no fue tan deslumbrante como para menoscabar los estilos predecesores, ni mucho menos eclipsar a sus coetáneos.

Recapitulando lo disertado hasta ahora, acerca del límite inferior acotando esta tesis, mantenemos al margen -por lo dilatado en el tiempo y lo generalista que resultaría- los orígenes marcados por la historiografía arquitectónica. Nikolaus Pevsner partiría de un período premoderno, iniciado con William Morris. Kenneth Frampton retrocedería hasta la llustración para compeler de manera gradual, una historia de la arquitectura moderna. Leonardo Benévolo, plantearía como preludio del Movimiento Moderno otro punto de violenta ruptura, la industrialización y el movimiento Arts \& Krafts. Peter Collins, remontaría doscientos años el preámbulo, hasta el iluminismo, evocando una evolución histórica continuista.

Conscientes del distante y prolongado inicio del Movimiento Moderno, centramos el arranque de nuestro periplo investigador en el confluir de corrientes arquitectónicas embarcadas en la década de los años veinte. Recurrimos a los albores arquitectónicos de Albert y, su primera obra ejecutada en hormigón armado para nuestra metrópoli, e incluso anticipándonos, señalamos como punto de partida su propuesta, como estudiante conjuntamente a Gaspar Blein, para el concurso Nacional del Ateneo Mercantil en Valencia, 1927. Vencido proyecto, coincidente con la proclama precedente sobre el confluir de corrientes y vanguardias, a la espera de un estilo propio del momento Moderno. Concurrente con los comienzos 


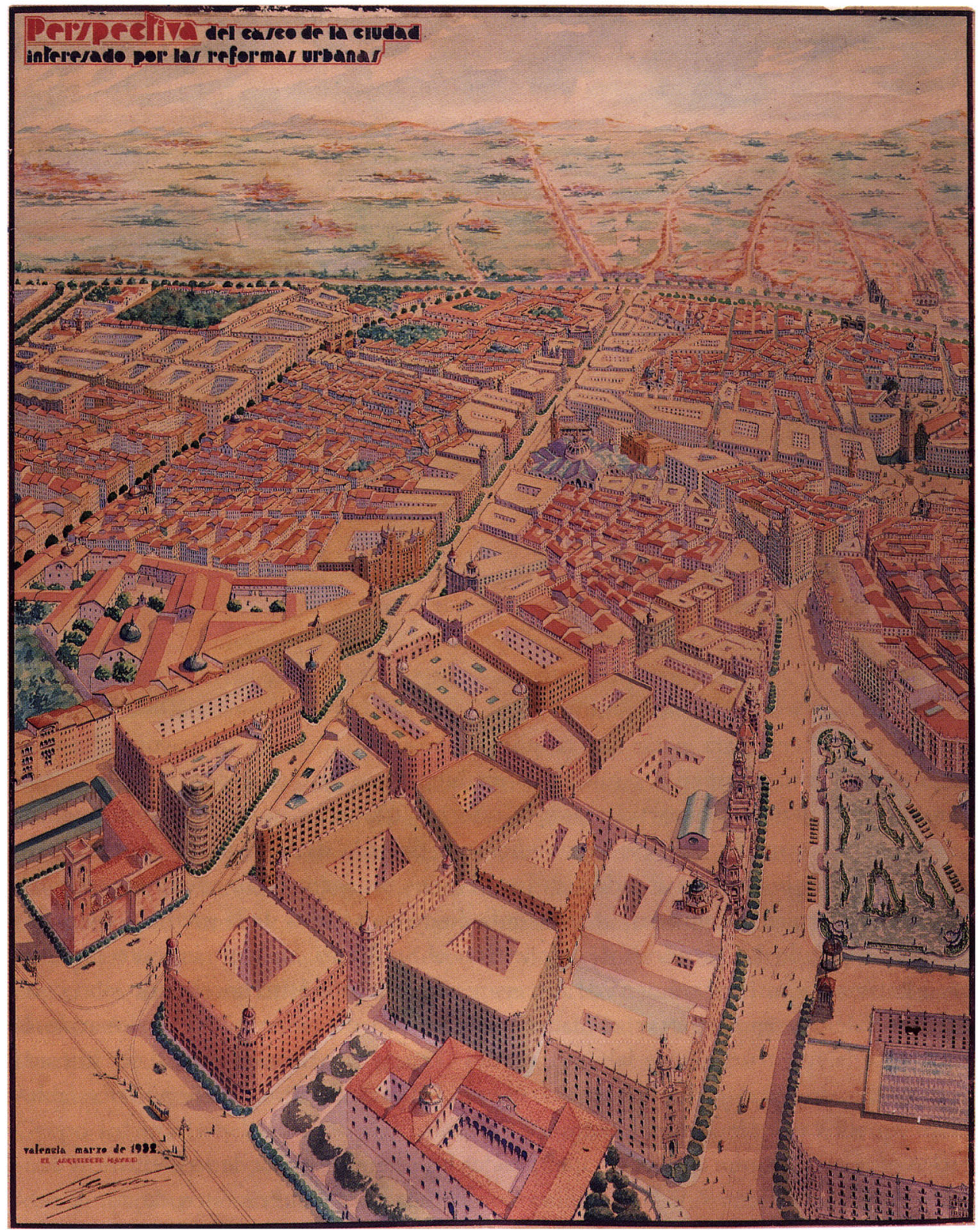

fig. 10

Javier GOERLICH. 1932. Plan de Reforma Interior: plaza de Emilio Castelar y apertura de la nueva avenida del Oeste; Archivo Histórico Municipal de Valencia (AHMV) 
de la generación del 25 madrileña, del GATEPAC en España y sus obras capitales.

En contrapartida, el límite superior no admite argumentos disyuntivos. La guerra civil española asomaría como frontera ineludible, puesto que su carácter traumático y sus desmesuradas consecuencias, se enunciaron decisivas en todos los aspectos, seccionando sustancialmente la arquitectura, y deteniendo el avance de sus profesionales. De este suceder, el punto álgido, recientemente alcanzado por la obra arquitectónica de Albert, justo antes del conflicto bélico, nunca volvería a ser alcanzado. En el transcurso de la posguerra, por conminadas depuraciones. Tampoco en la bonanza posterior, de la que jamás anduvo seducido.

De igual manera, surge inevitable la imposición de circunscribir el ámbito donde indagar físicamente el legado arquitectónico de Albert. Obviamente el compendio arquitectónico a investigar no queda ceñido al foco referente de la capital levantina, a la entonces mediática plaza de Emilio Castelar, ni su inmediato Ensanche (fig. 10). Nuestro ámbito se alarga, tal como sucedió con la labor del arquitecto -exactamente como la urbe-, hasta rozar la incomparable luz del Mediterráneo. Incluso traspasando provincia, allende maridaje. No obstante, concentramos logros y al igual que limitamos temporalmente sus rendimientos profesionales, acotamos el espacio de actuación específicamente analizado, sin perjuicio de relegar aquello no profundizado.

Se decide acotar el análisis del grueso edilicio, a la propuesta arquitectónica auspiciada bajo el afán racionalista. Una fracción de la basta aportación arquitectónica generada por Albert, acotada en tiempo y espacio. 


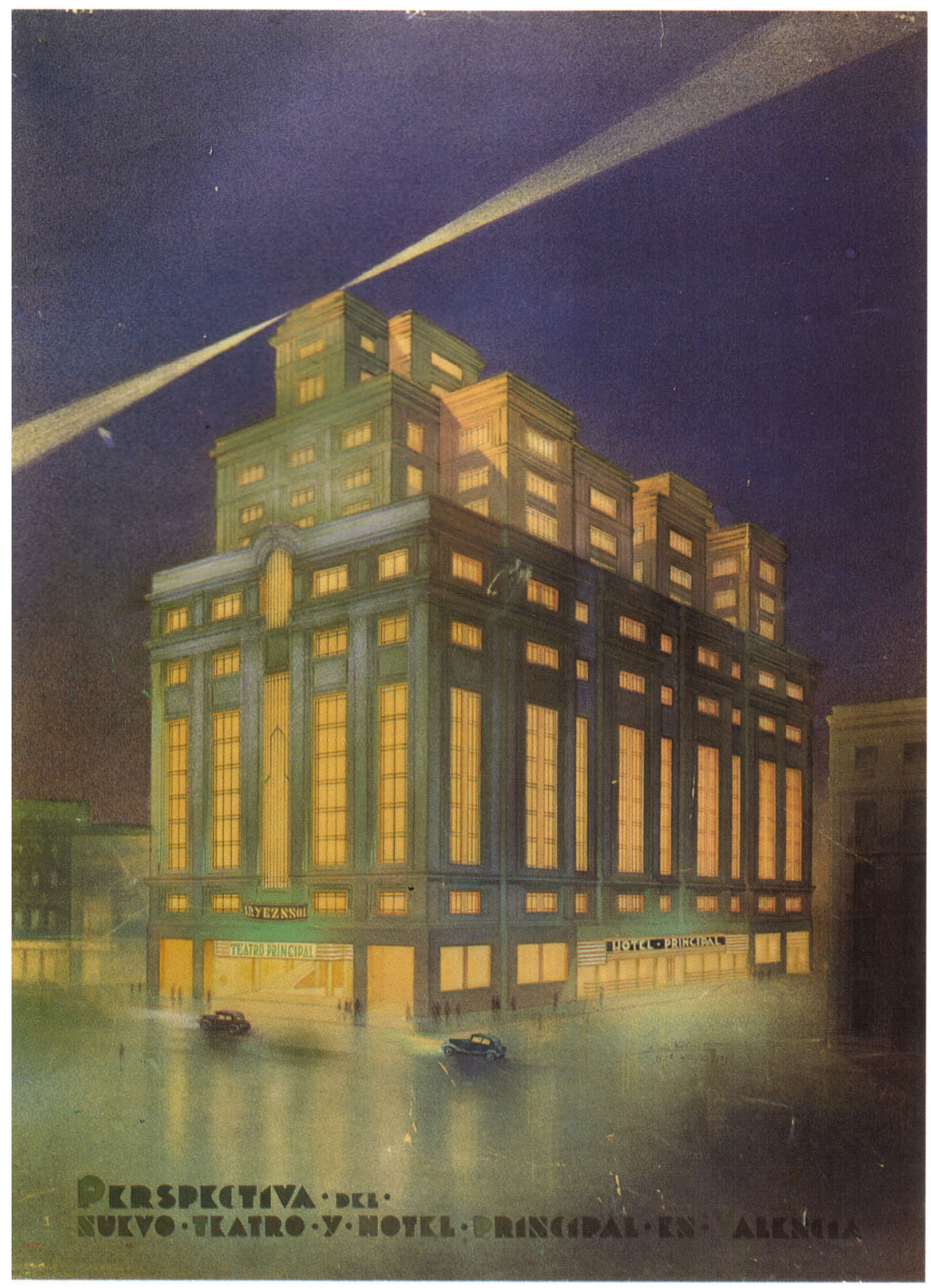

fig. 11

Luis ALBERT, 1933. Perspectiva lápiz, tinta y acuarela del proyecto para el nuevo Teatro y Hotel Principal en calles de las Barcas y del Poeta Querol: (AHMV) 
Una vez inmersos en tan selecto reducto, concentramos la atención en segregar sus aportaciones más emblemáticas a la ciudad de Valencia, en su periplo de mayor libertad creativa. Y lo hacemos focalizando, de entre lo compendiado, una utópica propuesta y un hito arquitectónico. La propuesta -utópica por la escasez de miras, propia de aquellos políticos incapaces de discernirla y aprobarla- engloba una trilogía circundando la metrópoli (fig. 11). El referente edilicio, se materializa mediante una dupla referente para la época, dos volúmenes habitacionales, enclavados en el primer Ensanche, faros de la moderna ciudad instaurada.

Denostada y postergada, la triada albertiana -exenta de compromisos próximos, carente de imposiciones externas- abrirá el entendimiento sobre el compromiso del arquitecto con los principios racionalistas. No habiendo diálogo posible con referentes próximos, aislados arquitectónicamente en ocasiones, el emplazamiento no condiciona la respuesta del proyecto. No formando parte de la escena urbana, alejado del crítico ojo del transeúnte $y$, por supuesto distante de la necesidad especulativa de promotores, se perfilan las condiciones objetivas para decantar posturas propositivas, manifestarse enteramente racional, abrazar sin vacilaciones la filosofía del Movimiento Moderno (fig. 12). Este plausible compromiso, resulta aquello que intenta contrastar este trabajo, a la espera de poder cotejarlo con el remanente de sus propuestas erigidas.

Resta dilucidar este compromiso, en aquellas obras que se nos permitió admirar, obras que contribuyeron firmemente al legado moderno reconocido en nuestra ciudad. Asimilar su puesta en escena, con el decorado propio de la urbe que las asume, debe servirnos de parangón entre su aspiración racionalista y la realidad materializada. 


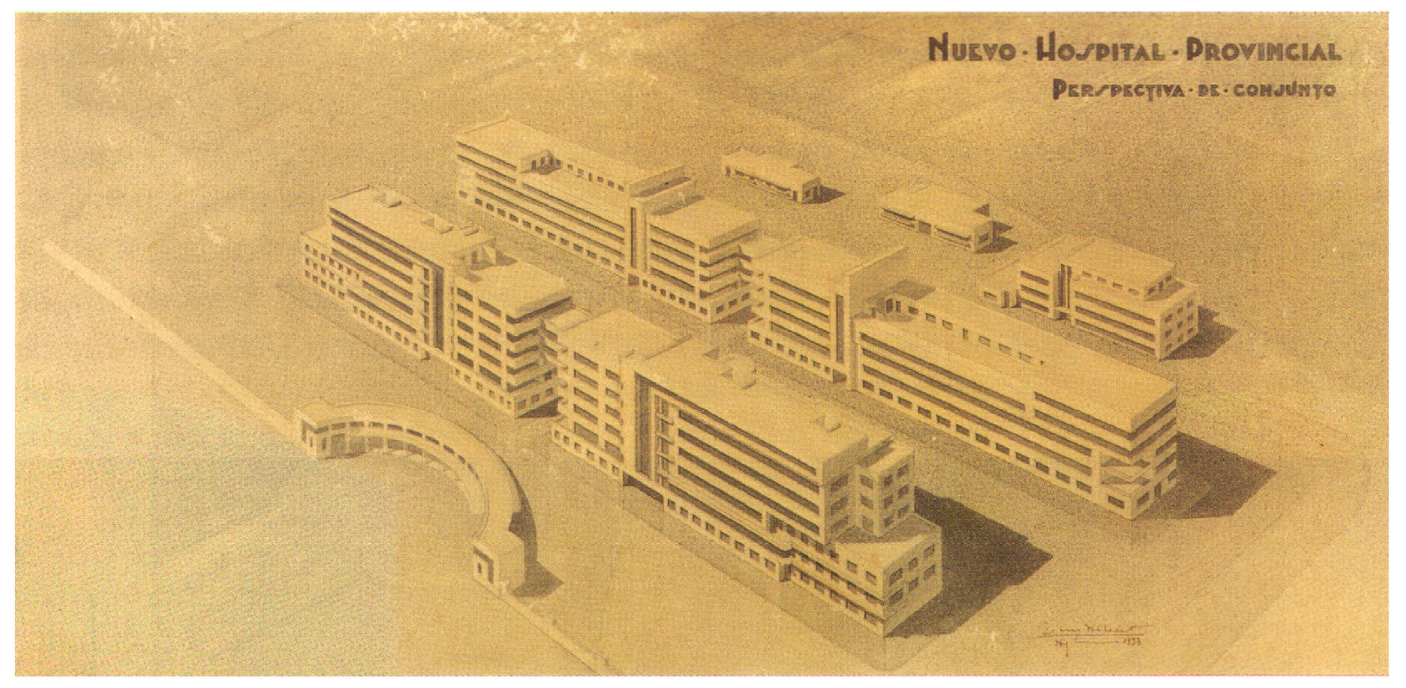

fig. 12

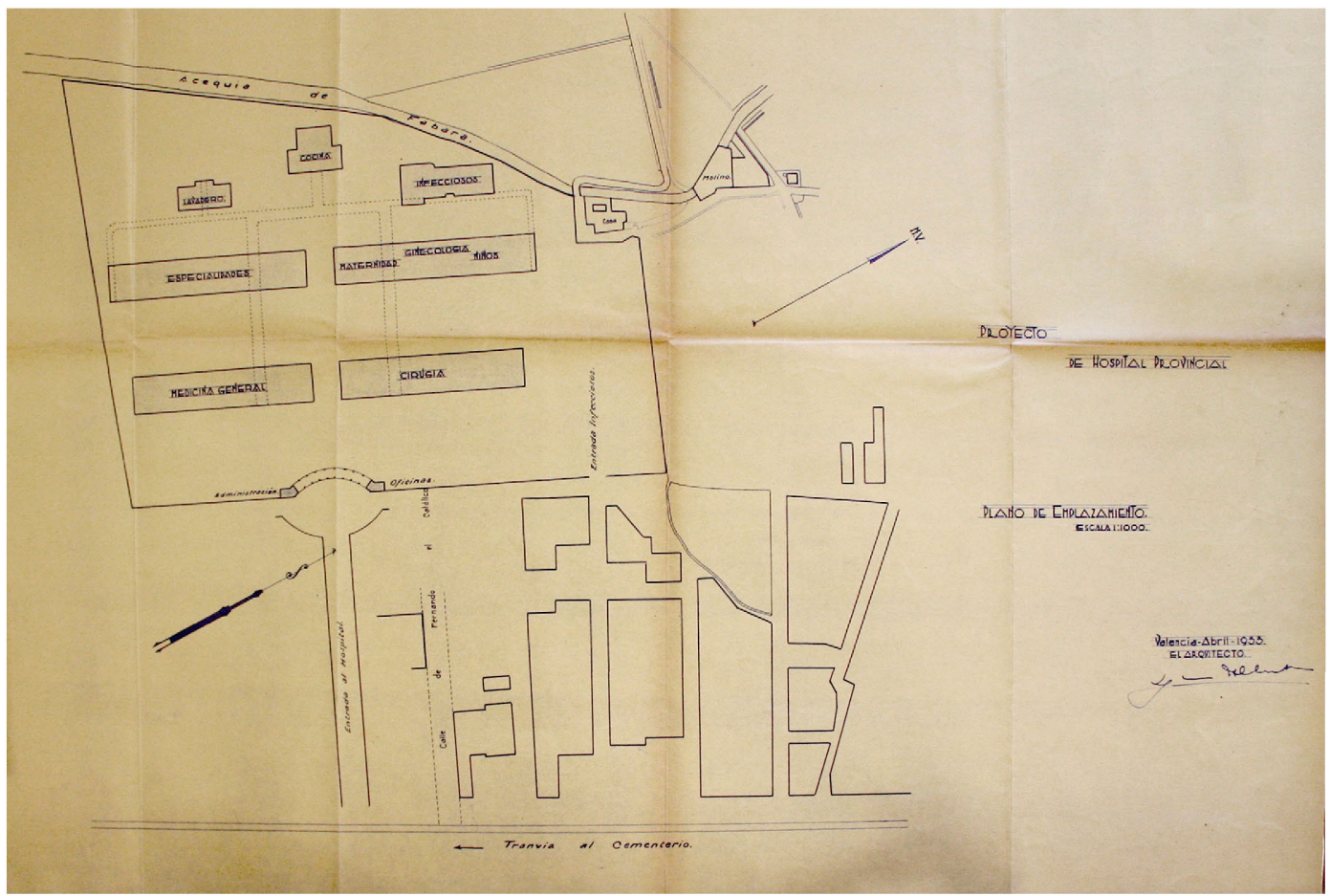

Luis ALBERT, 1933. Perspectiva lápiz, tinta y acuarela para la propuesta del nuevo Hospital Provincial y plano de emplazamiento, desligado de la metrópili; (AHDP) 
Quedan sometidos a juicio discriminado los dos bloques de vivienda entresacados, sintetizados en la dupla habitacional electa (fig. 13). En su debe amén de condicionados a las exigencias del promotor privado- resultaba ímproba tarea para su autor, atender condicionantes de emplazamiento, en una frontera temporal que, como hemos anunciado, aprobaba el espíritu moderno dejándose deslumbrar por el lujo decorativo o, los compromisos menos exigentes que recogían de todos los cauces estilísticos. En su haber, proclamarlos como referentes modernos a falta de analizar y concluir el grado de ortodoxia finalmente mantenida. 


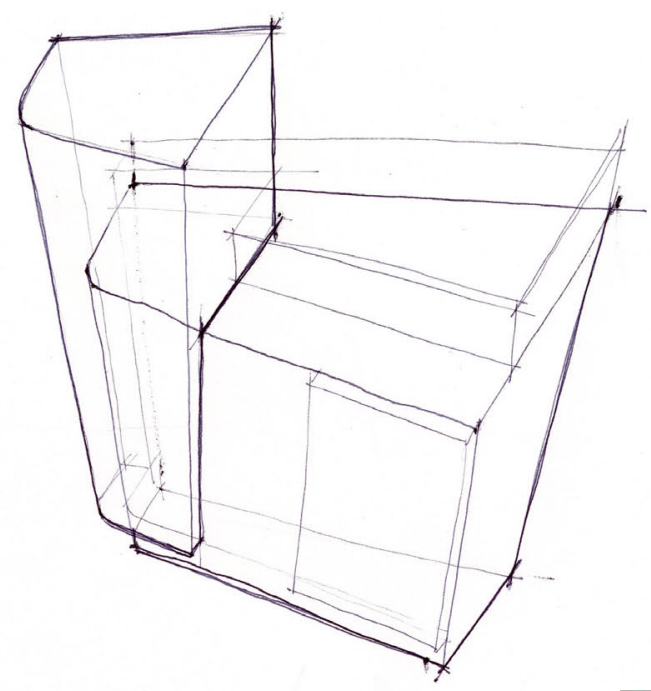

fig. 13

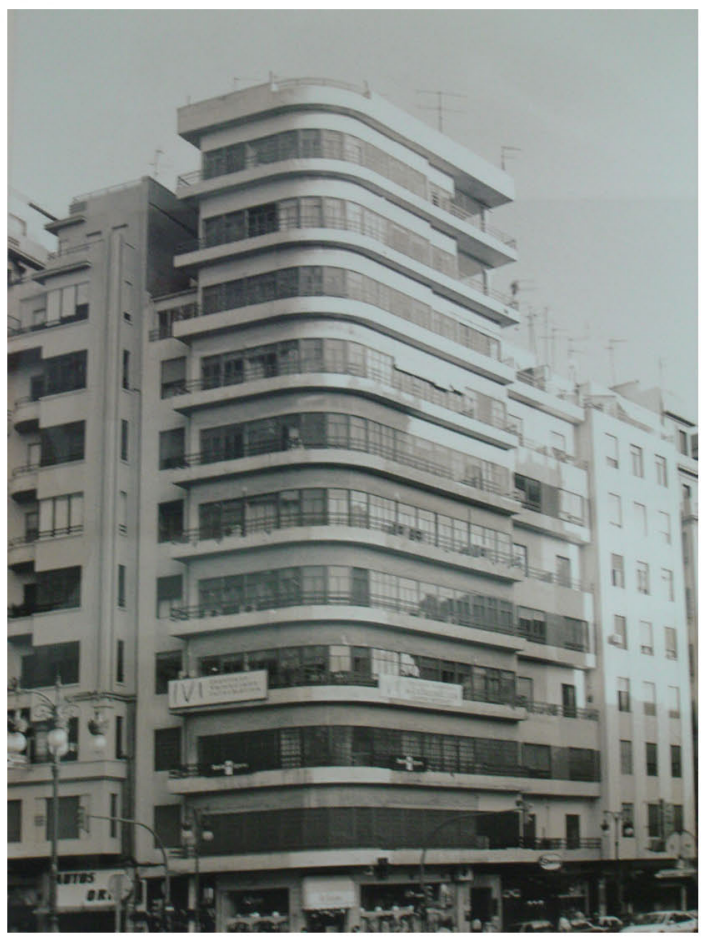

Luis ALBERT, 1935. Edificio de viviendas para Carmen ALONSO, c. Játiva, esquina San Vicente Análisis formal, dibujo doctorando; imagen época de su inserción urbana, exposición IVAM 


\section{PROPÓSITOS Y OBJETIVOS}

Ha quedado narrado, con anterioridad, el origen embrionario de la tesis que nos ocupa: otrora incesante periplo entre archivos municipales, una perenne consulta de expedientes en insaciable rastreo de la arquitectura moderna generada en Valencia, durante finales de los años veinte y la consecuente década de los treinta.

Ha resultado aquella intención primaria -sistematizar y catalogar la producción arquitectónica en la capital levantina, durante el final de los años veinte y los treinta- hilo conductor y mantenido propósito, capaz de orientarnos en el acercamiento a una de las figuras arquitectónicas esenciales para nuestro legado moderno. Aquel embrionario objetivo radicaba en formalizar un compendio de tablas, de fichas que permitieran acudir a una determinada obra arquitectónica, desde su autor y fecha de ejecución. Localizar su emplazamiento, su promotor y discernir las características formales de interés arquitectónico, ubicar su propósito racional dentro de la flota de corrientes arquitectónicas surcando nuestro patrimonio.

Obtuvimos justamente, la facultad de admirar la documentación extraída del Archivo Municipal-memorias, planimetrías y dibujos originales-, recopilada mediante fotografías digitales de expedientes. Adquirimos a su vez, la suficiencia para cotejar una obra arquitectónica electa entre sus compañeras de reparto $y$, rever un autor maniobrando conjuntamente a sus coetáneos. Y del propósito-aquel primigenio prontuario de fichas-, deviene el objetivo general, que no resulta otro más allá de analizar pormenorizadamente los datos recaudados, compulsando tanto la realidad construida, 

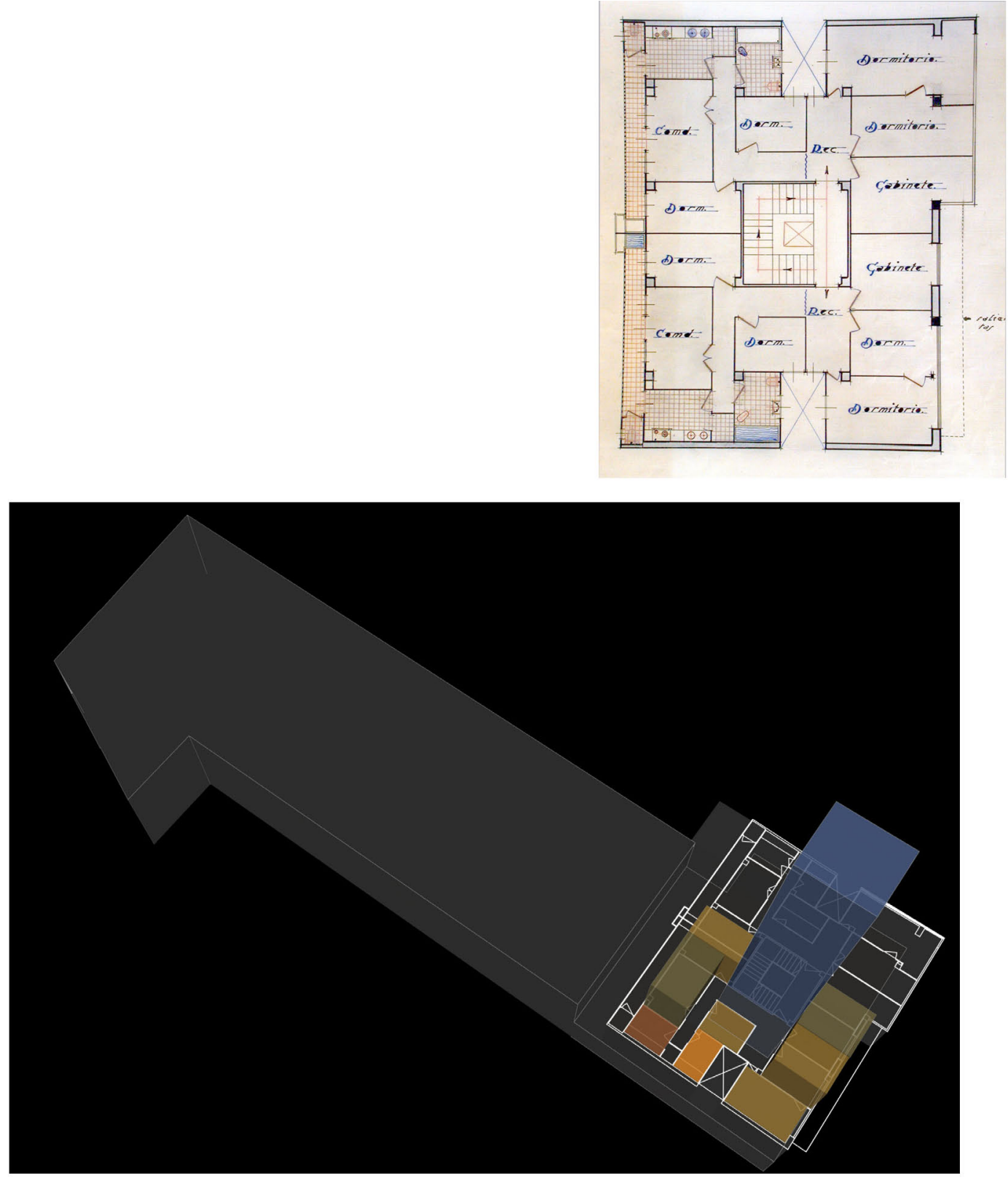

Luis ALBERT, 1935. Edificio de viviendas para Máximo BUCH: planta de distribución de pisos: análisis funcional del volumen habitable sobre la fábrica pretendida, dibujo doctorando 
fuentes materiales, como las fuentes escritas que precedieron nuestro análisis, centrados en Albert.

También reclama atención, adquiriendo rango específico de objetivo, la manipulación gráfica de las obras extraídas para su análisis (fig. 14). Volver a dibujar planimetría, erigir a través de procesos infográficos, electos edificios enclavados en la escena urbana, y sobre todo aquellos que no pudieron superar el grado de propuesta arquitectónica, nos posibilita volver a visualizar las intenciones sustanciales de los proyectos escogidos. Devolver una mirada nueva a edificaciones consolidadas en la metrópoli y confirmar bocetos originales, concretan el método para obtener el objetivo principal, profundizar en el conocimiento de la arquitectura moderna en nuestra ciudad a través de uno de sus actores.

Devolver la mirada analítica a una producción individual, debe comprometer la revisión del conjunto arquitectónico valenciano moderno y procurarle la denostada posición en la historiografía, negada al margen de Madrid y Barcelona. Procurar instrumentos críticos eficientes para generar el entendimiento de su evolución arquitectónica, debe colmar el objetivo final de nuestro trabajo investigador. Perfilaremos el propósito de revalorar nuestro pasado reciente, conjuntamente a la repentina proliferación de guías arquitectónicas, acompañadas de exposiciones -"Arquitectura racionalista en Valencia: la ciudad moderna" $\circ$ "20x20. Siglo XX. Veinte obras de arquitectura moderna" ampliadas con multitud de artículos, textos de autores contrastados y esfuerzos llevados a cabo por la sección 
Ibérica del Docomomo. Buscamos pues, la compensación del reconocimiento y la defensa institucional ${ }^{9}$ de una herencia antes desdeñada.

Entresacado de sus compañeros de profesión, coetáneos en la labor arquitectónica que configuraría la imagen moderna de la ciudad, Albert faculta el análisis pormenorizado que refiera y refuerce la comprensión conjunta de una producción edilicia, que incluso hoy marca nuestra formación y posterior desempeño profesional. Bajo ningún concepto, podemos permitirnos el lujo de condenar semejante aportación cultural, a un ostracismo propenso a su mutilación, su asolación.

Finalmente apuntar que, atender la factible ortodoxia racionalista de las propuestas de Albert, o llegar a mostrar el grado heterodoxo de sus realidades edilicias, invariablemente ha formado parte de los objetivos. No partieron como hipótesis previas con objeto de demostrar la viabilidad racionalista del arquitecto, del quehacer profesional del momento. Más al contrario, evitando prejuicios capaces de condicionar resultados, nos limitamos a las conclusiones finales para abordar tan sustancial controversia.

9 TORRES, Jorge. "Valencia moderna. Del eclecticismo a la Tendenza". Artículo publicado en la revista 'Arquitectura Viva' $n^{\circ}$ 61. Madrid, julio-agosto 1998. p 17 


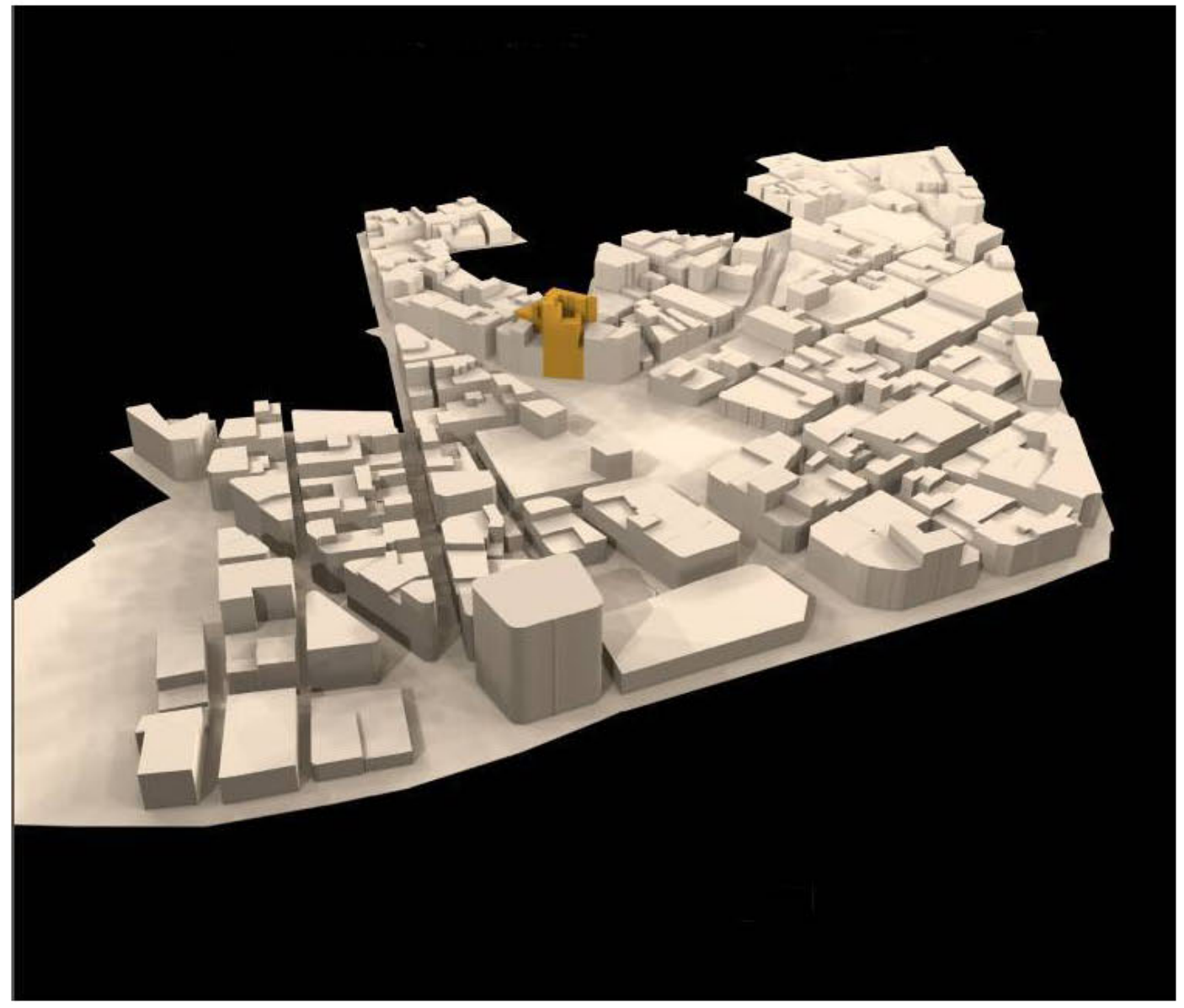

Inserción urbana para la propuesta de Luis ALBERT en el Concurso Ateneo Mercantil, 1929 maqueta del entornode la plaza de Emilio Castelar y avenida de Blasco Ibánez; doctorando 


\section{METODOLOGÍA}

Habiendo catalogado y sistematizado el grueso de la arquitectura moderna erigida en Valencia -han sido apostados justificadamente los márgenes temporales y espaciales- se ha dilucidado extirpar un arquitecto para su investigación y análisis. La metodología desarrollada en el Trabajo de Investigación, facultando la investigación del Tercer Ciclo, se desarrolla ahora, a través de un único actor en la escena urbana de la Valencia moderna. El carácter riguroso del método entonces emprendido, se mantiene y consolida en esta subsecuente labor de Tesis Doctoral. Se procura severidad, disciplina y orden, extrapolados a la observación de edificios construidos, de previas propuestas con precisa documentación anticipando las intenciones del arquitecto, no siempre escenificadas.

Compilada la propuesta arquitectónica de Albert, revisada -vuelta a ser atentamente mirada- su aportación y manifestados nuestros límites de investigación, mantenemos firme el criterio de emplear el análisis gráfico como herramienta inherente a la profundidad del conocimiento. Y semejante calado nos lo proporcionará, tanto la vuelta a dibujar planimetrías originales, como la recreación de esquemas, bocetos, perspectivas, detalles y el deleite de procurar maquetas, imágenes digitales (fig. 15). También la lectura de memorias, mediciones, presupuestos, artículos y textos referenciales del momento -fuentes escritas capacitadas para prestar apoyo- o actuales.

Sin embargo, el estudio pormenorizado e individual, estrictamente acotado, mantendría en desequilibrio al método propuesto en un principio. Amanece primordial invertir el sentido -no concentrarnos únicamente en un punto-, facultar la visión lejana y, retomar el momento histórico donde 

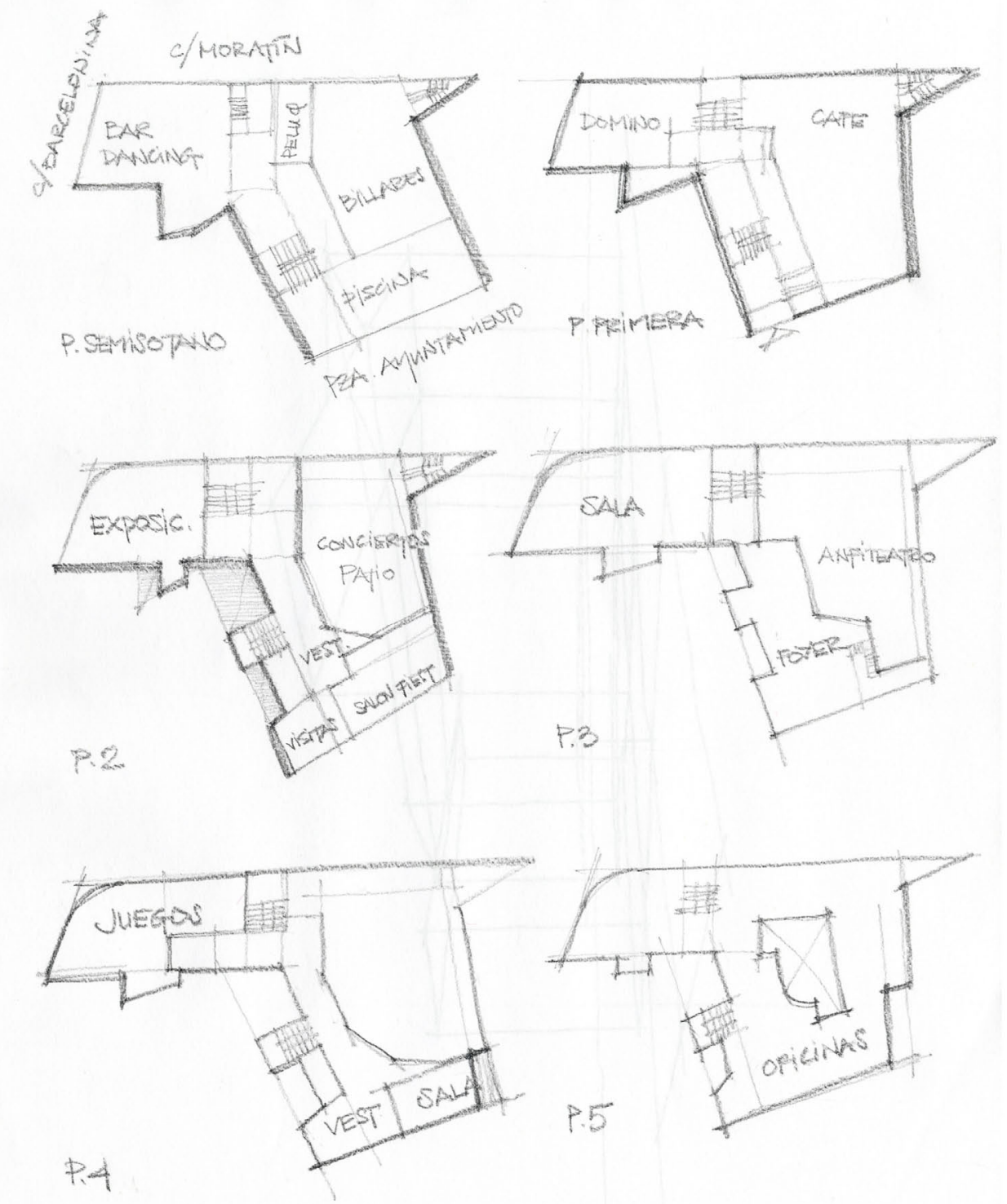

Análisis funcional sobre la propuesta de Luis ALBERT en el Concurso Ateneo Mercantil, 1929 : plantas inferiores: dibujos doctorando 
el arquitecto prepara sus propuestas, concibe su edilicia. Nunca quedaría validado un método que abandonase la historiografía y, a su vez, los condicionantes sociales, económicos y urbanísticos. El armazón dará comienzo con los antecedentes históricos, manifestando posiciones -y no tan sólo arquitectónicas- en el devenir que centre el periodo investigado. En nuestro cometido, consolidamos la estructura de trabajo, puntualizando el acontecer de las vanguardias y su devenir en el Estilo Internacional, exaltando paradigmas de la 'verdadera modernidad'.Prosigue con los condicionantes locales, del momento cultural que nos ocupay, finalmente planteada la estructura, se consolida la figura arquitectónica de Albert.

Consecutivo en la estructura planteada, trasluce una fracción de la totalidad. Tras el armazón genérico de las vanguardias, el funcionalismo y Estilo Internacional, se manifiesta evidente la arquitectura moderna valenciana a través de un ámbito individual y personal, el arquitecto Luis Albert. Particularizando el trabajo de investigación, durante años se han buscado las fuentes de sus proyectos, se han consultado archivos y fondos documentales, se han rastreado publicaciones, datos, referencias. Se ha contado con testigos y estudiosos. Se ha profundizado en el conocimiento de un arquitecto esencial para la evolución moderna valenciana.

Partiendo del global, de la totalidad de una producción edilicia y la evolución profesional de un único autor, se repite un sistemático análisis en sus propuestas aisladas. Proyectos frustrados y erigidos logros, facultan analizar su documentación original, revisar condicionantes del momento cultural que germinaban el proceso y completar, gráficamente, nuestro metódico análisis. 
fig. 16
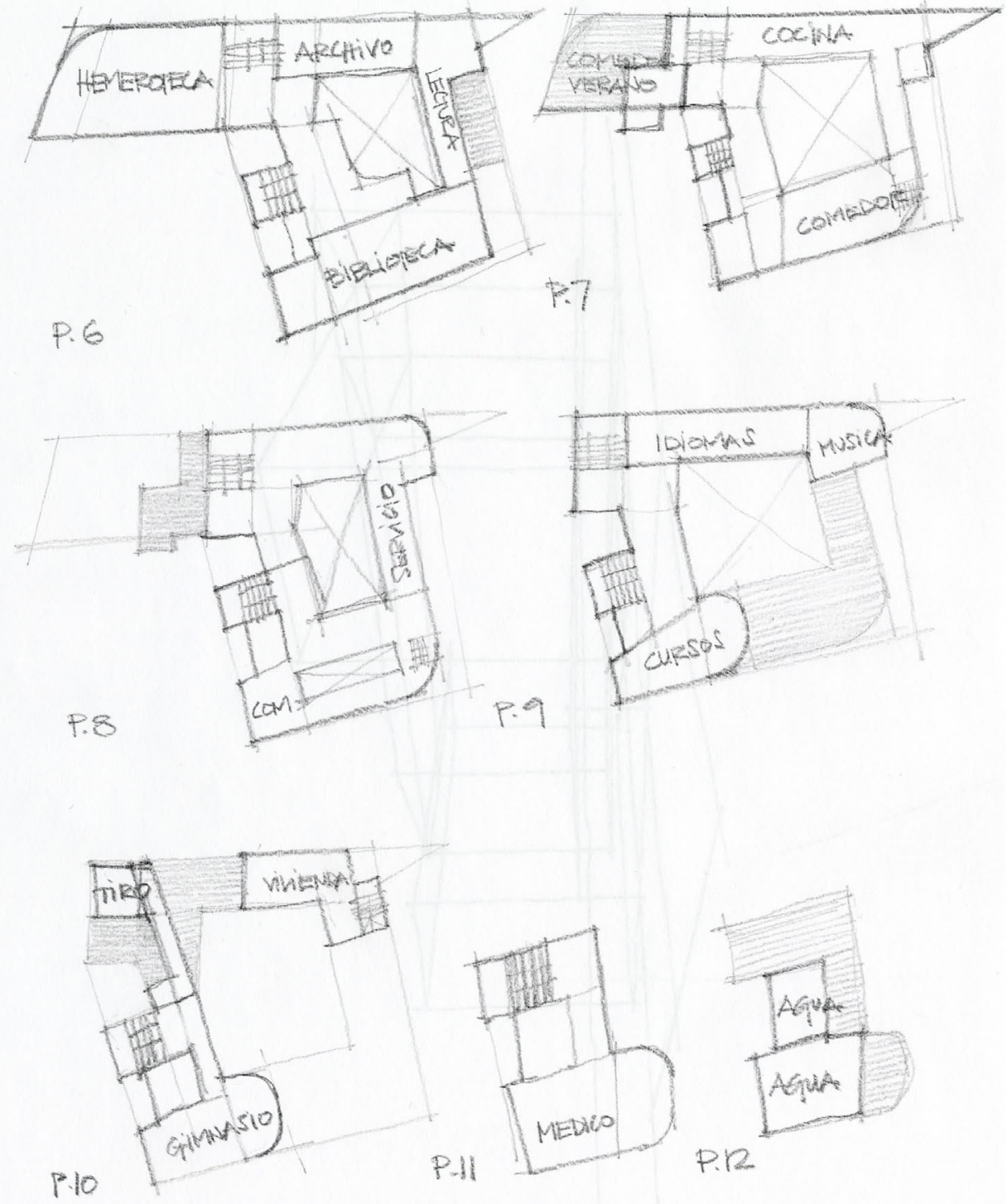

Análisis funcional sobre la propuesta de Luis ALBERT en el Concurso Ateneo Mercantil, 1929 : plantas superiores: dibujos doctorando 
Llegados a este punto, habiendo rescatado un único arquitecto del conjunto de modernos coetáneos, acotada local y temporalmente su edificatoria, urge afirmar intenciones. Escindido un único autor para semejante propósito experimental -Trabajo de Investigación con lo que supuso de reconductor- y limitado el ámbito de su producción arquitectónica, apremia ejercitar un renovado proceder. Acucia un lúcido método, gravitando en el análisis de ideas proyectuales originales. Una metodología indagando propósitos formales inaugurales, para finalmente, cotejarlos con la arquitectura edificada y concluir la fortuna de los ideales racionalitas.

Ambiciona nuestra intención, volver a ver la arquitectura pretendida en su gestación, afianzando su entendimiento activo. Esto supone, aprender a mirar (fig. 16) y tras ello, poder inquirir el propósito racional como mecanismo de transformación social y mejora del habitar en su integridad. Sacudir la vista para evadir del entendimiento el carácter iconográfico en la arquitectura y su autor, "actitud ésta que se revelaba entonces -y se revela ahora- poderosamente pujante como estrategia de aislamiento singular, en paralelo con la desestimación pública de la arquitectura como laboratorio promotor de avances solidarios por la que pasamos". 10

Revisar los principios proyectuales -facultada nuestra visión desde la renovación-, aportará capacidad para rastrear el propósito racionalista germinal, frente a la modernidad construida y comúnmente aceptada. Cotejar la conceptual proposición con la realidad edificatoria, dilucidará

10 BAYÓN, Mariano. "Luces inconclusas". Introducción en todos los cuadernos de investigación publicados con motivo de la exposición "Arquitecturas Ausentes del Siglo XX", publicados por editorial RUEDA S.L. Madrid, 2004 


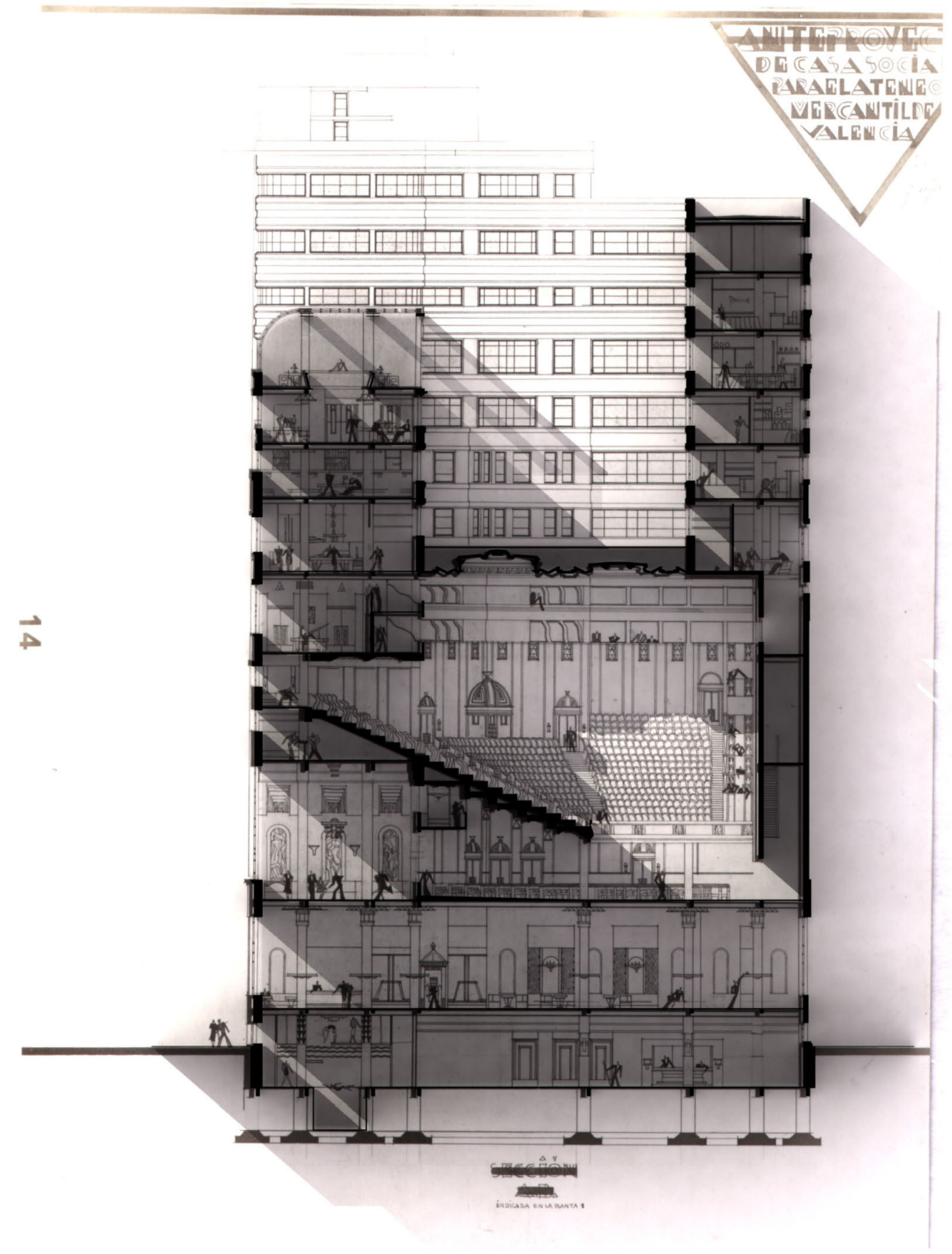

Luis ALBERT, 1929. Sección transversal para la propuesta del Concurso Ateneo Mercantil; estudio control lumínico en piscina. Salón de Actos, terraza y galería acristalada; dibujo doctorando 
la exposición ortodoxall frente al racionalismo al margen, la heterodoxia. En conclusión, asentamos el método sobre un meticuloso análisis hacia el reconocimiento de las intenciones incubadas en Albert y las capacidades de aquello proyectado, hacia los compromisos generadores con la arquitectura, descubriendo en el transcurso signos menos evidentes capaces de variar el ángulo de visión y provocar innovadas indagaciones.

Este análisis exhaustivo y sistematizado para el sumario de obras selectas, viene a desarrollarse gráficamente, perseverando una serie de ítems, de argumentos individualizados en el estudio para cada proyecto arquitectónico escogido, hasta dilucidar el compendio. A saber, estas partes o unidades se plantean inicialmente evocando, rastreando la forma proyectada, la composición pretendida, y tendrá en nuestro haber el evadir tratamientos superficiales pretendidos aisladamente (fig. 17). Abordamos inmediatamente el rechazo a la mímesis y las reminiscencias históricas, el abandono de las normas compositivas clásicas, de criterios antropomórficos, relaciones de armonía y simetría, de las conformaciones ornamentales. La sensibilidad por el lugar, prosigue el aditamento.

11 BoHIGAS, Oriol. "Modernidad en la arquitectura de la España republicana". Editor: Tusquets. Barcelona, 1998. p. 13

'Durante la República y sus años preparatorios hubo dos clases de modernidad, que se pueden distinguir de forma muy clara. Hubo un grupo integrado plenamente en las vanguardias europeas, y en la ortodoxia del racionalismo, y otro grupo, ambiguo y vacilante, que adoptó tan sólo los aspectos superficiales pero que mantuvo subterráneamente los métodos del eclecticismo de procedencia más o menos clásica o aprovechó sin más las desviaciones falsamente modernas que provenían del Art Déco francés o del repertorio iconográfico de los últimos suspiros decorativos de la Sezession vienesa. En el primer grupo están casi exclusivamente los arquitectos del Grupo de Artistas y Técnicos Españoles para el Progreso de la Arquitectura Contemporánea (en adelante, Gatepac) y en el segundo la mayoría de los profesionales madrileños de la llamada generación del 25 y los barceloneses que deambulaban en simplificaciones parecidas'. 


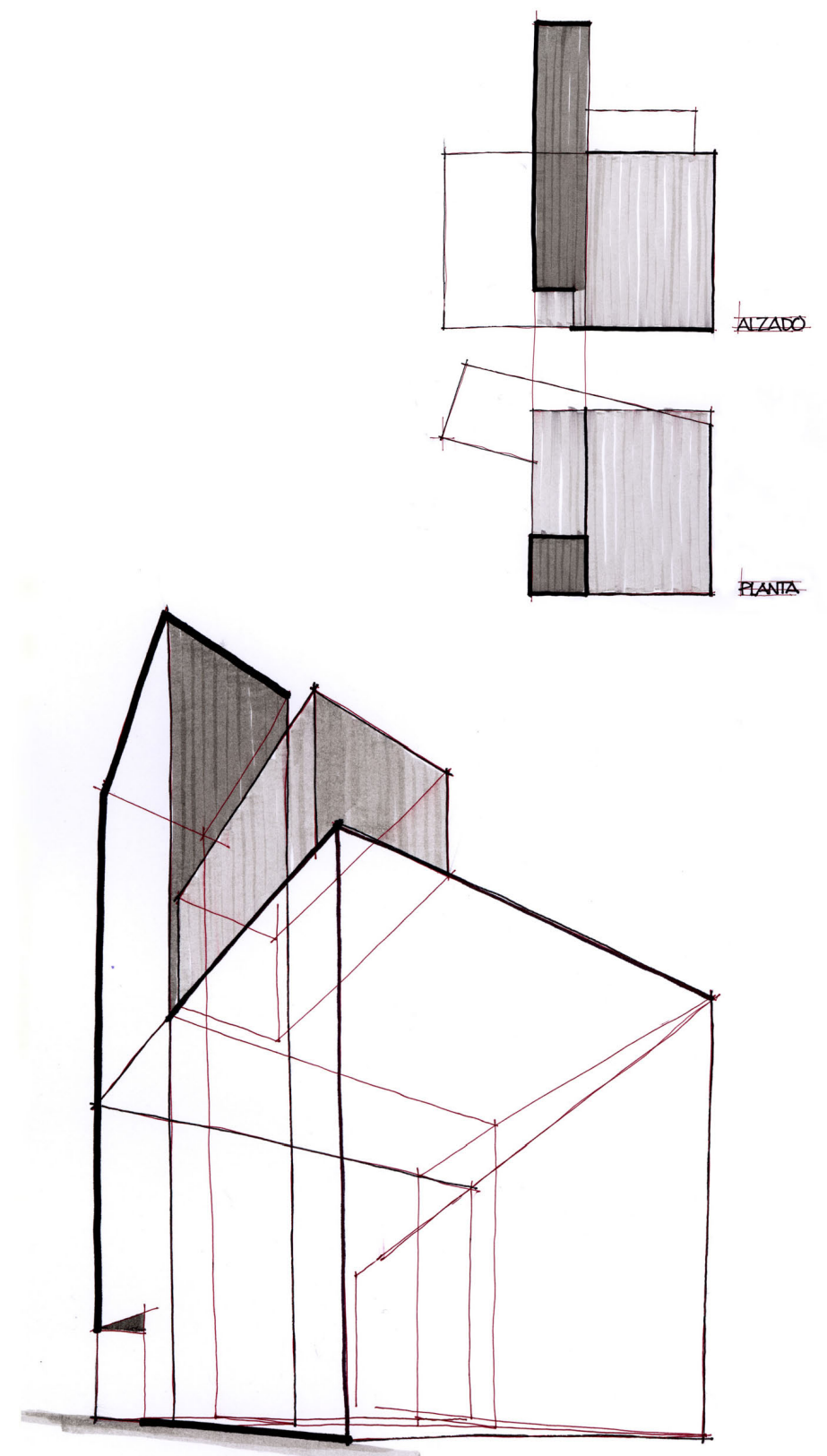

fig. 18

Análisis geométrico y formal sobre la propuesta de Luis ALBERT para el Concurso del Ateneo Mercantil; dibujos doctorando 
Dilucidar la mirada del arquitecto, a los condicionantes donde ubicar su propuesta, también debe aportar vestigios de intencionalidad racionalista en la voluntad de Albert (fig. 18). Habremos de indagar la irrelevancia del emplazamiento, la indiscutible autonomía racionalista del objeto arquitectónico, la adhesión germinal al no lugar de la arquitectura moderna.

Analizado el 'genius loci' y la voluntad de renovación formal, seguidamente entra en escena la construcción utilitaria, la funcionalidad. Analizar funcionalmente la organización distributiva de espacios, tendrá mucho de aclaratorio. El análisis de la estructura planteada en cada propuesta, asoma disoluble con la función y con los modernos tipos de expresión, afanosos de creación, invención, abstracción, conceptualismo, síntesis, elementalismo, purismo, organicismo y empirismo. Un proceso lógico que pretende el espacio ${ }^{12}$ como protagonista del movimiento moderno y que pretende indagarse en las intenciones proyectivas, de un Albert no exento de referencias vernáculas y un marcado 'sentido común' constructivo. Resta en el análisis, rastrear el sentido constructivo aplicado a la formalización, ideada en origen, desplegando fachadas edificatorias-incluida la cubierta como quinta- tanto como la oferta pretendida al espectador urbano.

\footnotetext{
12 MONTANER, Josep María. "La modernidad superada. Arquitectura, arte y pensamiento del siglo XX". Editorial Gustavo Gili S.A. Barcelona, 1999. $3^{\circ}$ edición, p.28. '(...) la concepción que desarrollan las vanguardias se basa en un espacio libre, fluido, ligero, continuo, abierto, infinito, secularizado, transparente, abstracto, indiferenciado, newtoniano, en total contraposición al espacio tradicional que es diferenciado volumétricamente, de forma identificable, discontinuo, delimitado, específico, cartesiano y estático'.
} 


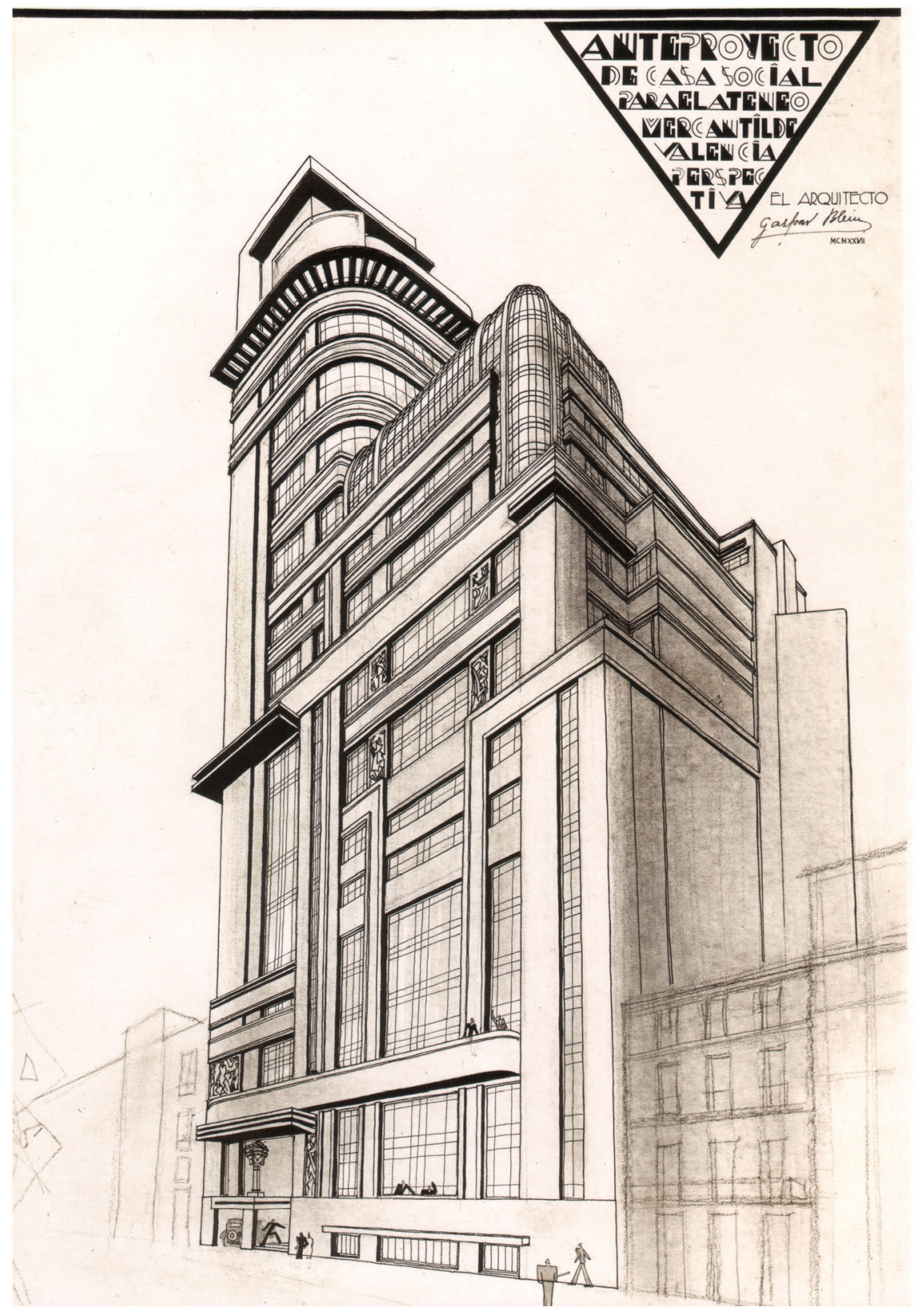

fig. 19 
Y este análisis propuesto, se lleva a término gráficamente, se inquiere bajo la batuta de las técnicas gráficas como herramientas de comprensión y captación de la voluntad racionalista del autor. El bosquejo, el apunte, el dibujo preciso y la escala apropiada, han configurado -bajo sus propias exigencias, bajo sus diversas manifestaciones- un laboratorio de trabajo acerca de los contenidos de los proyectos estudiados. Un laboratorio de investigación donde atrapar la imagen exacta de los propósitos nonatos, la imitación estricta de los edificados y así poder confrontar intención con realidad, voluntad proyectada con su quebrada construcción (fig. 19).

Re-dibujar planimetrías originales, plantas y secciones de edificios proyectados, auspicia nuevas sugerencias a través de su re-visión. Todos han requerido del acercamiento gráfico a la idea gestante, a la documentación original, extraída del Archivo Municipal y del Archivo de la Diputación. Todos han demandado el desplazamiento personal 'in situ' para discernir el entorno al que procurar respuesta arquitectónica. También aquellas que no pudieron nacer en un lugar físico, exigían perspectivas, croquis y esquemas. Innumerables fotografías, dibujos de detalles y puestas a escala, permiten comprobar fehacientemente la consecuencia de lo proyectado, las aspiraciones y las influencias del emplazamiento, su encarnación edificatoria.

Re-pensar mediante esquemas la composición pretendida, aquella platónica pureza volumétrica anhelada, renueva la visión de la esencia universal, la voluntad permanente. Exactamente sucede con la comprometida funcionalidad, cuyos esquemas traducen la batalla frente a aprehendidas reglas vernáculas. Re-construir plantas, volúmenes mediante perspectivas 


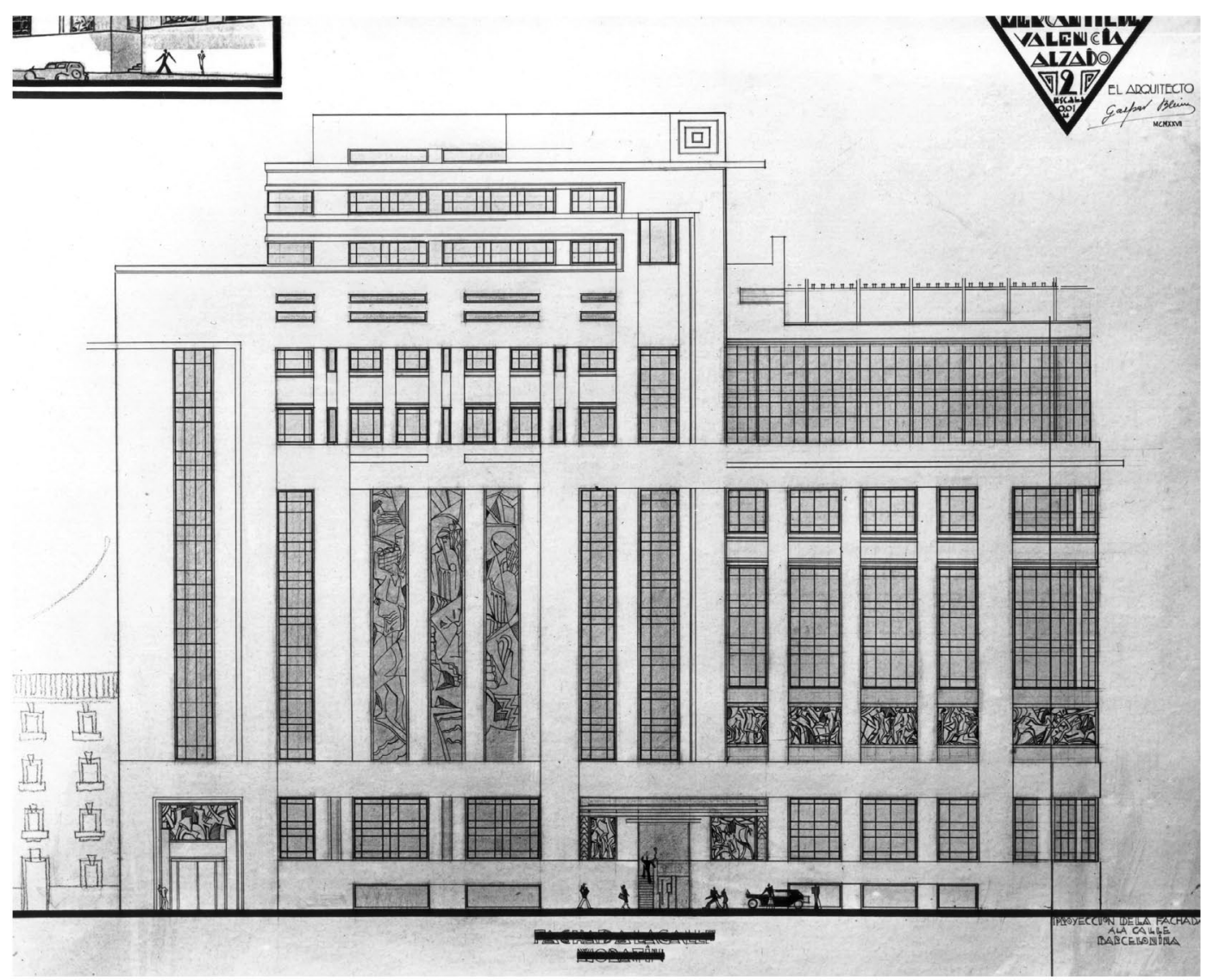

Luis ALBERT, 1929. Documentación para la propuesta del Concurso del Ateneo Mercantil; fachada a la calle Moratín: aportación Archivo Histórico del Ateneo Mercantil Valencia 
perspectivas intuitivas o maquetas reproducidas, asumen nuevamente el debate sobre el innovador espacio moderno, autócrata sobre el pasado. Cabe indicar el firme propósito de rechazo, en la comprensión del objeto elaborado -la imagen virtual- como re-formulación con diferente léxico del objeto analizado. La voluntad arquitectónica se indaga en su esencia, en su valor propositito y su análisis gráfico autoriza cotejar la realidad edilicia, faculta dilucidar la intención racionalista, e incluso arrancar nuevas incógnitas en las ausentes.

Indicado el propósito -también el proceso- tan sólo resta acudir a la realidad y disociar los condicionantes que distorsionan el resultado construido. El dibujo como herramienta de comprensión, promueve la doble dirección del discurso gráfico, procurando la opción de validar intenciones racionalistas, al devolvernos la mirada apoyada en la realidad erigida. El diálogo entre papel y analista, faculta para sentenciar el quiebro de la voluntad pretendida. Sabemos la ruptura experimentada en el empeño moderno tras el trauma bélico, sufrido por los comprometidos arquitectos. Para el autor que nos ocupa, la tenacidad inicial permanecerá encubierta tras el rigor demandado por la rehabilitación y no volverá a suscitarse aquella pujanza aventurada.

Resta concluir si en el periodo analizado, la fractura entre intención y objetividad llega a estar comprometida por las condiciones privadas o públicas del promotor. Conclusiones fácilmente confrontables, en el asunto entresacado de bloques habitacionales, y sin embargo resultando más limitadas en el lance público, lidiando en una triada no acaecida y que nos avenimos a disfrutar en su re-composición idealizada. 


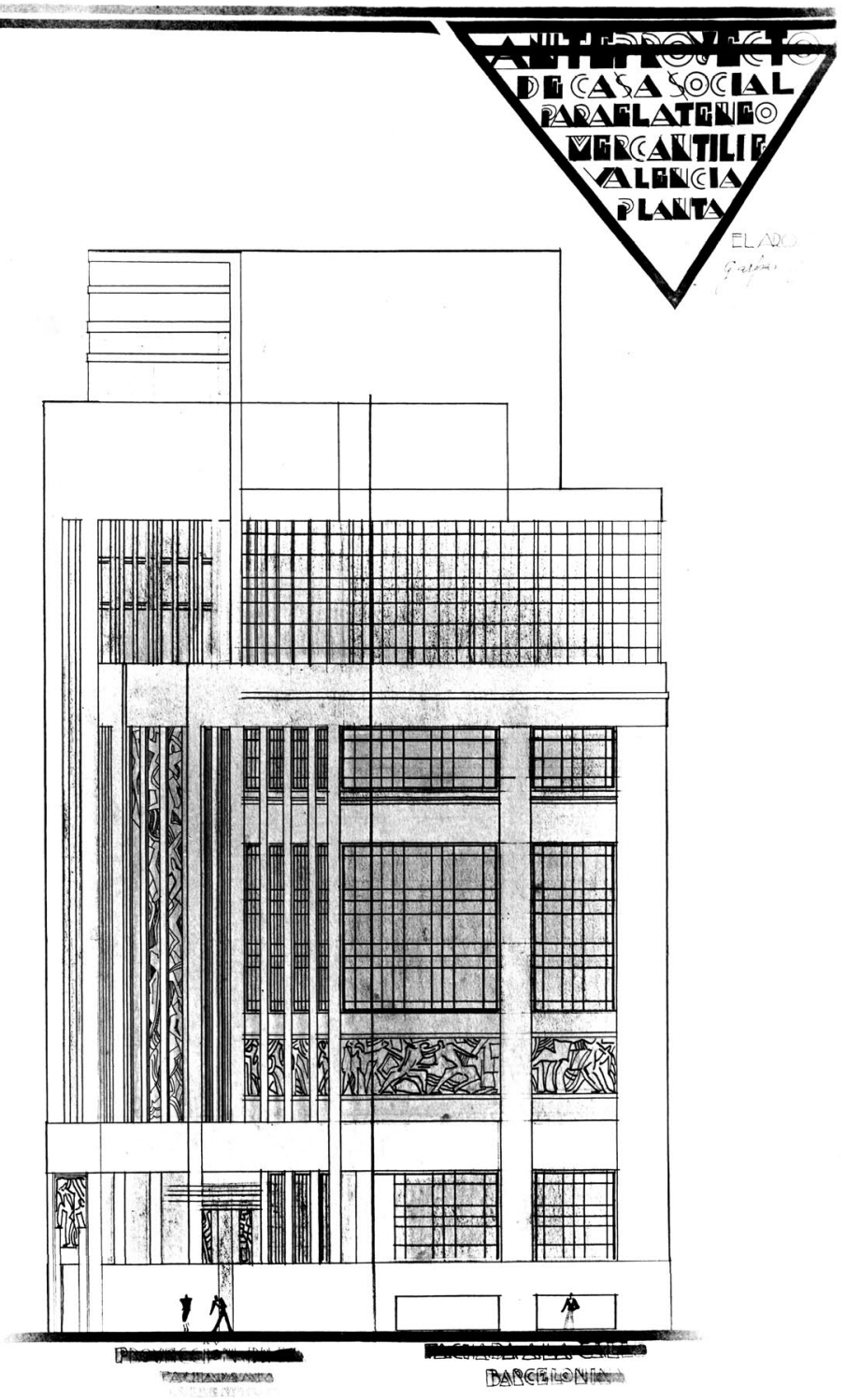


Parte de la fascinación del método argumentado, basado en el análisis gráfico y culminado en óptimas figuraciones e ilusorias fotografías, permanece pues en su desarrollo, en el camino sin necesidad de concluirlo. La sugestión por la senda abierta, por el instante congelado se oferta a su prosecución, como experimentada proposición inconclusa a su continuidad.

Dejamos aquí plasmada la sistematización del análisis gráfico, para aventurar culminadas las apuestas racionalistas, elegidas en la voluntad gestante. Individualmente han dado lugar al cotejo con la materialidad construida y a la apertura de incógnitas ocultas dentro del ser del proyecto. Conjuntamente han desarrollado un estimulante laboratorio de investigación acerca de los contenidos arquitectónicos estudiados y acerca de imaginativos y novedosos sistemas de producción de recursos gráficos y volumétricos. 
Introducción urbanística 

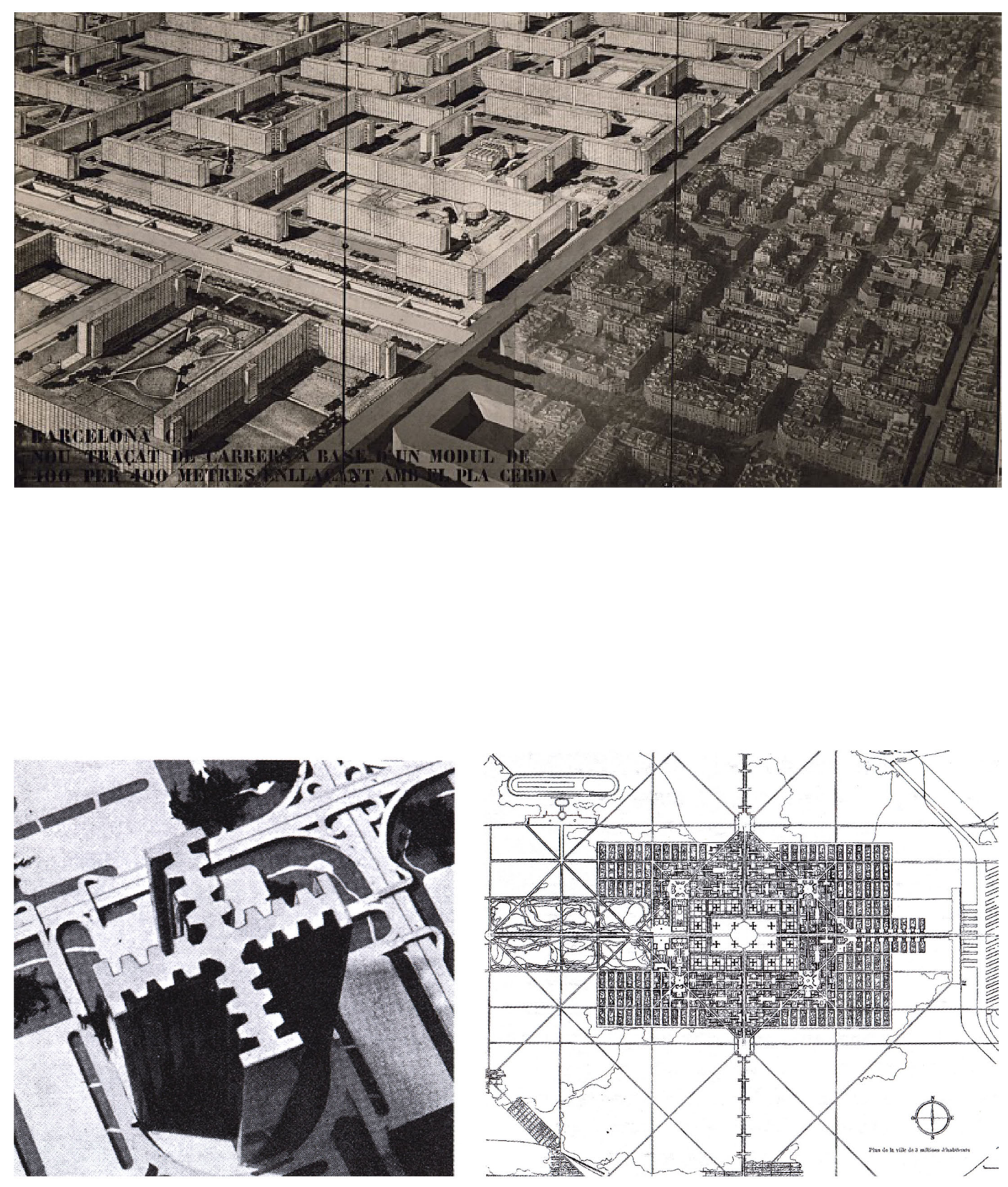

GATCPAC, 1932. Pla Macià: Le CORBUSIER, 1929. Rascacielos cruciforme, Rio de Janeiro: Le CORBUSIER, 1922. Ciudad para tres millones de habitantes; distribución funcional 


\section{EL PROCESO DE RECONSTRUCCIÓN URBANÍSTICA}

Convertida en el rasero de modernidad, la ciudad experimentó desde principios de siglo, aquellas transformaciones inspiradas en el método cartesiano' que la culminarían en racionalista. Concepto recurrente en la teoría arquitectónica -conjuntamente con Realismo, Abstracción, Organicismo, Empirismo- impulsor de la modernidad e identificado con el Movimiento Moderno.

Imperó la fidelidad en la metodología científica, en la exigencia de precisión y objetividad. Anhelando una sociedad orgánica, perfectamente ordenada, evidenciaron su excelencia en la obligación de una disciplina científica, cartesiana: el urbanismo. Ambicionaron una ciudad moderna, "materialización directa de la carta de Atenas, el gran libro de la ciudad positivista elaborado durante el Congreso CIAM celebrado en aquel trasatlántico que viajaba desde Marsella a Atenas en el año 1933".2

Cabría interpretar este devenir, bajo el predominio exclusivo de la razón y el conocimiento individual. Autonomía con el pasado, infringiendo tabula rasa y una contumaz oposición a la tradición en aras de ideas innatas, semejantes en el contexto europeo. Urbanismo moderno insensible por el lugar, contumaz en su primera generación. Únicamente las primeras

1 DESCARTES, René. "Discurso del método". Traducción, estudio preliminar y notas de Rivieri Frondizi. Editorial Alianza. Madrid, 1979.

El filósofo francés (1596-1650) planteó cuatro cautelas para todo razonamiento: no aceptar nunca ningún a priori; subdividir los problemas; razonar desde lo simple hacia lo complejo; realizar exhaustivas enumeraciones de todo proceso lógico. Defendió, por tanto, un racionalismo que negaba la autoridad del pasado, estableciendo tabula rasa y aplicando como método la experiencia propia interpretada a la luz de la razón.

2 ÁBALOS, Iñaki. "La buena vida. Visita guiada a las casas de la modernidad". Editorial Gustavo Gili, S.A. Barcelona, 2000. p. 79 

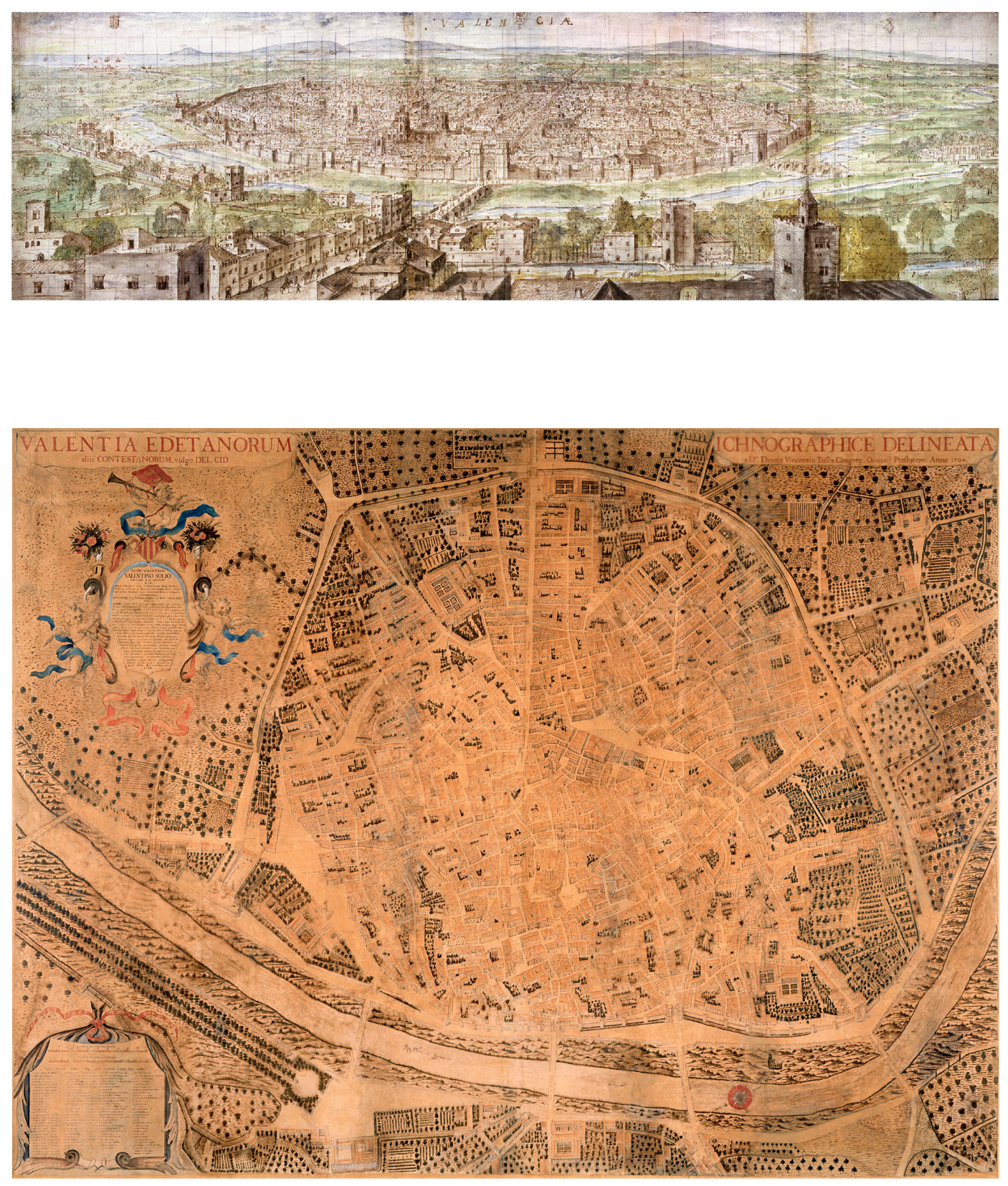

Anton van der WYNGAERDE (dibujante paisajista flamenco) Valencia medieval intramuros: Tomás Vicente TOSCA, 1704. Valentia Edetanorum aliis Contestanorum, vulgo del Cid 
Siedlungen alemanas y los planteamiento de ciudades-jardín de Ebenezer Howard, fisurarían el triunfo del racionalismo, la nueva objetividad y Le Corbusier en sus primeros planes urbanísticos.

Sin embargo resultaría utópico en exceso, observar como exclusivo el método racionalista, empobrecedor de las complejidades y cualidades de la realidad, tal como evidenciaron sus críticos. Indispensables en la transformación resultarían pues, los afanes socializadores, los movimientos migratorios, los anhelos de mejora de vida, el nuevo diseño de funciones y ofertas urbanas, el sistema económico capitalista y el desarrollo tecnológico de la época. La llegada al poder de la burguesía mercantil reorganizó el equilibrio de poder de la sociedad valenciana, con la trasgresión que esto conllevaría en la forma de reinterpretar la ciudad.

Valencia no resultaría ajena a este proceso de modernización de la estructura urbana y renovación formal de la ciudad -medieval de origendesarrollado durante la primera mitad del siglo XIX. Sociológicamente convino instaurarse, durante el segundo tercio del $X I X$, un período de reestratificación social. Variaría el funcionamiento de una sociedad señorial y estamental, dividida en compartimentos más o menos estancos, pasando a convertirse en una sociedad dinámica, preindustrial y agraria, con unas características específicas y, con una movilidad social mayor que la anterior. La antigua clase dominante, la nobleza, pasaría a ser sustituida por la burguesía terrateniente, que a su vez englobaba a la antigua aristocracia no emigrada hacia la Corte y el poder ${ }^{3}$.

${ }^{3}$ PE ÑIN IBÁÑEZ, Alberto. "Valencia. 1874-1959. Ciudad, Arquitectura y Arquitectos". Escuela de Arquitectura de Valencia, $n^{\circ} 4$. Valencia, 1978. Nota a pie en p. 10. 

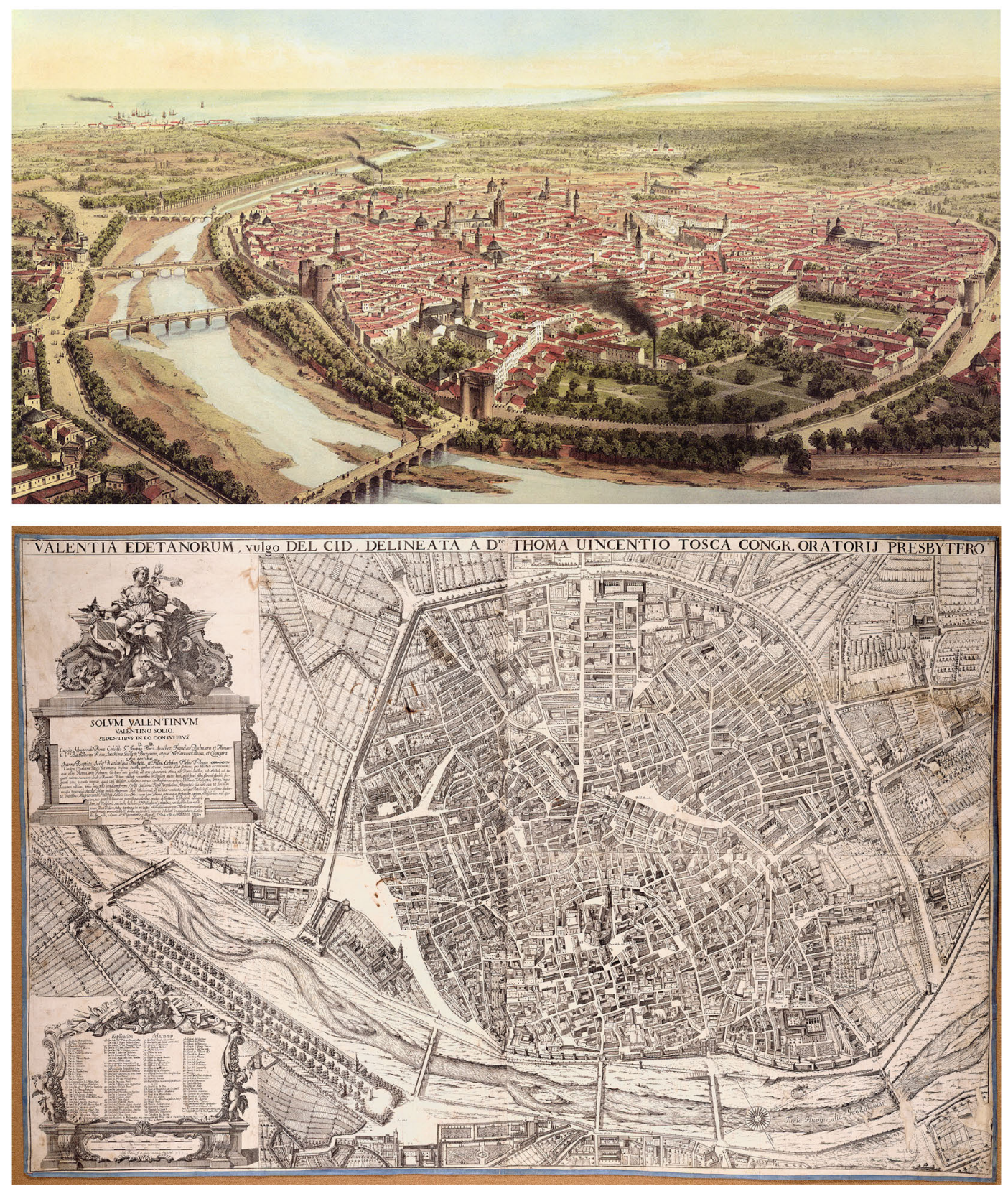

Alfred GUESDON, 1858. Vista desde el puente de San José; serie L'Espagne a vol d'oiseau Tomás Vicente TOSCA, 1738. Valentia EDETANORUM, vulgo del Cid 
J. L. Piñón ${ }^{4}$ nos habla de nuevas estructuras productivas, tramas urbanas, que conllevan la transformación de la ciudad conventual y nobiliaria, de carácter artesanal, en un producto de mercado. La ciudad se convierte en generadora de las rentas para la nueva capa burguesa dominante, frente al anterior sistema de rentas rurales de la nobleza y el clero. Para la burguesía, educada en parámetros de productividad, radicalmente enfrentados con la concepción de posesión típica de las clases nobiliarias, la ciudad es, antes que nada, un instrumento productivo, que necesariamente ha de producir una rentabilidad 5 . La ciudad como impulsora de rentas, fomentaría un incremento de la actividad constructiva y una renovación casi total del patrimonio arquitectónico. Las rentas urbanas generarían más poder económico a la oligarquía dirigente, en una ciudad con urgencias de crecimiento capaz de responder a la fortísima demanda social.

La Valencia obsoleta del plano del Padre Tosca y su estructura urbana del XVIII, quedaban incapacitadas para responder a los nuevos problemas planteados tras el afianzamiento social de la burguesía y su acceso al control del poder: la accesibilidad a las nuevas actividades industriales; las diferencias tipológicas de sus edificaciones en respuesta a la rentabilidad de la propiedad urbana; la necesidad de espacios para las actividades comerciales y también, para la figuración y la ostentación. La transformación

4 PIÑón PAllarés, Juan luis. "Los orígenes de la Valencia Moderna". Edicions Alfons el Magnánim. Colegio Oficial de Arquitectos de la Comunidad Valenciana. Valencia, 1988.

${ }_{5}$ AA.VV. "Estudio histórico del color del barrio de Velluters para su rehabilitación". Departamento de Expresión Gráfica Arquitectónica. Universidad Politécnica de Valencia. Valencia, 1997. 


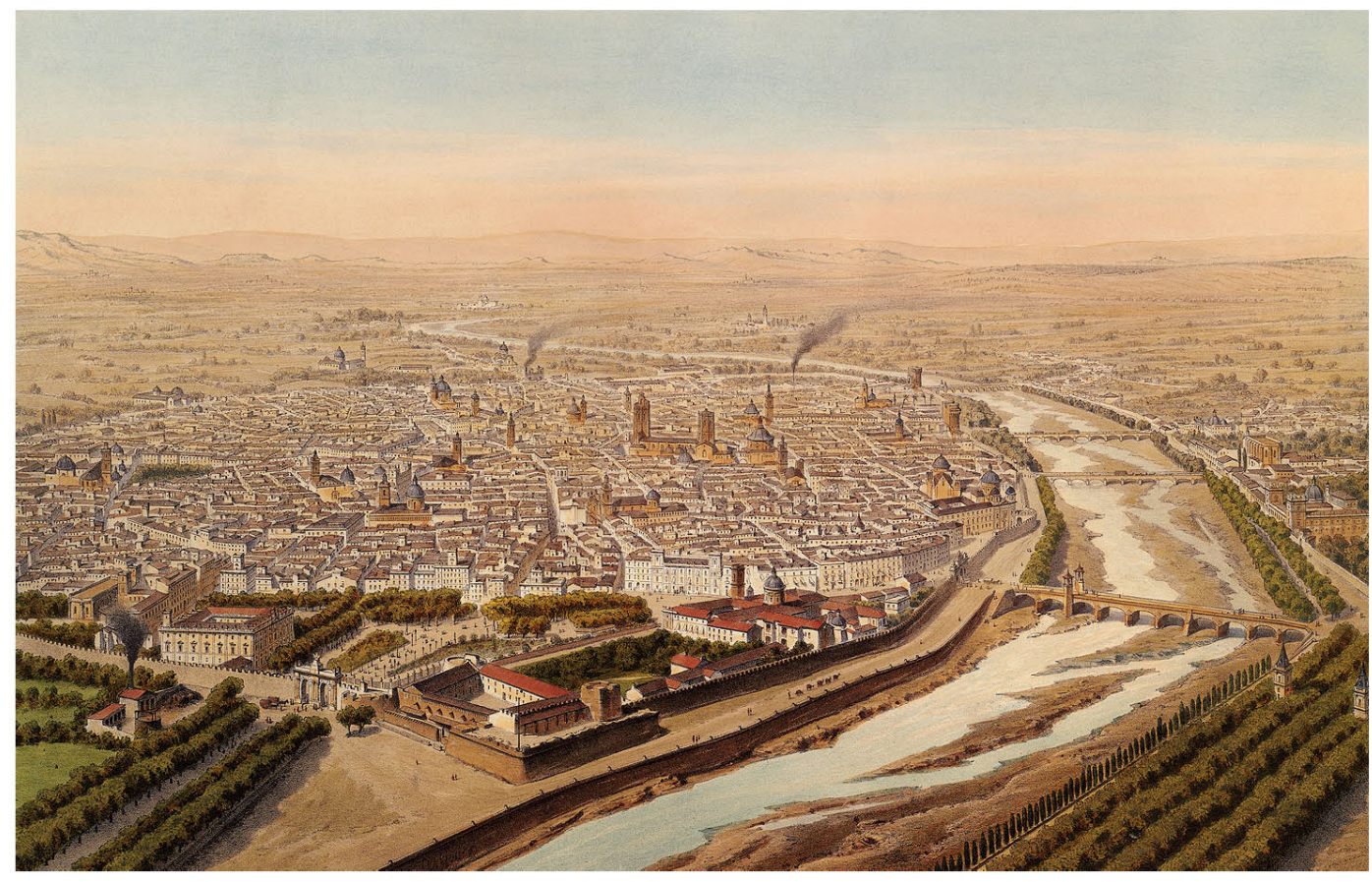


de la estructura urbana ya asomaba improrrogable. Sería una nueva concepción de ciudad hasta llegar a la nueva Valencia moderna.

En 1836 la desamortización de Mendizábal supuso el cambio de propiedad de una parte importante de los inmuebles urbanos de la ciudad, de entre los cuales destacaban dieciséis conventos religiosos intramuros. La intención primaria pretendía el cambio de propiedad del mayor número de posesiones eclesiásticas buscando aportar suficiente suelo a la ciudad como para afrontar con garantías sus procesos de transformación. No obstante la trasformación en la reedificación que esto supuso, no se realizaría de una forma lógica ni controlada, sino más bien todo lo contrario perdiendo así la posibilidad de una reforma sustancial de la ciudad a través de la remodelación del casco histórico.

Transferir el funcionalismo en aquellos edificios religiosos, innovar funciones, otorgar usos rentables tras la desamortización no cobraba una interpretación empírica, apta para resolver problemas urbanísticos. La incapacidad manifiesta por el Ayuntamiento, debido a su escasa solvencia económica, para adquirir las extintas propiedades eclesiales, paliando así el problema de falta de espacio libre y terciario, empeoran las ya de por sí paupérrimas condiciones de habitabilidad e insalubridad del antiguo núcleo urbano. El aumento indiscriminado en altura, el incremento de la reedificación en la mayoría de las zonas libres y la transformación descontrolada de la edificación con la intención de utilizarla como objeto de mercado generador de rentas, todo esto en condiciones de fortísima especulación, tiene como consecuencia un marcado fenómeno de hacinamiento en el núcleo antiguo de la ciudad. 


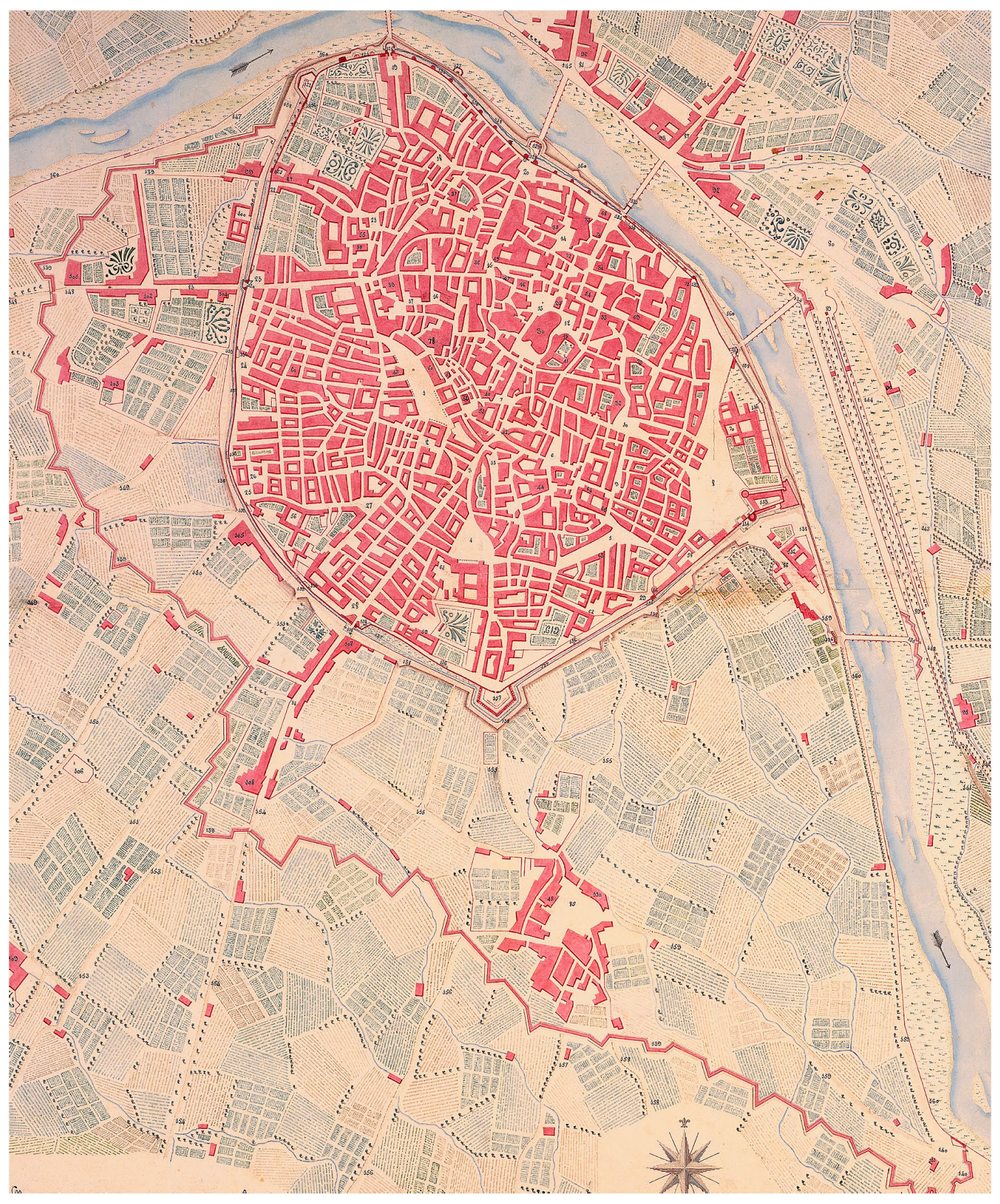

Francisco CORTÉs y CHACÓN, 1817. Capitán del Real Cuerpo de Ingenieros; plano Geométrico de la Plaza de valencia y sus contornos, con las obras de fortificación 
Este proceso de intensa densificación se iniciaba a mediados del siglo XIX, y lo cierto es que hasta ese momento parecía posible hablar de es-

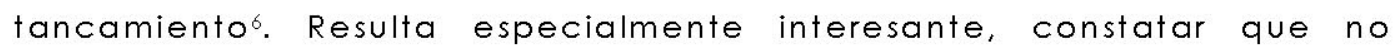
transcurrió homogéneo, produciéndose marcadas diferencias en las densidades de población de los diferentes barrios. Tampoco afectó por igual a todas las capas sociales, pues como indica Ignacio Boix7, "es innegable que la clase acomodada y la clase media viven también mejor que antes y con algunas comodidades; pero estas dos clases juntas, al paso que residen en los barrios más nobles y encentrados, ocupando más de la mitad de la superficie del terreno habitable, componen apenas la tercera parte del vecindario; mientras que otra clase tan numerosa como necesitada, constituye sus dos terceras partes, replegada en la otra mitad de la superficie del suelo".

Bajo estas tremendas pautas tan solo podían generarse espacios de vida con unas manifiestas condiciones de insalubridad e inhabitabilidad. Fueron estas las que provocaron la redacción de una legislación higienista que se culminaría con los dos procesos capitales de modernización y renovación urbana más significativos del siglo XIX: la Reforma Interior del centro histórico de la ciudad y el Plan de Ensanche de la periferia. Las intervenciones en el Ensanche resultaron ser económicamente mucho más

6 "Fue a partir de mediados de siglo cuando los sectores mejor colocados y dinámicos de la burguesía valenciana incrementaron su interés por esa nueva mercancía que eran suelo e inmuebles urbanos... Hasta entonces, en efecto, la ciudad creció tan ligeramente que bien puede hablarse de estancamiento para la primera mitad de siglo".

AZAGRA ROS, Joaquín. Propiedad inmueble y crecimiento urbano: Valencia $1800-$ 1931. Editorial Síntesis, Madrid, 1993; p. 78.

7 Boix, Ignacio. "Memoria para el Ensanche de Valencia". Excmo. Ayuntamiento de Valencia. Valencia, 1859. 


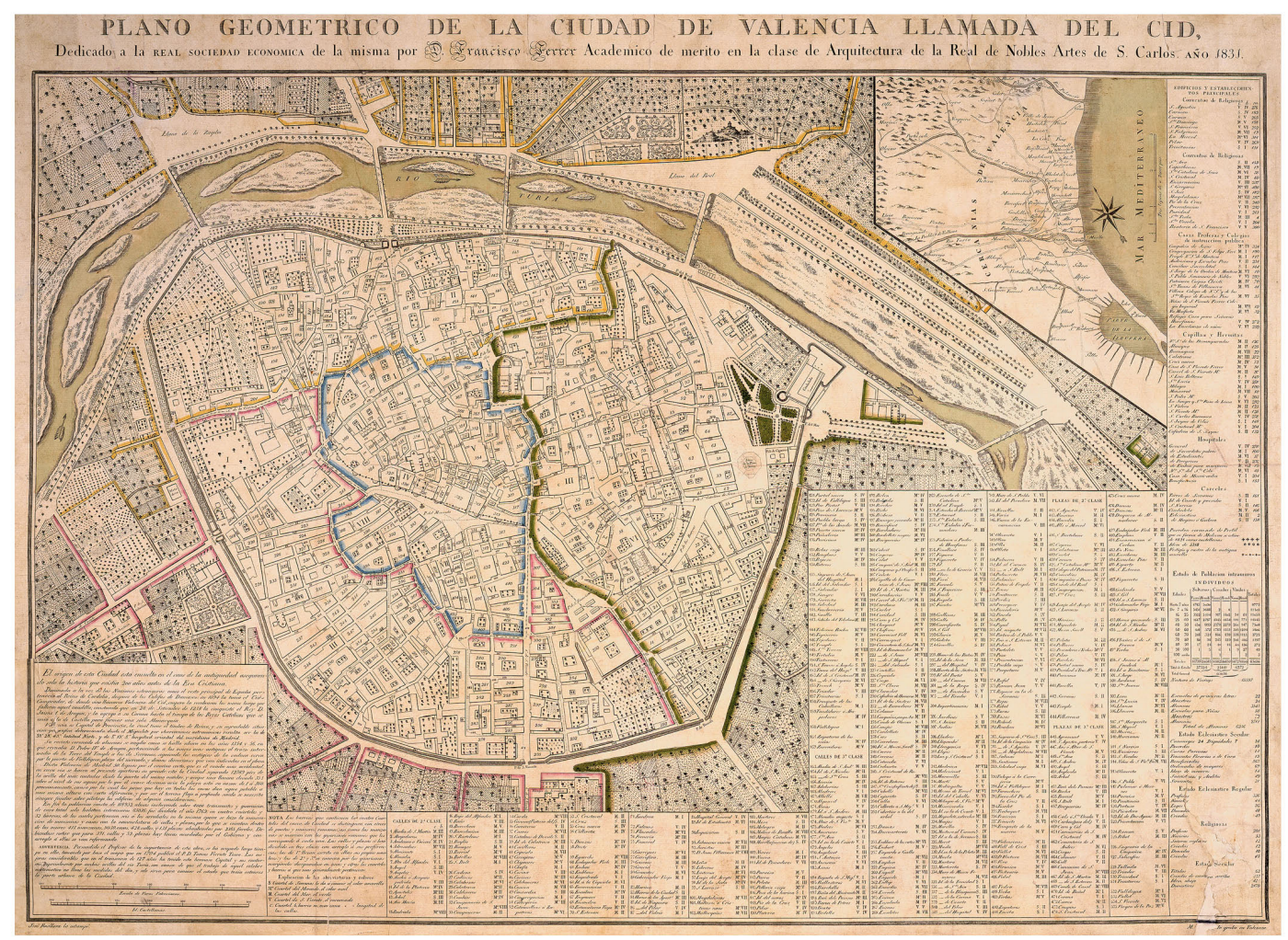

Francisco FERRER y Guillén, 1831. Plano Geométrico de la ciudad de Valencia llamada del Cid; dedicado a la Real Sociedad Económica. (AAU/ETSA) 
rentables para el promotor privado, además de ofrecer mayores facilidades para su elaboración y gestión que los proyectos de Reforma Interior. Esto propició un claro desequilibrio que condujo a abordar estos últimos como figura secundaria de planeamiento.

Aspiraban las vanguardias europeas a lo magnífico -la disección científica, la zonificación- sirviendo a la creación de una sociedad orgánica, perfectamente ordenada, plausible demostración de la necesidad de una doctrina cartesiana de ciudad: el urbanismo. La máquina social planificada, subdividida sin aceptar aprioris, razonada de lo simple a lo complejo, exenta de reminiscencias históricas, liberada del lugar. Brasilia materializaba el sueño de la ciudad magnífica, el monstruoso sueño de la razón parafraseando a Iñaki Ábalos: "Vemos reproducida en la escala de la ciudad los mecanismos proyectuales de la casa. El gran documento será de nuevo la planta, su optimización mediante la disección de los momentos equilibrados -el zoning-y su restitución final orgánica e higiénica. Pero también podemos entender el proyecto de la casa como una traslación de la ciudad: el proyecto de la casa positivista se resuelve en el zoning, un microzoning brindando al sol que descompone las piezas para restituirlas en un engranaje mecánico y orgánico de máxima eficiencia; la famosa máquina de vivir". ${ }^{8}$

Localmente arribaríamos con retraso al tren de las vanguardias -años veinte- y se suplió con intuición, fulminando el método racionalista, no obstante incurriendo en sus contradicciones: La socialización y su mejora

${ }^{8}$ ÁBalos, Iñaki. "La buena vida. Visita guiada a las casas de la modernidad". Op. cit; p. 80 


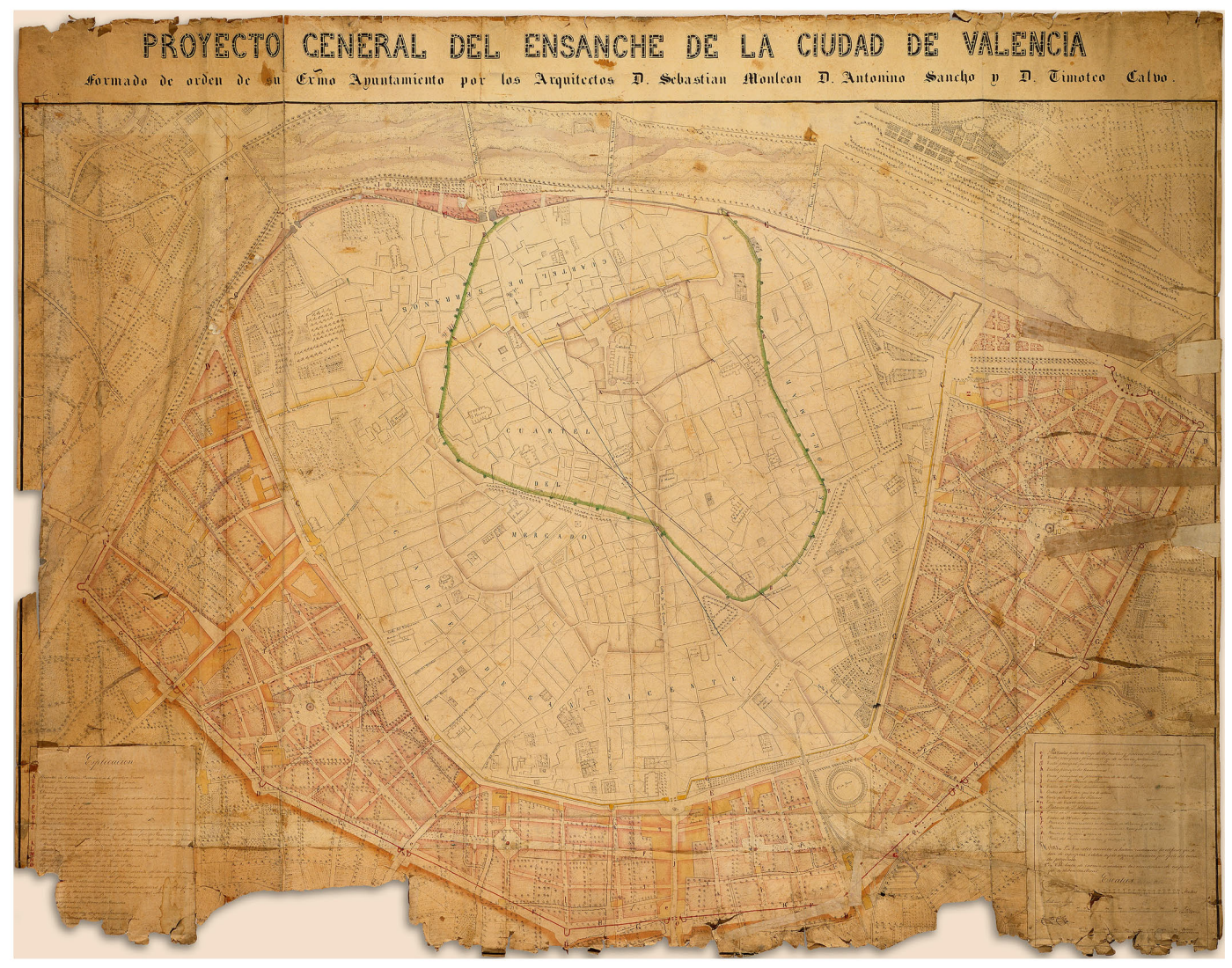

Sebastián MONLEÓN, Antonio SANCHO y Timoteo CALVO, 1858. Proyecto General del ENSANCHE de la ciudad de Valencia; Archivo de Arquitectura y Urbanismo (AAU/ETSAV) 
de vida colectiva, conllevarían la dominación del individuo; El desarrollo tecnológico, la visión cientifista de la Naturaleza concluirían con su explotación; La ciudad universal, positivista gestaría pura especulación y desorden.

\section{LA REFORMA INTERIOR DEL CENTRO HISTÓRICO}

Dos tipos de actuaciones generaron los mecanismos de control administrativo en el proceso de renovación urbana, dentro de las operaciones de Reforma Interior: el Reglamento de Policía Urbana y Rural de Valencia, editado en 1844, y el plano de Alineaciones. Ejercieron ambos instrumentos el control de la edificación realizada en la ciudad. Mecanismos para supervisión administrativa del proceso de renovación urbana, supusieron la implantación de los nuevos conceptos higienistas como respuesta al progresivo deterioro de las condiciones de vida de la ciudad. La otra gran apuesta de la ideología ilustrada fue la creación de la Academia de San Carlos, con el espíritu de garantizar y difundir el neoclasicismo, y que si bien en las grandes capitales inspiró grandes proyectos de ordenación urbanística, aquí se limitó al proceso de reedificación 


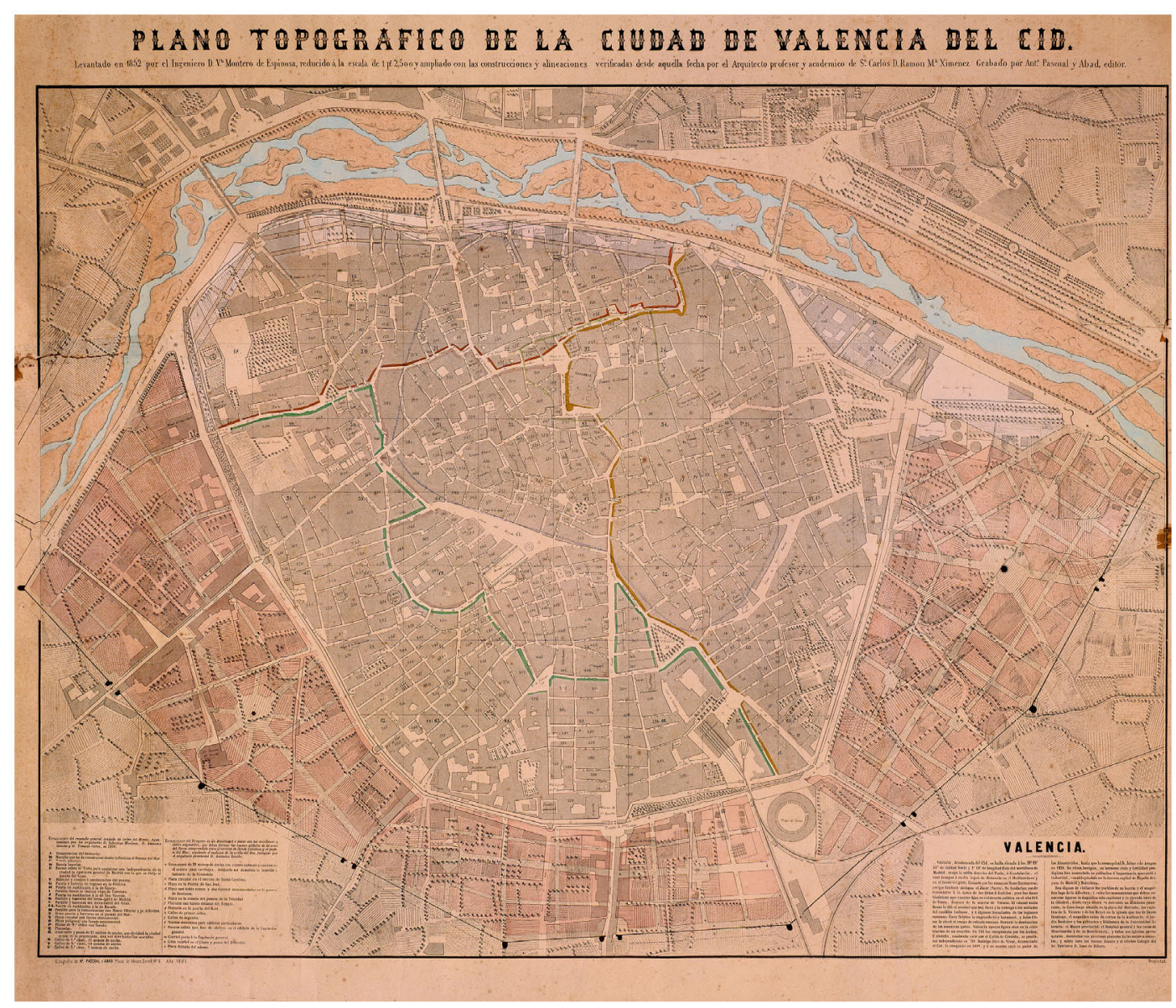

Ramón María XIMÉNEZ, 1860. Plano Topográfico de la ciudad de Valencia del Cid; con las construcciones y alineaciones verificadas del levantamiento de Vicente MORENO, 1852 
a través de la regularización de las composiciones de fachada?. Este proceso quedó reforzado con la aparición de ordenanzas dibujadas para el control de las intervenciones arquitectónicas más emblemáticas de la ciudad; proceso que, de manera semejante a las experiencias llevadas a cabo en importantes capitales europeas, pretende la renovación controlada de la ciudad y su monumentalización arquitectónicale.

La ambigüedad resultó la lógica consecuencia de este proceso. La precisa voluntad integradora del neoclásico en la composición formal del conjunto frente a la indefinición formal del Reglamento respecto a las actuaciones independientes en cada intervención. La calle se renovaría casa por casa, con un control administrativo limitado a la alineación de fachada, adaptando formalmente la edificación existente al nuevo gusto neoclásico dictado desde la Academia. La imposición del pensamiento neoclásico comenzó con el siglo y se prorrogó hasta la irrupción de las nuevas tendencias eclécticas del último cuarto de siglo.

Un breve apunte merece la organización administrativa de la ciudad de Valencia, en este período de claro predominio del pensamiento neoclásico. La reforma administrativa de 1796, que se mantendría hasta la llegada

\footnotetext{
9 AA.VV. "La recuperación de los espacios cromáticos en la ciudad histórica: el barrio del Carmen de Valencia". Revista de Expresión Gráfica Arquitectónica. Año 2. Valladolid, $1994, n^{\circ} 2 ;$ p. 24.

10 "En nuestro caso, la puesta en práctica de una ordenanza dibujada supone, en primer lugar una voluntad resuelta a ejercer un control sobre la construcción de la ciudad; y en segundo lugar, la aceptación de un modelo cultural cuyo principal exponente es la monumentalización de la ciudad, no desde el acontecimiento arquitectónico aislado, sino desde el conjunto de la edificación". PIÑÓN PALLARÉS, Juan Luis. op. cit; p. 175.
} 


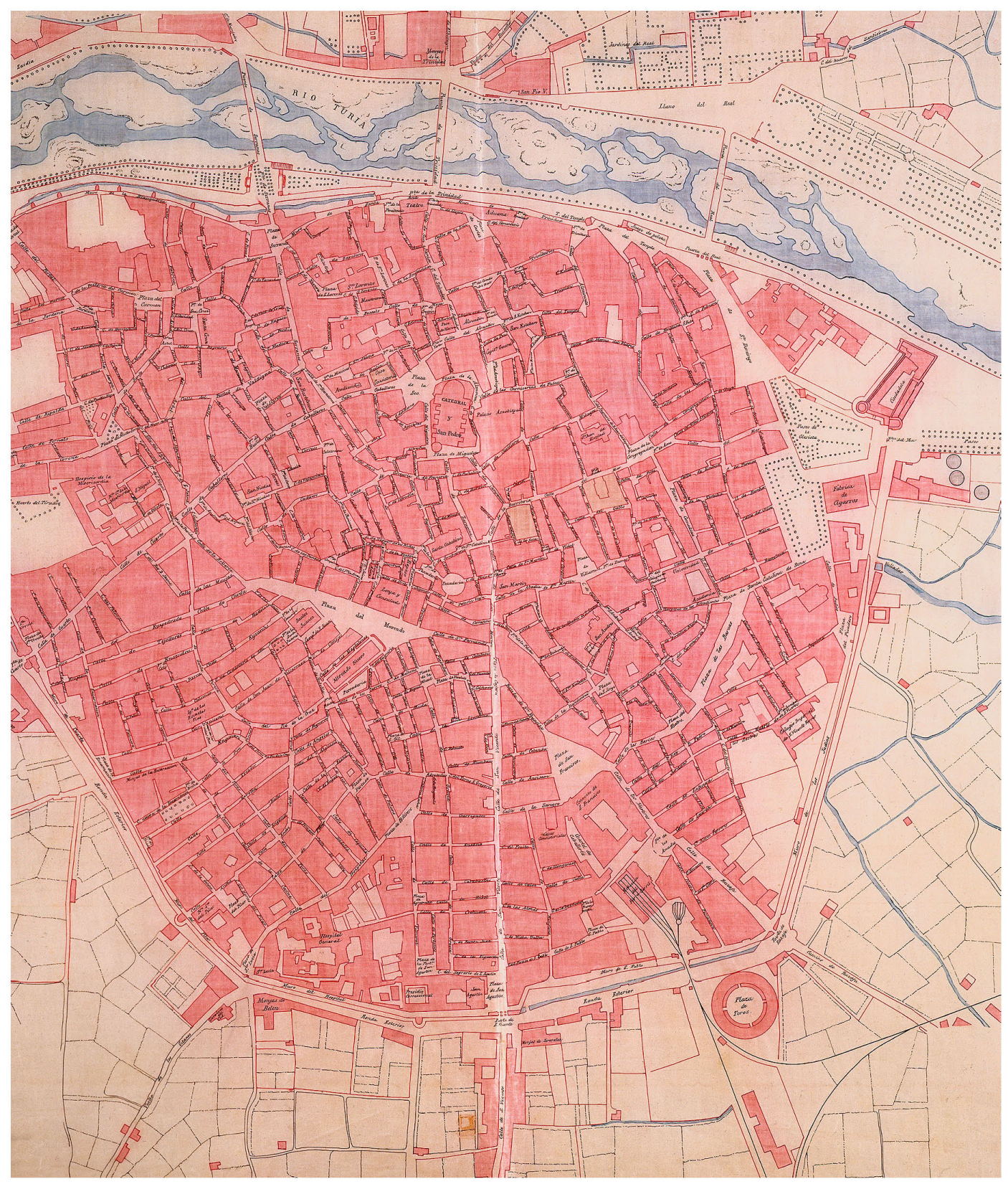

Cuerpo de Ingenieros del Ejército, 1869. Plano de Valencia; Archivo de Arquitectura y Urbanismo (AAU/ETSAV) 
de las nuevas tendencias eclécticas, consistió en la división de la ciudad intramuros en cuatro cuarteles, Mercado, Mar, Serranos y San Vicente, que a su vez se dividían en ocho barrios. Puede apreciarse esta división en el Plano Geométrico de la Ciudad de Valencia llamada del Cid, obra de Francisco Ferrer del año 1831, donde se pueden observar el perímetro de los cuatro cuarteles en diversos colores y donde se delimitan la totalidad de las 411 manzanas, numeradas según el Padrón Municipal de 1769, señalándose los 32 barrios en los que se dividían los 4 cuarteles que constituían el recinto amurallado". Esta organización administrativa permanecería vigente hasta el año 1881, cuando el cuartel como criterio administrativo fue sustituido por el de distrito.

El impacto del Eclecticismo se limitó a las zonas urbanas de nuevo desarrollo donde mantendría los criterios formales del clasicismo, mientras que en el centro histórico, la influencia se concentraba en un número reducido de ejes viarios, en su mayor parte periféricos. La solución urbanística se bifurcaba hacia abordar el problema desde extramuros, con un carácter global en sus propuestas, o adoptar medidas drásticas y puntuales desde el interior del casco antiguo, con la dificultad añadida que suponía la ruptura de la trama, la pugna de los diversos intereses particulares y el pago de las indemnizaciones tras las insuficiencias planteadas desde la Ley de Expropiación y la normativa sobre Alineaciones.

\footnotetext{
1 Para el estudio detallado del funcionamiento y la implantación de los cuarteles, así como de los barrios y manzanas comprendidos en los mismos ver:

TEIXIDOR DE OTTO, María José. "Funciones y desarrollo urbano de Valencia". Edicions Alfons el Magnánim. Valencia 1976; pp. 306-308.
} 


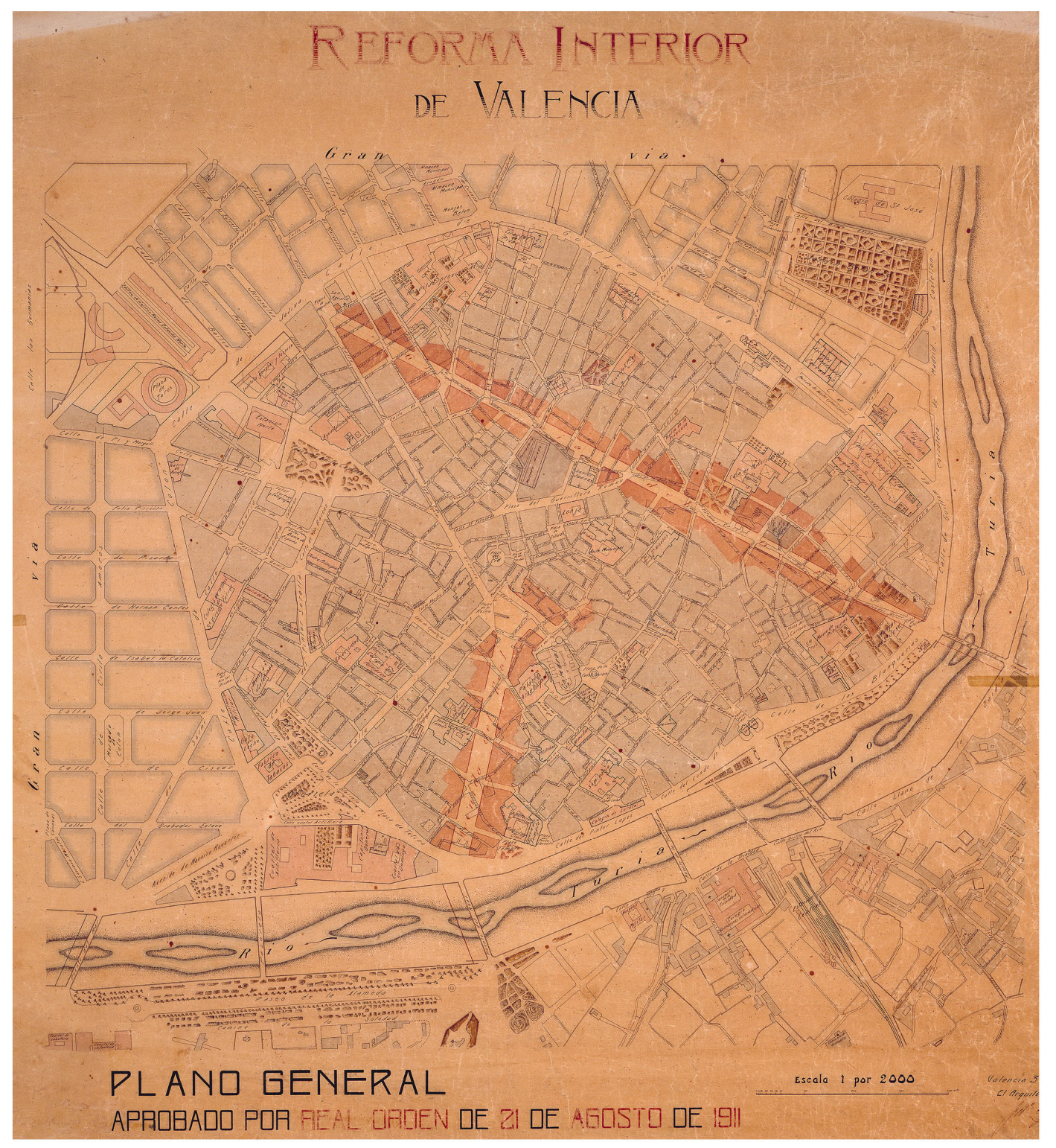

Federico AYMAMÍ FAURA, 1910. Reforma INTERIOR de Valencia. (AAU/ETSAV) 
Acontecía semejante disyuntiva cuando en 1891, Luis Ferreres Soler, abordó para Valencia la reforma interior, centrando sus esfuerzos en una avenida de inusitadas dimensiones -rotundos 30 metros- que seccionaba el casco antiguo de norte a sur. El autor fundamentaría la propuesta desde la ineludible mejora en la accesibilidad a los puntos neurálgicos de la población y en proporcionar facilidades al tráfico rodado. Destaca la sencillez en el planteamiento $y$, encomiable resultan las ansias generadoras que conllevaba semejante propuesta. Francisco Taberner la recoge desde el acta del Ayuntamiento'2:

1. La apertura de una calle de 30 metros de ancho que, partiendo de la ex-puerta de Ruzafa, termine en la de San José, sin cambio alguno de línea, y de cuyos treinta metros se destinen siete a cada una de las aceras, y los diecisiete restantes a arroyo central para tranvías y carruajes.

2. Que se continúe la calle de la .Paz con el ancho que tiene hoy hasta el Mercado Central, tomando como base para el cambio de línea, la arista del campanario de Santa Catalina, recayente a la calle Sombrerería.

3. Que se termine la plaza de la Reina en la forma proyectada por V. E. hasta la calle de Zaragoza, prolongándose hasta la calle de la Capilla de la Comunión de San Martín, en la forma indicada en el croquis.

12 TABERNER PASTOR, Francisco. "Valencia entre el ensanche y la reforma interior". Edicions Alfons el Magnánim. Valencia 1987; p. 79. 


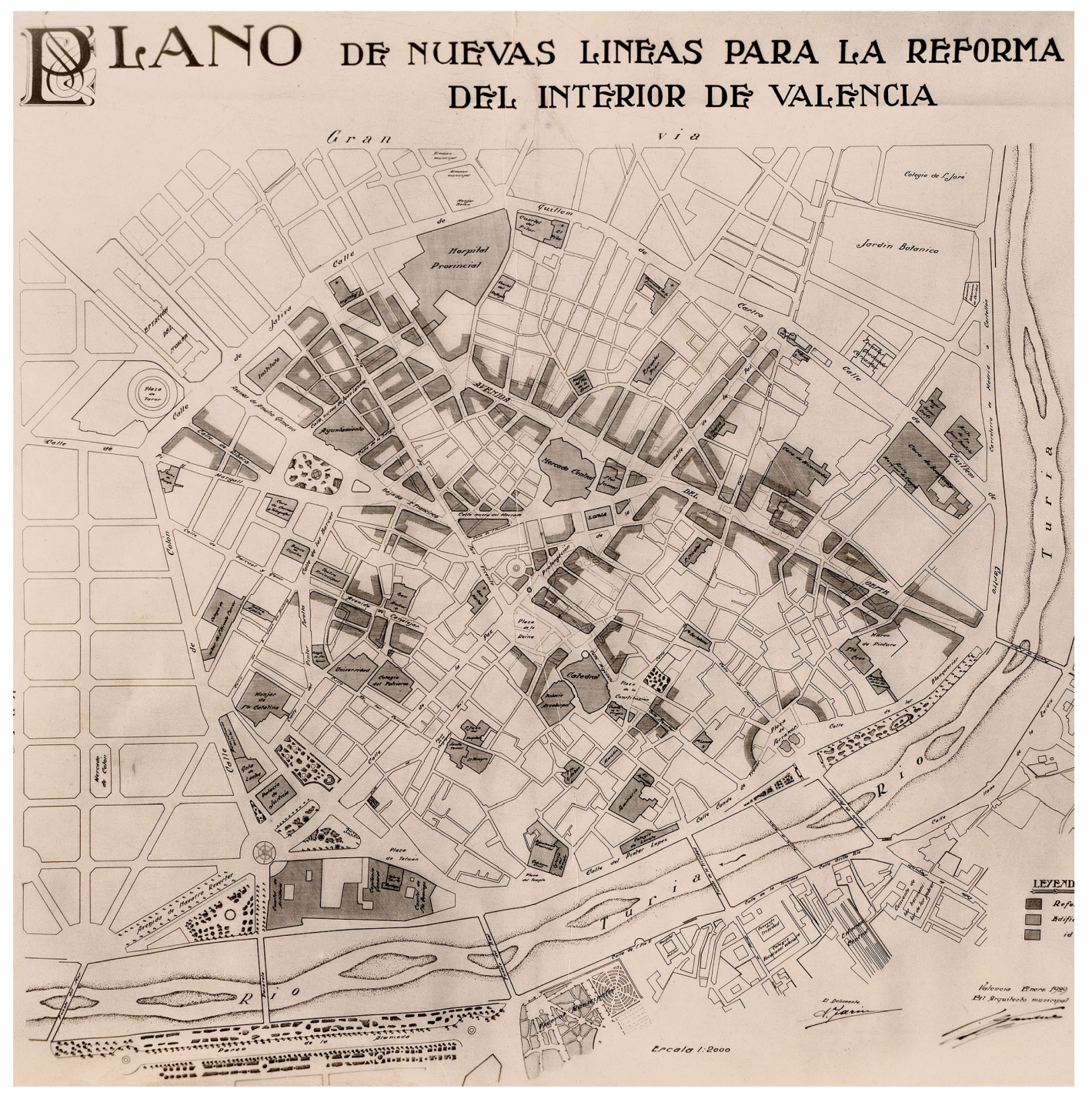


4. Que se prolongue la calle de la Corona, con el ancho proyectado para ésta, desde la plaza de Mosén Sorell, hasta la gran calle objeto de este proyecto.

5. Que todas estas reformas se proyecten en la forma prevenida (sic) para los interiores de las grandes poblaciones, con la expropiación de las zonas laterales que la ley autoriza y

6. Que se expropien todas las casas entre la gran calle en proyecto, y la de San Vicente, y la prolongación de la de la Paz destinándose el solar resultante para la construcción de un edificio monumental donde poder instalar con el decoro con que debe hacerlo la tercera capital de España, las Casas Consistoriales y el Palacio de Justicia, y quizás algún otro servicio público si las dimensiones y la distribución interior del edificio lo permitieran.

La teoría de Haussman de la calle ancha y recta que surca las zonas más degradadas de la ciudad, provocando su regeneración y saneamiento, imperaba en la mayoría de las ciudades europeas, aún cuando sus consecuencias para los edificios y su entorno histórico-artístico hayan resultado cuanto menos dudosas, provocando su deterioro en nombre de una supuesta ciudad moderna.

Federico Aymaní sería el encargado de abordar la resolución de los problemas generados por la fuerte inmigración a la ciudad, la inalterabilidad de los antiguos trazados y la decadencia de la mayoría de las viviendas, propugnando una propuesta radical. De su propuesta de Reforma Interior planteada en 1906, se mantuvieron las principales intervenciones 


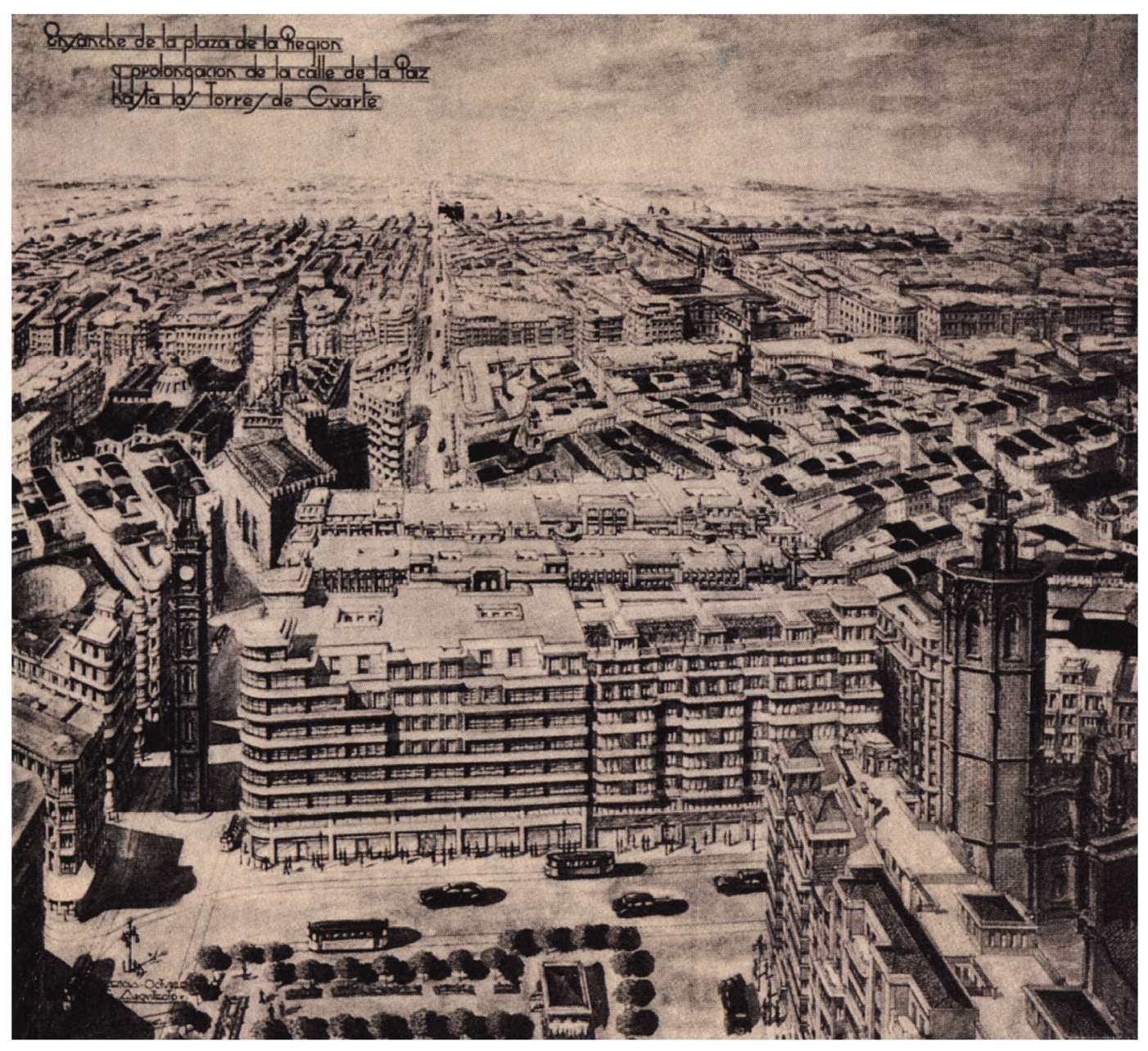

Javier GOERLICH, 1931. Prolongación de la calle de la Paz, pasando por el Mercado Central y hasta las Torres de Cuarte, tomando como base para el cambio de línea, la arista del campanario de Santa Catalina: reforma y ensanche de la plaza de la Reina 
previstas en el anteproyecto ${ }^{13}$-la avenida del Real entre la nueva plaza de la Catedral y el puente de Real y, la gran vía del Oeste y el ensanche de la plaza de la Reina- renunciando a las numerosas intervenciones menores que articulaba el resto de la trama viaria inserta entre las principales avenidas. El plan se acometió, por primera vez, buscando una solución del planeamiento con carácter unitario, acometiendo numerosos problemas que la ciudad tenía planteados y planteando la mejora en accesibilidad a un centro cada vez más impenetrable, pero generando también no pocas dificultades que acabarían por imposibilitar la reforma planteada.

El Plan de Reforma Interior de Javier Goerlich, de 1928, recogió algunas de las propuestas del plan de Federico Aymaní, de entre las que cabe destacar la avenida del Oeste, que ya aparecía en la propuesta de Luis Ferreres de 1891; la prolongación de la calle de la Paz "por encima de Santa Catalina" y no ya hasta el mercado sino hasta las torres de Quart; el ensanche de la calle de San Vicente entre la antigua plaza de Cajeros y la ronda; el ensanche de la calle Ribera, junto con la apertura de la avenida de María Cristina; y las reformas de la plaza del Ayuntamiento y la

13 "Se subraya como reformas de mayor interés el trazado de la avenida. del Oeste, la avenida. del Real y la ampliación de la plaza de la Reina, y como mejoras complementarias, la prolongación de la calle de la Paz hasta la Lonja, el trazado de una gran vía desde la plaza de la Reina hasta las Torres de Serranos y otra desde el Puente de la Trinidad hasta la Lonja, el ensanche de la Bajada de San Francisco, y otras reformas secundarias, entre las que destaca quizá el tratamiento barroco que se aplica a las Torres de Serranos, a las que enmarca en una gran plaza circular de la que surgen radialmente nuevos trazados viarios".

AA. Vv. "Cartografía Histórica de la ciudad de Valencia; 1704-1910". Ayuntamiento de Valencia. Valencia, 1985; p. 144. 

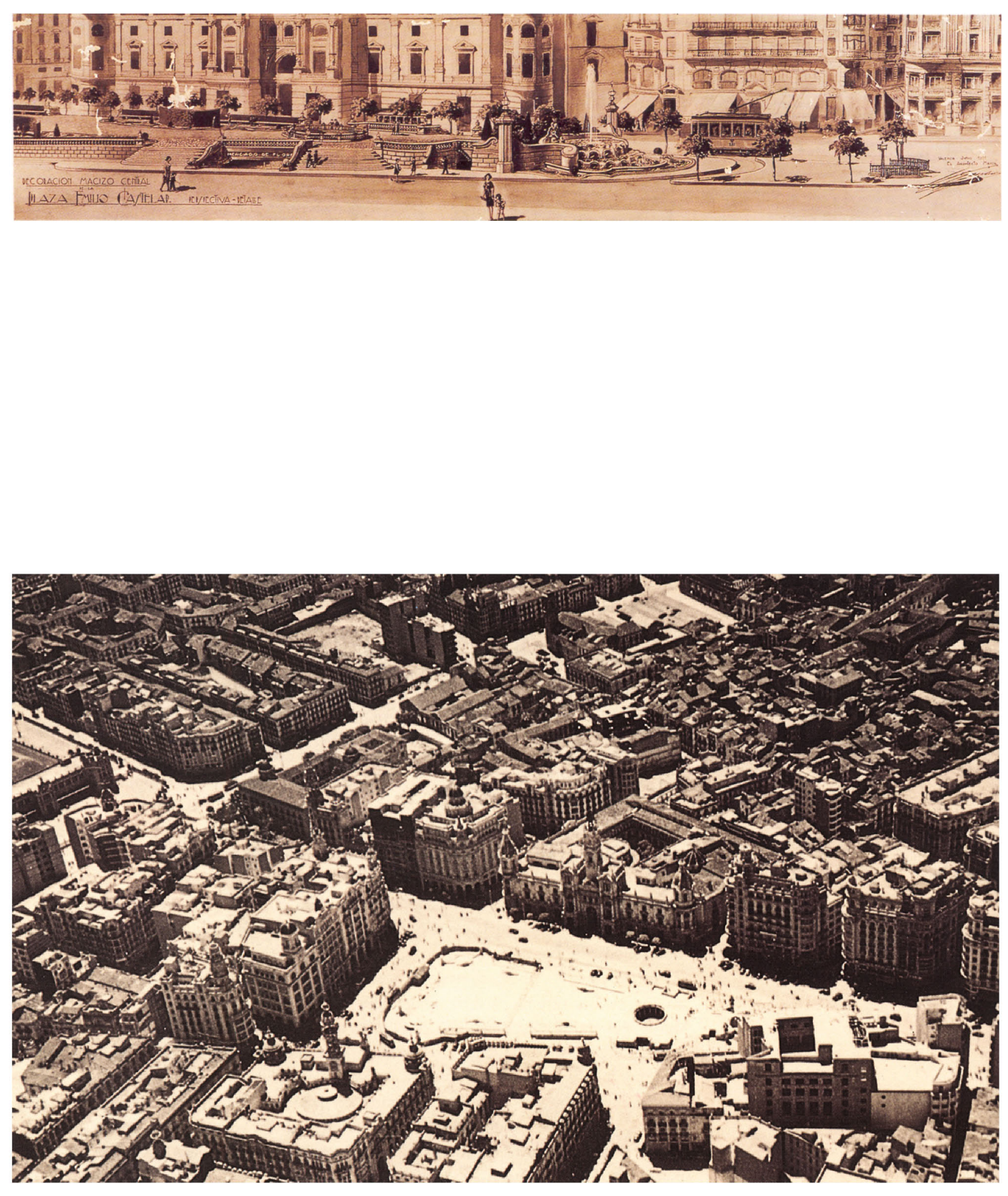

Javier GOERLICH, 1929. Perspectiva de detalle para la reforma de la plaza de Emilio Castelar; retrospectiva fotográfica aérea de la intervención en el macizo central 
plaza de la Reina cuya modificación se inicia en 1931 siguiendo el proyecto del propio Goerlich.

El inicio de apertura de la avenida del Oeste se retardó hasta la década de los años cuarenta. De todo lo propuesto en un principio, a las mínimas intervenciones parciales que si tuvieron incidencia en la trama urbana, se desprende el aislamiento de barrios como el de Velluters del resto del centro histórico, reforzando el deterioro de los mismos. Algunas de las propuestas serían realizadas en la segunda mitad del siglo, recordándose las figuras del arquitecto Javier Goerlich y, sobre todo, la del Marqués de Sotelo como alcalde, como principales impulsores de la nueva imagen que la ciudad comenzaba a presentar. Las mejoras urbanas se produjeron, como indica F. Pérez Puche, "mediante una gestión personalista, propiciada por el momento político y por la ausencia de una oposición en el seno de la Corporación Municipal que contraste debidamente los planes de reforma y su gestión financiera". La ampliación y monumentalización de la plaza de Emilio Castelar, la apertura de la avenida de Blasco lbáñez, la creación de la nueva calle del Mercado conocida como avenida de Pablo Iglesias y posteriormente por María Cristina, la ampliación de las calles que accedían a la plaza de Castelar, Ribera, Convento Santa Clara, Periodista Azatti, La Sangre, En Llop y Cotanda, formalizarían la pretendida y emblemática imagen de la ciudad de los años veinte. 


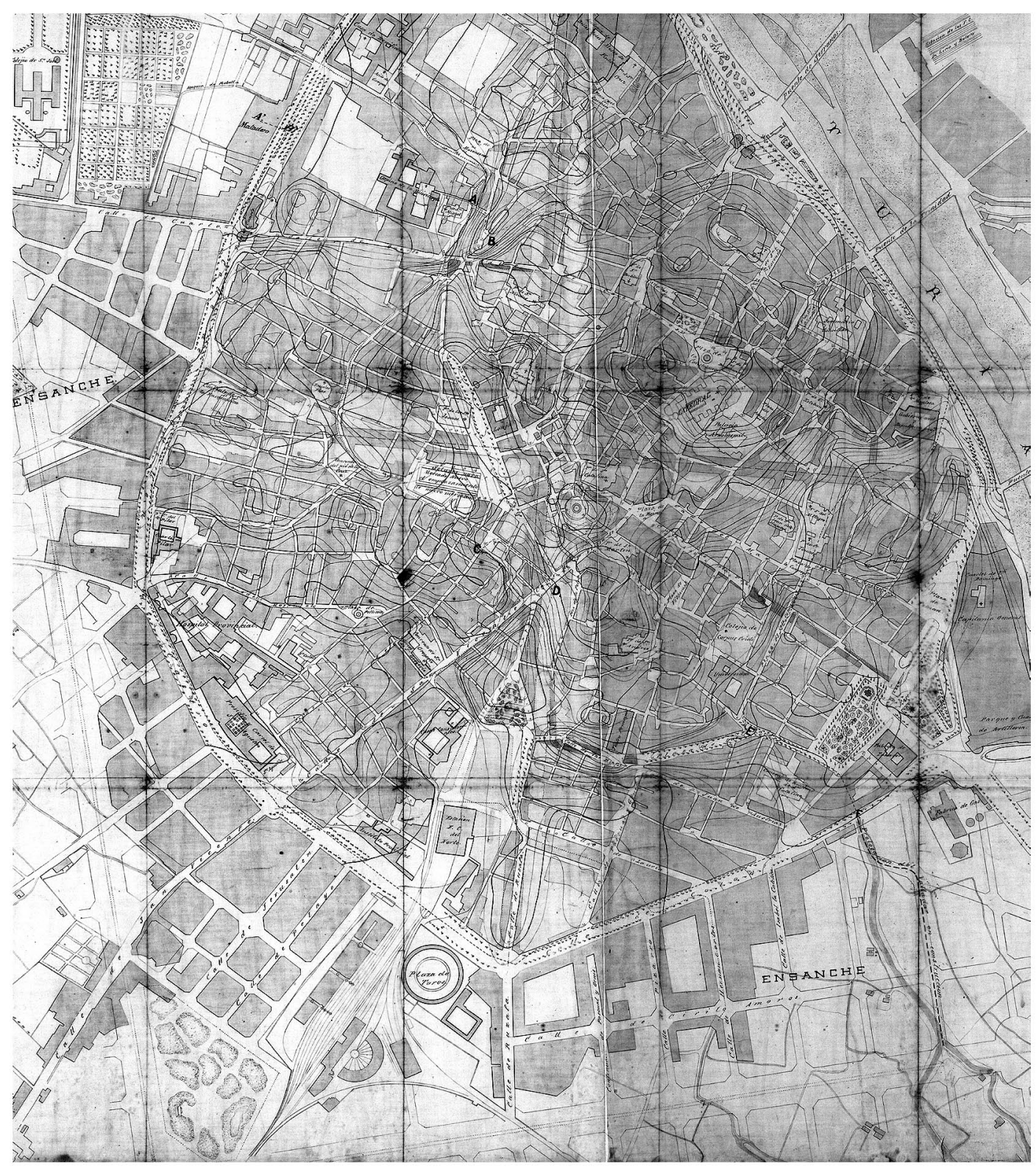

José CALVO, Luis FERRERES y Joaquín ARNAU, 1894. Plano General de Valencia y sus ENSANCHES 


\section{EL PLAN DE ENSANCHE DE LA PERIFERIA}

La situación urbanística del último cuarto de siglo, en el momento de emerger el Eclecticismo en la arquitectura valenciana, contaba como referentes los sucesivos planes de Reforma Interior, el desarrollo del Plan del Ensanche gestado en el año 1858 -coincidente cronológicamente, no en su planteamiento, con los planes de Madrid y Barcelona ${ }^{14}$ - y el comienzo del derribo de las murallas en el año 1865 que supuso la completa transformación de la urbe, encorsetada e imposibilitada en su expansión. Habían acaecido, durante este período ecléctico, el planteamiento y la ejecución en Valencia de una serie de proyectos urbanísticos que cerraron el ciclo de modernización iniciado a finales del XIX.

Calvo Serraller analizando los problemas que se pretendían resolver con la promulgación de los ensanches, apuntó fundamentales: económicos, higiénicos y estéticos. "Económicamente el ensanche se justifica por la progresiva escasez y encarecimiento de los solares urbanos; higiénicamente, por la imposibilidad de separar viviendas e industrias y la incapacidad de evitar el hacinamiento y la insalubridad de las casas tradicionales; estéticamente, por la elaboración de un sistema viario más cerrado, eficaz y sencillo" 15 .

14 "Los planes de Madrid y Barcelona parten de una malla rectangular en la que la regularidad de la manzana es elemento base de trazado. El de Valencia, en cambio, será el trazado viario quien configure el espacio edificable, asumiendo la manzana un papel de elemento residual, opuesto por completo a las propuestas de Castro y Cerdá".

TABERNER PASTOR, Francisco. op. cit; p. 49.

15 CALVO SERRALLER, Francisco. "El urbanismo de los Ensanches: La transformación de Madrid durante el siglo XIX". Revista "Arquitectura" $n^{\circ} 217$. Madrid, 1979. 


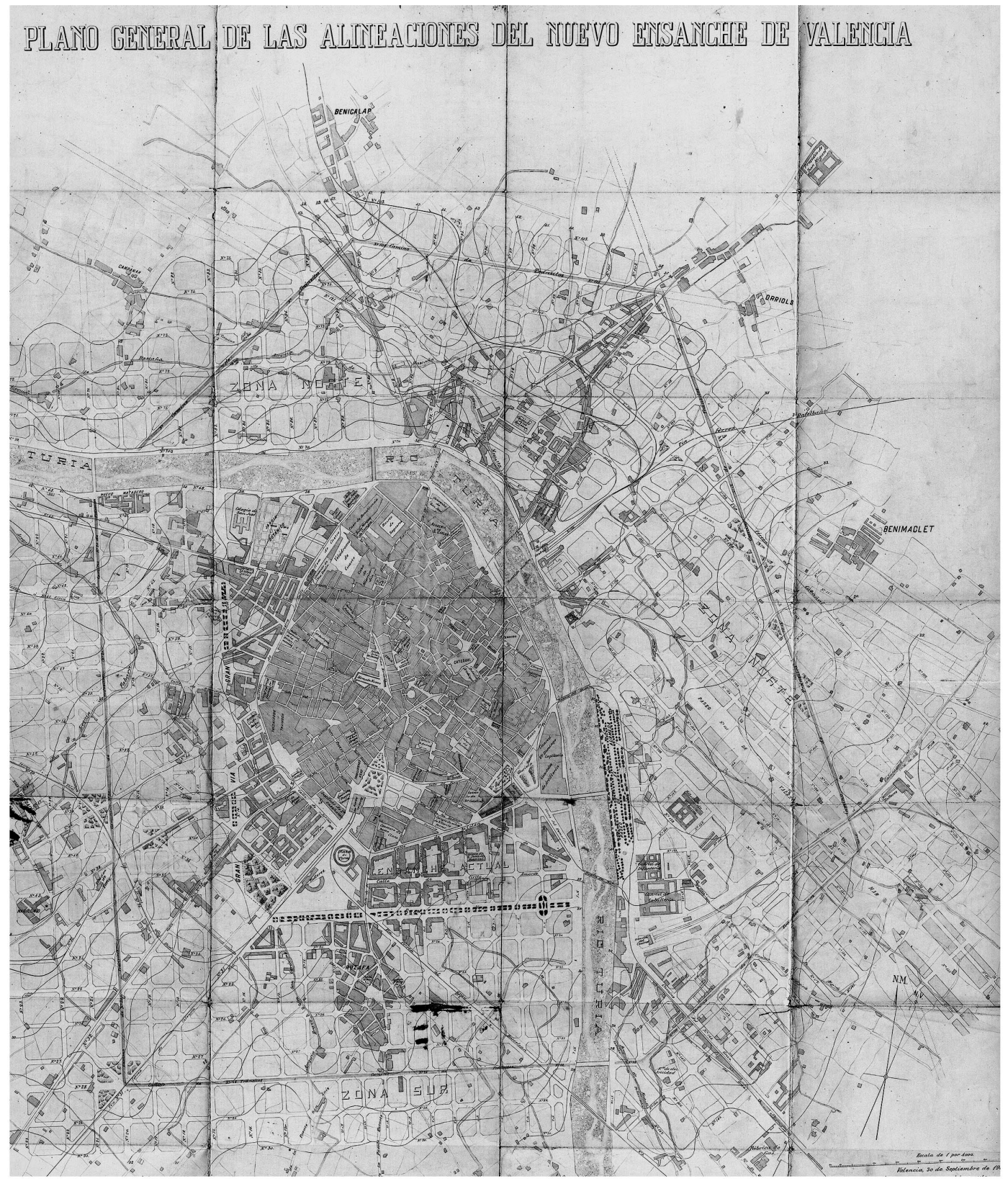

Francisco MORA, 1907. Plano General de Alineaciones del nuevo ENSANCHE de la ciudad de Valencia 
Quedaba compuesto, el equipo técnico encargado del Proyecto general del Ensanche de Valencia, por los arquitectos Sebastián Monleón y Antonio Sancho junto con el arquitecto Mayor Timoteo Calvo. El Plano se concentró en el trazado de una calle principal de 15 metros de ancho, articulada en cuatro tramos de longitudes desiguales $y$, paralelos sensiblemente, equidistantes del lienzo de la muralla existente. La nueva trama urbana buscaba -cuanto menos planimétricamente- la unidad con la existente mediante el trazado de nuevas calles, forzando paralelismos y perpendiculares casi imposibles. La irracional geometría de las manzanas resultantes -escasamente correspondía con la imagen de ciudad moderna pretendida frente al casco viejo-, la presunción del desplazamiento hacia el sur del centro cívico y la mínima repercusión en la iniciativa privada contribuyeron a que el Plan nunca se aprobara. En su haber cabe reseñar la intención de diversificar el uso del suelo según las distintas zonas: una zona comercial relacionada con los accesos al mar y con las líneas de Madrid y Barcelona; una zona industrializada con la zona de expansión lógica del barrio de la seda y; una zona residencial y lúdica en la zona Norte.

Desde aquí ya se han citado las premisas por las que se hacía imprescindible emprender la expansión de la ciudad más allá del recinto amurallado demolido: el proceso de desamortización supuso una ocasión fallida de remodelar el casco antiguo; el cambio de uso en los edificios desamortizados contribuyó a agravar el problema de las condiciones higiénico-sanitarias ${ }^{16}$ del espacio habitable; la escasez de oferta disparó el alto

16 Fue Benévolo quién estudió los inicios de la Legislación sanitaria en Europa, remarcando su carácter precursor en la legislación urbanística.

BENÉVOLO, Leonardo. "Orígenes de la urbanística moderna". Editorial Tekne, 1967. 


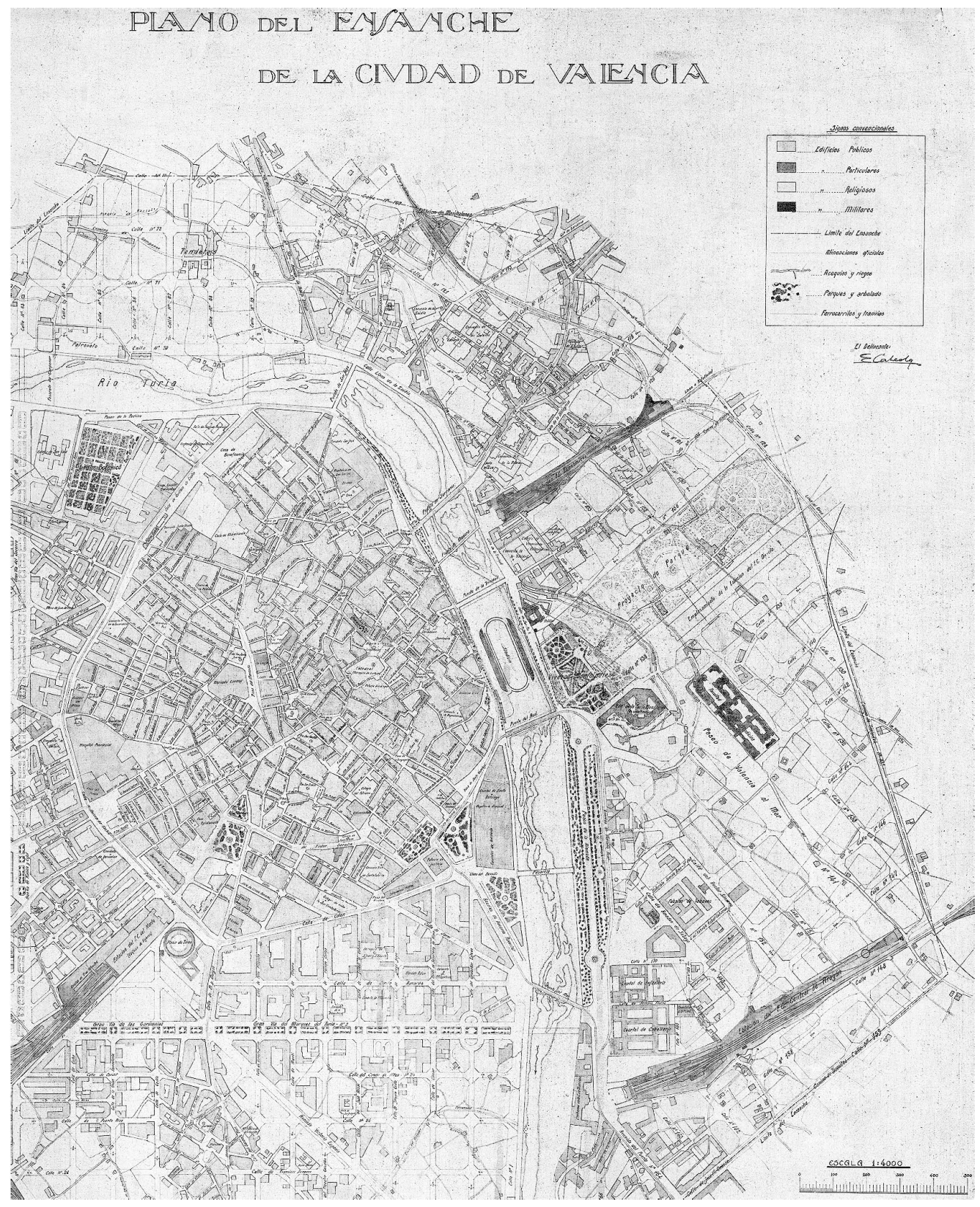

Francisco MORA, 1924. Plano del ENSANCHE de la ciudad de Valencia 
precio de los alquileres, muy a pesar del deplorable estado de sus edificaciones y del poder adquisitivo del mercado; la elevada demanda provocada por el aumento demográfico registrado en las últimas décadas; las facilidades económicas y la mayor rentabilidad para el promotor privado, así como las mayores facilidades para la elaboración y gestión de los planes de Ensanche frente a los proyectos de Reforma Interior.

Que el ensanche proclamaba esencias de progreso, conllevaba mejoras urbanas importantes, y que su trazado regulador facilitaba la parcelación de sus manzanas, se mantuvo aceptado por unanimidad. No obstante, favoreciendo un aumento sustancial de terreno, también generaba opciones especulativas y no podía negarse la lentitud de su ejecución confrontada con la oposición de propietarios expropiados. Con todo ello, e iniciado el nuevo siglo, la ciudad moderna pretendida, distaba de ser realidad y como señaló el arquitecto municipal Luis María Cabello, enjuiciando el ensanche, "Valencia como toda ciudad de cierta época, lo que más necesita son reformas interiores". Manifiesto debate entre dos figuras urbanísticas simultáneas, programadas a encontrarse y obstinadamente electas, reflejo del doméstico entramado político y social, alejado del planeamiento científico y cartesiano, de la sociedad universal, racional y positivista.

En la segunda mitad del siglo XIX el desarrollo de las ciudades españolas más vanguardistas pasaba por acometer y ejecutar sus autóctonos planes de Ensanche. Aprobados los de Madrid y Barcelona en 1860, el resto de capitales principales redactaron y construyeron sus ensanches, no $\sin$ bastantes dificultades. El Plano de Ensanche de Valencia se gestó en 1887 por los arquitectos José Calvo, Luis Ferreres y Joaquín Arnau. Escasamente 


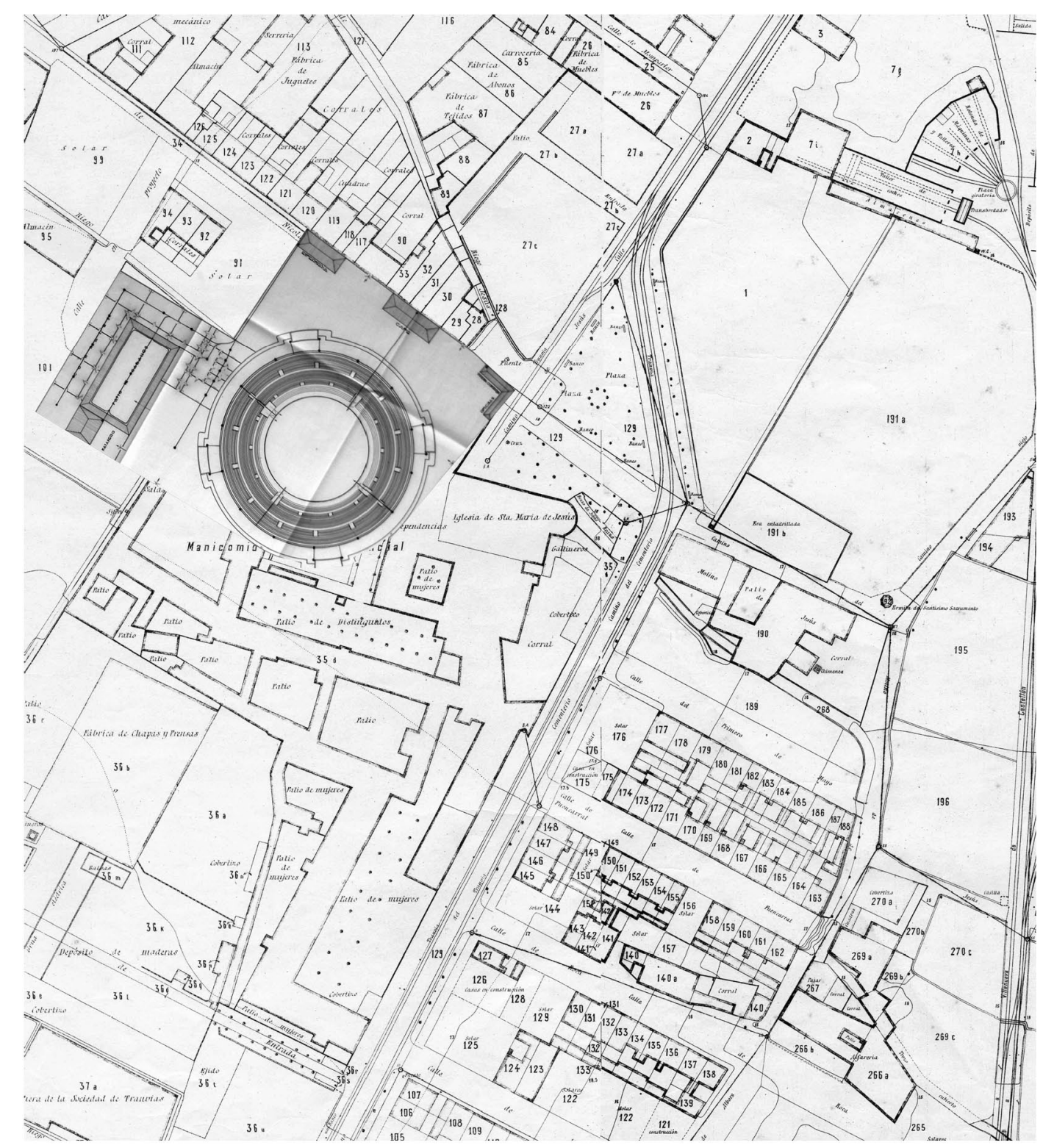

Instituto Geográfico y Catastral, 1930. Patraix: fotomontaje del doctorando acerca de la reubicación de la moderna Plaza de Toros, propuesta por Luis ALBERT, en el emplazamiento del entonces Manicomio de Jesús, impropio en las nuevas propuestas de Ensanche 
originales en la génesis de sus planteamientos a la hora de formalizar la propuesta -resultaron evidentes las influencias de los modelos norteamericanos del siglo XIX-, en su haber acumularon desestimar la barroca concepción de la perspectiva y el edificio singular como eje de planeamiento. El trazado geométrico ortogonal retomó protagonismo, favorable frente a la inversión de capital privado por la facilidad que procura de parcelación y venta, agilizando el desarrollo del Plan.

Despuntó por su inmediatez la creación de la Comisión de Ensanche, sin embargo los inadecuados instrumentos legislativos españoles pronto frenarían los intentos municipales de aprobación del Plan, forzando a otorgar licencias provisionales de edificación, de forma que cuando se produce la aprobación definitiva del Plan este no hace más que consolidar una situación de hecho, debiendo acomodarse el trazado a las preexistencias, no a la inversa como hubiera sido deseable. La superficie del ensanche quedaba dividida en cinco "agrupaciones" ubicadas desde la calle Colón a la Gran Vía, donde a su vez las manzanas se subdividían en solares regulares, cuya reparcelación se formularía conforme con todos los propietarios.

Durante este período, y hasta la aprobación definitiva del plan, el casco viejo trataba de adecuarse a las nuevas demandas y conectarse con el moderno Ensanche prescrito. Sus actuaciones se fundamentaban en proyectos de nuevas alineaciones. Reseñables, dos reformas como las más ambiciosas: la reurbanización del antiguo Barrio de Pescadores y la reconversión del Convento de San Francisco, origen de la pretendida moderna imagen del centro de la ciudad. 


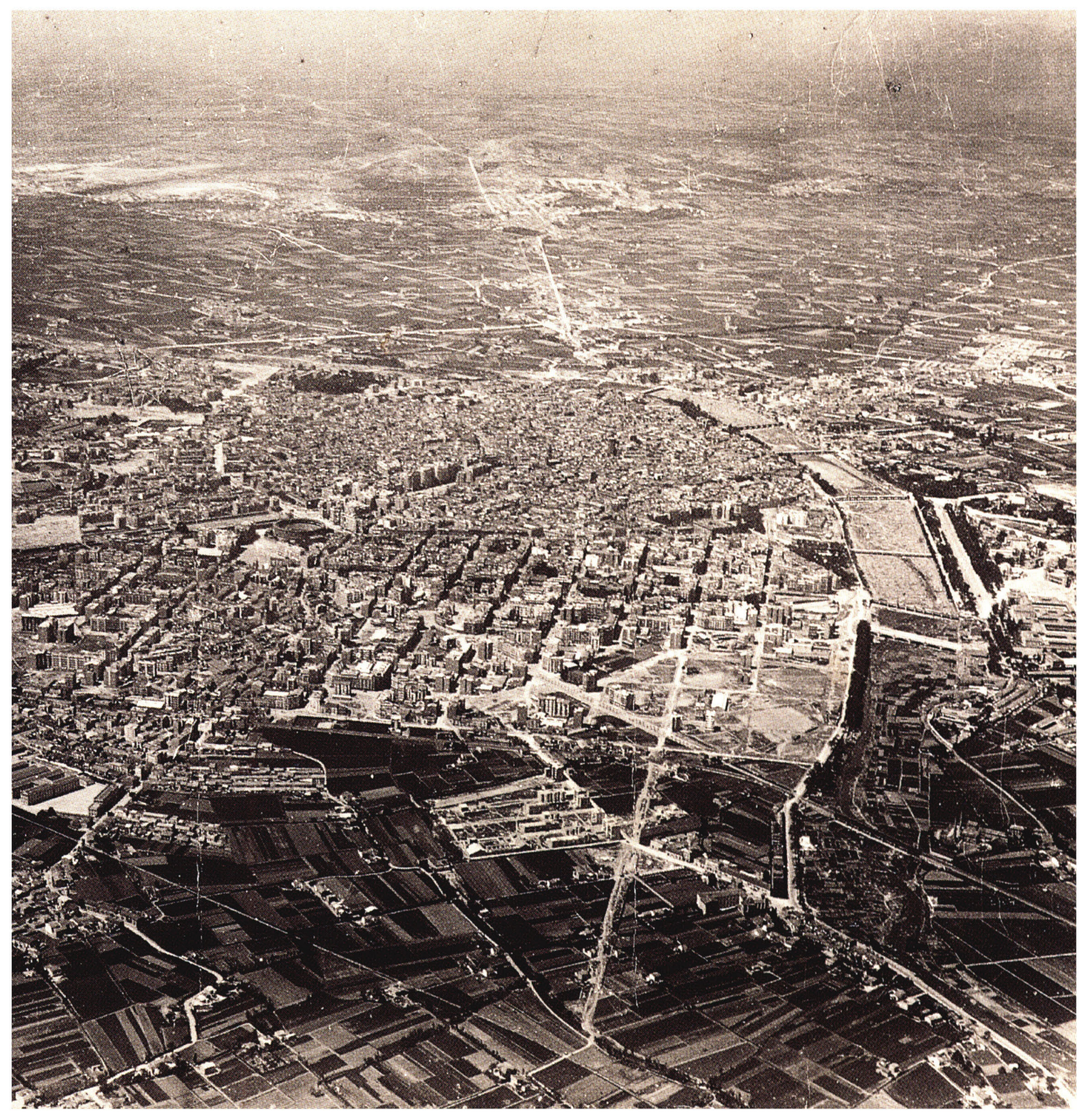


En diciembre de 1912 resultaría aprobado definitivamente el Plan de Ensanche proyectado, esta vez, por el arquitecto Francisco Mora y por el ingeniero Vicente Pichó, mientras se rotulaba el tramo de la Gran Vía, acotado entre el río y la calle Ruzafa, con el nombre de Marqués del Turia. Esta propuesta no aportaba novedades en el planeamiento respecto al esquema emprendido con el plan Ferreres, Calvo y Arnau. La diferencia fundamental radicó en la extensión que abarcaba: "absorbe Ruzafa, Benimaclet, Orriols y los caseríos de las carreteras de Madrid (Quart) y Barcelona (Sagunto), salta el río, incluye los terrenos de la Exposición Regional y la antigua ensoñación del Paseo Valencia al Mar, y a todos trata con una cuadrícula más o menos standard, desde la ronda hasta Tránsitos y los poblados citados. Fuera de lo dicho, pocas novedades: las Grandes Vías previstas en el primer Ensanche, la transformación en Avenida diagonal del antiguo acceso del ferrocarril hoy avda. del Reino de Valencia) y poco más. El mercado de Colón se decide a última hora en 1914, seccionando una de las manzanas más largas, y la nueva estación se había ya comenzado en 1909 tras la primera ronda, al margen del primer plan y tras enconada polémica" ${ }^{17}$. Si la modulación de la trama no supuso más que un alarde de destreza compositiva, si tanto el control del ancho de calle como la altura de fachada y, la estipulación de la distancia entre forjados, declamaba una fiel reproducción de las Ordenanzas aprobadas para el Ensanche de Ferreres, Calvo y Arnau, podemos considerar la propuesta de Mora y Pichón un tanto desconectada del lugar en el que habría de implantarse y muy insensible a las necesidades de equipamiento: mercados, parques, escuelas, aparecen escasamente

17 PEÑIN IBÁÑEZ, Alberto. "El marco urbano y socioeconómico. Arquitectos y Arquitecturas". Catálogo de la exposición "La ciudad moderna. Arquitectura racionalista en Valencia". IVAM Institut Valencià d'Art Modern, 1998; p. 66. 

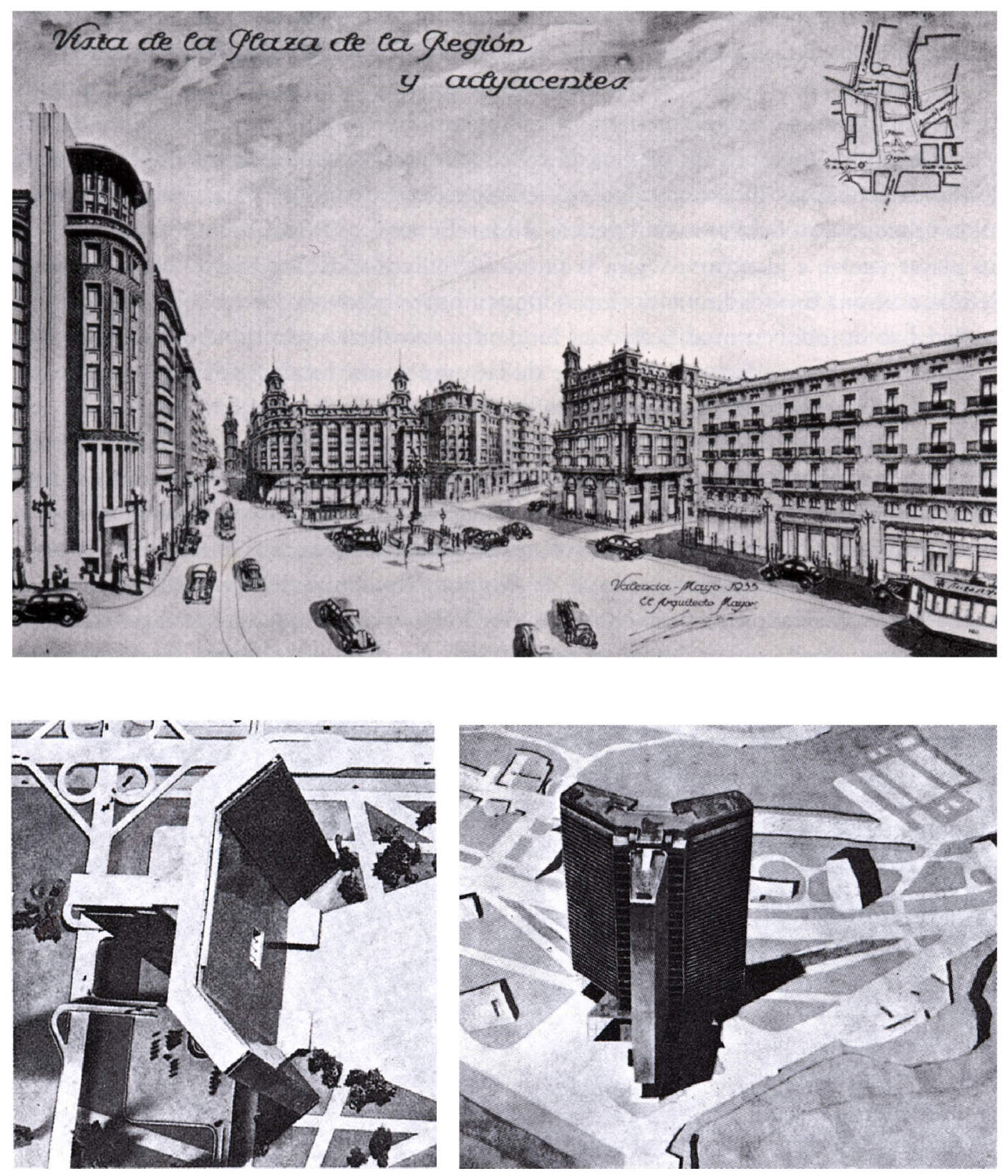

Javier GOERLICH, 1935. Ensanche de la plaza de la Reina (antigua plaza de la Región) vistas generales de la fachada oeste; Le CORBUSIER, 1929. Rascacielos Brasil 
repartidos sobre la trama. A pesar de todo ello, estamos por primera vez, ante una ejecución disciplinada del crecimiento urbano, desarrollada en función de la accesibilidad, higiene y rentabilidad de la parcelación.

Acceder al debate europeo descentralizador, al modelo anglosajón de la ciudad-jardín howardiana, relegando la propuesta metropolitana al ámbito puramente comercial y terciario, recaló en iniciativas privadas proyectando núcleos organizados residenciales, autárquicos e inconexos del Ensanche. Asentamientos obreros enclavados en la anarquía urbanística, carentes de planes de extensión globales, de mecanismos racionales de ordenación, de cartesiana zonificación, de regularización de densidades y usos. Si habíamos anunciado, en su momento utópico en exceso, observar como exclusivo el método racionalista por empobrecedor de las complejidades y cualidades de la realidad, los poderes fácticos desinteresados -tal vez incapaces- por conectar el espacio rural con el urbano, facultaron la actuación inversa: el proceso de modernización urbana se ejecutó con los ojos puestos exclusivamente hacia el centro de la ciudad, mientras que la renovación formal de la ciudad pretendía ser captada puntualmente en iconos erigidos. Arquitectura reclamo frente a la ciudad positivista, ciudad funcional ${ }^{18}$, Urbanismo racionalista.

18 "La ciudad funcional debe ser construida sistemáticamente, a partir de sus elementos, ordenándola en un sentido completamente nuevo. Tiene que cumplir todas las exigencias urbanísticas básicas. Su trazado debe ser claro y lógico".

HILBERSEIMER, Ludwig. "La arquitectura de la gran ciudad". Editorial Gustavo Gili, S.A. Barcelona, 1979. Traducido por Pedro Madrigal Devesa. Título original: "Grosstadt Architektur". Publicado en inglés en 1927. 
introducción arquitectónica 


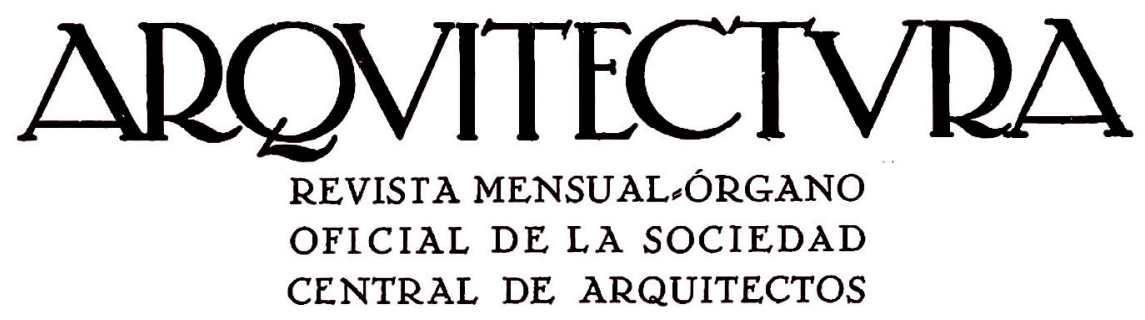

P R I N C I PE, 16

Año X Núms. 108 y 109

MA D R I D

Abril y Mayo de 1928

\section{ATENEO MERCANTIL I)E VALENCIA CONCURSO DE ANTEPROYECTOS}

IISTA DE CONCERRFATES-IA XCMFRACION SLSTITCYE A SLS NOMBRES FN LOS ESTADOS O CLADROS.

\footnotetext{
1.-I). Joaquin Maggioni. Barcelona.

- D. Feruaudo Arzadum. Madrid.

3.-D. Saturnino Liargui. Madrid.

4.-1). José Gimeno tlmela Castellin.

5-1). Rafael Hidalgo y D. Luis Ortiz de la Torre. Madrid.

6.-D. José Maria Castell y 1). Casio Peruindez-Slaw. Iturralde. Madrid.

7-D. Luis Sala y de Marin. Madrid.

6.-D. Pedro Guimón. Vizcaya.

c.-1). Miguel Angel Navarro. Zaragoza.

iu-D. J Rodrimuez Llobera \& D. Santiago Casulleras. Barcelona.

11-D. Bienvenido Marin lispinusa. Barcelona.

12.-I). Andrés Audet Puig. Barcelona

12-D. A. Aldrés Audet Puig. Barcelonia.

14-D. Francisas Portillo y D. Juan Gordillo. Barcelona.

15-1). Attonio Piera Connis. Barceiura.

rt-D. José Maria Arrillaga. D. Beruirdo Giner de los Rios y D. José Ostula lajarto. Madrid.

17.-D. Ricardo Samta Cruz de lat Casit. Málaga.

18-D. Isidro Puig Boada y D. José F. Raiols. Barcelon:ı.

19-D. Fernatido Garcia Mercadal y D. IEmilio J. Moya. Madrid.

c.-D. Gaspar Bicin. Madrid.

21. D. Enrique Huidlobro y D. Mignel Micg. Madrid.

rz-D. Tolmo Sáncliez. Ciưdad Real

a-D. Manuel Martinez Chumillas y D. R. Anilnal Alrarez. Madrid

24-D. Antonio Rubio Marin. Maurid.
}

2:-D. Vicente Rodrigt: $:$ r. Valencia.

at.-D. José Maria Jordlan y D. lecruando Tarragó. Barcelona.

7.-1). Rebertu Oms. Badalour.

a.-1). Sajvador Donderis Tatay. Vajencia.

-1). Francisce Mora y D. Fituardo Burges. Valencia

30-D. Cesar Cort y D. Jose Cort. Madric.

30-D. Cesar Cort y D. Jose Covier Yarnoz. Madrid.

3t-D). Javier Yarnoz. Madrid.
?2-1). (arlos Cardcatal y D. Antomio Fisis. Barcelouta.

33-D. Juan de Zabala y D. José Maria Rivas. Madrite.

31.-D. Carlos Mosjucra y D. Enrique l.épez Izquicrdo. Madrid.

15-D. Lorenzo Criato Oltra. Valencia.

36-D. Santiago I:stevian de la Mora y 1). Franciseo Se. dano. Madrid.

2:-D. Migucl de ios Sa:tos y D. Agustín Aguirre. So luciön A. Madrid.

28.-Los mismos senieres. Sulución B. Mladrid. 35:-Los mismos señores. Solución C. Madrid. a-Clos mismus seniores. Solucion D). Madrid. 4i-Los nismos señores. Solución E. Madrid. t=-D. Juan Carles y D. Luis Costa. Valercia. 4..-D). Autonio Miguel Sstićn. Guipúzcoa. 4.:-D. Autonio Miguel Seticti. Guipuzcea.

45-Sres. Gecerlich, Testor, Artal, Pedrós, Burgucra y Borso. Solución A. Valencia

4tí-Los mismos señores. Solución B. Valencia

ti- - I.os mismos señores. Solución C. Valericia ż-D. Ricarto Pérez Fernández. Salamanca. 


\section{LA EVOLUCIÓN DE LO MODERNO}

Concluiría el siglo XIX anhelando una profunda alteración de los vínculos con el pasado $y$, amanecido el siglo $x x$, se llevaría a cabo parcialmente la deseada metamorfosis, una vez desentendida del bagaje artístico la "mimesis de la realidad" transcribiendo a Josep Maria Montaner. Urgía desprenderse del lastre intelectual, desligarse, prescindir de criterios antropomórficos, de armonía y simetría, de conformaciones ornamentales, rechazar las normas compositivas clásicas. En suma, desatender la Historia y su longevo repertorio expresivo, en aras de una nueva arquitectura, rigurosamente contemporánea, imagen de la modernidad impulsada por la sociedad burguesa, colectivo ávido de diferenciación.

Una moderna concepción proyectual, formularía una arquitectura contemporánea, cuyo método de creación gravitaría en ideas congénitas, evitando reminiscencias históricas. El quehacer arquitectónico habría de quedar recluido, discriminado al interior de los despachos profesionales, evitando las referencias miméticas e indagando procedimientos sistemáticos, manipulando nuevos materiales, yuxtaponiendo texturas, componiendo percepciones, maquinando formas. Habrían de generarse inéditos idearios, suscitar modernos tipos de expresión fundamentados en la abstracción -invención, conceptualización, simplificación, elementalismo, purismo-y proyectar hacia delante, una nueva concepción del espacio, sin memoria.

Moderno espacio basado en medidas, proporciones y relaciones. Cuantitativo, abstracto, lógico, científico y matemático. Espacio por construcción mental. Acotado mediante planos horizontales -infinito en suelo, inmaculado en techo e ingrávido verticalmente- no obstante abierto e ilimitado. Sus magníficos prototipos, proclamados por Le Corbusier en las 

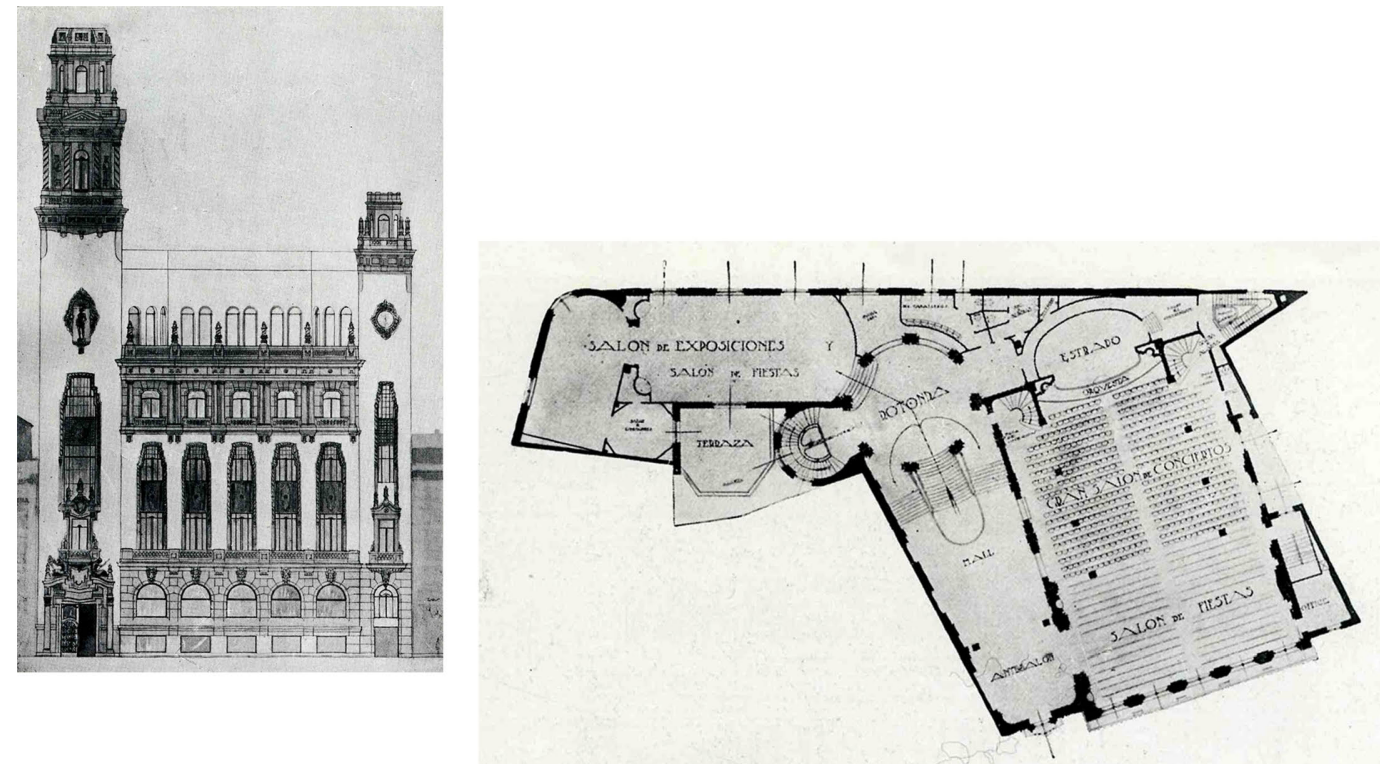

Planta principal.

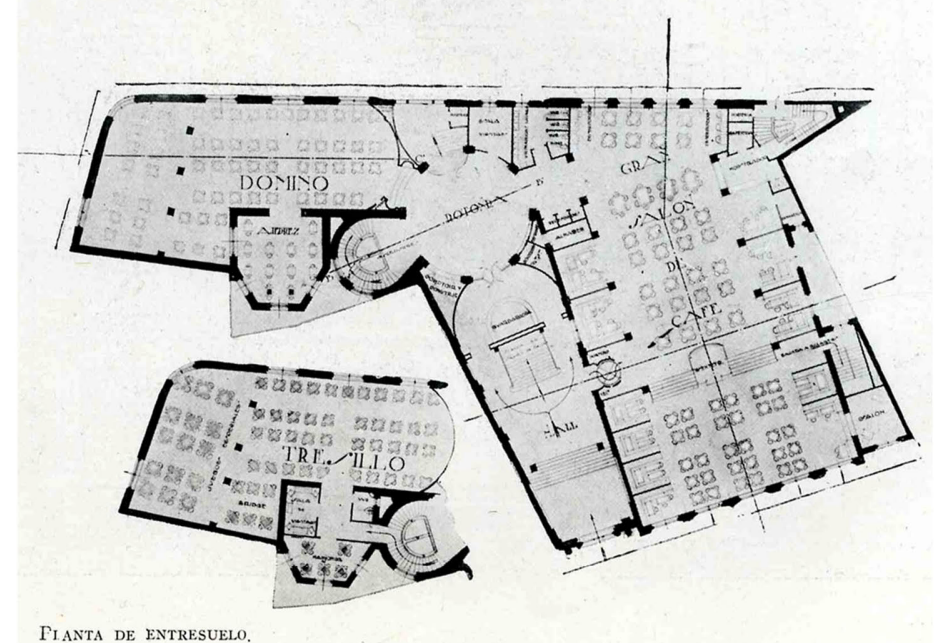

José María CASTELL y Casto FERNÁNDEZ SHAW, 1927. Anteproyecto presentado al concurso Nacional convocado por el Ateneo de Valencia; moderadamente regionalista, con mínimos elementos neobarrocos en referencia a la torre de Santa Catalina 
Citrohan y Domino, materializados por Mies van der Rohe en los pabellones de Barcelona y Berlín, repercutirían en las vanguardias, culminando en un posicionamiento definitorio para la evolución de la arquitectura: la concepción de espacio del internacional19.

Tanto el innovador proceso proyectual, insubordinado del pasado, como su moderna aportación para la concepción del Espacio-recogidas por la teoría arquitectónica- instaurarían un método científico, cartesiano: el racionalismo. Dos tendencias opuestas se desarrollarían a su amparo. Aquella que interpretaba el racionalismo como predominio exclusivo de la razón, del conocimiento, haciendo tabula rasa y negando tradición en aras de las ideas innatas. Opuesta a esta, aquella que interpretaba el racionalismo desde un punto de vista empírico -fundado en la acumulación de experiencias, aún sin contraponerse a la razón-y el valor positivo de la tradición, de la acumulación de conocimientos.

19 "Se ha afirmado muchas veces que la arquitectura moderna no implica simplemente una actitud mental frente a los problemas tecnológicos y sociológicos, sino que se basa en una radical reorientación de la capacidad de concebir el espacio, y puesto que, de modo implícito, se reconoce que los elementos de ese nuevo orden espacial han existido desde hace tiempo, y que su síntesis efectiva es un logro de los años veinte, será útil clarificar ciertos preceptos de lo que llamaremos (a falta de un término mejor) el Estilo Internacional. El espacio del Estilo Internacional es, para nuestros fines, el espacio de Garches, de la casa de Mies para la Exposición de Construcción de Berlín de 1931 y el foyer de Le Corbusier para el edificio Centrosoyus de Moscú, por ceñirnos sólo a algunos destacados ejemplos. Todos ellos son ejemplos de la revolución espacial de los años veinte. Y todos ellos han ejercido y continúan ejerciendo una profunda influencia en la práctica arquitectónica; y aunque la estrategia espacial que representan sólo se ha alcanzado en contadas ocasiones, su idea del espacio no es por ello menos significativa."

ROWE, Colin. "Manierismo y arquitectura moderna y otros ensayos". Editorial Gustavo Gili, S.A. Barcelona, 1978. Título original: "The Mathematics of the Ideal Villa and Other Essays". The Massachussets institute of Technology, Cambrigde y Londres, 1976. Capítulo Neoclasicismo y arquitectura moderna /1. p. 138 

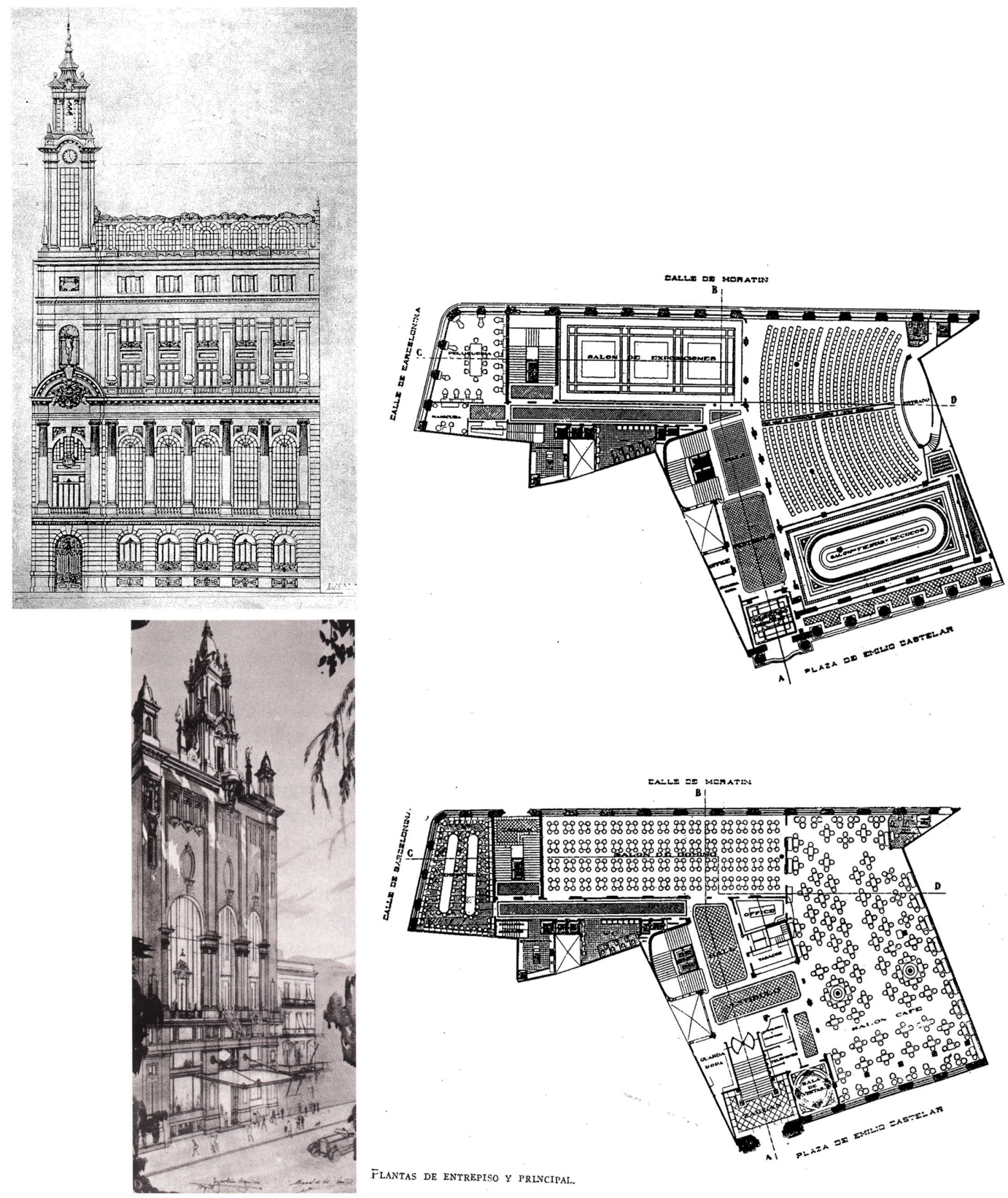

Vicente RODRíGUEZ, 1927. Anteproyecto presentado al concurso Nacional convocado por el Ateneo de Valencia; lenguaje cosmopolita y un marcado clasicismo 
Inicialmente el Movimiento Moderno derivó del concepto de racionalismo, del método que negaba la supremacía del pasado, marcando un impoluto comienzo e implantando como proceso, la propia experiencia interpretada desde la razón. Y si habíamos tachado de utópico en exceso, observar el proceso excluyente por empobrecer las complejidades y cualidades de la realidad, no resultaría menos cierto observar que tampoco navegaría en solitario, eludiendo compartir su discurrir entre coetáneas teorías arquitectónicas, con las que compartiría un pretendido rechazo a los historicismos y la angustia por encontrar la expresión propia, el estilo adecuado a su circunstancia histórica. Conformando conjuntamente las complejidades y cualidades de una época, de una realidad arquitectónica, de un crítico periodo, difícil por la serie de contradicciones macladas en la arquitectura producida y sus autores. Esclarecedora lógica que propicia comprender la futura transformación del método cuando los arquitectos de la llamada "tercera generación" -Louis Kahn, Jørn Utzon, Denys Lasdun, Aldo van Eyck, José Antonio Coderch, Luis Barragán, Fernándo Távora, Carlos Raúl Villanueva, Lina Bo Bardi20- rechazaron el formalismo y el manierismo del estilo internacional, reclamando retomar la visión hacia los monumentos, la historia, la realidad y el usuario, hacia la arquitectura vernácula.

Cohabitarían al albor del siglo $x x$, posturas arquitectónicas tan diversas $y$ dispares -hasta el punto de intuirlas irreconciliables- como eclecticismo internacional con todas sus variantes, casticismo, art déco y racionalismo, quedando sus límites difícilmente establecidos. No obstante, todas

20 MONTANER, Josep Maria. "La modernidad superada. Arquitectura, arte y pensamiento del siglo XX". Editorial Gustavo Gili S.A. Barcelona, 1999. p. 12 

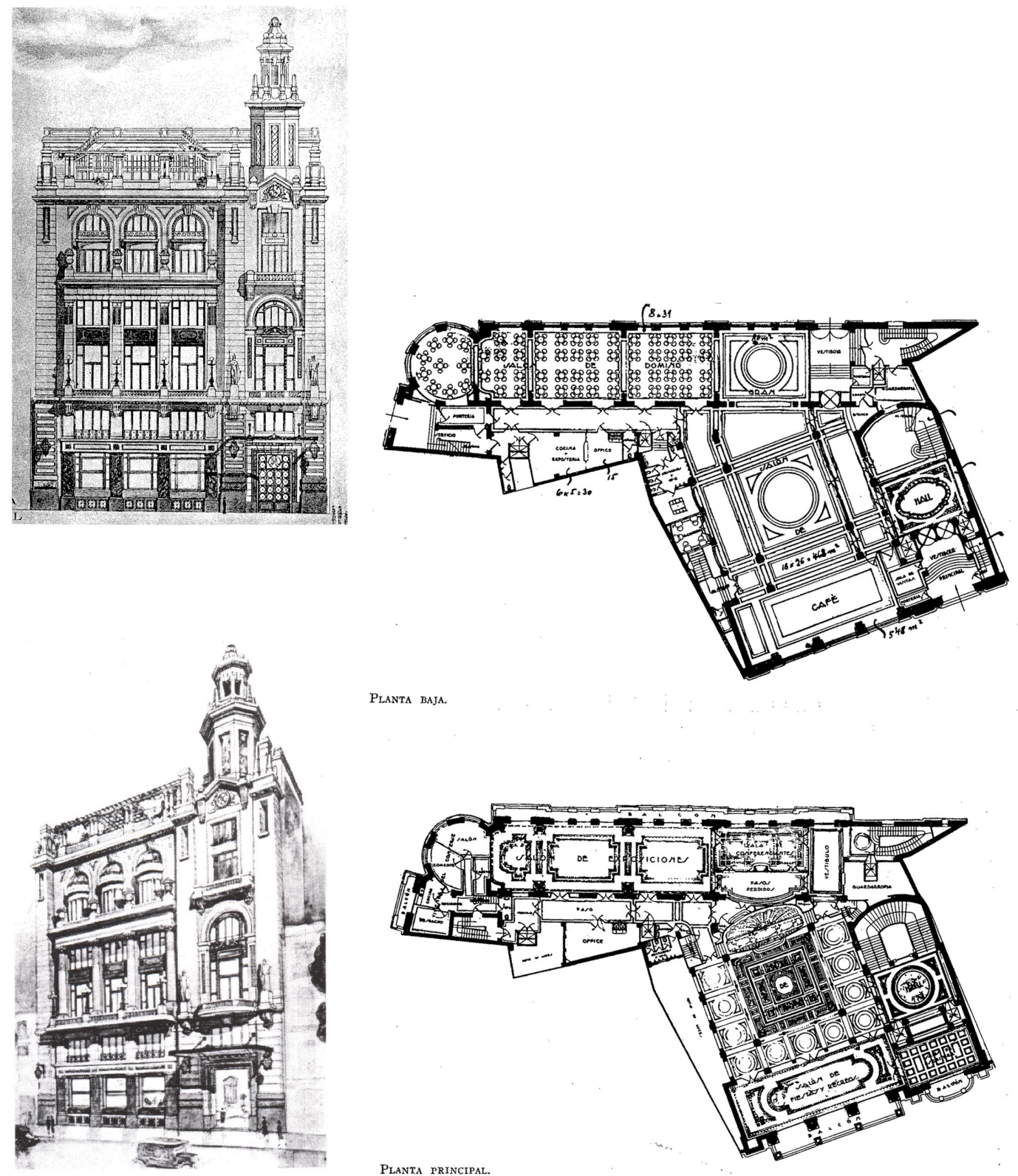
dominadas, unas revisadas e incluso mezcladas varias, en interpretaciones con diversos grados de libertad, llegando a formalizar una edificación rápidamente identificable con la ciudad, asumida por la urbe y por sus actores edilicios, en un proceso de mutua asimilación. Excepcionales se mantendrían los escasos ortodoxos, coherentes ante la crítica hacia lo establecido, estandartes para abdicar la mímesis, en la fiesta para los sentidos que dispuso la sociedad no sólo valenciana, como europea de los años veinte.

"Al plantearse una revisión de las bases del movimiento moderno, Peter Collins toma sin duda una actitud polémica. Se trata de romper definitivamente la ilusión de un nacimiento "ex novo" de la vanguardia arquitectónica de nuestro siglo, y de las bases que durante años se creyeron de tal modo originales, que habían de ser capaces de crear una arquitectura radicalmente distinta". ${ }^{21}$ Tampoco entendemos desde aquí, la generación espontánea de corrientes arquitectónicas, independientes de la compleja realidad histórica, del pasado doméstico y la cultura nativa, inconexas con las necesidades de ruptura y corrección del rumbo. Esto es, abundancia y confusión de propuestas arquitectónicas obligadas a convenirse en el primer cuarto del siglo $x x$, compelidas a resolver el proceso de transición que supuso el XIX, a disputarse el epílogo de los

21 "Collins, situando hacia 1750 el origen ideológico del movimiento moderno, cumple un doble objetivo. Por una parte, completa la acción desmitificadora contra el origen próximo de la arquitectura actual. Por otra, al alejar en dos siglos el nacimiento de las actuales ideas arquitectónicas, prácticamente diluye este origen, planteándolo como una larga génesis de debates, intentos fallidos y experiencias múltiples"

de Solá-Morales Rubió, Ignacio. Octubre de 1969. Prólogo a la edición española de: Collins, Peter. "Los ideales de la arquitectura moderna; su evolución (17501950)". Editorial Gustavo Gili, S.A. Barcelona. 

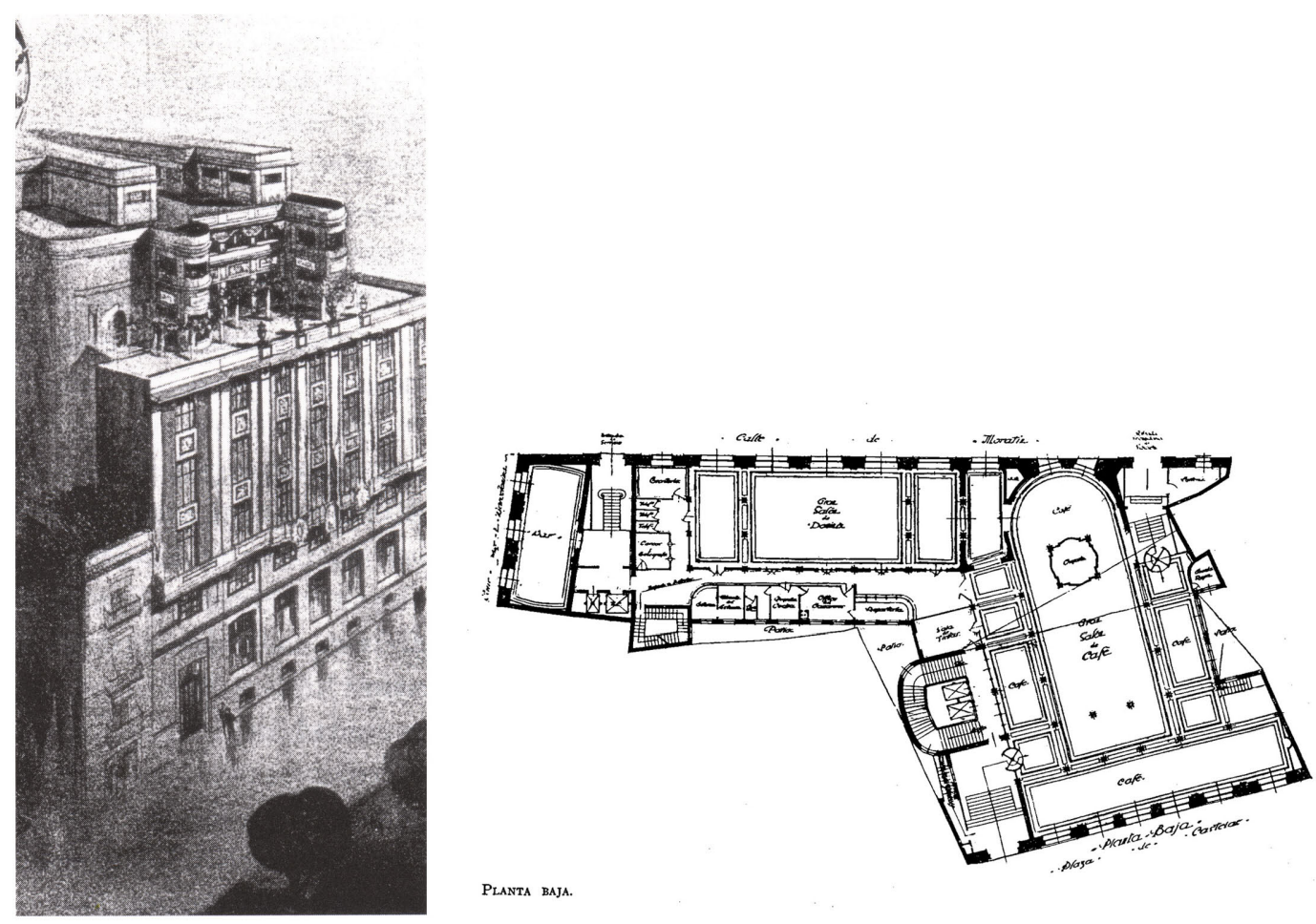

Planta baja.

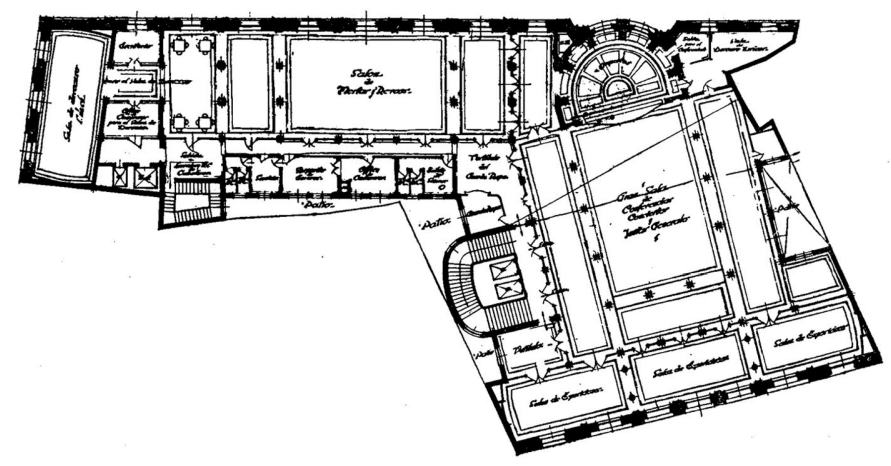

PLANTA PRINCIPAL. 
eclecticismos. Definitivamente, previo a la crisis de la visión espacial establecida y la autonomía de la mímesis -ambas anunciadas racionalmente- se requería un caldo de cultivo, unas corrientes arquitectónicas que allanaran la senda. Y una vez superadas, deberían cohabitar, disolviendo sus límites, en un proceso evolutivo lógico, continuado y próximo a la realidad. "La historia no es una compilación de hechos, sino una visión interior de un proceso vivo que va transcurriendo". 22

Intentando desenmarañar tan complejo proceso y ultimar así una mejor comprensión de los evanescentes lindes por los que devino el Movimiento Moderno, mantendremos la estructura del trabajo de Daniel Benito Goerlich ${ }^{23}$, precisando con idéntico rigor histórico: los precedentes, el desarrollo de las diversas etapas para historicismos y eclecticismo, sus diferentes acepciones transfiguradas, el modernismo como variante, la arquitectura de las exposiciones, para terminar entroncando la arquitectura valenciana en torno a los años 20 del siglo $x x$, con el llamado "estilo internacional" tan ecléctico en sí mismo como lo podía ser la arquitectura del XIX24. Avanzando una década, y retomando la estructura, posicionaremos el Movimiento Moderno, conviviendo con el eclecticismo internacional, el nacionalismo casticista y, entrelazado, con el Art Déco.

22 GIEDION, Sigfried. "Espacio, tiempo y arquitectura (El futuro de una nueva tradición)". Editorial Científico-Médica. Barcelona, 1968. Prólogo, p. $V$

${ }^{23}$ BENITO GOERLICH, Daniel. "La arquitectura del eclecticismo en Valencia. Vertientes de la arquitectura valenciana entre 1875 y $1925^{\prime \prime}$.

Editorial. Excmo. Ayuntamiento de Valencia, 1983.

${ }_{24}$ NAVASCuÉs, Pedro. Véase el prologo para la obra de Daniel Benito Goerlich. Ob. cit. p. XI 

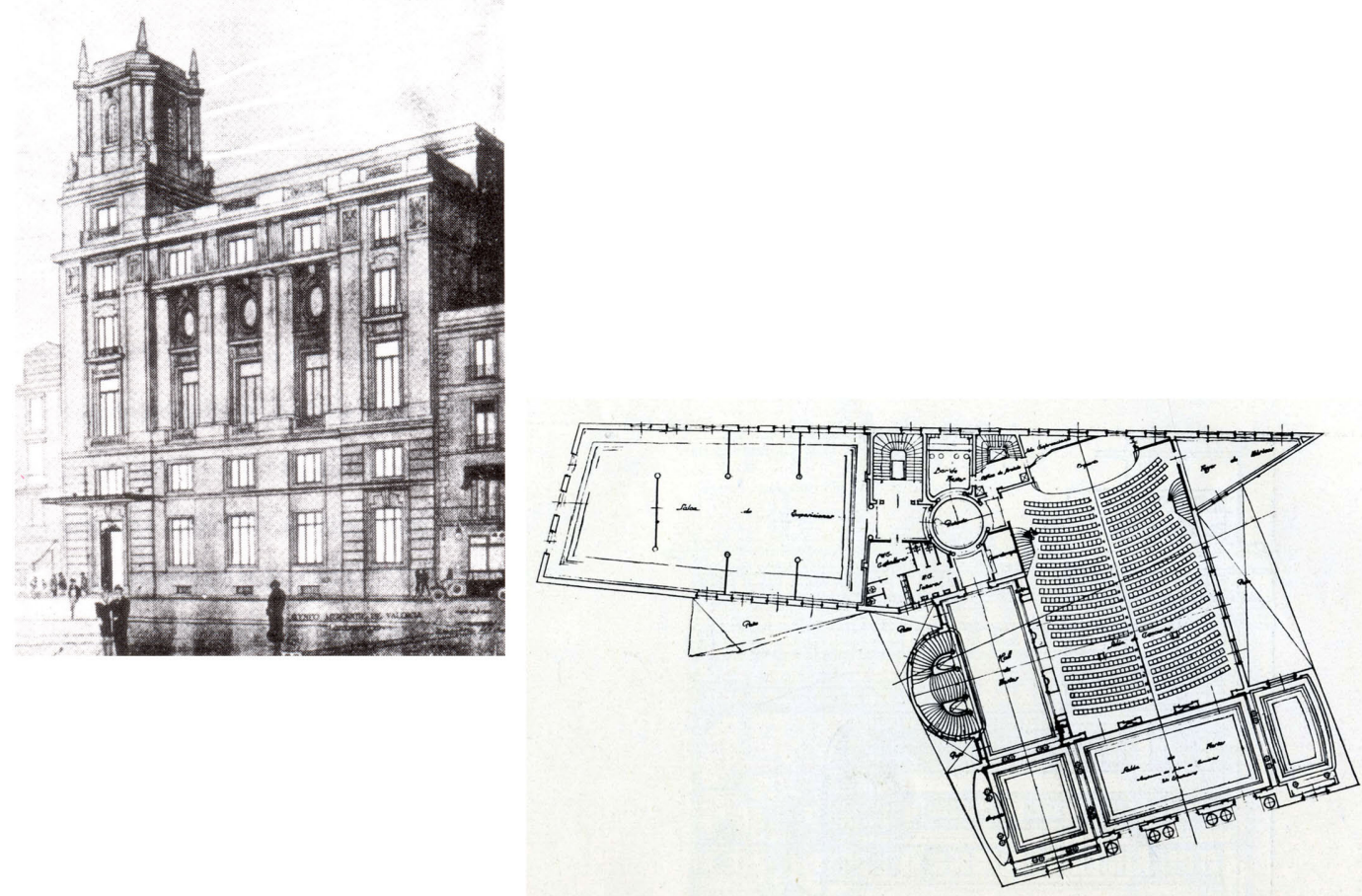

PLANTA SEGUNDA,

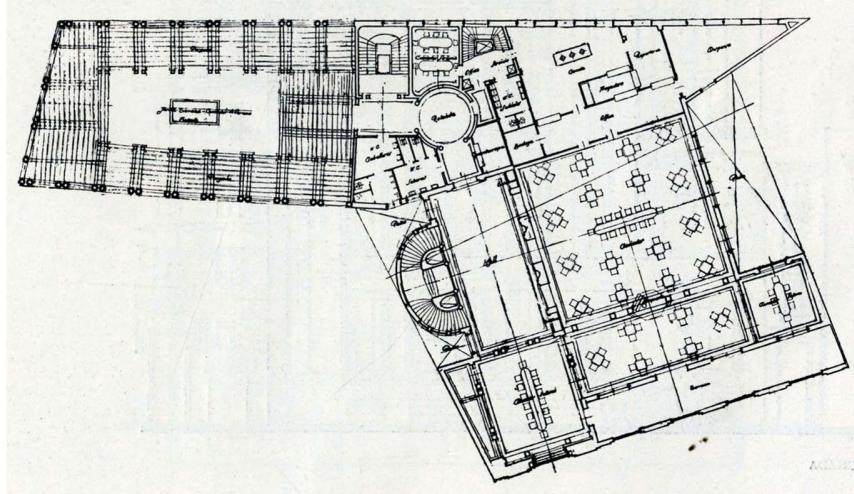

PLANTA gUiNTA.

Juan de ZABALA y José María RIVAS, 1927. Anteproyecto presentado al concurso Nacional convocado por el Ateneo de Valencia; clasicismo madrileño con influencia del proyecto de Secundino ZUAZO para el Círculo de Bellas Artes de Madrid 


\section{LA RENUNCIA DE LA HISTORIA}

"Siglo XIX", "romanticismo", "historicismo" resultaron términos empleados en negativo y sobre los que positivar el movimiento moderno. El vacío a vencer y sobre el cual saltaría la arquitectura moderna, pasando de una gran etapa -el Renacimiento- a la victoria del siglo XX25. Confinarían estos nombres, tan sólo, un proceso de transición ante la crisis de la arquitectura aferrada a la enseñanza Académica.

En buena lógica, de todas las artes, la arquitectura es aquélla que menos se presta a excluir la idea de racionalidad y es la que está más condicionada por la utilidad y la necesidad ${ }^{26}$. El evolutivo racionalismo planteado por Eugène Viollet-le-Duc -basado en la propuesta de síntesis entre el idealizado arte constructivo en la Edad Media y la incipiente tecnología del hierro- sustentado en los principios metodológicos de Descartes, fue aplicado como generador para la teoría de la nueva arquitectura del siglo XIX, como medio capaz de innovar ideas ajustadas a las necesidades de la época. Entre 1850 y 1909, el ROMANTICISMO preconizado por el teórico francés, fue la elección de las primeras promociones de arquitectos egresados de la Escuela de Madrid, y donde se acomodó e identificó la clase burguesa dominante. En Valencia esta corriente arquitectónica, se mimetizaría aunque sin asimilar su bagaje teórico e investigador y serviría

25 "Una de las acepciones más populares hace veinte años del término uarquitectura modernan era que significaba la victoria del siglo $x x$ sobre el Renacimiento, o, en otras palabras, sobre toda imitación de los estilos del pasado".

COLLINS, Peter. Ob. cit. p. 57

${ }^{26}$ COLQUHOUN, Alan. Véase Racionalismo: un concepto filosófico en arquitectura, en "Modernidad y tradición clásica". Editado por Jucar Universidad. Madrid, 1991 . 

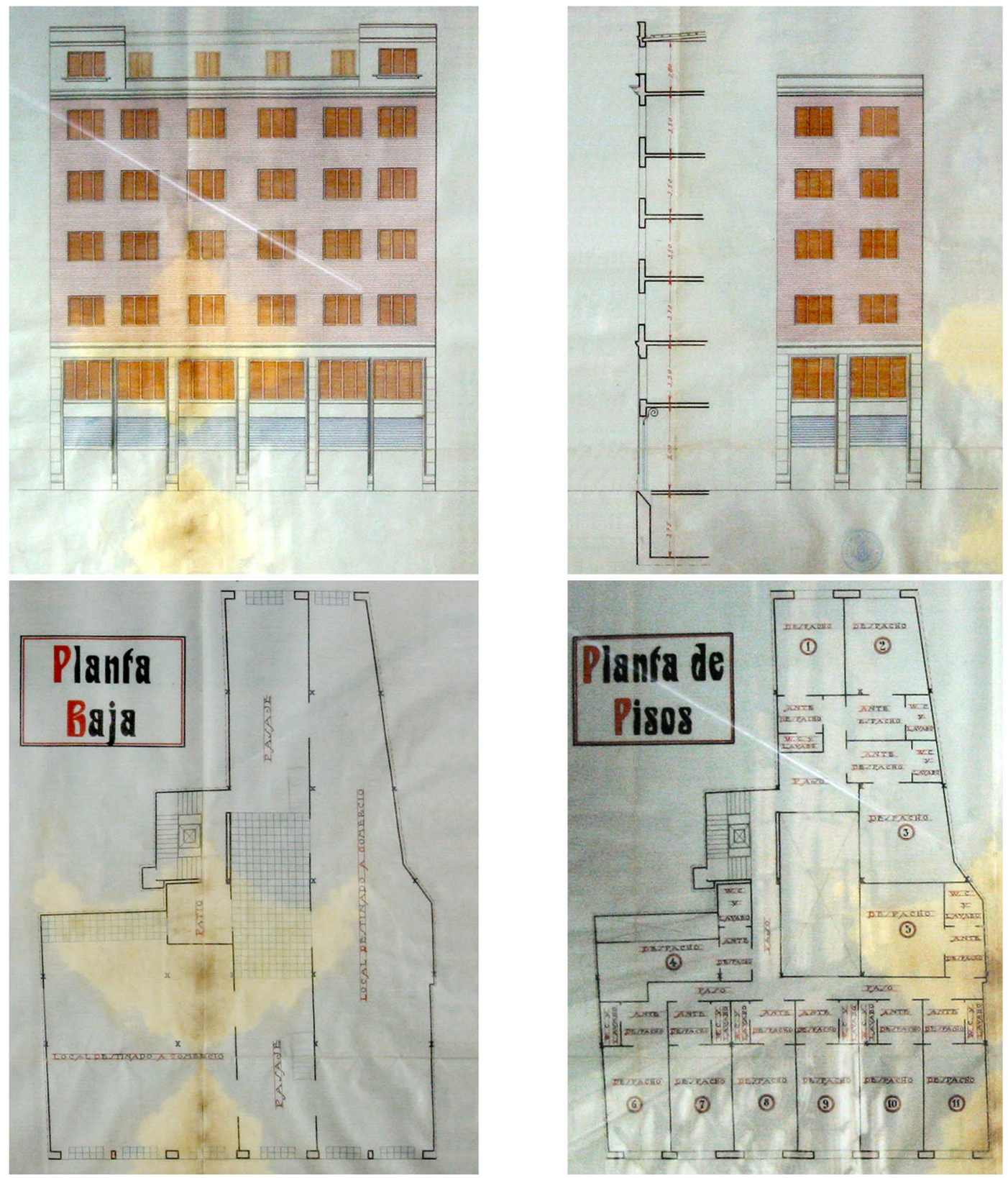

Francisco ALMENAR, 1929. Edificio despachos de alquiler para Joaquim ROVIRA, calles del Llop 10 y La Sangre 15: Archivo Histórico Municipal de Valencia (AHMV) Policia Urbana 33 
de excusa para excluir, definitivamente, el neoclásico promulgado desde la Academia de San Carlos $^{27}$.

Precisamente por este mimetismo y por el retraso que supuso su puesta en escena respecto a las vanguardias europeas, el romanticismo se desvirtuó rápidamente, ampliando a la totalidad de estilos históricos sus recursos formales. La senda bifurcaría, bien en la recreación del pasado magnificado -período señalado como HISTORICISMO-, bien combinando elementos de diversos estilos, deformando y estilizando en continua búsqueda de la nueva arquitectura contemporánea -ECLECTICISMO- sin atreverse a abandonar formas y movimientos históricos. Si el desarrollo de los historicismos y del eclecticismo resultó un intervalo, un paréntesis informe a la espera de un estilo propio, necesitaría de un proceso de sedimentación, de asimilación, de oposición y discernimiento. Una salida al aparente caos de tendencias contradictorias en el que se veían inmersos.

27 "La titulación de arquitectos y facultad de construir no fue mediatizada más que por la práctica hasta la llustración, con la creación de las Academias, de las que la de San Carlos de Valencia (1753) fue la segunda de España tras la de San Fernando (1744). A partir de 1768 la Academia Valenciana otorgó titulaciones, en principio equivalentes a las de los gremios, ciudades, tribunales o iglesia, y desde 1787 en carácter exclusivo, al ser declaradas como único organismo reconocido. Se transformaron en centros de estudio y de censura de proyectos (Junta de la Comisión de Arquitectura, 1789) -en aquel momento dirigida a salvar la pureza neoclásica y prohibir otros modos expresivos, como el barroco- que dura hasta que el propio desarrollo de su competencia y la necesidad de equilibrar la enseñanza académica con las nuevas técnicas, fuerzan la creación de las Escuelas de Arquitectura (Madrid 1844, Barcelona 1897)".

PEÑíN IBÁÑEZ, Alberto. Valencia 1874-1959. Ciudad, arquitectura y arquitectos. Escuela Técnica Superior de Arquitectura. Universidad Politécnica de Valencia. Valencia, 1978; cita 12, p.16. 


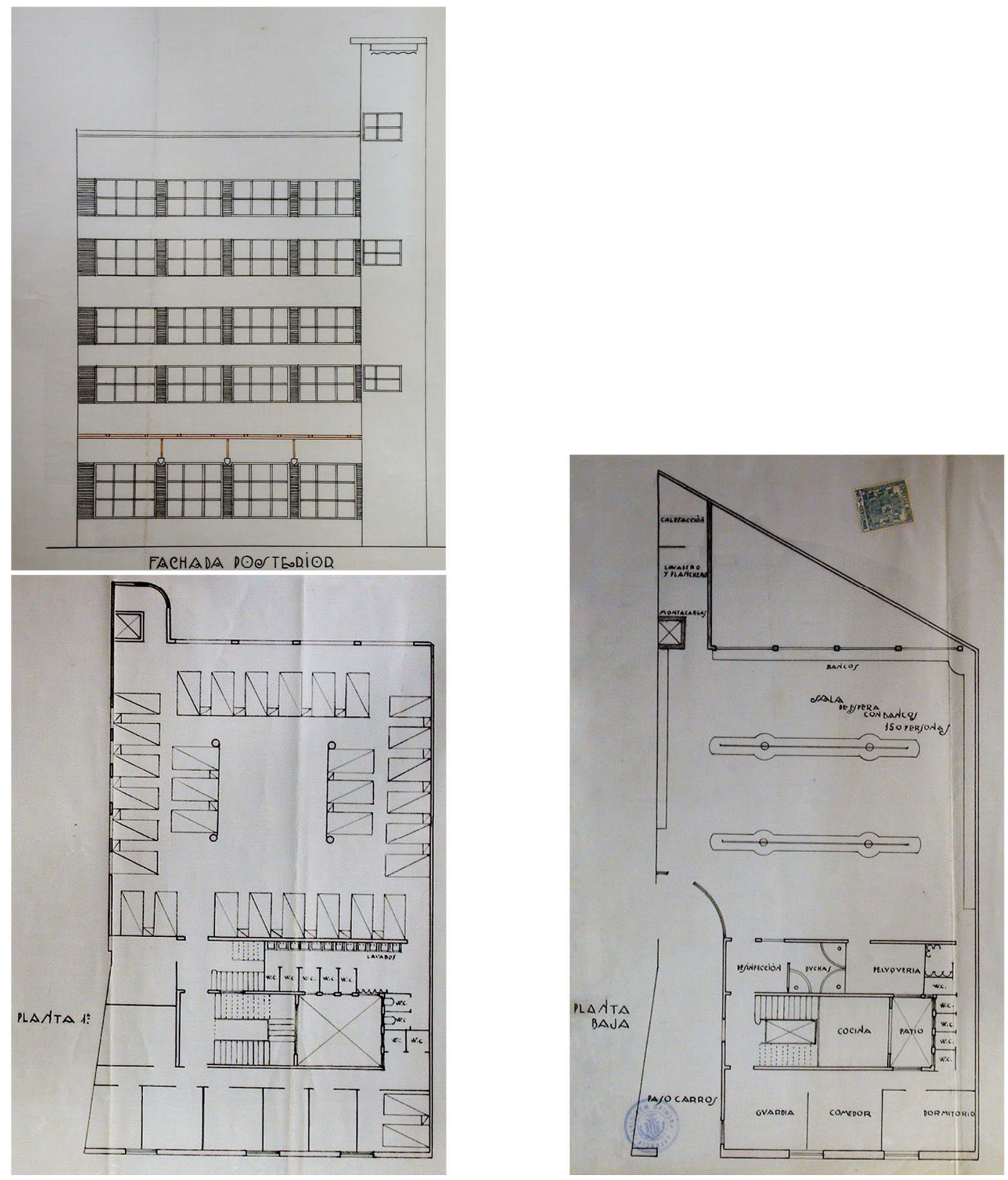

Francisco ALMENAR y José CORT, 1933. Albergue de la Asociación Valenciana de Caridad, paseo de la Pechina 11. Promotor Antonio NOGUERA; (AHMV) Ensanche, legajo 5 


\section{LA EXPOSICIÓN REGIONAL}

La Exposición Regional festejada en Valencia en 1909, se significó como una espléndida muestra del eclecticismo arquitectónico. Trascendería como uno de los hechos más relevantes hacia la modernidad en la urbe y la vida ciudadana. Supondría un compendio de estilos, una amalgama de motivos decorativos, de lujo y magnificencia, cosmopolitismo e internacionalidad. Este encantamiento excesivo por la decoración, junto con la versatilidad, casi promiscuidad obligada a nuestros profesionales autores -despertando la mala conciencia frente a los grandes estilos- cuestionaría la validez del Eclecticismo. El dilema de aproximar la disciplina arquitectónica a las artes, o posicionarse emparejándola con ingenieros, con la ciencia, precipitó su crisis. Europa daría por finalizada esta postura, con la aparición del Modernismo. Tras nuestras fronteras, sin embargo, se prolongaría bajo unas características diferenciadas, fundamentadas en la formación neoclásica de los arquitectos instruidos en la Academia y en las peculiaridades culturales, populares, vernáculas de árabes, mudéjares.

EI MODERNISMO supuso un movimiento romántico, individualista y antihistórico, basado en los diseños artesanales de William Morris y las teorías medievalistas de John Ruskin, con el que no se identificó la alta burguesía. Se difundiría entre 1890 y 1910 , por toda Europa bajo diferentes acepciones: Art Nouveau, Modern Style, Jugendstill, Sezessionsstill, Stile Floreale, Modernisme... El desarrollo industrial en Cataluña, sus ansias europeas y la crisis castellana de 1898, impulsarían a Barcelona como foco polarizador de cultura en el comienzo del nuevo siglo. Al contrario que en el resto del país, el Modernisme supone para la burguesía industrial catalana, con la mirada puesta en el poder central, una seña de identidad y la 

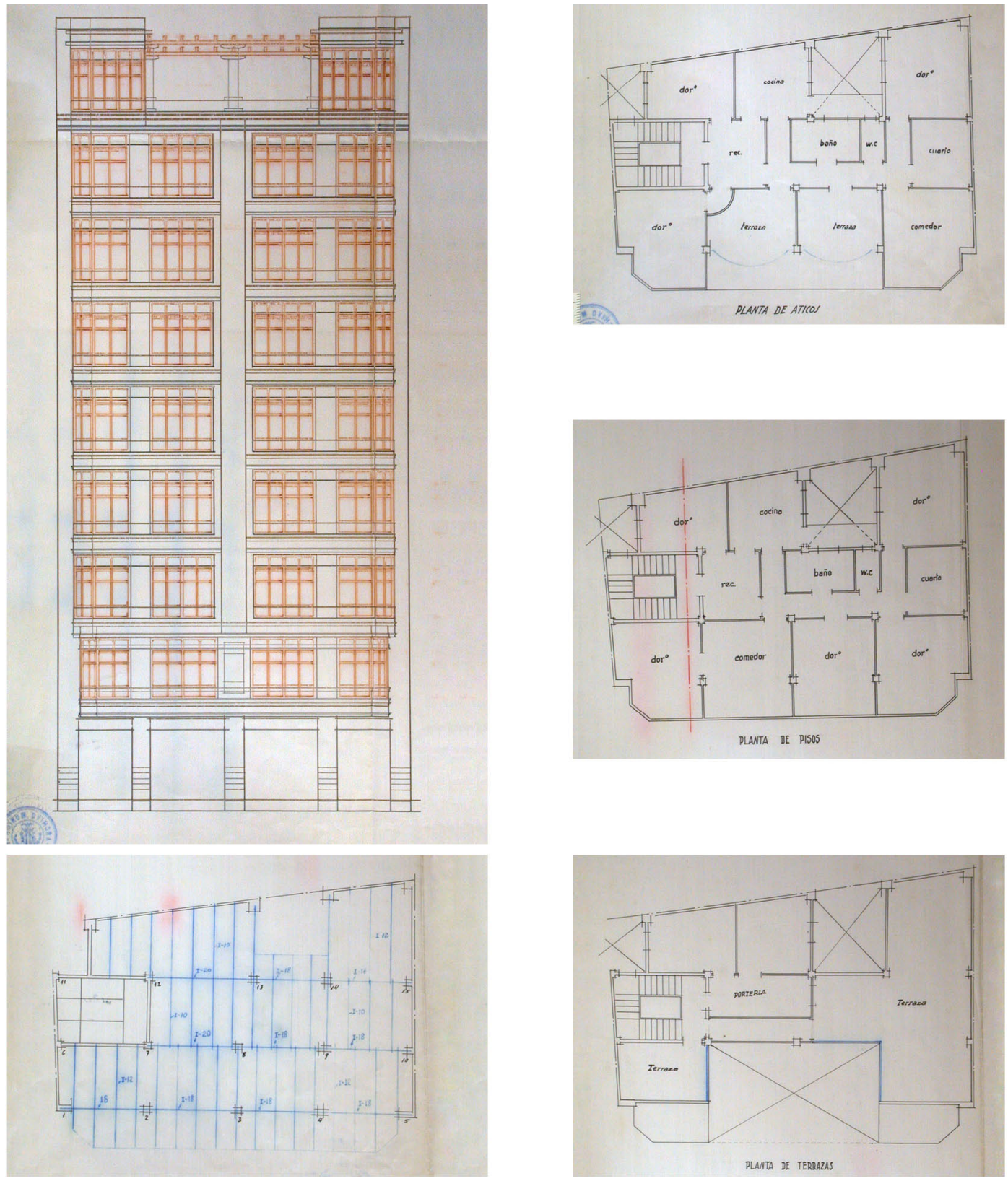

Emilio ARTAL, 1935. Edificio de viviendas para José MICó, gran vía Germanías 3; (AHMV) Ensanche, legajo 4 
reivindicación de una cultura propia conocida como Noucentisme. Más relajados en la provocación, llegarían a Valencia los primeros edificios modernistas, aceptados por una burguesía que se miraba en la catalana y recorría epatada las muestras de la Exposición Regional. Durante su breve espacio vital, se vería obligado a coexistir y competir con historicismos y eclecticismo, de los que tomaría los ingredientes esenciales.

Con bastante retraso había penetrado en nuestra ciudad y, a pesar de su auspiciada corta vida como vanguardia europea, alcanzó dilatarse más tiempo, atendiendo a la distinta procedencia de formación en sus profesionales. Bien observando lenguajes extensivos del repertorio ornamental ecléctico -aquellos adoctrinados en la escuela de Barcelona: Francisco Mora, Manuel Peris-, bien preservando referencias de Viena, de Otto Wagner y la Sezessión -Demetrio Ribes, Vicente Ferrer, encaminados desde la escuela de Madrid- siendo esta última la que finalmente arremetería contra el modernismo, por ornamental, iniciando la búsqueda hacia una arquitectura nacional, asociando un evidente matiz regionalista.

Demetrio Ribes -autor de edificios públicos modernistas en la ciudad de Valencia, tan reseñables como la Estación del Norte, y en parte del Mercado de Colón- debido a su personalidad y su coherente trayectoria, aportaría un nuevo punto de ambigüedad dentro del panorama extremadamente diversificado que supuso la evolución de la arquitectura valenciana, donde el grueso de profesionales continuaba sorbiendo su inspiración del Eclecticismo, decantándose según su formación por determinados lenguajes. "Los alumnos de Madrid lantes inclinados al Neogótico y Neoárabe) mostrarían una predilección hacia el racionalismo 

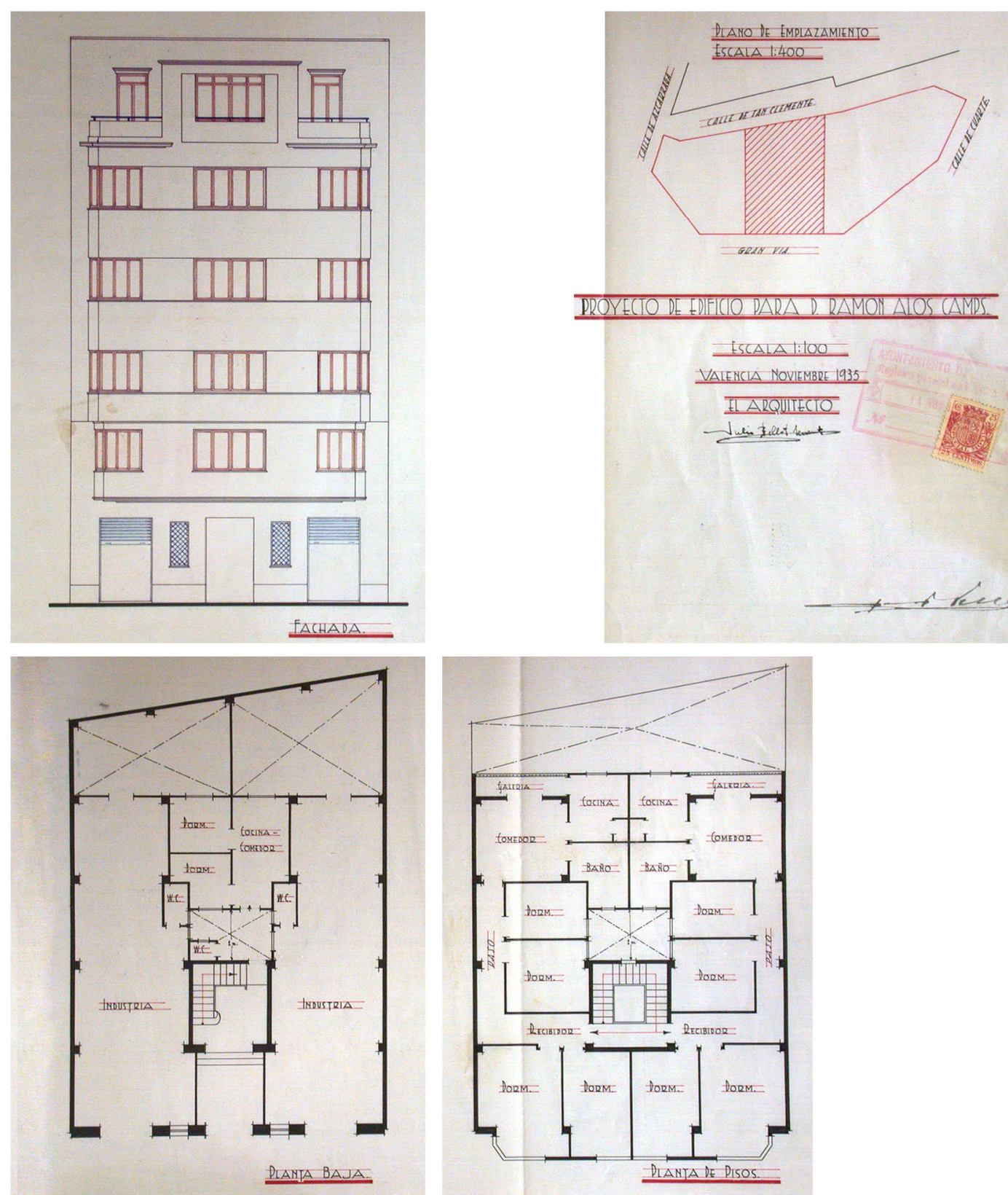

Julio BELLOT, 1935. Edificio de viviendas para Ramón ALós, gran vía Fernándo el Católico y calle de San Clemente: (AHMV) Ensanche, legajo 4 
constructivo que hemos llamado premoderno y cuyos resultados fueron más visibles en aquellas construcciones no ligadas a objetos significantes, y los de Barcelona (antes neorrománico) al Neobarroco y Neorrenacentista"28.

"Frente a la valoración del Modernismo valenciano, la etapa siguiente no ha merecido, hasta fecha muy reciente similar difusión". Con esta frase el historiador Javier Pérez Rojas29, posiciona la arquitectura acaecida en nuestra ciudad entre las décadas de los años veinte y treinta, apenas incluida en los manuales de la arquitectura española. Nada apareció comparable a toda aquella arquitectura que se compiló bajo el pseudónimo de Modernista, por lo menos eso es lo que se desprende del tratamiento dado a toda la arquitectura valenciana posterior a esta corriente de finales del siglo XIX. Pero su devenir no fue tan deslumbrante como para menoscabar los estilos predecesores, ni mucho menos eclipsar a sus coetáneos.

Quedaba pendiente una nueva forma de hacer arquitectura, contemporánea y esclarecedora del complejo panorama de ideas y tanteos que enmarañaban discursos. "El esplendor del Eclecticismo Internacional en Europa se caracteriza no por la revitalización de un estilo o una época, sino más bien por el propio sincretismo de estilos"30. Esta amalgama de

\footnotetext{
28 PEÑÍN IBÁÑEZ, Alberto. ob. cit; p.47

29 PÉREZ ROJAS, Javier. "Formas de la ciudad moderna. Neobarrocos, Decós y Aerodinámicos". Catálogo de la exposición La ciudad moderna. Arquitectura racionalista en Valencia. IVAM Institut Valencià d'Art Modern, 1998; p. 7.

30 SERRA DESFILIS, Amadeo. "Eclecticismo tardío y art déco en la ciudad de vaIencia. 1926-1936". Ayuntamiento de Valencia. Valencia, 1996; p.19.
} 

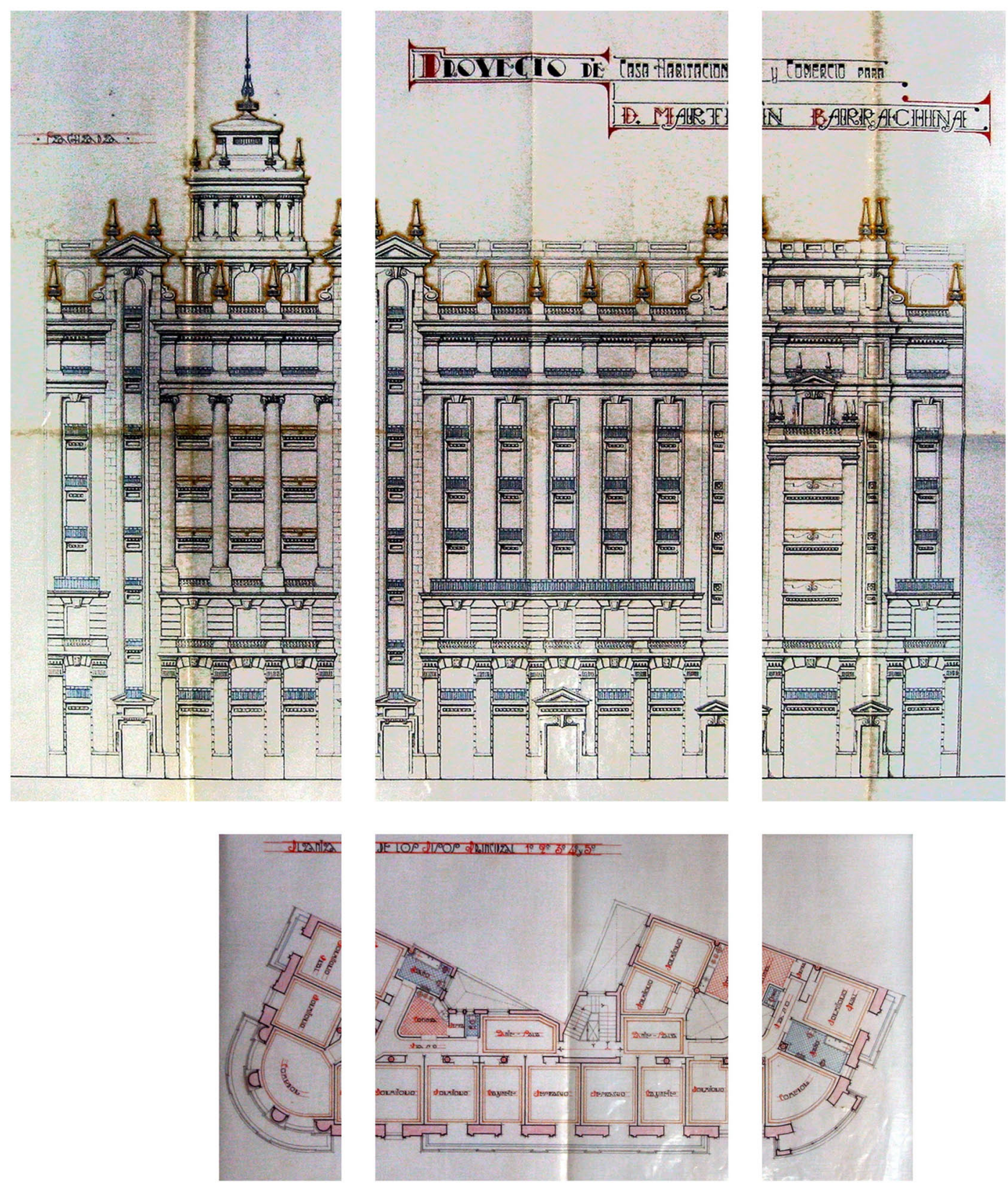

Cayetano BORSO, 1929. Edificio de viviendas para Martín BARRACHINA, plaza de Emilio Castelar (actual del Ayuntamiento), calle del Llop: (AHMV) Centro Histórico 
elementos, reunidos en un excesivo encantamiento decorativo, adscritos al lujo y la modernidad, al cosmopolitismo y la internacionalidad, instruidos en versátiles autores capacitados para erigirlos, alterarlos con arrogancia o desconocimiento suponía un exhaustivo conocimiento del repertorio académico y Beaux-Arts y su combinación en una misma creación, bajo ningún pudor estético. Amanecía una "mala conciencia" de los arquitectos frente a la gran Arquitectura ${ }^{31}$ y en aquella reclamada búsqueda por una nueva forma de hacer, los ingenieros profirieron otra hendidura en la concepción la Arquitectura, asombrando con el empleo de materiales, especialmente el hierro y el cristal.

La acuciante exigencia de una nueva arquitectura que reflejase los espectaculares avances técnicos y constructivos del siglo, se adhiere al propio carácter de provisionalidad, para iniciar una crisis prematura que se perpetuó durante el primer cuarto del siglo $x x$, hasta su desplazamiento definitivo tras la acometida del racionalismo. En España el ritmo de la industrialización fue visiblemente menor, lo que no favoreció las profundas transformaciones económico-sociales que en el resto de la Europa occidental fomentaron el caldo de cultivo para una nueva arquitectura. El descontrolado incremento en altura de los inmuebles, las imperiosas mejoras higienistas que buscaban aumentar la superficie de los huecos de fachadas persiguiendo luz y ventilación, y los ya comentados avances constructivos, erosionaron el lenguaje formal, su ornamento y, en definitiva, el sistema compositivo académico. Tampoco ayudaba el exceso de ornamentación, en la rapidez de construcción para responder ante la elevada demanda de viviendas. Cabe reseñar como efecto en esta crisis,

31 BENITO GOERLICH, Daniel. ob. cit. p. 123 


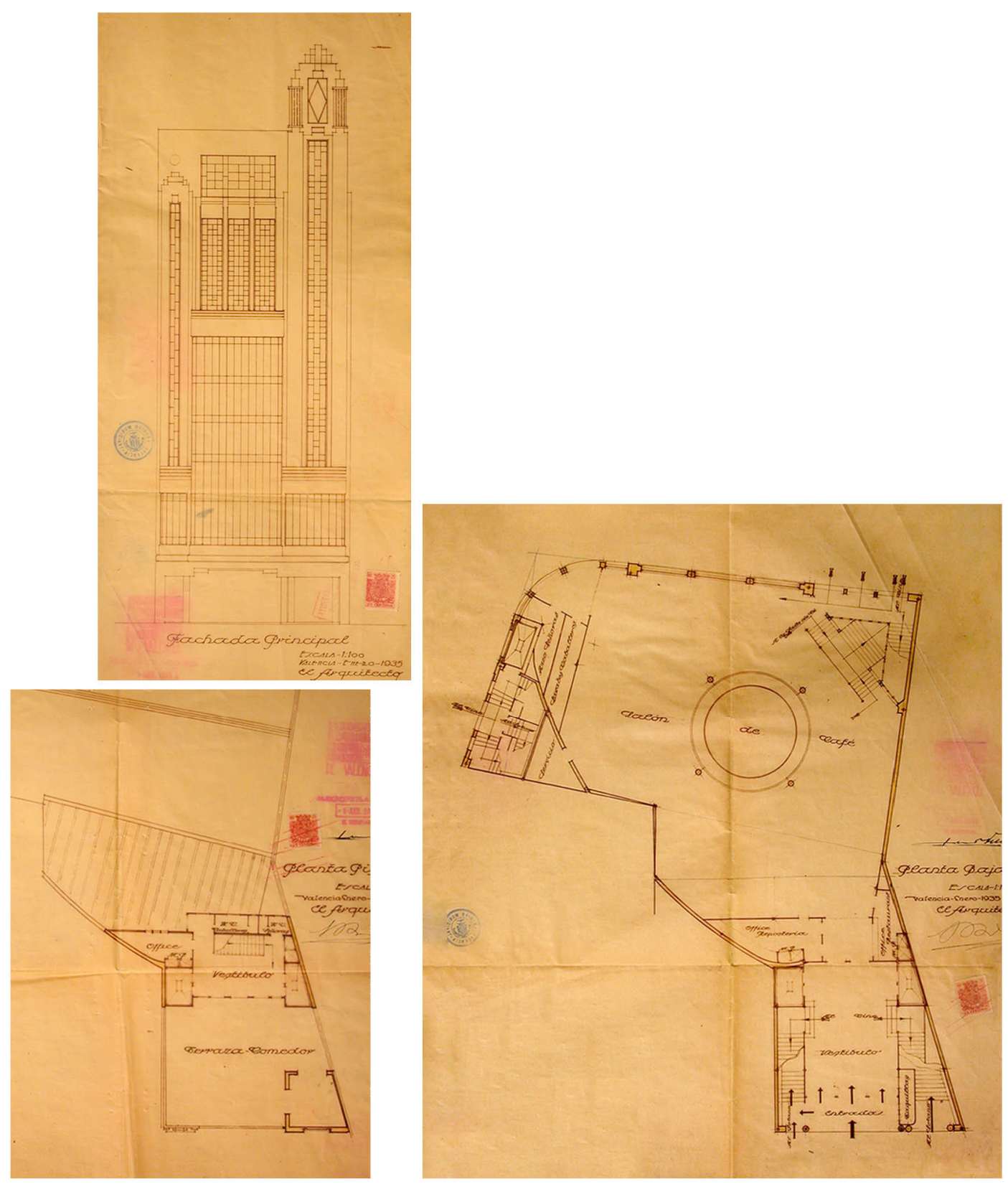

Cayetano BORSO, 1935. Cine Rialto para Vicente LASSALA, alzado plaza Emilio Castelar hoy del Ayuntamiento, plantas Ático y Baja; (AHMV) Policía Urbana, legajo 5b 
la constante común de todos los estilos que convivieron con el Eclecticismo Internacional: la oposición de todas las arquitecturas modernas al Academicismo. Los profesionales valencianos, en su mayoría, reaccionaron adaptándose a la situación, manteniéndose en un Eclecticismo cultural $y$, concentrando su interés en el rigor y el oficio por la obra bien ejecutada.

EL PARÉNTESIS DICTATORIAL PREVIO A LA REPÚBLICA

La coyuntura política acaecida en España tras la Dictadura del general Primo de Rivera en 1923, favoreció la concreción de una ARQUITECTURA NACIONAL o regionalista. Un contexto de exaltación nacional transferido vertiginosamente a nuestra arquitectura. Resurgiría el espíritu generador, la constante oposición al Academicismo, esta vez ecléctico, en la medida que supuso una reacción en contra de cualquier influencia extranjerizante, un enfrentamiento con el Eclecticismo Internacional que estaba alcanzando su máxima influencia en la primera mitad de los años veinte.

Acaeció el VI Congreso Nacional de Arquitectos, celebrado en 1915, y precisamente San Sebastián albergaría la cuestión de un estilo popular y 

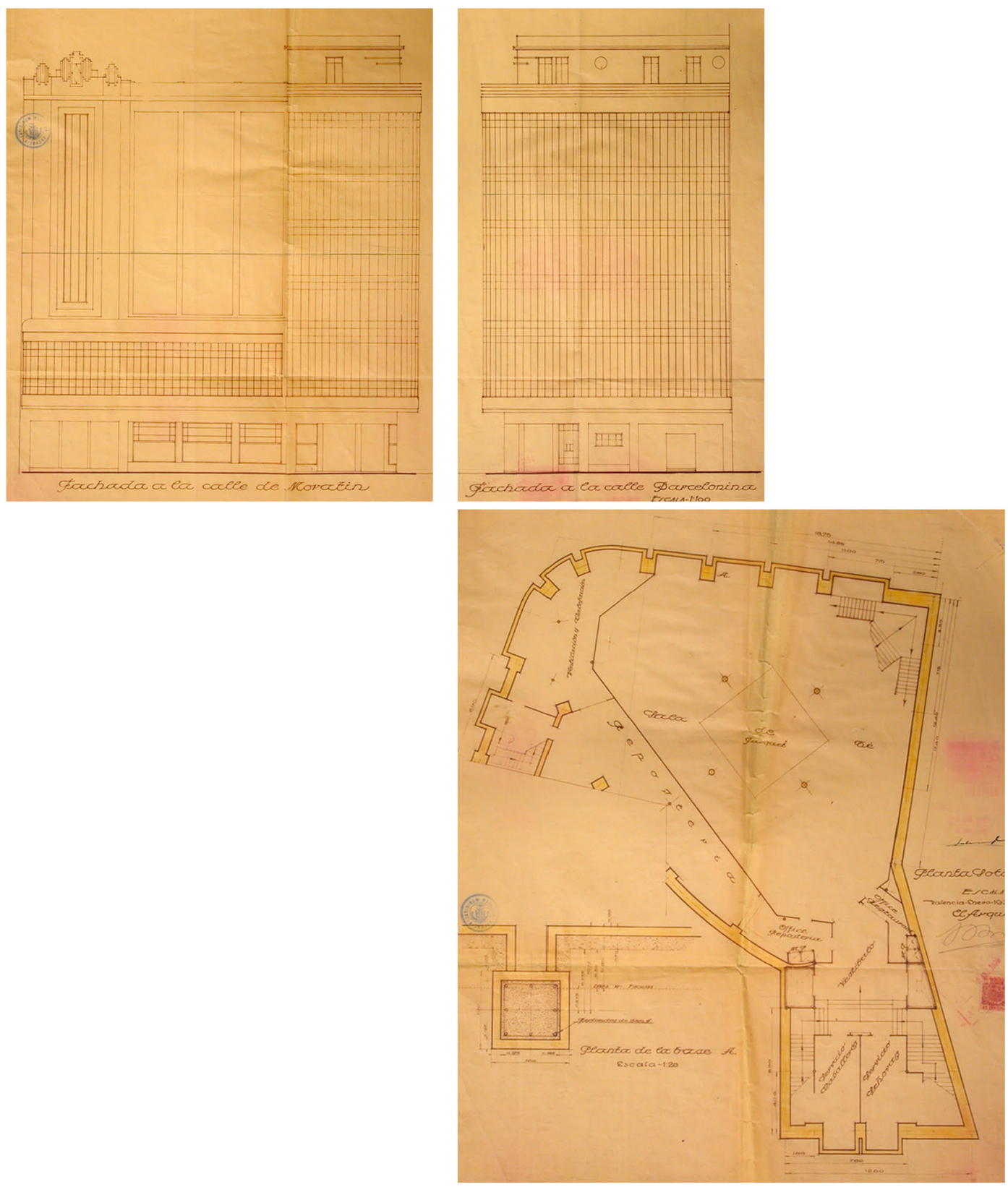

Cayetano BORSO, 1935. Cine Rialto para Vicente LASSALA, alzados a calle Barcelonina y Moratín, planta Sótano: (AHMV) Policía Urbana, legajo $5 b$ 
tradicional, mientras en Alemania, y tan sólo cuatro años atrás, Walter Gropius con la fábrica Fagus elaboraba los cimientos del movimiento moderno, plasmados en 1914 erigiendo el pabellón de la Werkbund para la Exposición de Colonia. La trasnochada polémica patria, surgiría entre la ponencia oficial presentado por Leonardo Rucabado, que abogaba por una arquitectura nacional basada en nuestros estilos históricos, alejada de academicismos extranjerizantes y, la opción del racionalismo constructivo defendida por Demetrio Ribes, abalada por una intachable coherencia en su evolución ideológica, refutada a su vez por obras como los Almacenes Ferrer o la casa Pérez Pujol. Si hay un arte nacional, afirmaría, "pero es aquel en el que trabajamos todos los arquitectos españoles" y, tras agrias réplicas, alegaría libertad de creación sin dirigismos.

Carlos Flores ${ }^{32}$ distinguió dos vertientes dentro de la arquitectura nacional. Aquella que bebía en las fuentes del Renacimiento y el Barroco españoles para cantar las excelencias de nuestra gran arquitectura de otros tiempos, tan favorable al nuevo régimen dictatorial y, por otra parte, el tradicionalismo casticista como yuxtaposición de las diversas arquitecturas regionales.

Valencia tributaría atención al Casticismo, con el acostumbrado retraso, con el escepticismo que favorece la distancia y desde un prisma más próximo, regionalista, asumiendo el estilo vernáculo en el Neobarroco. Francisco Mora, había anunciado su capacidad regionalista, casi arqueológica y mimética con el Palacio Municipal para la Exposición Regional

32 FlORES López, Carlos. Arquitectura española contemporánea. Aguilar. Bilbao, $1961 ;$ p.72 

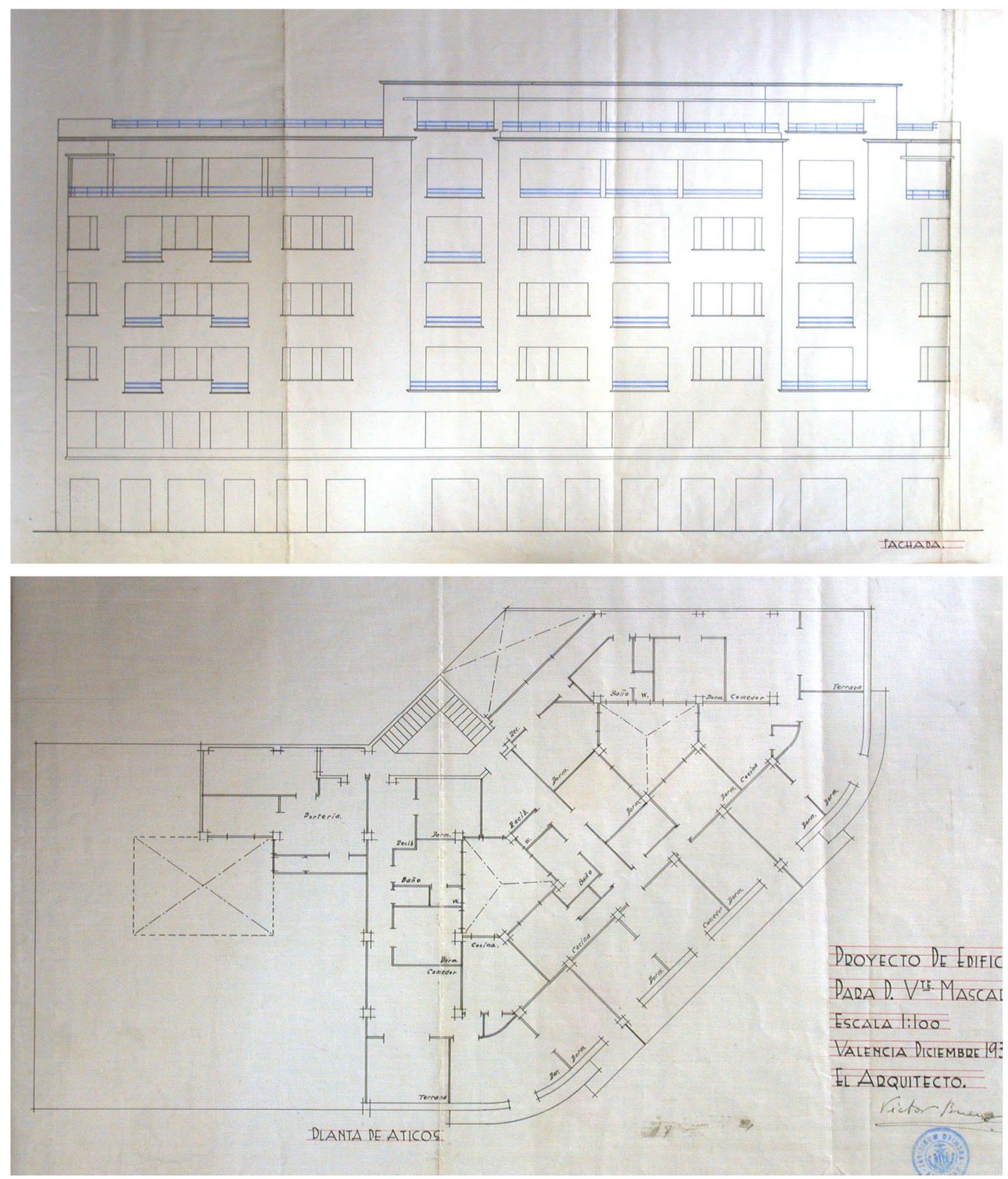

Víctor BUESO, 1935. Edificio de viviendas para Vicente MASCARELL, gran vía Ramón y Cajal, calle 59 del Plan (hoy Calixto III): (AHMV) Ensanche, legajo 7 
de 1909. Posterior paradigma erigiría como Mercado en 1916, y su repertorio casticista alcanzaría cierta integridad en el Banco Hispano Americano de 1923.

La crisis económica internacional de 1929, la consumación de la Dictadura y el nuevo clima de autonomía propiciado por la II República favorecerían el regionalismo arquitectónico valenciano. Reseñables arquetipos resultarían el Instituto Nacional de Previsión de Enrique Viedma, la Caja de Ahorros de Antonio Gómez Davó y el tardío Banco de Valencia de Javier Goerlich junto con Francisco Almenar, Gómez Davó y Vicente Traver. La incapacidad de la burguesía valenciana, ostentadora del poder, en afrontar una personalidad propia, exenta de tópicos y mimetismos, así como también la arribada forzosa de población obrera y asalariada se irían reflejando sucesivamente en nuestra ciudad. Esta etapa casticista, de inspiración localista y que terminó atada al Neobarroco, se perpetuaría por toda la República, resurgiendo otrora tras la Guerra Civil.

\section{UNA EXPOSICIÓN INTERNACIONAL}

La Exposición de las Artes Decorativas de París en 1925, fue consensuada como punto de inicio del ART DÉCO, estilo interpretado como la corriente más representativa del arte decorativo -hasta su ocaso en la década de 

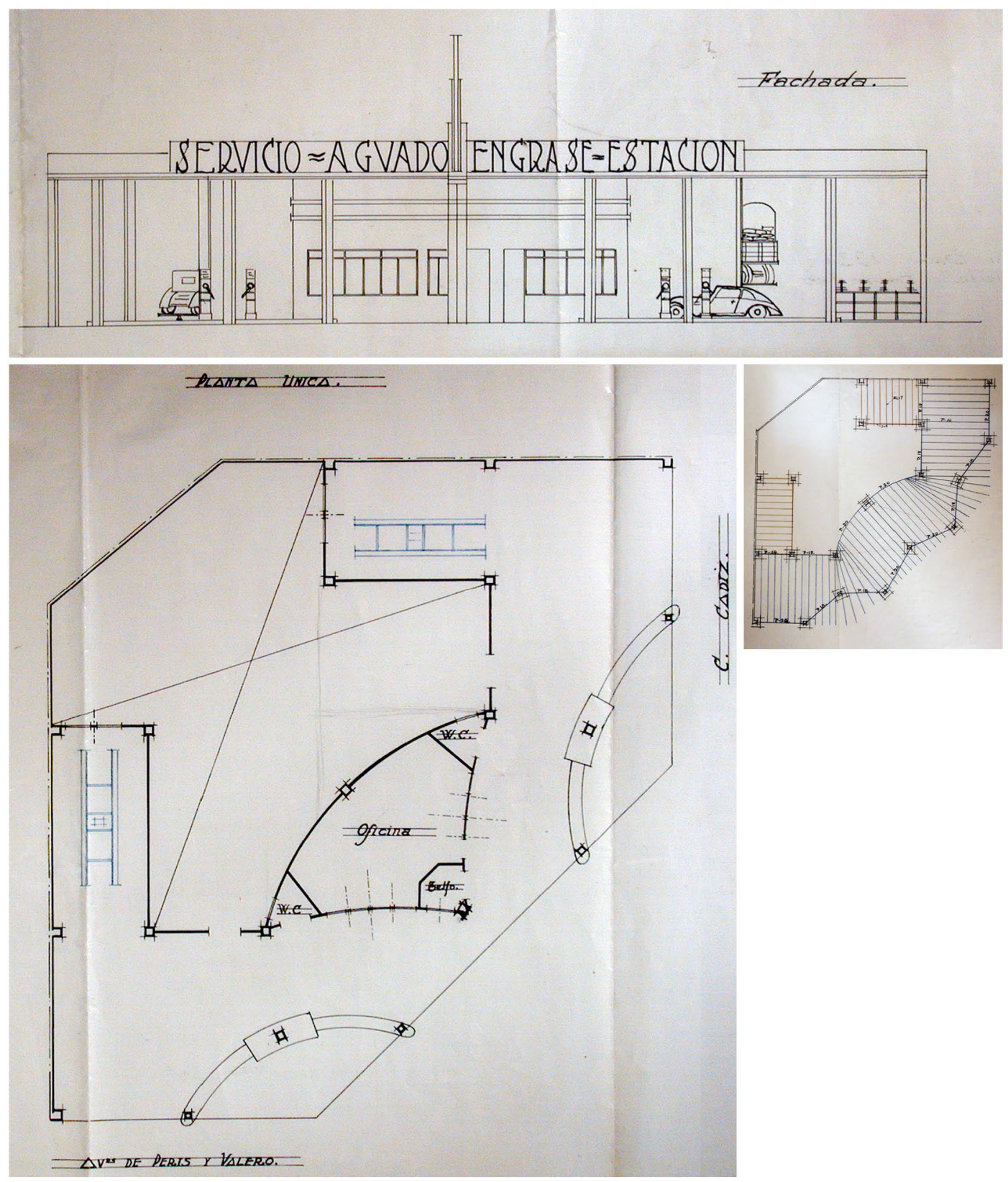

Manuel CERVERA, 1936. Estación de servicio para Automóviles Luis AGUADo, avenida Peris y Valero, calle Cádiz: (AHMV) Ensanche, legajo 1 
los años treinta- e influyente en la suma de las artes. Aunque el término no se manifestaría como tal hasta 1966, en la exposición retrospectiva sobre Les Années $25^{33}$, si bien, y con dos décadas de adelanto, un grupo de artistas, entre ellos los arquitectos Josef Hoffmann y Eero Saarinen, ya habían instituido las bases de la estética Art Déco. Supondría, para la colectividad de los profesionales ilustrados durante la supremacía ecléctica, el principio desde el cual fundamentar y emprender una cultura moderna, un nuevo estilo vital, moderno.

Nuevamente se apelaría a la constante de oposición al Clasicismo, a los Historicismos, para liberar las ansias de una arquitectura contemporánea. "Lo que no podían notar los pioneros del Movimiento Moderno, tanto por falta de perspectiva histórica como por su jacobinismo cultural, era la contribución del Art Déco a la quiebra del espíritu académico. Es de notar, una vez más, el papel desempeñado por el art déco como solución transitoria y de compromiso entre el Eclecticismo tardío de raíz decimonónica y el Racionalismo"34.

Despreocupado y jovial, geométrico y lineal, fue abrazado con ímpetu por la sociedad europea de los felices años veinte. Navegando entre aguas convulsas, las radicales vanguardias, no obstante sin descuidar la segura ribera del buen gusto tradicional, lograría regenerar las artes decorativas y la arquitectura, sin definir un estilo propio del Xx. No supuso entonces, la pretendida ruptura con la ecléctica arquitectura decimonónica,

${ }^{33}$ El título completo de la muestra era Les Années 25. Art Déco. Bauhaus. De Stijl. Esprit Nouveau. Catálogo correspondiente publicado por el Museo de Artes Decorativas. París, 1966. Cita extraída de PÉREZ RO JAS, Javier. ob. cit. p.20

34 SERRA DESFILIS, Amadeo. op. cit; p.116 

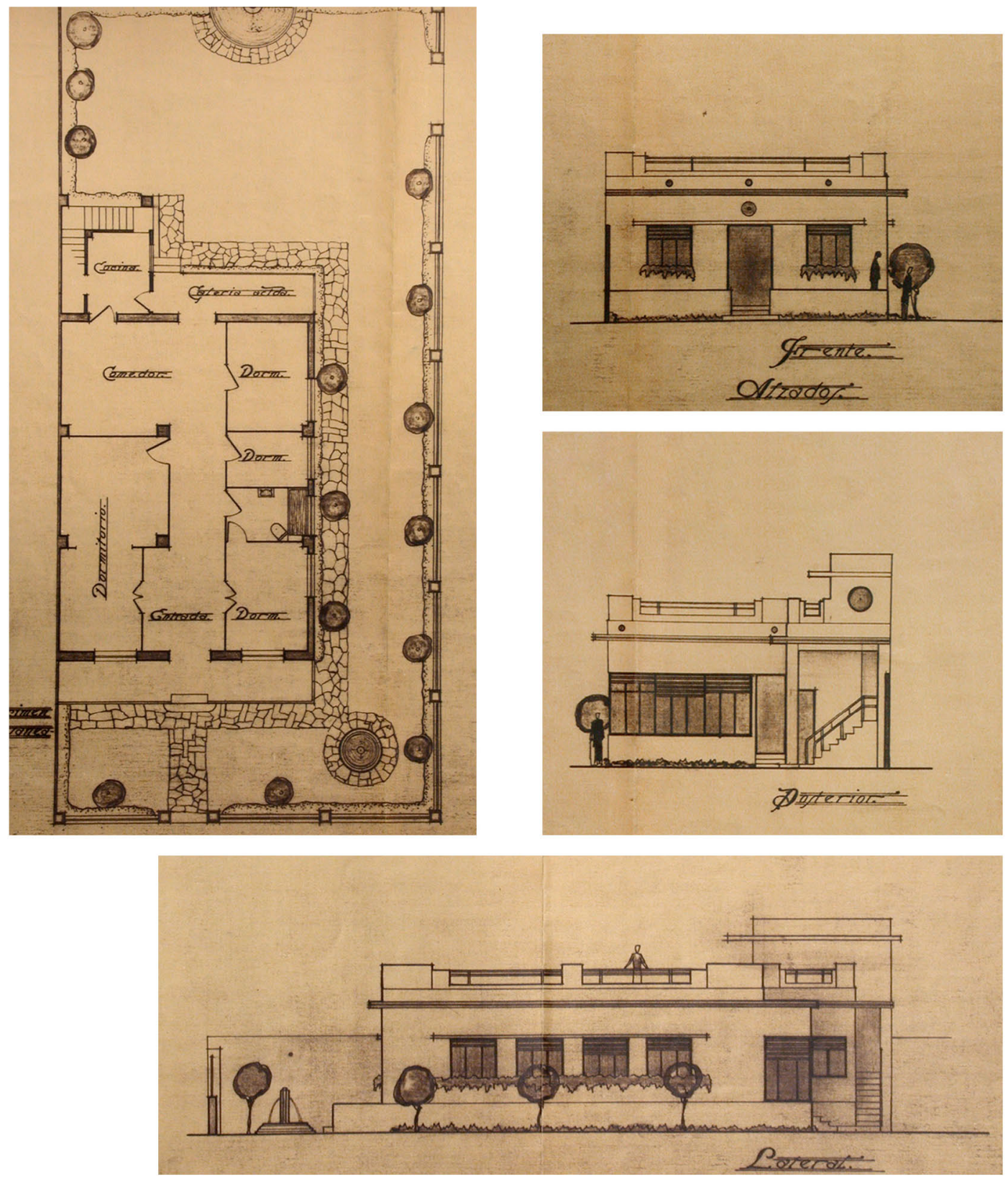

Salvador DONDERIS, 1935. Vivienda Unifamiliar para Manuel FERRANDO, calle Libertad 33 , Benimamet; (AHMV) Policía Urbana, legajo 2 
aunque tampoco un nuevo concepto de arte. En una época tan diversificada, donde coexistían y se relacionaban diversas concepciones arquitectónicas, intercambiando recursos formales, resultaría la valía del art déco de su ánima contemporánea, abierta e integradora, capaz de aglutinar y reconducir al resto de corrientes artísticas.

Una arquitectura con decoraciones geométricas, con un repertorio iconográfico ornamental característico. Una arquitectura de síntesis y abstracción en los elementos compositivos, estilización formal, con una primera génesis basada en el orden y la verticalidad de ejes en fachada. Una naturaleza no excluyente que supondría, en algunos casos, una incorporación al conjunto de repertorios eclécticos en la decoración de fachadas, en otros, la alternancia de los regionalismos en que andaban impregnados los arquitectos valencianos, e incluso la pacífica convivencia con el combativo espíritu del Movimiento Moderno. Algunos envolvieron sus construcciones, a lo largo del ensanche, bajo los recursos que el Art Déco les permitía, otros como Luis Albert y Cayetano Borso acudieron en innumerables ocasiones al trabajo de artistas déco para dulcificar las escuetas y rigurosas imposiciones del racionalismo en sus fachadas más vanguardistas. La influencia de la Escuela de Ámsterdam confluyó en la raíz déco para dejarnos de la mano de Enrique Viedma una de las obras valencianas más emblemáticas, la Finca Roja en la calle Jesús, de 1929. La figura de Berlage, también resultó legible en la obra del arquitecto Joaquín Rieta, uno de los más destacados por su trabajo meticuloso, cuidado, sensible y conciliador con el entorno, por su síntesis regionalista y Art Déco, de todos cuantos trabajaron en nuestra ciudad. El edificio Gil, en la plaza del Ayuntamiento, de 1931 y, sobre todo, el cine Capitol 

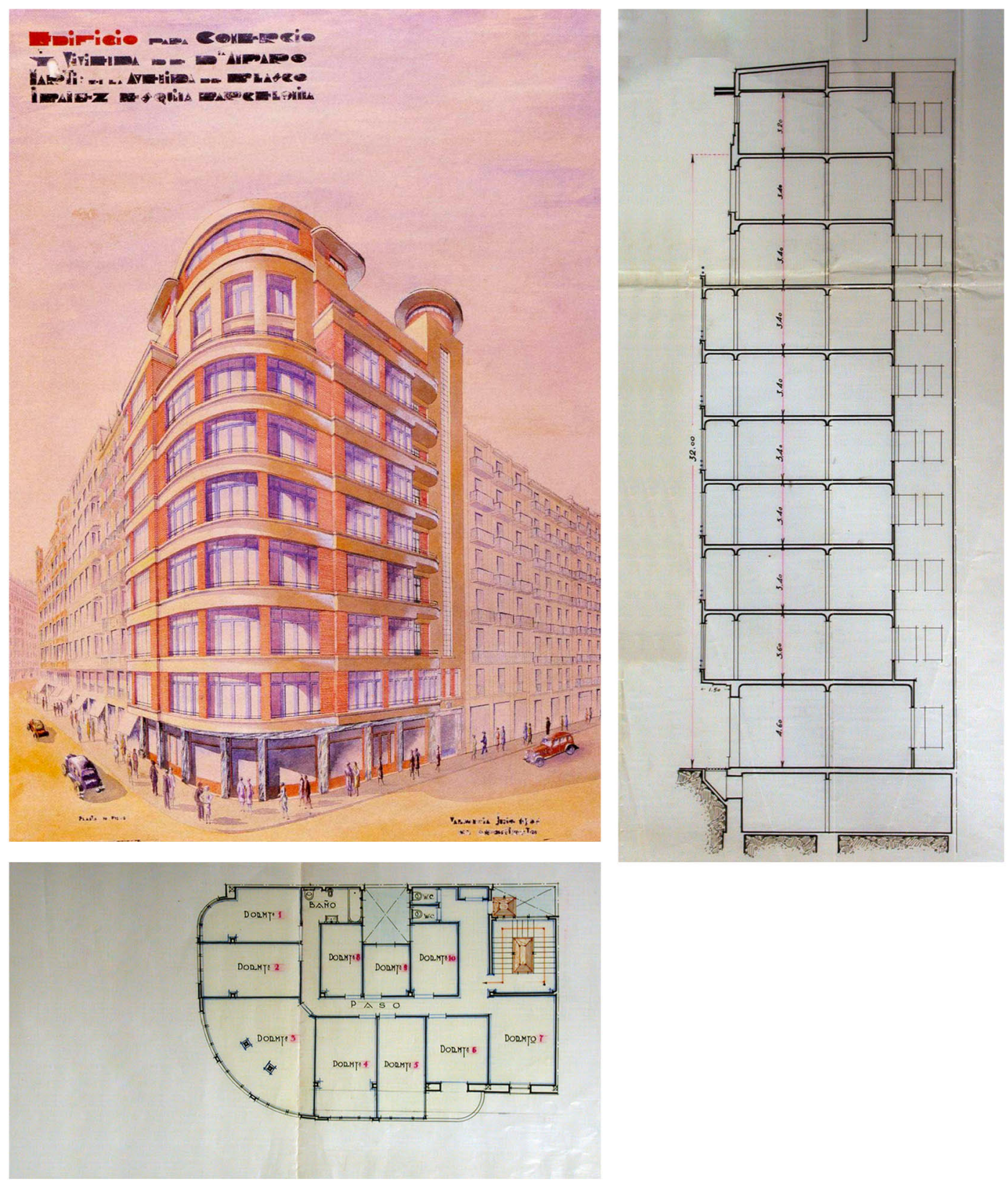

Javier GOERLICH, 1933. Edificio para comercio y vivienda (Hotel Londres) para Amparo MARTI, avenida de Blasco lbánez y calle Barcelonina: (AHMV) Policía Urbana, legajo 3 
de 1930, resultaron unos excelentes ejercicios de composición rígida, reticulada y geométrica, realizadas con ladrillo.

\section{UN COMPENDIO DE ESTILOS}

"A finales de los años veinte y durante los treinta, se desarrolló un eclecticismo de lo moderno, una síntesis de nuevas formas que inauguran un período de la arquitectura valenciana bajo el signo de un internacionalismo que se impone en la misma vida cotidiana"35. Cita de Javier Pérez Rojas que junto con Amadeo Serra Desfilis califican esta época bajo el apelativo de Eclecticismo tardío. Apuntaría como corriente de expresión mayoritaria, en un mar convulso surcado por multitud de estilos arquitectónicos -opuestos a su raíz clásica y academicista-, compartiendo ciudad y profesionales, incluidos Casticismos, Art Déco, a más del tardío y suavemente adoptado Movimiento Moderno.

35 PÉREZ ROJAS, Javier. ob. cit; p.21 

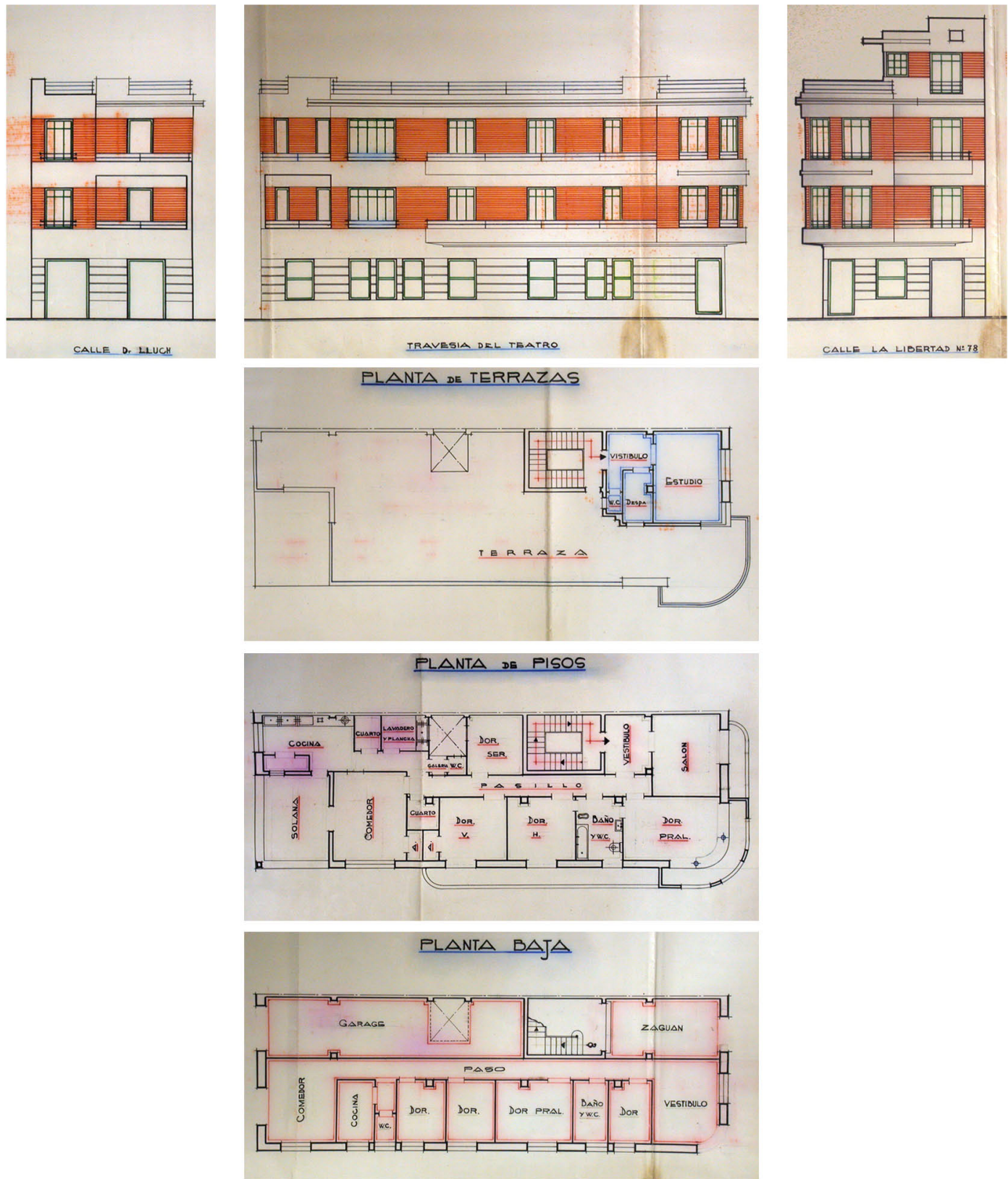

Javier GOERLICH, 1935. Vivienda Unifamiliar para Rafael VALLS, calles Libertad, travesía del Teatro y Doctor Lluch, El Cabanyal: (AHMV) Policía Urbana, legajo 9 
Evocaría, esta versión del Eclecticismo, un reencuentro con el orden, con las reglas clásicas y la nueva práctica constructiva, la simplificación de elementos formales clásicos hasta reducirlos a sus formas primarias básicas, inmersas en una retícula de líneas ortogonales abstracta, donde incorporar una rigurosa y espartana decoración. Supondría el preámbulo para la llegada del Racionalismo, y la valía como estilo residía en su misma transitoriedad. El edificio de los almacenes Ernesto Ferrer en la plaza de Rodrigo Botet, estuvo considerado, dentro de la arquitectura valenciana y previamente a su impune demolición, como el primer edificio prerracionalista. Racional en cuanto al método, y estricto en todo lo referente a sus planteamientos, Demetrio Ribes enfatizó la estructura en fachada, en una ordenada y potente retícula de hormigón armado, mostrándonos una vez más, su conocimiento y actualidad en el uso de las modernas técnicas constructivas.

La diversidad de estilos con los que convivir, aportó un espíritu renovador a nuestras ciudades, aquellas mismas donde empezaban a coexistir Regionalismo, Eclecticismo Internacional, Art Déco y las primeras propuestas del MOVIMIENTO MODERNO. Las exposiciones iberoamericanas de Sevilla y la internacional de Barcelona de 1929 narraron perfectamente esta situación descrita, el sincretismo de la época moderna. Junto a la construcción del Pueblo Español y otros edificios historicistas, apareció el Pabellón de Alemania de Mies van der Rohe, que pasaría totalmente desapercibido hasta padecer, lamentablemente, su posterior demolición.

Y como nada se muestra inmediatamente desde lo oculto, tampoco lo moderno tuvo una gestación sin anuncio, ni supuso una revolución sin premisas, más bien necesitaría de varias décadas, de una coherencia como 

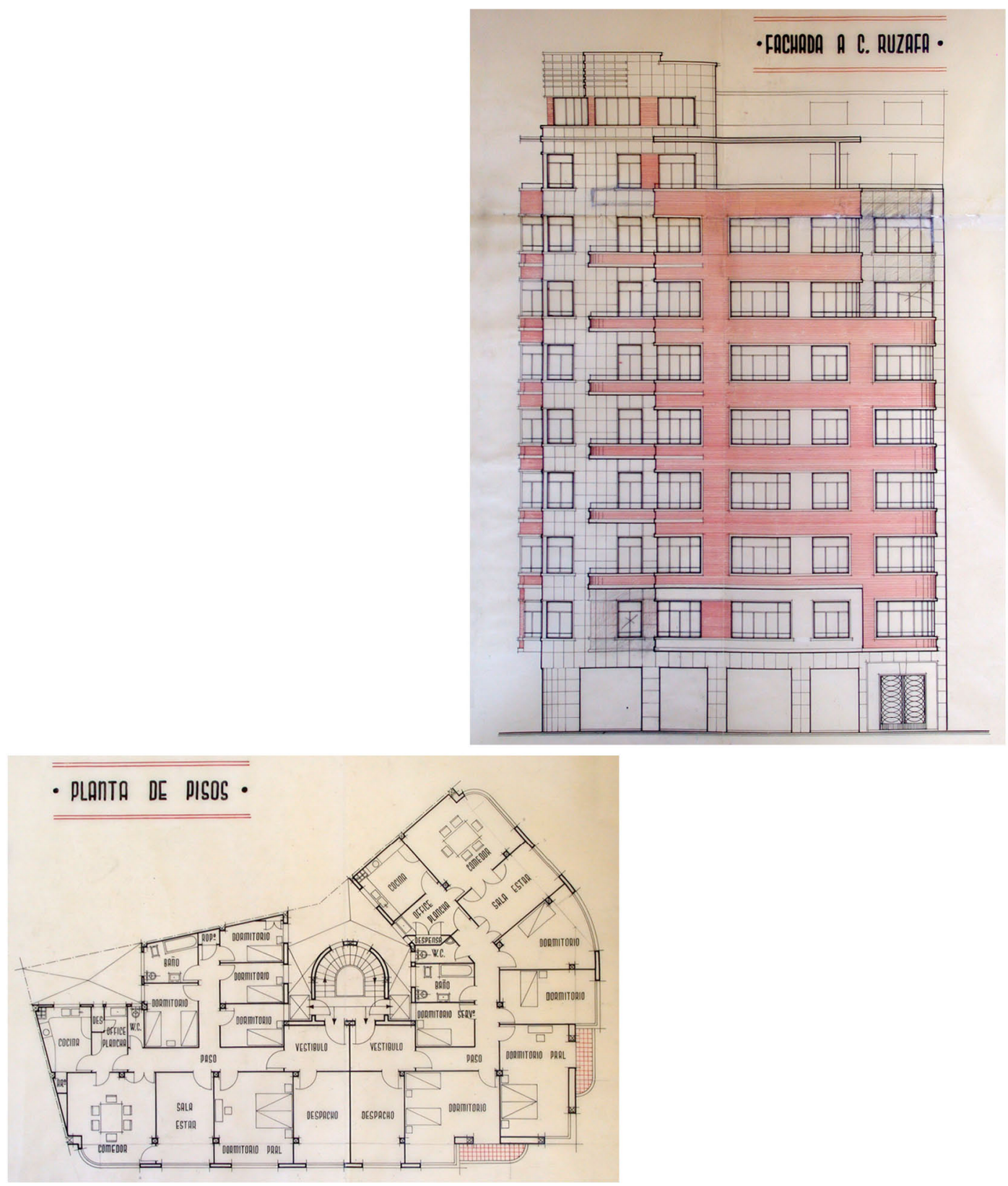

Javier GOERLICH, 1941. Edificio de viviendas para viuda de PATUEL LONGAS, calles Ruzafa y General San Martín: (AHMV) Ensanche, legajo 7 
movimiento cultural, sosteniendo una ofensiva sobre la vida diaria de la sociedad burguesa afiliada a los historicismos arquitectónicos, y la continua revolución que mantuvo frente al academicismo decimonónico. Nikolaus Pevsner ${ }^{36}$, uno de los gestores teóricos del movimiento moderno nos habla de un período premoderno, iniciado con William Morris y alcanzando su momento de esplendor en la dirección de la Bauhaus por Walter Gropius. Kenneth Frampton ${ }^{37}$ reinicia desde la llustración y construye de manera gradual, una historia de la arquitectura moderna. Leonardo Benévolo, plantea como preludio del Movimiento Moderno otro punto de violenta ruptura, la industrialización y el movimiento Arts \& Krafts. Peter Collins ${ }^{38}$, remonta doscientos años el preámbulo, hasta el iluminismo, evocando una evolución histórica continuista, abnegando de los saltos sobre el vacío.

Mediante una nueva cita se refuerza el concepto evolutivo: "Si convenimos finalmente en que no hubo tanta ruptura, si seguimos el curso lógico y concatenado que trazaron Labrouste, Choisy, los urbanistas utópicos, los avanzados ingenieros del XIX, la secta morrisiana, los rascacielos americanos, el cántico estructural de Viollet-le-Duc, el ingenio wrigthiano, el calvinismo arquitectónico de escandinavos y holandeses, y en fin, los sucesos, ya más ponderados, de Glasgow, Viena o Weimar..., entonces ya no

36 PEVSNER, Nikolaus. Pioneros del diseño moderno, de William Morris a Walter Gropius. Primera versión original, 1936. Versión española, Infinito, Buenos Aires. 1958.

${ }^{37}$ FRAMPTON, Kenneth. Historia crítica de la arquitectura moderna. Primera versión original, Thames and Hudson, 1981. Versión española, Gustavo Gili, Barcelona. 1993.

38 Collins, Peter. "Los ideales de la arquitectura moderna; su evolución (17501950)". ob. cit. 

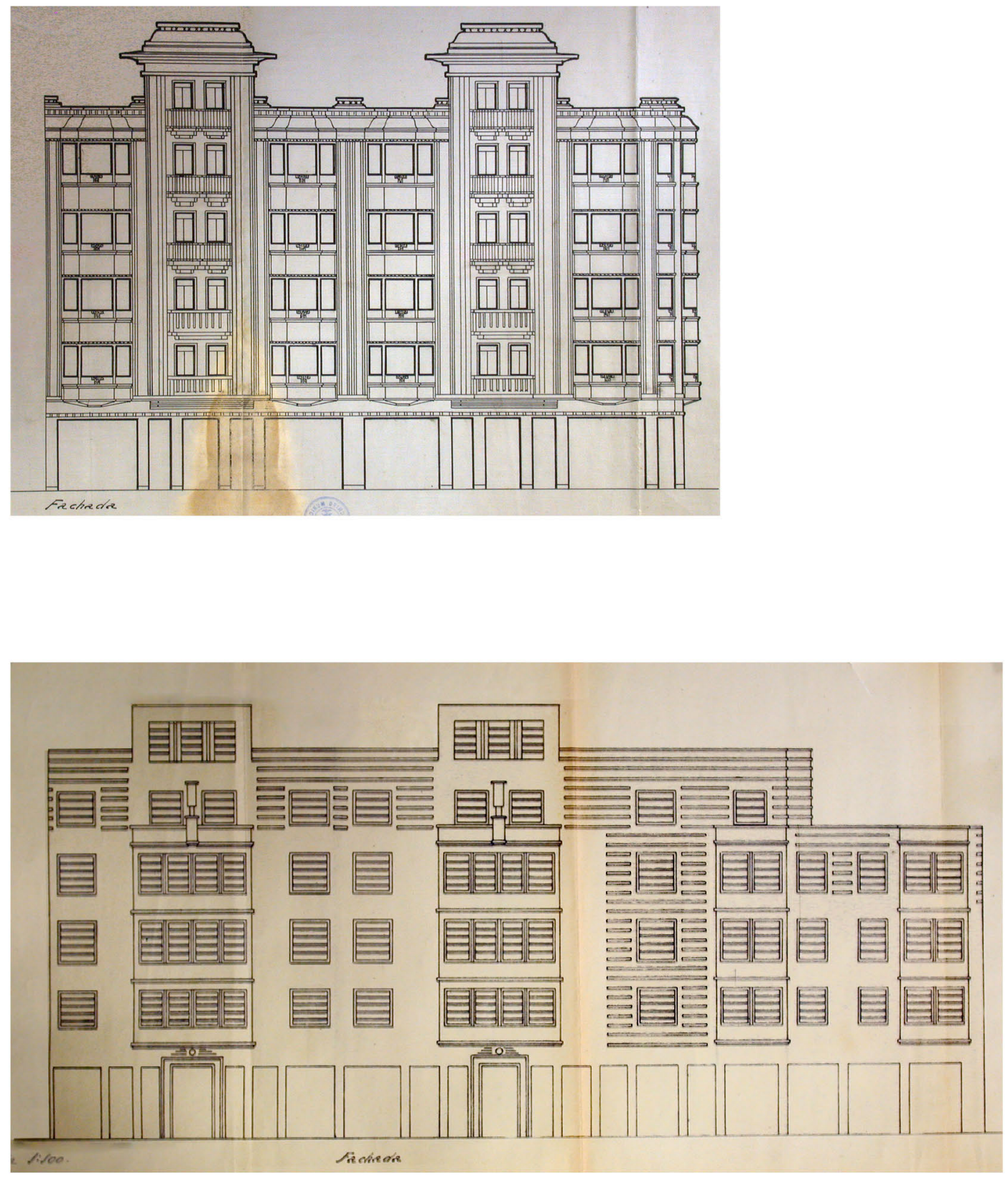

Antonio GÓMEZ, 1935. Edif inmobiliaria SERRATOSA. Moratín 5 y 7: ecléctica composición en su primera propuesta frente al proyecto modificado: (AHMV) Policía Urbana, legajo 11 
parecen tan espasmódicos el manifiesto futurista, las maquetas soviéticas o el infatigable apostolado de Le Corbusier". ${ }^{39}$

"Todos creemos saber lo que ha sido el Movimiento Moderno, cuáles sus ideales, quiénes sus protagonistas principales y, sobre qué supuestos se han levantado sus mejores realizaciones". 40 Pensamos en una determinada arquitectura cuando empleamos los términos Vanguardias Arquitectónicas, Movimiento Moderno, Funcionalismo, Racionalismo. Pensamos en edificios carentes de ornamentación, con marcada presencia horizontal en sus lienzos de fachada, en sus ventanas apaisadas. Pensamos en planos continuos y lisos configurando los techos, en su planta libre, funcional $y$, sobre todo, en el nuevo espacio moderno configurado, despojado de las constricciones estructurales y constructivas tradicionales. Si el edificio se resuelve con formas puras, buscando una nueva expresión desde la abstracción, asimetría, elementarismo, yuxtaposición y comparece exento de dudas compositivas, entonces pensamos en Arquitectura Racionalista.

Calificar con semejante término el conjunto de la producción arquitectónica de toda una ciudad, incluso de una nación parece problemático. Hablar de estricta uniformidad, de la hegemonía del Estilo Internacional, resultaría pretencioso, tanto como asumir la obra completa de un autor, depurada, adscrita a una única corriente arquitectónica-aquí se evita

39 LAGARDERA, Juan - Llopis, Amando. Modernos periféricos, razones dinámicas. Arquitectura racionalista en la Valencia de los años treinta. Catálogo de la exposición "La ciudad moderna. Arquitectura racionalista en Valencia". IVAM Institut Valencià d'Art Modern, 1998; p. 66.

40 BALDELLOU, Miguel Ángel - CAPItel, Antón. Arquitectura española del siglo $x X$. Volumen XL de Summa Artis. Espasa Calpe, Madrid, 1995. 

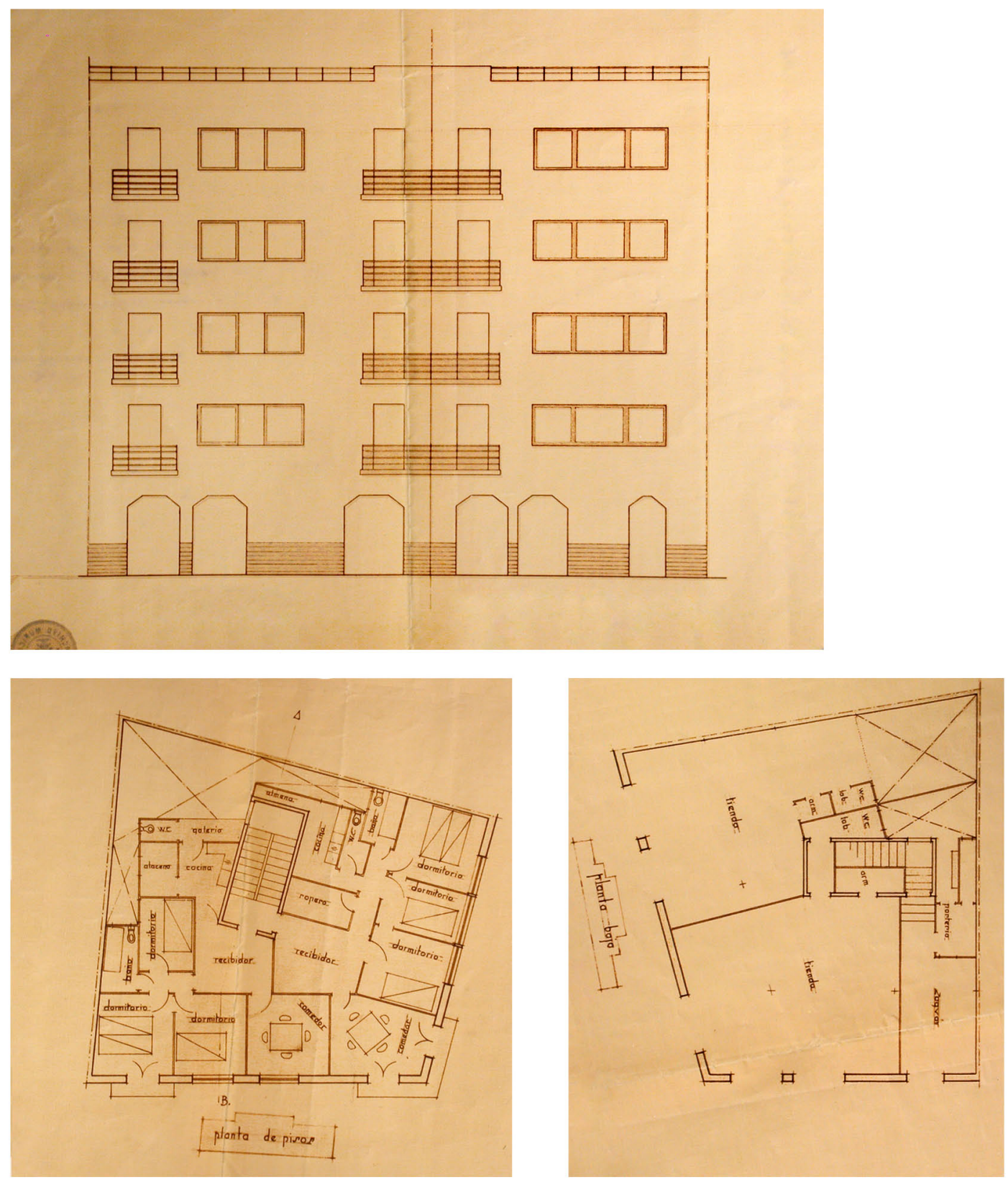

Enrique PECOURT, 1933. Edificio para Francisco NAVARRO, plaza Maestro Ripoll 8 y calle Monteolivete: (AHMV) Ensanche, legajo 4 
deliberadamente el vocablo estilo- tan radicalmente estricta en sus renuncias miméticas, abdicaciones históricas y tan distante de la tradición. Excluiríamos a conciencia, arquitectos como Frank LLoyd Wright, Alvar Aalto, Eric Mendelsohn, Otto Wagner, Peter Behrens o Augusto Perret. Y siendo así, cabría preguntarse, cuantificar aquellos parámetros conformadores de la "ortodoxia" racionalista -término acuñado con cierta dilación- para deducir entonces la exclusión "al margen" por falta, por incumplimiento de cual principio. Cabría añadir la imperiosa necesidad de confinar la "heterodoxia", limitada a manejar códigos compositivos modernos, y afinar el punto donde la denostada mímesis estilística -ahora mímesis del lenguaje moderno- habría sido expulsada de los postulados racionalistas.

HETERODOXOS RACIONALISTAS VALENCIANOS

Descartando el desconocimiento por parte de nuestros jóvenes profesionales de las aludidas premisas ortodoxas; habiendo quedado planteada, con anterioridad, la imposibilidad de germinación espontánea y, muy al contrario, evidenciada la necesidad de continuidad en su devenir, de unas favorables condiciones sociales y políticas que aquí no coadyuvaron, podemos limitar la concreción ortodoxa en obras esporádicas, en 

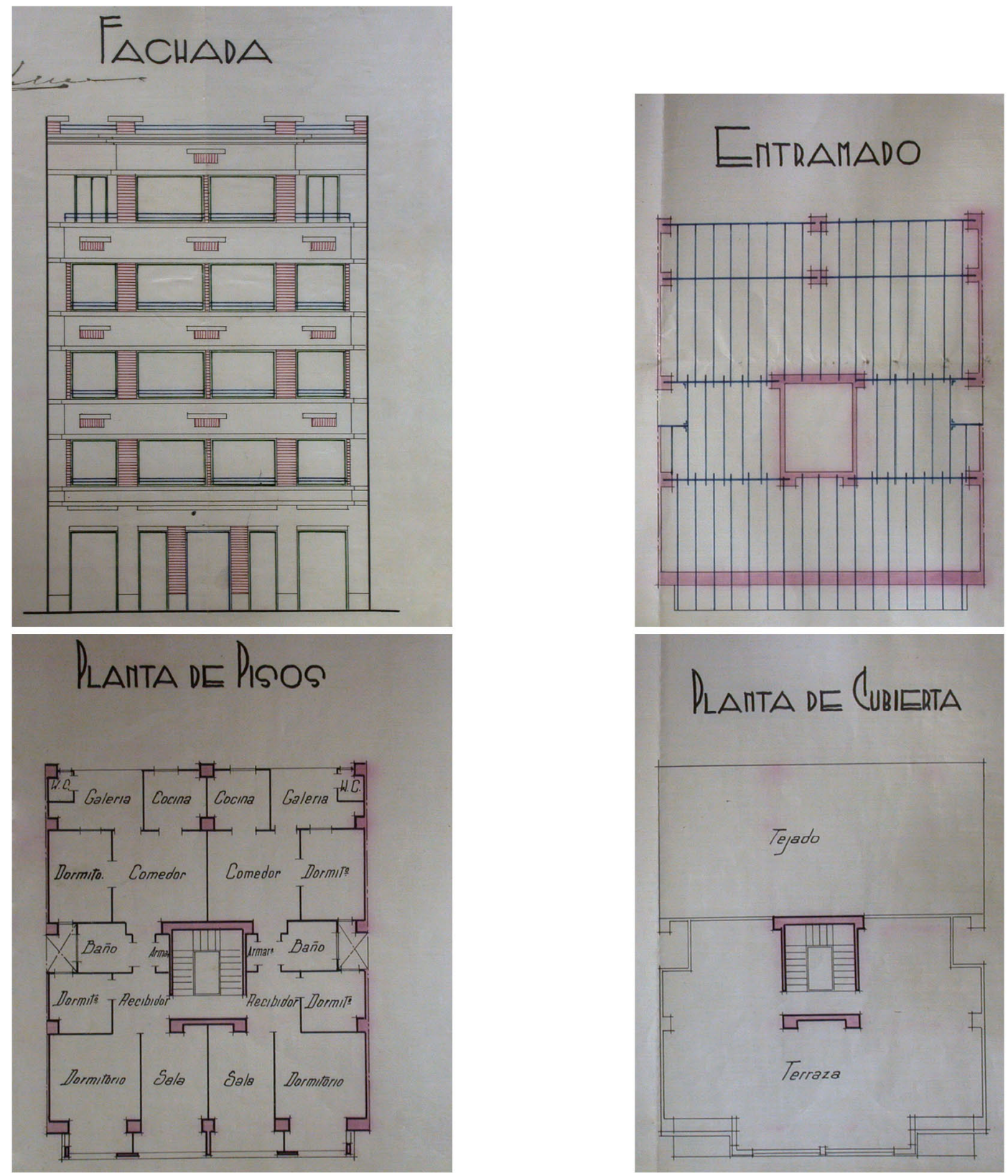

Mariano PESET, 1935. Edificio de viviendas, promotor José TORMO, calle Turia 65; (AHMV) Ensanche, legajo 8 
propuestas muy concretas y difícilmente extensibles a una obra íntegra, ni mucho menos a un autor.

Penetraría la modernidad en España en la década de los treinta, habiendo sufrido, con anterioridad en Europa, la revisión de sus postulados. Se marca el año 1925 como el inicio de la arquitectura moderna española, mediante obras emblemáticas de García Mercadal -el Rincón de Goya-, Bergamín -la casa del marqués de Villora-, Fernández Shaw -la gasolinera de Porto Pi-. "Mucha de la arquitectura realizada en España en las primeras décadas de este siglo se califica genéricamente de racionalista. Los críticos más finos han intentado matizar distinguiendo a la producción menos ortodoxa como racionalismo al margen", ${ }^{41}$ racionalismo periférico. De esta manera Miguel Ángel Baldellou posiciona la arquitectura valenciana en el panorama español, señalando aquellos arquitectos adscritos a lo moderno y recuperando a aquellos que estaban al margen por reinterpretar superficialmente, suavizando y haciendo asimilable, el nuevo modelo moderno y la nueva forma de vida. Racionalismo epidérmico. "En todo caso, la epidérmica racionalidad, tan subrayada, no estuvo motivada por el desconocimiento",42 ni de la actualidad internacional, ni del amplio debate en torno a la arquitectura.

41 BALdellou, Miguel Ángel - Capitel, Antón. Summa Artis. Historia general del arte. Espasa Calpe, S. A. Madrid 1995, Vol. XL.

42 ESTELLÉS, Juan José - GIMÉNEZ, Emilio. Los arquitectos valencianos de los treinta: influencias y compromisos. Las Escuelas de Arquitectura, las revistas especializadas y los nuevos canales de información. Catálogo de la exposición "La ciudad moderna. Arquitectura racionalista en Valencia". IVAM Institut Valencià d'Art Modern, 1998. 


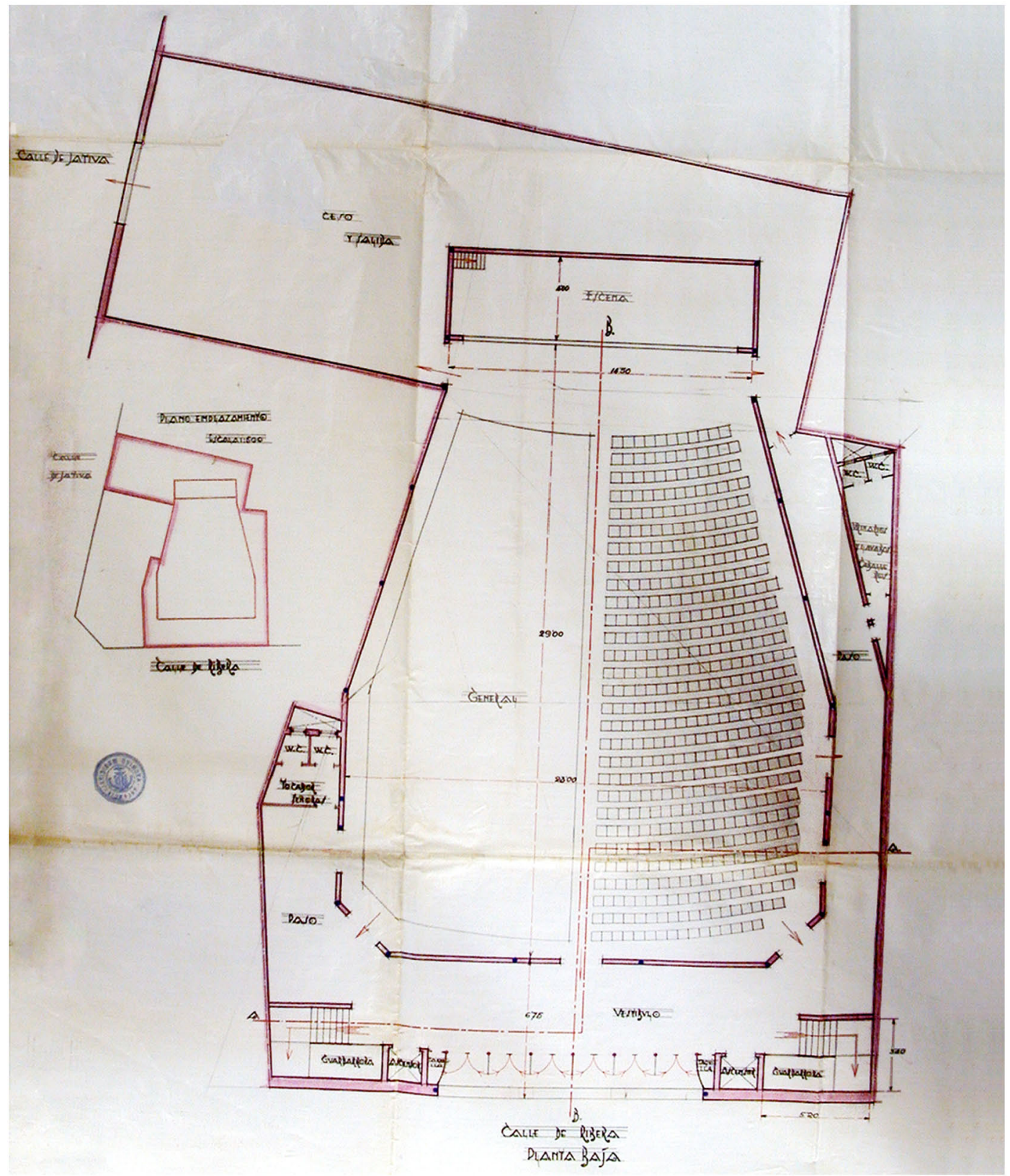

Joaquim RIETA, 1930. Cinematógrafo CAPITOL, promotor Emilio PECHUÁN, calle de Ribera y calle Játiva: (AHMV) Policía Urbana, legajo 13 
Oriol Bohigas, postulando sobre arquitectura española del período republicano, acuña dos términos definitorios para sendos grupos con pretensiones profesionales, disocia dos posicionamientos frente a la nueva arquitectura: ortodoxia y heterodoxia. La primera aspiración, adoptaría los cánones formales -peculiar término para quienes negaban la forma como premisa- apuntados por Le Corbusier y se aglutinaría en el GATEPAC. La segunda demanda, se mantendría reservada para el resto, carente de la radicalidad obligada, exento de oportunas circunstancias sociales y políticas.

En Valencia, proclama Alberto Peñín -recogiendo el personal léxico de Bohigas-, "ejercen arquitectos racionalistas y, a partir de ese momento ya tenemos racionalismo en Valencia, pero impuro, heterodoxo, contaminado por expresionismo y otras rarezas"43. Atestigua así, un paralelismo incompleto, cargado de connotaciones comunes, con el grupo catalán de "heterodoxos racionalistas" esforzados en la modernidad, alejados del proceso generador de la nueva arquitectura, "cuyo racionalismo expresivo está mezclado con continuas referencias eclécticas". Establece también a la postre tres grupos, tres opciones entre los profesionales valencianos para afrontar el Movimiento Moderno. Inaugura el misceláneo catálogo con el "racionalista fallido" Enrique Pecourt, participante en la exposición del GATPAC -con un proyecto para Clínica- de Galerías Dalmau. Autor del edificio en la calle Donoso Cortés ejecutado en 1924, en sus comienzos laborales marcados por una neta aspiración racionalista.

43 PE ÑIN IBÁÑEZ, Alberto. Valencia. 1874-1959. Ciudad, Arquitectura y Arquitectos. Escuela de Arquitectura de Valencia, $n^{\circ} 4$. Valencia, 1978. 


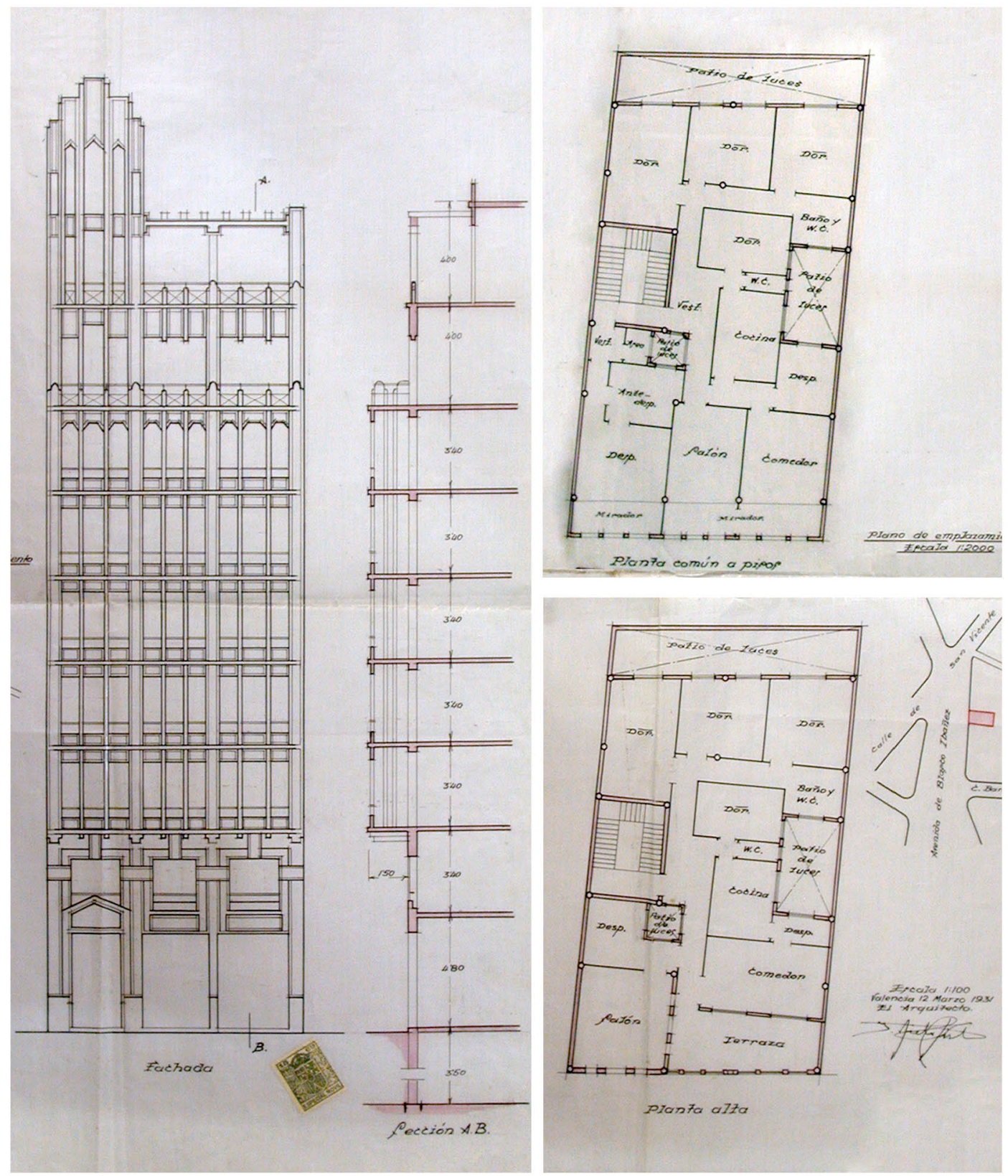

Joaquim RIETA, 1931. Edificio de viviendas para Ricardo CERVERA, avenida de Blasco Ibañez 10, hoy plaza del Ayuntamiento: (AHMV) Policía Urbana, legajo 5 
Abandonaría, posteriormente sus ideales, por inclemencias sociales, por falta de perseverancia, retomando un asequible y convencional eclecticismo. Completarían el grupo Ramón Liern y Juan Villa Pedroso.

El segundo grupo, declamado "heterodoxos racionalistas" quedaría constituido por Joaquín Rieta, Cayetano Borso, Luis Albert, Emilio Artal, José Pedrós, José Luis Testor y Enrique Viedma. Avalados por su procedencia burguesa, su espíritu de servicio debido hacia el cliente y cierta brillantez, alcanzarían reconocido prestigio, valiéndose del mismo para introducir del Movimiento Moderno, lenguajes racionalistas y expresionistas. El momento clave, en fecha temprana-comparando con las citadas exposiciones del GATPAC, y la generación madrileña del 25-surgiría con la convocatoria del concurso para el Ateneo Mercantil valenciano, donde amanecerían incipientes expresiones vanguardistas, en $1927^{44}$. Los avatares políticos de la época en cuestión -los ideales de modernidad republicanos- favorecerían la adopción de modernos gestos vanguardistas, también en la burguesía valenciana, aunque asumir sus postulados terminaría siendo exclusivo de una sociedad catalana plena de ansias europeas, y su clase gobernante -la Generalitat de Catalunya-cómplice en ansiedad evolutiva con los jóvenes arquitectos modernos. Queda justificado, al menos en el grupo de "heterodoxos racionalistas" valencianos, un predicamento posterior limitado, tal vez resignado, a una mimética pretensión del menos provocativo discurso expresionista, mucho más consumible, lastrando el radical lenguaje racional a contadas excepciones.

${ }^{44}$ La primera exposición del grupo formado en la Escuela de Barcelona y base de GATEPAC, a la vez que la superación de casticismos y nacionalismos en Madrid, se producirían en el mismo año 27. Los siguientes dos años resultarían clave para el racionalismo europeo (Congreso CIAM, Escuela Dessau, pabellón de Alemania para la Exposición de Barcelona, casa Stein...) 


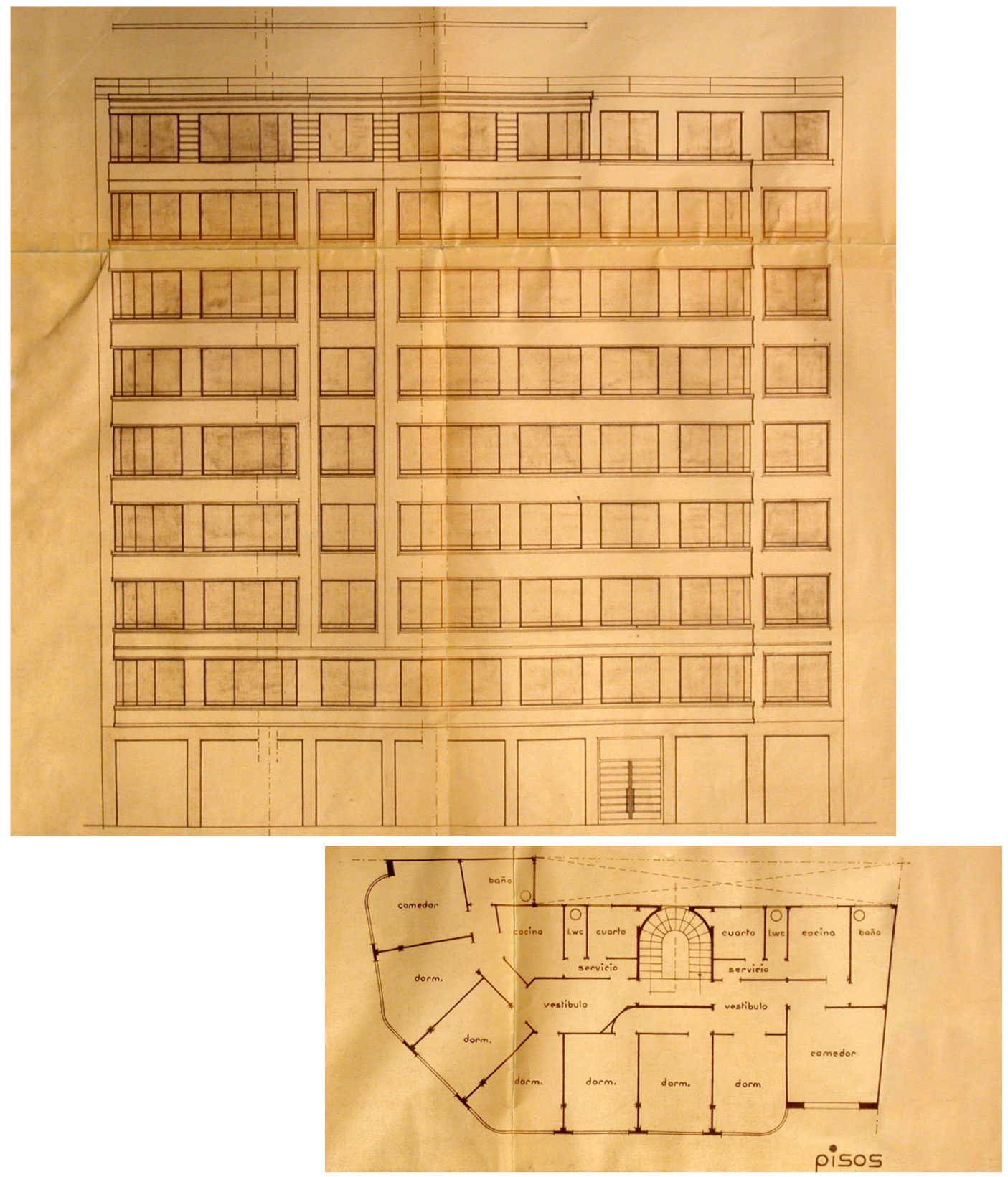

Ricard ROSO, 1934. Edificio de viviendas para José LLOPIS (1), calles de San Vicente 51 y La Sangre: (AHMV) Policía Urbana, legajo 16 
Una premisa más a tener en cuenta es la formación académica de aquellos profesionales que hicieron de la arquitectura valenciana uno de los focos de modernidad y que, según Oriol Bohigas, pueden considerarse de alguna manera como subsidiarios de Madrid y Barcelona, las dos únicas ciudades que en aquellos años tenían una Escuela de Arquitectura. Con las debidas excepciones, los arquitectos del norte de España acudían a estudiar a Madrid, mientras que los de Valencia lo hacían en Barcelona. Relación docente que a menudo se prolongaría en lo profesional. Es por esto, la seguridad del conocimiento, en nuestros profesionales, de los postulados vanguardistas europeos, sus canales de distribución y su praxis a través de sus compañeros universitarios. Bien diferenciadas habrían de discurrir las circunstancias locales.

La sensación de progreso económico-social y cultural vivido en Valencia, instaurada como capital de la II República, el trasiego de gente de alto bagaje y poder, impulsarían el ideal de la vida moderna. Pero la arquitectura valenciana de los treinta no sabría aprovechar la oportunidad que propiciaba el cambio y elegiría encomendarse al RACIONALISMO HETERODOXO como forma de expresión, sin atender a su ideología. Si en la propia génesis del art decó se diluían las fronteras con el regionalismo, otro tanto vuelve a pasar en su tangencia con el racionalismo. La arquitectura racionalista, matizada de heterodoxa, tuvo mucho de versión desornamentada e integradora del art decó, frente al sentido abstracto y purista de la arquitectura racionalista. Continuando este hilo conducto, Javier Pérez Rojas habla de "otras arquitecturas objetuales que aunque participan de la funcionalidad y el antitradicionalismo del racionalismo, en realidad son más emotivas y barrocas, no son menos modernas y 

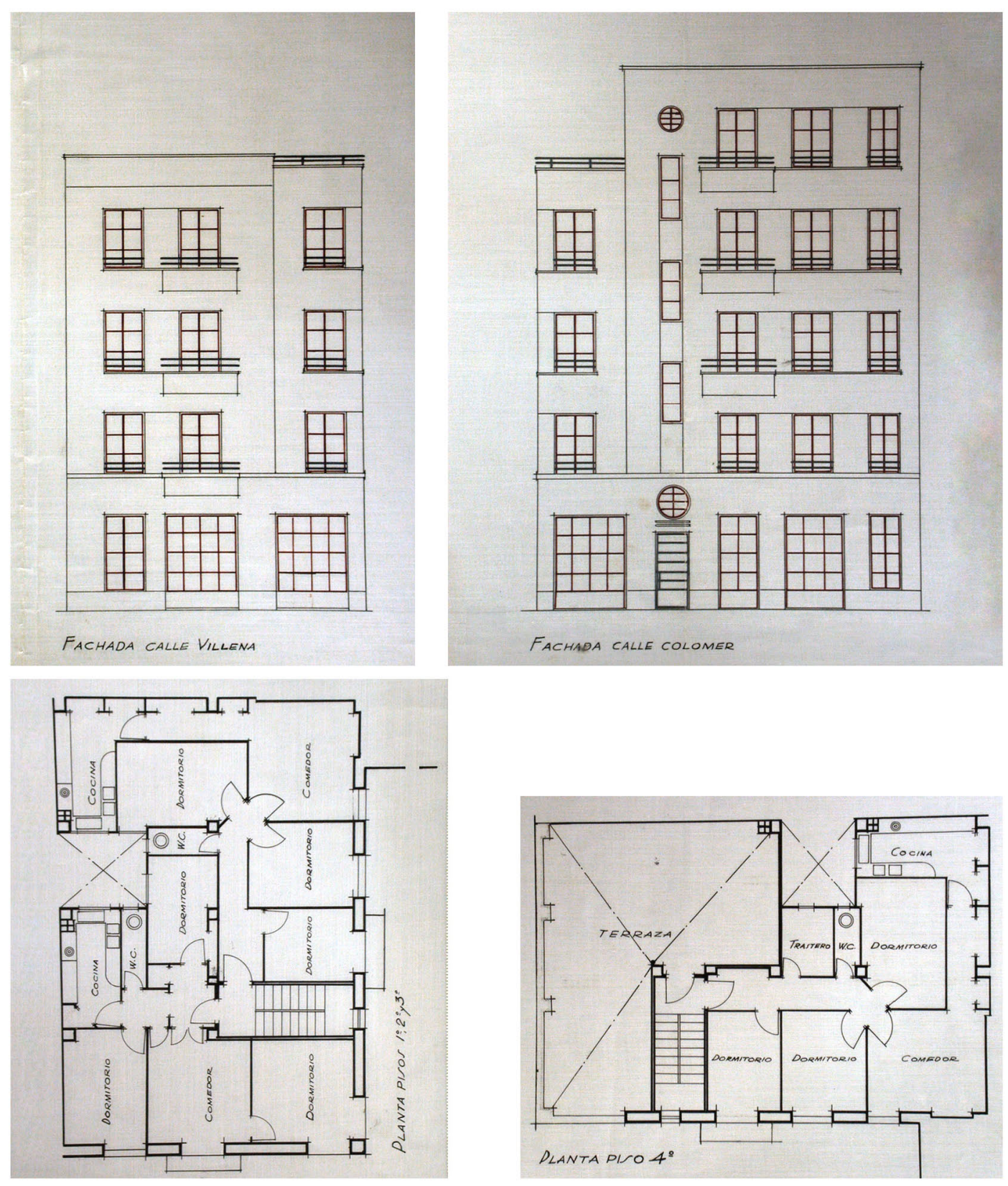

Ricard ROSO, 1935. Edificio de viviendas para Felix RAUSELL, calles Colomer y Villena 8: (AHMV) Policía Urbana, legajo 19 
vanguardistas, aunque puede que, según los criterios, sean más impuras"45. Nos está narrando lo que el propio autor transcribe como el racionalismo y las ARQUITECTURAS AERODINÁMICAS. Ambas tienen en común su fascinación por la relación máquina, ingeniería y arquitectura. El remate faro para reforzar la concepción vertical de las creaciones modernas, de las máquinas de habitar en la urbe metropolitana, terminaría siendo el icono formal de las propuestas representativas en la ciudad metropolitana, en arquitectos valencianos, como Cayetano Borso, destacando el edificio Rialto de 1935, en la plaza del Ayuntamiento e igualmente el edificio Vizcaíno de 1936, en la calle Ribera, $n^{\circ} 3$.

Erich Mendelsohn y sus impresionantes trazos curvos impregnarían las nuevas líneas de la arquitectura moderna, asumida de inmediato en piscinas, clubes náuticos, cines, gasolineras, viviendas unifamiliares, etc. Resultaba un gran ejemplo, el Club Náutico de Valencia, realizado por Javier Goerlich y Alfonso Fungairiño, tanto como lo había venido siendo el edificio de las piscinas de Las Arenas, de 1933, del madrileño Luis Gutiérrez Soto, hasta la impune vulneración de su esencia racionalista. Aunque el de mayor relevancia, bien por la fecha en la que se planteó, bien por lo atrevido de la propuesta, fue el proyecto para el concurso del Ateneo Mercantil de Valencia presentado por dos compañeros de la Escuela de Madrid, Gaspar Blein y el valenciano Luis Albert. Su intento renovador y moderno, su espíritu emblemático y monumental para la nueva ciudad, lo aerodinámico de sus formas, la expresividad de las curvas embebidas de Mendelsohn, manteniendo una denostada lucha con el

45 PÉREZ ROJAS, Javier. op. cit; p.28 

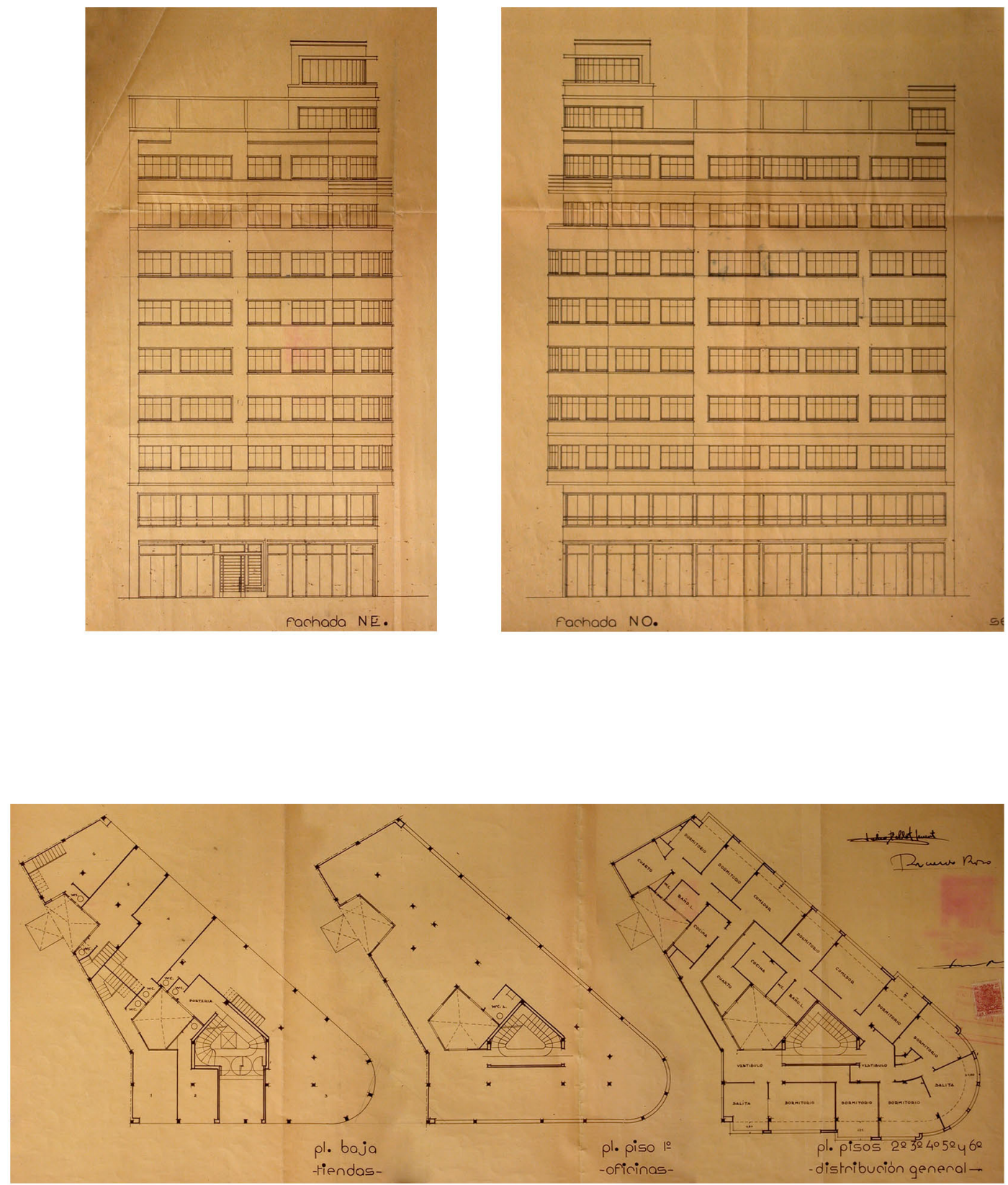

Ricard ROSO, 1935. Edificio de viviendas para José LLOPIS (II), avenida de Pablo Iglesias, plaza de Porchets y calle de Ribalta: (AHMV) Policía Urbana, legajo 10 
resto de propuestas, incluida la triunfadora, más en línea con el espíritu nacional acorde a la ideología política de 1927.

Tan sólo restaba discernir el tercer y último grupo planteado por Peñin. Aquel constituido por un conjunto de profesionales allegados de la generación precedente, que admitirían el racionalismo circunstancialmente, pues el campo de acción que les fue propio-Modernismo, Regionalismo, Eclecticismo-había quedado "fuera de demanda". Esta adopción forzosa, más que convencida, no resultaría óbice para lograr meritorios resultados, en contadas ocasiones. Javier Goerlich, Francisco Almenar, Antonio Gómez Davó, Carlos Carbonell y, en cierta medida, Enrique Viedma navegarían entre dos corrientes, retornando a la primigenia cuando las circunstancias políticas -una vez finalizada la guerra Civil española-obligaron a abnegar involuntariamente de posturas ligadas al régimen pasado, del racionalismo.

Todo este complejo entramado de estilos arquitectónicos, aprehendidos y enraizados con diferente profundidad entre los actores que debían llevarlos a escena, conviviendo en una sociedad burguesa con aspiraciones de modernidad, industrializada y convulsa por los acontecimientos políticos que impedían un desarrollo sostenido, configuró un Racionalismo valenciano marcado por la emotividad y el efectismo, más que por la razón, el funcionalismo y la abstracción. Una producción menos ortodoxa y matizada por los críticos más finos como "racionalismo al margen". Una arquitectura con bastante condición para adoptarla estilísticamente racionalista $y$, no obstante, tanto quienes suscribieron la edificación como su clientela, no aspiraban más que a ser modernos. 


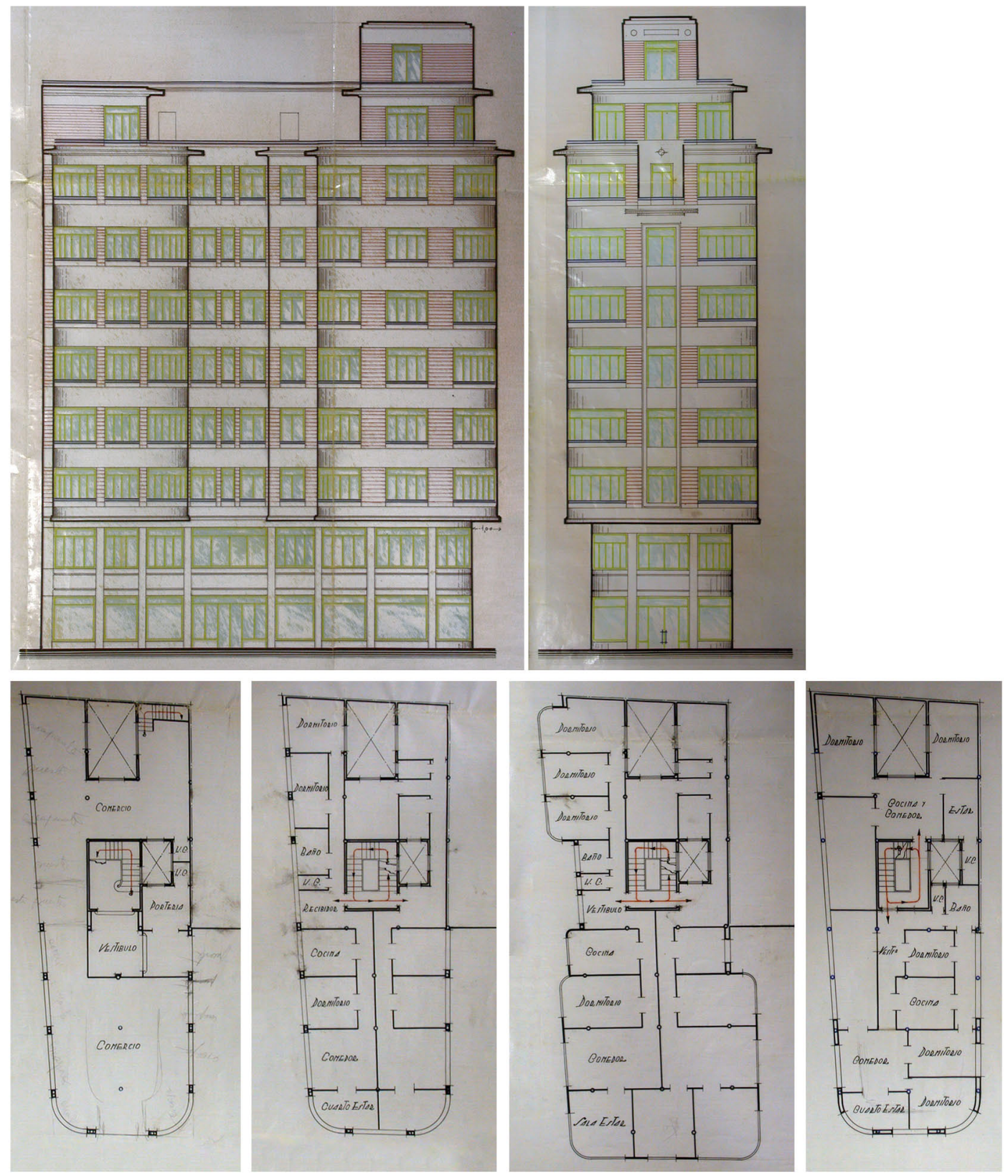

Vicente VALLS, 1934. Edificio de casas y alquiler, propiedad de la Señora viuda de Miguel ROCA, calle de San Vicente; (AHMV) Policía Urbana, legajo 16 
El resultado es una arquitectura Racionalista con grandes dudas proyectuales, desnutrida del profundo debate entre modernidad y tradición, desvinculada de la subversión sobre la que las vanguardias europeas concibieron la evolución racionalista. Dudas en la racionalización del moderno espacio, en la optimización dimensional y los estándares productivos. Dudas en la formalización exterior, la composición de fachadas, prácticamente desatendidas del análisis funcional. Dudas para alcanzar aquello imprescindible, lo esencial y sustantivo de lo proyectado, prescindiendo de lo superfluo para pretender la abstracción.

En realidad términos aquí citados como racionalismo heterodoxo y otros como expresionismo funcionalista, aseveran las dudas apuntadas, pero también serán manejados para entendernos y entender la compleja producción arquitectónica valenciana, para negar sus pretendidas atribuciones unívocas de identidad, y refutar calificaciones estilísticas de validez universal. Todas estas imprecisiones previas, ineludibles para narrar con cierta lógica un proceso evolutivo, exigen de concreción y profundidad en el análisis de la obra de Luis Albert, evitando forzar etiquetas que lo rescaten superficialmente del "margen" y aclaren cierta "ortodoxia". 
biografía 


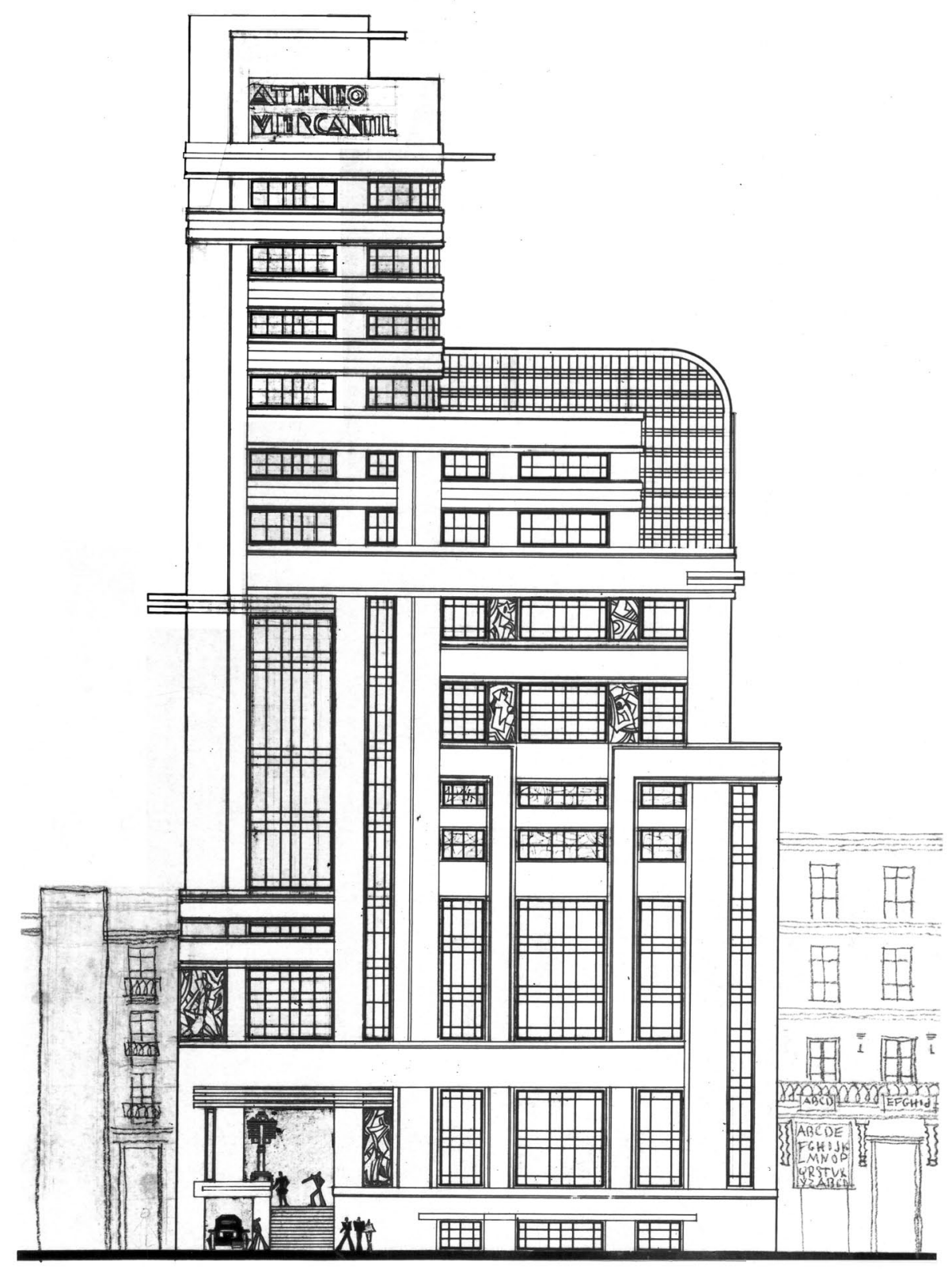

Gaspar BLEIN, Luis ALERT, 1927. Alzado principal, plaza de Emilio Castelar; propuesta al Concurso Nacional de anteproyectos convocado por el Ateneo Mercantil de Valencia: Fondo Documental Biblioteca del Ateneo 
Natural de Valencia, Luis Albert Ballesteros (1902-1968) nació el 10 de diciembre. Recibió formación, maduró y atesoró su esquema de valores al amparo de una acomodada familia. Estudiaría bachillerato con los padres Jesuitas. Reivindicaría de su padre -abogado-la urgencia de una titulación superior y se trasladó al Madrid de los años veinte, para hacerla propia, para cursar estudios y formarse como Técnico. Egresado de la Escuela Superior de Arquitectura de Madrid, obtuvo su título de arquitecto el 5 de marzo de 1928. Alfonso Fungairiño, Vicente Eced, Luis Moya, Joaquín Labayen y, sobre todos, Gaspar Blein -de su misma edad y tres cursos avanzado-, compartieron aula, profesores y aspiraciones. Mantendría con sus compañeros una reseñable afinidad, confinante con la observación profesional, llegando a la lealtad, manifiesta en su obra y en su alineamiento público con el Manifiesto de la Alhambra de 1953. Firmado conjuntamente con sus amigos de Madrid, redundaría parte fundamental del consecutivo análisis de la arquitectura pergeñado en su discurso de ingreso en la Academia de Bellas Artes. Los ingenieros Janini y Villamil completan el círculo de amistades, emprendiendo una relación que, más tarde, trasladarían al quehacer profesional. Ultimó el ciclo formativo doctorándose el 3 de diciembre de 1964.

Jorge Torres define su personalidad como culta, y alude a la persona inteligente, de una gran educación y exquisitez, dotado de una gran voluntad y, a su vez, de un acusado pragmatismo en el momento de resolver los proyectos.?

1 TORRES CUECO, Jorge. "Los primeros modernos. Los arquitectos valencianos entre la permanencia del academicismo y la renovación de los lenguajes". Catálogo para la exposición realizada por el IVAM Centre Julio González, del 20 de enero al 5 de abril de 1998. "La ciudad moderna. Arquitectura racionalista en Valencia". Volumen II. p. 42 


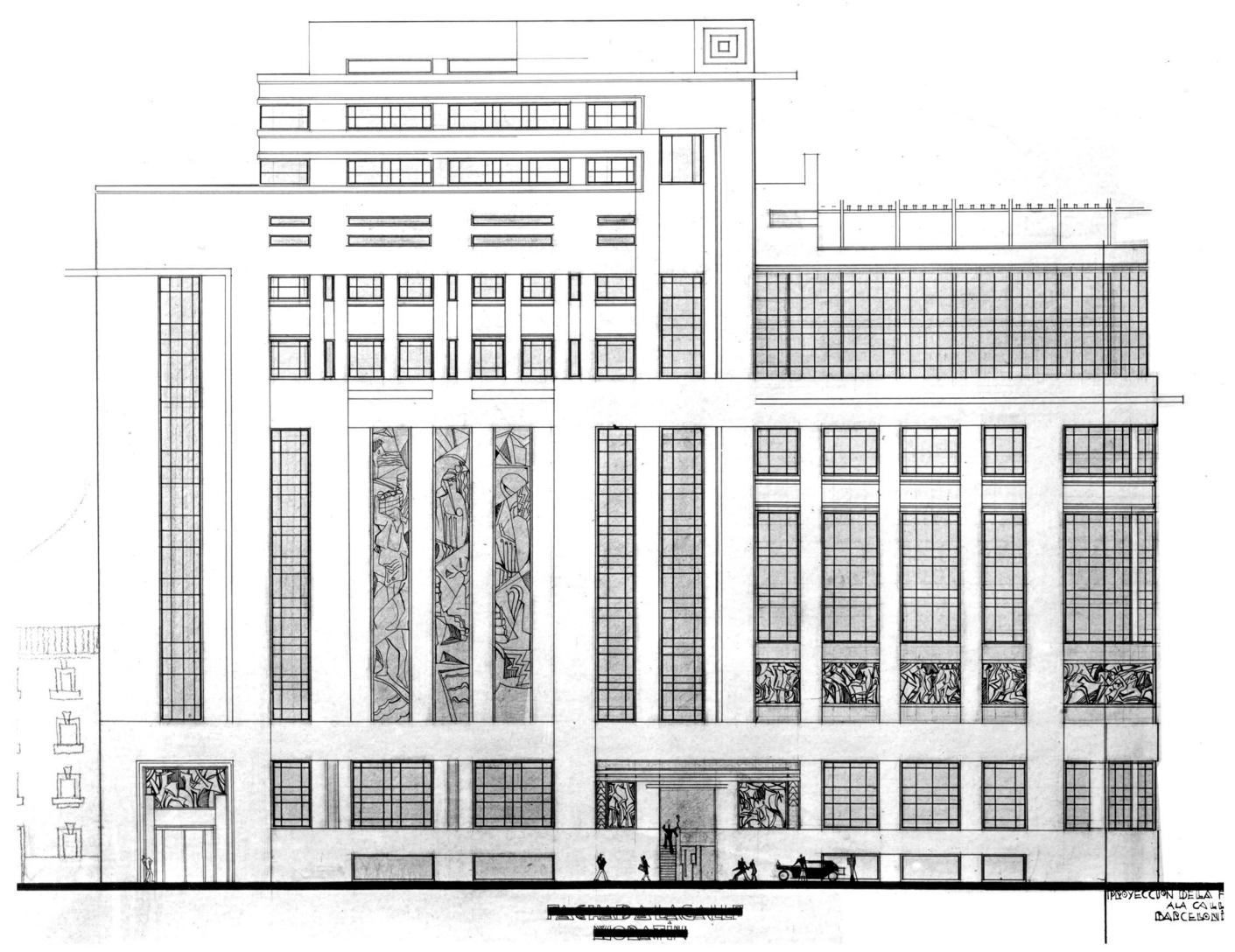

Gaspar BLEIN, Luis ALERT, 1927. Alzado de la propuesta para el concurso, recayendo a Ia calle Moratín más su desarrollo en proyección del alzado de la calle Barcelonina; (FDBA) 
Fue honesto, discreto, suave, agradable de trato, no agresivo ni en hechos ni en planteamientos, profesional ante todo con ese sentido de "servicio público" del nuevo arquitecto, alejado del simple artista o del negociante. Alberto Peñín ${ }^{2}$-colaborador, numerario en el despacho profesional, contigua su etapa concluyente- así legaba el carácter, la personalidad de quien lo inició en el mundo laboral, de cuya observancia igualmente abstrajo referencias: No llegó -salvo uno o dos pequeños intentos siempre frustrados por desinterés- a participar ni mucho menos a promocionar empresa constructora $\circ$ industria alguna, a pesar de vivir unos tiempos tan proclives a ello. Su fuente exclusiva de ingresos fue su trabajo de arquitecto y sólo a través de él aspiró a la mejora de su posición social y económica.

Compaginó, simultaneó y ajustó su práctica profesional privada, recién titulado, con el funcionariado público, con sucesivos cargos, hasta su cese laboral conexo con su deceso en 1968. Esta marcada bifurcación se manifestó patente a lo largo de toda su metodología profesional y, fehacientemente, henderá nuestro análisis de su obra arquitectónica.

Tendrá bajo dependencia, esta bifurcación, nuestro posterior análisis del trabajo de Luis Albert. Justificará la escisión en capítulos independientes limitados unos a la promoción privada y, por ende, otros implicados en su edilicia pública, manteniendo las dos líneas regidoras de su trabajo. Probada escisión a través de dispares planteamientos racionales, diversos grados de heterodoxia en función del promotor, del escenario y del público.

2 PEÑ ÍN IBÁÑEZ, Alberto. "Luis Albert. Arquitecto. Valencia. 1902-1968" Editado por el Colegio Oficial de Arquitectos de Valencia, en 1984.p. 9 

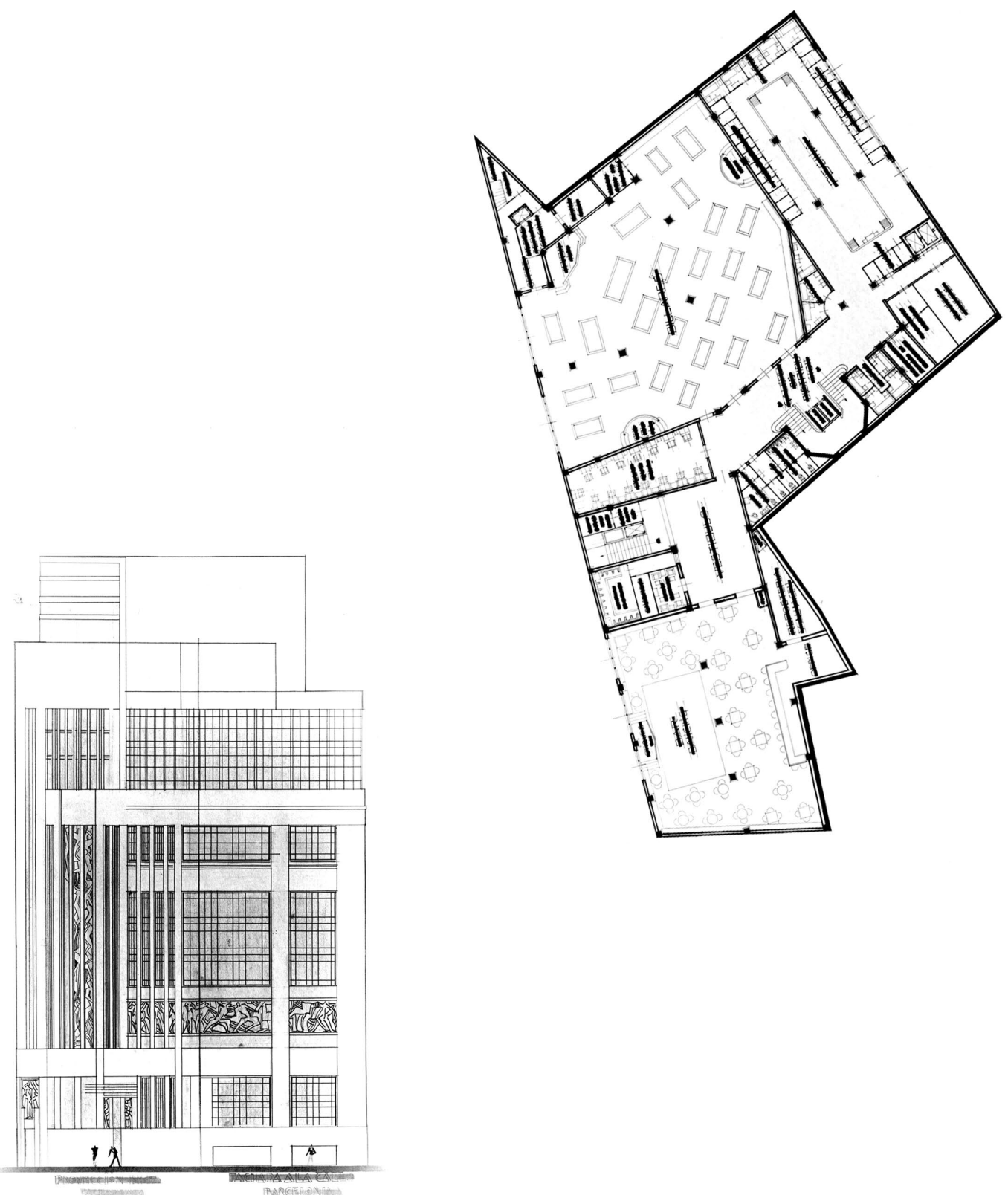
Por una senda, el epicentro urbano y su continuo, el Ensanche. La metrópoli donde exponía públicamente sus encargos privados y pasaba juicio social. Donde sus intenciones de modernidad quedarían supeditadas al interés particular de quién arriesgaba y promovía en un reducido núcleo escénico. Hilvanaría aspiraciones racionalistas -propias de juventud-con pragmáticas demandas contratistas, menos proclives a ideologías y más atentas a recelosas miradas. El coraje inaugural, el fervor preliminar, las trazas proyectadas según principios de modernidad, habían sido confinadas a un funcionalismo integro, a una expresión formal anhelada y, en definitiva, al rigor constructivo, al ajuste económico, compendio de apetencias por alcanzar una ortodoxia que no fue reputada.

Imperceptiblemente paralela resultó la senda facilitada por la Administración. El instinto de insurrección contra los referentes historicistas marcados, encontró la libertad, externa a la urbe. Sus modernas propuestas para edificaciones públicas, trasladadas lejos del centro, propiciando el esponjamiento interior, encontraron las facilidades de proyectar en ausencia de premisas impuestas, salvo las personales y por convicción. Lamentables acabarían siendo las indecisiones políticas, las provincianas miras y los intereses personales de quienes dependía su aprobación. Las propuestas de juventud quedaron en trazos. Intenciones analizables por su aspiración moderno, más allá de la sencilla funcionalidad. Los edificios públicos elevados, en su madurez -recibida al instante de iniciarse la posguerra- resultarían menos admirables, aunque correctos como toda su labor profesional, también en el ámbito privado y en los diferentes cargos oficiales desempeñados. 


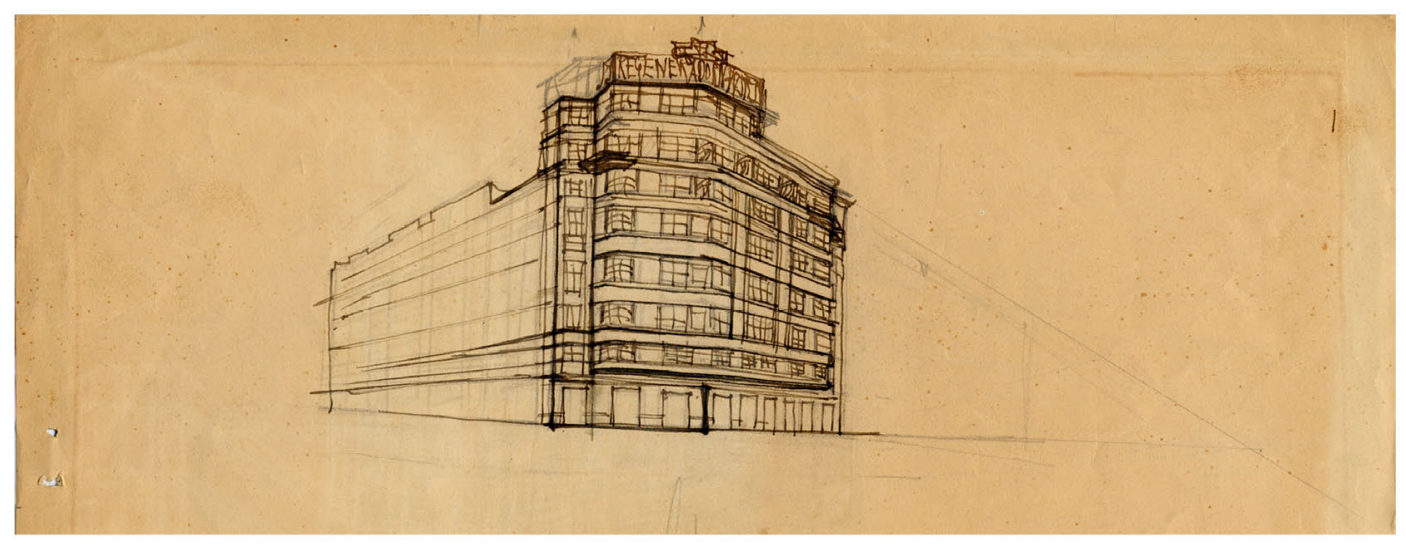

fig. 2

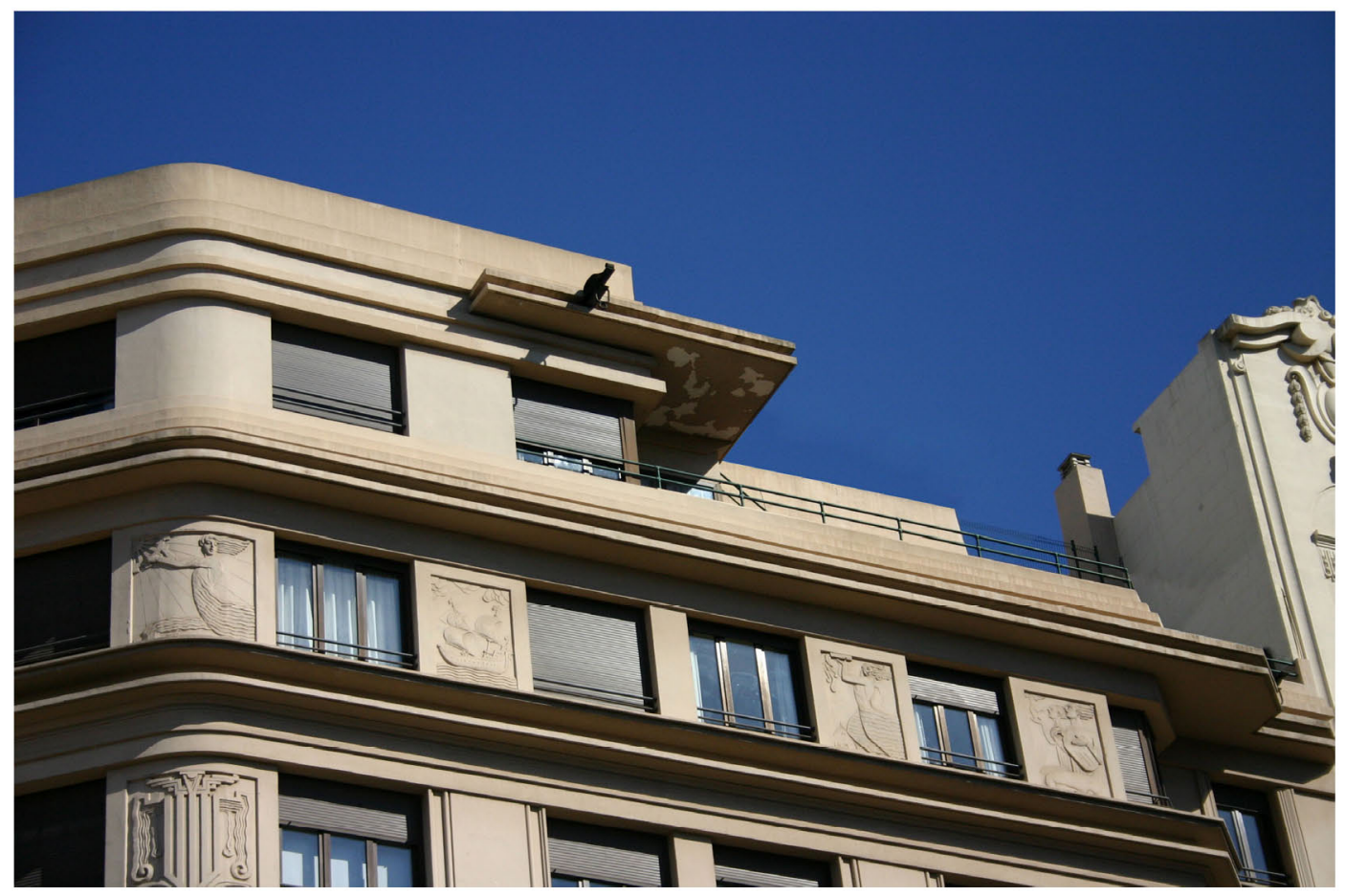

Luis ALBERT, 1929. Edificio para Francisco CARBAJOSA, calles Játiva y Ribera; perspectiva del arquitecto(Archivo de Alberto PEÑín) y fotografía del doctorando 
Rezan en la propia elaboración de su currículum vitae, -preparando el ingreso para el año 1961 en la Real Academia de Bellas Artes de San Carlos- los siguientes cargos detentados y aquellos disfrutados hasta el momento de su redacción: Arquitecto provincial de Castellón desde 1928 hasta 1930; Arquitecto municipal de Alboraya desde 1929 hasta 1936; Arquitecto de los ferrocarriles de la Compañía del Norte desde 1928 hasta 1941; Arquitecto jefe de la Comisión Provincial de Reconstrucción de Valencia, desde 1939 hasta 1942; Presidente de la Comisión Técnica Asesora de la Junta de Reconstrucción de Valencia desde 1939 hasta 1942; Arquitecto asesor de la Junta Provincial de Sanidad desde 1939 hasta 1952. Actualmente -entiéndase aquí el tiempo de redacción- Arquitecto provincial de Valencia desde el año 19313; Arquitecto municipal de Almácera desde 1933; Arquitecto vocal de la Junta Provincial de Beneficencia desde 1939; Arquitecto de la Comisión Provincial de Servicios Técnicos desde 1932.

Luis Albert integró aquella generación que inauguró estatus profesional. Se tituló tres años antes de la constitución del Colegio de Arquitectos de la zona de Valencia en 1931. Un solo Colegio Territorial de Arquitectos por ámbito territorial, un único órgano corporativo, intermediario, garante ante el Estado y la sociedad. Una congregación de jóvenes arquitectos persuadida por la ética, por su adscripción a quien contrata, por el servicio y el oficio técnico. Obviarían la arenga social, aquella que consideraba reunidas la tarea formativa e innovadora, la capacidad de teorizar, como labor activa propia del arquitecto.

${ }^{3}$ en el currículo vitae redactado por Luis Albert, preparando su ingreso en la Real Academia de Bellas Artes de San Carlos, año 1961, aparece sobrescrito un 2 en el borrador mecanografiado al que se ha tenido acceso 


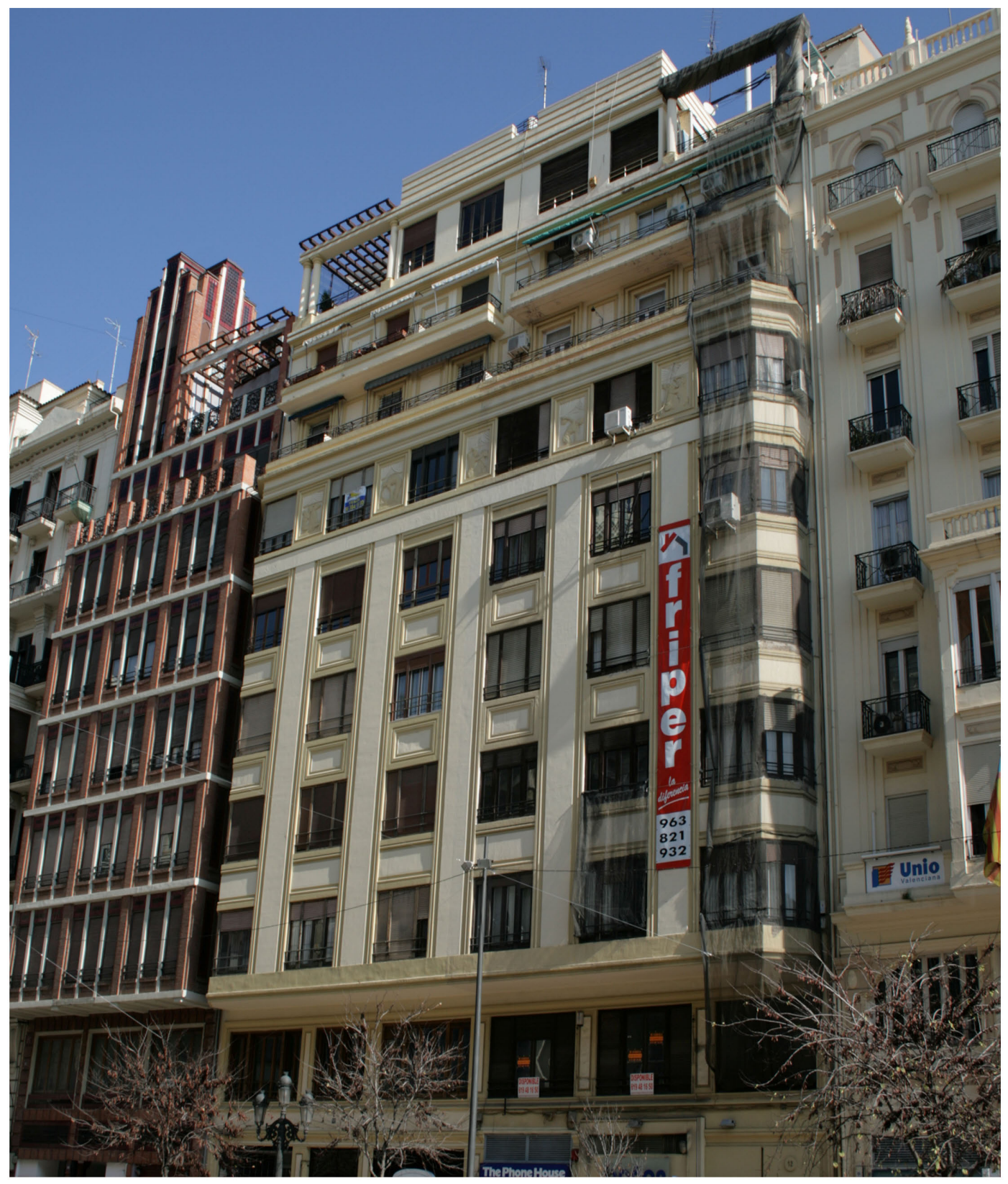

Luis ALBERT, 1930. Edificio para Tomás SANCHEZ, modificado para Rufino GARCíA, avenida de Blasco lbáñez en el comienzo de la plaza de Emilio Castelar; fotografía doctorando 
Probablemente la distancia física a los movimientos de vanguardia, a los epicentros europeos inmersos en debates culturales, sociales, ideológicos $y$, por ende arquitectónicos, evitó el compromiso. Incluso la indolente sociedad valenciana, rural, auto contemplativa, recelosa, dificultó la incorporación de estos jóvenes arquitectos a -Oriol Bohigas instauró la calificación- la ortodoxia racionalista. Tan solo una minoría, vanguardia congregada mayoritariamente en Cataluña, concentrada en el GATEPAC pudo aproximarse al término ortodoxia.

Aquellos heterodoxos que configuraban la escena metropolitana, elevarían las ciudades, resultando ambiguos, eclécticos, eficaces, comprometidos y escasamente ideólogos. Habrían de ratificarse funcionales, auspiciados en un término que, consideraban, les dotaba de modernidad, garante del estilo internacional. La forma seguiría a la función. Y muy probablemente, detenidos en este punto de la secuencia, conociendo que no bastaría organizar el nuevo espacio en base a la función, sabedores que la forma generadora ha de conmover ${ }^{4}$, se desligaron de la radicalidad del movimiento moderno. Preparados e informados, su accesibilidad a revistas como Architettura, L'Architecte, Innen Dekoration, L'Architecture d'Aujourd'hui, Moderne Bauformen, The Architecture Review, o las españolas Arquitectura -revista del colegio oficial de arquitectos de Madrid-, A. C. -revista del GATEPAC-, Cortijos y Rascacielos, Nuevas Formas -revista de arquitectura y decoración-, Viviendas -revista del hogar-, les permitió introducir rasgos vanguardistas en la arquitectura de nuestras

\footnotetext{
${ }^{4}(\ldots)$, "mediante un programa más o menos utilitario que habéis superado, habéis establecido relaciones que me han conmovido. Esto es arquitectura."

LE CORBUSIER. "Hacia una arquitectura". p.145
} 

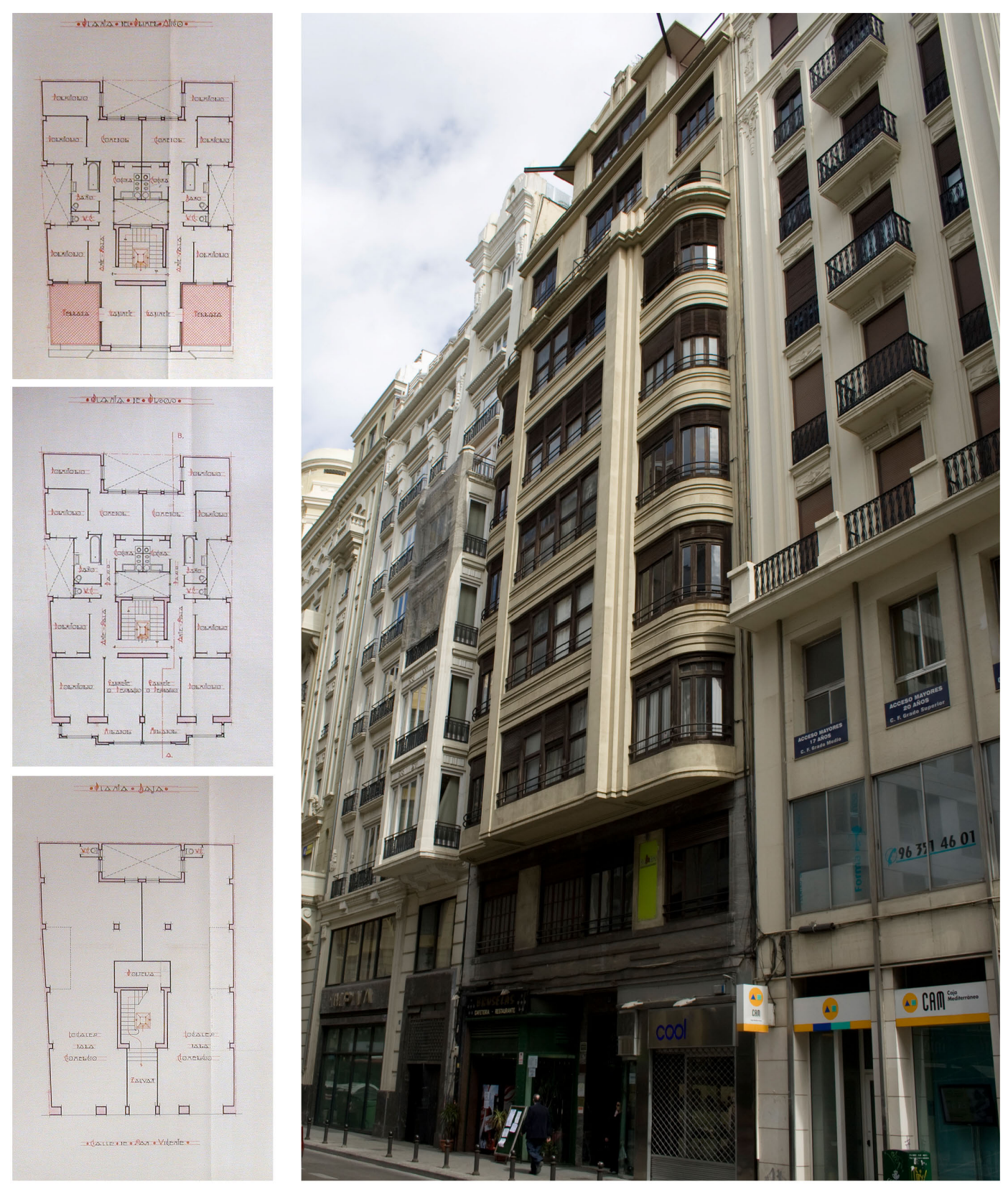

Luis ALBERT, 1930. Edificio para Juan Antonio MOMPÓ, calle San Vicente, n³3; plantas de distribución (AHMV) Policía Urbana, legajo 27 expediente 21; fotografía doctorando 
ciudades, denostar antiguos historicismos anhelando modernidad. Revistas usuales en sus estudios también fueron las de luminotecnia, sonido, y decoración, e imprescindibles amanecían los libros de estructuras, las maquetas de sus proyectos y toda una remesa de catálogos sobre novedosos materiales. Este afán por conocer lo nuevo en formas, tecnologías y materiales que mantuvo hasta sus últimos días -escribió Alberto Peñín de Luis Albert-, le aprehendían en sus aspiraciones de modernidad y coincidimos en "situarle en un lugar de honor entre los arquitectos valencianos de los últimos años". 5

El carácter receptivo de Albert, su interés por la innovación, su minuciosidad y rigurosidad, su precoz afinidad con las corrientes contemporáneas, a través de los manifiestos doctrinales, afloraban como estudiante cuando presentó con Gaspar Blein -bajo colaboración- el conocido anteproyecto al concurso del Ateneo $(\mathrm{fig}, 1)^{6}$, en su último año de carrera. Colaboraba siendo estudiante, con Alfonso Fungairiño, en diversos proyectos, planes de ensanche e incluso, posteriormente en la dirección ejecutiva de las obras para la Facultad de Medicina, en el Paseo al Mar (fig. 3), interpretando el primitivo proyecto de José Luis Oriol.

5 PEÑíN IBÁÑEZ, Alberto. Op. cit. p. 13

- Descollaría la forzada vista urbana de modernidad tanto como la formalización expresiva de sus fachas en un Concurso que despertó el interés participativo de una ingente representación profesional, incluyéndose arquitectos de renombre. Casto Fernández Shaw y Fernando García Mercadal, Luis Moya y Aníbal Álvarez, concurrieron con proyectos historicistas, escasamente innovadoras como las propuestas del resto de arquitectos valencianos, cercanos al regionalismo. No obstante, Blein y Albert recogieron, como único reconocimiento, la publicación en el monográfico de la revista Arquitectura n 107-108, año 1928. 


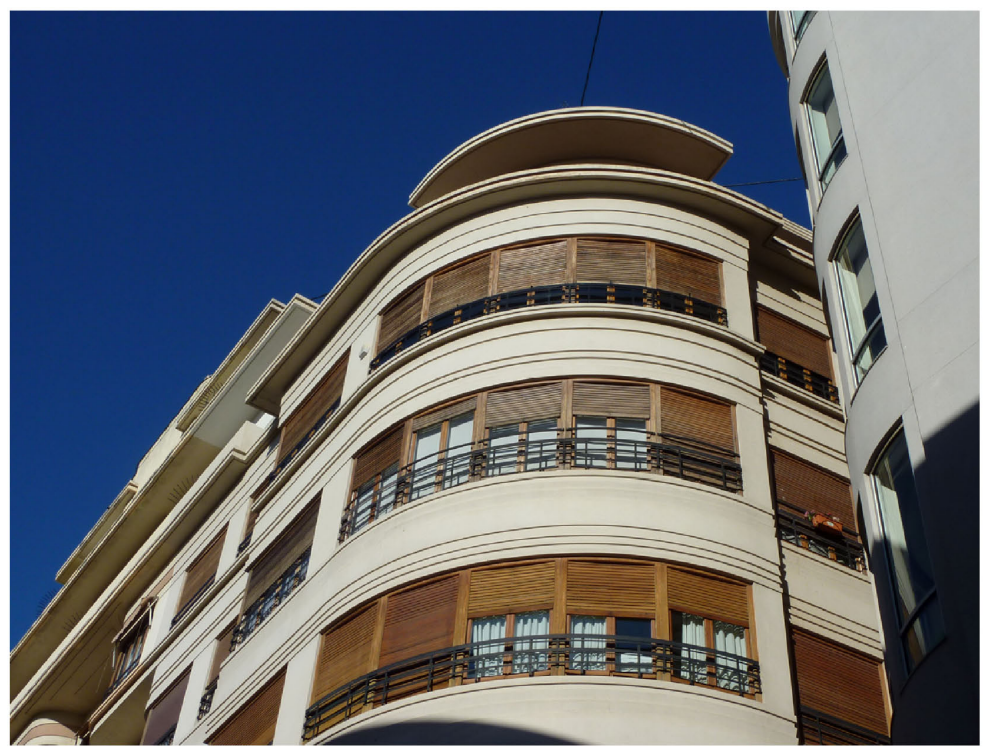

fig. 3

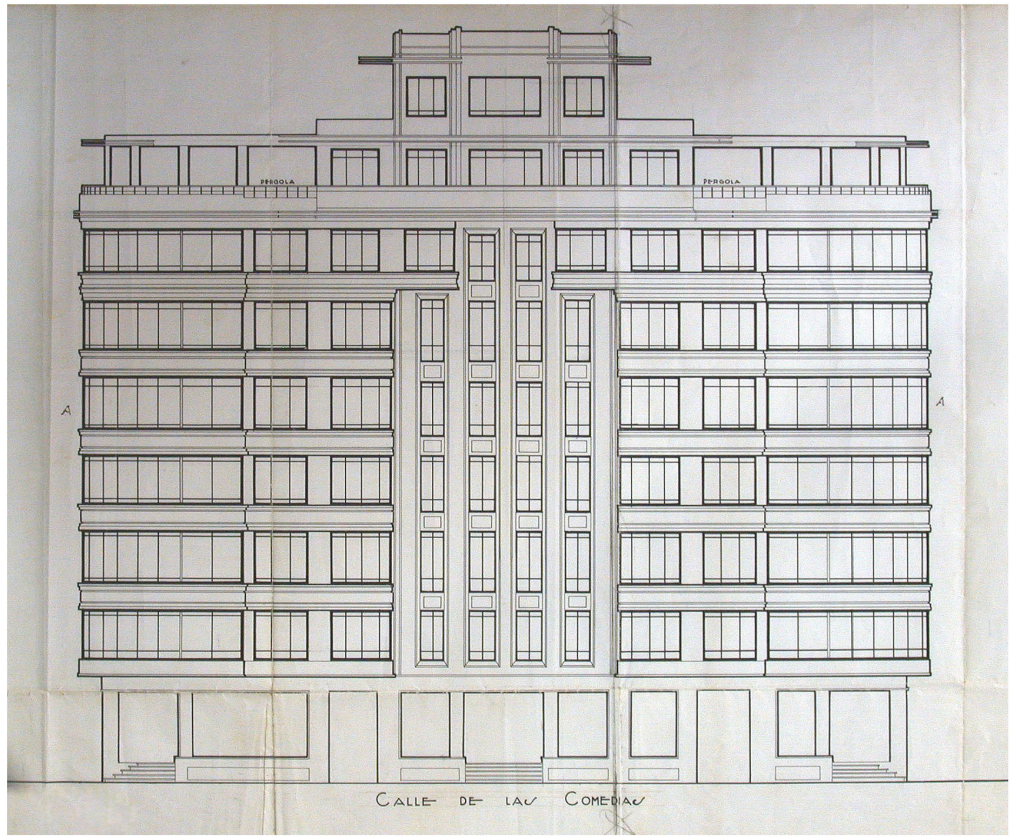

Luis ALBERT, 1931. Edificio Pilar TORTOSA, calles de las Comedias, de la Nave y de BarceIona; fotografía doctorando, alzado de proyecto(AHMV) Policía Urbana, legajo 8, exp. 6 
Estrenaba su andadura individual, abriendo despacho en 1928. Roberto Sales, aparejador avecinado en el Cabañal, fue su compañero de viaje escoltándole en sus primeros proyectos de pequeñas viviendas, típicas del barrio y del momento. Garantizarse un sustento continuado, ingresos paralelos, regulares aparte de los propios del despacho, marcaban sus esfuerzos por adquirir un cargo de funcionario, compaginado con un trabajo esporádico en la Compañía de Caminos de Hierro del Norte, al que tuvo acceso nada más titularse. Tras diferentes intentos infructuosos en diversas tentativas, adquirió la plaza de arquitecto provincial de castellón. Transcurridos escasos años -tres siendo estrictos- se produjo el paso a la Diputación de Valencia, auxiliando a Vicente Rodríguez Martín, hasta ser nombrado, en 1932, arquitecto de la Comisión Provincial de Servicios Técnicos de la Diputación de Valencia.

Edificó en la calle Játiva (fig. 2), para la familia Carbajosa (1929) la que supuso una primera construcción en hormigón armado para esta ciudad. Como punto de arranque, le arropó prestigio profesional, apreciación social e impacto mediático."El arquitecto de estilo y gusto inconfundible" titulaban para afirmar: "Cuando uno ve la finca de la calle de Játiva, frente a la Plaza de Toros, queda verdaderamente asombrado; es de un gusto tan original y moderno, tiene tal señorío y elegancia, se aparta tanto de cuantos edificios existen no solo en Valencia sino en las más importantes capitales, y es tal su belleza de línea, que sin querer se piensa en el arquitecto que la proyectó (...) del edificio más original, más sencillo y más bello".7

7 Album "Valencia-1931". Ediciones Regionales. Director Jorge Cartier, Francisco Sempere. Valencia 


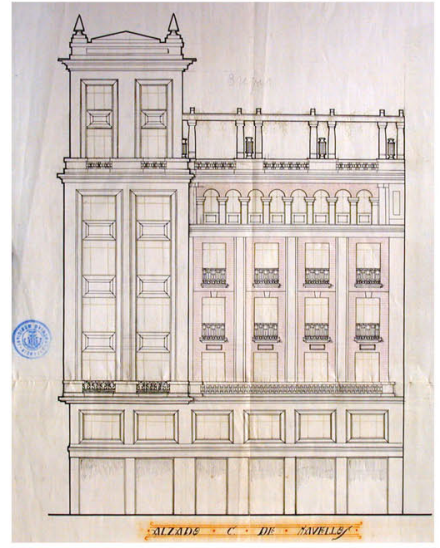

fig. 4
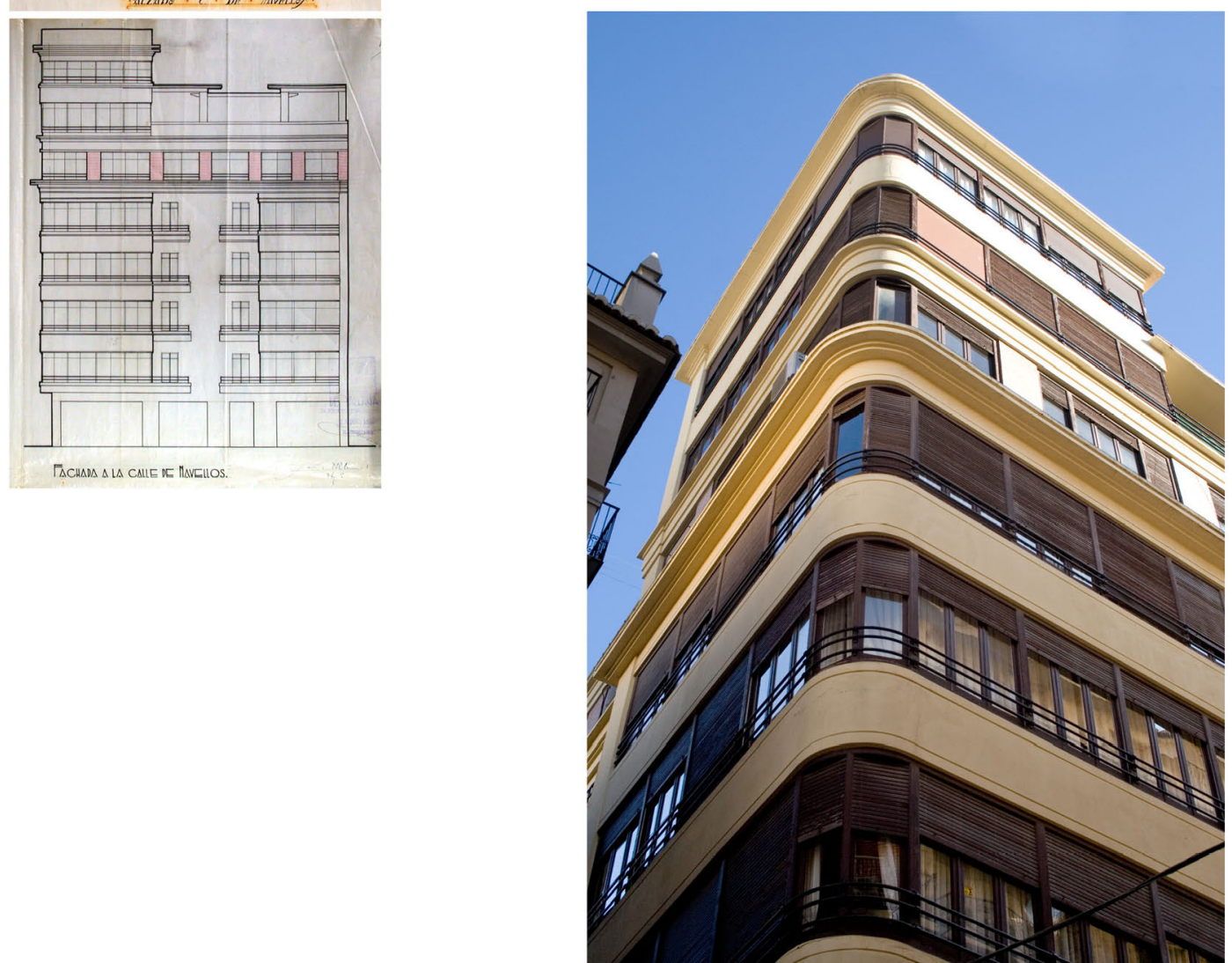

Luis ALBERT, 1932. Edificio Manuel CÁNOVAs, calles Navellos, Micer Tarazona y Yerba: alzados del primer proyecto y su posterior modificado. (AHMV) Policía Urbana, legajo 13 
Semejante inicio auspició sus primeros edificios en Valencia, apuntando, en su mayoría, hacia propuestas historicistas adaptadas siguiendo sus propias pautas, ya apuntadas desde aquella propuesta para el concurso del Ateneo. Alberto Villalba, contratista, constructor del edificio Mercantil, fructificó uno de sus primeros contactos laborales. Con él realizaría la ejecución del proyecto primigenio Edificio de Oficinas Públicas de de la Administración Republicana, de Luis García de la Rasilla, en la calle Jacinto Benavente (1935) -finalizado en 1943 para la Jefatura de Aviación, por Fernando Bueso y actualmente demolido, evitando consideracionesasí como los cuarteles para la Guardia Civil en Patraix (1936). Coincidían pocos arquitectos, escasamente cuarenta al constituirse el Colegio de Arquitectos en 1925, y resultó un momento -proclamada la II Repúblicadonde la identificación con la arquitectura racionalista, donde la demanda de obra era suficiente para garantizar su acceso profesional. Sigfrido Blasco lbáñez o Pilar Tortosa, para la que elevaría una finca (1931) en la calle Comedias (fig. 3) y un chalet en el Vedat, engrosaban sus contactos laborales.

Pretensión de modernidad, aportación técnica, innovación formal, expresionismo funcionalizado ${ }^{8}$, apuntaban aquellos edificios Carbajosa y Tortosa. No obstante, el arraigo profesional, el concluyente afianzamiento de su prestigio en el ámbito local le alcanzó con el edificio Cánovas (1932), en la calle Navellos (fig. 4). Desvinculado de los axiomas de composición clásica, "pone en evidencia la rotunda superioridad de la nueva técnica sobre el valor contemplativo de los estilos clásicos, que si merecen reverencia y respeto como valores monumentales, no tienen eficiencia ante las

${ }^{8}$ TORRES CUECO, Jorge. Op.cit. p. 2 


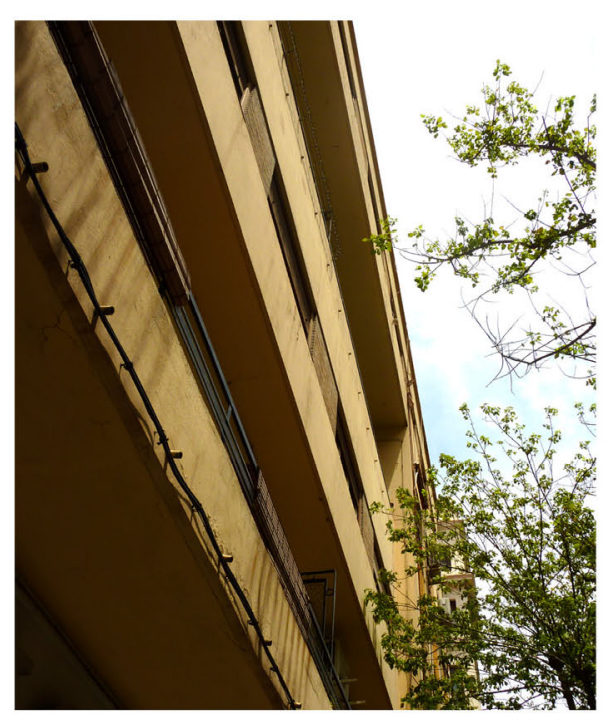

fig. 5

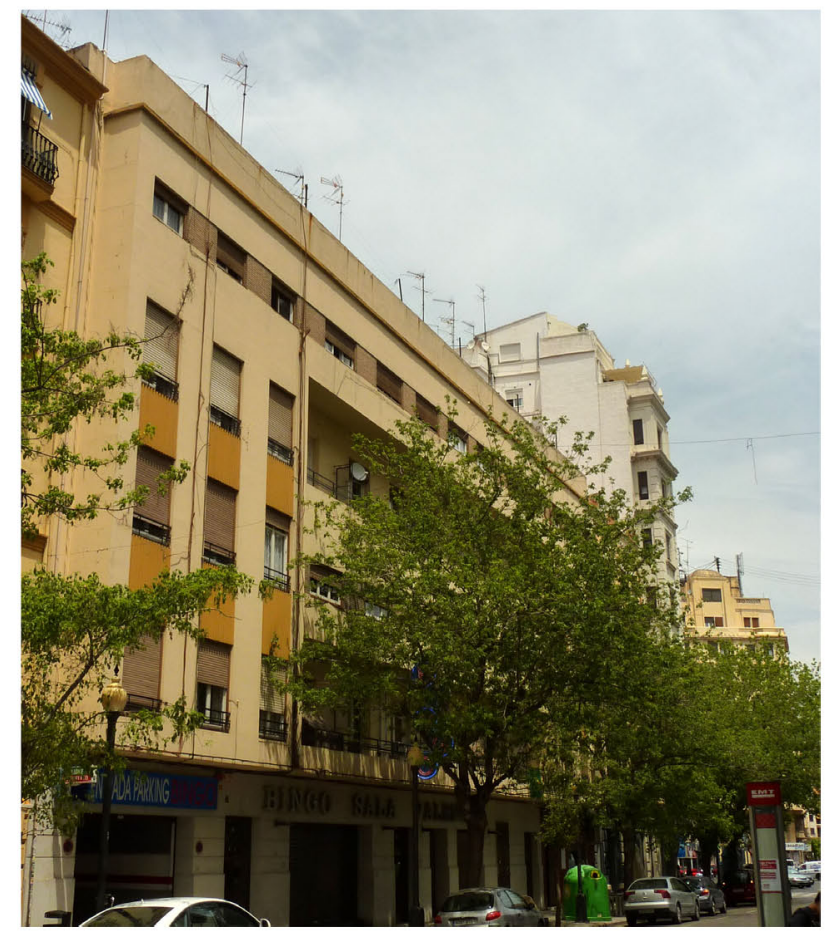

Luis ALBERT, 1935. Edificio José Manuel ZABALA, calle Cuenca n¹6; fotografías doctorando, volumetría y detalle de la equívoca imagen de disposición en viviendas duplex 
exigencias de la vida y estética actuales", escribían -en alusión a su maqueta de la casa del señor Cánovas- sobre el señor Allbert' en un artículo de prensa constatando el triunfo-segunda medalla en la Sesión de Arquitectura- del joven arquitecto de La Diputación tras la clausura de la III Exposición Regional de Bellas Artes.

Completaría su arquitectura de juventud el edificio Zabala (1935) en la calle Cuenca (fig.5) y la casa y fábrica de cepillos para el cónsul alemán Máximo Buch (1935) en la calle Cuarte (fig. 6), ambos alejados de las expectantes miradas que apuntaban al epicentro escénico de la urbe, alejados de los trascendentalismos de los encargos céntricos u oficiales. Molduras rectas y corridas, cuerpos salientes sin decorar y hasta atrevidos -en Valencia- juegos de volúmenes en diferentes plantas, confirman el lenguaje del autor. De su época más "cubista», como él la llamaba, declamando el ocaso juvenil, es el edificio Alonso (1935), en la calle San Vicente (fig. 7). Innegable inspiración expresionista, proclamada por Alberto Peñín, rezumaba su fachada acristalada continua, ejecutada con una notable escasez de medios de la que tan quejoso quedó el arquitecto y transcurrida una década de los almacenes Schocken de Eric Mendelshon. "Este distanciamiento hacia adelante de Albert con respecto a su medio no llega a anular un trabajo más normal en claves de adecuación económica, al sistema constructivo y al uso que señalará como condiciones de su arquitectura en su discurso de $1961 " .10$

9 "Un triunfo del arquitecto señor Albert" titulaba un artículo del 18 de agosto de 1935, en el diario El Pueblo.

10 PEÑ ÍN IBÁÑEZ, Alberto. Op. cit.p. 14 

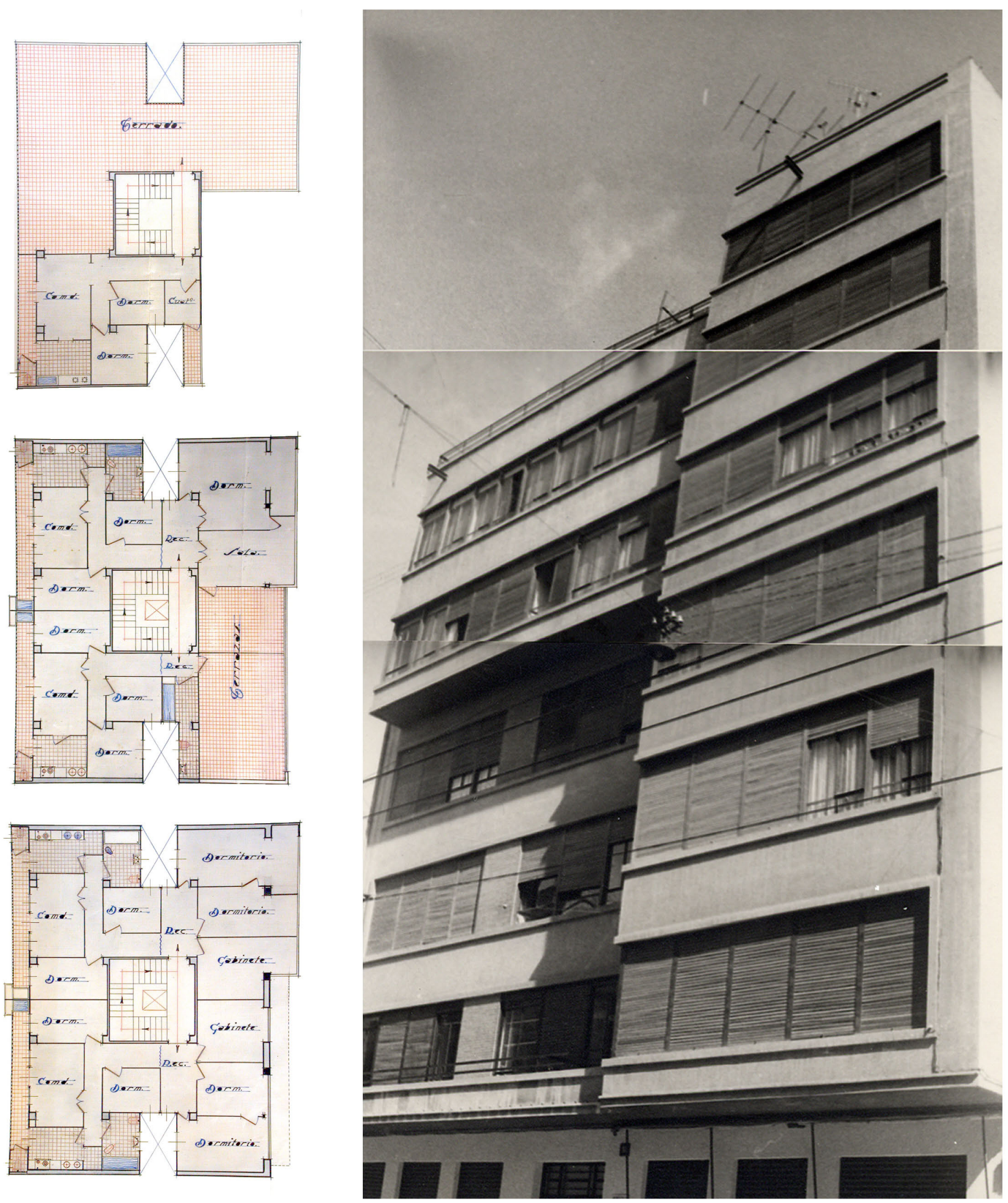

fig. 6

uis ALBERT, 1935. Edificio Máximo BUCH, calles Cuarte nº114 y San Jacinto n³; planos originales distribución (AHMV) Ensanche, legajo 3; fotografía época (arch. Alberto PEÑín) 
No podemos cerrar este ciclo de juventud sin referenciar sus propuestas para la administración, su arquitectura de encargos oficiales. Apuntábamos una manifiesta disociación de los proyectos planteados bajo encargo público y aquellas obras erigidas bajo auspicio particular. Disociación preconizadora de sus logros inmediatos al racionalismo ortodoxo y, esclarecedora de sus posiciones al margen, heterodoxas. Disociación condicionada, no tan sólo por sus demandantes, también por el emplazamiento, por el escenario donde representar y los espectadores a quienes causar satisfacción. Resultará relevante como condición de partida, de planteamiento y por ende restrictivo en la solución definitoria, acometer actuaciones en la impetuosa vorágine urbana, o bien liberarse de concurrencia -despejado el auditorio- trasladando el hecho proyectual apartado de la ciudad. Examinaremos atentamente la sutil distancia respecto al epicentro y su sustancial alteración en edificios de viviendas de promoción privada, y la menos sutil afección respecto de la "triada albertiana", ofertada desde la Diputación Provincial de Valencia (fig. 8).

Trascendente y de honda repercusión pública. Controversia -valdría el término- como calificativo de lo suscitado por los proyectos de un nuevo Hospital Provincial, un nuevo Manicomio y una nueva Plaza de Toros. Nuevamente el contratista Alberto Villalba entraba en escena, proponiendo una operación de marcado contenido inmobiliario. Se prevalió la Diputación Provincial para plantear una acción global sobre la ciudad, encontrando un magnífico vínculo en su arquitecto. Sin embargo, presentados los bocetos ante la Comisión Gestora Provincial en 1935, no se aceptó la instancia suscrita por el arquitecto y el constructor "Después de pequeña discusión y en votación, quedó para estudio este magno proyecto". Reseñas periodísticas narraban: "Más que la Diputación de Valencia 

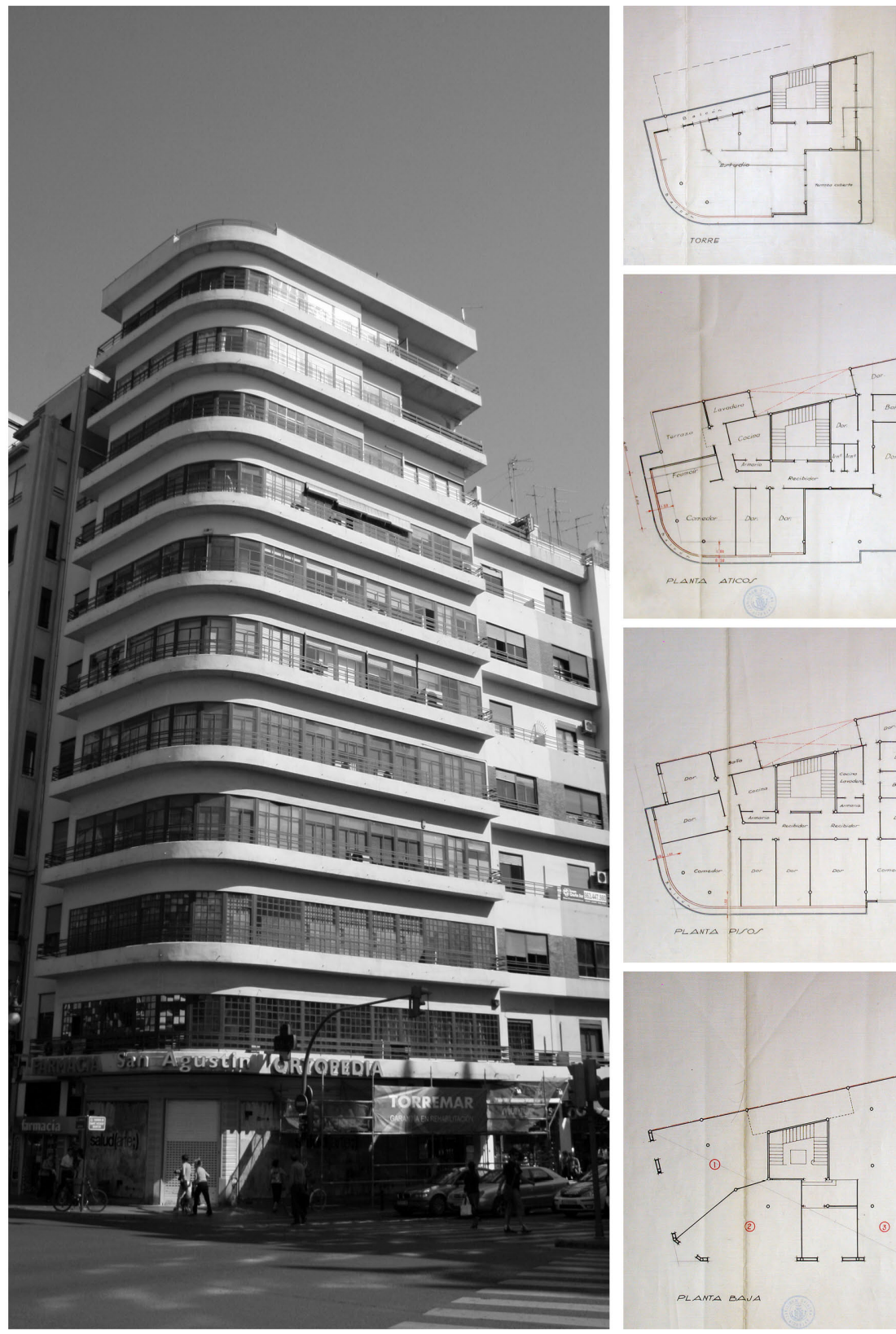

fig. 7
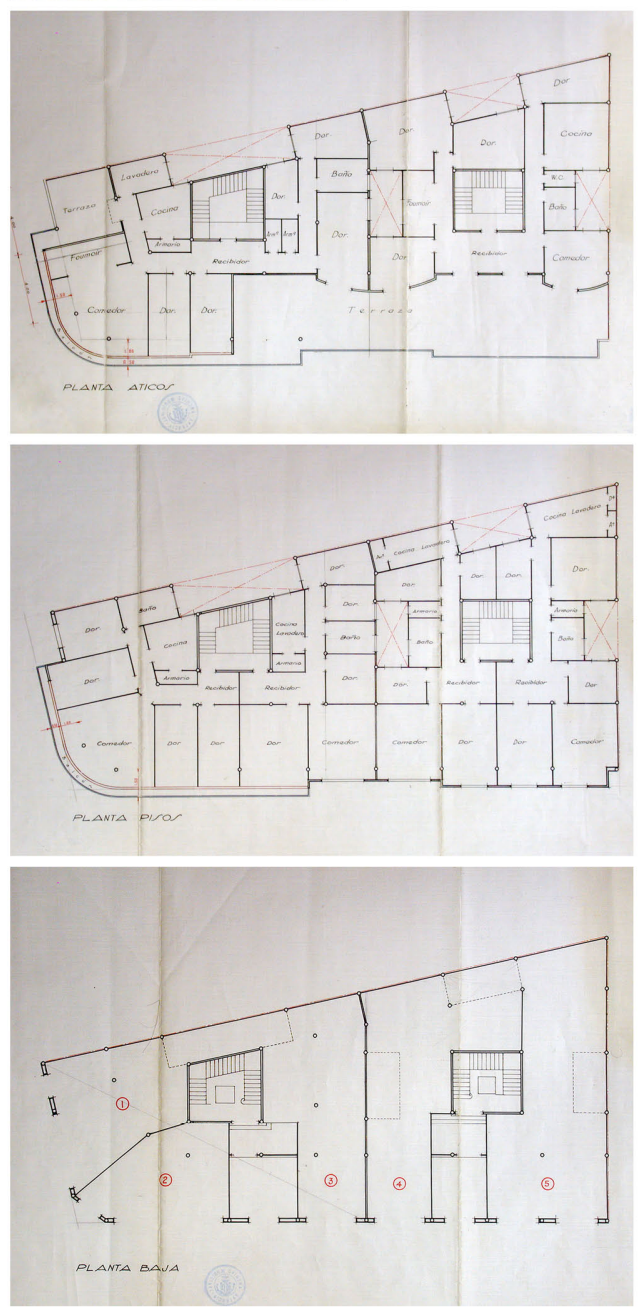

Luis ALBERT, 1935. Edificio Carmen ALONSO, calles Játiva y San Vicente; fotografía doctorando iconografía de rascacielos y, planimetría original (AHMV) Ensanche, legajo 4 
parecía estar reunido el Ayuntamiento del último villorrio, con sus egoísmos y pequeñas pasiones"." "El hecho de que ni siquiera se haya tomado en consideración el magno proyecto del señor Villalba acusa en los señores diputados, o incomprensión del problema o un espíritu mezquino para este linaje de mejoras"12.

Citemos, para completar la referencia, el horror suscitado por esta arquitectura en determinados ambientes locales, cuando Albert la presenta en la III Exposición Regional de Bellas Artes (1935). En la crónica de "El Mercantily sobre la misma, el autor se despacha contra el proyecto de Hospital Provincial, al que califica de "detestable", de "enorme disparate" al no responder "a su crédito (de la ciudad de Valencia) en arten y arremete contra "eso que llaman arquitectura nueva, que no es sino negación de arte y pura ingeniería». Por su parte, "El Pueblo" califica la exposición como "un resonante triunfo del joven arquitecto" y alaba en el proyecto el "alarde de moderna técnica" identificándole con "el temperamento de la nueva escuela que todo lo arrollan a la vez que le recomendaba desoír "la crítica de ultratumba»; citas recogidas de Alberto Peñín.

Hubo contraído matrimonio en 1929, con María Leach Ausó, alicantina. De esta unión nacieron tres hijos, María Luisa, Luis y María Teresa, falleciendo el varón finalizada la Guerra Civil española. Ambas hijas se casaron

11 "La sesión de hoy en la Diputación" titulaba el diario "La voz valenciana", el 7 de agosto de 1933., y hablaba de: Un proyecto de la magnitud del presentado, bueno o malo. que no es momento de ser discutido ello, merecía de la Diputación tomarlo en consideración, par después hacer todos los estudios y pedir todos los asesoramientos técnicos que se estimaran precisos.

12 "La Correspondencia". 7 de agosto de 1933. 


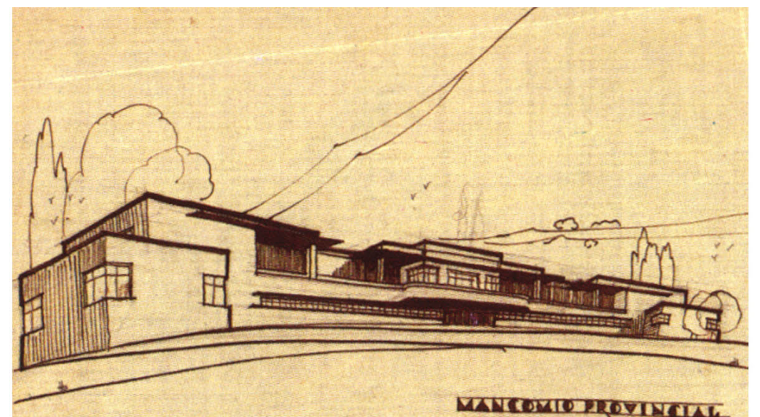

fig. 8

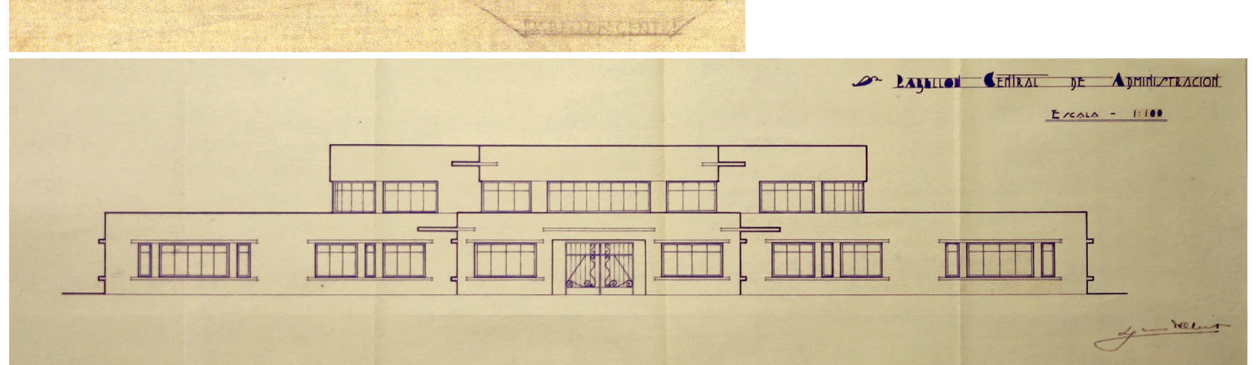

LAgELIOI CEHERAL

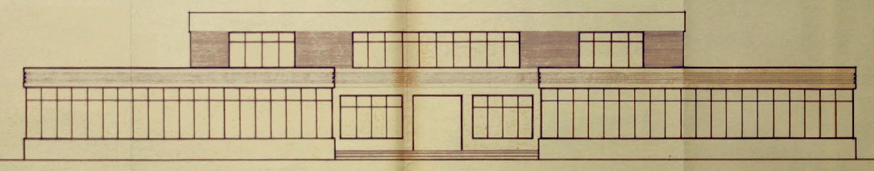

- reen

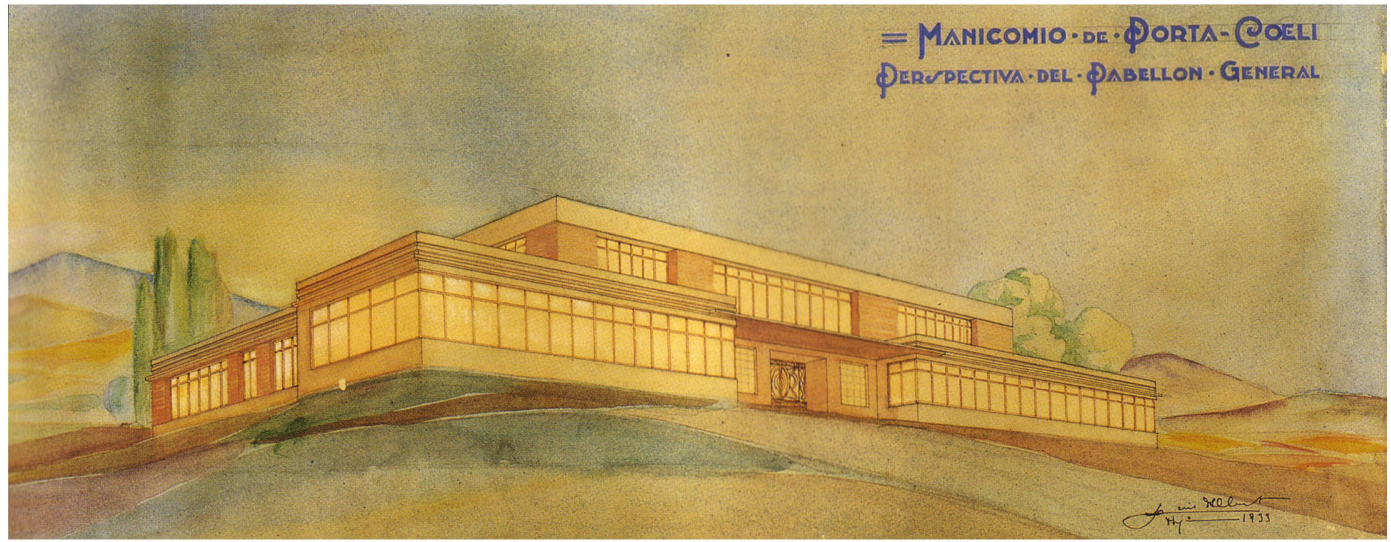

Luis ALBERT, 1933. Manicomio PORTA COELLI, para la Diputación Provincial de Valencia; perspectivas y planimetrías originales de los diferentes pabellones del conjunto(AHDP) 
en Alicante, donde residen actualmente, sin haber continuado ninguna, profesionalmente, los pasos del padre.

Acometía España una Guerra Civil, en un estadio crucial en el proceso del desarrollo profesional de Luis Albert. Finalizaba 1935, año fundamental en el devenir del arquitecto, en aquella evolución mediante la cual llegó a convencerse racionalista, heterodoxo en un incesante trayecto de asimilación y praxis; reconocida continuidad. Había completado alrededor de 80 encargos, algunos de elevada condición o mérito-viviendas citadas para Carbajosa, Cánovas, Zabala, Alonso y Buch- y había visualizado una triada -el Hospital Provincial, un nuevo Manicomio y la nueva Plaza de Toros- proyectada contigua a los ideales racionalistas, por lo menos alcanzado su máximo inmediato, concurrentes -triada y límite racionalista- en el acontecer del conjunto profesional, de su obra integra. Conjunto formalizado siempre dentro de un estudio nunca grande, o bajo su cargo público en la Diputación. Roberto Sales seguiría firmando como aparejador. Dos delineantes y, Enrique Meseguer, un aprendiz, que acabaría siendo el aparejador en la etapa final.

La posguerra derribó el número de encargos hasta reducirlos a la ausencia. El trauma se personó mayúsculo, en todo el gremio. Luis Albert ya venía lastrado, tras la profunda desesperanza que le supuso la desestimación de sus propuestas por la Comisión Gestora de la Diputación Provincial y la reprensión social de su arquitectura. Nada importaba la ideología profesada, la conmoción llegaba de ambas posiciones. Padeció el oprobio por su acometida al funcionariado durante la República, por su afiliación al lenguaje racionalista y su pretendida modernidad, por su inclinación hacia pompas blasquistas. Detenido. Expedientado. Exacerbado 

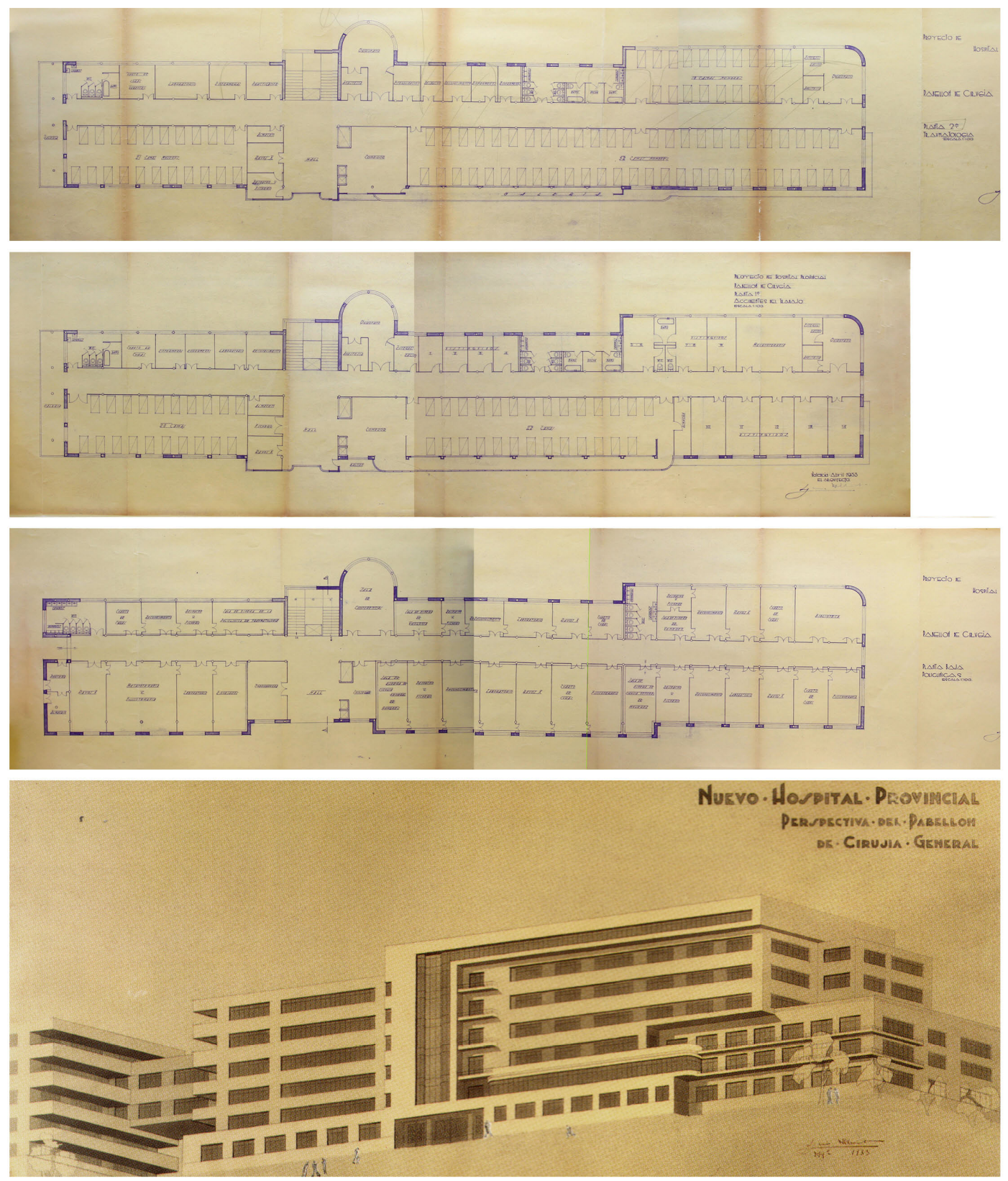

Luis ALBERT, 1935. Propuesta de nuevo Hospital Provincial para la Diputación valenciana; planimetría de distribución y perspectiva del arquitecto, de uno de los pabellones(AHDP) 
hasta el escepticismo, la cautela, la clausura y próximo al aislamiento hasta renegar de sus referencias expresivas racionalistas y escudarse en la restauración de obras ajenas, manteniendo apartadas sus propias apreciaciones, enclaustradas en consideración al patrón inicial.

Mantuvo la dicotomía -electa en su juventud- frente al trabajo dedicado a la Administración y su labor como profesional liberal, solventando encargos privados. Encontró en la primera postura -finalmente en la labor patrimonial- un amplio abanico de ilimitadas satisfacciones, pequeños estímulos. Su impuesta minuciosidad, su rigurosidad y disponibilidad en la dirección de obra se manejaban libres frente a imposiciones estilísticas, proporcionándole, ante cualquier planteamiento ideológico, la independencia profesional precisada. En la esfera laboral privada, coincidiendo con la apertura de la avenida del Oeste, el escaso trabajo acometido desde su estudio se debatiría, entre su antigua senda evolutiva hacia la modernización, el racionalismo desatendido y el rechazo hacia el estilo nacional ${ }^{13}$ pretendido por el nuevo gobierno autócrata. El temperamento vanguardista permanecería constante, a lo largo de toda su trayectoria $y$, finalmente responsabilizado de tales actitudes, restarían escuetas opciones de expresión arquitectónica. Un reducido lenguaje formal afín, experimentado y dominado, con el que trabajar seguro, al margen de innovaciones, modernidad o perseguidos -entiéndanse las dos finalidades: como logro personal y como represión dictada-ideales.

13 FERnÁndez ALBA, Antonio. "La crisis de la arquitectura española (1939-72)". Editorial Edicusa, 1972. Madrid. 172 p. 

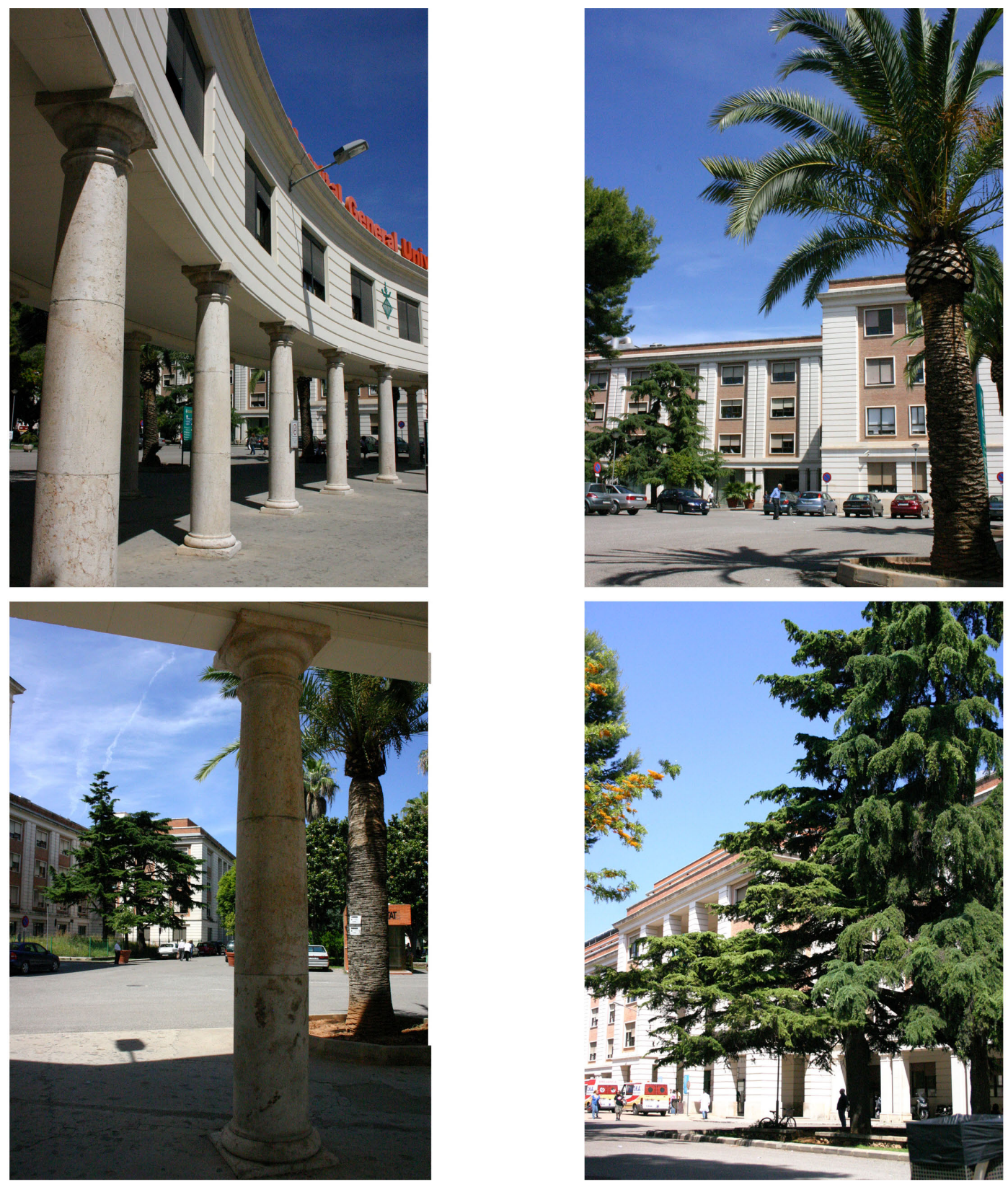

Luis ALBERT, 1948. Hospital Provincial para la Diputación de Valencia, avenida del Cid; fotografías doctorando donde cotejar diferencias con la racional propuesta de 1935 
Tampoco lograrían eludir esta situación sus coetáneos, jóvenes y disgregados colegas arquitectos sin agremiar. Sufridas represalias algunos, exiliados otros y expedientados la mayoría, llegarían a proyectar desde la Cárcel Modelo de Valencia -firmando sus colegas externos- para garantiza una exigua manutención familiar. Ricardo Róso, Emilio Artal, Enrique Pecourt, Cayetano Borso, Jose Luis Testor, Joaquín Rieta, Mariano Pesset emprenderían direcciones diversas, acompañados por un Javier Goerlich que los establecía, desde su cargo en el Ayuntamiento de Valencia. Nunca labraron una dirección común coherente, una línea maestra consecuente -comenzando por el arquitecto Municipal-, más bien cosecharon en todo tipo de terrenos. No obstante, en su descargo, cabe insistir en una excepción frente a la dispersión promulgada, y no es otra que su denominador generacional, el nexo común, aquel estricto sentido de servicio y eficacia, presente en todos ellos.

Vertiginosamente se distanciaron del espíritu de su juventud, de la sinceridad de sus convicciones, del instinto de insurrección hacia la Academia y lo que aquella suponía, la tradición. Un antes, otrora libre y en ese instante adultos, la madurez consumada. Flagrante etapa que se estrenaba porfiada, orquestada en el lenguaje y con escasez de encargos para cualquiera desaprobado. En esta primera fase de la posguerra, Luis Albert no filiaría en el colectivo selecto para ejecutar grandes planes de urbanismo, viviendas oficiales, iglesias y colegios. Tampoco los pretendió. La premura se resolvería con el afianzamiento institucional de la Diputación Provincial, cuyo cargo nunca abandonaría, acometiendo propuestas desdeñadas del período republicano, forzándole a retomar posturas profesionales determinadas y cotas de protagonismo apartadas de su retraída inclinación y circunspección. No obstante, los problemas de exhibición 

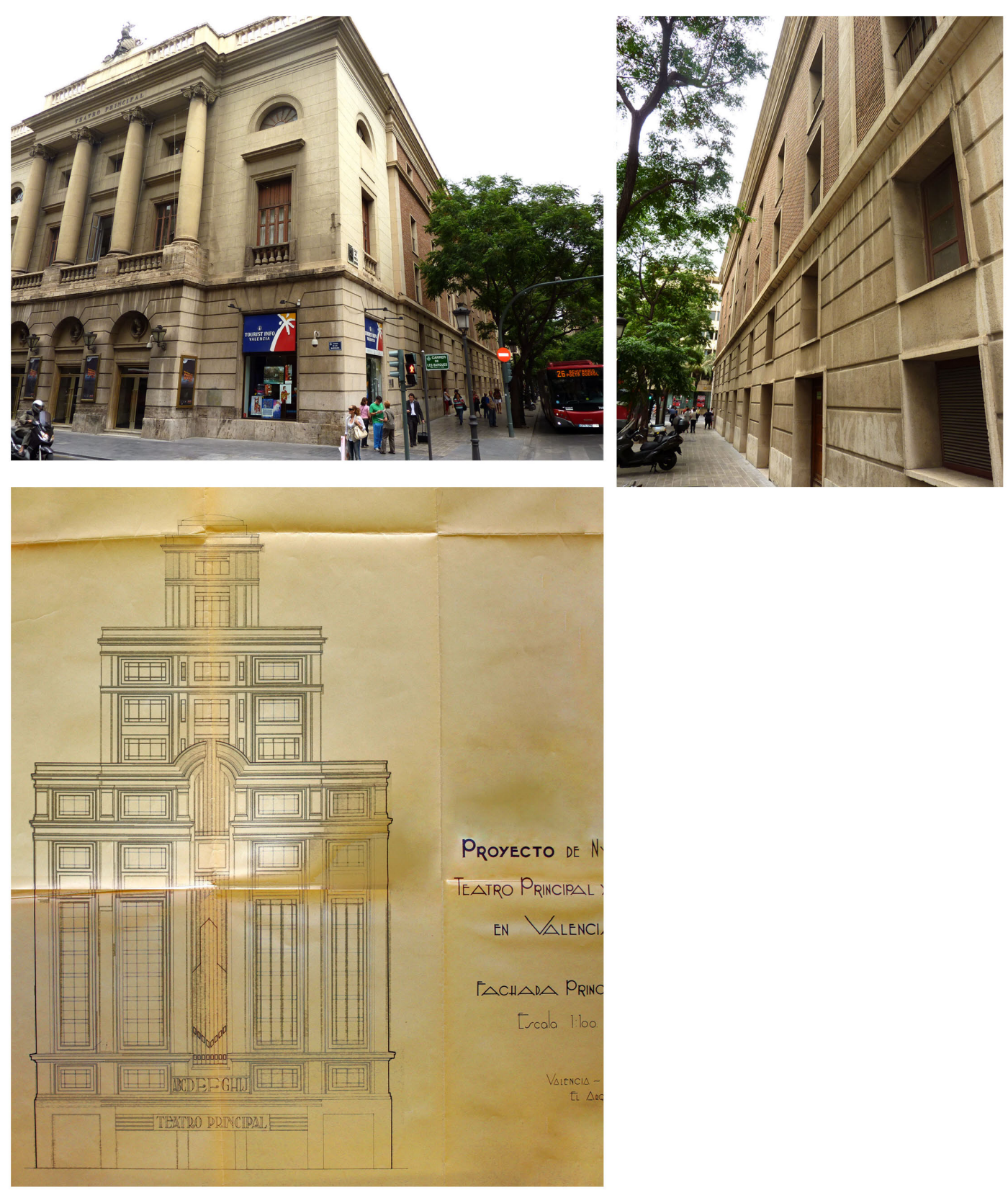

Luis ALBERT, 1934. Proyecto Nuevo Teatro Principal y Hotel, calles Barcas y poeta Querol; posterior intervención en vestíbulo y fachada lateral de inspiración no racionalista (1945) 
y conciencia se despejaban, trasladando los intereses a comentarios exclusivamente constructivos -adecuación al clima, riesgos de filtraciones de agua o de desprendimiento de cornisas-, a discursos sucintamente estéticos -pesadez- y acudiendo finalmente a la consabida funcionalidad. La reforma del vestíbulo y las escaleras del Teatro Principal (1945), el proyecto del Hospital Provincial (1948, posteriormente ejecutado en $1965)$ tan distanciado de convicciones radicales y juveniles particulares de la "triada albertiana" (fig. 9), la Casa de Nuestra Señora de la Misericordia (1948), la Escuela de Capataces de Requena, los edificios para Ayuntamiento en Albuixech y Benifairó de la Valldigna, resultarían los trabajos acometidos para la Administración, evitando siempre compromisos formales, resolviendo mediante un lenguaje sobrio, rotundo, correctos cada uno en su funcionalidad y solvencia estructural mediante hormigón armado.

Inspiración alemana, provocadora, para resolver formalmente estas construcciones. Planos regulares en fachada, que se resolvían mediante el rojo que materializaba el ladrillo y se rasgaban verticalmente, zurciendo huecos con una jamba continua, un nuevo plano de piedra que encontraba su final en zócalo y cornisa. Recurriría a idéntico proceder, algo más moderado y acorde con su carácter, en obras posteriores como la fachada lateral del Teatro Principal (fig. 10) O la restauración del Palacio del Temple (1962).

Hemos hablado que buscó guarecerse en la restauración -incitado desde Regiones Devastadas, al concluir la guerra- y probablemente ahí encontremos sus obras de madurez más significativas, encuadradas en el ámbito de la Administración Pública. La restauración del Claustro de Santo 


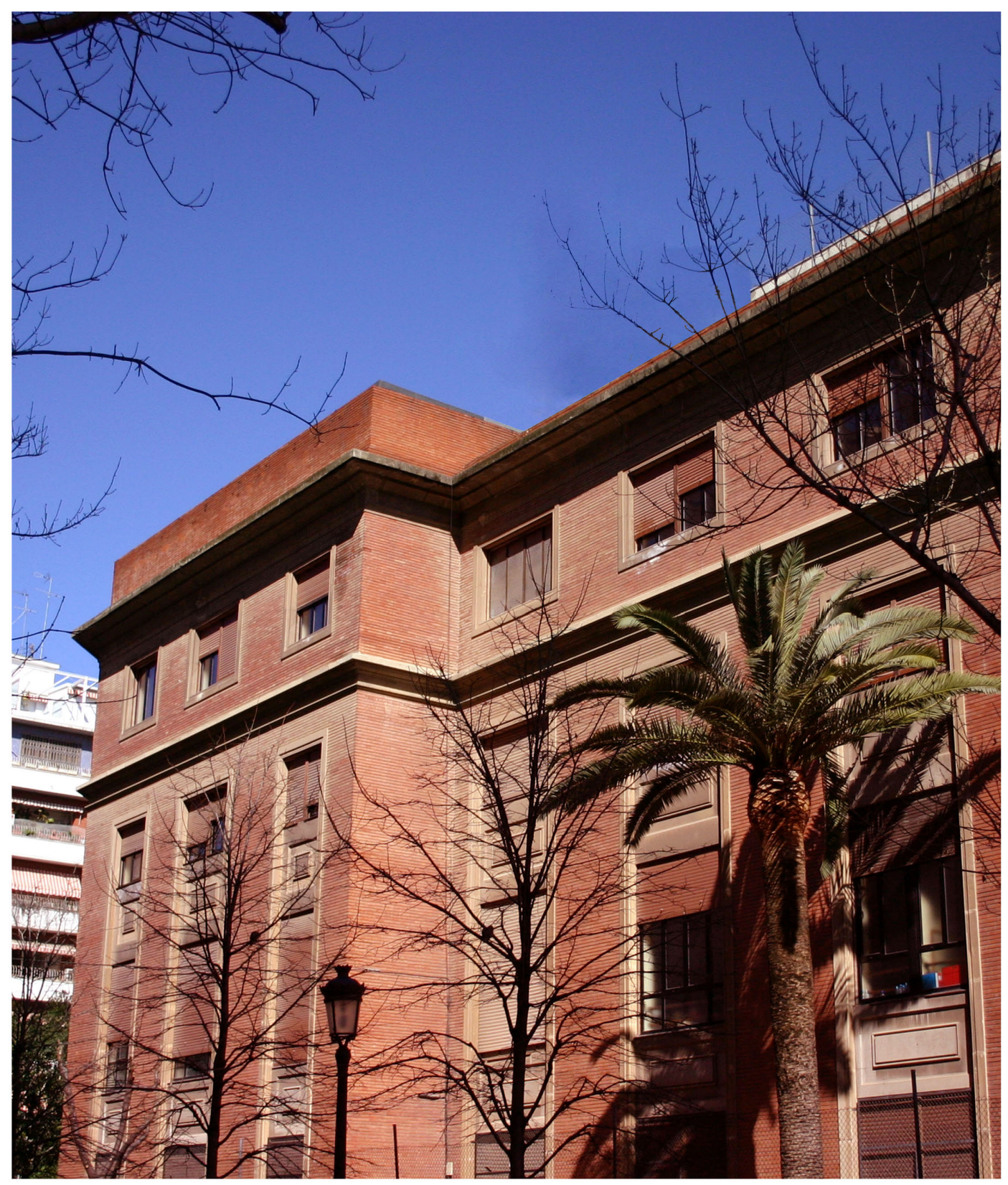

fig. 14

Luis ALBERT, 1939. Colegio LORETO, promotora Isabel RODRíGUEZ, avenidas de Jacinto Benavente, Peris y Valero, calle Salamanca; (AHMV) Ensanche, legajo 4 expediente 44228 
Domingo (1951) y sobre todo la restauración y la ampliación del Palacio de la Generalitat (1952) donde concluyó las propuestas de 1580 (fig. 11). "El trabajo, serio y riguroso, respetó las trazas primitivas (fechando convenientemente el añadido) sin caer en las concesiones retóricas del momento; comprendió la mitad del cuerpo central, el segundo patio y el torreón oeste, la sustitución de casi todos los forjados y pavimentos, y la restauración de buena parte de la obra antigua, la introducción de instalaciones y un nuevo sistema de comunicaciones. Quizá este punto, en su relación con el antiguo edificio, fue el menos adecuado a la nueva carga funcional de oficinas públicas, pero el trabajo del Palau puede considerarse, en su conjunto, como su obra más importante de este período. EI encofrado perdido de piedra caliza para la losa de hormigón de la escalera puede ser uno de los hitos constructivos de su trayectoria profesional". ${ }^{14}$

Faltaría apuntar su retorno a la senda por la que transcurrieron los encargos privados. Derrotero reemprendido, tras el desenlace bélico, mediante un encargo propio coincidente con el momento de apertura de la avenida del Oeste. Proyecto de edificio para Luis Albert Ballesteros (1941), esquina con la plaza Pellicer (fig. 12), pendiente de edificar hasta la aprobación de su ampliación (1944), "canto de cisne de una época ya periclitada". ${ }^{15}$ Dos edificios más del arquitecto, concurrirían en esta escisión quirúrgica del planeamiento emprendida por Javier Goerlich. Un edificio para Aparisi, mediada la primera década de la posguerra, en la esquina con la plaza Grabador Selma y otro en el inicio del arranque de la apertura

14 PEÑ ÍN IBÁÑ EZ, Alberto. Op. cit. p. 22

15 TORRES CUECO, Jorge. Op.cit. p. 46 


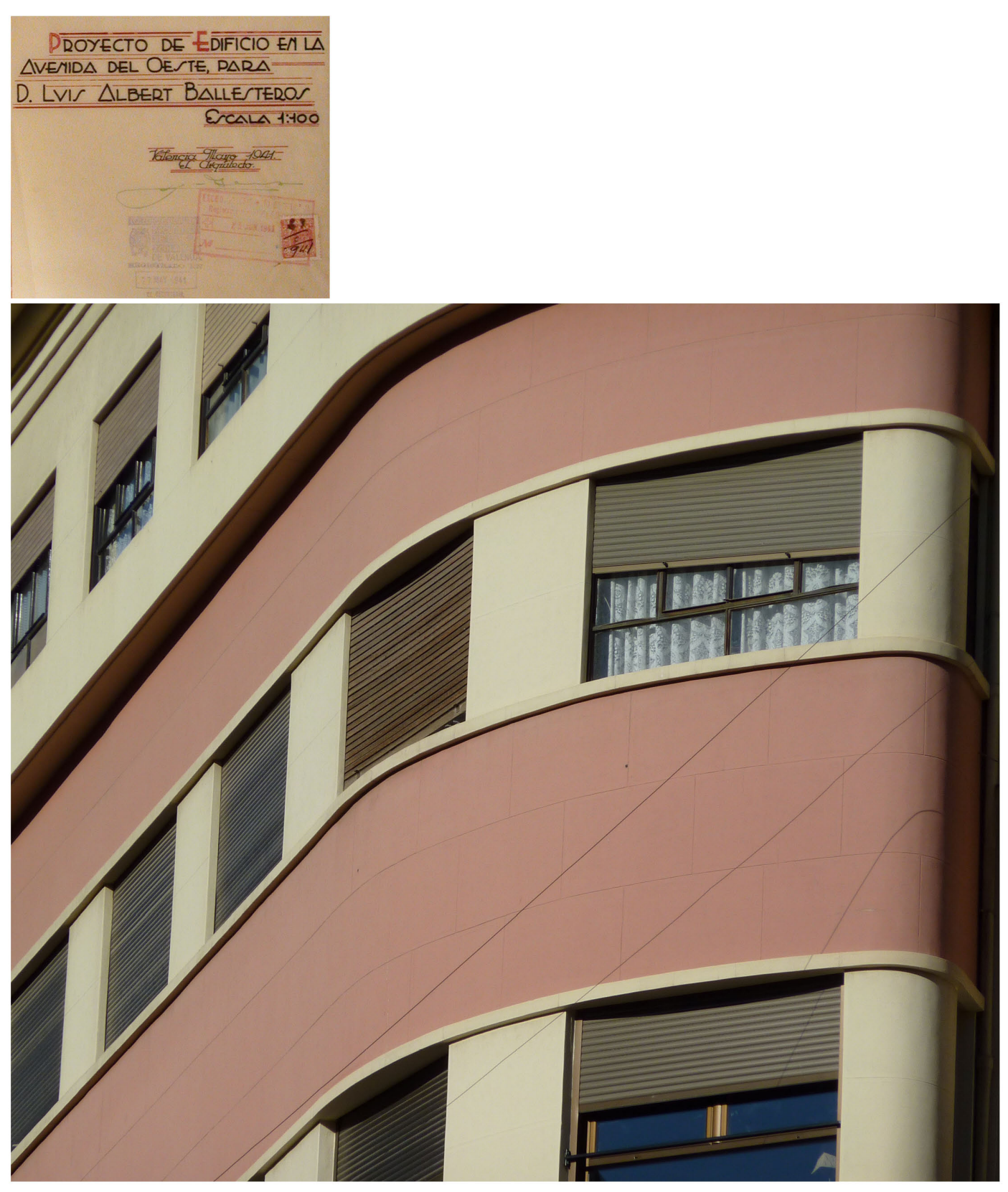

fig. 12

Luis ALBERT, 1941. Edificio ALBERT BALLESTEROS de promoción propia, avenida del Oeste: carátula de proyecto (AHMV) Policía Urbana, legajo 9, exp. 11643; fotografía doctorando 
de la avenida entre la plaza de San Agustín (fig. 13) y el puente de San José, edificio para Gil Colomer (1953). Sus expresiones formales, ya quedaban despachadas. Planos rojos sobrios, con rotundas disecciones donde alojar la fenestración. Recurso léxico, ya ensayado en el edificio para Lorenzo y Esteban Martínez (1941) en la calle Sorní, y manifestado en el colegio para Nuestra Señora del Loreto (1939) al final de Jacinto Benavente (fig. 14). Probablemente devino esta radicalidad expresiva, tan alemana y escasamente propia, del edificio en esta misma vía para las oficinas públicas de la Administración Republicana.

Luis Gutiérrez-Soto impregnó con referencias oficiales, el lenguaje común de los años cincuenta. Luis Albert permanecería exento de vanidades y decidido a amagar sus intenciones de juventud, y por ende inmutable al adaptar expresiones, ajenas a programas funcionales diversos. Alcanzó no mostrarse salvo en las descritas cuestiones constructivas y en sus inquietudes tecnológicas e históricas. Ejemplos elocuentes fueron los recercados de huecos de Gil Colomer, adelantando el vértice superior de las jambas tras un marcado interés por acentuar el vuelo del dintel y reforzar la protección frente al agua. Y recabado un modelo significativo, cabría integrar el grupo Lassala, con cuarenta viviendas de renta limitada (1957) en la plaza de la Bocha-Triador (fig. 15), para funcionarios de la Diputación. Brillante inmersión en la compleja ideación de propuesta urbana, para un bloque semiabierto dispuesto en una manzana, con un patio ajardinado al que recaen los apartamentos y predisponiendo el edificio con su entorno, relacionándolo con una zona comprometida, de sofocante densidad. Un pulso entre lo aprendido, la historia de la arquitectura del primer cuarto de siglo y el emplazamiento, la disposición metropolitana como principio generador de un proyecto, alcanzando una 


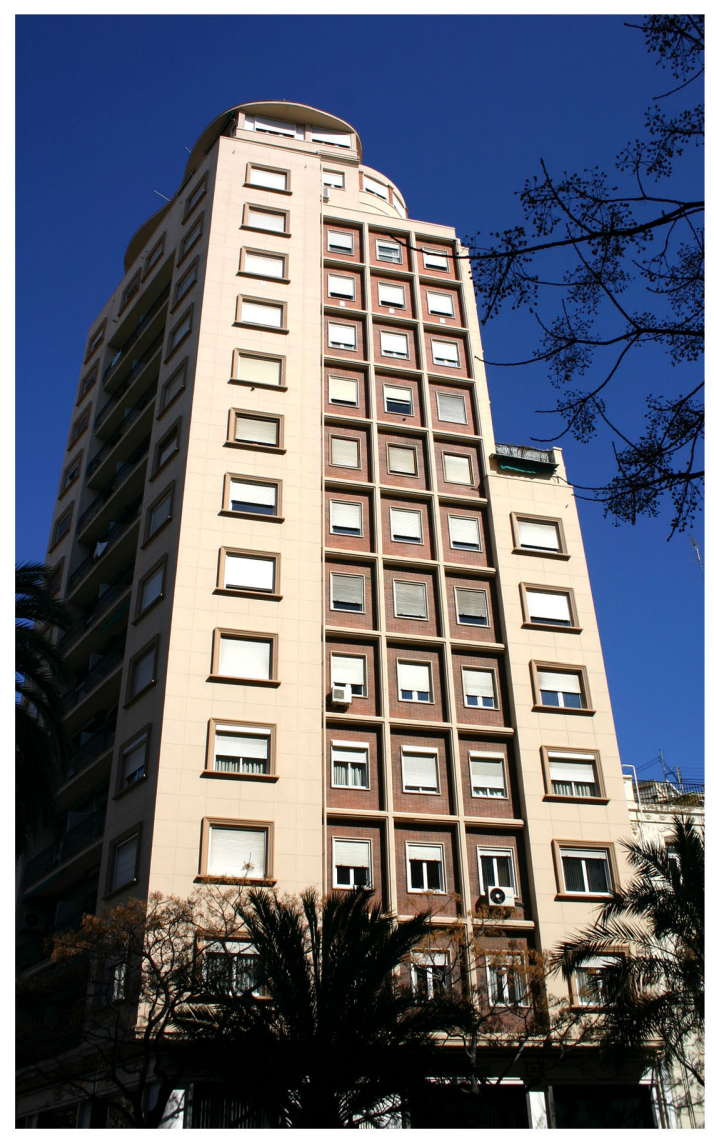

fig. 16

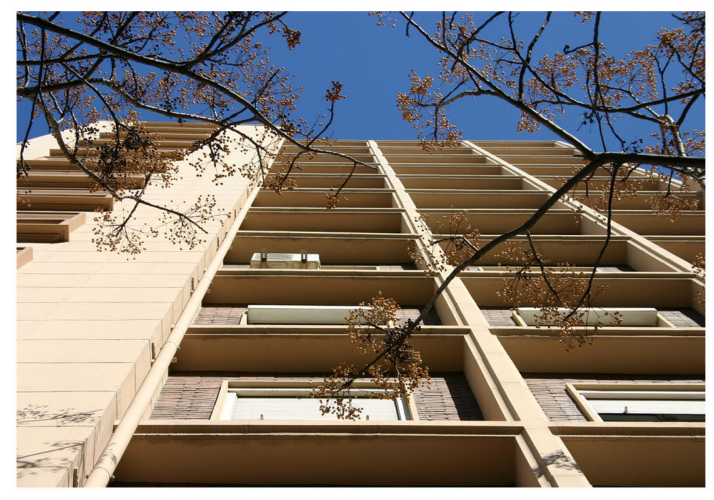

Luis ALBERT, 1944. Edificio de viviendas para Gastón ILLUECA, gran vía Marqués del Turia; (AHMV) Ensanche, legajo 4, expediente 15133; fotografías doctorando 
interesante convivencia. La Residencia-Hospital del Cottolengo (1951) en Benimaclet, las oficinas Navieras para Cofruna en los poblados marítimos o el edificio lllueca (1944-47) en la avenida Marqués del Túria, esquina con la actual avenida del Antiguo Reino de Valencia (fig. 16), representan aquella época, previa a los últimos años de atención a promociones privadas.

Retomando impulso tras la impuesta interrupción de la actividad laboral, refulgiría en estos años -los sesenta- la competencia en la construcción de viviendas, la avidez en la pujanza urbanística y la carrera por lograr clientes preponderantes que facultaran encargos de cierto nivel. El número de arquitectos colegiados en la provincia pasaba limpiamente, del doble del comienzo profesional de Luis Albert. El volumen de obra promovido también se duplicaría, empero en esta ocasión, respecto de la década anterior. Una febril tesitura muy alejada de la coyuntura donde el arquitecto se hallaba cómodamente posicionado, desunido de las grandes empresas y en una Diputación cercana en el trato y desahogada en la cadencia de trabajo. Amanecía un tiempo donde ceder protagonismo a los jóvenes, de espíritu idealista e inagotable capacidad. Mauro LLeó sería el proclamado, aquel que tomó la impronta en el despacho, para finalizar el Palacio del Temple.

Arropado por la resolución juvenil, recuperaría en cierta medida el lenguaje moderno, aunque carente de la radicalidad, del brío y la espectacularidad de antes. Hurtado de Saracho, reemplazaba a Alberto Villalba en el papel de contratista frecuente. El edificio para la sede del Banco Bilbao (1966) en la calle pintor Sorolla, resultó uno de los muchos trabajos en común. No obstante, destacaría y así lo corroboró el premio Marqués 


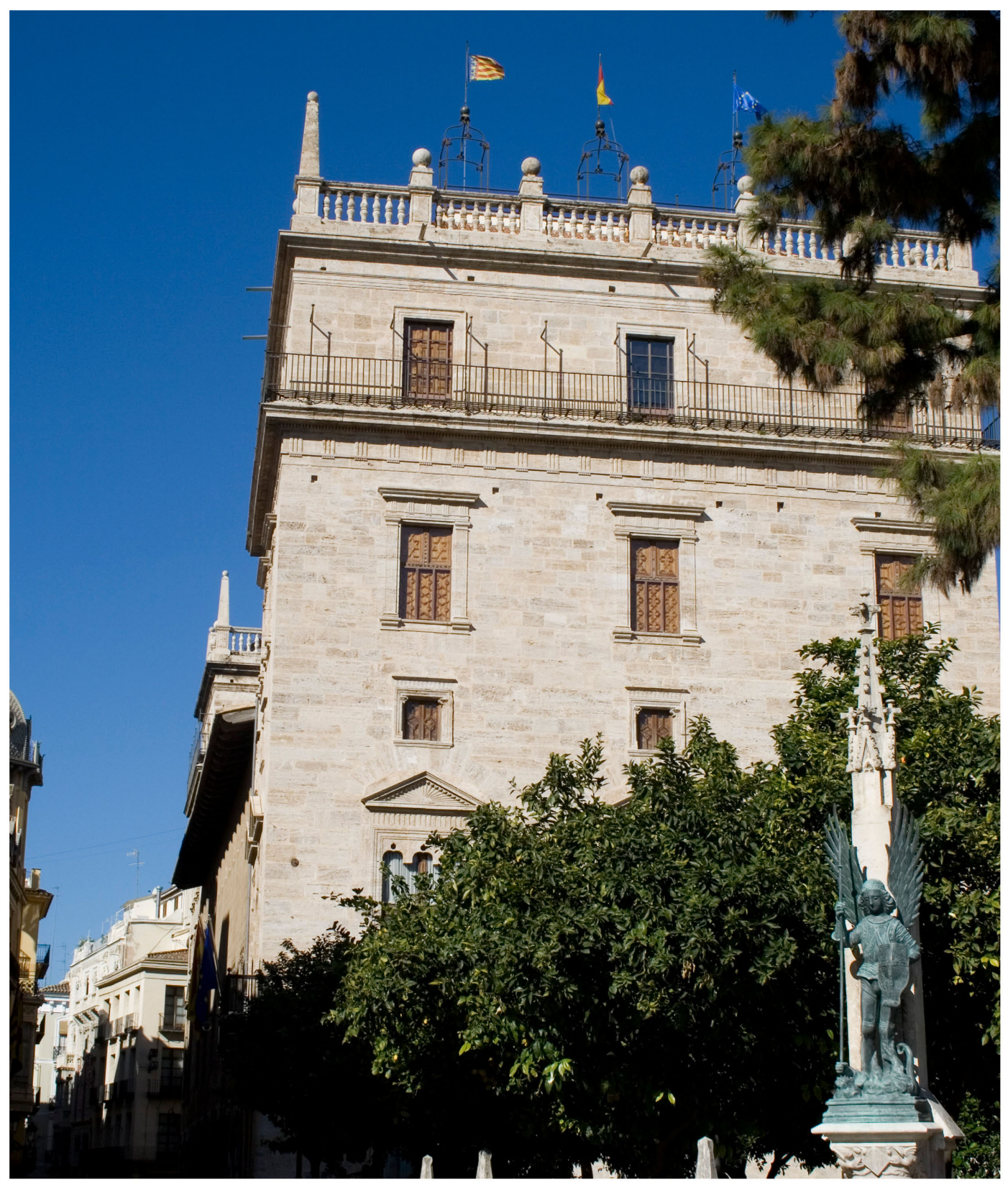

Luis ALBERT, 1951. Restauración del Palau de la Generalitat Valenciana, calle Caballeros, promotor Diputación Provincial Valencia; fotografía doctorando desde plaza de la Virgen 
de Sotelo otorgado, su grupo edilicio compuesto por 86 viviendas protegidas (1960) en la avenida Pérez Galdós, esquina calle Lorca (fig. 17).

Guillermo Stuyck y Alberto Peñín, se incorporarían a su plantilla como estudiantes, y al concluir sus estudios participaban en la reconstrucción de la Plaza de Toros (1965) -consumida en parte por las llamas de un incendio- que el arquitecto no pudo ver finalizada. Alcanzaba el momento de su último edificio completo, el proyecto de la Cámara de Comercio (1966) en la calle Poeta Querol (fig. 18) y se mantuvo coherente a su ucamino de la verdad"16 emprendido en aquel primer edificio con estructura de hormigón para la ciudad de valencia, en 1929. Cuarenta años de actividad profesional en espacio y tiempos precisos y determinantes para la arquitectura valenciana, innovadores, comprometidos.

Cabe asimismo acercarse al Urbanismo -obviedad ineludible-, como disciplina exiguamente abordada por el arquitecto y cuyos referidos inicios nos retraían a aquel primer proyecto de Ensanche y Urbanización de Torrente, en el cual colaboró con Alfonso Fungairiño en 1927. Sobresaldría su interés por la Historia -sin descartar la reciente- y su puesta en práctica de aquellos conocimientos adquiridos. Interés, no significaría aplicación directa, inmediata de las premisas académicas. "Cuando los pioneros de la arquitectura moderna rechazaban las 'formas del pasado', no se referían sólo a algunos motivos concretos, sino también a las concepciones espaciales en general, como la perspectiva lineal del Renacimiento o

16 Albert ballesteros, Luis. "La evolución de la arquitectura en el transcurso de los siglos". Discurso leído el 3 de marzo de 1961, en su recepción pública como académico de número en la Real Academia de Bellas Artes de San Carlos. Editado por la Diputación Provincial de Valencia, con la contestación del llmo. Sr. D. Antonio Gómez Davó. 


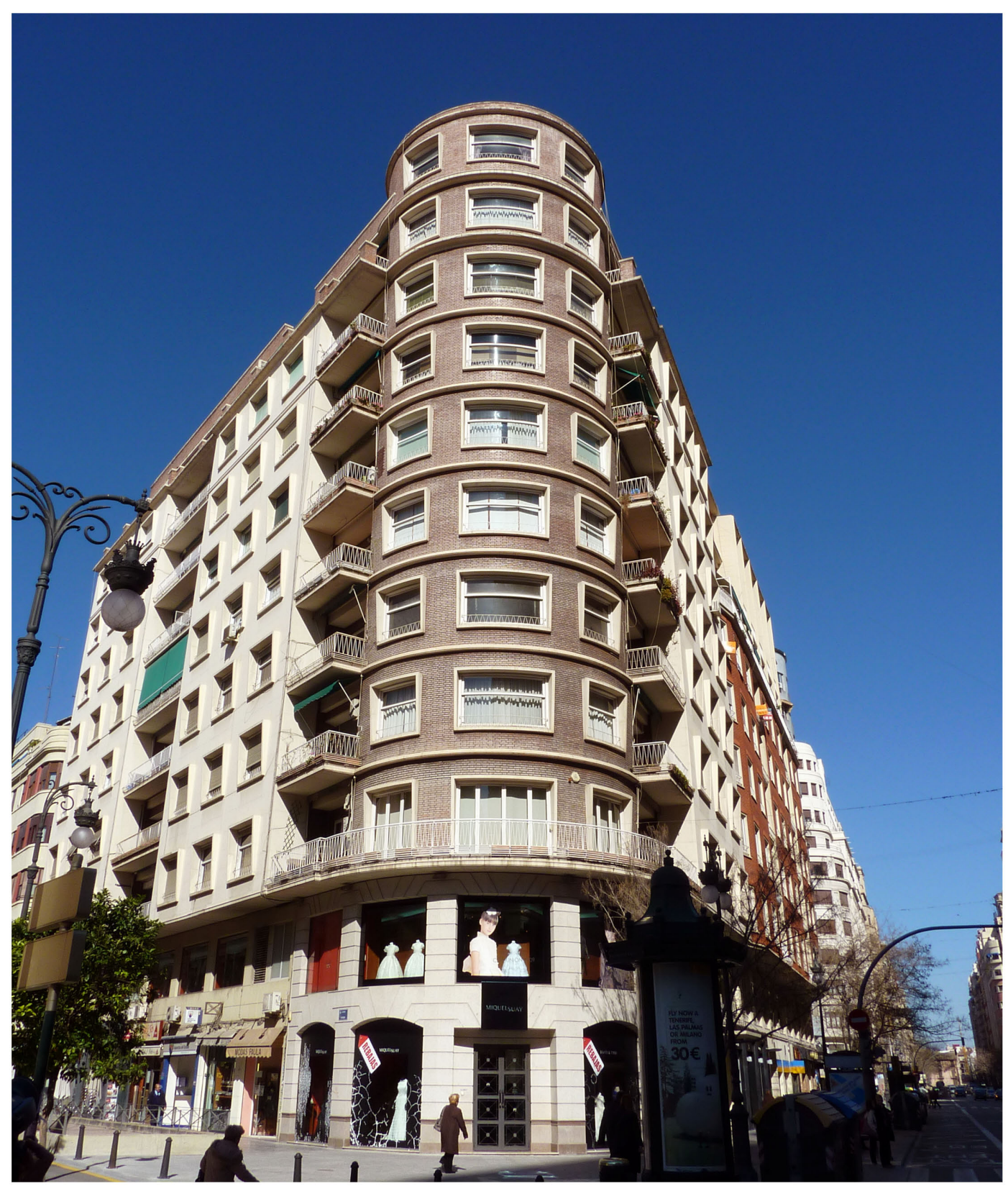

Luis ALBERT, 1953. Edificio de viviendas para Francisco GIL COLOMER, avenida del Oeste calle Huesca; (AHMV) Policía Urbana, legajo 8, expediente 16162; fotografía doctorando 
los trazados totalitarios del Barroco. En particular se oponían a las composiciones 'académicas' de la arquitectura oficial del siglo XIX". ${ }^{17}$ Rescatando axiomas tales como el respeto a la urbe histórica, la nueva concepción del espacio concedería una importancia primordial a la apertura y la continuidad, al esponjamiento, trasladando al Ensanche la renovación urbana y el aumento demográfico, priorizando las modernas preocupaciones por la circulación.

Cualquiera de las propuestas analizadas en posteriores capítulos, tanto aquellas propiciadas desde la administración -la declamada triada albertiana- como otrora las promovidas por particulares, albergarían semejantes principios de apertura, movilidad y modernidad, con los cuales imbuía sus propuestas edilicias inmersas en el espacio urbano, nunca indiferentes al lugar como opción de proyecto, como decisión arquitectónica. Periclitada la Guerra, interviene como asesor de la Junta de Reconstrucción de Valencia, plataforma desde la cual derramaría diversos informes rechazando la apertura de la avenida del Oeste, el plan del Grao para su urbanización y otras operaciones de cirugía urbana formuladas y escenificadas por el Ayuntamiento de Valencia, inmerso en una política de "sventramento" o "desguace urbano", tal cual apuntó Alberto Peñín.

Quiso exportar su exigente minuciosidad, su rigor profesional a sus propuestas de planeamiento para la Diputación. Proyectos urbanos solventando municipios menores valencianos, afectando énfasis al diseño de calles,

17 NORBERG-SHULZ, Christian. "Los principios de la arquitectura moderna". Edición en español: Editorial Reverté, S.A. Barcelona, 2005. Traducción Jorge Sainz. p. 22 


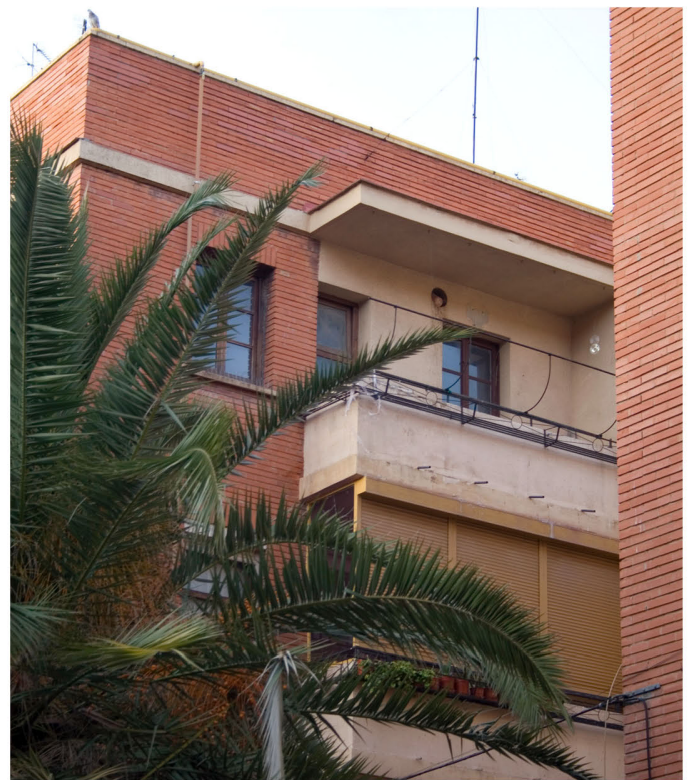

fig. 15

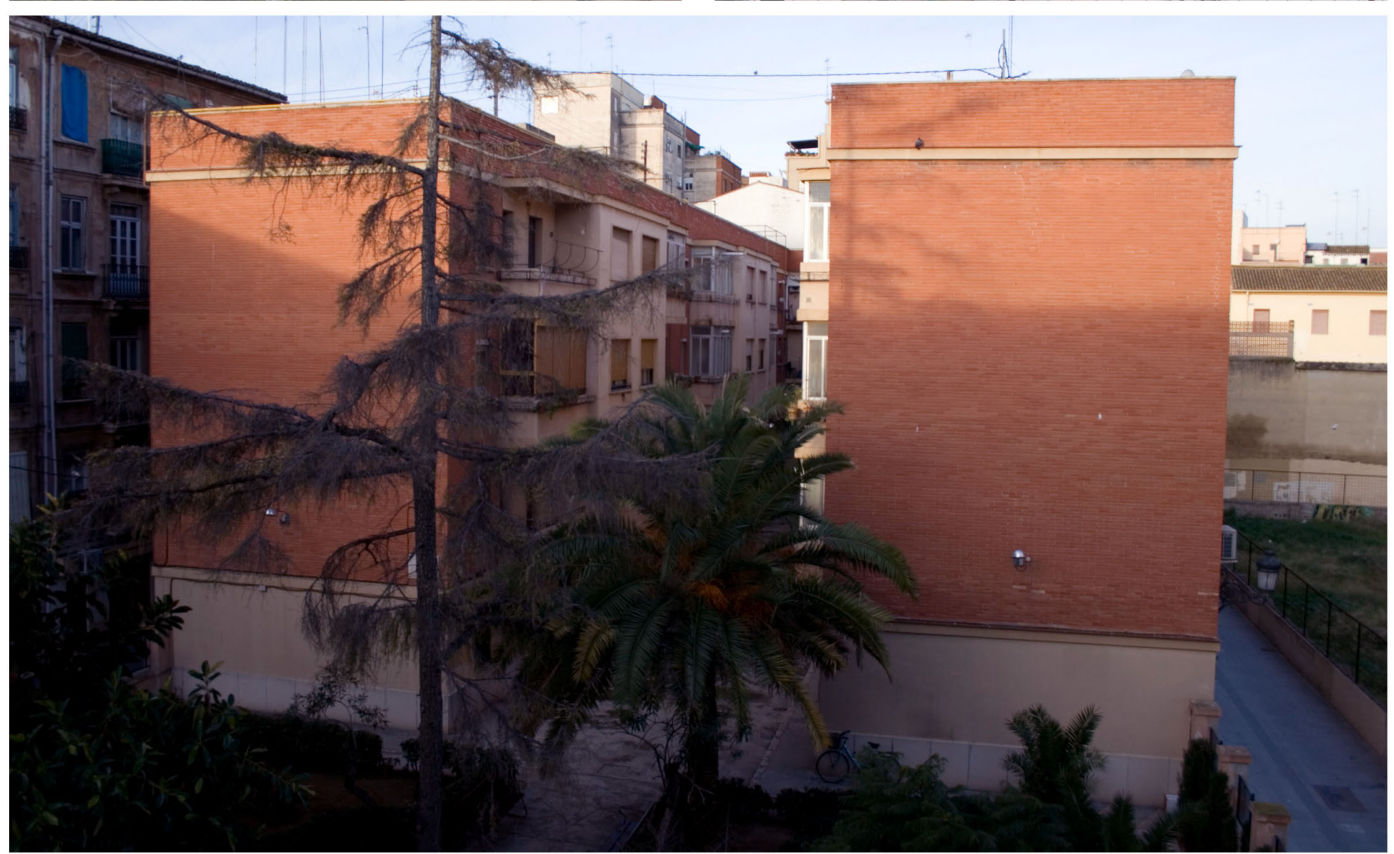

Luis ALBERT, 1957. Bloques residenciales para funcionarios Grupo LASSALA, plaza la Bocha y calle Camarón; reordenación no cerrada final de manzana; fotografía doctorando 
árboles, plazas y encuentros, zonas verdes precedentes al núcleo urbano atribuyéndoles capacidad de vetar futuras construcciones. Planteamientos higienistas, escuetos en ofrecimiento, desprovistos de operaciones de reforma interior. No acuñaría el término urbanista en su haber, al menos en cuanto a especialista renombrado en aquella disciplina, sin embargo y siendo coherente con su devenir profesional, buscó la corrección e integridad en su aproximación disciplinar.

Escasa aportación escrita obtendríamos de una generación de arquitectos, valencianos, excesivamente distantes -ya se comentó la insoslayable lejanía a los centros culturales de vanguardia europeos y la desconexión con el GATEPAC, excepciones honrosas- que no profanos, de los manifiestos doctrinales, elucidarios modernos de los que jamás hesitaron, infiriendo más bien todo lo susceptible de aportación para esta sociedad burguesa donde emplearse, agraria, recelosa y arcaica. Luis Albert no varió -exceptuando su epílogo ineludible- pareja actuación, limitándose a introducir en las memorias de sus proyectos de ejecución, paráfrasis e incluso textos esculpidos por Le Corbusier en "Vers une architecture".

Eventualmente, en 1960, cometió la referida excepción redactando su discurso público de ingreso en la Academia de Bellas Artes de San Carlos, leído en marzo del año ulterior, y dedicándose casi en exclusividad a tal fin. Vertería en su discurso, todo lo aprehendido como arquitecto, aquello libremente adquirido en su juventud y encubierto al madurar. Acometería su diatriba como su ocasión autografiada para sincerarse públicamente, expresarse acerca del estilo y la necesidad, la verdad y la función, el racionalismo y la época. Para concluir rememoraría la inscripción de un azulejo, rescatado en una rehabilitación -aquellas que tanto disfrutó- 


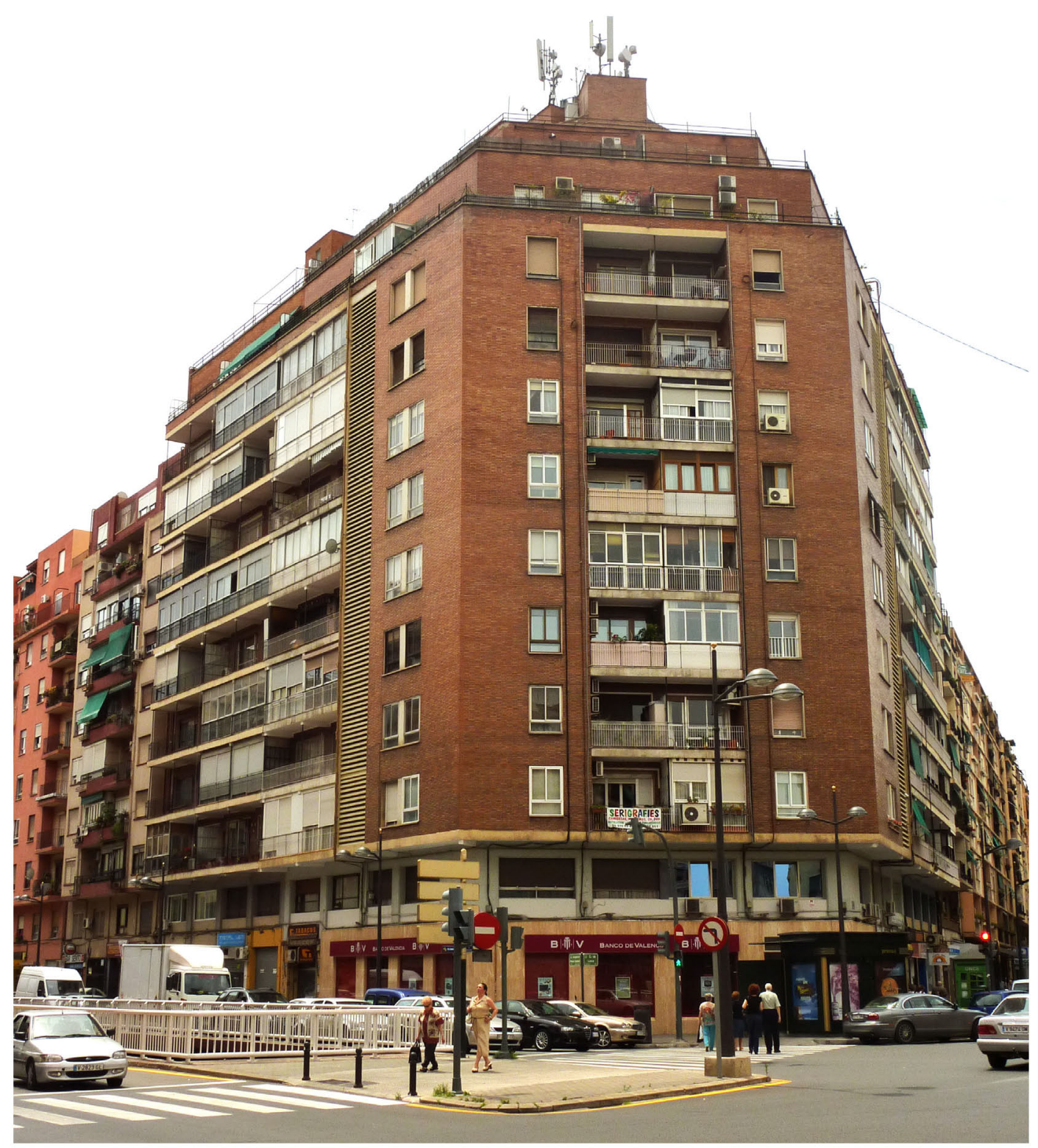

Luis ALBERT, 1960. Edificio con 86 viviendas protegidas. Avenida Pérez Galdós, esquina calle Lorca: fotografía doctorando 
de otra casa-palacio valenciana, que rezaba: "Bien va el que sigue el camino de la verdad ${ }^{18}$.

Sobrevendría entonces, el momento dedicado a consolidar su posición social e intelectual, ausente de urgencias y necesidades. La firma del Manuscrito de La Alhambra, el grado de Académico, el Doctorado, la petición a su favor de la Cruz de Alfonso $x$ el Sabio, su dedicación al Colegio de Arquitectos. Una labor profesional, constante, perseverante e íntegramente dedicada a la arquitectura, con mayúsculas.

Recapitulación final implica su sinceridad evolutiva, extensa a su completa trayectoria arquitectónica. Exegeta de la verdad, presagiada en sus albores profesionales, innovada en su devenir laboral, amagada durante los premiosos momentos de posguerra y moderada en sus últimos ejercicios. Profesionalidad y rigor, intérpretes de aquella verdad, directrices constantes para una labor compilada en tres estadios diferenciales, coincidentes con tres momentos reseñables de su periplo: el período republicano -esperanzada modernidad-, la fractura bélica-demolición ideológica- y la autarquía nacional -ambivalencia y crisis del movimiento moderno-.

De entre ellas, nos serviremos únicamente de la iniciática primigenia -no siendo óbice ni menoscabo en la estima y valía del resto-, para su análisis, en el discurrir de nuestra tesis. Segregada por lo que tubo de premonitoria y conductiva en una trayectoria lineal hacia la verdad, con sus

18 AlbeRT ballesteros, luis. "La evolución de la arquitectura en el transcurso de los siglos". Op. Cit. p. 30 


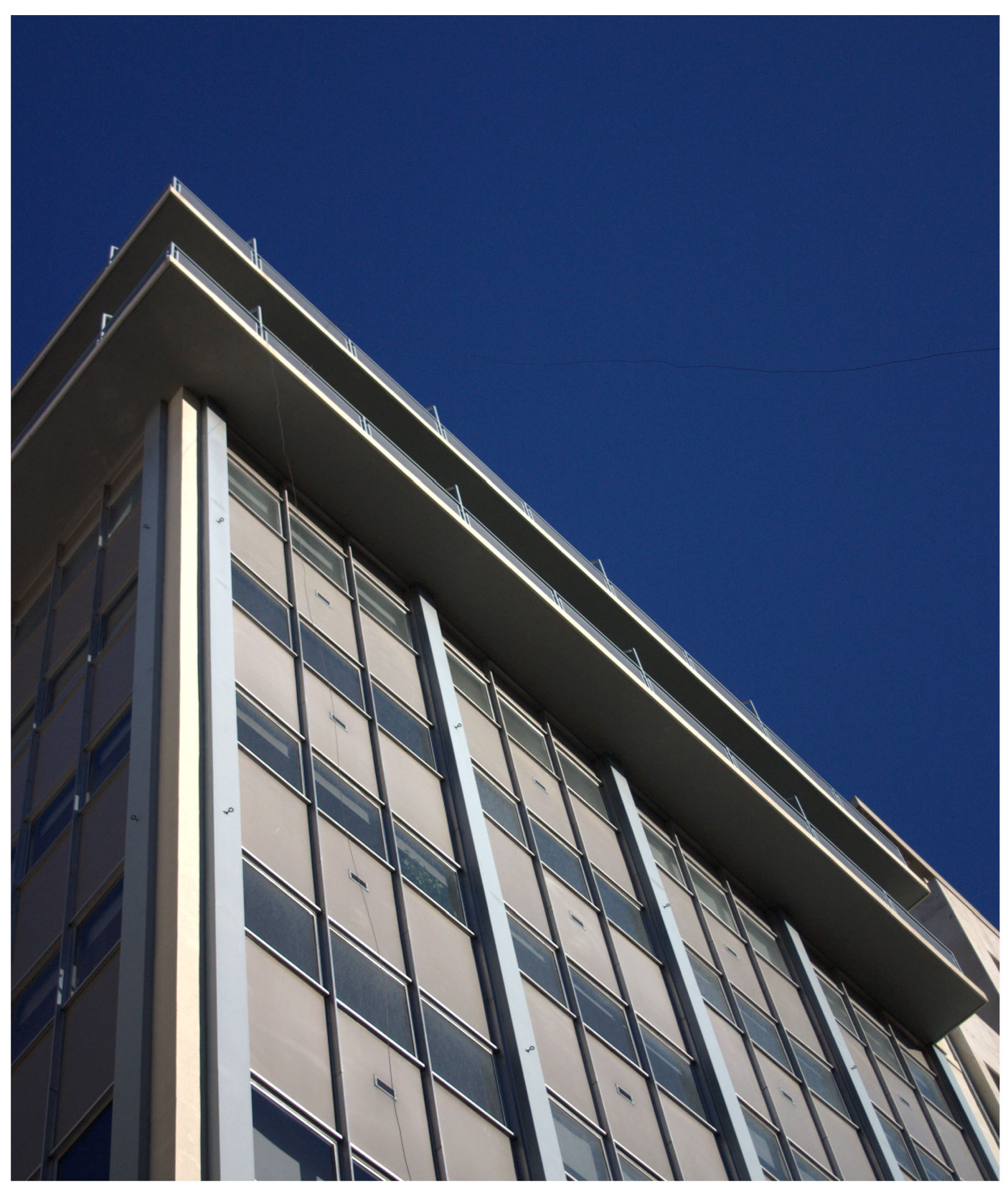

ig. 18

Luis ALBERT, 1933. Fdificio para la CAMARA de Valencia, calle del Poeta Querol, esquina con calle de Miñana: fotografía doctorando 
recesos, traspiés y dudas, no obstante madurada en todas sus diversas partes. Discriminada por aquellos oteros alcanzados, jamás igualados, ni cercanamente superados. Diferenciada por lo que representó de inaugural y referente a la profesión, en una creciente metrópoli, anhelante de una arquitectura iconográfica-tal cual mantenida-con la que ser identificada. Distinguida por aquello que pudo haber sido y que homenajeamos desde esta aproximación a su quehacer profesional, erigiéndolo así en nuestra conciencia. 
triada albertiana 


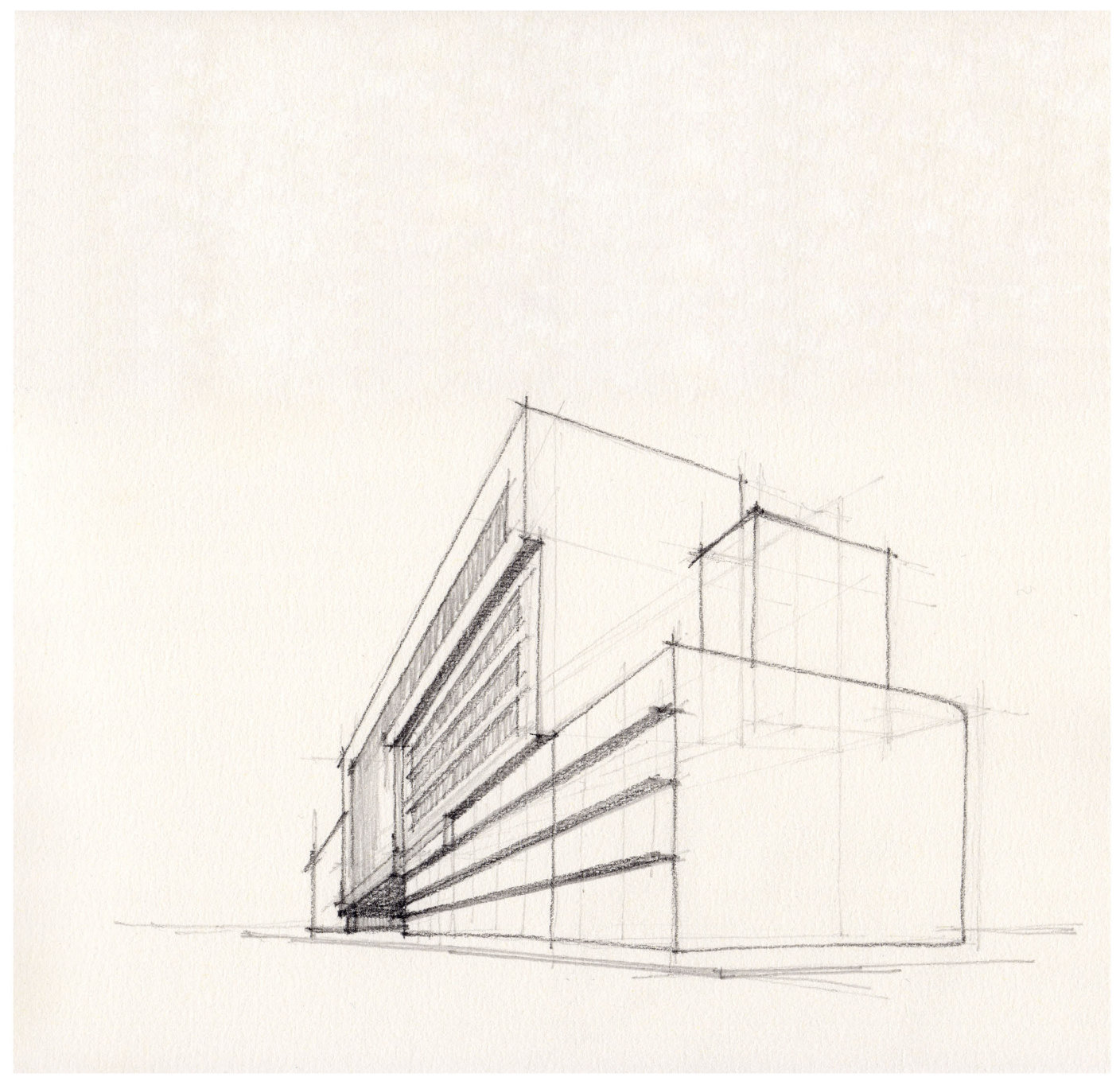

Pabellón de Cirugía del HOSPITAL Provincial; proyecto de Luis ALBERT, inconcluso, para la Excelentísima Diputación Provincial de Valencia. Perspectiva a lapiz doctorando 


\section{OBJETIVOS DEL PROYECTO}

El Hospital Provincial, el Manicomio Provincial y la Plaza de Toros de Valencia, no surgieron como proyectos aislados, temporalmente inconexos uno de los otros. Desde la Diputación Provincial de Valencia, se plantearon como un conjunto de tres obras ineludibles para alcanzar la modernidad, de una ciudad que ya había iniciado ese camino. Un plan total -así lo define el propio autor en la memoria descriptiva-para sustituir los edificios existentes pero de tal forma que los nuevos establecimientos superaran en todo a los construidos hoy en España. La Diputación Provincial de Valencia, y Luís Albert desde su posición de arquitecto jefe, sirvieron de plataforma para lanzar una propuesta global, capaz de transformar la imagen de una ciudad que parecía dispuesta a variar su aspecto formal y a horadar su composición urbana extirpando de su núcleo residencial formas y funciones obsoletas frente a las nuevas demandas.

Y esto era así porque para bien o para mal desde principios de siglo en el contexto europeo, la ciudad se había convertido en el rasero de la modernidad'. Olvidada la gran Guerra, superados los desalentadores movimientos culturales en contra de las ciudades, evidenciadas las posiciones higienistas frente a la creciente presión demográfica hacia la ciudadcentro, amaneciendo el desarrollo económico urbano e industrial con el despunte de las nuevas tecnologías, la nueva sociedad urbana plantearía su futuro más tangible desde la ciudad. Una nueva forma de vivir que debe su origen -parafraseando a Ludwig Hilberseimer-, en última instancia,

1 GIRONA, Albert. "Una nueva forma de vivir: la urbe como modelo de atracción". Catálogo para la exposición realizada por el IVAM Centre Julio González, del 20 de enero al 5 de abril de 1998. "La ciudad moderna. Arquitectura racionalista en valencia". Volumen I. 


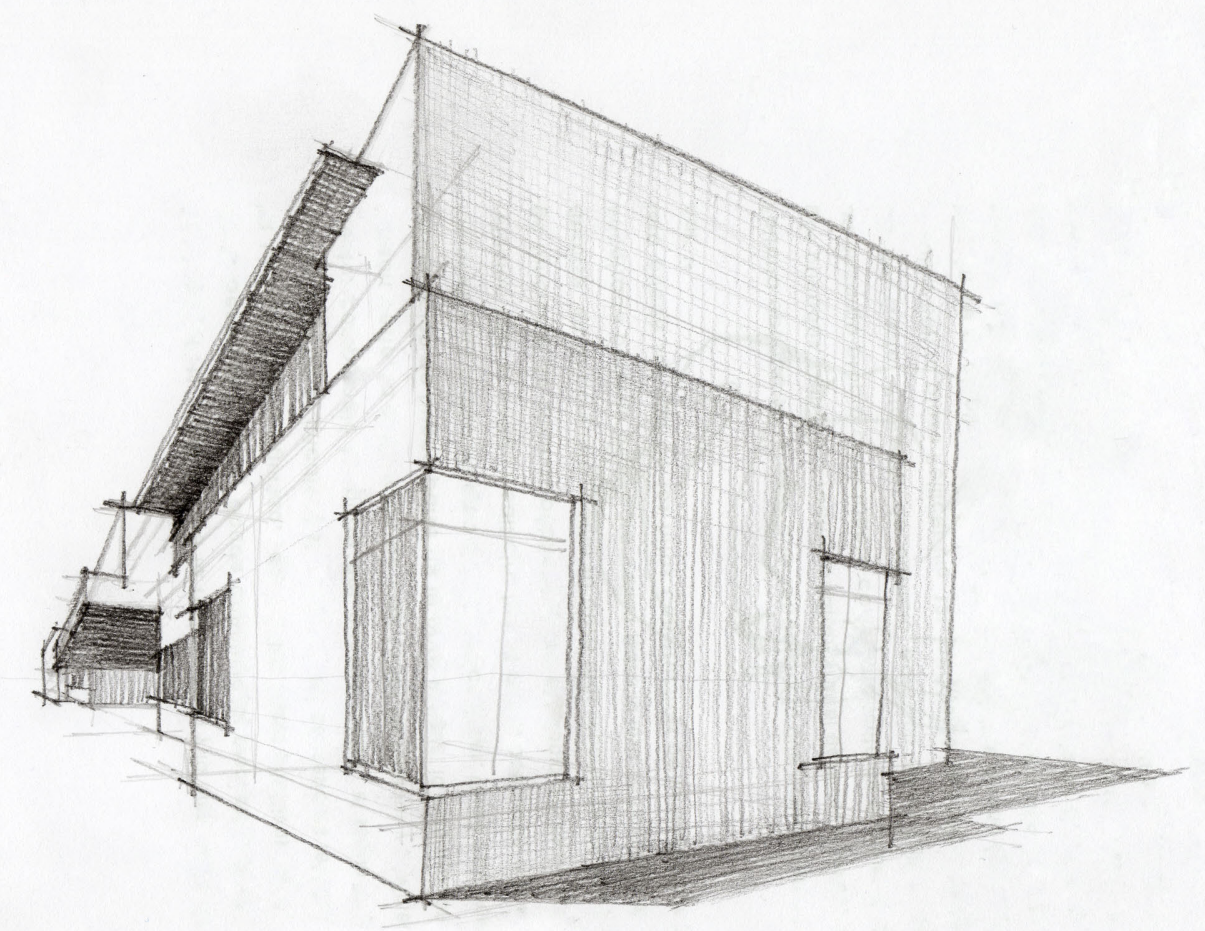

Pabellón de Administración del MANICOMIO Provincial; propuesta de Luis ALBERT para Ia Excelentísima Diputación Provincial de Valencia. Perspectiva a lapiz doctorando 
al sistema económico del imperialismo capitalista que, por su parte, está estrechamente relacionado con el desarrollo de las ciencias y las técnicas productivas.

En Europa el debate se centraba en el sistema descentralizador, el modelo anglosajón de la ciudad-jardín siguiendo las propuestas de Ebenezer Howard. La vieja ciudad se relegaba al ámbito puramente comercial y terciario, proyectando núcleos organizados residenciales externos. Ofertando complemento, la urbanística alemana introducía, dentro de la idea del Grosstadt, el mecanismo del zoning que regulaba las densidades y los usos de las diferentes áreas urbanas. De esta manera se tenía una visión global del hecho urbano que permitía, a partir de un esquema inicial de vías radiales, introducir en el territorio próximo a la ciudad aquellas piezas que no podía admitir la uniformidad del ensanche, como son las áreas verdes, la industria y, sobre todo, la vivienda modesta de baja densidad².

Valencia, cuyo desarrollo durante los años veinte había resultado evidentemente agrícola, con una menor carga de crecimiento industrial y comercial, comenzaría los años treinta variando la estructura socioprofesional, expandiéndose por un crecimiento demográfico que, ante la falta de grandes proyectos urbanísticos, obligaba a su auto transformación urbana. Los asentamientos obreros se implantaban en el extrarradio,

2 BLAT, Juan. "El crecimiento urbano en Valencia: entre la ciudad-jardín y el planeamiento de extensión". Dentro del catálogo para la exposición realizada por el IVAM Centre Julio González, del 20 de enero al 5 de abril de 1998. "La ciudad moderna. Arquitectura racionalista en Valencia". Volumen I. 


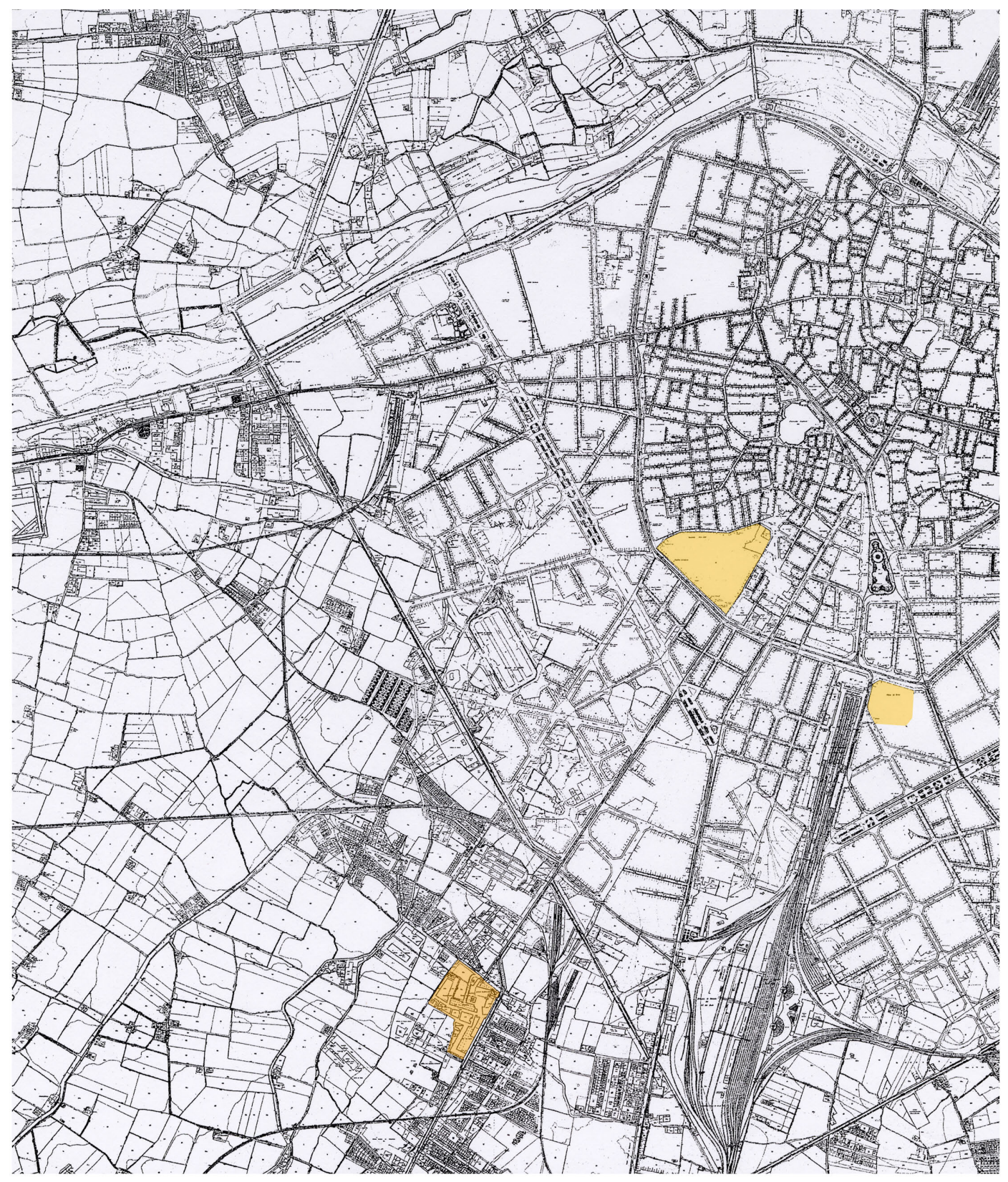

plano 1:1000 Emplazamientos de los edificios a sustituir y nueva reubicación propuesta desde la triada albertiana: Hospital Provincial, Plaza de Toros y Manicomio de Jesús 
casi desde la anarquía, sin planes de extensión globales que los posicionara, mientras los poderes políticos miraban exclusivamente hacia el centro de la ciudad.

El desinterés municipal, tal vez su incapacidad, llevó a las empresas privadas valencianas a asumir la responsabilidad de salvaguardar el crecimiento fuera del centro urbano, si bien desinteresadas por el modo de conectar el espacio rural con el espacio urbano y totalmente ausentes de anexionar las poblaciones próximas. Administrativamente, el problema más importante y esencial del urbanismo del momento se inclinaba por el centro consolidado y su desarrollo en el ensanche de la ciudad. Y si el plan finalizaba como resultado, ahora se exigía como condición previa necesaria. Surgen entonces las leyes de Reforma Interior y las de Ensanche, resultado de una simple traslación geométrica. Nuevamente alejados del debate europeo. "Este sistema ha quedado totalmente desacreditado por lo esquemático de su aplicación. Por comodidad, irreflexión y falta de imaginación ha sido empleado de forma totalmente insensata, sin consideraciones hacia el terreno o a su posición respecto al sol, sin razones más elevadas y sin ningún interés por la Arquitectura". ${ }^{3}$

En esa tesitura por sanear y embellecer la vieja ciudad, desarrollar las alineaciones del Ensanche, sumar poblaciones adyacentes y descentralizar la metrópoli, Luís Albert encuentra el lienzo donde plasmar su propuesta global. Excluir del centro aquellas funciones que no corresponden

3 HILBERSEIMER, Ludwig. "La arquitectura de la gran ciudad". Editorial Gustavo Gili. Barcelona 1979. Título original: "Grosstadt Architektur". Publicado en inglés en 1927. Traducido por Pedro Madrigal Devesa. 


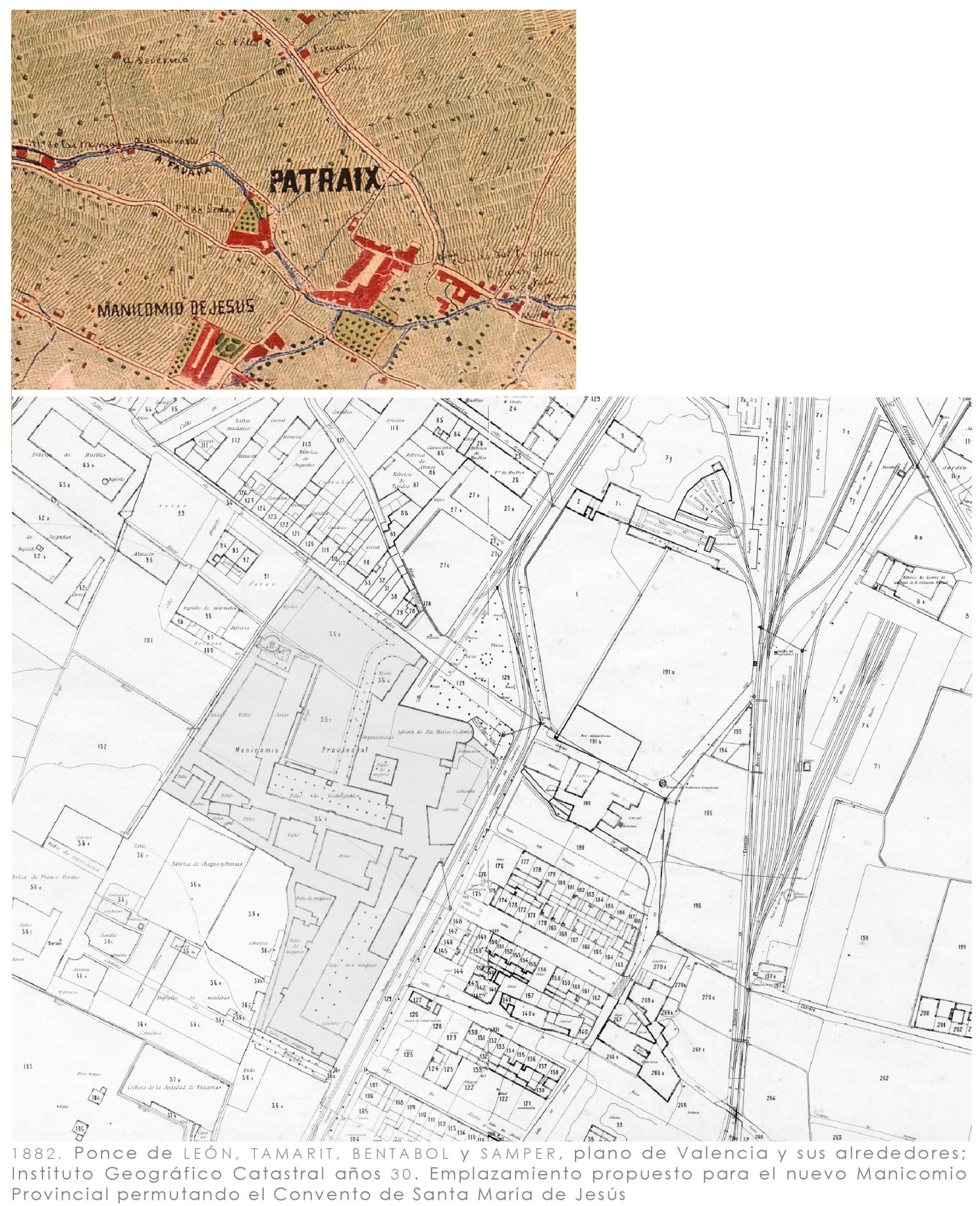

fig. 1 
con el moderno programa de uso pretendido para la metrópoli, liberando espacio para el desarrollo de los planes de Reformas Interiores y de Ensanche. Descentralizar estas funciones a falta del tejido viario que delimitase los sectores donde implantarlas y que los articulase con la trama del Ensanche. Se mostraba, Albert, conocedor del método orgánico alemán, al menos en cuanto a su visión global moderadora del entorno urbano pretendido, y parecía compartir el debate descentralizador, aún sin alcanzar las propuestas anglosajonas. Limitar, regular funciones en el centro de la metrópoli, asomaría como premisa para la propuesta urbanística, desde su triada. Extrapolar, alejando del epicentro urbano, aquellos usos extirpados rezumaba derivaciones científicas de orden superior.

El entonces edificio para MANICOMIO PROVINCIAL de Valencia, inmerso en una de las zonas limítrofes de la ciudad -la avenida de Jesús (fig. 1)-, elevado como adición de diversas construcciones de otras tantas épocas, se presentaba falto de las primordiales condiciones para desarrollar su función terapéutica moderna -también la medicina recorría el camino hacia lo moderno, trazado desde la sociedad en la que aspiraba a desarrollarse- y sin las mínimas condiciones exigibles de higiene o comodidad. Promovía Albert -un tercio de la triada- un nuevo emplazamiento, una moderna construcción. "Estructura de hierro. Carpintería metálica. Paredes de ladrillo con cámaras y con aislamiento para asegurar unas condiciones adecuadas en el interior. Sistemas de pabellones aislados en forma semicircular en torno al Pabellón Central de Administración. El cierre perimetral no se propuso de tapia, si no el llamado "salto del lobo" para que el enfermo dominara el horizonte y el soberbio pinar donde se emplazaría». 


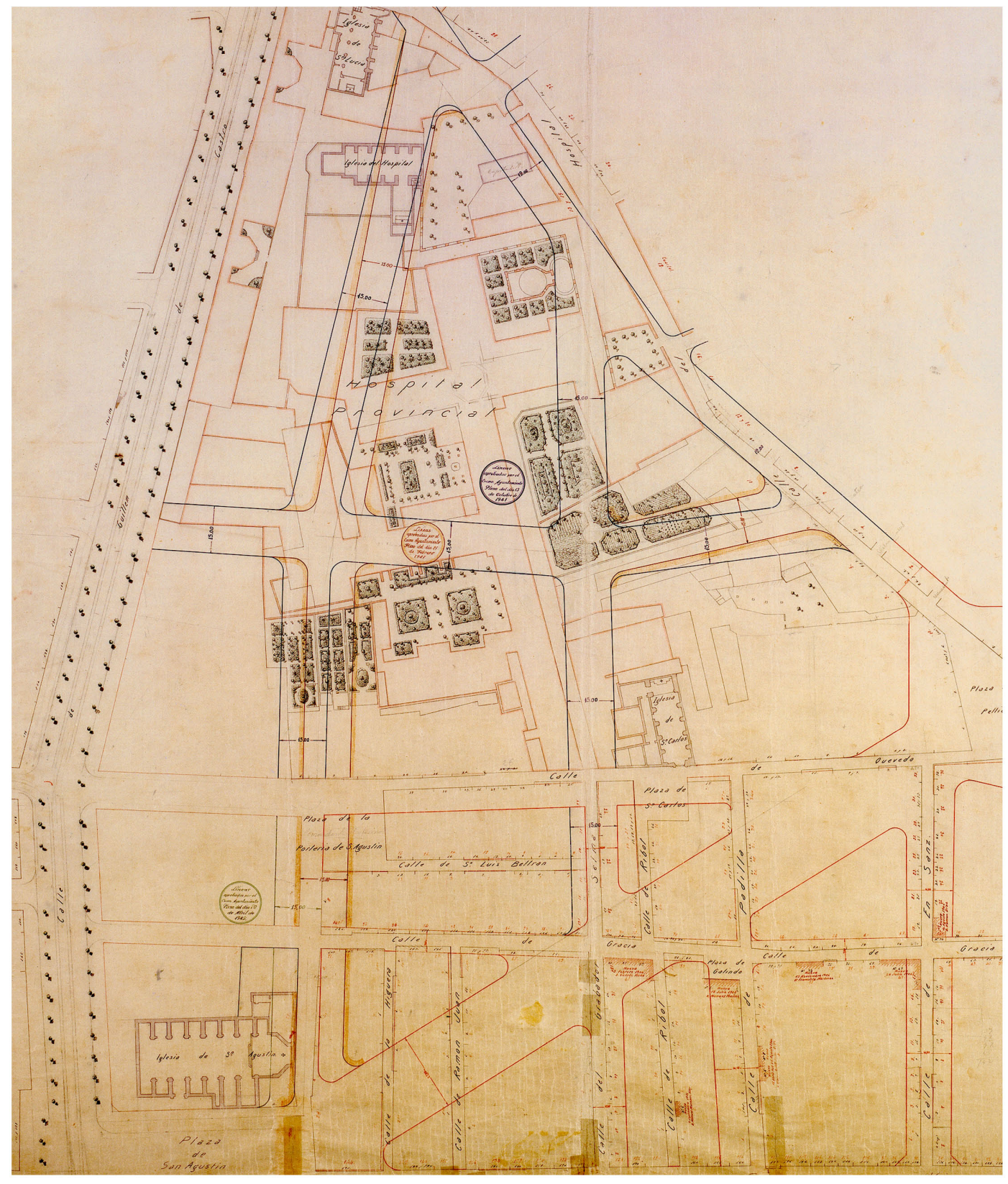

1892. Plano GEOMÉTRICO 13. Emplazamiento antiguo edificio del Hospital 
El entonces edificio para HOSPITAL PROVINCIAL, aunque no se presentaba en tan malas condiciones constructivas, resultaba anticuado e insuficiente, pésimamente ubicado en el consolidado casco histórico, al principio de la actuación prevista para el Ensanche noroeste (fig. 2). La proximidad al centro de población planteaba la necesidad de su alejamiento y el aprovechamiento del solar resultante, de importante valor, para mejorar y urbanizar la zona. Surgía la posibilidad de ejecutar un nuevo Hospital. "Todo ello en estilo moderno, sujetándose el exterior a las necesidades del interior y al fin al que se destina el edificio". "Estructura de hierro. Carpintería metálica. Paredes de ladrillo con cámaras y con aislamiento para evitar el calor y el frío en el interior. Cuatro grandes pabellones (Medicina General, Cirugía, Maternidad-Niños y Especialidades) unidos entre sí, dos a dos, por grandes puentes con vigas Wierendel, y por galerías subterráneas con los de Cocina, Lavadero, Desinfección e Infecciososn.

Lo impropio de su ubicación resultaba ser el nexo de unión en la demanda -no ya de la Diputación, sino de toda Valencia, citando al propio autor- de descentralizar estos edificios del corazón de la ciudad y, del centro comercial y de mayor concurrencia de la Capital. Un nexo que vinculaba y también concluía la triada albertiana: el entonces edificio para PLAZA DE TOROS, inmerso en el primer cinturón previsto de Ensanche, a falta de extirpar la Estación del Norte, demanda que llevaba tiempo reclamándose (fig. 3 ).

${ }^{4}$ BALlesteros, Luís Albert. "Plan General de las obras: Hospital Provincial, Plaza de Toros y Manicomio". Archivo de la Diputación Provincial de Valencia. 


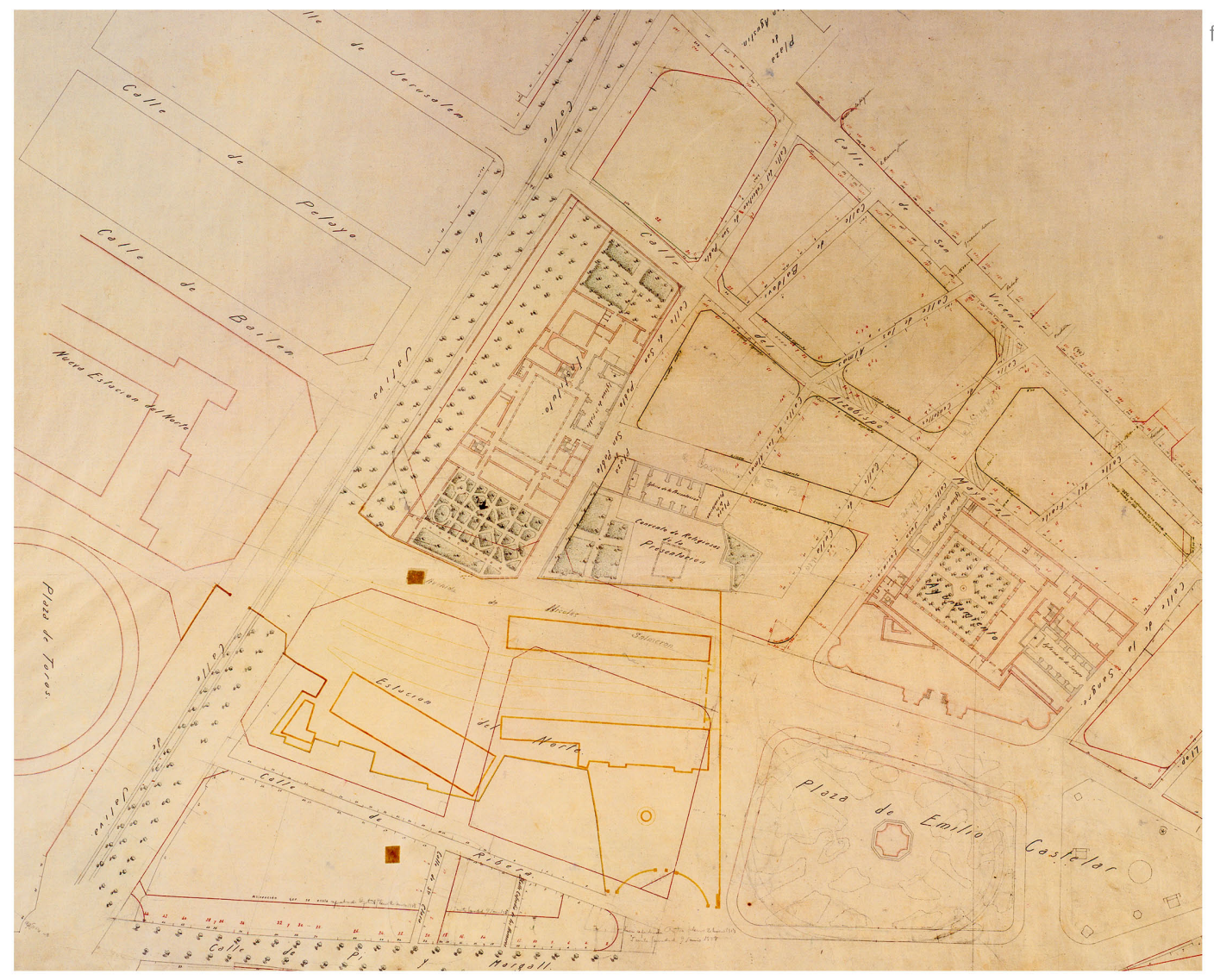

fig. 3 
Con las premisas planteadas, y la apremiante necesidad de resolver estos tres puntos, propuso Albert reubicar los nuevos edificios en terrenos propiedad de la Corporación Provincial, aligerando así trámites y facilitando económicamente la gestión, liberando retales del tejido urbano consolidado, propiciando su saneamiento pecuniario, funcional y orgánico.

El Hospital Provincial se ambicionó trasladar a un enclave inmediato a la población y al mismo tiempo separado del centro, integrando condiciones específicas para su construcción y su emplazamiento. Un solar que hasta ese momento venía cumpliendo funciones como Granja-Vaquería, y cuyo titular era la propia Diputación (fig. 4). Mediante la propuesta se lograba erigir un moderno Hospital y alcanzar una mejora urbanística de la zona que ocupaba entonces, orilla del desarrollo pleno del ensanche noroeste de la ciudad.

Porta-Coelli surgió como enclave óptimo para trasladar el Manicomio -así nos lo presentaba Albert- recomendado por los propios médicos directores del actual centro, circundado por un excelso bosque de pinos y a una distancia prudencial de la Capital, con una rápida comunicación por carretera. La consecuencia inmediata tras el vacío suscitado por este traslado, conduciría a la ocupación del solar resultante por la que se planteaba como nueva Plaza de Toros en la avenida de Jesús. Este traslado liberaría parcialmente la zona donde se pretendía el Ensanche de la ciudad.

El volumen total de las obras se calculó en 28.455 .501 '93 pesetas y la financiación económica para las tres obras pasaba entonces por una 


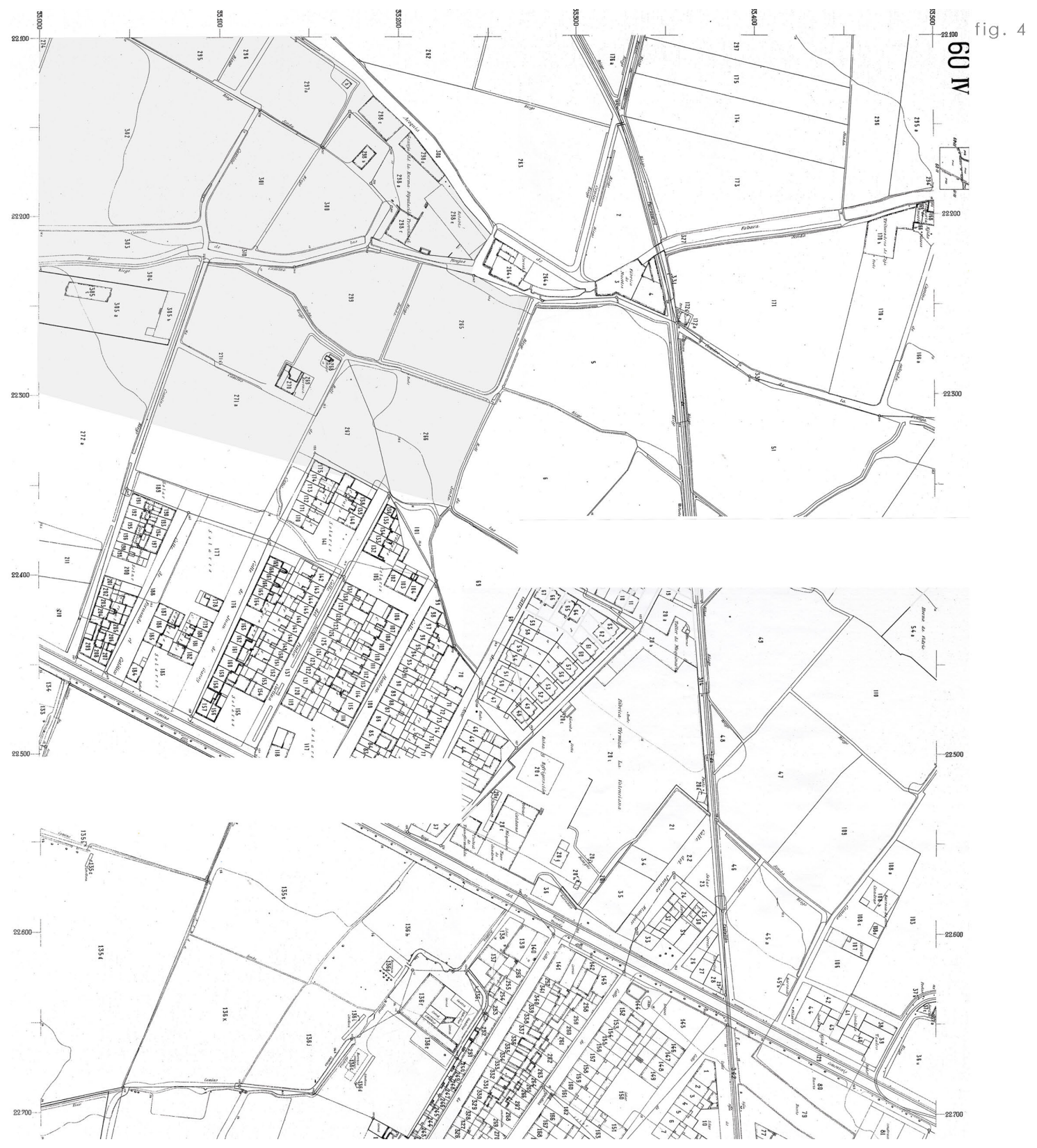

1882. Ponce de LEÓN. TAMARIT, BENTABOL y SAMPER, plano de Valencia y sus alrededores: Instituto Geográfico Catastral, años 30. Emplazamiento previsto para el nuevo Hospital 
proposición de escaso coste provocada por aprovechar el alto valor de los solares donde estaban implantados el Hospital y la Plaza de Toros y por evitarse la compra de los terrenos - propiedad de la Diputación Provincial- donde emplazar los edificios. Permutas que propiciarían beneficiarse de una parte importante de suelo en el centro de la ciudad, dispuesto para ser calificado según los requisitos modernos que se demandaban, y entendían aquí el beneficio que supondría una manzana de edificación acorde con los nuevos principios de racionalidad, funcionalidad y composición, capaces de servir a los intereses modernos a los que la sociedad aspiraba en los inicios del nuevo siglo (fig. 5). El periodo de construcción se estimaba en cinco años, y el orden dispuesto para los trabajos se presentaba dispuesto como sigue:

- Construir un Manicomio en Porta-Coelli y un Hospital en la GranjaVaquería.

- Derruir el Manicomio viejo y obrar en sus solares la Plaza de Toros.

- Derruir al mismo tiempo que la anterior, el Hospital y la Plaza de Toros, y enajenar sus solares en el plazo de dos años.

Beneficiosa puesta en escena de vanguardistas construcciones, ante una sociedad comprometida en la exigencia de modernización-localmente menos elevada, escasamente racional, más pedestre y realista, al menos sus poderes públicos-, y acorde a tal magnitud "la disección científica sirve así a la ceración de una sociedad orgánica, perfectamente ordenada, que demuestra en el esplendor de su perfección la necesidad de 


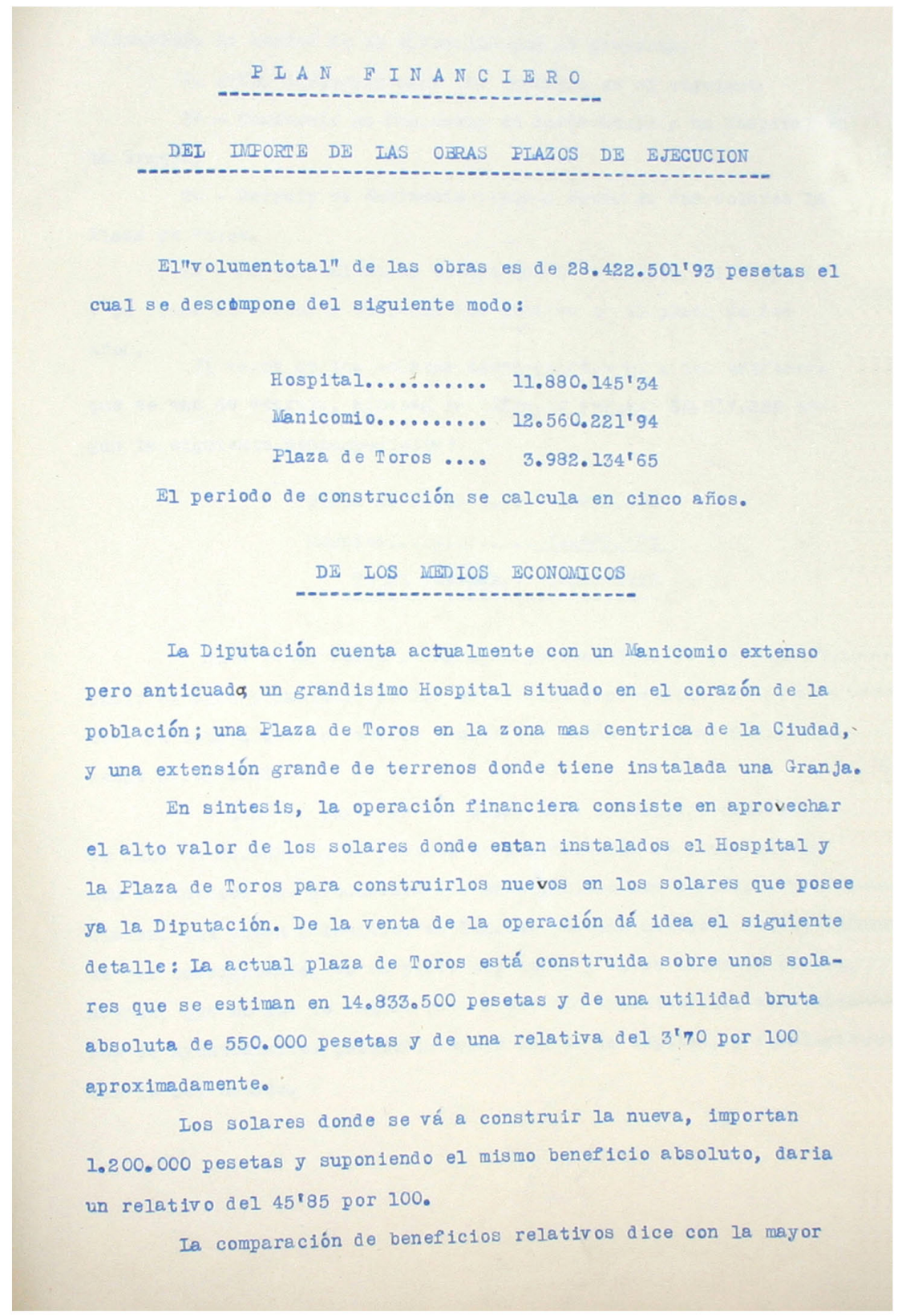

Memoria de intenciones para la triada propuesta por Luis ALBERT, para la Diputación Provincial de Valencia: plan financiero del importe de las obras y plazos de ejecución 
una doctrina científica de la ciudad: el urbanismo". 5

Y tan necesario resultaría elevar, en el extrarradio, modernas dotaciones propuestas, máquinas de habitar, como extraer de la metrópoli edificación coagulada. Quirúrgicas operaciones urbanísticas para una ciudad moderna, positivista. La ampliación controlada de la ciudad, en dirección sur, entraba en ese intento de acercarse a los beneficios racionales. Literalmente, rescatado del propio autor, es muy digno tener en cuenta las dos "grandes ventajas" que para Valencia ha de tener la construcción de los edificios ya mencionados: una de carácter social, representada por la gran masa de trabajadores que ocuparán estas obras; y otra, la que supone la posibilidad de urbanización del núcleo de población más sana de Valencia, pues la construcción en aquel punto del Hospital y la Plaza de Toros, unido a un posible traslado de la Estación del Norte, llevará a aquella zona un núcleo urbano muy digno de tener en cuenta.

Merece señalarse el propósito de inmersión de esta propuesta global dentro del urbanismo moderno -refutando aquella distinción establecida entre espacios internos y espacios externos- donde la arquitectura se asociaba al urbanismo para solventar las nuevas cuestiones planteadas. "Afrontando los grandes fenómenos que siguen a la revolución industrial, principalmente el fenómeno migratorio hacia las ciudades y el advenimiento de los nuevos medios de locomoción, el siglo Xx se enfrenta con

5 ÁBALOS, Iñaki. "La buena vida. Visita guiada a las casas de la modernidad". Editorial Gustavo Gili, S.A. Barcelona, 2000. Del capítulo La máquina de habitar de Jacques Tati: la casa positivista. p. 79 
elocuencia la bondad de la operación que se proyecta.

El orden dispuesto para los trabajos es el siguiente:

12 - Construir un Manicomio en Forta-Coel1 y un Hospital en 1a. Granja.

2. - Derruir el Nanicomio viejo y obrar en sus solares 19 Plaza de Toros.
32 - Derruir al mism
ue la anterior, el Hospital

y la Plaza de Toros, y enaje

lares en el plazo de dos

años。

El valor de los sol

spondientes a los edificios

que se han de derruir, alcan

a de pesetas 26.517 .222 se-

gún la siguiente descomposición:

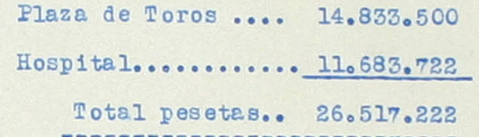

Si a estas sumas se agregan pesetas 500.000 que puede producir el aprovechamiento de los materiales procedentes de los derribos, se tendrá que los medios economicos sumán en la actualidad pesetas 27.017 .222 .

Y como el coste de las obras esta calculado, como antes se dice en 28.422.501'93 pesetas esta diferencia se puede cubrir con el interes que produciera los establecimientos beneficos provinciales, que estan calculados en 100.000 pesetas anuales, amortizandose por consiguiente, en un plazo muy corto y si se tiene en cuenta, ademes, que no han de faltar para fines tan humanitarios, subvenciones de Ayuntamientos particularmente del de la Capital, y finalmente con la del Estado.

Memoria de intenciones para la triada propuesta por Luis ALBERT, para la Diputación Provincial de Valencia: continuación con el presupuesto detallado 
los problemas del espacio ciudadano, irrumpe más allá de las murallas antiguas, crea nuevos barrios periféricos, formula los temas sociales del urbanismo en el sentido moderno de la palabra"6.

Propósito que responde a las demandas de Hilberseimer, en 1927, para la ciudad del futuro: una formación metódica, de un organismo razonado; construida sistemáticamente, a partir de elementos, ordenándolos en un sentido completamente nuevo; que cumpla las exigencias urbanísticas básicas; de trazado claro y lógico; manzanas abiertas y ventiladas; con un ancho de calle proporcionado a la altura de los edificios ${ }^{7}$. Propósito a destacar, premisa del proyecto albertiano, frente al desentendido planeamiento municipal, que bebiendo de las fuentes modernas que manaban por Europa, desatendía implicaciones sociales, planteamientos climáticos y de implantación, desatendía intereses arquitectónicos, dejando libre juego a la actividad empresarial, a la especulación que proporcionaba elevados intereses capitalistas.

- ZEVI, Bruno. "Saber ver la arquitectura: Ensayo sobre la interpretación espacial de la arquitectura." 1951. Editorial Poseidón, S.R.I. Buenos Aires. Argentina. Barcelona, 1991. Editorial Poseidon Joan Merli.

${ }^{7}$ HILBERSEIMER, Ludwig. Op. cit. p. 3 
hospital provincial 


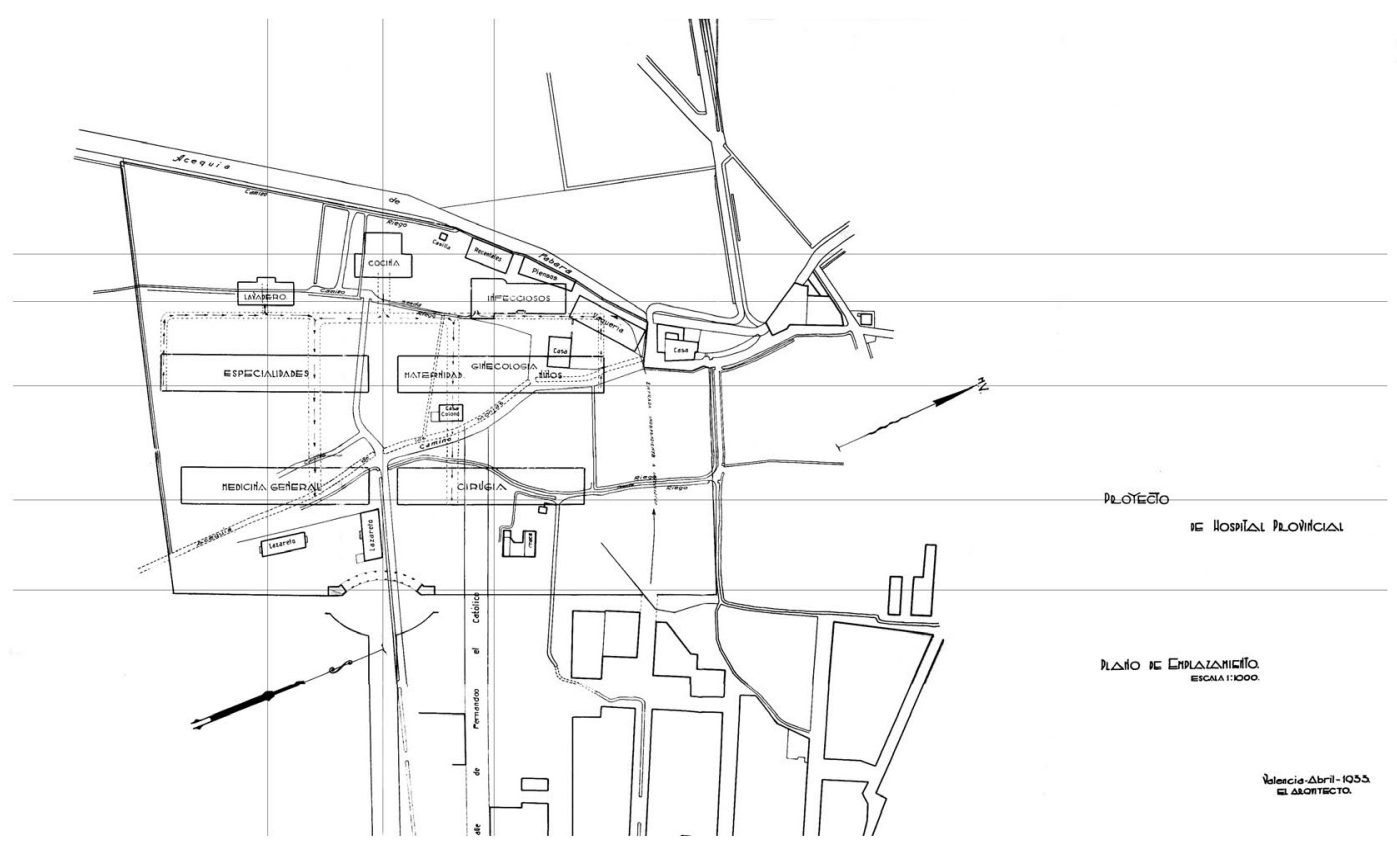

fig. 6 


\section{COMPOSICIÓN VOLUMÉTRICA}

El programa requerido, dilatado y complejo en cuanto a Hospital Provincial, sería planteado y desarrollado por Albert, mediante un conjunto de cinco pabellones longitudinales, alineados siguiendo una triada de ejes paralelos suroeste-noreste (fig. 6). Los pabellones de Cirugía y Medicina General, y los de Maternidad-Ginecología-Niños y Especialidades forman los grupos iniciales, agrupados por parejas respecto al eje trasversal que los simetriza, mientras el pabellón de Infecciosos, simétricamente desparejado, se posiciona en la paralela concluyente. Ultiman el conjunto el pabellón de Lavadero -alineado en el eje último, simétrico en ubicación respecto del pabellón de Infecciosos, no obstante desvinculado formalmente- y el pabellón de Cocina, que junto con el pabellón de entrada generan los ejes menores - previo y final al trío fundamental precedenteque traman la ordenación, arraigando el eje perpendicular que atraviesa y simetriza el conjunto.

Generada la malla compositiva por tres ejes principales paralelos -por donde discurren los volúmenes funcionalmente públicos, de atención médica- y dos ejes menores siempre suroeste-noreste -donde posicionar los pabellones sirvientes-, esta queda materializada transversalmente, una vez atravesada por un eje sureste-noroeste, perpendicular, de recorrido y simetría, cuya repetición ordena los pabellones en la trama consolidada. Eje perpendicular a los anteriores primigenios y, a su vez marcadamente visual, comenzando su singladura bajo el pabellón porticado de acceso y concluyendo en el pabellón de Cocina. Una visión última, un final del eje perspéctico de escaso carácter representativo y débil como principio compositivo, inmerso en un planteamiento ciertamente rígido, clásico y geométrico, una matriz ordenante cuya potencia compositiva se procura desvirtuar con la formalización propia de los volúmenes a 


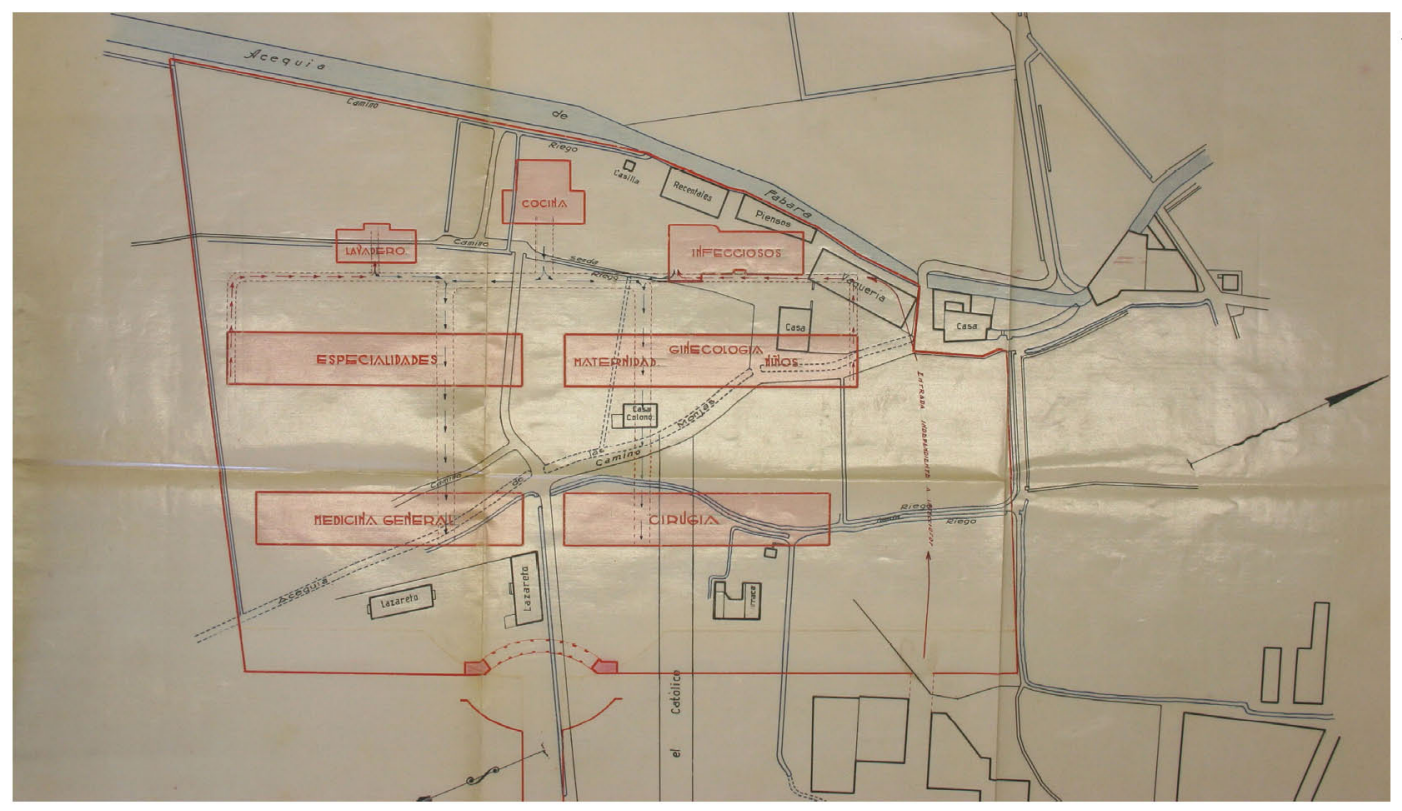

fig. 7

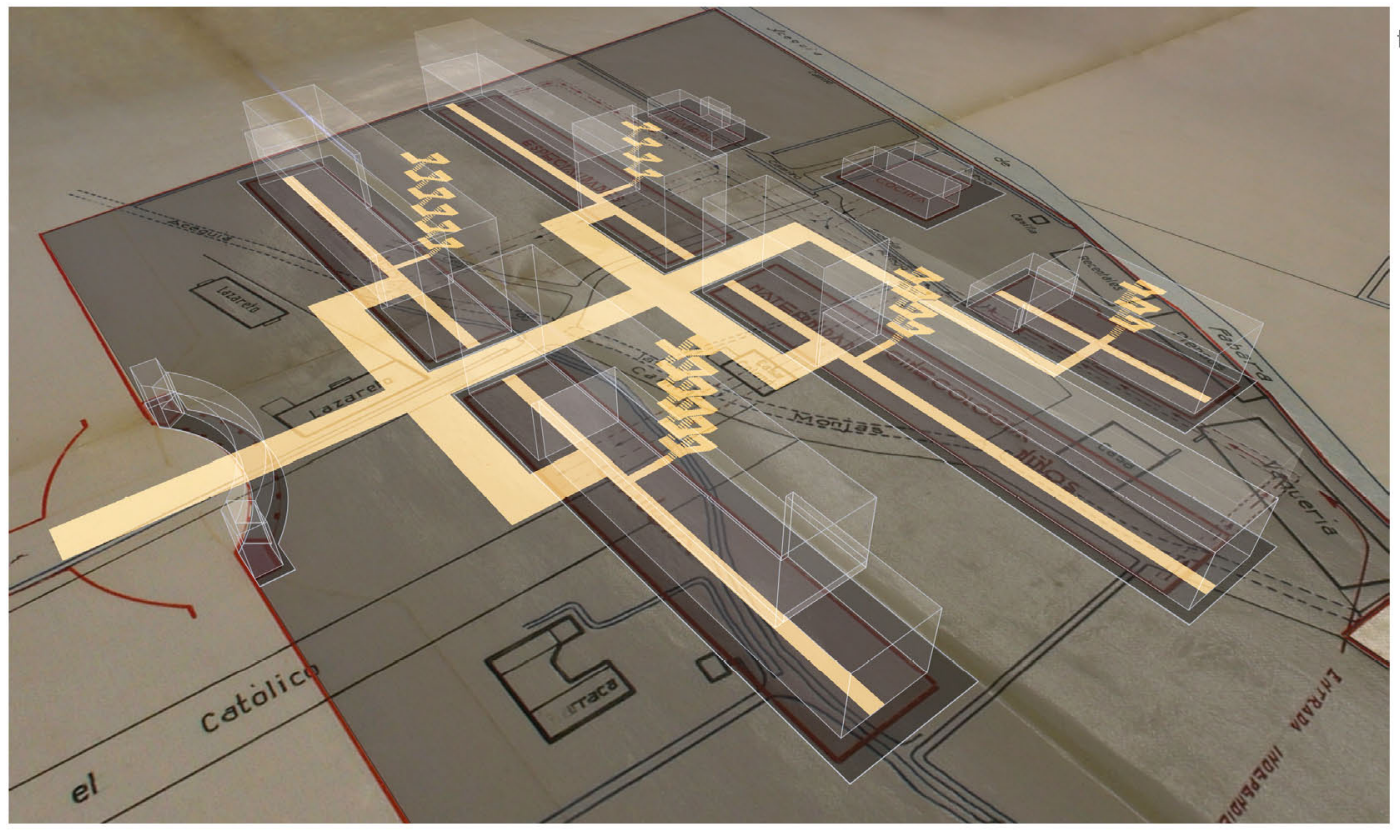

Luis ALBERT, 1935; plano de emplazamiento del proyecto de ejecución (papel tela); estudio volumétrico de la ordenación y sus circulaciones públicas exteriores por doctorando 
construir, rompiendo el simétrico emparejamiento, bien abandonando la estricta linealidad en justificables curvaturas. Un principio generador y compositivo, falto de condicionantes propiamente impuestos, de relaciones visuales, imbricaciones formales y con el lugar, escaso de pesquisas más profundas que la ligera alteración geométrica (fig. 7).

Geometrizar, componer volúmenes con preponderancia lineal, se lleva al extremo mediante unos puentes, proyectados con vigas Wierendel y catorce metros de luz, comunicando los pabellones de los dos primeros ejes fundamentales -aquellos que acogían uso médico-, enfatizando una intención por aunar todo el conjunto en oposición al aislamiento compositivo. Hitos exentos conectados por un orden superior, un proyecto unitario de elementos individuales englobados dentro del colectivo. Retornan dudas proyectuales, incomprensión sobre potenciar el marco visual que crean estos puentes, dirigiendo la vista de quien traspasa el umbral y recorre visualmente la ordenación, culminando aquel eje con un pabeIlón menor. Cabría retomar la perspectiva, las relaciones entre las partes elementales, como método para alterar, injerir complejidad en el discurso fundamentalmente funcional y geométrico elegido.

Coinciden en potencia y ubicación tanto el eje de recorrido visual como el principal del itinerario público, recorrido peatonal (fig. 8). Este último atraviesa el pabellón de acceso, para derivarse a lo largo de su longitud, transversalmente, hacia los demás pabellones de uso público-médico. Al contrario que la perspectiva visual, ya no concluye en el pabellón de Cocina, provocando giros ortogonales de aproximación a los diferentes pabellones servidos, para finalizar en el pabellón de Infecciosos. Pabellón que dispone de un nuevo eje de acceso, independizado del principal, 


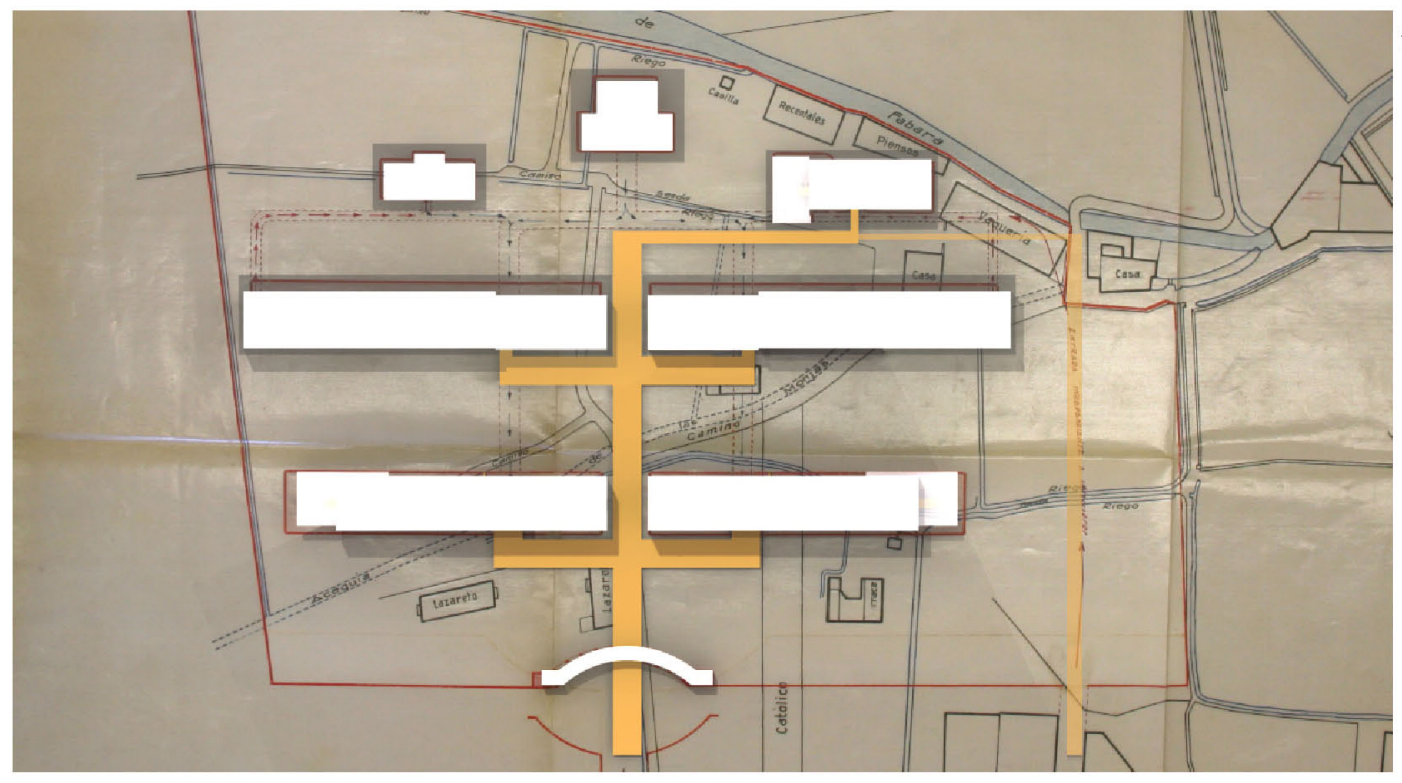

fig. 9

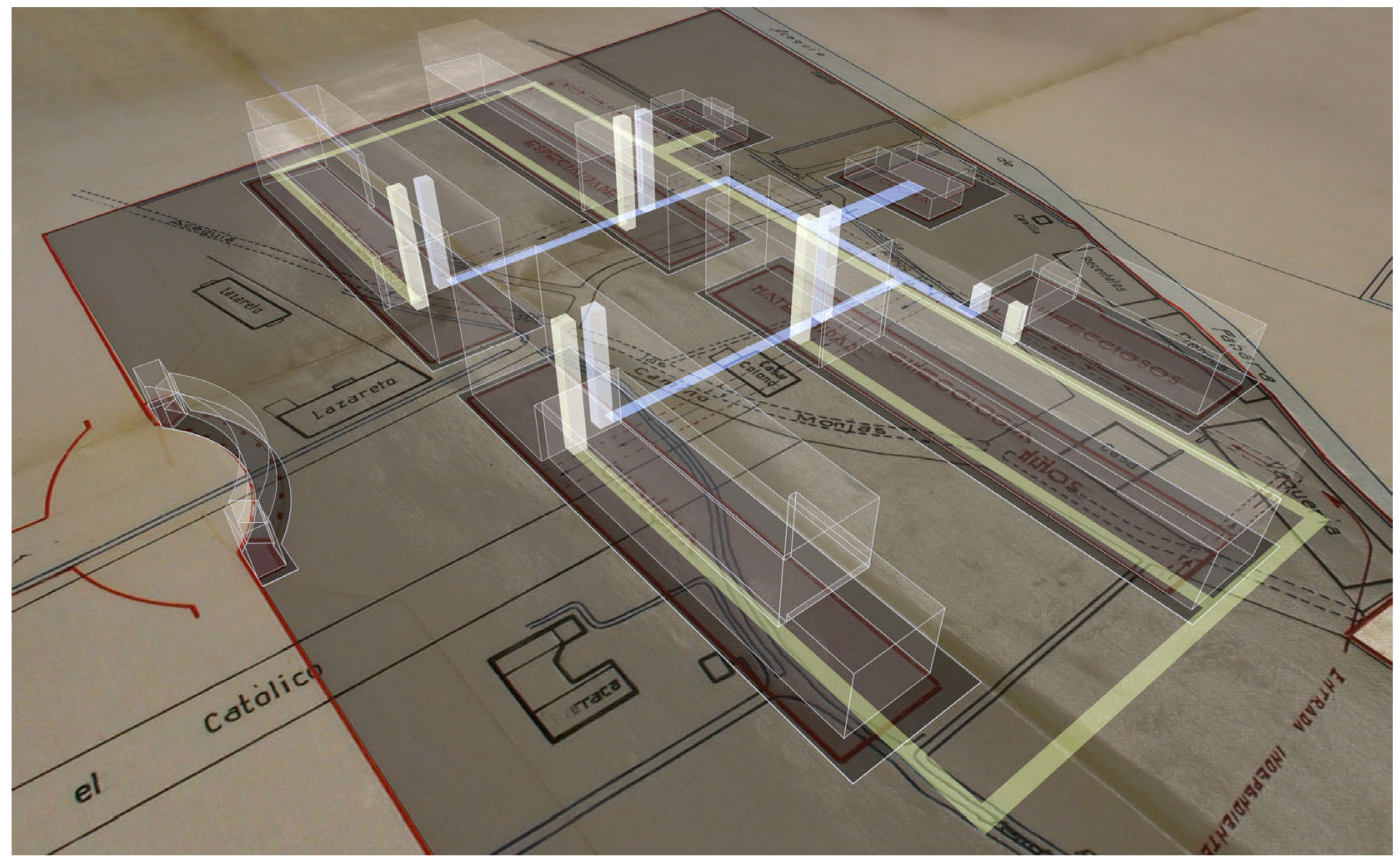

Luis ALBERT, 1935; estudio de volúmenes y circulación sobre plano de emplazamiento: análisis volumétrico y circulaciones de servicio subterráneas - verticales, por doctorando 
mediante un eje paralelo al que comenzaba desde el pabellón de acceso, en una fisura intencionada del perímetro (fig. 9). La circulación de servicio para funciones internas del hospital queda segregada de este eje peatonal, y consecuentemente potenciada por un sistema de túneles y ascensores que conectan los usos de asistencia con cada pabellón, mediante una línea oculta que permite suprimir el tránsito exterior y evitar el contacto, si quiera visual, con el recorrido público (fig. 10).

Albert analiza los elementos requeridos desde el programa, independizándolos funcionalmente, proponiendo volumetrías exentas, elementos zurcidos tras una propuesta unitaria, sirviéndose para ello de recursos contrastados, las comentadas pasarelas-puente, o mediante el entramado oculto de túneles, vinculando servicios a la totalidad de pabellones. No obstante, su interés por construir un conjunto edilicio-consolidado y global- le postula hacia la búsqueda de la integración. "Y mediante unos carretones eléctricos, será distribuida la comida y ropas que subirán a las distintas dependencias de cada pabellón mediante los ascensores que llegan desde el piso del túnel hasta el último de cada edificio". " Los túneles se disocian en generales y de servicio de infección -así puede observarse en el plano de emplazamiento- con el objeto de no encontrarse desinfección con las comidas y ropas limpias, extremando el hermetismo de ambos circuitos.

8 Albert ballesteros, Luís. "Memoria de proyecto del Hospital Provincial". Valencia, 1933. Archivo de la Diputación Provincial de Valencia. 

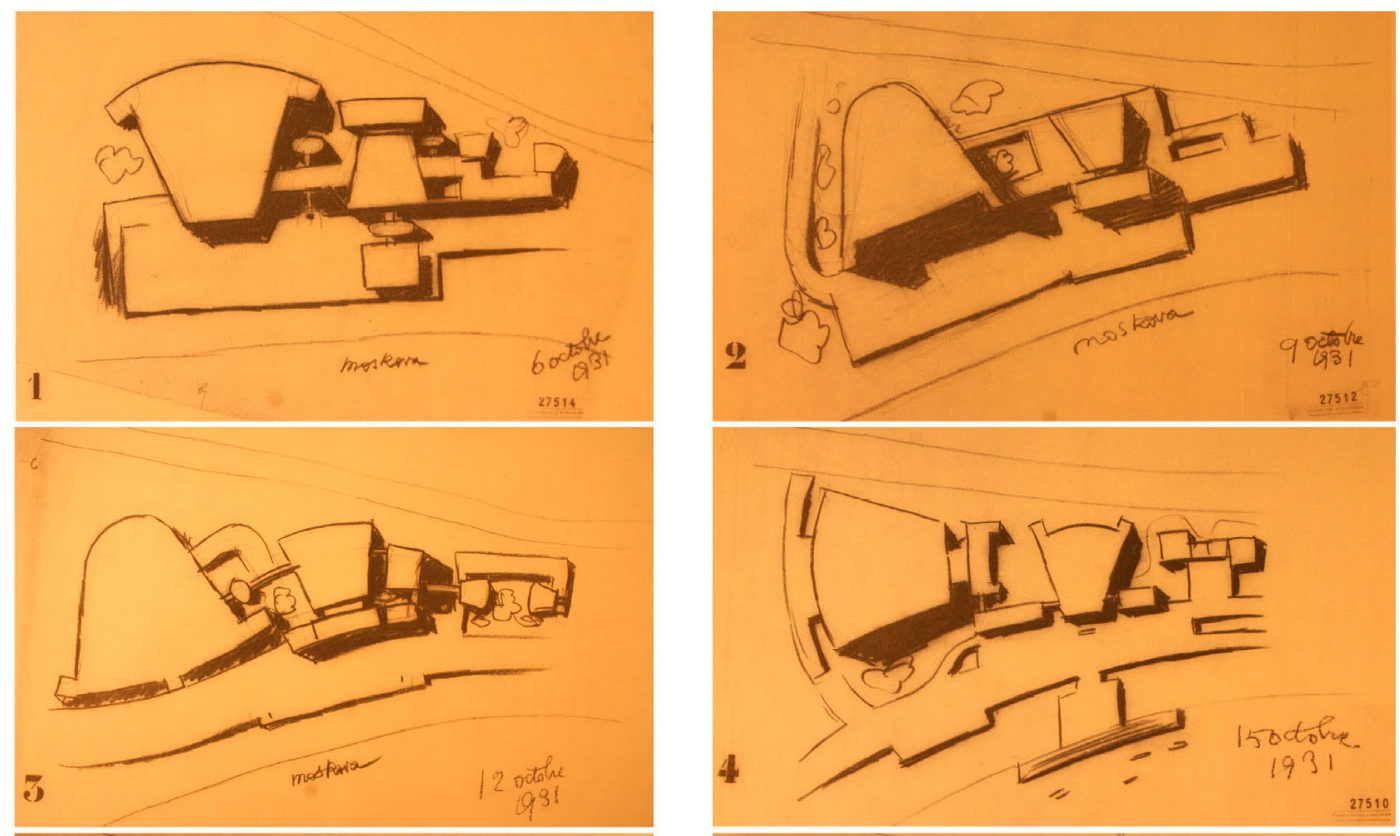

fig. 11
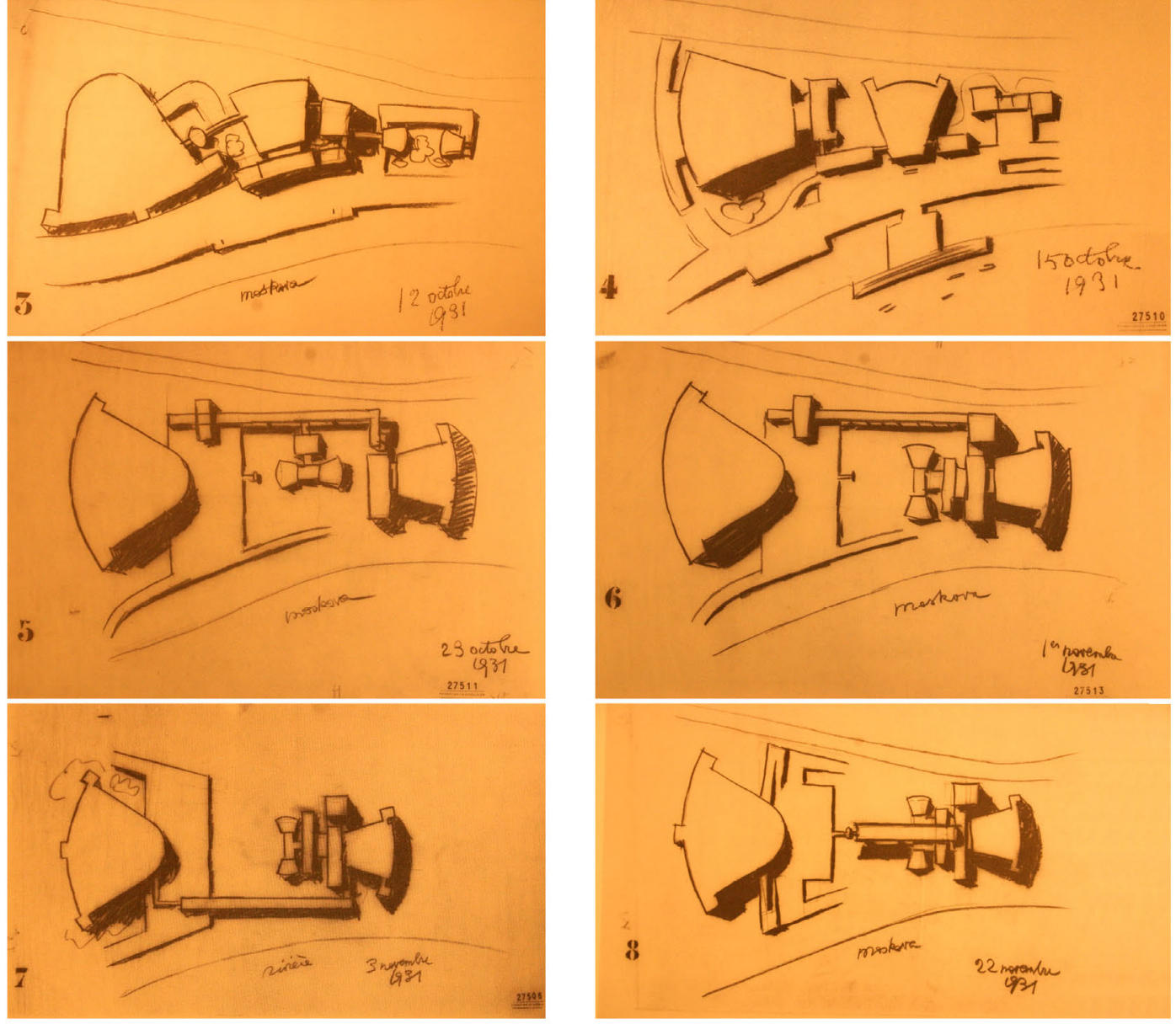

Le CORBUSIER, 1931: Palacio de los Soviets, propuesta de concurso en Moscú: Evolución del proceso compositivo; dibujos del arquitecto (Fundación Le Corbusier) 
Ubicar los volúmenes mediante un estricto sistema geométrico y de alineaciones, resulta más propio de una disciplina clásica y ortodoxa, desacreditada por lo esquemático de su aplicación, sin embargo licita como premisa proyectiva, génesis arquitectónica. Hilberseimer ${ }^{9}$ planteaba en 1927 consideraciones hacia el terreno, a la posición respecto al sol, incluso razones más elevadas y de interés Arquitectónico. Aalto buscaba en Paimio la célula habitacional como interés generador del proyecto, fijando la orientación sur-este. Mies en el Instituto politécnico de lllinois (ITT $)^{10}$, obligado a conservar la red de circulación existente, dividió el terreno según una trama de $7,3 \mathrm{~m} \times 7,3 \mathrm{~m}\left(24^{\prime} \times 24^{\prime}\right)$, sobre la cual proyectó el conjunto de edificaciones. Le Corbusier evolucionaría el método elementalista de Guadet, generador a través de la reposición de partes, reformulando volúmenes, llegando a propugnar diversas propuestas en el proyecto para el Palacio de los Soviets, Moscú, 1931. Gropius adelantaría la variación del método, componiendo para la Bauhaus en Dessau, 1926, avanzando el recurso del puente conector. Mantener por parte de Albert, la retícula desde la implantación hasta la estructura edilicia suponía, en parte, génesis e interés Arquitectónico (fig. 11).

Resultaría en su disposición y alteración geométrica, una composición racional, de principios organizadores similares a los de Le Corbusier -al menos aquel dedicado a edificación pública en sus comienzos profesionales- por los que Albert intenta asociar organización y función, jerarquizar figuradamente según alturas, y construcción. En sus edificios públicos,

\footnotetext{
9 HILBERSEIMER, Ludwig. Op. cit. p. 3

${ }^{10}$ BLAZER, Werner. "Iudwig mies van der rohe". Editorial Gustavo Gili, Barcelona. $2^{\circ}$ edición, 1992. Traducido por Nuria Nussbaum/Gram. Thomson
} 


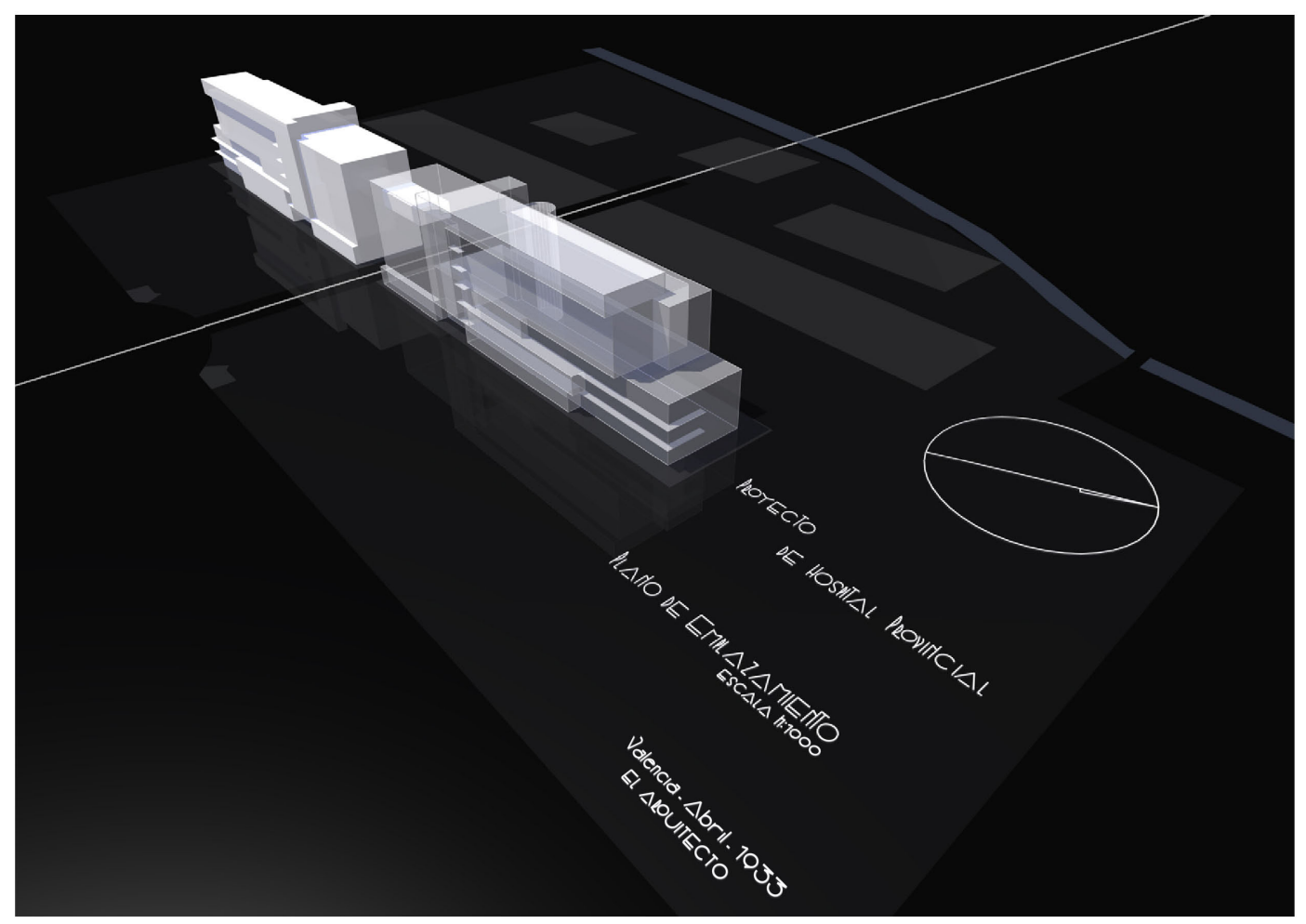

fig. 12 
Le Corbusier "adoptó un planteamiento muy distinto al de sus casas. En lugar de incluir las irregularidades funcionales dentro de un exterior platónico, el edificio se rompe en sus partes componentes, que consisten principalmente en pastillas lineales qque contienen módulos repetitivos, como oficinas) y volúmenes centralizados (que contienen espacios de reunión pública). Y luego estos elementos se vuelven a componer libremente de tal modo que tienden a escaparse y multiplicarse". 11

Este enfoque elementalista de la disposición, estableciendo primero los elementos y manipulándolos después con el fin de generar cierto número de disposiciones alternativas, esta prolongación del elementalismo profesado a principios de siglo por Julián Guadet ${ }^{12}$, nunca llega a descomponerse y desembarazarse de la retícula en el proyecto del Hospital.

La simetría se muestra como generadora de la ordenación del conjunto, e irracionalmente ${ }^{13}$ se mantiene en la génesis volumétrica de las dos primeras líneas de construcción. No imperan las exigencias organizativas, más bien se reflejan miméticos volúmenes, desatendiendo las diferencias de programa (fig. 12). Empero al llegar a la tercera serie horizontal, se abandona la rigidez compositiva para responder a los requerimientos funcionales que demanda cada volumen. Resulta este el único signo por

11 COLQUHOUN, Alan. "La arquitectura moderna una historia desapasionada". Editorial Gustavo Gili, Barcelona. 2005. Título original: "Modern Architecture", publicado en inglés en 2002: Traducido por Jorge Sainz. p 152.

12 FRAMPTON, Kenneth. "Historia crítica de la arquitectura moderna". Editorial Gustavo Gili, Barcelona. Novena edición, 1998. Título original: "Modern Architecture: A Critical History", publicado en inglés en 1980: Traducido por Jorge Sainz. p 160 .

13 entiéndase irracionalmente en clara alusión al término "arquitectura racional". 
$\approx$ 
componer libremente, por rescatar las alteraciones volumétricas desde la reorganización, siguiendo aquel enfoque elementalista y liberarse de una composición geométrica tan estricta. Premisa esta que, en los postulados modernos, debería haberse tomado como principio, como planteamiento inicial, pues en ningún momento justifica Albert la necesidad de simetrizar pabellones. Únicamente aparece una referencia en la memoria de proyecto ${ }^{14}$ donde se ratifica - sin razonarse funcionalmente- la no inclusión de documentación gráfica descriptiva de las construcciones simetrizadas.

Se han señalado dudas manifiestas desde el principio generador, en uno de los planteamientos modernos más contundentes: acometer la ubicación del edificio en su entorno. Momento exacto en que las premisas proyectuales quedan desvinculadas de principios racionalistas, del urbanismo moderno, revertiendo hacia posturas miméticas, retomando propuestas ensayadas, evitando nuevos planteamientos. Cuando los pioneros de la arquitectura moderna rechazaban las 'formas del pasado', no se referían sólo a algunos motivos concretos, sino también a las concepciones espaciales en general, como la perspectiva lineal del Renacimiento o los trazados totalitarios del Barroco. En particular se oponían a las composiciones 'académicas' de la arquitectura oficial del siglo XIX, en la que

14 PABelLón de MEdicina general. Este pabellón es simétrico del anterior, la distribución de sus plantas es exacta, por cuyo motivo no figuran los planos en el proyecto. Está unido a el en dos pisos por un puente de catorce metros con vigas Wierendel. (...)PABELLÓN DE ESPECIALIDADES. No se expresa en los planos este pabellón, pues en nada se diferencia del más arriba descrito de Maternidad y solo en esta memoria consignaremos las diferencias que pudiésemos llamar de rotulación o destino, de cada una de las dependencias.

ALBERT BALLESTEROS, Luís. Op. cit. p. 8 
los centros y los ejes significativos del urbanismo barroco habían degenerado en un juego con figuras formalistas ${ }^{15}$. Posiblemente la falta de referentes próximos con quienes convenir la imbricación de premisas, la mengua de condicionantes inmediatos a imponer como arranque proyectual, la lejanía de la ciudad facilitaban esta simplificación compositiva trasnochada, este retorno a referentes vernáculos. Rotundamente, el eje principal que simetriza la disposición de los pabellones, el iconográfico pabellón circular de acceso -manido hasta perpetrarlo en la irracional propuesta finalmente erigida- centrado en este eje, y el muro de cierre plagado de setos vivos y enredaderas, no trabaron la propuesta arquitectónica con los modernos requerimientos urbanísticos de un centro público sanitario, con aquellos planeamientos racionales de la Carta de Atenas. Más bien quedarían asociados a las realidades de las "ciudadesjardín" construidas en el alborear del siglo, en las cuales a una ausencia de interés arquitectónico correspondía, al menos, "un orden urbanístico, una voluntad organizadora, movida por estímulos más nobles que la megalomanía y la especulación. El siglo XIX, por lo menos, intentó encauzar el desastre urbanístico, aclaró los problemas y propuso las primeras soluciones a la ciudad moderna". ${ }^{16}$

15 NORBERG-SCHULZ, Christian. "LOS PRINCIPIOS de la arquitectura MODERNA. Sobre la nueva tradición del siglo XX". Edición en español: Editorial Reverté, S.A. BarceIona, 2005. Traducción Jorge Sainz. p. 22

16 ZEVI, Bruno. Op. cit. p. 6 

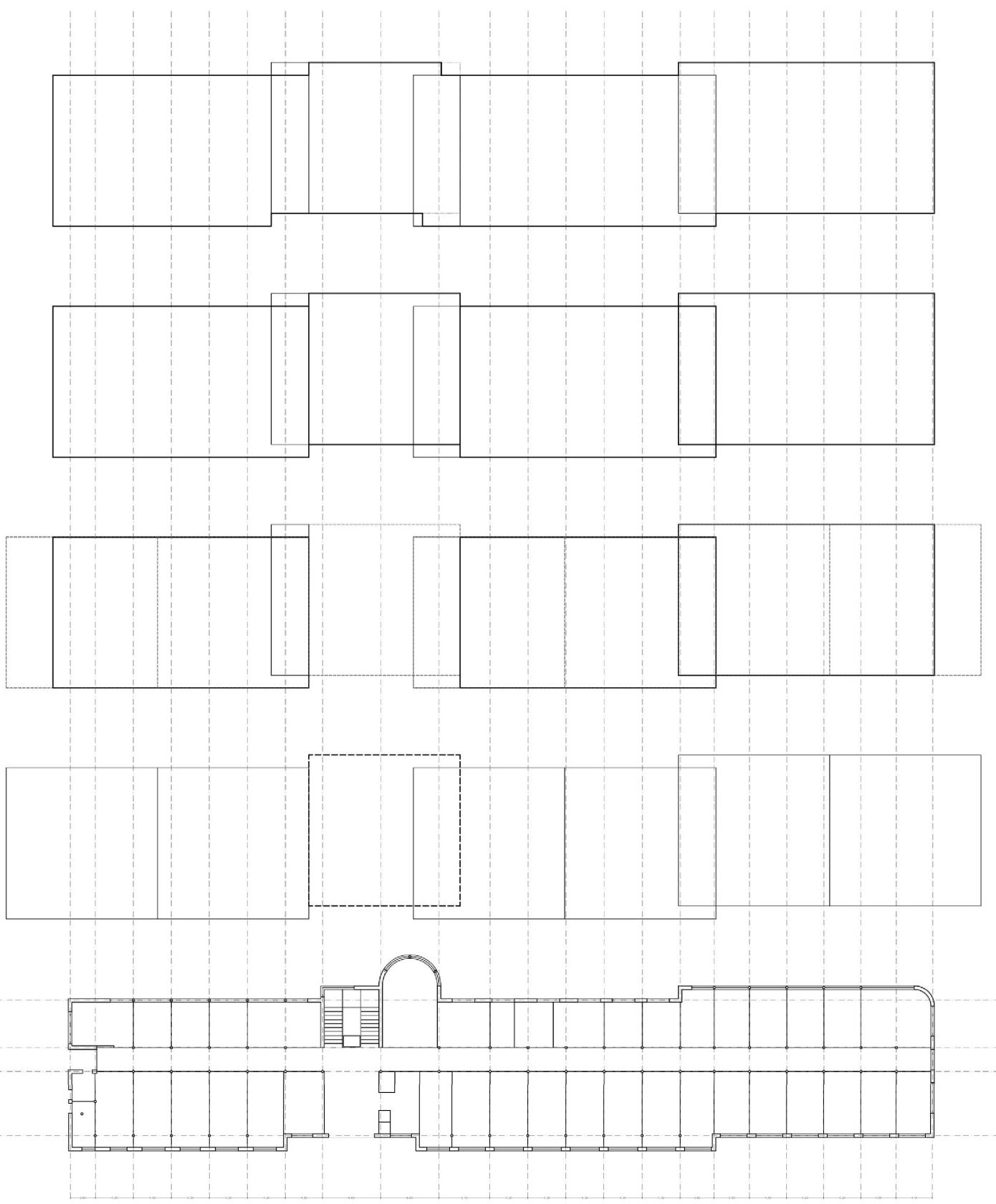

Hospital Provincial; composición, ejes y modulación del pabellón de Cirugía, simétrico el pabellón de Medicina General-descrito en memoria de proyecto, no compilado en plano 


\section{ORGANIZACIÓN FUNCIONAL}

"Un nuevo edificio destinado a Hospital, debe ser en su parte arquitectónica de belleza en el conjunto, sobriedad en sus detalles, grandiosidady sencillez, ostentando como cualidades principales, la armonía, limpieza, solidez, luminosidad y agradable disposición de masas, con un perfecto equilibrio de ellas, que den un juego de luz y sombraje, al contemplarlo, lleven al ánimo sentimiento de bienestar y atracción, que tanto influyen en el ánimo de los que por su delicada salud, deben ingresar en el establecimiento". ${ }^{17}$

Semejante decálogo -valores básicos propugnados desde el movimiento moderno- sería retomado y transliterado indispensable por Albert en su moderna propuesta para Hospital. Proyecto social con marcada voluntad de renovación formal, donde debería cobrar existencia el precepto funcional, la construcción utilitaria. Se presume baldía la necesidad de texto, cuando permanece interiorizada -la funcionalidad- como premisa proyectual, cuando función y composición elementalista discurren asociados.

Albert proyectó pues la edificación global -inalienable de las partes- y la llevaría al análisis detallado mediante elementos programáticos, argumentándola íntegramente, con la determinación de una recomposición última basada en su ordenación geométrica, estrictamente rígida, formalizando así un conjunto de alineaciones funcionales de gran sencillez.

17 Albert ballesteros, Luís. Op. cit., p. 8 


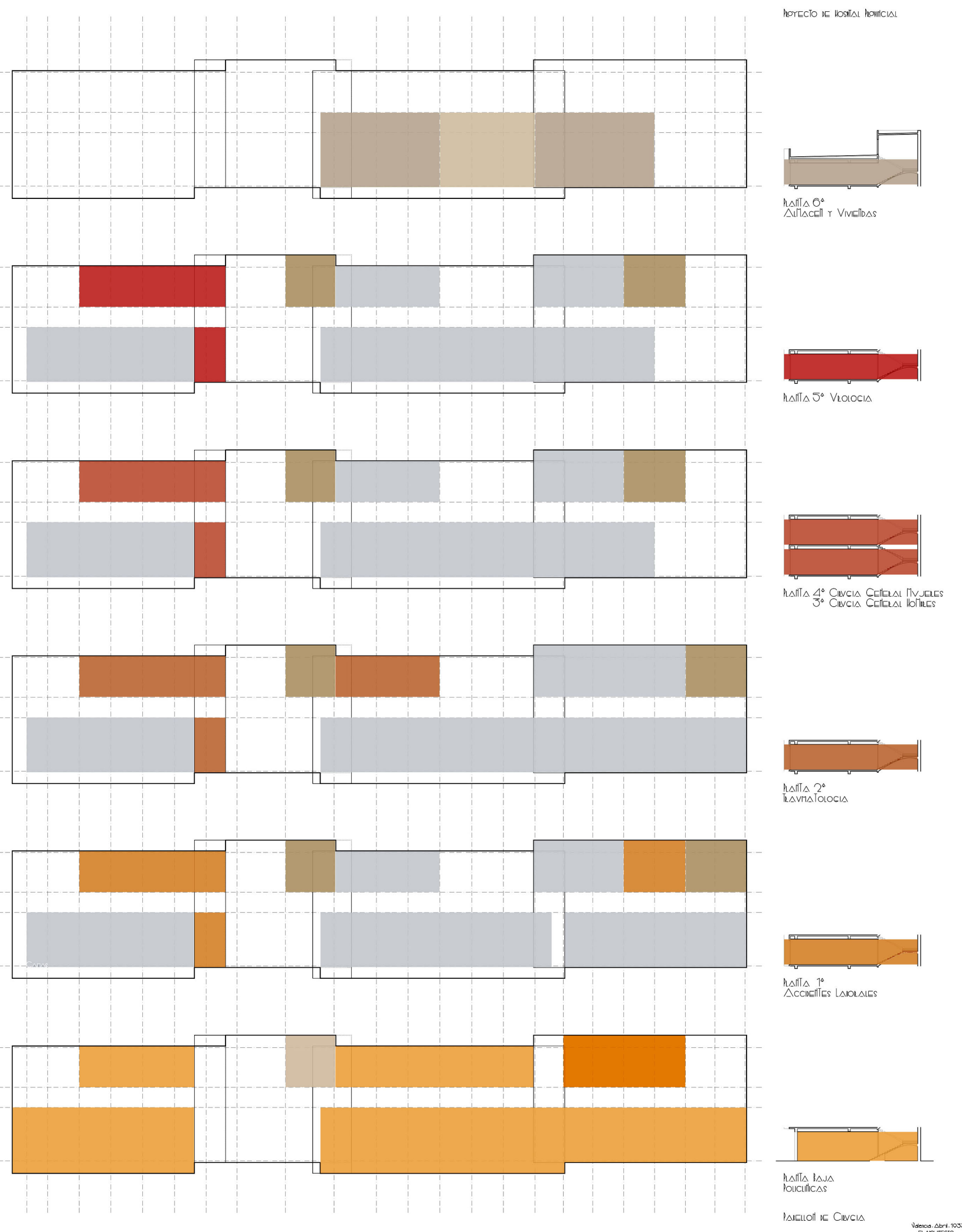

fig. 13

Hospital Provincial; análisis funcional del pabellón. En sección: Policlínicas; Accidentes Laborales; Traumatología: Cirugía General Hombres; Mujeres; Urología; Almacenes 
Moldear elementos volumétricos organizándolos por funciones, pormenorizadas desde el programa, resultaba la inmediata premisa. Posicionar cada volumen siguiendo sus necesidades funcionales, variar la altura individualmente dependiendo de las jerarquías de uso, consentir aspiraciones individualizadas de espacio, aire, higiene y comodidad, ordenar rigurosamente -emplear geometrías ordenantes como medio para componer y nunca como fin en si mismo-, concretaría finalmente las funciones en una forma eficiente, una definición rigurosa.

Aproximadamente, el aforo del edificio-comprendido como el conjunto de todos los pabellones- radicaría en 1.500 camas, excluidos los residentes trabajando en el centro sanitario. Cinco son los pabellones proyectados donde se organizan y distribuyen las funciones clínicas. A más dos pabellones, de menor dimensión, recogen los trabajos hospitalarios de servicio -cocina y lavandería- a los anteriores. Completa el programa un volumen para administración, elevándose del terreno -el cual, por consiguiente, se desliza por debajo (...). Otra superficie igual se gana también en la techumbre plana ${ }^{18}$ - acotando el avance, comprimiendo la vista y proporcionando el acceso al conjunto tras su curvatura-concavidadreceptiva.

Cirugía y Medicina General asomaban los dos primeros pabellones, mostrados tras cruzar el acceso porticado. Su jerarquía funcional -ambas piezas albergarían cuantitativamente el uso clínico por excelencia- exigía

18 LE CORBusier. "Cinco puntos sobre una nueva arquitectura". (De Zwei Wohnhänser von Le Corbusier und Pierre Jeanneret, por Alfred Roth, Sttutgart, 1927). Véase ARQUITECTURA, revista mensual del Órgano Oficial de la Sociedad Central de Arquitectos, número 130. Año X, 1928. 


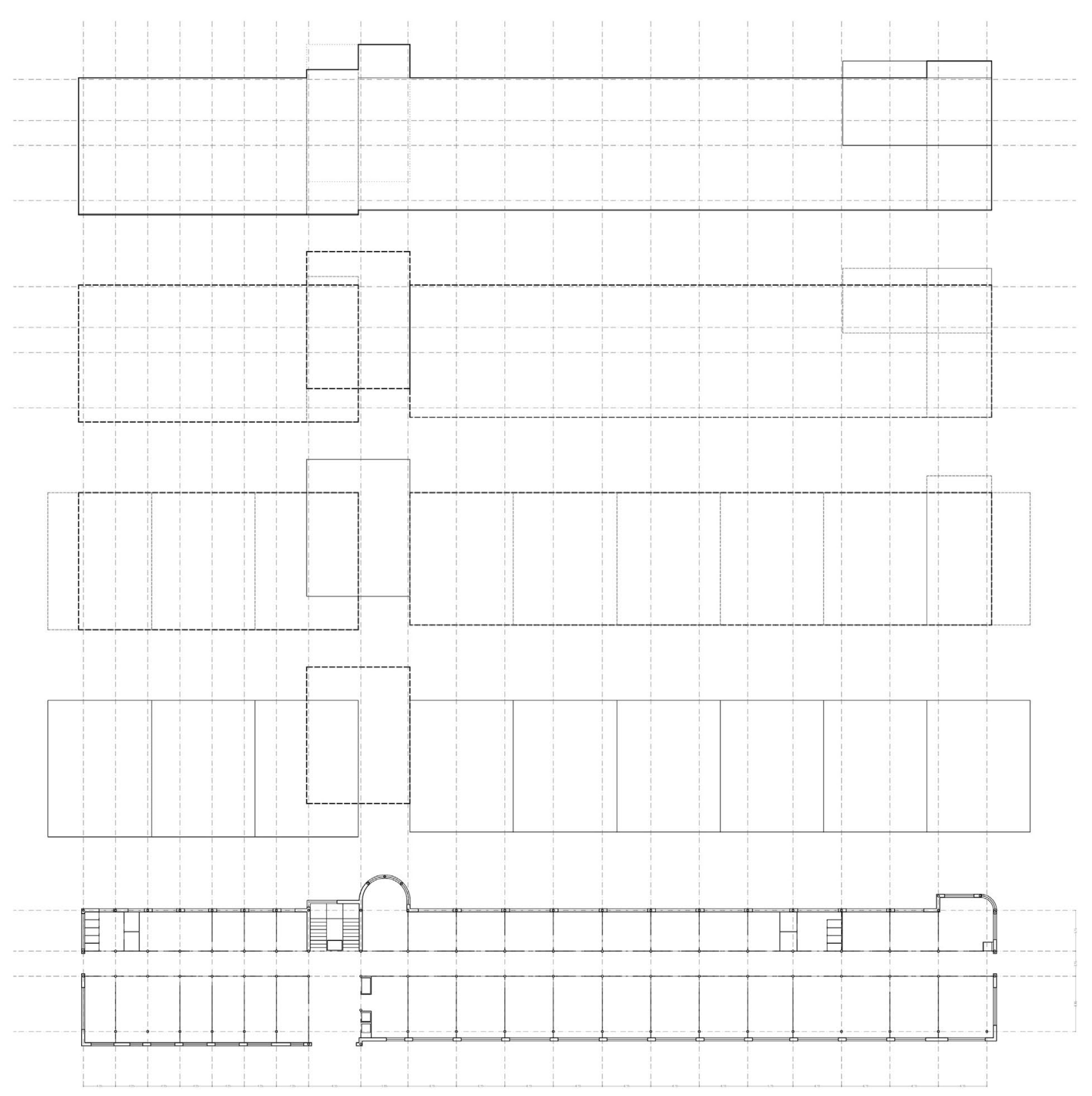

Hospital Provincial: composición, ejes y modulación del pabellón de Maternidad, Ginecología y Niños: narrado, simétricamente dispuesto, el pabellón de Especialidades 
dotarlas de mayor altura. Su preponderancia, posicionarlas inmediatas al acceso, previamente a los demás pabellones, a los que postergaba visualmente. Concentrando el tránsito de personal externo, liberaban los pabellones posteriores a un uso más selectivo y específico.

Ante tal rigor programático, tan elevada exigencia de elementos mínimos satisfaciendo necesidades, ante tal requerimiento funcional y racionalista, deja de comprenderse la forzada simetría distributiva entre ambos pabellones. Las Policlínicas siempre en planta baja, gestionando acceso directo, sin objeciones. A partir de aquí, cada pabellón distribuía verticalmente su propio y diferencial programa: Cirugía albergando Accidentes de Trabajo en primera planta; Traumatología en segunda; Cirugía para hombres en la tercera y en la cuarta para mujeres; Urología concluyendo la quinta planta; y finalmente, formalizando la planta destinada a cubiertas, un solarium -imprescindible en todo edificio sanitario racional19- mezclado con almacenes (fig. 13). Medicina General destinaría las dos primeras plantas -a caballo sobre la Policlínica, en planta baja- a su función propia; asumiría en planta tercera especialidades en Respiratorio y Circulatorio; la cuarta disponía Nervioso; segregando Tuberculoso en la quinta. Como parece coherente la cubierta recibiría el mismo destino al pabellón precedente -solarium, tan racionalmente relacionado con la función inmediatamente inferior- de Cirugía (fig. 14).

19 Referentes elogiables, destacan el Sanatorio en Paimio de Alvar Aalto y, más cercana referencia, en Barcelona, el Dispensario Central Antituberculoso, de J. LI. Sert, J. Torres Clavé y J. B. Subirana. 


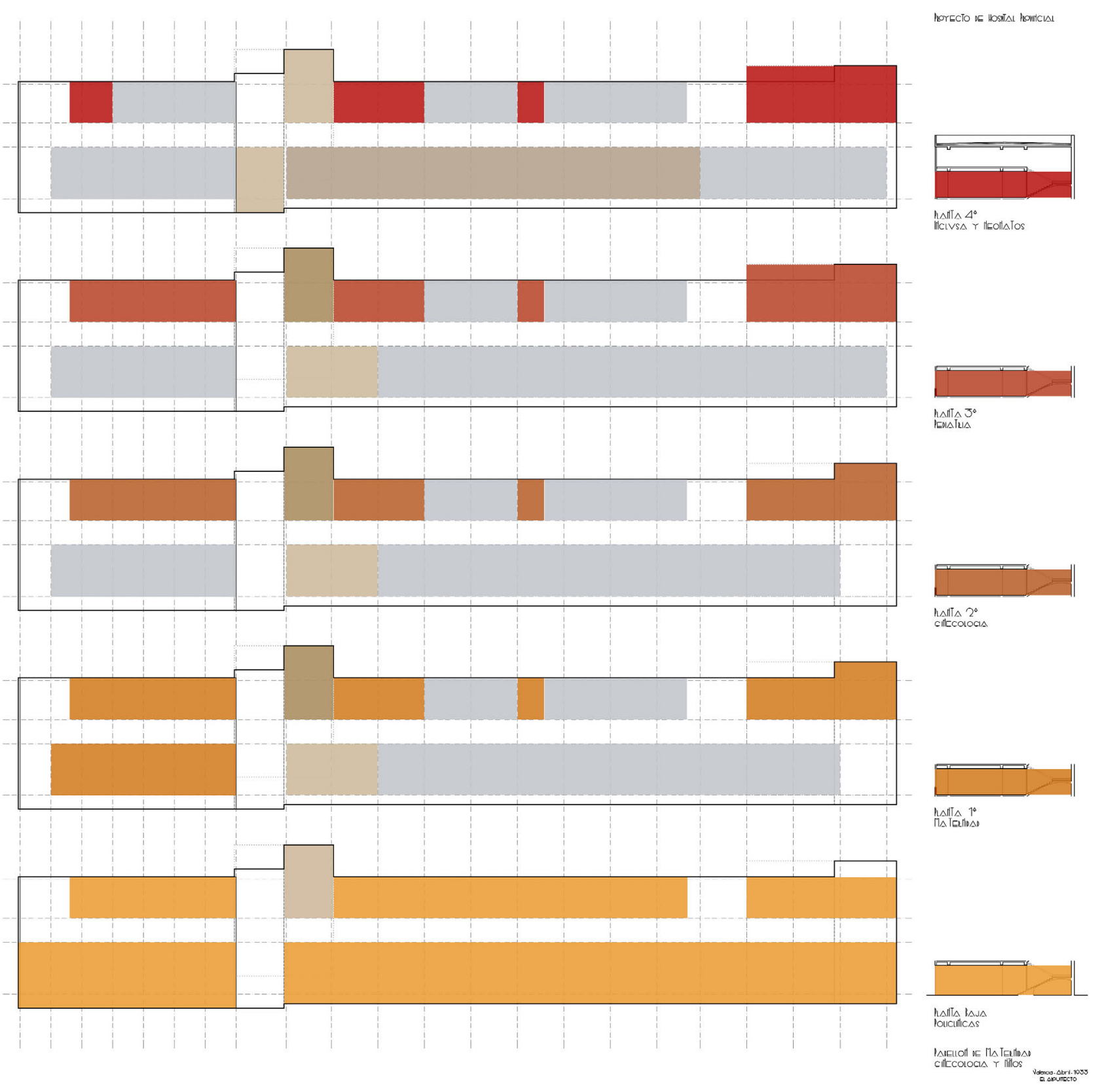

Hospital Provincial; análisis funcional. En sección: planta baja Policlínicas: planta $1^{a}$ Maternidad: planta $2^{a}$ Ginecología; planta $3^{a}$ Pediatría: planta $4^{\circ}$ Inclusa y Neonatos 
Esta puntual coherencia simétrica, se intuye -nunca aparece expresada gráficamente- cuestionable cuando la exactitud métrica en cada espacio de trabajo, relaciona Accidentes de Trabajo o Traumatología con Urología; Cirugía para Hombres con Respiratorio; Cirugía para Mujeres con Nervioso; o bien Urología con Tuberculoso. Ni tan siquiera la capacidad -referenciada en camas- resultaría similar entre Accidentes de Trabajo o Traumatología con Urología, por dar un ejemplo. Menos comparables resultarían las necesidades de salas previas, consultas médicas, enfermerías, tratamientos específicos y, ya sin necesidad de entrar en las particularidades y exigencias de una sala de quirófano, disponiendo de los modernos avances médicos pretendidos. Tal cual, se desprende del análisis funcional comparativo -volviendo a Sert- del Dispensario Central Antituberculoso en Barcelona.

Mucho más forzada resultaría la exacerbada exactitud geométrica, empeñada por componer el pabellón de Maternidad, simétrico nuevamente en su distribución, con el equiparado de Especialidades. Las policlínicas retomaban la planta baja, sin embargo, ya en la primera planta se disponía Maternidad exactamente distribuido a Oftalmología -con la diversidad de instrumental moderno que las separa- del pabellón de Especialidades, Ginecología frente a Otorrinolaringología en la segunda planta, Pediatría y Dermatología en la tercera, mientras que la cubierta dejaba de estar ajardinada, para albergar con idéntico replanteo, la Inclusa y Neonatos en el pabellón de Maternidad frente a Odontología, viviendas y almacenes en el de Especialidades.

Albert generó la propuesta funcional, consecuencia de la comprensión y asimilación parcial de los ideales racionalistas. Y señalamos parcial, pues 

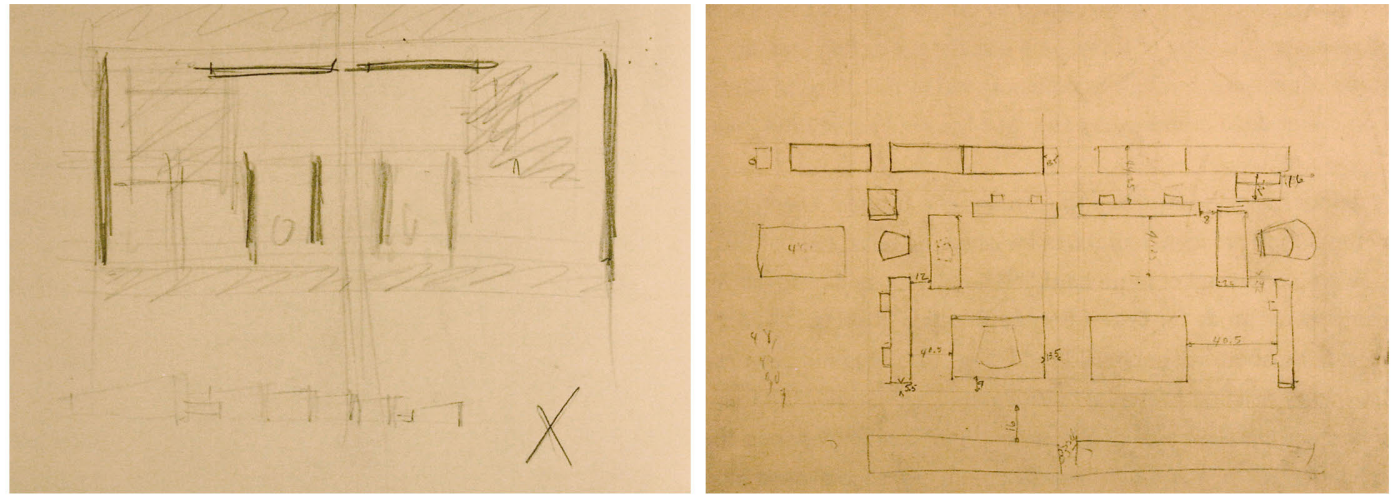

fig. 15
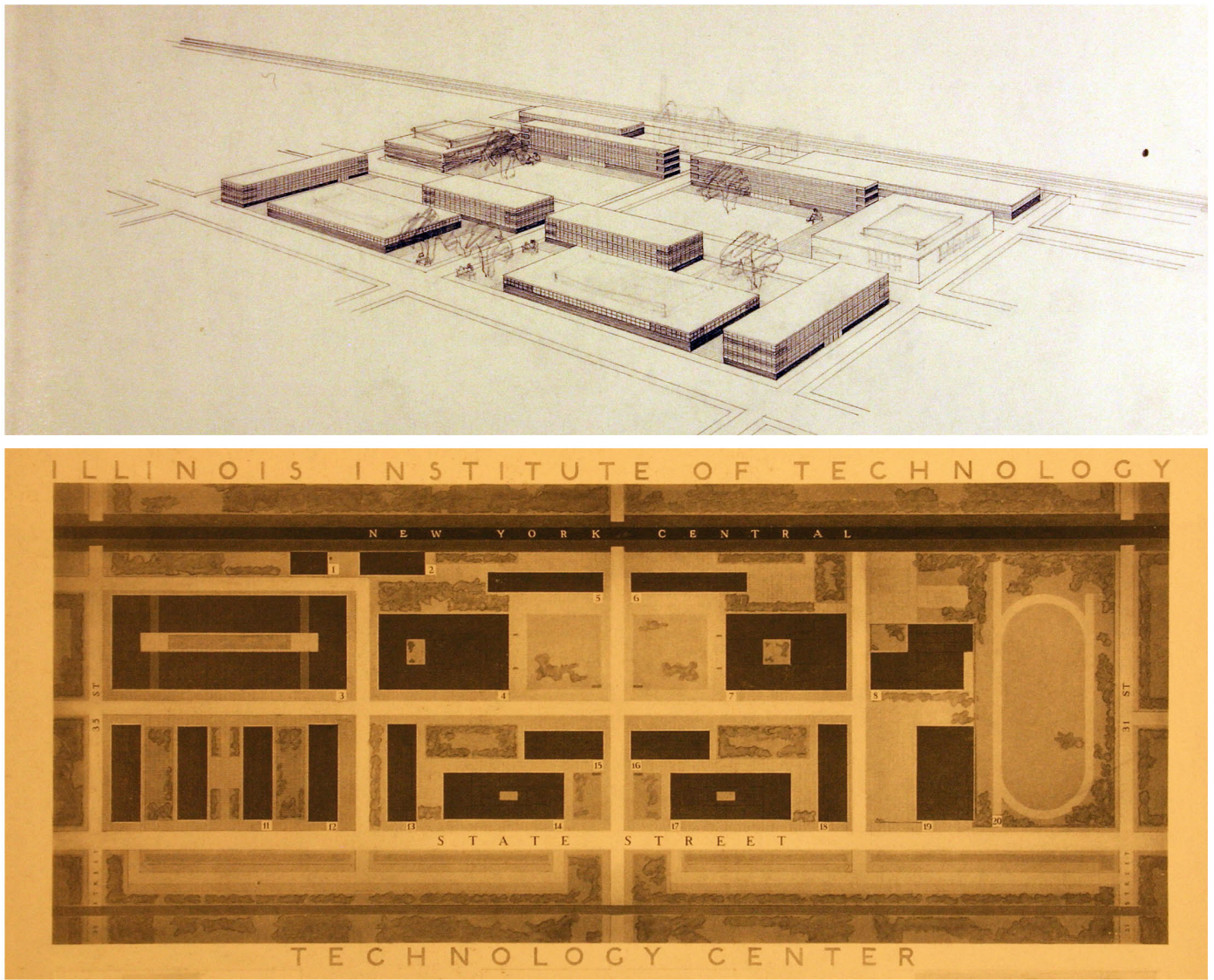

MIES van der ROHE, 1938; ILLINOIS Institue of Technology, Chicago: proceso formal, composición por partes, ordenación en retícula establecida 
la simetría venía proscrita desde los valores promulgados por el racionalismo -apuntada norma compositiva clásica- conjuntamente con criterios antropomórficos, conformaciones ornamentales y declamados modelos históricos. No obstante, su empleo compositivo en ordenaciones volumétricas por refutados maestros racionalistas, queda manifiesto en cualquier previa composición elementalista para el Illinois Institute of Technology, hasta completar la propuesta final, también simétrica (fig. 15).

"Buscando ante todo cubrir las necesidades del fin a que se destina el edificio, tanto en distribución como en cantidad y calidad de los servicios $y$, una vez hallada la planta ideal, buscar con ella la composición de una fachada cuyos entrantes y salientes den la armonía de luz de quehemos hablado". ${ }^{20}$ El discurso racional, no quedaba relegado a la inmediata relación funcional y su traslación semántica. El espacio moderno también reclamaba intenciones.

Parte de la ortodoxia metodológica adoctrinada por los maestros del Movimiento Moderno se cimentaba indagando el límite funcional, planteado en la resolución del proyecto como principal premisa del edificio y resolviéndolo en el mínimo espacio admisible, con las mínimas concesiones. Revisando -entendido aquí por rever- uno de los iconos del Movimiento, el Hospital Antituberculoso de Paimio, conocemos como Aalto profundiza en el estudio de aquello que entiende debería ser ese límite funcional, el elemento programático y generador, la habitación de un hospital. Alcanzado ese mínimo, lo asume y repite tantas veces como necesita

${ }^{20}$ Albert ballesteros, Luís. Op. cit., p. 8 


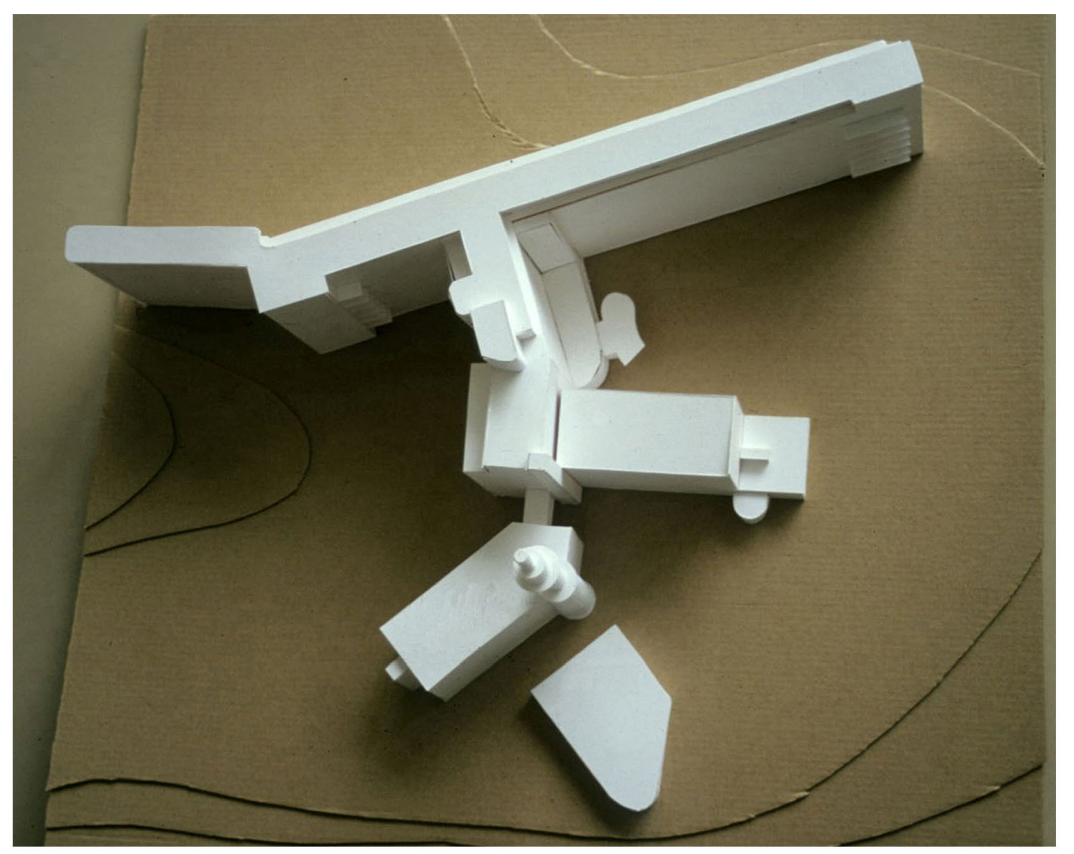

fig. 16

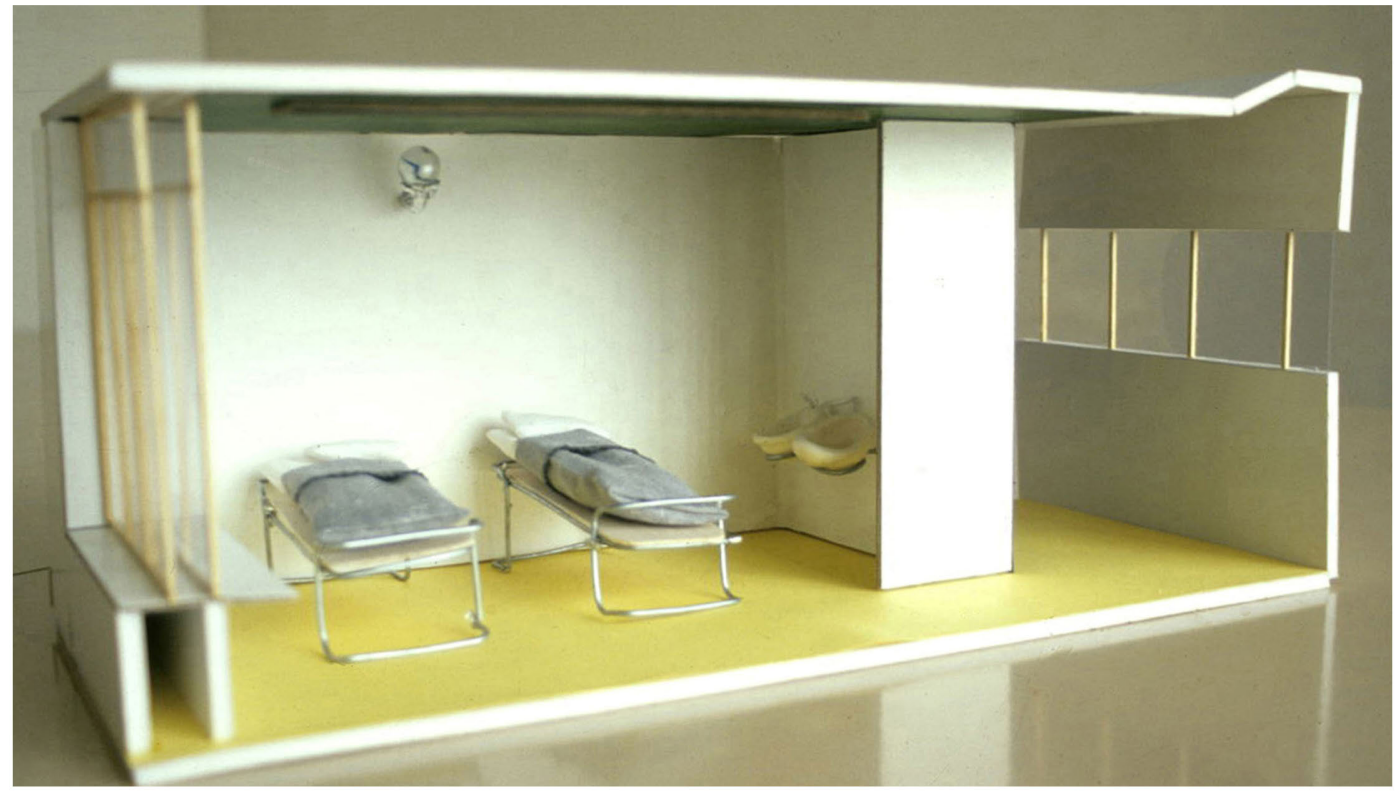

Alvar AALTO, 1928: Hospital Antituberculoso en Paimio, concurso: maqueta doctorando y análisis espacial de la habitación como Mínimo Funcional en la génesis de proyecto 
para concluir el programa. Un espacio reducido a su mínima dimensión, en el que proyectar los elementos imprescindibles desde la estandarización -siguiendo las máximas de Gropius- sin perder la escala humana, concediendo a cada uno sus aspiraciones en espacio, luz, aire, higiene y comodidad $^{21}$. El sistema de ventilación y calefacción oculta, la instalación sanitaria, las dos camas, el mobiliario y el almacenamiento de objetos personales, todo modulado configura el espacio. El límite funcional (fig. 16).

El Dispensario Central Antituberculoso de Barcelona (fig. 17) de Josep Lluís Sert, Josep Torres Clavé y Joan Baptista Subirana -tan referente y válido para nosotros como el Hospital Antituberculoso de Paimio- aplica un mínimo funcional "a las salas de consultas, que se organizan en un pasillo que recorre ambos edificios. La célula tipo la forman dos salas de consulta con su sistema de vestuarios y un cuarto de rayos $X$ compartido".22

Albert no parece inquirir el límite funcional, ni como principio de proyecto, ni como método para ser repetido dependiendo de la función a resolver. Es más una operación integral de usos para ajustar un programa y concluir el espacio. Una operación correcta, llevada con escrupuloso

21 HILBERSEIMER, Ludwig. "No se puede bajar de una cota mínima en el tamaño de una habitación. Ésta, en todos los casos, queda determinada por la finalidad, el número de persona que tenga que albergar y por el mobiliario. En especial, los muebles, estrechamente adaptados a la mediad de hombre, influirán sin ninguna duda en la medidas de los espacios". Op. cit. p. 3

22 MANNINO, Edgardo y PARICIO, Ignacio. "J. LI. Sert: Construcción y Arquitectura". Editorial Gustavo Gili, S.A. Barcelona, 1983 

oficio ${ }^{23}$ en cada uno de los pabellones y por ende al conjunto resultante. "Estudiada la distribución de los pabellones, concibiéndola integralmente en sus múltiples aspectos, de perfecta disposición interior para la mejor ordenación de los diversos departamentos, de muy complejo destino, cristaliza todo ello, en una gran sencillez de conjunto".

Pabellón de Cirugía General

COMPENDIO DE LOS ELEMENTOS A ANALIZAR

Argumentado el conjunto edilicio concebido integralmente en sus múltiples fracciones, surge preciso el análisis individual e indiferenciado como método de alcanzar las conclusiones equivalentes para la totalidad. Indiscriminadamente, es el pabellón de Cirugía el segregado para ser examinado. Simétrico con el pabellón de Medicina General, la distribución de sus plantas es exacta, motivo argumental para que los planos no figuren en el desarrollo planimétrico del proyecto.

23 el métier, que dicen los franceses que es más general que oficio, que aquí tiene un sentido más restrictivo a las artes mecánicas. José Antonio Coderch de Sentmenat. "Conversaciones con J.A. Coderch de Sentmenat". Enric Sòria. Colección de Arquitectura 3. Colegio Oficial de Aparejadores y Arquitectos Técnicos. Librería Yerba. Caja Murcia. Murcia 1997 


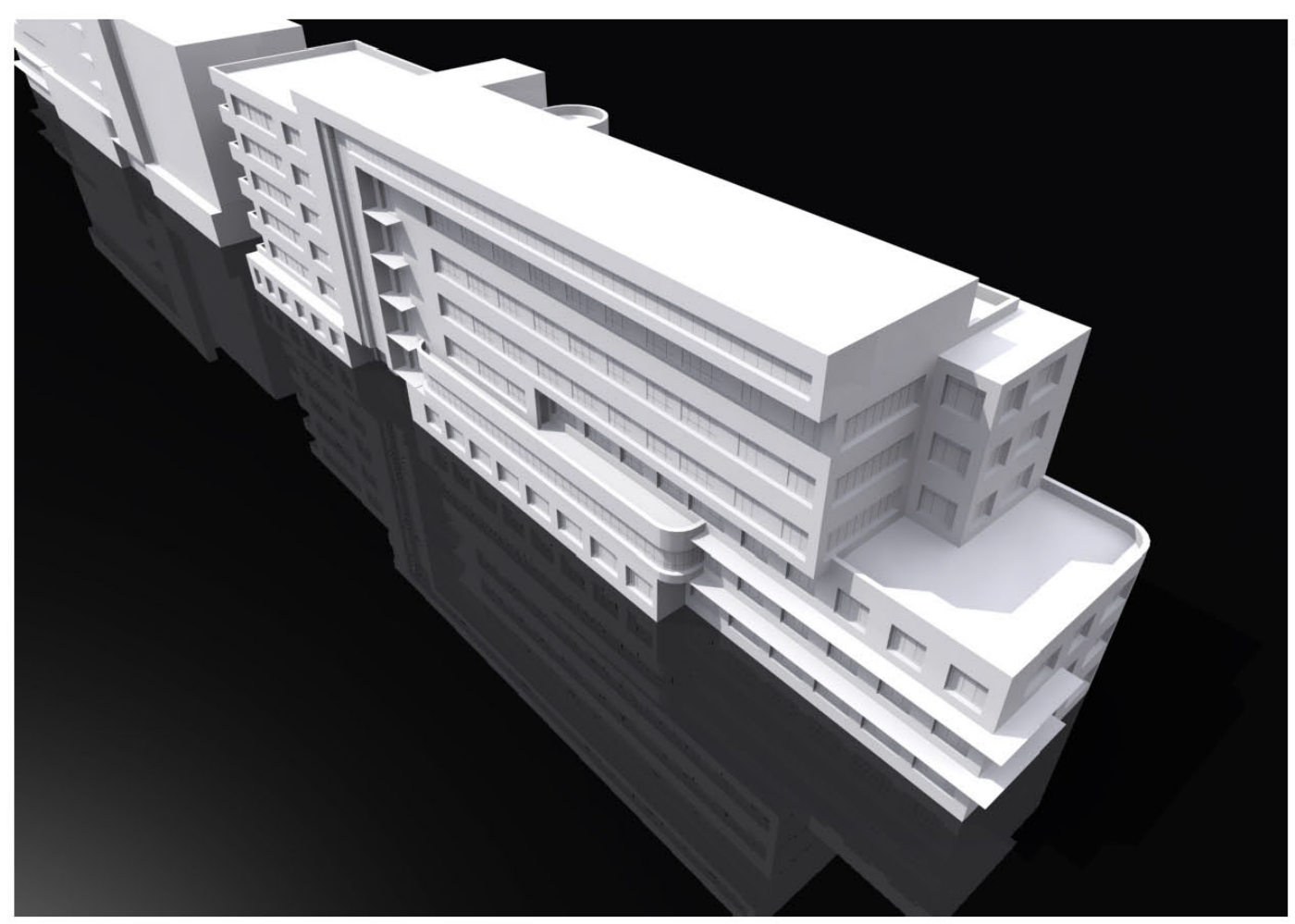

Re-visión de la propuesta de Luis ALBERT a la Diputación, 1935; maqueta infográfica doctorando, del pabellón de Cirugía del Hospital Provincial 
Rever el pabellón de Cirugía -alzarlo figuradamente mediante maqueta virtual (fig. 18)- y su exposición será motivo de este estudio y objeto de consecuencias en su análisis. Colegir de la comparación, acaparando los principios fundacionales del Movimiento Moderno y verificar su concreción a lo largo del planteamiento constructivo formaliza el eje de estudio. L'Esprit Nouveau y los cinco puntos de una arquitectura nueva ${ }^{24}$ infieren parte del análisis. Adolf Loos por la enorme influencia en la inmediata generación de arquitectos, especialmente en Le Corbusier. Las vanguardias europeas surgidas en el albor de la primera gran Guerra, dando paso a una nueva conciencia de la época, a un nuevo arte, contribuyen a la hora de sacar consecuencias. El compromiso de transformación cultural y artística bajo la influencia de la arquitectura. Nombres fundamentales, influyentes. En España el G.A.T.E.P.A.C. y las Escuelas de Arquitectura de Madrid y Barcelona, únicos puntos análogos con la cultura modera.

Presentados los márgenes por donde buscar y concluir, es inmediato marcar los elementos de análisis -en el edificio apartado-de los cuales inferir conclusiones.

La formulación constructiva de la fachada del edificio asoma como punto a proponer desde el ejercicio (fig. 19). La envolvente exterior no portante, compuesta en libertad sin supeditarse estructuralmente, perforada horizontalmente sin límites. Su propuesta conceptual de independizar el cerramiento frente a la ordenadora estructura, y su concreción en la volumetría, presidirán las posteriores intuiciones. La propuesta transcurre

24 BOesiger, W. / GIRSBERGER, H. "Le Corbusier 1910-65". Editorial Gustavo Gili, S.A. Barcelona, 1987. p. 44 


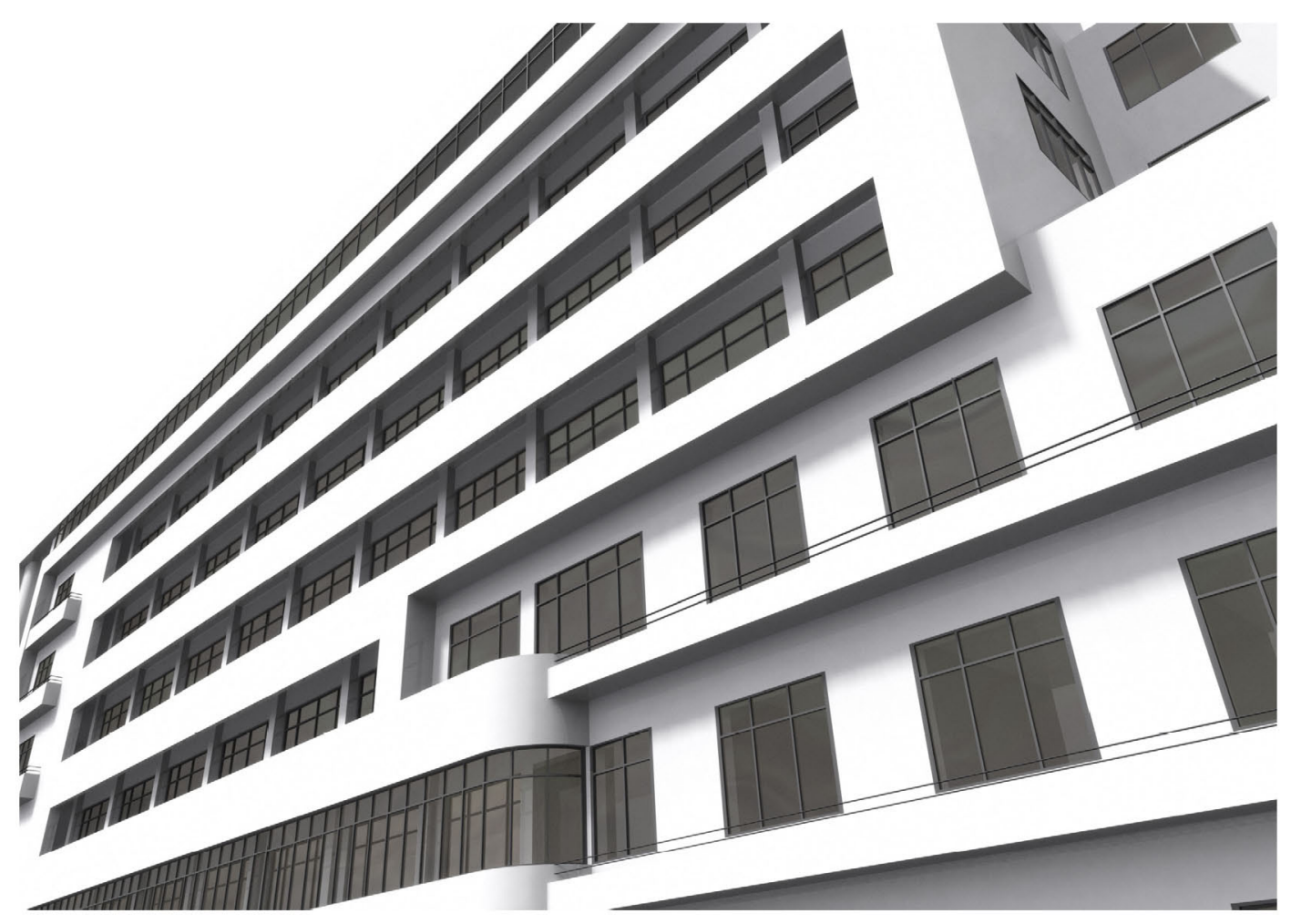

Análisis de la formulación constructiva de la fachada del edificio; detalle de la maqueta infográfica por el doctorando, del pabellón de Cirugía del Hospital Provincial 
entre las premisas conceptuales plasmadas en la memoria descriptiva y la documentación gráfica presente en un proyecto, carente de detalles constructivos. Cabría justificar su ausencia, en el hecho de constituirse como documentación aprobatoria ante la Diputación, sin embargo podría comprobarse práctica habitual -tanto en proyectos ejecutivos presentados ante el Ayuntamiento de Valencia como en la Diputación Provincial- al configurar la documentación que generaba la solicitud de licencia de obra.

La fachada principal (sureste) como receptora de los habitáculos para los enfermos $y$, la fachada posterior (noroeste) que alberga las funciones médicas propiamente dichas, plasmarán aquel principio del Movimiento Moderno de prestar la debida atención a la función ${ }^{25}$. Le Corbusier incorporaría: "Con las materias primas, mediante un programa más o menos utilitario que habéis 'superado', habéis establecido relaciones que me han conmovido. Esto es arquitectura". ${ }^{26}$ Premisa racionalista, metodología analítica y suposición comparativa con el resto de obra ejecutada por Albert en su trayectoria profesional.

El hall de acceso al edificio, el espacio de relación y distribución por cada planta, así como sus conexiones con el núcleo vertical de comunicación y el paso horizontal -cuya disección, señalada, entre usos segrega distintas fachadas-, ultimando el análisis pormenorizado de recorridos internos del edificio.

${ }^{25}$ NORBERG-SCHULZ, Christian. Op. Cit. p.31

${ }^{26}$ LE CORBUSIER. "Hacia una arquitectura". Editorial Poseidón, Buenos Aires, 1965. Título original: "Vers une architecture". pp. 123, 145 y 165 


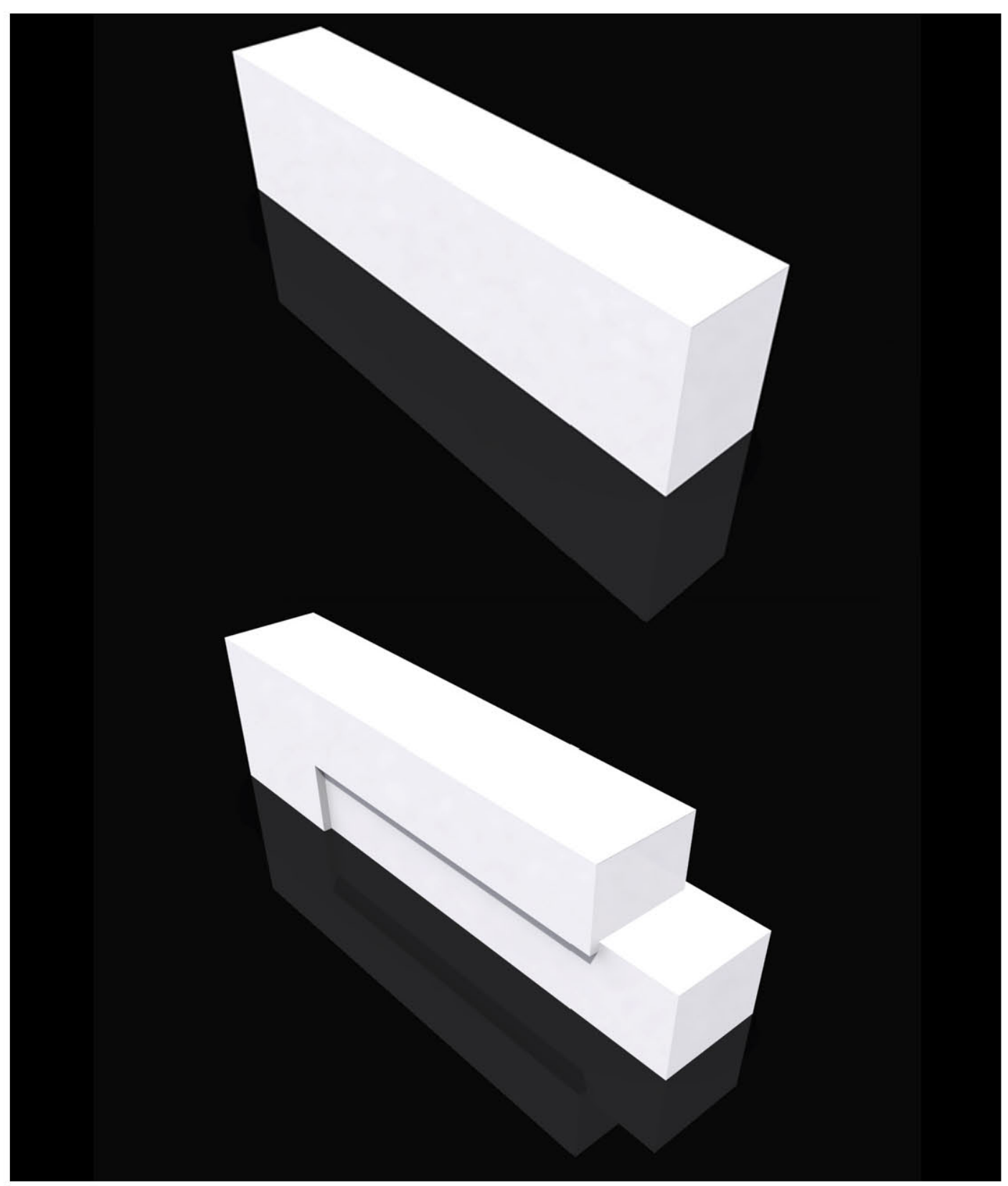

Volumetría virtual pabellón Cirugía General; propuesta doctorando evolución de la forma: dinamismo lineal del prisma básico; primeros pasos: duplicidad y deslizamiento rectilíneo 
El estudio de la cubierta -plana-culminará la envolvente arquitectónica y el proceso analítico del edificio propuesto. Una fachada ignorada, que trasciende constructivamente y, ahora presente en su composición, en la distribución de funciones, dotando de una moderna relación del edificio con el entorno, a una cota hasta aquí manejada sin soltura.

COMPOSICIÓN VOLUMÉTRICA

Tratándose de una pieza evidentemente tan direccional, las variaciones esenciales sufridas por la primigenia y prismática figura longitudinal, las transformaciones volumétricas de la misma, aparecen propuestas en el sentido transversal y también, durante su proceso de crecimiento, su desarrollo en altura.

En un marcado prisma rectangular (fig. 20), recostado en la superficie de mayor dimensión, la evolución de la forma discurre duplicando el prisma y desplazando en altura este segundo. Transversalmente también inicia el movimiento esta trascripción formal, de manera ínfima pero perceptible, y sin embargo tomando evidente consciencia en la dirección longitudinal, deslizándose sobre la primigenia figura y en última instancia alcanzando el terreno en su tramo final. Estos movimientos horizontales, avanzando para provocar la atención, generan transversalmente el acceso 


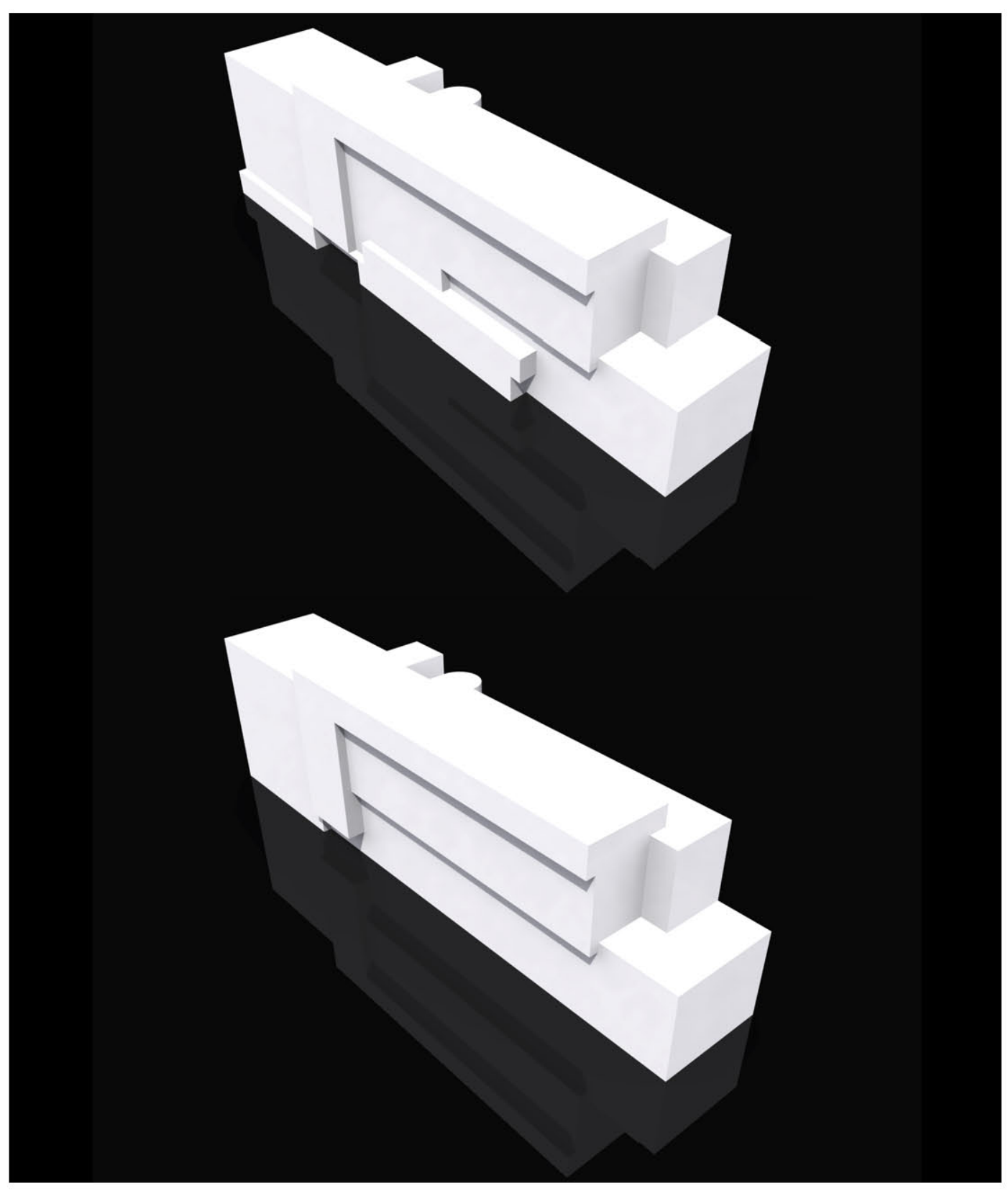

Volumetría virtual pabellón Cirugía General; propuesta doctorando evolución de la forma: transformación volumétrica hasta su composición definitiva 
clásico al edificio, allí donde el único desplazamiento vertical entrega parte del volumen al terreno y provocando, nuevamente, la discordancia de evitar el centro geométrico. "La organización asimétrica adoptada finalmente indica un conflicto entre la lógica circulatoria del trazado simétrico y la predilección clásica por una aproximación axial a la fachada representativa del edificio principal" ${ }^{27}$

El movimiento final redundará ofertando dudas compositivas. Una nueva adición longitudinal inspira la planta de cubierta, retomando el desplazamiento transversal hacia el acceso. Retomar la verticalidad en una propuesta tan horizontal, para generar evidente este acceso, descender en vertical acometiendo puntualmente al terreno e indicando su posición exacta, desvirtúa la yacente, apaisada racionalidad. En una composición tan radicalmente horizontal, esta expresión dubitativa ${ }^{28}$ vertical le resta

27 Disertando sobre el enfoque elementalista del diseño profesado a principios de siglo por Julián Guadet, con el hecho de adoptar este enfoque general al enfrentarse Le Corbusier a grandes conjuntos como en sus estudios preliminares para el proyecto del Palacio de los Soviets, de 1931, y en el proyecto de la Sociedad de Naciones en Ginebra, de 1927.

FRAMPTON, Kenneth. Op. cit. p. 9

28 Dudas compositivas que lo alejan de la ortodoxia racionalista. 'La difusión del racionalismo en Histoire de l'Architecture y la pervivencia de los sistemas académicos con la propagación de la idea de composición elemental transmitida por Julien Guadet en su curso Elements et Théorie de I'Architecture (1902) -donde la decisión estilística era ajena al problema de la disposición de los uelementos de la arquitecturan- facilitó el acercamiento a las corrientes de la modernidad con formalizaciones vacilantes entre el casticismo, el Art Déco, el racionalismo purista, las imágenes expresionistas que colmaban las páginas de Moderne Bauformen, el 'clasicismo moderno' estilizado, la arquitectura de ladrillo de los precursores holandeses como Berlage, o la iconografía practicada por Joseph Hoffman y la Wienner Werkstatte, dispuestas sobre, una base abstracta, ordenada y esencialmente clásica, indiferente a las componentes doctrinales que encierran'. TORRES CUECO, Jorge. "Valencia Moderna. Del eclecticismo a la Tendenza". Revista Arquitectura Viva, número 61, julio - agosto de 1998. 


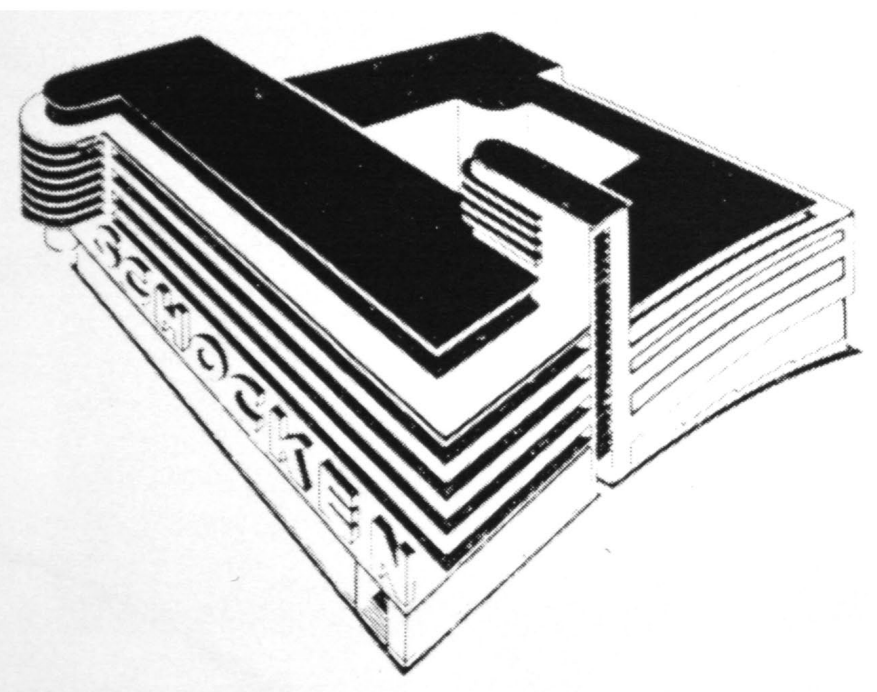

fig. 21

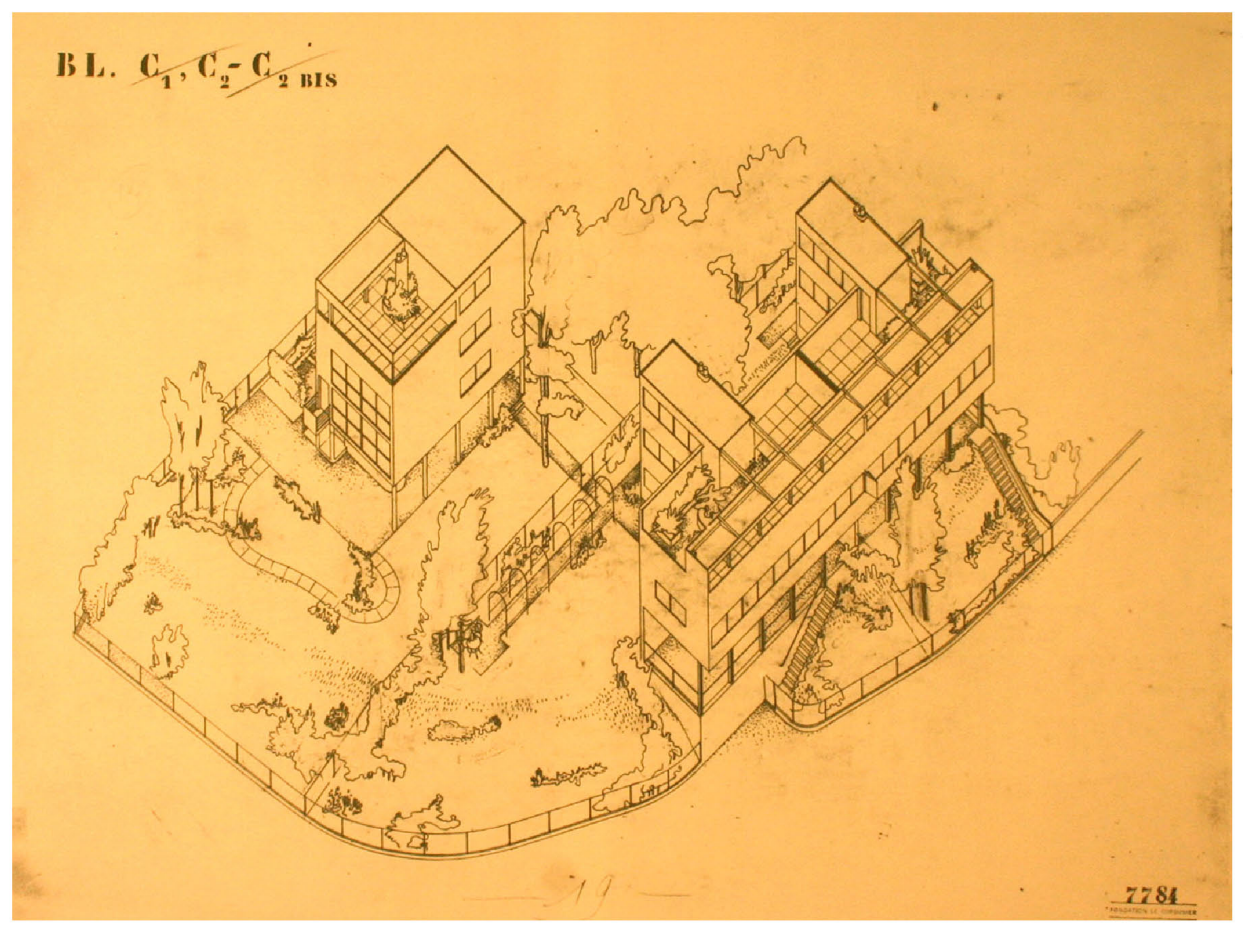

Erich MENDELSOHN, 1926-1928; Almacénes Schocken en stuttgart. Le CORBUSIER, 19251927; inmuebles para la Weissenhofsiedlung, Stuttgart 
potencia a la propuesta, tan dentro de los planteamientos racionalistas.

Podemos citar a Bruno Zevi analizando los Almacenes Schocken en Stuttgart, de Mendelsohn (fig. 21), parafraseando a Schömberg: El término "emancipación de la disonancia" significa que su compresibilidad es equivalente a la de la consonancia. La característica más notable es la de la extraordinaria brevedad de cada una de sus piezas ${ }^{29}$. Frente a la dicotomía del platónico y puro prisma propuesto por Le Corbusier (fig. 22) en las casas Citrohan - serie comenzada en 1920 y cuya última manifestación es construida en la exposición de la Weissenhofsiedlung, en Stuttgart, 1925-1927-expresión del volumen más que de la masa y donde se permite libre la planta, tanto como la distribución del interior, Albert está a menor distancia de la disonancia propugnada por Mendelsohn. Desbordar la fachada bidimensional y procurar dinamismo. Elogio a la disonancia desde la correcta horizontalidad de la fachada, inmaculado prisma, enfrentado a una gestual verticalidad.

Albert se nos presenta más cercano al método mendelshoniano, donde la elegante construcción en voladizo, fijando su posición asimétrica delimita el acceso, desequilibra la fachada y le confiere la tercera dimensión.

\footnotetext{
29 Aquí triunfa la disonancia: por un lado, el bloque del almacén que exalta su horizontalidad a través de las franjas llenas y vacías, con la marquesina y el letrero colocado encima de ella; por el otro, los dos pernos de los semicilindros, uno tonante y prolongado, en la calle inclinada, y el otro que le hace eco, encima de la cubierta, en el lado opuesto". Escribiendo a cerca de los Almacenes Schocken, Stuttgart. $1926 / 1928$.

ZEVI, Bruno. "Eric Mendelsohn". Editorial Gustavo Gili. Estudio Paperback. $2^{a}$ edición, 1986. Barcelona. Versión castellana de Mariuccia Galfetti. Versión original publicada por Zanichelli en 1982.
} 


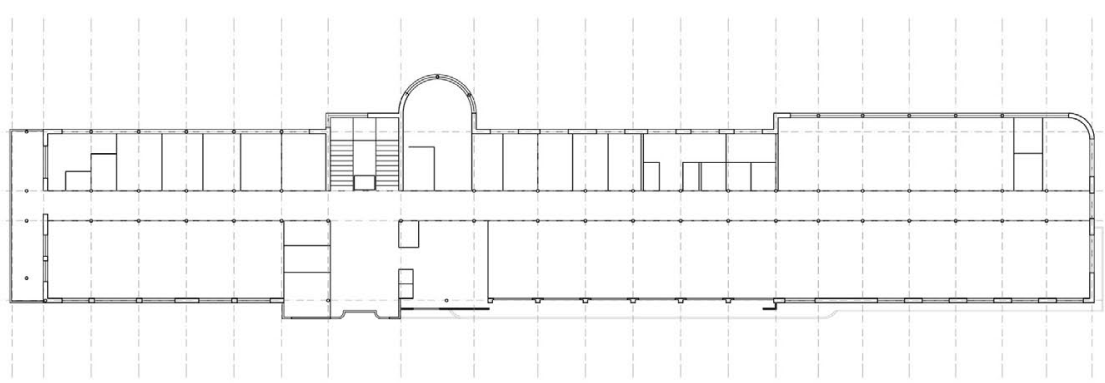

WOTECTO IE HOSIIAL: hoWICLAS

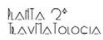

fig. 23

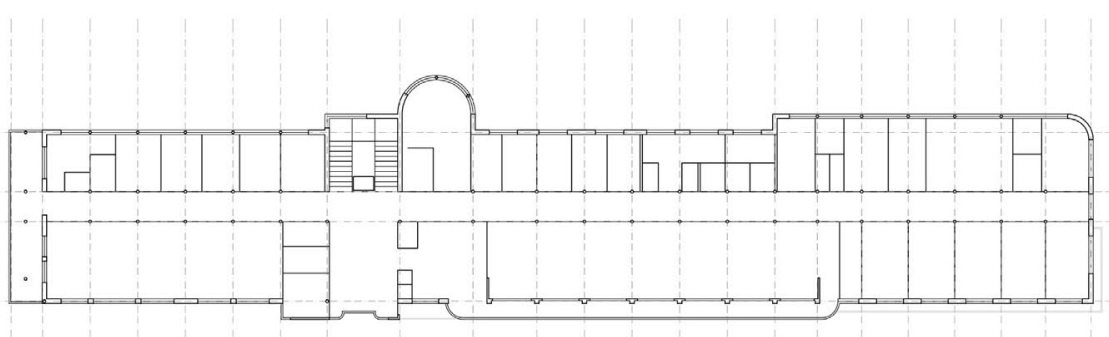

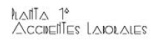
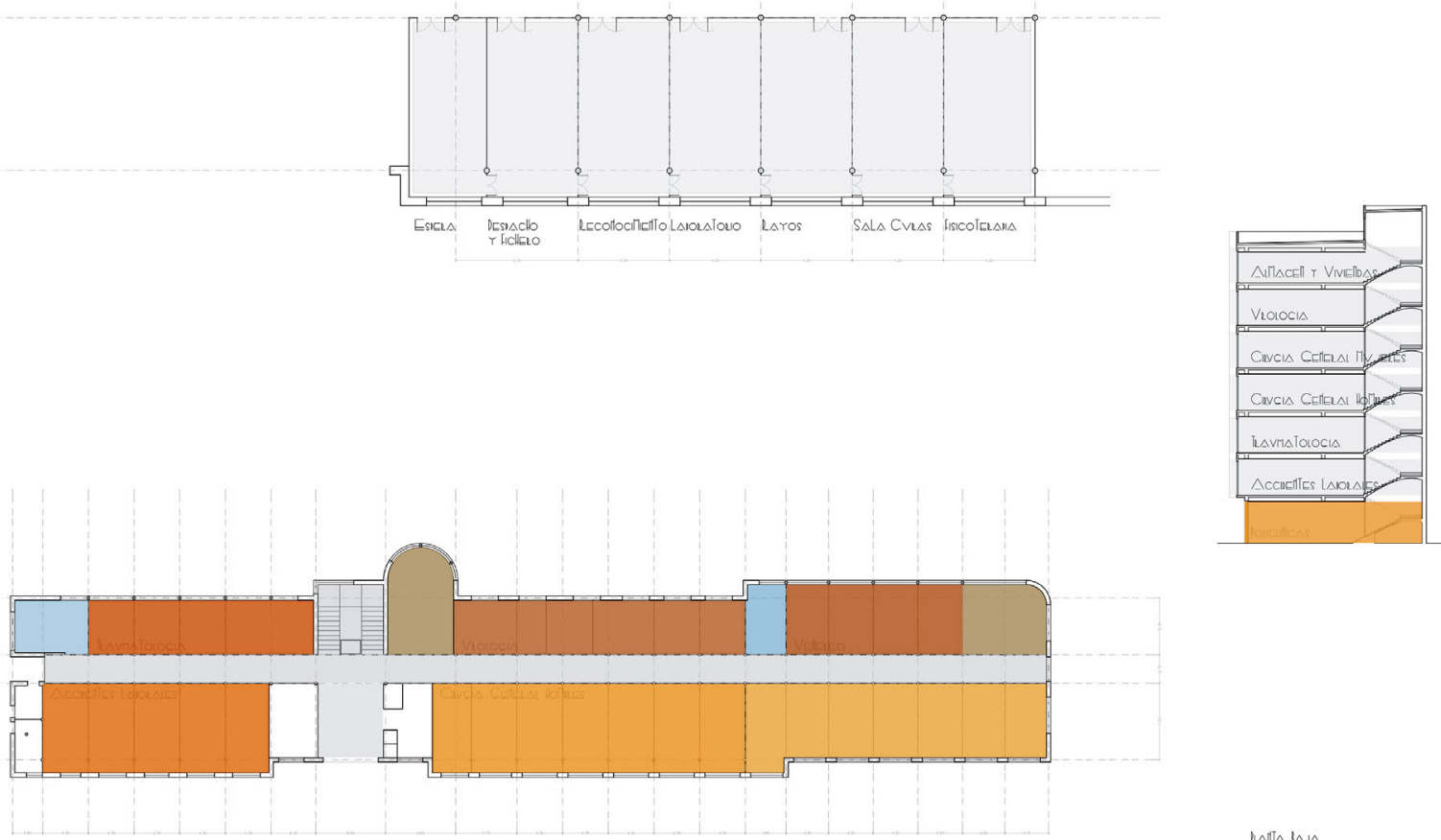

Marian ins

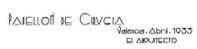

Pabellón de Cirugía, mínimo funcional generatriz de proyecto; organización funcional: Salas de consulta y distribución por plantas, génesis racionalista 
Se emancipa de la consonancia horizontal incluso en el propio vuelo. La libertad que le confiere la estructura a la fachada, permite estos vuelos y también grandes aperturas acristaladas que precisan la visión arquitectónica y facilitan las disputas entre superficies repletas y líneas transparentes. Sin ninguna duda, la visión que Albert pretende de su Arquitectura.

\section{ORGANIZACIÓN FUNCIONAL}

Este pabellón aglutina diversas especialidades clínicas en un mismo edificio, ya enumeradas en el capítulo dedicado al cúmulo y con idéntico subtitulo. En la pieza electa, el límite funcional se esboza en la sección. La sección del edificio abunda en la premisa -que se impone el propio Albert-de sencillez racional, en la ordenación de las diferentes especialidades (fig. 23). En planta baja aparecen una Policlínica por especialidad, la sala de conferencias y la biblioteca. Las plantas superiores confinan su aforo a una especialidad por planta y sus convenientes habitaciones, objetando así, la respuesta requerida por las policlínicas a cota de terreno. Traumatología, Cirugía General de hombres y de mujeres, Accidentes de trabajo, Urología y una sección de Venéreo.

El límite funcional como planteamiento de proyecto, como principio generador que asuma la génesis proyectual, impuesto como premisa, a resolver en el mínimo espacio admisible y con ninguna o escasas concesiones, 


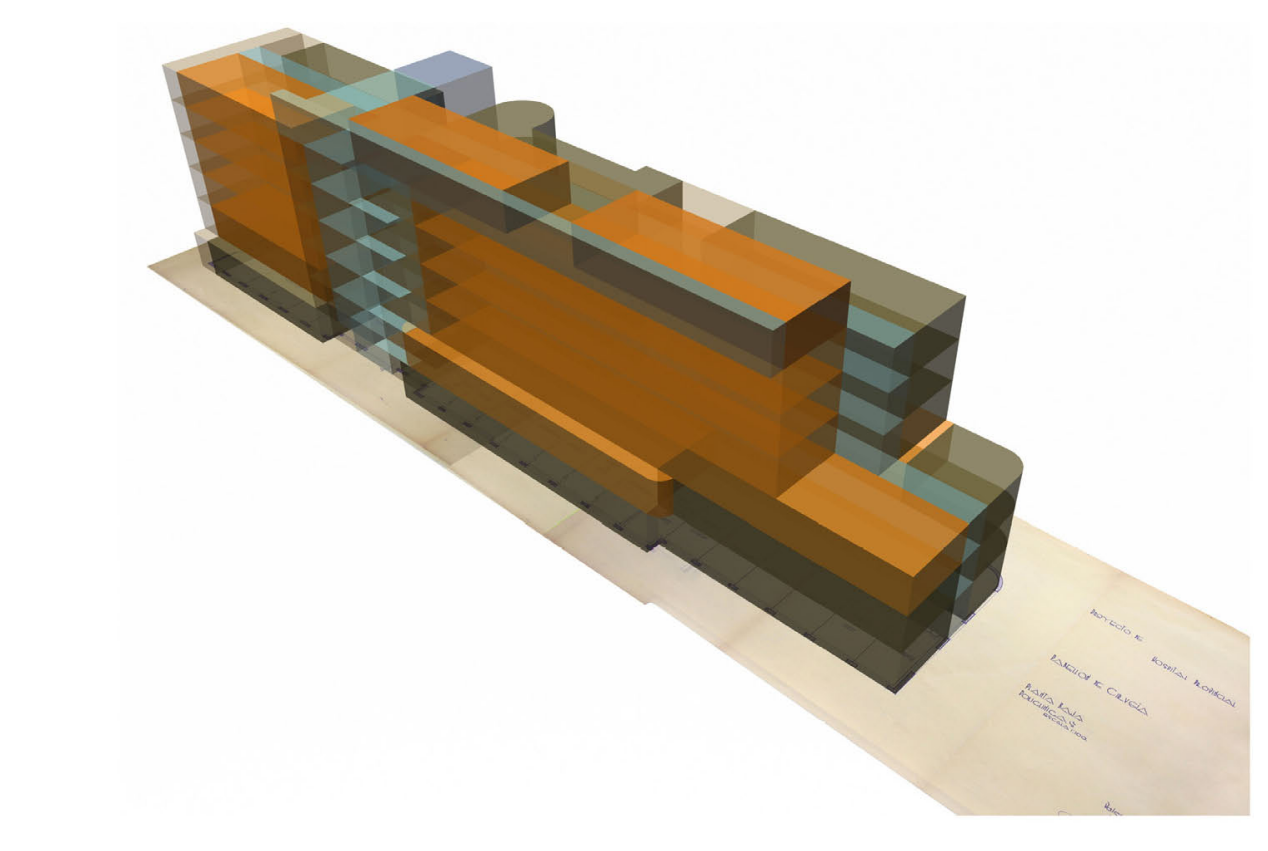

fig. 24
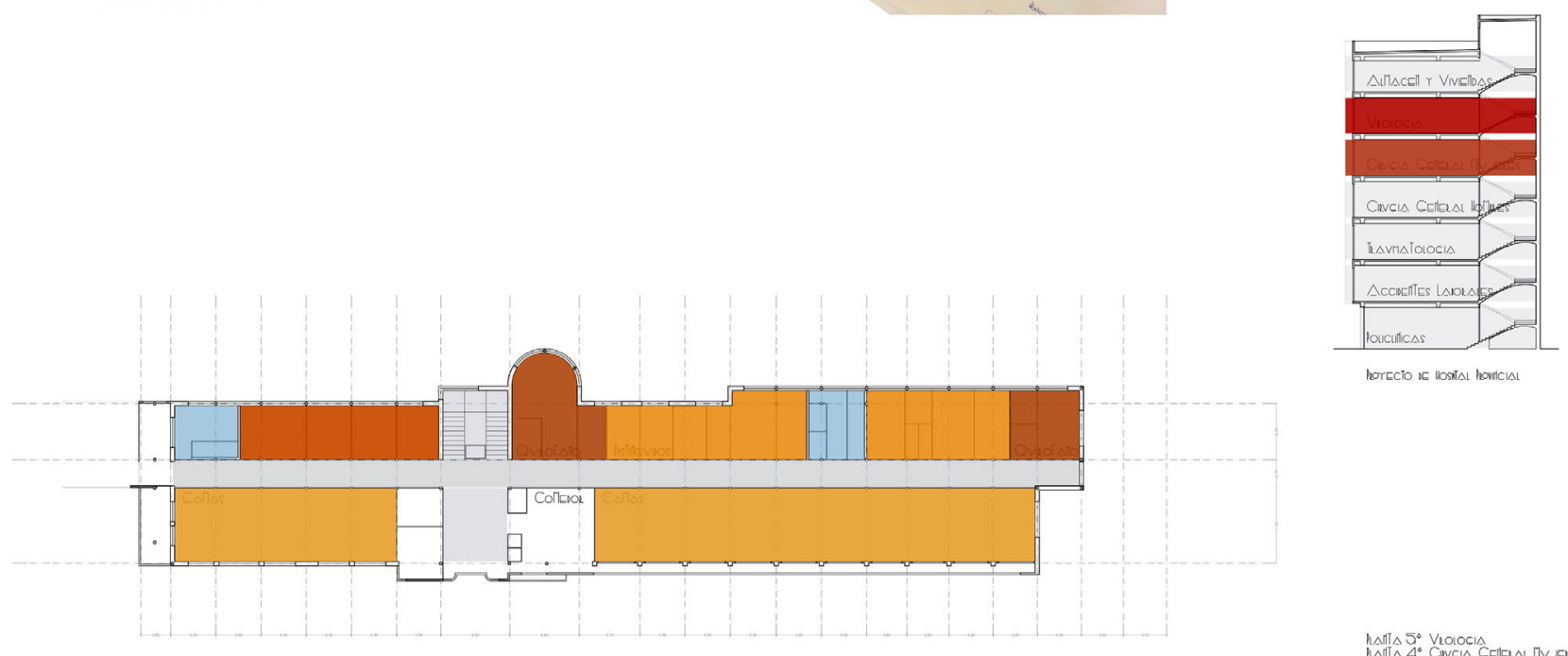

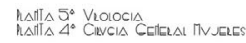

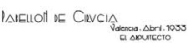

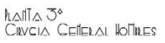

Volumetría infográfica del doctorando, donde observar la funcionalidad del edificio: plantas de Cirugía General; agrupación habitaciones y consultas médicas 
se recluye dentro de los lindes confinados por la sección. Una especialidad a resolver en cada planta. Cada especialidad es el objeto funcional para llevar a estudio y cuya conclusión deberá exportarse a las demás plantas. Trasladar el límite funcional a la distribución en planta, a la resolución del problema de "especialidad", no limitarse a la sección, sería la postura definitiva. Solventada la sistémica en altura, cabría entrar a resolver especialidades, sus requerimientos indispensables, sus relaciones internas, equipamientos y servicios de apoyo. En definitiva, disponer espacios rigurosamente integrados, regularizando dimensiones. Las especialidades se limitan mediante una sala de espera, un despacho médico y su fichero, la sala de reconocimiento, Laboratorio, rayos $X$, cuarto de curas y, Fisioterapia (fig. 24). Pero más que concretarse en una célula mínima, cerrada y exportable a cada especialidad, se distribuyen o se colocan en planta, adaptándose a los diferentes espacios desocupados por las camas y habitaciones de distinguidos, probablemente requeridas desde el programa. Entonces podrían haber sido los núcleos de dormitorios los límites funcionales que ordenaran la propuesta. No obstante, un recinto de enormes dimensiones donde acumular camas, nada tiene que ver con las mínimas dimensiones donde todo se industrializa y se dirige en alas de la función. Nada puede aportar espacialmente al ideario del espacio moderno, a su control volumétrico, lumínico o visual. Tampoco infiere en compromisos, en avances o mejoras sociales y, posiblemente, dificulte toda praxis médica, sus condiciones sanitarias e higiénicas.

No asoma el profuso estudio de Aalto sobre el espacio mínimo para la habitación de Paimio, pero tampoco el minucioso estudio que Sert aplica al módulo de consulta para resolver el Dispensario Central Antituberculoso en Barcelona. Cabría preguntarse si el límite funcional era posible en 


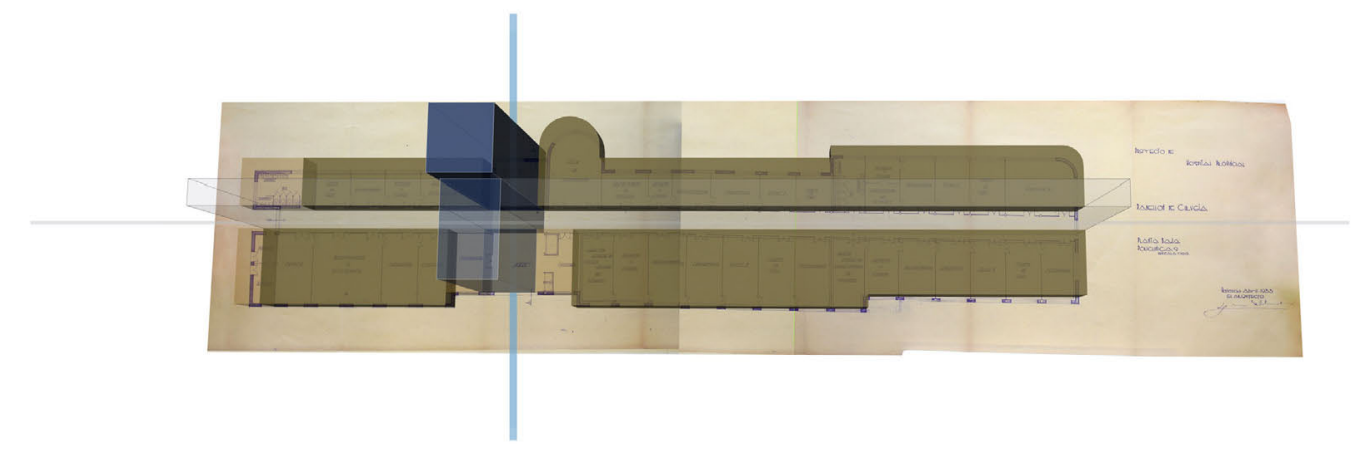

fig. 25
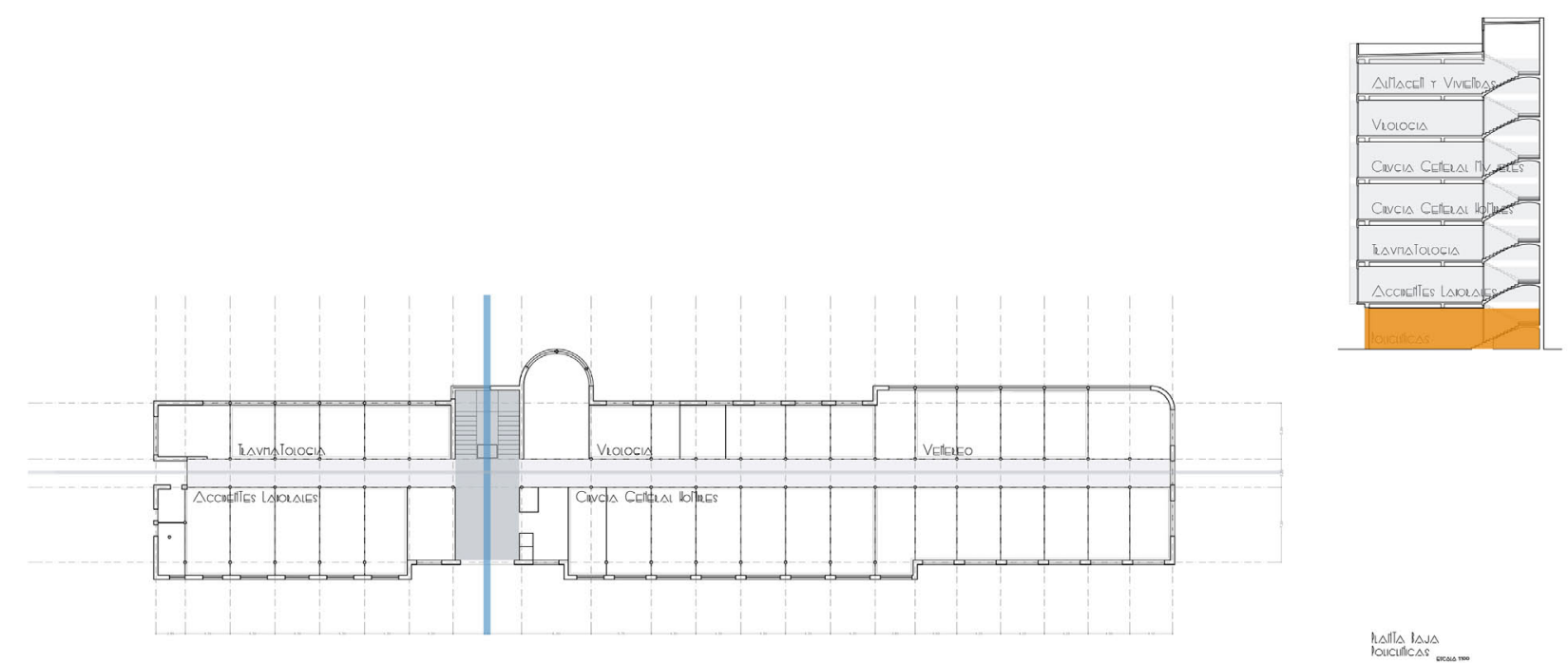

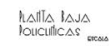

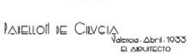

Volumetría infográfica del doctorando para el análisis funcional planta baja Policlínicas: ejes compositivos: principal y transversal; ejes de comunicación horizontales y vertical 
una propuesta tan clasista que proyecta habitaciones de distinguidos, en un edificio donde este uso se disocia y hace tabula rasa del excedente, - más bien este planteamiento invalida los fundamentos sociales de una moderna propuesta arquitectónica.

El esquema se repite por planta, pero no de forma estricta ni rigurosa. Si bien es cierto que la fachada principal siempre alberga el compacto de camas y parte de los dormitorios para distinguidos, las variaciones en función del número de camas necesitadas, provocan ínfimas modificaciones en la distribución de una planta con la inmediatamente superior. Variaciones que afectan, normalmente a la zona destinada a personal interno del hospital. La variación volumétrica también resulta condicionante en la distribución de las especialidades por planta y no lo contrario como evidenciaría la lógica racional. La disminución de superficie en el vértice noreste de la propuesta altera la seriación de las plantas, provocando el deslizamiento, nunca la desaparición, de uno de los dos quirófanos de planta, reduciendo nuevamente el espacio dedicado a personal interno y anulando uno de los dos núcleos húmedos de planta.

Analizando el sistema de comunicaciones horizontales y verticales, asoman evidentes los ejes de jerarquía funcional, bidireccionales, desplazados planimétricamente del centro de gravedad de la composición, huyendo de incurrir en denostadas simetrías. Escasa, aunque evidente, es la variación del eje longitudinal que divide las funciones-dormitorios y médicas- respecto a las fachadas principal y posterior. Desvinculado de la equidistancia, deslizado hacia el noroeste y haciéndose concordar al paso distribuidor, genera espacios a sureste, destinados principalmente a camas, que exceden en dimensión a sus opuestos, diferenciando además 


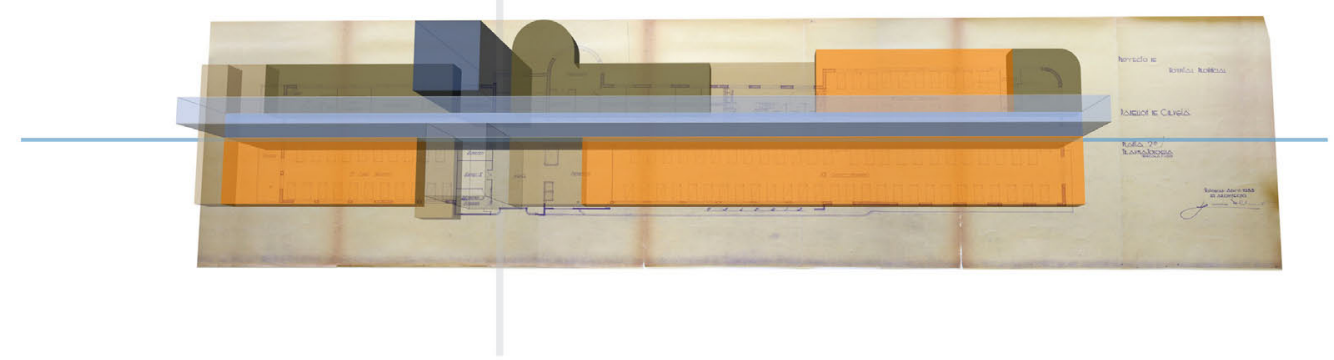

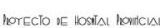

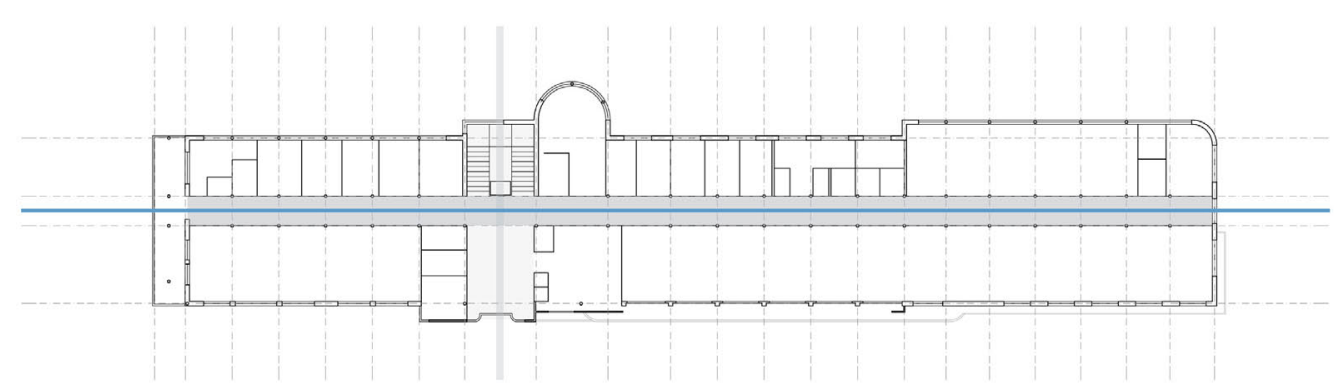

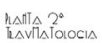
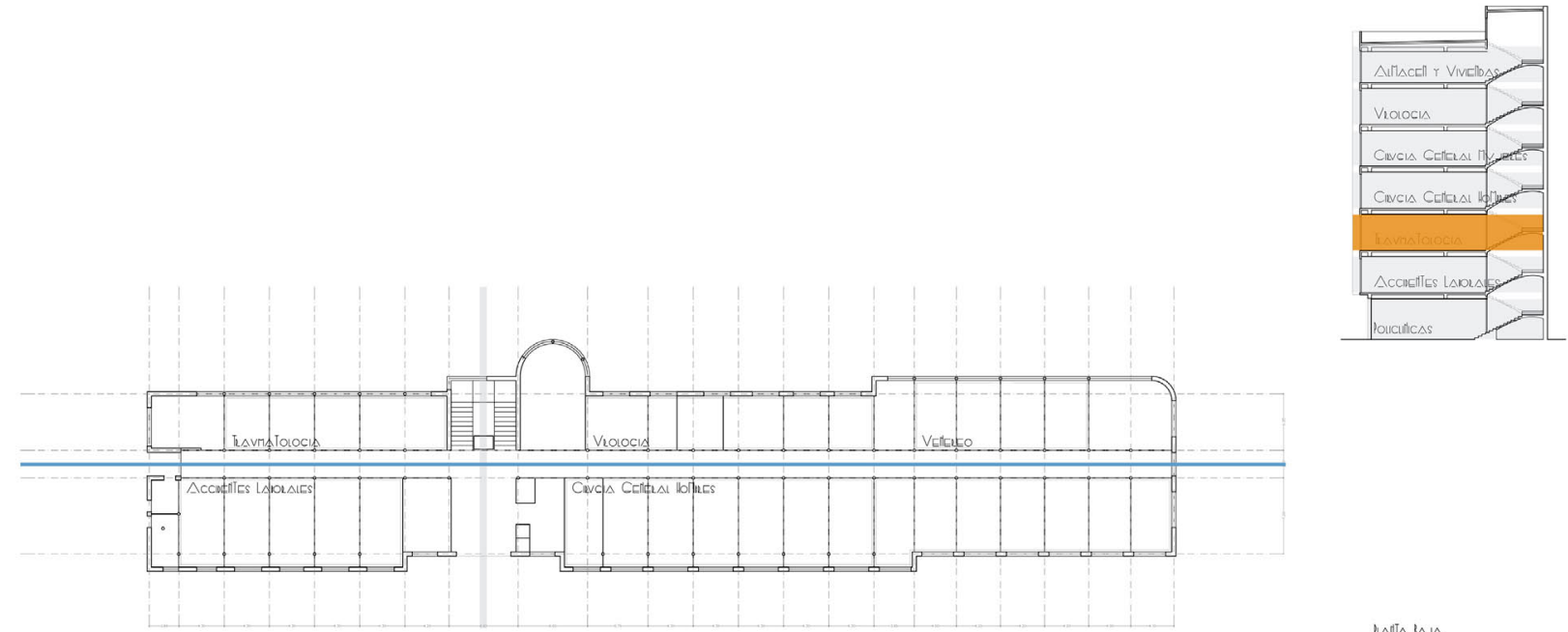
la compartimentación libre de tabiquería y, la ventilación, el soleamiento a través del tratamiento de fachadas. Las estancias contrarias, respecto de este eje longitudinal, quedan relegadas a superficies menores, bastante más compartimentadas albergando especialidades médicas, sus funciones asistentes, aseos y todo con un tratamiento en fachada diferenciado. Surge la excepción, en la numérica necesidad de hospedar camas en esta banda noroeste, concentrándose en su conclusión norte, modificando su ancho y por ende la volumetría, y equiparando dimensión con su ahora simétrico oponente en la fachada principal (fig. 25).

Rinde una variación más significativa, visualmente más acusada, el eje transversal, desplazado claramente del centro geométrico. Fundamentalmente, facilita ubicar el acceso al edificio, alejado del eje simétrico en el alzado, descomponiendo ningún intento clásico formalizador. Tras reflejar verticalmente semejante cometido en fachada -un hall de espera y distribución en cada planta se asomará en este eje-, se erige receptor del sistema de comunicación vertical para toda la propuesta, también recogido en la fachada contraria (fig. 26). Más allá de jerarquizar accesos y comunicaciones verticales, este núcleo trasversal no oferta preponderantes condiciones funcionales.

Queda precedida la escalera por un hall que presenta generosas dimensiones, siendo este quien faculta el acceso al eje de comunicación horizontal-con tres metros de ancho- que recorre toda la planta longitudinalmente. Este paso genera el acceso a dos salas de camas y un núcleo de distinguidos que recaen a la fachada principal de mejor orientación. El acceso posterior lleva a las especialidades, al señalado límite funcional de especialidades, interrumpido, invadido parcialmente por habitaciones, 
fig. 27

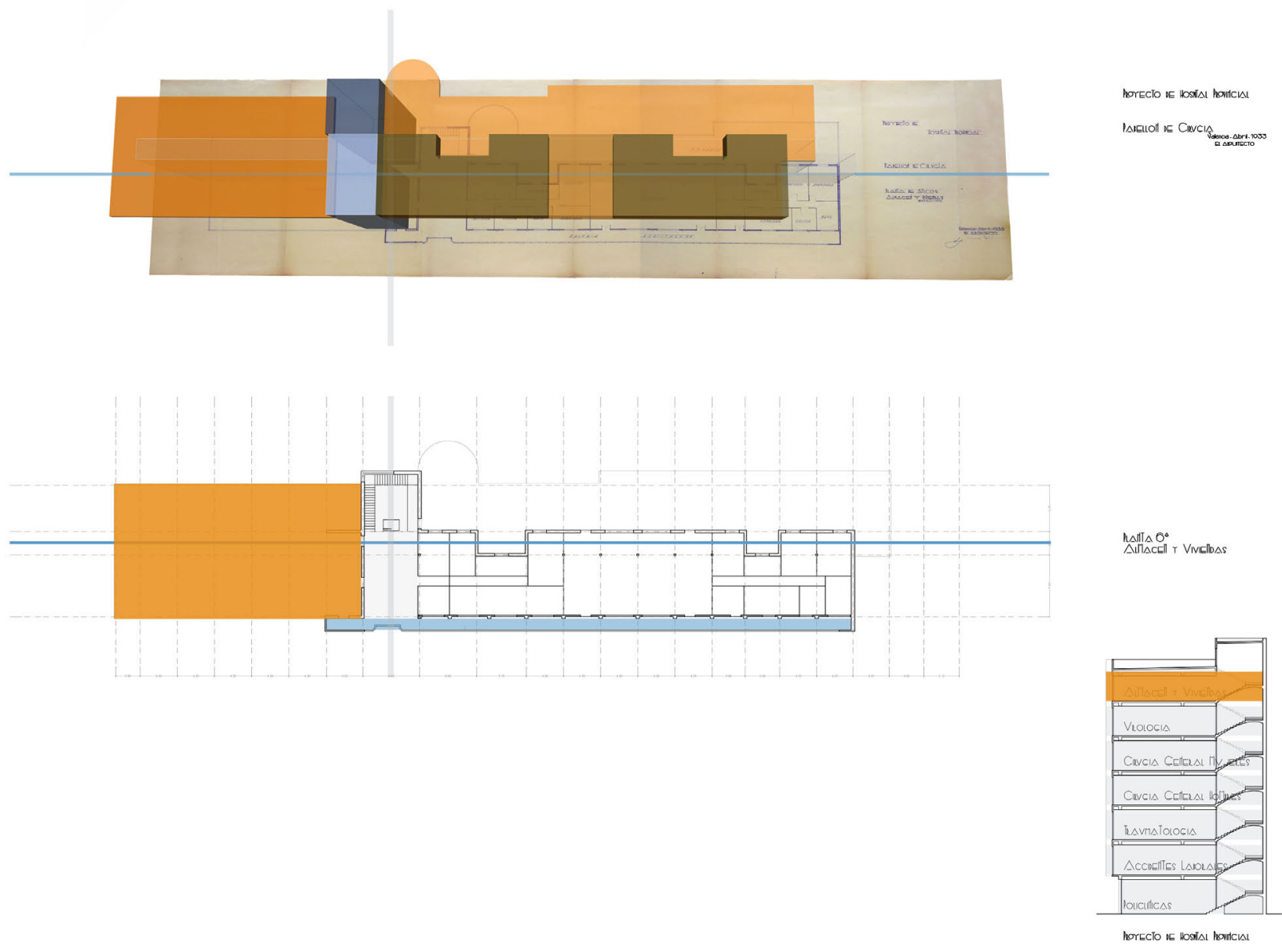

Volumetría infográfica del doctorando para el análisis funcional planta ático, vivienda y almacén; ejes compositivos: principal y transversal; comunicación horizontal y vertical 
allí donde se necesitan.

La cubierta del edificio -si por esta entendemos la planta sexta- es accesible con uso excluyente para vivienda-almacén y, disfrute público como solarium. La cubierta ajardinada, prototipo fundamental del Movimiento Moderno, no aparece como génesis compositiva para esta quinta fachada del edificio. La necesidad funcional por incorporarla a los germinales condicionantes del proyecto, comienza a distanciarse al equiparar jerarquía de usos, en sección. En definitiva, la necesidad demandada por los maestros racionalistas, por atender su proyección como fachada y, dotarla de contenido funcional explícito, categórico, se desvanece o deja serias dudas en su planteamiento. Algo muy dispar y alejado de los ejemplos ya citados de Aalto y Sert -precedentes en el texto que no en el tiempo- del hospital antituberculosos de Paimio y dispensario de Barcelona, donde se proyectan como solarium para los enfermos y jardines "con plantas y toldos" para los médicos ${ }^{30}$, donde presuponen precisas funciones médicas, tan excelentes como la mejor resuelta célula habitacional, el más avanzado núcleo de atención facultativa.

Desvincular el disfrute público de la terraza, disociarlo del tan privativo uso vivienda-almacén, no pasa por compartir el hall que, tras las escaleras, es generado también en esta planta por el eje transversal (fig. 27). Orientar las terrazas en función del soleamiento, en lugar de aprovechar el vacío surgido de las masas que componen la volumetría, habría supuesto impulsar esa quinta fachada racionalista. Generar tan potente visual arquitectónica-llenos y transparencias- con la contundente masa

30 MANNINO, Edgardo y PARICIO, Ignacio. Op. cit., p. 13 


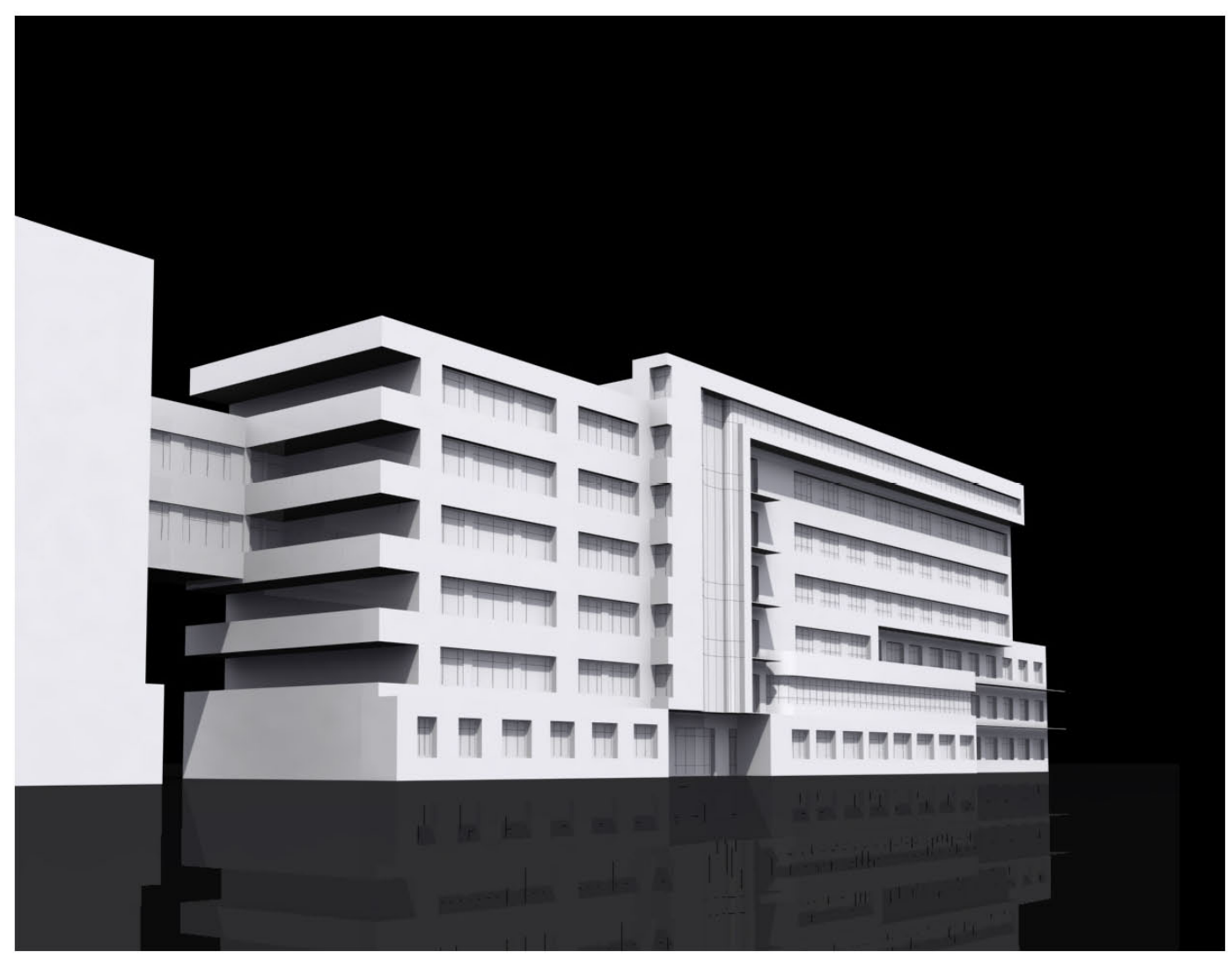

fig. 28 
horizontal volada, aquella contradicha verticalmente hasta llegar al suelo marcando así la entrada (fig. 28), demanda dotarla de contenido explícito, categórica función -debería ser el programa quien exigiera el movimiento compositivo para el volumen- más allá de la simple función distributiva dando paso a almacenes y viviendas.

Resultan planteamientos funcionales convencionales, adeudados en una aprehendida conclusión volumétrica, correctos en lógica distribución de superficies. No obstante, escasos en lo referente a la nueva arquitectura que surgiere liberar la planta, también la de cubiertas y reinventar su contenido, su concepto y disfrute.

\section{LA ESTRUCTURA DE PÓRTICOS METÁlicos}

Explicar una obra inconclusa -proyectada y no construida- suscita el temor de parafrasearla diferente al autor, fundamentalmente por haberla hecho ínfimamente nuestra. El propósito previsto, pasa por devolver la mirada, como método para generar una nueva visión de la arquitectura. Una revisión, un entendimiento activo de la arquitectura, en una época crucial hacia la modernidad cuya teoría reclamaba sobriedad de expresión, a más de un absolutamente nuevo modo de construir, alejado de 

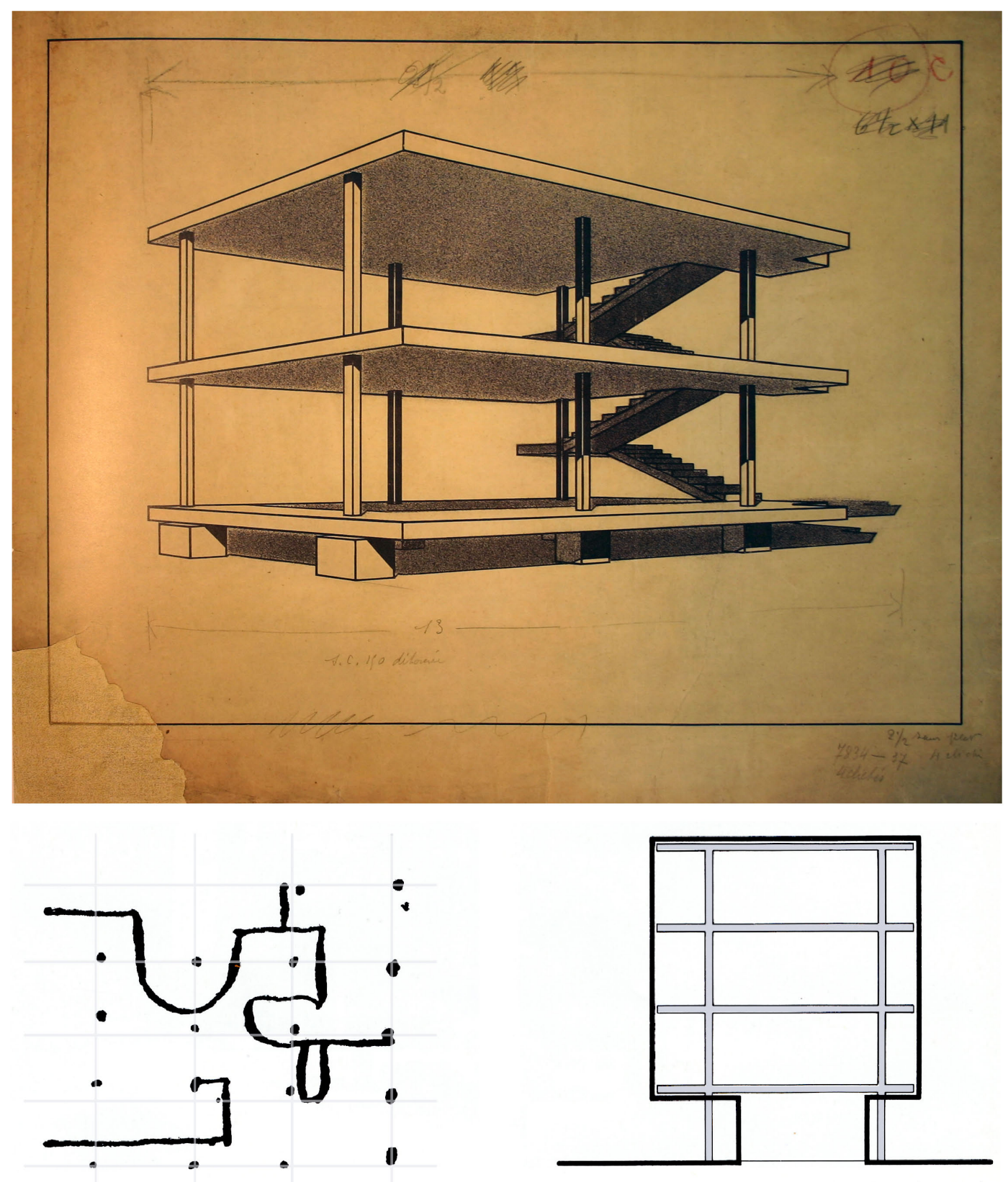

Le CORBUSIER; estructura Dom-ino, 1914; planta libre y fachada independiente de la estructura: Les cinq points d'une architecture nouvelle (1926) 
efectos a la moda. Una constatación de aquellas verdades arquitectónicas.

Analizar la estructura, la distribución en planta desvinculada de funciones resistentes, la fachada libre -'Les cinq points d'une architecture nouvelle' formulados en 1926 por Le Corbusier ${ }^{31}$ - supone devolver la mirada, rever al pabellón inconcluso para Cirugía del Hospital Provincial de Valencia. Su aprehendida independencia, evoca la estructura Dom-ino donde pilares y forjados constituían un sistema prefabricado, independiente de muros y tabiques, convirtiendo el edificio en un prisma abstracto (fig. 29). No obstante, Albert no limitó a hormigón armado su esqueleto estructural. Justificar la elección de una estructura metálica porticada en la Memoria original del proyecto32, quiere indicar la segregación de las partes que llevan el peso del edificio de quienes nada soportan. Hace notar la pretendida racionalidad de la época, la economía y la sinceridad constructiva.

31 'Les cinq points d'une architecture nouvelle'. 1, los pilotis que levantan la masa por encima del terreno; 2 , la planta libre, conseguida mediante la separación de las columnas portantes y las paredes que subdividen el espacio; 3 , la fachada libre, corolario de la planta libre en el plano vertical; 4, la ventana larga, horizontal y corredera o fenetrê en loungeur; 5, la cubierta ajardinada, que supuestamente recupera la superficie del terreno ocupada por la casa.

FRAMPTON, Kenneth. Op. cit., p. 9

32 'Así pues si tratamos de construir hoy un edificio, a más que de cumplir con las necesidades del fin a que se destina, haya de ser económico dentro de su confort, sólido, y a la par bello, habremos de huir de los estilos antiguos que no nos servirían para otra cosa que para disfrazar con imágenes embusteras, los elementos en otros tiempos necesarios, la verdad constructiva de hoy siempre estética si realmente es verdad constructiva, pues que nunca la ficción fue belleza y siempre la vista de la realidad de la construcción, bien combinada en luces y sombras, es armonía de masas'.

ALBERT BALLESTEROS, Luís. Op. cit., p. 8 


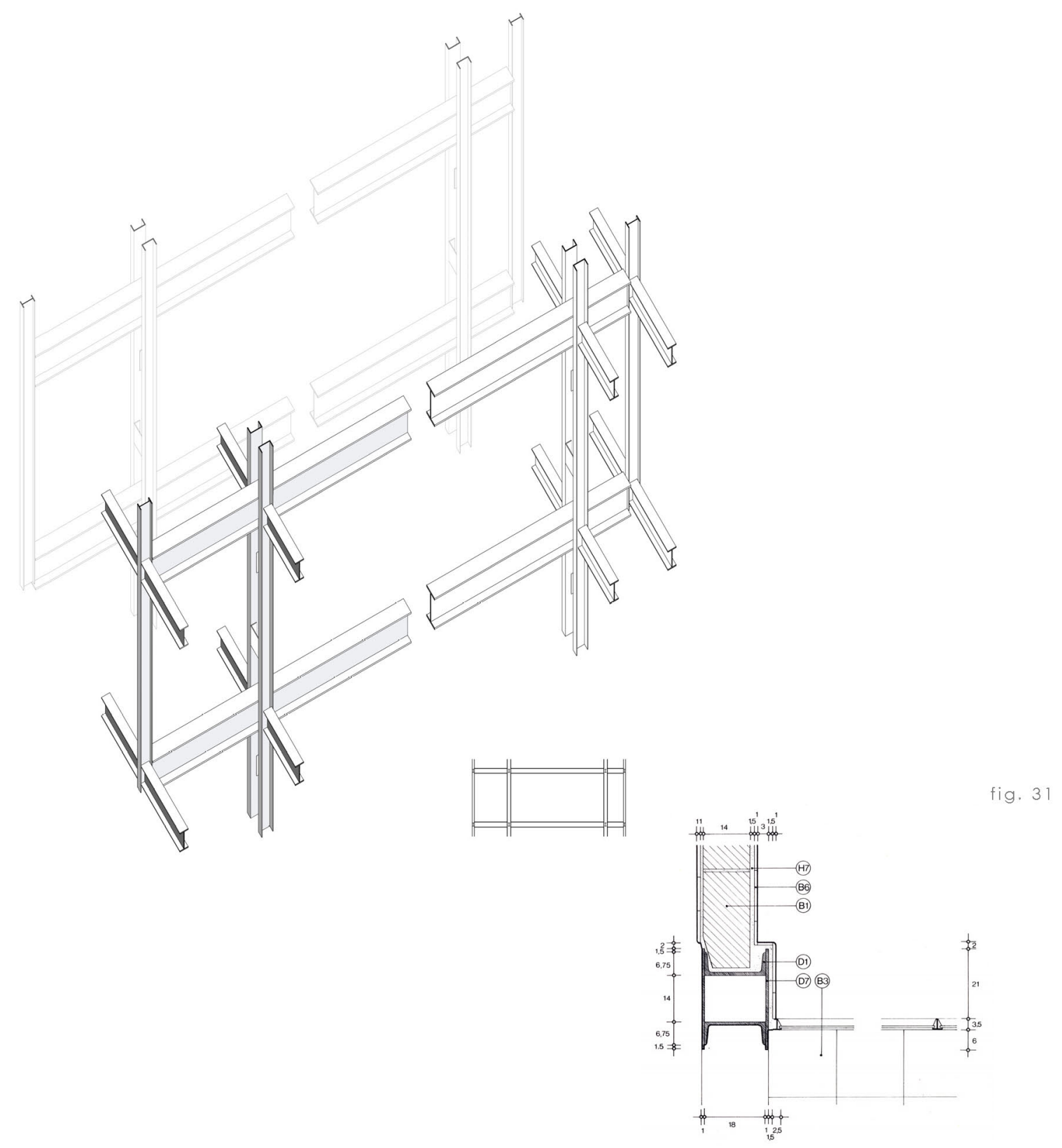

Dispensario Antituberculoso de Barcelona: sistema porticado de perfiles metálicos: detalle perfiles empresillados en U para pilares y doble T para las jácenas 
Los soportes son ordenados mediante una retícula discurrida numéricamente, según distancias determinadas e intencionadas, ausentada la mirada de la disposición funcional (fig. 30). Este entramado metálico, límpidamente organizado, facilita adaptar la distribución en planta a los diferentes usos requeridos desde el programa. Este armazón estandarizado libera espacios, posibilitando considerables superficies exentas de impedimentos sustentantes. Estructura liberada de la planta. También de la fachada, que sobresale del esqueleto. Estructura porticada de acero laminado que facilita la rapidez en el montaje, libera espacio -por su rendimiento, logrado con una menor sección- y posibilita futuras reparaciones, adaptaciones y ampliaciones. El muro de carga no es razonable, ni tiene cabida ${ }^{33}$.

Luís Albert se nos presenta, tras su elección estructural, claro conocedor de los principios racionalistas, de sus planteamientos -abanderados territorialmente por el G.A.T.E.P.A.C.- débilmente amanecidos por Valencia. Con una convicción limitada, proyecta la estructura del Hospital, rozando las referencias formales europeas y las más próximas de arquitectos catalanes. Limitada rotundidad, allí donde los pilares pierden la forma compuesta por perfiles empresillados (fig. 31) tema recurrente en Josep Lluis Sert-, para simplificarse en sección circular. Limitada contundencia en una retícula de puntos organizados, liberando tabiques de cualquier cometido sustentante, hasta que los abraza, con la dificultad que para ello

${ }^{3}$ La revista $\mathbf{A C}$, en su primer número de 1932, ensalza la figura de Mendelsohn por la estructura metálica elegida para encumbrar la Columbus House, y pasa a demonizar el espesor del lienzo murario de la fachada que la cros elevaba en el Paseo de Gracia de Barcelona. 
opone la cerrada circunferencia. Pilares y paredes siempre presentes, pero nunca con presencia categórica, pues el cilindro nunca se desvanece en los elementos distributivos, al contrario, los interrumpe. La planta libre se limita a descargar tabiques de su función portante, mientras que su distribución es encorsetada, contradictoriamente, en la trama estructural. Con dificultad se logra la amplitud requerida por las espaciosas salas, al impedir el libre transcurrir de los elementos de cierre.

Ni claramente exentos, ni embebidos en la planeidad vertical de las fachadas, tampoco se aboga en el plano de cierre por la liberación completa de la fachada. Mientras se la descarga de su función portante para concentrarla, únicamente en su acción aislante del exterior, se le adhiere la estructura parcialmente, con los graves problemas que suscitan materiales de comportamientos tan dispares en la obra construida. Dilataciones y puentes térmicos. Nuevamente dudas compositivas para una solución ya experimentada, aunque todavía relativamente.

Analizando la documentación recabada -planos de proyecto, bocetos previos y definitivos, memoria de proyecto, mediciones y presupuestos, expedientes, reparos, etc.-, sus obras conclusas, y edificios coetáneos, se puede aventurar una estructura, por lo demás carente de detalles constructivos con los que contrastar, en la documentación gráfica que generaba cualquier proyecto. Las jácenas se intuyen como perfiles en doble T dificultando su continuidad al entregarse a los pilares circulares, planteando la decisión de forzar esta continuidad de los elementos horizontales y verticales de sustentación mediante complejos capiteles. En cualquier caso una solución menos limpia y escasamente ensayada hasta ese momento. Una solución en la que para garantizar la estabilidad frente a 


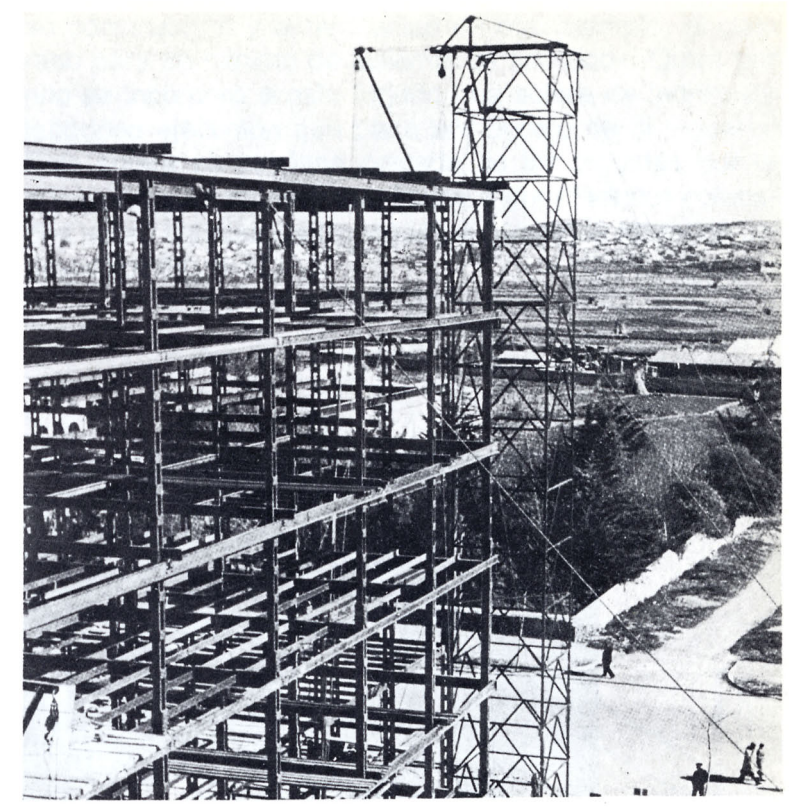

fig. 32

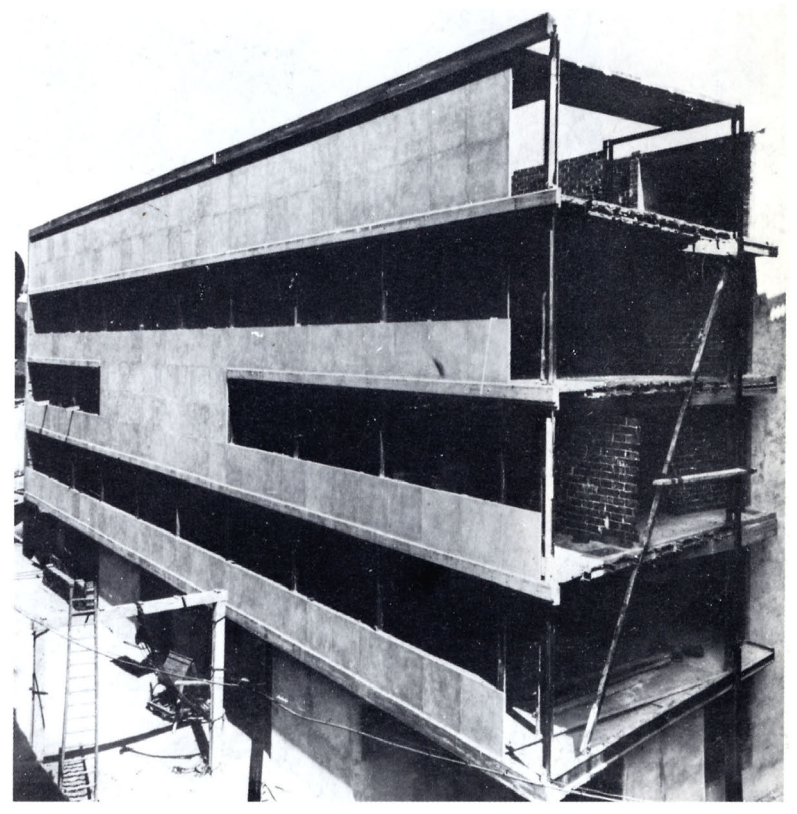

Estructura casa Bloc, Barcelona 1932, G.A.T.C.P.A.C. Dispensario Central Antituberculoso, estructura y cerramiento durante su construcción; imágenes Mannino/Paricio, 1983 
esfuerzos horizontales es necesario bien rigidizar los nudos, bien recurrir a pantallas o elementos de gran rigidez confiados en medianeras o núcleos de comunicación vertical. La rigidización de los nudos viga - pilar era complicado en aquel momento, pues la única solución constructiva pasaba por resolverse mediante tornillería. El roblonado se ejecutaba en taller -rara vez se ejecutaba en obra-y la soldadura no despuntó hasta la década de los sesenta.

El forjado se plantea empotrando riostras y viguetas metálicas con perfiles en doble T, menores que las precedentes, y completa su planeidad mediante hormigón armado sobre bovedillas. Los voladizos se aventuran prolongando las jácenas, atadas por riostras que soportarán la carga del cerramiento exterior, cosidas verticalmente por un tensor, un perfil coincidente con la prolongación paralela de los pilares en el vuelo, Rigidización vertical del plano de cierre supuesta, aunque poco probable en esta obra.

Toda una proposición estructural compleja, teniendo en cuenta la nada esmerada puesta en obra -habitual para la época- de este tipo de detalles constructivos en estructura metálica. La falta de descripción gráfica, compensada con una exhaustiva dirección de obra, dejaba huecos que agrandaba la ineficacia técnica mostrada por la escasamente cualificada mano de obra.

Toda una proposición arriesgada, relativamente cercana a posturas de la ortodoxia racionalista, que en España venían representadas entonces por autores enraizados en Barcelona (fig. 32). Estructuras habituales en obras emblemáticas del G.A.T.C.P.A.C. 


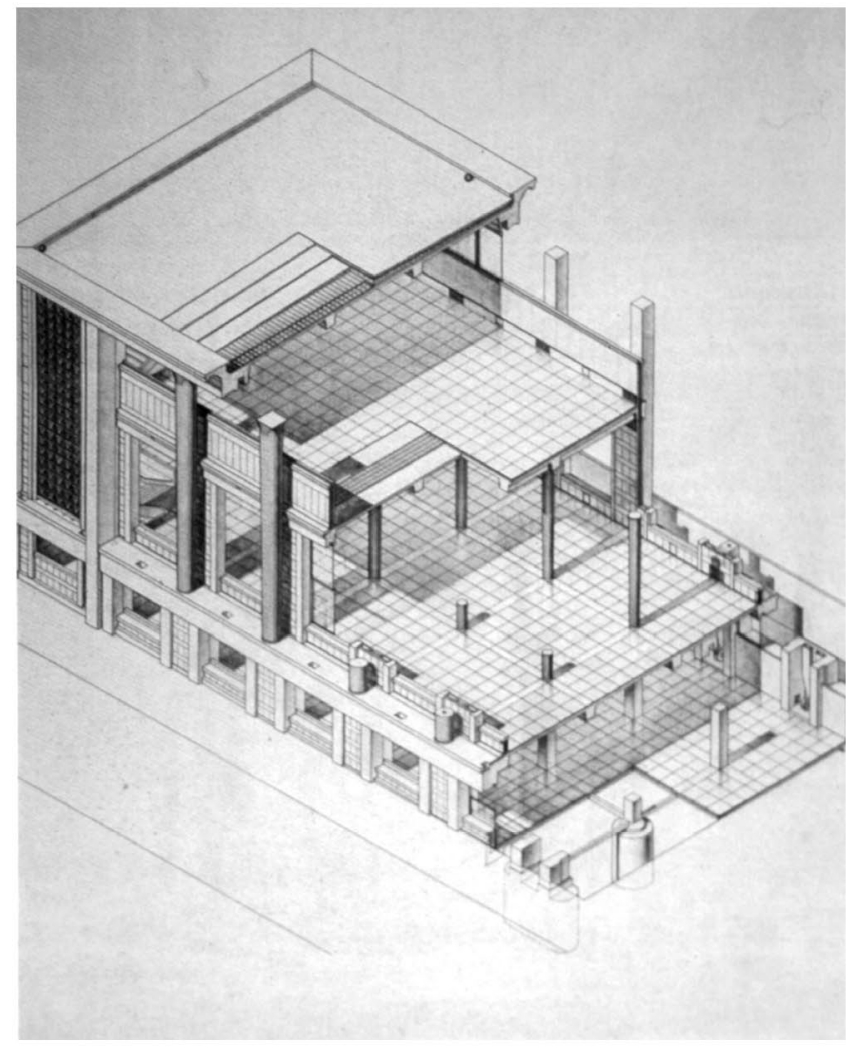

fig. 33 
Un buen ejemplo podría ser el Dispensario Central Antituberculoso del distrito $\vee$ de Barcelona, y sus publicados ${ }^{34}$ detalles de la construcción. Exactamente coetáneos, permiten una comparación entre propuestas.

\section{LAS FACHADAS}

Uno de los postulados fundamentales racionalistas, pasaba por independizar los cerramientos exteriores de la estructura portante del edificio. Separar partes sustentantes y partes únicamente de cerramiento, esto es sustentadas, como ya materializó Auguste Perret, en 1903, en su casa de alquiler de la rue Franklin en París. No obstante, Perret asumía los principios académicos del racionalismo estructural, manteniendo la estructura legible en fachada (fig.33). A diferencia de Perret, Le Corbusier descargaría la fachada de su condición portante, pero haciéndole perder su memoria tectónica. Esto suponía facilitar la composición en libertad, sin supeditarse a los rígidos condicionantes que imponía la estructura, así como la capacidad ilimitada de perforaciones horizontales -llevando a coser huecos hasta la rasgadura corrida- en un desmaterializado muro, convirtiendo edificios en abstractos volúmenes.

${ }^{34}$ MANNINO, Edgardo y PARICIO, Ignacio. Op. cit., pág. 13 


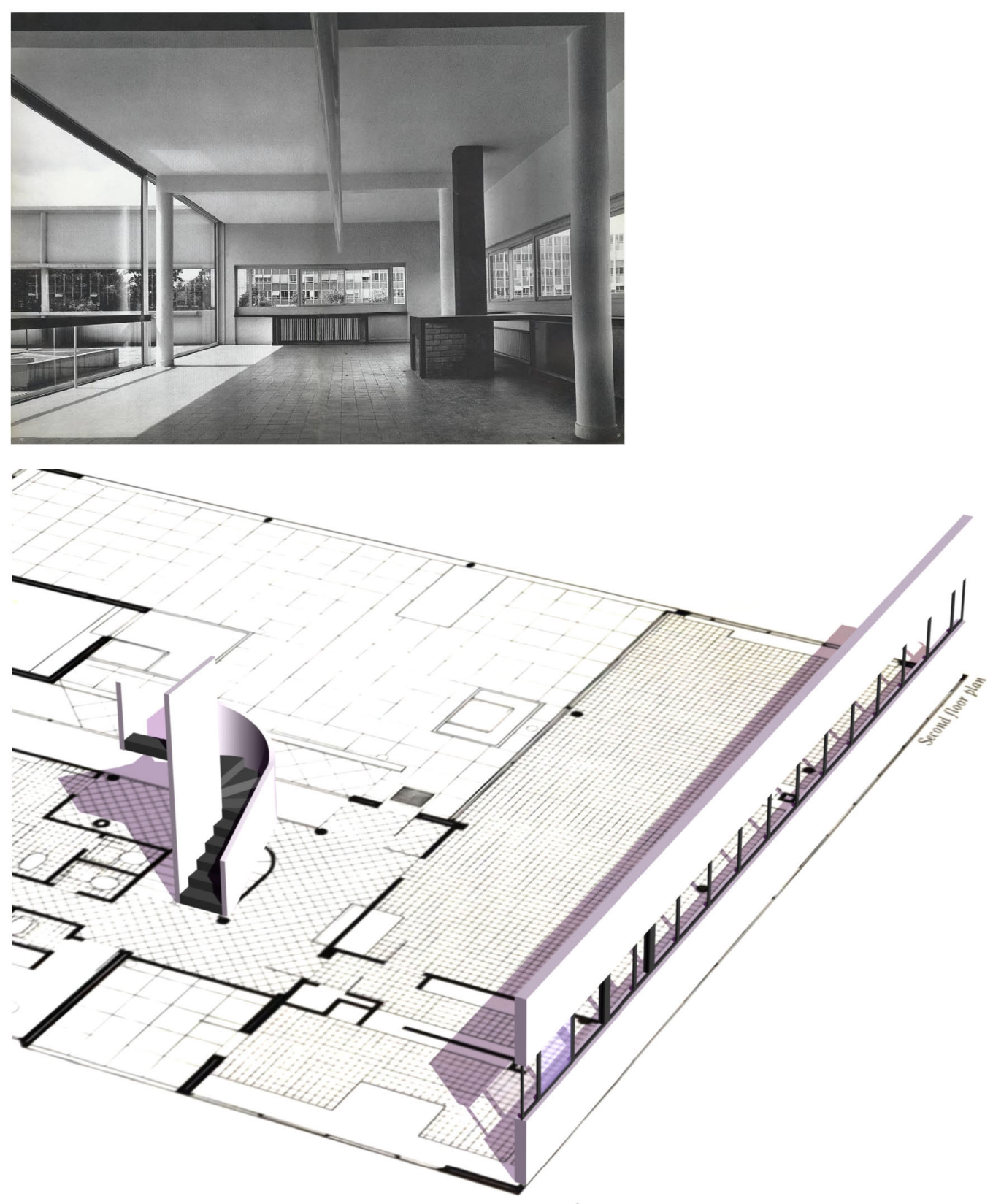

fig. 34

Le CORBUSIER, 1929; Villa Savoie, Poissy. Imagen virtual y montaje fotográfico del doctorando: planta libre, ventana corrida y fachada independiente del sistema estructural 
La planeidad de las fachadas, lograda mediante un esfuerzo resolutivo de coplanaridad, generaba la pureza volumétrica anhelada desde proyecto. "La arquitectura es el juego sabio, correcto y magnífico de los volúmenes reunidos bajo la luz. (...) Como la arquitectura es el juego sabio, correcto y magnífico de los volúmenes reunidos bajo la luz, el arquitecto tiene por misión dar vida a las superficies que envuelven esos volúmenes, sin que estos se conviertan en parásitos, devoren el volumen y lo absorban en su beneficio". Le Corbusier ${ }^{35}$ negaba el plano agujereado por puertas y ventanas, por destructores de la forma. La tensión entre el interior libre y su correspondiente exterior "límpido" en la obra de Le Corbusier, durante la década de 1920, alcanzó su punto culminante con la villa Savoye (fig. 34), en Poissy. Dentro de la pureza geométrica del cubo de cerramiento, el interior permanecía libre y asimétrico, y obedeciendo a su propia lógica dinámica. Pero el muro que separaba los dos mundos, interior y exterior, resultaba tan sólo una fina membrana en la que se había recortado una ventana corrida horizontal. Al ocupante,

\footnotetext{
35 Tres advertencias a los señores arquitectos. I. El Volumen. 'Nuestros ojos están hechos para ver las formas bajo la luz. Las formas primarias son las más bellas puesto que se leen con claridad. Los arquitectos de hoy ya no realizan las formas simples. Guiándose por el cálculo, los ingenieros utilizan las formas geométricas, satisfacen nuestros ojos mediante la geometría y nuestro espíritu mediante la matemática.; sus obras marchan por el camino del gran arte'.

Tres advertencias a los señores arquitectos. II. La Superficie. 'Un volumen está envuelto por una superficie, una superficie que está dividida según las directrices y generatrices del volumen, que acusan la individualidad de ese volumen. Hoy los arquitectos temen los constituyentes geométricos de las superficies. Los grandes problemas de la construcción moderna tienen que ser solucionados mediante la geometría. Sometidos a las estrictas obligaciones de un programa imperativo, los ingenieros emplean las generatrices y las acusatrices de las formas. Crean realidades plásticas, límpidas e impresionantes'.

Le Corbusier. "Hacia una arquitectura".Título original: "Vers une architecture". 1930. Primera reimpresión: septiembre de 1998. Ediciones Apóstrofe, S.L. Traducción de Josefina Martínez Alinari.
} 


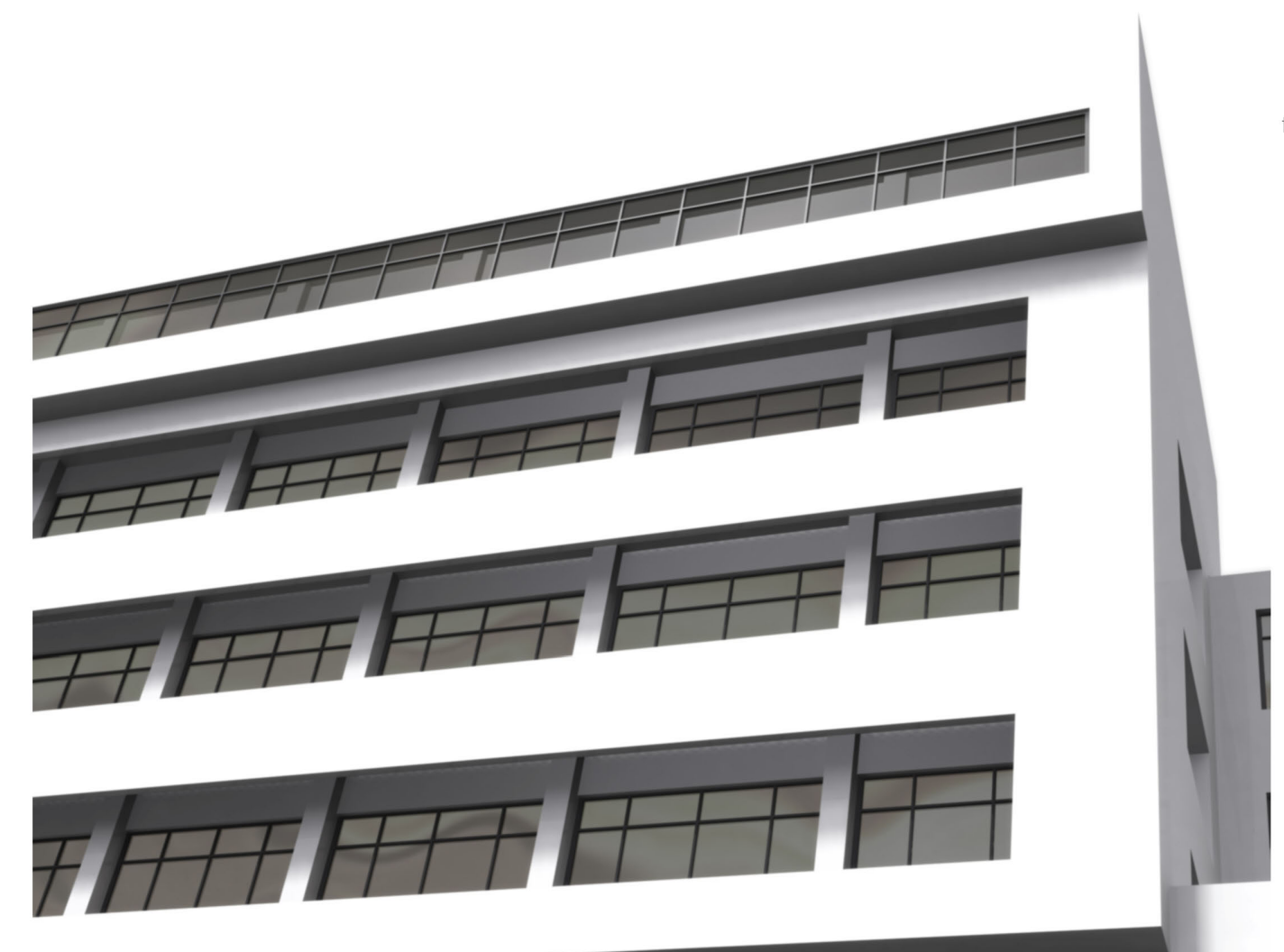

fig. 35
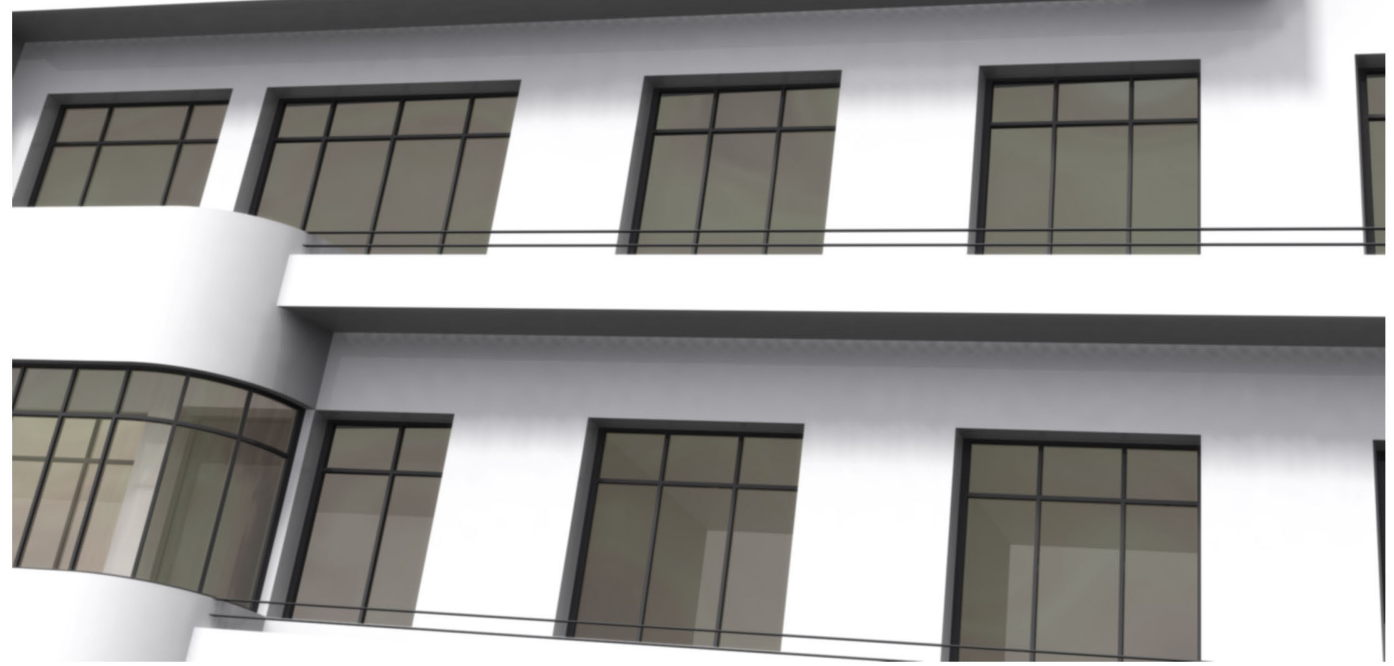

Hospital Provincial, pabellón de Cirugía; detalle de la maqueta infográfica del doctorando 
tras haberle apartado primero del paisaje bucólico, se le volvía a obsequiar con su imagen enmarcada ${ }^{36}$.

Albert, parejo, plantea las fachadas como membranas opacas donde plantearse potentes fisuras horizontales, para devolver al enfermo y a los usuarios del edificio el paisaje del que han sido relegados (fig. 35). Una dialéctica de superficies llenas y de transparencias capaces de determinar la visión del edificio, la imagen arquitectónica. Sin embargo busca la tercera dimensión, y así escapar de la planeidad del lienzo de fachada, descomponiendo la abstracción de la forma arquitectónica exterior ${ }^{37}$. La caja platónica de Le Corbusier comienza a distorsionarse, a desbordarse en busca del dinamismo con el que Mendelsohn "confiere una tercera dimensión, intrínseca al lenguaje arquitectónico". 38 Resaltar un rectángulo, interrumpir la continuidad de una fachada, de manera tridimensional había quedado resuelto en la Deukon Haus, de Berlín (fig. 36), utilizando verticalmente la franja del letrero, doblándola para formalizar la marquesina de entrada. Al momento de poder emplear voladizos, transformaba Mendelsohn la componente vertical formal, construyendo una elegante voladizo, asimétrico y desequilibrante para la fachada, rectangular y continua, de los almacenes Cohen-Epstein.

COLQUhOUN, Alan. Pág. 148. Op. cit.p. 24

37 En 1921, Theo van DOESBURG en los trabajos realizados por sus alumnos de la Bauhaus de Weimar, planteaban la abstracción de las formas arquitectónicas, a través de abatir en vertical las plantas asimétricas de las casas proyectadas, para así crear volúmenes maclados. Resultaban estudios de escultura puramente arquitectónica a partir de una planta. En este estudio, la composición asimétrica de volúmenes cúbicos se generaban estrictamente a partir de la planta, eliminando cualquier acentuación ornamental.

38 ZEVI, Bruno.p 85 . Op. cit. p. 17 


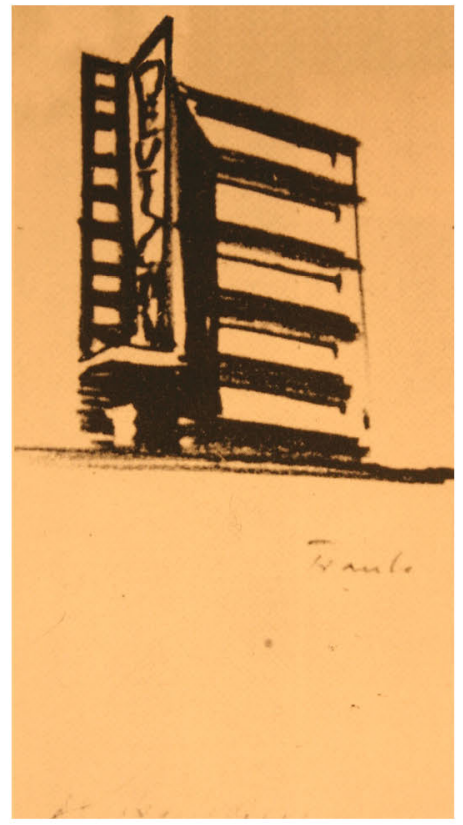

fig. 36
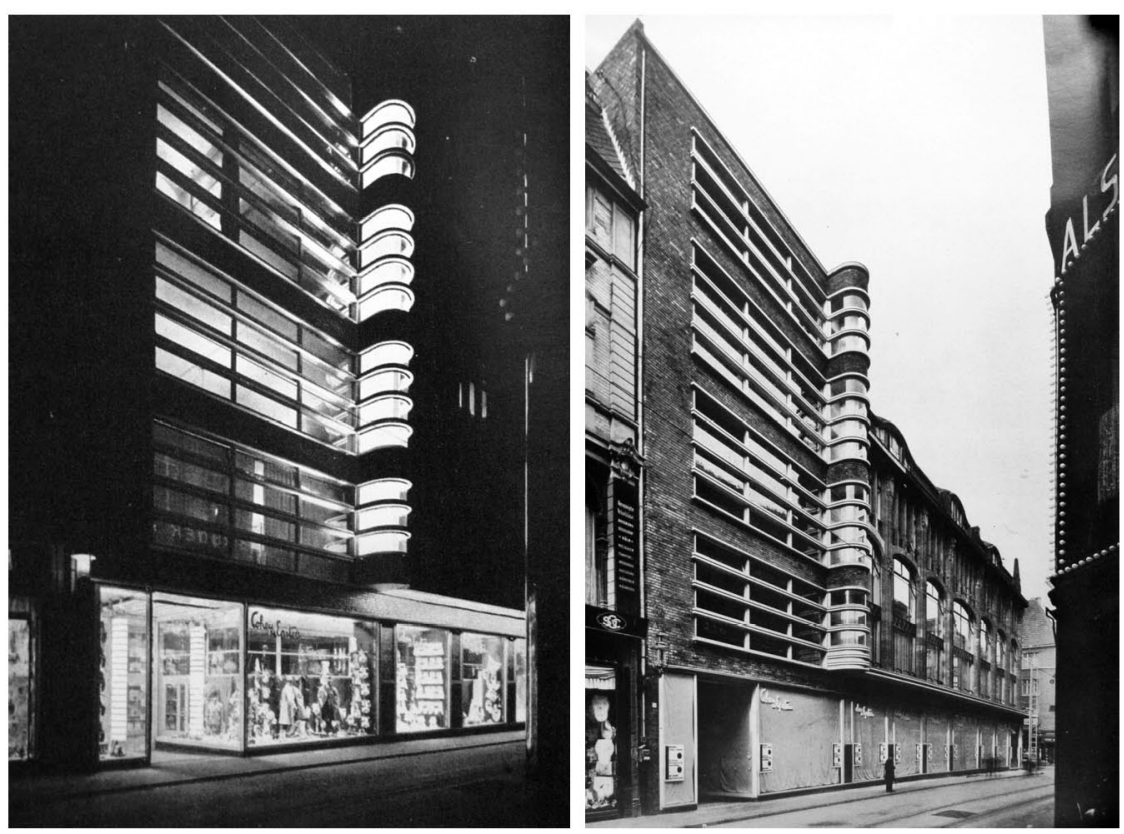

Erich MENDELSOHN. DEUKON Haus, Berlín (1927): Almacenes COHEN-EPSTEIN, Duiburg (1927) 
Semejante recurso es propuesto para el pabellón de Cirugía, adelantando verticalmente un volumen, formalizando el ático -no un alero construido que disocia la planta de entrega al terreno- al plegarse. Tampoco resulta esta la única diferencia esencial con el método mendelsohniano, pues potenciando una lectura lineal -fenestración vertical corrida perforando la membrana del voladizo longitudinal-, interrumpe la visión rectangular de la fachada, en contra de dotarla con su pretendida dimensión añadida. Las dudas emanan, en una fachada tan próxima a la planeidad y en una volumetría tan rigurosa, cuando se quiebra la horizontalidad de las superficies que envuelven los volúmenes. Aquí, los titubeos verticales no se asumen con tanta facilidad. La controversia racionalismo-expresionismo no se justifica en un ejercicio tan riguroso de aproximación a la ortodoxia, aún siendo intencionadamente buscada.

No puede presentarse como incapacidad del autor. Más bien resultan vacilaciones compositivas aplacadas bajo gestos tranquilizadores, experimentados y aceptados. Nikolaus Pevsner juzga, cuando Mendelsohn se aleja en los almacenes Schocken de Chemnitz -en 1928/1929, punto culminante del éxito profesional- de aquellos elementos verticales que dinamizan la fachada, como "la obra maestra más pura".

Conjuntar estos principios, sin asomo de confusiones, parece reservado para escasas figuras. Desviarse, ínfimamente, aparece como otra opción a la rectitud. Los motivos elegidos aparecen complejos de revelar. Claramente no resultan económicos. La presión social tampoco parece probable, en un proyecto para la administración, hasta que se le presenta y ella misma lo rechaza. Tampoco el desconocimiento, pues no permitiría 


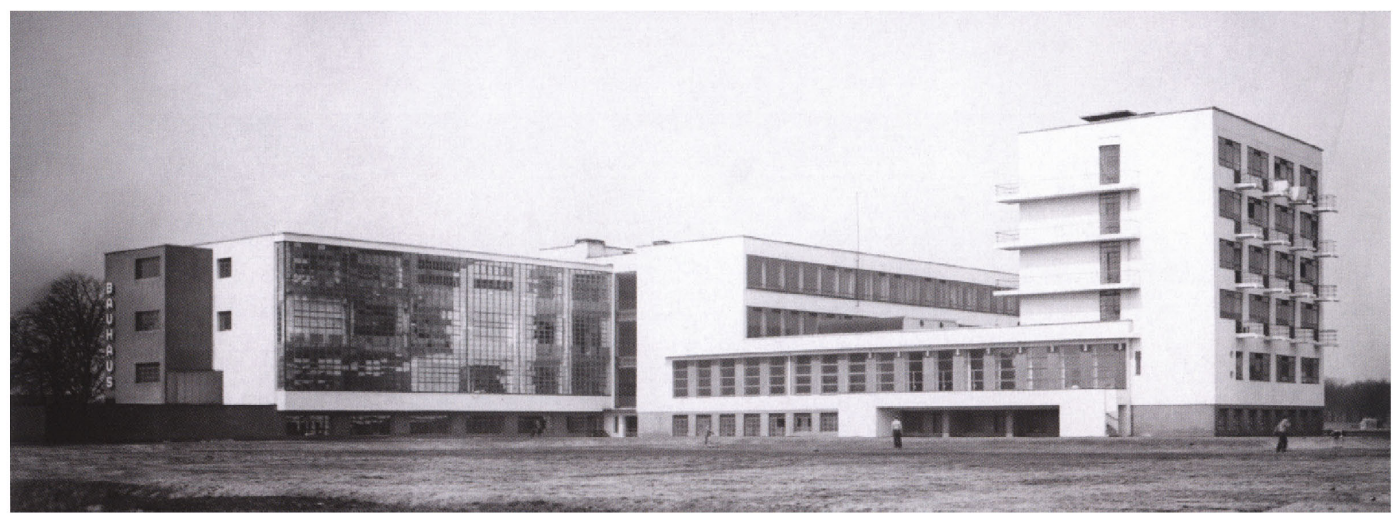

fig. 37
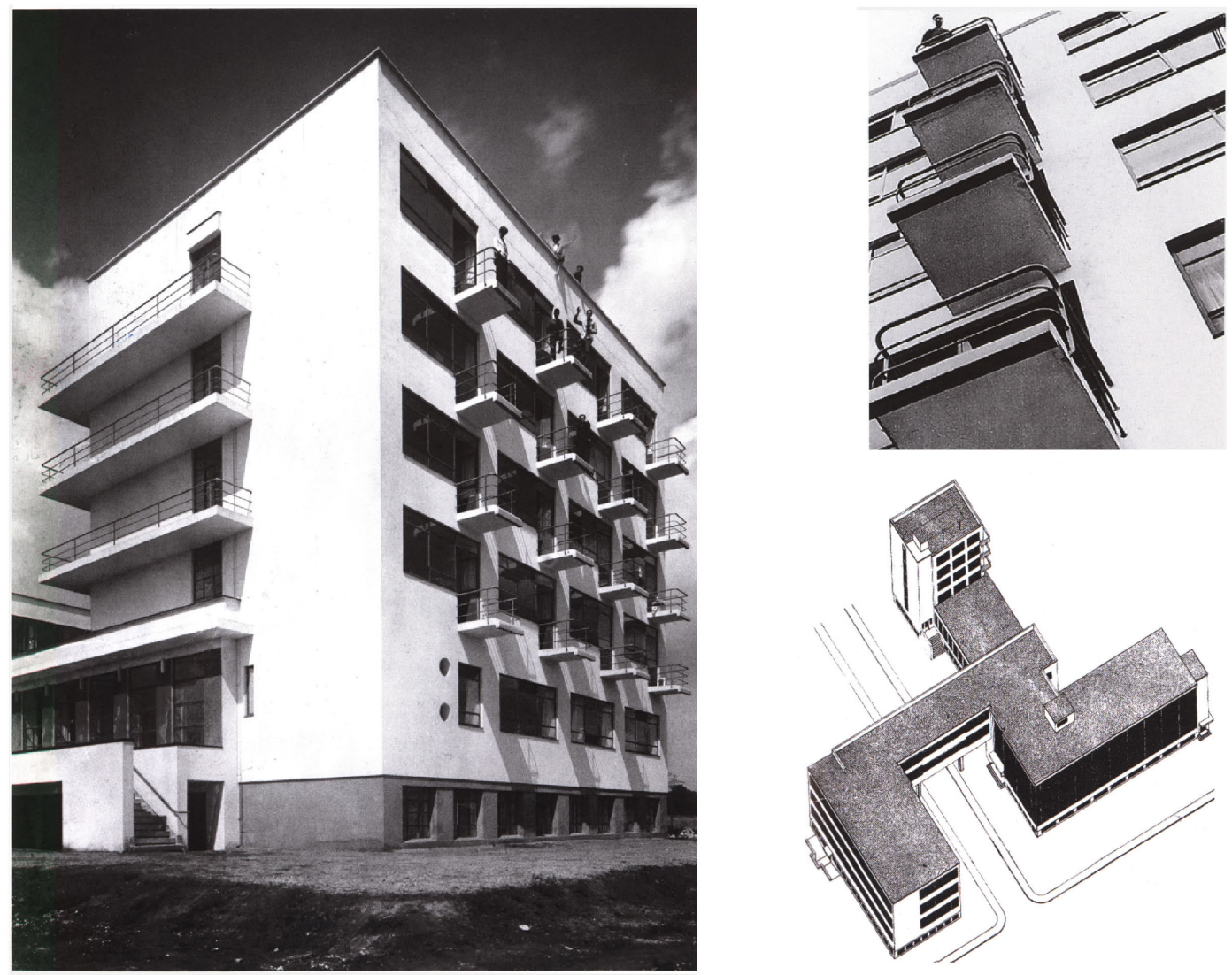

Walter GROPIUS, 1926; edificio para la Bauhaus, Dessau. Disposición volumétrica del complejo programa, en equilibrio dinámico y asimétrico 
llevar la propuesta tan lejos, para luego cometer mínimas faltas. Nuevamente inseguridad y falta de firmeza en sus convicciones.

Caben otros postulados fundamentales racionalistas en el análisis de las fachadas del pabellón de Cirugía: su puesta a tierra. Conectar la masa edilicia al plano horizontal, vendría a diferenciar propuestas modernas, de aquellas convencionalmente académicas. Replantear la fachada como membrana adherida, facultaba el desligarla del plano horizontal, en cota cero y así, retomar para el transeúnte una superficie tomada a cuenta del volumen. Venía entonces a cuenta, la imposición de variar la contundente entrega. Cabría desligarse de tectónicas y despreocupadas conexiones aprehendidas. La tecnología acudiría en ayuda de los nuevos planteamientos.

En Dessau, de 1925 en adelante, Gropius emprendió tres tareas constructivas diferentes: el edificio de la escuela, las casas de los maestros y el barrio Törten. El edificio de la Bauhaus se erigió mediante fachada moderna, no tradicional, que se extendía espacialmente en tres direcciones. El complejo incluía una sección de talleres, la casa estudio, el puente con la administración y la oficina de construcción. Cada una de estas construcciones, con diferenciado diseño, procuraba evidenciar en el exterior su función interior. Al mismo tiempo, los volúmenes horizontales y verticales, dispuestos en cuidadosa armonía, lograban un equilibrio "dinámico" y asimétrico (fig. 37). Propagaba Gropius una "percepción espacial transformada" que reflejaba el movimiento y la circulación de nuestro tiempo, "algo flotante, liviano, movido rítmicamente se extiende sobre 

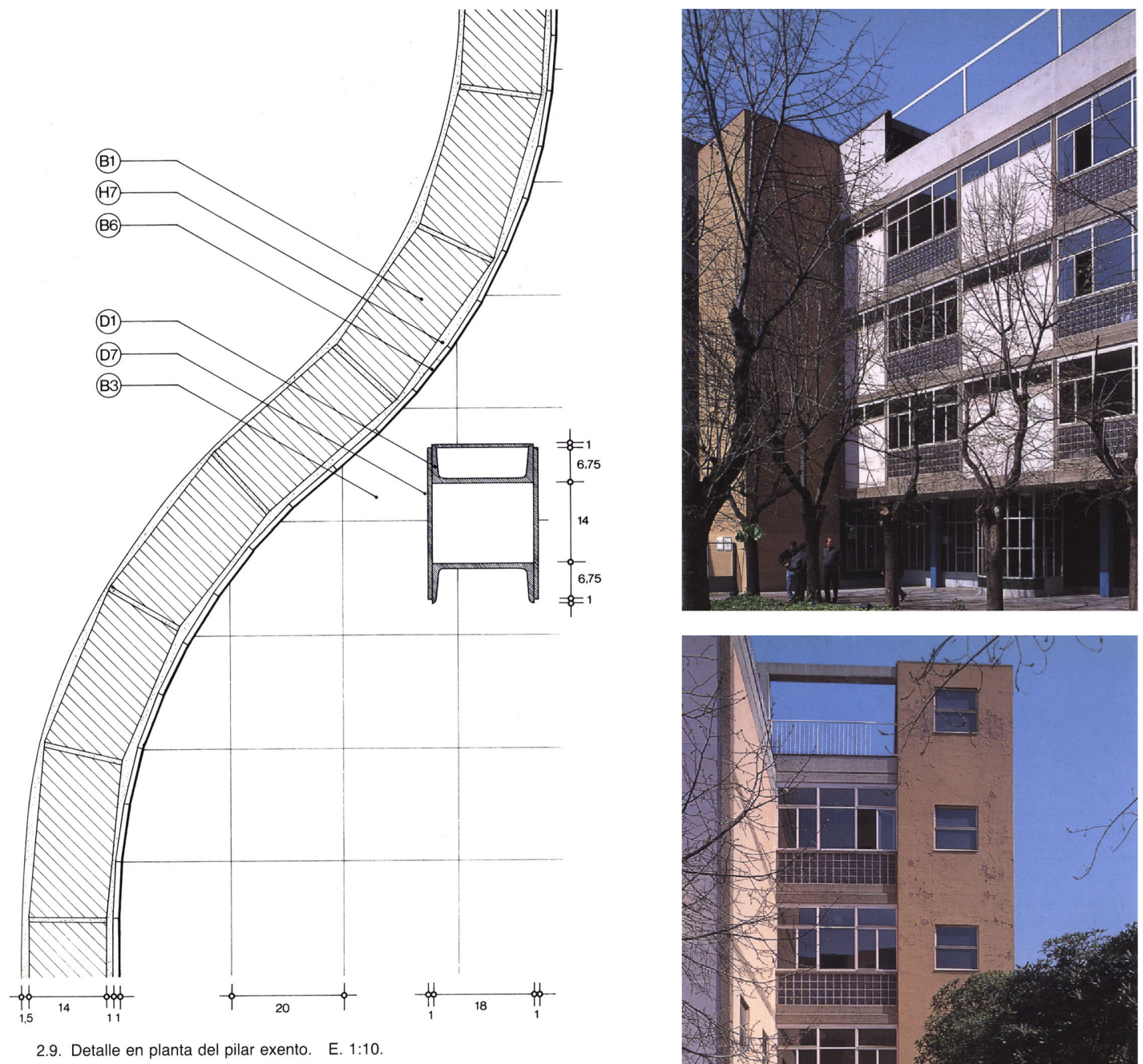

fig. 38

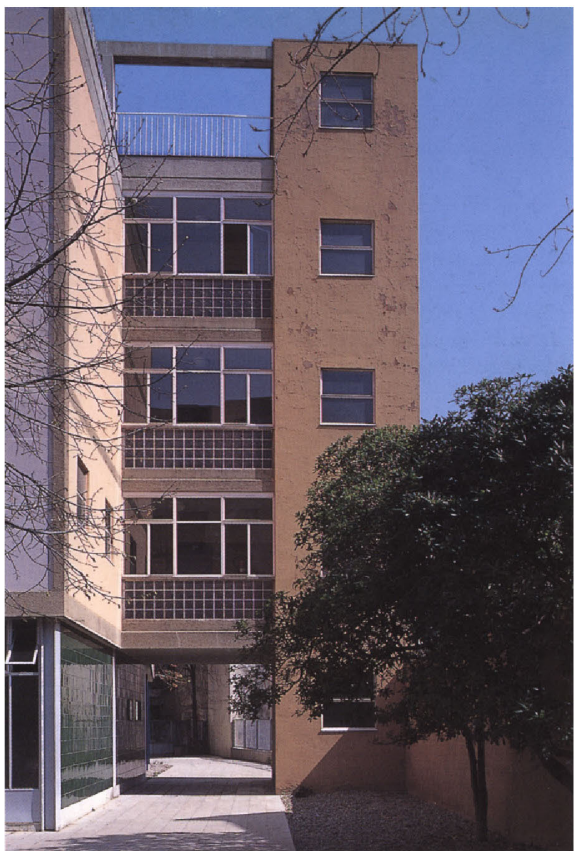

B1 - Ladrillo cerámico doble hueco

B3 - Pavimento de mosaico hidráulico

B6 - Loseta cerámica vidriada

D1 - Pilar formado por dos perfiles metálicos en

$\cup$ empresillad

H7 - Platabanda

SERT, SUBIRANA Y TORRES, 1935. Dispensario Central Antituberculoso, Barcelona: liberación del cerramiento de fachada de sus cargas estructurales 
los edificios". Esto había sido posible gracias a los nuevos materiales: hierro, hormigón armado y vidrio ${ }^{39}$.

Resultaba admisible no diferenciar-ascender de forma evidente, efectista- el edificio del terreno, también tratándose de un edificio público. Una variación de material en la membrana más externa, un tratamiento diferente en la epidermis de acabado final, una potente fisura en sombra debida al retranqueo del cierre en planta baja $(\mathrm{fig} .38)^{40}$ con el resto del edificio volando adelantado, resultaba suficiente para no anclar la construcción al terreno. Desligar la condición tectónica de aquella envolvente, ya suponía preconizar su disposición ingrávida, frente a experimentados muros portantes que necesitaban emerger desde tierra.

Cuando tratándose de un todo, una concepción global y unitariamente proyectada, la facultad de elevar el conjunto edificado, la totalidad de los pabellones que configuran el Hospital, hubiera facilitado la comprensión de los usuarios, su percepción visual y la materialización del axioma racionalista dotando de contenido al plano del suelo, más allá de auspiciar la accesibilidad. Luís Albert decidió que la disposición final de las piezas

39 DROSTE, Magdalena. "La Bauhaus 1913-1933.Reforma y vanguardia". Editorial Taschen. Köln. Alemania, 2006.p. 46

${ }^{40}$ De acuerdo con el planteamiento expuesto en el capítulo anterior, los cerramientos en la planta baja se sitúan con absoluta libertad entre los pilares de la estructura, pero siempre dentro de la proyección del volumen de las plantas superiores. Esa libertad se utiliza para acompañar, con cualquier tipo de formas, las diversas exigencias que se plantean a lo largo del perímetro envolvente. Curvas que suavizan los paramentos que forman el acceso privado, singularización de elementos como la portería, e incluso, los aseos de las salas de espera, etc.

MANNINO, Edgardo y PARICIO, Ignacio. Op. cit., p. 13 

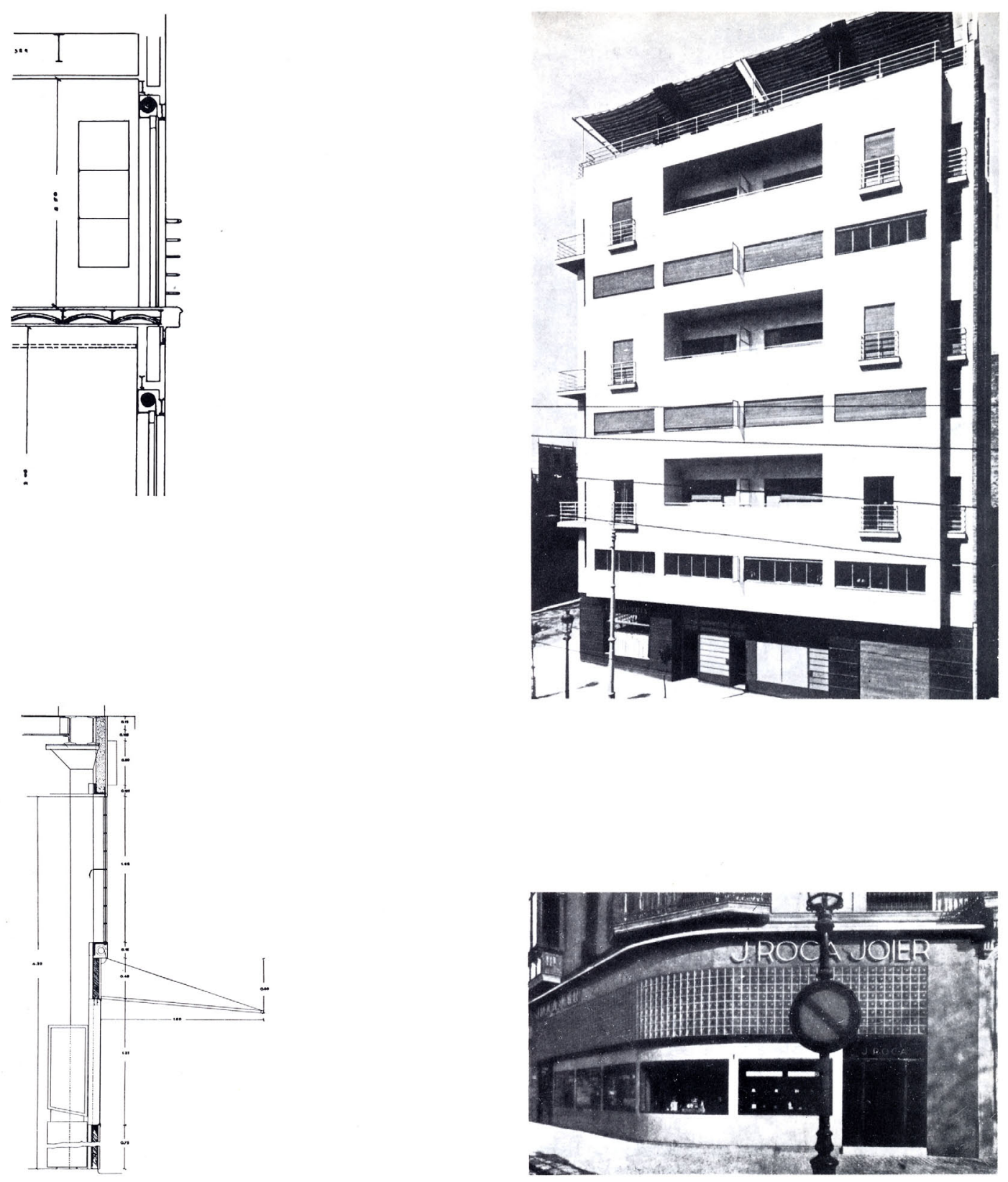

José Luis SERT, 1929 y 1934. Edificio de viviendas en la calle Muntaner, Barcelona; lienzo de fachada para la Joyería Roca, Barcelona 
necesitaba enraizar en el plano del suelo, por encima de retornar la cota horizontal al viandante. Probablemente bastaba incidir en la capacidad epidérmica de la fachada.

Una fachada capacitada para responder a principios racionalistas que, sin demasiado desfase temporal, se recorrían en su moderno planteamiento. Un arquitecto nunca separado de L'Esprit Nouveau, tampoco demasiado cercano al Neves Baven y ciertamente contaminado de algunos elementos dinámicos mendelsohnianos, pero sin una sobresaliente $y$ ortodoxa rotundidad. Albert quedaba distanciado del G.A.T.C.P.A.C. donde encontramos precedentes notables, a más del referido Dispensario Antituberculoso, donde las dudas no caben y, en su lugar se plantean soluciones a los nuevos problemas: el edificio de alquiler-proyectado en 1931 por Josep Lluis Sert- en la calle Muntaner, de Barcelona (fig. 39), la sección constructiva para la fachada de la Joyería Roca, 1934.

Los requerimientos proyectuales de la fachada, sus ideadas pretensiones, quedaban sometidas al buen hacer constructivo y al discurrir temporal, imponiendo además sus leyes. Reducir los vierteaguas, suprimir aleros y canalones aumenta las ecuaciones a resolver, en el diseño de fachadas. Demanda detalles constructivos - pericia para inusuales soluciones constructivas a pie de obra- a plantearse, solventar nuevas cuestiones como el incremento del flujo de agua que circula por los paramentos verticales de cierre. Aproximar las carpinterías al plano de fachada conlleva poner en contacto materiales totalmente impermeables, como el vidrio, junto a otros que los son menos o ni tan siquiera presentan semejante cualidad. Actuar en la zona crítica donde todo interactúa, en el encuentro entre la 


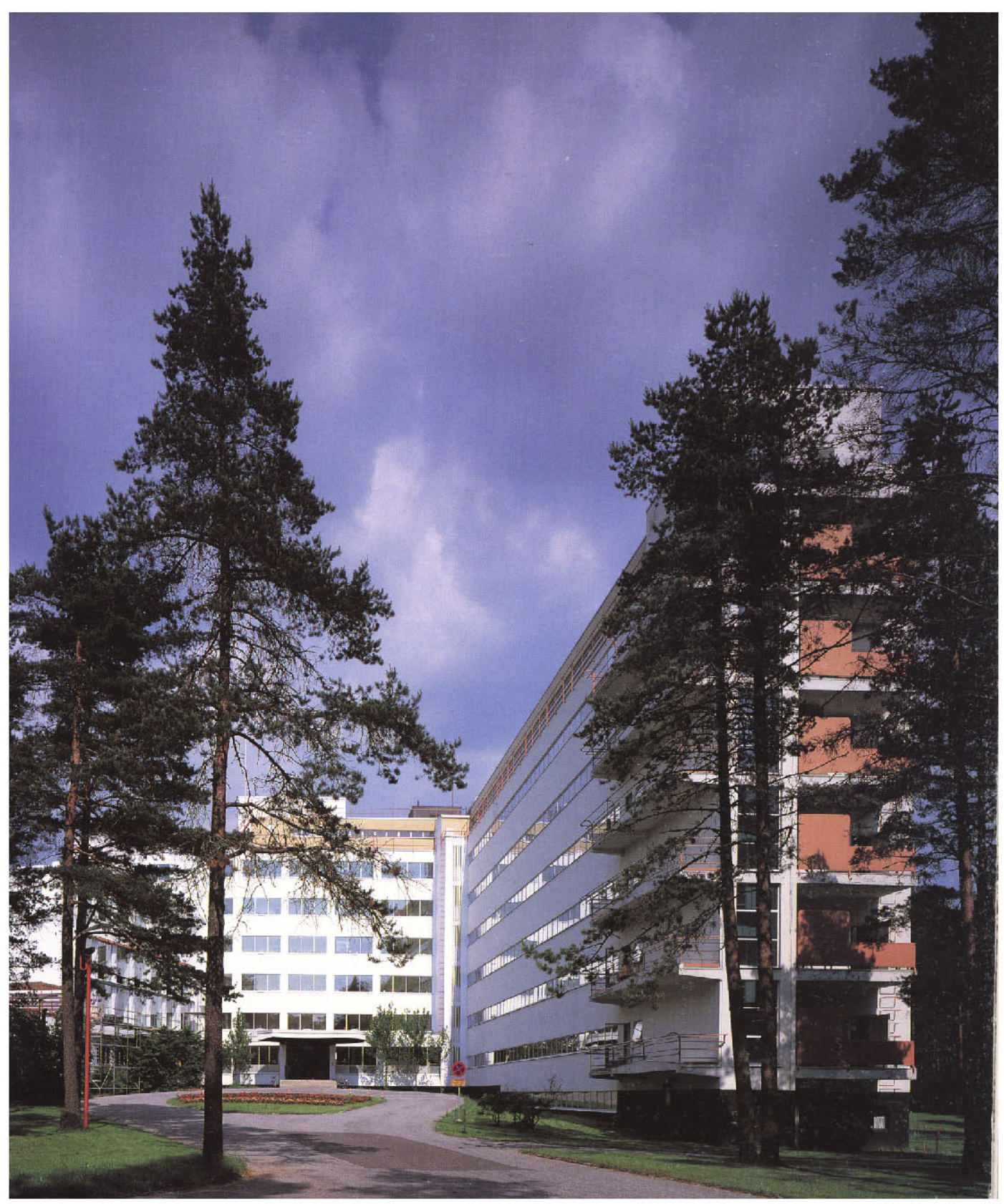

Alvar AALTO, 1928. Hospital Antituberculoso, Paimio; concurso 
carpintería y cerramiento vertical de fachada, clásico punto de inicio del deterioro.

Cuestiones teóricas, de imposible observación, puesto que no aparece detalle constructivo alguno en el conjunto de planos que conformaban el proyecto de ejecución redactado por Albert, y en una reconstrucción virtual nunca surgirán. La puesta en obra -minuciosamente ejecutada según corresponde al estricto director-, los problemas de encuentros entre diferentes materiales, el envejecimiento por exposición climatológica,el deterioro debido al uso, la falta de mantenimiento y reposición, quedan malogradas. Cuestiones hueras para finalizar.

\section{LA CUBIERTA}

"El terrado-jardín. El hormigón armado es el nuevo medio que permite la realización de la cubierta homogénea. El hormigón armado se dilata mucho. La dilatación causa el agrietado de la obra en las horas de contracción brutal. En lugar de procurar evacuar rápidamente el agua de lluvia, esforzarse por el contrario en mantener una humedad constante en el hormigón de la terraza y por ello una temperatura regular en el hormigón armado. Medida particular de protección: arena recubierta de gruesas losas de hormigón, con juntas separadas, en las que se siembra 


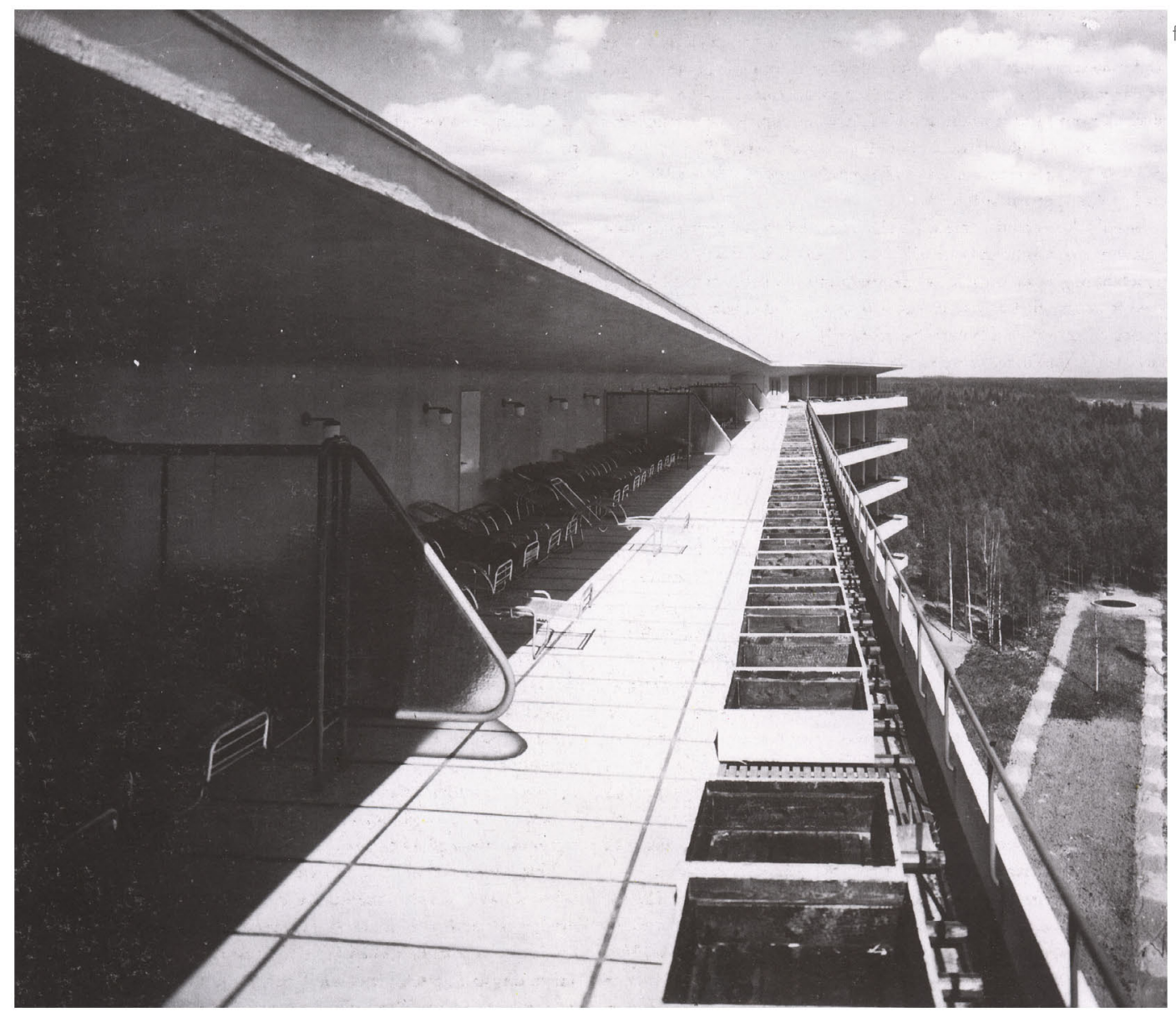

fig. 40 
césped. Arena y raíces sólo dejan filtrar el agua lentamente. Los terrados-jardín adquieren opulencia: flores, arbustos, árboles, césped. Razones técnicas, razones de economía, razones de confort y razones sentimentales nos llevan a la adopción del terrado como cubierta". ${ }^{41}$

Le Corbusier planteó en 1926 la cubierta como elemento paradigmático en la concepción racionalista de la Arquitectura. La cubierta plana dotada de uso, justificada desde el propio programa del edificio. El Movimiento Moderno, con la quinta fachada recuperaba la parte de terreno usurpada para implantar la pieza construida. Al ocupante, tras haberle apartado primero del contacto con el terreno, se le vuelve a obsequiar con la tierra bajo sus pies y el cielo como cubierta. Albert justifica plenamente la utilidad de la cubierta plana desde el programa, y su validez constructiva. Inmejorable ubicación para albergar un tratamiento médico basado en el aprovechamiento del sol -la Helioterapia (fig. 40)-, del aire libre y de las impresionantes vistas con las que relacionar al usuario, desde semejante cota.

Corresponde la cubierta plana a la construcción clásica de las culturas del Mediterráneo42. El anhelo racionalista disponía de una ocasión inmejorable para estudiar y solucionar un tema no abordado hasta el planteamiento de esta nueva fachada. Los arquitectos del Movimiento Moderno publicaron sus propuestas en Das Neve Frankfurt, bajo la dirección de Ernst May.

41 BOESIGER, W. / GIRSBERGER, H. "Los cinco puntos de una arquitectura nueva", pág. 44. Op. cit. p. 14.

42 MANNINO, Edgardo y PARICIO, Ignacio. Op. cit., p. 13 


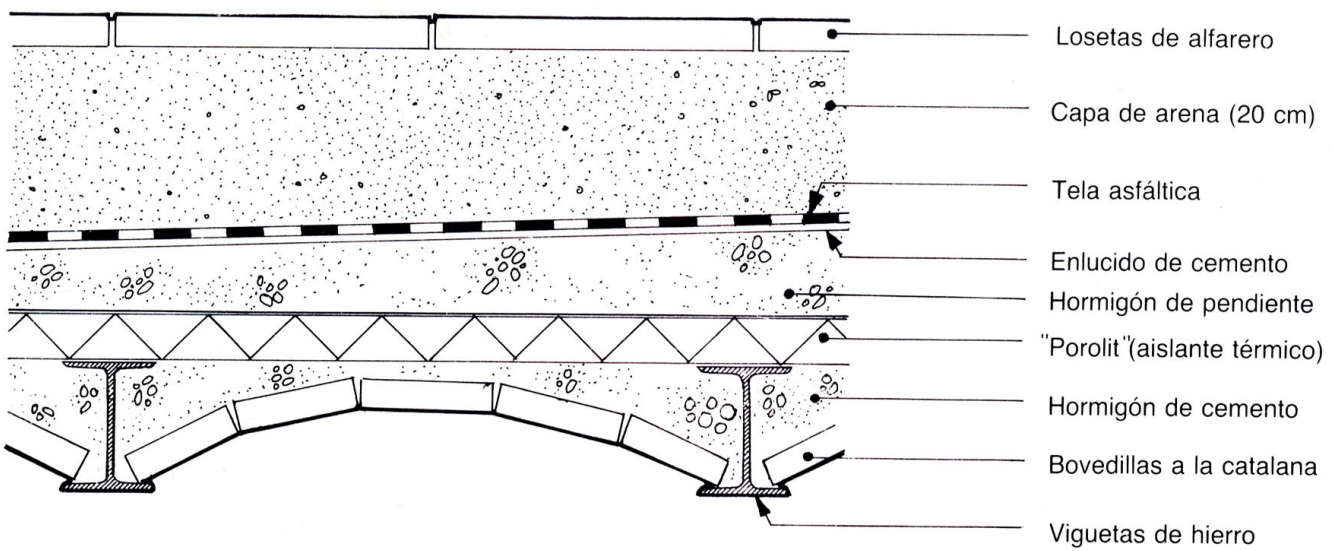

fig. 41

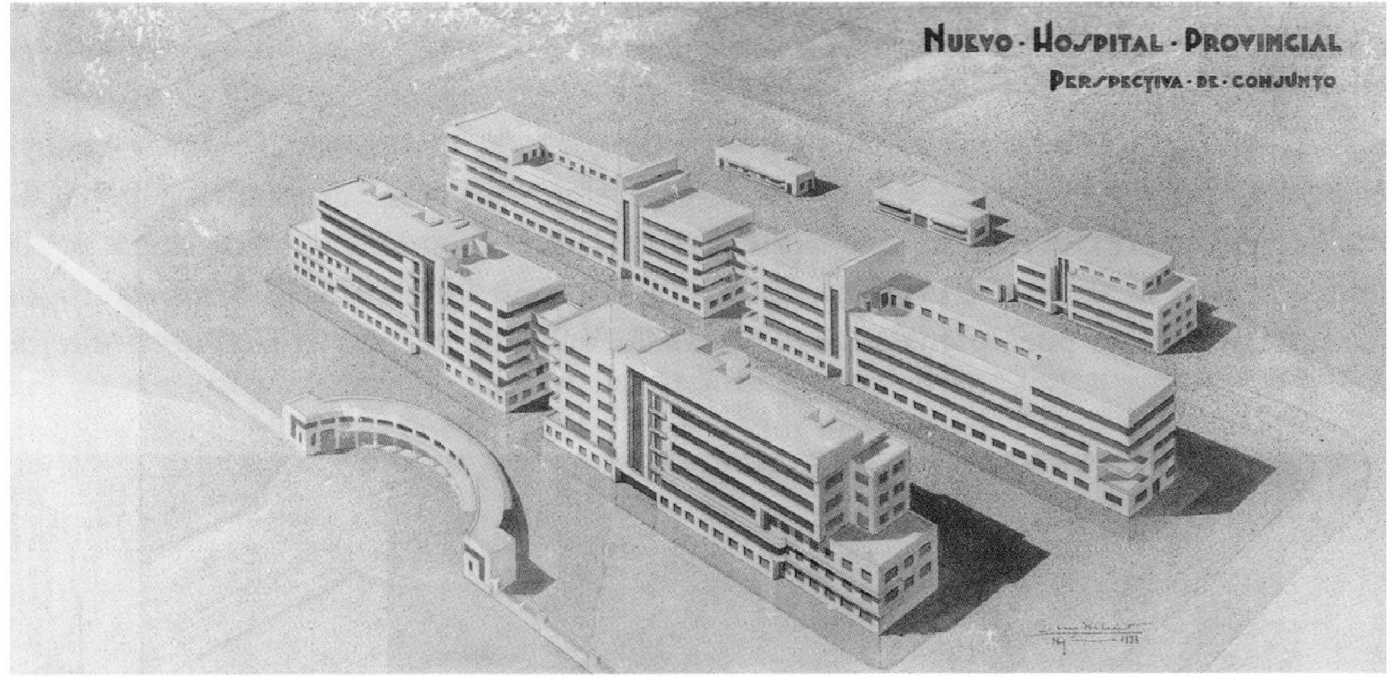

Sixto ILLESCAS, 1934; esquema de cubierta, solución constructiva muy habitual en el G.A.T.C.P.A.C. Luis ALBERT, 1935; perspectiva axonométrica del nuevo Hospital Provincial 
Garantizar constructivamente los nuevos planteamientos fue uno de los motivos del esfuerzo de diseño que el G.A.T.E.P.A.C. se impuso. Una solución contemporánea, muy válida, es la cubierta realizada por Sixte Illescas en la calle Padua de Barcelona, (fig. 41). Losetas de alfarero, solera de rasilla, como superficie pisable, primera barrera para captar el agua y reconducirla hacia los puntos de recogida. Una capa de arena filtrante, tobas para reconducir las filtraciones que al llegar a la tela asfáltica encuentran el segundo sistema de captación y drenaje. Una fina capa de mortero de cemento sirve para tomar esta lámina impermeabilizante sobre el hormigón de pendiente. Inmediatamente aparece el aislamiento térmico sobre el forjado de viguetas metálicas doble $\mathrm{T}$ y bovedillas de revoltó. Una clásica propuesta de cubierta invertida, pisable pero no ventilada.

Queda propuesta, más bien se intuye como hipótesis, la solución de cubierta -de ser otra solución pasaría por una respuesta muy similar- tal cual se aventuraron soluciones estructurales y de fachada. Aluzada, al no disponer documentación que formalice las legadas perspectivas aéreas de Luis Albert (fig. 42), anunciadoras del proyecto de ejecución para el Hospital Provincial de Valencia y, por ende para el analizado pabellón de Cirugía. 
manicomio provincial 


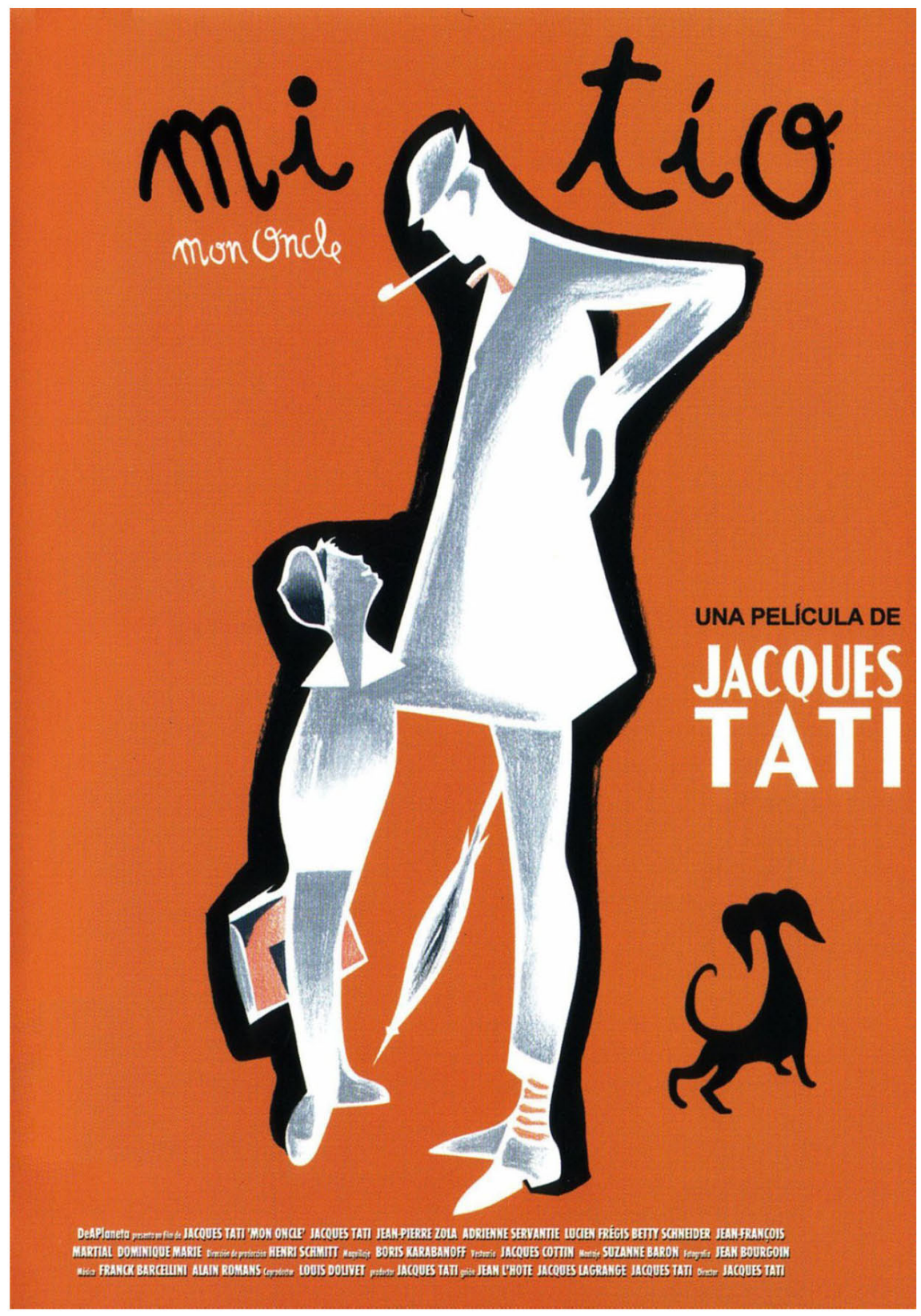

Cartel de la película Mon Oncle; la ultramoderna villa Arpel, en manos de Jacques Tatí, alojaba una ácida crítica hacia la máquina de habitar, la ciudad moderna del siglo XX 


\section{MODERNIDAD}

Constituirse en colectividad, insertarse en una sociedad perfecta, unidireccional. La idea de progreso colectivo resultaría el objetivo último del espíritu de modernidad. Espíritu de distanciamiento con el pasado. Espíritu de avance, en el pensamiento global, acorde al momento. Formar parte del orden y del progreso científico, por encima de la individualidad, así aluzaban las aspiraciones modernas.

Infería pues su principio, el hombre, como una célula dentro de un gran cuerpo social superior. El hombre-tipo lecorbusierano. Nunca sustantivo, más inmerso en la familia estadística, en una constructo mental que permitió a los arquitectos ortodoxos objetivar su comportamiento social y cuantificarlo en aquella experiencia casi delirante que fue el Existenzminimun'. Arquitectura abstracta y empírica, elementalista, cúbica y platónica, culminada en el racionalismo, todos, conceptos pertenecientes a la esfera del pensamiento. Afirmación del poder de la razón analítica. Exigencia de método cartesiano. Demanda de la sistematicidad científica.

Orientaba este espíritu moderno, el positivismo. La base filosófica de una vida feliz inmersa en el orden y el progreso científico, posicionando al individuo en un gran cuerpo social donde reinaba la unidad, la perfección y el orden. Un cuerpo higiénico, saludable. Pretendía, el pensamiento moderno, un valor superior hacia lo colectivo, evidenciando su destino último: configurar y resolver el espacio urbano, hacer ciudad. Cada unidad,

1 ÁbAlos, Iñaki. "La buena vida. Visita guiada a las casas de la modernidad". Editorial Gustavo Gili, S. A. Barcelona, 2000. pág. 72 

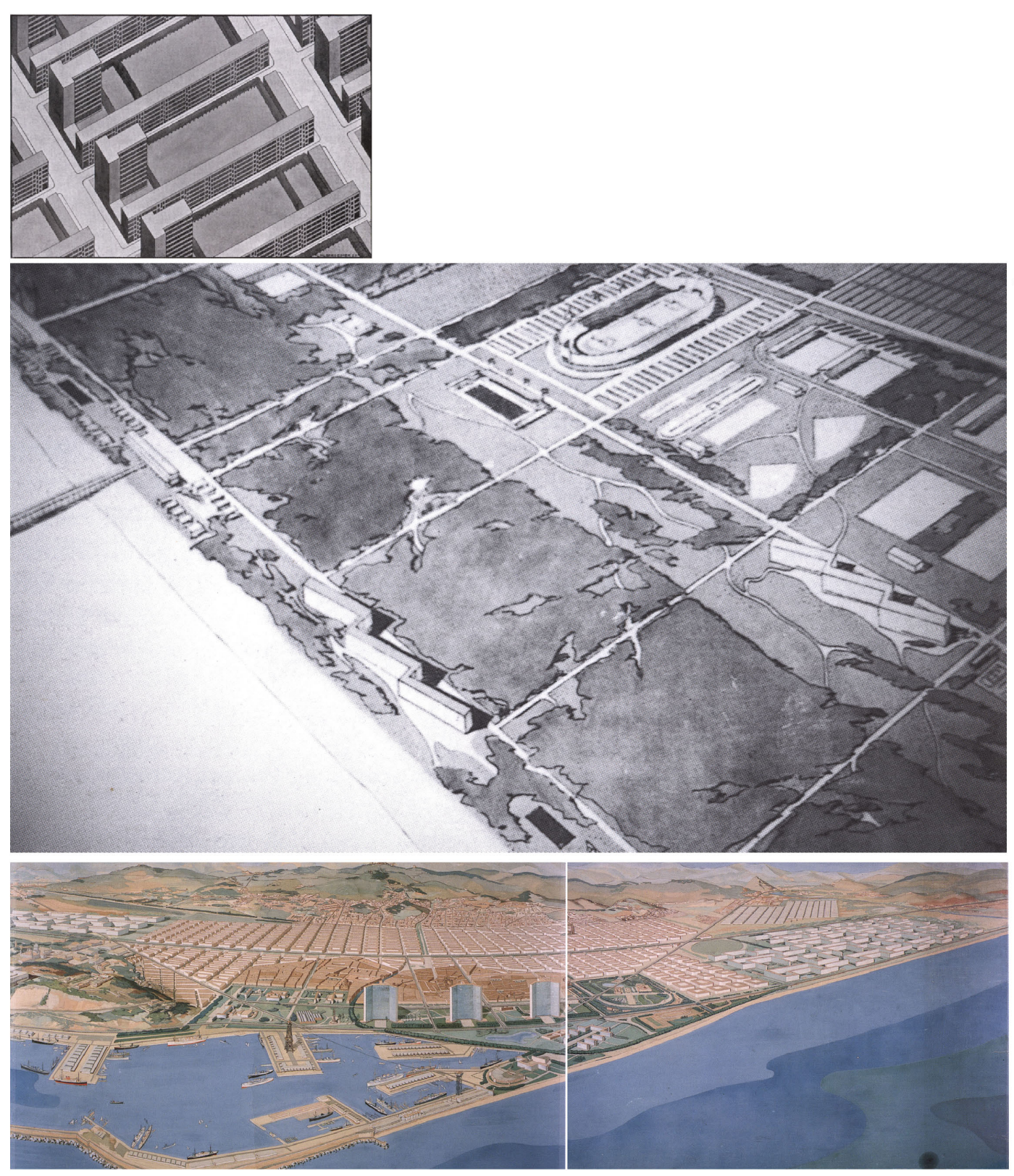

Ludwig HILBERSEIMER. Ilustración de la revista Bauhaus (1929, fascículo 2): J. LI. SERT con G.A.T.C.P.A.C. La Ciutat de Repós i de Vacances (1931-1935) plan Macià para Barcelona, 1932. G.A.T.C.P.A.C. con Le Corbusier. Diorama 
diseccionada con anterioridad, al constituirse en conjunto adoptaría una organización antropomórfica. La Ville Radieuse. Dividir la complejidad de la ciudad en partes susceptibles de ser tratadas genéricamente e independientemente. Siguiendo las premisas cartesianas, la ciudad como problema se descompone por zonas de manera que funcione como una máquina productiva².

La ciudad moderna, la máquina planificada servía así a la creación de una sociedad jerarquizada, estructurada, científicamente ordenada, grafiada de forma abstracta para inferir en el esplendor de su perfección la necesidad de una doctrina métrica de la ciudad; el urbanismo.

E insertada en aquel orden superior, la famosa "maquina de vivir" deducía un microzoning, diseccionado racionalmente en austeras piezas, alcanzada su mínima expresión y descompuestas para restituirlas en un engranaje mecánico y orgánico de máxima eficiencia. Su destino último, su optimización se trasladaría al zoning, mecanismo de la urbanística alemana, regulador de densidades y usos para las diferentes áreas urbanas. De esta manera se tenía una visión global del hecho urbano que permitía introducir en el territorio próximo a la ciudad aquellas piezas que no podía admitir la uniformidad del ensanche (fig. 1), como son las áreas verdes, la industria y, sobre todo, la vivienda modesta de baja densidad $^{3}$.

2 MONTANER, Josep Maria. "La modernidad superada. Arquitectura, arte y pensamiento del siglo XX." Editorial Gustavo Gili, S.A. Barcelona, 1997. pág. 69

3 BLAT, Juan. "El crecimiento urbano en Valencia: entre la ciudad-jardín y el planeamiento de extensión". Dentro del catálogo para la exposición realizada por el IVAM Centre Julio González, del 20 de enero al 5 de abril de 1998. "La ciudad moderna. Arquitectura racionalista en Valencia". Volumen I. 

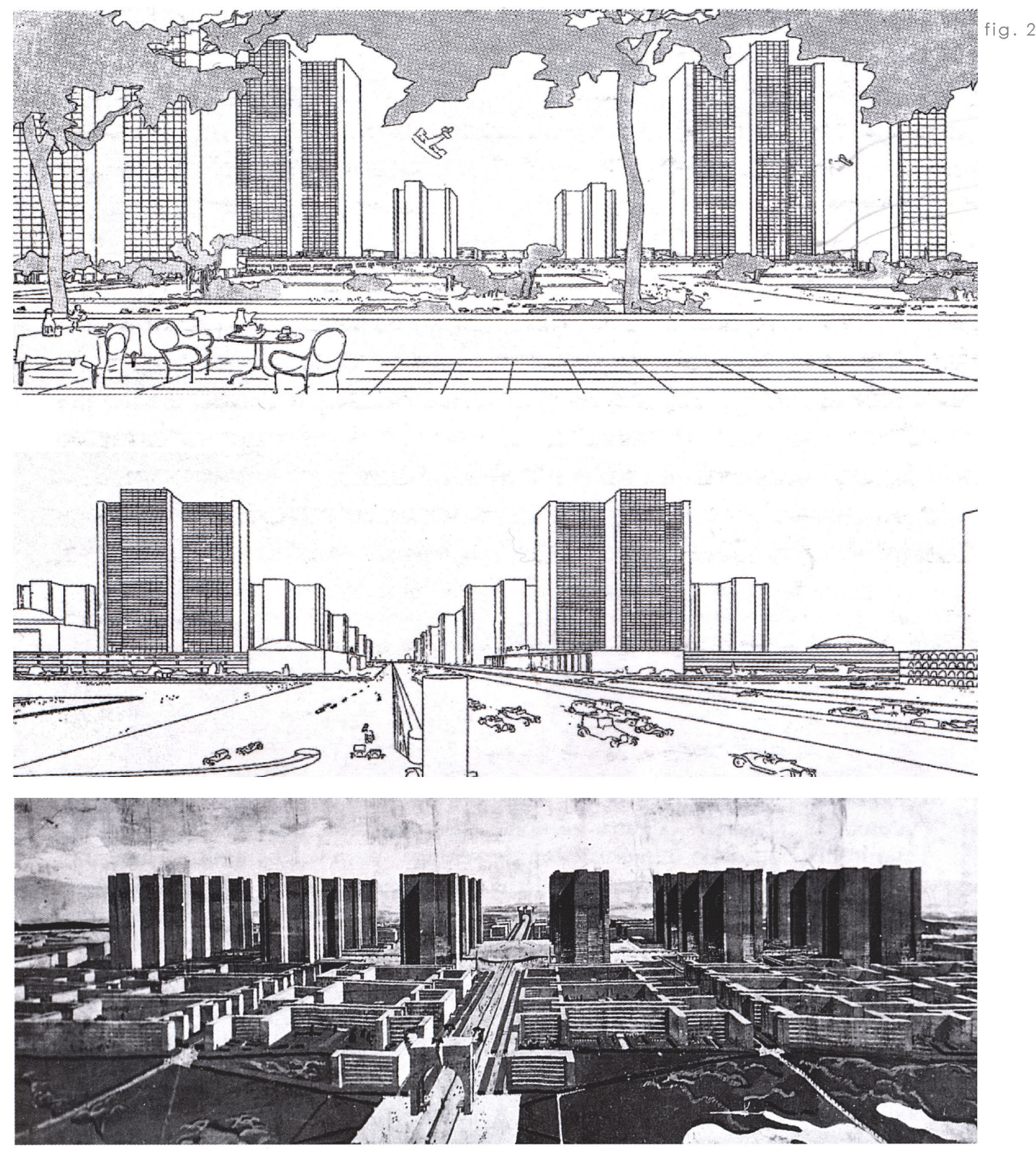

Le CORBUSIER, 1922. Ville Contemporaine pour 3 millions d'habitants sans lieu; diorama de la principal arteria de circulación; vistas del centro de la ciudad 
Hasta ese momento, la insostenibilidad, la ineficacia de los métodos de ensanche urbano aplicados, habían conducido a un sistema urbanístico disconforme. Escindiendo, casi quirúrgicamente, los barrios de viviendas de los centros urbanos, considerados de producción o disfrute, la intención pasaba por dibujar, planificar zonas residenciales optimizando posibilidades. Constituir prioridades, organizar barrios y zonificar, permitiría emancipar todo el interior urbano, independizarlo para la vida laboral, comercial y lúdica.

La ciudad funcional ${ }^{4}$ debe ser construida sistemáticamente, erigida a partir de entidades elementales, irreductibles y abstractas, dotándola de orden en un sentido completamente nuevo. Habría de cumplir con todas las exigencias urbanísticas básicas (fig. 2). Su trazado debe ser claro y lógico. Las viviendas, sanas y cómodas. Evitar patios interiores. Las manzanas, abiertas y ventiladas. El ancho de calles y patios, proporcionado a la altura de los edificios. El tráfico debe ser regulado, distribuido según los tipos de transporte, de modo que en cada nivel sólo circulen vehículos de un mismo tipo ${ }^{5}$.

\footnotetext{
${ }^{4}$ AC revista trimestral, $n^{\circ} 11$. Año tercero, tercer trimestre de 1933. Publicación del G.A.T.E.P.A.C. Barcelona. Monográfica del IV CONGRESO DEL C.I.R.P.A.C. primero que trata sobre "La Ciudad Funcional", a bordo del "Patris II" y en Atenas del 29 de julio al 15 de agosto de 1933. Congreso que inicia la fase primera (analítica) sobre este extenso tema, basándose en los trabajos y datos presentados por los distintos grupos. Planos de 31 ciudades y otros tantos "rapports" sobre cada una de éstas. Cada ciudad presentaba un mínimo de tres planos: ।, zoning. II, circulación. III, zona de influencia de la ciudad.
}

${ }^{5}$ HILBERSEIMER, Ludwig. Op. cit. pág. 13 

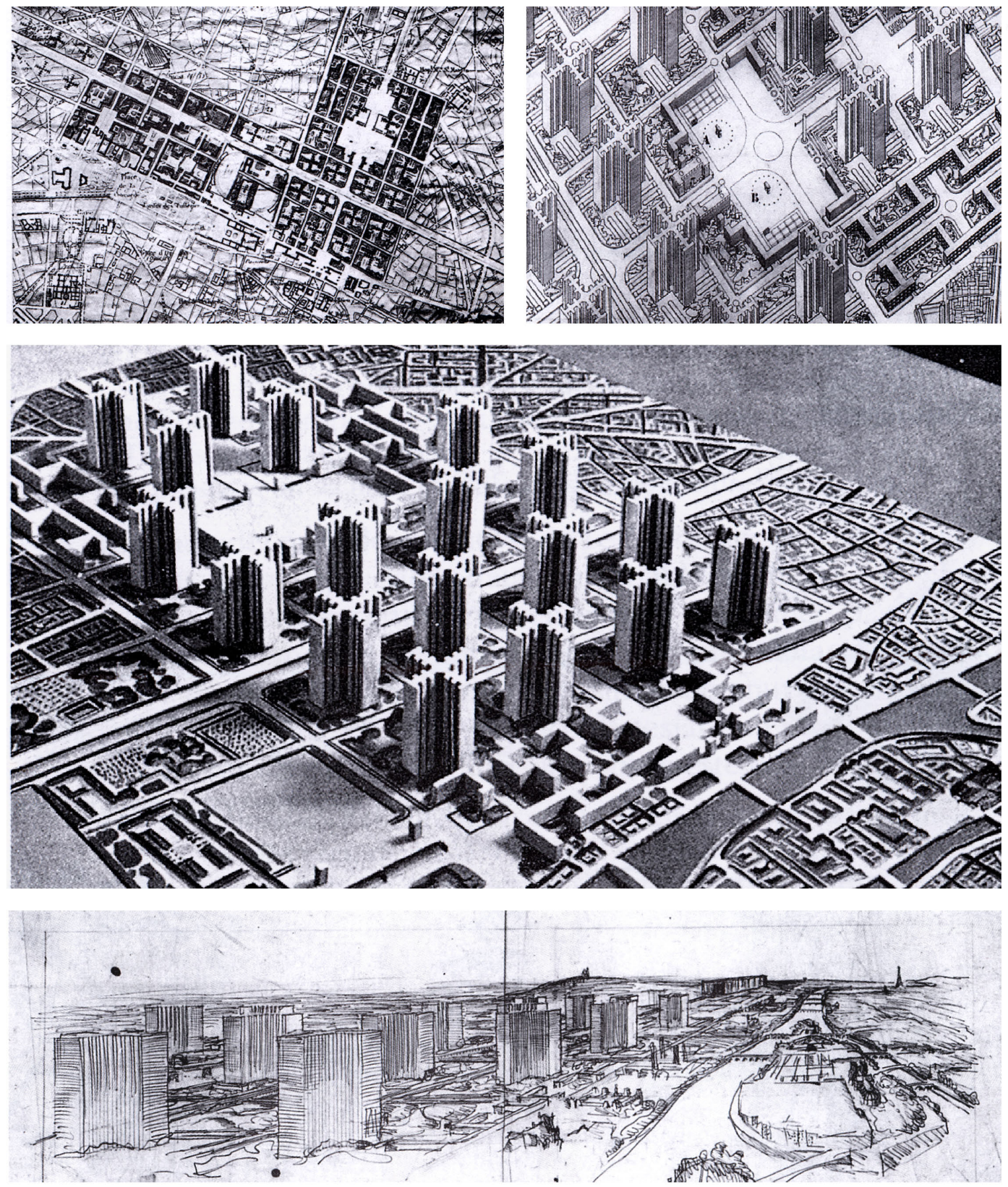

Le CORBUSIER, 1925. Plan Voisin; Reinstalación en el centro de París sobre el eje del bule var de Sebastopol; maqueta del proyecto; perspectiva (imágenes fundación Le Corbusier) 
Habrían de regularse calles, rediseñar nuevamente su sección, demoler edificios -manzanas en su totalidad, estrechas, insanas y mal edificadasy abrir nuevos trazos a la ciudad. Volver a edificar, sin concesiones para con historicismos sentimentales. Toda memoria tiene un rango inferior, no tiene cabida en la condición moderna. "No puede permitirse que por un culto mezquino del pasado, se ignoren las reglas de la justicia social", rezaba en "la Carta de Atenas". Insensibilidad -derivada de los valores positivistas- mentora hacia el final en el que concluye la ciudad moderna e inductora de las críticas sistemáticas para otras formas de pensamiento y habitar.

Frente a la propuesta del zoning, la urbanística anglosajona formulaba un modelo de carácter descentralizador. En el plano propositivo, dos referentes urbanos e ideológicos: garden city de Ebenezer Howard y las New Towns. Contener dimensiones, la envergadura de las grandes ciudades circundándolas de poblados satélites y áreas verdes siguiendo el esquema de la cuidad-jardín venía a contraponer las leyes de Ensanche y Reforma Interior, centradas exclusivamente en prosperar la metrópoli (fig. 3).

En Valencia, con relación a estos dos modelos básicos de organización del crecimiento urbano, no se producirían intentos de introducir una adecuada zonificación por densidades y usos dentro del propio ensanche. En cambio, al menos inicialmente, sí parece tener cabida el modelo anglosajón, como alternativa factible a un planeamiento anquilosado y complaciente en su centralidad. Alternancia propositiva para conformar la periferia metropolitana. Asomarían ejemplos manifiestos, puntuales como las barriadas erigidas por la Sociedad Constructora de Casas para Obreros de Valencia, o las propuestas de ciudades-jardín en la playa de 

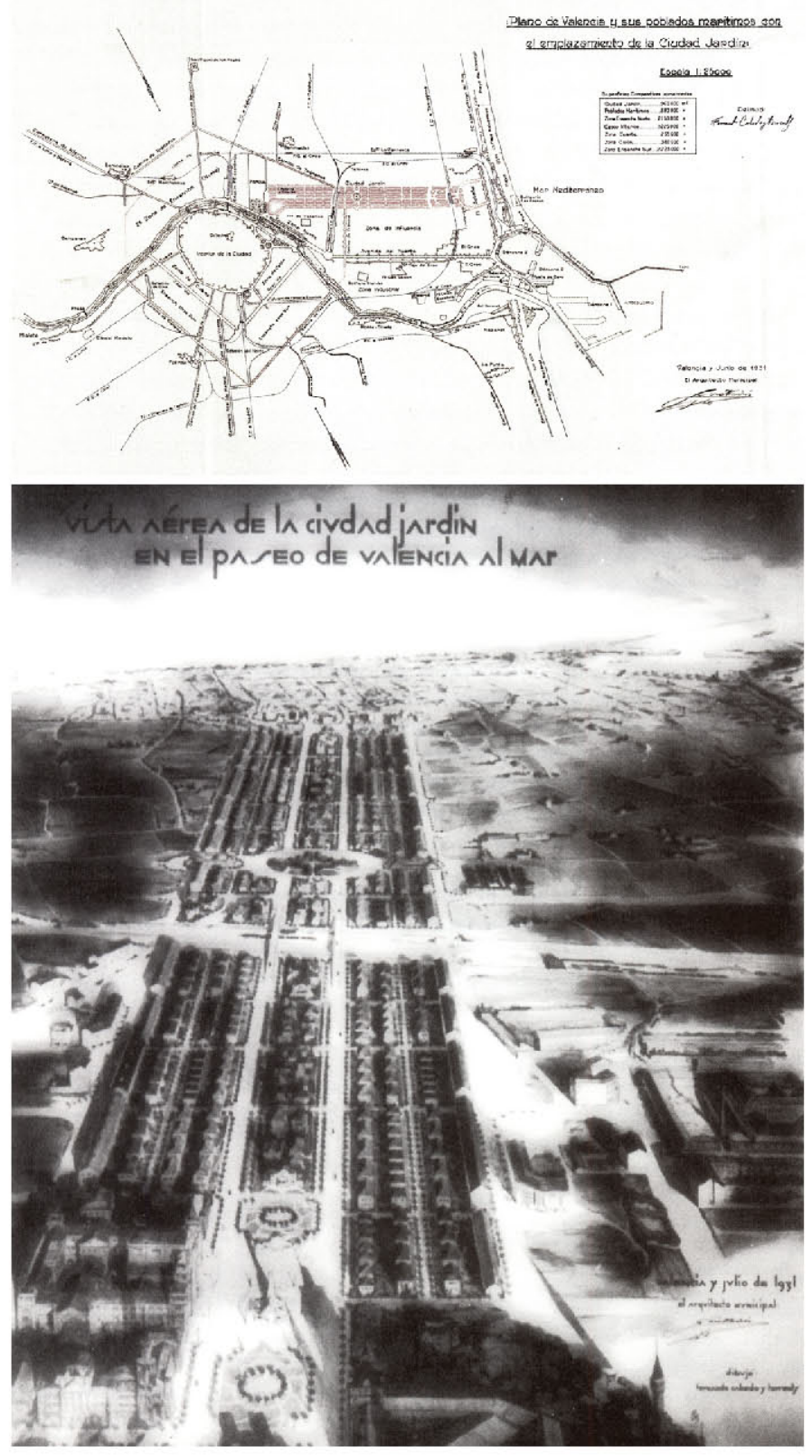

José PEDRós, 1931. Ciudad-jardín en el Paseo de Valencia al Mar. Perspectiva; relación del proyecto con el núcleo urbano y los poblados marítimos 
Levante, la de Nueva Habana, la Cañada o Campolivar. Edificar a escala humana, teniendo en cuenta la personalidad del individuo y su contacto íntimo con la naturaleza.

El interés entre los urbanistas por este modelo, como alternativa a un planeamiento de ensanche en crisis, se debe a su capacidad para conformar una nueva periferia. La "universalidad" de este instrumento urbanístico se debía a la posibilidad de elegir los lugares donde era posible implantar las ciudades-jardín, a la propia indeterminación de su tamaño, a su capacidad para absorber edificaciones con una amplia variedad estilística y tipológica, a la presencia del elemento verde, y a un cierto atractivo formal próximo al pintoresquismo ${ }^{6}$. No obstante, estas referencias al urbanismo anglosajón remitirían, perdiendo interés hasta agotar la posibilidad de manejar los poblados adyacentes como núcleos o barrios dormitorio, e implícitamente, malbaratando la recuperación del pretendido proyecto del Paseo de Valencia al Mar (fig. 4), ejercicio significativo, periférico de la urbe primigenia.

En cierto sentido, Albert lindó entre ambos frentes. Su plan global bien podría conjeturarse como praxis de la teoría germánica del zoning. Su triada tendría cabida encuadrada dentro de una actuación sistemática, orgánica, planimétricamente científica. Y a la par, sus propuestas fuera de la urbe, enarbolarían una descentralización casi anglosajona, una apuesta por la concordancia sincera entre los nuevos núcleos habitados y la naturaleza.

${ }^{6}$ BLAT, Juan. Op. cit. pág. 95 


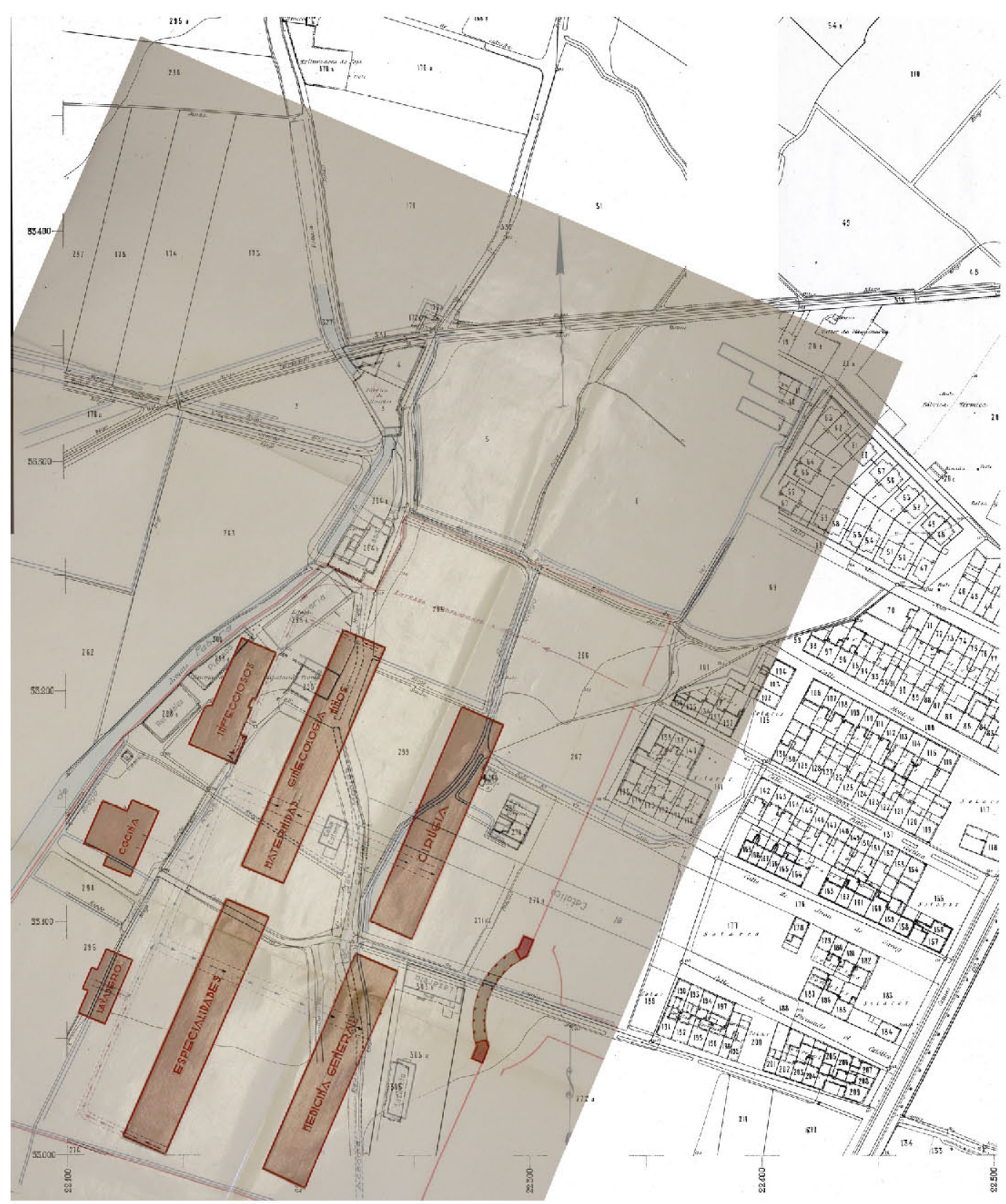

fig. 5

( superposición del proyecto de Albert para el Hospital Provincial en los terrenos de la Diputación 
Resultaba pues, planimétricamente, un somero inicio, una fútil inmersión en el hecho inherente de la urbanística moderna. Sin embargo, no parece aventurado referir la ausencia de un análisis riguroso de las densidades y los usos de las diferentes áreas urbanas del ensanche, quizá predispuesto por la impotencia de la Diputación frente al planeamiento urbano, impulsado mayoritariamente por organismos municipales. Si tras semejante carencia metodológica en un intento de zoning, tan solo derivan puntuales áreas vacías (fig. 5), solares dotacionales, tampoco parece producir mayores logros el insustancial acercamiento al microzoning, entendido como los desmembramientos de la gran urbe donde aplicar las teorías howardianas. La ampliación controlada de la ciudad quedaría reducida a un marcado empeño por abocar los beneficios racionales de la arquitectura y el urbanismo modernos.

Introducir en el terreno próximo a la ciudad aquellas piezas que no podía admitir la urbe moderna, la uniformidad del ensanche -planteado previamente en 1915 para Barcelona- reglando hacia el exterior de la metrópoli, industria, áreas verdes y de esparcimiento, vivienda de baja densidad, resultaba un buen principio. Conformar una nueva periferia, urgía frente a la inoperancia administrativa. Incapacitadas las fuerzas vivas de la ciudad para promover, ni tan sólo para proponer, proyectos urbanísticos que transformasen la urbe, unido al marcado carácter conservador y agrarista de sus dirigentes ${ }^{7}$, provocaría el anárquico crecimiento extrarradio sin planes globales que lo previesen.

7 GIRONA, Albert. "Una nueva forma de vivir: la urbe como modelo de atracción". Catálogo para la exposición realizada por el IVAM Centre Julio González, del 20 de enero al 5 de abril de 1998. "La ciudad moderna. Arquitectura racionalista en valencia". Volumen I. 


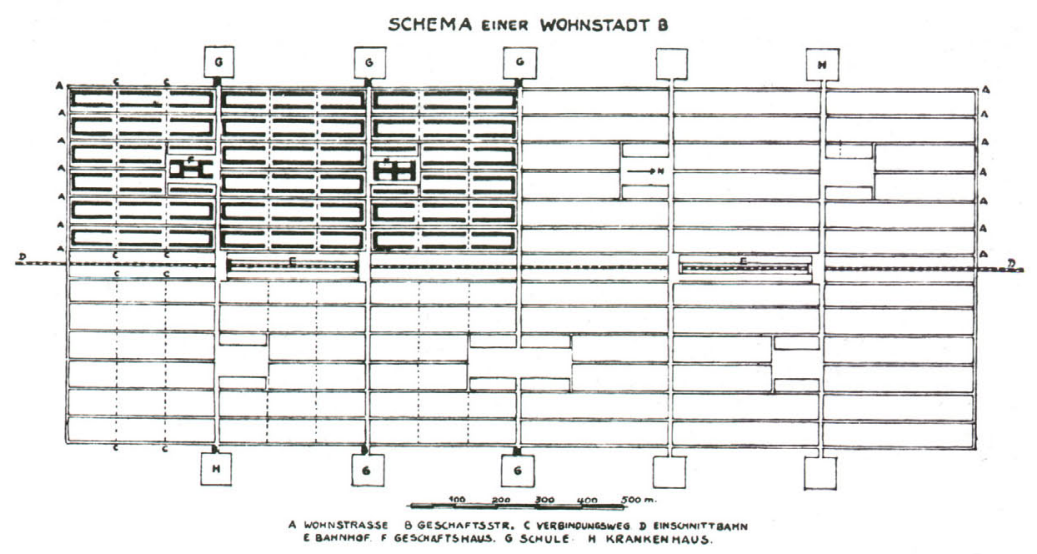

fig. 6
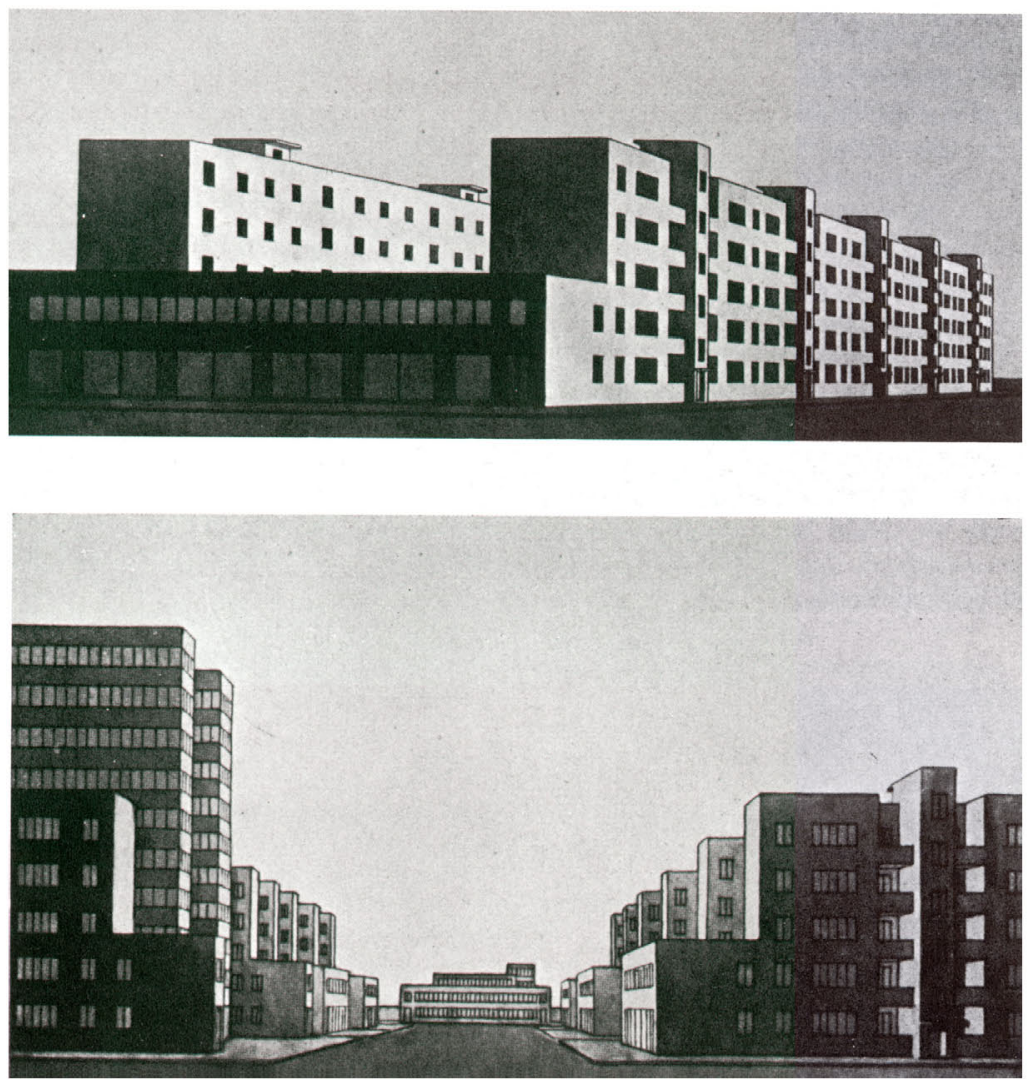

LUdwig HILBERSEIMER. Esquema de ciudad residencial; edificación en manzana abierta 
Frente al desentendido planeamiento municipal, a la autónoma transformación urbana, en los años treinta, de una ciudad en crecimiento, asoma la propuesta de Albert, unitaria, global, racional y moderna. Propósito que responde a las demandas de Hilberseimer-1927-para la ciudad del futuro: una formación metódica, de un organismo razonado; construida sistemáticamente, a partir de elementos, ordenándolos en un sentido completamente nuevo; que cumpla las exigencias urbanísticas básicas; de trazado claro y lógico; manzanas abiertas y ventiladas; con un ancho de calle proporcionado a la altura de los edificios (fig. 6).

Inevitablemente la realidad se empecinaba en oponerse a la teoría. La ciudad del futuro resultaría inabarcable y sucumbiría, concentrada en intervenciones puntuales, desde una dirección aislada. La individualidad de la propuesta -la triada albertiana- carecía de la potencia requerida, de la globalidad imprescindible para acometer un estricto y riguroso análisis de densidades y usos, para zonificar y planificar la nueva urbe pretendida. La ambición urbanizadora se desvanecería en un conato, una primera y puntual intención, restando el esfuerzo final en las actuaciones precisas limítrofes a la ciudad.

Plasmar las características intrínsecas de la ciudad jardín de Howard, en la ciudad sanitaria incorporaba profundidad programática a la proposición de Albert. Ebenezer Howard dispone la propiedad de la tierra a la titularidad pública; tanto el asentamiento como la población están determinados, su extensión y crecimiento son limitados; y su oportunidad y planificación constituyen una nueva pauta de equilibrio territorial y demográfico entre la ciudad y el campo. El pensamiento de Howard, por tanto, más que sintetizar un nuevo prototipo urbano, plantea un modelo 
de organización global de comunidades productivas autosuficientes. Es una apuesta explícita por la coexistencia entre industria y agricultura en el marco de una unidad residencial, con la finalidad de solucionar la expansión y la densificación indiscriminadas de las ciudades. Si bien no trataba Albert, la condición de autosuficiencia para su propósito, no resultaba óbice al resto de prioridades howardianas.

Una ciudad Sanitaria orgánicamente estructurada, limitada en extensión y crecimiento, prototipo urbano, comunidad en conclusión. Comunicada con la gran urbe de la cual se proclamaba consustancial, indivisible. Arquetipo de cohabitación interpolando ciudad y naturaleza. Asomaba la ambición programática de ésta ciudad en su denominación, en su encabezamiento. Efectivamente, existe en la génesis de la ciudad Sanitaria un componente socializante que pone parcialmente en relación esta intervención con el ideario primigenio de la ciudad-jardín. Restaría comprobar si los diagramas del modelo de Howard de 1902 -incluidos en Garden Cities for Tomorrow'- no se desvirtúan en pura geometría, se desvanecen relegando el trabajo racional y cartesiano, a la plástica formalización en su planimetría.

8 NIETO, Francisco J. "Tapiola: origen, evolución y prospectivas". Documents de Proyectes d'Arquitectura. Publicación del Departament de Proyectes d'Arquitectura de la Universitat Politècnica de Catalunya (UPC). Barcelona, 2006. pág. 20

9 HOWARD, Ebenezer. "Garden Cities for Tomorrow". Cambridge, Mass. Mit Press, 1965. 


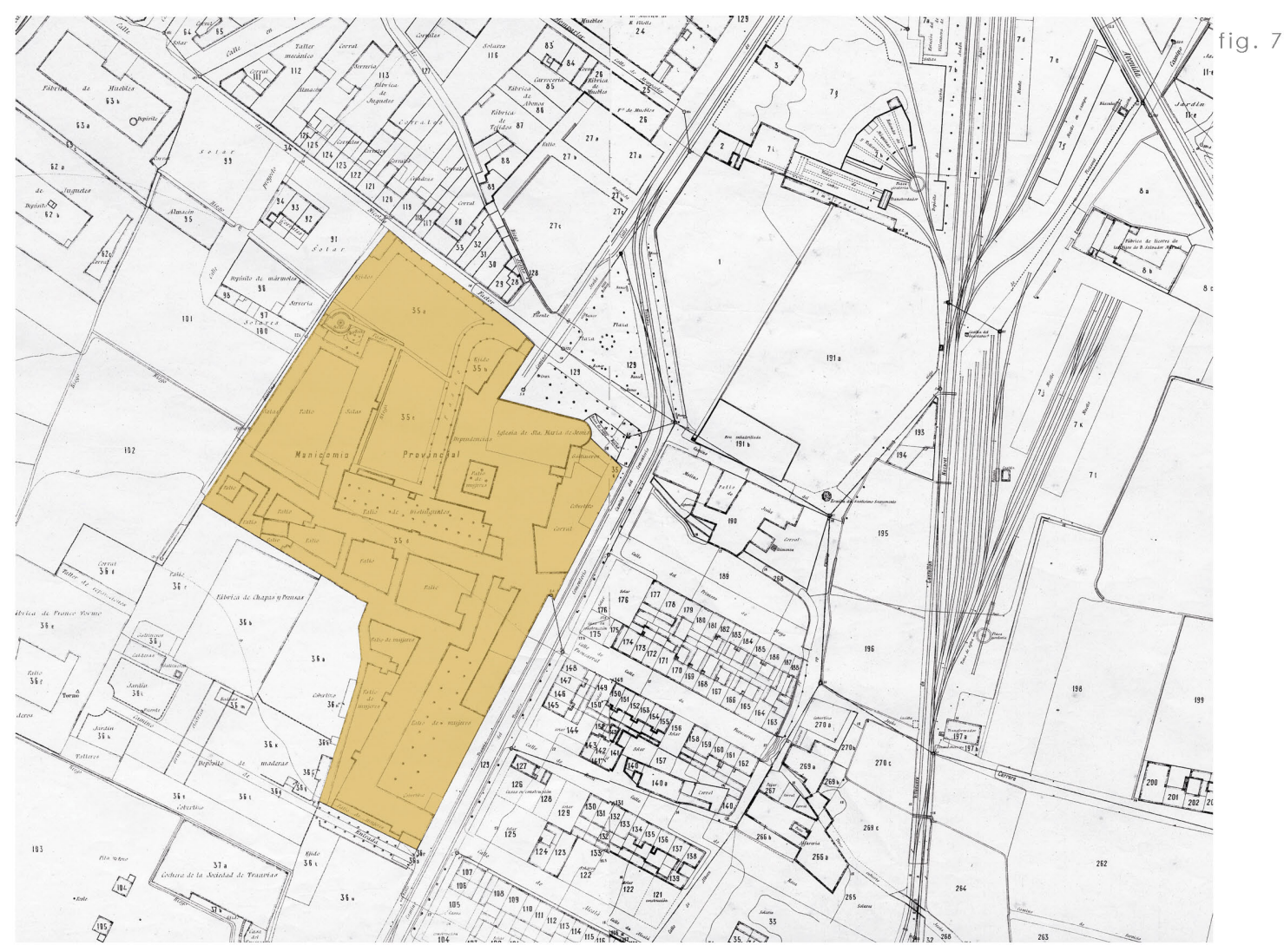

Instituto Geográfico y Catastral, 1930; plano del término municipal de Valencia, hoja 60 IV. Superposición del emplazamiento para Nueva Plaza de Toros, propuesta en Santa María de Jesús 


\section{COMPOSICIÓN VOLUMÉTRICA}

Extirpar del núcleo urbano -planificado para resolverse como ensanche residencial- formas y funciones arcaicas, transformar limpiamente la imagen de una ciudad en disposición de regenerarse atendiendo a las nuevas demandas de modernidad, refulgía en el propósito albertiano, despuntaba en el pensamiento global, analítico e impulsor de una ciudad dispuesta a su transformación acorde a la época.

Inquirir emplazamientos inéditos, adecuados a las nuevas demandas médicas, higiénicas y sociales conllevaría a concluir una ciudad Sanitaria -comenzada tiempo atrás, con la dirección de obra del Pabellón del Sanatorio Antituberculoso, cuyo proyecto ejecutivo llegaba impuesto desde Madrid- en un emplazamiento propiedad de la Corporación Provincial, la finca Porta-Coeli, facilitando trámites y con ello agilizando económicamente la gestión. "Las condiciones deficientes que tiene el actual Manicomio Provincial de Jesús de Valencia (fig. 7), ha motivado el que durante mucho tiempo haya tenido la Excelentísima Diputación el pensamiento de la construcción de uno nuevo". 10

Dispuesto, el arquitecto de la Diputación Provincial, como proponente, a abandonar el actual entramado de la calle Jesús - de cuyo vaciado surgirá el emplazamiento para la nueva Plaza de Toros- señalaría Porta-Coeli para administrar el nuevo Manicomio Provincial. Enclave óptimo para trasladar el centro Sanitario -nos lo presenta Albert como recomendado por los propios médicos directores del actual centro- asociado a excelentes, concretas condiciones, para su ubicación y su construcción, circundado

10 albert ballesteros, Luis. "Memoria de proyecto del Manicomio Provincial". Valencia, julio de 1933. Archivo de la Diputación Provincial de Valencia. pág. 1 


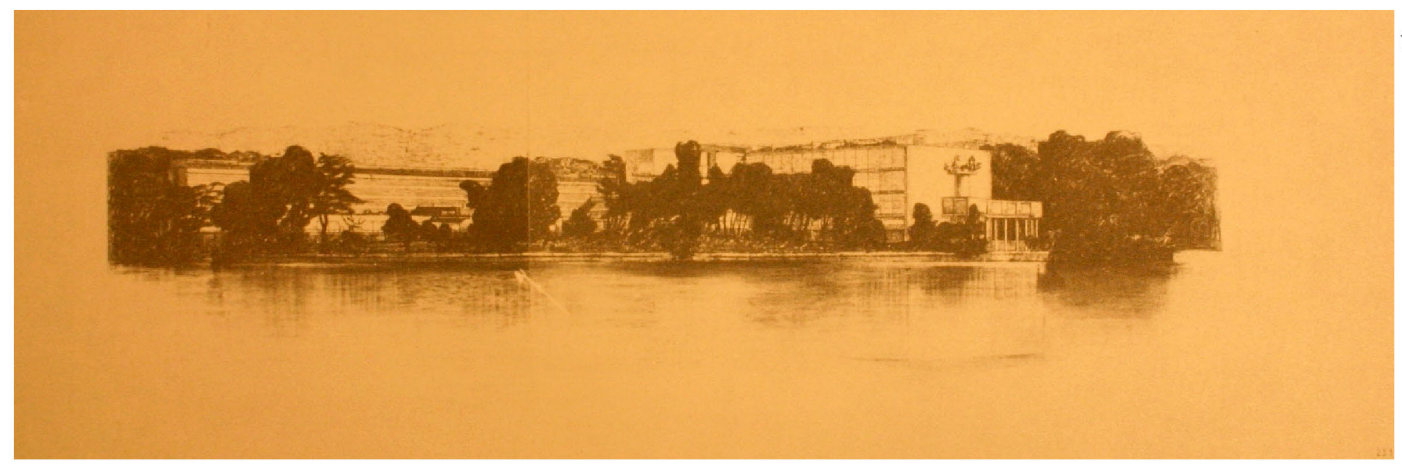

fig. 8

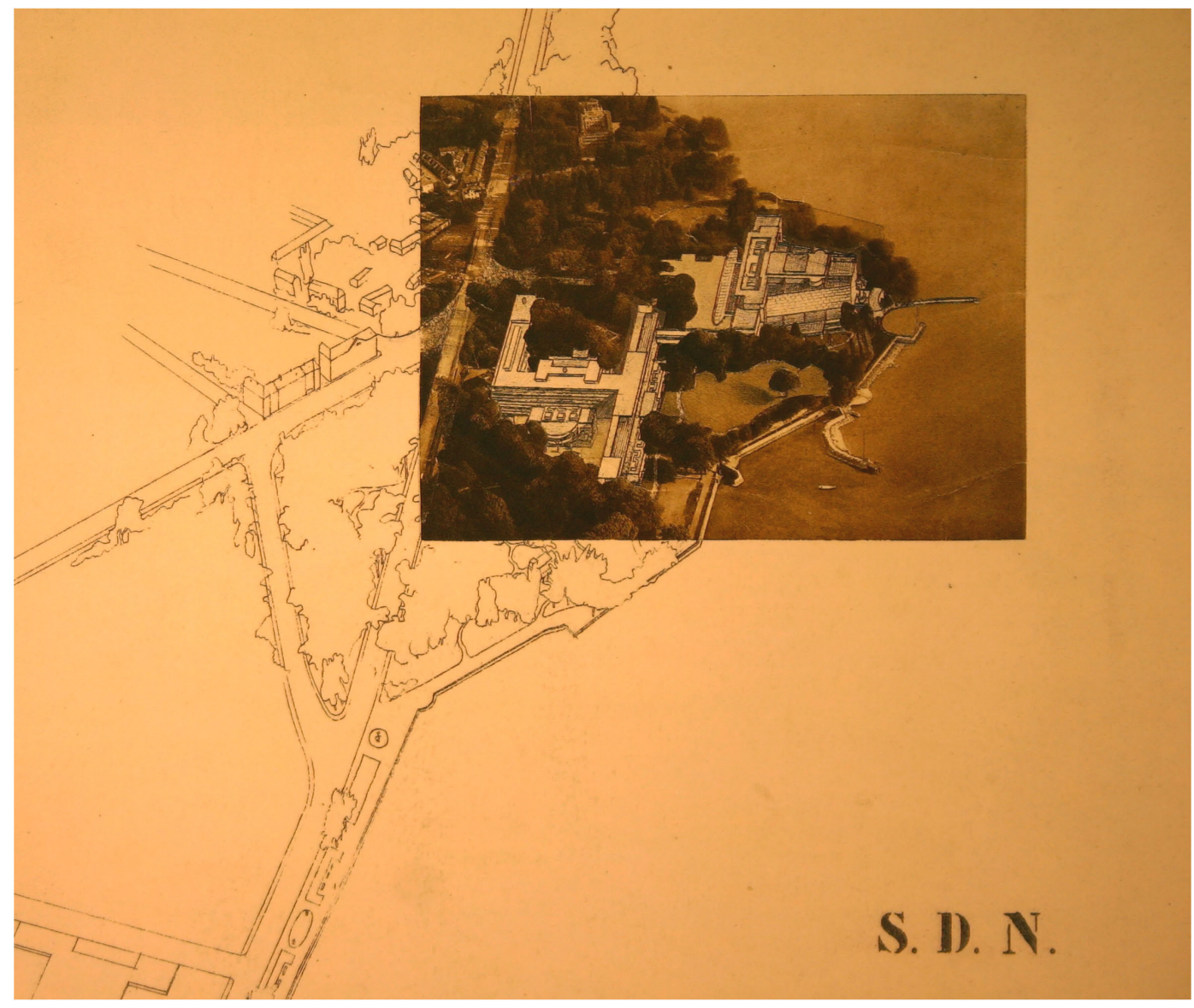

Le CORBUSIER, 1927. Palais de la Societé des Nations. Genève, Suisse; fotomontaje alzado y emplazamiento. Propuesta de concurso (imágenes Fundación Le Corbusier 
por un excelso bosque de pinos y a una distancia prudencial de la Capital, con una rápida comunicación por carretera.

Magnífica oportunidad abierta para imponer una microciudad moderna, descentralizada, orgánica y científicamente planeada. La máquina de habitar trasladada a una abordable escala urbana, cuyos condicionantes los singularizaba su propio autor. Un marco propicio donde proponerse las teorías racionalistas sobre ordenación y territorio, donde enfrentar las ideas de ciudad-jardín que parecen intuirse en la propuesta de la ciudad Sanitaria.

Retoma el problema de plantear un proyecto carente de condicionantes urbanos, sin líneas de ordenación predeterminadas, ausentes los hitos edilicios, exento en definitiva de referentes. Deberá pues, el proyecto, proclamar sus planteamientos iniciales, sus premisas germinales y solucionarlas como método proyectual sin aceptar ningún a priori. Albert esboza su primera hipótesis, subdividiendo los problemas impuestos y razonando desde lo simple hacia su complejidad. Entiende así, la ordenación de un programa complejo como una composición por elementos, por partes, reordenándolos hasta conseguir acoplar, a la luz de la razón y la experiencia, el resultado arquitectónico. Una premisa académica, desarrollada racionalmente -por ende universal, intemporal- para plantearse la arquitectura, su sistematización.

Subsumir del objeto, del Manicomio, sus componentes funcionales y posteriormente plantear un nuevo montaje por piezas indivisibles, por elementos irreductibles, por pabellones aislados, pone de manifiesto un 


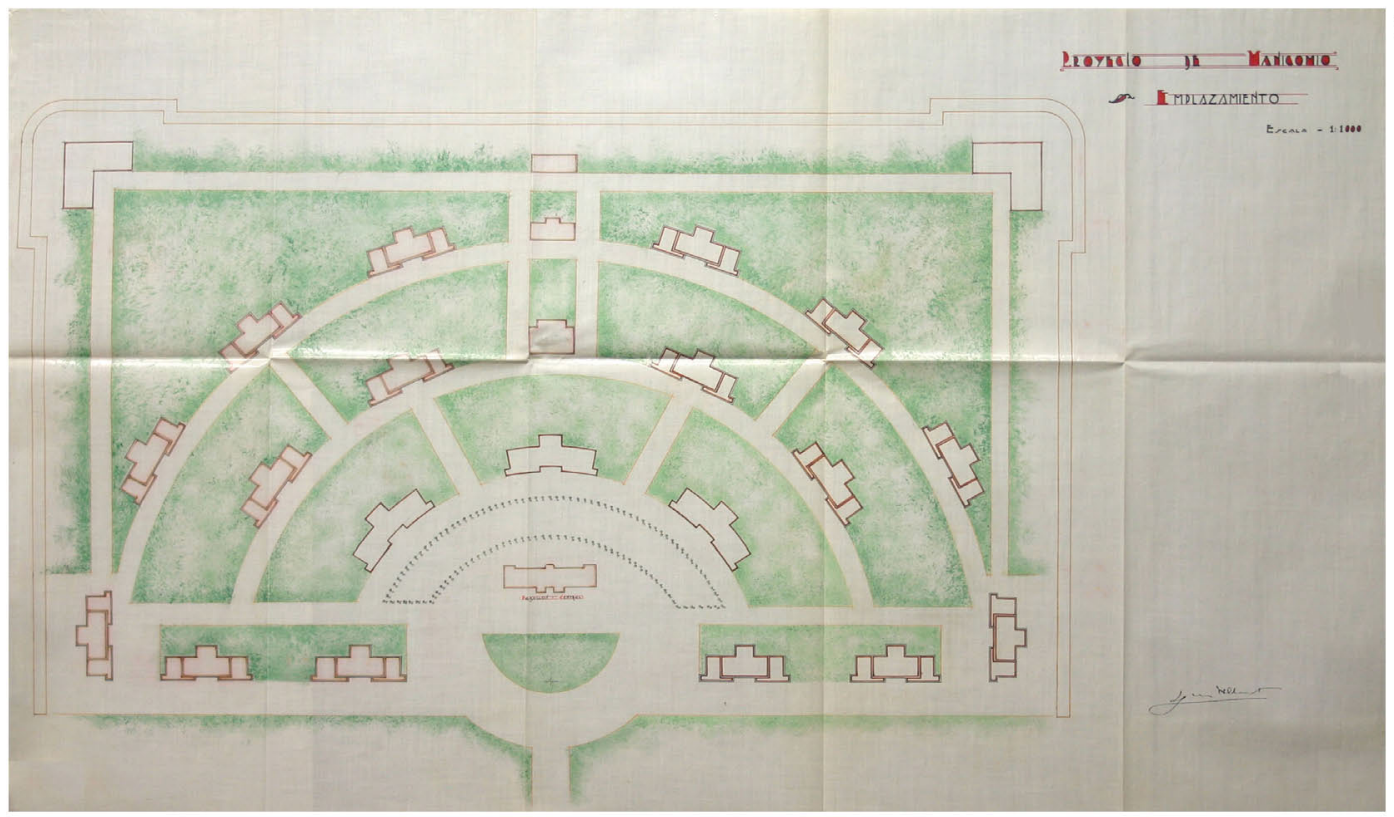

fig. 9 
racionalismo cartesiano ${ }^{11}$, una científica sistematización, probablemente exacerbada en su geometría elementalista. Aislados en oposición a la excepcional capacidad en la concatenación de heterogéneos volúmenes funcionales, después de haberlos distinguido'2. Aislados en oposición a la metodología explorada y desarrollada por Le Corbusier, en el proyecto para el concurso de la sede de la Sociedad de Naciones de Ginebra (fig. 8), sin limitar a condicionantes geométricos, transformaciones y conexiones volumétricas.

Proyecta Albert, un sistema de pabellones aislados, donde la naturaleza parece asumida para interconectar con el programa sanitario, coexistir. Característica intrínseca de la ciudad-jardín howardiana, resulta su segunda premisa proyectual. Oportuna planificación dotada para equilibrar territorial y demográficamente ciudad y campo. Organizados bajo un orden superior, los pabellones se someten a una estricta geometría semicircular, tal cual los diagramas modelo de la ciudad (fig. 9), que en 1902 propuso el reformista anglosajón. Una ciudad cuyas circunferencias se ocupaban mediante células residenciales a partir de un centro dotacional, circunferencias reservadas a zonas verdes y limitando la concluyente para la industria, alejada así del hábitat.

"Un sistema radial de Pabellones aislados, alrededor del Pabellón Central de Administración" citando al propio Albert, cuyo centro genera una disposición concéntrica de pabellones Generales, albergando a los diversos pacientes. Un total de diecinueve pabellones y un radio vertical que,

11 MONTANER, Josep Maria. "La modernidad superada". Op Cit. pág. 61

12 ZEVI, Bruno. "Espacios de la arquitectura moderna". Editorial Poseidon, S.L. Barcelona, 1980. Título original: Suazi dell'architettura moderna. pág. 154, 155. 

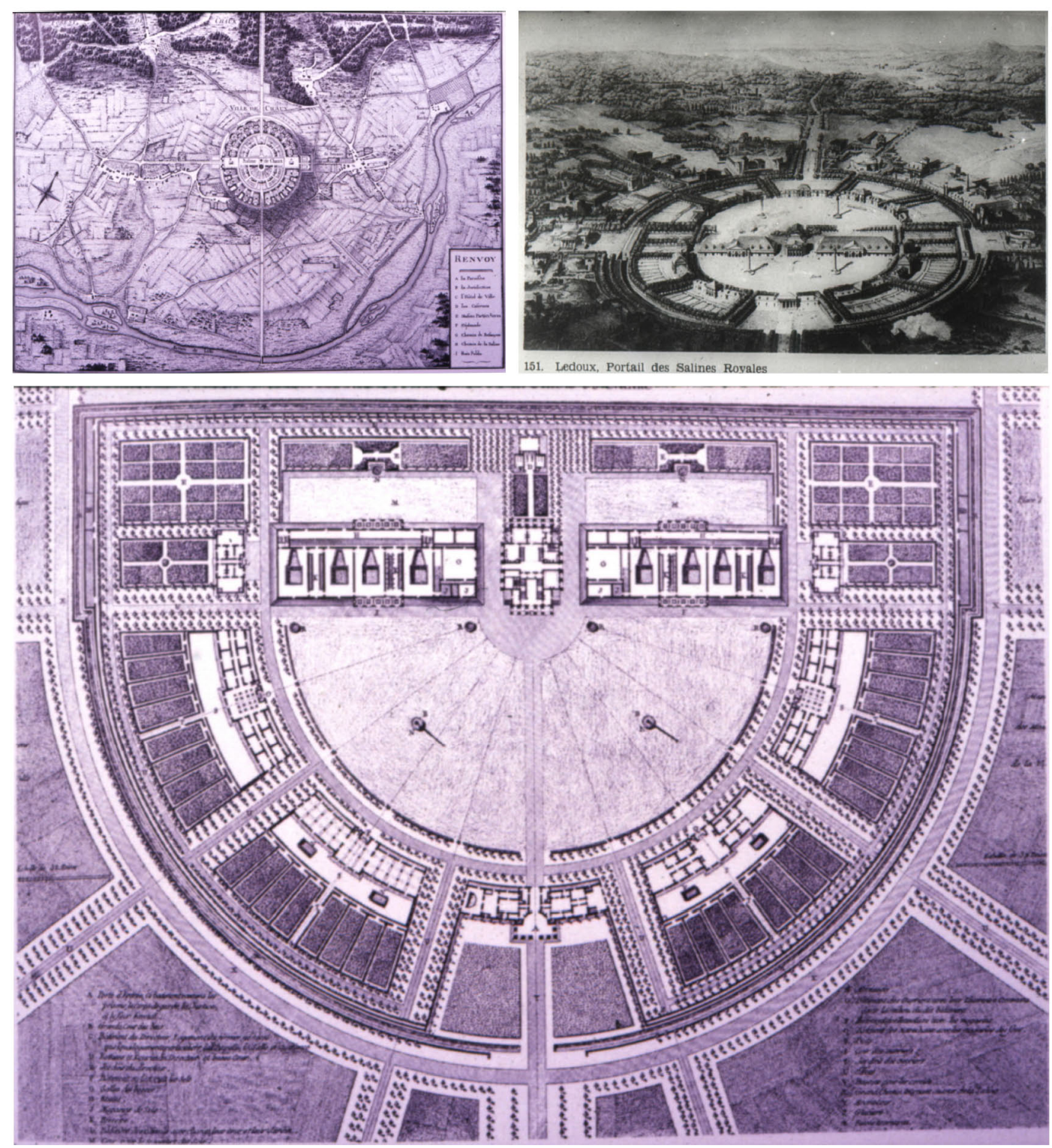

Claude-Nicolas LEDOUX, 1775. Salines Royales de Arc-et-Senans, ville de Chaux; complejo semicircular, intención de una organización jerárquiça en la disposiçón del trabajo 
sesgándolos, genera un eje de simetría donde acoger los pabellones de servicio y apoyar al resto de funciones. En ambos vértices superiores, de los dos cuadrados que envuelven a la semicircunferencia, culminan sendos pabellones especiales -no tan sólo por su disposición, también su volumetría difiere del resto- que responden a las necesidades de Viviendas y Peligrosos.

Presentar un frente de pabellones -con enfermos de pago pacíficos que al disponerse más próximos y visibles formarán un conjunto de vistas más simpático ${ }^{13}$ - perpendiculares al recorrido externo que lleva al Manicomio, gestiona el diámetro que secciona la circunferencia, visualiza un primer perímetro construido y, permite señalar el centro geométrico. El pabellón Central de Administración. La pieza elegida para dar fin al eje visual y de recorrido, que acompaña hasta el acceso al Centro.

Resulta complejo entrever el componente socializante, la ambición programática de la ciudad-jardín, perdida en una pretendida oferta visual capaz de postergar al ostracismo aquella parte no mostrable, por incomoda para la moral de la sociedad moderna.

Amanece entonces una ordenación, una propuesta donde la relación forma-función y la geometría generan el discurso arquitectónico. Una gestación volumétrica ya expresada en las Salinas de Chaux (fig. 10) por Ledoux, la Ville Sociale ${ }^{14}$, ensayada mediante una forma circular, un anillo formado por las residencias con los servicios comunes, mientras que

${ }^{13}$ ALBERT BALlesteros, luís. Op. cit. pág. 2

14 ZEVI, Bruno. "Espacios de la arquitectura moderna". Op. cit. pág. 6 


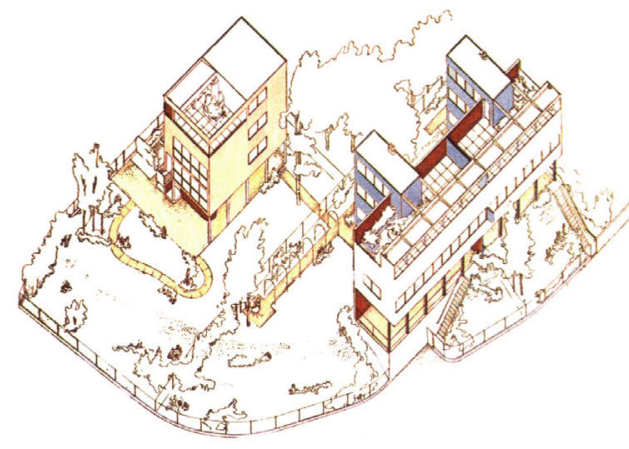

fig. 1
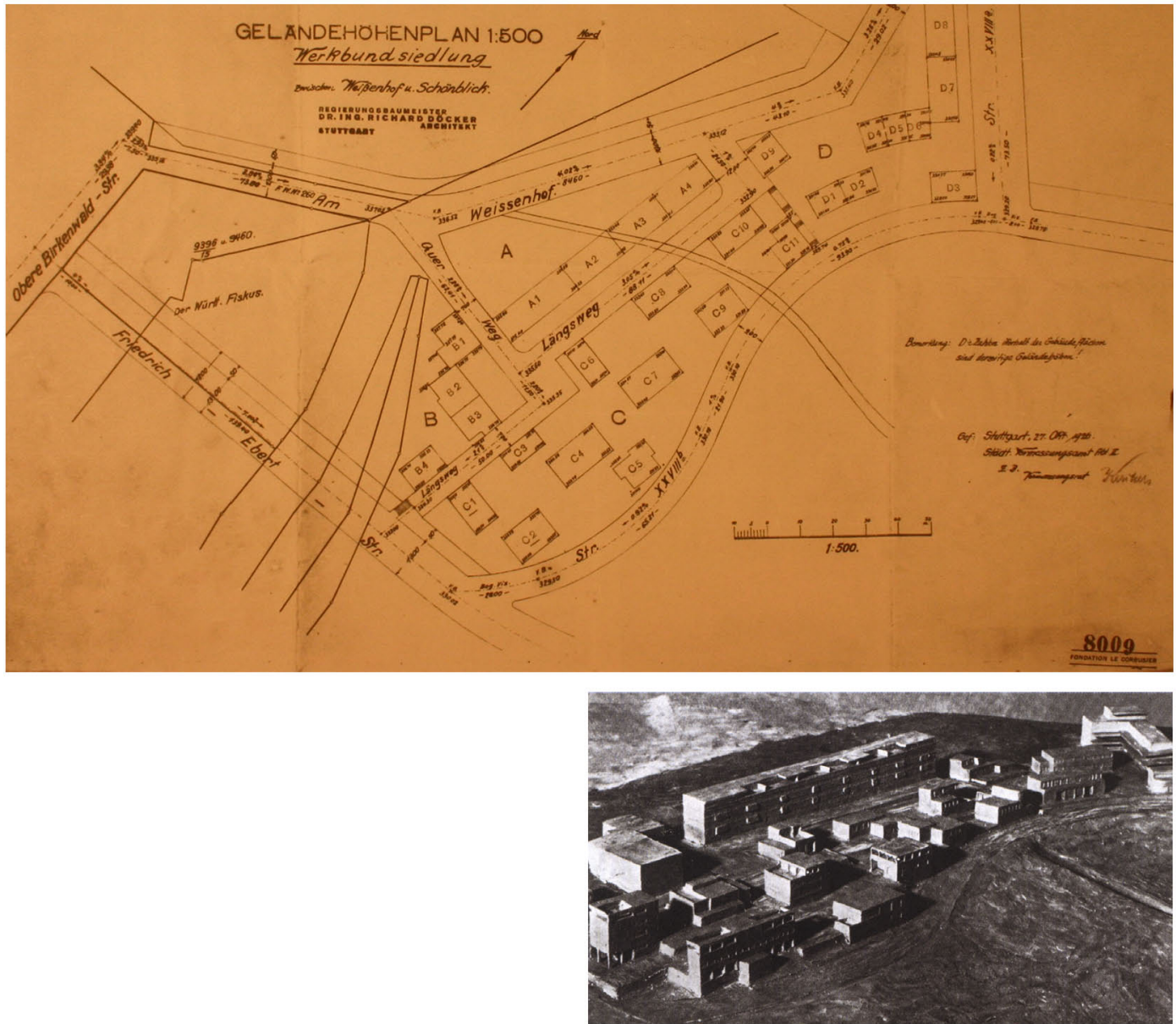

Le CORBUSIER, 1925-1927. Inmuebles para la Weissenhofsiedlung en Stuttgart: plano de emplazamiento (fundación Le Corbusier) y maqueta de la ordenación para la Exposición 
a todo lo largo del diámetro, a ambos lados del eje central, se ubicaban las industrias. Amanece un estricto sistema geométrico de alineaciones concéntricas donde, esta vez sí, aplicar los principios racionalistas de ordenación.

Mies van der Rohe firmó el plano regulador, la concepción para la ordenación de las Weinssenhofsiedlung (fig. 11), la primera manifestación de la arquitectura moderna en Alemania. Un laboratorio para las nuevas formas de vivienda, para la aplicación de los modernos métodos racionales en arquitectura, para las nuevas construcciones y materiales, para mostrarse los jóvenes impulsores de los principios racionalistas. Una manifestación formal de la nueva Arquitectura. Stuttgart acogería en 1927 la Exposición la vivienda de la Deutsche Werkbund, la Weissenhofsiedlung, y con ella las teorías de Hilberseimer frente a la ciudad-jardín, considerando problemas como el terreno, la orientación respecto al soleamiento y ventilación e incluso razones más elevadas y de interés Arquitectónico, como premisas proyectuales a la hora de abordar la disposición de los edificios que formalizan el conjunto del proyecto y su ordenación final.

Albert no trabaja en un encargo de semejante trascendencia, no obstante, maneja con soltura los principios elementalistas y el discurso social de Guadet, Laugier y Ledoux. Se había convencido en sus conocimientos acerca del urbanismo alemán, de la propuesta miesiana para Stuttgart y de su antagonista opción anglosajona ${ }^{15}$. Y sin embargo acabarían siendo ingobernables teorías, principios no incorporados como premisas proyectuales, resignándose a un escueto orden geométrico, una sistematización

${ }^{15}$ COHEN, Jean-Louis. "Mies van der Rohe". Ediciones Akal, S.A. pág. 52 
1- 4 Ludwig Mies van der Rohe (Am Weißenhof 14-20)

5- 9 J. J. P. Oud (Pankokweg 1-9)

Victor Bourgeois (Friedrich-Ebert-StraBe 118)

Adolf G. Schneck (Friedrich-Ebert-Straße 114)

Adolf G. Schneck (Bruckmannweg 1)

Le Corbusier mit Pierre Jeanneret (Bruckmannweg 2)

14-15 Le Corbusier mit Pierre Jeanneret (Rathenaustraße 1-3)

Walter Gropius (Bruckmannweg 4)

Walter Gropius (Bruckmannweg 6)

Ludwig Hilberseimer (Rathenaustraße 5)

Bruno Taut (Bruckmannweg 8)

Hans Poelzig (Rathenaustraße 7)

Richard Döcker (Bruckmannweg 10)

Richard Döcker (Rathenaustraße 9)

Max Taut (Bruckmannweg 12)

Max Taut (RathenaustraBe 11)

Adolf Rading (Am WeiBenhof 22)

6-27 Josef Frank (RathenaustraBe 13-15)

28-30 Mart Stam (Am Weißenhof 24-28)

31-32 Peter Behrens (Hölzelweg 3-5)

33 Hans Scharoun (Hölzelweg 1)

Houses 16-20, 22-25

were not reconstructed

according to the old

design.

House 21

was not reconstructed.
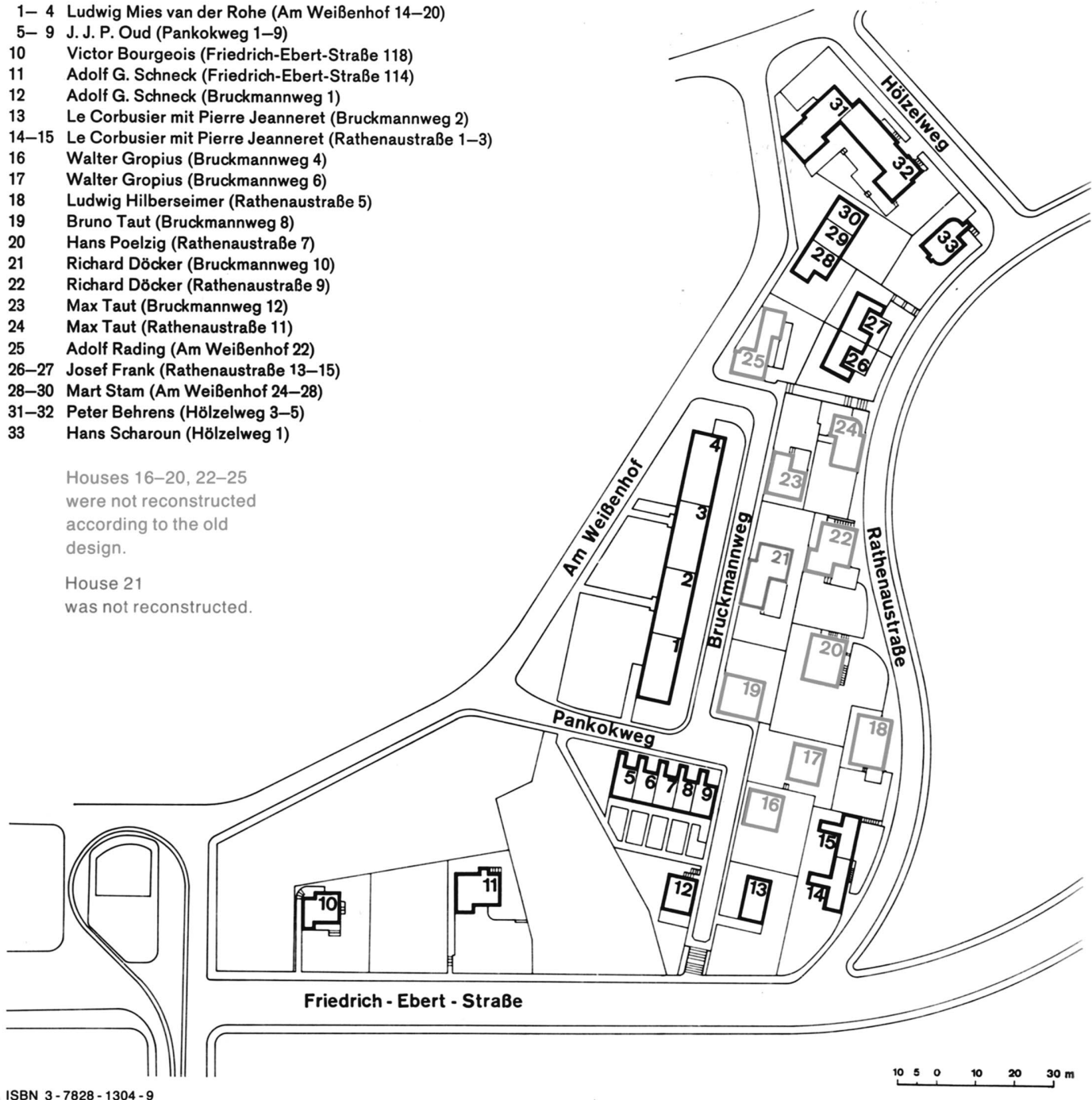

ISBN 3 - 7828 - 1304 - 9 
gráfica, variando elementos en respuesta a la función que debiesen albergar.

Una elementalista ${ }^{16}$ disposición volumétrica -falta de la evolución y manipulación racionalista de sus contemporáneos- fundamentada en la sencillez geométrica y en la simetría, rige la ordenación de la propuesta. Una disposición de construcciones para resolver de manera escrupulosa el programa requerido, propia de los albores del siglo, resulta el planteamiento inicial y concluyente, para solventar el proyecto. Su génesis y, al momento su ocaso, su declinación.

Gobierno formal, influencia del carácter compositivo, frente a las concepciones cartesianas, funcionalistas, racionales y modernas. Abandono de la zonificación y el estudio de las conexiones entre usos, de la circulación, frente a la potente imagen prestada por la axialidad, por la repetición y por la simetría. Arquitectura pendiente de si misma, frente a una arquitectura lógica, liberada de esa carga iconografía, en donde sin prejuicios enfrentarse a los problemas a resolver, utilizando la metodología apropiada. Resulta curioso comprobar cómo es necesario el uso de la totalidad de los datos y cómo no da producto la falta de tan sólo uno de ellos ${ }^{17}$.

16 FRAMPTON, Kenneth. Op. cit. pág. 160

17 DE LA SOTA, Alejandro. "Por una arquitectura lógica", Quaderns d'Arquitectura i Urbanisme, número 152, mayo-junio de 1982. Escrito recogido de la publicación "Alejandro de la SOTA, Arquitecto". Ediciones Pronaos, S.A. 1989. Segunda edición, pág. 225 


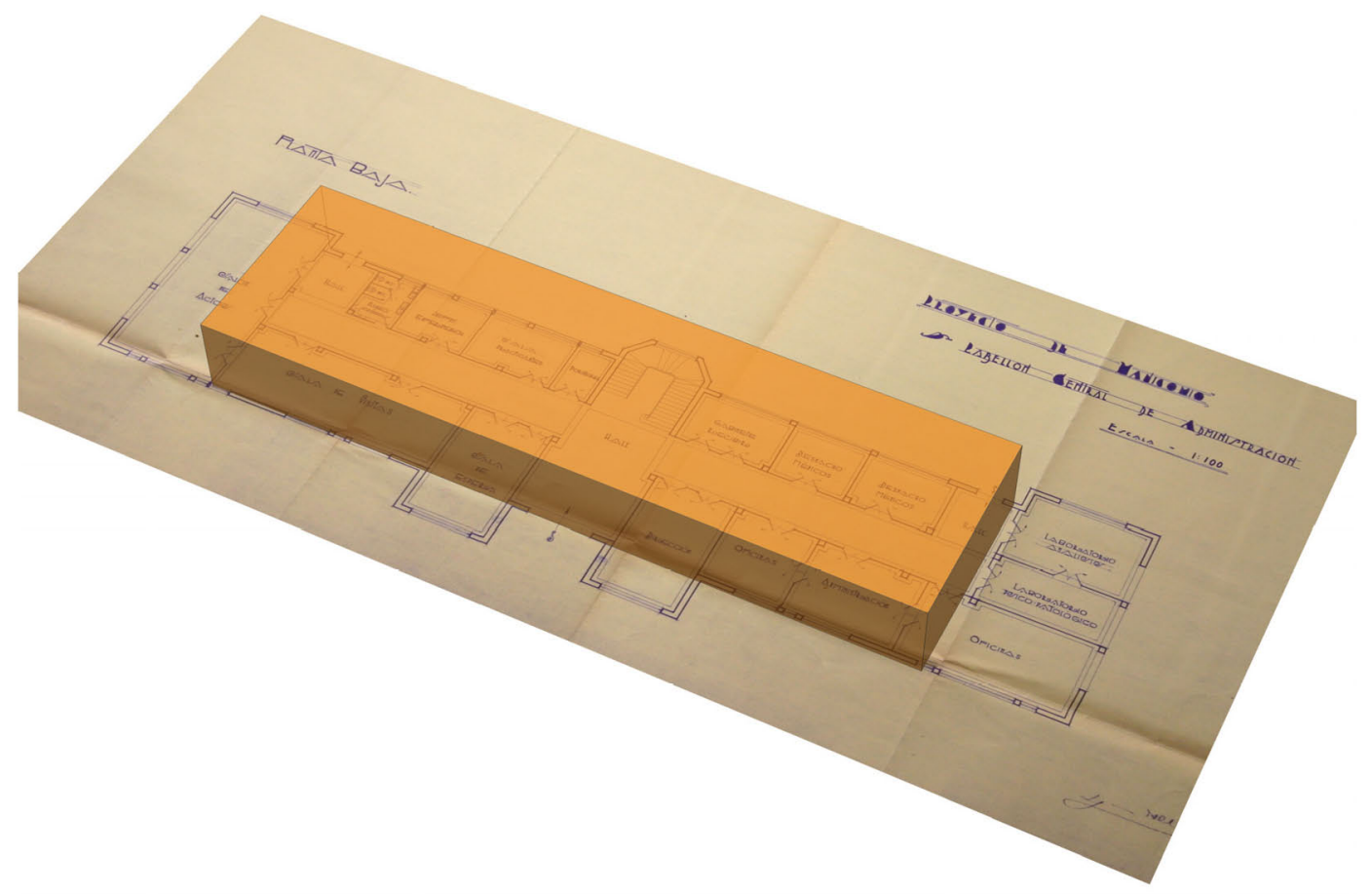

LUis ALBERT, 1925-1927. Manicomio Provincial de Valencia, proyecto para la Diputación Provincial. Pabellón General de Administración; geometría y dinamismo en su línealidad como génesis 


\section{ORGANIZACIÓN FUNCIONAL}

Forma-función parece regir como premisa proyectual en la organización del conjunto Médico. Disponer diferentes volumetrías, moldearlas según el uso pretendido, repetirlas hasta completar el programa de necesidades para, en el último acto, componerlas ordenadamente y formalizar la ordenación, resurgen del académico método con el cual atender un proyecto, resolviendo el programa. Una respuesta a las dispares funciones requeridas desde el centro Sanitario, como premisa gestante.

Finalmente resulta un organismo fragmentado en sectores funcionales, donde cada elemento irreductible encuentra su propia forma, respondiendo a la función que lo requiere ${ }^{18}$. Cada uno se presenta subsumido y dispuesto independiente a los demás. Exclusión, desconexión frente a la yuxtaposición de formas -tal como proponía Gropius en el pabellón del Werkbund en la Exposición de Colonia de 1914- y evidentemente sin aspirar a un ensamblaje unitario a la manera corbusierana, citado con anterioridad, para la sede de la Sociedad de Naciones de Ginebra.

Rechazado un único cuerpo orgánico, jerarquizado, sistemático, surge preciso organizar la circulación que relacione el cúmulo y, siendo improbable otro postulado desemejante, se hacía preciso acudir nuevamente a la geometría. Radial, desjerarquizada en sucesivos arcos de circunferencia, manifiestamente simétrica y enormemente simple, que no sencilla, la matemática planimetría limita la razón analítica -aquella apoyada en la distinción y clasificación- a un proceso gráfico, compositivo y desligado

18 'En los momentos culminantes de la búsqueda de la utilidad, el racionalismo en arquitectura coincide siempre con el funcionalismo'.

MONTANER, Josep Maria. "La modernidad superada". Op. Cit. pág. 67 

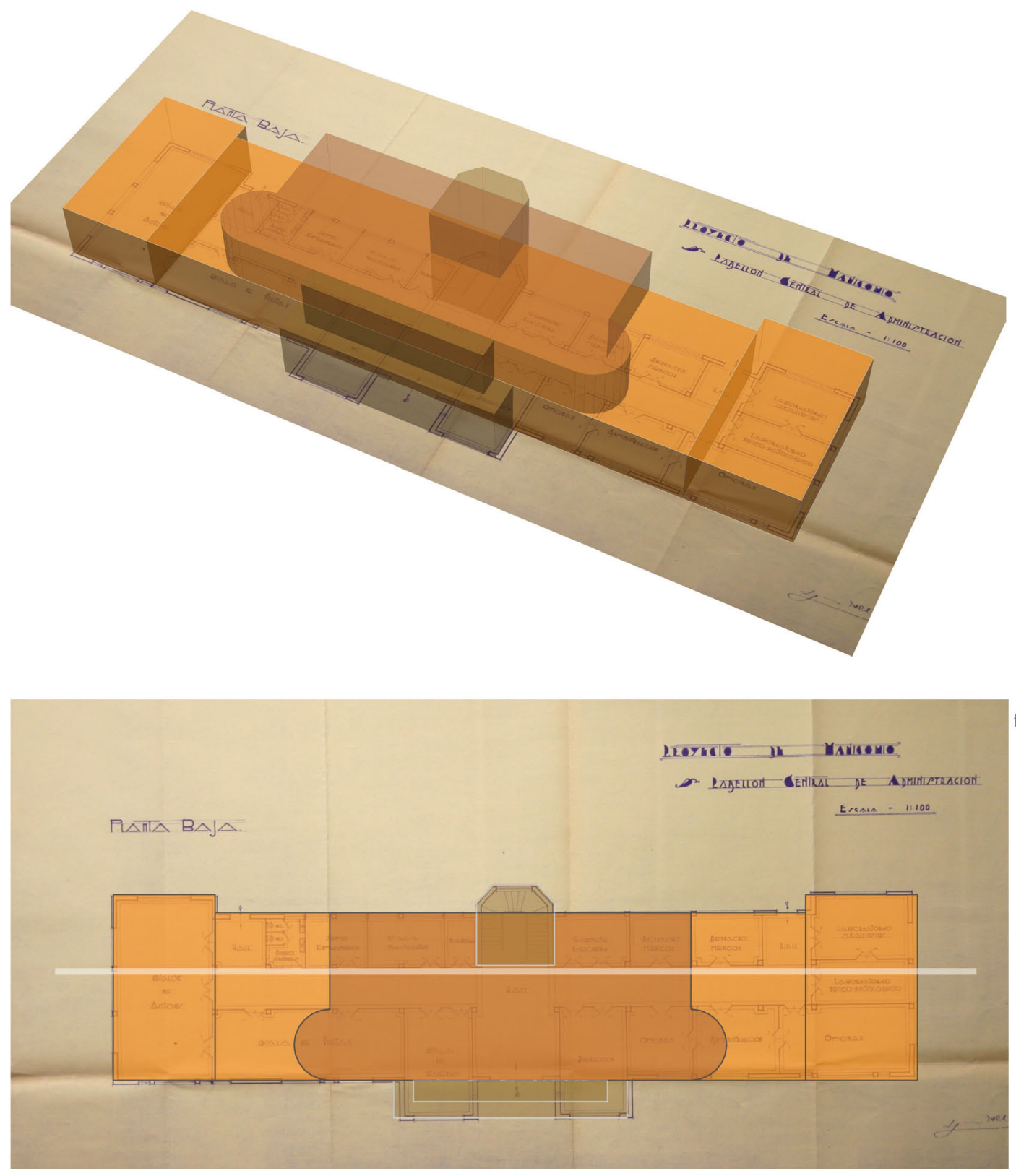

Manicomio Provincial. Pabellón General de Administración; fotomontaje doctorando maqueta virtual sobre planimetría original (AEDP): relación forma-función tras reelaborar la geometría primaria 
de la abstracción. Desvinculada de la topografía presente, desdeñando irracionalmente las orientaciones, las visuales y las afinidades, todo el esfuerzo se concentra en contactar con el punto central, principio del radio, donde albergar el pabellón general de administración.

PABELLÓN CENTRAL DE ADMINISTRACIÓN. Asoma esta pieza, erigida promenade visual y recorrido iniciático, como acceso al complejo sanitario proyectado por Albert. Meticulosamente elaborado, resulta el final de un eje de recorrido externo que, tras alcanzar un vacío circular -punto central de la circunferencia gestora de la ordenación del Manicomio- tropieza con el pabellón, circundado de forma visible, por el resto de pabellones dispuestos en sucesivos semicírculos.

Volumen prismático - de base rectangular-, dinámico y hasta platónico en su concepción, avanza linealmente, componiéndose y transformándose conforme a su acusado eje longitudinal. Su evolución formal detenta por premisa responder a las funciones que alberga, adhiriéndose una tras otra a la línea arquitectónica promotora del dinamismo (fig. 12). La simetría como ley ordenadora, la repetición y por ende la armonía distancian el planteamiento lineal del modo racionalista de entender la génesis. Plausible resulta la detección del problema que suscita la línea aplicada a la arquitectura, esto es, la premisa consabida que repetir elementos seriados implica una solución desigual en los extremos. Configurar adecuadamente los límites.

Menos racional resulta la simetría como ley generadora, la repetición y por ende la armonía, distancian el planteamiento lineal del moderno modo de entender la génesis. Funcionalmente propone el autor, concretar 


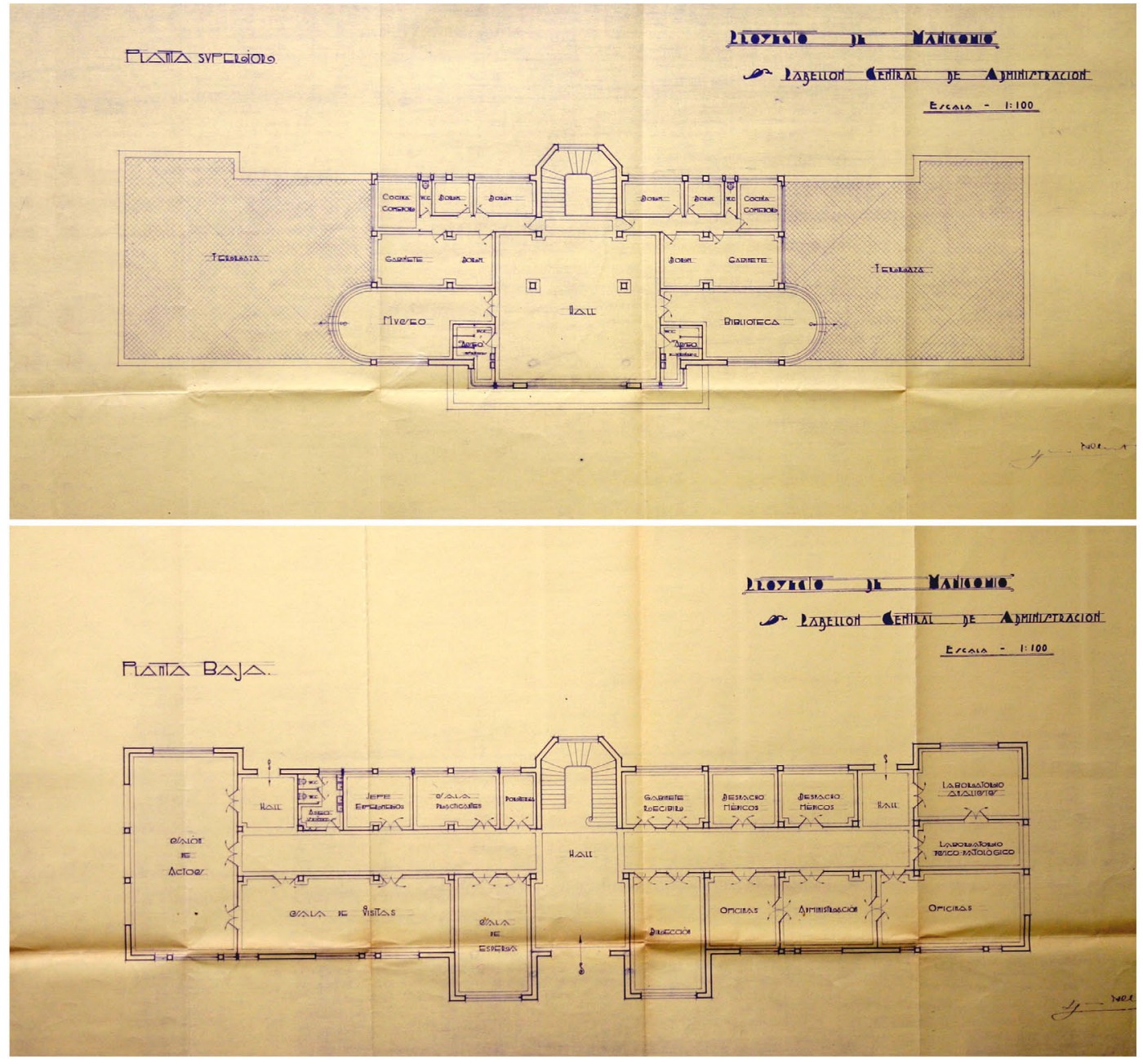

Luis ALBERT, 1935. Planimetría del pabellón General de Administración, plantas baja y primera: Archivo de la Excelentísima Diputación Provincial de Valencia (AEDP) 
la planta baja destinándola al trabajo administrativo y de recepción externa al Centro. Un salón de actos - de uso dispar a las propias tareas de administración- perpendicular a la serie lineal responde al límite volumétrico, empero pierde su concordancia, su correspondencia simétrica, en el extremo opuesto que alberga módulos para trabajo interno. Una particular ruptura para una disposición tan rancia en su simetría, reforzada al ubicar el acceso al edificio, centrado y transversal al mencionado eje, disociado del núcleo vertical de comunicación encajado exactamente tangente a la línea arquitectónica.

Discurren los recorridos horizontales, nuevamente desplazados del centro geométrico, paralelos al eje longitudinal. El final de los pasos -punto de especial interés proyectual- oferta tan sólo uso representativo en un extremo, si bien el opuesto se pierde en funciones menores, debido al forzado, atemporal esfuerzo por reafirmar la simetría y ofreciendo por respuesta una equivalente conclusión, académicamente compuesta, volumétricamente análoga, no obstante de una calidad espacial mermada por la sucesiva fragmentación, manteniendo pareja cota de techos. Extremada preocupación formal y geométrica, germen del discurso proyectual, que concluirá forzando una solución menos ortodoxa, abandonando opciones como encontrar la luz, experimentadas, coetáneas y racionalistas.

Pierde la planta superior el carácter dinámico y longitudinal, para concentrarse en torno a una desmesurada sala de recepción-comparando asume mayor proporción que los espacios a los que sirve- estática y centrada, asistida por una enjuta terraza dominando el acceso al centro Sanitario. Abrazándola aparecen, simétricamente, el museo y la biblioteca, 

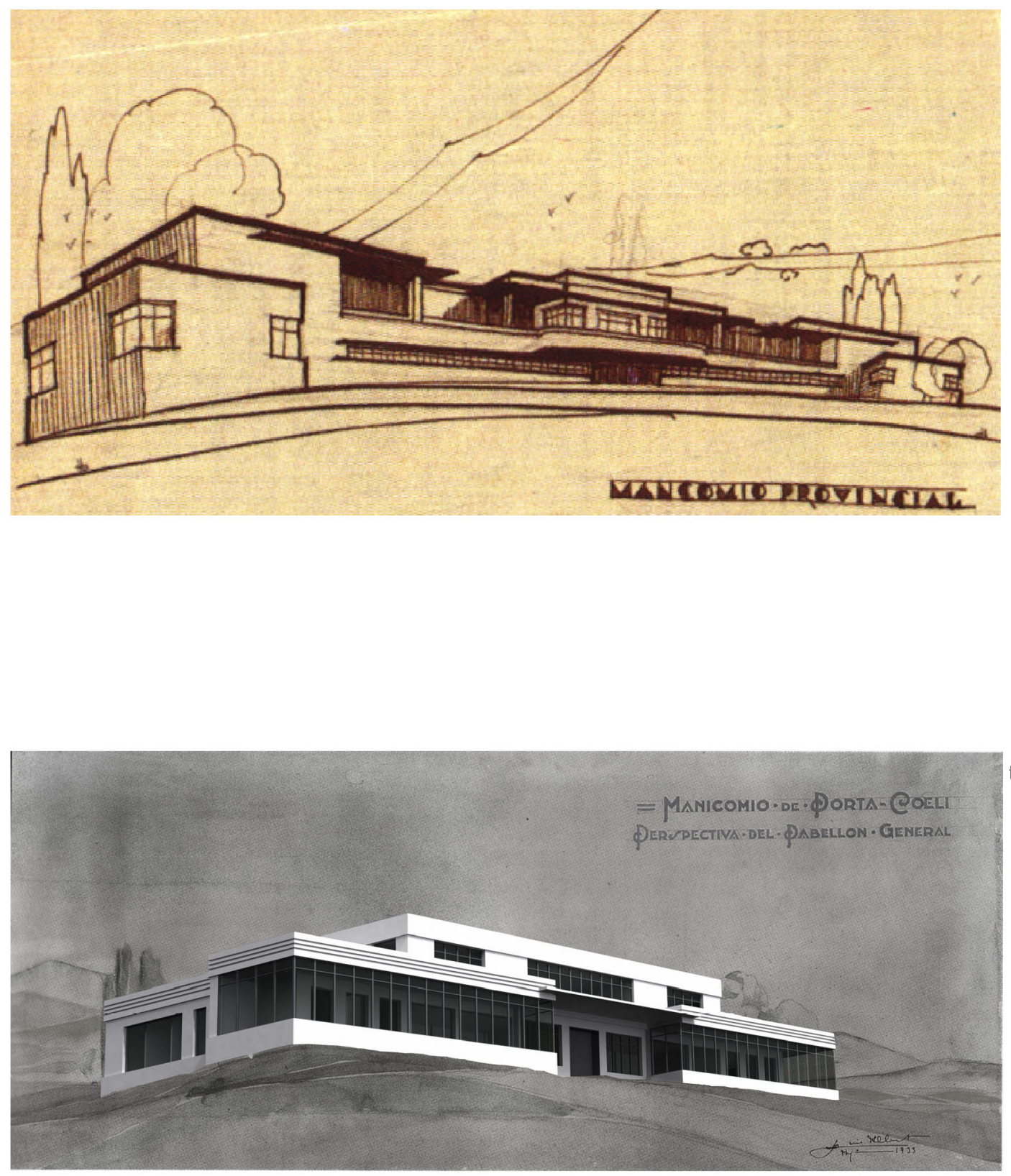

Luis ALBERT, 1935. Perspectiva del pabellón General de Administración (AEDP); maqueta informatizada doctorando, del pabellón General, repetido como tipología ordenadora 
austeros espacios con funciones representativas, de uso externo, ahora con generosas terrazas restituyendo el contacto con el terreno, recordando la pérdida de inmediatez externa. Otras funciones internas de Administración -los dormitorios, gabinetes, pequeñas cocinas y serviciosfinalizan los usos a distribuir. Nuevamente, las terrazas desestiman un tratamiento moderno, capaz de albergar un interés superior al de su métrica como superficie. Solarium, zonas de sombra, vegetación, agua, son problemas a incorporar en la cubierta, desde el movimiento Moderno, sin haberse retomado en el discurrir de esta propuesta.

PABELLÓN GENERAL. Sería injusto no reconocer el avance cartesiano en esta tipología de pabellones, frente al empecinamiento geométrico y de simetría del pabellón anteriormente descrito. Viene a mostrarse como la tipología por excelencia del complejo Sanitario. Alcanza protagonismo, no tan sólo por resultar la pieza más repetida de toda la ordenación, a lo largo de los anillos que la configuran, también su evolución compositiva, formal la deslizan hasta acaparar menesteres figurativos (fig. 13). Muy posiblemente, esa primacía provocó la atención y concretó el trabajo de Albert, repensando y elevando la complejidad de su estudio, focalizando, reduciendo a la esencia su discurso.

Una construcción que redispuesta en la primera semicircunferencia, aquella más distanciada del centro, forma el perímetro donde disponer a enfermos gratuitos, pacíficos. El diámetro horizontal que secciona la circunferencia -desvaneciendo su cuadrante inferior- materializa una inminente línea de pabellones para enfermos pacíficos, esta vez de pago. Maniobra consciente con el firme propósito de cercar tras un perímetro exterior -resuelto y aviado, como se ha indicado, para pacientes pacíficos- 

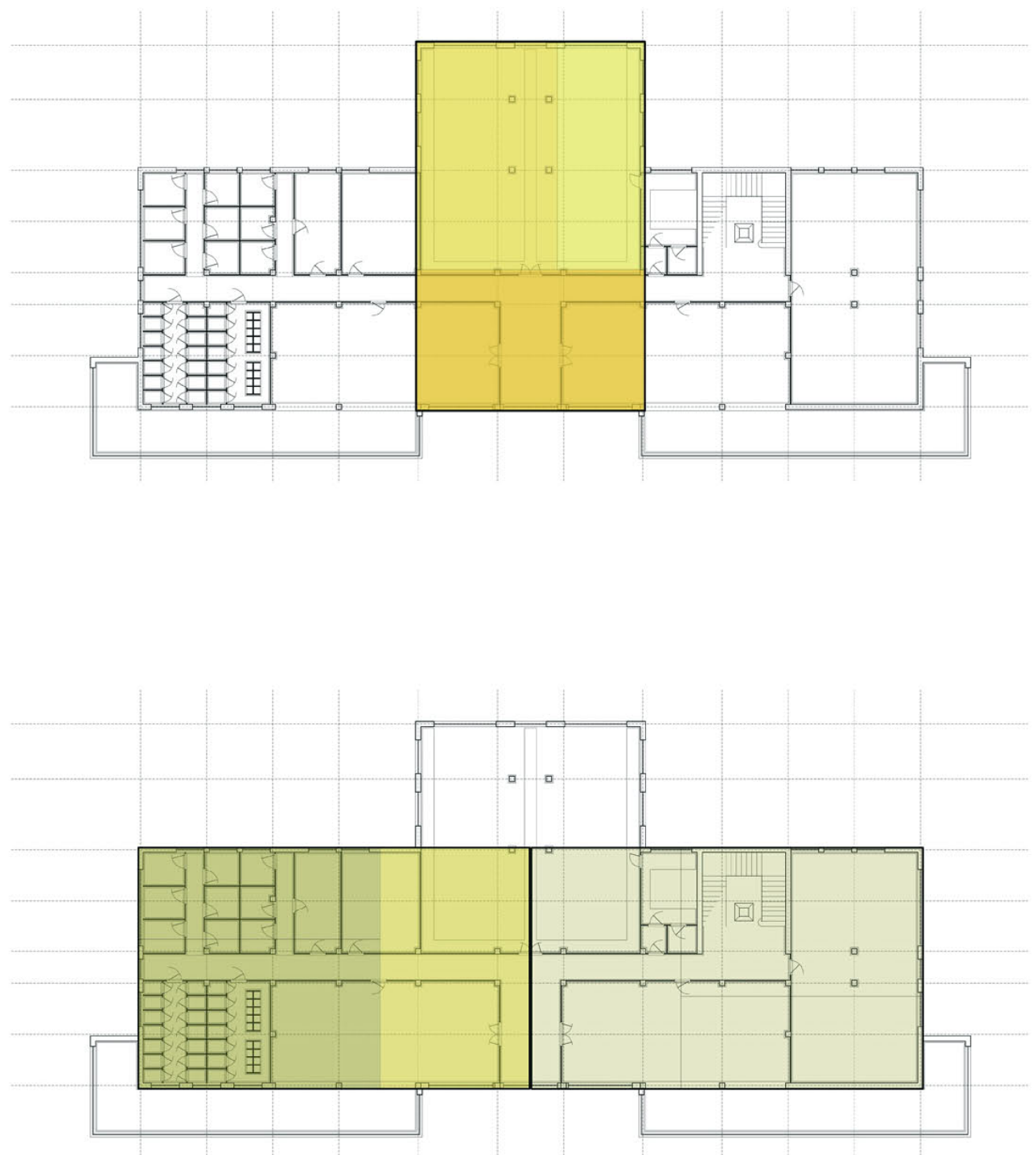
a dos semicírculos interiores donde despachar los alterables. La igualdad social, capaz de equiparar frente a las adversidades, como premisa racionalista, no parece calar en los pretendidos proyectos Sanitarios.

Ordenar un programa mediante elementos irreducibles, integrados en una disposición matemática, un trazado geométrico, se insinúa como primera premisa o requisito proyectual. Definir estas piezas acorde a las funciones requeridas tras el encargo, actúa de mecanismo para resolver los diferente volúmenes, elementos dispares, partes de una composición entendida como método para resolver la ordenación de un programa complejo.

Singularizar un elemento seriado, diferenciar la figura por excelencia y sin embargo la más reiterada se aviene como segunda premisa. Su composición, su específica variación de la forma genérica, áurea (fig. 14), así lo esboza. La presunción de linealidad, el dinamismo formalizando las partes, al menos y, generalmente los elementos más importantes.

Junto a las anteriores, una última premisa, desarrolla la manera racionalista de enfrentarse a un proyecto, supuesto que recupera una determinada estética, adscribirá los edificios al Estilo Internacional, y esta no es otra que los volúmenes horizontales, los huecos corridos o rectangulares y repetidos y el color blanco de los paños ${ }^{19}$. Mantener el criterio de condicionar la forma a la función que alberga, habría de mostrarse como hipótesis de partida, aquella que gesta la totalidad de pabellones y por ende,

19 CApitel, Antón. "Alvar Aalto. Proyecto y método". Ediciones Akal, S.A. 1999. Madrid. Colección Akal arquitectura. Volumen 18, pág. 13. 

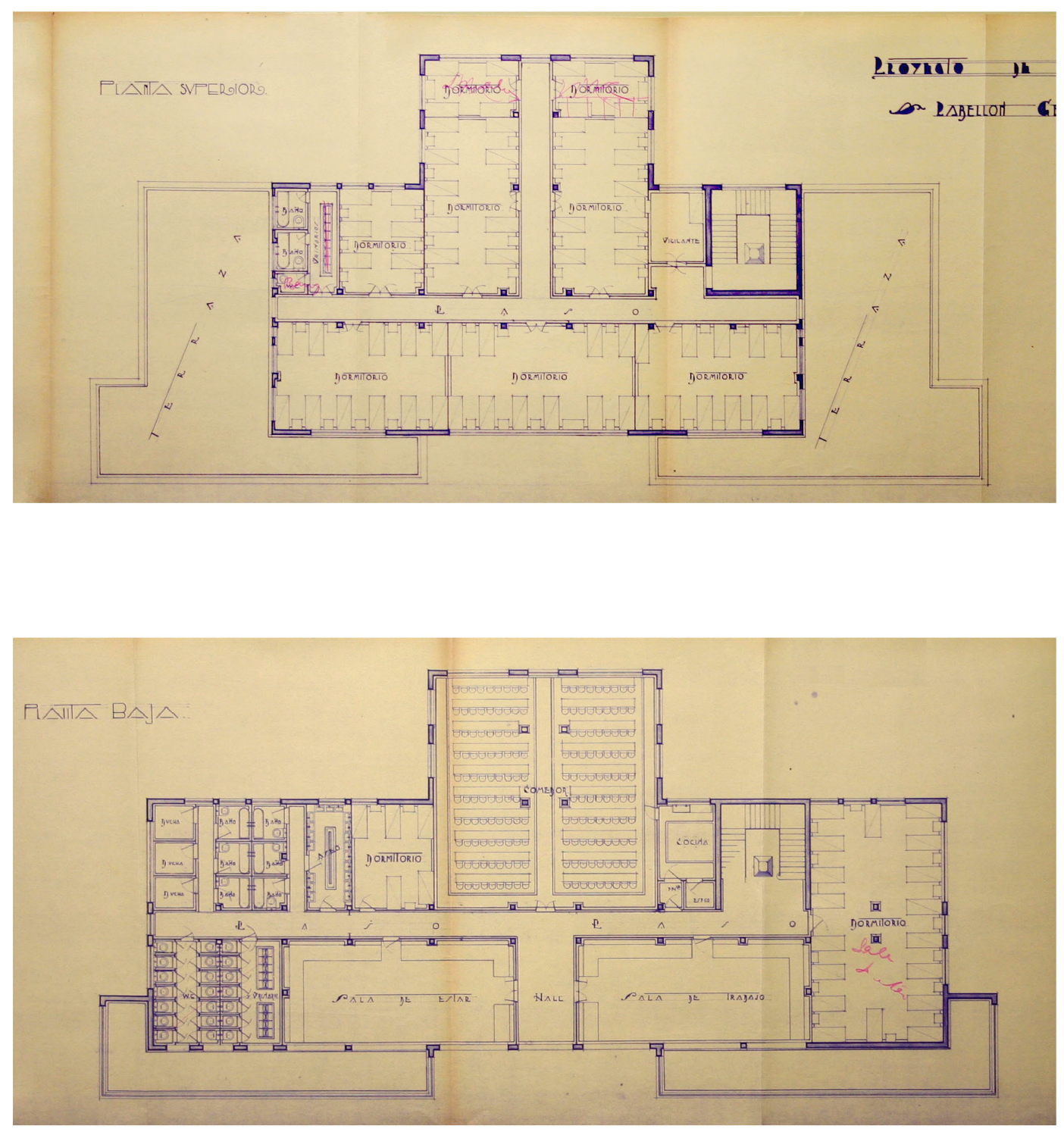

Luis ALBERT, 1935. Planimetría del pabellón General, plantas baja-con corrección manuscrita-y primera; Archivo de la Excelentísima Diputación Provincial de Valencia (AEDP) 
también los pabellones Generales. Formados exclusivamente por salas dormitorio, salas de trabajo y receso, comedor y los correspondientes servicios sanitarios, la reubicación de usos resulta su génesis.

Sin abandonar la geometría como base generadora, quedamos facultados para apreciar el rectángulo áureo dominando la traza planimétrica. Una dupla, simétricamente dispuestas en planta, confirma el concluyente rectángulo circunscrito. Cruzado, en el propio eje de simetría, un nuevo rectángulo transversalmente dispuesto, merma el dinamismo volviendo a concentrar las intenciones en el centro geométrico, receptor del acceso. Particularmente, resulta más aparente la simetría formal de lo que realmente gestiona respecto a la disposición de funciones. Se hace más compleja la distribución, abandonando la sencillez de jerarquizar usos en sección -uso específico por planta-y se llega a un modelo donde la función principal, los dormitorios, discurren en ambas plantas, sin una razón justificada de relación interna con el resto, ni tan siquiera de relación directa con el uso exterior.

Si atendemos a la corrección manuscrita, caligrafía del arquitecto, variando el plano correspondiente a la planta baja (fig. 15) -desdeñado en los archivos de la Diputación Provincial de Valencia- observamos recomponerse la jerarquía de usos por niveles y retornar el precepto de configurar los límites en la línea arquitectónica. Había mostrado Albert su conocimiento y pericia en semejante requisito proyectual ya, en el pabellón de Administración y, vuelve a ejercitarse ahora, restringiendo a uno la conclusión a través de la función, del uso representativo. El opuesto confín, parece reforzar la intencionalidad de eludir un espacio figurativo y concluyente, capacitado para dotar de final al dinamismo lineal, 
fig. 16
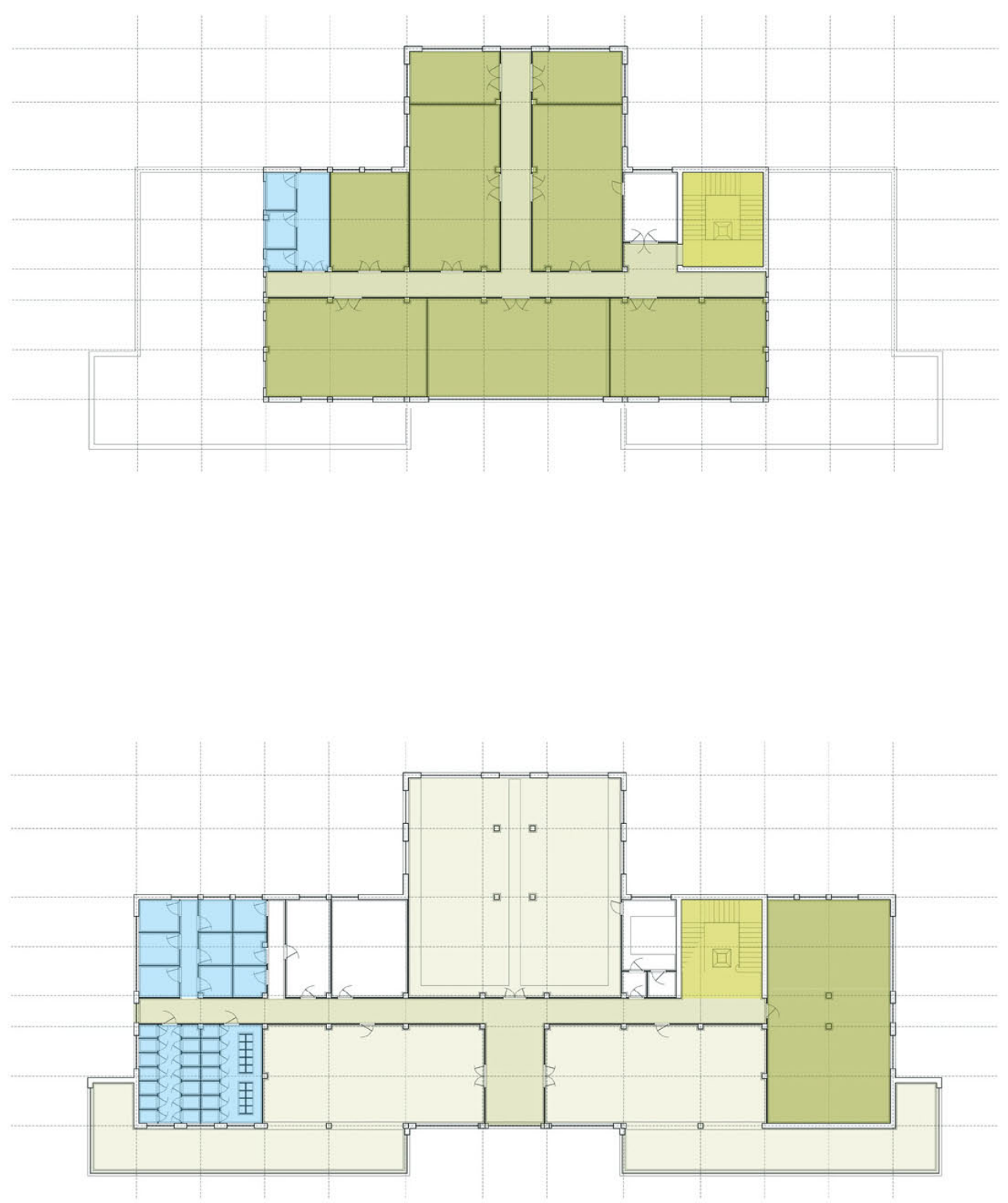

Planimetría redibujada doctorando donde plantear el análisis funcional del pabellón; sobre una retícula de ejes organizadores se ordenan las distribuciones en planta baja y primera 
manifestando en su ausencia la conexión con el espacio exterior, la luz. Nuevamente fracturado al máximo, con piezas menores, ahora serviles y recayendo a la galería acristalada -propósito figurativo, coadyuvando al carácter iconográfico-parece arremeter a la simplicidad repetitiva en la distribución. Asoman contradicción y ambigüedad, consientes en la idoneidad simétrica formal, contestada por el propio autor desde la asimetría distributiva.

Académico, inadaptado a las circunstancias y corrientes del momento, resulta el acceso. En planta y por el eje transversal de simetría, enfatiza formalmente aquello que funcionalmente se niega. Predispone a ubicar inmediato el núcleo vertical de comunicación y transversalmente el eje de distribución horizontal, el resultado final, sin embargo, deja de ser convencional, desplazando la escalera a uno de los extremos del eje longitudinal de recorrido interior. Eje al que aporta abstracción racional, cualidad funcional acentuada al concluir con el espacio exterior en su otro extremo. Forzar la asimetría, la cadencia variable, implica equiparar los límites lineales de un uso predominante, que en este pabellón pasa por ser el dormitorio -ya se ha cuestionado lo inapropiado de desagrupar usos en diversas alturas- o en su mejor versión, sala de estar (fig. 16).

Concentrar núcleos húmedos sería el resultado del buen hacer racional, y una manera de romper premeditadamente la simetría, aunque una vez más surge la duda de la falta de radicalidad y empeño en los principios, sembrada al separar la cocina de tal concentración, en el lado opuesto del comedor $y$, en su lugar dar entrada a un reducido y oprimido dormitorio. Cabe plantearse la conveniencia de acumular núcleos húmedos 

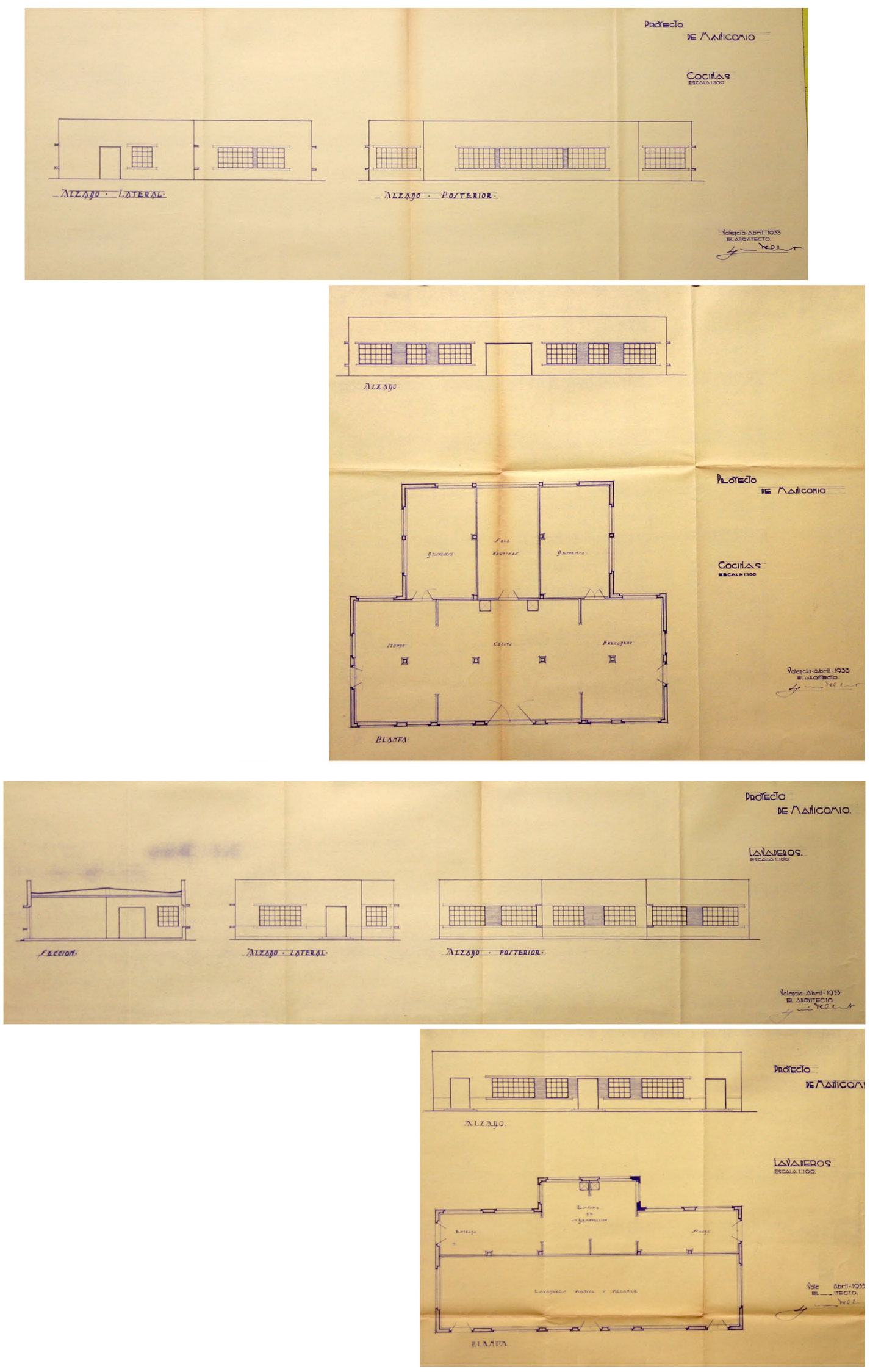

Luis ALBERT, 1935. Planimetría del pabellón de Cocina y del pabellón de Lavandería planta baja y alzados: Archivo de la Excelentísima Diputación Provincial de Valencia (AEDP) 
en esta planta, donde es puntual la presencia de dormitorios, frente a su indisposición en planta primera, donde se ubica el grueso de camas.

Hablar de la planta superior suscita las consabidas dudas sobre la cubierta como parte de la ortodoxia racionalista, y de la nula repercusión con la que llega a esta propuesta. Una planta totalmente dedicada a dormitorios, desperdiciando las propiedades específicas y curativas de un soleamiento controlado, buscando la mejor orientación, el control propiciado por la sombras.

PABELLONES DE COCINA, LAVADERO-DESINFECCIÓN, y ESTUFA. Coinciden en adquirir una composición similar, prismática, rectangular cada uno de ellos, repitiendo altura y modificando únicamente su superficie en planta, reduciendo por ello dinamismo y rotundidad lineal, no obstante procurando respuesta en función de la capacidad requerida. Dependiendo del uso, el prisma se altera y modifica en planta, aumentado su superficie en el eje menor del rectángulo. Son pabellones menores y como tales desarrollan una estructura funcional simple y escasamente elaborada (fig. 17). Las estancias se suceden en orden -resolviendo necesidades- y relacionadas colateralmente de manera directa y sin espacios previos de relación.

Ocurre algo parejo con su ubicación dentro de la ordenación del Centro, en el eje central de la circunferencia "a fin de que puedan prestar el servicio con la mayor comodidad, y algo alejados de la rotonda central a fin de evitar la mala vista que ello pudiera dar lugar". Albert manifiesta especial interés en disponer cada función en su precisa posición, teniendo en cuenta el resto de usos con los que se relaciona, su jerarquía y sin descuidar la apariencia social, la elegancia visual y el rigor estético. 

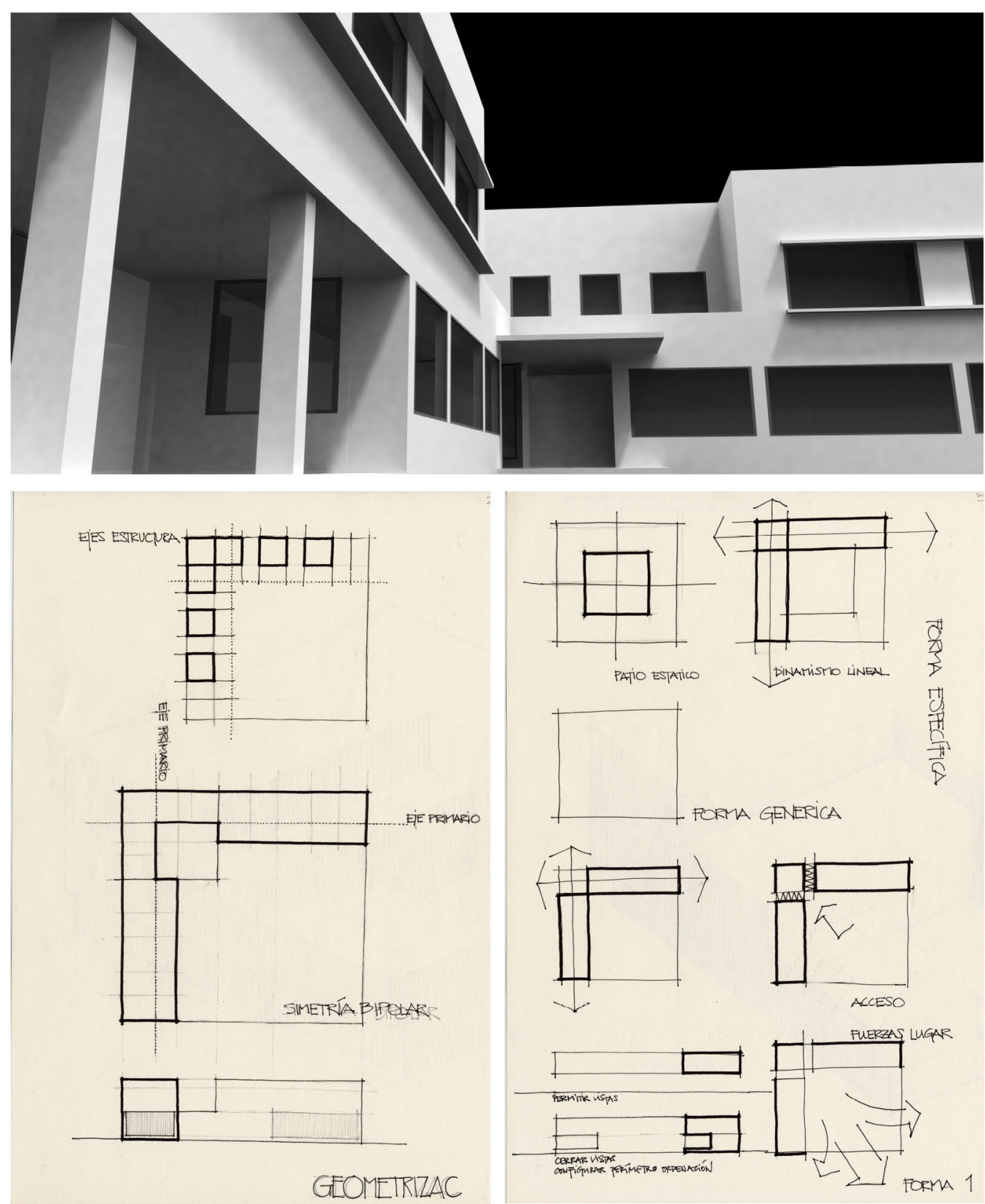

fig. 18

Manicomio Provincial, pabellones de Peligrosos y Viviendas. Imágen de la maqueta infográfica, esbozando la charnela de acceso en los: análisis geométrico de la forma, "L" 
Todo lo visualmente conflictivo recae en la parte interna de la circunferencia, salvaguardado por el perímetro expuesto.

PABELLONES DE PELIGROSOS Y VIVIENDAS. Demandas diversas, requieren las dos piezas especiales que formalizan los vértices del rectángulo que enmarca la seriación de semicircunferencias. Dos formas elementales, muy diferenciadas del conjunto, tanto por su disposición -externa a los anillos de circunferencia que organizan la ordenación- como por su morfología, tan marcada, tan puramente lineal y doblegada en ángulo ortogonal. Si la forma genérica podría pensarse estática, inmutable en los extremos de la composición del grupo, rectangular, bien distinta resulta su forma específica. Repensada la forma, tras el patio de acceso, rezuma el dinamismo lineal que ha estado acompañando al cúmulo de piezas componentes del puzzle Sanitario. Nuevamente formas puramente lineales, ahora bien, en estos precisos pabellones, la linealidad pierde inmediatez al quebrarse, favoreciendo en su articulación la concavidad para ubicar el espacio de acceso. Responden las líneas a las fuerzas del lugar, configurando el perímetro de la ordenación y manejando el dominio permisivo sobre las vistas propias, también de las exhibidas.

Transformar volumétricamente, la dinámica línea arquitectónica, queda mostrado como trabajo salvado por Albert. Sustraer fracciones del espacio comprendido dentro de límites determinados, suministra ahora espacios de relación con el exterior, de comunicación visual (fig. 18). Espacios porticados, terrazas abiertas o el claustro previo -cercado únicamente en dos alzados- concilian el perímetro conformado con la secuencia de semicírculos que envainan. Se echa en falta, idéntico tratamiento en la conclusión de la línea -tema tratado en el global de pabellones-, espacios 

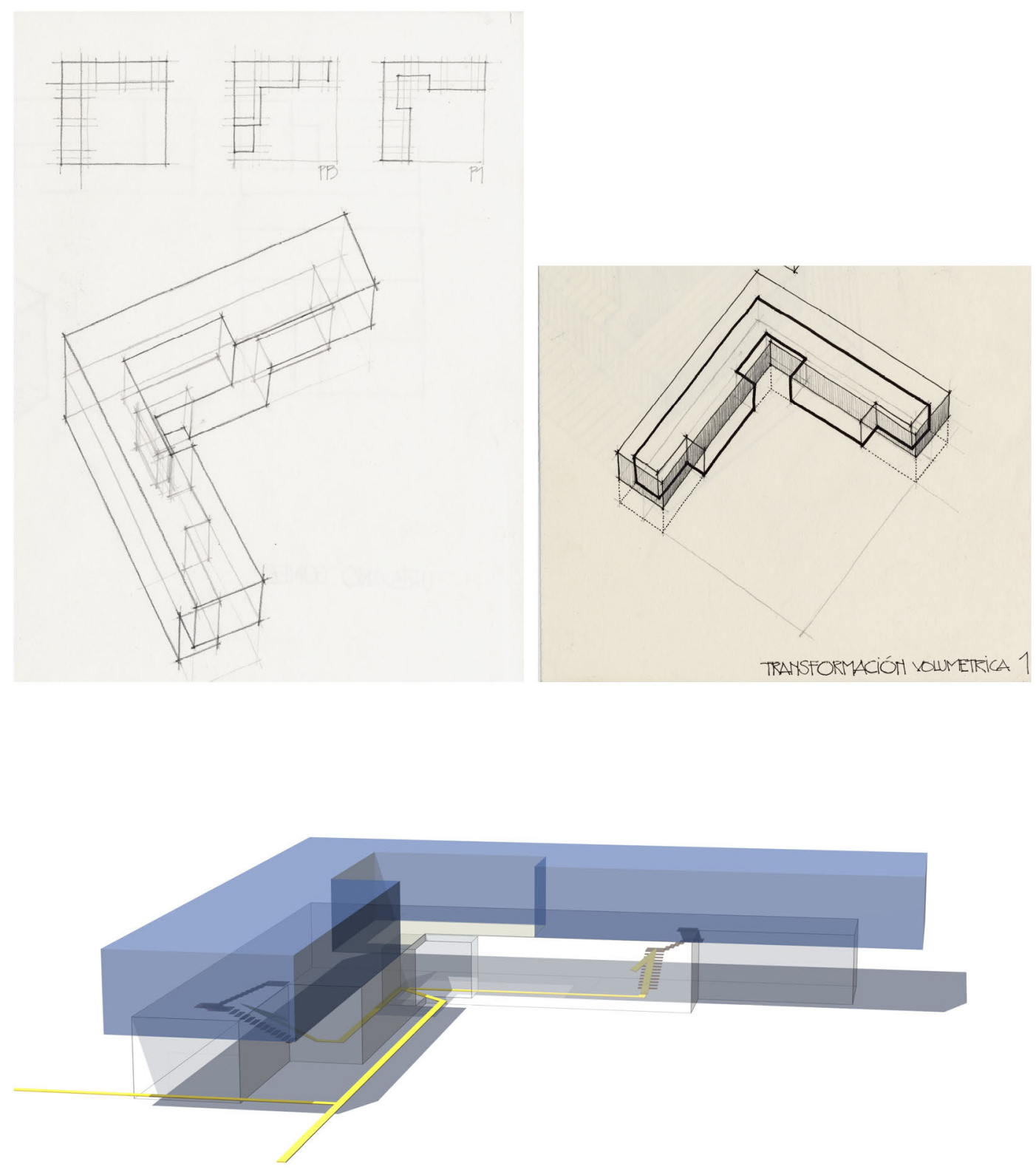

Manicomio Provincial, pabellones de Peligrosos y Viviendas. Esquemas de la variación volumétrica en los pabellones: volumetría representativa donde figurar la conexión entre los recorridos de aproximación y acceso con los núcleos verticales de comunicación 
singulares, relaciones exteriores.

Siendo una composición tan geométrica y simétrica-observando de manera individualizada-, surgen apremiantes los ejes principales. Perpendiculares y sin diferenciación jerárquica, volcando un tramado de ejes secundarios donde organizar, indistintamente agrupaciones de dormitorios, o bien, cúmulos de viviendas. Usos aparentemente diferenciados, resueltos mediante volúmenes exactos, una bien aparente contradicción con todo lo expuesto hasta el momento. Morfológicamente, hasta este momento, la relación forma-función había obtenido una respuesta, un planteamiento estricto, pero que en el caso de Viviendas y Peligrosos dispara las dudas de cómo una misma forma responde a usos tan dispares. Cabe la opción de concentrase en disipar oposiciones y, como principio, simplemente inferir el gesto, una sencilla respuesta geométrica, que finaliza la propuesta de ordenación.

Con individualidad, apuesta planimétrica en forma de L. Siempre simétrica aisladamente y transformada con idéntica rigurosidad en referencia a la dupla conformada, hasta focalizar el propio acceso tras un incipiente plinto, por el punto charnela de los dos brazos que la conforman, sincerándose innecesario en el pabellón de Viviendas. Dos núcleos de comunicación vertical, dispuestos exactamente simétricos, gemelos y con un protagonismo parcial. Lejos quedan las proclamas racionalistas sobre asimetría, jerarquía, equidad forma-función, y más rememorando paradigmas como la Roche Jeanneret, de idéntico principio compositivo y distanciada conclusión. Elevar la jerarquía de un único eje, proponer la jerarquía del espacio de acceso donde volcar planos de distribución horizontal y marcar la diferencia entre las posteriores comunicaciones, 

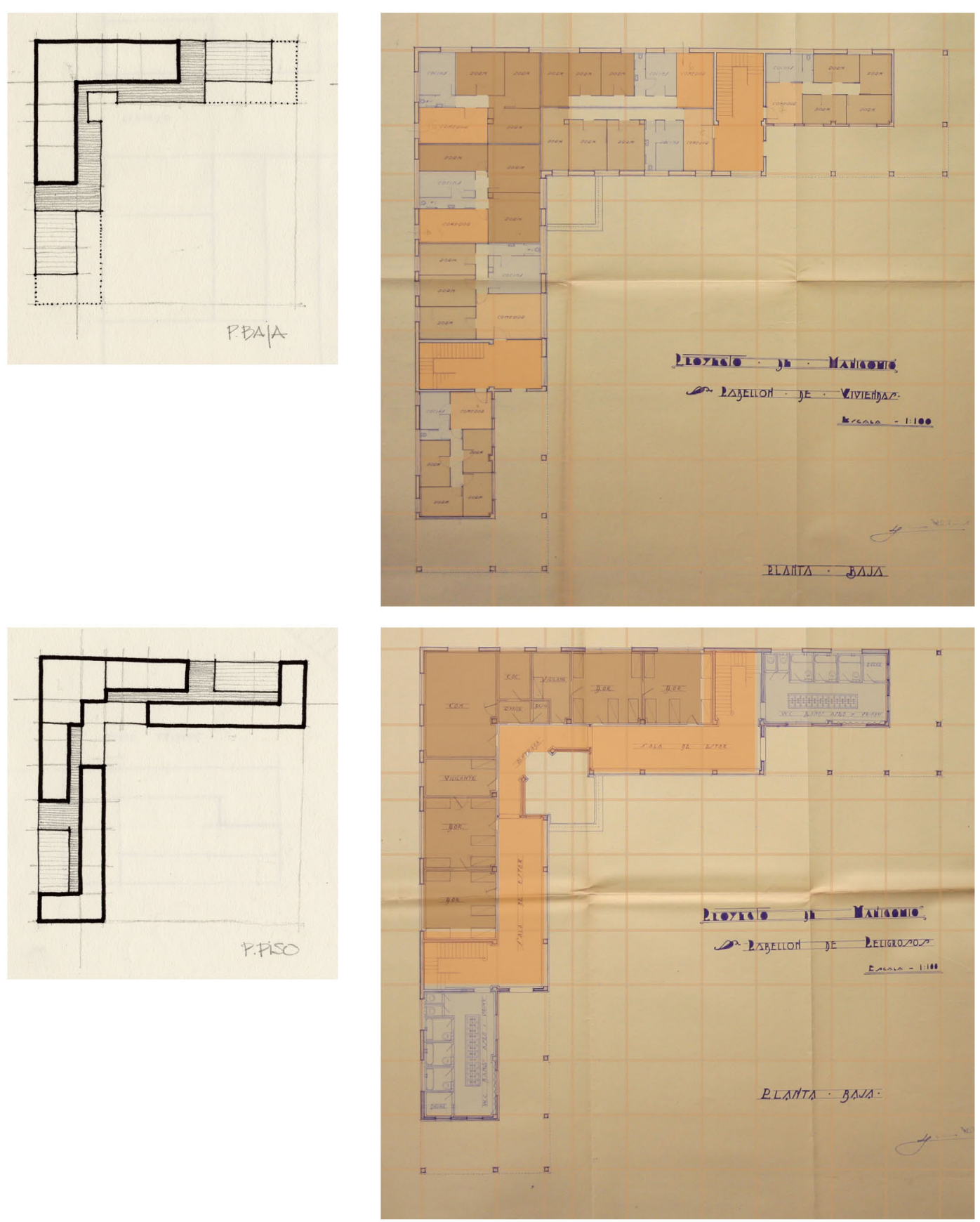

Pabellones de Peligrosos y Viviendas; esquemas de análisis sobre la organización funcional: planimetría original de ambos pabellones en planta baja, donde reconocer la variante de accesos y de distribuciones horizontales sin modificar la forma genérica 
aproximaría a la ortodoxia, más cuando la funcionalidad asoma claramente asumida.

Finalmente, la resolución parece atender a múltiples variables, programáticas, espaciales y formales, haber surgido de necesidades diversas, tales como dormitorios organizados para peligrosos y a la par viviendas organizadas en un bloque (fig. 19). Hábilmente consigue Albert equiparar funciones, relacionadas en torno a espacios de relación, alrededor de pasos y distribuidores -duplicados en paralelo, inmersos en las Viviendas- para asumir la composición concatenada.

Ciertamente el lapsus compositivo, la exacerbada simetría, el empeño de llevar la elementalista organización hasta la subordinación geométrica, quedarían diluidos tras el apasionamiento racionalista por redescubrir el espacio, la aprehendida funcionalidad, el lenguaje moderno.

La nueva arquitectura pudo entenderse en función de dos aspectos básicos: la organización del espacio y la forma construida. El 'espacio' y la 'forma'. Le Corbusier, Gropius y Mies sin duda prestaban la debida atención a la función, pero ninguno de ellos creía que las formas sencillamente 'siguiesen' a las funciones o se dedujesen de ellas ${ }^{20}$. La pretendida volumetría platónica resulta evidente en la propuesta albertiana, la inmaculada blancura de los paños en fachadas queda conseguida, tal

20 NORBERG-SCHULZ, Christian. "Los Principios de la arquitectura moderna. Sobre la nueva tradición del siglo $X X "$ ". Edición original: "Principles of Modern Architecture". Andreas Papadakis Publisher, Londres, 2000. Edición en español: Editorial Reverté, S.A. Barcelona, 2005. pág. 31 


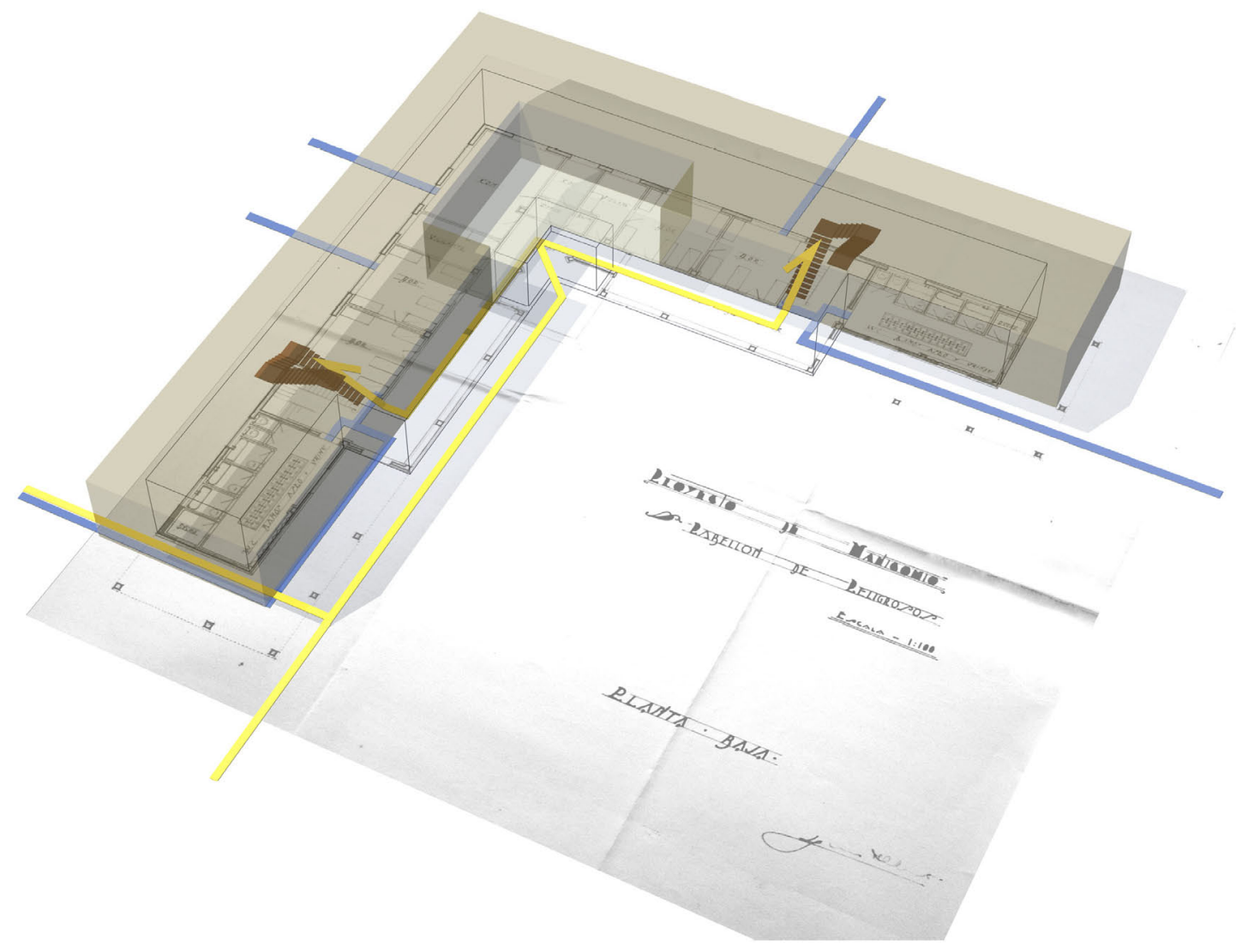

Pabellones de Peligrosos y Viviendas. Recorridos horizontales de aproximación al pabellón de Peligrosos (en amarillo) y de Viviendas (en azul): la distribución vertical y sus distribuciones coinciden en ambos pabellones, al igual que su organización funcional invariable 
como sucede en la fractura de huecos corridos -las fenêtres en longueur y su continuidad en las jambas-, los remates, los pilotis y la cubierta plana. Todo un decálogo de la imaginería moderna, asumido y envolviendo una pretendida sinceridad proyectual, suficiente para disculpar cualquier falta cometida por descuido, toda cercana heterodoxia.

En general, la forma construida -tal como la definía Le Corbusier- alberga un nuevo y moderno planteamiento vital, acorde con el espíritu de apertura para la nueva época, dando respuesta a la búsqueda de la nueva arquitectura, sin dogmas impuestos y visualizando un nuevo concepto de especialidad. 


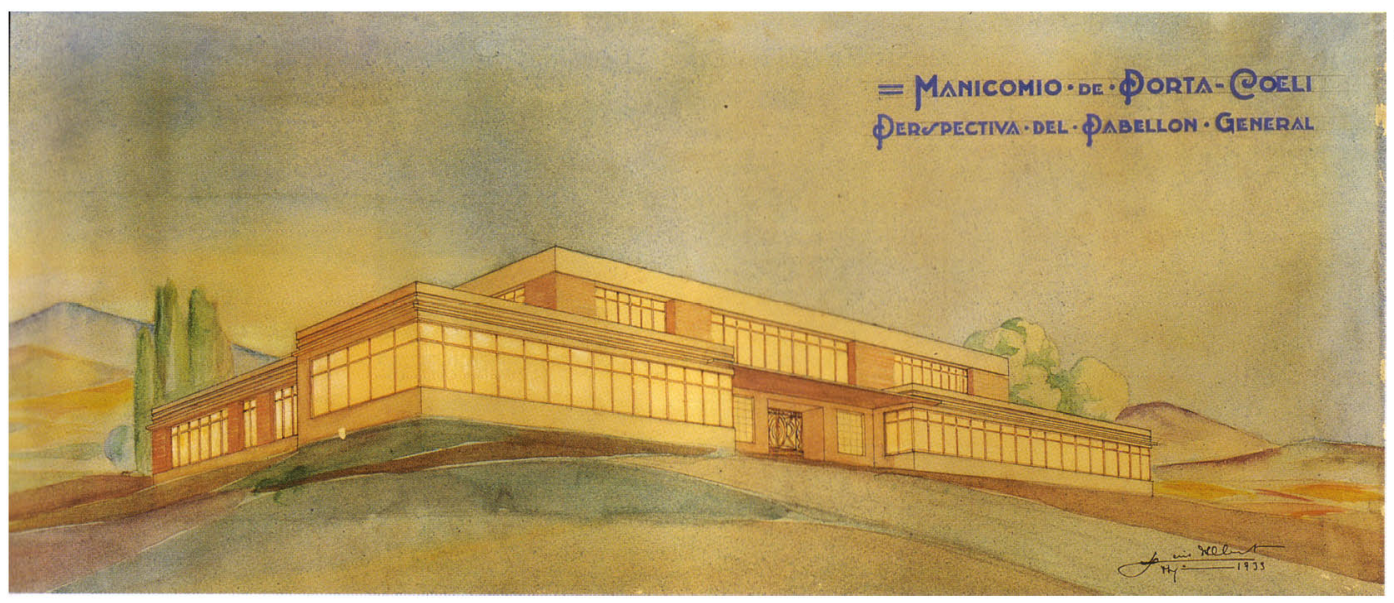

fig. 20 
Presente en la retina, grabada en la memoria, asociamos con fruición la perspectiva cónica del pabellón General que elabora Albert para invitarnos al acercamiento y al examen del Manicomio Provincial (fig. 20). Prácticamente suya es la elección, el posicionamiento, la exclusión para el análisis individual facultando determinar unas conclusiones equivalentes para la totalidad.

Cuantitativamente es el volumen con más presencia, el más reiterado en la ordenación del Manicomio. Posiblemente no llega a ser la pieza más emblemática, en detrimento del Pabellón de Administración que asume esta tarea, en el mismo momento en que pasa a formalizarse como final del eje visual y de acercamiento al complejo sanitario. Sin embargo, y por delante de esta arquitectura reclamo, pendiente de sí misma -tan presente y asumida actualmente- el pabellón General guarda un interés más elevado y cercano a los principios doctrinales del Movimiento Moderno, un grado de compromiso con la cultura moderna, con la interpretación funcional y racional de su arquitectura, con la configuración formal, más precisa que cualquiera de los demás pabellones, sin prescindir de dos joyitas que solucionan la ordenación geométrica -los vértices del cuadrado envolvente que desmitifican la circunferencia- y funcional, los pabellones de viviendas. 


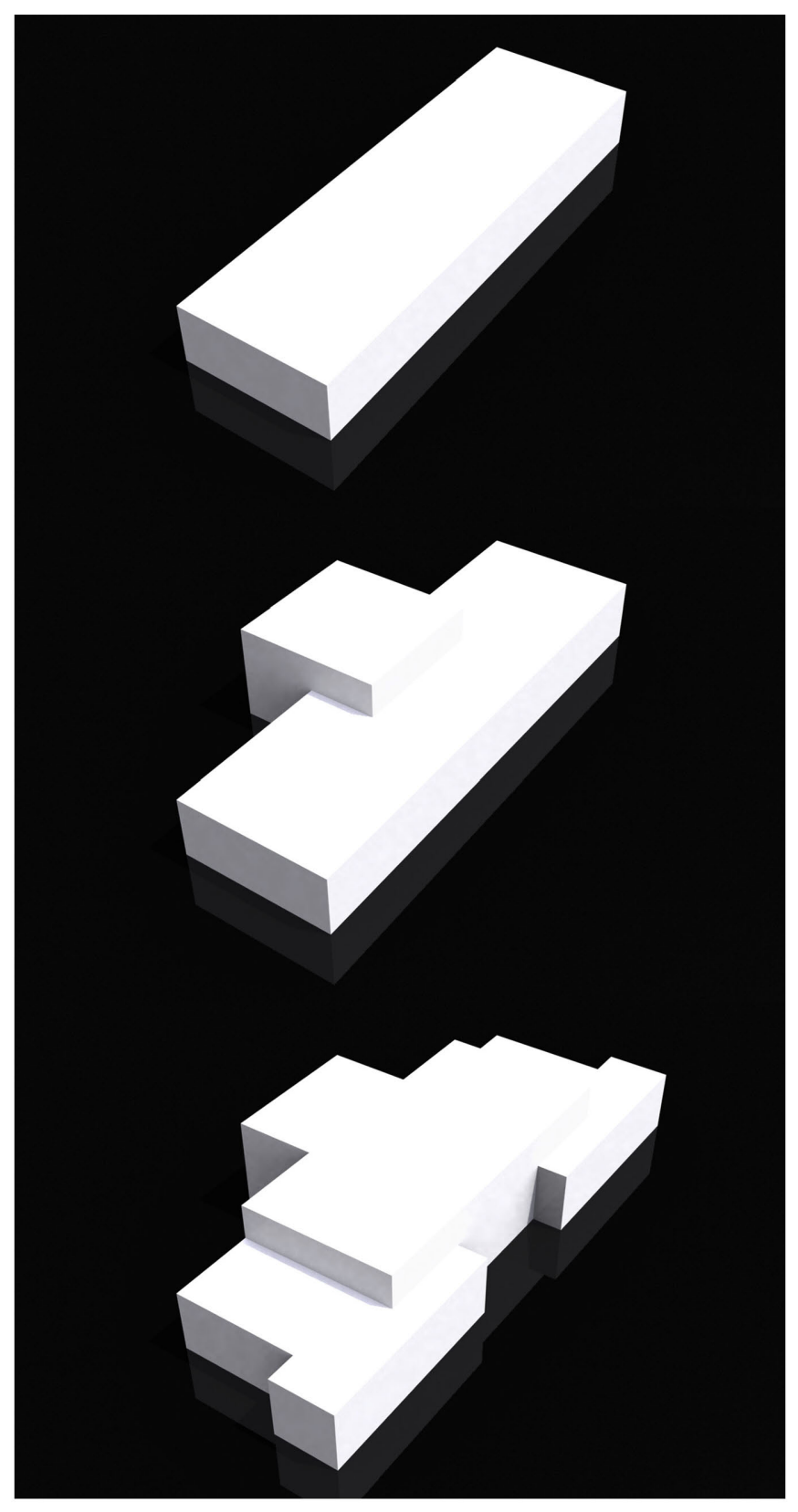

fig. 21

Pabellón General; maqueta infográfica del doctorando para el análisis compositivo sobre la génesis, configurada horizontalmente y alterada su linealidad por adhesiones sucesivas 
Seleccionada una tipología por estudiar y sentenciados los márgenes -tal como precede el capítulo dedicado al Hospital Provincial, primigenio en el análisis- construir figuradamente el pabellón General, interpretar la documentación planimétrica, la memoria escrita, retomar los dibujos con los que esclarecer la propuesta proyectada y no construida, dilucidar una obra a la que no nos podemos asomar, supone un decálogo de intenciones. "Se quiere insistir una vez más que no hay arquitectura sin ideas, y que idea y obra son simultáneas, para que aparezca esa arquitectura que no se sabe si es catalogable, explicable, culta, formante de una escuela determinada. Se escapa uno conscientemente de un mundo hablado, todo escrito y de verdad de verdad sin ningún otro fondo que el de pertenecer o no a si mismo."21

COMPOSICIÓN VOLUMÉTRICA

Empezar la andadura compositiva con un prisma horizontal (fig. 21), un volumen puro, una marcada linealidad, asoma la pretensión de ofertar una imagen, anteponer una fachada, preludiar un edificio, anunciar un

${ }^{21}$ DE LA SOTA, Alejandro. Memoria de la vivienda unifamiliar Sr. Domínguez Cayera. Pontevedra 1966. Editorial Pronaos. Madrid, 1989. Pág. 165 

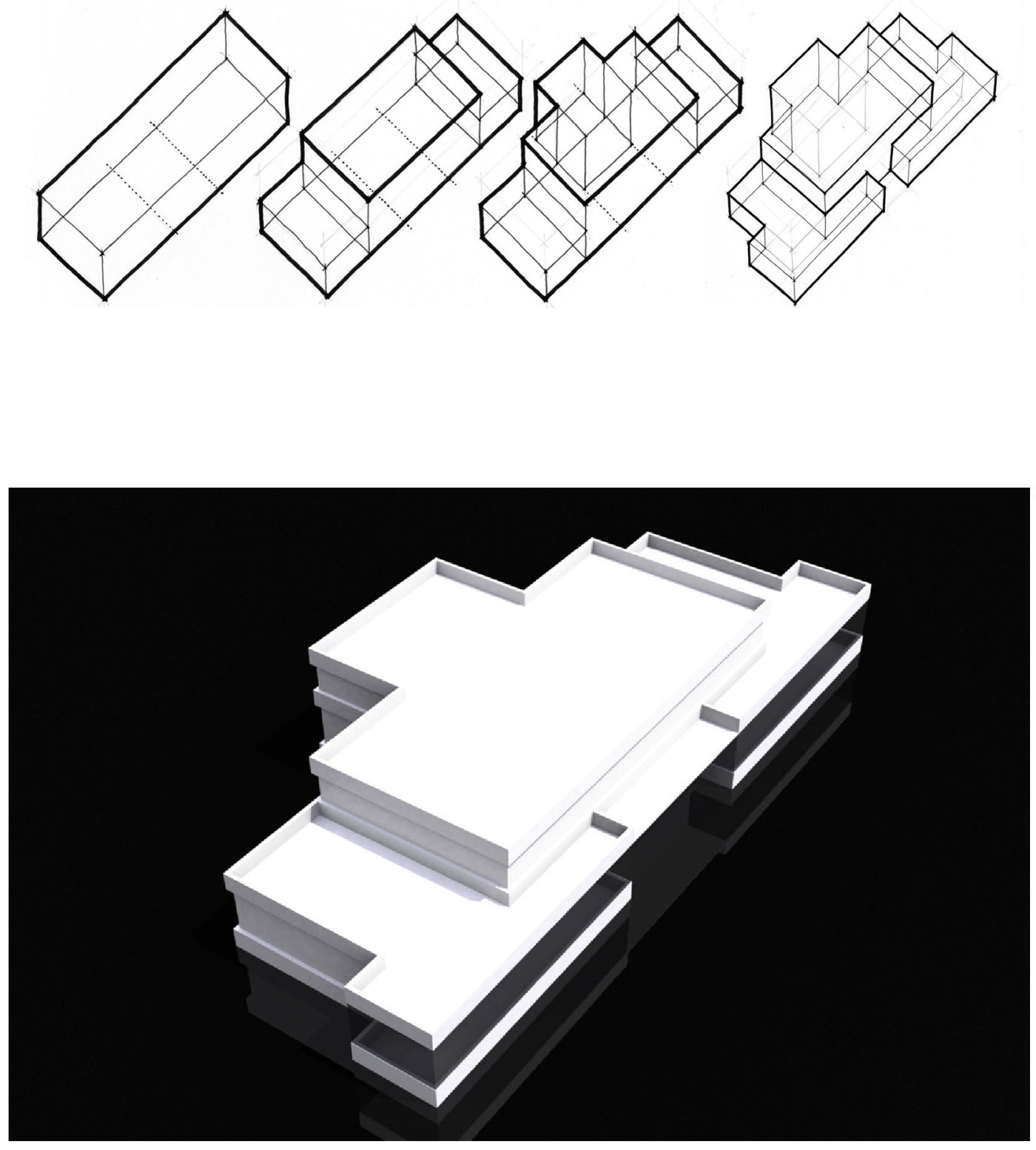

ig. 22

Pabellón General; esbozos doctorando donde figurar la evolución volumétrica; maqueta infográfica, respuesta final para los elementos generadores y su redisposición compositiva 
método compositivo. Un principio académico, practicado ya de modo sistemático desde la popularización de las enseñanzas de Durand y que tomó cuerpo más definitivo, si se quiere, cuando el eclecticismo Beaux Arts, de final y de principios de siglo, fue también un 'Estilo Internacional'22. La composición por partes. Un método que acontece yuxtaponiendo al prisma horizontal primigenio, una nueva fracción, un cubo perfecto, que a su vez opone a la linealidad inicial, un mesurado planteamiento vertical.

Dicotomía volumétrica, dos partes generando tanto el volumen como la planta. Aparentemente, intuitivamente, esta dupla resulta el principio generador, el método compositivo en el que la división conviene por un lado dormitorios y piezas que les sirven, y por otra parte el comedor, espacio yuxtapuesto, dispar, particular.

Aunque la exactitud, de esta composición por partes, no es tal. Amanece más como nivel de referencia, punto de partida, perímetro cerrado-puro y platónico-donde dividir libremente, encajar espacios que se someten a un volumen común. Volumen que tornado, abandona su pureza prismática para someterse a la complejidad (fig.22), a la transformación controlada. La forma del edificio y sus espacios prosperan, se perfeccionan y enriquecen, se liberan de su inicial esquematismo y rigidez lineal, pero sin transgredir los límites en su complejidad. Manteniendo los principios racionalistas, esta complejidad habrá de responder -debería hacerlo si rigen los infranqueables limites racionalistas- a necesidades programáticas, resolviendo el edificio concebido al servicio del programa.

22 Capitel, Antón. Op. cit. pág. 17 

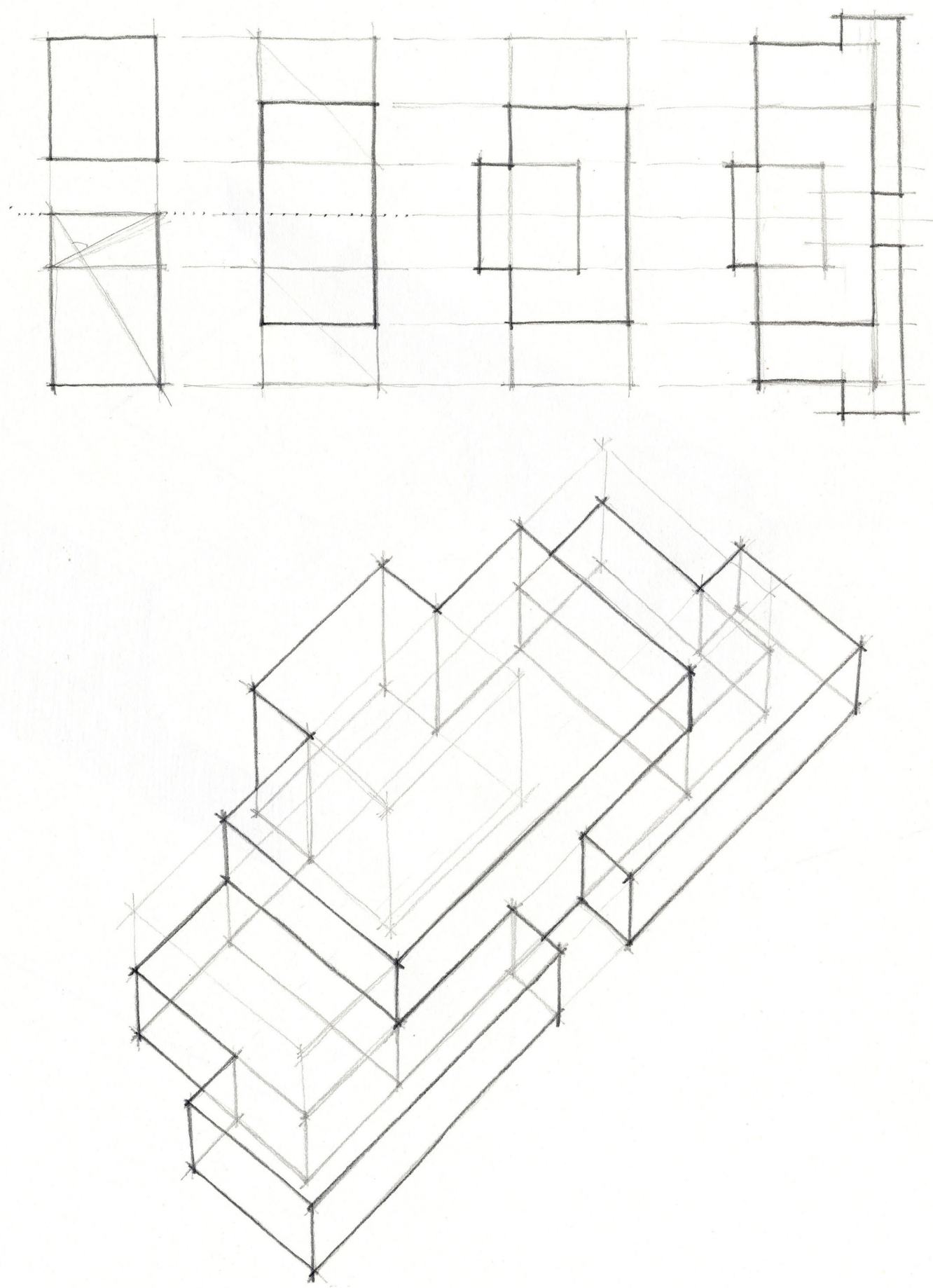

Pabellón General; sección áurea, génesis de la composición y, desenlace del pabellón en planta hasta alcanzar su dinamismo lineal; preconizado en axonometría 
Un prisma lineal para embalar un programa básico, el de un pabellón General. Un rectángulo yuxtapuesto en el eje transversal, por el que se desplaza hasta incluirse en el anterior, y presto a duplicarse en altura. Un nuevo prisma lineal, acoplado sobre el primero, pero sin abarcar la totalidad, sin alcanzar los límites impuestos por la primigenia línea que descansa sobre el terreno. Y finalmente un conciliábulo, una logia, también yuxtapuesta a este primer prisma, abrazando los extremos de su fachada y disociada por el eje transversal, para en su concavidad formalizar el acceso al edificio. Así resulta la transformación controlada, su complejidad mesurada.

Complejidad solventando un programa en un contenedor, dividiendo libremente un espacio confinado, controlado racionalmente, inmerso en una volumetría platónica y compuesta por dos sencillas partes que nunca aparentarán esta complejidad. Intrincar la dupla conllevaría a la perdida de rotundidad, alejarse del control racionalista y debilitarse en juegos geométricos.

Adelantar ambas logias, aquella pareja acristalada -nunca ideada en liviana adhesión, en una totalidad vítrea-, impone complejidad en la configuración inaugural, desvirtúa la rotundidad volumétrica, su pureza. Escalonar la linealidad del frente, disipada tras dos apósitos transparentes, semejan juegos de destreza geométrica. Fundamentarlo en aras de los condicionantes funcionales, desvirtúa la dupla propositiva, sobre todo cuando los espacios generados -logias y terrazas- no cobran la dignidad que inspiran y asemejan. 


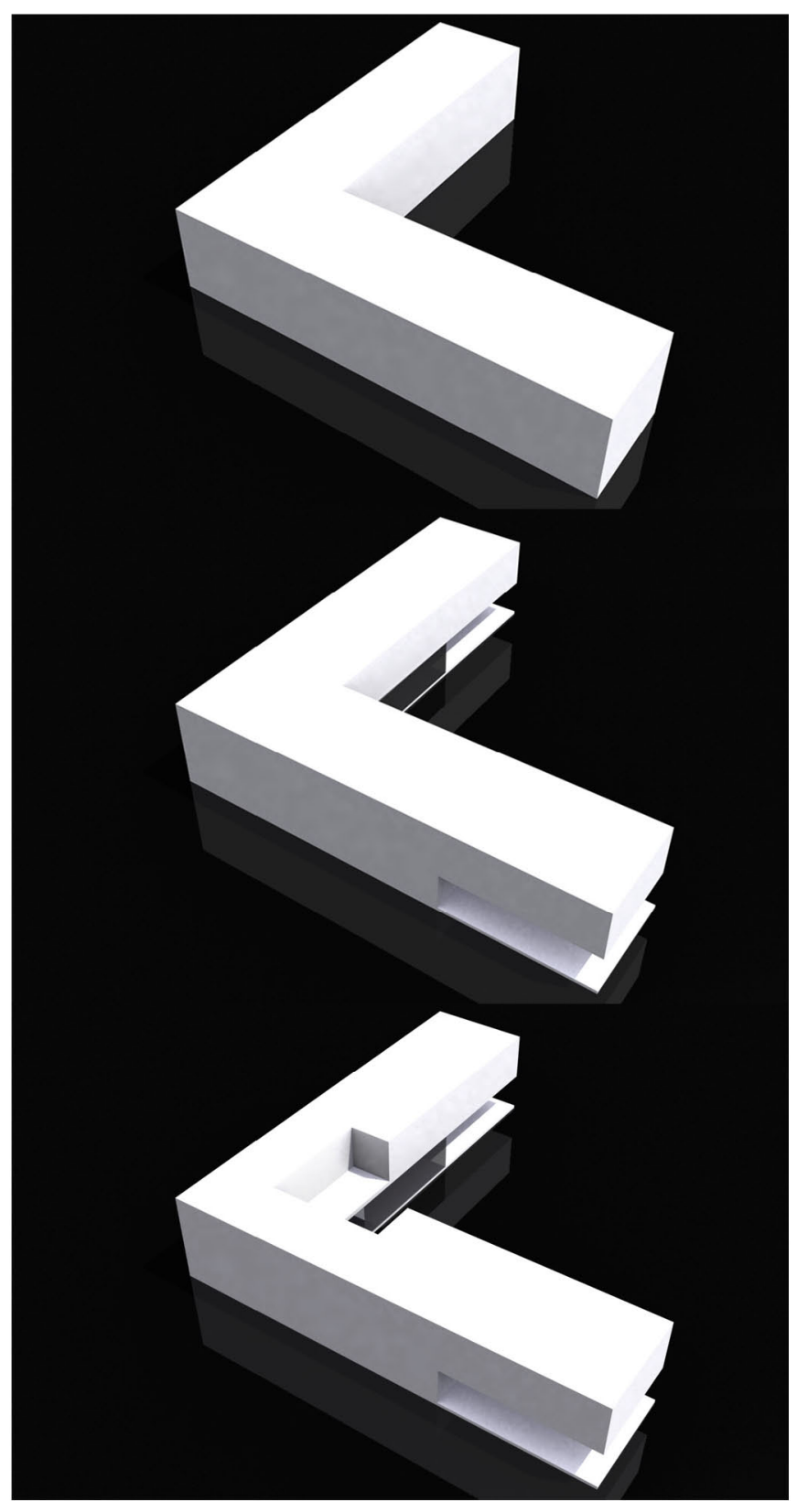

fig. 23

Pabellón Peligrosos-Viviendas; maqueta virtual doctorando para el análisis compositivo sobre la génesis configurada en "L", quebrada horizontalmente y transformada por sustracciones sucesivas 
Si parece oficiarse el método y proceder racionalmente, hasta concluir, en los pabellones -anteriormente descritos- destinados a Viviendas y Peligrosos, edificios que afianzan y cercan la ordenación. La concesión geométrica, esa vez, resultaba de quebrar ortogonálmente la linealidad arquitectónica, por su mitad (fig. 23). Las transformaciones, las ausencias volumétricas resultaban entonces, espacios abiertos, relaciones de lo edificado, lo no construido y el exterior. La linealidad germinal nunca negada, perduraba siempre manifiesta. La relación forma-función si parecía retomar los principios racionalistas de control.

Inferir el control de las proclamas ortodoxas, en los pabellones Generales, exhibe incógnitas. Razonables dudas que se deben posicionar, plasmar y solventar dentro del análisis funcional. Despejarlas racionalmente, tal como desvela Antón Capitel cuando lucubra sobre la Biblioteca de Viipuri (1930-1935) de Alvar Aalto, supone potenciar, complicar una propuesta para evitar perderse en la inmediatez de un planteamiento geométrico. "Es esta una importante y matizada forma de complejidad, que no se manifiesta de modo demasiado aparente, pues el edificio se presenta en sus imágenes y percepciones como si fuera realmente muy sencillo". 


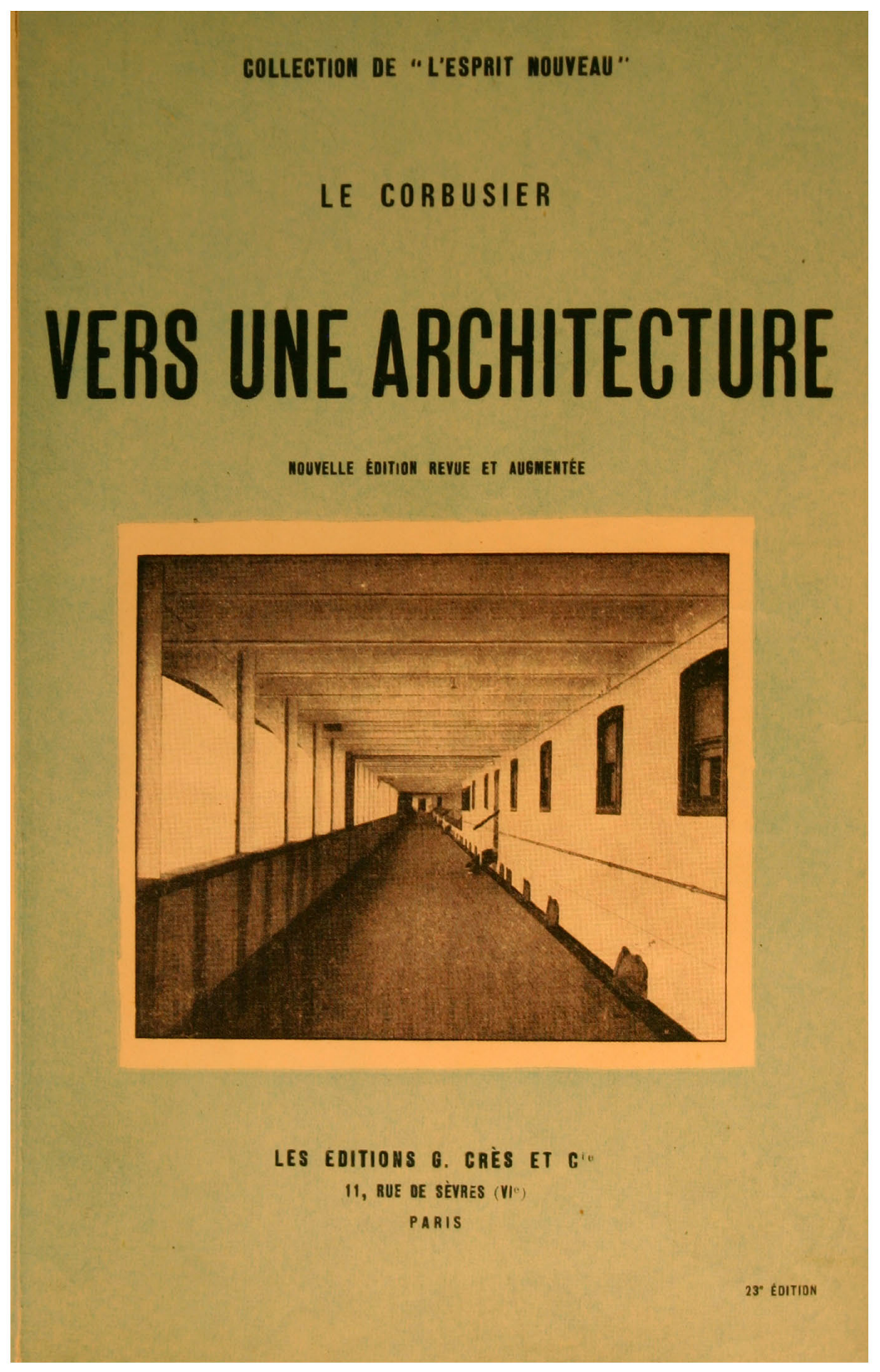

fig. 24

Le CORBUSIER. "Vers una architecture"; portada del texto-referencia sobre el Arte y la nueva Arquitectura, presente en todos los estudios de arquitectura, también Luis ALBERT 


\section{ORGANIZACIÓN FUNCIONAL}

Utiliza Albert la dinámica de la linealidad, para resolver transversalmente demandas funcionales. Reciprocidad, correlación forma-función. Habíamos registrado al arquitecto, cercano a Gropius, a Le Corbusier y Mies en la manida formulación de Sullivan "la forma sigue a la función". No obstante el moderno planteamiento sobre arquitectura, dejaba de residir exclusivamente en la atención a la planificación, la organización, limitarse al cálculo, a los aspectos técnicos y económicos. Mies hablaba, además, de solventar el problema arquitectónico con un pensamiento creativo ${ }^{23}$. Gropius mencionaba la 'la racionalización', considerándola generalmente como un principio cardinal de la nueva arquitectura, sencillamente como un agente purificador y, a su vez ratificaba 'la satisfacción estética del espíritu humano' igualmente trascendente. Vers une architecture ${ }^{24}$ irrumpía en los despachos profesionales de entonces ilustrando con 'de pronto, me conmovéis, me hacéis bien, soy dichoso y digo: es bello. Esto es arquitectura. El arte está aquí'. (fig. 24)

No bastaba con solventar la función, detenerse en un funcionalismo radical-aquel pretendido en la Bauhaus, sólo en 1928 cuando Hannes Meyer alcanzó su dirección- para evidenciar posteriormente la forma, fiel reflejo cartesiano. La nueva arquitectura demandaba superar el programa, conmover a través del 'espacio' y la 'forma'.

${ }_{23}$ MIES van der ROHE, Ludwig. Prefacio de Bau und Wohnung: Die Bauten des Weissenhofsiedlung in Stuttgart; publicación oficial de la colonia Weinssenhof (Stuttgart, 1927), versión castellana en "Escritos, diálogos y discursos". pág. 36

${ }_{24}^{4}$ LE CORBUSIER. "Hacia una arquitectura". pág. 123, 145 y 165. 


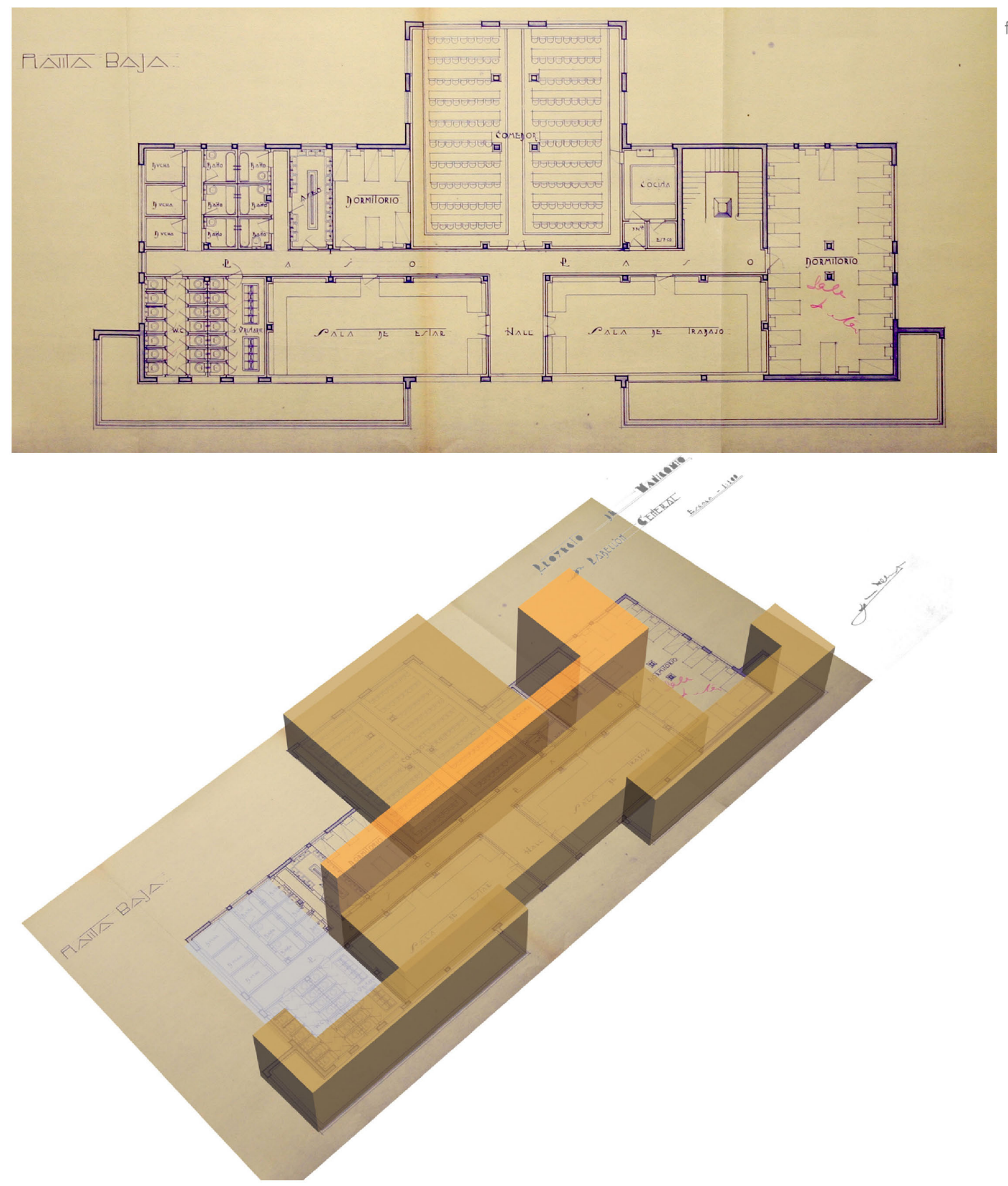

fig. 25

Luis ALBERT, 1935. Planimetría original del proyecto; esquemas de la organización funcional del pabellón General en planta baja, recorridos horizontales y comunicación vertical 
Un prisma lineal gestando el pabellón General, una forma ofertando al programa requerido respuestas a dos manos. Esto es, una circulación horizontal -una línea arquitectónica- sirviendo a los usos demandados, desde programa, en sus dos prismas longitudinalmente paralelos, aquellos que espacialmente conforman la arquitectura. También la sección incide en esta génesis lineal, idea organizativa de proyecto, haciéndola coincidir en ambas plantas y relacionándolas mediante el núcleo de circulación vertical. De cualquier manera, este arranque necesita racionalizarse, exige superar la tradición académica, superar tanto los límites aprendidos como los proyectados.

El espíritu de la nueva arquitectura fascina a los jóvenes arquitectos. Parecen impregnados de la idea de que el espíritu de la arquitectura moderna no se halla en los detalles que uno elimina. Lo desnudo no es forzosamente el fin último de lo moderno. No será lo más moderno una construcción con ventanas horizontales, o descoronada de su cornisa, si el arquitecto no ha exprimido el espíritu de lo que ha construido ${ }^{25}$.

Le Corbusier había contribuido en gran medida al desarrollo de este espíritu, el amor profundo por lo que se piensa, por lo que se hace. Albert requiere con sincera convicción, un principio racionalista para involucrar su prisma lineal. Limitar la línea arquitectónica, finalizarla intencionadamente, evitando reducir su dinamismo repentinamente. El Sanatorio

25 ZERvos, Christian. "Jóvenes arquitectos". Cahiers d'Art, 1935, n 1-4, pp. 75 y 91. A propósito de su exposición en la Galería de Cahiers d'Art. Febrero-Marzo de 1935. Versión castellana: DC 13-14. Revista semestral de Crítica Arquitectónica. Departament de Composició Arquitectónica. ETSAB-UPC. Barcelona, 2005. pág. 23 


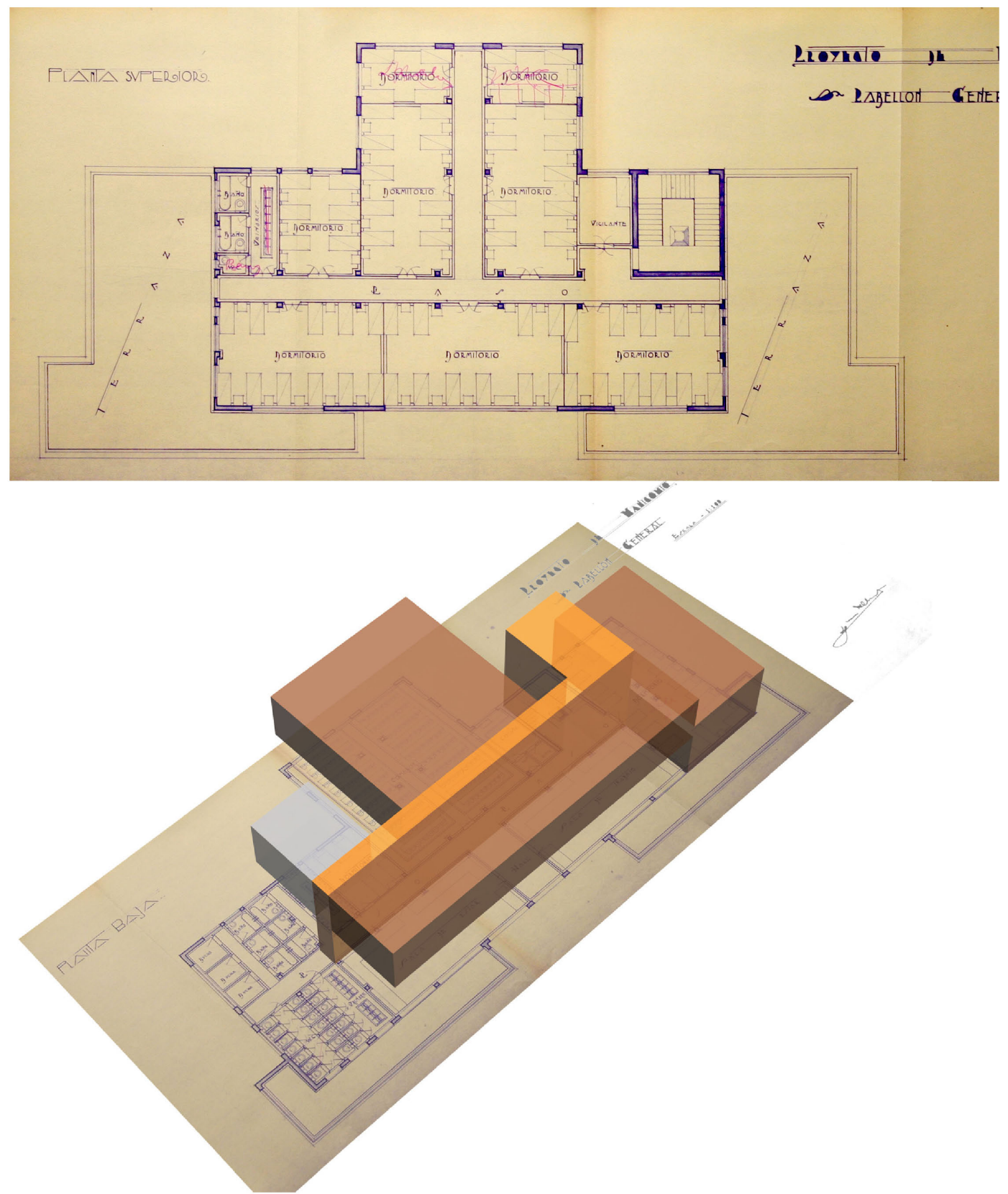

Luis ALBERT, 1935. Planta primera original de proyecto; esquema funcional, representando la concentración núcleos húmedos, los recorridos horizontales y la comunicación vertical 
Antituberculoso de Aalto, en Paimio, resulta un merecido y notorio referente coetáneo, de semejante destino funcional y racional conclusión.

Aspirar a semejante fin, comienza por ofrecer una excelsa relación con el exterior en uno de los límites del Pabellón -aparejar cuartos de aseos, comunes, como último compañero de travesía ya no se asoma tan excelente- mientras que, en el opuesto final dispone perpendicularmente un espacio -representativo demandaría la ortodoxia citada- carente de la gravedad prescrita, salvo si atendemos a la consabida corrección manuscrita (fig. 25).

Retomando el discurso metodológico, aquella dupla formal -intentando conmover-, propone Albert en planta, adjuntar un cuadrado exacto en sus proporciones, posterior a esta primera pieza de arranque, a aquel trazo iniciativo. Desliza este, perpendicularmente hasta la tangencia con la línea arquitectónica y titulándose áureo macla hasta coincidir con el lado máximo del prisma iniciático rectangular. Cabría sugerirle a esta pieza, principios racionales, entusiasmo funcional, enjundia espacial. Exorar emancipación a la estructura que la erige, redimensionar su sección. En definitiva, demandar un uso representativo, un espacio que no debería coincidir en alturas, ni equipararse con equivalentes convencionales. Prever una estructura capaz de vaciar la totalidad del volumen, quizá una doble altura recogiendo los postulados modernos, respondiendo a la demanda espacial moderna y, obligando a redimensionar longitudinalmente, hasta concluir el programa desaparecido, reorientar usos idénticos y completar la volumetría para concluir y retomar el prisma puro, platónico o evolucionarlo. 


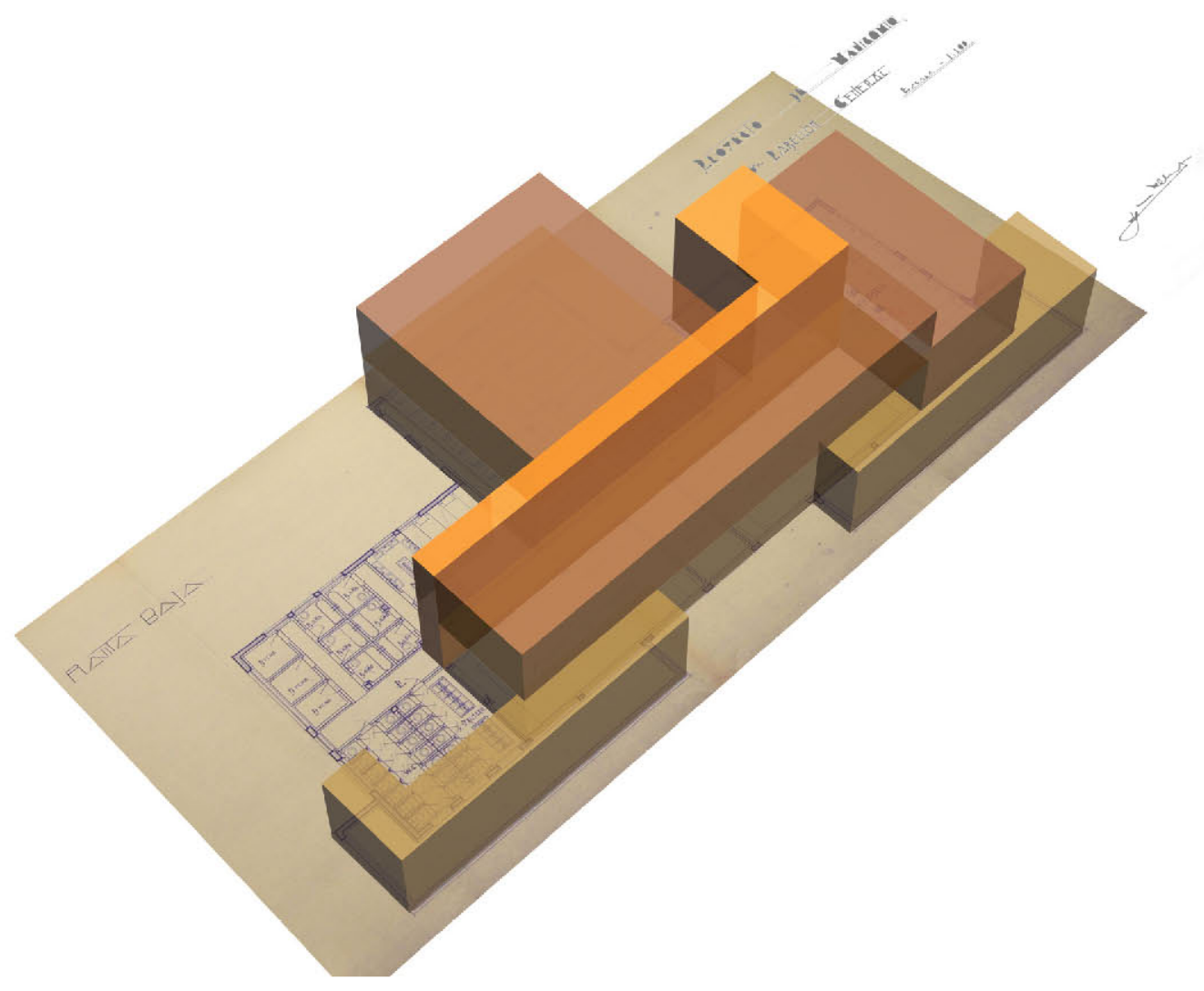

Volumetría informatizada para superponer, sobre plano de proyecto, funciones y reproducir circulaciones, hasta esbozar la organización final del pabellón General 
Pureza que, probablemente niegue cualquier dogma aprehendido a priori, métodos académicos impuestos, desanimando la propia experiencia, el empirismo como metodología. Pureza que, sin duda habría forzado evitar las simétricas galerías acristaladas, reubicando este espacio de silencio-Arquitectura para los que buscan el Conocimiento26-, en aquel límite, requerido de un uso elevado, procurando fin a la línea arquitectónica, a la moderna arquitectura.

Reagrupar, concentrar usos resulta evidente. Repensar la sección, una necesidad para cumplir los principios más ortodoxos y modernos. Trabajo de síntesis y posiblemente una última revisión del proyecto sin eludir la tercera dimensión, un postrero análisis más racional y espacial. El límite funcional-perfectamente esbozado en la sección del Hospital Provincialcapaz de resolver el programa en el mínimo espacio admisible y sin concesiones. Los jóvenes arquitectos pagan con gran coraje sus convicciones como para profesarles una profunda simpatía ${ }^{27}$.

26 NIETzSCHE, Friedrich Wilhelm. "La Gaya Ciencia". Llegará un día-muy pronto quizás- en el que se reconocerá lo que les falta a nuestras grandes ciudades: lugares silenciosos, vastos y espaciosos, para la meditación; lugares con largas galerías acristaladas para los días de lluvia y de sol, a los cuales no llegue el ruido de los coches ni el pregón de los mercaderes, y donde una etiqueta más sutil prohibiría al sacerdote orar en voz alta: edificios y construcciones que en su conjunto expresaran lo que tiene de sublime la meditación y el alejamiento del mundo.

${ }_{27}$ ZERVOS, Christian. "Jóvenes arquitectos". Op. Cit. pág. 22 
ESTADO NÚM.

\section{CUBICACION}

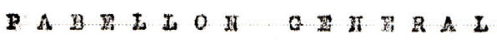

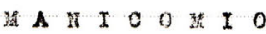

\begin{tabular}{|c|c|c|c|c|c|c|}
\hline \multirow{2}{*}{ CLASE DE OBRA } & \multirow{2}{*}{ 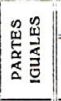 } & \multicolumn{3}{|c|}{ DIMENSIONES EN METROS } & \multirow{2}{*}{ 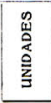 } & \multirow{2}{*}{$\begin{array}{c}\text { CANTIDAD } \\
\text { DE } \\
\text { OBRA }\end{array}$} \\
\hline & & LONGITUD & LATITUD & $\begin{array}{l}\text { ALTURA. } \\
\text { GRUBSO } \\
\text { O ESPESOR }\end{array}$ & & \\
\hline \multicolumn{7}{|l|}{ 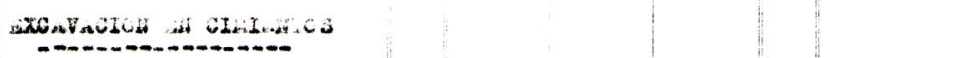 } \\
\hline \multirow[t]{3}{*}{ Faohrata jalnotpal } & 2 & 49.00 & 0.60 & 1.00 & ma & 31.830 \\
\hline & 2 & 20.90 & 0.655 & 1.00 & & 27.170 \\
\hline & 2 & 2.30 & 0.65 & 2.00 & & 2.990 \\
\hline Lateralos & 2 & 5.30 & 0.65 & 2.00 & & 6.890 \\
\hline \multirow[t]{2}{*}{. } & 2 & 2.30 & 0.63 & 2.00 & & 2.990 \\
\hline & 2 & 14.40 & 0.05 & 1.00 & & $-\quad 18.720$ \\
\hline se02000 & 2 & 6. 40 & 0.65 & 2.00 & & 8.320 \\
\hline \multirow[t]{3}{*}{ Powteriox } & 2 & 27.00 & 0.65 & 2.00 & & 22.200 \\
\hline & 2 & 7.20 & 0.65 & 1.00 & " & 9.360 \\
\hline & 1 & 14.60 & 0.65 & 2.00 & & 9.490 \\
\hline \multirow[t]{2}{*}{ 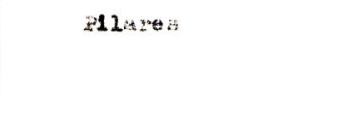 } & 25 & 0.63 & 0.65 & 2.00 & & 10.362 \\
\hline & To $t a$ & $1 \mathrm{mz}$. & 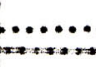 & 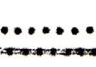 & & 150.442 \\
\hline \multirow[t]{4}{*}{ 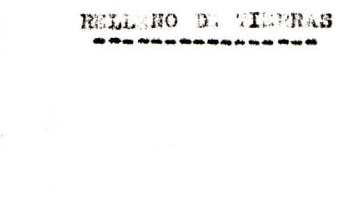 } & 2 & 19.80 & 2.63 & 0.60 & m3 & 62.964 \\
\hline & 2 & 3.00 & 2.65 & 0.60 & & 9.540 \\
\hline & 1 & 48.00 & 14.70 & 0.60 & & 423.360 \\
\hline & 2 & 28.60 & 7.80 & 0.60 & 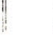 & 65.648 \\
\hline
\end{tabular}

Luis ALBERT. Pabellón General; de la memoria del proyecto para la ciudad sanitaria de

Porta-Coelli (AEDP): Precios -unitarios y descompuestos-, mediciones y presupuesto 


\section{ESTRUCTURA DE PIES DERECHOS}

Dada la reducida altura de los pabellones, la estructura de ellos queda concebida a base de ladrillo en muros y pies derechos, jácenas y viguetas de hierro en piso y azotea, estando construida esta última con cámaras de aireación y aislamiento, juntas de dilatación y un especial impermeabilizado aportando mayor garantía que los convencionales tejados. Este es el sistema general constructivo empleado en el edificio, viene minuciosamente detallado en mediciones y presupuesto para la obra ${ }^{28}$.

Estructura y fachada postergan su libre relación, postulada en "Les cinq points d'une architecture nouvelle", para ligarse en los 0,40 metros de espesor que materializa los paramentos de fachada mediante ladrillo ordinario (fig. 26), según reza en la descomposición de precios y cubicación de la obra. Los modernos pórticos metálicos se disocian horizontalmente y extravían los esbeltos soportes verticales, relegando los perfiles metálicos a jácenas y viguetas. Las bovedillas de rasilla clausuran una estructura, lo más económica y típica del país ${ }^{29}$.

'Los sistemas arquitectónicos, históricos, no fueron obra de fantasía y de capricho, expresan los caracteres esenciales de una época y de una región; estructura social, procedimientos de construcción, materiales propios, necesidades económicas, exigencias espirituales'. El retorno a lo elemental, la simplificación sistemática que preside la modernidad, la economía

28 Albert ballesteros, Luís. "Memoria de proyecto del Manicomio Provincial". Op. cit. pág. 2

29 RODRIguez arias, G. "Memoria del Sanatorio de San Juan de Dios (Manresa)". Revista AC, número 6. Año segundo - segundo trimestre de 1932. 


\begin{tabular}{|c|c|c|c|c|c|c|}
\hline \multirow[b]{2}{*}{ CLASE DE OBRA } & \multirow{2}{*}{ 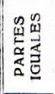 } & \multicolumn{3}{|c|}{ DIMENSIONES EN METROS } & \multirow{2}{*}{ 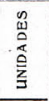 } & \multirow{2}{*}{$\begin{array}{c}\text { CANTIDAD } \\
\text { DE } \\
\text { OBRA } \\
\end{array}$} \\
\hline & & LONGITUD & LATITUD & $\begin{array}{l}\text { ALTURA, } \\
\text { ORUESO } \\
\text { O ESPESOR }\end{array}$ & & \\
\hline \multicolumn{7}{|c|}{ FABRICA D LADIUILIO ONDMUKRIO } \\
\hline \multirow[t]{3}{*}{ Fáohada prinolpel } & 2 & 20.50 & 0.40 & 4.80 & $\mathrm{~m} 3$ & 78.720 \\
\hline & 2 & 2.60 & 0.40 & 4.80 & & 9.984 \\
\hline & 1 & 48.70 & 0.40 & 4.80 & & 93.504 \\
\hline \multirow[t]{3}{*}{ Laterales } & 2 & 5.65 & 0.40 & 4.80 & & 21.696 \\
\hline & 2 & 3.00 & 0.40 & 4.80 & & 11.520 \\
\hline & 2 & 15.40 & 0.40 & 4.80 & & 59.136 \\
\hline Esoale ra & 2 & 6.40 & 0.40 & 4.80 & & 24.576 \\
\hline \multirow{3}{*}{ Po ste rior } & 2 & 16.30 & 0.40 & 4.80 & & 62.592 \\
\hline & 2 & 8.20 & 0.40 & 4.80 & & 31.488 \\
\hline & 1 & 13.60 & 0.40 & 4.80 & & 26.112 \\
\hline Pllares & 25 & 0.40 & 0.40 & 4.80 & & 19.200 \\
\hline \multirow[t]{4}{*}{ An tepe aho azo tea } & 2 & 3.00 & 0.25 & 1.00 & & 2.500 \\
\hline & 2 & 5.60 & 0.25 & 1.00 & & 2.800 \\
\hline & 2 & 20.50 & 0.25 & 1.00 & & 20.250 \\
\hline & 2 & 2.60 & $0: 25$ & 1.00 & & 1.200 \\
\hline \multicolumn{7}{|l|}{ PLANTA SURERIOR } \\
\hline \multirow{3}{*}{$\begin{array}{l}\text { Fachada prinoipal } \\
\text { Iaterales }\end{array}$} & 1 & 32.40 & 0.25 & 3.40 & - & 8.100 \\
\hline & 1 & 14.60 & 0.15 & 3.40 & & 7.446 \\
\hline & 1 & 8.20 & 0.15 & 3.40 & & 4.182 \\
\hline \multirow[t]{2}{*}{ Escalera } & 2 & 6.40 & 0.25 & 3.40 & & 20.880 \\
\hline & 1 & 5.10 & D.25 & 3.40 & & 4.335 \\
\hline \multirow[t]{3}{*}{ Posterior } & 2 & 9.30 & $c .25$ & 3.40 & & 35.810 \\
\hline & 2 & 7.90 & $c .25$ & 3.40 & & 13.430 \\
\hline & 2 & 13.60 & 0.25 & 3.40 & & 11.560 \\
\hline \multirow{3}{*}{$\begin{array}{l}\text { Pilares } \\
\text { Antepecho de azoteas }\end{array}$} & 15 & 0.40 & 0.40 & 3.40 & & 8.160 \\
\hline & 1 & 32.40 & 0.12 & 1.00 & & 3.888 \\
\hline & 2 & 15.20 & 0.12 & 1.00 & & 3.648 \\
\hline
\end{tabular}

Luis ALBERT. Pabellón General; de la memoria del proyecto para la ciudad sanitaria de Porta-Coelli (AEDP): Precios -unitarios y descompuestos-, mediciones y presupuesto 
y sinceridad constructiva se comprometían en las arquitecturas de los jóvenes renovadores. 'Se conocen nuevos procedimientos y materiales de construcción de uso universal'. A aquellos flamantes profesionales, aventurados y comprometidos, les urgía adoptarlos. 'La estructura de un edificio cambia con los materiales. Las necesidades económicas -LEY DE ECONOMIA- exigen la rapidez sin olvidar la perfección. La industria (maquinismo) puede resolverlo produciendo elementos-tipos fabricados en gran cantidad. SERIE'.

Llevar a la práctica estos postulados publicados por el Grupo GATEPAC, en el primer número de su propia publicación ${ }^{30}-A . C$. Documentos de Actividad Contemporánea- supuso establecer una 'base universal', como son las necesidades comunes del individuo, susceptible de ser traducida en un lenguaje estrictamente algébrico y convertirse en cosas necesariamente precisas. No obstante, la austeridad cartesiana no bastaba para erigirse en nueva arquitectura. La 'apariencia plástica' anhelada por el espíritu humano involucraba esqueleto, estructura, volúmenes, cubos de aire, superficie de iluminación, cantidad de ventilación, medidas de puertas y ventanas. Semejantes compromisos redactaba José Luís Sert, en la publicación del segundo número de $A C^{31}$ distinguiendo su obra para viviendas de alquiler en la calle Rosellón.

30 "A.C. Documentos de Actividad Contemporánea". Revista trimestral. Publicación del GATEPAC. Barcelona-Madrid-San Sebastián. Año $1^{\circ}$, primer trimestre. 1931. Ver "AC Publicaciones del GATEPAC". Colección Arquithemas, número 15. Edición Fundación Caja de Arquitectos. Barcelona, 2005. pág 13, AC 1

31 "A.C. Documentos de Actividad Contemporánea". Op. Cit. pág 58, AC 2 


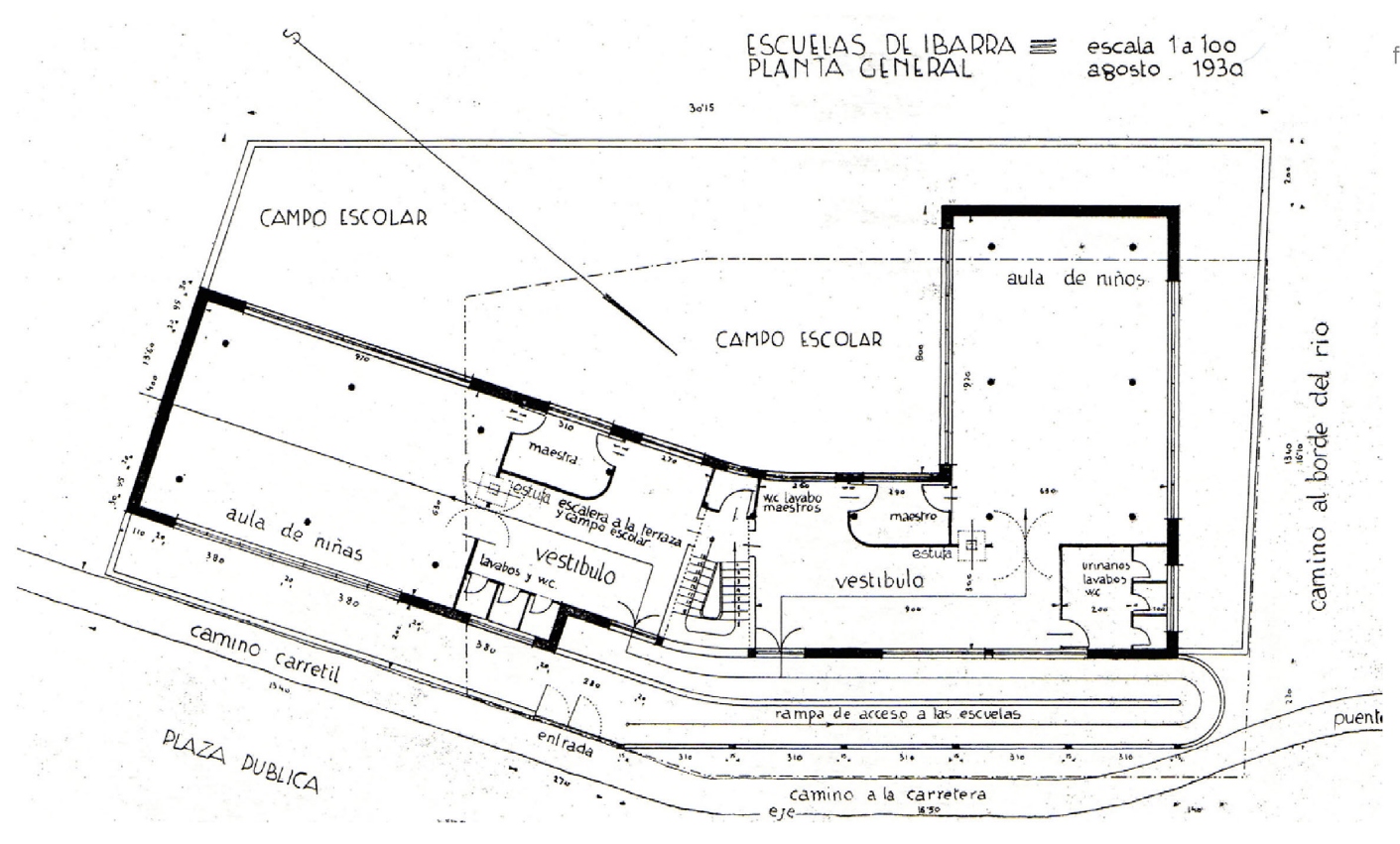

fig. 27

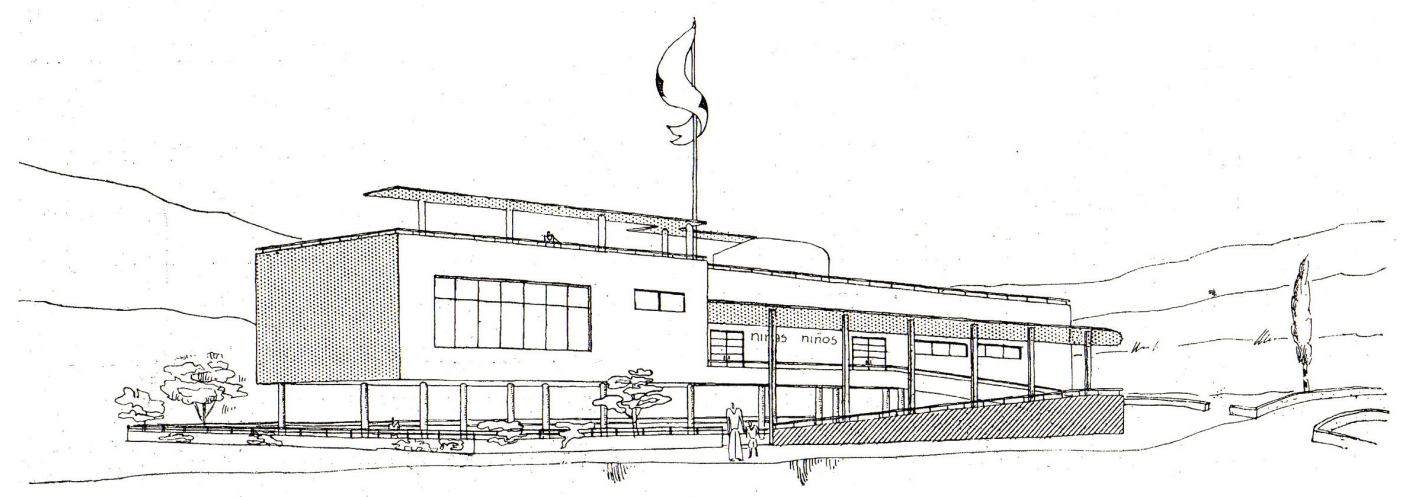

AIZPURÚA y LABAYEN, 1930. Proyecto de Escuelas elementales en Ibarra, Guipúzcoa; organización funcional en planta primera y perspectiva visual (AC publicación G.A.T.E.P.A.C.) 
Premonitorio, estrictamente fidedigno al espíritu de la época, a los cinco puntos de Le Corbusier, resultó el Proyecto de Escuelas elementales en Ibarra (Guipúzcoa), de Aizpúrua y Labayen (fig. 27). Edificio sobre pilotis, estructura metálica desprendida de la fachada-libre igual que la distribución interior- y cubierta en terraza aprovechable para impartir clases al aire libre ${ }^{32}$.

Reseñada en la Exposición de Arquitectura y Pinturas Modernas de San Sebastián ${ }^{33}$, al igual que la casa Vilaró, de sixto lllescas modélica en su estructura. Se ha adaptado a las necesidades de la planta, teniendo siempre en cuenta la economía: Pies derechos de hierro laminado en forma de vigas doble TT. Dinteles de las aberturas, techos y losas de cemento armado. Paredes de ladrillo de 0,15 metros de espesor y tabique de 0,05 metros, con una cámara de aire de 0,05 metros, al objeto de evitar aislarla de las temperaturas del exterior.

Cabe cuestionar si la elemental puesta en obra para el pabellón General del Manicomio, la sinceridad y la simplificación constructiva, la economía estructural suponen motivos, suficientemente justificados, para no elevar la propuesta a soluciones incluidas en una disciplina más ortodoxa,

32 "A.C. Documentos de Actividad Contemporánea". Op. Cit. pág 17, AC 1

33 Durante el mes de Septiembre de 1930 tuvo lugar, en San Sebastián, una exposición de pintura y arquitectura contemporánea organizada por el Ateneo Guipuzcoano. En cuanto a arquitectura, que es lo que nos ocupa, concurrieron arquitectos de toda España y dado el número de proyectos y diversidad de los mismos, fue la exposición nacional más importante de esta naturaleza realizada hasta la fecha. De esta exposición nació el "Grupo de Arquitectos y Técnicos Españoles para el Progreso de la Arquitectura Contemporánea", GATEPAC. 

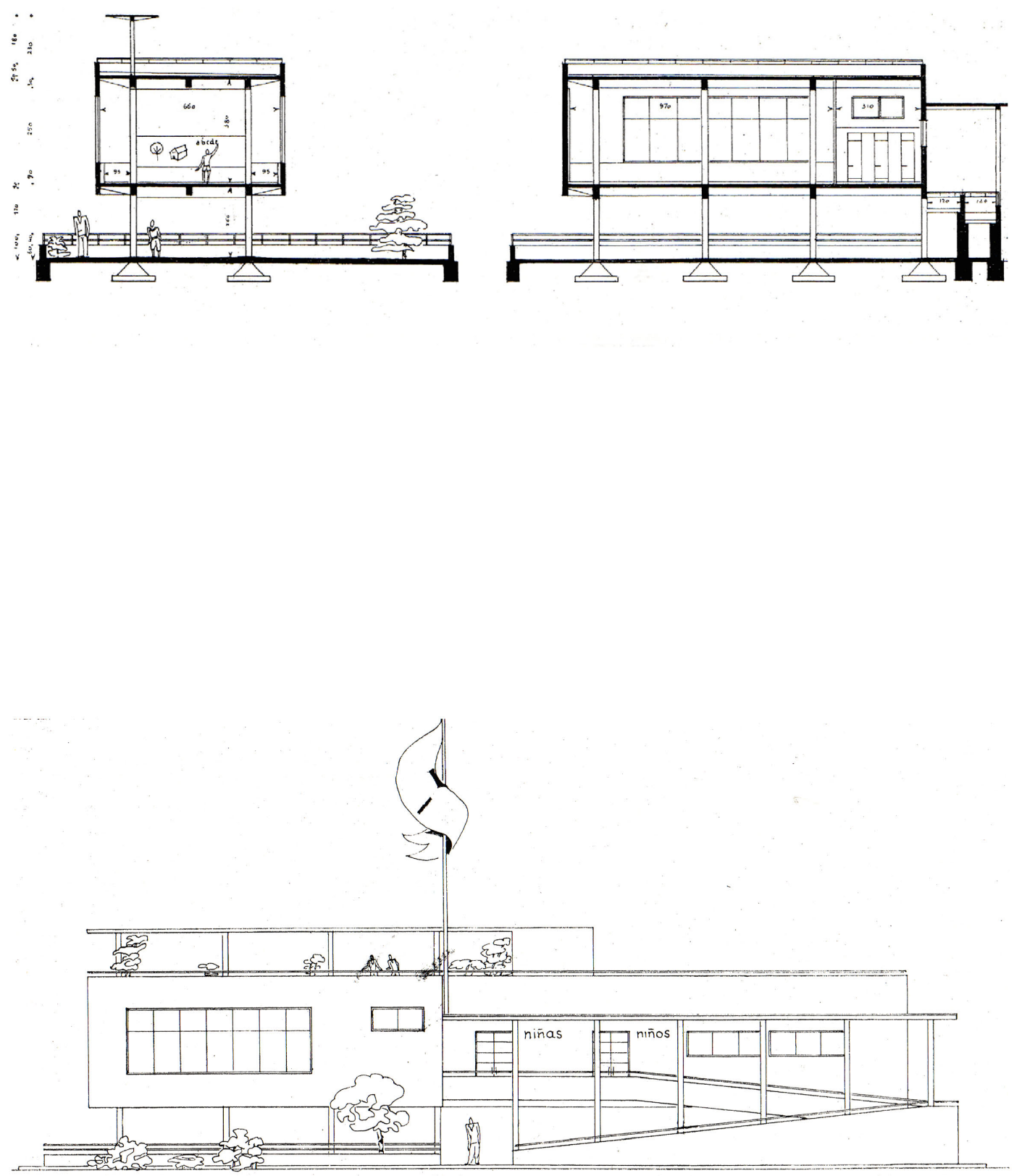

AIZPURÚA y LABAYEN, 1930. Proyecto de Escuelas elementales en Ibarra, Guipúzcoa; secciones y alzado desde la plaza pública, mediante rampa (AC publicación G.A.T.E.P.A.C.) 
liberando estructura, facultando exentos cerramientos, adoptando pilotis. Un prisma simple, unos alzados blancos, unos materiales universales, modernos, y una fenestración horizontalmente corrida, son síntomas de un lenguaje pretendido, quedando alejados de la verdad racionalista, relegados per sé. Conviene necesariamente exprimir el espíritu de lo que se ha construido.

Arquitectura racional, elevada ortodoxia. Alcanzarla apremia ineludiblemente a un trabajo de síntesis, de reagrupación, una investigación que reduzca a puntos comunes, a paradigmas que orienten el edificio hacia un proyecto moderno. La realidad es más compleja, y deja en evidencia aquello que permitía afirmar una disciplina pragmática capaz de relacionar el lenguaje funcional con los usuarios y las circunstancias constructivas. La realidad supera a la propuesta y se demuestra, normalmente, llena de matices, compleja. La obra arquitectónica concreta así su impronta, rechazando cualquier apremio por catalogarla.

\section{FACHADAS}

Analizar constructivamente el edificio estudiado, implica un nuevo estadio en el proceso, una estación donde detenerse en indagaciones, un último elemento susceptible de análisis. En particular, resultan determinantes las relaciones entre construcción y cerramiento, concluyentes las afinidades construcción y estructura. 


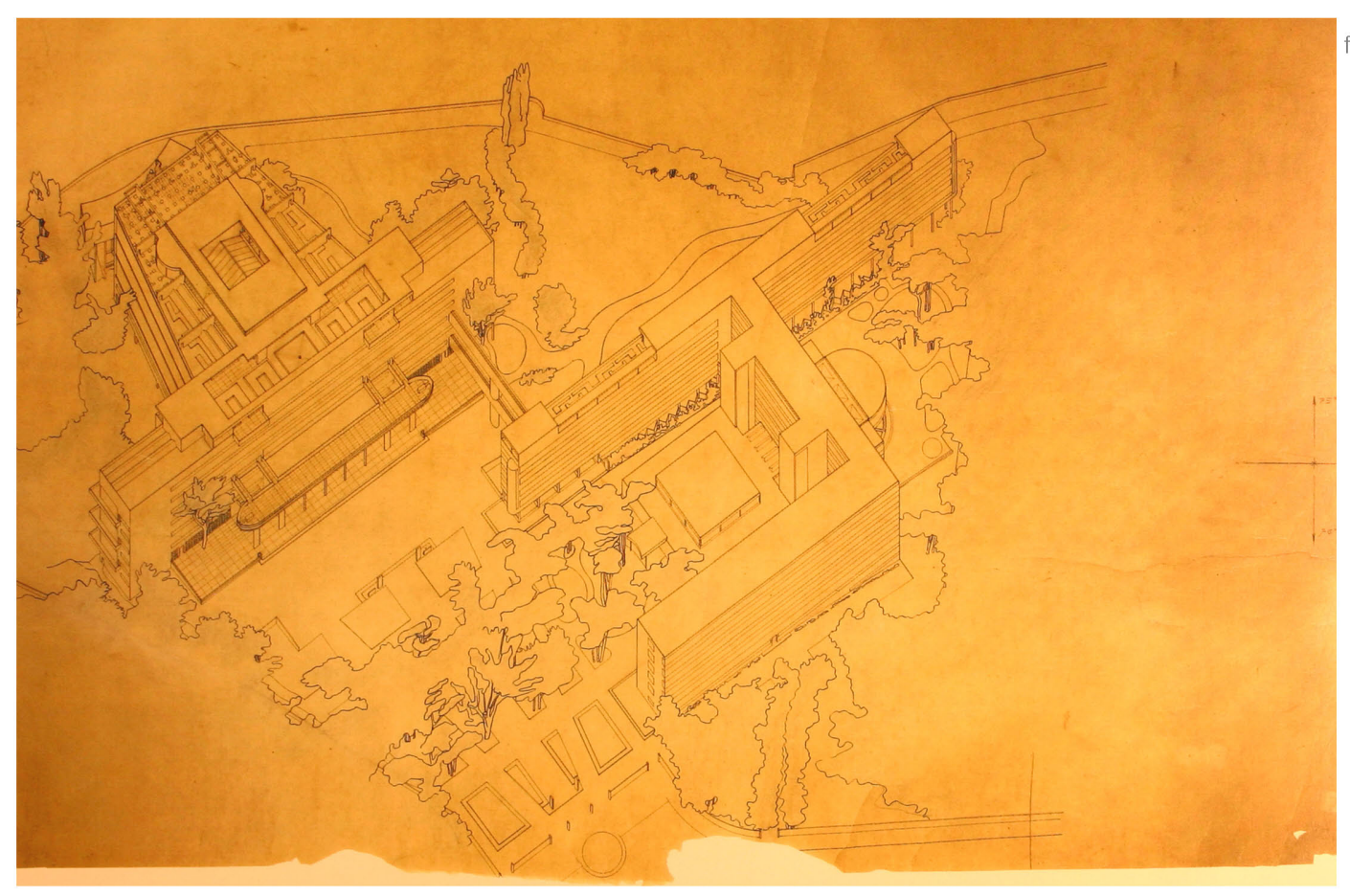

fig. 28

Le CORBUSIER, 1927. Palais de la Societé des Nations. Genève, Suisse. Propuesta para concurso; axonometría gestada por partes, por elementos reposicionados 
Proyectar un prisma íntegro, perfecto, ortodoxo. Confirmarlo con su construcción. Apasionar por medio de la ideación de fachadas, ofertando asimismo respuesta al espacio que abrazan. Elaborar sus fachadas como respuesta al contenido, a la distribución que tras ellas transcurre. Condicionar el sistema constructivo a la forma. Estas resultan las premisas a confirmar. Una envolvente exterior independiente de la estructura portante, libre de la compartimentación de funciones, liberada de toda imposición - ni tan siquiera constructiva-, buscando disipar su espesor a mínimos, hasta alcanzar la evanescencia vítrea, la permeabilidad lumínica y el flujo de aireación culminantes.

Reveamos la composición de cada pabellón General, su volumetría compleja gestada por partes, retomando el académico método de Guadet, reinterpretado en la Sede para las Naciones Unidas de Ginebra (fig. 28), por Le Corbusier. Elementos funcionales, dispuestos conjuntamente en dimensión orgánica, y recompuestos -posiblemente con menor grado de elaboración que el precedente escogido- hasta su concreción definitiva. Orientadas perpendicularmente a los radios de circunferencia, generadores de la ordenación del complejo hospitalario, seriadas e independientes, inconexas.

Semejante principio de composición por partes, no se infiere de manera tajante, más bien perdura como armazón, desadvirtiendo aportar complejidad y rotundidad. Permanece a la espera de las transformaciones que lo complementen, lo concluyan. Cuantitativamente aparecen prolijas y cualitativamente, plásticas. Estas adiciones -a completar aquel elemento primario-, el apilamiento de estratos espaciales, los añadidos al volumen lineal común, repercuten en su imagen externa, en su materialidad construida. 

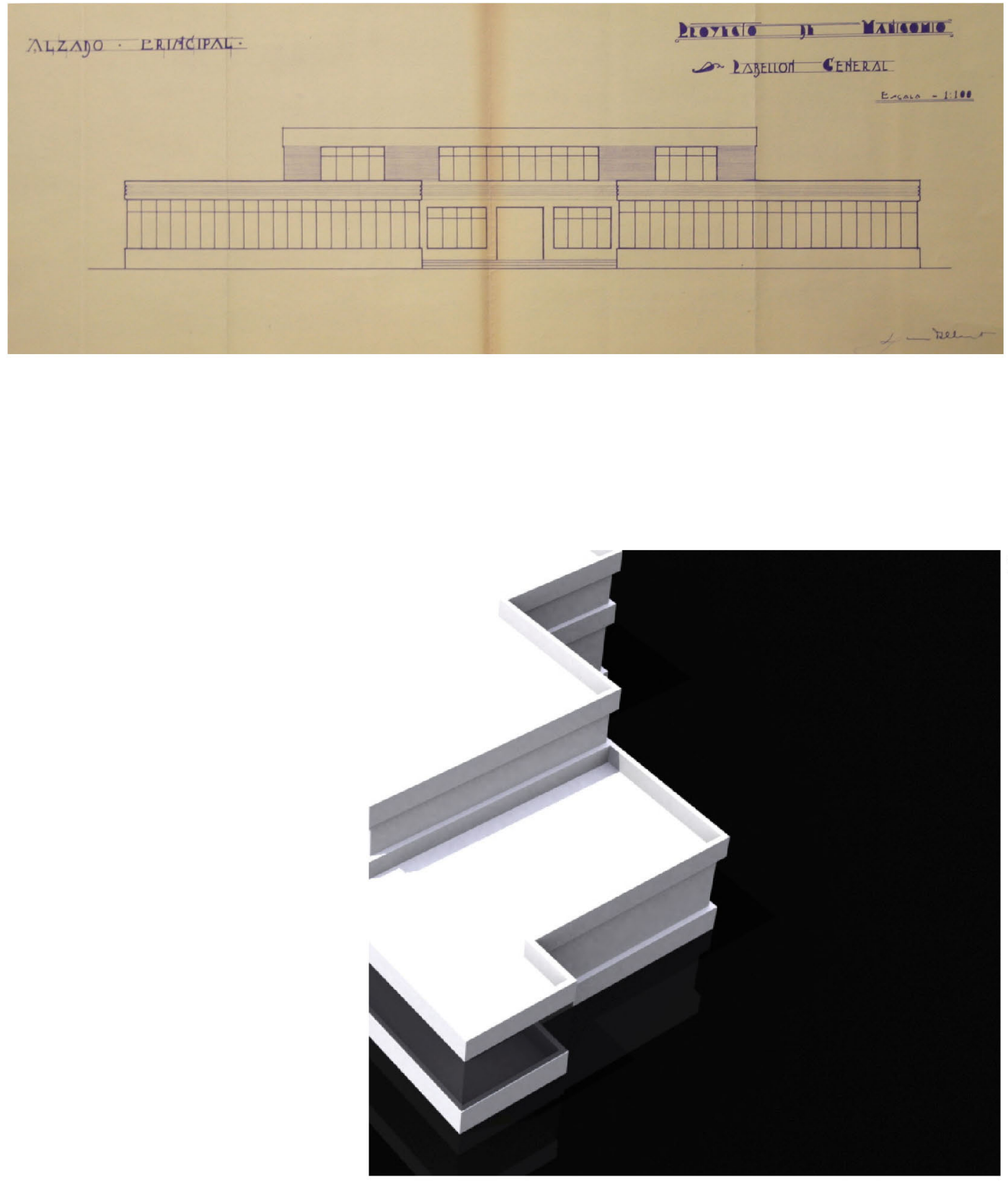

Luis ALBERT. Planimetría original del proyecto para Manicomio Provincial (AEDP). Pabellón General, alzado principal; detalle parcial de la maqueta informatizada 
Indaguemos su complejidad constructiva, la materialización de una envolvente para moldear una forma. Diversidad arquitectónica. Dos elementos yuxtapuestos en el volumen y en la planta. Una pieza lineal ofertando fachada, siempre al centro de la circunferencia, al pabellón de Administración, acceso al Manicomio.

Un zócalo de piedra caliza, presenta al terreno este prisma rectangular primigenio y anticipa el nexo futuro, previo a su alteración (fig. 29). Un muro de 0,40 metros de espesor, rasgado horizontalmente y en todo su perímetro, desde la cara superior del zócalo, hasta la coronación nuevamente horizontal. Una fisura en longueur ejecutada mediante ladrillo a cara vista, carpintería metálica y vidrios inastillables hasta una determinada altura. Un perfecto prisma cuya pureza empieza a desvanecerse en las yuxtaposiciones y cuya formalización constructiva integra en la diversidad. Resolver en la igualdad, las piezas asociadas, evita un decálogo de nuevos materiales y aporta unidad al edificio. Integrar piezas en una forma compleja, compuesta por partes, para generar una referencia, una fachada principal.

Adscribir nuevos prismas, yuxtaponerlos hasta la macla, supone desvirtuar el volumen común latente. Verticalmente se eleva, con igual lógica constructiva, empleando ahora como zócalo el propio prisma inicial, aunque sin retomar su perímetro y, evidenciando su menor altura (fig. 29). Horizontalmente, se intuye prescindible abandonar el borde, retranquearse del basamento.

Moldeada ya la forma-compleja siguiendo una composición por partes-, perseverar en la complejidad supone dotar de nuevas formas, de menor 


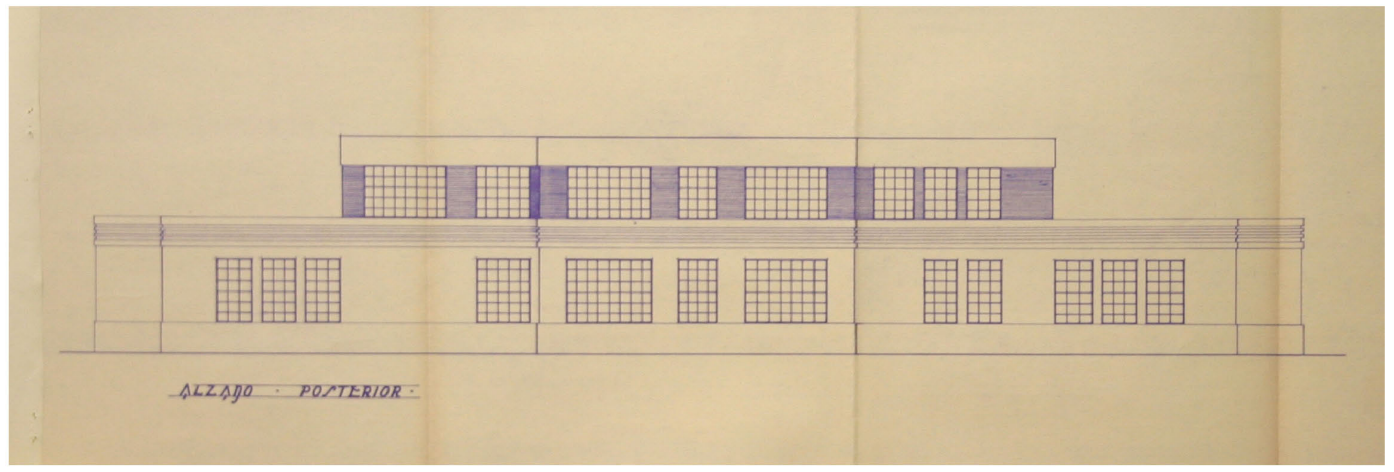

fig. 30

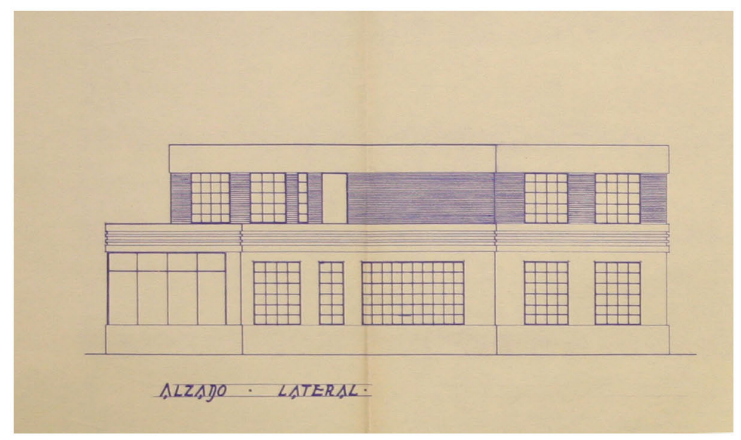

LUis ALBERT. Planimetría original del proyecto para Manicomio Provincial (AEDP). Pabellón General, alzado posterior y simétricamente proyectados los alzados laterales 
potencia y macladas. Dos cuerpos clausúrales, discrepantes, vítreos en toda su horizontalidad -expresión añorada y pretendida por el volumen que las adopta-, precisan geométricamente espacios para la meditación y concretan funciones de relación, abstrayendo el resultado último condicionado a su solución constructiva.

Variar la materialidad y con ello -con dos galerías transparentes-, generar el oscuro que provoca su separación. Una dupla adherida, que acompañando al eje de simetría y, bajo el volado de hormigón que las asocia en el último instante, componen académicamente el acceso, construyen una fachada, presentan un frente a la ordenación (fig. 30).

Jerarquía en fachadas, en alzados, como respuesta a la jerarquía de volúmenes compositivos, a la primacía funcional. Quizá las cuestiones de programa, de uso, plantean las dudas respecto a los espacios de meditación y contemplación, que enmarcan el acceso por la fachada principal. Forzar la simetría para generar el acceso por el centro del volumen prismático longitudinal, por su eje transversal, conlleva a crear dos prismas acristalados, uno de los cuales sirve a un espacio común de relación, mientras en el otro recaen piezas de servicio y aseos.

Retomando los pabellones de Viviendas y Peligrosos, ya antes comparados, se puede observar como ante una idéntica solución constructiva y un planteamiento volumétrico semejante, la rotundidad volumétrica sin necesidad de adscripciones, lo innecesario de forzar una simetría gestada por el quiebro del prisma, conllevan un resultado menos dubitativo. 


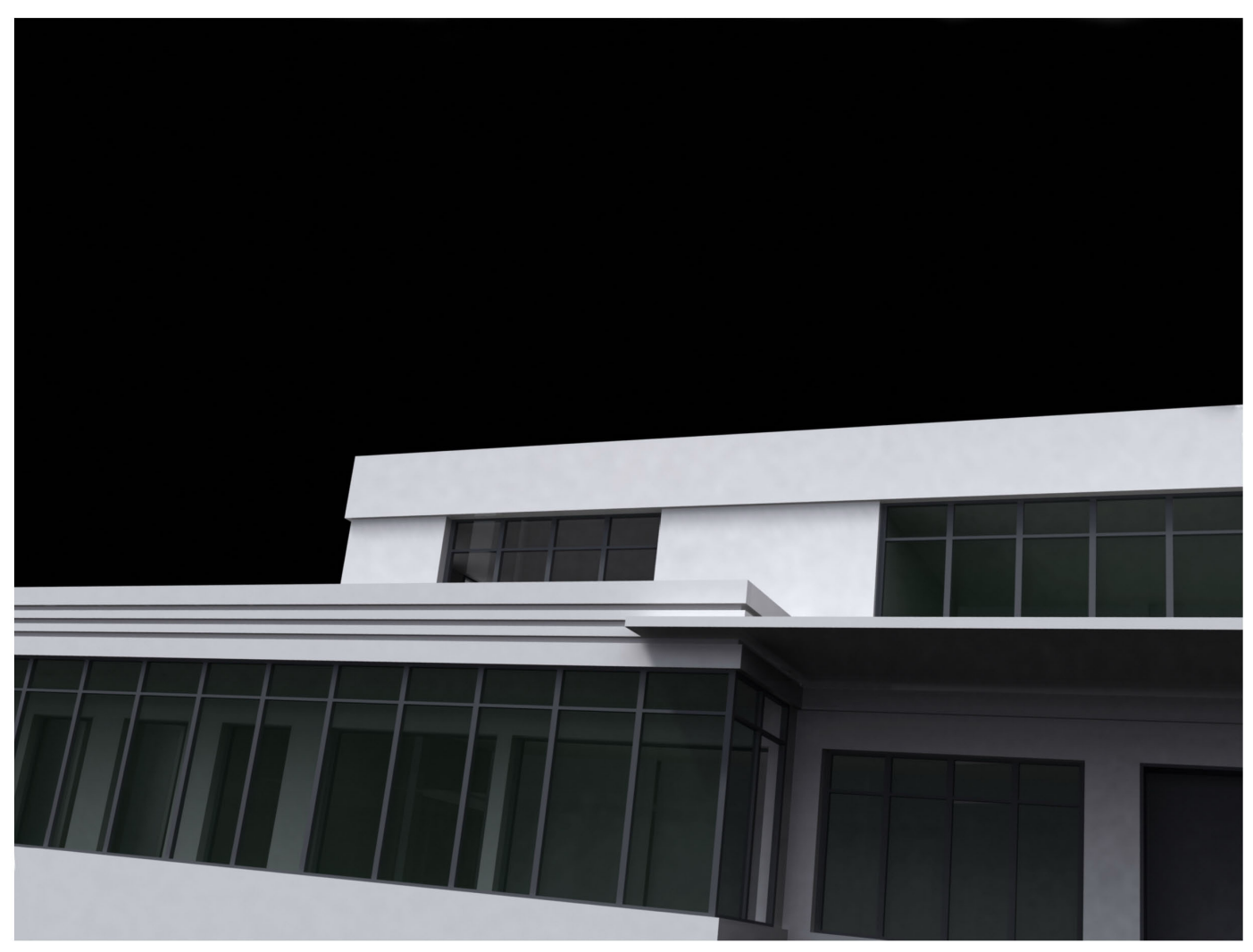


Cuestiones fundamentales relativas a una ortodoxia racionalista como la ventilación de estancias -una potente línea de circulación horizontal carente de ventilación cruzada, exactamente como los espacios a los que propicia accesos-, la orientación del edificio, el control del soleamiento, la jerarquía de alzados para responder al espacio y el uso que protegen, se eluden de estudio en aras de una implantación en la ordenación propuesta.

Cuestiones pragmáticas, soluciones constructivas, detalles de puesta en obra finalizan las dudas. Aproximar las carpinterías al plano de fachada, reducir vierteaguas, suprimir aleros y canalones, delimitar la función portante de la estructura del edificio sin acometerla en fachada, universalidad en los nuevos procedimientos y materiales de construcción, son cuestiones modernas no abordadas dentro de una ortodoxia racional. Seguirá el dubitativo camino marcado, la quinta fachada, la cubierta que cierra el edificio, el recorrido por su envolvente exterior. Las necesidades económicas, la rapidez no pueden justificar, ni despejar incógnitas. La insurrección brindada por la modernidad, el espíritu racionalista, la opción de realizar una obra de semejante enjundia por un fervoroso arquitecto, ofrecía una situación excelente para estudiar y resolver problemas no abordados. 
promociones privadas 


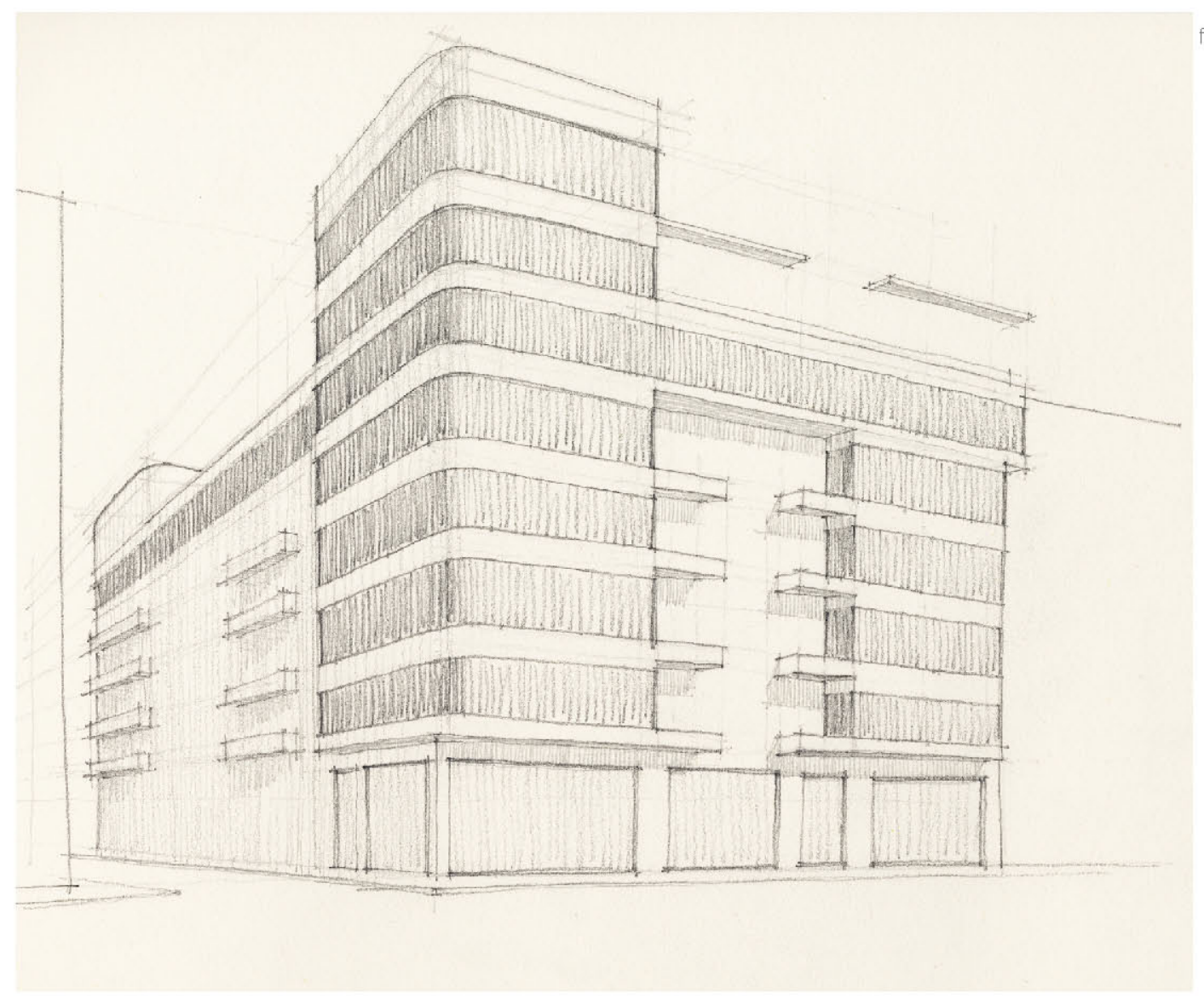

fig.

Luis ALBERT, 1933. Edificio de viviendas para Manuel CANOVAS, en las calles de Navellos, Micer Tarazona y Yerba: cónica perceptual, dibujo a lápiz del doctorando 


\section{DEAMBULATORIO RACIONALISTA}

Aislar un edificio individual, una producción arquitectónica e incluso un autor, normalmente presupone una integración dentro de un colectivo, de una época, de una práctica arquitectónica común. Genera un sistema global capacitado para aunar propuestas teóricas, normas estilísticas y producción edilicia, donde reconocer un producto aislado y aseverar sus axiomas, esencia y componentes.

Reemprendemos la metodología de trabajo, ya experimentada en esta tesis, esta vez en base a edificios públicos. Promociones aquellas, precedentes en el discurso a estas privadas (fig. 1). Antecedía en este método, el estudio individualizado de un edificio Sanitario, una parte del conjunto hospitalario, para concluir su integración en el total. Sucesivo en el discurso, se desarrollaba un elemento del Manicomio Provincial, hasta concluir el compendio de arquitectura oficial. No difiere ahora la evolución por variar una de las premisas, la condición del demandante del encargo. Nuevamente, el modesto empeño narrativo de una fracción, augura conclusiones al global. Individualizar una obra, tal vez una dupla, definirá el conjunto de obra privada emprendida por Albert. Integrando esta arquitectura, suscitada bajo encargo público y privado, culminaremos el procedimiento de analizar un autor y su obra. Igualmente ultimaremos la naturaleza del armazón, la producción arquitectónica valenciana, inmersa en un período concreto, enclavada en un espacio comenzado con marcadas premisas.

Afinar los vínculos, las ligazones, también las discrepancias, entre la obra individualizada y una estructura asociativa, una práctica colectiva, supondrá afirmar un sistema de trabajo, una práctica arquitectónica. En este 


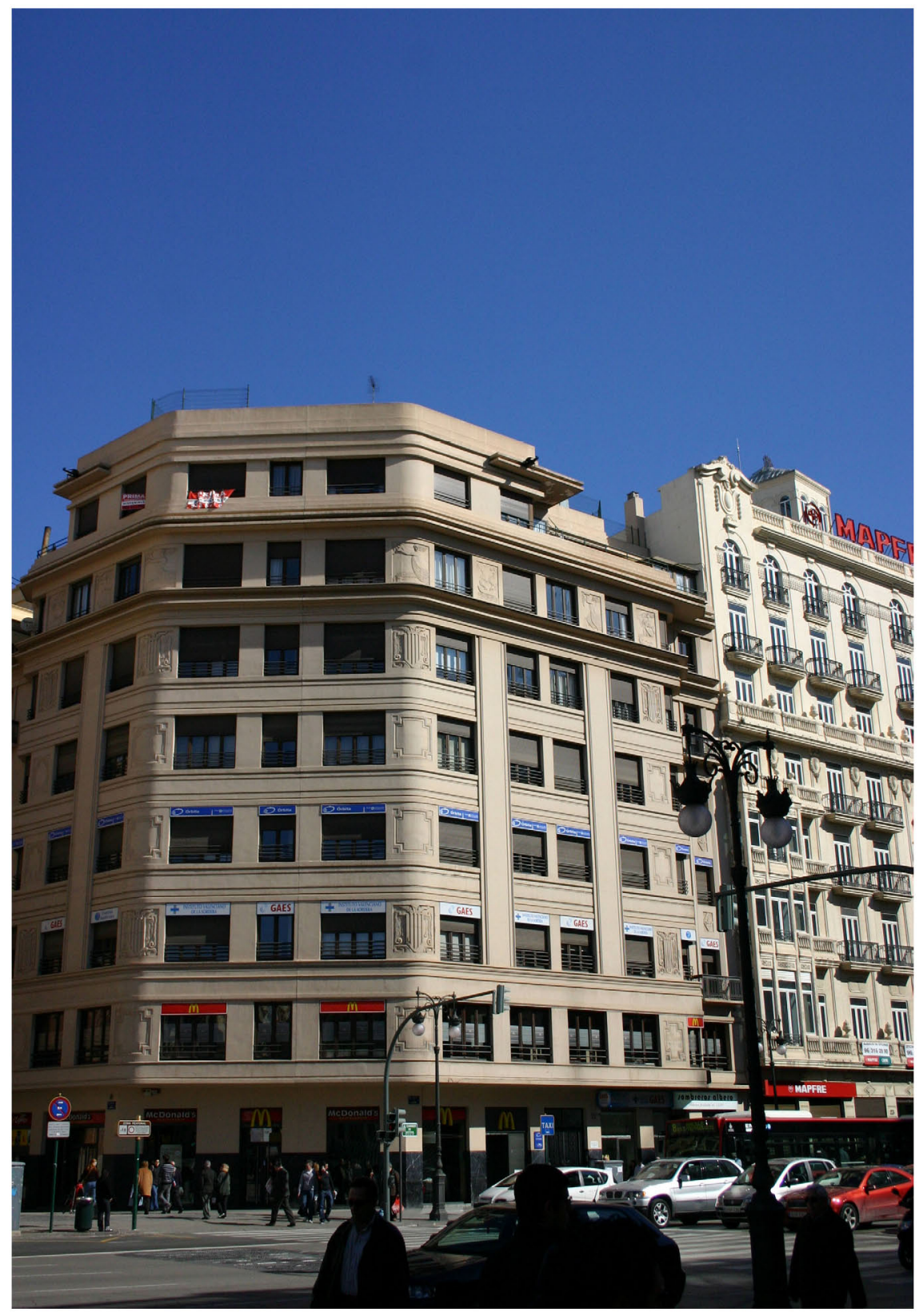

fig. 2

Ribera: fotografía del doctorando 
cuerpo común resulta factible integrar estas arquitecturas, analizadas con carácter aislado, cuya macla es producto de sus semejanzas.

Individualmente, cada proyecto puede ser la práctica de una escuela o de una tendencia en un momento determinado, o la práctica predominante de una etapa en el interior de una época. No obstante, si analizamos una práctica concreta, es decir, la relación que establece un proyecto individual con su fuente colectiva, observamos que se trata de dos momentos de un mismo proceso: su composición actual y las condiciones de esa composición, y que se trata, en todo caso, de un complejo de relaciones activas en expansión, cualquiera que sea el grado de eclecticismo (fig. 2) que se atribuya al proyecto del arquitecto individual en relación con los orígenes que lo definen'.

Abordar previamente el estudio de la arquitectura racionalista -allí donde involucrar el análisis individualizado- localizada en la ciudad de Valencia, referido ya un cierto grado de homogeneidad entre el sistema colectivo y la práctica concreta, ofrece diversas alternativas y no necesariamente un único recorrido. Señalar las trazas comunes inmersas en un modelo urbano, en un momento histórico determinado -la modernización pretendida, la sociedad receptora y su capacidad para asumir unos códigos formales-, se propone a través de un percorso, un recorrido por la ciudad, reviendo las viviendas trazadas por Albert en clave de modernidad.

1 PORTACELI, Manuel. "Una época troyana. Continuidad y renovación en la arquitectura de los años treinta en Valencia". Catálogo para la exposición realizada por el IVAM Centre Julio González, del 20 de enero al 5 de abril de 1998. "La ciudad moderna. Arquitectura racionalista en Valencia". Volumen I; pág. 177 

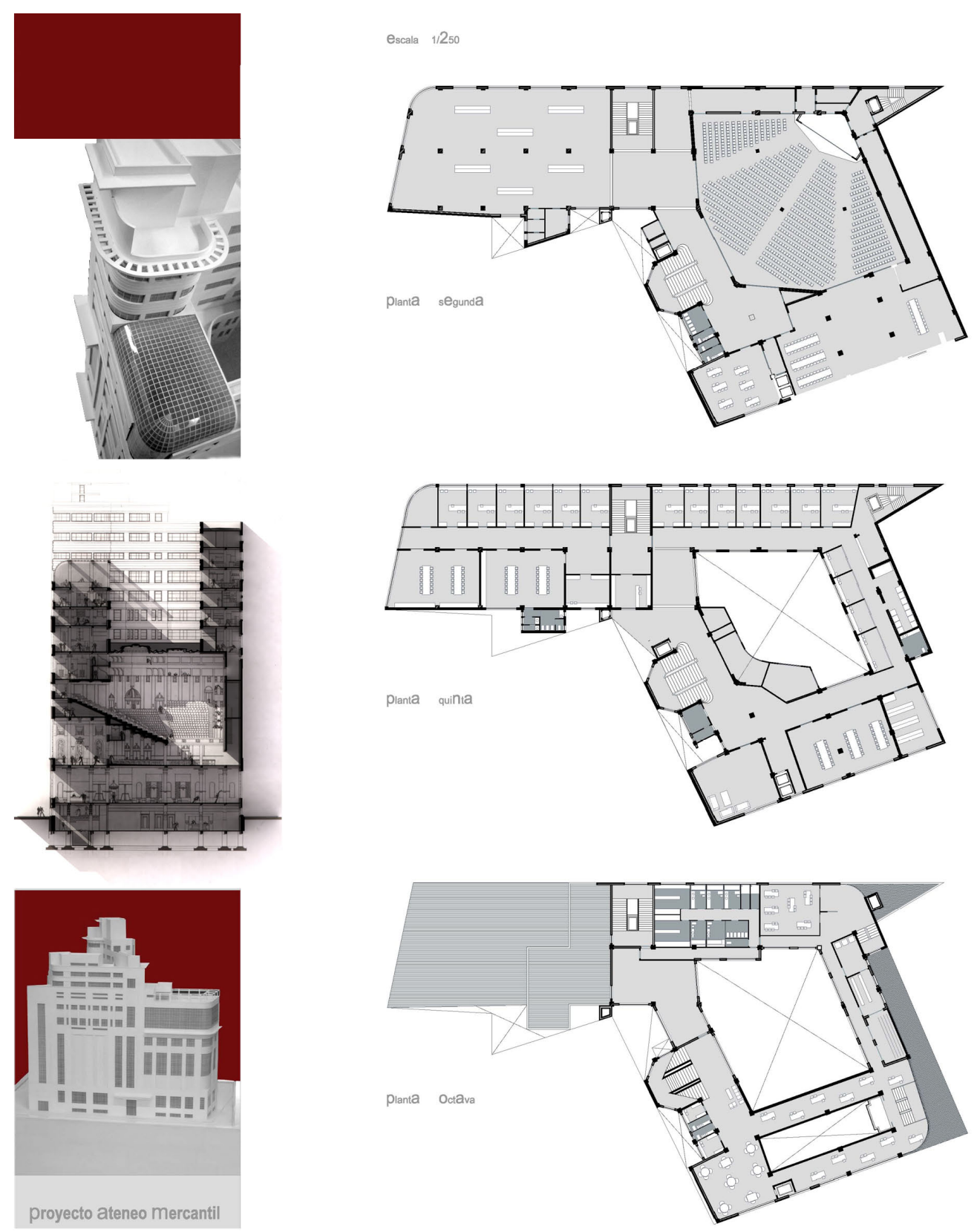

Gaspar BLEIN, Luis ALERT, 1927. Concurso Nacional para el Ateneo Mercantil de Valencia; planos redibujados, análisis de la luz en sección y maqueta virtual, por el doctorando 
Transitar la urbe, reconocer en ella arquitecturas avezadas, capaces de anunciar el nuevo espíritu de cambio, nos faculta para descifrar la producción de un arquitecto acompasado por la moderna esencia social y sirve como discurso preliminar al análisis individualizado.

Emprendamos pues, un recorrido metropolitano -encaminado mediante la localización física y la incorporación temporal de cada edificio al escenario urbano- con la intención de involucrar la fórmula electa, de encabezar el estudio de las promociones privadas de vivienda en la ciudad de Valencia. Al contener los pasos, habremos hallado una forma de incorporar las propuestas de Albert dentro de la pretendida modernidad para la metrópoli. Habremos asentado los principios para poder valorar aspectos urbanos, propuestas funcionales, códigos formales, compromisos ideológicos e innovaciones técnicas. Habremos dispuesto un ensayo donde introducir referencias a la profesión y también a sus coetáneos intérpretes-copartícipes de los hechos objeto de análisis- imprescindibles en la complejidad del momento y en la intensidad para involucrar, comprometer a una sociedad nada inclinada a contingencias, a la incorporación de una arquitectura donde acontecer verdaderos cambios alejados de los aceptados historicismos.

Albert anuncia con precocidad, en el CONCURSO2 DEL ATENEO MERCANTIL

2 Concurso de gran resonancia por la cantidad de trabajos presentados y la participación de alguno de los arquitectos más representativos del momento, hasta el punto de ser objeto de un monográfico de la revista Arquitectura ( ${ }^{\circ}$ 108-109. Madrid, abril-mayo 1928). Así aparecen los nombres de Casto Fernández Shaw y Fernando García Mercadal, Luis Moya y Aníbal Álvarez, con proyectos oscilantes entre el más recio casticismo, el noucentisme italianizante o un neobarroco folclorista de escaso interés. Respecto a los arquitectos de Valencia impera el casticismo con pinceladas más o menos regionalistas. 

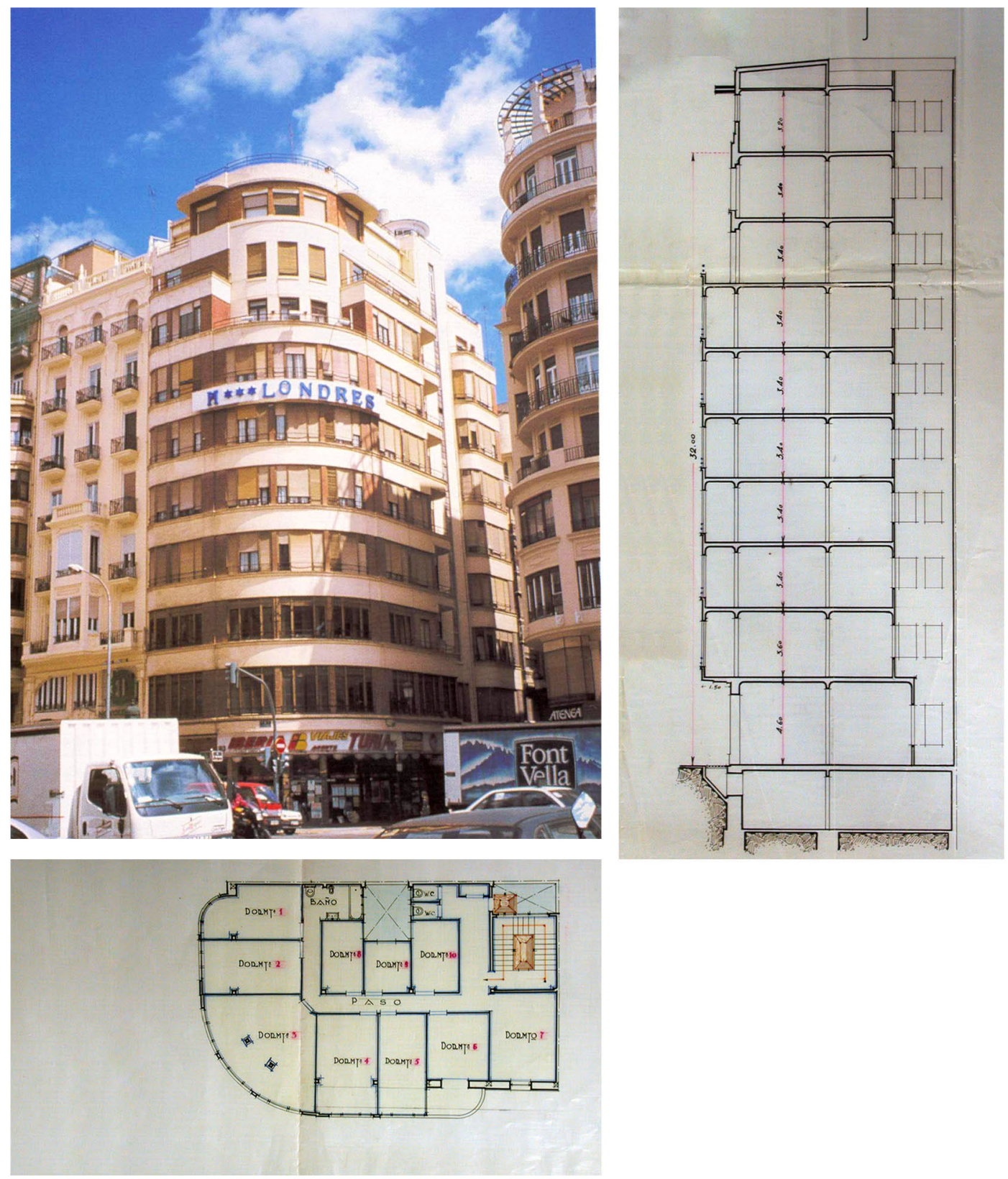

Javier GOERLICH, 1933. Edificio para comercio y vivienda (Hotel Londres) para Amparo MARTI, avenida de Blasco lbáñez y calle Barcelonina: (AHMV) Policía Urbana, legajo 3 
convocado en Valencia (1927) -junto a Gaspar Blein y finalizando sus estudios en la Escuela de Madrid- su firme propósito de incorporarse a una ciudad que ya había iniciado el camino ineludible para alcanzar la modernidad. Una única propuesta, entre todas las presentadas a concurso, afín a las corrientes europeas contemporáneas, exenta de pasadas reminiscencias y fastos nacionalismos, históricos casticismos (fig. 3). Eremita proposición ofertando, acorde a renovados propósitos, una amalgama de intereses tan diversos como la recurrente imagen del rascacielos, el diseño elementalista y la iconografía art déco, la cubierta acristalada, los efectos caligráficos sobre la fachada y un dinamismo expresionista a través de aleros y voladizos. El conjunto, desmesurado en escala y formas, muestra su precoz afinidad con las corrientes contemporáneas por él conocidas a través de revistas como Architettura, L'Architecte, Innen Dekoration, L'Architecture d'Aujourd'hui o Moderne Bauformen ${ }^{3}$.

Una implicación puntual, capaz de transformar la imagen de una ciudad que parecía dispuesta a variar su aspecto formal, reafirmando el tránsito emprendido de ciudad agrícola a metrópoli. Una propuesta enclavada en un señalado entorno, la plaza de Emilio Castelar -reordenada expedita, hendida por Javier Goerlich- formalizada mediante frentes urbanos, sometidos estos, a la época en que se elevan y a los autores que los enarbolan.

3 TORRES, Jorge. "Los primeros modernos. Los arquitectos valencianos entre la permanencia del academicismo y la renovación de los lenguajes". Catálogo para la exposición realizada por el IVAM Centre Julio González, del 20 de enero al 5 de abril de 1998. "La ciudad moderna. Arquitectura racionalista en Valencia". Volumen I; pág. 42 


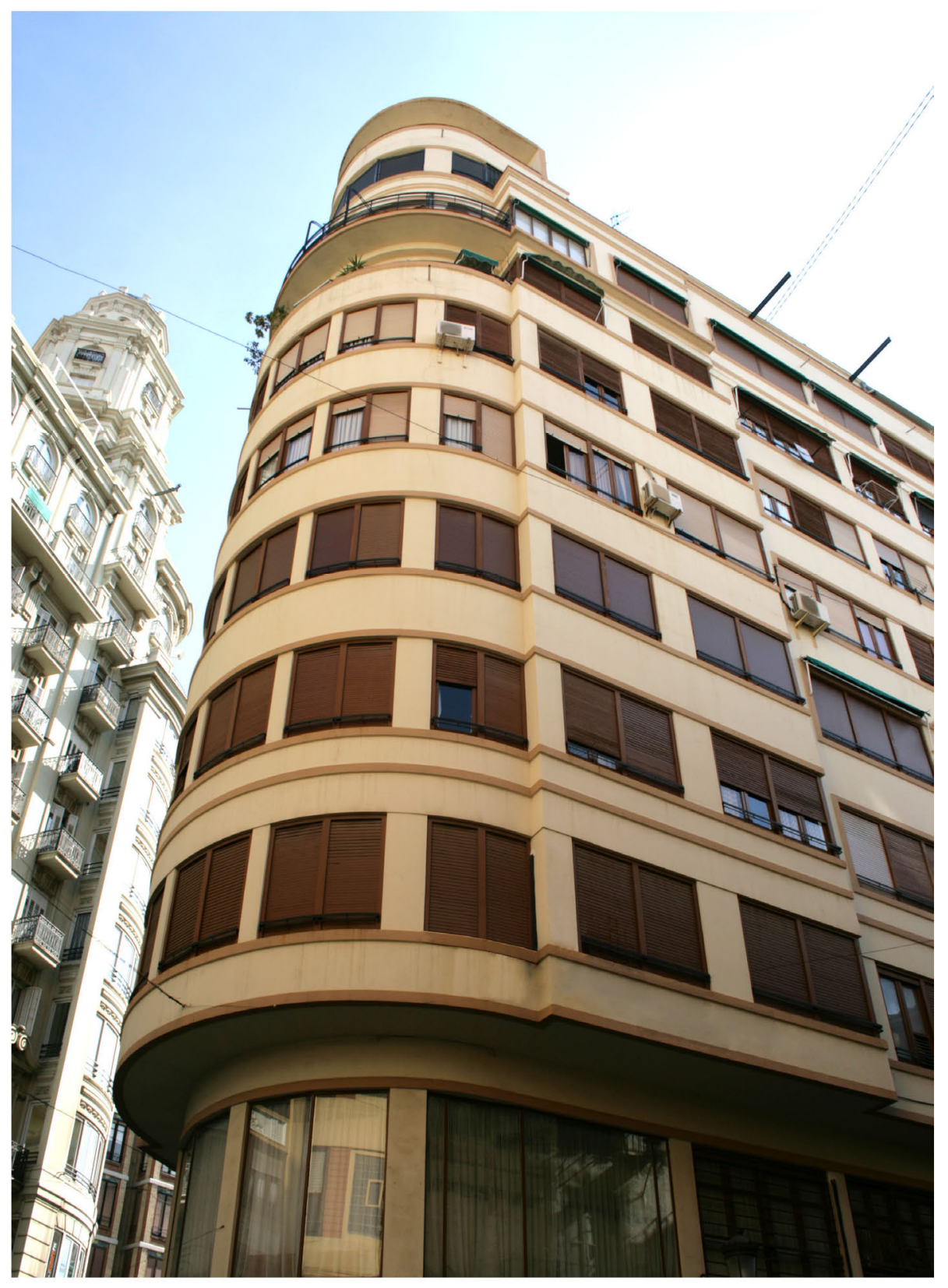

fig. 4

Ricard ROSO, 1935. Edificio de viviendas para José LLOPIS (II), avenida de Pablo lglesias plaza de Porchets y calle de Ribalta: fotografía Ricardo Perelló ROSO 
Un compendio de estilos arquitectónicos generaría la ansiada imagen moderna. Ecléctico resultaba el alzado urbano -el frente a la plaza desde las cuatro manzanas conclusión de la nueva estructuración del barrio de Pescadores- responsabilidad de Francisco Mora, en los años veinte. Clasicistas resonancias presentaban los edificios Balanza, los cuatro entre Ribera y Marqués de Sotelo, y la mayor parte de aquellos que levantan el frente desde el Ayuntamiento a la avenida María Cristina, en los años de la dictadura de Primo de Rivera (fig. 4). Racionalista acuñaba el término entresacado de cualificados autores4- que agrupó el frente de la bajada de San Francisco al solar de concurso del Ateneo, emprendido bajo el auspicio de los años treinta y, precozmente visualizado en la proposición de Blein y Albert.

Jerarquizar el espacio urbano volumétricamente, rever la composición urbana de la plaza desde el orden, condiciona la proporción formal propuesta a concurso. Una dupla volumétrica, dos diferentes alturas para desatender una visión urbana homogénea. Desordenar un espacio arquitectónico, previamente desmesurado en escala, descalificadora para los miembros del jurado.

Superado el concurso, en sus primeros edificios en Valencia, encontramos siempre propuestas noucentistas, transformadas siguiendo las aprehendidas

4 COLOMER, Vicente. "La arquitectura como forma crítica de hacer ciudad". Catálogo para la exposición realizada por el IVAM Centre Julio González, del 20 de enero al 5 de abril de 1998. "La ciudad moderna. Arquitectura racionalista en Valencia". Volumen I; pág. 113 


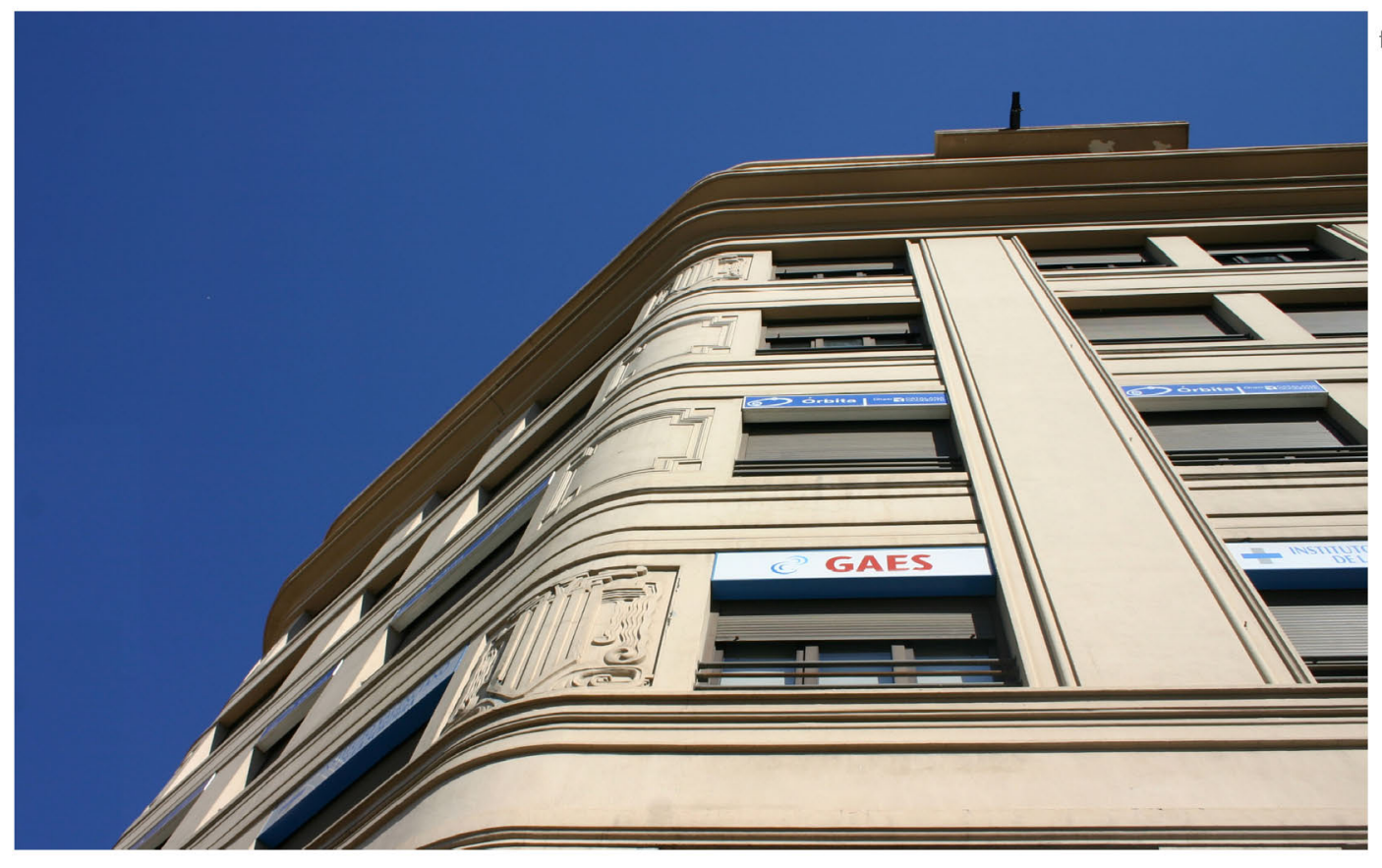

fig. 5
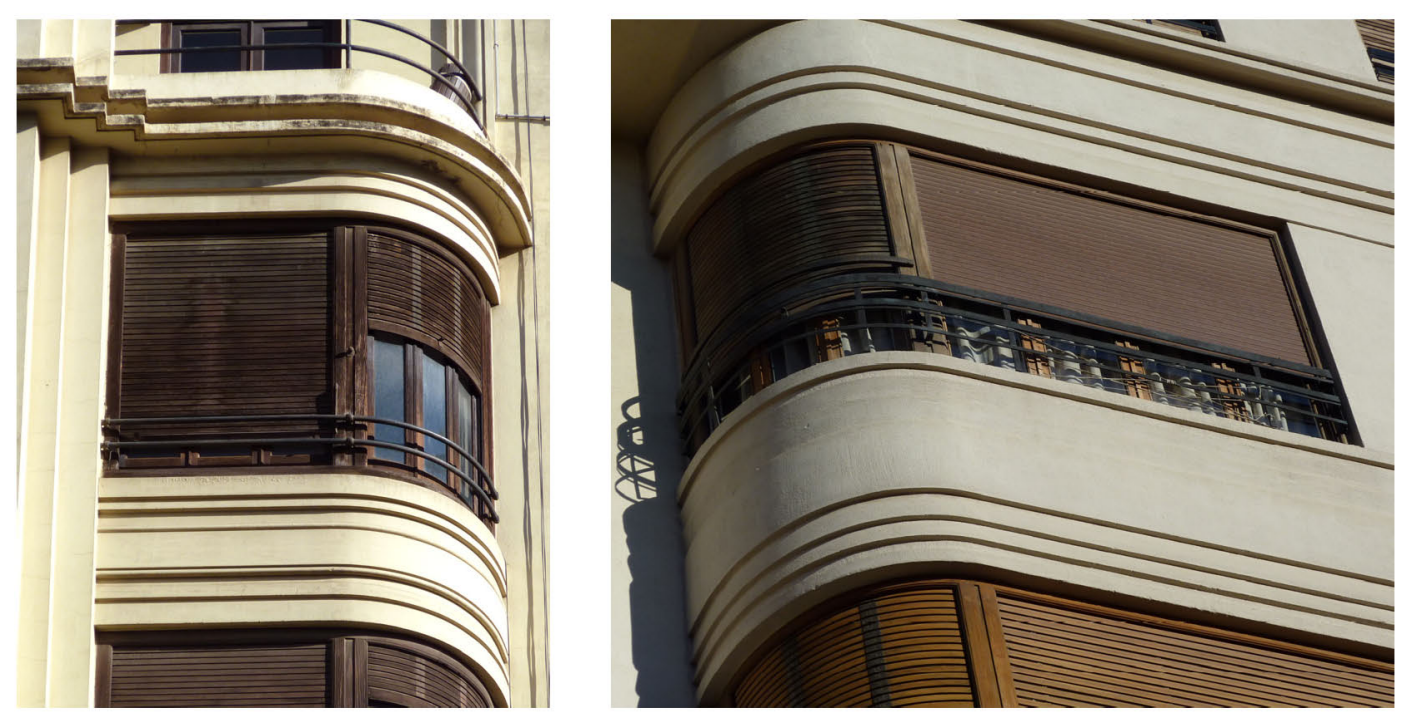

Edificios CARBAJOSA, MOMPó Y TORTOSA; fotografías del doctorando recreando detalles de molduras, aleros, incisiones lineales en antepechos, ventanas corridas en esquina 
pautas del edificio del Ateneo. Así sucede en sus primeras intenciones fraguadas, donde molduras y aleros ganan en relieve y expresividad (fig. 5). Las incisiones lineales en los antepechos, las persianas americanas, las ventanas continuas en esquina, la cerrajería geometrizante o los paneles de diseño art déco, son atributos comunes de aquel "expresionismo funcionalizadon difundido desde centroeuropa ${ }^{5}$.

Suscitan referencias de la arquitectura moderna que comienzan a impregnar la ciudad, referencias para el contingente de profesionales que erigen la moderna urbe y la sociedad que las tolera -término conscientemente rescatado para matizar la intransigencia social a aceptar los avances- y sin embargo, en su trasfondo, referencias asépticas y distanciadas del debate vanguardista desatado en Europa con el Manifiesto Cubista e iluminado por Le Corbusier tras publicar Vers une Architecture. Posiblemente la bisoñez que agrupaba localmente a los agentes participantes, les incapacitó para asumir las modernas formas concatenadas al discurso programático y les destinaría a refugiarse en referencias menos anunciadoras, abruptas e iconográficas.

Le Corbusier, Mendelsohn, Mallet-Stevens y todos los referentes europeos de la modernidad arquitectónica son objeto de cuestionable aceptación, de difícil asimilación y compromiso. Un sincretismo conciliador, una postura ecléctica presenta una mayor aceptación y verosimilitud, al tiempo que

5 TORRES, Jorge. "Los primeros modernos. Los arquitectos valencianos entre la permanencia del academicismo y la renovación de los lenguajes". Op. Cit; pág. 42 


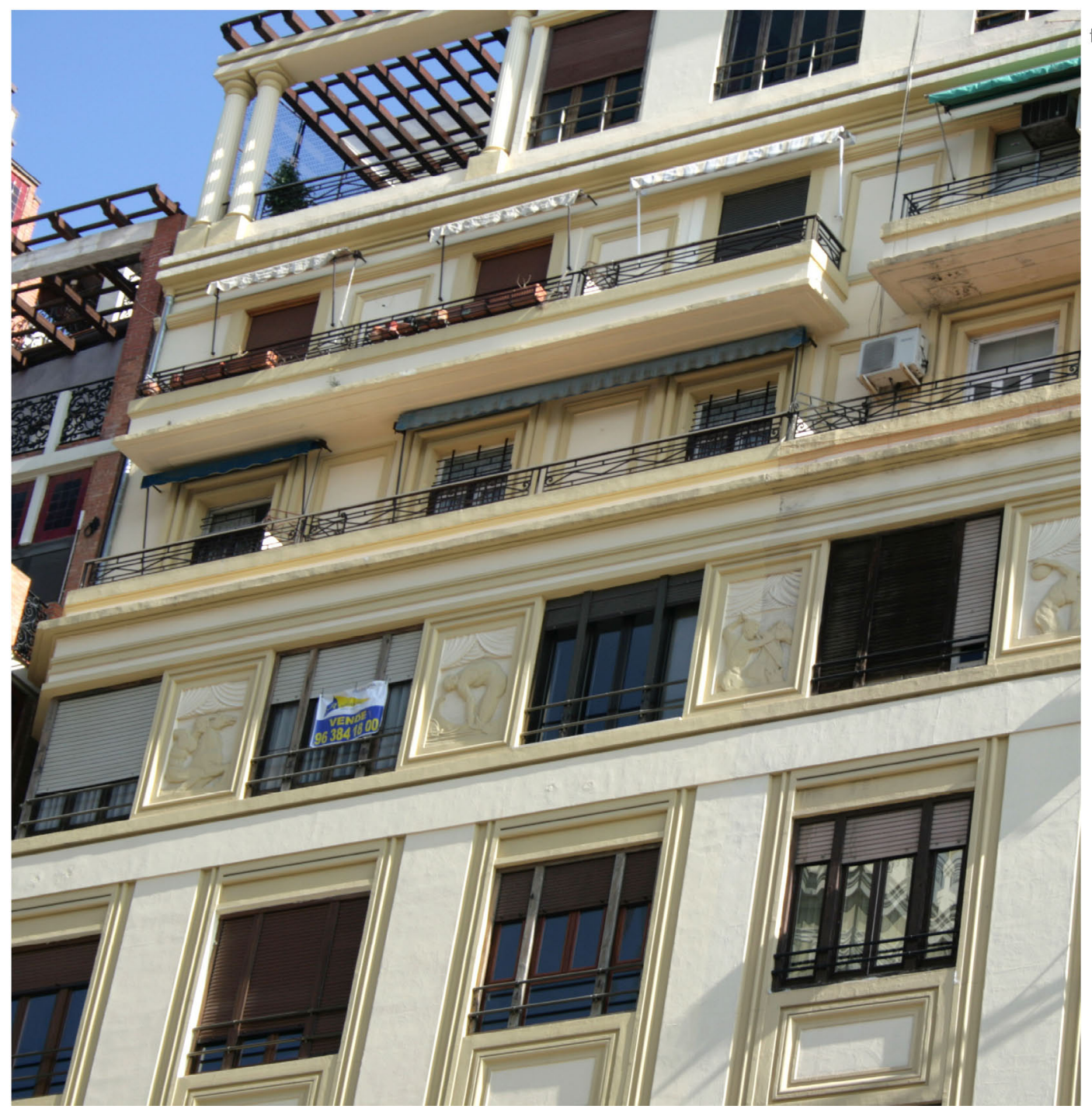


manifiesta, patentes e infinitas dudas. Los afranjados e impostas horizontales quedan cortados por grandes pilastras y equilibrados por ángulos y aristas en un sistema compositivo de influencias decó (fig. 6). La composición es cuidada y el decorativismo, que incluye altorrelieves en los entrepaños, trata de restar virulencia a un planteamiento innovador. ${ }^{6}$

Evidenciar los vertiginosos avances de la sociedad moderna, manifestarlos en arquitectura suponía evolucionar, desarrollar un proceso iniciado con el derribo de las murallas (1865) y su lógica consecuencia, las reformas urbanas para alcanzar la ciudad moderna. Leyes específicas para el Ensanche y leyes para abordar la Reforma Interior, pondrían de manifiesto una urbe contemplándose así misma, ensimismada en su propio ombligo. Mínimas propuestas y escasos esfuerzos para gobernar la desurbanización. Agravio contra la razón, donde por riesgo y cuenta particular, emanarían leyes de Casas Baratas para conformar ciudades-satélite y disponer una oferta inmobiliaria, de barrios enteros en el extrarradio, suficiente para mitigar el problema de los expropiados. Disociar entre la metrópoli y la ciudad-jardín howardiana, convencer en el debate y, resolver en favor de una, se afrontaría como la única opción, desatendiendo la viabilidad de conjuntar ambas y supeditarlas a un orden superior: 'zonnig'.

Contemplar ambas posturas se mostraba inabordable para el consistorio y, ante la abulia, el tedio mostrado más allá del límite del ensanche para responsabilizarse frente a cualquier proyecto, amanecieron cooperativas

" COLOMER, Vicente. "La arquitectura como forma crítica de hacer ciudad". Op. Cit; pág. 117 


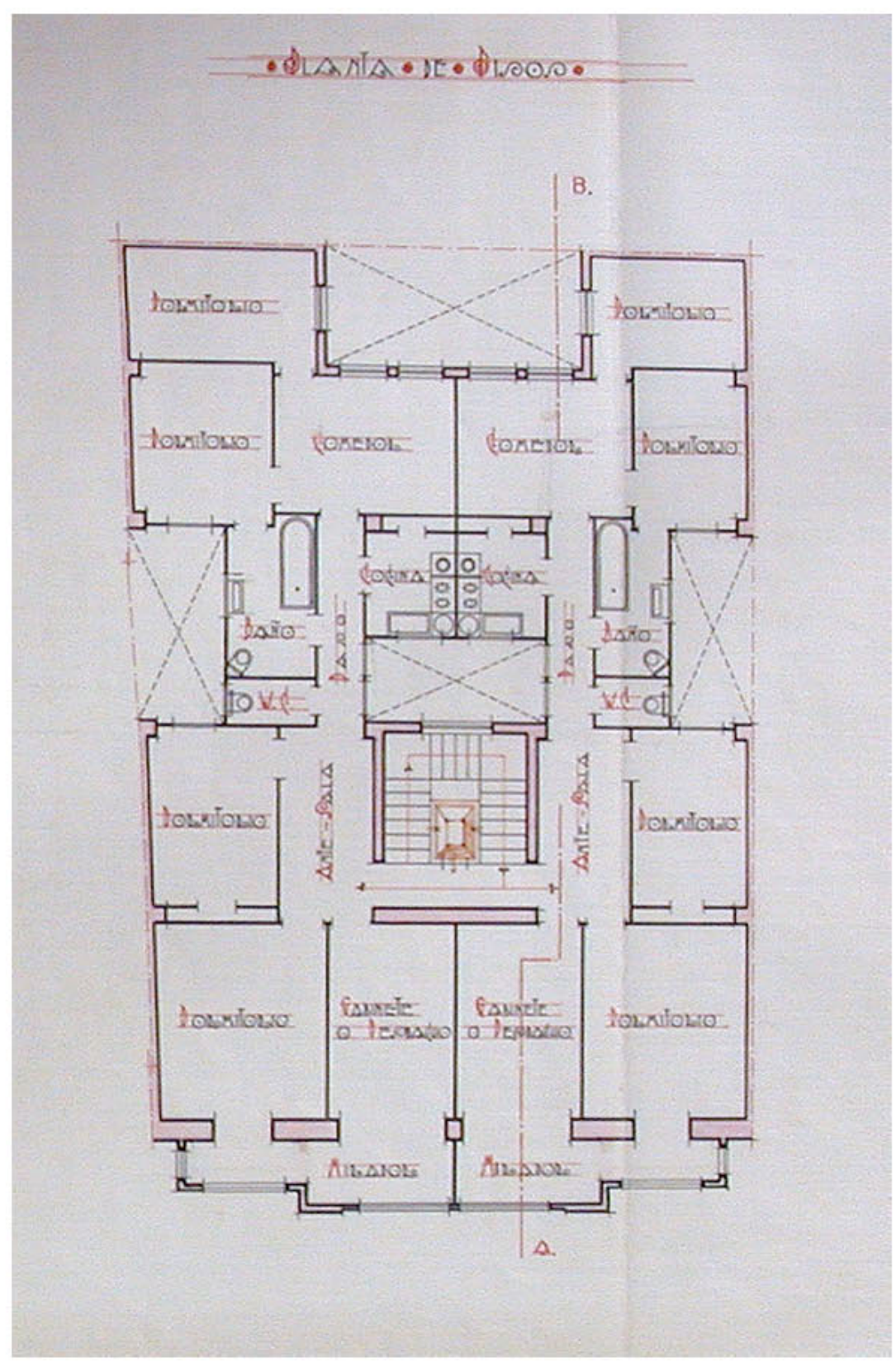

fig. 7

Luis ALBERT, 1930. Edificio de viviendas para Juan Antonio MOMPó, en calle san Vicente, $n^{\circ}$ 33: planta de pisos (AHMV) Policía Urbana, legajo 27 expediente 21 
y empresas privadas. La administración afrontó una visión disciplinada del problema migratorio hacia la urbe, consolidando la vida urbana mientras observaba el auge del negocio inmobiliario, proporcionando céntricos solares donde erigir edificios en altura. Y si las reformas urbanas del XIX, promovían volumetrías equilibradas, homogéneas, las reformas posteriores variaron considerablemente esta predisposición, aumentándolas y -todavía más discutible-, sin ninguna consideración sobre el resto de parámetros urbanísticos.

Probablemente porque el ulterior desarrollo de la ciudad capitalista, también recayó en la iniciativa privada, se suscita la apuesta por edificar viviendas -poco más o menos sin límite vertical-, en contrapartida de equipamiento terciario, edificios públicos. La consecuencia resultaría evidente; la episódica concentración de arquitectura racionalista desnaturalizada, navegando inmersa en la avalancha de arquitectura ecléctica o sencillamente clasicista, eficazmente sirviente de la burguesía valenciana. Un estilo alejado de la esencia de la nueva arquitectura, aquella que preconizaba, precisamente la ausencia de mímesis estilística. Un estilo ramplón en su mayoría, desentendido de la necesidad de una época, pero atento a los caprichos de la sociedad que lo promovía.

Concentraban en la vestimenta externa, la imagen escénica, el grueso de trabajo por alcanzar el espíritu moderno. En cuanto a funcionalismo, a la tipología de vivienda, primaría la seguridad de lo consolidado a finales del siglo XIX, las enseñanzas Beaux Arts, la confianza en aquello contemplado, lo burguesmente inteligible. Organizar la vivienda a partir de una axialidad referida a la perpendicularidad desde la fachada (fig. 7). Ordenar espacios subordinándose a la jerarquía funcional y someter funciones a 


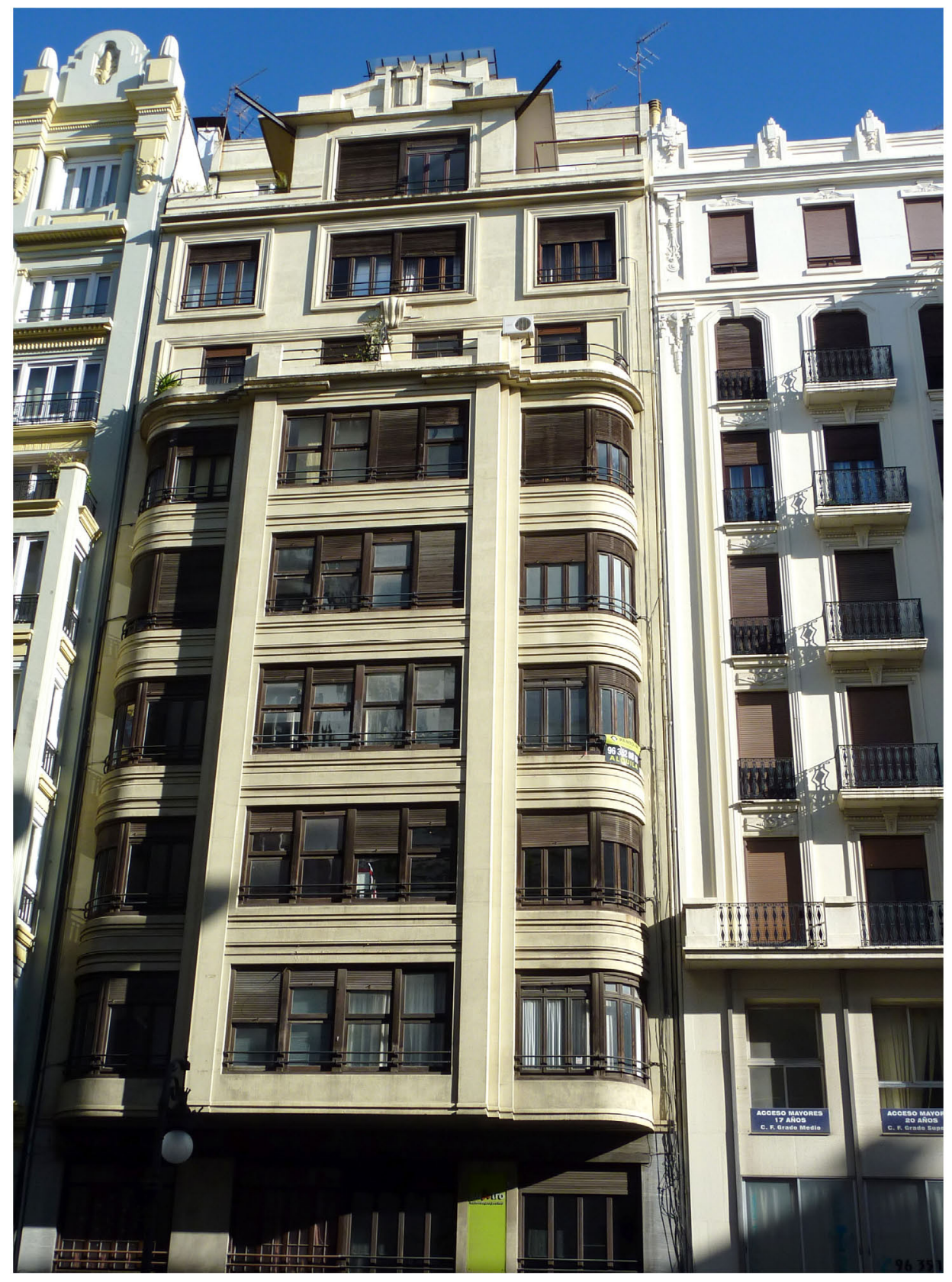

Luis ALBERT, 1930. Edificio J. A. MOMPÓ, calle San Vicente, n³3: fotografía doctorando 
las vistas exteriores. La tipología de ensanche ensayaba este modelo, delimitado por sus fronteras a la calle y al patio de manzana. Resultó una arquitectura ligada a las bases de un clasicismo académico, pero alejada de la fuerte 'carga programática' de la vanguardia. ${ }^{7}$

Racionalismo higienista como solución distributiva, jerarquizando usos, uniformizando espacios trabajados con un alto grado de confort, presentando la estructura al alcance de la vista y concentrando núcleos húmedos. Un método compositivo rescatado de convenciones asumidas, conciliador con las nuevas demandas y los nuevos lenguajes de las vanguardias europeas. No podrían englobarse estas composiciones distributivas, dentro de soluciones innovadoras para las nuevas demandas de viviendas o en su relación con la ciudad. "Se afirma una paulatina depuración tipológica a partir de las consignas higienistas difundidas desde principios de siglo con una asignación sensata de superficies disponibles, pero de modo convencional, sin incidir en las posibilidades de la planta libre ni experimentar con materiales y tecnologías ajenas a la construcción más convencional". 8

Constructivamente modernizada e incorporada a los cambiantes sistemas de producción, Portaceli encuadró esta arquitectura dentro del eclecticismo. Más que adecuar a los problemas entonces, formulaciones arquitectónicas del pasado -así sucedía a mediados del siglo XIX-, el compendio de la

7 PORTACELI, Manuel. "Una época troyana. Continuidad y renovación en la arquitectura de los años treinta en Valencia". Op. Cit; pág. 179

${ }^{8}$ TORRES, Jorge. "Valencia Moderna. Del eclecticismo a la Tendenza". Arquitectura Viva, $n^{\circ} 61$. Julio-agosto 1998. Madrid 


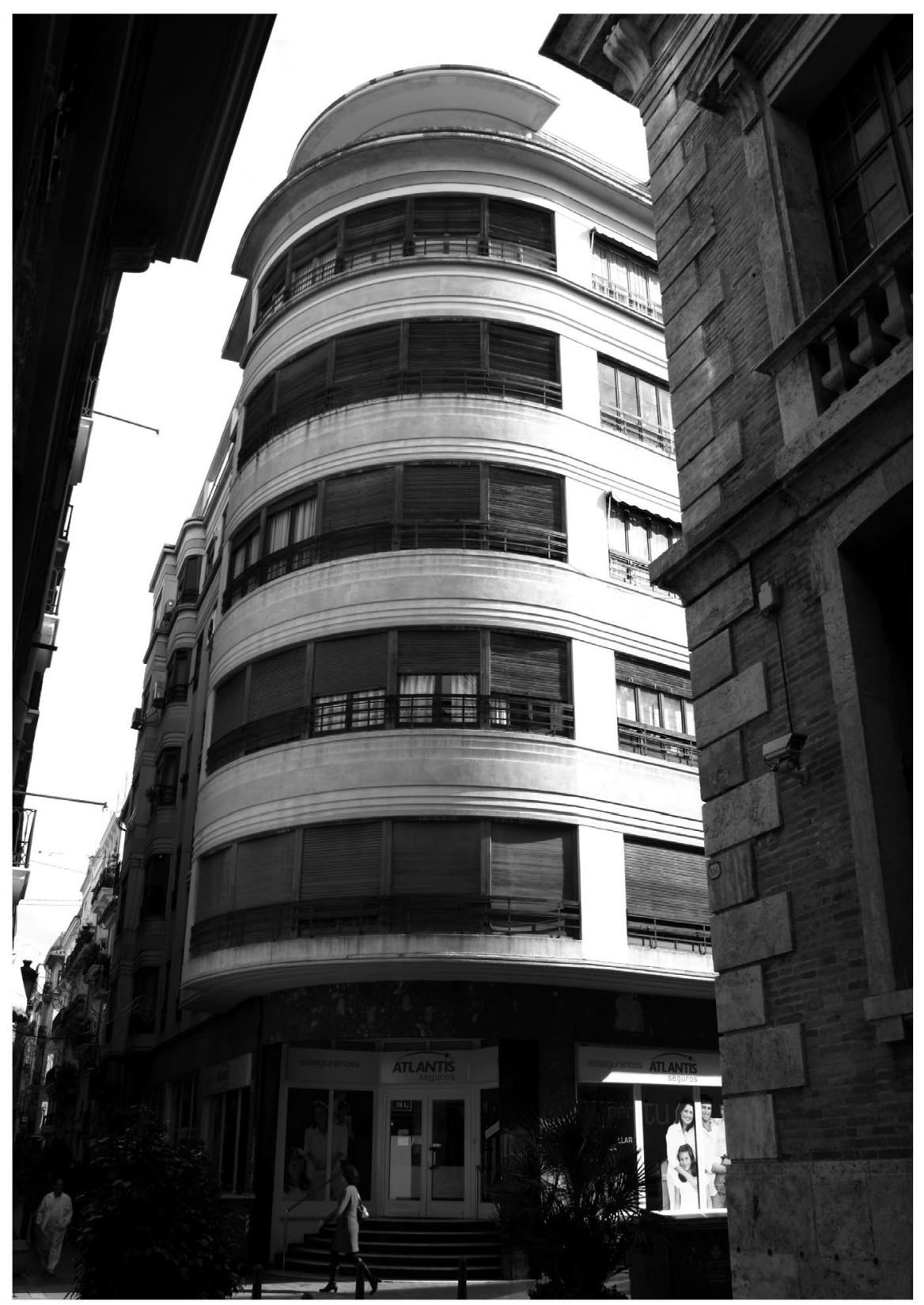

fig. 9

Luis ALBERT, 1931. Edificio Pilar TORTOSA, calles de las Comedias, de la Nave y de BarceIona: (AHMV) Policía Urbana, legajo 8, expediente 6; fotografía Ricardo Perelló Roso 
arquitectura valenciana añadía a la resolución de los problemas prácticos creados por las necesidades de la época, algunos elementos históricos, en general distorsionados, elogiando deseos del cliente.

Inauguramos nuestro particular periplo por edificios de vivienda y comercio, con el erigido para Manuel MOMPARLER (1929), en las calles Arzobispo Mayoral, Juan Lorenzo y San Pablo, y también el edificio para Juan Antonio MOMPÓ (1930) en la calle de San Vicente (fig. 8). Denotan aparentemente la ausencia del remozado ímpetu vanguardista de Albert, todavía no impuesto sobre las historicistas demandas de sus promotores. En la plaza de Emilio Castelar, concretamente en la bajada de San Francisco, el edificio para Rufino GARCíA (1930) y su postrera versión para Tomás SÁNCHEZ, retoman la composición formal mediante este racionalismo higienista e historicista, cada vez más próximo a la abstracción geométrica experimentada en el edificio de la calle Játiva.

Francisco CARBAJOSA (1929), encargaría al joven profesional, proyectar el chaflán de las calles Játiva y Ribera. La intención del arquitecto amanece expresionista en un marcado afán de modernidad que, de una forma u otra, mantiene Albert durante toda su trayectoria. El trazado evita la manida respuesta en cubillo, apostando por la pureza conceptual, la rigurosidad volumétrica, empero dulcificada por su tratamiento formal. Asumida la concepción formal mediante secuencias de bandas molduradas -geometría horizontal y vertical, interpretadas con cierta ambigüedad-, ya liberada de cargas dictadas por los códigos clásicos, influida por imágenes y textos alemanes, resulta el comienzo de una progresiva depuración compositiva y, según manifestaba el propio autor, "el primer edificio de viviendas en Valencia de hormigón armado en estructura". 


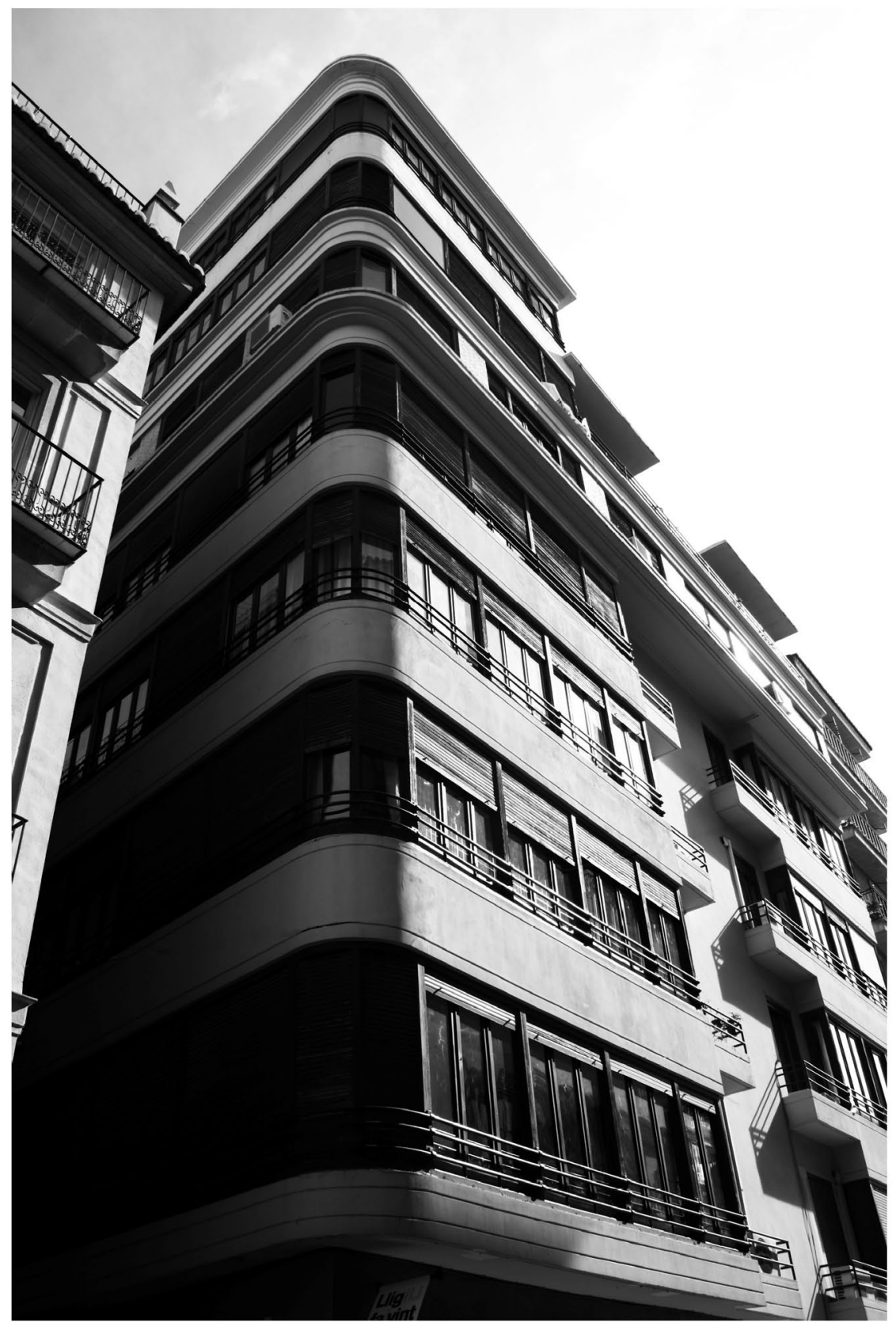

fig. 10

Luis ALBERT, 1933. Edificio Manuel CÁNOVAS, calles Navellos, Micer Tarazona y Yerba 
Resuenan espartanas enseñanzas, no obstante afloran dudas. Hemos citado a Vicente Colomer manifestando contradicciones entre los afranjados e impostas horizontales, cortados por grandes pilastras y equilibrados por ángulos y aristas en un sistema compositivo de influencias decó. Una indeterminación latente $y$, ciertamente cotidiana al contingente de jóvenes arquitectos valencianos.

La aproximación a las vanguardias ya vemos que no resulta inminente, ni tan siquiera exhaustiva. Amanece paulatinamente, imponiéndose la experiencia en la controversia desatada con las demandas burguesas. Así sucede en el edificio para Pilar TORTOSA y Martínez Sala (1930), en las calles de la Nave, de las Comedias y de Barcelona (fig. 9), reforzando la ambigüedad, promulgada por una severa simetría -tanto en el alzado principal recayendo a la calle Comedias, como en sus respectivos testeros- enfrentada al lenguaje moderno, contraviniendo los eximidos a prioris racionalistas. En semejante contradicción de principios cabe rememorar la manida dicotomía de líneas horizontales, puestas en cuestión mediante verticales masas, escindiendo aquellas. Menos acusada asoma la disputa, en el edificio de las calles de Navellos, Micer Tarazona y Yerba, para Manuel CÁNOVAS (1933), en la versión modificada (fig. 10), tangente al expresionismo funcionalizado, muy diferente de la ecléctica primera propuesta. La contienda no está ni mucho menos cobrada, pero las intenciones apuntan en esa dirección. Albert profundiza su comprometida vanguardia, allí donde los elementos más públicos convencen al promotor de la modernidad de la obra y donde pueda visualizarla la peatonal burguesía. El posicionamiento urbano del edificio, su entrega al espacio público. Descender al detalle, al moderno confort en los acabados. 


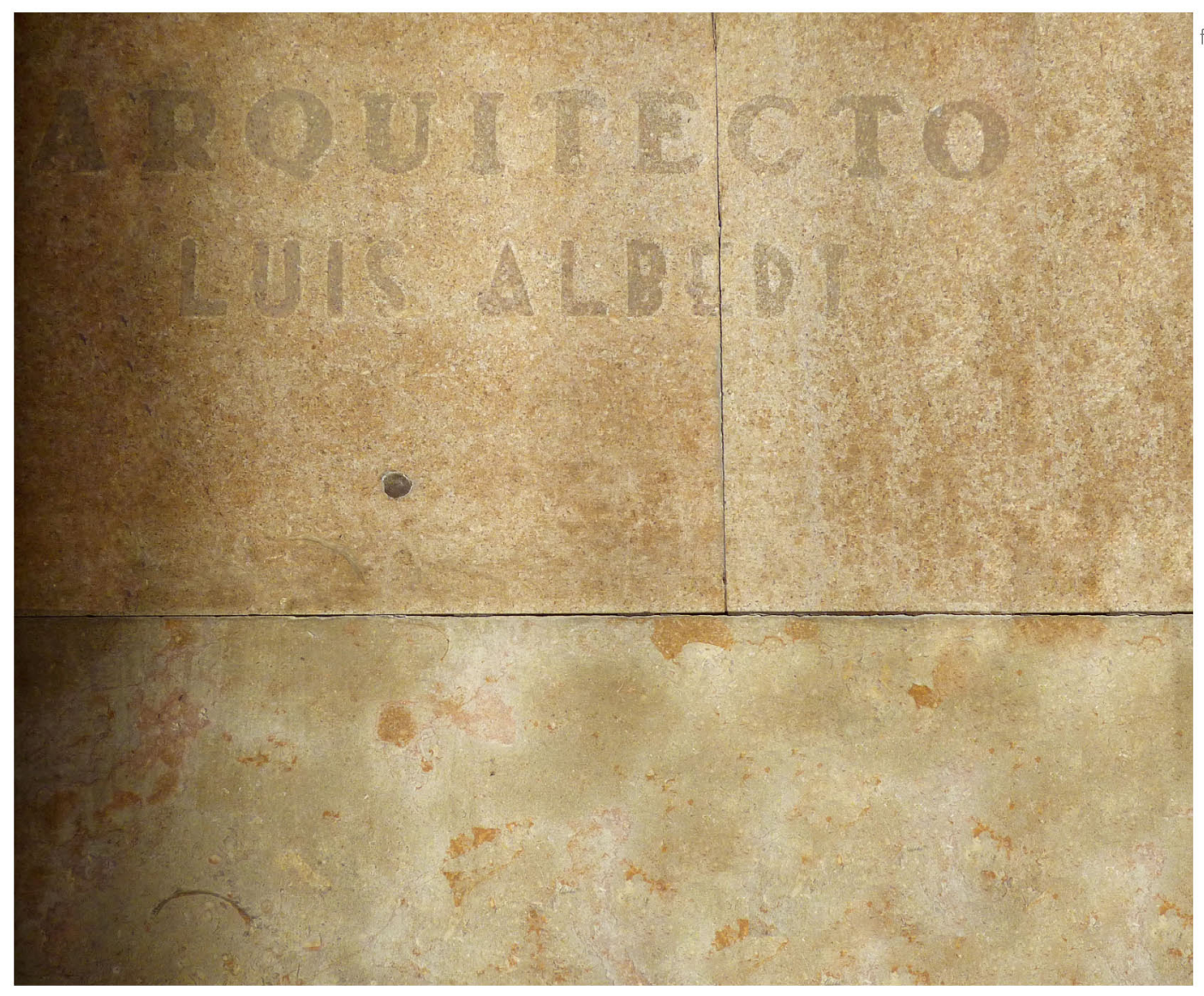


Todo un transitado catálogo de detalles constructivos, exquisitamente presentados en la escena metropolitana -labor donde Albert se desenvuelve con innata pericia- propicia la comunión de transeúntes con los nuevos ideales de modernidad. La moderna técnica, los noveles materiales afanados a servir de vínculo, a presentarse socialmente. Bajos comerciales incorporados al tratamiento de fachada, igualmente compuestos, revestidos por pétreos enmarcando membranas transparentes, planos de vidrio que permitan la relación visual. Diseño de rejas de seguridad con capacidad invisible al ocultarse en la propia jamba. Zaguanes donde plantear, además de la función de relación que le es propia, relaciones visuales entre escaleras, ascensores -instalaciones técnicas innovadorasy usuarios, espacios naturalmente iluminados. Modernas tipografías de señalética, al igual que sucede con los mecanismos incorporados en el edificio y en las viviendas, reforzando el gusto por los nuevos materiales en el advenimiento de la modernidad. Resolver con rigor compositivo, descender a la sutileza del detalle, innovar, implicarse rigurosa y minuciosamente en el oficio, comprometerse éticamente hasta los límites posibles, representará el acomodo para la moderna arquitectura (fig. 11).

Percibía Albert los clamores del cambio, las epístolas de los movimientos de vanguardia, los clichés kodak 9 en las páginas de Architetttura, L'Architecte,

- GÓmEz DAVó, Antonio. Término extraído de la contestación de este, al discurso, en la recepción pública de Albert como académico de número en la Real Academia de Bellas Artes de San Carlos, el 3 de marzo de 1961. Publicado por la Diputación Provincial de Valencia, 1963; pág. 35 


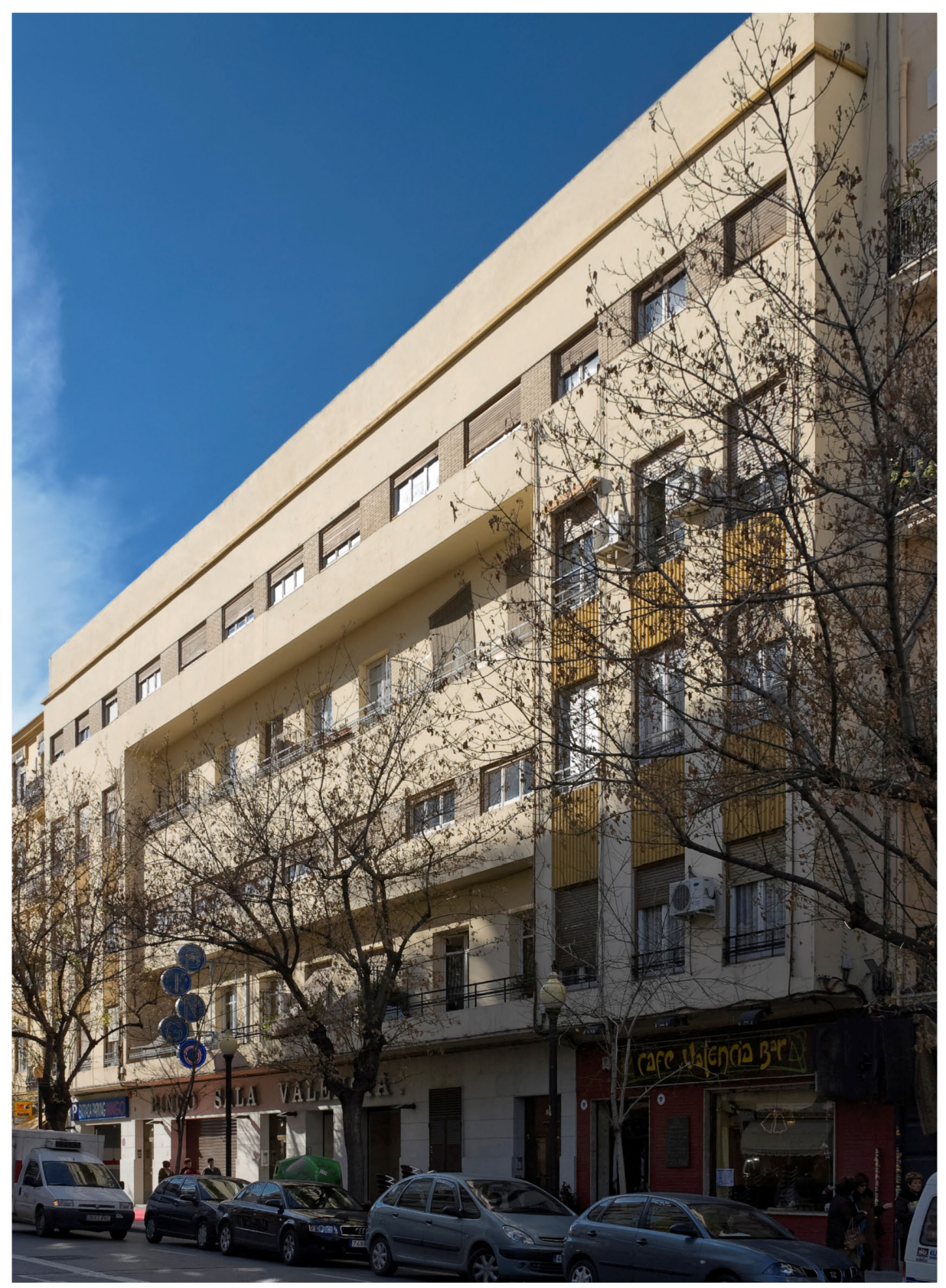

fig. 12

Luis ALBERT, 1935. Edificio José Manuel ZABALA, c. Cuenca; fotografía de Ximo MICHAVILA 
Innen Dekoration, AC, Architecture d'Aujord'hui, como también los catálogos de luminotécnia, sonido y decoración, libros de estructura y nuevos catálogos de materiales. Y alejado del núcleo convulso, aislado en una sociedad atrasada, opta por la racionalización hasta donde alcanzarse, por el compromiso funcional, por la arquitectura sin artificios-como arte esencialmente sincero-, por la información y el afán renovador. "Este afán por conocer lo nuevo en formas, tecnologías y materiales que mantuvo hasta sus últimos días, como le consta a quien lo escribe, permiten calificarle como un arquitecto moderno". 10 Alcanzamos a ver sus obras más significativas, su nivel más alto de coherencia y claridad de expresión.

Queda inmerso, en este mencionado proceso de depuración, el bloque de viviendas para Juan y Arturo ZABALA López (1935) (fig. 12), en la calle Cuenca $n^{\circ}$ 16. Resulta evidente en el edificio la reinterpretación de una académica composición tripartita, tanto como la catarsis aplicada al método compositivo. Un basamento empecinado en contactar con el espacio urbano, un cuerpo principal concentrado en viviendas reforzando la composición y un exiguo remate, visualmente casi inaccesible para los transeúntes. Una concepción personal según las exigencias de los palacios contemporáneos. Habla Albert de "no caer de nuevo en los mismos errores pasados, copiando motivos sólo por creer que uhacen bienn y que están dentro del estilo, cuando el estilo que perseguimos no es la línea, sino la verdad". ${ }^{11}$

10 PE ÑÍN IBÁÑEZ, Alberto. "Luis Albert. Arquitecto. Valencia 1902-1968". Editorial del Colegio Oficial de Arquitectos de Valencia. Diciembre 1984; pág. 13

1 ALBERT bALLesteros, Luis. "La evolución de la rquitectura en el transcurso de los siglos". Discurso leido el 3 de marzo de 1961, en su recepción pública como académico de número en la Real Academia de Bellas Artes de San Carlos. Editado por la Diputación Provincial de Valencia, en 1963. pág. 26 


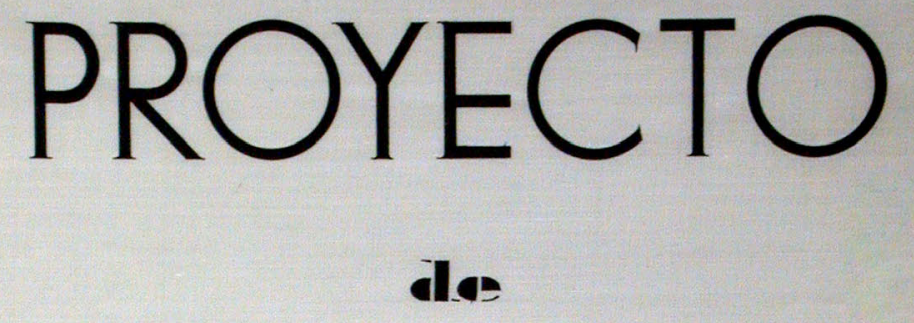

\section{cansan viviendan}

\section{en Ia calle ale Cuencan 16}

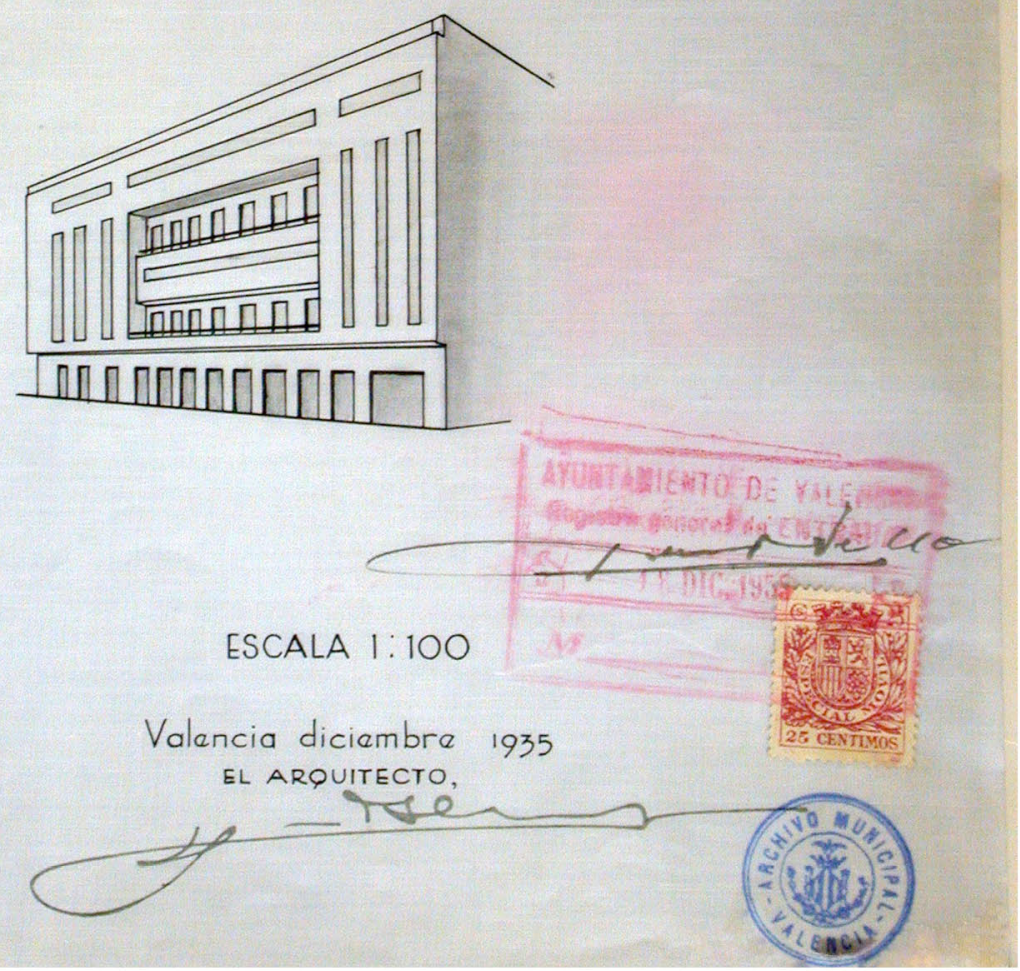

Luis ALBERT, 1935. Edificio de viviendas para José Manuel ZABALA, calle Cuenca n 16 : perspectiva arquitecto, guarda en planimetría de proyecto (AHMV) Ensanche, legajo 3 
Mediante un tratamiento unitario -enlucido para la totalidad con mortero de Pórtland y revoco-, resuelve la materialidad, la puesta en escena y, exclusivamente con el juego volumétrico, reafirma las partes. Grandes concepciones de los tiempos antiguos diría un Erich Mendelsohn, que "a lo largo de los años veinte fue eliminando los cornisamentos que sobresalían dramáticamente y proyectaban mucha sombra, hasta acabar por completo con la decoración expresionista". ${ }^{12}$ La ornamentación de la fachada queda abandonada, nula en este bloque de viviendas y -según describe el propio Albert en la memoria del proyecto- su belleza se ha buscado en la proporción de las masas y el equilibrio de las mismas.

Ahora bien, mientras el modelo principal de Mendelsohn se basaba en la continuidad del volumen y el contraste -contraposición de ventanas alineadas horizontalmente frente a cajas de escaleras verticales; también la equivalente oposición entre lo rectilíneo y lo curvilíneo- Albert contradice la horizontal fenestración, centrada en la composición del volumen, frente a la simétrica verticalidad de los extremos. Másica opacidad, enmarcando, delimitando el dinamismo dispuesto horizontalmente con los miradores destinados a viviendas.

Aparentemente oferta, a la vista del peatón, la pureza prismática del conjunto de viviendas dúplex -Le Corbusier había proyectado una tipología

12 PEHNT, Wolfgang. "Fantasía, que no locura". Cuaderno de investigación nº 16. "Cine Universum. 1926-28. Erich Mendelsohn". Exposición "Arquitecturas ausentes del siglo $x \times "$. Editorial del Ministerio de Vivienda y Editorial Rueda, S.L. Madrid, 2004 . 

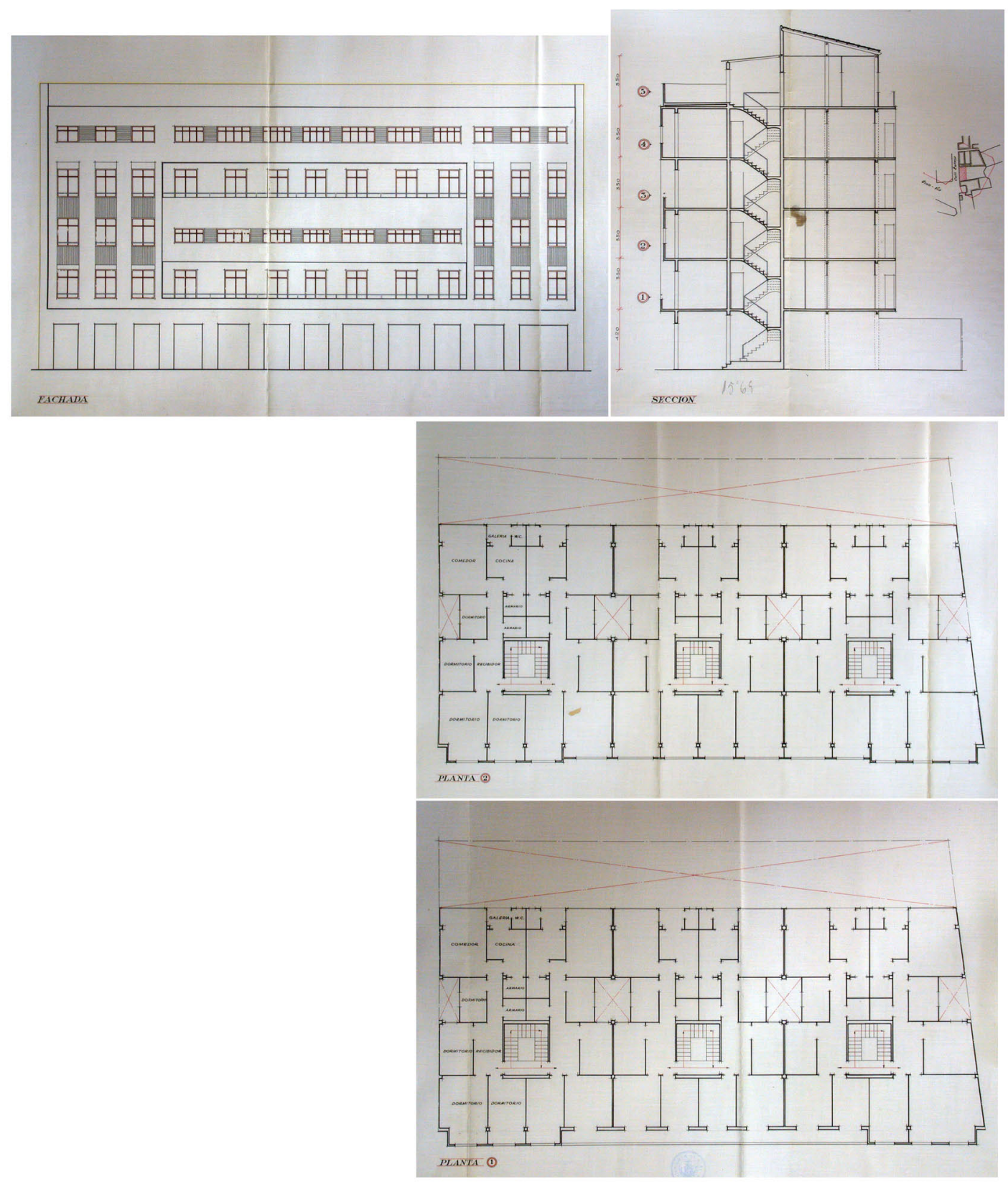

Luis ALBERT, 1935. Edificio de viviendas para José Manuel ZABALA, calle Cuenca n 16 : planimetría de proyecto (AHMV) Ensanche, legajo 3 expediente 43257 
semejante para los Inmuebles-Villas, sin conseguir erigirlas ${ }^{13}$ - por la alternancia de volúmenes cerrados y terrazas abiertas, en una serie horizontalmente infinita. Dinamismo lineal, súbitamente paralizado por la verticalidad que contrastan los extremos. Alejado de la fidelidad cartesiana, asoma ardua la tarea de formalizar los principios de sinceridad arquitectónica; la diversidad en los planos de fenestración, en nada corresponde con la repetitiva disposición funcional (fig. 13). Y no sucumbe tan sólo la forma en su compromiso con la función. Idéntico uso distributivo dormitorios abiertos al espacio urbano- ampara diversas superficies, múltiples espacios desemejantes, para completar una serie de tres duplas, deslavazadas en sección. Por oposición a la privacidad de funciones principales, las piezas públicas de la vivienda recaen al espacio abierto del patio de manzana. El resto de funciones menores y zonas húmedas, agrupadas en torno a patios internos.

Resultaba laborioso el compromiso racionalista, estricta en demasía su ortodoxia, a más persistiendo ausentes los referentes cercanos. Rechazar la Historia, refutar la mímesis, rebatir la herencia educadora y la tradición percibida, batallaba conjuntamente con axiomas renovadores, las convicciones en la propia experiencia cartesiana. No obstante, el consabido aislamiento profesional, la ausencia de grupo persuadido, la omisión de apoyos institucionales y sociales, mermaban persuasiones juveniles.

Funcionalismo, racionalismo, dinamismo o expresionismo, cohabitaban con académicos lenguajes, experimentados discursos acomodados. La nueva

13 CAPItel, Antón. "Notas en torno al arquitecto Jose Luis Sert". 4 centenarios: José Luís Sert. Valladolid. Universidad de Valladolid, Secretariado de Publicaciones e Intercambio Editorial, 2002; pág. 19 


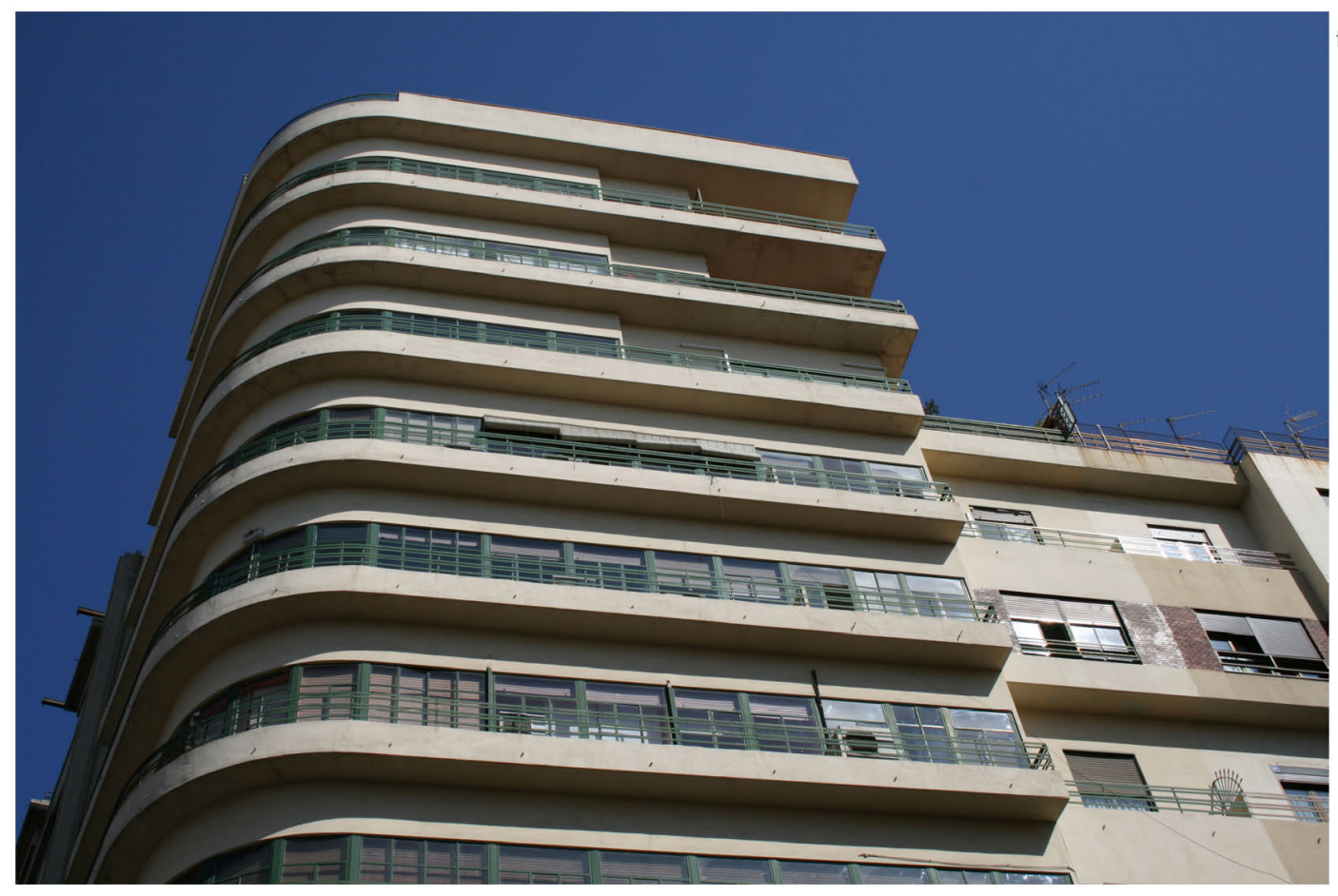


concepción del espacio expedito de toda estructura, la planta libre, la libre disposición de los huecos de fachada, lidiaban singularmente en su firme propósito de sinceridad, de 'evitar errores ya cometidos'. Resultaba intrincado aspirar a una ortodoxia, que no llegaría súbitamente; precisaba de una evolución personal y colectiva, costosa, nada habitual entre el colectivo de arquitectos valencianos y su público.

Pronunciado devenir hacia la depuración arquitectónica profesa Albert. Arduo recorrido, emprendido y desarrollado con tenacidad, hasta alcanzarlo en sus dos obras más representativas; las que profesionalmente más le acercan a la funcionalidad, a la racionalidad o el dinamismo, aquellas en las que empeñar su trayectoria. El edificio ALONSO (1935) de la calle Játiva esquina con la calle San Vicente (fig. 14), como cabecera, icono y referente para el epicentro metropolitano. De inspiración expresionista y mendelsohniana pero con una puesta en obra, en lo que respecta a la solución técnica de fachada acristalada corrida y curva, no tan precisa como el modelo alemán que la inspira -los Almacenes Schocken ${ }^{14}$, 1927 - y ejecutada bajo una notable falta de medios, demanda permanente del arquitecto. De lenguaje más puro que el empeñado en los edificios precedentes y con una volumetría demasiado apurada y subordinada hacia el aprovechamiento intensivo de la parcela.

14 PEÑín IBÁÑEZ, Alberto. "Valencia 1874-1959. Ciudad, Arquitectura y Urbanismo". Editado por la Escuela Técnica Superior de Arquitectura, Universidad Politécnica de Valencia, 1978; pág. 124: Expresionismo mendelsohniano que aparece casi siempre en Valencia mistificado con el racionalismo, como se ha dicho, y que Fernández Alba generaliza para España (Crisis de la Arquitectura española, 19391972, Madrid 1972) donde el "funcionalismo ha sido siempre un expresionismo camuflado". 


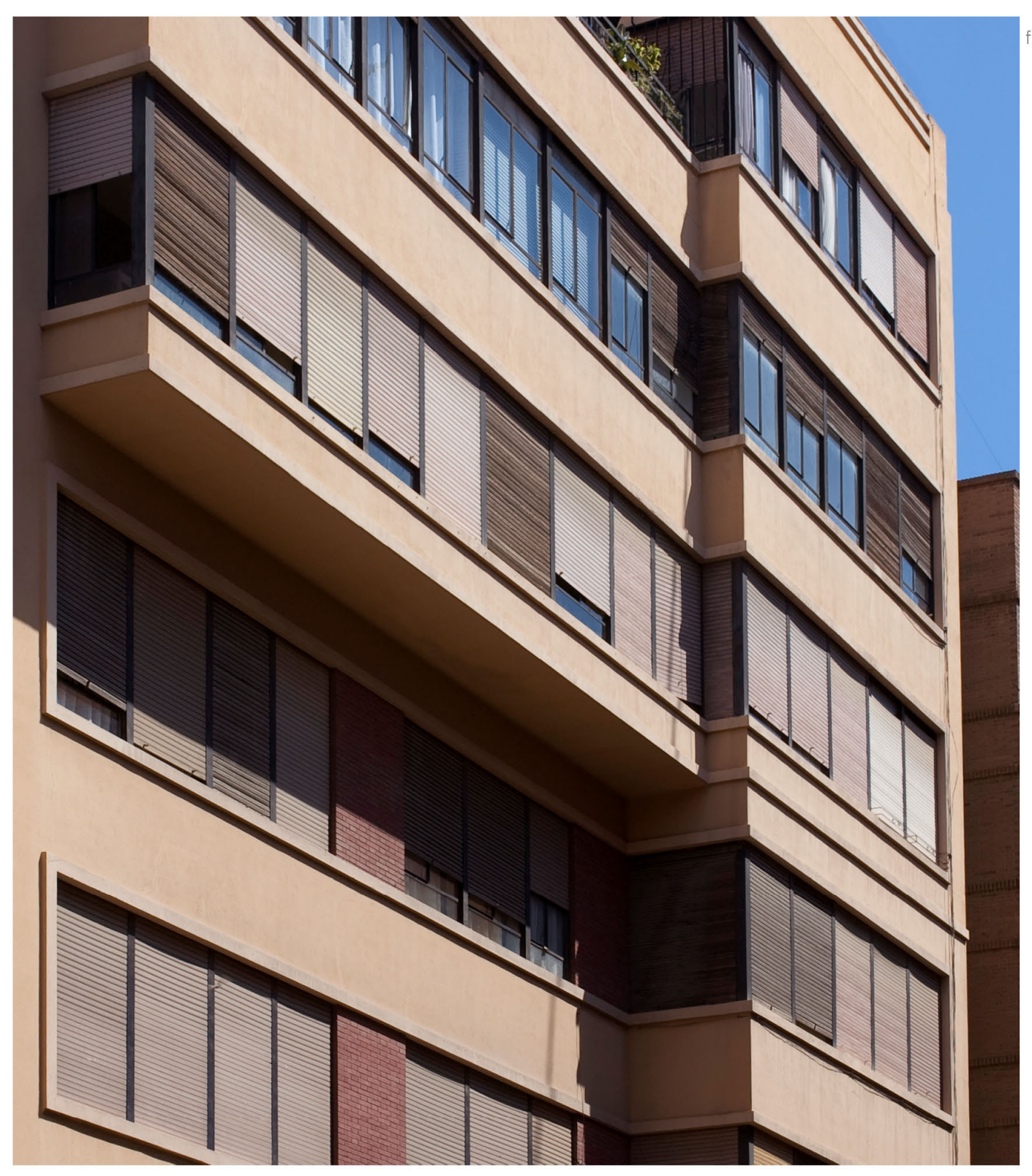

Luis ALBERT, 1935. Edificio Máximo BUCH, calles Cuarte no 114 y su paralela, calle San Jacinto $n^{0}$ 3; fotografía Ximo MICHAVILA 
Complementario, el edificio de viviendas y fábrica de cepillos para el cónsul alemán Máximo BUCH (1935), en la calle Cuarte (fig. 15) y su paralela calle de San Jacinto, puede señalarse como la pareja representativa de la obra de Albert $y$, probablemente, el canto del cisne en su trayectoria profesional. Desatenta de miradas críticas, de las presiones burguesas acumuladas en el epicentro de la urbe, resulta una obra menos oprimida, más indicativa de su postura arquitectónica y principios personales. Ambas, sin excepción, pasan a formar parte del desarrollo de esta tesis, quedando diferido su pormenorizado análisis al discurso transitado por la obra privada del arquitecto -circunscrito a un espacio físico y temporalque inmediatamente prosigue.

Consabido enlace resultan estas obras con los escasos trabajos de posguerra. Alberto Peñín -que se incorporó al equipo de Luís Albert en su tramo final- dibuja el estudio, que coexistió con la contienda, como estable, formado por dos delineantes, un aparejador y un aprendiz (que posteriormente sería su aparejador desde 1945 hasta 1968). Desmigaja 1935, un año importante, con casi 80 trabajos; 5 proyectos de obra nueva con cierta categoría, los citados de Buch, Zabala y Alonso, más el Teatro Principal y unas escuelas en Buñol.

EI TEATRO PRINCIPAL (1935), en la calle de las Barcas, esquina con Poeta Querol (fig. 16), puede equipararse -vertiente privada- con la revisada triada albertiana. Más concretamente con la acontecida decepción del Hospital Provincial, al menos en cuanto se refiere a su potencia germinal -una moderna propuesta dotacional para la metrópoli- y la conclusión infringida; un ejercicio final, sin convicciones racionalistas, devaluadas con el devenir acaecido. Aquello codiciado como regeneración urbana, 


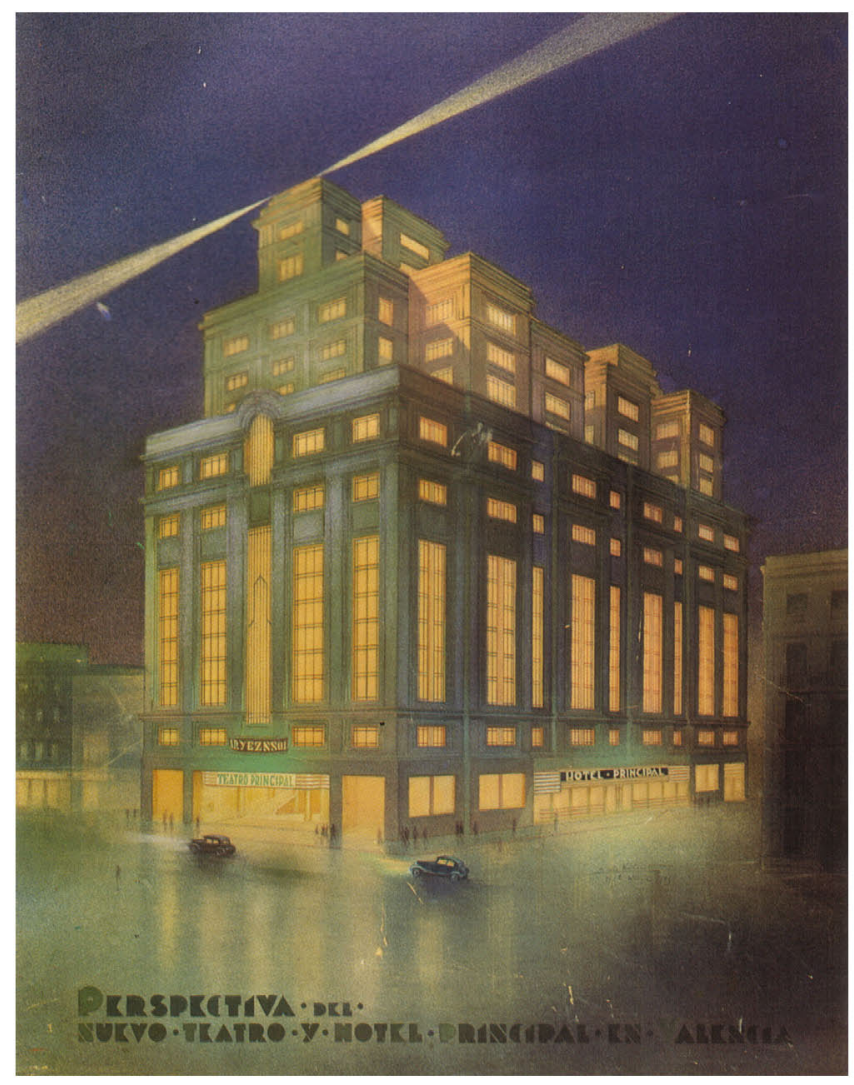

fig. 16

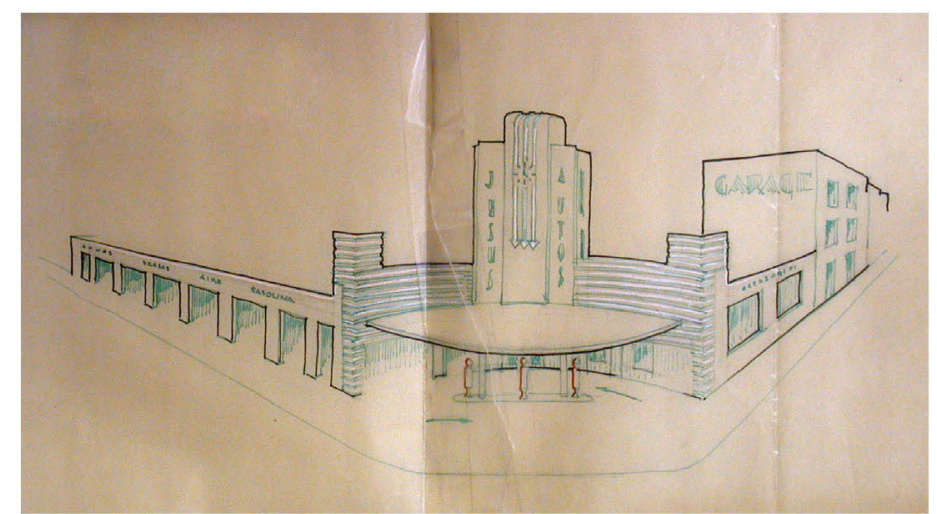

LUis ALBERT; perspectivas. Proyecto no ejecutado Nuevo Teatro y Hotel Principal en calle de las Barcas y Poeta Querol; estación de engrase para autos, en calles de Jesús y Alcira 
ambicionado faro en la urbe, hito referente, Hotel erguido sobre un Teatro contemporáneo, se agota en una mayor amplitud de sección en la calle poeta Querol y, la rehabilitación del espacio noble de acceso al Teatro, más un alzado contextualizado y tallado con corrección, carente de todo compromiso.

La posguerra reduciría los encargos profesionales a la nada durante años consecuentes. Salvo un repunte en 1941, convenido con la apertura de la avenida del Oeste, hasta 1945 no recobraría -lo mismo sucedería con la mayoría de sus compañeros- el caudal de trabajo precedente, la entrada de nuevos proyectos. Reseñable resulta una ESTACIÓN DE ENGRASE para autos (1939) en la calle Jesús y Alcira (fig. 17), tan racionalista en el lenguaje como su precursora -la estación de servicio para 'petróleos Porto Pí en Madrid (1927) de Casto Fernández Shaw- con una interesante solución en esquina inversa a la manida en cubillo, con una losa de hormigón para la marquesina que lo referencia $y$, una estructura de cuchillos formalizados mediante cerchas metálicas, calculadas a compresión, según rezan los planos del proyecto para ejecución.

Dos edificios de vivienda, menos expresivos, y tal vez menos convencidos, que el mencionado para el cónsul, resultaron los de Lorenzo MARTínEz, en plena calle Sorní -una obra de gran claridad, donde los excesos aerodinámicos se reduce a la nada, adentrándose en un lenguaje epidérmico con un alto esfuerzo de depuración- y un edificio de autopromoción en la avenida del Oeste, de 1941 en su primera propuesta, ampliada en 1944, en altura y disponibilidad de solar (fig. 18).

Remanentes de la crisis de la posguerra resultan un edificio de viviendas 

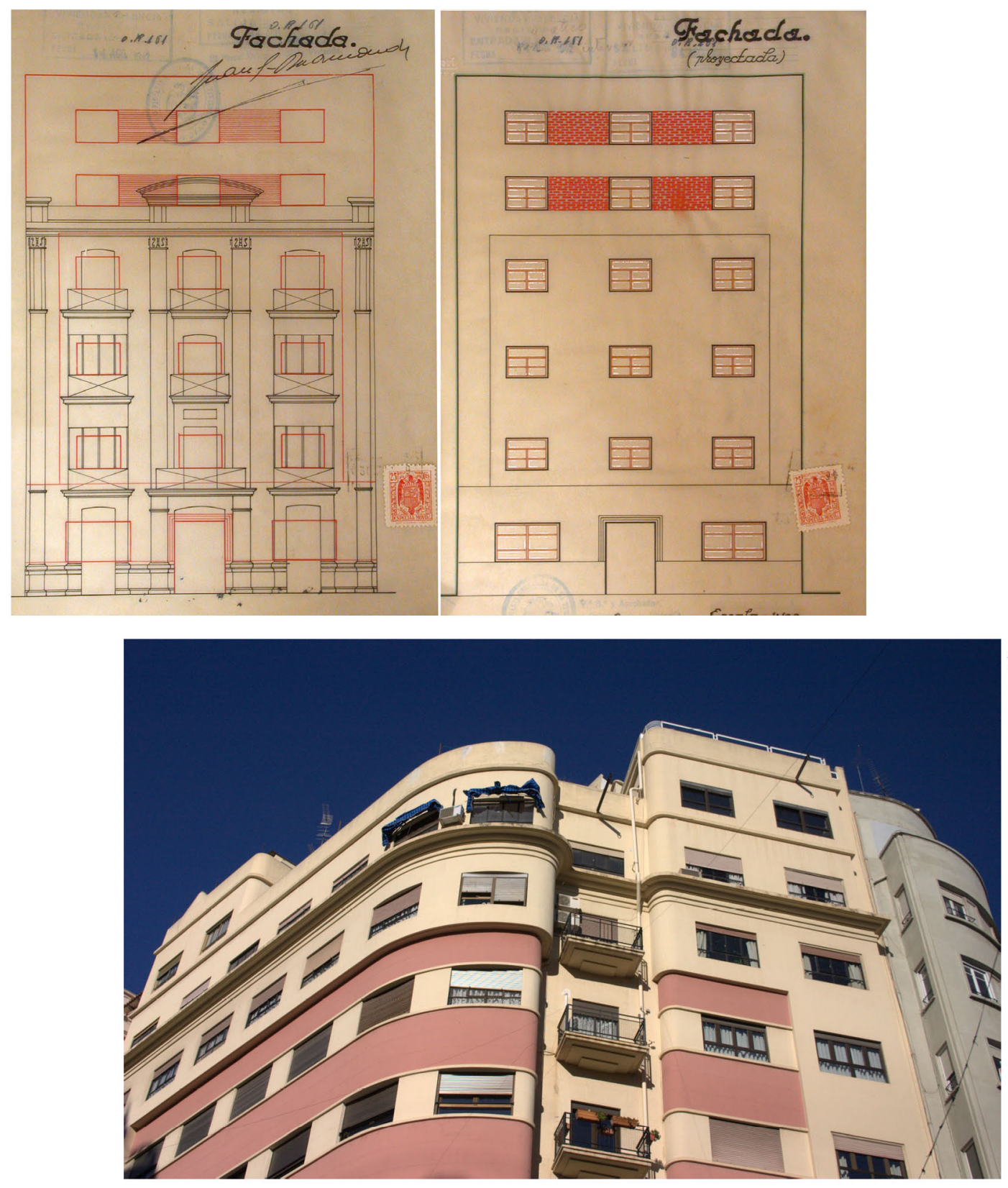

Luis ALBERT, 1941. Edificio de viviendas MARTínEZ en la calle Sorní, planimetría proyecto de ejecución (AHMV): y edificio ALBERT BALLESTEROS, avenida del Oeste, promoción propia 
para Miguel GINER, y una dupla para Fernando SEVILLA en las calles doctor Sumsi y Turia. Bien es cierto, que el discurso arquitectónico oficial fomenta la recuperación de líneas tradicionales, pero tan indiscutible como que únicamente supone un revestir de retórico enmascaramiento los esquemas anteriores ${ }^{15}$. Prolonga pues, el lenguaje expresionista, superado, y el talante moderno que nunca abandonará, en una fase -la de los años cuarenta- de promociones privadas, edificaciones religiosas, reconstrucciones y donde primaron encargos oficiales y grandes planes de urbanismo de iniciativa semipública; trabajos normalmente ajenos a su estudio.

Resultó un tiempo convulso, de imposiciones y posicionamientos, de huida hacia delante aferrándose a un estilo nacional pretendido, denostando cualquier identidad republicana y, si los principios modernos jamás entraron en liza en esta disputa bidireccional -quizá porque ni tan siquiera habían enraizado en el campo de la arquitectura valenciana moderna-, el lenguaje funcional y expresionista quedaría encadenado a pasadas esperanzas de modernizar España, y por ende denostado y represaliado.

Luis Albert alberga desquites de ambos contendientes, antagónicas animosidades. Frente a la disensión de estilos, proclama un lenguaje independiente, alejado de las pretensiones nacionales y reservando, silenciando su afán moderno, racionalista. Se hospeda en el refugio que le ofrece

15 PÉRez RoJAs, Javier. "Formas de la ciudad moderna. Neobarrocos, Decós y Aerodinámicos". Catálogo para la exposición realizada por el IVAM Centre Julio González, del 20 de enero al 5 de abril de 1998. "La ciudad moderna. Arquitectura racionalista en Valencia". Volumen ॥; pág. 38 


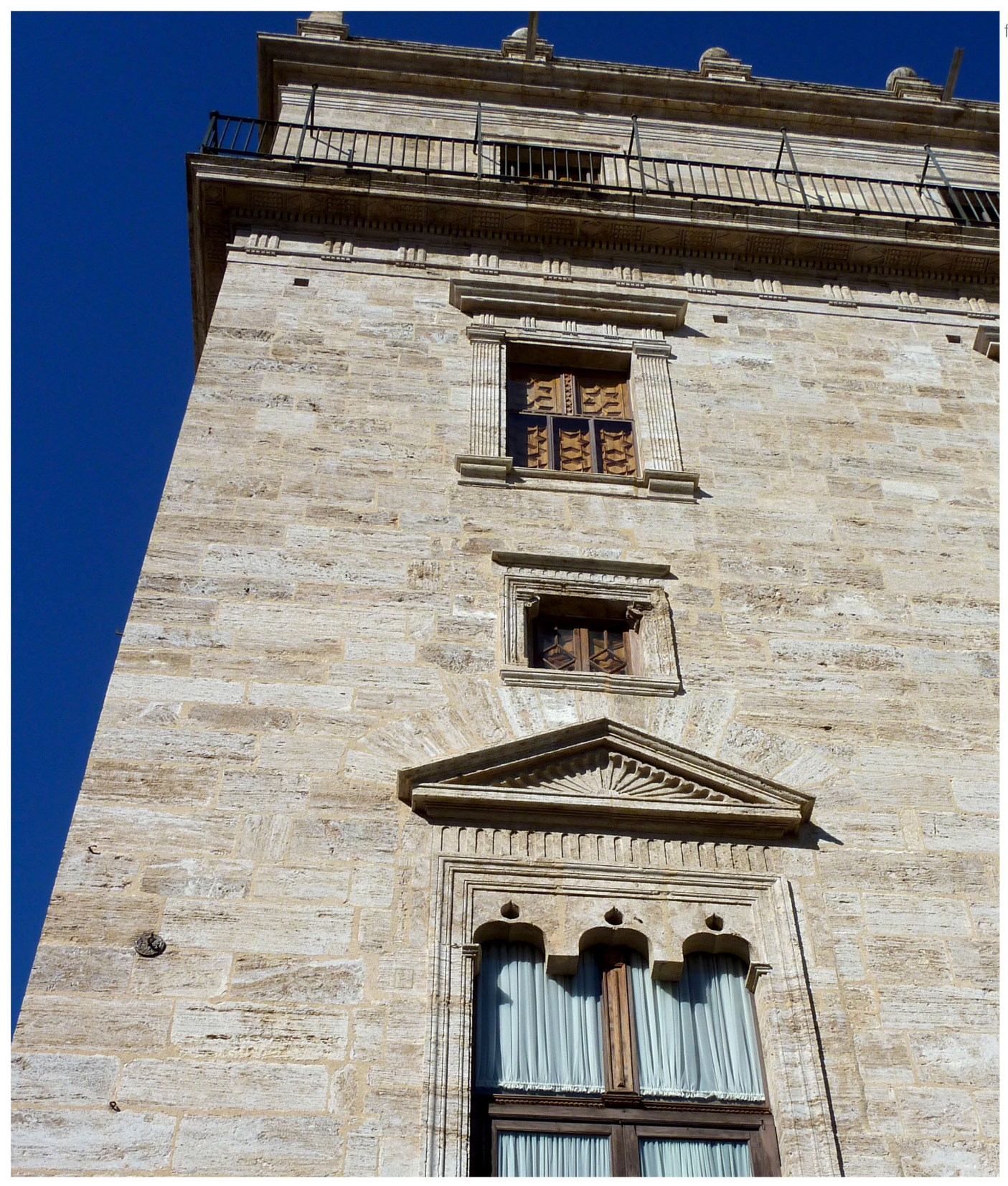

Luis ALBERT, 1951. Restauración del Palau de la Generalitał Valenciana, calle caballeros, promotor Diputación Provincial Valencia; fotografía doctorando desde plaza de la Virgen 
ofrece el campo de la restauración. El riguroso quehacer profesional, el estricto y meticuloso trabajo de estudio histórico -reclamado en este tipo de obras-, el análisis demandado desde su experiencia, le permiten mantenerse asépticamente distante de concesiones retóricas, defenestrar referencias expresivas repudiadas, evitar estandartes, abanderar una posición minuciosa, respetuosa con las trazas primitivas. El tesón por una exigente dirección de obra y por los detalles, le acomodan en un campo laboral, donde destacan obras como la restauración del Claustro gótico de los DOMINICOS en Valencia (1951) y la magnífica restauración y ampliación del Palau de la Generalitat (1952) para la Diputación (fig. 19).

Previo a retomar nuestro discurso entre las sendas marcadas por las promociones privadas, antecede -y asombra por su destierro- la crisis debida al abandono del lenguaje racionalista. Profesar modernas convicciones formales, expresiones arquitectónicas comprometidas y, tras un salto en el vacío, confinarlas por tiempo inconcreto y devengando un léxico común, supone asumir una recesión. Ejercitado discurso racional, depurado en su obra de los años treinta, es momentáneamente mantenido al margen por negación manifiestamente institucional, constatándose su destierro por tiempo indefinido. Para no referenciar ninguna posición ideológica, frente al nacionalismo exasperante, se retira Albert de todo compromiso, retrocede al desapercibimiento silencioso. Y cuando la Diputación Provincial de Valencia asume autónomo protagonismo, cuando se plantea rescatar polvorientos -nunca vetustos- proyectos republicanos, al doliente arquitecto le compele abandonar sus bocetos funcionales, su discurso en ocasiones racionalista, otrora expresionista.

No parece hesitar, en aquel momento, entre inverosímiles equilibrios, vacilar 


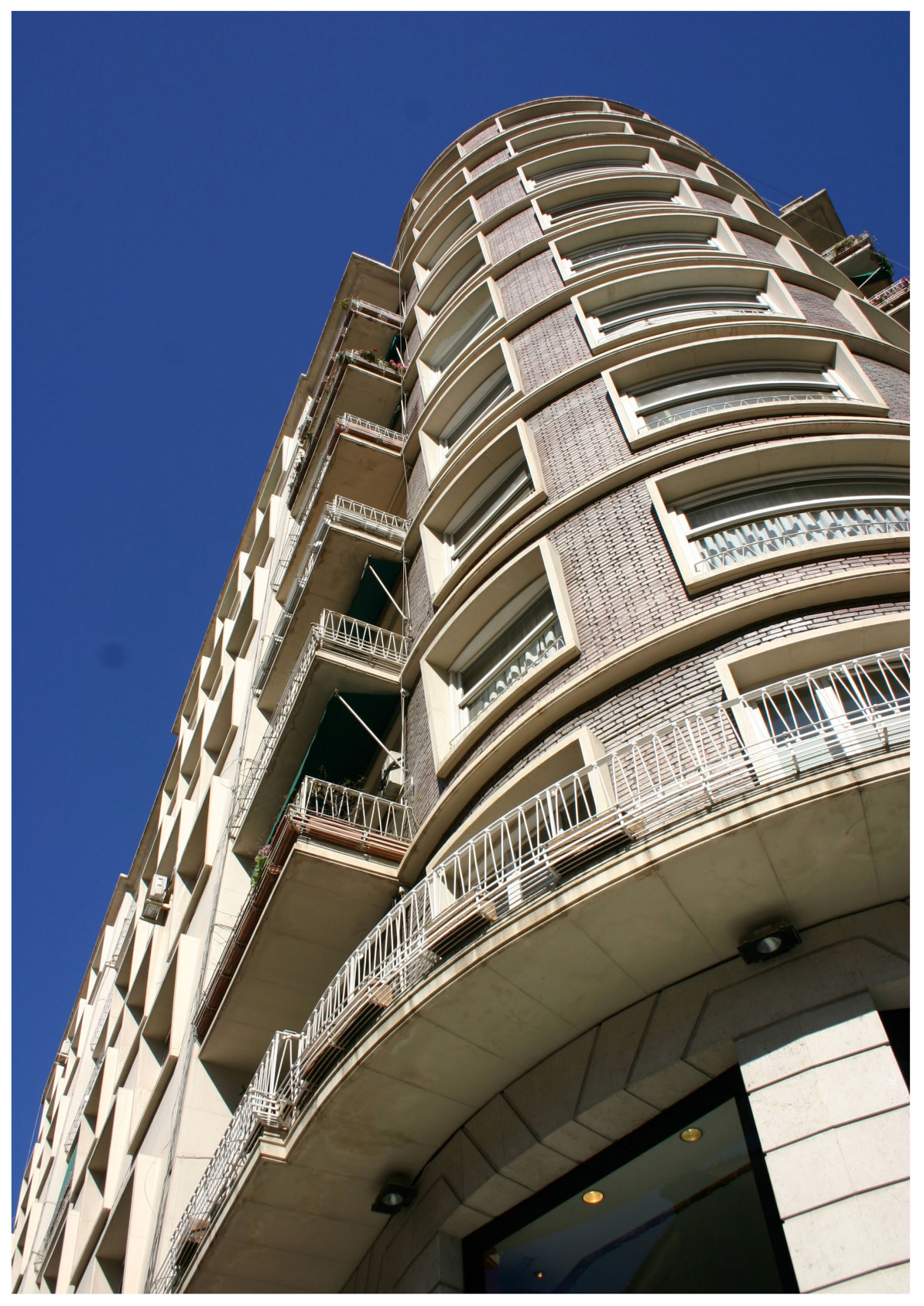

fig. 20

Luis ALBERT, 1953. Edificio para Francisco GIL COLOMER, avenida del Oeste y calle Huesca 
con fatuas añoranzas. Más bien afronta soluciones basadas en la limpieza estructural, ordenadas mallas reticulares de hormigón armado. Compromete el lenguaje a la sobria arquitectura alemana de los años cuarenta, rotunda, incluso agresiva frente a la actitud personal y profesional del arquitecto. Facilita programas mediante simples que no sencillos- esquemas funcionales, huérfanos de doctrinas que aporten innovación programática, validez colectiva.

Arquitectos afines, que desde su excelencia contribuyeron a elevar la valencia moderna de la segunda república, emprendieron sendas dispares, y en algún caso diversas en un mismo autor. Emilio Artal, Cayetano Borso, Vicente Bueso, Manuel Cervera, José Cort, Javier Goerlich, Antonio Gómez Davó, Enrique Pecourt, Mariano Peset, Joaquín Rieta, Ricardo Roso, José Luis Testor, Vicente Valls y otros, no aglutinaban una generación coherente, más bien congregaron una escuela señalada por su eficaz profesionalidad y su espartano sentido de servicio hacia el cliente, aquellos que habitarían sus creaciones. Se había clausurado un ciclo, otra época que exhortaba, urgía evolucionar.

Volviendo a tomar el devenir por la praxis privada, alcanzamos los años cincuenta. Acaecían inéditos planteamientos, entre aquel plantel profesional, ante el advenimiento del nuevo empresariado promotor de viviendas, en una urbe imbuida del gutiérrez-sotismolb, burguesmente convencida de sus bondades. Amanecía un referente próximo, un persuasivo dictamen, visual y táctil.

16 PEÑín IBÁÑEZ, Alberto. "Luis Albert. Arquitecto. Valencia, 1902-1968". Op. Cit; pág. 25 


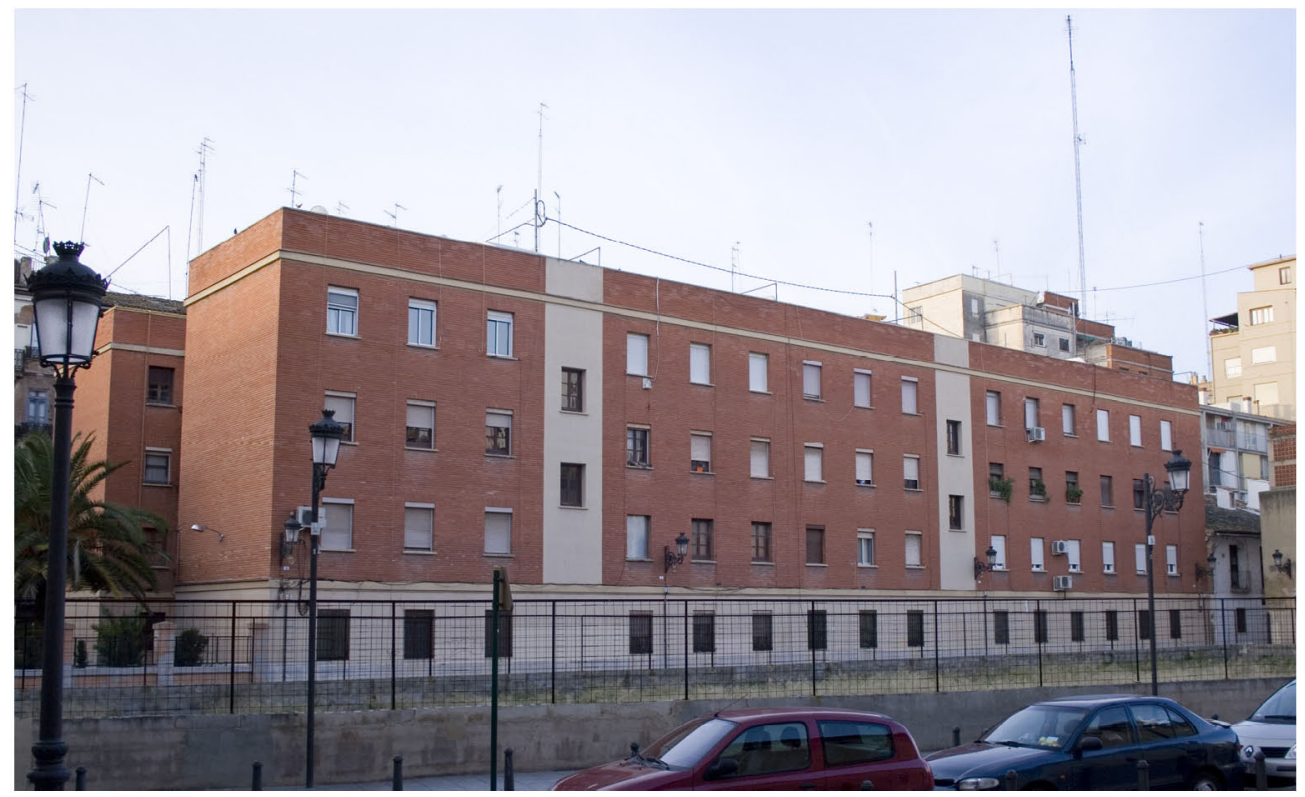

fig. 21

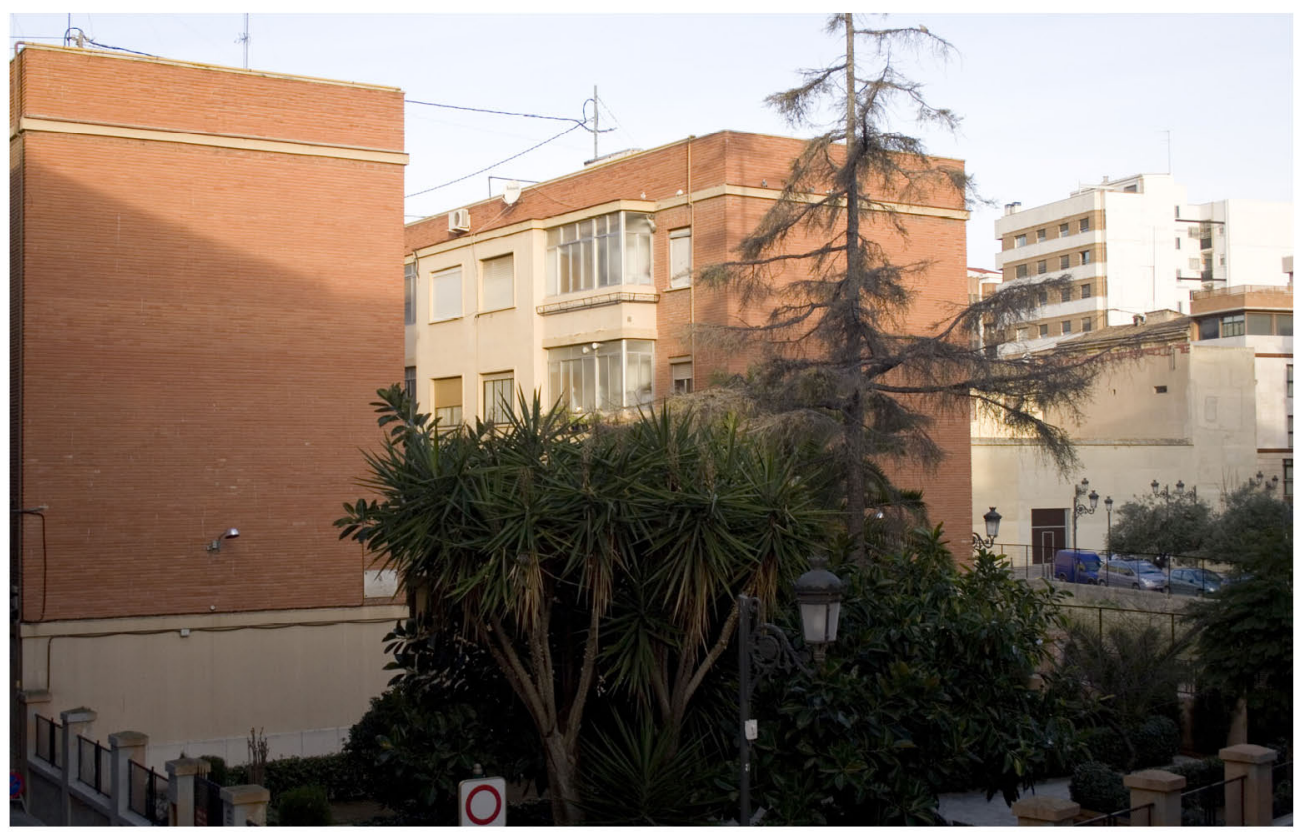

Luis ALBERT, 1957. Bloques residenciales para funcionarios Grupo LASSALA, plaza la Bocha y calle Camarón; ordenación de manzana sin cerrar; fotografía Ricardo Perelló Roso 
Entre tanto, el volumen de obra -en pesetas-, casi triplicaba al de la década pasada y se duplicaría en la ulterior. La práctica liberal de la profesión concentraba esfuerzos en la disputa de promotores con disposición convencida $y$, en la influencia urbanística. Luis Albert batalla por edificios como el de GIL COLOMER (1956) en la avenida del Oeste (fig. 20), concentrando sus intereses en la excelencia de la práctica constructiva, en la memoria histórica.

Idéntica inclinación le conduce en el grupo de 40 viviendas -único ejercicio grupal, al contrario que sus colegas con los que cede en la batalla por la promoción de viviendas- de renta limitada para los funcionarios de la DIPUTACIÓN (1957) en la plaza de la Bocha y la calle Camarón (fig. 21), donde retoma soluciones de los años treinta planteando un bloque abierto, no a la manzana que completa sino al espacio urbano público que le antecede, formulando un previo común ajardinado donde liberarse de la agobiante densidad de un área ardua e intrincada 'per se'.

Supone el preludio a desligarse del despacho profesional, que nunca desatendió pero donde comenzaba a delegar responsabilidades en manos de sus ayudantes -Mauro Lleó sería el que más acompañase, según reza un Alberto Peñin muy cercano a aterrizar en el estudio- permaneciendo más atento a su ingreso en la Academia de Bellas Artes de San Carlos -cuyo discurso expone el 3 de marzo de 1961-y dedicado a su actividad en el Colegio de Arquitectos.

Encontrada postura con las prioridades dinerarias de las más potentes empresas que promueven, construyen la ciudad de los sesenta. Escasos ejemplos encontraremos de culto proceder, de lúcidas arquitecturas y 


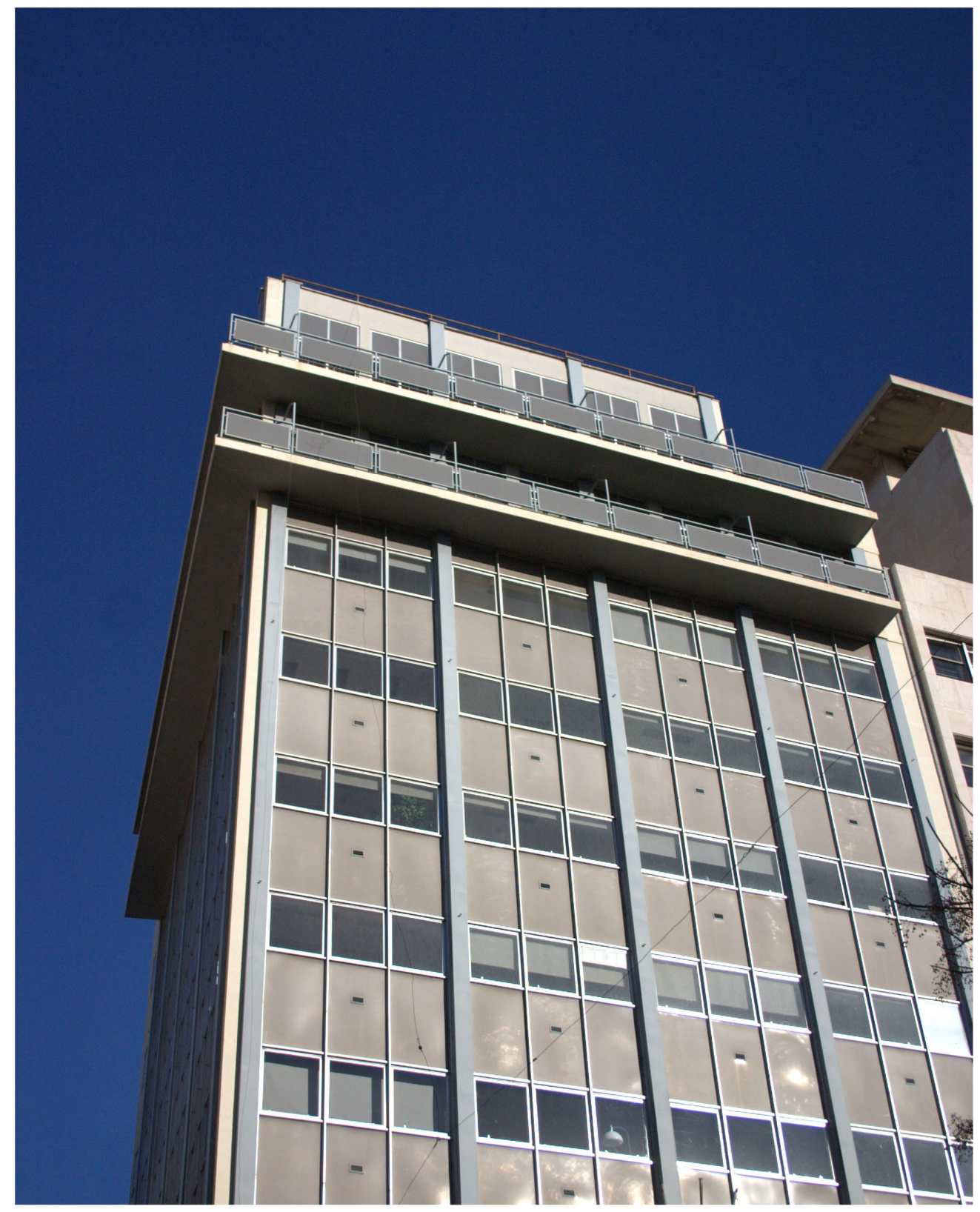

fig. 22

Luis ALBERT, 1933. Edificio para Ia CÁMARA de Valencia, calle del Poeta Querol, esquina con calle de Miñana; fotografía doctorando 
arquitectos, salvando contadas aportaciones como las primeras de Luis Marés y Emilio Giménez, en el universo edilicio de la ciudad de Valencia $^{17}$. Ante semejante escenario, retoma el lenguaje moderno -menos convencido que el de su juventud-para abordar sus últimas obras, aunque siempre fiel a 'su camino de la verdad' emprendido con el primer edificio de estructura de hormigón armado para la ciudad de Valencia. Un premiado grupo de 86 viviendas protegidas (1960) en la avenida Pérez Galdós, la sede del banco Bilbao en la calle Pintor Sorolla y el edificio de oficinas para la CÁMARA DE COMERCIO (1966) en la calle Poeta Querol (fig. 22), auguran la conclusión arquitectónica.

Egresa de su actividad profesional tras cuarenta años de meticulosa dedicación y, citando a Alberto Peñín, en los momentos más duros y, a la vez más innovadores de la vida española de los últimos tiempos. En ellos intervino con profesionalidad, moderación, rigor y, en muchos casos, con extraordinaria brillantez. Punto final concluyente para una trayectoria, una primera parte de la anunciada metodología, cuya aportación ha tenido por objeto rever arquitectura y metrópoli, encuadrar un colectivo profesional y las propuestas capaces de aunarlos, en un espacio físico común y en una época concreta. Epígrafe de edificios, ora coartados por un encargo particular, circunscriptos los anhelos creativos con los límites del demandante. Epígrafe que posibilita plantear algunas reflexiones respecto de aquellos encargos sin condiciones. Epígrafe pues, que precede a la dupla escogida, a desarrollar en el inminente estadio.

17 Colomer, Vicente. "La arquitectura como forma crítica de hacer ciudad". Op. Cit; pág. 123 
edificios para vivienda colectiva 


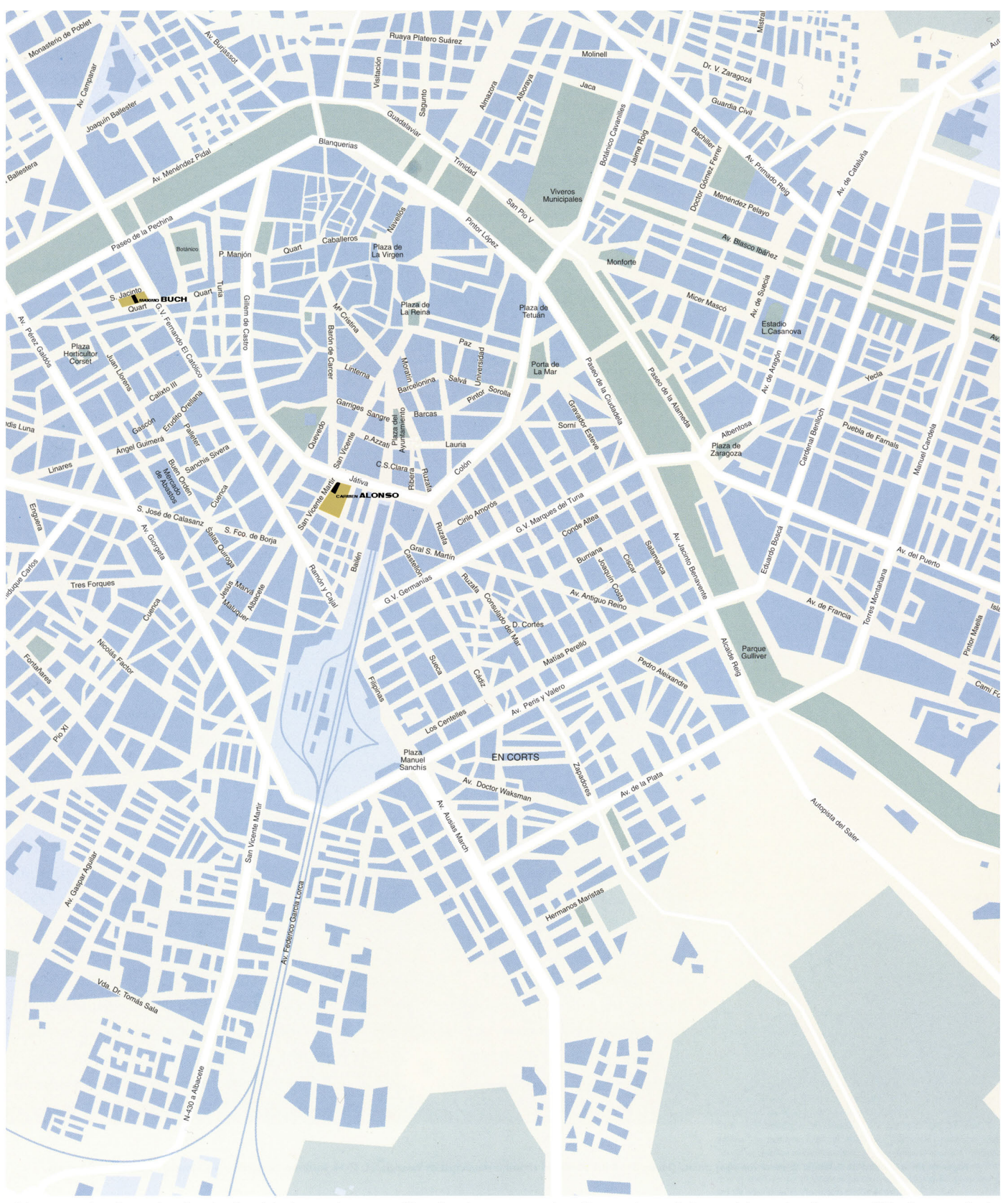

Plano de la ciudad de Valencia, redibujado para indicar la ubicación de los edificios erigidos por ALBERT, dentro del itinerario reemprendido y propuesto en este capítulo 


\section{COMPENDIO ANALÍTICO}

Haber revisado, seriado las propuestas de Albert para vivienda colectiva, inmersas en un singular escenario urbano, coetáneas a una determinada aceptación social e institucional, navegando entre los titubeos de un deslavazado conjunto profesional, proporciona una relación ordenada, una panorámica edilicia y una visión de su devenir profesional; preciso marco donde pormenorizar el análisis de las promociones privadas -los edificios BUCH y ALONSO- ubicadas en este capítulo, incorporadas en el centro urbano de Valencia.

Exponerse públicamente, en un contexto tan acotado y comprometido, epicentro de la metrópoli (fig. 1), presupone cobrar conciencia sobre la estimación social, sobre la impronta deparada a la escena urbana. En un único gesto, antagónico al impresionismo, había de atenderse a la razón de ser -ser modernos-, rebasar reminiscencias eclécticas, oponerse al decorativismo Art Nouveau, y todo mediante la construcción, la forma.

Soluciones formales que no sólo se corresponden a su función, sino que la expresan en cuanto movimiento vital integrado en el dinamismo de la realidad social' -así definía Argán el expresionismo de las construcciones urbanas de Mendelsohn -cargando el instinto sobre la realidad objetual-

' ARGÁN, Giulio Carlo. "El arte moderno. Del iluminismo a los movimientos contemporáneos". Editorial Akal, D.L. Madrid, $1^{\circ}$ edición 1991. 20 edición 1998. Capítulo quinto: El arte como expresión. El Expresionismo. pág.232 


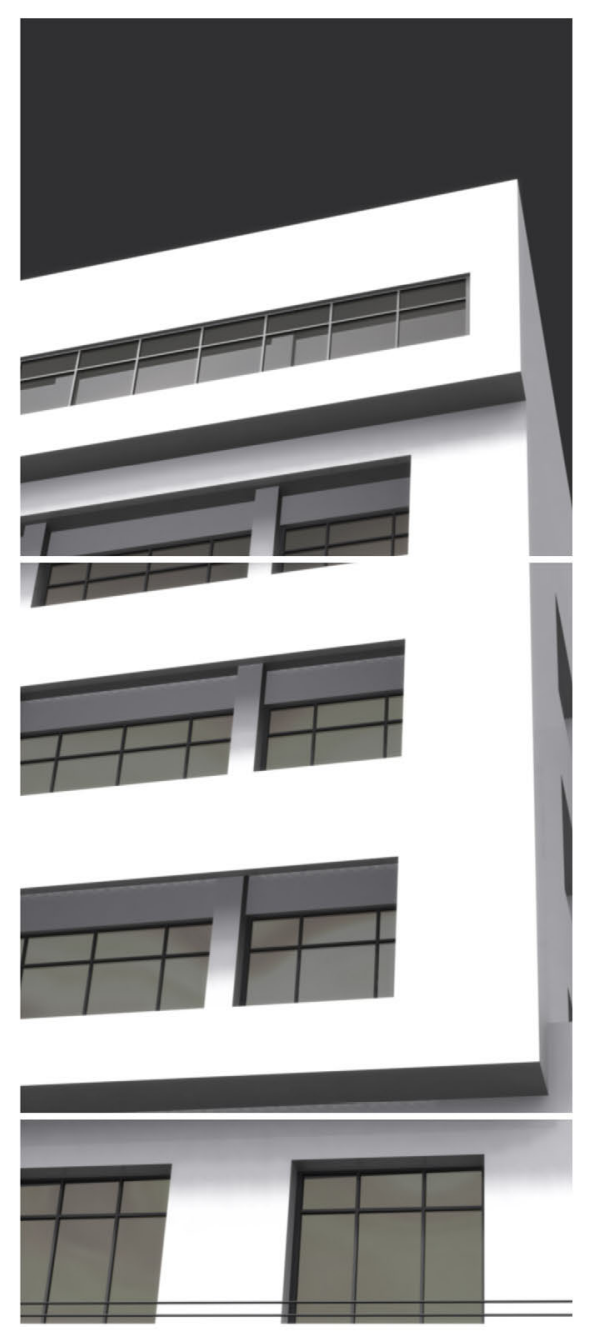

fig. 2

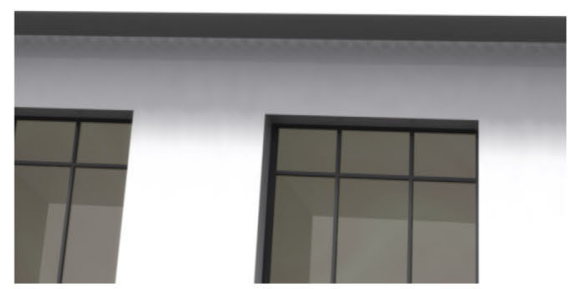

Maqueta infográfica, revisión de la propuesta para la Diputación Provincial del pabellón de Cirugía del Hospital Provincial de Valencia. Luis ALBERT, 1935 
funcional de lo construido. Probada influencia expresionista ha quedado manifiesta en el devenir profesional de Albert. Mendelsohinana impronta en su evolución edilicia ha venido marcando nuestro discurso.

Claramente no resulta simétrico -entrando a confrontar su obra institucional- para las propuestas del arquitecto, enfrentarse a semejante escenario o imaginar una propuesta disociada de la escena pública, alejada del centro urbano. Afrontar un encargo privado sometido a neófita aceptación o acometer un encargo público carente de recelosas premisas y desconfiadas exigencias, no permite gestar propuestas en equidad, no autoriza una conformidad donde habite la posibilidad de traslucir anhelos teóricos y convicciones tecnológicas. Resulta obvia la disparidad de premisas entre aquellos proyectos previstos para Hospital (fig. 2), Manicomio Provinciales, respecto de otros elevados en la capital levantina, inmersos en el Ensanche de Valencia (fig. 3).

Propedéuticamente, el análisis reiterado -rehaciendo exactamente aquellos epígrafes emprendidos en edificios públicos precedentes- capacita la comparación, permite cotejar y extraer conclusiones de cierta similitud o, marcadas diferencias entre los propósitos modernos y la ejecución moderada; heterodoxia por parte del arquitecto, sufragada bien por el promotor particular, bien por los condicionantes sociales. Importar el esquema metódico, sistematizado en capítulos precedentes, ahonda en la diferencia entre imposiciones o inexistencia de premisas, en los condicionantes de un emplazamiento yermo, límpido o consolidado entre pares. Retornar a la disciplina ensayada, inquiere sobre una presión social-económica que difiere radicalmente ambos extremos, bien por su práctica ausencia, bien por el influjo que imprime el centro urbano. 


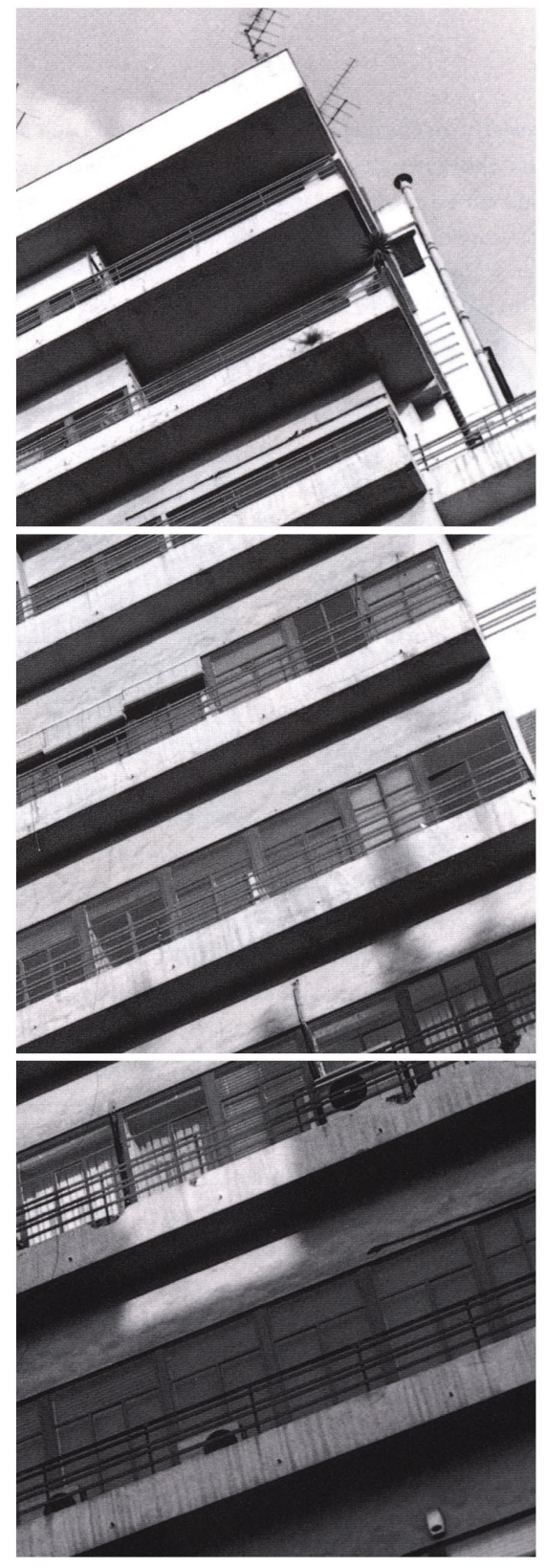

fig. 3

Luis ALBERT, 1935. Edificio viviendas para Carmen ALONSO, calle Játiva esquina con calle San Vicente: fotomontaje del prisma ascendente, configurando el rascacielos en chaflán 
Dilucidar por la arquitectura reclamo, o el nuevo espíritu racional suponía la siguiente vuelta de tuerca, evidenciado el encargo y su emplazamiento. Arquitectura, formal o ideológicamente moderna, en su circunstancia de pérdida de la noción de imitación -así explicita Sola-Morales la 'condición moderna' del arte vanguardista ${ }^{2}$ como noción fundamental. Determinarse por axiomas racionalistas, platónicas volumetrías o resolverse por hitos formales, referencias expresionistas distanciadas de la ortodoxia, refleja nuevamente la controversia, la interna contienda en su evolución profesional. Trataremos de posicionar a un Albert, esforzándose ante un dilema que repercute en su arquitectura, comprometida ante el debate acaecido en la modernidad y su consecuencia urbana.

Constatar criterios profesionales, de entrega respetuosa ante una arquitectura tipificada marcaría la entrega final. Inquirir la alternativa del trabajo individual, frente a los colectivos instaurados. "Fueron heterodoxos racionalistas o racionalistas no ortodoxos como los circunscribirá Oriol Bohigas. Ambiguos, eclécticos, expertos más que ideólogos. No obstante eficaces y numéricamente mayoritarios. Eran los que construían nuestras ciudades. Limítrofes, la minoría vanguardista española, centrada en Cataluña y el GATEPAC, planteaba rupturas donde ellos veían trabajo. Etiquetándolos como racionalistas -ortodoxos o fronterizos- tampoco les identificaremos cabalmente. Ellos eran 'funcionales', como en principio "toda buena arquitectura debía ser", frase que encierra suficiente dosis de moralidad para ser adecuada al caso $^{3}$.

2 SOLA-MORALES, Ignasi. "Teoría de la forma de la Arquitectura en el Movimiento Moderno"

3 PEÑÍN IBÁÑEZ, Alberto. "Luis Albert, arquitecto. 1902-1968". Editorial: Colegio Oficial de Arquitectos de Valencia, 1984. pág. 10 


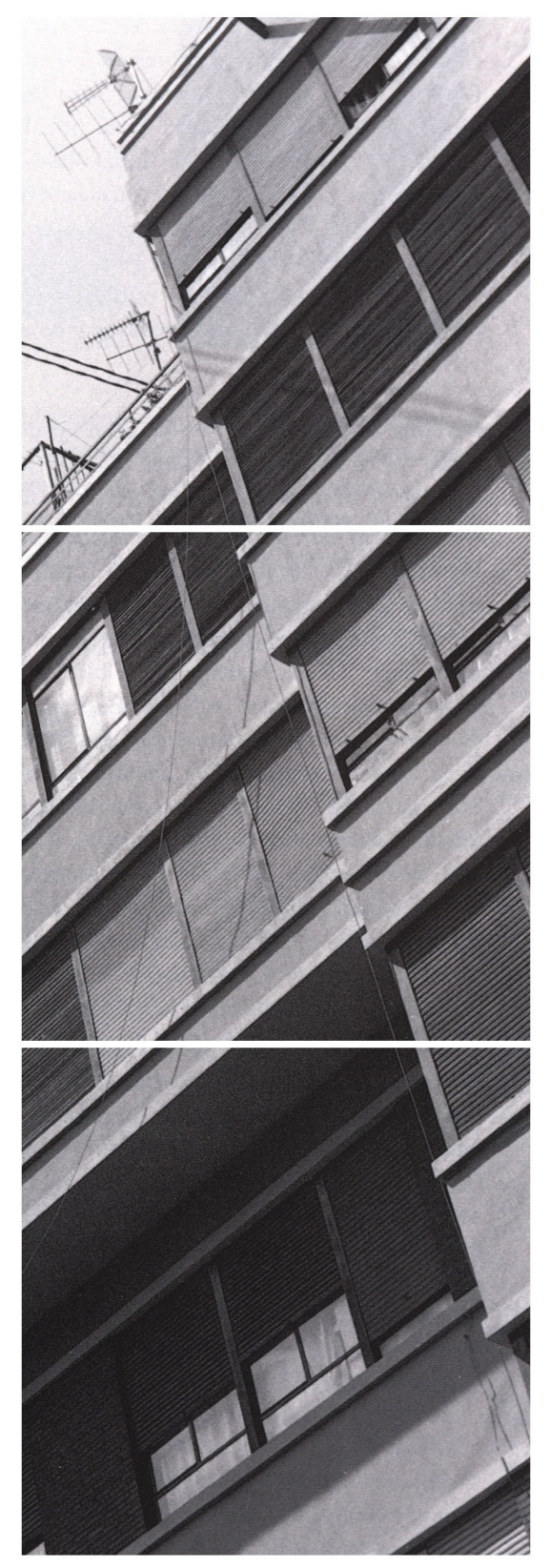

Luis ALBERT, 1935. Edificio viviendas para Máximo BUCH, calle Cuarte y su paralela calle San Jacinto; fotomontaje mostrando el cruce de líneas horizontales y el prisma vertical 
Desemejanza no pretendida en la trayectoria profesional de Albert, apasionado por la postura contraria, ortodoxa; coherencia propia, evolución doctrinal, progresión constructiva y síntesis racional. Sin embargo, disparidad efectiva, abatida rectitud coartada por manidos condicionantes sociales, infringida vacilación tras autárquicos infortunios, motivada por inapetencia combativa. Refleja la mirada de sus obras semejante devenir, iniciado en unos primeros impulsos mendelsohnianos para el concurso del Ateneo Mercantil, extendiéndose atronadores con la experiencia decisiva -hormigón armado y art déco geometrizado- tras su iniciática obra de la calle Játiva, prosiguiendo hasta el punto culminante -lo supusieron las dos obras a confrontar inmediatamente-, hasta plantarse a las puertas de una Guerra Civil y una difícil posguerra, paralizando su cenit, cercenando una evolución que jamás retomaría convicciones racionalistas de juventud.

Construcciones urbanas para Carmen ALONSO y Máximo BUCH, lindan la senda de su perseguida ortodoxia; se acomodan al ápice de una trayectoria profesional apuntada funcionalista. Avenimos a esta dupla edilicia con la intención de confrontar ortodoxias predecesoras y heterodoxias concluyentes. Traslucimos esta dicotomía electa donde parangonar discursos y contrastar desemejanzas en respuesta a los criterios anunciados: las exigencias, las fuerzas del lugar y la propia evolución del autor. Finalizamos el análisis preciso e individual donde determinar últimas conclusiones, equivalentes para la totalidad.

En definitiva, el propósito incide en indagar la propuesta de vivienda colectiva más depurada, en aquel afán moderno que condujo constantemente al arquitecto por su devenir profesional y constatar su límite. 


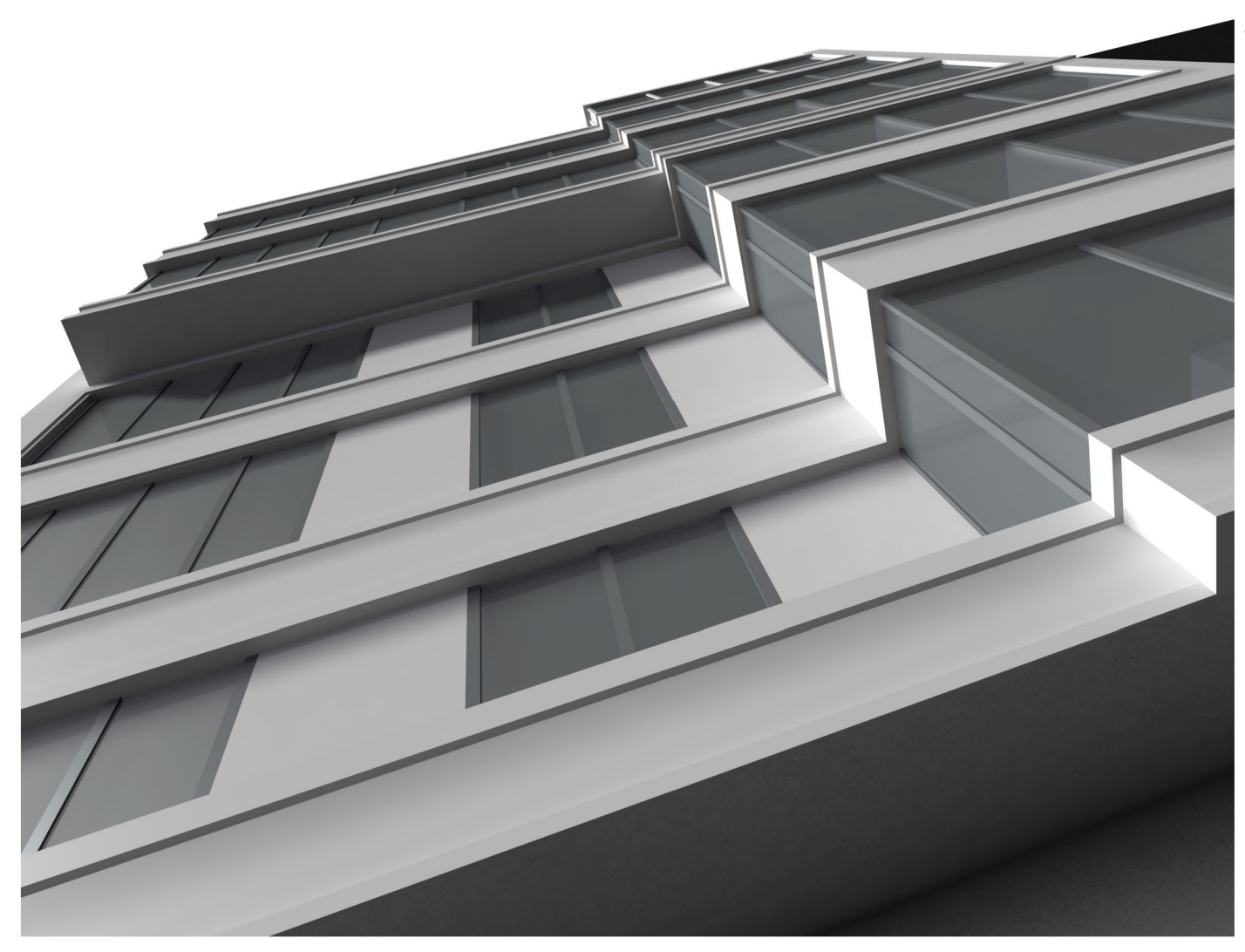


Inquirir la puesta en escena, contrastar una ejecución más funcional y racionalista elevada en la calle Cuarte para Máximo BUCH (fig. 4). Construirla figuradamente, como ejercicio de comprensión y conocimiento. Rever documentación gráfica original, intenciones plasmadas en perspectivas del arquitecto como proceso de diálogo interior, conversación intimista para reafirmar posiciones. Manipular planos de entonces, leer memorias, pliegos y mediciones. Volver a componer volumétricamente. Entrar en la organización funcional de espacios y dependencias para comprobar su relación con la forma. Retomar circulaciones. Pensar nuevamente la estructura y la materialidad de la obra.

Idéntico esquema retomamos en su complemento electo sito en la calle Játiva, posicionando al edificio expresionista por excelencia, igualmente depurado y probablemente más representativo, elevado para Carmen ALONSO. Icono registrado en todas las retinas -incluidas aquellas escasas de criterio- e ineludible en la cultura moderna de la ciudad que lo recibió. En definitiva, un proceso paralelo donde confluir. Un recorrido entre los límites, estrechamente próximos, del racionalismo y de la arquitectura objetual. Desde la génesis, incluyendo el proceso, hasta su conclusión. 


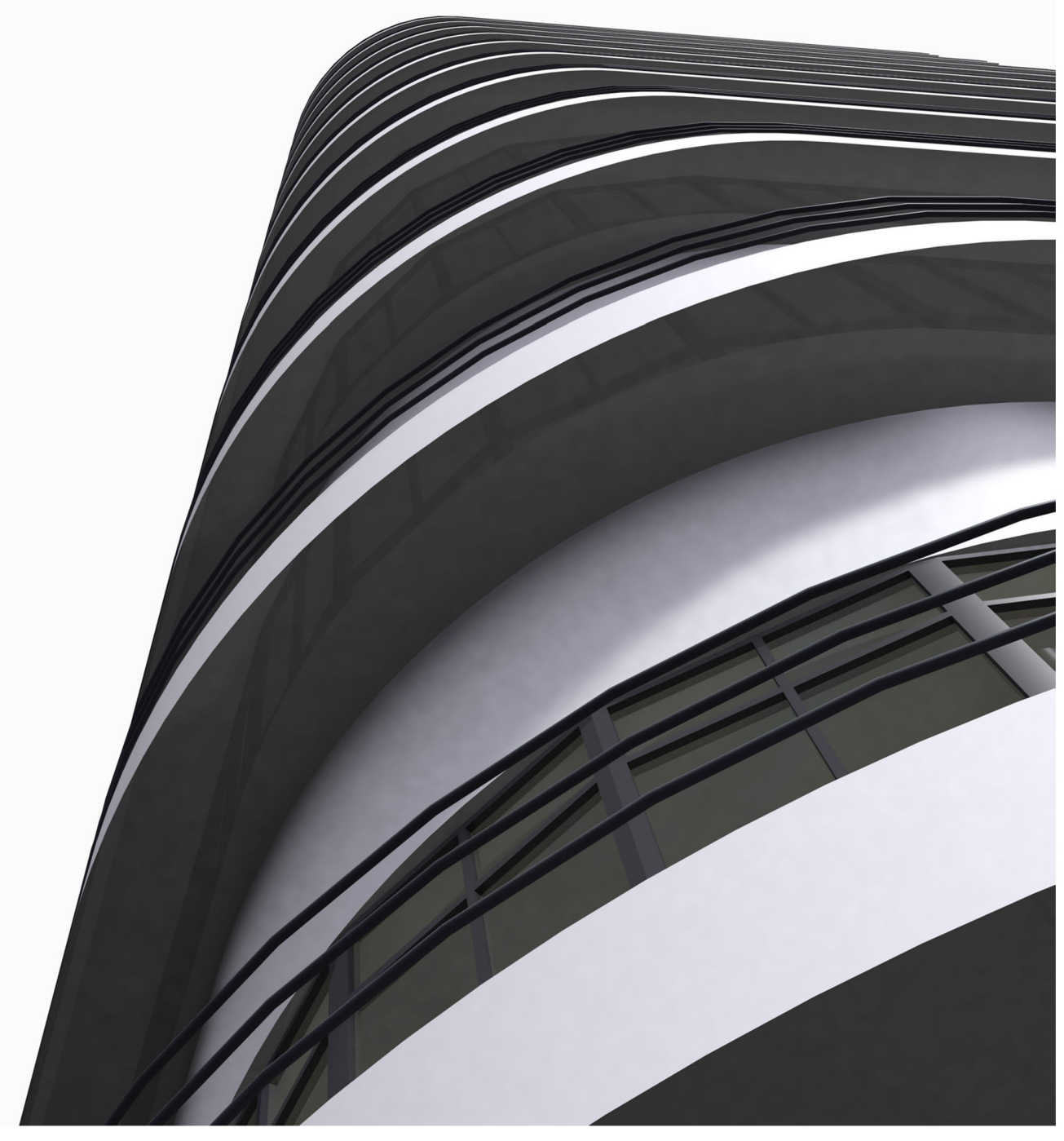

1935. Edificio ALONSO: maqueta infográfica del doctorando, exponiendo a la ciudad el chaflán en cubillo, solventado por ALBERT como resultado del juego entre llenos y vacíos 


\section{COMPOSICIÓN VOLUMÉTRICA}

Comenzar analizando el edificio de la calle Játiva -bloque residencial promovido por Carmen ALONSO- no conlleva la premisa de sobrestimar su valía, referida en términos de modernidad, racionalidad, internacionalidad, y mucho menos en menoscabo del volumen edificado en la calle Cuarte, comparado de seguido. Tan sólo pretende un orden narrativo, establecido desde su emplazamiento. Un primer posicionamiento, al que incorporar la construcción para Máximo BUCH, narración ulterior y, si se quiere, complementaria en la exposición de la completa aportación de Luis Albert; profesional, comprometido y avenido al usuario, a sus clientes.

\section{EDIFICIO PARA CARMEN ALONSO.}

Contraponer un impulso ascendente, una fuerza vertical, a un volumen horizontal enclavado en el terreno, implica acción. Dinámica inmersa en toda configuración lineal, que demuestra energía y una dirección concretas. Y sucede en esta dinámica de la forma que, cuando se conjuntan las acciones horizontales y verticales, se introduce un principio de oposición equilibrada de tensiones ${ }^{4}$. Dicotomía anunciadora de una pretensión,

${ }^{4}$ BAKER, Geoffrey H. "Le Corbusier. Análisis de la forma". Título original: "Le Corbusier. An análysis of form"; versión castellana de Santiago Castán. Primera edición, 1985 Editorial Gustavo Gili, S.A. Barcelona. pág. 7 


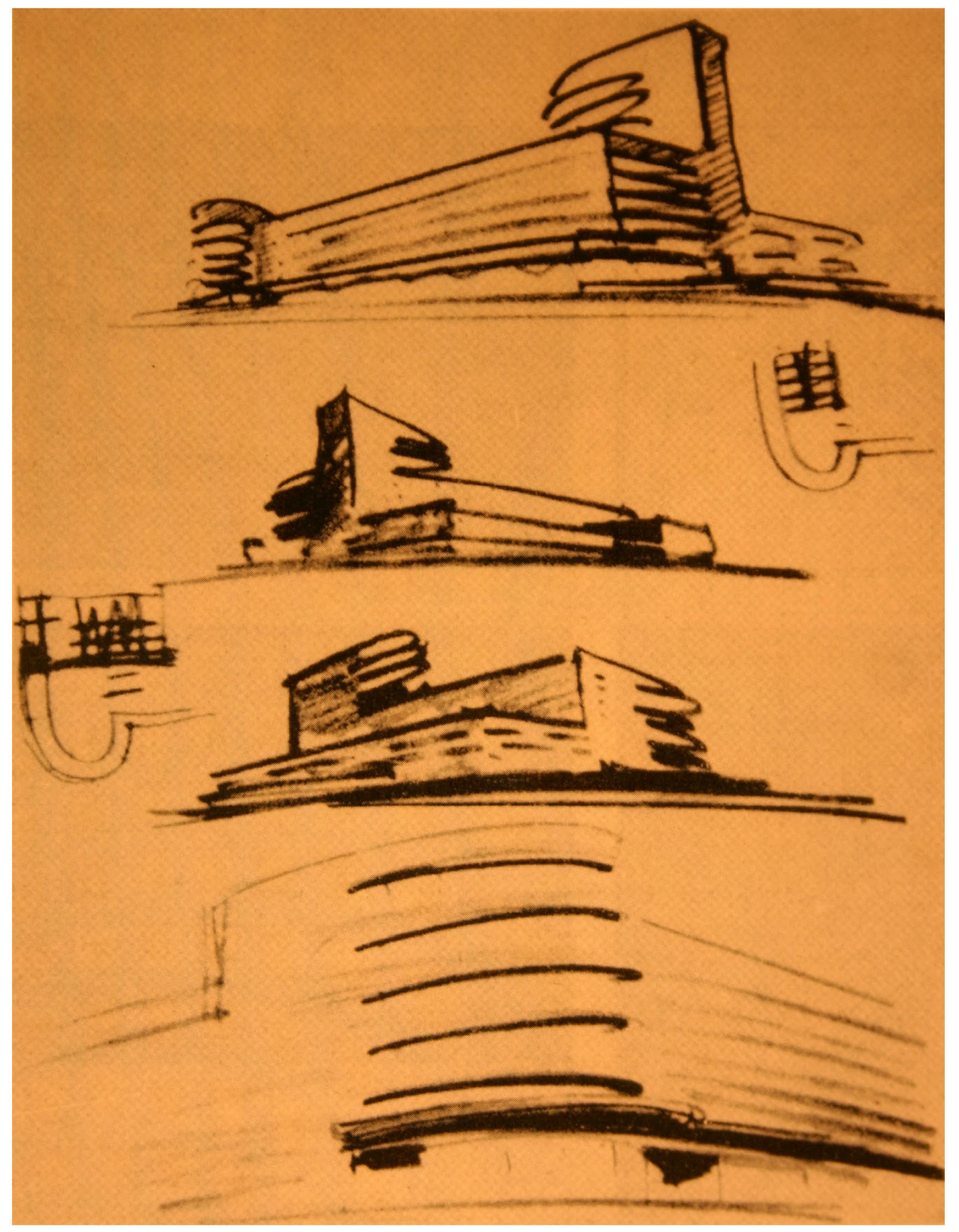

fig. 6

Erich MENDELSOHN, 1926-1928. Almacenes SCHOCKEN, Stuttgart; esbozos de la composición, ideada resaltando la tridimensionalidad, la disonancia y el dinamismo espacial 
traslucir el icono, objeto referente enclavado en la trama urbana.

Amarrar el rascacielos (fig. 5), constreñir su intento de ascensión, entrecruzar una volumetría vertical con otra asentada masa horizontal, focaliza el ideal metropolitano, proclama una pretendida modernidad, resultando al tiempo el triunfo de la disonancia, corroborando el anunciado manantial mendelsohniano.

Retomando el discurso de Bruno Zevi sobre los almacenes Schocken en Stuttgart (fig. 6), trasladándonos hasta Schönberg y su "emancipación de la disonancia" para caracterizar el edificio de Mendelsohn, encontramos los antecedentes de la contradicción, de la disputa: por un lado, el bloque del almacén que exalta su horizontalidad a través de las franjas llenas y vacías, con la marquesina y el letrero colocado encima de ella; por el otro, los dos pernos de los semicilindros, uno tonante y prolongado, en la calle inclinada, y el otro que le hace eco, encima de la cubierta, en el lado opuesto.

Expresividad y dinamismo mendelsohnianos, traslucidos en curvas seriadas de profusa horizontalidad, acusados voladizos e impulsos ascendentes a imagen de los rascacielos.

Expresividad, dinamismo y disonancia recogidos por Albert, adelantados en el audaz proyecto de líneas aerodinámicas para el concurso del Ateneo de Valencia, donde un dibujo en perspectiva publicaba la verticalidad de la propuesta, elevada hasta incumplir las bases del concurso. "El entrecruzamiento de verticales y horizontales de la fachada acentúa una ascensionalidad muy de rascacielos, que hacía de este barroco edificio 


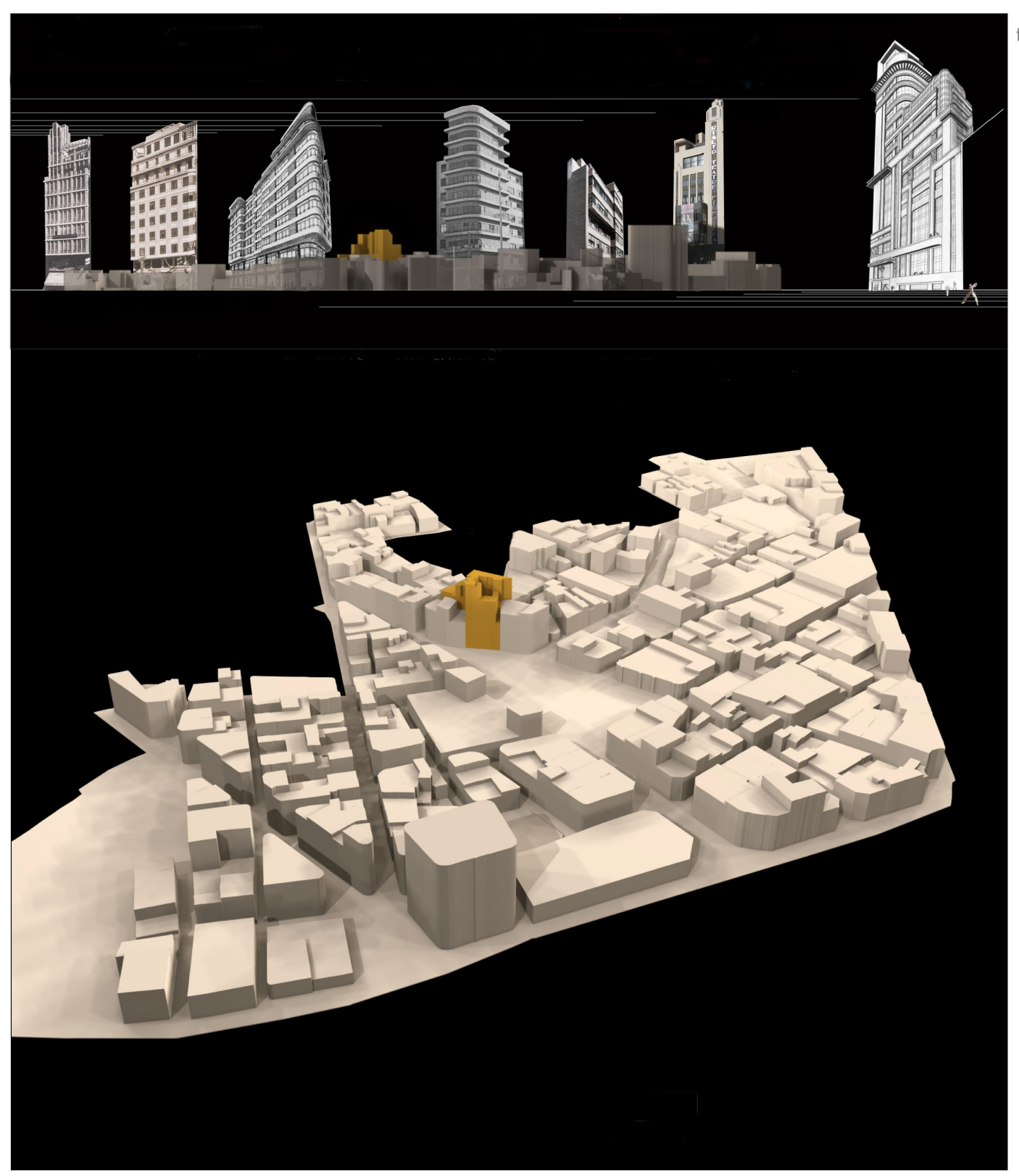

1927. concurso Nacional del ATENEO MERCANTIL convocado en Valencia; fotomontajes doctorando comparando alturas con edificios singulares de la metrópoli; emplazamiento 
un quimérico ideal metropolitano". 5 Una propuesta de renovación arquitectónica, de adscripción a las modernas corrientes europeas, de rechazo a cualquier historicismo y, sin embargo, confinada exclusivamente al lienzo de fachadas, a la volumetría escalonada, desatendidas las plantas funcionales, asimilación de la nueva arquitectura (fig.7).

Albert habría de esperar, tampoco en exceso, para evidenciar lo asimilado, pergeñar la modernidad aprehendida tras semejante preludio. No obstante, una gradual depuración -constante en su trayectoria como arquitecto- le conduce a intenciones no tan apasionadas, a dibujos menos forzados en sus propuestas, a geometrizar y abstraer decoraciones, aspirando a formas aerodinámicas más veraces, 'expresionismo depurado' por último'. Alcanza en el edificio para Carmen ALONSO, resultados más libres de referencias figurativas, habituales y cercanas al art déco, aun sin alcanzar la razón abstracta y purista de la arquitectura racionalista, recobrando parentescos con la torre, acristalada, escindida en su vuelo, del prisma horizontal anclado al terreno.

Eleva una dupla consistente, averiguando dinamismo. Morfológicamente, disocia ambos prismas, anclando en el terreno una forma linealmente horizontal y, contraponiendo la anunciada verticalidad. En principio, este

5 PÉREZ ROJAS, Javier. "Formas de la ciudad moderna. Neobarrocos, Décos y Aerodinámicos". Catálogo para la exposición realizada por el IVAM Centre Julio González, del 20 de enero al 5 de abril de 1998. "La ciudad moderna. Arquitectura racionalista en Valencia". Volumen II. pág. 28

- 'Su estilo es el que corresponde a la época actual, sacrificando en algunas ocasiones al confort interior los prejuicios de estilos arcaicos, buscando en la combinación y proporción de masa la armonía y belleza del conjunto'

ALBERT BALLESTEROS, Luis. De la memoria del proyecto 

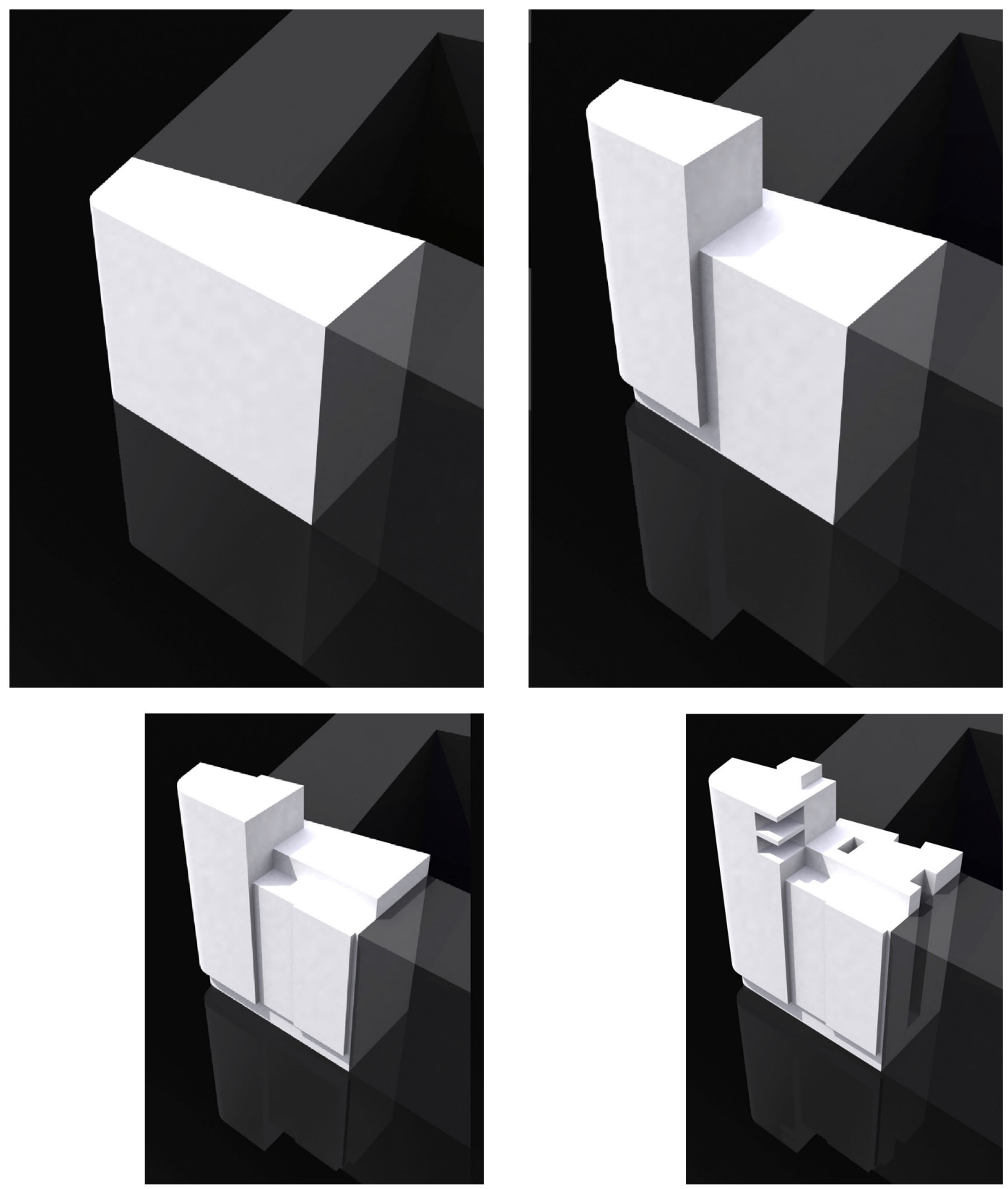

1935. Edificio ALONSO maqueta virtual recreando la re-visión compositiva en el desarrollo volumétrico del prisma anclado al terreno y la disonante verticalidad opuesta 
dinamismo formal, continúa ocupando disposiciones abstractas, platónica pureza racionalista, y remarcamos principio, pues resulta en el discurrir formal, en la evolución de los volúmenes, cuando suceden insinceridades léxicas -al menos aglutina la depuración en una- que conllevan a la ausencia de asociación volumétrica (fig. 8).

Conserva en la calle San Vicente, la anunciada dicotomía entre horizontalidad y verticalidad, titubeos expresionistas en un lienzo envolvente, prescindibles refuerzos compositivos que aseveran la propuesta de ascensión en la calle Játiva -de mayor representatividad urbana, excelso reclamo- desmoronando la unidad volumétrica, cuestionando la coherencia semántica. Escasea la rotundidad -disipar hábitos compositivos instaurados en la casi totalidad, del quehacer edilicio de esta ciudadpara marcar, en sus trabados márgenes, el discurrir hacia lo racional 0 , cuanto menos, hacia maneras expresionistas. Dada la evolución, desde aquellas primigenias pretensiones aerodinámicas en 1927 para el concurso del Ateneo Mercantil, hasta la cuidadosamente elaborada construcción para Carmen ALONSO, nunca podríamos considerar concluso el proceso de constante depuración, imbuido en el ánimo del arquitecto y, mucho menos, limitarlo a la dialéctica formal.

Reflexionar sobre este límite, por el que disciernen arquitecturas aerodinámicas y racionalistas supone, entre otras sendas, reputar objetos elevados como iconos, buscar emblemas arquitectónicos, abandonando principios estrictamente funcionales. Aludir a sus conclusiones formales mediante vertientes, en apariencia desornamentadas, procura aproximar ambos discursos. Distinguir la intención racionalista de aquellas arquitecturas objetuales, pretendidas aerodinámicas, no asoma tarea liviana en 


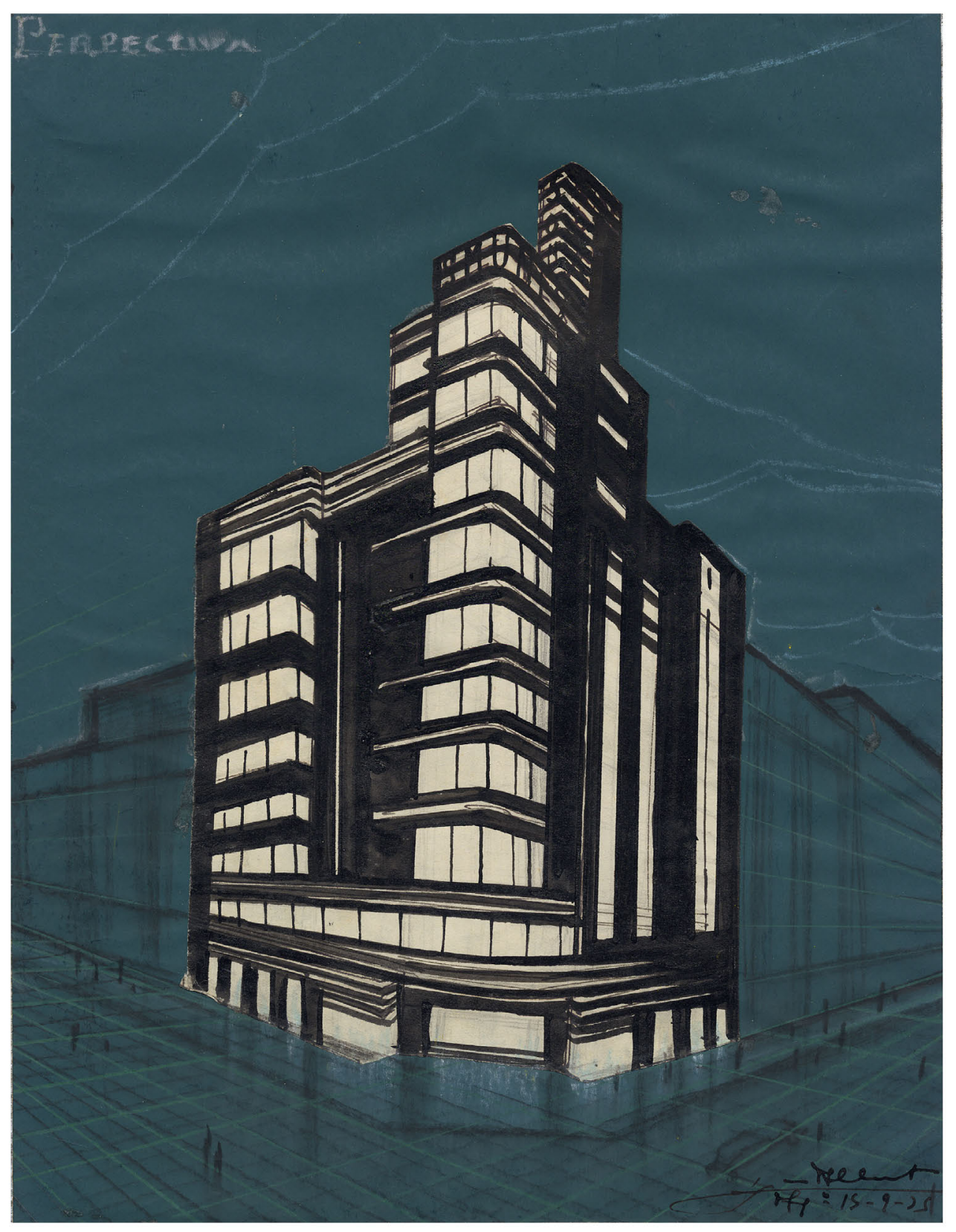

fig. 9

Luis ALBERT, 1935. Edificio ALONSO: calle Játiva, chaflán san Vicente; perspectiva nocturna del arquitecto, esbozando sus pretensiones de rascacielos (archivo Alberto PEÑIN) 
aquel posicionamiento volumétrico inicial, en el equilibrio pretendido con las formas contrapuestas. Disociar posturas es condición de proyecto, y no admite inadvertencias.

Concebir un edificio como un objeto inserto en la trama urbana - un faro, un barco, un avión, una máquina- responde a una intención de avanzar hacia la modernidad, de superar históricas reminiscencias, caducos eclecticismos y adaptarse a las nuevas reivindicaciones.

Fascinadas, ambas arquitecturas, con la incorporación de la máquina y las actuaciones ingenieriles, con la funcionalidad, la modernidad y la vanguardia, disienten en el fondo, no en la forma y ahí subyace la disimilitud. Mientras la arquitectura racionalista persigue principios de precisión industrial, rigor tecnológico y de estandarización; la objetual busca, instintivamente, la plasticidad del objeto, el uso hedonista de la forma, permaneciendo desligada de la ortodoxia que entendía las formas arquitectónicas como deducciones lógicas (efecto) de exigencias objetivas (causas) ${ }^{7}$.

Semejante a la disyuntiva del faro, se infiere la propuesta compositiva de Albert, incontestable tras un primer apunte del rascacielos irradiando en la oscuridad (fig. 9). Imagen nocturna capaz de transferir al observador, ideales de progreso, de avanzada tecnología, fotografía de la máquina surcando noche cerrada. Apoyada en la imagen que trasciende, convence una arquitectura objetual, que enfundando una función distinta a

7 ARGÁN, Giulio Carlo. "El arte moderno. Del iluminismo a los movimientos contemporáneos". Op. cit. pág. 249 


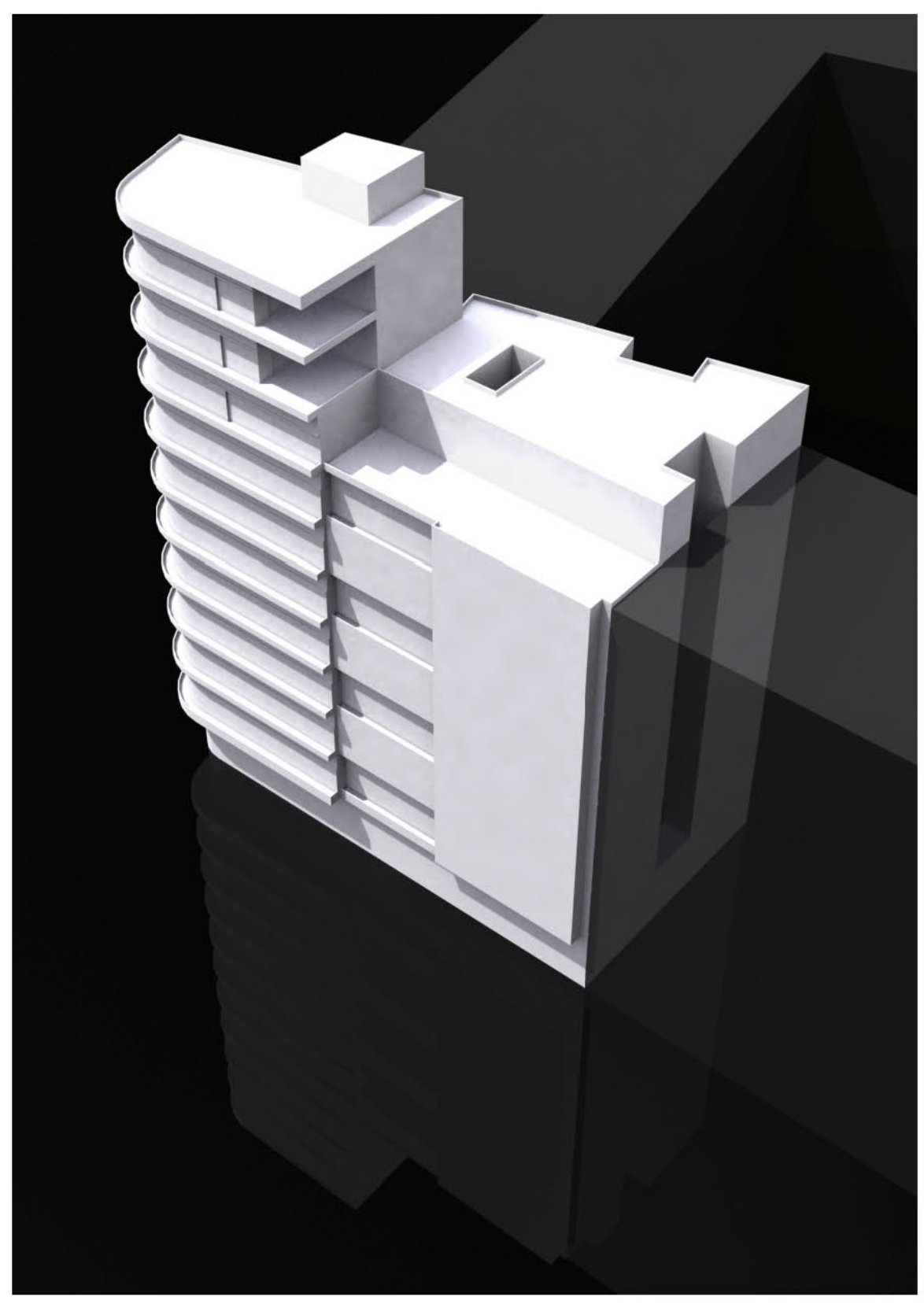

fig. 10

1935. Edificio ALONSO; maqueta virtual doctorando percibiendo la respuesta final de ALBERT a la composición volumétrica de los prismas generadores de horizontalidad y verticalidad 
la propia de dirigir-encaminar, incorpora la utilidad de una realidad habitable, recostada cuando no desempeña su hierática actividad fundamental de guía. La gravedad, la horizontal aporta la primaria sensación de sustentación. La vertical, el hombre erguido sobre el terreno, evoca equilibrio.

Con el edificio Alonso, se eleva la determinación implícita en el proyecto para el Ateneo Mercantil de Valencia; erigir una arquitectura que irradia el espíritu de prosperidad, el dinamismo de una metrópoli moderna. Encallar un barco en la trama urbana, exhibiendo su proa para resolver la esquina, nuevamente en cubillo. Una máquina, un objeto moderno y cosmopolita. Un mecanismo nuevo de referencia visual y de progreso.

EDIFCIO PARA MÁXIMO BUCH.

Probablemente la futilidad de convertirse en referente ideográfico como premisa conceptual, la escasa trascendencia para un proyecto alejado del foco escénico, del epicentro metropolitano -también de sus pretensiones burguesas-, transigen un mayor grado de depuración racionalista, inmediata a su génesis proyectual. La ausencia de enjuiciamientos aprobatorios propicia el alejamiento de la arquitectura como objeto admirable 


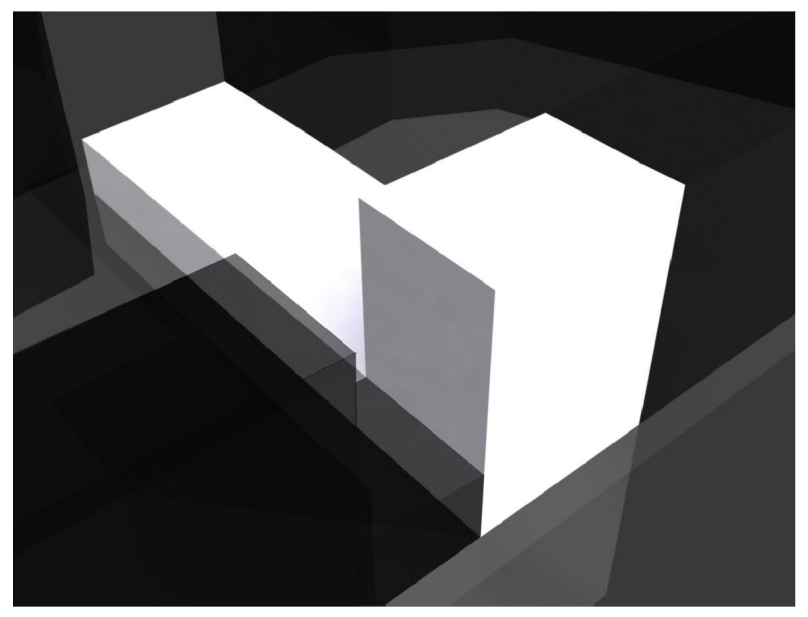

fig. 10
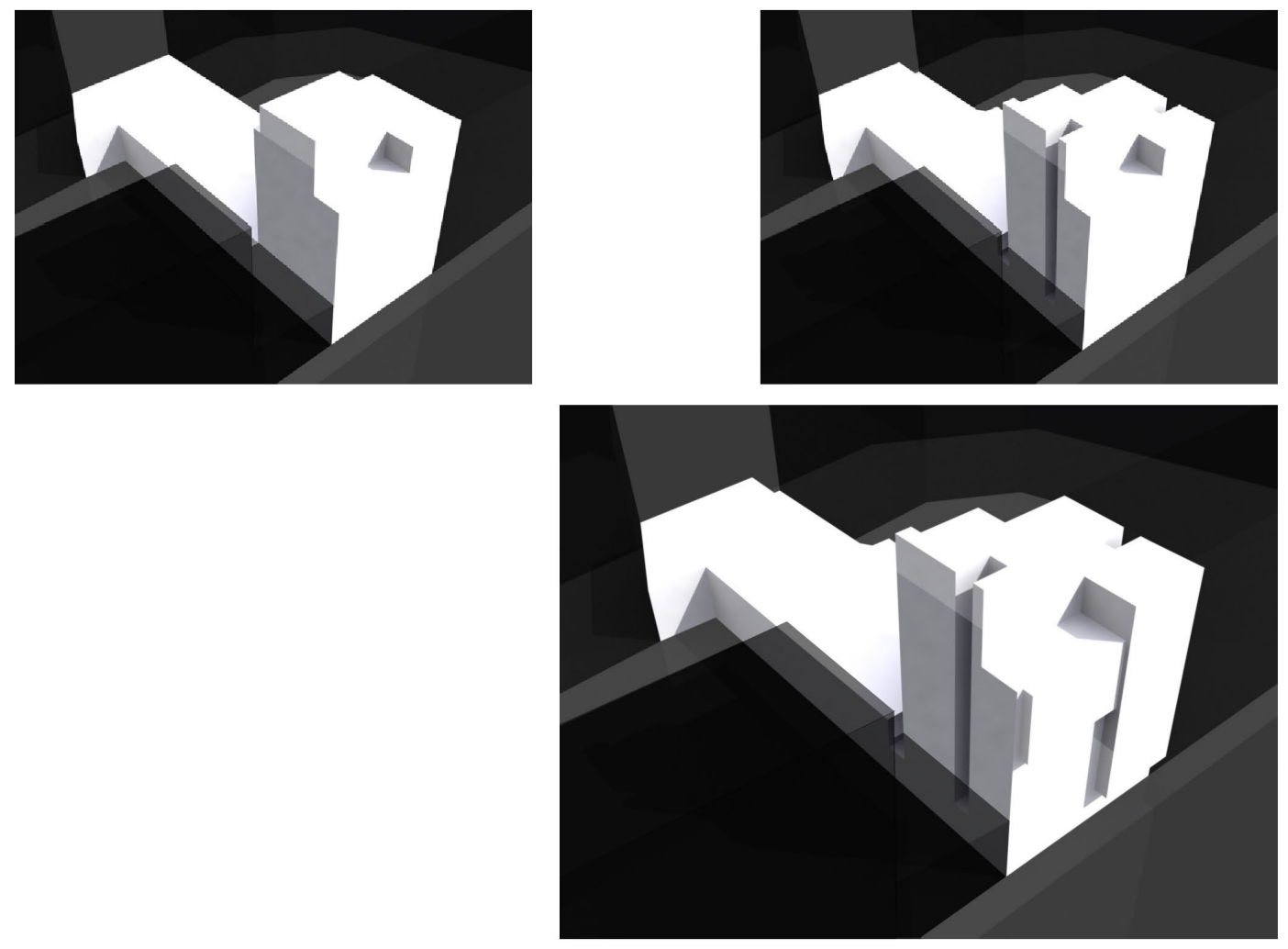

1935. Edificio BUCH; volumetría infográfica doctorando perfilando la génesis compositiva de ALBERT, configurando la volumetría vertical en Cuarte y su opuesta horizontal en San Jacinto 
y favorece la racionalización en su discurrir formal. Faculta un vocabulario más radical en su verbo, legitima una volumetría netamente prismática, una arquitectura cúbica secundando el dictado del propio Albert. Radica aquí, la diferencia con el edificio precedente y, la posibilidad de alcanzar en este, un grado más elevado de pureza, de sobriedad y ortodoxia. Probablemente, sea su situación entre medianeras, extramuros y con menor carga representativa, lo que permite una utilización más radical del lenguaje de la "arquitectura cúbica" -en palabras del propio Albert-. El punto más elevado en un devenir profesional regido a acendrar formas.

Manteniendo el análisis conductor, cotejando con el precedente edificio para Carmen ALONSO, caben parejos planteamientos de torre, de verticalidad, ascensión y linealidad. Análogas volumetrías en equilibrio asimétrico, preservando la disonante contraposición horizontal, lastrando la elevación para entregar ambos prismas al terreno. Observamos una idéntica disociación de piezas contrapeadas, materializada tras el avance del cuerpo vertical, encaramado sobre la base, hasta convertirse en cuerpo volado (fig. 10).

Advienen las primeras desavenencias, en la contraposición de los prismas. El volumen horizontal para Máximo BUCH no retoma el programa funcional de la torre -tampoco lo asume el edificio ALONSO-pasando a su vez a colonizar parte de ella. Difiere radicalmente en un uso habitable, para disociarse en utilidad fabril y sus precisas dependencias administrativas. La trama urbana que lo acoge, aún menos le faculta a presentarse en el terreno con su alzado más extenso, aspecto diverso de la propuesta comparada. Es por todo, forzosamente obligada la necesidad de redisponer la base horizontal perpendicular esta vez al recorrer urbano 


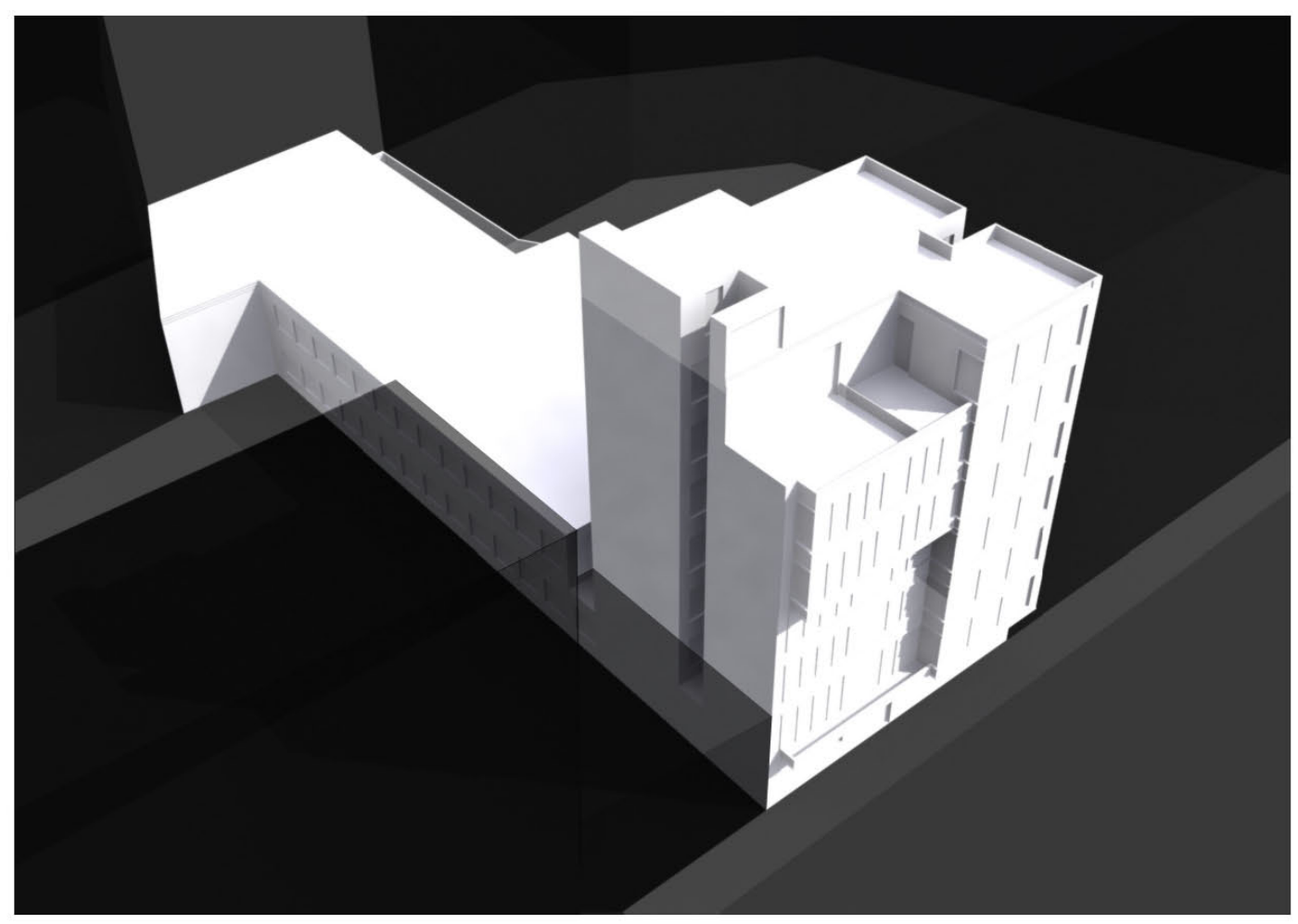

fig. 11 
y por ello, imperceptible su totalidad para el viandante.

No cabe entonces, el faro como elevación visible de la masa horizontal que le sirve. Abandona su concepción como objeto referente, como máquina focal. Asume el edificio BUCH, una semejante composición formal, derivada a colindante senda, aunque conclusa en diferente empeño: el reclamo expresionista atendido, frente al cartesiano racionalismo desentendido.

Desestima Albert, el carácter objetual, hedonista y singular de las formas aerodinámicas. Por el contrario recorre este edificio, una mayor distancia en su aproximación a la funcionalidad, la simplificación, las impregnaciones racionalistas que, tras infranqueables límites, reclamaban evitar el ornato del volumen platónico. Un entendimiento más integrador, más permeable, permite al menos tras su depuración geométrica, mantener recercados que faciliten una visión horizontal de la fenestración y otras contrastadas referencias visuales -como las persianas americanas, las barandillas de tubo- que le acerca a la evolución gradual proclamada.

Modificar la composición exterior, reforzando la asimetría tras redimensionar las piezas recayentes a la calle Cuarte, aumentando las superficies de un reducido grupo, a más de quebrar una axialidad tan llamativa y desequilibrar en parte la simetría de usos en planta, facilita volar un volumen, interrumpiendo la planeidad del lienzo de fachada, comprometiéndose no obstante en preservar la continuidad horizontal de la fenestración (fig. 11).

Escalonar la volumetría, colonizando parte del espacio público, infiere el propósito asimétrico, la evolución contemporánea carente de reminiscencias 


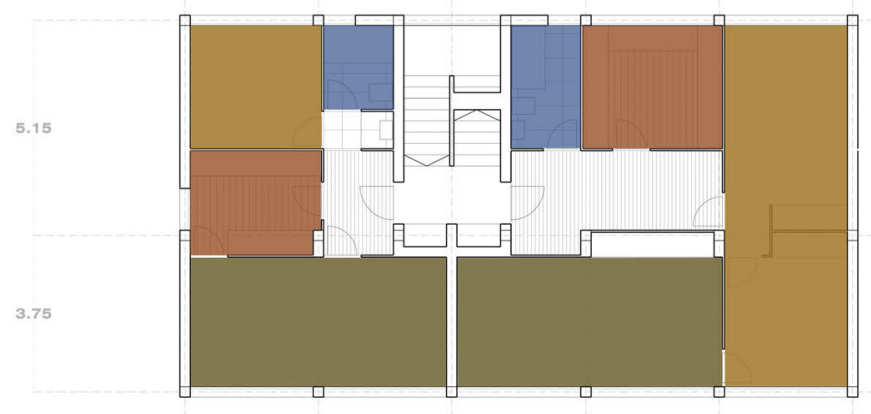

fig. 12

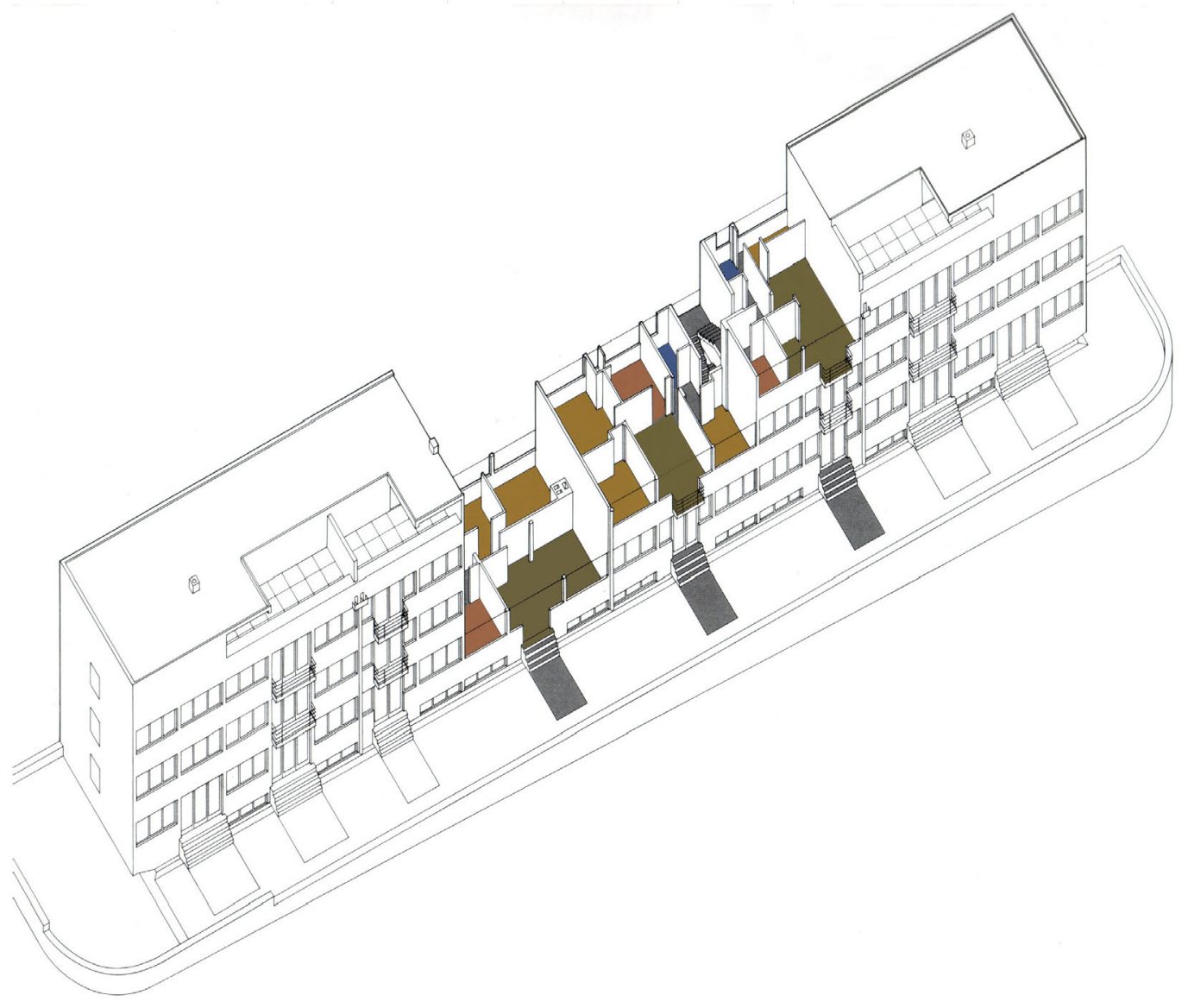

MIES van der ROHE, 1925-1927. Weissenhofsiedlung en, Stuttgart; planimetría redibujada por el doctorando para el análisis funcional del inmueble inmerso en la propuesta urbana 
históricas $s^{8}$, la pureza cúbica ya escatimadas las decoraciones, finalmente limitado a una composición elementalista, expresionista, empero distante del anhelado funcionalismo, discurriendo entre los intangibles límites expresionistas y los estrictamente racionales.

ORGANIZACIÓN FUNCIONAL

Cómo pergeñaron distribuciones en sus proyectos para inmuebles urbanos, aquel grupo de profesionales recién egresados de las Escuelas Superiores de Arquitectura alrededor de los años veinte, provocará discernimiento en sus diluidas posiciones ortodoxas. Sabemos de su formación ignorante en la existencia de una 'construcción con vida actual' que solventara problemas según exigencias del 'individuo tipo' que integraba la colectividad (fig. 12). Discernimos su académica enseñanza, al igual que somos conocedores de sus protestas encaminadas a desprenderse rápidamente de aquella arqueológica intención docente.

8 'El estilo en sus líneas generales es moderno, siendo su decoración sencilla'. ALBERT BALLESTEROS, Luis. De la memoria del proyecto

9 AC-4. Revista Trimestral, publicación del GATEPAC. Barcelona, Madrid, San Sebastián. Año $1^{\circ}$. Cuarto trimestre 1931. pág.15 


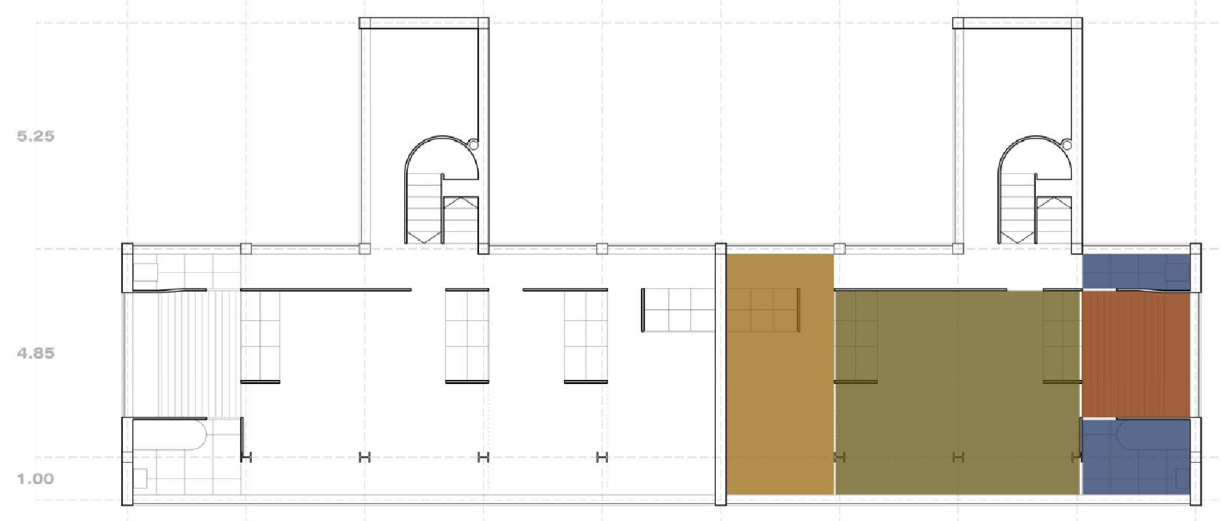

fig. 13

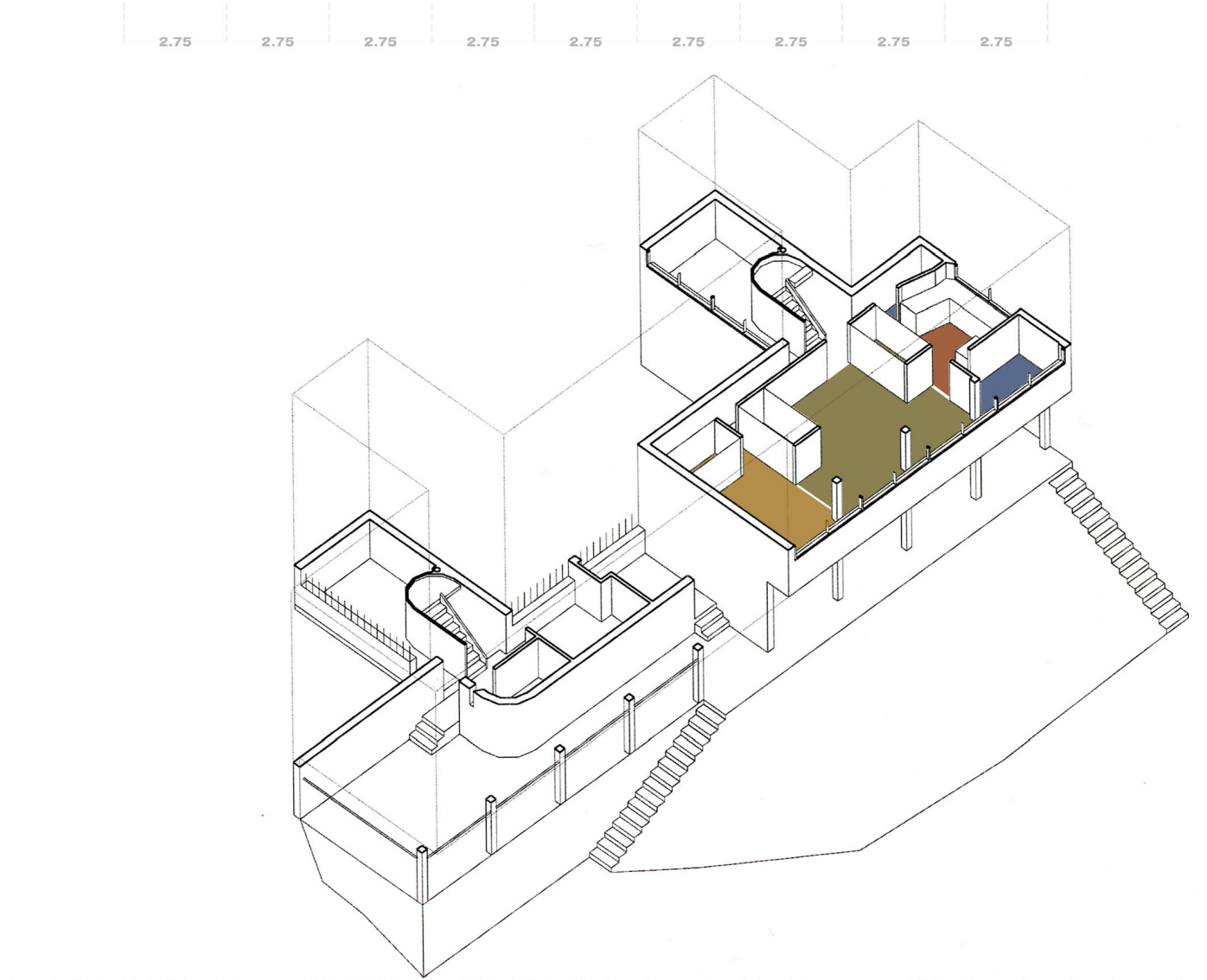

Le CORBUSIER y Pierre JEANNERET, 1925-1927. Weissenhofsiedlung en, Stuttgart; planimetría redibujada ilustrando la organización funcional del versátil inmueble "sleeping-car" 
Sabemos de su cautiverio metodológico, capacitándoles una seguridad desde la cual afrontar sus propuestas habitacionales. Resultaron cartesianas planimetrías -tanto las plantas de distribución, como sus alzados correspondientes-, racionales en su mayoría $y$, sin embargo ausentes de una visión espacial indispensable, carentes de modernos procedimientos, exhausta en la ambicionada evolución del método.

Restaba adaptar aquellas investigaciones, en los Congresos Internacionales de Arquitectura Moderna del CIRPAC, indagando mínimos habitacionales, estandarizando elementos y reduciendo costes, auspiciados por el adelanto de la industria (fig. 13). Arduo se presentaba el compromiso con el moderno ideal positivista; afanosa traslucía la tarea por llevar al hombre hacia una sociedad perfecta, organizada científicamente; laboriosa pretensión infería socializar el acceso masivo a la nueva metrópoli. Modernizar el hábitat humano resonaba alejado, enconada puesta en escena frente a la escasa permeabilidad -no exclusiva de promotores-social, frente a las aprehendidas planimetrías, experimentadas en la recién finiquitada centuria.

Confrontar disposiciones planimétricas, distribuciones en planta de finales del XIX adscritas a históricas doctrinas académicas, con aquellas que representaban principios racionales en los albores del $x X$, dilucidará la postura ecléctica, heterodoxa para el grupo de jóvenes arquitectos valencianos, dispuestos a reafirmarse en la modernidad, no obstante vencidos en el ímpetu de inculcar en sus clientes los fundamentos sociológicos, el espíritu innovador de las nuevas corrientes europeas; las dos corrientes de la ortodoxia moderna, el funcionalismo y el organicismo, tal cual clasificadas por Iñaki Abalos. 


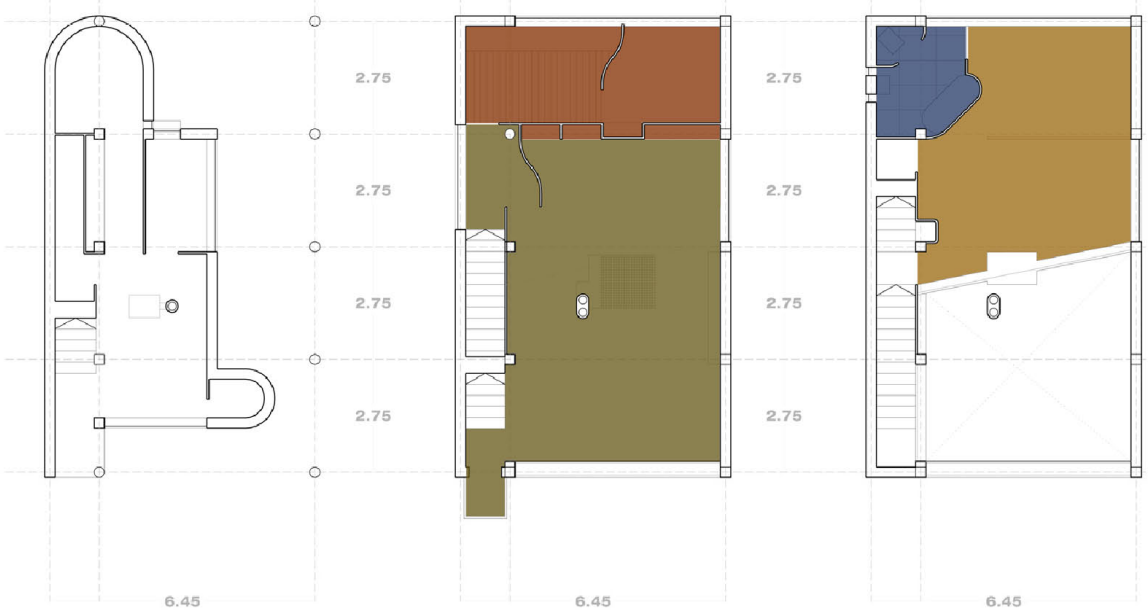

fig. 14

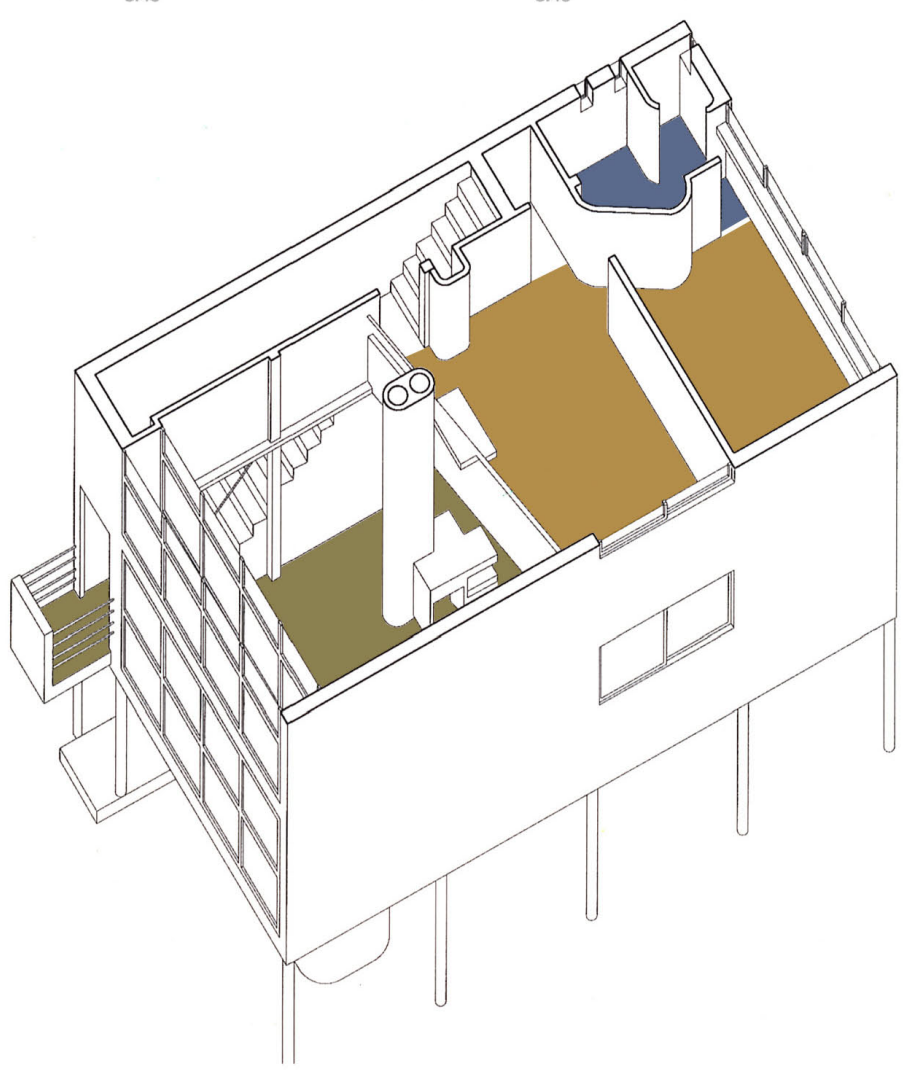

Le CORBUSIER y Pierre JEANNERET, 1925-1927. Weissenhofsiedlung en, Stuttgart; distribución del inmueble aislado consecuencia del tipo "Citrohan" ideado previamente 
Posturas coetáneas, debatiéndose -inmersas en un futuro de progreso, en una Europa positivista- entre el Existenzminimun para la optimización de tipos estandarizables ${ }^{10}$ y la reinvención del espacio doméstico (fig. 14), desvinculándose del pasado y constituyéndose mediante leyes universales.

Optimización de funciones, eficiencia y economía, estandarización de plantas expuestas en los congresos CIAM ${ }^{11}$-temáticamente inmersos en el Existenzminimun, sus investigaciones se dirigían a encontrar las medidas mínimas correctas, asumiendo que la arquitectura significa sobre todo eficiencia y economía- comparando superficies, cuantificando normativa, pretendiendo mínimos a través de la producción industrial para compilar, allegar propuestas y concluir la minoración -reducción cientifistadel espacio habitable. La vivienda, profesa Alexander Klein 12, ha pasado a ser un problema de la industria que debe estudiarse con el mismo espíritu que cualquier otro proceso industrial.

Reinventar el espacio donde albergar la familia tipo, estadística, orgánica e inmersa en una sociedad codificada, sugería lanzarse al futuro, comprenderse voluntariamente en un organismo social superior. No asomaba suficiente la célula familiar, resultaba preciso insertarla en el bloque residencial que alentado por el valor superior de lo colectivo, como máxima,

10 NEUFERT, Ernst. "Baventwurfslehre". Esta obra supone un producto característico de este período. Véase versión castellana, "El arte de proyectar en Arquitectura", editorial Gustavo Gili, S.A. Barcelona, 1976

11 AYMONIO, Carlo. "La vivienda racional. Ponencias de los Congresos CIAM: 19291930". Editorial Gustavo Gili, S.A. Barcelona, 1973. Título original: "L'abitazione razionale. Atti dei congressi CIAM. 1929-1930". Versión española de J.F. Chico, J.M. Marco, J.C.Theilacker, arquitectos.

12 ÁbAlos, Iñaki. "La buena vida. Visita guiada a las casas de la modernidad". Editorial Gustavo Gili, S.A. Barcelona, 2000. pág. 74 


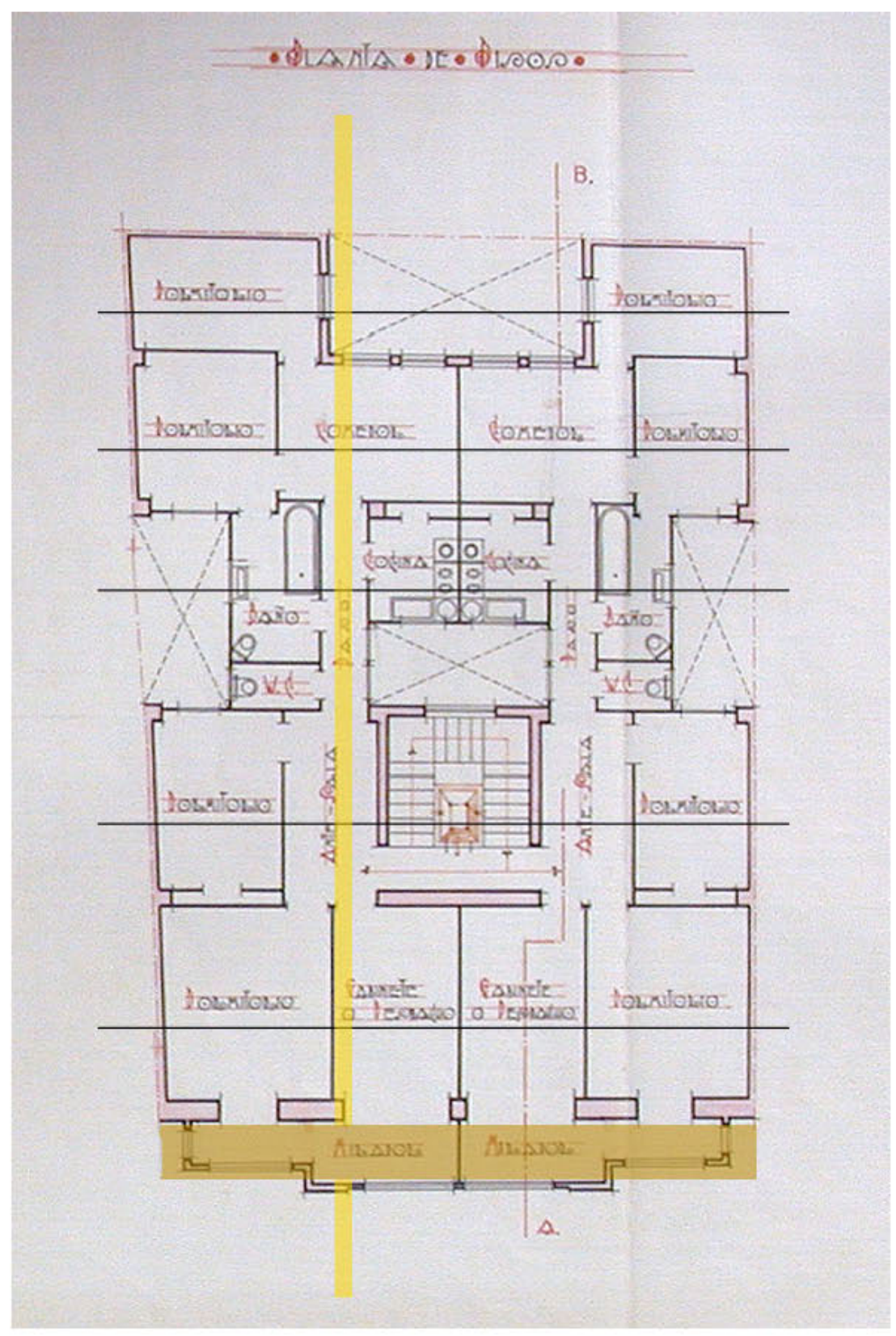

Luis ALBERT, 1930. Edificio Juan Antonio MOMPó: planta pisos distribuida en líneas ortogonales al eje principal organizado perpendicular a fachada, según método academicista 
definiría el destino último de la vivienda moderna como generador de ciudad, actor principal para formalizar la escena urbana, resolver el espacio público.

Observar el espíritu que posibilita distribuciones racionales, funcionales, advenía ardua tarea, ilusoria y alejada para los arquitectos valencianos, condicionados por el receptor de sus trabajos. A la par de las premisas establecidas en la legislación vigente, el arquitecto debía considerar la rentabilidad del edificio a proyectar, las exigencias funcionales e incluso estéticas de los encargos, inhabilitados en la intención de una arquitectura moderna, imposibilitados para "introducir en las plantas de sus proyectos, local que no tenga uso sancionado", afirmación de Manuel Aníbal13. Junto con el cumplimiento de las ordenanzas y el aprovechamiento máximo del espacio, las indicaciones compositivas en el trazado-casi de la totalidad de propuestas en planta-, no alteraban la académica metodología empleada anteriormente -el sistema conocido Beaux Arts- en la tradición académica del Eclecticismo ${ }^{14}$. Amadeo Serra las compendia en una regla principal, la distribución organizada a partir de líneas ortogonales tomando como eje principal la perpendicular a la fachada (fig. 15).

Evitar el desacuerdo, la incomprensión de sus usuarios con la Arquitectura planteó el dilema y profirió la división entre arquitectos, radicalizando posiciones mediante un nuevo contacto con el pasado o rechazando todo

13 SERRA DESFILIS, Amadeo. "Eclecticismo tardío y Art Déco en la ciudad de VaIencia (1926-1936)". Editado por el Excelentísimo Ayuntamiento de Valencia, 1996. Valencia. pág. 30

14 VAN ZANTEN, D. "Le sistema des Beaux Arts", L'architectura d'aujourd'hui, número 182, noviembre-diciembre 1975, pág. 97-106 


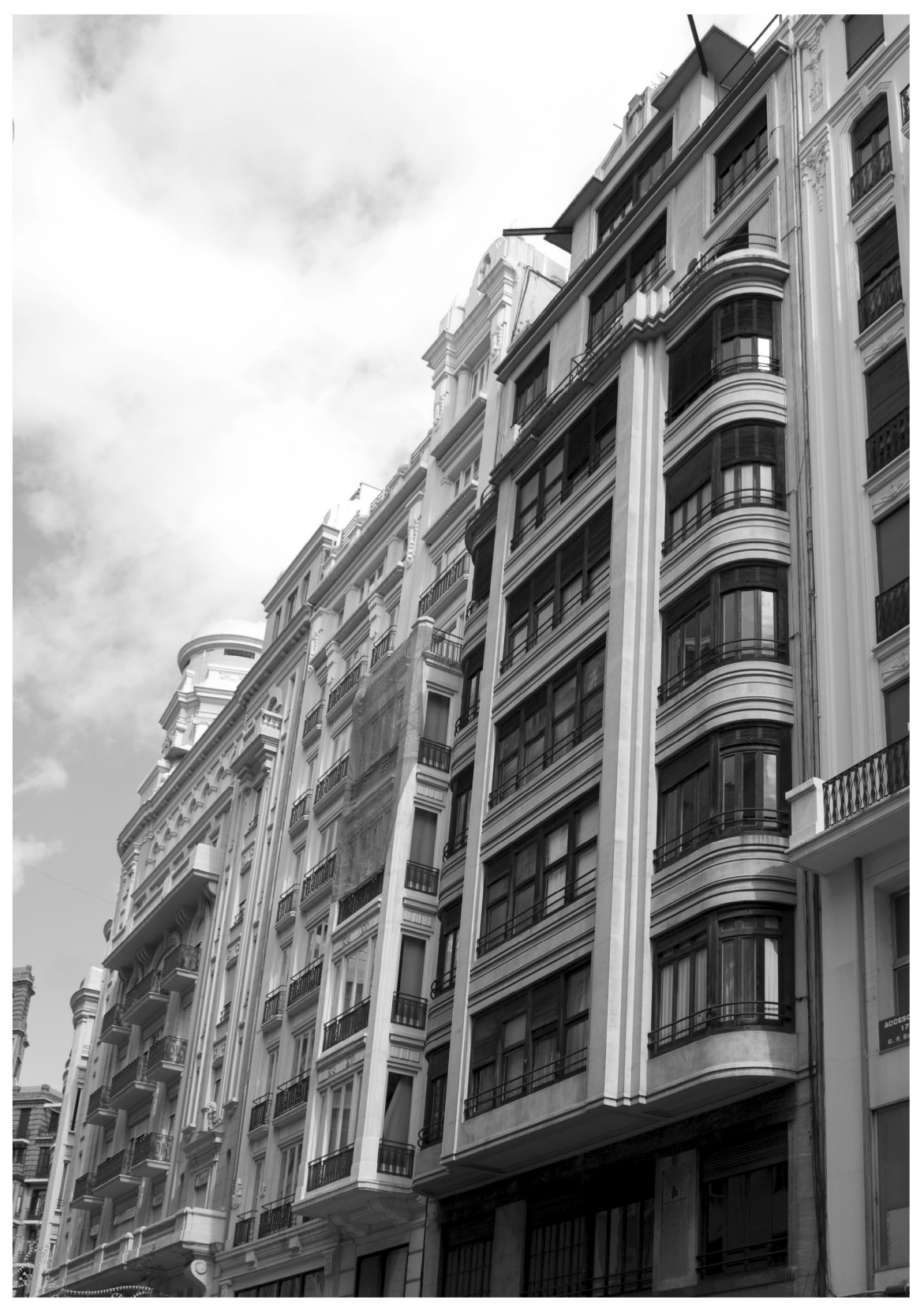

1930. Edificio Juan Antonio MOMPó; percepción del alzado principal, recayendo a la calle San Vicente, generador del eje de distribución funcional; fotografía R. Perelló Roso 
tipo de historicismos y en su lugar la nueva funcionalidad. La burguesía valenciana no llegó a entender la nueva orientación -radical en excesoy condujo, a los divididos arquitectos, por sendas eclécticas. Es por esto, la semejanza planimétrica de cualquier edificio del Ensanche, construido durante el período que nos ocupa, independientemente de si el espíritu que los gestaba arrancaba en posiciones historicistas, eclécticas o anhelaba de las nuevas fuentes contemporáneas, funcionales 15 , estandarizables, cuantificadas hasta mínimos eficientes.

Honrosas, contadas y espontáneas excepciones distaban del esquema clásico, manido, de piezas nobles recayentes a fachada, sobrevenidas ortogonálmente por piezas menores, seriadas en derredor a reducidos pozos de ventilación, hasta culminar en el nexo común familiar, una pieza aluzada por patios de manzana, desdeñados por criterios modernos de ventilación e iluminación, frente a los bloque de habitación racionalmente ordenados ${ }^{16}$.

Composiciones eclécticas donde no disociaban proporciones espaciales, aplicando superficies equivalentes a usos tan dispares como dormitorios, gabinetes, salas de estar. Sucedía lo propio, a menor escala, en las estancias mínimas, pequeñas piezas de servicio, higiene y algún dormitorio,

15 'El funcionalismo de los años veinte y treinta tomó esto como punto de partida y nos legó el primer intento sistemático de examen de los tipos edificatorios' NORBERG-SCHULZ, Christian. "Intenciones en Arquitectura". Editorial Gustavo Gili, S.A. Barcelona 1979, colección Arquitectura/Perspectivas. pág.1 2

16 LE CORBUSIER. "¿Edificación alta, media o baja?" Conclusiones del ller Congreso Internacional de Arquitectura Moderna. Bruselas. Ver AC-3, pág. 34. 'No hacen falta ya más patios. -El patio es insociable. Crea alrededor de su tristeza y su insalubridad, una división social: los que tienen vistas a la calle y los que dan a los patios'. 


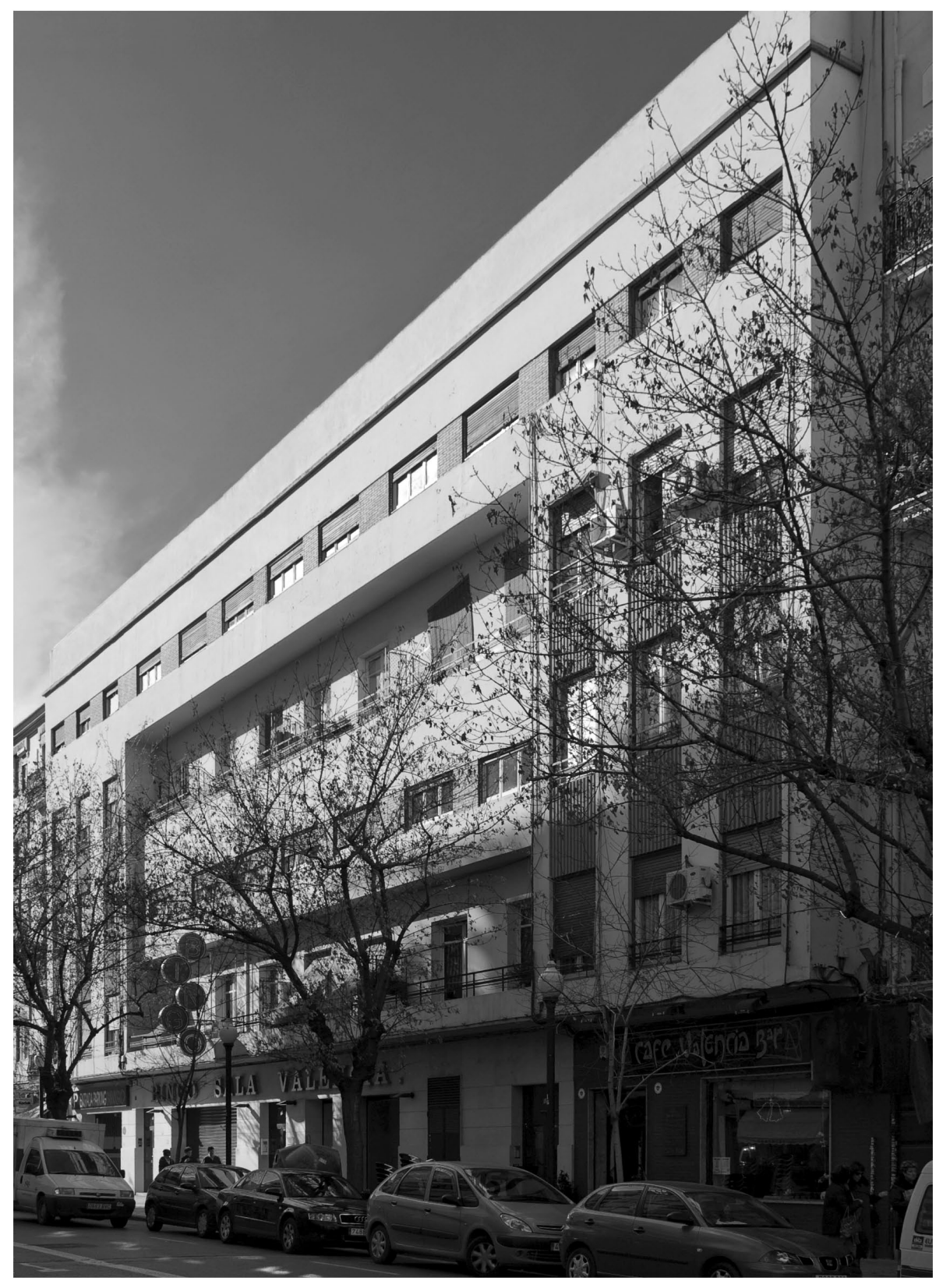

1930. Edificio José Manuel ZABALA; fotografía del alzado principal, recayendo a la calle Cuenca, donde Albert plantea el eje de organización funcional de cada inmueble 
unidos a estrictos patios interiores -generadores de menesterosa iluminación y ventilación, mediante un espacio ya entonces normalizado-para prolongar la distribución, organizada según espacios transversales respecto al eje perpendicular a fachada. Concluían normalmente, con una pieza algo más generosa y de proporciones equivalentes a las primeras en secuencia, planteada con todo lo relacionado con la preparación, elaboración e ingesta de alimentos -comedor y cocina generalmente próximos entre sí- recayendo a un patio de manzana, siempre a través de una galería.

Esta abstracción organizativa del espacio, reiterada en la totalidad del Ensanche, se distorsionaba, en las construcciones del centro histórico de nuestra ciudad, en base a la irregularidad que presentaban los solares que soportaban la propuesta. En cuanto al resto, todo un continuo excepcionalmente alterado.

Reinterpretar el concepto historicista de distribución en planta, supuso el discurrir habitual de propuestas edilicias, alejadas de la ortodoxia propositiva. Menospreciar la reinvención, conforme a modernas necesidades sociales, conllevaría una menor carga programática y sin embargo una manejable aceptación social. Alcanzar la independencia del lenguaje, empleado como moderna indumentaria, acaecía por añadidura, concluyendo un discurso con dirigida atención a su aspecto exterior-aceptado incluso racionalista- y desdeñando la máxima de la forma siguiendo a la función. Aquella incomprensión entre aquiescencia y Arquitectura, amagaba una sutil bocanada de modernidad, siempre limitada al tratamiento externo, aquel que distinguía socialmente, no obstante, cercenando el concepto racional de construir-de acuerdo al nuevo espíritu- un todo 


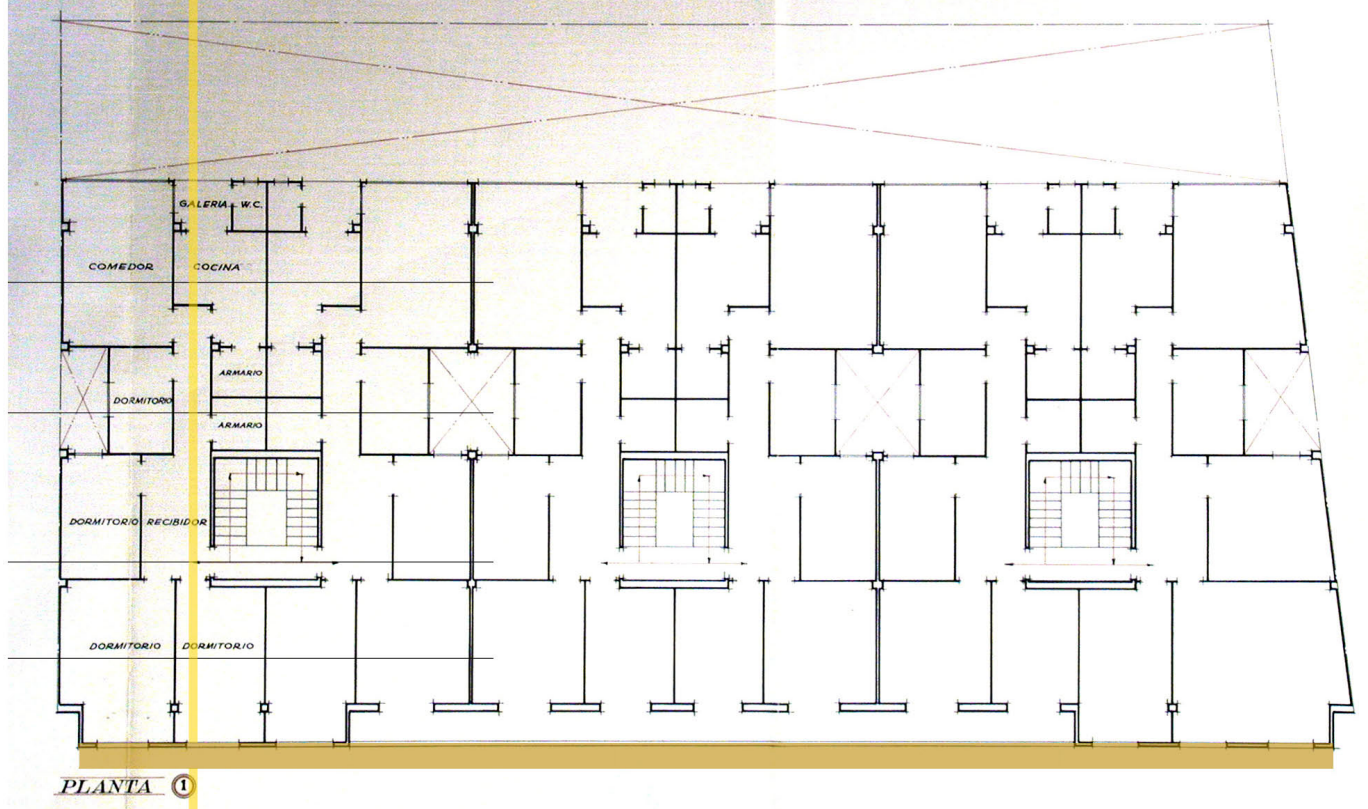


arquitectónico. Por norma, semejaba inalcanzable evitar la dicotomía al proyectar una fachada y distribuir funciones, tratados como procesos independientes -propio de la arquitectura ecléctica-concediendo proyectos alternativos, incluso de opuestos lenguajes decorativos frente a desnudos paramentos, para una idéntica distribución.

Lo desnudo no es forzosamente el fin último de lo moderno. No será lo más moderno una construcción con ventanas horizontales, o descoronada de su cornisa, si el arquitecto no ha exprimido el espíritu de lo que ha construido ${ }^{17}$.

EDIFICIO PARA CARMEN ALONSO

"El edificio que se proyecta consta esencialmente de cinco plantas bajas, siete pisos a cuatro habitaciones (viviendas) por planta, un ático a dos habitaciones por planta y dos pisos en el torreón para dos estudios" ${ }^{18}$

17 ZERvos, Christian. "Jóvenes arquitectos". A propósito de su exposición en la Galería de Cahiers d'Art. Febrero-Marzo de 1935. "Cahiers d'Art", año 1935, n 1-4 18 ALbert ballesteros, Luis. De la memoria del proyecto. Archivo Municipal de Valencia/1935/Ensanche/caja 4bis/exp. 4566 


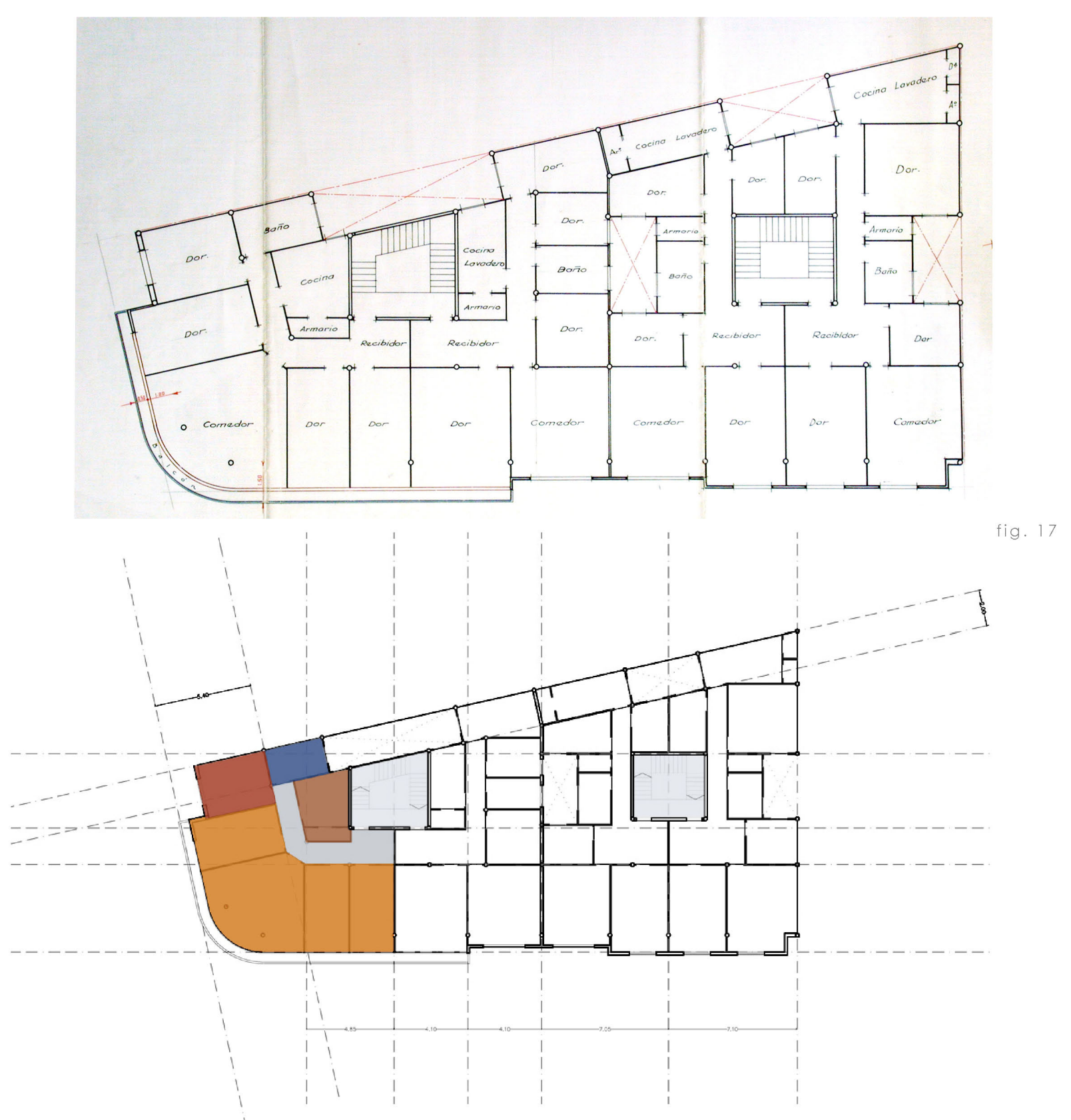

Luis ALBERT, 1935. Edificio para Carmen ALONSO; distribución de la planta de pisos y organización funcional del chaflán a la calle Játiva, esquina con calle San Vicente 
Una primera lectura funcional, siguiendo aquel académico código establecido para componer distribuciones, normalizado en organizaciones planimétricas, induce a mantener denostada la anunciada homogeneidad-también entre los jóvenes arquitectos valencianos- de respetar el constatado sistema Beaux Arts. Adoptado tanto en edificios comunitarios eclécticos, como en aquellos de consabida pretensión racionalista, solventaban el dilema funcionalista al mantener expedita la facultad de aplicarse en ambos lances. No parece discurrir, la propuesta albertiana, entre estériles debates compositivos

Todo lo contrario, las particulares características métricas -configuradas en superficie- del solar que debía albergar el edificio, exhortaban a no pensar en una respuesta lineal zurcida de patios, no reiterar la manida distribución ecléctica para la composición de plantas, no perdurar un eje orgánico ortogonal a la fachada principal-ineludiblemente de dimensión reducida frente a la longitud del eje, con todos los inconvenientes acarreados-integrando usos transversalmente $y$, en secuencia según pierden importancia, hasta culminar en un patio de manzana-apremiado para entregar luz y ventilación- aquellas piezas dedicadas a la manutención familiar.

Albert no evidencia una drástica excepción -remarcamos su constante evolución profesional- y, el edificio para Juan y Arturo ZABALA (fig. 16), en la calle Cuenca 16, reafirma metódicamente dicho sistema tomado, surcado en la memoria. Resulta un claro exponente del eclecticismo aplicado en la composición distributiva y funcional. Dormitorios en fachada $y$, opuesto con idéntica métrica, comedor acomodado al patio de manzana, con la secuencia de piezas menores reincidiendo en la sistematización 


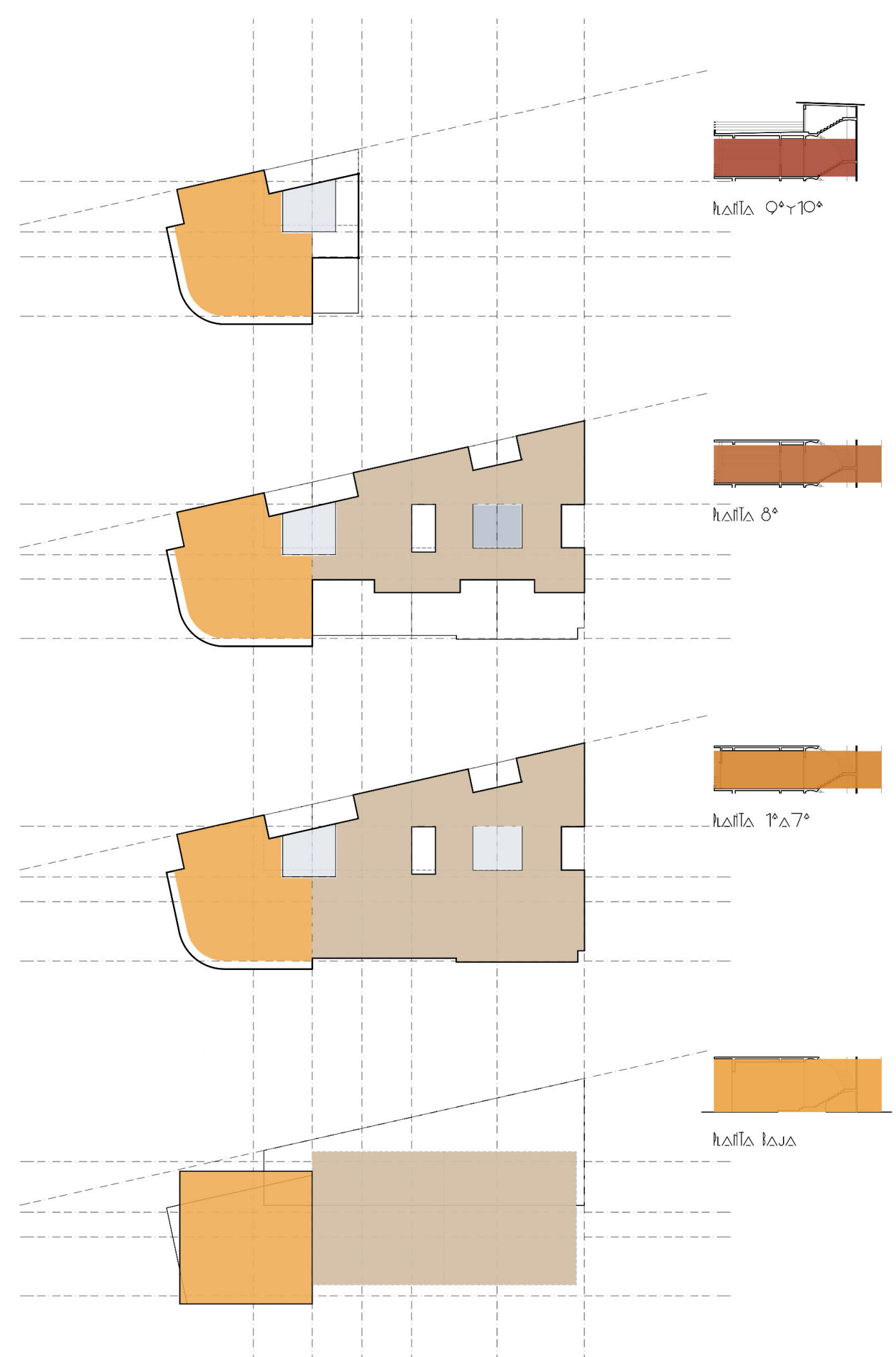

Luis ALBERT, 1935. Edificlio parta Carmen'ALONSO; asociación entre la articulación volumétrica y su distribución funcional; cuatro vilviendas arganizadas en torno a dos escaleras 
de proporciones para dormitorios y recibidor -en este paso menores- y retomando pequeños patios interiores.

Rezaba reiteradamente tal abstracto sistema de organización espacial en las trazas planimétricas de los arquitectos que elevaban el Ensanche, preocupados ulteriormente por el oficio, las exigencias de higiene y habitabilidad. Atronaban lejanos conceptos como estandarización, optimización de funciones, eficiencia y economía, sin embargo reclamaban compromisos, principios que los acostumbraban inalcanzables en la cultura, la política y la sociedad valenciana de la época. Requería tácito, compelía o simplemente se preguntaba Albert: Posiblemente estamos en la época de la fabricación de elementos constructivos en serie, desde las puertas, pasando por los ventanales y tabiques, hasta las cubiertas. Pero, ¿llegará todo ello, en definitiva, a satisfacer las correspondientes funciones materiales, económicas y estéticas en los futuros edificio? 19

Una rauda mirada -previamente anunciada- al edificio ALONSO, podría sugerir la excepción a la tradición académica aprendida. Cuanto menos en las ocho viviendas que formalizan la torre y finalmente en los dos estudios-apartamento que terminan por erigirla. Optimización de funciones, estancias correctamente dimensionadas ofertando una adecuada respuesta a la necesidad que las gesta, apuntan disconformes al manido método compositivo. Espacios nobles, de interrelación familiar y externa, generosamente proporcionados, frente a aquellos individuales o privados.

19 Albert ballesteros, luis. "La evolución de la arquitectura en el transcurso de los siglos". Discurso leído el 3 de marzo de 1961 en su recepción pública como académico de número en la Real Academia de Bellas Artes de San Carlos. Editado por la Diputación Provincial de Valencia, en 1963. pág. 25 

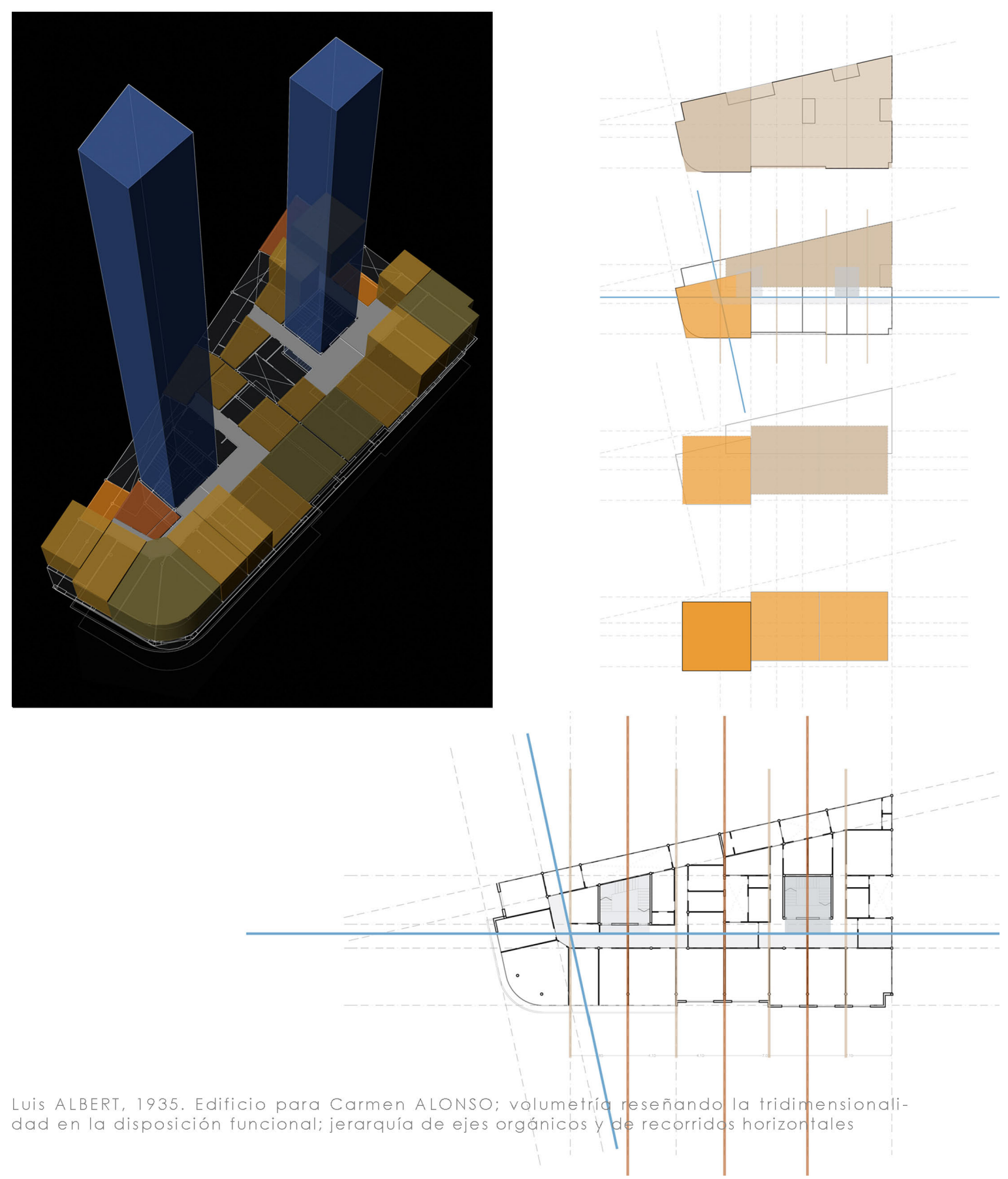

Luis ALBERT, 1935. Edificio para Carmen ALONSO; volumetríd reseñando la tridimensionalidad en la disposición funcional. jerarquí de ejes organicos y fe recorridoshorizor 
Imbuidos en su totalidad del espíritu principal, racional y por ende no historicista, negando la consabida predisposición ortogonal a fachada aquella que impelía agrupar en profundidad edificatoria, alrededor de patios- y priorizando la adquisición del lienzo exterior, donde distribuye Albert esta jerarquía de espacios, ubicados en fachada, relacionados de manera evidente, inminente, con el exterior (fig. 17). Accesos principales o recorridos internos, tan estrictos como eficientes, traslucen igual de cartesianos. Espacios mínimos de trabajo, accesibles y correctamente vinculados a las piezas que sirven, ventilados e iluminados en su justa necesidad, colmatan la nunca ecléctica distribución funcional.

Cuando el arquitecto decide completar la dupla volumétrica, asociando a la torre otras ocho plantas de habitación, la construcción se precipita apartándose de los principios modernos. Resurgen las imposiciones del sistema urbanístico vigente -gravitando en la tipología edificatoria de manzana cerrada-, el cual no permite prescindir de los pequeños patios de ventilación y luz con todos sus inconvenientes. Reaparece el sistema compositivo ecléctico albergando las funciones distinguidas en el alzado $y$, sin embargo, extinta la posibilidad del gran patio de manzana. Lejos de desviarse del método clásico establecido, comedores y dormitorios principales, mantienen ahora la equivalencia superficial, en contra de proponer respuesta a las necesidades que los generan, al número de usuarios a servir. Siguiendo normas urbanísticas e imposiciones higienistas, sirviéndose de exiguos patios, el resto de estancias repiten el sistema de seriarse y posicionarse en un recorrido nuevamente lineal y transversal hacia el interior donde alumbran los patios de dimensión algo más generosa, sin acercarse a la dimensión del cuestionado, manido patio de manzana. 
fig. 18

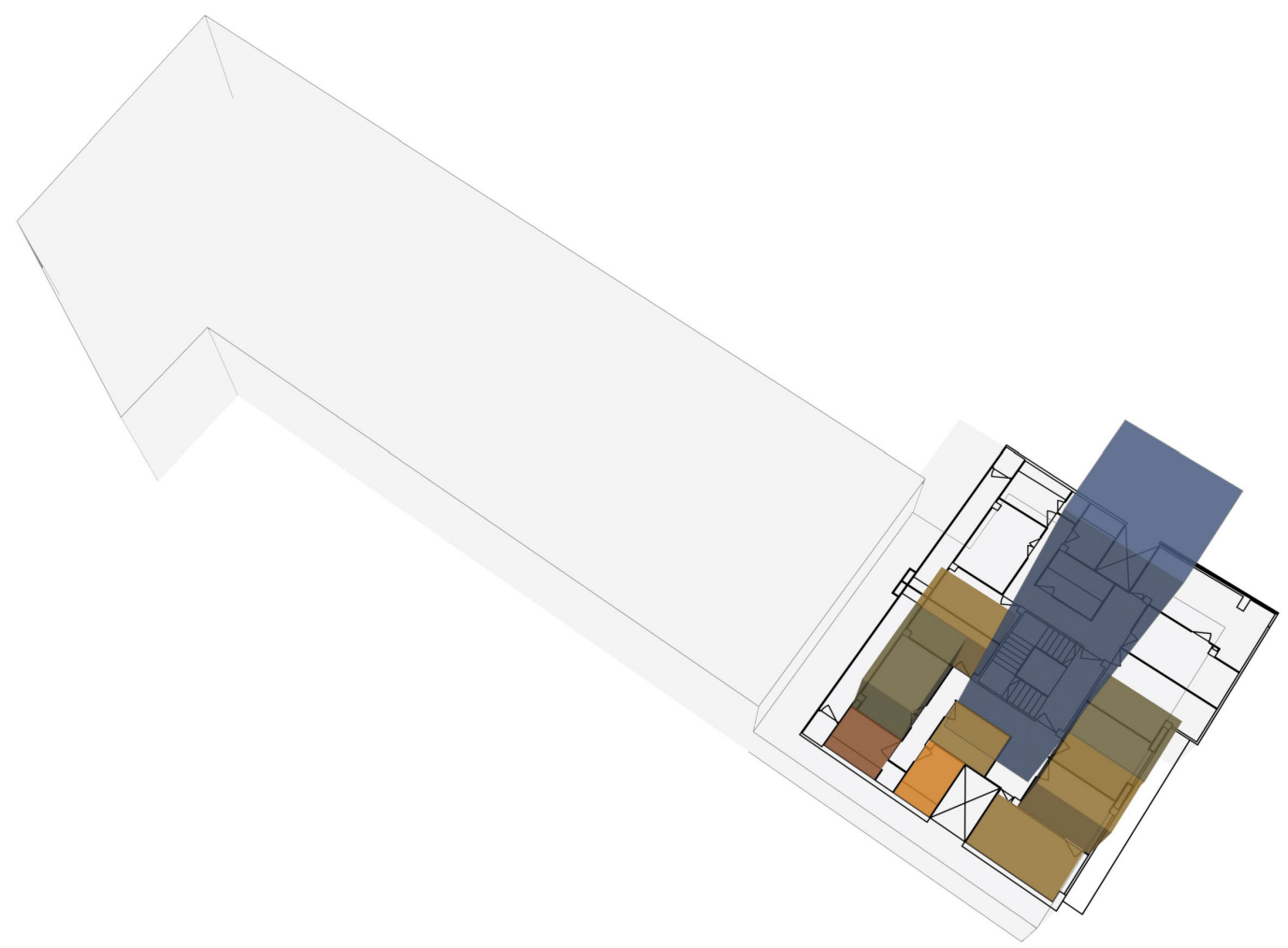

Luis ALBERT, 1935. Edificio para Máximo BUCH; esquema volumétrico anunciando la organización de funciones de la vivienda tipo y la ubicación del único recorrido vertical 
Nuevamente recobra fuerza la disección volumétrica del rascacielos, inhibido en su elevación por el cuerpo horizontal, las modernas aspiraciones funcionales del faro coartadas por las historicistas, eclécticas, previsibles formas de habitar. Enraizados al plano del suelo, horizontales, paralelos y experimentados sistemas compositivos, alejados de cualquier compromiso de futuro, opuestos a esa primera mirada funcional que ofertaba la torre emblema del cruce de calles Játiva y San Vicente.

EDIFICIO PARA MÁXIMO BUCH

"Consta esencialmente el edificio que se proyecta de un cuerpo principal, recayente a la calle Cuarte, destinado a viviendas, despachos y oficinas (fig. 18), y otro interior, construido en dos plantas y comunicado con la calle de San Jacinto, que se destina a fábrica de cepillos y dependencias anejas". 20

La construcción, el edificio de viviendas y fábrica para Máximo BUCH, puede adscribirse poco menos como la más excelsa adaptación, lograda

20 Albert Ballesteros, Luis. De la memoria del proyecto. Archivo Municipal de Valencia/1935/Ensanche/caja 3bis/exp. 25001 

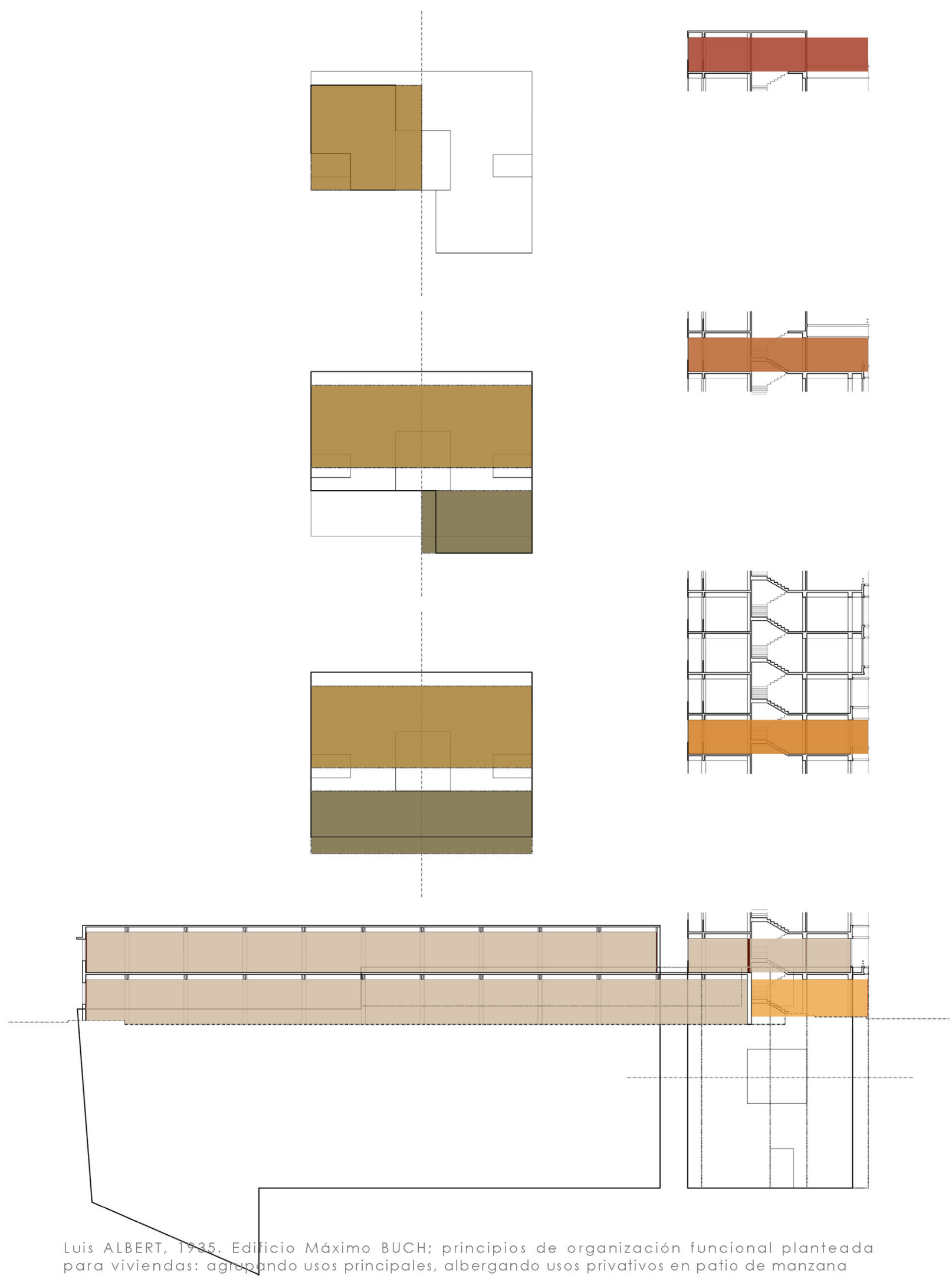
por Albert, a los principios modernos. Y esta escasa diferencia con la ortodoxia racionalista, aquella que por observancia lo aleja, es reflejo de la inconcreción en el proceso de organización, de reparto racional, capaz de articular la cantidad mínima individual a la cantidad mínima social, casi por acumulación. Precisión y compromisos esenciales -hacia la vivienda racional- evidenciados en los congresos CIAM de 1929 y de 1930: Las tesis del congreso de Frankfurt son tan sólo representaciones en planta, subrayando el carácter primario que la organización y la distribución racional de la vivienda deben tener respecto a las exigencias de representatividad arquitectónica ${ }^{21}$

"Las necesidades comunes del individuo, susceptible de ser traducida en un lenguaje estrictamente algebraico y de convertirse en cosas necesariamente precisas lesqueleto, estructura, volúmenes, cubos de aire, superficie de iluminación, cantidad de ventilación, medidas de puertas y ventanas)", dejaría escrito sert para sus viviendas de alquiler en la calle Rosellón.

Un reparto racional adaptado a las necesidades de la célula individual. Una célula habitacional preludio del edificio construido, precedente al mismo tiempo del urbanismo pretendido. Hacer ciudad. Albert, muy probablemente, intuye las necesidades tanto individuales como metropolitanas, asume la bidireccional respuesta -individual y colectiva-, construyendo para un cliente al que atender, a más de edificar en un escenario atento y expectante, necesitado de evolución y modernización. Una complicada tesitura que le acarrea decantarse por la exigencia de representatividad,

21 AYMONIO, Carlo. "La vivienda racional. Ponencias de los congresos CIAM 1929$1930 "$ Op. cit. pág. 90 


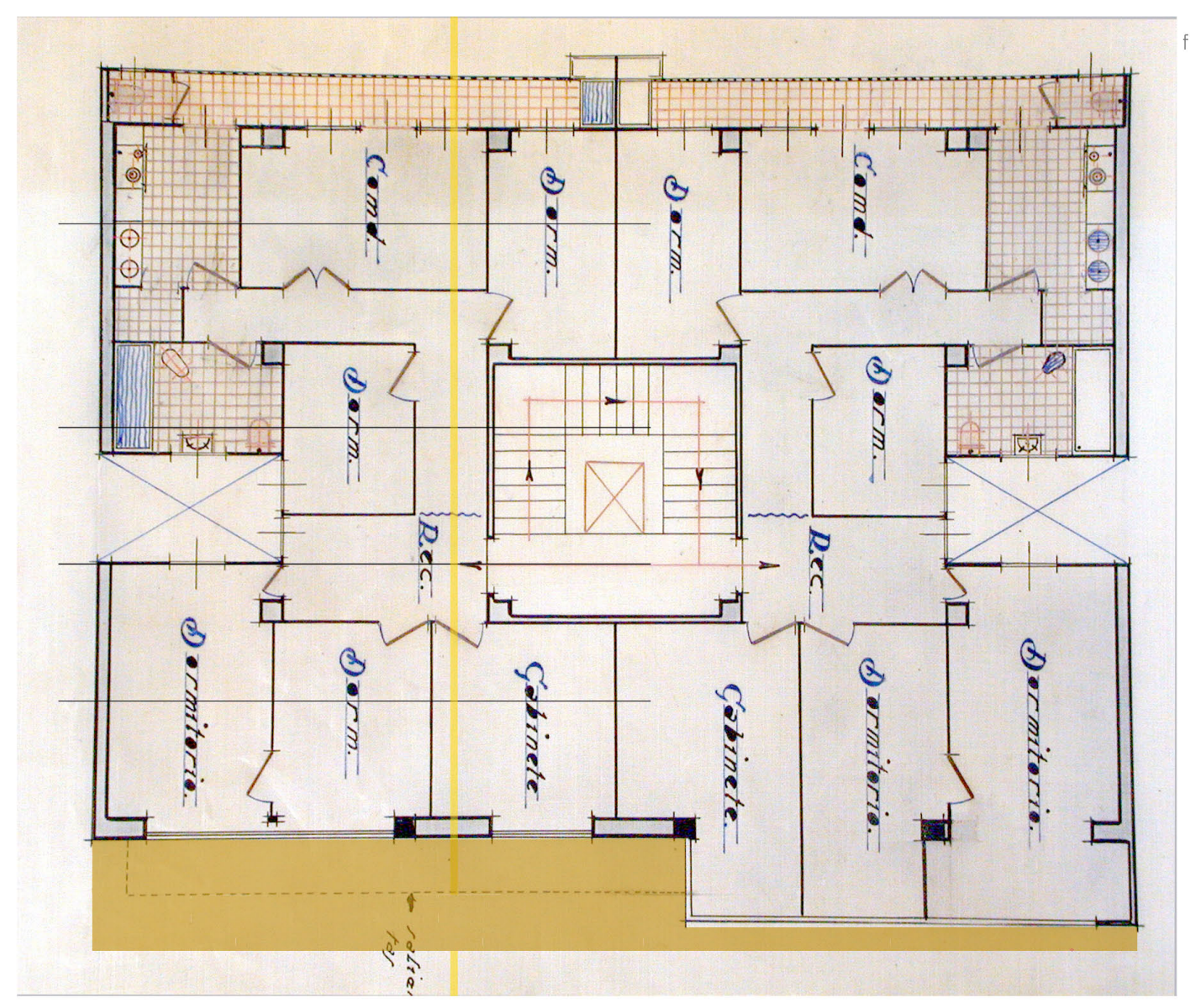


y ahí concentra el máximo expresivo lo cual le induce a una concordancia complicada, a un diálogo sumamente difícil entre la racional distribución interior y la representación escénica expuesta, la volumetría urbana. Nuevamente la renombrada formulación de Sullivan "la forma sigue a la función" requiere otra acepción a 'seguir', sencillamente disconforme a deducirse de ellas.

En semejante predisposición por la presencia exterior, por la forma, incurre Albert en errores funcionales, asumiendo dificultades al justificar diferencias métricas en una disposición simétrica, disparidades espaciales albergando un mismo cometido, con el dinamismo compositivo en el trasdós intencional. La cama -no interpretada como simple mobiliario, sino desde la concordancia, entre ella y el espacio que faculta su utilización- junto con los comunitarios servicios familiares, surgieron como patrón de referencia de las propuestas arquitectónicas contemporáneas y, precisamente aquí amanece la falta de concreción en el inmueble habitacional para Máximo BUCH, en la distribución racional, equitativa y justificada de sus células familiares. Falta de precisión para satisfacer necesidades del individuo, de la organización colectiva y, por ende de la representación urbana. Escuetas concesiones en favor de la funcionalidad-agrupando áreas húmedas, aproximando comedor y cocina-, por la cual invertir el proceso de prioridad representativa. Más bien al contrario parece conceder la vuelta al clásico método académico de composición planimétrica (fig. 19).

Sin embargo, haciendo suyos los avances tecnológicos, la aplicación en las conquistas higienistas, los modernos materiales constructivos, resuelve -contrariamente al regularizado método ecléctico- la organización de la vivienda. El espacio de recepción a cada vivienda, iluminado y ventilado, 

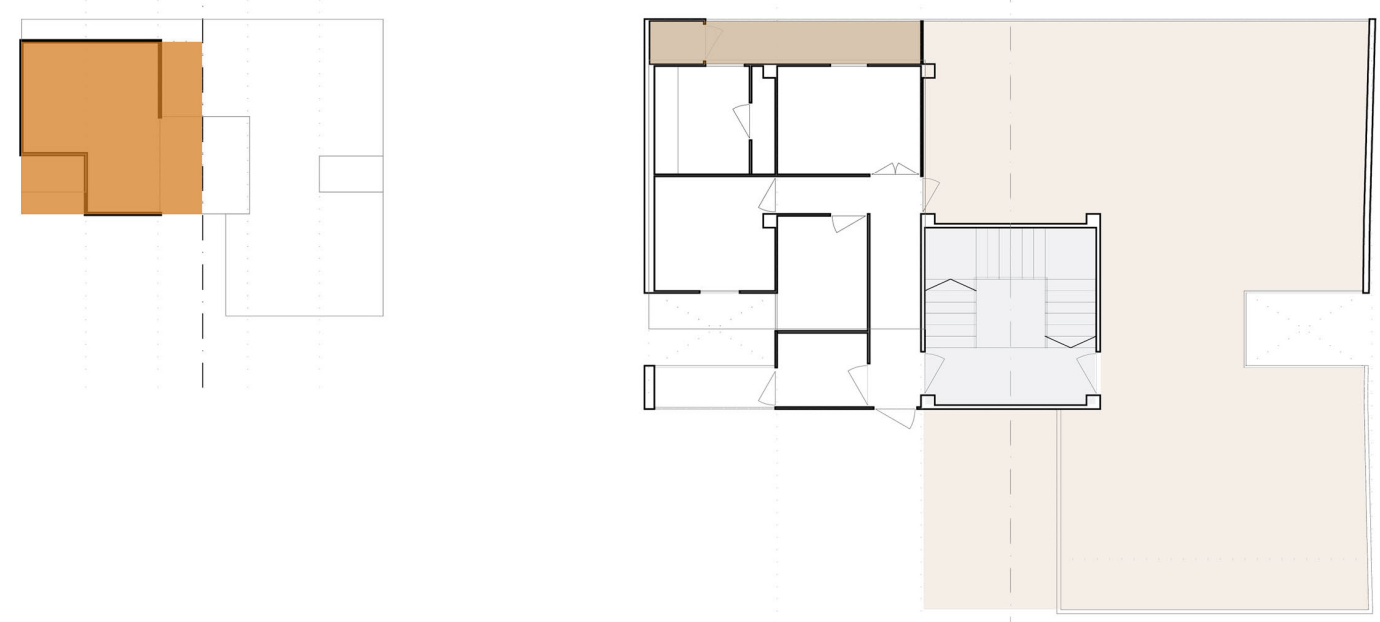

fig. 20
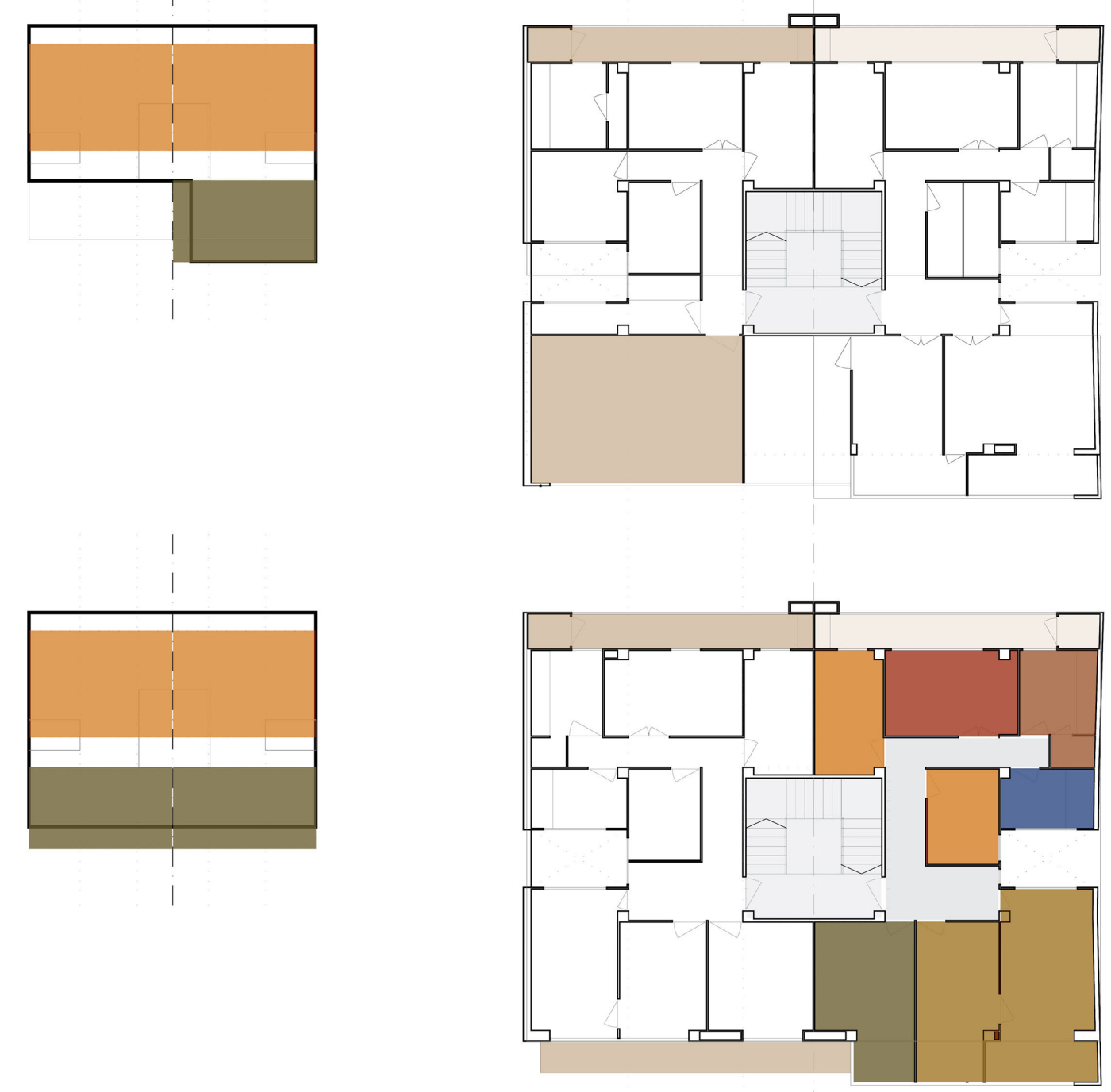

Luis ALBERT, 1935. Edificio Máximo BUCH; esquemas y organización funcional diferenciando usos, emancipando terrazas según fachada a calle Cuarte o patio de manzana 
aparece proporcionado respecto a los recorridos, nunca prolongado en demasía, nunca inacabable, ni tedioso con creces por su excesiva altura en relación a su ancho. Igualmente acertada resulta la concentración de núcleos húmedos, inmediatos a la zona que asisten, no obstante a cierta distancia del acceso a la vivienda (fig. 20). Ensartados al ecléctico eje ortogonal de fachada, y equívocamente de igual jerarquía, área y volumen, dispone Albert gabinetes, dormitorios -excepción en una pieza- y comedores, dominados por la luz exterior de la calle principal o del patio de manzana, evitando en lo posible patios interiores impuestos desde los reglamentos edificatorios.

Ernst May -director del congreso de Frankfurt- afirmaba que "todavía hoy es difícil de comprender, para muchos arquitectos, que, al construir viviendas, no deben ser consideradas como tareas absolutamente principales el aspecto exterior del edifico y la composición de la fachada, sino que la esencia del problema la constituye la construcción de la unidad de habitación. Además de lo cual tiene el deber... de insertar estas unidades de habitación en el marco de la ciudad de forma tal que para cada unidad sean creadas condiciones igualmente favorables».

Precisado el precepto funcional, cabría dar comienzo al proceso artístico, sin contradecir la interpretación habitual de la arquitectura moderna como funcionalismo. Probablemente aquí radicaba la reformulación que del precepto de Sullivan, llevaron a cabo Gropius, Mies y sobre todos Le Corbusier. "Con las materias primas, mediante un programa más o menos utilitario que habéis 'superado', habéis establecido relaciones que me han conmovido. Esto es arquitectura". 22

22 LE CORBUSIER. Hacia una arquitectura. Op. Cit. pág. 123,145 y 165 


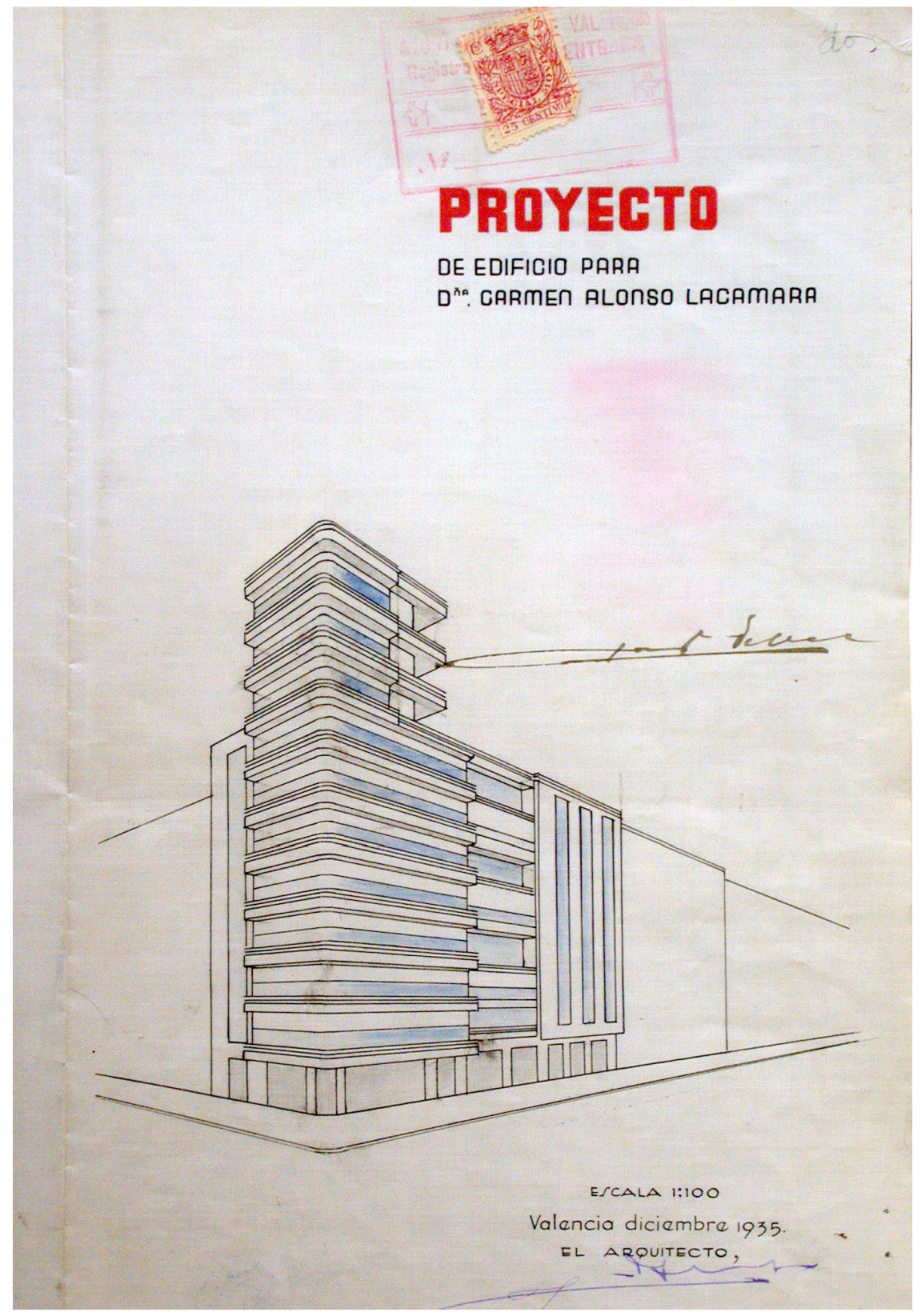

fig. 21

Luis ALBERT, 1935. Edificio para Carmen ALONSO; perspectiva del arquitecto para el proyecto, recogido en AHMV, Ensanche, legajo E04, Expediente 45662 
Precisado el precepto universal, se abre el proceso de proyectar su compostura exterior, su fisonomía, su "apariencia plástica, traducción del ser humano complejo, a cuyo espíritu no le basta la austeridad del lenguaje algébrico. Pero entiéndase bien, esta concesión a la emoción no significaba de ninguna manera un retorno a las antiguas complicaciones caprichosas. La emoción debe tamizarse con el conocimiento. Esta preocupación por la expresión exterior del sentimiento que preconizamos no excluye bajo ningún concepto el conocimiento ni el aprecio de las adquisiciones científicas. Nuestro tiempo exige esta complejidad del arquitecto. Es necesario que el arquitecto se identifique con su época para expresarla". ${ }^{23}$

\section{FACHADAS}

Analizando la representación diédrica - plantas y alzados haciendo constatar funciones pretendidas, tridimensionalmente- y su reflejo construido, en ambos edificios distinguidos, mantiene Albert la controversia, la incertidumbre de aseverar un lenguaje de fachada, empleado más como recurso

${ }^{23}$ SERT, José Luis. Memoria del proyecto de ejecución para las viviendas de alquiler en la calle Rosellón, Barcelona. A.C. 


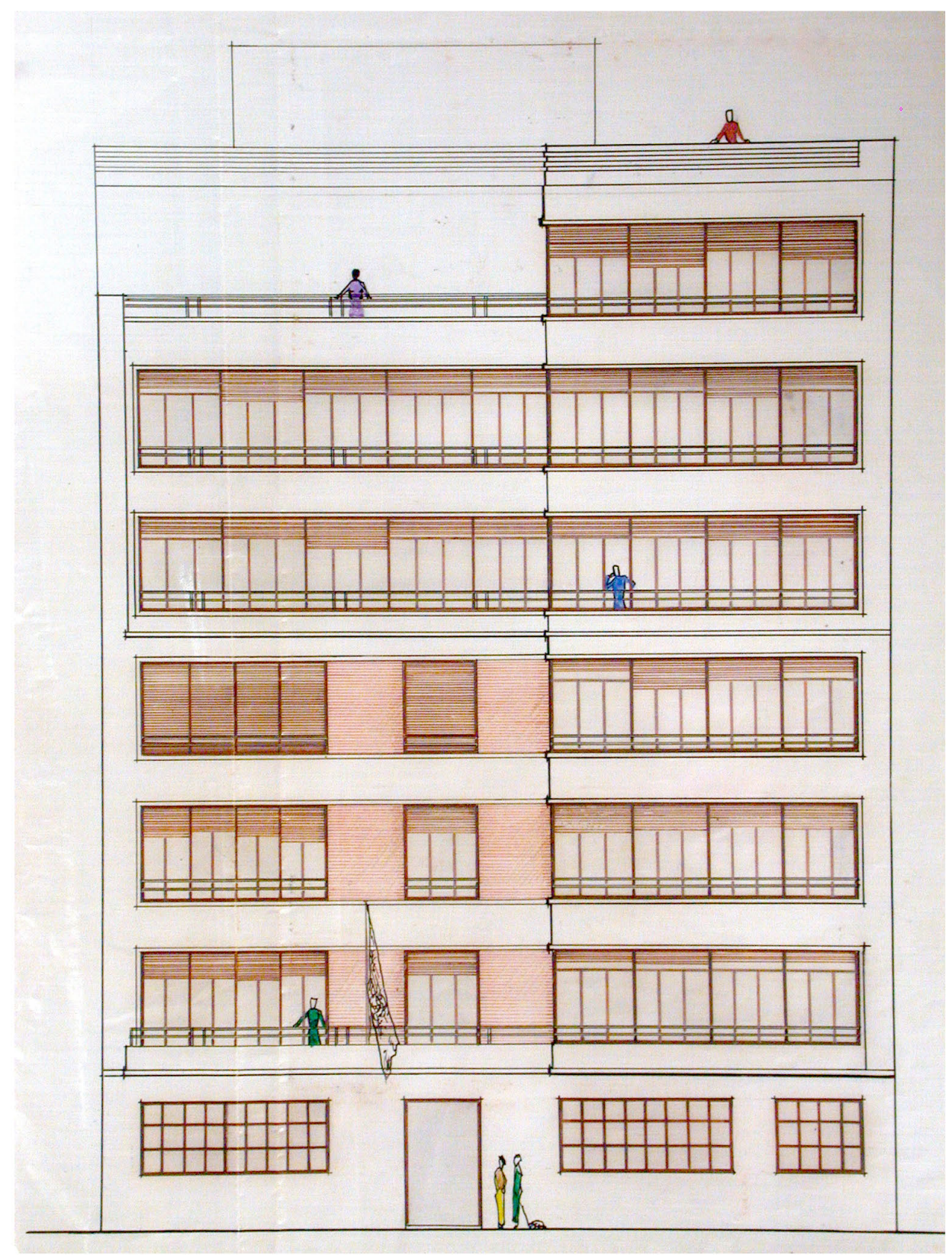

fig. 22

1935. Edificio para Máximo BUCH; plano del alzado principal, según documentación del proyecto extraído del AHMV, Expediente, Ensanche, legajo E03, Expediente 25007 
narrativo bidimensional, que como reflejo del reparto funcional ordenado (fig. 21).

Cabría plantearse si fuerza Albert, penetrar en la polémica objetividad. Cuestionarnos si pretende tomar el testigo de posiciones antifuncioanlistas, rechazando aquellos puntos de vista 'unilaterales y doctrinarios' sobre racionalización y estandarización. Sabemos de su conocimiento en la exigencia por conmover, pretendida por Le Corbusier para la arquitectura, de su dimensión artística, de las intenciones en la concepción del espacio. En general, percibe clamores sobre la forma construida-tal como la definía Le Corbusier- y su capacidad para dar cabida a un nuevo modo de vida, su aptitud para recabar la libertad del espacio moderno. Habiendo quedado aclarado el término 'seguir' a la función, tampoco la forma pensada suponía una meta en sí misma. "Rechazamos toda especulación estética, toda doctrina y todo formalismo. La arquitectura es la voluntad de la época pensada espacialmente. Viva. Cambiante. Nueva". ${ }^{24}$

Cabría dilucidar si fuerza conmover, mediante su discurso narrativo disociado de la funcionalidad, o por el contrario resulta una dicotomía fruto del reflujo académico. Esto es, una distribución ecléctica, una composición aprendida de usos, admitiendo la eventualidad de componer un alzado, un lienzo al espectador urbano (fig. 22), manteniendo un estilo historicista $y$, sin embargo facultando a su vez, adornar un alzado racional, e incluso coexistir ambos hasta resolverse por el conveniente, provechoso.

24 MIES VAN DeR ROHE. "Bürohaus", publicado en la revista G, nº 1, julio de 1923 , pág. 3 


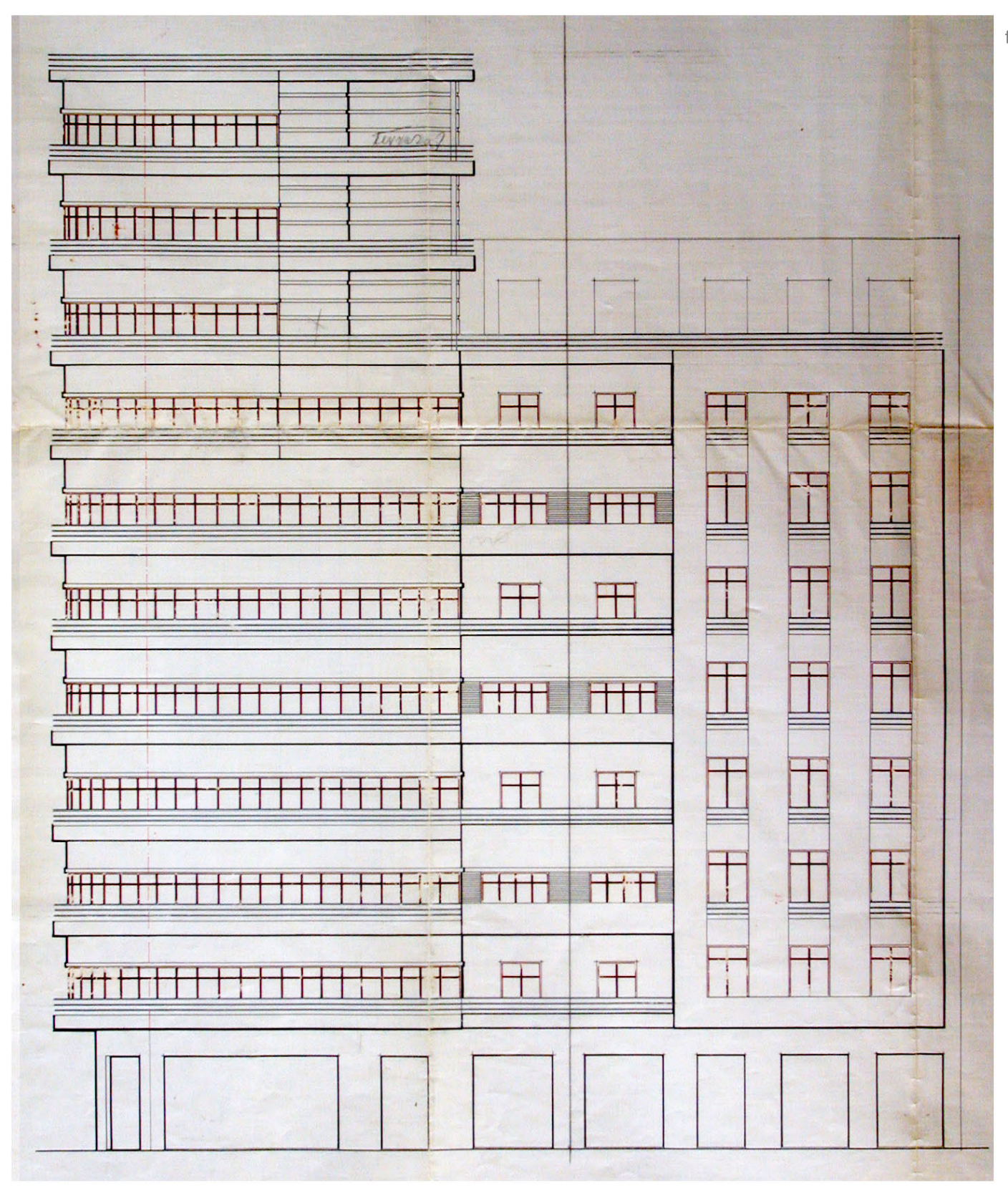


Valdrían las distribuciones planimétricas propuestas, o cualquiera capaz de mantener seriadas las proporciones de las estancias recogidas, hasta componer el frente a la vía pública. "Adaptar un sistema histórico, es falsear el sistema, y negar la época". Exordio expuesto en el decálogo publicado por el GATEPAC, en el primer número de su publicación trimestral, conjuntamente con "la Arquitectura responde a una utilidad, a un fin. Debe satisfacer la razón. Partir de elementos, programa, materiales, espacio luz... desarrollándose racionalmente del interior (función) al exterior (fachada) de una manera simple y constructiva, buscando la belleza en la proporción, en el orden, en el equilibrio". 25

Nada más alejado del retorno a lo elemental, la simplificación sistemática que preside las manifestaciones de la arquitectura moderna respondiendo a una necesidad, que el sincretismo compositivo, tratando de conciliar plantas con alzados. "El plan procede de dentro a fuera; el exterior es el resultado del interior" exhortaba Le Corbusier en su libromanifiesto Hacia una arquitectura ${ }^{26}$, breviario espiritual del GATEPAC, libro de memoria o de apuntamiento.

No obstante, en Albert cabe un planteamiento diverso, desemejante. Ni componer por separado plantas y alzados para coserlos en una aséptica

25 AC-1. Revista Trimestral, publicación del GAtepac. Barcelona, Madrid, San Sebastián. Año $1^{\circ}$. Primer trimestre 1931. Epígrafe. pág.13

${ }^{26}$ LE CORBUSIER. "Hacia una arquitectura". Editorial Poseidón, Buenos Aires, 1965. Traducción de Josefina Martínez Alinari. Serie: Arquitectura y urbanismo. Primera reimpresión. Ediciones Apostrofe, 1998. pág. XXXII 


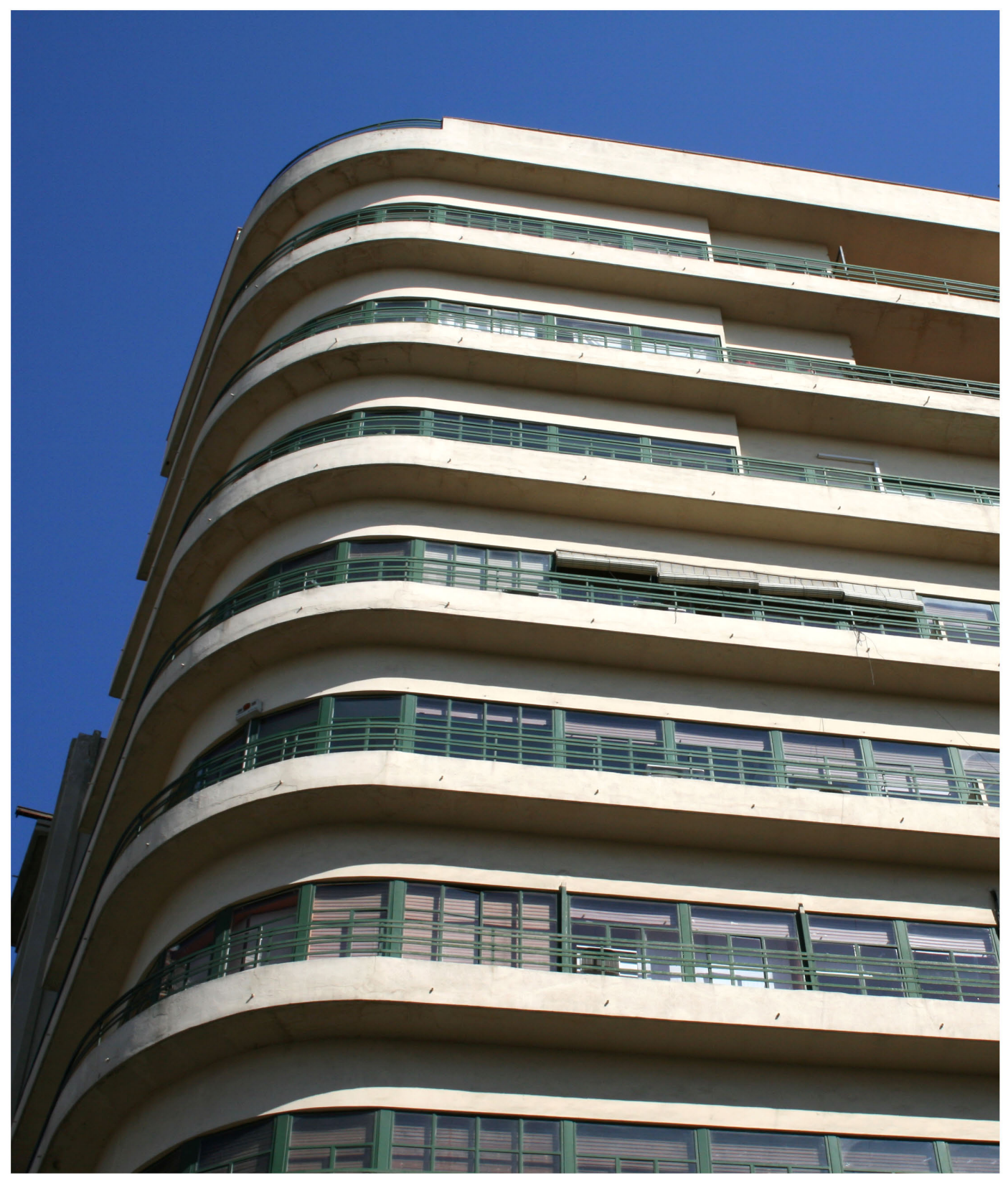

Edificio Carmen ALONSO; percepción visual de la composición generadora de macizos y vacíos horizontales, aleros y vuelos enfrentados a la verticalidad (fotografía Perelló ROSO) 
operación, ni exportar el plan al exterior. Más bien imbricar los métodos, superponer entre ambos -interior y exterior- un orden, un módulo gestor del plan y de la imagen, una estandarización de la fachada trasladada a la distribución interior (fig. 23). "La ordenación es la jerarquía de los ejes, y por lo tanto, la jerarquía de los fines, la clasificación de las intenciones" inducía, nuevamente Le Corbusier. Y Albert concentra sus intenciones en la mirada urbana, planteando una trama tridimensional de ejes, de intenciones. Un orden que también se comprende de fuera hacia dentro.

La fortuna de las proporciones interiores, de los diferentes espacios distribuidos tras la fachada-ordenados por su métrica y liberados de ella- ya quedó explicita en el capítulo precedente, dirigido por los principios fijados desde las Escuelas de Bellas Artes, desvirtuada tras el juego compositivo mediante ejes, desacreditada al consagrar signos exteriores. La variación espacial no dependía del módulo seriado con el que establecer el orden tridimensional, no venía condicionado por la célula mínima, ni tan sólo por la estandarización constructiva; ya quedó patente la escasa convicción en la reinvención del espacio, la ausencia de compromiso funcional, eficiente y económico del espíritu moderno y los mínimos eficientes expuestos en los congresos CIAM, el desesperanzado convencimiento de la mayoría de los jóvenes arquitectos valencianos frente a la burguesía valenciana dominante.

Componer pues, un alzado racional, funcional o expresionista y trasladar su modulación al plan, evita emprender el problema de la casa moderna, como máquina de habitar, establecer nuevas normas atendiendo al nuevo espíritu. Elude pensar en el habitante de la casa y en la multitud de la 

ciudad. Muy al contrario, atiende al cliente, al que encarga, elige, corrige y paga; aquel destinatario de "los ojos que no ven".

\section{EDIFICIO PARA CARMEN ALONSO.}

Disonancia, había resultado el término empleado por Zevi, al punto de transcribir volumétricamente los almacenes schoken, en Stuttgart: un bloque horizontal en intención -horizontalidad reforzada mediante franjas llenas y vacías, intensificada por la marquesina y robustecida con el letrero colocado encima de ella- flanqueado por dos semicilindros, uno imponiendo límite y otro sobre la cubierta horizontal manteniendo un diálogo arquitectónico, confiriendo una tercera dimensión. Manifiesto queda el método mendelsohniano, esto es, imponer a través de su arquitectura su mensaje en la escena urbana. Convertir su construcción en protagonista, icono ineludible de la moderna metrópoli.

Comparable significación ambiciona Albert en la expectante calle Játiva $y$, no duda en recurrir al método consolidado por el arquitecto alemán, maridando esquemas volumétricos e incluso, adoptando su lenguaje expresionista, casi al dictado. A saber, un volumen horizontal recogiendo los 

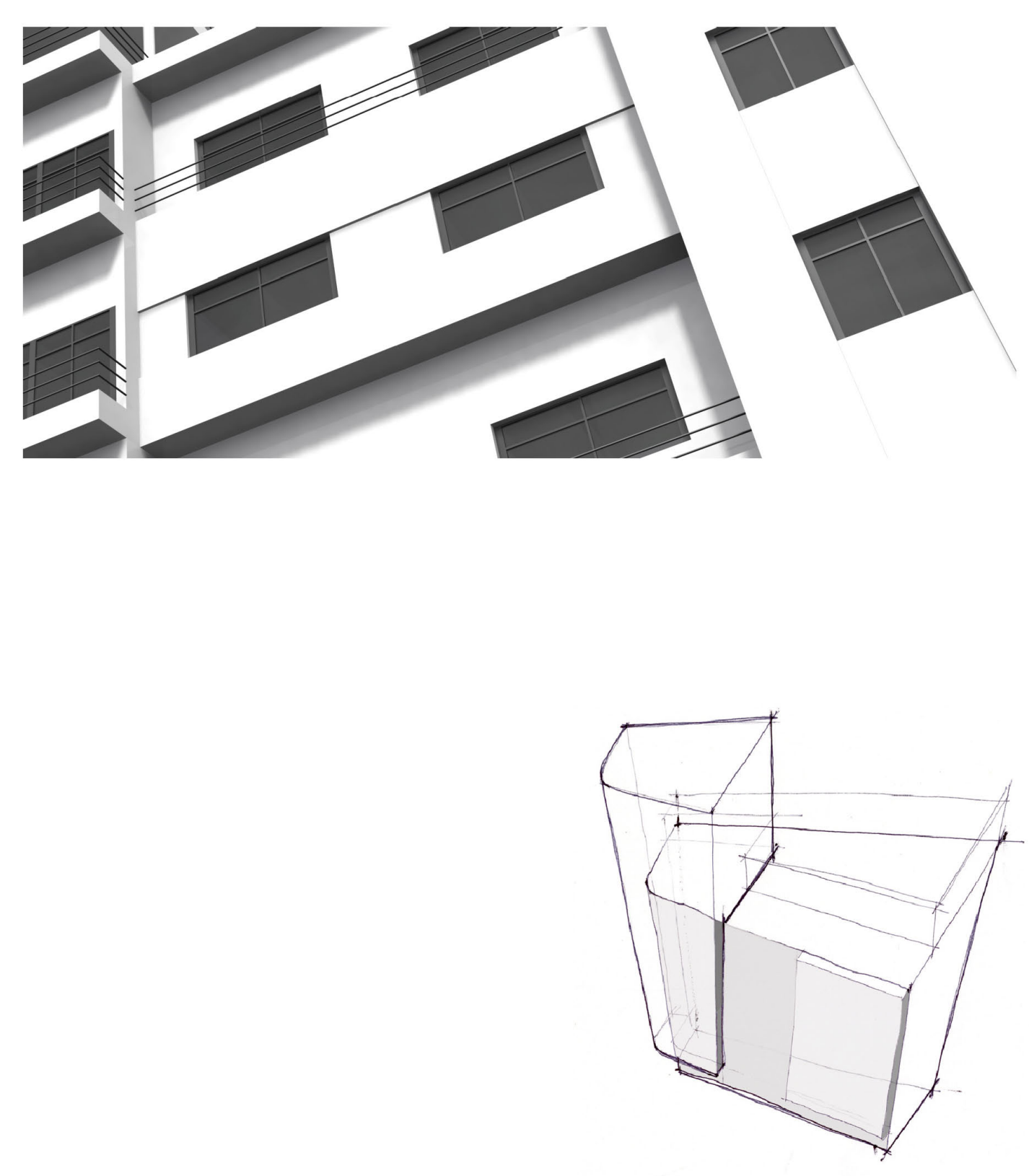

fig. 24

1935. Edificio Carmen ALONSO; maqueta infográfica doctorando, señalando en detalle el contradictorio encuentro entre la tendida linealidad horizontal y el prisma ascendente 
límites de la parcela y dos cuerpos verticales contrapuestos, con la finalidad de trazar los límites (fig. 24). Un primer elemento en esquina, donde quebrar la horizontal, y un segundo anunciando detención, esbozando la conclusión antes de arribar a la propiedad colindante.

Conclusiones verticales -ambas componentes lineales narradas- asegurando una tercera dimensión, cerciorando con su presencia en la volumetría, parte del método instaurado por Mendelsohn. El dinamismo arquitectónico yuxtapuesto a la puesta en escena -urbana-, para concluir el método, asumido por Albert en su intento por abrazar la modernidad.

Depositar una arquitectura referente, dotar a la urbe de un hito, profiere la ansiada evolución hacia la modernidad. Todavía más, expresarla mediante un refutado lenguaje, resulta garante en este compendio de emociones artísticas, edilicias.

Restaría, a nuestro púdico parecer, eludir exhibirse en las aprehendidas compensaciones verticales, en recelosos trazos lineales compilados en alzado, profiriendo en el arquitecto seguridad compositiva y a su vez detrayendo convencimiento a su discurso. Un recurrente recurso en Albert y sus coetáneos, consecutivamente explícito - a lo largo y ancho de sus carreras profesionales-, capaz de restar coherencia al discurso horizontal. Surgen estos trazos y minimizan potencia a aquellas componentes verticales, formas que facultaban la tridimensionlaidad, reblandeciendo en definitiva un método avezado, referente allí donde se aplicaba en toda su contundencia. Así sucede en la honrosa torre rascacielos asomando a la calle Játiva, modelo escénico desde entonces. De cualquier manera, estas mínimas dudas, no desmerecen al icono. 


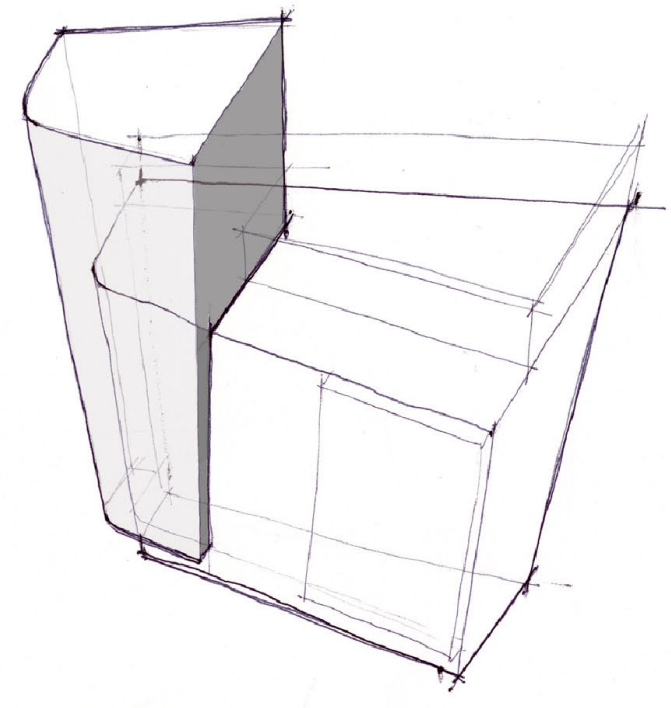

fig. 25

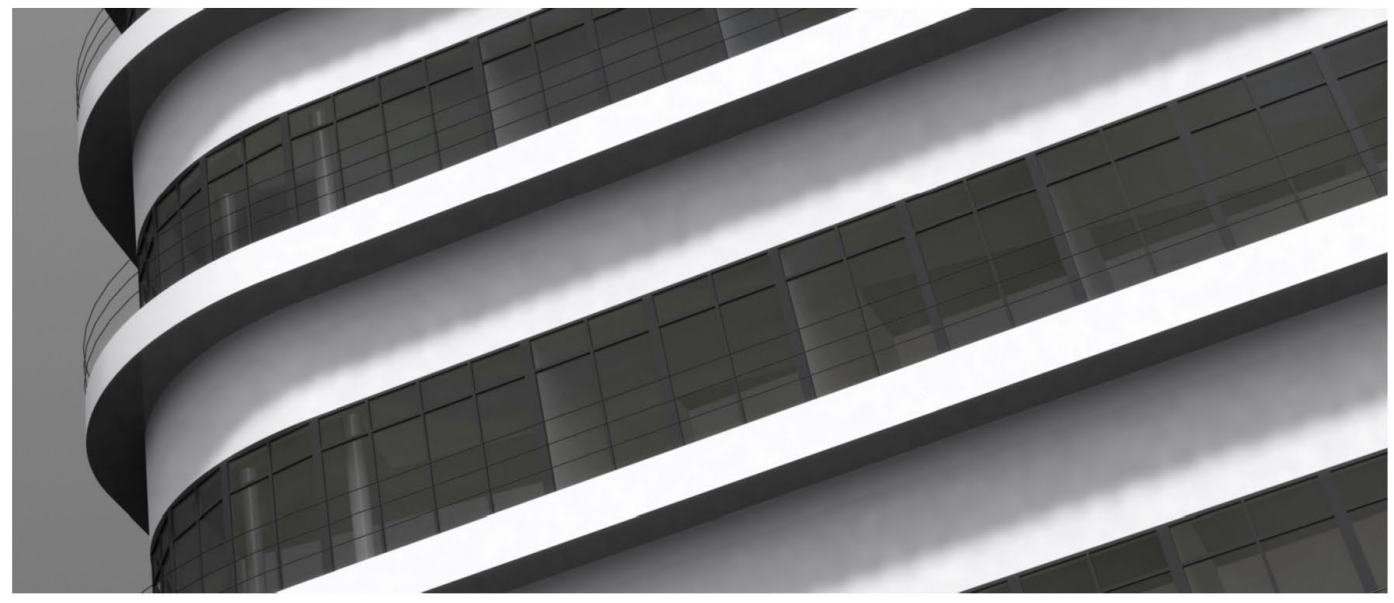

1935. Edificio Carmen ALONSO; maqueta virtual, detalle de la transparente horizontalidad, reflejo del dominio de ALBERT en el tratamiento de exteriores, asimilado expresionismo alemán 
A primera vista, la esquina redonda sugiere que se ha pasado por alto cualquier preferencia por la calle Játiva en detrimento de la calle San Vicente. Sin embargo, la exigencia urbana persiste y, una mirada más atenta pone de relieve que aunque el prisma horizontal presenta una apariencia sin jerarquía -tendido, horizontal e inusualmente seriado en su ascensión-, el prisma vertical se torna dominante (fig. 25) -rememoremos que precisamente alberga la distribución de funciones más racionalmediante el uso de balcones en voladizo.

Apremian incertidumbre -sobre la verticalidad pretendida en cuanto al preludiado rascacielos-, aquellas composiciones verticales insertas en el volumen fiado al terreno. Vacilación incrementada al comparar con el modelo esculpido por Mendelsohn, siempre reforzado en su horizontalidad, obstinado en su dinamismo para contrapuesto al erguido cilindro. En su discurso, y ya centrados en la torre vidriada -opuesta a la yaciente solidez- trasladaba el vidrio a plano de fachada, protegido y formalmente dinamizado por líneas voladas.

Albert en una magnífica reinterpretación metodológica, emplea la dialéctica entre superficies llenas, vetas transparentes y fajas voladas (fig. 26). Las grandes aberturas acristaladas de ininterrumpida dinámica, las potentes horizontales, determinan la imagen, mimetizada con posterioridad en el volumen -aquel ocupado con los almacenes por Mendelsohn y donde se forzaba el antagonismo, contrario a la mímesis aquí planteada- que le amarra al terreno. Suficiente hubiera sido proponer una superficie rasgada, donde nuevamente vuelen balcones, sustituyendo al límpido volumen de vidrio. Mantener la repetida contribución de materiales, su continuidad en el discurso y sin embargo forzar la horizontal solidez frente a la transparente 


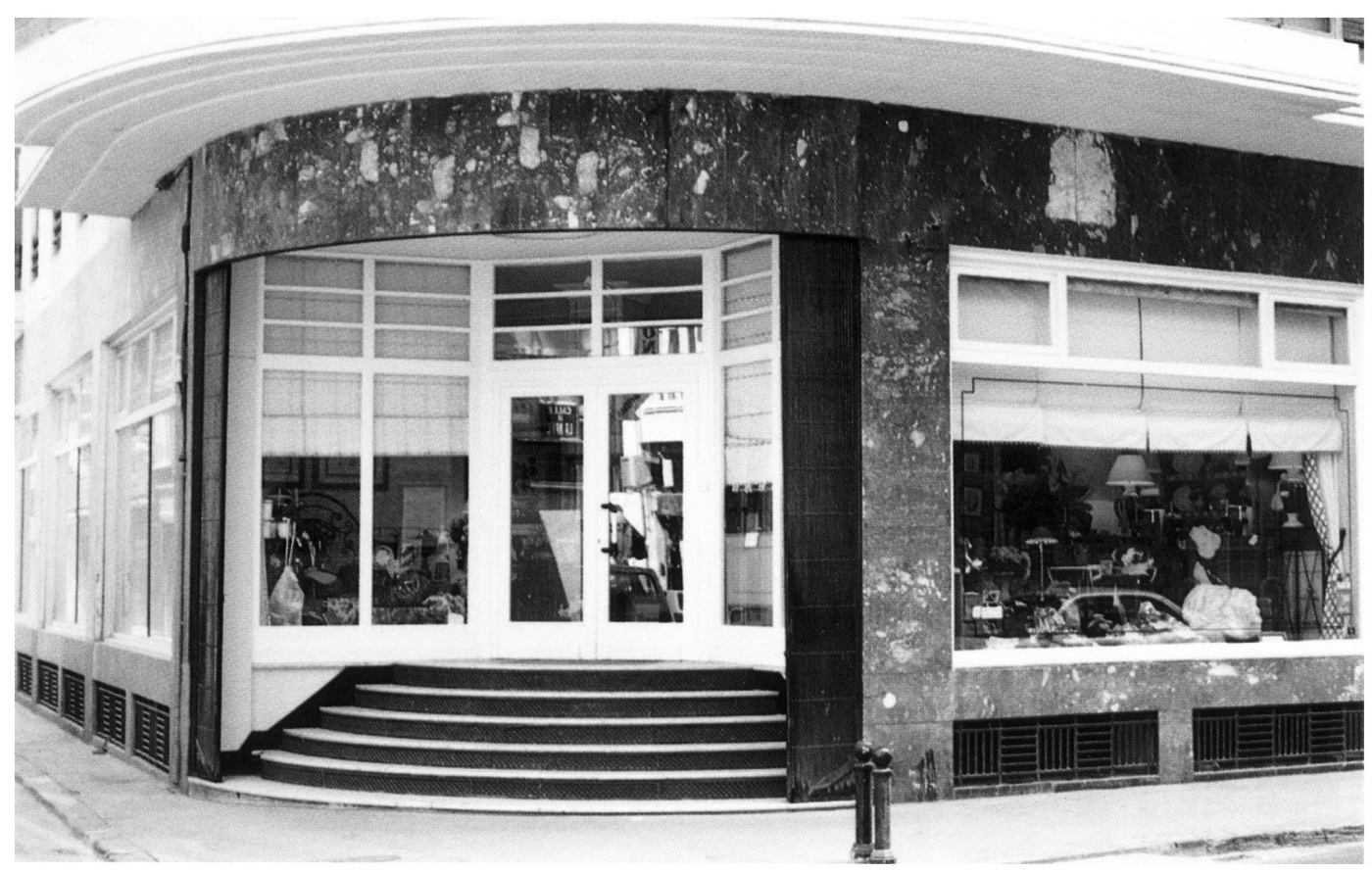


verticalidad. Tal vez el recurso de la barandilla metálica no hubiese sido factible, pero conceptualmente ganaría en rotundidad.

Similares dudas sugiere la dupla vertical que cierra el edificio. Si Mendelsohn lo apoyaba sobre el prisma horizontal, para hacerse eco de la primera torre, Albert lo vuela -escasamente, si tenemos en cuenta que su predecesor ya viene volado- sin escindirlo. Un gesto insuficiente que requiere de la verticalidad, diferenciadora, perforando las superficies llenas e indagando transparencias verticales, debilitando el orden, la jerarquía.

Extrapolar conclusiones del prisma horizontal induce, nuevamente, a interpelar acerca de la perversión léxica de llevar a fachada la composición de las viviendas en dos alturas, con una primera planta perforada su superficie -horizontalidad transparente- y una superior donde el plano rasgado por la fenestración no avanza, para contribuir a la linealidad otorgada con los balcones. No obstante, cabe un nuevo interrogante, el motivo por el cual se escinde -de nuevo sucintamente- la poderosa masa designada a habitaciones, de aquella breve planta dedicada a bajos comerciales, en un escaso vuelo que la aleja de su entrega razonada al terreno.

Vicente Colomer, en un recorrido de arquitectura racionalista en Valen$c a^{27}$, rubrica la importancia de, por vía de ejemplo, "la forma en que un edificio urbano se entrega contra el espacio público y establece la fachada con la calle al nivel del peatón. Es importante, en la medida en que

27 Colomer, Vicente. "La arquitectura como forma crítica de hacer ciudad". Catálogo para la exposición realizada por el IVAM Centre Julio González. Op. cit. Volumen I. pág. 115 

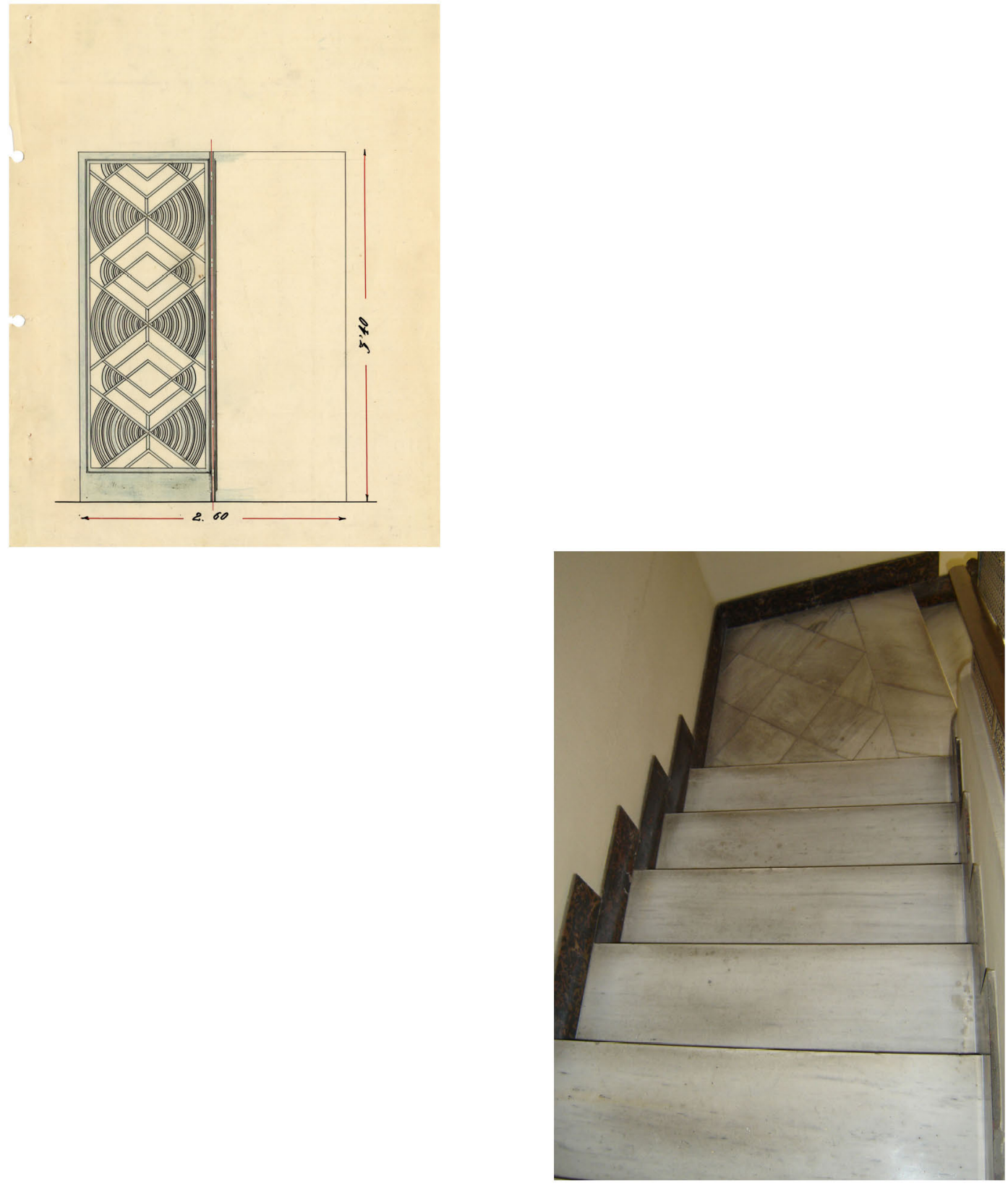

Luis ALBERT, 1935. Edificio Carmen ALONSO: muestra el arquitecto, su oficio con el diseño pormenorizado de los zaguanes de entrada a los edificios, escaleras, señalética, etc 
formando parte de la fachada, los bajos ya no constituyen un referente lejano, como el resto, sino que dan lugar a locales comerciales y zaguanes de acceso a las plantas superiores, y como resultado de ello, el peatón se acerca, atraviesa umbrales que lo introducen en tiendas, restaurantes y cafeterías... Todo ello desde la proximidad y el uso real de la fachada" (fig. 27).

Albert, profunda y meticulosamente comprometido con la ejecución de su obra -llevada a termino con una notable escasez de medios de la que tan quejoso quedó el arquitecto ${ }^{28}$, se reconoce en los rasgos generales del racionalismo o el expresionismo, con su puesta en escena, con el diseño pormenorizado en los zaguanes de entrada a los edificios, en sus elementos comunes, tales como escaleras, antepechos y barandillas, herrajes, señalizaciones diversas, tipografías utilizadas en rótulos, remates de cubiertas... Con el camino de la verdad. Sinceridad recitada en su discurso de ingreso en la Real Academia de Bellas Artes de San Carlos de Valencia. "Todos, antes y ahora, hemos caído en los mismos errores, trayendo a colación en nuestros edificios, unas veces, líneas de estilos que murieron; hoy, líneas y elementos de otras arquitecturas funcionales, que por sí solos no se justifican, sino sólo en su lugar, en su edificio, en su país, pero no en cualquier sitio a no ser que cumplan plenamente su función". ${ }^{29}$

28 PEÑ IN IBÁÑEZ, Alberto. "Luis Albert, arquitecto. Valencia. 1902-1968". Editorial Colegio Oficial de Arquitectos de Valencia, 1984. pág.1 4

29 Albert ballesteros, Luis. Discurso de ingreso en la Real Academia de Bellas Artes de San Carlos de Valencia. 3 de marzo de 1961. pág. 26 


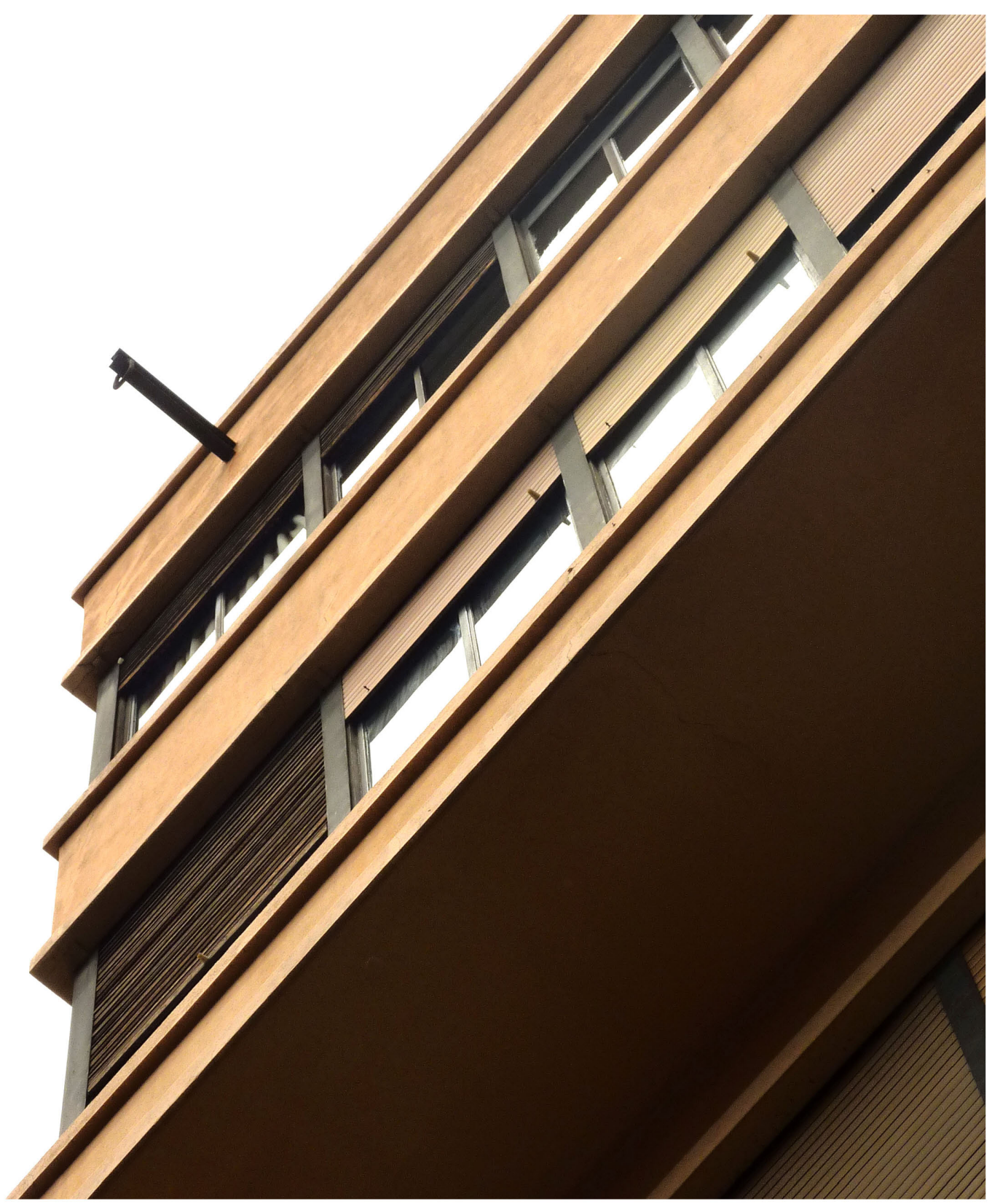

Luis ALBERT, 1935. Edificio para Máximo BUCH: calles Cuarte n¹l4 y san Jacinto n³. contraste del prisma bidimensional de fachada y el dinamismo espacial adquirido 
EDIFICIO PARA MÁXIMO BUCH.

Plantea Albert, resolviendo las exigencias programáticas -fábrica y vivienda- de Máximo BUCH, una disposición formal equiparable a la inmediatamente analizada en la calle Játiva. Obviamente difiere su inmediato entorno y, siendo observador, reinterpreta el planteamiento germinal hasta completar una innata propuesta. Atendiendo a su exclusiva ubicación, procurando respuesta funcional pormenorizada, componiendo volumétricamente en respuesta programática y sin desatender la emoción arquitectónica, concreta su propuesta para la calle Cuarte (fig. 28) a través de un léxico racionalista, cercano a la ortodoxia -rozando su techo, casi con certeza- auspiciado por detalles constructivos impecables y una atenta e intachable dirección ejecutiva.

No limita su arquitectura a la simple alteración formal, de una composición experimentada, probada. Su proposición edilicia, altera una composición volumétrica estudiada, nunca redundante $y$, como hemos dilucidado, alejada de la simple traslación formal, volumétrica y su alteración léxica. Resulta evidente, haber retomado la dicotomía de piezas, tanto como su traslucida ortogonalidad, manifestando exigencias funcionales. Rinden evidentes similitudes la dupla perpendicular, puros prismas opuestos tridimensionalmente. No obstante, un pormenorizado análisis de sus alzados infiere diferencias, impugna cualquier trascripción, toda relación directa con la obra equiparada y precedente.

Dos cuerpos construidos diferenciados, uno tendido y fabril, otro ascendente y habitable, difieren de la duplicidad vertical y horizontal de viviendas en el proyecto anteriormente analizado. Y tampoco se detienen aquí las divergencias, el discurso sintáctico, el diálogo entre las piezas 


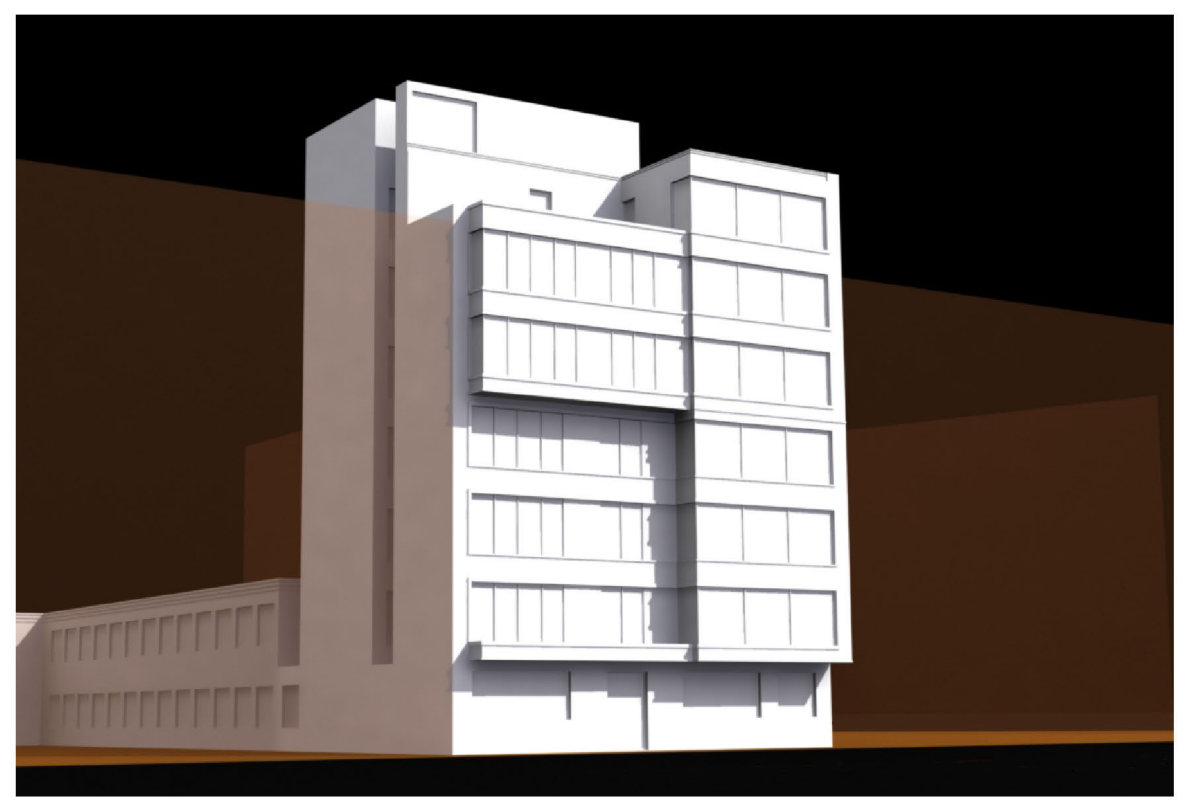

fig. 29

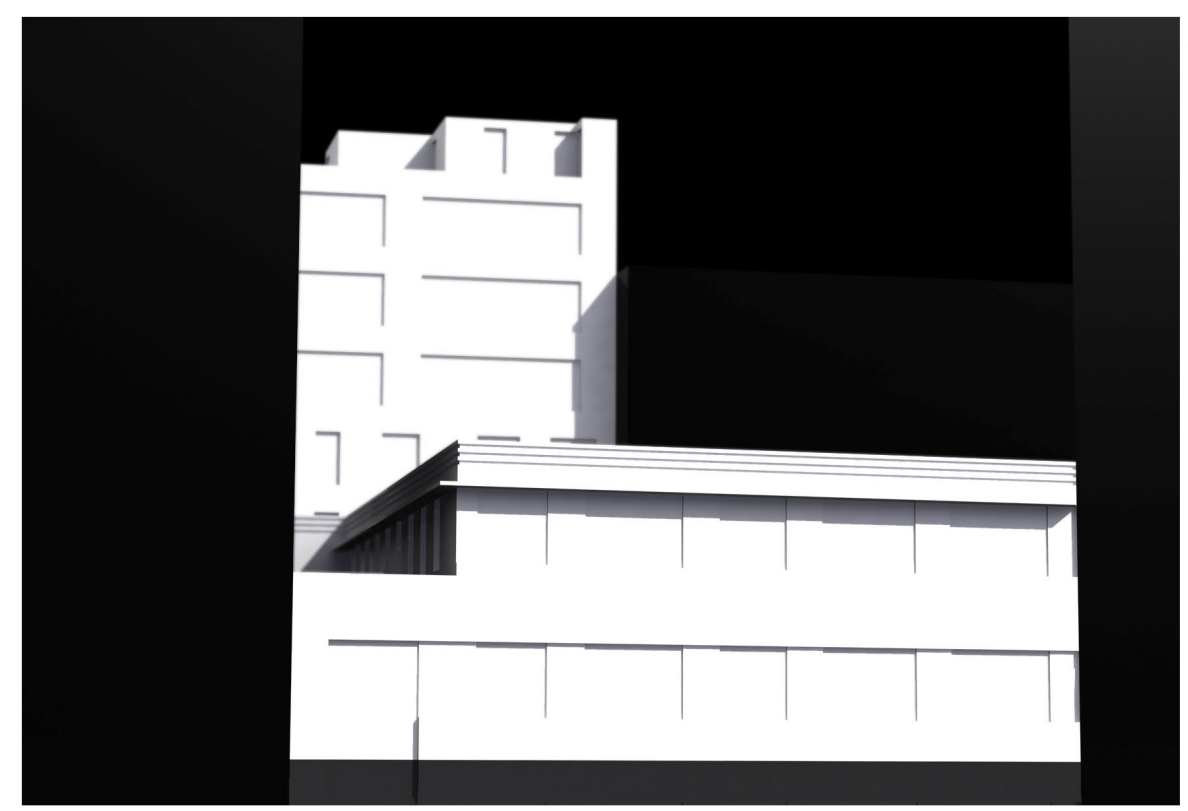

1935. Edificio Máximo BUCH; maqueta virtual doctorando, revelando la fachada a la calle Cuarte y, el alzado posterior ofertado al patio de manzana y a la calle san Jacinto 
resurge preciso y a su vez evoca disimilitudes. El lenguaje a manejar en la fábrica, habla de idéntica autoría con el léxico empleado en el volumen dedicado a viviendas $y$, sin embargo refulge inherente a su cometido, diferenciado de los recursos sintácticos con los que Albert presenta la torre habitable en la escena urbana, al peatón que la recorre. Dispares, perpendiculares y desplazadas piezas, haciendo referencia, una a la fábrica horizontal, pesada, entregada al terreno, y otra al bloque habitacional -viviendas entre medianeras-, vertical, ascendente, autárquico.

Como no podría discurrir de otra manera, la fábrica presenta una composición correcta, seriada y rítmica, sin más pretensiones que seguir un oficio aprehendido y depurado, una entrega a la geometría y la abstracción (fig. 29). Es en la torre de viviendas donde se pretende la no consonancia, la dicotomía como precepto generador de la obra y característico del autor, el dinamismo.

Resulta insuficiente -al menos para Albert- variar el tratamiento del plano de fachada, la superficie que envuelve a los volúmenes platónicos, diferenciando exclusivamente fábrica y habitaciones. Se requiere necesario distinguir, en este último, la superficie a observar desde el patio de manzanas (fig. 30) y aquella que forma frente urbano, la disfrutada por los viandantes que transcurren por la calle Quart. La posterior proyectada simétrica, con el recurso directo de los balcones volados y corridos. Continuos cortes en fachada, repetidos uno sobre otro, reforzando la ascensionalidad. Una potente seriación de líneas llenas-blancas y otras oscuras-vacías, persistiendo. Fenetres en longer. 


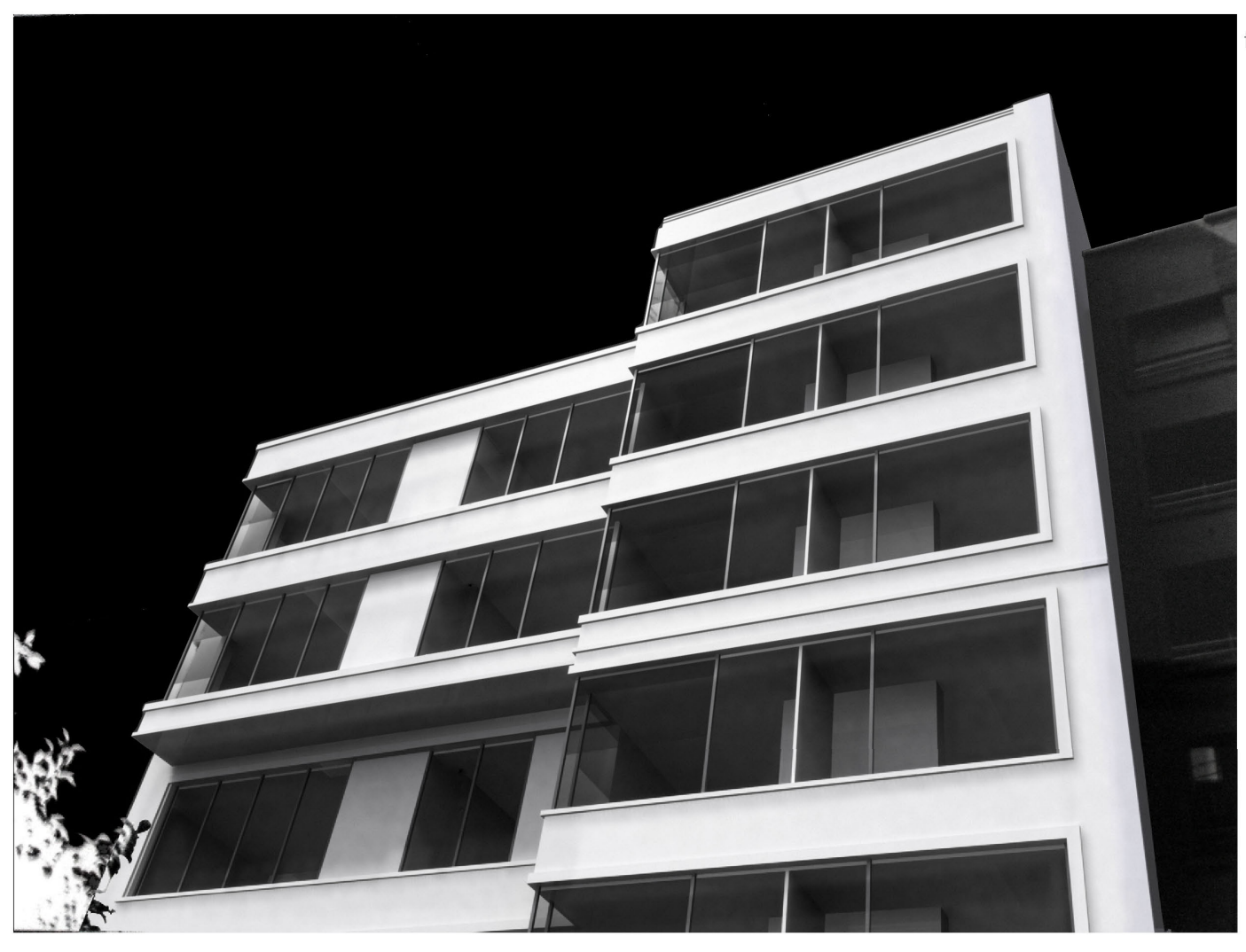

fig. 31 
Reconocimiento aparte obliga el alzado principal, de dominio vertical y fuerte asimetría. Ninguna aparente seriación. Jerarquías inapreciables a la mirada no formada. Esencialmente dinámica, consecuencia del libre juego de voladizos y simples volúmenes de geometría pura, aristada y sin distracciones, adelantándose al cuerpo primario.

Disonancia en el movimiento vertical, ascendente y la potencia de líneas horizontales (fig. 31), lleno-vacío engrosada por un cuerpo volado desde la superficie de fachada, corrido hasta topetar con el volumen vertical. "Sinceridad y oficio. Sin duda alguna, el mejor ejemplo valenciano de arquitectura purista, próximo a la línea racionalista defendida por los miembros del GATEPAC"; cuanto menos así queda reflejada en la guía de arquitectura del colegio de arquitectos de valencia ${ }^{30}$.

No podemos olvidarnos de la máxima "el exterior es siempre un interior"... Una estricta lectura funcional de la planta, siguiendo un código establecido y normado, indica una primera simetría zurcida al centro de gravedad de la escalera de tres tramos. En ambos lados, una vivienda con simetría propia. Tres espacios principales paralelos a la calle Quart, de semejantes dimensiones y perpendiculares a un eje centrado. Tres espacios repartidos frente al patio de manzana, de equitativas dimensiones, con las necesidades que resuelven y, nuevamente simétricos respecto al

30 GUíA DE ARQUITECTURA DE VALENCIA. Colegio territorial de arquitectos de VaIencia. ICARO. CTAV. Editada en 2007. pág.172 


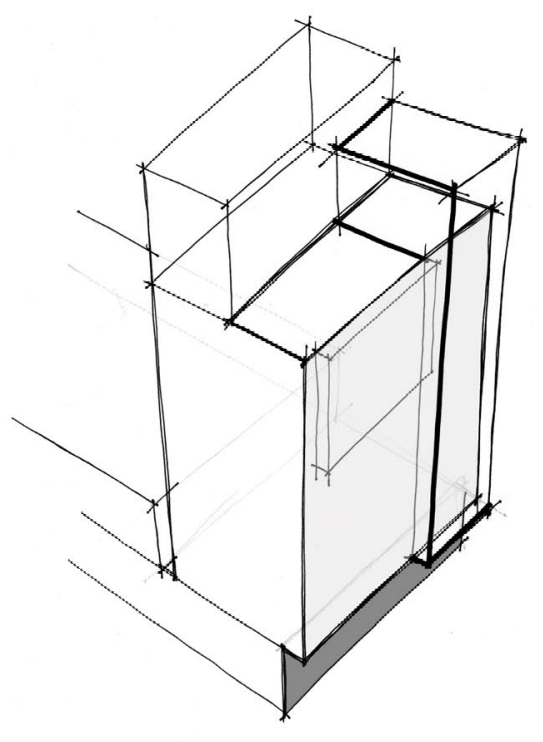

fig. 32

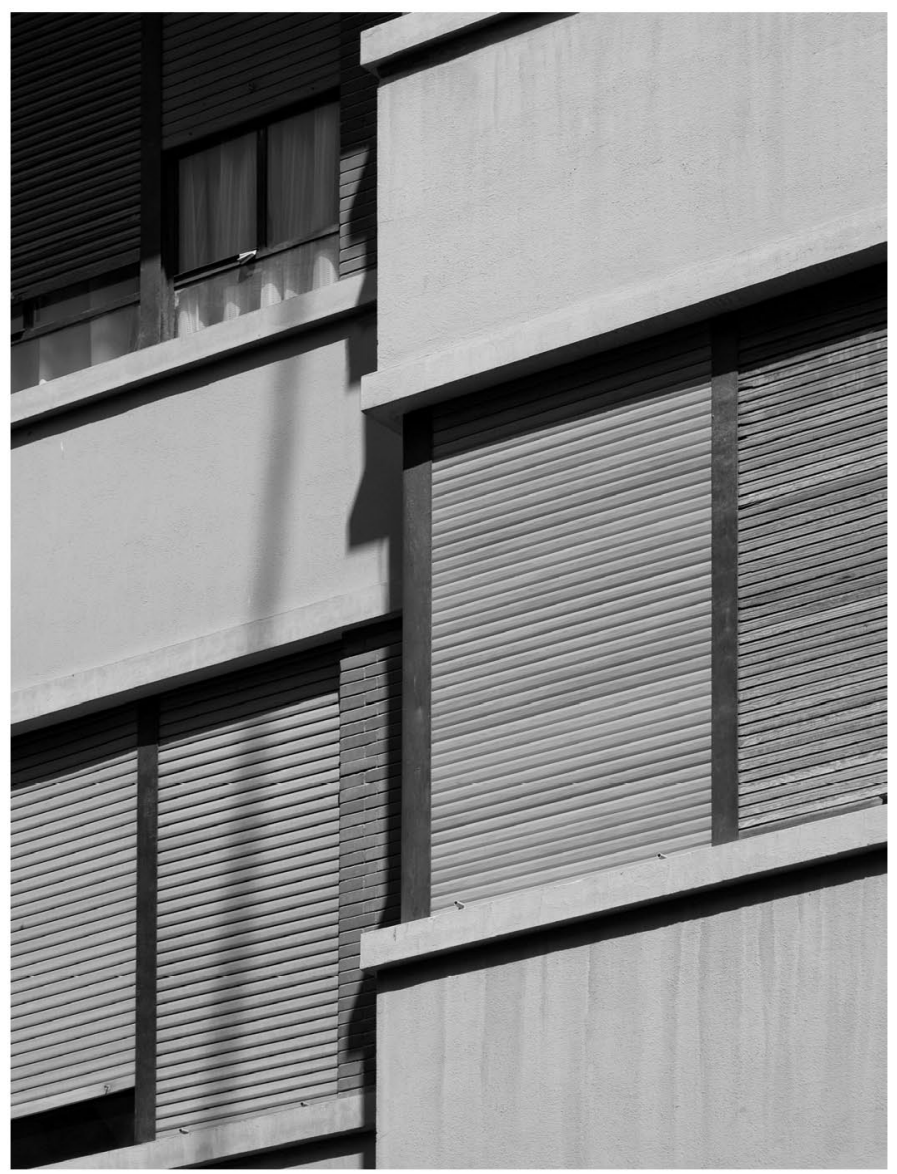


eje de la vivienda. Tan solo precisamos retomar la imbricación anunciada entre el orden en planta, la jerarquía de sus ejes, y el orden en fachada, para inferir las intenciones del arquitecto. Dinamismo en tres dimensiones.

"La ordenación es la jerarquía de los ejes, y por lo tanto, la jerarquía de los fines, la clasificación de las intenciones", volviendo a citar a Le Corbusier. El plan no procede de adentro hacia fuera, más bien el orden es complejo y demanda la interacción de planta y alzado. Así la fachada amaga, tal cual reflejaba la planta, un eje central de simetría (fig. 32).

Inserto en el machón de ladrillo visto -cuyo módulo comprende 1,80 m.desaparece su lectura cuando en el vuelo de las dos últimas plantas se sustituye la opacidad por la transparencia del vidrio, cuya carpintería recoge, tan sólo en una ocasión, el módulo de 1,80 sin continuidad horizontal, estirando su dimensión hasta $1,95 \mathrm{~m}$. El módulo reaparece para simetrizar -y esta es la subsimetría coincidente con la de cada viviendala rasgadura corrida en cada planta del prisma ascendente.

Eje de simetría en el volumen vertical, para ordenar las perforaciones longitudinales -en su totalidad- de la pieza que se adelanta y eleva. Módulo para reponer en la carpintería la seriación, la estandarización, la ingeniería habitable.

Y será en su afán de dinamismo, y de hacer complejo el orden -al menos en lo referente a su lectura- cuando Albert altera el módulo. En la superficie del volumen primario, del prisma gestado en el origen como esencia platónica, la simetría se descentra. Desestima coincidir con aquella traslucida en planta, para utilizar dos veces el módulo -en un nuevo machón 

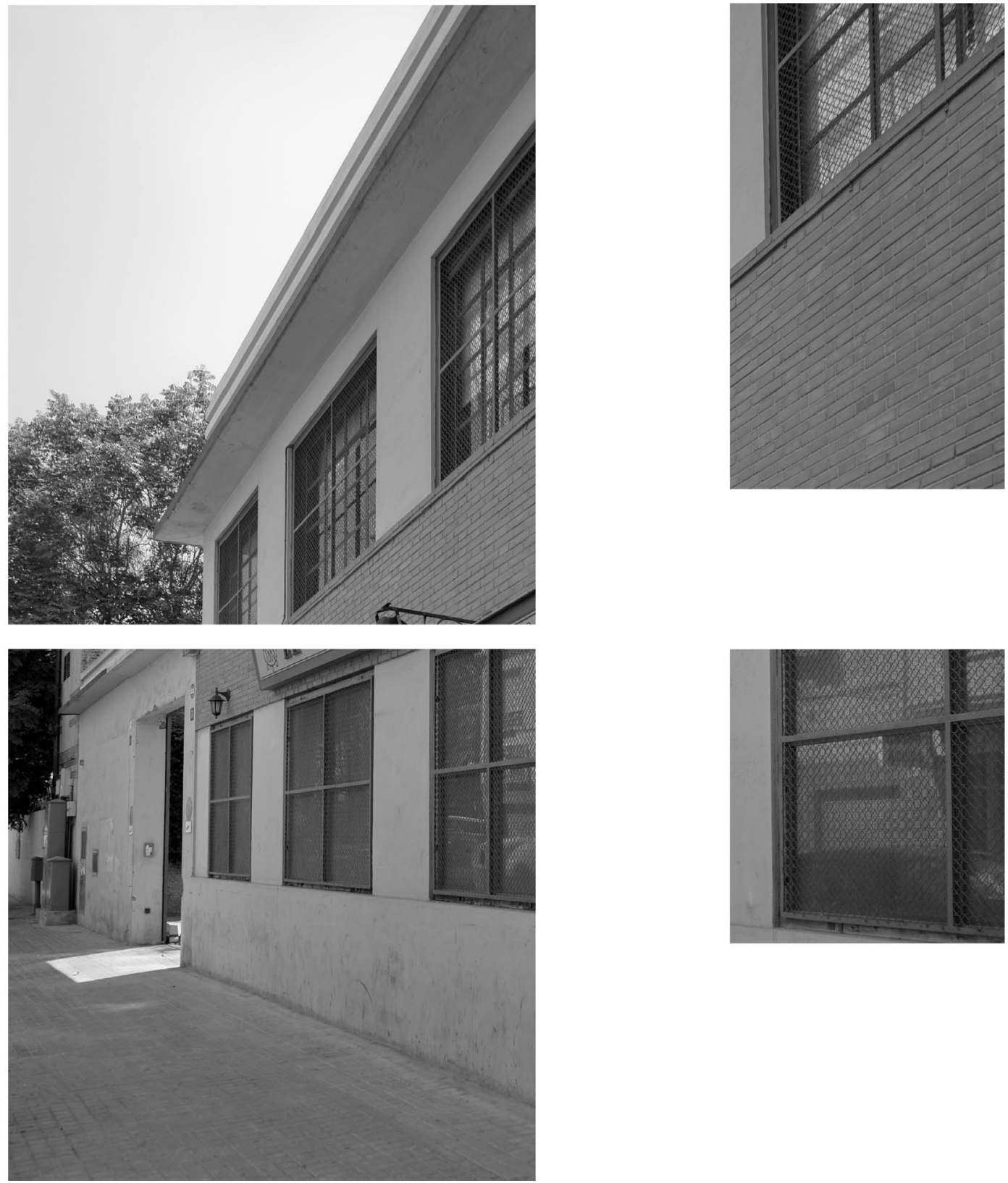

1935. Edificio Máximo BUCH: fotomontaje de la fachada recayendo a la calle San Jacinto, de menor convicción en la corrida horizontalidad para su fenestración 
y su par transparente- y adoptar otra métrica para las únicas carpinterías de $2,10 \mathrm{~m}$.

Una ordenación racional y compleja. Sin distracciones, exenta de recursos léxicos importados de otras tipologías de vivienda-duplex, dobles alturas, etc.-, con aquella absoluta sinceridad pretendida en el devenir de su trayectoria profesional y que, con cierta seguridad, nunca superará. Su nivel más alto de coherencia y claridad de expresión, como rubrican Juan José Estellés y Emilio Giménez en Los arquitectos valencianos de los treinta: Influencias y compromisos. ${ }^{31}$

\section{ESTRUCTURA}

Mies no perdió jamás de vista a Viollet-le-Duc, ni su precepto según el cual "toda forma que no es ordenada por la estructura debe ser rechazada". También un orden estructural, procurando rigor formal, amanece

${ }^{31}$ ESTELLÉS, Juan José-GIMÉNEZ, Emilio. "Los arquitectos valencianos de los treinta: Influencias y compromisos Las escuelas de Arquitectura, Ia revistas especializadas y los nuevos canales de información". Catálogo para la exposición realizada por el IVAM Centre Julio González. Op. cit. Volumen I. p. 163 


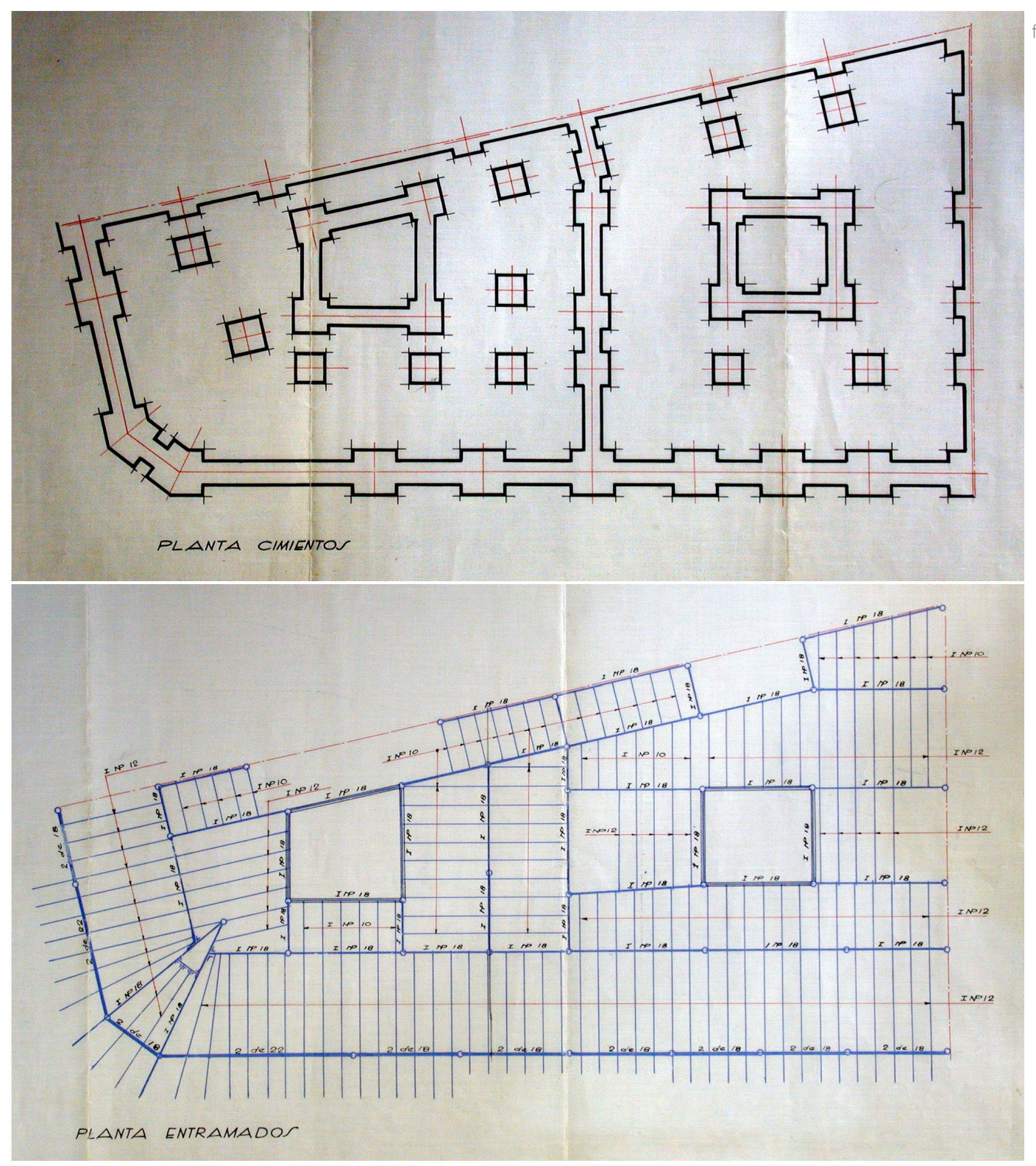

ig. 33 
como máxima, estrictamente cumplida por Albert en la dupla significada, en ambos bloques habitacionales requeridos a estudio.

Aquella sinceridad -ya preconizada y distinguida- funcional, para la casi totalidad de sus proyectos, para sus construcciones formales y por ende, para sus discursos gráficos, vuelve a consolidarse, esta vez en la veracidad estructural, clarificando orden y rigor compositivo al proyecto, tanto en planta, como en alzado.

El autor del primer edificio de hormigón armado en la capital levantina, estableció con pulcritud una trama estructural (fig. 33), una austera malla que siempre le acompañaría. Una retícula coordinadora como precepto, llevado hasta el final como estructura aparente $y$, orquestando forma al tiempo que función.

Así sucede en los proyectos ejecutivos de ambos edificios propuestos a análisis, exactamente como trasluce su exposición gráfica, como plasman sendas memorias de proyecto y, tal cual traslada Albert durante la ejecución administrativa de las obras, tan minuciosamente llevadas a término, según hemos citado con anterioridad. He aquí, parte de las mismas, donde podemos comprobar el anhelo de sinceridad esgrimido por su autor; fascinado por la sinceridad constructiva, el riguroso orden compositivo, el progresista confort tecnológico y la cortejada modernidad edilicia. 


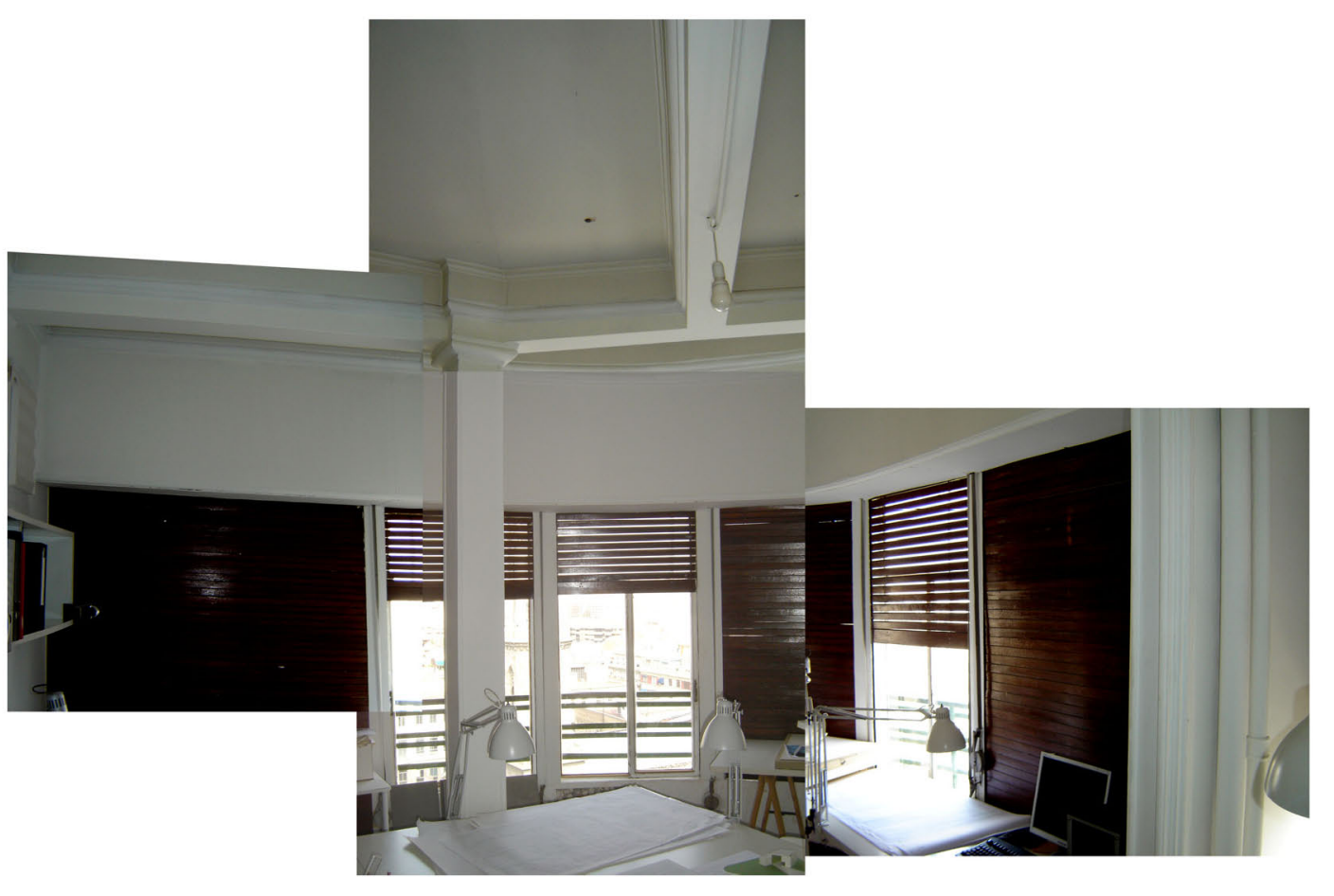

fig. 34 
EDIFICIO PARA CARMEN ALONSO.

'La estructura general del edificio será de entramados de hierro con bovedillas de cemento, y pies derechos de hierro laminado (fig. 35) u hormigón armado. En los tabiques, medianeras, muros de cierre, etc. se emplearán placas ligeras, rigas o ladrillo hueco, a fin de evitar peso, procurando aislamiento y aumentando el confort de la vivienda. En cuanto a las condiciones de los materiales, detalles de construcción, instalaciones, etc. se determinarán por el arquitecto director durante la ejecución administrativa de las obras.

La construcción que nos ocupa, de tipo moderno, tendrá en líneas generales las siguientes características: zaguán con decoración lujosa aunque sencilla; escalera de mármol con pasamanos de tubo cromado; protección de ascensor de tela metálica, sin cubrir el total del perímetro de la escalera; pintura de la escalera y habitaciones de fachada a la colamina picada; puertas de escalera contrachapadas con chapa de $7 \mathrm{~mm}$. lisas de madera palo santo; puertas interiores vidrieras con cristal helado de una pieza; puertas opacas contrachapadas con chapa de ocume de 5 $\mathrm{mm}$. pintadas al Duco en tonos claros, marco al Duco oscuro y cantoneras cromadas; pavimentos lisos en un solo tono o jaspeados en varios tonos según la iluminación de los pisos dada su altura; carpintería exterior metálica con persianas rollables; carpintería exterior a patios a la catalana o sencillamente con vidrieras sin contraventanas según las habitaciones; cuartos de baño compuestos por bañera empotrada Rister, lavabo de regulares dimensiones sobre pie de porcelana, WC de cisterna baja, bidet, etc. en porcelana blanca sobre chapado de azulejo oscuro o lincrustas de tonos asimismo oscuros y pavimento de linóleum en tonos vivos. 

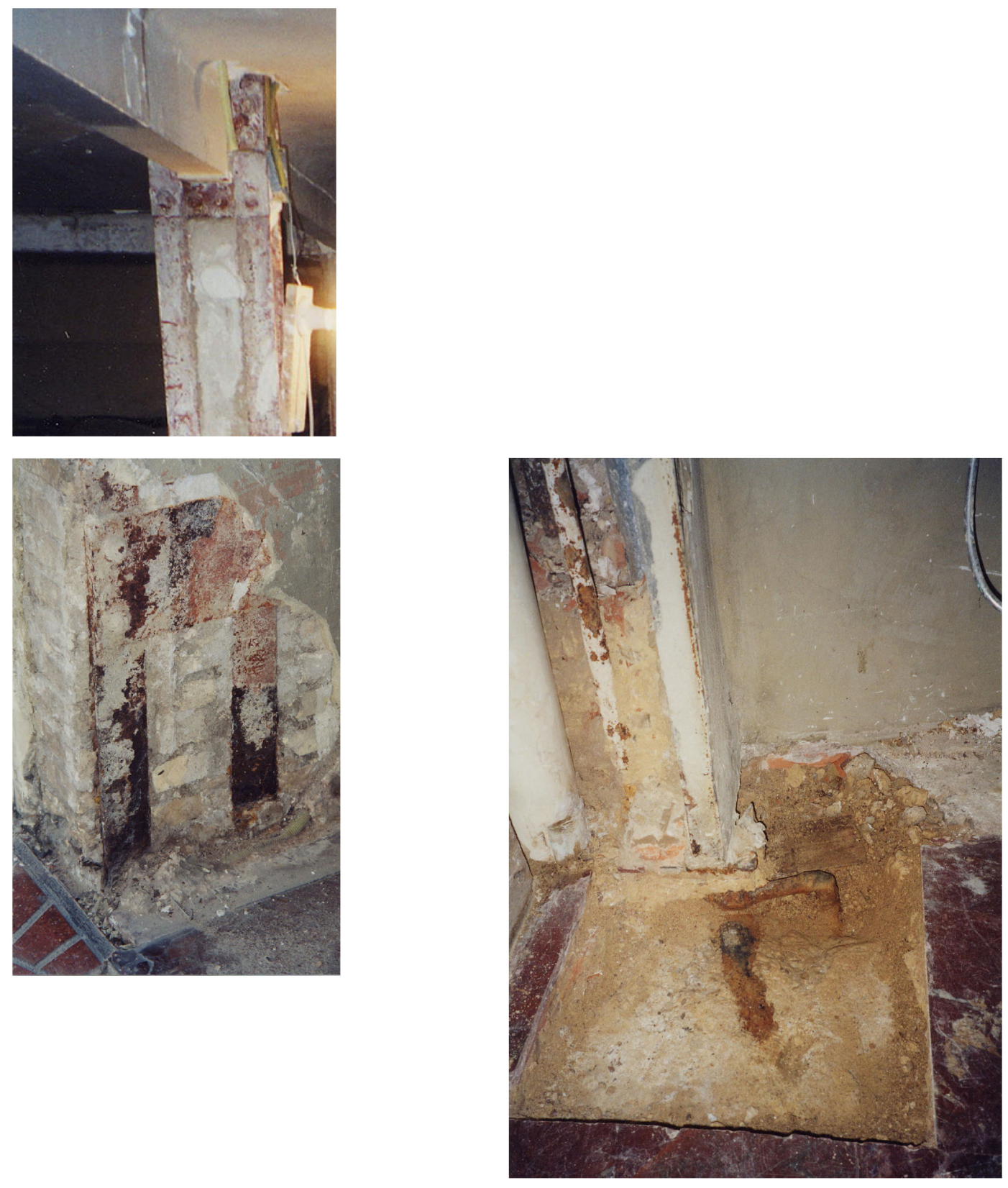

1935. Edificio Carmen ALONSO; detalle de la estructura mediante perfiles conformados en frío, empresillados y macizados para los soportes verticales 
Cada piso estará provisto de instalación de gas para la cocina y cuarto de baño que llevará calentador, instalación eléctrica embutida con tubo Berman y enchufes en la cocina y cuarto de baño, calefacción individual y extractor de aire en las cocinas, y telefonía privada con la portería'. ${ }^{32}$

EDIFICIO PARA MÁXIMO BUCH.

La estructura general del edificio será de hormigón armado con forjado de paredes de fábrica de ladrillo; tabiques de panderete; carpintería metálica en la fábrica y en la fachada principal, y ordinaria en el interior, según las condiciones determinadas en el Pliego de Condiciones; servicio sanitario moderno con su correspondiente red de ventilación en los cierres hidráulicos (sifones); instalación de fontanería, agua, gas, electricidad bajo tubo Werman empotrado, etc.

El estilo en sus líneas generales es moderno, siendo su decoración senciIla. En la fachada llevará un chapado de piedra del país (borriol)'. ${ }^{33}$

\footnotetext{
32 Albert ballesteros, Luis. De la memoria del proyecto. AMV/1935/Ensanche/caja 4bis/exp. 45662

${ }_{33}$ ALBERT BALLeSTEROS, Luis. De la memoria del proyecto.

AMV/1935/Ensanche/caja 3/exp. 25001
} 

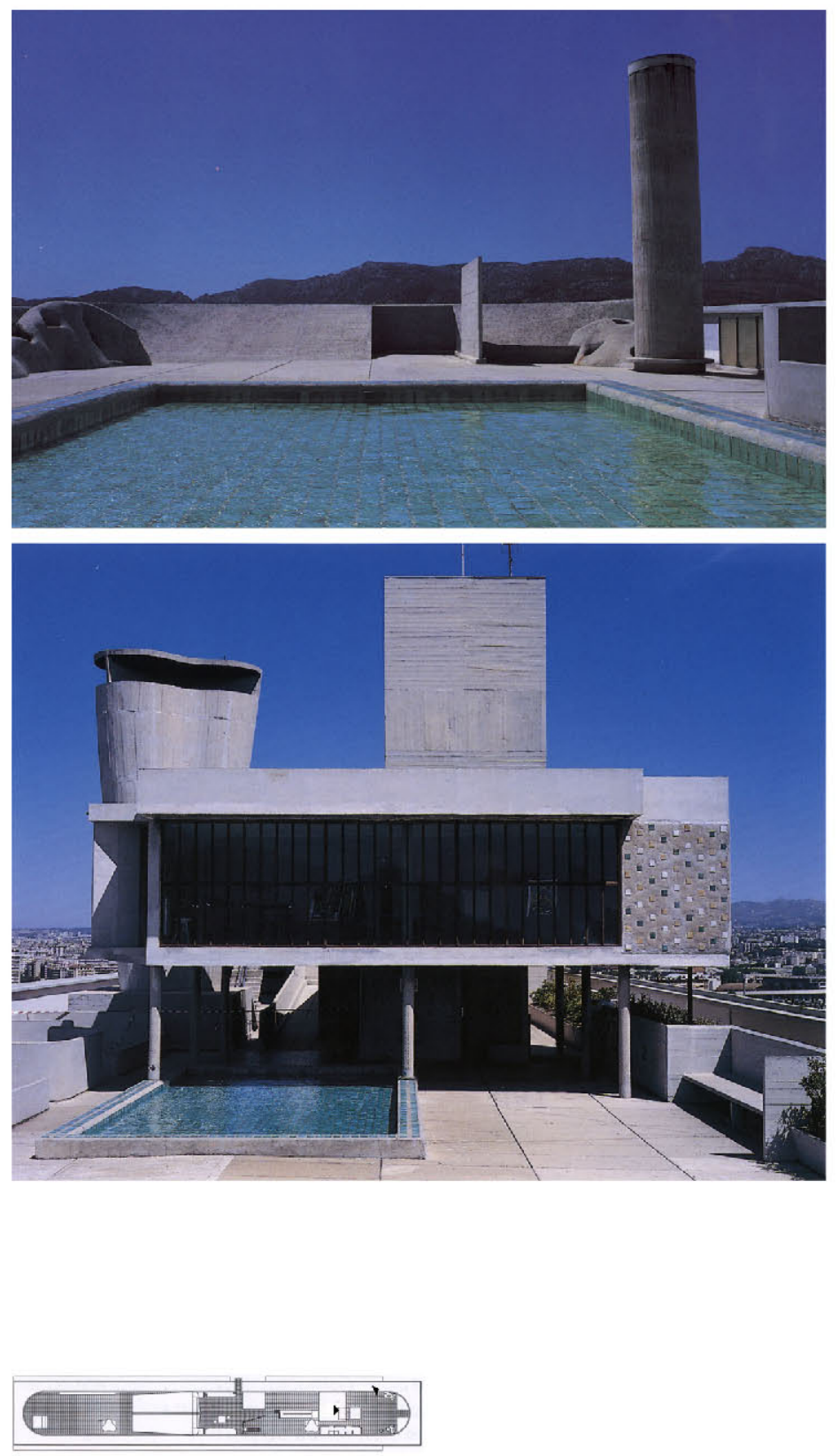

Le CORBUSIER, 1945-1952. La Unité d'habitatión de Marsella; imagen de la guardería y la piscina en la cubierta-terraza ajardinada 


\section{CUBIERTA}

"A mediados de los años veinte, en la Unión Soviética, fue evidente que asignar a cada familia una habitación en un edificio de apartamentos tradicional, con cuarto de baño y cocina de uso colectivo, no resultaba una táctica aceptable, y (...) la Asociación de Arquitectos Contemporáneos (OSA) elaboró diversas propuestas de casas comunitarias destinadas a proporcionar comodidades colectivas como una cantina, cocina, gimnasio, biblioteca, guardería diurna y azotea jardín como justificación para reducir el tamaño de la unidad individual. Las Unidades Stroikom".34

Una propuesta concreta amaneció en Moscú, en 1928: los apartamentos Narkomfin. Resultaba en sección, un esquema de viviendas con niveles dobles. A cada unidad individual se le procuraba acceso a través de corredores, dispuestos cada tres plantas, en los cuales había escalera de subida y bajada. Una de las unidades individuales quedaba generada por dos dependencias con un dormitorio. La unidad tipo complementaria se formalizaba mediante tres dependencias con dos dormitorios. Ambas disfrutaban de una doble altura en su sala de estar, con cocina e instalaciones sanitarias mínimas.

Recuperando la sección, los apartamentos se aglutinaban dispuestos en un bloque separado del suelo. Experimentando una vuelta más de tuerca, funcionalmente, la sección forzaba el piso más alto y la planta baja para

34 SHERWOOD, Roger. "Vivienda: Prototipos del Movimiento Moderno". Editorial Gustavo Gili, S.A. Barcelona, 1983. Título original: "Modern Housing Prototypes"; publicado por Harvard University Press, Cambridge (Massachusetts), 1978. Versión española de Iris Menéndez. pág. 118 


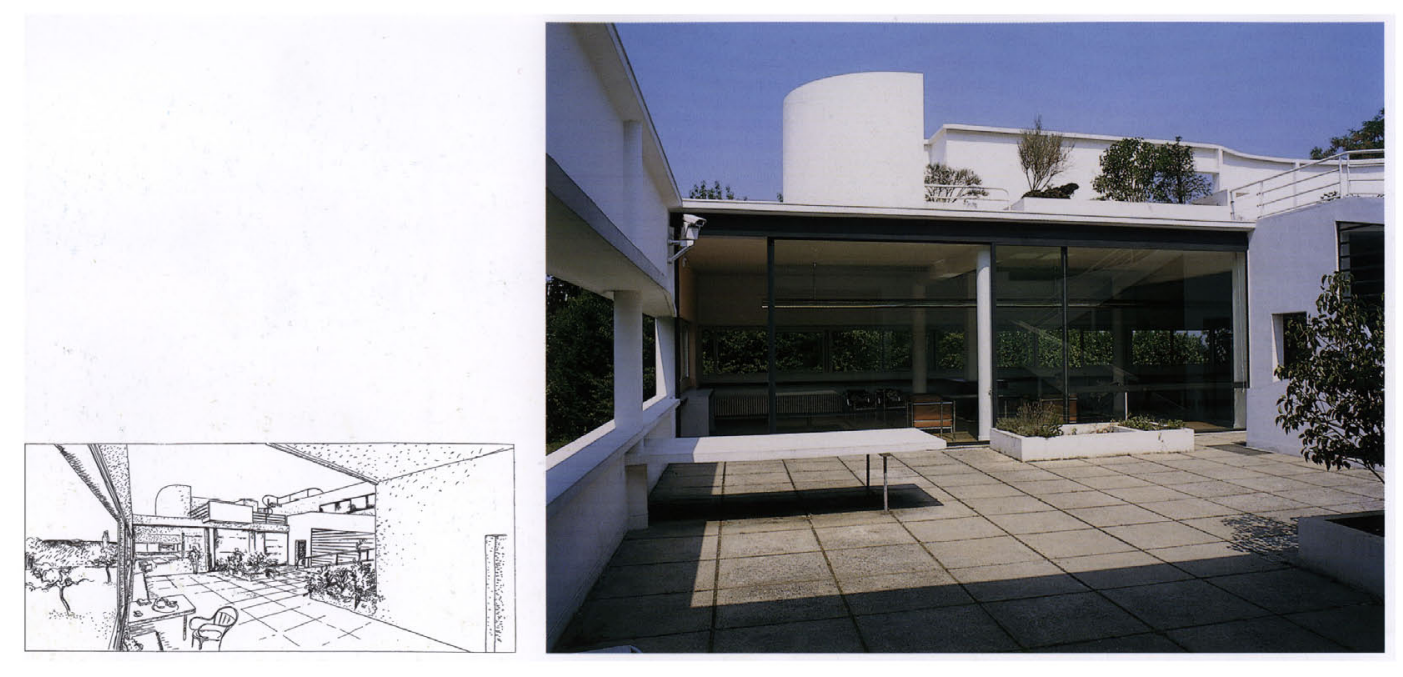

fig. 35

Le CORBUSIER, 1929-1931. Villa Savoie, Poissy. La orientación solar resulta intencionadamente opuesta a las vistas inducidas, otorgando protagonismo a la cubierta 
utilizarlos como servicios públicos. Se generaba un bloque adjunto, con acceso desde los corredores, que absorbía otras funciones colectivas.

Premonitorias ideas, que posteriormente fueron modificadas y adaptadas por Le Corbusier: el edificio sobre pilotes, la azotea pública o con funciones colectivas (fig. 35), los corredores con paradas intermedias y los apartamentos completos en dos niveles.

Claramente, ninguno de los edificios que nos ocupa-Carmen ALONSO y Máximo BUCH- presenta el carácter experimental, socializante y elucubrador de unidades mínimas, dispuestas bajo el amparo de servicios comunes a todo el edificio. Expectativas muy alejadas de sus promotores, más próximos a una clientela con mayor poder adquisitivo. Tampoco resultaban bloques aislados, en ninguno de los dos emplazamientos, en los cuales plantear corredores exteriores de acceso a varios niveles, dobles alturas, ni tan siquiera la elevación sobre pilotis. Sin embargo, las posibilidades que planteaba la sección, invitaban a mantener una razonable experimentación al concentrar unidades de vivienda, entre la planta de entrega urbana y la cubierta del edificio. Propuesta que había quedado patente con anterioridad al preludio moscovita.

Perret hubo anunciado avances como la estructura vista, los techos planos y las azoteas. Antecesor de la planta libre, sus logros exaltaron indudablemente a la siguiente generación de arquitectos. Los apartamentos en la rue Franklin anticipaban ciudades elevadas sobre una malla de pilares de hormigón, capacitados para albergar todos los servicios de la vida urbana, tiendas parisinas convertidas en un espacio de dos pisos de altura con un entresuelo, el despacho de Perret. No serían menos las azoteas 

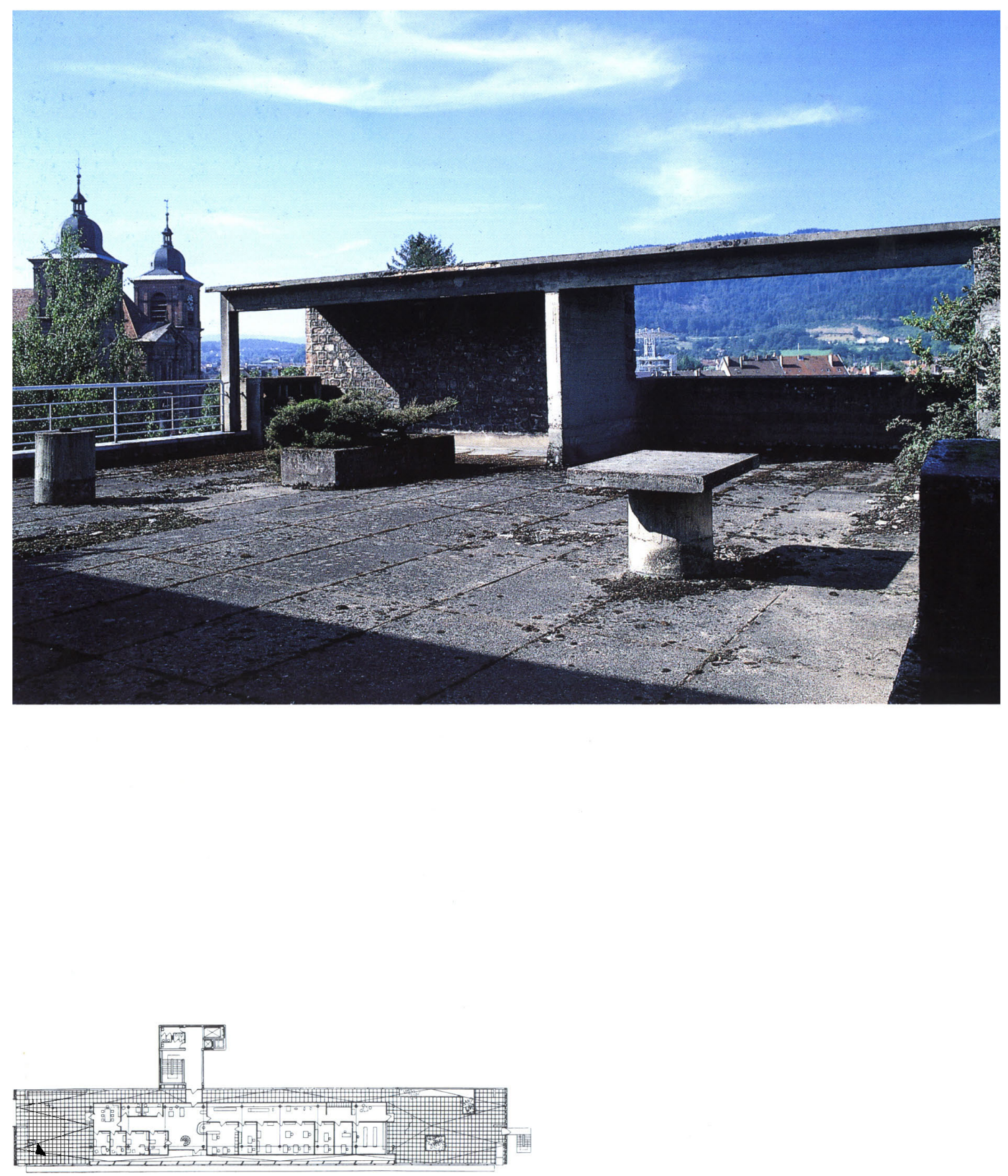

Le CORBUSIER, 1946-1951. Manufactura Duval, en Saint-Dié. Loggia sobre la cubierta jardín 
que preludiaban nuevos servicios comunes a sus habitantes, o jardines entregados a los detallados apartamentos del ático, retirados en terrazas a medida que el edificio ascendía en sección.

EDIFICIO PARA CARMEN ALONSO.

Albert desoye propuestas con servicios comunes y espacios exteriores en cubierta. Paradigma que Mies ya había planteado en la casa de apartamentos para la Weissenhof de Stuttgart, en 1927 -edificio previsto como prototipo de bajo coste y considerado sobre todo por su estandarización y prefabricación. Igualmente pasa por alto la enaltecida 'cubierta ajardinada', doctrinaria, pública y específicamente terciaria. Desatiende la esencia comunitaria de la quinta fachada $y$, en definitiva, su espíritu convocante.

Se inclina más bien, por aquellos avances de Perret, retomados por Le Corbusier (fig. 36) en los apartamentos Porte Molitor en París, de 1934: anunciada compresión de viviendas entre la planta baja -ofertada al servicio urbano, al acceso propio de vecinos y a la vivienda del porteroy la planta superior de cubierta. Azotea que el maestro suizo la arrogaría 


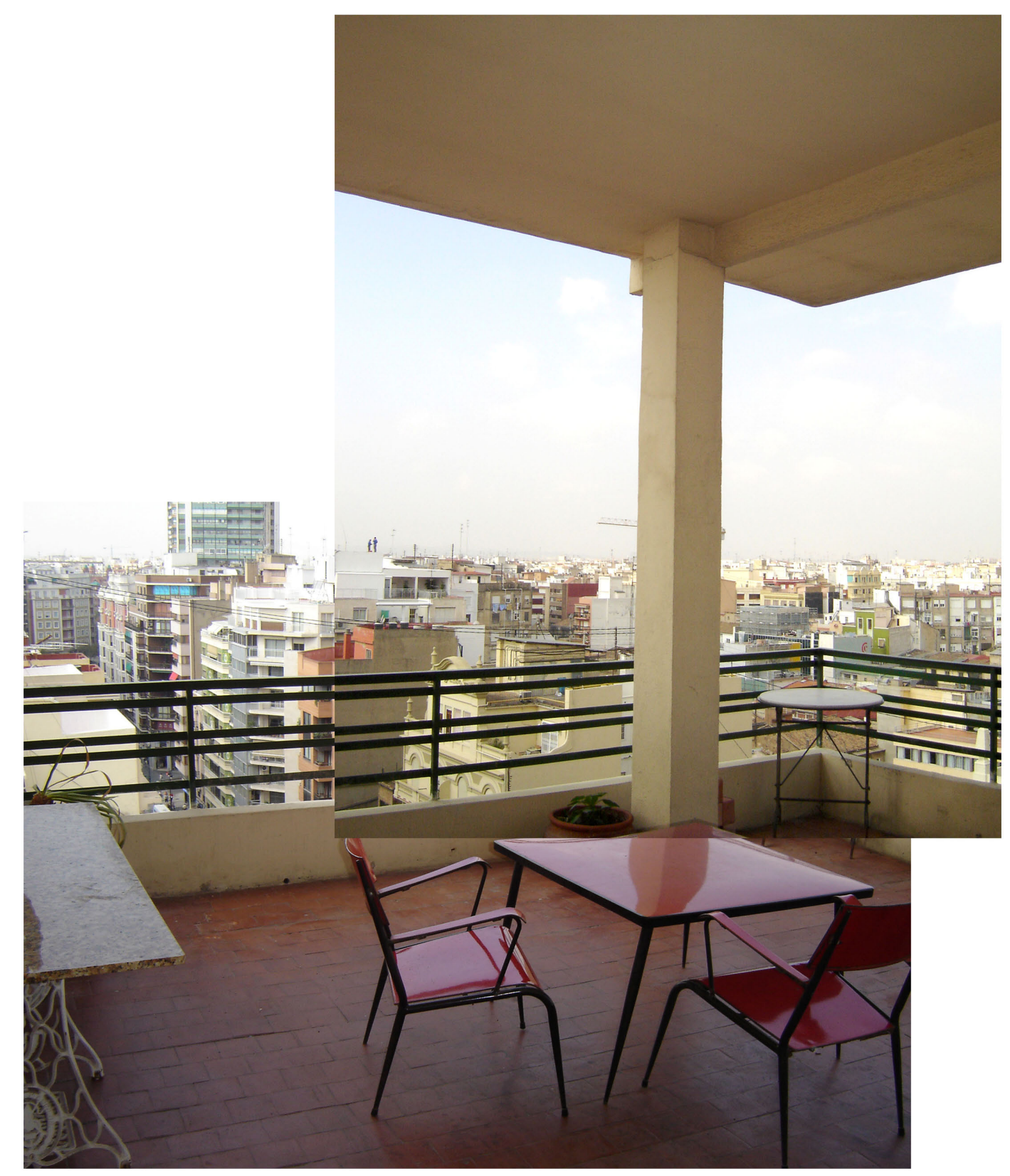

fig. 37 
en pos de su propia vivienda y estudio.

Opta Albert, por configurar la cubierta como una de las láminas que comprimen en sección al grueso de viviendas y, tal cual sus predecesores, la exime de una función distintiva conjuntamente con la lámina inferior -comerciales al servicio público y zaguanes-, congregadota. Muy al contrario concluye reiterando el hábitat privado. Resultan pues, en sección, siete plantas dedicadas a viviendas seriadas, intercaladas entre la planta baja -entregada al comercio relativo a la ciudad y dos zaguanes de acceso a sendos núcleos verticales de comunicación- y el detallado ático ocupando tres niveles (fig. 37). Albert retoma los principios de Perret, proclamando terrazas en los áticos, retirados del plano de fachada en su ascenso, exceptuando la esquina en cubillo, inalterable en la consolidación volumétrica. El primer nivel de la cubierta reorganiza dos apartamentos, en relativamente equiparable espacio que en plantas inmediatamente inferiores - debe restarse la superficie dedicada a terrazas particulares- destinaba a cuatro núcleos habitacionales. Adapta dos plantas sucesivas para estudio, con sus terrazas, privativas, en la torre. Y finalmente encala la vivienda del portero a una cubierta, casi despreciada como propuesta, defenestrada funcionalmente, contrariamente a un Le Corbusier empecinado en forjarle un merecido protagonismo.

Todo un exceso métrico, proscrito a la contemplación exterior, vetado al provecho comunitario, negado a las relaciones colectivas. Cubiertas planas transitables, sin aspiración mayor al disfrute por quien las detenta. Solución clásica de la cultura mediterránea, dominada y recurrente en demasía, desaprovechando aquellas posibilidades aportadas para la quinta fachada desde el Movimiento Moderno. Conviene suficiente, satisfacer 


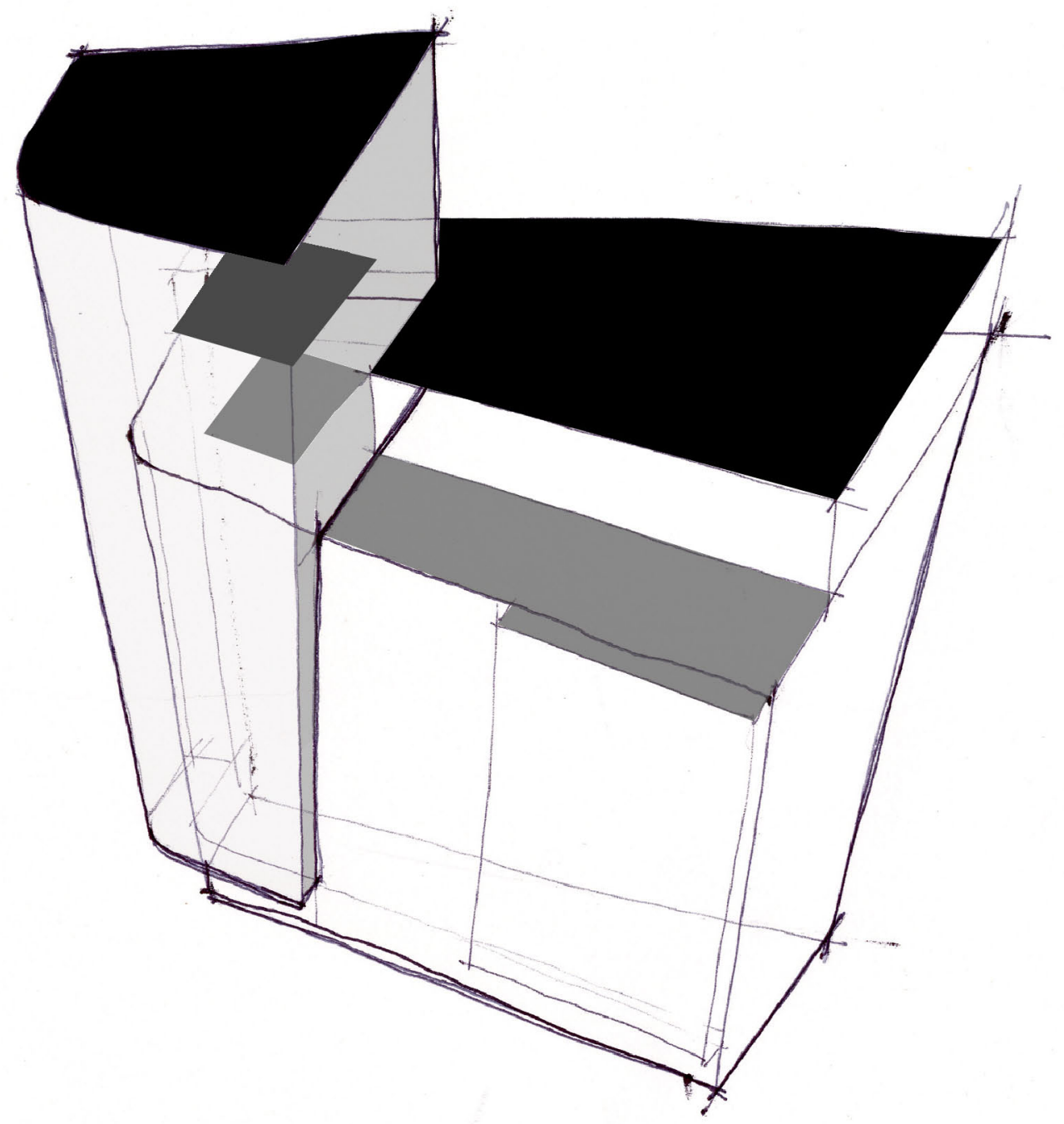

Luis ALBERT, 1935: Edificio de viviendas para Carmen ALONSO. La cubierta funcional. 
constructivamente el anhelo racionalista por la cubierta plana. Un logro, tan extenuante, que impelía proseguir el combate por instaurar superiores ganancias sociales.

EDIFICIO PARA MÁXIMO BUCH.

Arcano hubiera amanecido un planteamiento innovador, una componenda social instalada en la cumbre edilicia. Resonaban conquistas modernas sobre el clamor constructivo tradicional y, colma en suficiencia la materialización horizontal de la cubierta plana. En esta oportunidad, descentralizada, tampoco parecen tener cabida planteamientos sociales, colectivos.

Retorna Albert al aprehendido tratamiento de la cubierta, como estricta lámina compresora. Un tratamiento sincero y humilde en sección, para un edificio necesitado de una entrega urbana inusual, zurcido a una fábrica de cepillos y sus oficinas, demandante de otros esmeros. Recóndita cubierta ligada al oficio mediterráneo como añadido germinal, evitando un reconocimiento -rescatando su acepción aprobatoria- social complejo. Opta Albert por reasumir plantas habitables intercaladas, sencillamente, entre la planta baja -repitiendo espacio comercial y, esta vez, un único zaguán-y el detallado ático, ahora de escasos dos niveles. 


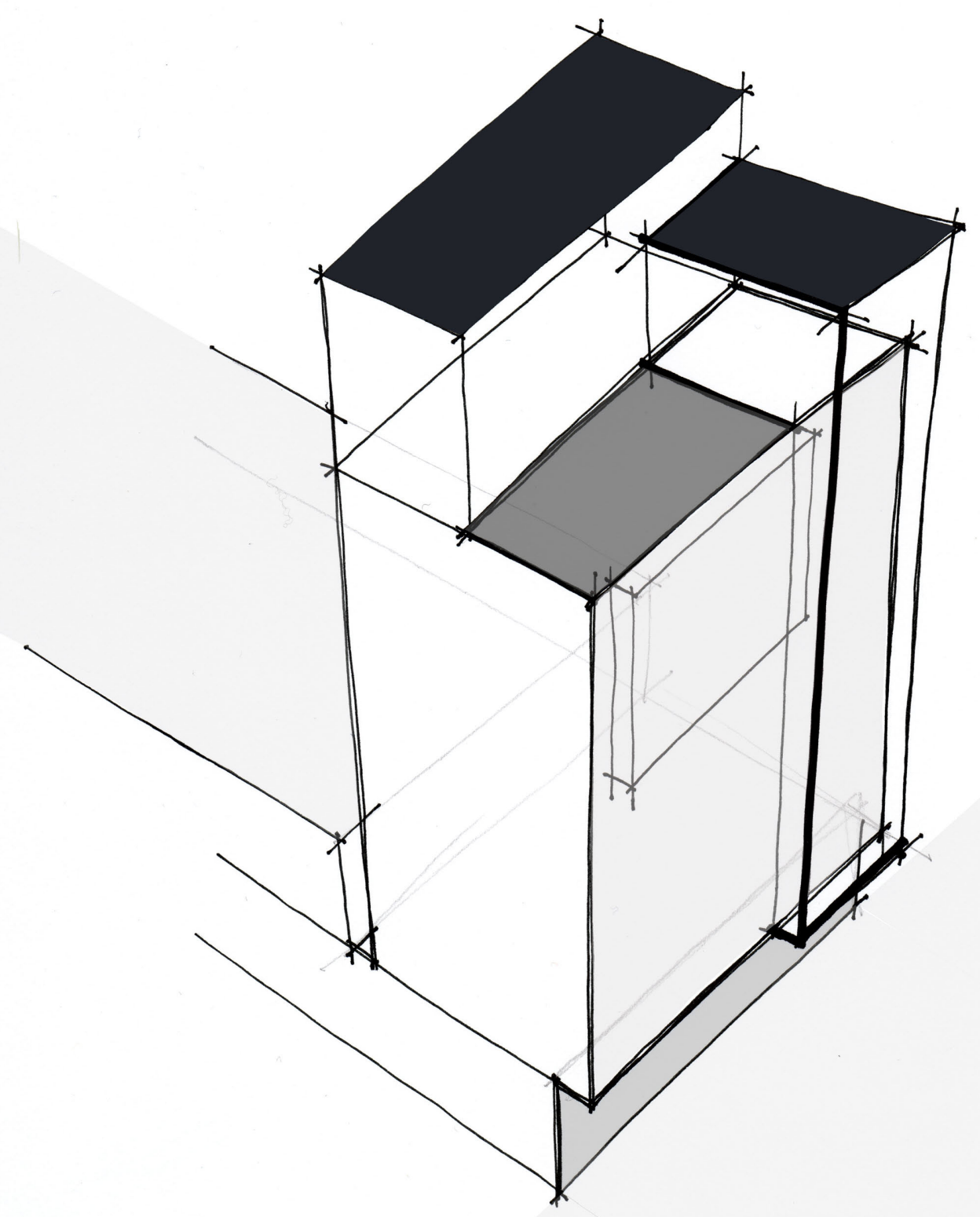

Luis ALBERT, 1935; Edificio de viviendas para Máximo BUCH. La cubierta funcional, retornando al terreno la superficie usurpada y, recuperando contacto en la cota elevada 
Restaba garantizar el disfrute del plano horizontal de cubierta. Limitado su aprovechamiento a aquellos apartamentos que las privatizaban, en su primer nivel y legitimada la ocupación volumétrica del nivel postrero. Este último nivel de terraza, no queda dotado con servicios terciarios, sencillamente reflejan un espacio exterior común, distante del tratamiento preeminente ofertado en el prototipo de Mies para la Weissenhof. Excedente métrico desocupado, defenestrado funcionalmente y adjudicado a un exiguo apartamento colindante con el plano horizontal comunitario.

Garantizar constructivamente el plano, aislarlo y alejarlo del agua -en lugar de retenerla y tratarla para limitar las dilataciones del hormigón- se imponían como únicos motivos del esfuerzo de diseño. Una solución válida, contemporánea, es la cubierta invertida, transitable pero sin ventilar. Losetas de alfarero, solera de rasilla, como superficie pisable, primera barrera para captar el agua y reconducirla hacia los puntos de recogida. Una capa de arena filtrante, tobas para reconducir las filtraciones que al llegar a la tela asfáltica encuentran el segundo sistema de captación y drenaje. Una fina capa de mortero de cemento sirve para tomar esta lámina impermeabilizante sobre el hormigón de pendiente. Inmediatamente aparece el aislamiento térmico sobre el forjado de viguetas metálicas doble $T$ y bovedillas. Corresponde la cubierta plana a la construcción clásica de las culturas del Mediterráneo35.

35 MANNINO, Edgardo y PARICIO, Ignacio. "J. LI. Sert: Construcción y Arquitectura". Editorial Gustavo Gili, S.A. Barcelona, 1983. pág. 13 
conclusiones 


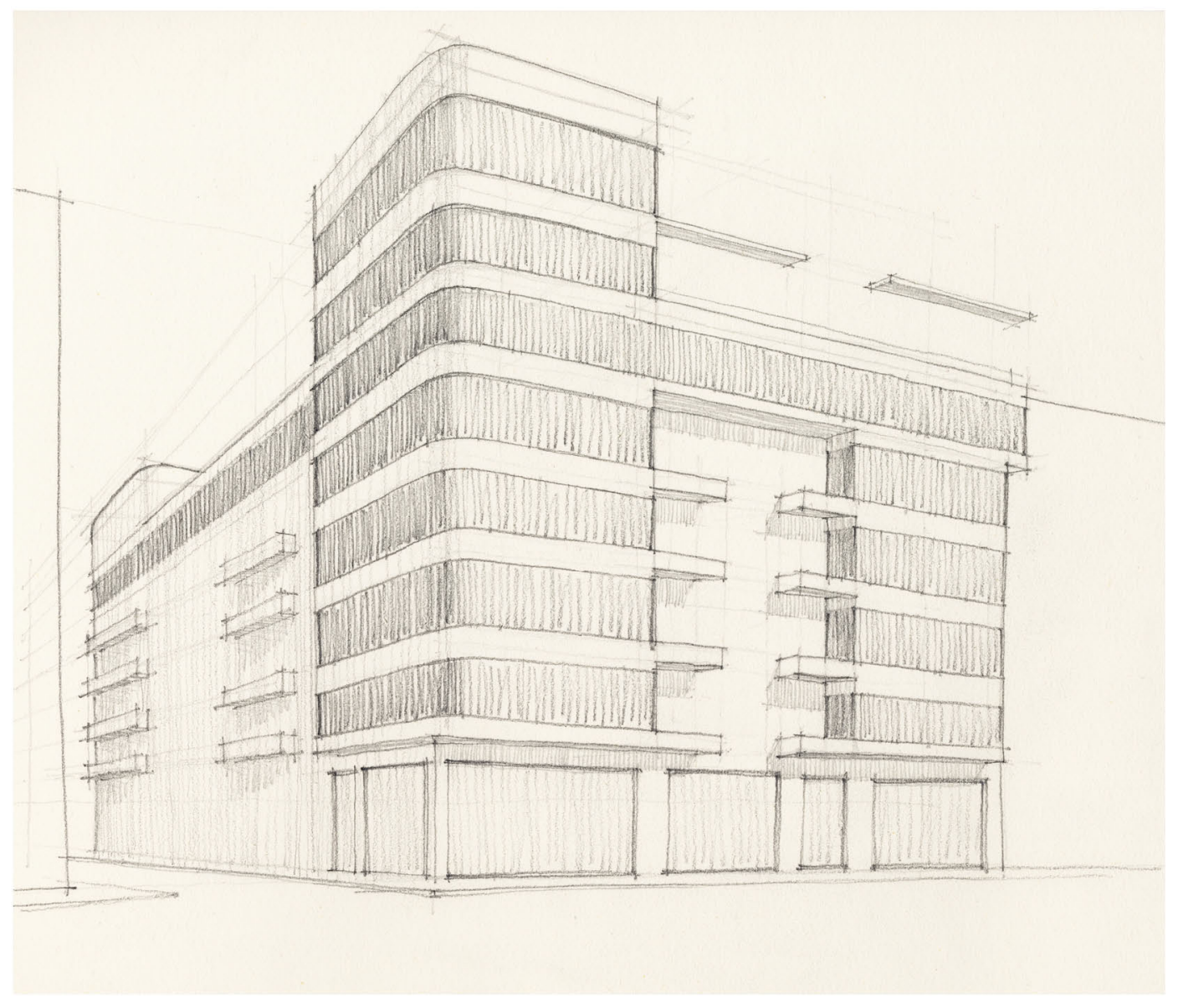

Luis ALBERT, 1932. Edificio Manuel CÁNOVAS, calles Navellos, Micer Tarazona y Yerba 
INFERENCIAS DEL RECORRIDO CONCLUIDO

Cabe consolidar una base sólida donde cimentar las inducidas conclusiones finales, extraídas a partir de las observaciones compiladas durante el periplo analítico, también durante la gestación y consumación de esta tesis doctoral. Cabe afianzar una orientación implícita, una directriz en orden al proceder de Luis Albert Ballesteros. Trasluce entonces, como punto de partida, su ponderada adscripción racionalista y la consecución razonada de sus ideales, de sus logros erigidos o sencillamente esbozados.

Consolidado como principio general, el haber deteniendo Albert su mirada en los ideales racionalistas, en la idea de arquitectura moderna, no convenimos en declamarlo ideólogo comprometido, al menos ciñéndonos a sus manifiestos legados, escasos. Tampoco asoma como vanguardista radical al indagar en sus edificaciones concluidas, conjuntamente a sus propuestas más convencidas, aunque frustradas.

Su convencimiento por superar todos los límites aprehendidos -la tradición adoctrinada por la Academia, los estilos pasados impuestos desde las Escuelas, despreocupados por discernir su trascendencia- si trasluce evidente, además de conjura con el espíritu de la arquitectura moderna, con la honestidad, la responsabilidad y el oficio.

Una actitud sencilla al abordar las dificultades del hábitat, una concepción básica al gestar sus propuestas, no conlleva mantener el rigor ansiado, los ideales anhelados en los primeros momentos de pureza. "La arquitectura moderna no se halla en los detalles que uno elimina. Lo desnudo no es forzosamente el fin último de lo moderno. No será lo más moderno una construcción con ventanas horizontales, o descoronada de su cornisa, 


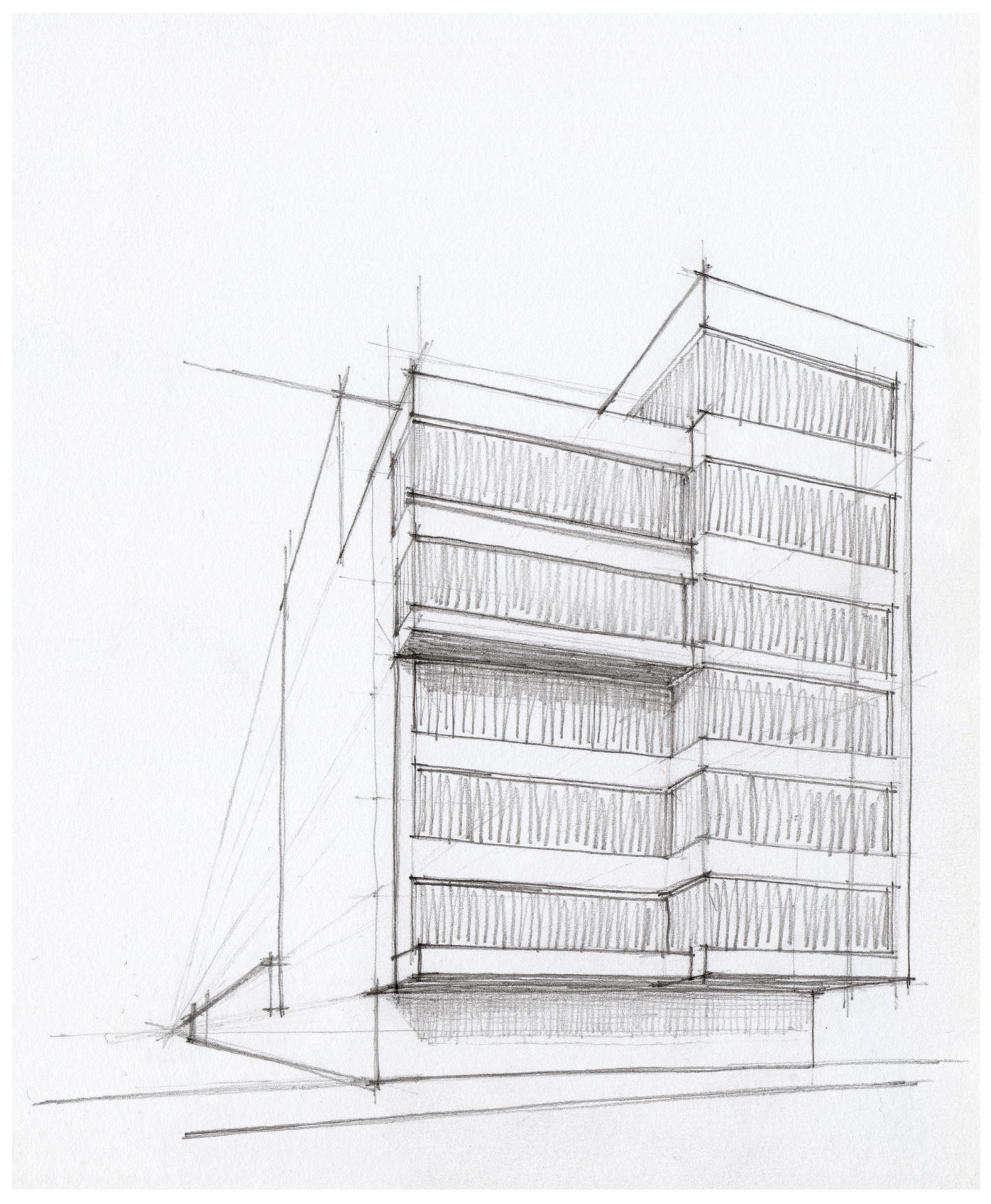

Luis ALBERT, 1935. Edificio para Máximo BUCH, calle Cuarte y su paralela calle San Jacinto 
si el arquitecto no ha exprimido el espíritu de lo que ha construido".? Albert, maneja tanto la concepción racional, como la ejecución minuciosa-apetecida tecnológica, denunciada su escasez de medios- y por ende puede considerarse inmersa en la intención de renovación, de modernidad. Su convicción le va vinculando, desde sus comienzos laborales, al compromiso con los ideales racionalistas. Una constante evolución profesional, consciente, lo deriva hacia la autenticidad racional.

No obstante, el cometido racionalista, resulta elevado frente a las obligaciones implícitas, y más observando el ámbito donde aplicar semejante compromiso pretendido. La intensidad de sus realizaciones, pende subordinada a semejantes ideales arquitectónicos, ideológicos, más también a la realidad social, política, económica, cultural y urbanística que las acoge e interconecta. Desde su arranque en 1927, con la premonitoria propuesta para el concurso del ATENEO MERCANTIL VALENCIANO, hasta su canto del cisne, entonado en el inmueble de viviendas para Máximo BUCH y el de Carmen ALONSO, truncado por el conflicto bélico nacional, la interferencia entre realidades siempre deviene -en tránsito perseverante, constante y coherente- a la renovación. A partir de 1936, quiebra el espíritu moderno interferido por la alteración de condicionantes, traumático rumbo. Se distancia entonces, de sus intenciones racionalistas señaladas "modernizadoras" y vinculadas a los poderes públicos progresistas, aquellos que facilitaron emanar la eminente arquitectura moderna.

1 ZERVoS, Christian. "Jóvenes arquitectos". Cahiers d'Art, año 1935, n 1-4, pp. 75 y 91. A propósito de su exposición en la Galería de Cahiers d'Arten febrero y marzo de 1935 


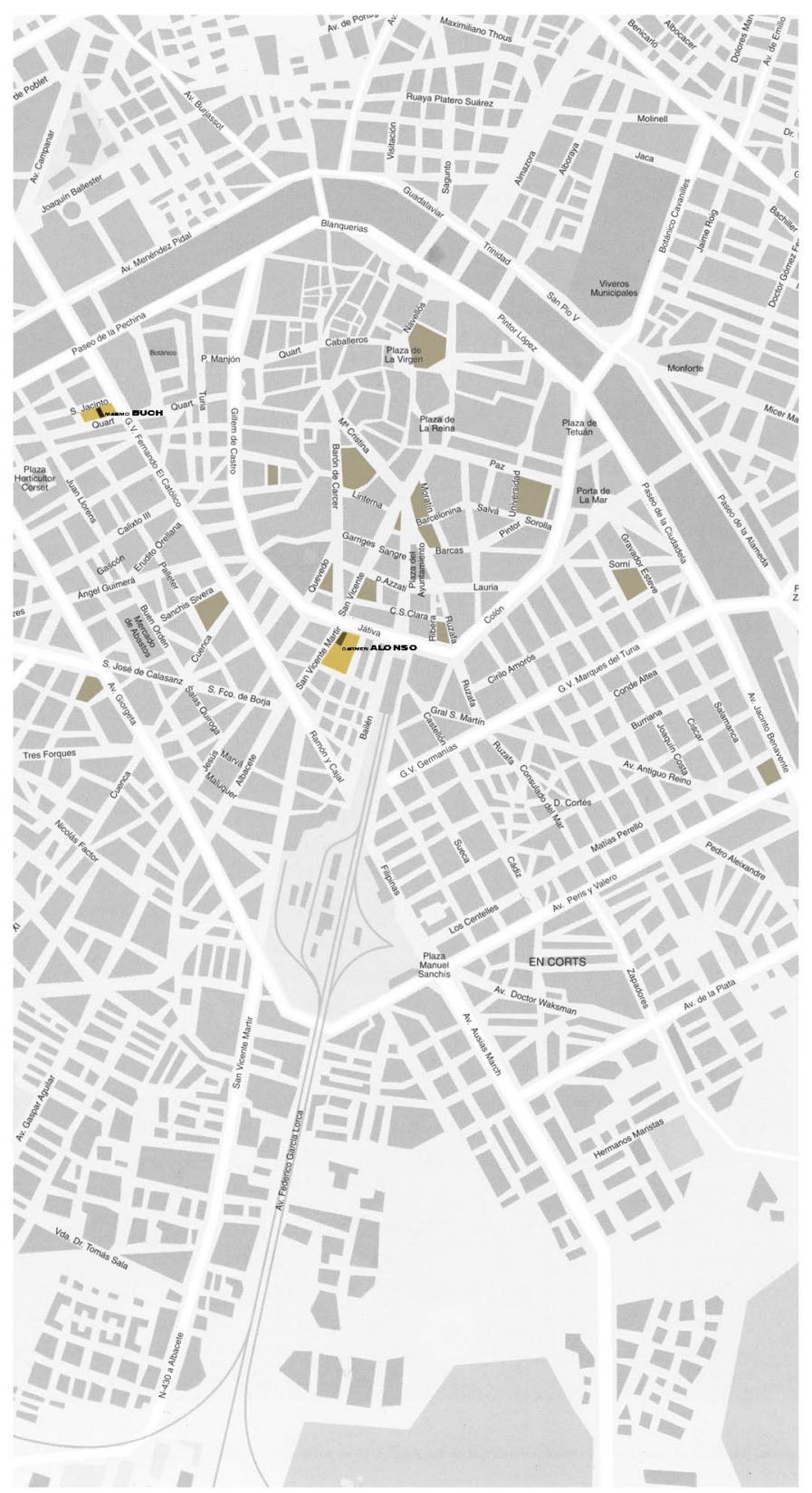

Plano de la ciudad de Valencia, indicando la ubicación de los edificios erigidos por ALBERT 
Evidentemente resulta intrincado dilucidar la previsualización aprehendida de arquitectura moderna. También, aseverar semejante logro en la figura de Albert -al menos en una parte concreta de su obra, durante un periodo determinado- deriva complejidad. Quedando ceñidos por variables arquitectónicas, al procurar precisar la fortuna de los ideales racionalistas, trataremos de ajustar unos principios concretos donde cotejar premisas y concretar conclusiones. Uno tras otro, se han ido analizando en cada obra electa. Cada cual vertió conclusiones preliminares, evidenciadas a lo largo del trabajo. Va a ser labor, de estas conclusiones, sistematizarlas y bajo su luz, discernir el grado de compromiso ideológico, en Albert, con la arquitectura moderna.

GENIUS LOCI

Analizando las intenciones, incubadas por Albert, siempre que presta atención hacia el entorno donde proyectar, cada ocasión que encara el dilema del emplazamiento como premisa proyectiva, albergamos la certeza de su cultivada formación y su crecida disposición por una disciplina como la urbanística. El sistemático ZONING alemán, abanderado por Hilberseimer $y$, las teorías anglosajonas elucubradas por Ebenezer Howard sobre el GARDEN CITY, permanecen latentes en las intenciones propositivas 


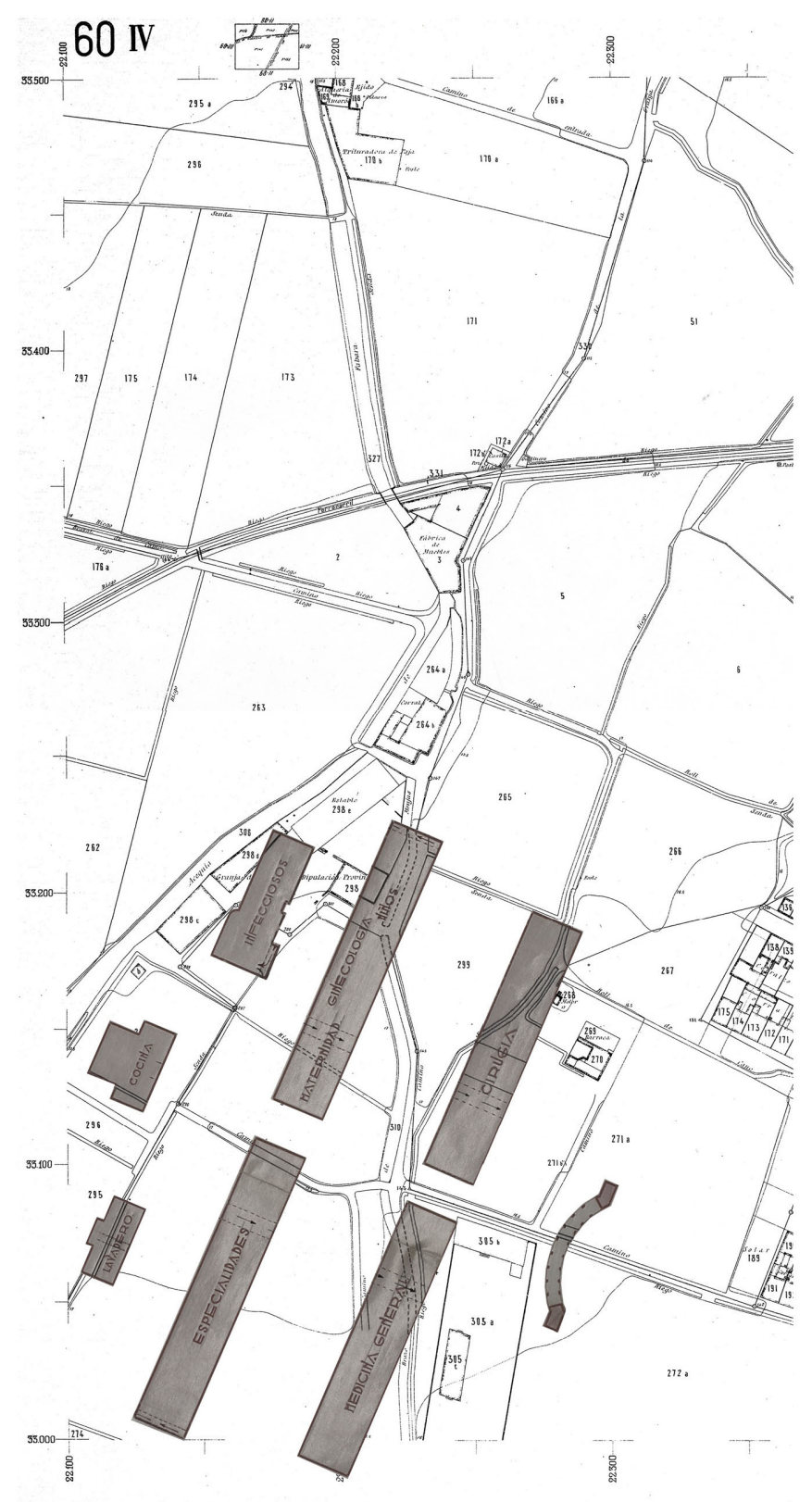

Luis ALBERT, 1935. Hospital Provincial para la Excelentísima DIPUTACIÓN PROVINCIAL de Valencia 
de Albert. Una pugna constante por solventar el futuro crecimiento de la metrópoli, inmersa entonces en un debate centrado por desarrollar el Ensanche o preparar asentamientos periféricos. Inquietudes que acomoda a la urbe donde interviene, como agente privado, también desde su cargo público en la Diputación y que además traslada a sus proposiciones allende la retícula urbana.

Precisamente su cometido en la Diputación Provincial, posibilita su planteamiento a gran escala en la ciudad, con una propuesta global extirpando funciones inadecuadas, regenerando y ordenando el tejido urbano del Ensanche. Mediante vacíos o bolsas de crecimiento habitacional, propone zonificar, sistematizar el centro urbano. Mantener la trama histórica, ampliar el Ensanche planeado y procurar conexiones, relativamente rápidas, con aquellos extintos usos amputados, depositados externamente.

Al recabar las capacidades proyectadas en la triada albertiana -aquella tripleta pretendida para desprender a la metrópoli de usos inadecuados y dotarla de una modernidad anhelada- se vislumbran convicciones racionales, una concepción descentralizada, orgánica y científicamente planeada. No obstante, jamás alcanzaremos a cotejar compromisos, pues nunca lleva a término la ejecución de su propuesta global, menospreciada en desconciertos políticos provincianos.

Convencimiento racional, certidumbre científica, dogma de modernidad. Y tras extirpar semejantes funciones, acaricia las teorías anglosajonas alejándolas del núcleo residencial, insertándolas allende la urbe. No obstante, nunca planea asentamientos habitacionales alejados de la metrópoli, aprovecha las bolsas generadas en la operación quirúrgica sobre la ciudad. 
E 
Reinvierte el uso del escaso espacio liberando pensando en rendimientos inmediatos residenciales o bien, genera apoyos -aquí debemos considerar su propuesta para la nueva Plaza de Toros- terciarios y de servicios. Nunca pretende la radical descentralización del núcleo urbano. No contempla reubicar asentamientos organizados en el extrarradio. Jamás aspira, ex profeso, a seguir el dictado de las ciudades jardín. Sin embargo, para aquellas funciones desarraigadas, trasladaría de los principios howardianos, fielmente, su relación con el emplazamiento, con la Naturaleza. Su preocupación por el soleamiento, el control ambiental y su ambición por dominar las vistas a percibir, tanto como la visión externa de su arquitectura reflejan. Las previsiones de Hilberseimer, y los apuntes howardianos denotan una racional postura frente al genius loci.

Al atender sus proyectos ejecutados en el escenario urbano, esta vez bajo severos condicionantes privados -resultan significativas las exigencias del promotor y la escrutadora mirada peatonal- y sometidos a rígidas limitaciones -geometría impuesta de solar, ordenanzas urbanas- la exigencia racional cambia de registro. La proporción de la sección de calle frente al edificio -tributo de Hilberseimer- se justifica con la impronta visual. El control lumínico, la ventilación la jerarquía de los espacios recayendo al escenario urbano, reducen su exigencia racional, frente al carácter iconográfico y referente, tal cual practicaba el ideario moderno. La sensibilidad por el escenario urbano, la mirada curiosa del arquitecto a los condicionantes donde ubicar su propuesta, aportan vestigios de intencionalidad racionalista. Coincide Albert, en la perversa oportunidad de indagar la irrelevancia del emplazamiento, la indiscutible autonomía racionalista del objeto arquitectónico, la adhesión germinal al no lugar de la arquitectura moderna, para formar parte de la ortodoxia. 

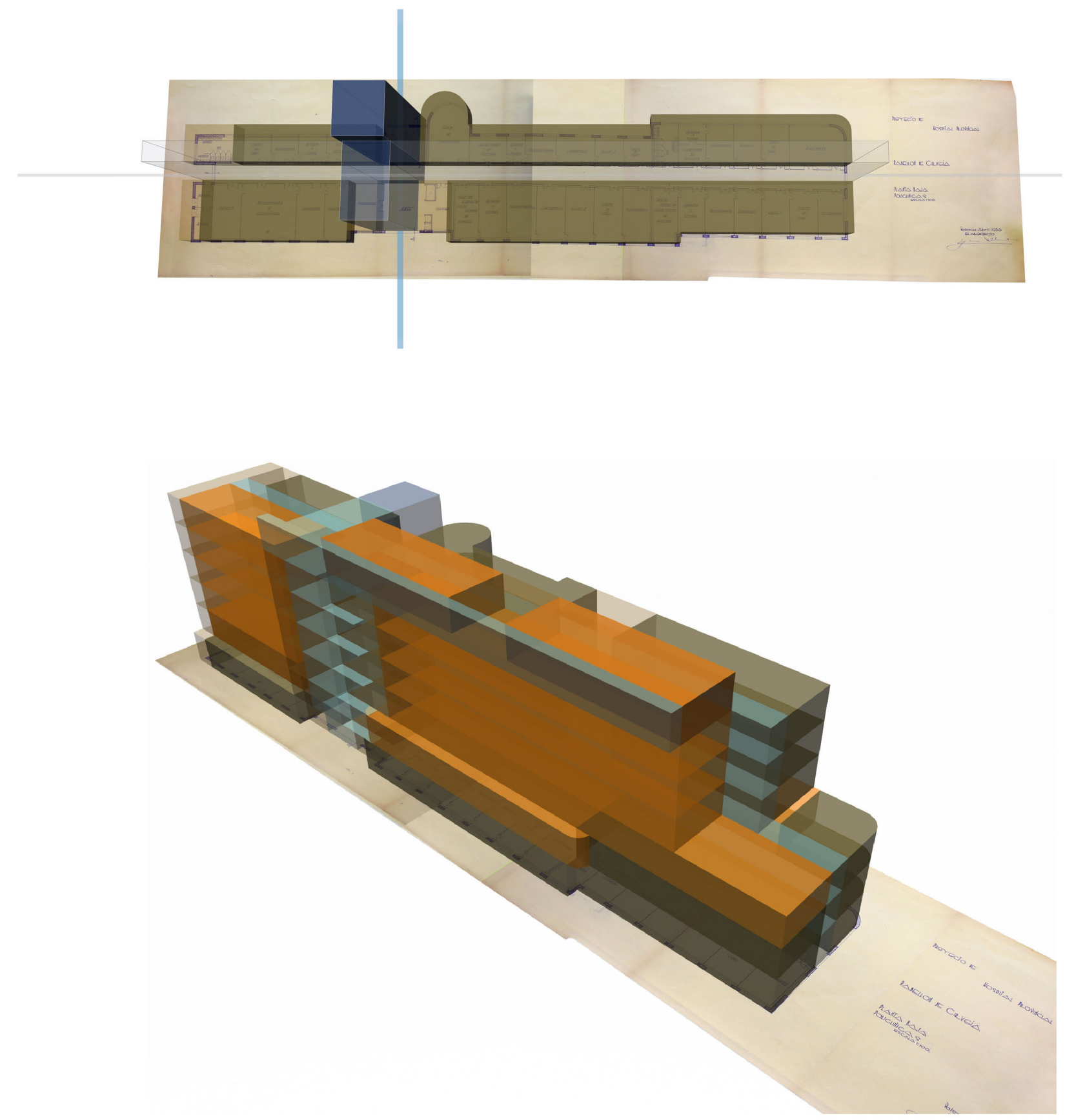

Luis ALBERT, 1935. Pabellón de Cirugía del HOSPITAL Provincial, propuesta del arquitecto para la Excelentísima DIPUTACIÓN PROVINCIAL de Valencia; volumetrías infográficas 
Donde posicionar el límite racional, entre el 'genius loci' o la prioridad como referente escénico, nunca resulta tarea sencilla. Albert parece aproximarse a la segunda opción, más ortodoxa en su posicionamiento autónomo, sin desoír las fuerzas del lugar. "Evidentemente lo que es o lo que se ha pensado que puede ser la IDEA DE ARQUITECTURA MODERNA es un tema bastante confuso... Además y a fin de establecer cualquier criterio de juicio, referirnos a una teoría ortodoxa de la arquitectura moderna es injustificable; invocar sus éxitos canónicos es exagerado y aludir a la existencia de un Estilo Internacional, puede llegar a ser, incluso, una ofensa". ${ }^{2}$

FORMA Y COMPOSICIÓN

Desde aquella exhortada ilación entre forma y función, desde la observancia a la materia y la pulcritud del oficio constructivo, se infiere la forma arquitectónica. Aquí radica parte de la modernidad inducida desde el ideario racionalista, ya sentenciada por Sullivan en "la forma sigue a la

2 ROWE, Colin. "Manierismo y Arquitectura Moderna y otros ensayos". Editorial Gustavo Gili, S.A. Barcelona, 1999.p. 121 


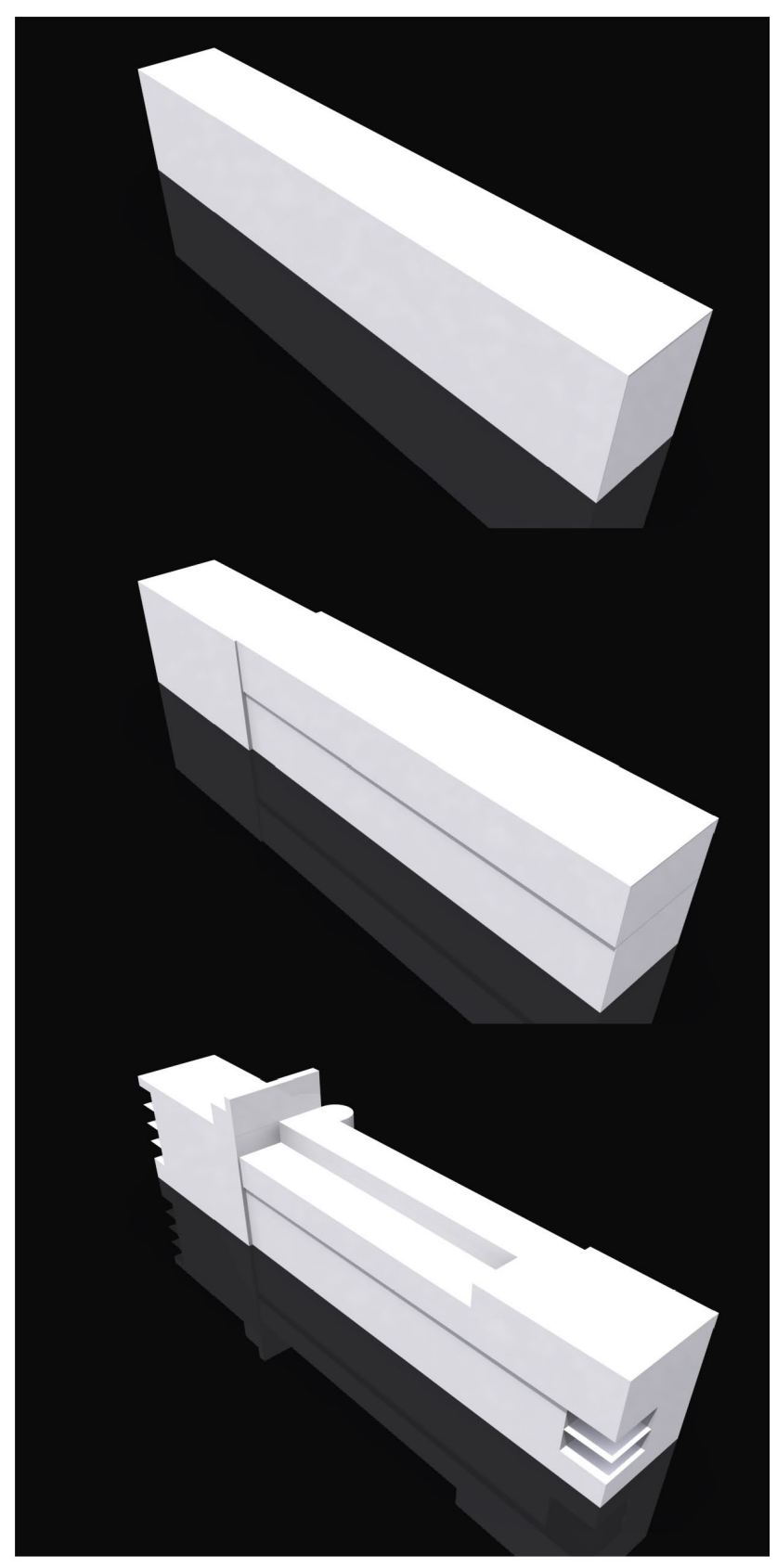

LUis ALBERT, 1935. Figuración pabellón de Maternidad, Ginecología y Niños; HOSPITAL PROVINCIAL 
función". "La nueva revolución" en palabras de Kauffmann³, debe armonizar semejante disposición renovadora, con la imprescindible figura del promotor -bien institucional, bien privado, siempre consuetudinario- y el éxito social inherente. La moderna concepción de la arquitectura, no debe limitarse a organizar un programa necesario, a planificar sistemáticamente y solventar compromisos económicos, estructurales, constructivos, avances técnicos. No bastará observarse en un funcionalismo radical, para dilucidar posteriormente la forma. La moderna arquitectura exige superar el programa, conmover mediante el 'espacio' y la 'forma'.

Albert, atiende este espíritu renovador, aplicándolo en la concepción formal de sus edificios. Proyecta organizando funciones, independizándolas en volúmenes, con la determinación de una recomposición última basada en una ordenación geométrica. Formaliza un conjunto de alineaciones funcionales de gran sencillez, compuestas en orgánica linealidad. Cuanto menos, este resulta el germen inferido tanto del proyecto para el Hospital Provincial como del Manicomio en Porta Coelli.

Cuando el promotor es la Diputación, el excelso programa requerido le permite romper el edificio en partes componentes, según el uso requerido. Resulta significativo el tratamiento de volúmenes, manteniendo formas básicas. Pero también podemos considerar significativa la permanencia -escasamente alejada- del clásico método compositivo ELEMENTALISTA, tanto como la sucinta reordenación formal y funcional, limitando

${ }^{3}$ KAUFFMANN, Emil. "De Ledoux a Le Corbusier. Origen y desarrollo de la arquitectura autónoma". Editorial Gustavo Gili, S.A. Barcelona, 1982. 


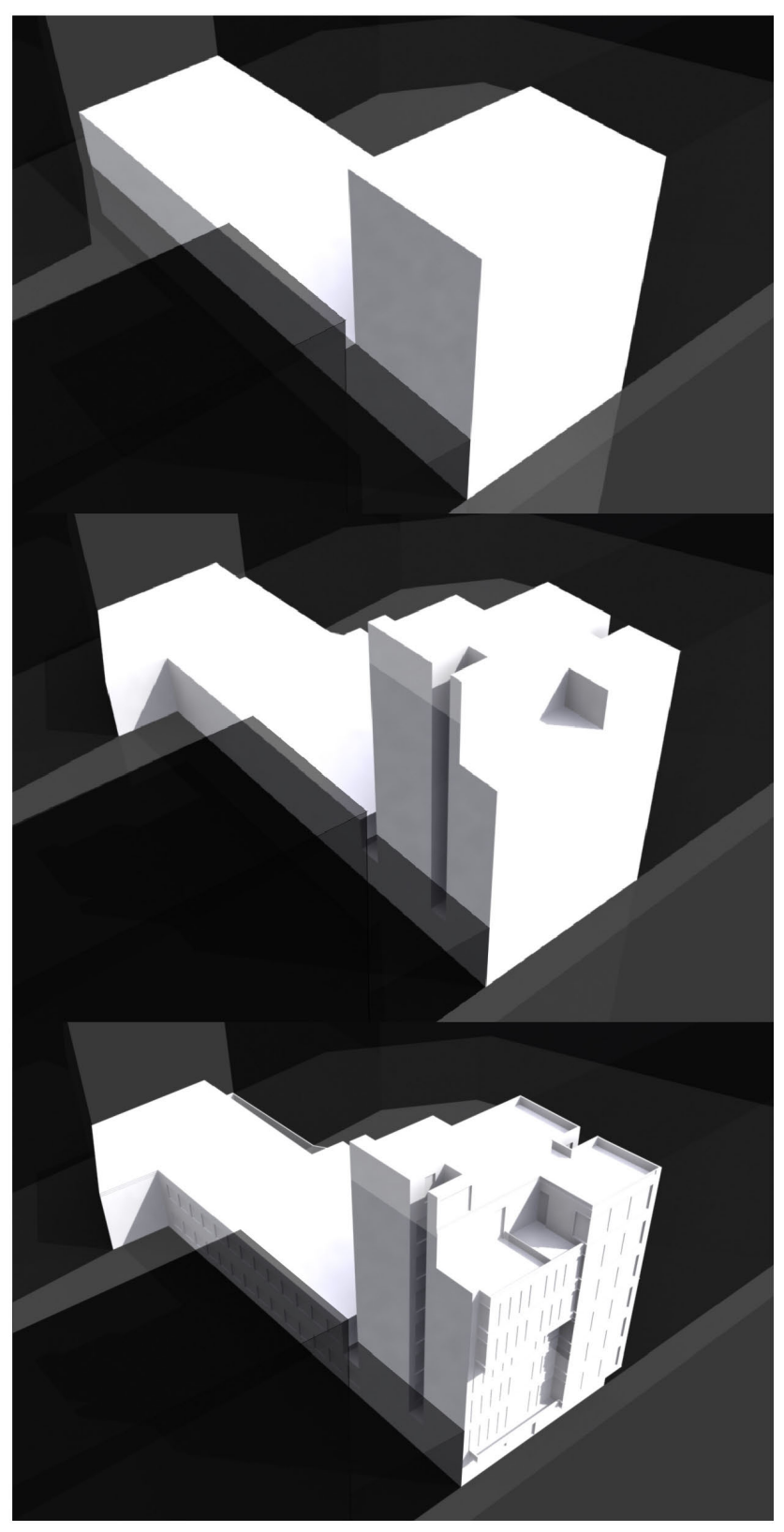

1935. Edificio Máximo BUCH; maqueta virtual: génesis compositiva configurando la volumetría vertical en calle Cuarte y su disonante replica horizontal en la paralela calle san Jacinto 
la razón analítica a un proceso gráfico, geométrico. Evidenciando la linealidad, la repetición sistematizada de módulos, se inclina Albert por la simplificación, la ESQUEMATIZACIÓN GEOMÉTRICA. Simétricas disposiciones axialmente organizadas, proporciones, subdivisiones, repeticiones, orden, relaciones gráficas y matemáticas, refieren una ambigüedad reiterada en clásicas composiciones, frente a las pretensiones modernas.

Cuando se aproxima Albert a volúmenes habitacionales, cuando el promotor resulta ser privado -atrapado en la seguridad que propician las costumbres-, si alcanza la evolución necesaria, la reorganización, la alteración formal demandada desde la nueva revolución. Se desprende entonces Albert, de simetría, ejes compositivos, repetición y orden. Amanece la ABSTRACCIÓN, la reordenación, el desequilibrio y el dinamismo, confiriendo la tercera dimensión. Resultan horizontales los movimientos y la trasformaciones lineales propuestas para los volúmenes proyectados para la Diputación, mientras que sugieren verticalidad el dinamismo ejecutado en los prismas ascendentes inmersos en la trama urbana.

Resulta pues, esta variación individual de la forma, priorizada en volúmenes aislados, singularmente concretados, la más próxima a los ideales revolucionarios, modernos, racionales. La evolución formal de aquellos prismas horizontales, recostados y duplicados -caso particular de cada pabellón del Hospital Provincial- desplazando el superior, avanzando hasta provocar atención tridimensional, fijar intuitivamente el acceso, suscitar incluso espacios singulares, nuevos y alejados de la tradición. Atendiendo a las construcciones de linealidad vertical, a los volúmenes residenciales, la desviación del prisma inicial retoma la contraposición, más que el sencillo deslizamiento. Quiero decir, al primigenio prisma anclado 

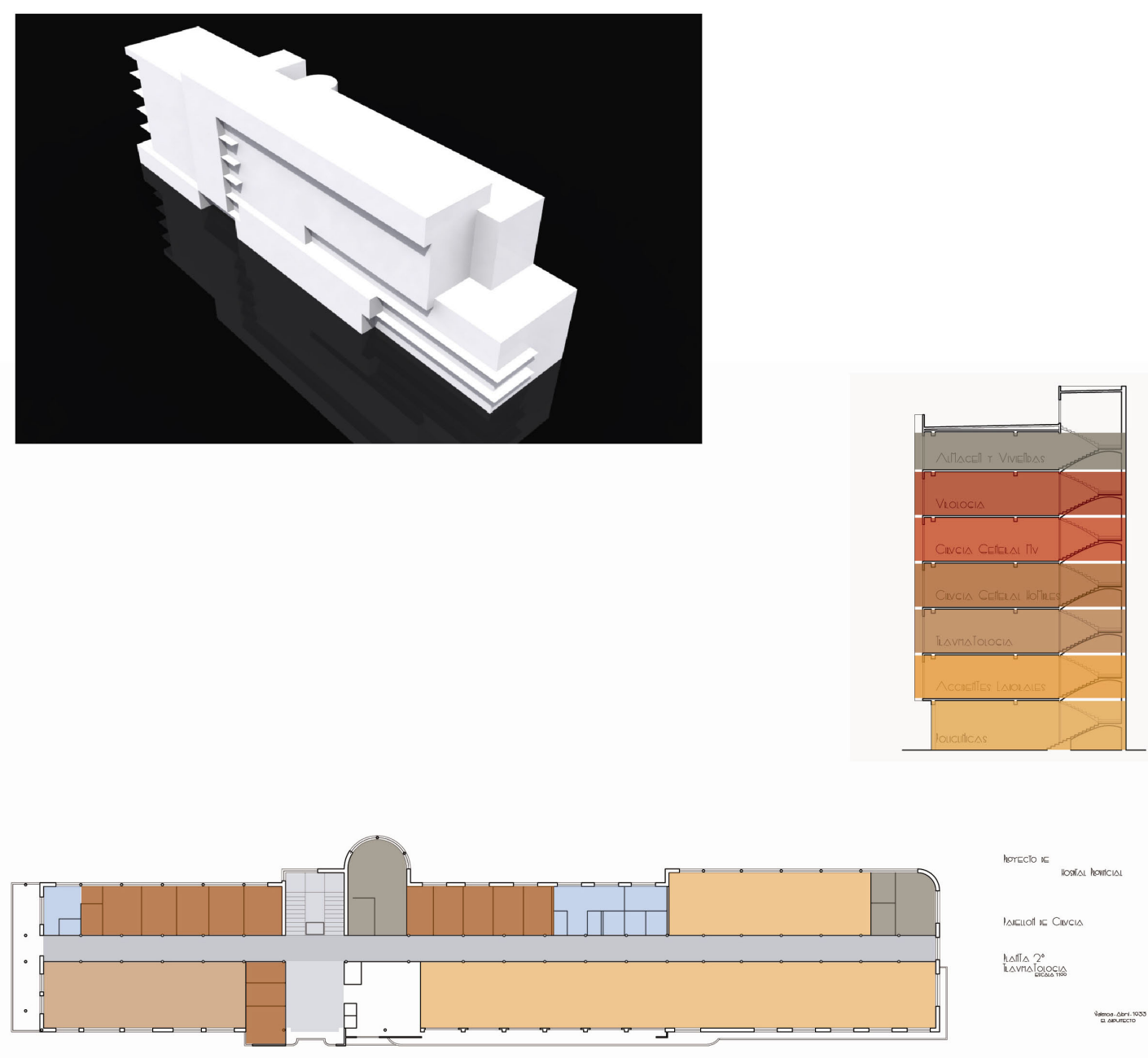

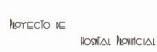

|arcuot in Civcis

Matra $2^{\circ}$

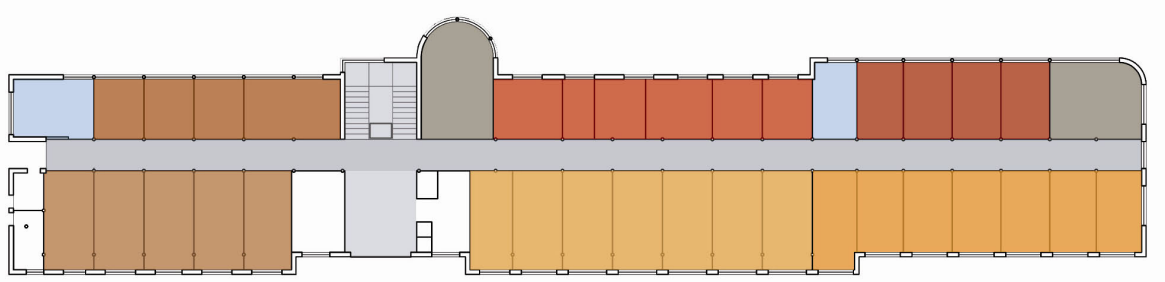

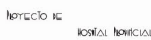

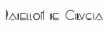

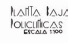

Génesis racionalista: mínimo funcional en el pabellón de Cirugía del HOSPITAL PROVINCIAL: organización del programa requerido en sección, también en su distribución por plantas 
al terreno, exactamente horizontal -tal cual hemos narrado-, le contradice un volumen vertical, ascendente e incluso aerodinámico. El rascacielos, irrumpe en la escena metropolitana, como hito de ansiada modernidad y referente de ideales racionalistas.

FUNCIONALISMO

En los momentos culminantes de la búsqueda de la utilidad, el racionalismo en arquitectura coincide siempre con el funcionalismo. No obstante, hemos reseñado que resultaba insuficiente, desde el ideario racionalista, restringirse en un funcionalismo radical -aquel preconizado por Hannes Meyer cuando alcanzó la dirección de la Bauhaus- para extraer posteriormente la forma. Surgía imperativo superar el programa, para llegar a la emoción con el espacio.

Albert avanza también, más allá de la resolución analítica del programa. En sus propuestas para la Diputación -especialmente en el proyecto del Hospital Provincial- abunda en la premisa de sencillez racionalista y prosigue la investigación, extrapolando a la sección de los pabellones la respuesta funcional. Si todos los pabellones albergan en planta de terreno 


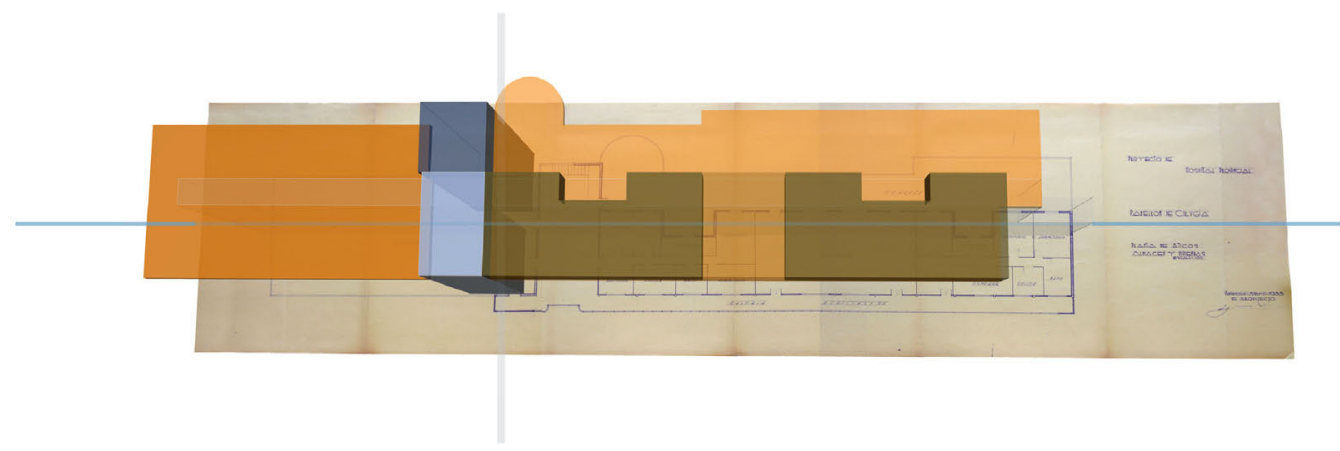

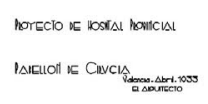

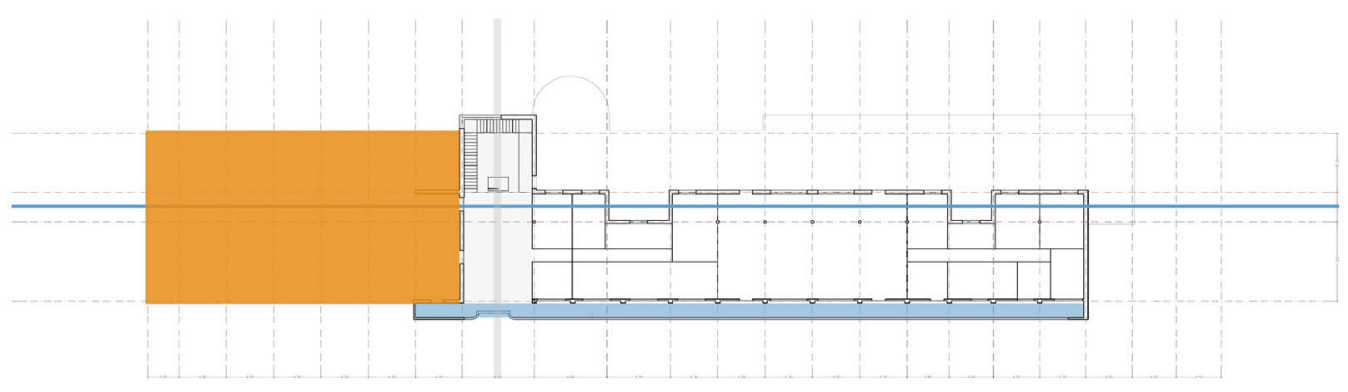

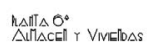

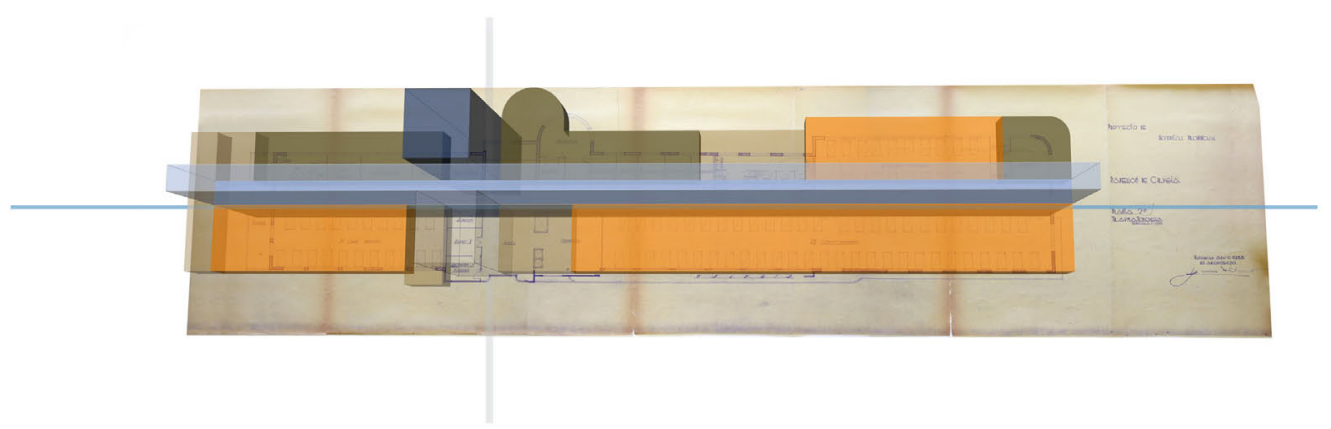

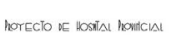

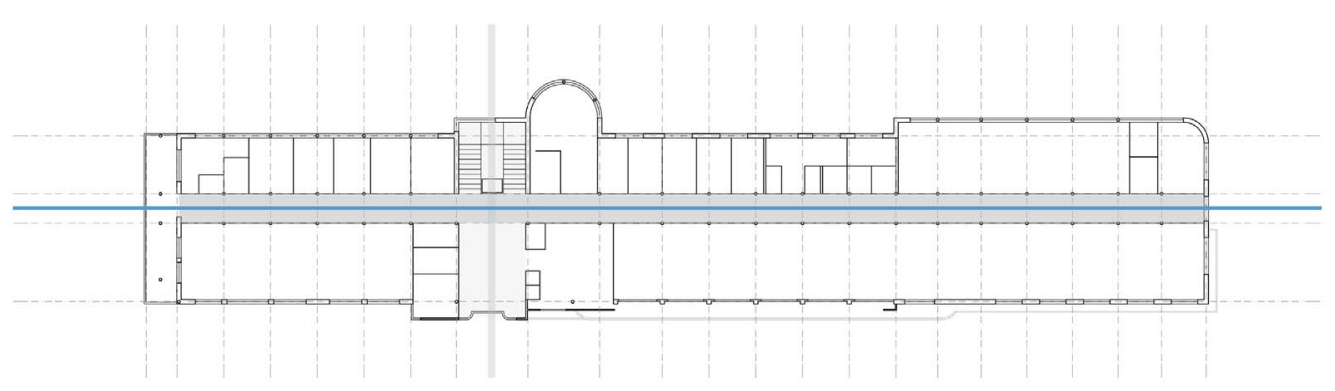

Infográficas y planimetrías narrando análisis funcional, ejes compositivos y circulaciones 
una genérica organización funcional, al distribuir en vertical el programa, cada prisma lineal resuelve por plantas sus especialidades inherentes. Solventada la funcionalidad, superada la génesis organizativa, urge retomar el proceso de reordenar, componer la forma hasta alcanzar un nuevo espacio moderno.

Podría haber proclamado su investigación en el módulo de consulta, tal como había anticipando Sert con su Dispensario Antituberculoso de Barcelona. Sin embargo en el caso que nos ocupa, asoma insuficiente presentar una célula clínica-despacho médico, enfermería, curas, archivo, etc.- extrapolable a toda especialidad, siempre que no sea llevada al MÍNIMO DIMENSIONAL y, sobre todo siempre que perezca, distribuida en planta, en espacios desocupados por habitaciones para enfermos. Bien cierto es, que también podrían haber resultado, estos recintos para alojar pacientes, depositarios de camas, los investigados para alcanzar el espacio moderno, dimensionando mínimos, industrializando sus contenidos, dominando el CONTROL LUMínICO y VISUAL, tal cual indicó Aalto en Paimio.

Propone Albert, la emancipación entre módulos de consulta y alojamiento de pacientes, mediante el surco circulatorio, organizados en uno de los lados de la línea arquitectónica, en función la cantidad de luz y ventilación requerida, del control visual. No siempre de manera exacta o empecinada y, manejando ambigua la jerarquía de ambos usos. Y además, a esta aspiración moderna del espacio, todavía le falta liberarse por completo de la estructura, que abraza en parte, sin asumir su total independencia, para proferir evidencia a la reinvención del espacio moderno. Muy próximas permanecen las propuestas albertianas del ideario racionalista, 

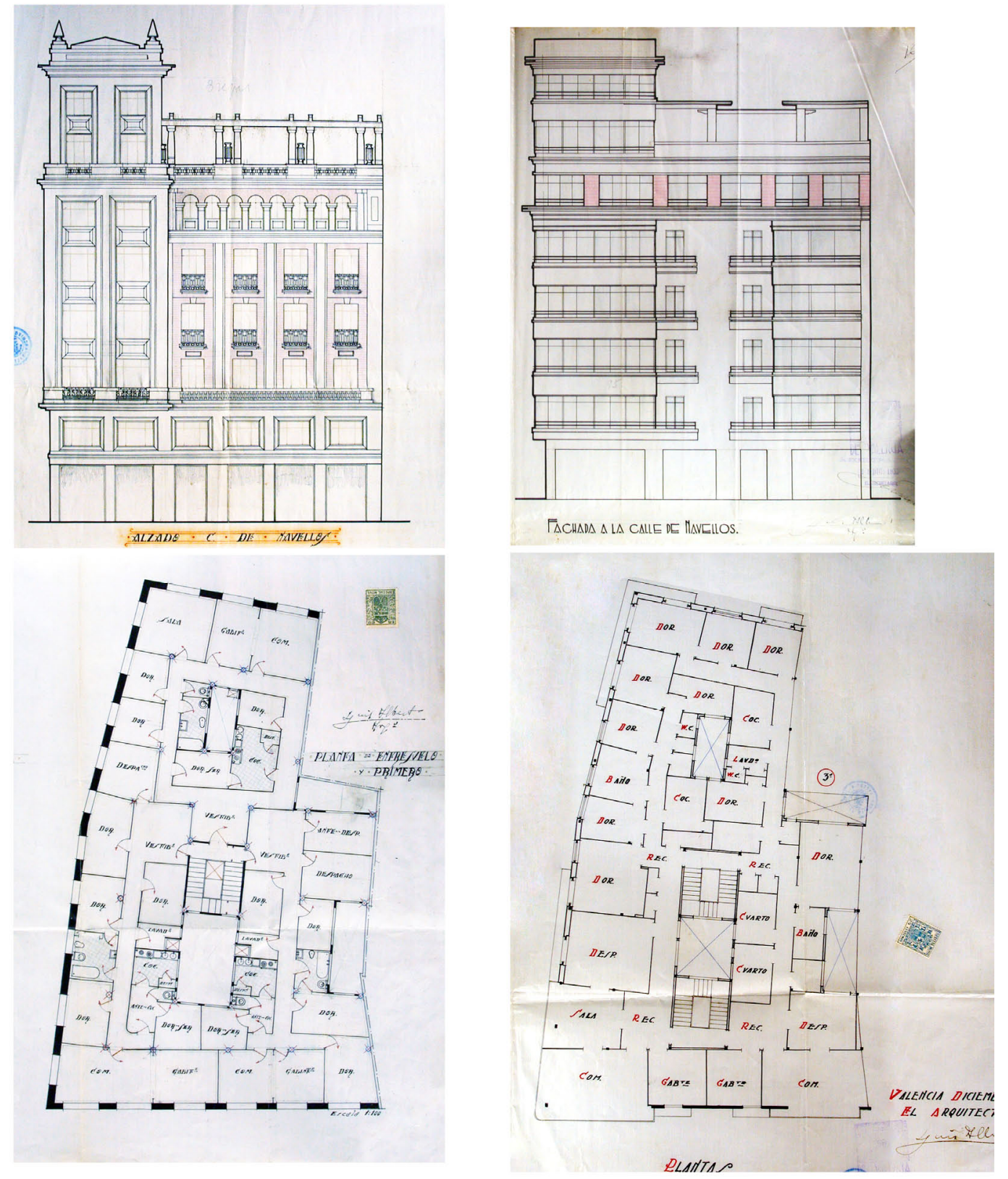

Luis ALBERT, 1932. Edificio Manuel CÁNOVAs, calles Navellos, Micer Tarazona y Yerba: una ecléctica primera propuesta y su modificado (1933) de escaso avance distributivo 
cuando su cliente proviene de la Administración. Seriados módulos, organizados a dos manos de dinámicas líneas. Asimétricamente distribuidos, jerarquizados y dispuestos a lo largo de circulaciones horizontales coincidentes en sección y relacionados mediante el núcleo de circulación vertical inminente a los espacios receptivos de cada planta.

Cuando concentra el interés del promotor privado, en los edificios residenciales, a erigir en una escena metropolitana consumada, Albert navega entre posturas coetáneas. Permanece dilucidando entre, ora organizaciones funcionales aprehendidas, academicistas de finales del XIX, constatadas posiciones eclécticas, ora distribuciones orgánicas resolviendo problemas según exigencias del 'individuo tipo', del espíritu innovador de las corrientes europeas, con una funcional respuesta a la carga programática planteada desde las vanguardias.

Alejadas se intuyen aquellas investigaciones publicadas en los congresos CIAM. Improbable asoma experimentar con mínimos habitacionales, tipos estandarizables, EXISTENZMINIMUN. La apuesta por reinventar el espacio doméstico, desvinculado del pasado y construido mediante leyes universales queda relegado a la ortodoxa vivienda moderna, cuyo destino último, generar ciudad si resulta atendido por Albert.

Tiene escaso margen de innovación cuando se maneja con clientes habituados a clásicas fórmulas probadas. Evitar la desaprobación del usuario con los inmuebles habitables plantea el dilema y profiere la escisión heterodoxa, aferrados a sendas eclécticas. Independientemente del espíritu generador pueden observarse semejantes planimetrías en cualquier edificio del Ensanche. La burguesía provinciana, no consintió atender 

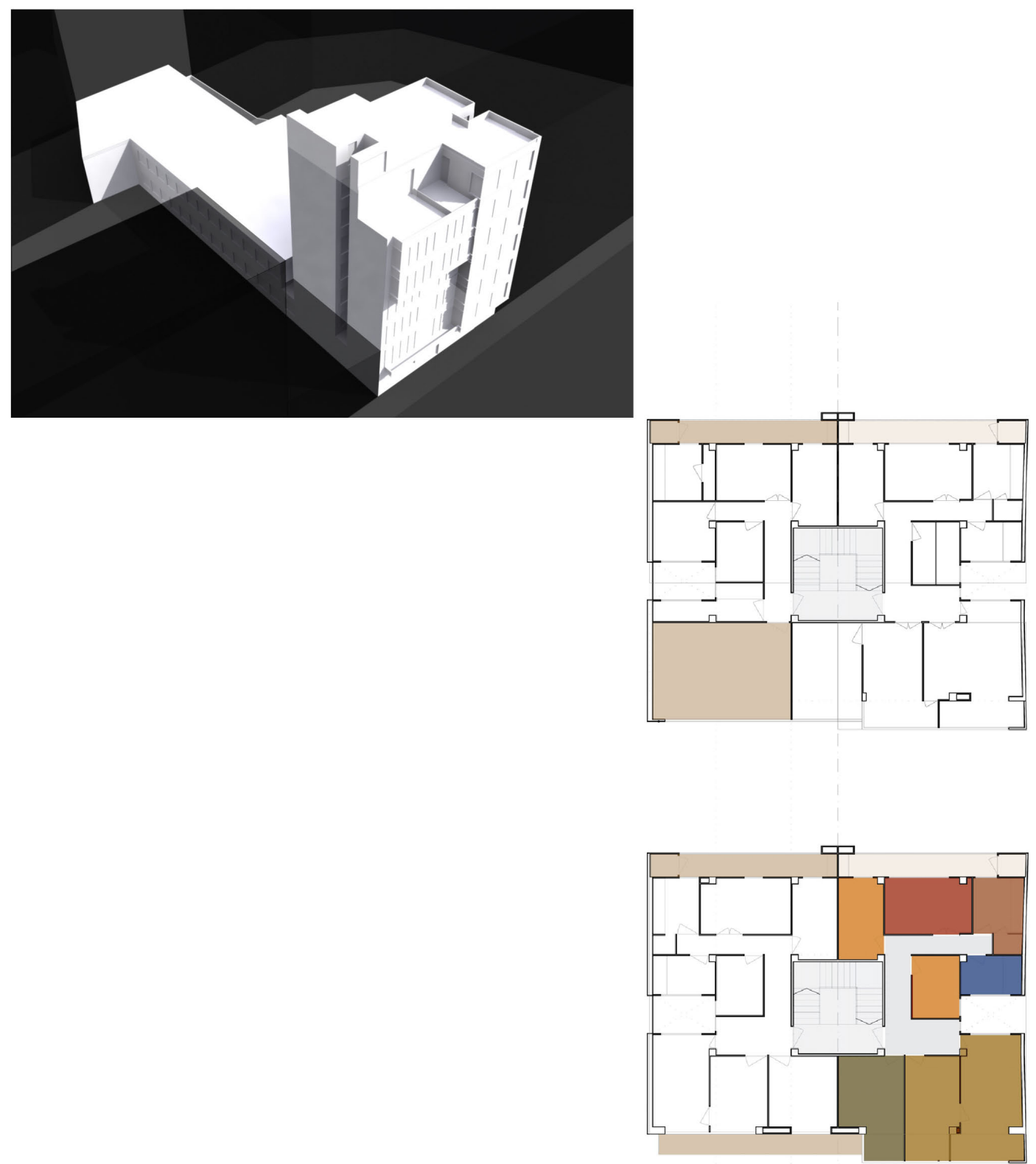

1935. Edificio para Máximo BUCH; maqueta con la composición final de prismas, su articulación y dinamismo volumétrico; esquemas de organización funcional, evidenciando agrupaciones de usos y diferenciado terrazas según fachada a calle Cuarte o patio de manzana 
la nueva orientación moderna, rechazando distribuciones vanguardistas y limitando su exigencia al tratamiento externo -una fachada era capaz de distinguir socialmente-. Semejante tratamiento entre forma y función, disociados como procesos independientes, propio de la arquitectura ecléctica, procuró proyectos con alzados alternativos para idénticas distribuciones, basadas en el esquema clásico del XIX. Semejante evidencia la podemos discernir en el edificio para MANUEL CÁNOVAS, donde una primera propuesta ecléctica revierte su lienzo de fachada, hasta ofertar una dinámica forma, convencida en su tercera dimensión. Organizar usos transversales, siguiendo un eje perpendicular a fachada-aquella recayente a calle principal- que van restando dimensión e importancia según avanza la secuencia hasta el patio interior de manzana, no parece impedimento en la aportación a la escena urbana.

Tan sólo un atisbo de luz, nos permite dilucidar Albert en su edificio para CARMEN ALONSO, concretamente en la disposición funcional de la torre ascendente. Tan sólo un atisbo de racionalidad - ni tan siquiera exportado al remanente distributivo del edificio- abandonando la senda ecléctica, aquella que conduce a una preclara heterodoxia en el grueso de sus propuestas residenciales. Honrosa excepción supone el legado del edificio para MÁXIMO BUCH, donde encontramos una dupla de viviendas por planta evidenciando la funcionalidad de sus esquemas distributivos. Agrupando usos principales, congregando núcleos húmedos con servidores, relacionando comedor con cocina y, finalmente, manifestando la segregación de funciones nobles -enlazadas a la asimétrica fachada urbana sobre la calle Quart- de aquellas sirvientes -ofertadas al patio de manzana- constituye el moderno espacio pretendido. Mediando luz, dimensión y movimiento, Albert alcanza los ortodoxos ideales racionalistas. 

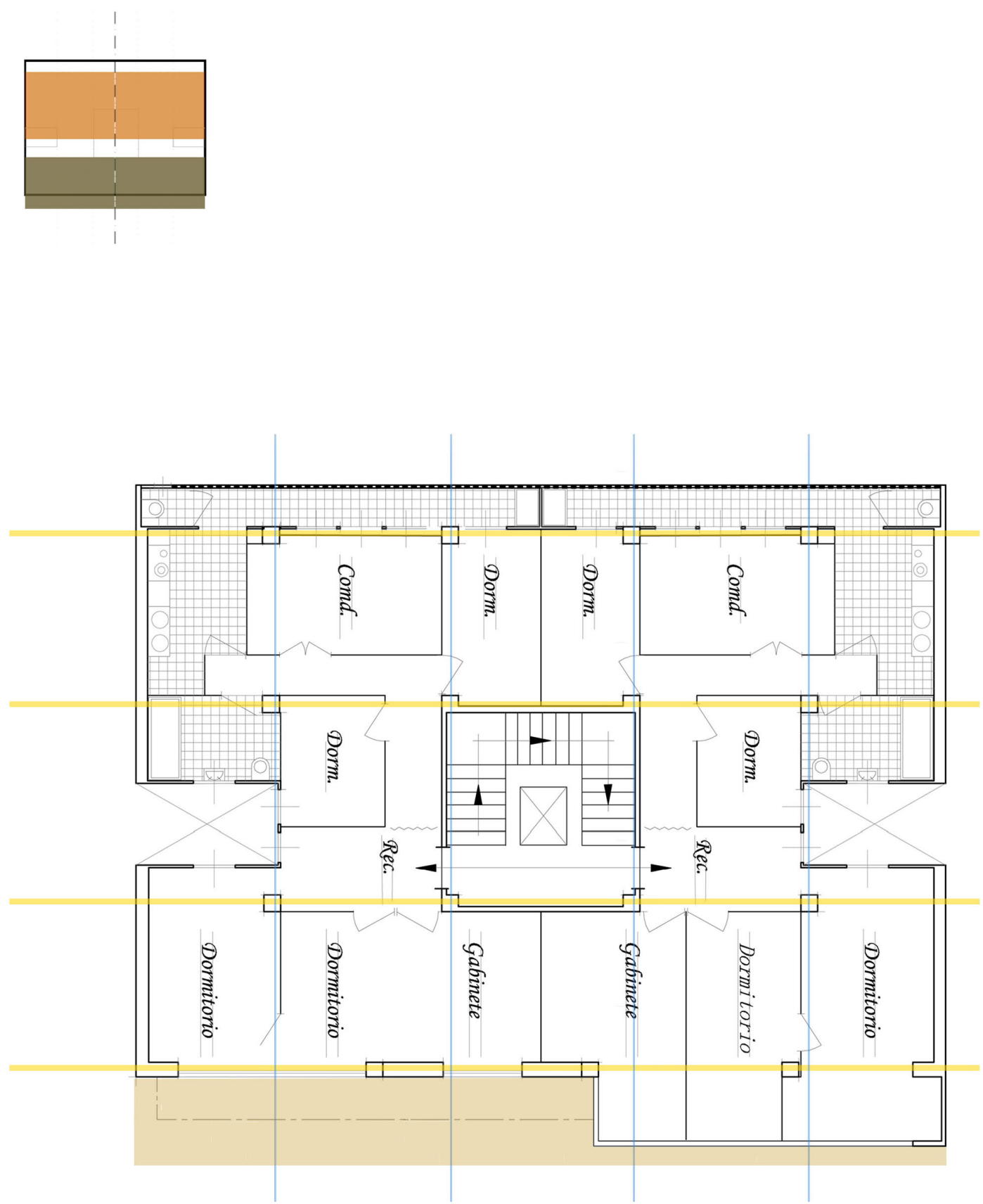

Edificio para Máximo BUCH; trama generadora de pórticos estructurales; retícula compositiva funcional, con líneas ortogonales a eje principales organizados paralelos a fachada 


\section{SISTEMAS ESTRUCTURALES}

Usando de procesos lógicos, geométricos, matemáticos y también abstractos, plantea Albert el orden estructural de sus intervenciones arquitectónicas. Siempre una RETícULA ordenada, una retícula de puntos organizados en su distribución en planta. Siempre una métrica sistematizando líneas equidistantes y ordenadas.

Sin embargo semejante retícula, lejos de dominar con espartano rigor el proceso de ideación edilicia, se aviene a las exigencias funcionales y espaciales. Lejos de encorsetar la distribución funcional, tanto en las propuestas públicas como en las rígidas promociones habitacionales, adapta la distancia inter-ejes, modifica el entramado reticular descomponiendo estrictas equidistancias. Sucede otro tanto cuando la exigencia surge al introducir espacios diferenciados de la sistematización funcional. Esto se exhibe -por dejar un apunte- con preclara nitidez en los pabellones del Hospital Provincial, en los espacios de cruce entre comunicaciones horizontales y verticales, destinados a relacionar usos, al igual que transversalmente, varía la distancia entre ejes estructurales dependiendo si el espacio contenedor debe albergar pacientes, pasos o módulos de consulta. El orden racional, acompaña en los sistemas estructurales.

ORDEN, UNIDAD y SIMPLIFICACIÓN. Independientemente del material que formalice la retícula estructural. Bien el acero estructural, restringido a unos puntos ordenados en planta, bien el hormigón armado regodeándose en la trama reticulada, siempre el orden preside la métrica del entramado. Estructura presente 'siempre', más nunca con rotunda comparecencia. Si los tabiques habían quedado liberados de toda función portante, restaba desligarlos del corsé estructural, aflojar el abrazo estructural 


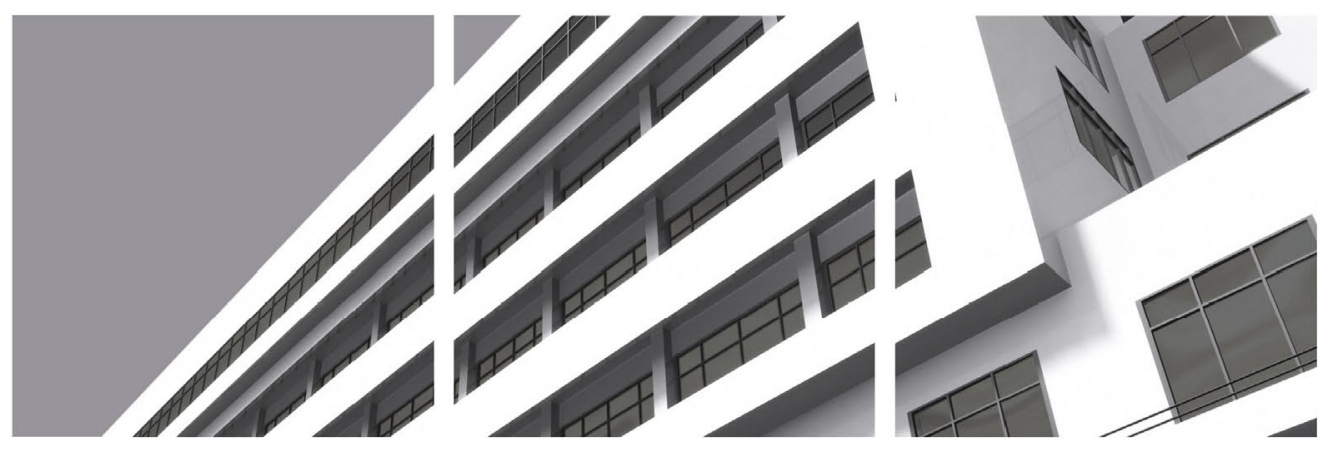


y alcanzar la preconizada 'PLANTA LIBRE'. Ante todo, azuzaba apremiar espacios racionalistas. La moderna pretensión espacial, desprendida de las ataduras estructurales e historicistas, añoraba un nuevo tratamiento, diferenciado según estancias. 'Componer es ordenar cosas desiguales, y su punto primero y principal es el determinar cuál será la principal señalaba Ruskin. Otro tanto demandaban las fachadas, los planos de cerramiento.

MEMBRANA EXTERNA

Olvidada su restrictiva función portante -aquella que inhabilitaba pretensiones de autónoma fenestración-, adquirida su independencia frente a la transmisión de cargas, impelía poder concentrar su acción en aislar del exterior, en expresar mediante un lenguaje moderno su relación con la función envuelta. Instigaba -su recién personada potestad-componer en libertad, sin atender 0 , muy al contrario, dejándose guiar por trazados geométricos y anticipar aquello que guardaba de los rigores climáticos.

Desvincularse de las austeras imposiciones por parte de la estructura, debía erigirse como premisa primera. Adquirir la capacidad ilimitada de 


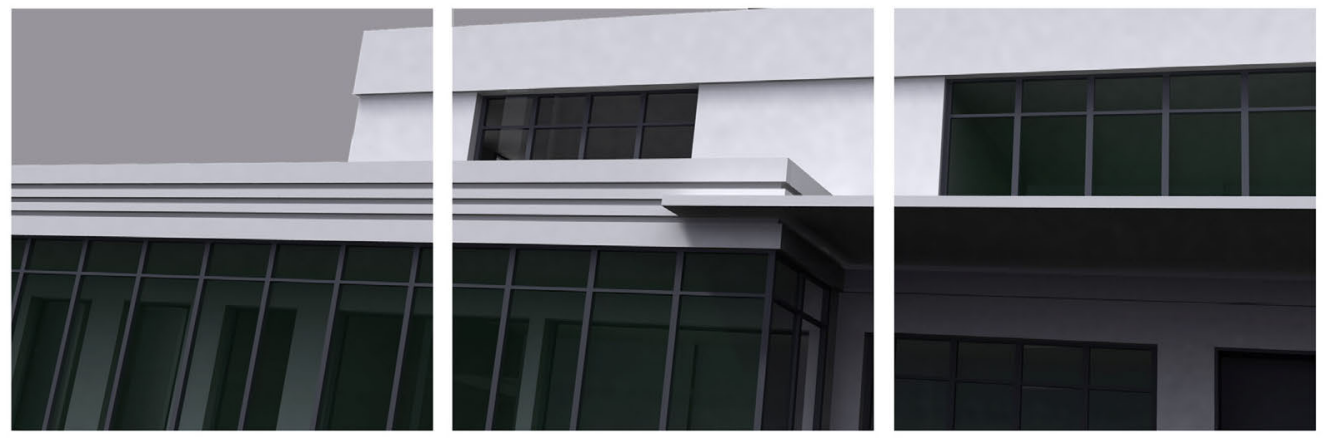


horadar en continuidad la membrana preservadora, culminaba las aspiraciones. Ambas, facultarían los modernos postulados renovando la imagen edilicia. El ideario racionalista acuñaría el término 'FACHADA LIBRE', sintetizando las aspiraciones de aquellos ideólogos más estrictos y de los jóvenes profesionales embebidos de su espíritu renovador. Christian Zervos citaba el 'espíritu de la joven arquitectura' fuera de la estricta doctrina, del rigor de los primeros momentos de pureza, de las vanas sutilezas. "Lo desnudo no es forzosamente el fin último de lo moderno. No será lo más moderno una construcción con ventanas horizontales, o descoronada de su cornisa, si el arquitecto no ha exprimido el espíritu de lo que ha construido. (...) Sorprendido por los reproches que se han hecho a Le Corbusier de buscar en sus construcciones obras de esteta, engañados por fórmulas un poco más simplistas y elementales que hacen del arquitecto un constructor de máquinas de habitar, algunos de entre los jóvenes han llegado a considerar el arquitecto como el realizador de un encargo con fines utilitarios, desprovisto de fantasía y de corazón".

Surgiría la controversia, con aquellos otros arquitectos carentes de causa que utilizaron el lenguaje de estos jóvenes convencidos, para imprimar una pátina modernizadora a sus pretensiones, alejadas de toda fortuna racionalista. Composiciones planimétricas adscritas a determinados códigos formales - 'estilo'-, ostentando todo lujo de referencias y detalles de este nuevo lenguaje, aunque manteniendo posiciones más tradicionales, encubiertamente eclécticas.

Albert tampoco transita más allá de procurar una visión epidérmica del racionalismo expresivo, instaurado en la mayoría de sus encargos públicos por parte de la Diputación de Valencia. El expresionismo, la alternancia 


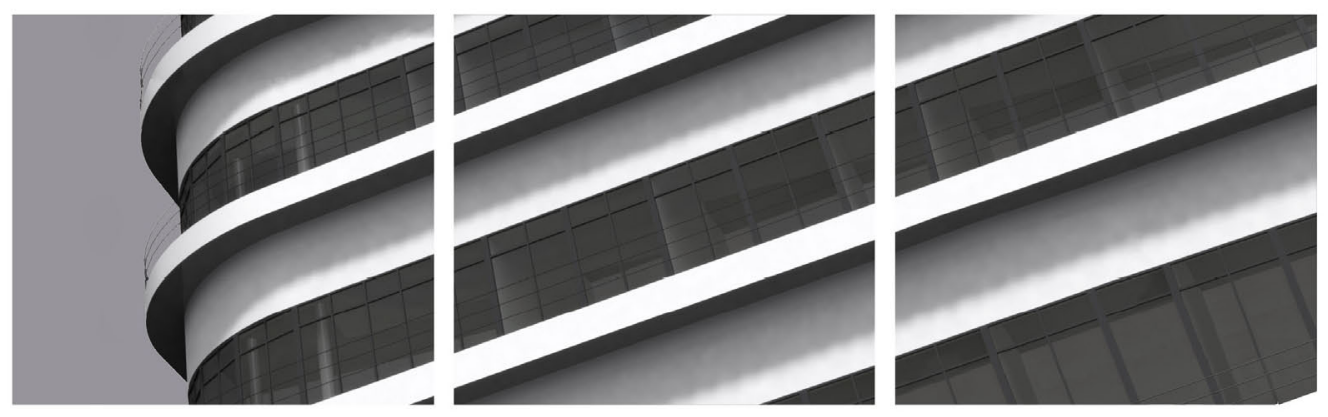


en franjas horizontales de vacíos y llenos, constituye la imagen característica en sus visuales proyectivas. Así rezan los lienzos de fachada propuestos para la totalidad de pabellones, en su propuesta para el Hospital Provincial y, también para el Manicomio de Porta Coelli. Plantea membranas opacas donde hender potentes fisuras horizontales, para devolver al usuario el paisaje del que ha sido arrebatado -obsequiarle con su visión enmarcada- y plantea una dialéctica de superficies llenas y trasparencias capaces de otorgar al espectador la imagen arquitectónica pretendidamente moderna. Allí, los pies derechos no amanecen claramente exentos, pero tampoco desaparecen embebidos en la planeidad vertical de las fachadas. El libre discurrir de los elementos de cierre abandona su ortodoxa ideación, para albergar un estilo, un lenguaje reconocible no obstante alejado del espíritu revolucionario e, incluso puesto en duda al introducir los elementos verticales dinamizando la fachada.

Otro tanto sucede en las promociones privadas, en los bloques habitacionales, erigidos para la metrópoli. El analizado edificio para CARMEN ALONSO, también el del cónsul MÁXIMO BACH, carecen de fachadas tradicionales. Cada una de estas construcciones, de diferente diseño, se extiende formalmente en tres dimensiones, mediante composiciones horizontales y verticales dispuestas asimétricamente en armonía, alcanzando el pretendido equilibrio dinámico. Y sin embargo, ninguna de ellas procura evidenciar en el exterior su función interior. Sus variaciones compositivas no responden a la métrica funcional de estancias, tanto como a la complacencia de una sociedad valenciana que demanda arquitectura moderna, aunque también como modo de producción, como forma de expresión, nunca como ideología. 

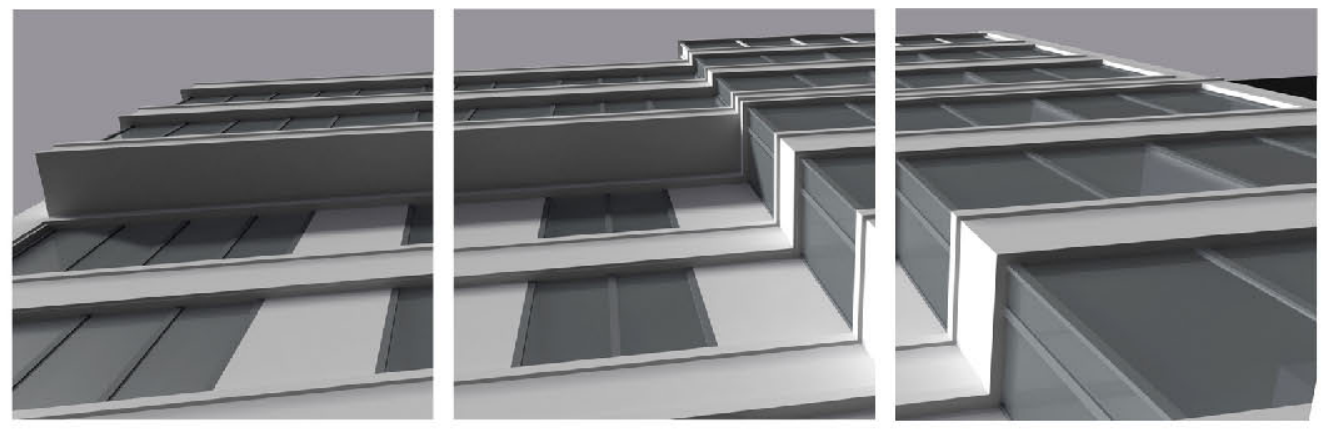

Maqueta virtual doctorando: Edificio Máximo BUCH, calle Cuarte y paralela san Jacinto 
Varios factores contribuyen a ello, apunta Peñin: 'la gran crisis económica estallada en 1929 y que desaconseja todo lujo superfluo, la emigración masiva a la ciudad del decenio 1930-40 con la existencia de un proletariado urbano que alojar cada vez más numeroso, la mayor fuerza de los sindicatos obreros y carestía de la mano de obra y, en último extremo, el apoyo que a la nueva arquitectura prestó la República'. También el empresariado prestó rápida aceptación a las nuevas técnicas, por su mayor ritmo de ejecución, sus posibilidades de construcción en altura y las mejoras ofertadas en el aprovechamiento de los solares. El hierro, el hormigón armado y el vidrio mejoraban las facultades para atender una demanda con menor poder adquisitivo, tanto como surcar horizontalmente la membrana externa.

\section{AZOTEA COLECTIVA}

Transformar la Naturaleza desde concepciones modernas, doctrinas científicas, encumbrándola en la azotea construida, supuso parte del nuevo espacio de la modernidad. Proyectado hacia adelante, olvidando el pasado y constituido por leyes universales. Retomar el espacio exterior y relacionarlo con el interior con la casa y, en definitiva, con la ciudad. 


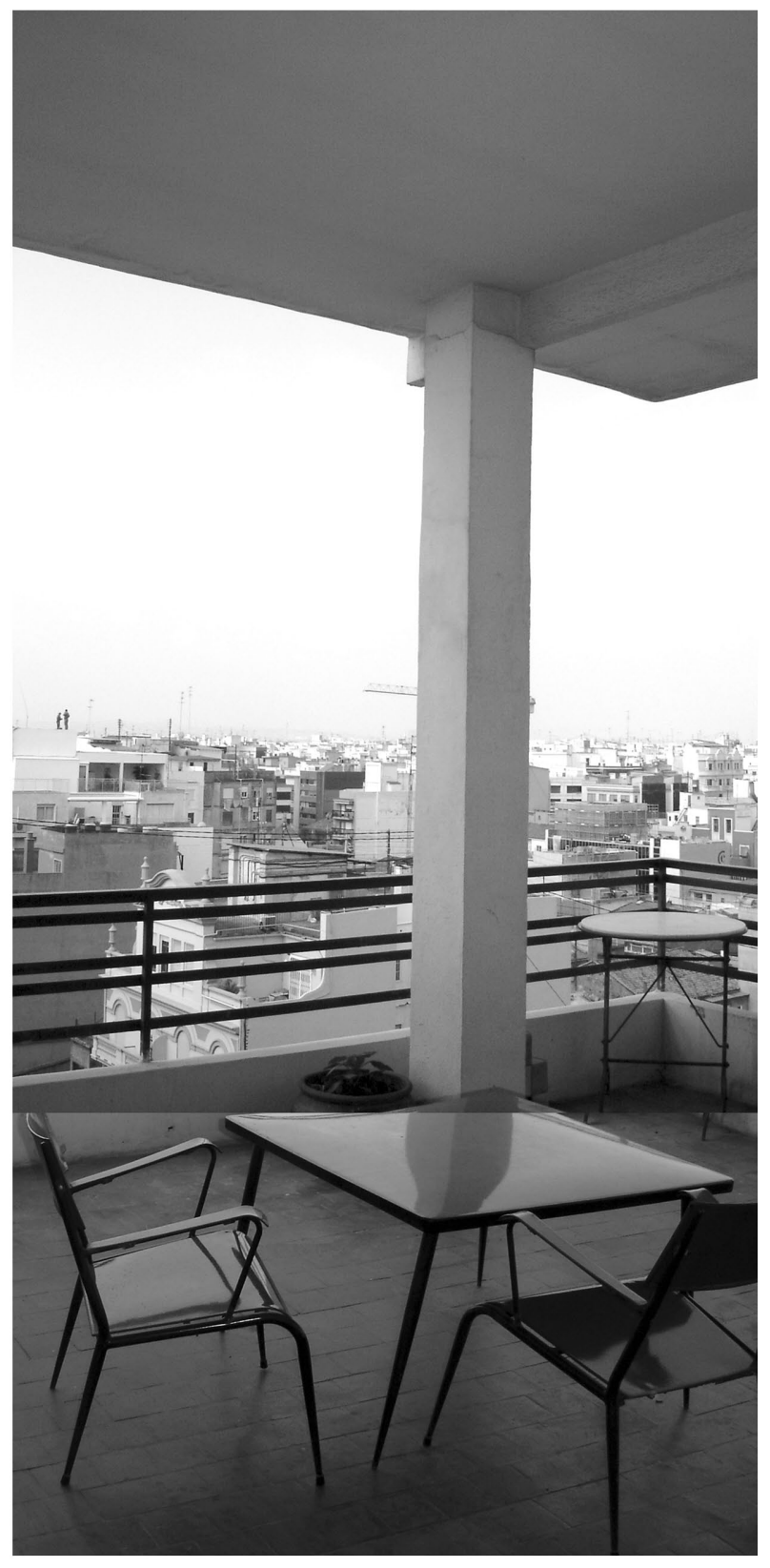

Edificio para Carmen ALONSO, fotografía de ático particular, mirando a calle San Vicente 
El Movimiento Moderno, con la quinta fachada recurría a idéntico tratamiento ejercido con los surcos longitudinales en fachada: usurpar primero para posteriormente retornar. Al usuario, tras implantar la volumetría edilicia y haberle segregado del terreno, se le vuelve a obsequiar con la tierra vegetal como firme y la bóveda celeste por cubrición.

Emulando concepciones médicas, ya entonces vigentes, dotar funcionalmente a la cubierta se imponía sencillo, cuando el edificio requiere un programa cuyas necesidades reclaman los beneficios solares como tratamiento sanitario $o$, simplemente, cuando el espacio privilegiado de la vivienda se exponía, cuando lo colectivo adquiría rango superior. El aire libre y las impresionantes vistas recuperadas desde cotas inusuales, facultan colectivamente el uso de la cubierta.

No parecía tener entrada, cualquier otro tipo de de solución constructiva que no fuera una superficie plana, horizontal, facilitando el tránsito y ofertando respuesta a través de los nuevos materiales y técnicas de construcción: el hormigón armado. Una cubierta, por otra parte, ya clásica en las culturas mediterráneas y llevada a la estricta viabilidad, austera comprobación de su diseño, en soluciones tan cercanas como la propuesta por el GATEPAC y la mencionada para el Dispensario de Barcelona.

Dotar de funcionalidad a la quinta fachada de un inmueble urbano, comienza a resultar preeminente. Requiere también, de una base teórica, unas imposiciones sociales, ideales racionalistas. Hemos atendido las propuestas soviéticas de los años veinte, reduciendo al mínimo la unidad habitacional individual y, en contrapartida, elaborar comodidades colectivas redistribuidas por el volumen construido, incluyendo la cubierta. 

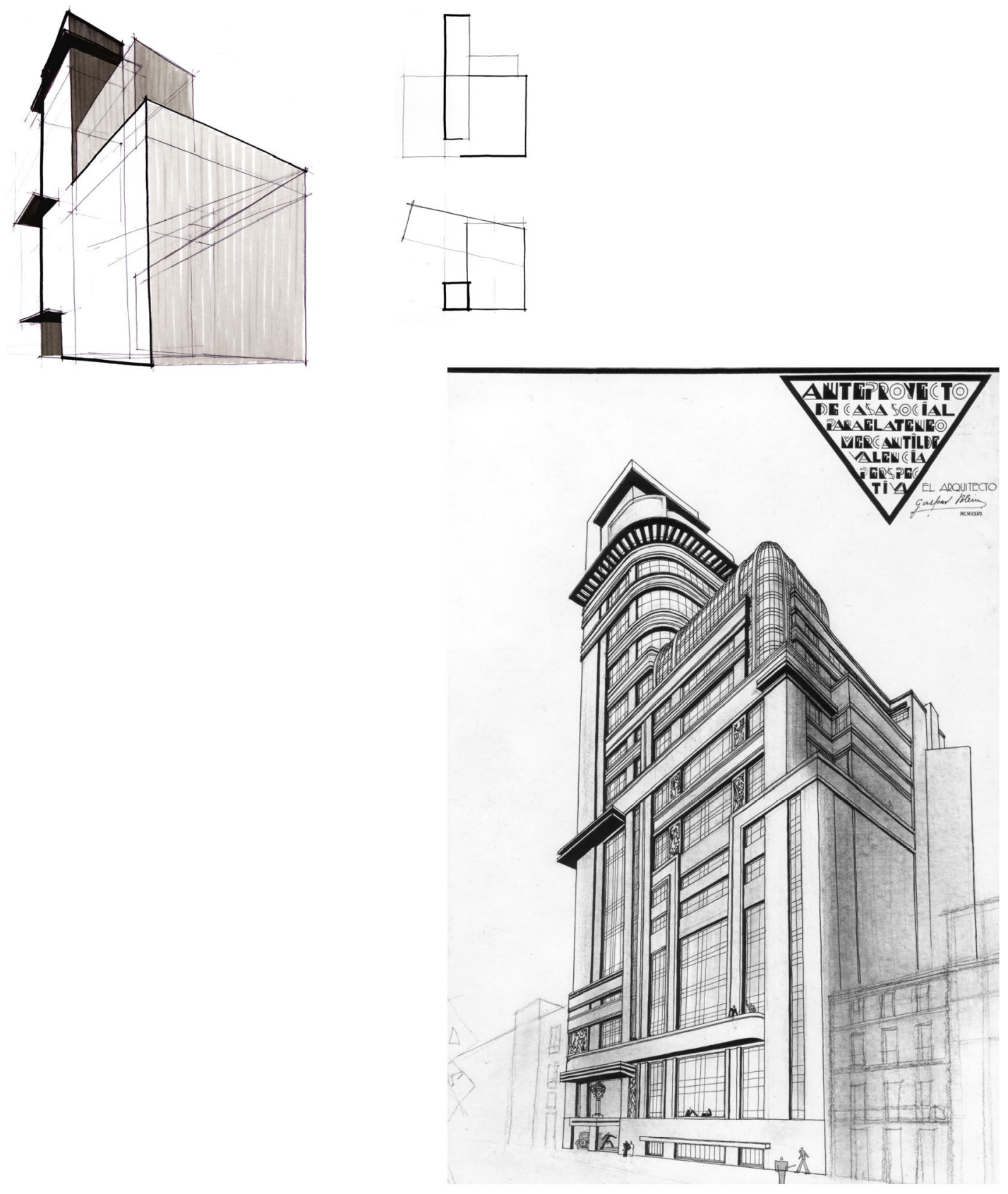
Hemos constatado a Le Corbusier modificando y adaptando las azoteas propuestas por Perret, preludiando servicios comunes a los habitantes, o jardines entregados a los detallados apartamentos de los áticos, retirados en terrazas a medida que el edificio ascendía en sección.

Albert permanece impermeable a los principios vanguardistas de socialización del inmueble $y$, por ende, desestima la propuesta de servicios colectivos en la azotea de sus edificaciones habitacionales, al igual que pasa por alto la cubierta ajardinada. Sus límites quedan fijados en el disfrute visual del entorno -por quien detenta su dominio, privado en la mayoría de las veces y, excepcionalmente colectivo- o la correcta garantía del plano horizontal, aislado y alejado del agua.

\section{INTENCIÓN MODERNA}

Cabe destacar a Luis Albert entre los promotores de la intención racionalista arquitectónica, para la capital levantina, en la trasnochada España de los años treinta. Paradigma entre aquellos jóvenes arquitectos valencianos que edificaron la metrópoli, tratando de consolidar los principios racionalistas, todavía sus aportaciones dejan traslucir su voluntad de modernidad, 


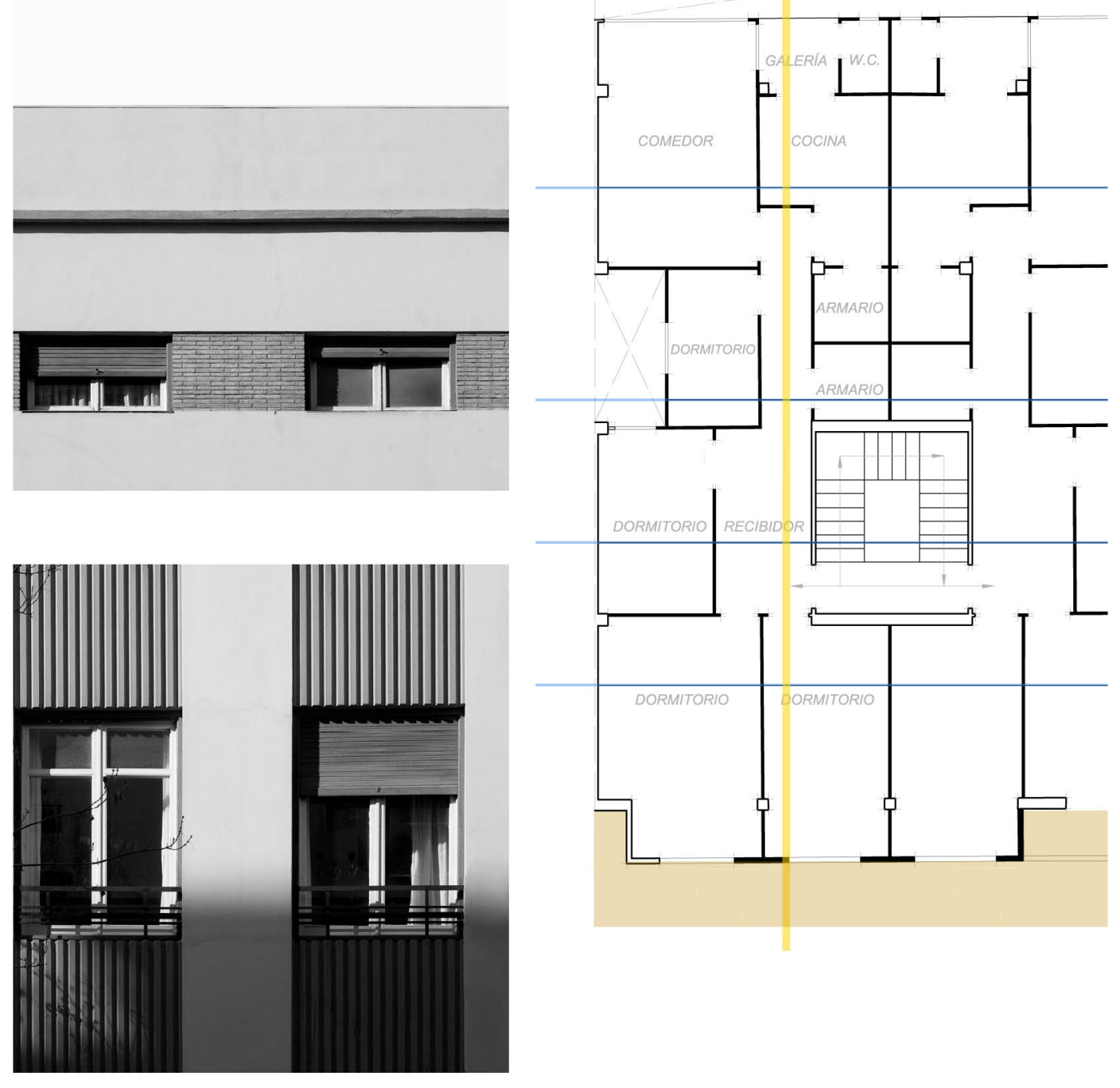

Luis ALBERT, 1935. Edificio de viviendas para José Manuel ZABALA, calle Cuenca n 16 
su concordancia con el espíritu trasgresor del momento, contrario a imposiciones historicistas.

Albert persiste engastado en un reducido elenco de flamantes arquitectos comprometidos por acomodar en la modernidad, toda una sociedad anhelante. Sus obras pretendidas, también en parte las construidas, se perpetúan como arquetipos de logros evidenciados y, otro tanto, reflejo del fracaso de una veraz arquitectura racionalista. Autor de propuestas intelectuales -nunca erigidas tras imponerse las limitadas miras de los poderes políticos locales- próximas a la ortodoxia y, a su vez, consolidado creador de iconos reconocidos en el deambular urbano contrastados "al margen", no alcanzaría rango suficiente para mantenerse adscrito en la minoría selecta o rectora, conforme a la doctrina moderna.

Resulta más evidente en Albert, si cabe, hablar de decepción en la intención ortodoxa, de frustración en su voluntad racionalista, de límites y cortapisas que indispusieron su producción y la inventariaron considerándola al margen; inalcanzable la cota marcada por el GATEPAC, los próceres de la arquitectura moderna española. Irrebatible se infiere esta segregación, cuanto menos advirtiendo la escasa impronta que hollarán sus aportaciones en los catálogos de arquitectura moderna, hasta hace escasas publicaciones. Manifiesta tras compartir semejante destino con el grueso edificado de la arquitectura patria, heterodoxa-cúmulo premioso en engancharse al tren de las vanguardias europeas-, exigua en sus convicciones. Incuestionable al estallar una guerra que proclamó el fin del apoyo institucional -favor prorrateado por desigual a lo largo y ancho de la geografía nacional, destacando en Valencia por su escasez- a toda modernización social, cultural y por supuesto edilicia. 


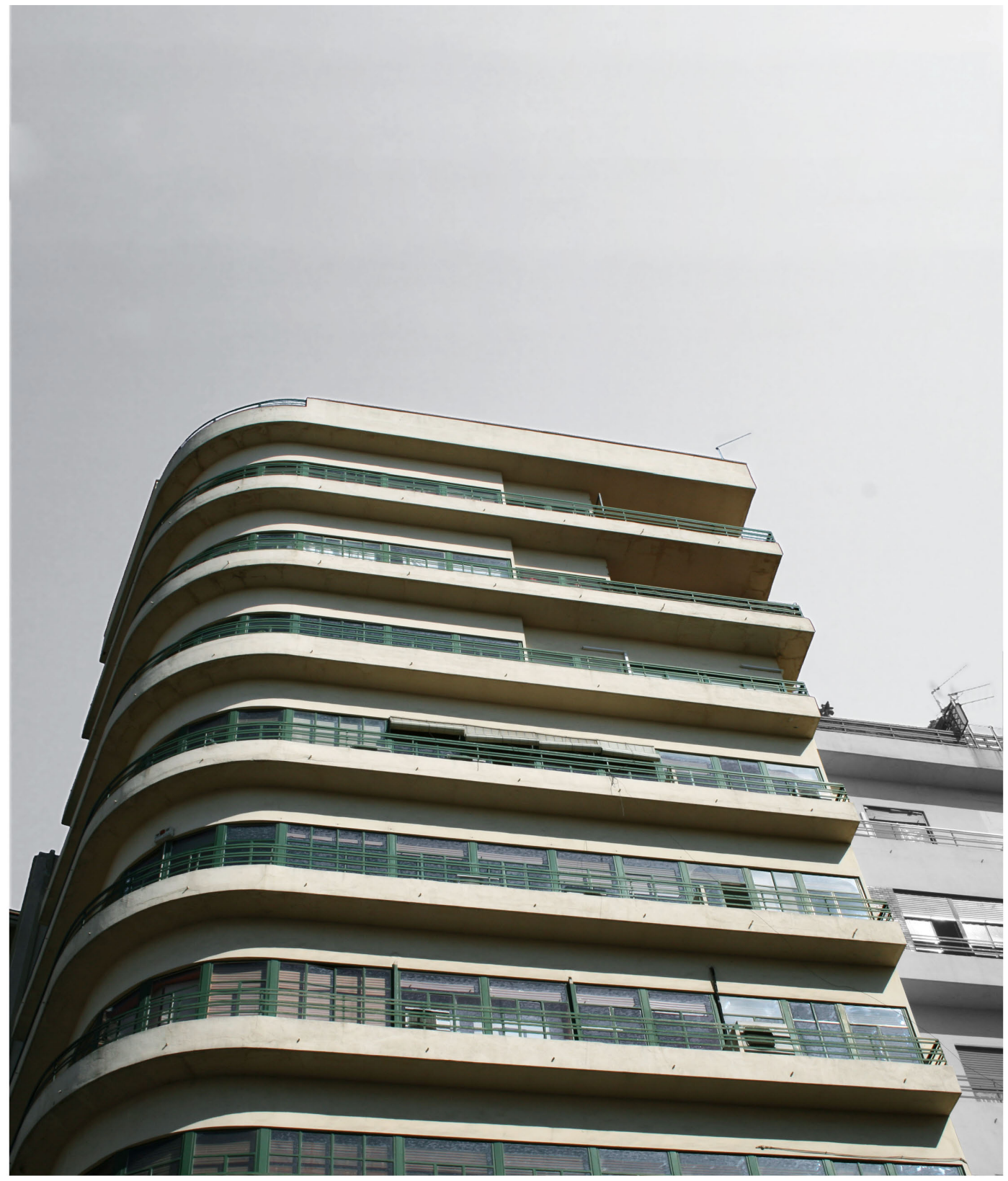

Edificio para Carmen ALONSO; la arquitectura procura imponer su mensaje en la escena metropolitan: convertir la construcción en icono ineludible de modernidad 
La voluntad RACIONALISTA resuena inherente en las distinguidas aportaciones -segregadas, repertorio electo en este documento- de Alberty, sin embargo, frente a esta intención ortodoxa, triunfa la reconocible imagen. Frente al fondo propositivo de su concepción, los clichés enfocan la modernidad como objetivo pretendiendo, persiguiendo una imagen, una iconografía. La FORMA, la desnuda piel envolvente, compuesta mediante ventanas horizontales, descoronada de cornisa y, en su caso el dinamismo expresionista, evocan la pretendida evolución moderna. La funcionalidad que postula al arquitecto al servicio de los hombres, atendiendo necesidades contemporáneas, aproxima - sin quedar sobrepasadas la distinción de obras selectas- los ideales racionalistas, acariciando el grado de compromiso emprendido -tiempo atrás- por las vanguardias europeas, o el muy próximo GATEPAC. Y semejantes pretensiones de identidad racionalista, ante la más mínima de las negligencias tolerada, la menor de las dudas traslucida, nunca podrán perpetuarse atentas a la doctrina moderna.

La interpretación de la MODERNIDAD concebida por Albert-sucede durante el periodo laboral analizado y localmente acotado- se evidencia desde su ferviente percepción de juventud, y mantiene su devenir en una actitud profesional desligada del continuismo academicista. El espíritu de rechazo a reminiscencias históricas consignadas, tanto como la urgencia por un nuevo modo de entender la sociedad, de producir la ciudad, resulta la bandera a enarbolar. Sin embargo, en Albert, antes que arrancar de un ideario racionalista, de un posicionamiento teórico, deriva de un espíritu revolucionario inherente a su época. Más que devenir de una conciencia colectiva de cambio social, queda adscrito al lenguaje de las vanguardias europeas. Una iconografía manifiesto de modernidad, tolerada 

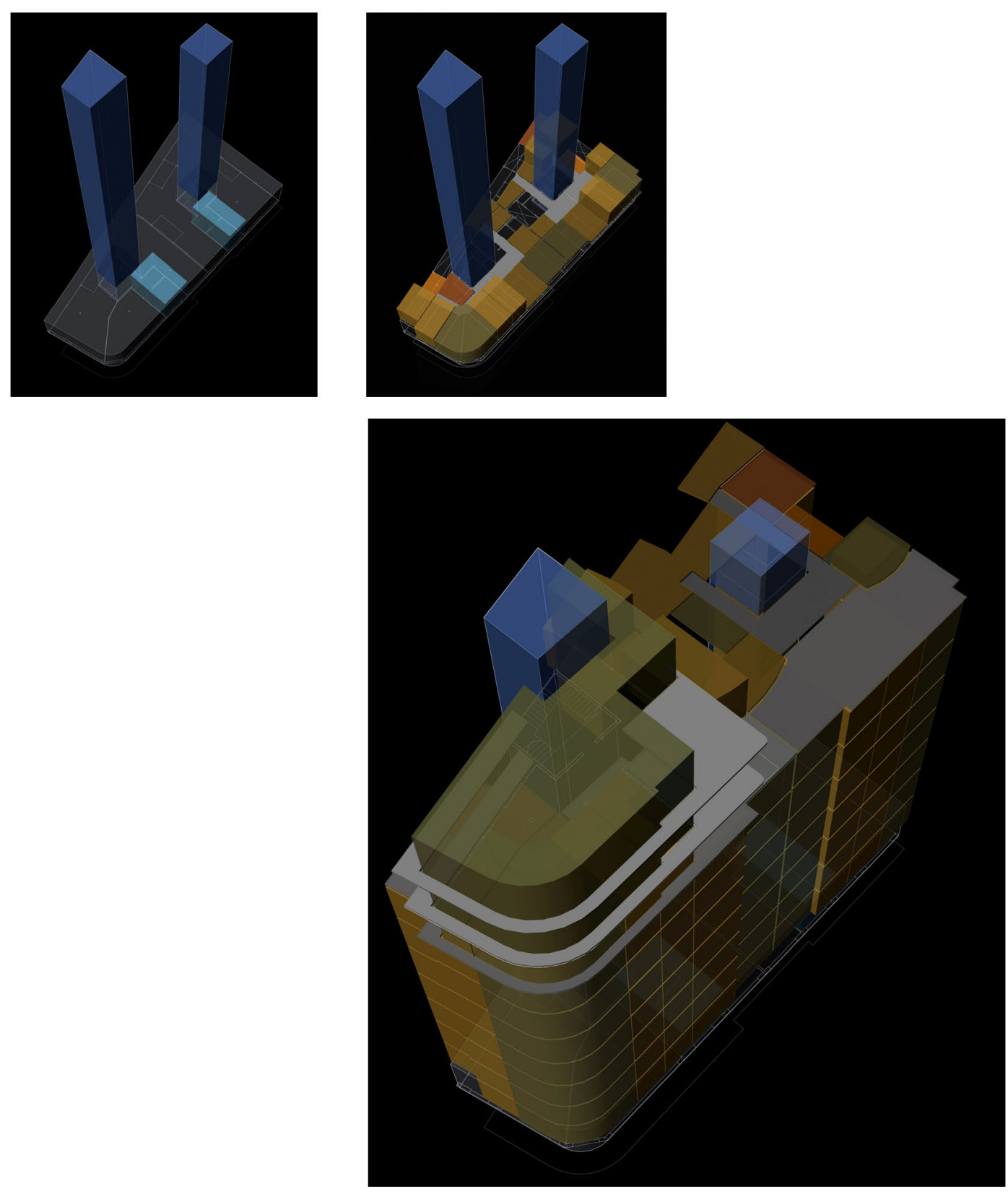

1935. Edificio para Carmen ALONSO: volumetría representando tridimensionalmente la disposición funcional; disposición de ejes orgánicos y de recorridos horizontales 
por patrocinadores e incomprendida por usuarios.

No obstante el LENGUAJE aprehendido, consentido y fácilmente asumible, aplica Albert con rigor esteta un código organizado, unas imposiciones propias, desde la sencillez y la sinceridad constructiva. El proclamado camino de la verdad, recitado en su discurso de ingreso en la Real Academia de Bellas Artes de San Carlos de Valencia -a más de este escrito, resultaron escasas las disertaciones comprometidas con el racionalismo, únicamente atendidas en las memorias de sus proyectos-, se preocupa por crear líneas puras y volúmenes armoniosos, tanto como fomenta la utilidad de lo construido. Y no debería ser menos como instrumento capacitado para desarrollar y ejercer la cultura de su tiempo. Así queda reflejado en las memorias de los consultados proyectos de ejecución, donde pasa reválida el emprendido sendero profesional desde la sinceridad, donde tienen cabida los argumentos más vanguardistas: manifestaciones del funcionalismo cartesiano y geométrico; Vers une architecture.

La FUNCIONALIDAD, el propósito y la finalidad, destacan como motivos fundamentales, junto con la honestidad, la sencillez en la concepción y ejecución. El desarrollo organizativo de funciones, en plantas de distribución, permite comprobar la sinceridad pretendida, la claridad asociativa de usos, la disposición ordenada de espacios y la relación en sus proporciones adecuadas. Otro tanto pretenden las disposiciones en altura, secciones proyectadas funcionalmente, en sus propuestas de promoción pública. Al surgir los rigores de exigencias privadas, se atenúa el compromiso con las alturas libres. Entonces, cuando las propuestas conciernen a conjuntos residenciales para la escena urbana, las prácticas comúnmente asumidas imponen condicionantes insoslayables 0 , al menos demandan un 

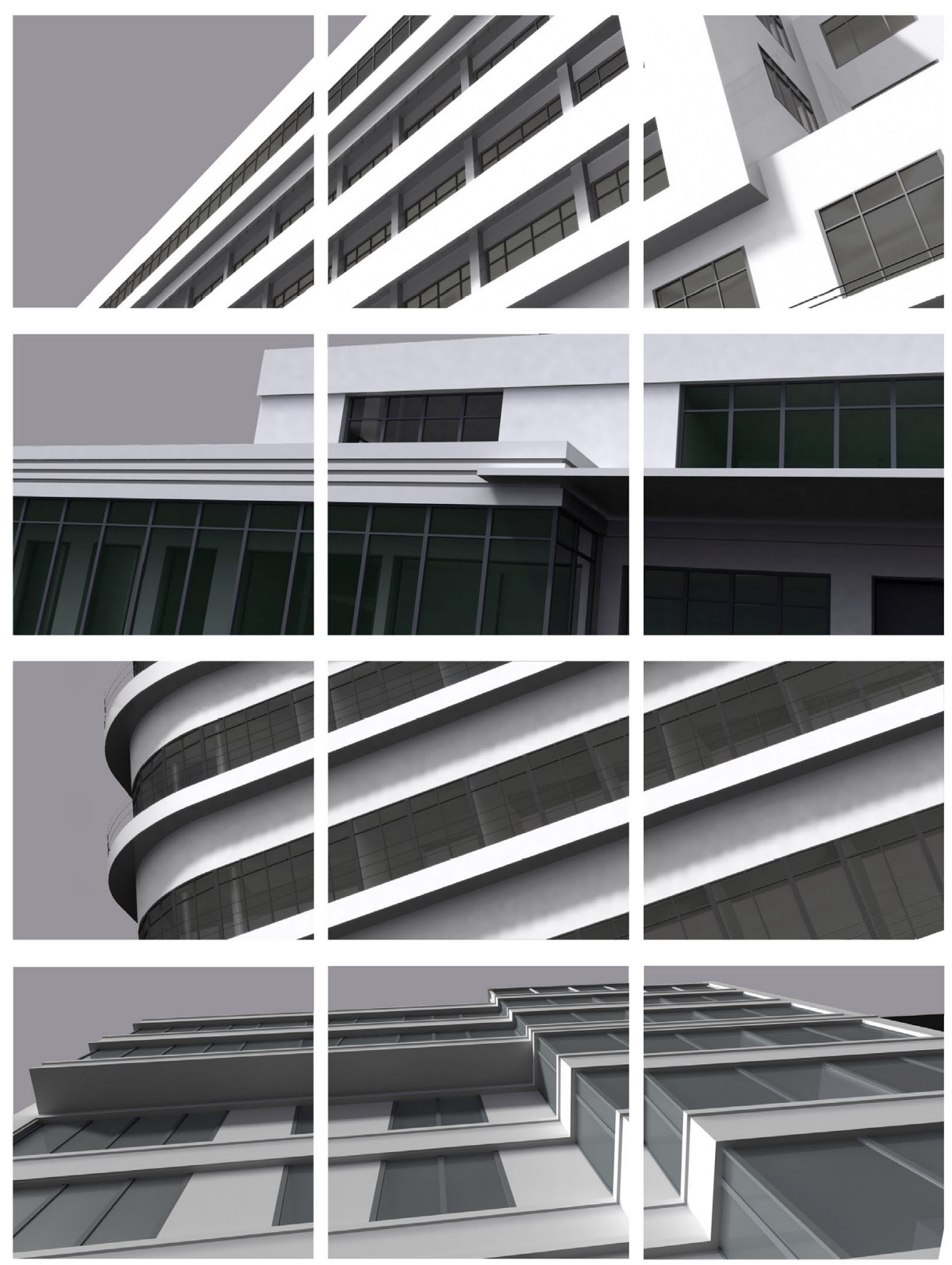
laborioso compromiso con el cliente -prioridad absoluta en su entender profesional- adquirido y solventado con brillantez allí donde le transigen. Especialmente el inmueble para MÁXIMO BUCH y la torre del edificio para CARMEN ALONSO asoman racionalidad, en el erial allanado por una sociedad predispuesta, tan solo, a intervenciones en superficie.

Difícilmente podía convencerse a un colectivo receloso. La metrópoli asume perder una oportunidad de racional modernidad. A deshora, y definitivamente, la guerra condena al ostracismo las aspiraciones renovadoras de un Albert, que jamás retomaría la sinceridad de sus convicciones. Acometería la profesión sin idearios, refugiado en el oficio como estandarte y la minuciosa puesta en obra como satisfacción laboral. La discreción edilicia acompaña su correcto quehacer, asevera su personal retraimiento, alejándolo de aquellas iconografías de juventud.

La arquitectura analizada en esta tesis doctoral, antología moderna en el grueso de la obra albertiana, debería resultar capacitada para aseverar la ortodoxia racionalista. $Y$ sin embargo, resuenan ateridos titubeos que impidieron reconocerlas en el compendio instituido de arquitecturas atentas a la doctrina moderna. Vacilaciones no imputables a condicionantes de promoción, en los proyectos para la Diputación Provincial. Indecisiones cuando resulta la escena urbana quien enjuicia la aportación edilicia, o escaso riesgo asumido cuando las convicciones pasan inadvertidas y constreñidas por intereses privados. No obstante, insuficientes razones para no evidenciar la fortuna racionalista, en buena parte de sus logros. 
bibliografía 
AA. VV. 2005, AC Publicación del GATEPAC, colección arqui/temas, $n^{\circ} 15$, Fundación Caja de Arquitectos, Barcelona

1996. Arquitectura del Movimiento Moderno. Registro DOCOMOMO Ibérico, 1925-1965, Fundación Mies van der Rohe, Barcelona

1995, "Espanya anys 30. Art i Arquitectura", $3 Z U \mathrm{n}^{\circ} 4$, Escuela Técnica Superior de Arquitectura de Barcelona, Barcelona

1971, "Fernando García Mercadal", Nueva Forma, n69, Madrid

2005, "G.A.T.C.P.A.C.", DC revista semestral de Crítica Arquitectónica, $n^{\circ} 13-14$, Departament de Composició Arquitectònica. ETSABUPC, Barcelona

1999, Guía de Arquitectura de la Provincia de Alicante, Instituto Juan Gil-Albert y Colegio Territorial de Arquitectura de Alicante, Alicante

2007, Guía de Arquitectura de Valencia, ICARO-CTAV y Colegio Territorial de Arquitectos de Valencia, Valencia

1980, "Il dibattito sul Movimiento Moderno", Casabella, n463-464, Milano

2009, La vivienda moderna. Registro DOCOMOMO Ibérico. 1925-1965, Fundación la Caja de Arquitectos y Fundación DOCOMOMO Ibérico, colección arqui/temas, $n^{\circ} 27$, Barcelona 
2007, "Racionalismo en España", Lars Cultura y Ciudad, ne especial, Iseebook S.L. Valencia

ABALOS, I. 2000, La buena vida. Visita guiada a las casas de la modernidad, Gustavo Gili S.A. Barcelona

A guILAR CIVERA, I. 1980, Demetri Ribes, Eliseu Climent/3i4, Valencia

- 1998, "La noción de arquitectura en la obra de Demtrio Ribes. Los preludios del racionalismo en Valencia", La ciudad moderna. Arquitectura racionalista en Valencia, IVAM Institut Valenciá d'Art Modern, vol I, Valencia

- 2004, Demetrio Ribes: arquitecto (1875-1921), Conselleria d'Infraestructures i Transports, Generalitat Valenciana, Valencia

A GUILERA CERNI, V. 1966, Panorama del nuevo arte español, Guadarrama, Madrid

1976, Arte y compromiso histórico (sobre el caso español), Fernando Torres D.L. Valencia

1998, Arte valenciano años 30, Consell Valencià de Cultura D.L. Valencia

ALBERT BALLESTER OS, L. 1949, "Restauración y ampliación del edificio de la Generalitat de Valencia del Cid", Revista Nacional de Arquitectura, $n^{\circ} 88$, Madrid 
1963, La evolución de la arquitectura en el transcurso de los siglos, Diputación Provincial de Valencia, Valencia

ARACIL, A. RODRÍGUEZ, D. 1982, El siglo $X X$. Entre la muerte del arte y el arte moderno, Istmo, Madrid

ARGAN, J.C. 1973, El concepto del espacio arquitectónico del Barroco a nuestros días, Nueva Visión, Buenos Aires

1977, El arte moderno 1770-1970, Fernando Torres D.L. Valencia 1991, El arte moderno. Del iluminismo a los movimientos contemporáneos, Akal D.L. Madrid

1977. El pasado en el presente: el revival en las artes plásticas, la arquitectura, el cine y el teatro, Gustavo Gili S.A. Barcelona

1983, Walter Gropius y la Bauhaus, Gustavo Gili S.A. Barcelona

AYMONINO, C. 1973, La vivienda racional. Ponencias de los congresos CIAM 1929-1930, Gustavo Gilis.A. Barcelona

AZAGRA ROS, J. 1993, Propiedad inmueble y crecimiento urbano: Valencia 1800-1931, Síntesis, Madrid

BALDELLOU, M.A. 1973, Luis Gutierrez Soto, Dirección General de Bellas Artes, serie: Artistas españoles contemporáneos, $\mathrm{n}^{\circ} 38$, Madrid 
1975, Alejandro de la Sota, Dirección General del Patrimonio Artístico Cultural, serie: Artistas españoles contemporáneos, $n^{\circ}$ 103, Madrid

1995, "Hacia una arquitectura racional española", Arquitectura española del siglo XX. Espasa Calpe, SUMMA ARTIS, Historia General del Arte, vol XL, Madrid

BANHAM, R. 1985, Teoría y diseño en la primera era de la máquina, Ediciones Piados, Barcelona, Buenos Aires, México

BASTLUND, K. 1967, José Luis Sert, Les editions d'Architecture, Zurich

BAYÓN ÁlVAREZ, M. 2004, "Luces inconclusas", Arquitecturas ausentes del siglo XX. Cuadernos de investigación. Ministerio de Vivienda y Rueda S.L. Madrid

Bebía I García, M. VAlera Botella, S. 1994, Alicante: Ciudad y Arquitectura, CAM, Fundación Cultural, Alicante

BENÉVOLO, L. 1974, Historia de la arquitectura moderna, Gustavo Gili S.A. Barcelona

1979, Los orígenes del urbanismo moderno, Editorial Blume, Madrid

BENITO GOERLICH, D. 1983, La arquitectura del eclecticismo en Valencia. Vertientes de la arquitectura valenciana entre 1875 y 1925 , Excelentísimo Ayuntamiento de Valencia, Valencia 
BENTON, T. 2004, Erich Mendelshon: 1887-1953, Ediciones Electa, Milano 2007, Corbusier conférencier, Le Moniteur, París

2007, Le ville de Le Corbusier e Pierre Jeanneret: 1920-1930, Electa. Milano

BENTON, T. BENTON, CH. 1981, El Estilo Internacional, Editorial Adir, Madrid

BENTON, T. BENTON, CH. SHARP, D. 1983, Las raíces del expresionismo, Adir, Madrid

BLAT PIZARRO, J. 1986, La arquitectura de la vivienda y la organización del crecimiento urbano. (Valencia 1853-1936), Editorial, Valencia

1988, "Crecimiento urbano y vivienda: Valencia 1921-1936". En trànsit a gran ciutat, ler Congrés d'història de la ciutat de València, vol II, Valencia

1998, "El crecimiento urbano en Valencia: entre la ciudad-jardín y el planeamiento de extensión", La ciudad moderna. Arquitectura racionalista en Valencia, IVAM Institut Valenciá d'Art Modern, Vol I, Valencia

BLAZER, W. 1992, Ludwig Mies van der Rohe, Gustavo Gili S.A. Barcelona

BOESIGER, W. 1973, Le Corbusier et Pierre Jeanneret. Oèuvre complete de 1910-1929, Les Editions d'Architecture, vol I, Zurich 


\footnotetext{
1973, Le Corbusier et Pierre Jeanneret. Oèuvre complete de 19291934, Les Editions d'Architecture, vol II, Zurich 1973, Le Corbusier. Oèuvre complete de 1938-1946, Les Editions d'Architecture, vol IV, Zurich

1979, Le Corbusier, Gustavo Gili S.A. Serie: Estudio Paperback, Barcelona
}

BOESIGER, W. GIRSBERGER, H. 1987, Le Corbusier 1910-65, Gustavo Gili S.A. Barcelona

BOHIGAS, O. 1980, "El GATEPAC: Vanguardia y Revolución", Casabella, $n^{\circ} 463-464$, Milano

1998. Modernidad en la arquitectura de la España republicana, Tusquets Editores, Barcelona

2000, "Racionalismo y vanguardia internacional", Arquitectura del siglo XX: España. Pabellón de España, EXPO 2000 Hannover, Tanais: Sociedad Estatal Hanover, D.L. Madrid

BOHIgAS, O. GONZÁlez, A. LACUESTA, R. 1983, Reseña y catálogo de la arquitectura Modernista, Lumen. Barcelona

BONET, J.M. 1999, Diccionario de las vanguardias en España. 1907-1936, Alianza Editorial, Madrid 
BORRÁS, M.L. 1974, Sert: arquitectura mediterránea, Polígrafa D.L. Barcelona

BOZAL FERNÁNDEZ, V. 1979, La construcción de la vanguardia (1850-1939), Cuadernos para el Diálogo, Madrid

1995, Arte del siglo XX en España, Espasa Calpe D.L. Madrid

BRIHUEGA, J. 1979, Manifiestos, proclamas, panfletos y textos doctrinales. Las vanguardias artísticas en España (1910-1931), Cátedra D.L. serie: Cuadernos arte Cátedra, $n^{\circ} 8$, Madrid

1979, La vanguardia y la República, Cátedra D.L. serie: Cuadernos arte Cátedra, $n^{\circ} 14$, Madrid

1981, Las vanguardias artísticas (1909-1936), Istmo D.L. serie: Fundamentos, $n^{\circ} 72$, Madrid

CALDUCH CERVERA, J. 2002, Temas de composición arquitectónica: Modernidad y arquitectura moderna, Club Universitario, Alicante

CALVO SERRALLER, F. 1979, "El urbanismo de los ensanches: La transformación de Madrid durante el siglo XIX", Arquitectura, n²17, Madrid

1988, Del futuro al pasado: Vanguardia y tradición en el arte español contemporáneo, Alianza, Madrid 
CAPITEL, A. 1995, Arquitectura europea y americana después de las vanguardias, Espasa Calpe, SUMMA ARTIS, Historia General del Arte, vol XLI, Madrid

1999. Alvar Aalto. Proyecto y Método, Akal S. A. Madrid

2000, "El siglo XX español. Notas para una síntesis", Arquitectura del siglo XX: España. Pabellón de España, EXPO 2000 Hannover, Tanais: Sociedad Estatal Hanover, D.L. Madrid

2002, "Notas en torno al arquitecto José Luís Sert", 4 centenarios: José Luís Sert, Universidad de Valladolid, Secretariado de Publicaciones e Intercambio Editorial, Valladolid

COHEN, J.L. 1998, Mies van der Rohe, Akal S.A. Madrid

1979, "Les neus Baven face à la critique: la Weissenhofsiedlung, Stuttgart, 1927", Architectures en Allemagne. 1900-1930, Centre de Création Industrielle (CCI), Centre Georges Pompidou, París

COLQUHOUN, A. 1991, Modernidad y tradición clásica, Jucar Universidad, Madrid

2005, La arquitectura moderna. Una historia desapasionada, Gustavo Gili S.A. Barcelona

COLLINS, P. 1977, Los ideales de la arquitectura moderna; su evolución (1750-1950), Gustavo Gili S.A. colección Arquitectura y Crítica, Barcelona 
COLOMER, V. 1998, "La arquitectura como forma crítica de hacer ciudad", La ciudad moderna. Arquitectura racionalista en Valencia, IVAM Institut Valenciá d'Art Modern, vol I, Valencia

CONRADS, U. 1973, Programas y manifiestos de la arquitectura del siglo $X X$, Lumen S.A. Barcelona

CORT, C. 1946, "El arquitecto ante el problema de la vivienda", Cuadernos de Arquitectura, $n^{\circ} 6$, Colegio Oficial de Arquitectos de Catalunya y Baleares, Barcelona

CURTIS WILLIAM, J.R. 1986, La arquitectura moderna desde 1900, Blume, Madrid

DAL CO, F. TAFURI, M. 1989, Arquitectura contemporánea, Aguilar, Madrid

DE ANASAgASTI, T. 1995, Enseñanza de la Arquitectura, Instituto Juan de Herrera, Madrid

DE FUSCO, R. 1976, La idea de la arquitectura, Gustavo Gili S.A. Barcelona 1981. Historia de la Arquitectura Contemporánea, Blume, Madrid

DE LA SOTA, A. 1989, Alejandro de la Sota, Arquitecto, Pronaos, Madrid

DE SOLÁ-MORALES RUBIÓ, I. 1980, Eclecticismo y vanguardia: el caso de la Arquitectura Moderna en Cataluña, Gustavo Gili S.A. Barcelona 
2004, Eclecticismo y vanguardia y otros escritos, Gustavo Gili S.A. Barcelona

DE ZURKO, E.R. 1958, La teoría del Funcionalismo en arquitectura, Nueva Visión, Buenos Aires

DIÉGUEZ PATAO, S. 1997, La generación del 25. Primera arquitectura moderna en España, Cátedra D.L. cuadernos Arte, Madrid

DROSTE, M. 2006, La Bauhaus 1913-1933. Reforma y vanguardia, Taschen, Köln

ECO, U. 1965, Obra abierta: Forma e indeterminación del arte contemporáneo, Seix Barral, serie Biblioteca breve, Barcelona

1983, Como se hace una tesis: Técnicas y procedimientos de estudio, investigación y escritura, Gedisa, Barcelona

ESTELLÉS CEBA, J.J. 1984, "Joaquín Rieta, impulsor de la Valencia Moderna", Papers, $n^{\circ} 2$ Valencia

1986, "La conexión valenciana con el Movimiento Moderno", Habitar $Q, n^{\circ} 3$, Valencia

ESTELLÉS CEBA, J.J. GIMÉNEZ, E. 1998, "Los arquitectos valencianos de los treinta: influencias y compromisos. Las Escuelas de Arquitectura, las revistas especializadas y los nuevos canales de información", La ciudad moderna. Arquitectura racionalista en Valencia, IVAM Institut Valenciá d'Art Modern, vol I, Valencia 
FLORES LÓPEZ, C. 1989, Arquitectura española contemporánea, Aguilar, Madrid

FRAMPTON, K. 1981, Historia crítica de la arquitectura moderna, Gustavo Gili S.A. Barcelona

1999. Estudios sobre cultura tectónica. Poéticas de la construcción en la arquitectura de los siglos $X I X$ y $X X$, Akal, serie: Akal Arquitectura, Madrid

FREIXA, J. 1979, Josep Lluís Sert, Gustavo Gili S.A. Barcelona

FREIXA SERRA, M. 1986, El modernismo en España, Cátedra, D.L. serie: Cuadernos de Cátedra, $n^{\circ} 20$, Madrid

FULLAONDO, J.D. 1984, Fernando García Mercadal. Arquitecto aproximativo, Colegio Oficial de Arquitectos, Madrid

1997. Historia de la arquitectura contemporánea española, Molly D.L. Madrid

GALLEGO JORRETO, M. 2004, "Encuadre de la obra en la Arquitectura de Alejandro de la Sota", Arquitecturas ausentes del siglo xx. Cuadernos de investigación, Ministerio de Vivienda y Rueda S.L. Madrid

GARCíA MERCADAL, F. 1971, "La enseñanza del Urbanismo", Nueva Forma, $n^{\circ} 69$, Madrid 
1981, La casa popular española, Gustavo Gili S.A. Barcelona

1998, La vivienda en Europa y otras cuestiones, Institución Fernando el Católico, serie: Cuadernos de arquitectura de la Cátedra Ricardo Magdalena, $n^{\circ} 9$, Zaragoza

GARCíA MORALES, M. 1975, Los Colegios de arquitectos de España 19231965, Castalia. Valencia

GARCía MOSTEIRO, J. 2000, "Primer cuarto de siglo: del eclecticismo al racionalismo", Arquitectura del siglo XX: España. Pabellón de España, EXPO 2000 Hannover, Tanais: Sociedad Estatal Hanover, D.L. Madrid

GIEDION, S. 1968, Espacio, tiempo y arquitectura (El futuro de una nueva tradición), editorial Científico-Médica, Barcelona

1997, Escritos escogidos, Colegio Oficial de Aparejadores y Arquitectos Técnicos, serie: Colección de Arquitectura, n³3, Murcia

GIRONA, A. 1998, "Una nueva forma de vivir: la urbe como modelo de atracción", La ciudad moderna. Arquitectura racionalista en Valencia, IVAM Institut Valenciá d'Art Modern, vol I, Valencia

GROPIUS, W. 1966, La Nueva Arquitectura y la Bauhaus, Lumen, Barcelona

HERRERA GARCÍA, J.M. 1983, Joaquín Rieta Sister. Arquitecto valenciano 1897-1982, Colegio Oficial de Arquitectos, Valencia 
HILBERSEIMER, L. 1979, La arquitectura de la gran ciudad, Gustavo Gili S.A. Barcelona

HITCHCOCK, H.R. 1981, Arquitectura de los siglos XIX y XX, Cátedra D.L. Madrid

HITCHCOCK, H.R. JOHNSON, P. 1984, El estilo internacional: arquitectura desde 1922, Colegio Oficial de Aparejadores y Arquitectos Técnicos, Murcia

HUMANES BUSTAMANTE, A. 1986, Madrid no construido, Colegio Oficial de Arquitectos, Madrid

ISAC, A. 1987, Eclecticismo y pensamiento arquitectónico en España. Discursos, revistas, congresos (1846-1919), Diputación D.L. Granada

1995, "Vanguardia al margen. Andalucía Años Treinta", $3 Z U, n^{\circ} 4$, Escuela Tècnica Superior d'Arquitectura de Barcelona, Barcelona

KAUFMANN, E. 1982, De Ledoux a Le Corbusier: origen y desarrollo de la arquitectura autónoma, Gustavo Gili S.A. Barcelona

1980, Tres arquitectos revolucionarios: Boullee, Ledoux y Lequeu, Gustavo Gili S.A. serie: Biblioteca de arquitectura, Barcelona

LACASA, L. 1976, Luis Lacasa, escritos (1922-1931), Colegio Oficial de Arquitectos de Madrid, Madrid 
LACUESTA, R. GONZÁlez, A. 1990, Arquitectura modernista en Cataluña, Gustavo Gili S.A. Barcelona

LAGARDERA, J. LLOPIS, A. 1998, "Modernos periféricos, razones dinámicas. Arquitectura racionalista en la Valencia de los años treinta", La ciudad moderna. Arquitectura racionalista en Valencia, IVAM Institut Valenciá d'Art Modern, vol I, Valencia

LE CORBUSIER. 1959, Mensaje a los estudiantes de arquitectura, Infinito, Buenos Aires

1962, La ciudad del futuro, Infinito, Buenos Aires

1965, Hacia una arquitectura, Poseidón, Buenos Aires

1980, El modulor, Poseidón, Barcelona

1980, A propósito del urbanismo, Poseidón, Barcelona

1999. Cuando las catedrales eran blancas: viaje al país de los tímidos, Apóstrofe S.L. Barcelona

LOOS, A. 1982, Ornamento y delito y otros escritos, Gustavo Gili S.A. Barcelona

LUPFER, G. SIEGEL, P. 2004, Walter Gropius. 1883-1969. Propagandista del nuevo diseño, Taschen, Köln 
LLINÀS CARMONA, J. 2004, "La casita desmontable en la Ciudad del Reposo y las Vacaciones del GATCPAC", Arquitecturas ausentes del siglo $x x$. Cuadernos de investigación. Ministerio de Vivienda y Rueda S.L. Madrid

LLORENS, T. 1974, "El Moviment Modern i el Racionalisme a l'arquitectura i I'urbanisme valencians". Arguments, $n^{\circ} 1$, Valencia

MANNINO, E. PARICIO, I. 1983, J. Ll. Sert: Construcción y Arquitectura, Gustavo Gili S.A. Barcelona

MARCHÁN FIZ, S. 1974, La arquitectura del siglo XX. Selección, introducción y notas, Alberto Corazón S.A. serie: Documentación/Debates, Madrid

MARTÍNEZ MEDINA, A. 1998, La Arquitectura de la ciudad de Alicante. 19231943. La aventura de la modernidad, Instituto de Cultura Juan GilAlbert y Colegio Territorial de Arquitectos de Alicante, Alicante

MARTÍN MARTÍN, F. 1983, El pabellón español de la Exposición Universal de París en 1937, Universidad de Sevilla D.L. Sevilla

MIES VAN DER ROHE, L. 1993, Escritos, diálogos y discursos, Colegio de Aparejadores y Arquitectos Técnicos, Murcia

MONTANER, J.M. 1999, Arquitectura y crítica, Gustavo Gili S.A. GG Básicos, Barcelona 


\footnotetext{
1999. La Modernidad superada. Arquitectura, arte y pensamiento del siglo $x x$, Gustavo Gili S. A. Barcelona

2003, Teorías de la arquitectura, Ediciones UPC, Memorial Ignasi de Solá-Morales, Barcelona
}

MUÑOZ COSME, I. 1986, La conservación del patrimonio arquitectónico español, Universidad Politécnica de Valencia, Valencia

NAVASCUÉS PALACIO, P. 1993, Arquitectura española 1808-1914, Espasa Calpe, SUMMA ARTIS, Historia general del arte, vol XXXV, Madrid

- 1996, "La creación de la Escuela de Arquitectura de Madrid". Madrid y sus arquitectos. 150 años de la Escuela de Arquitectura, Dirección General de Patrimonio Cultural, Consejería de Educación y Cultura, Madrid

- 2007, Arquitectura e ingeniería del hierro en España (1814-1936), El Viso D.L. Madrid

NAVASCuÉs PALACIO, P. AlONSO PEREIRA, J.R. 2002, La Gran Vía de Madrid, Encuentro D.L. Madrid

NORBERG-SCHULZ, Ch. 1980, Existencia, espacio y arquitectura, Blume, Barcelona

2001, Intenciones en Arquitectura, Gustavo Gili S.A. serie: G.G. Barcelona 
2005, Los Principios de la arquitectura moderna. Sobre la nueva
tradición del siglo $x$ X. Reverté S.A. Barcelona

PEHNT, W. 1975, La arquitectura expresionista, Gustavo Gili S.A. serie Biblioteca de Arquitectura, Barcelona

PEÑIN IBAÑEZ, A. 1978, Valencia. 1874-1959. Ciudad, arquitectura y arquitectos, Escuela de Arquitectura de Valencia, Valencia

1984, Luis Albert, arquitecto. 1902-1968, Colegio Oficial de Arquitectos de Valencia, Valencia

1998, "El marco urbano y socioeconómico. Arquitectos y arquitecturas", La ciudad moderna. Arquitectura racionalista en Valencia, IVAM Institut Valenciá d'Art Modern, vol I, Valencia

PÉREZ ESCOLANO, V. 2000, "La condición marginal de la arquitectura moderna 1924-1938", Arquitectura del siglo XX: España. Pabellón de España, EXPO 2000 Hannover, Tanais: Sociedad Estatal Hanover, D.L. Madrid

PÉREZ ROJAS, J. 1990, Art Déco en España, Cátedra, D.L. serie: Cuadernos arte Cátedra, $n^{\circ} 27$, Madrid 1993, "Opciones de la arquitectura valenciana entre 1927 y 1939", Actas Primer Congreso de Historia del Arte Valenciano, Valencia 
1994, "Regionalismo y neobarroco en la arquitectura valenciana, 1909-1936", Tiempo y espacio en el arte, Homenaje al profesor Antonio Bonet Correa, Madrid

1998, "Formas de la ciudad moderna. Neo-barrocos, Décos y Aerodinámicos", La ciudad moderna. Arquitectura racionalista en Valencia, IVAM Institut Valenciá d'Art Modern, vol II, Valencia

PÉREZ ROJAs, J. GARCÍA CASTELLÓN, M. 1994, El siglo XX. Persistencias y rupturas, Sílex, Madrid

PEVSNER, N. 1972, Pioneros del diseño moderno: de William Morris a Walter Gropius, Infinito, serie: Biblioteca de diseño y artes visuales, Buenos Aires

1978, Los orígenes de la arquitectura moderna y del diseño, Gustavo Gili S.A. serie Comunicación Visual, Barcelona

1979. Historia de las tipologías arquitectónicas, Gustavo Gili S.A. serie Biblioteca de Arquitectura, Barcelona

PIÑÓN, H. 1997, "El sentido de la arquitectura moderna", Materiales de la arquitectura moderna-ldeas, Edicions UPC, Universitat Politècnica de Catalunya, Barcelona

PIÑÓN, J.L. 1988, Los orígenes de la Valencia Moderna: Notas sobre la reedificación urbana de la primera mitad del siglo XIX, Colegio Oficial de Arquitectos de la Comunidad Valenciana y Alfons el Magnánim, Valencia 
PIZZA, A. 1993, Dispensario antituberculoso de Barcelona. 1933-1937: J.Ll. Sert, J.B. Subirana y J. Torres Clavé, Colegio de Arquitectos de Almería, serie: Archivos de arquitectura. España S. XX, $n^{\circ} 1$, Almería

1995, "Interpretaciones de lo 'moderno' en la arquitectura catalana de los años treinta", $3 Z U, n^{\circ} 4$, Escuela Tècnica Superior d'Arquitectura de Barcelona, Barcelona

1997, Guía de la arquitectura del siglo XX. España, Electa, Milano

PORTACELI ROIG, M. 1986, "La arquitectura de la ciudad: Valencia, 19311939". Arquitectura en Valencia durante la $\|^{\circ}$ República, Valencia

1998, "Una época troyana. Continuidad y renovación en la arquitectura de los años treinta en Valencia", La ciudad moderna. Arquitectura racionalista en Valencia, IVAM Institut Valenciá d'Art Modern, vol I, Valencia

RAFOLS, J.F. 1944, "Arquitectura de las tres primeras décadas del siglo XX", Cuadernos de Arquitectura, $\mathrm{n}^{\circ} \mathrm{l}$, Colegio Oficial de Arquitectos de Catalunya y Baleares, Barcelona

RIBES MARCO, D. 1918, "Orientaciones para el resurgimiento de una arquitectura nacional", "La tradición en la arquitectura", Arquitectura y Construcción, Barcelona

RODRIGUEZ ARIAS, G. 1932, "Memoria del Sanatorio de San Juan de Dios (Manresa) ", Revista $A C, n^{\circ} 6$, Barcelona 
ROVIRA I GIMENO, J.M. 1987, La arquitectura catalana de la modernidad, Universidad Politécnica de Catalunya, Barcelona 2000, José Luis Sert. 1901-1983. Electa. Milano 2004, "Una ciudad del GATCPAC para el orden de las vacaciones y la programación del reposo. Ciudad del Reposo y las Vacaciones y la caseta desmontable 1931-1935. GATCPAC", Arquitecturas ausentes del siglo $x x$. Cuadernos de investigación, Ministerio de Vivienda y Rueda S.L. Madrid

ROWE, C. 1978, Manierismo y arquitectura moderna y otros ensayos, Gustavo Gili S.A. Barcelona

RUSKIN, J. 2000, Las siete lámparas de la arquitectura. El sacrificio. La verdad. La fuerza. La belleza. La vida. El recuerdo. La obediencia, Altafulla, Barcelona

SAMBRICIO Y RIVERA-ECHEGARAY, C. 1999, "Arquitectura, Residencia y Exilio", Boletín de la Residencia de Estudiantes, $n^{\circ} 8$, Madrid

1999. De la ciudad ilustrada a la primera mitad del siglo XX. Dirección General de Urbanismo y Planificación Regional, Madrid

SAMBRICIO, C. PORTELA SANDOVAL, F. TORRALBA SORIANO, F. 1980, El siglo $X X$, Historia del arte hispánico, Alhambra, vol VI, Madrid

SANCHIS GUARNER, M. 1983, La Ciutat de València. Síntesi d'Historia y de Geografia urbana, Excelentisim Ajuntament de Valenica, Valencia 
SARTORIS, A. 1987, Alberto Sartoris, Colegio Oficial de Arquitectos de Madrid, D.L. Madrid

2000, Alberto Sartoris. 1901-1988: la concepción poética de la arquitectura, Instituo Valenciano de Arte Moderno D.L. Valencia

SCHNAIDT, C. 1979, "Les thèmes de la Nouvelle Architecture", Architectures en Allemagne. 1900-1930, Centre de Création Industrielle (CCI), Centre Georges Pompidou, París

SERRA DESFILIS, A. 1988, "La influencia del Art-Déco en la arquitectura valenciana, 1926-1936. En trànsit a gran ciutat". I Congrés d'història de la ciutat de València, vol II, Valencia

1990, Arquitectura y ciudad: el monumentalismo del nuevo centro urbano en la ciudad de Valencia (1900-1936), Saitibi, D.L. Valencia

1996. Eclecticismo tardío y Art-Déco en la ciudad de Valencia. 1926-1936, Ayuntamiento de Valencia, serie: Estudis, ${ }^{\circ} 7$, Valencia

SHERWOOD, R. 1983, Vivienda: Prototipos del Movimiento Moderno, Gustavo Gili S.A. Barcelona

SIEGEL, P. LUPFER, G. 2004, Walter Gropius. 1883-1969. Propagandista del nuevo diseño, Taschen, Köln

SIMÓ TEROL, T. 1971, La arquitectura modernista en Valencia, Universidad Politécnica de Valencia, serie Anales de la Universidad de Valencia, Valencia 
1973, La arquitectura de la renovación urbana en Valencia, Albatros, Valencia

1983, Valencia. Centro histórico. Guía urbana y de arquitectura, Institución Alfonso el Magnánimo, Cop, Valencia

SMITHSON, A.-P. 2001, Cambiando el arte de habitar, Gustavo Gili S.A. Barcelona

SOLÁ-MORALES RUBIÓ, I. 1999, "La nueva arquitectura y el asimétrico diálogo entre Madrid y Barcelona. Estrabismo barcelonés", Boletín de la Residencia de Estudiantes, $n^{\circ} 8$, Madrid

1980, Eclecticismo y vanguardia: el caso de la Arquitectura Moderna en Cataluña, Gustavo Gili S.A. serie Arquitectura y crítica, Barcelona

2004, Eclecticismo y vanguardia y otros escritos, Gustavo Gili S.A. Barcelona

TABERNER PASTOR, F. 1986, "Producción arquitectónica y desarrollo en Valencia". Arquitectura en Valencia durante la $\|^{a}$ República. Valencia 1987, Valencia entre el ensanche y la reforma interior, Alfons el Magnánim, Valencia

1998, "Valencia: las grandes reformas o la configuración de la nueva imagen del centro urbano", La ciudad moderna. Arquitectura racionalista en Valencia, IVAM Institut Valenciá d'Art Modern, vol I, Valencia 
TAFURI, M. 1976, Storia universale dell'architettura. Architettura comtemporanea, Electra editrice $r$ industrie grafiche editoriali, S.P.A. Milano

1997, Teorías e historia de la Arquitectura, Celeste D.L. serie Papel $451, n^{\circ} 6$, Madrid

TAFURI, M. DAL CO, F. 1980, Arquitectura contemporánea, Aguilar S.A. Madrid

TEIXIDOR DE OTTO, M.J. 1976, Funciones y desarrollo urbano de Valencia, Alfons el Magnánim, Valencia

TERÁN, F. 1968, La ciudad lineal: antecedente de un urbanismo actual, Ciencia Nueva D.L. serie Cuadernos Ciencia Nueva, Madrid 1969. Ciudad y urbanización en el mundo actual, Blume, Madrid 1982. Planeamiento urbano en la España contemporánea (1900-1980), Alianza, serie Alianza Universidad. Textos, n³9, Madrid

TORRES CUECO, J. 1995, "La fortuna del eclecticismo. Un siglo de arquitectura en Valencia", Tribuna de la Construcción, Cuadernos T.C. $n^{\circ} 25$, valencia

1998, "Los 'primeros modernos'. Los arquitectos valencianos entre la permanencia del academicismo y la renovación de los lenguajes", La ciudad moderna. Arquitectura racionalista en Valencia, IVAM Institut Valenciá d'Art Modern, vol II, Valencia 
1998, "Valencia Moderna. Del eclecticismo a la Tendenza", Arquitectura Viva, $n^{\circ} 61$, Madrid

2004, Le Corbusier: visiones de la técnica en cinco tiempos, Fundación Caja de Arquitectos D.L. serie: Arquithemas, $n^{\circ} 13$, Barcelona

VERY, F. 1979, "Peter Behrens, conseiller artistique de L'A.E.G.", Architectures en Allemagne. 1900-1930, Centre de Création Industrielle (C.I), Centre Georges Pompidou, París

WESTON, R. 1996, Alvar Aalto, Phaidon Press Limited, London

ZERVOS, CH. 2005, "Jóvenes arquitectos", Crítica Arquitectónica, n¹3 y 14, Departament de Composició Arquitectònica, ETSAB-UPC, Barcelona

ZEVI, B. 1978, El lenguaje moderno de la arquitectura, Poseidón, Barcelona 1980, Historia de la Arquitectura moderna, Poseidón, Buenos Aires 1980, Espacios de la Arquitectura moderna, Poseidón, Barcelona 1986, Eric Mendelsohn, Gustavo Gili S.A. Estudio Paperback, Barcelona 1991, Saber ver la arquitectura. Ensayo sobre la interpretación espacial de la arquitectura, Poseidón, Barcelona

ZURKO, E.R. 1970, La teoría del Funcionalismo en arquitectura, Nueva Visión, serie Arquitectura Contemporánea, Buenos Aires 
apéndice gráfico 
Quedan desglosados, a continuación, aquellos expedientes de nueva planta proyectados por Luis Albert, consultados durante el devenir del trabajo de investigación y entresacados -la relación completa de expedientes de obra se coteja dilatada al final del anexo-por su relevancia en la redacción posterior de esta tesis doctoral.

Rescatados -en gran parte- del Archivo Histórico Municipal de Valencia, así como de los Archivos de la Diputación Provincial de Valencia, y cotejados con la relación de expedientes aglutinada en el Archivo histórico del Colegio Oficial de Arquitectos, la finalidad de esta compilación no es otra que obtener una visión selectiva inmersa en la basta obra ejecutada en la ciudad de Valencia por el arquitecto. En el transcurso de su dilatada vida profesional, la selección mostrada en este apéndice, resulta diminuta y rozando lo escueto de una reseña, no obstante faculta para ubicar aquellas obras analizadas desde este documento y poder así entender los logros imputables en la ardua tarea de aproximación al Racionalismo, computados en el conjunto edilicio proyectado y construido por Albert, en un período muy concreto.

Cotejar su obra -no únicamente en los años analizados, también en su transcurrir posterior- es la razón fundamental para aumentar el periplo consultado y plasmado en este anexo. Comprender las decisiones arquitectónicas puestas en práctica por Albert en su evolución profesional. Entender su aprendizaje, sus posicionamientos y renuncias, llevan la razón de ser de esta disección en una prolija aportación arquitectónica. 


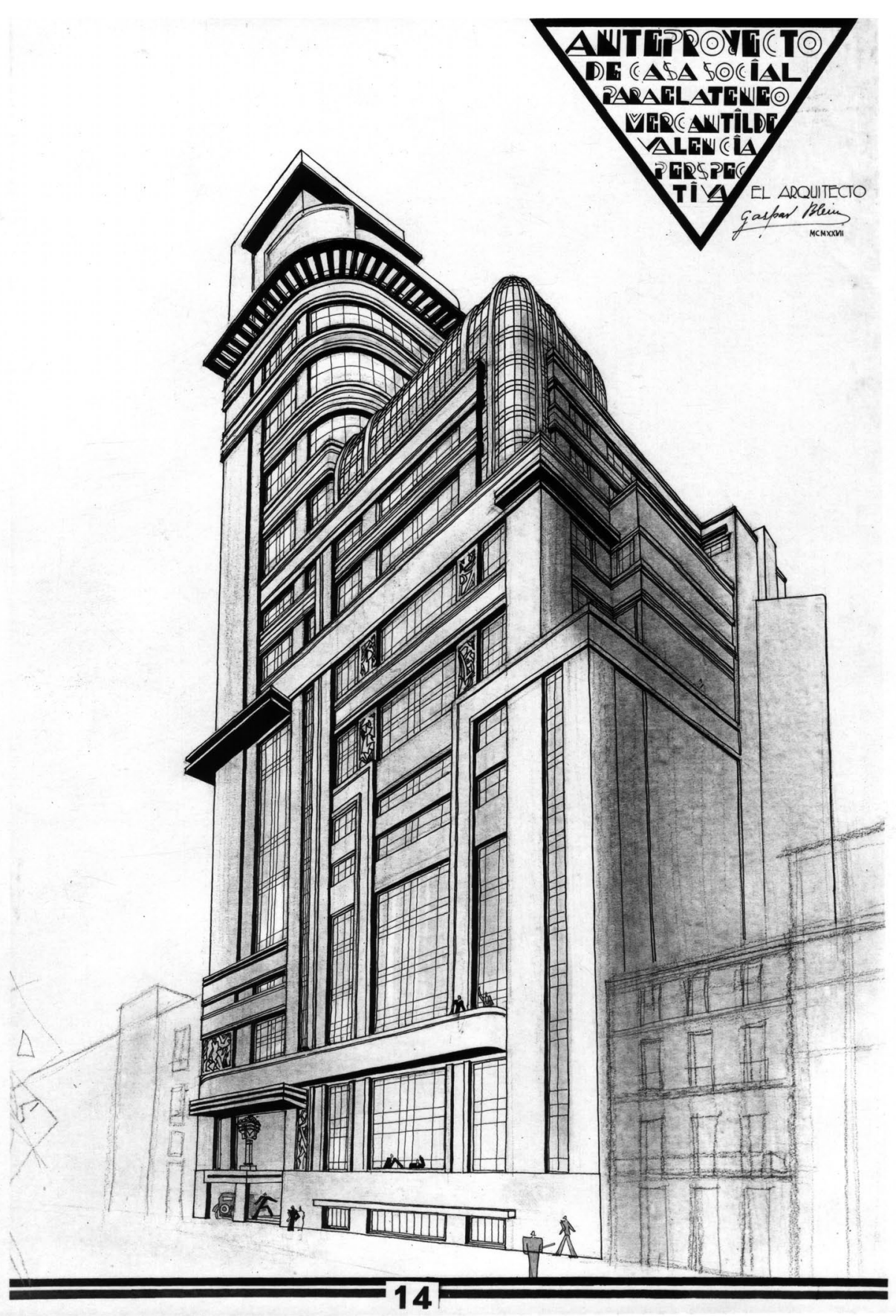


1927

EMPLAZAMIENTO: plaza Emilio Castelar

PROMOTOR: Sociedad Mercantil del Ateneo de Valencia
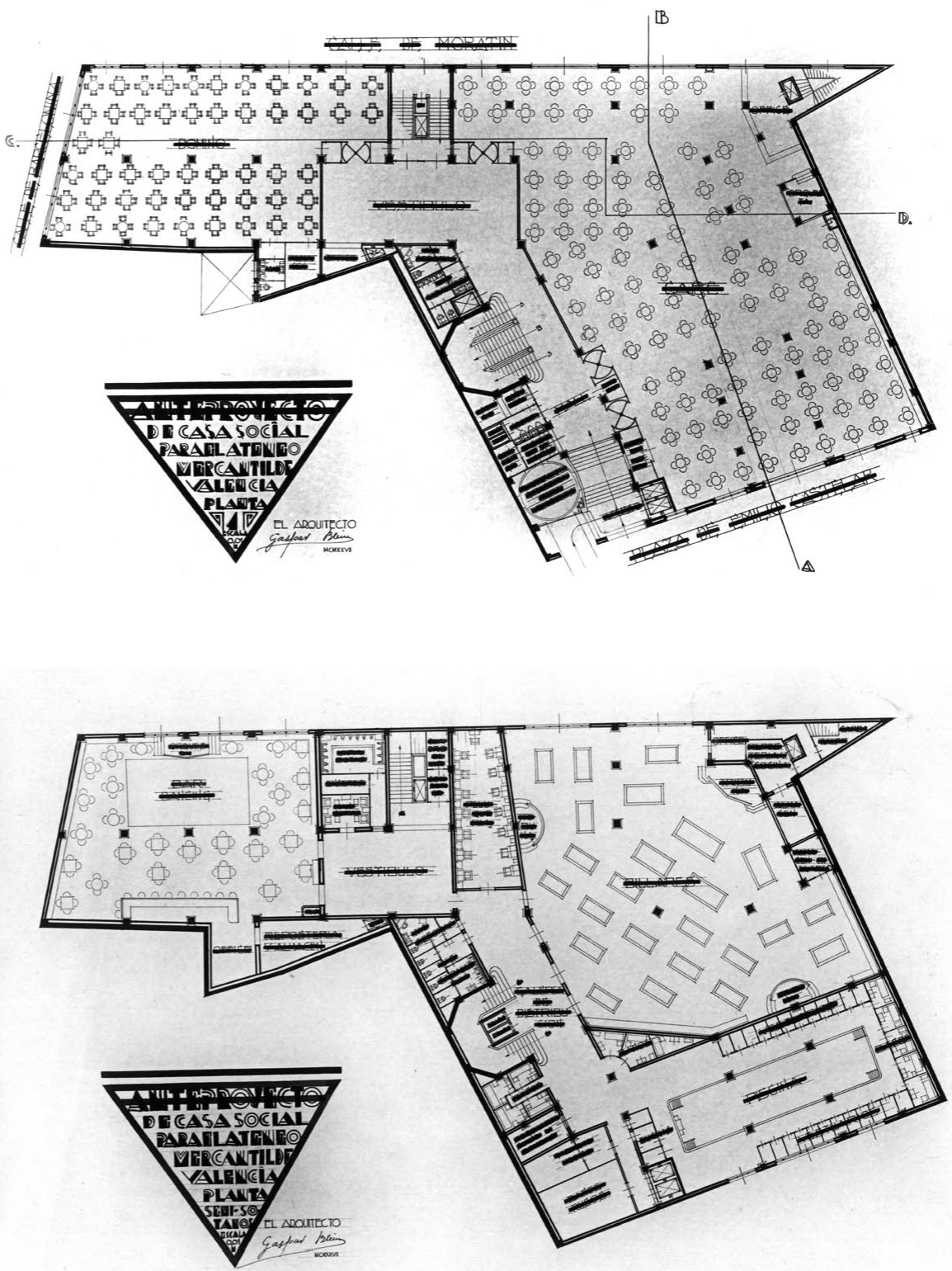


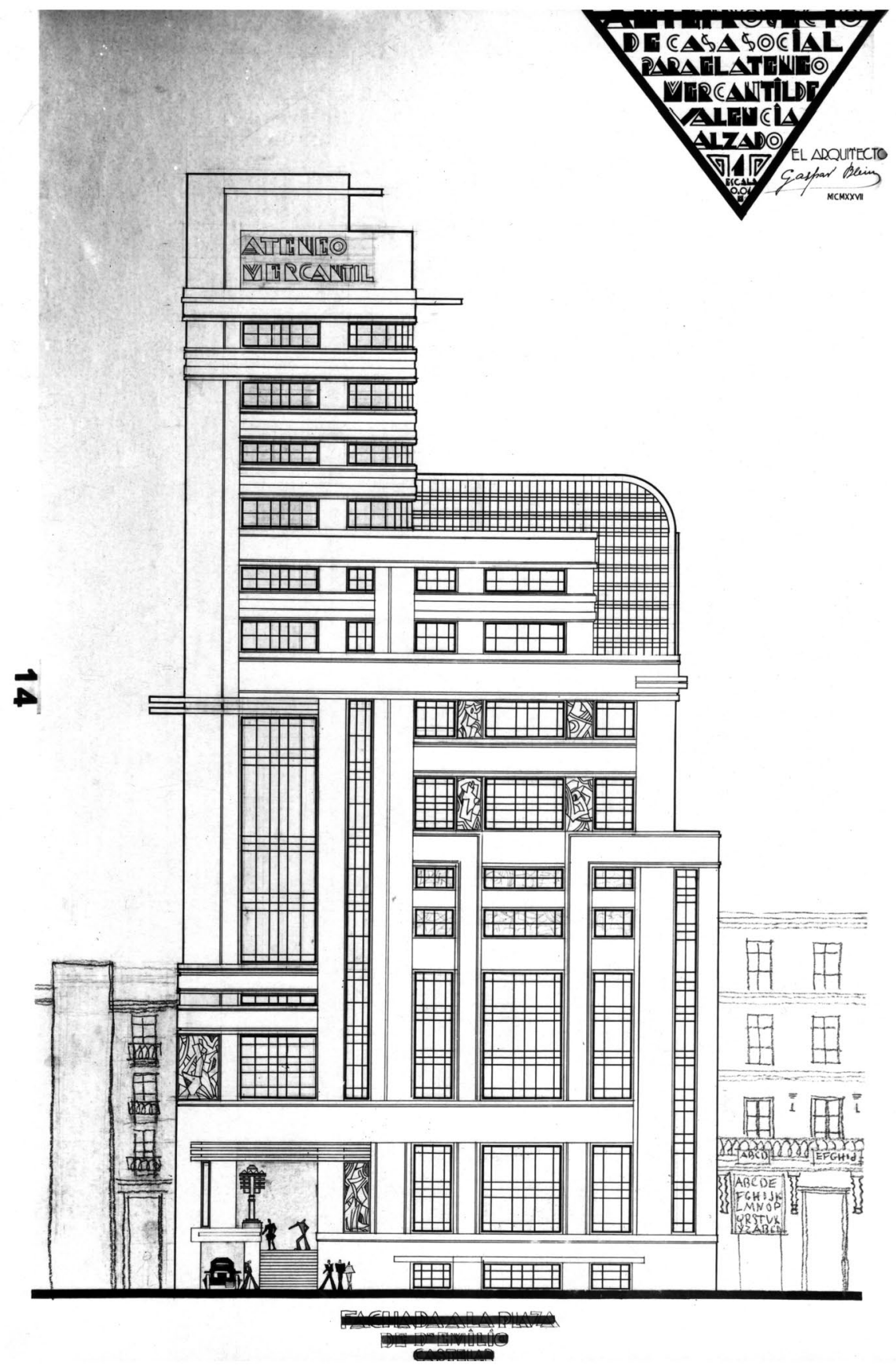



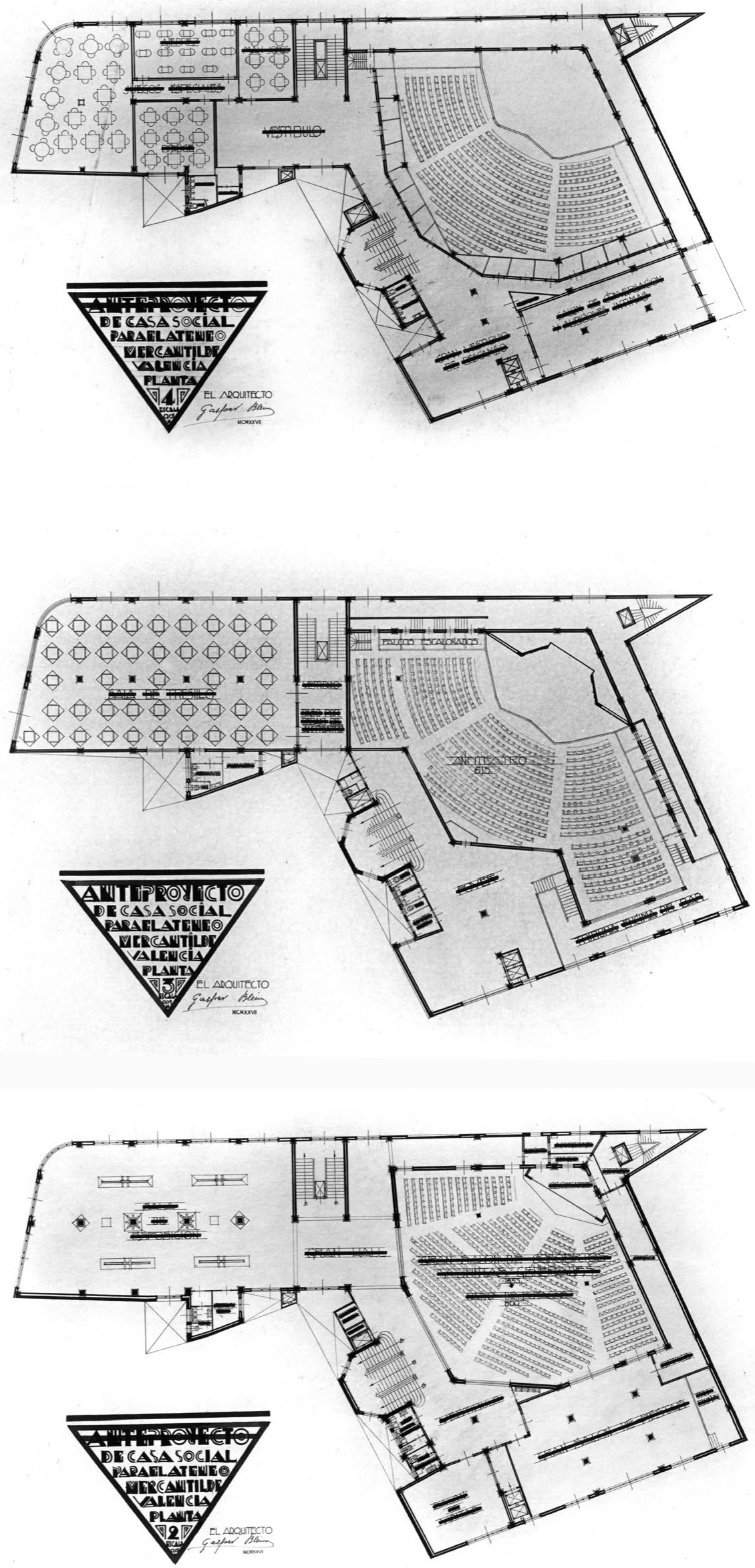


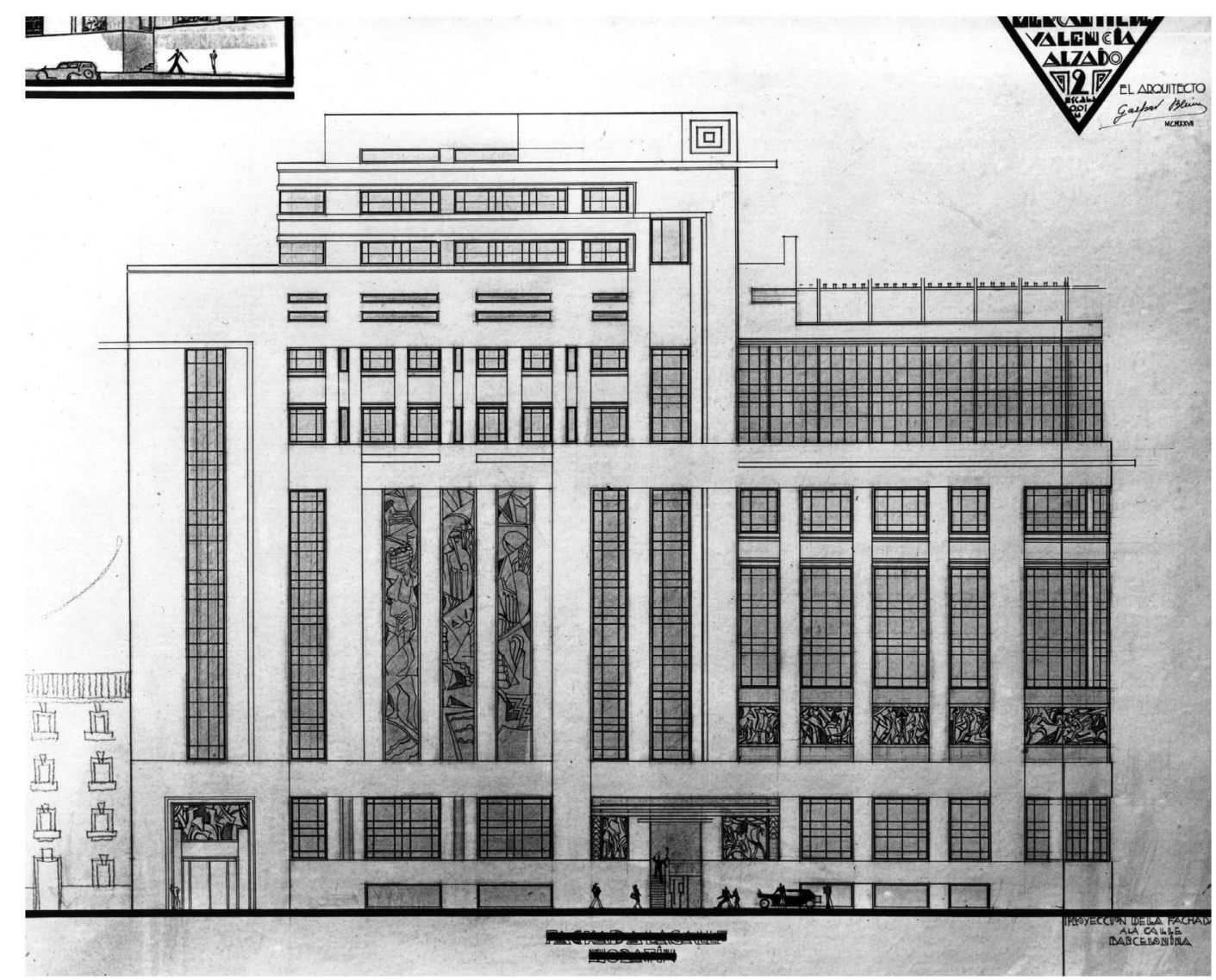



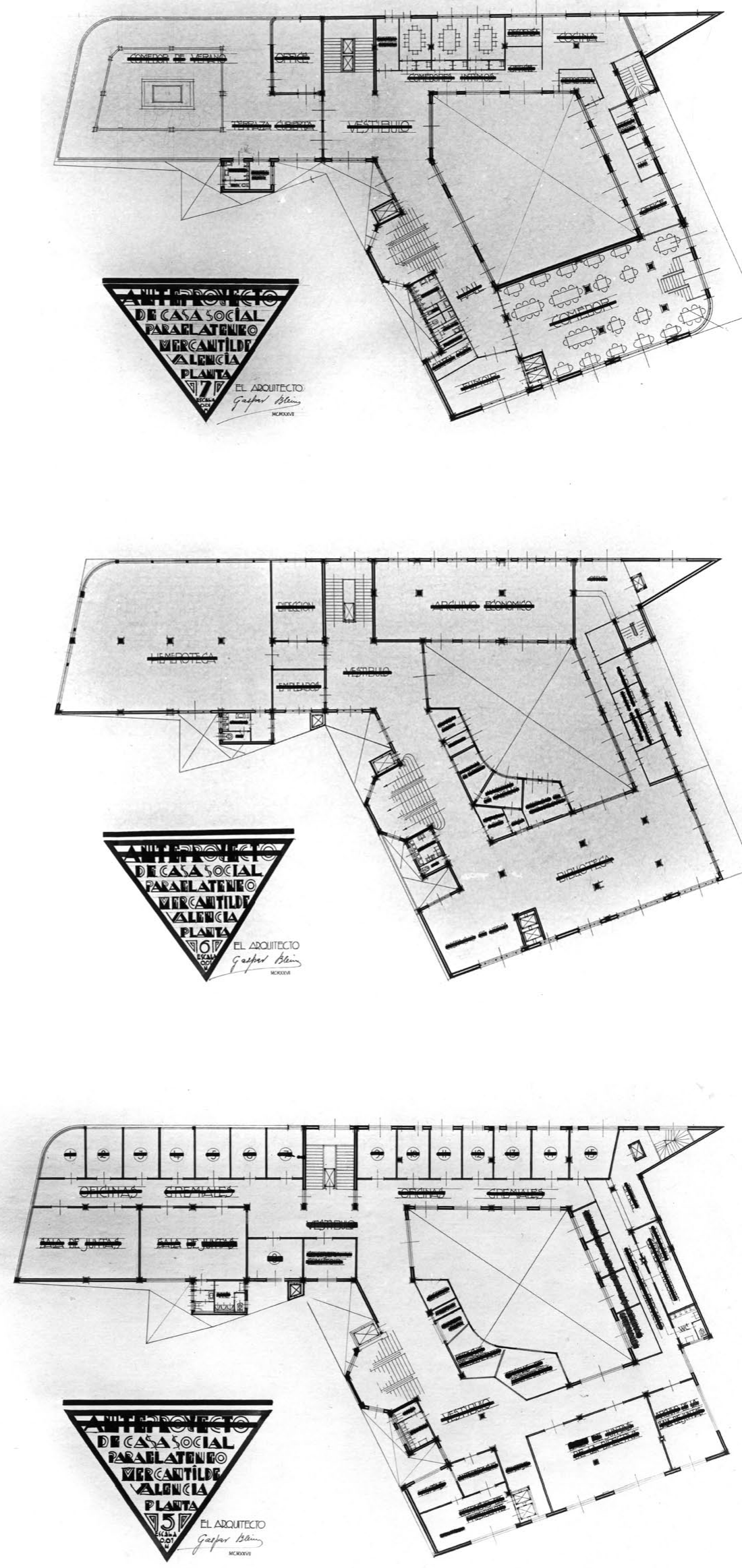


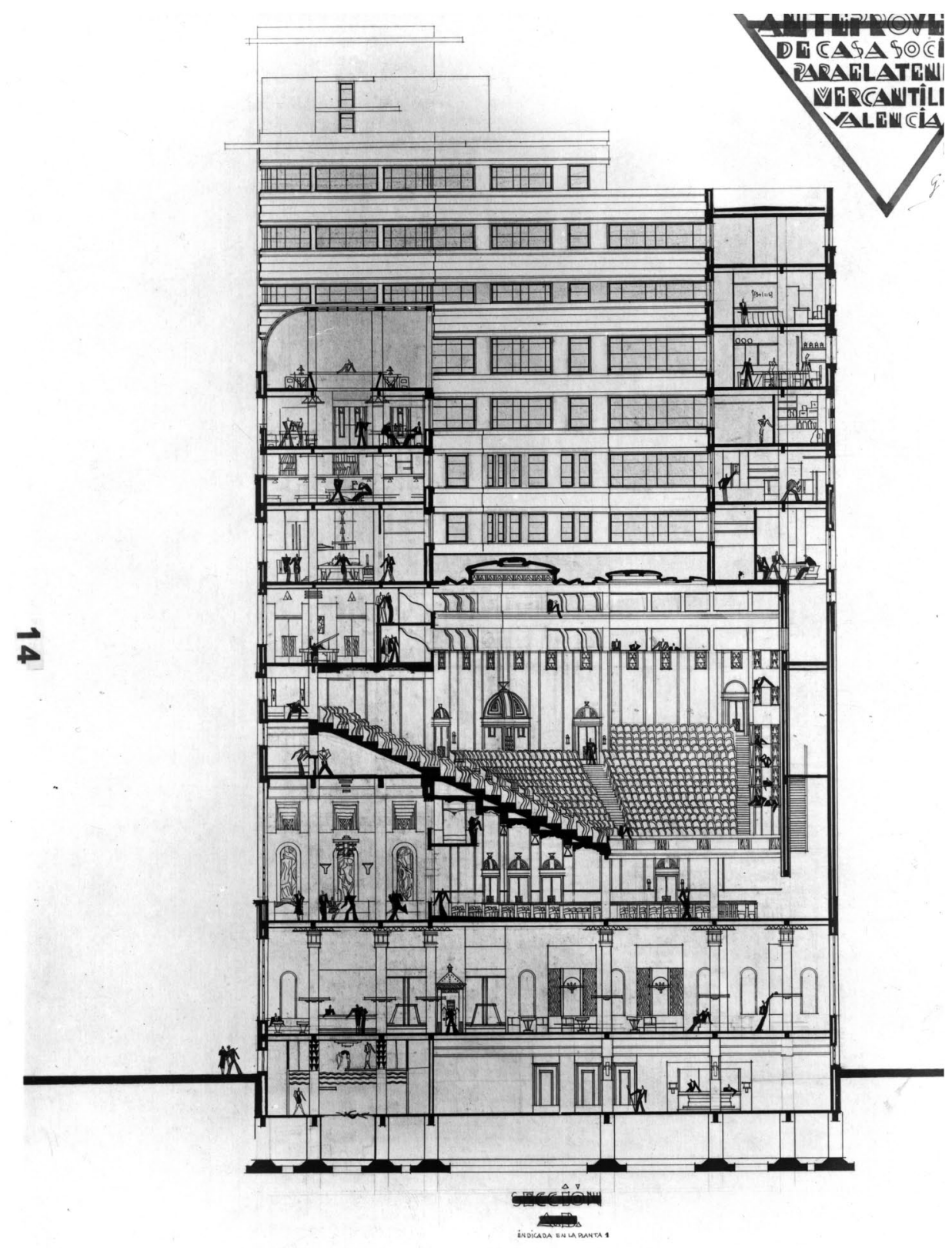



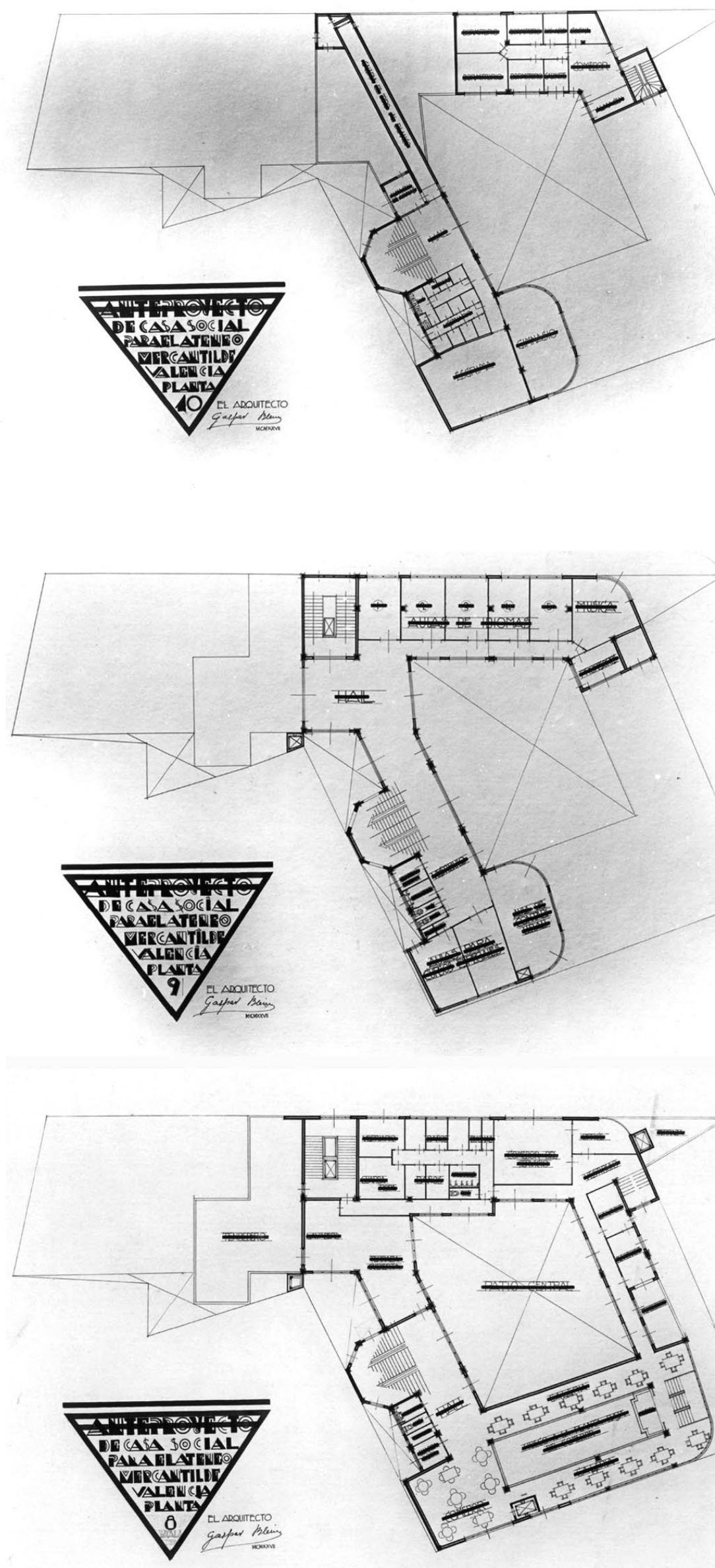

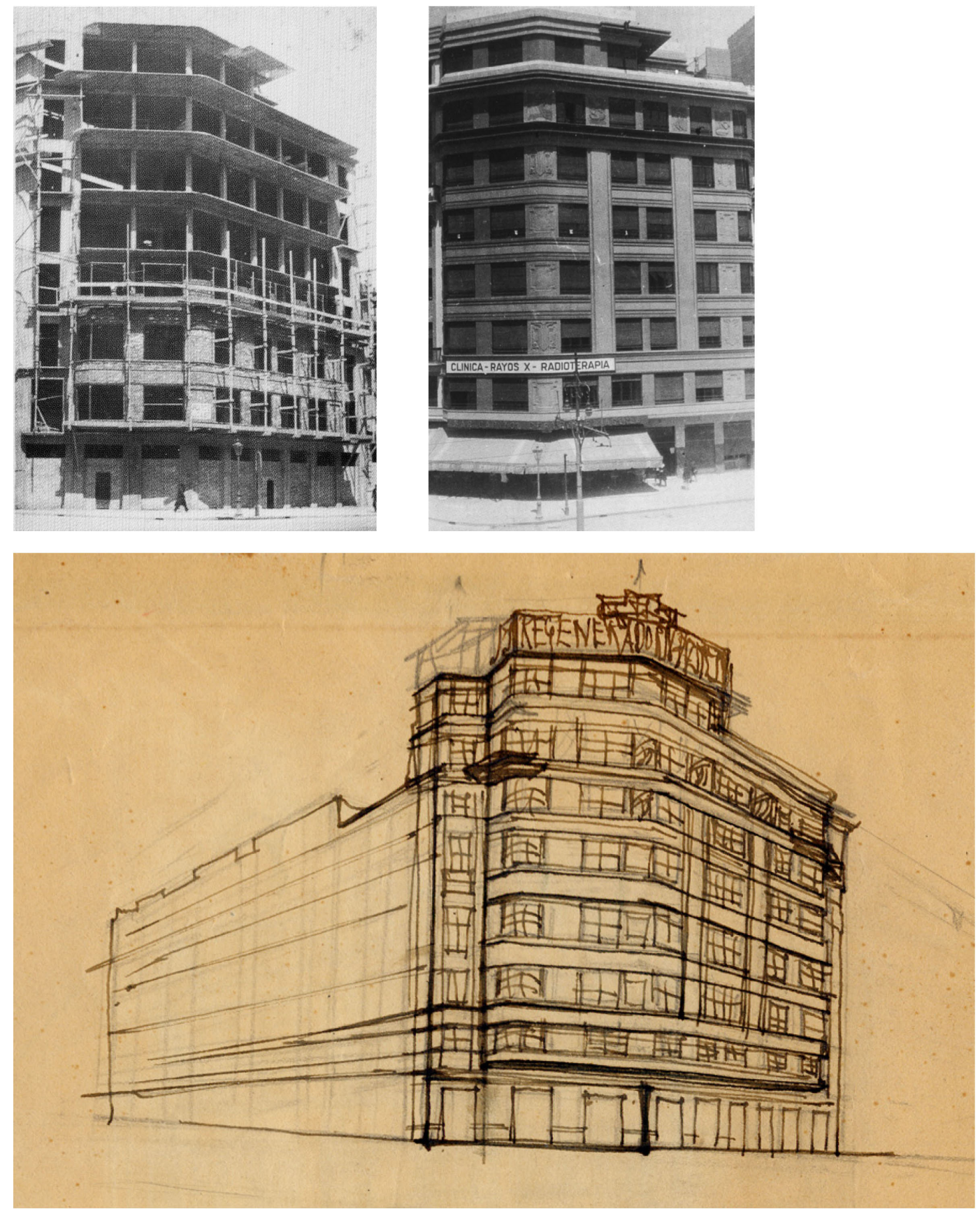
1929. Caja 17: Expediente 03388

EMPLAZAMIENTO: Játiva, 13 (actual 21) y calle Ribera

PROMOTOR: Carbajosa, Francisco

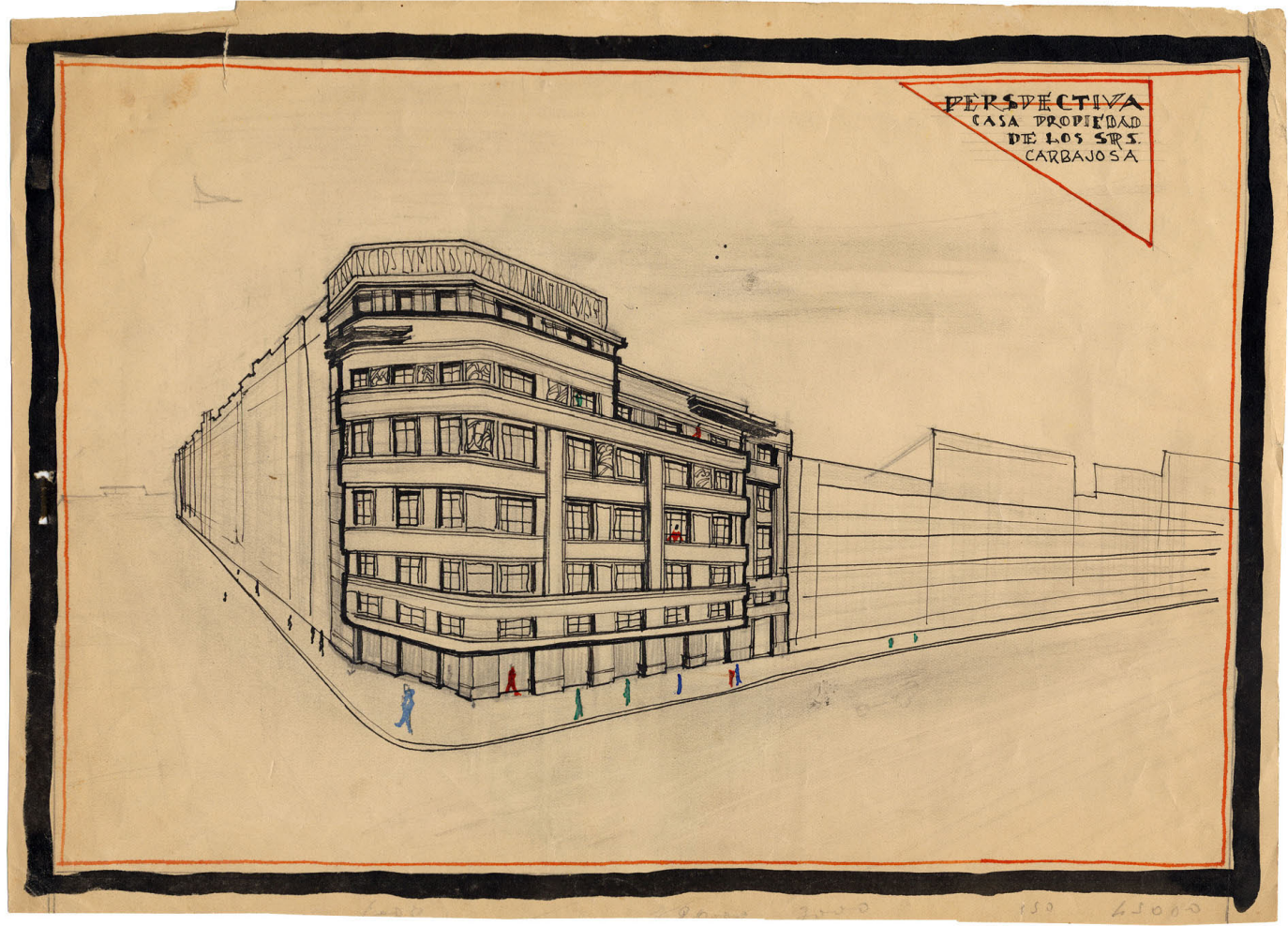




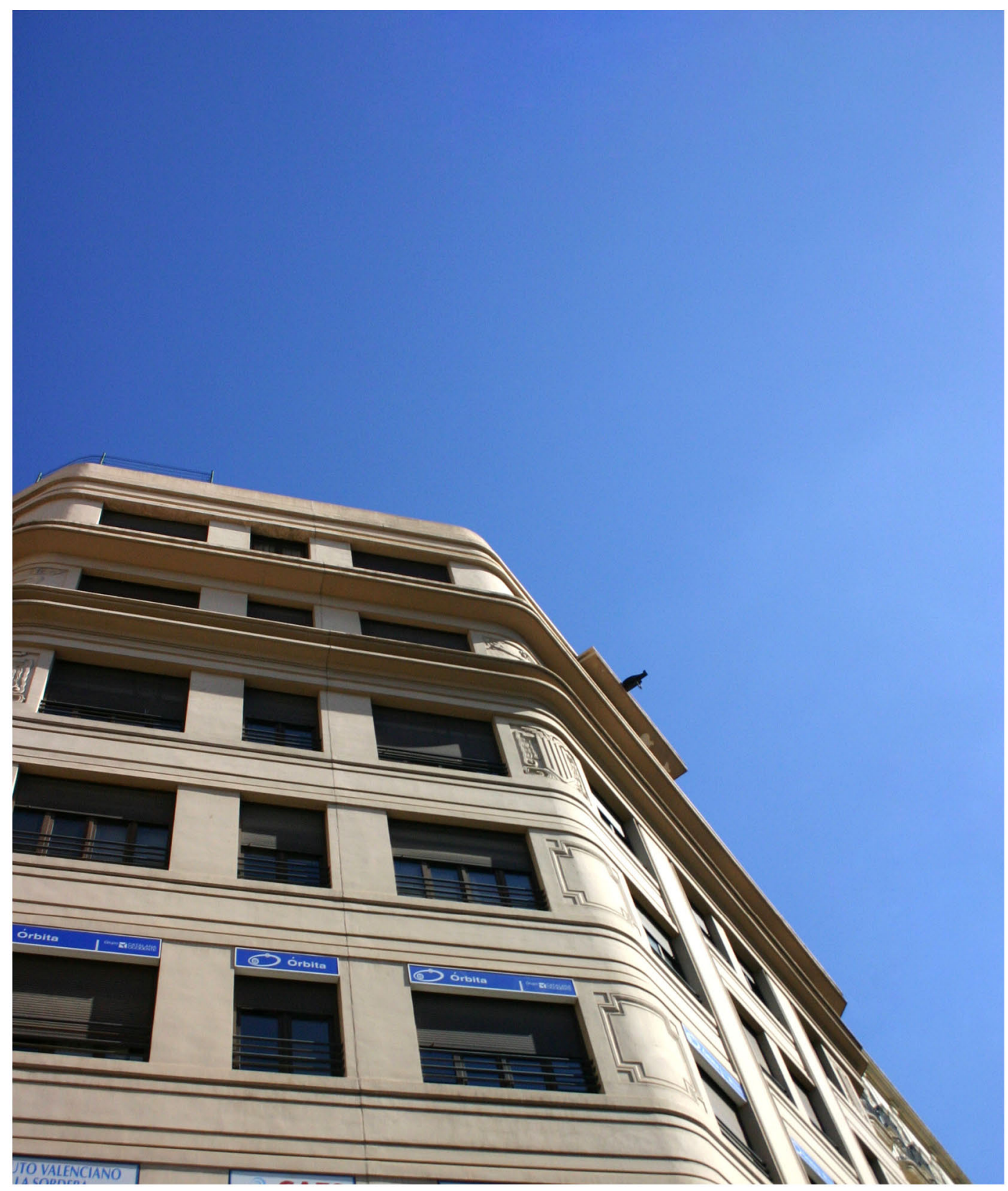



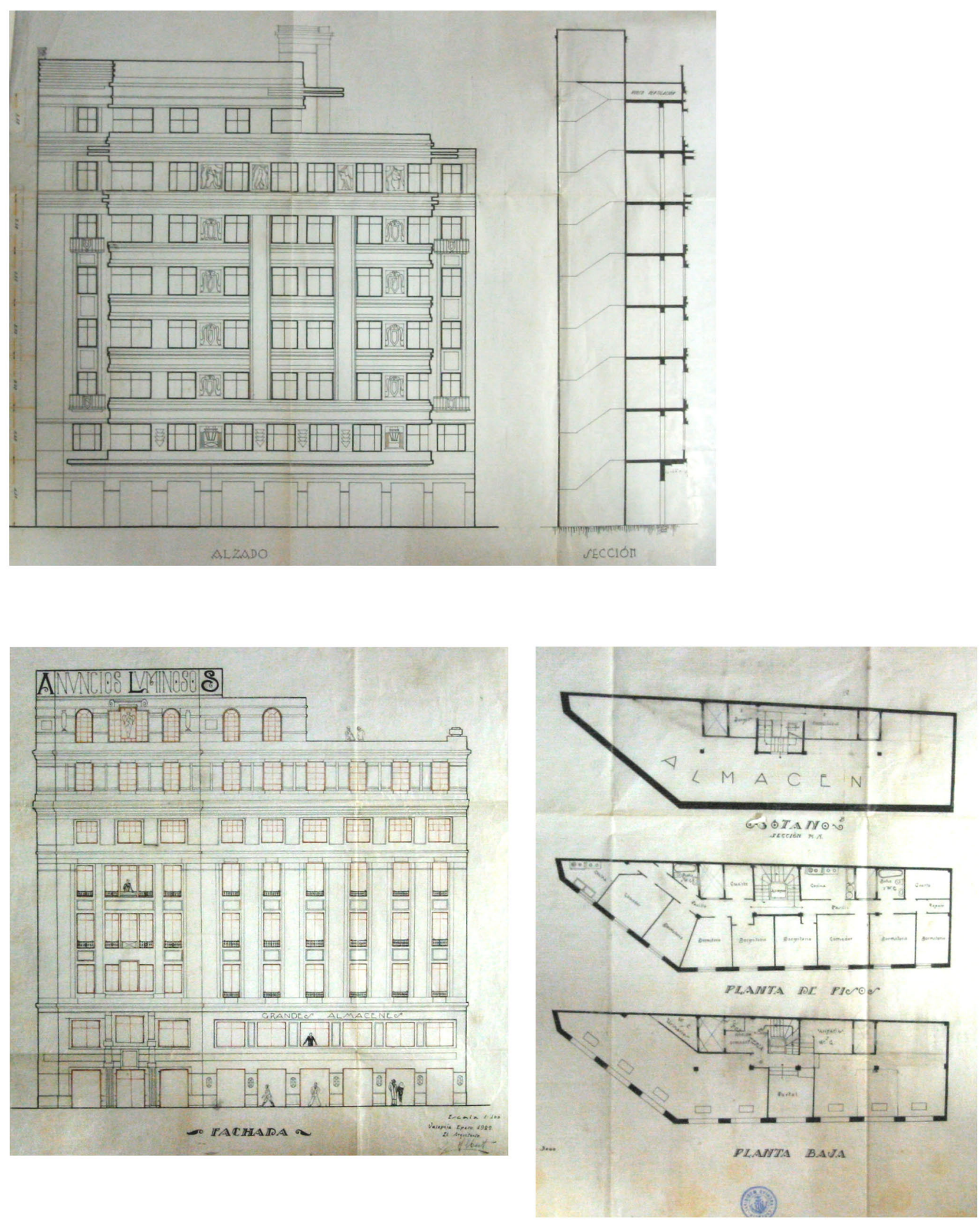


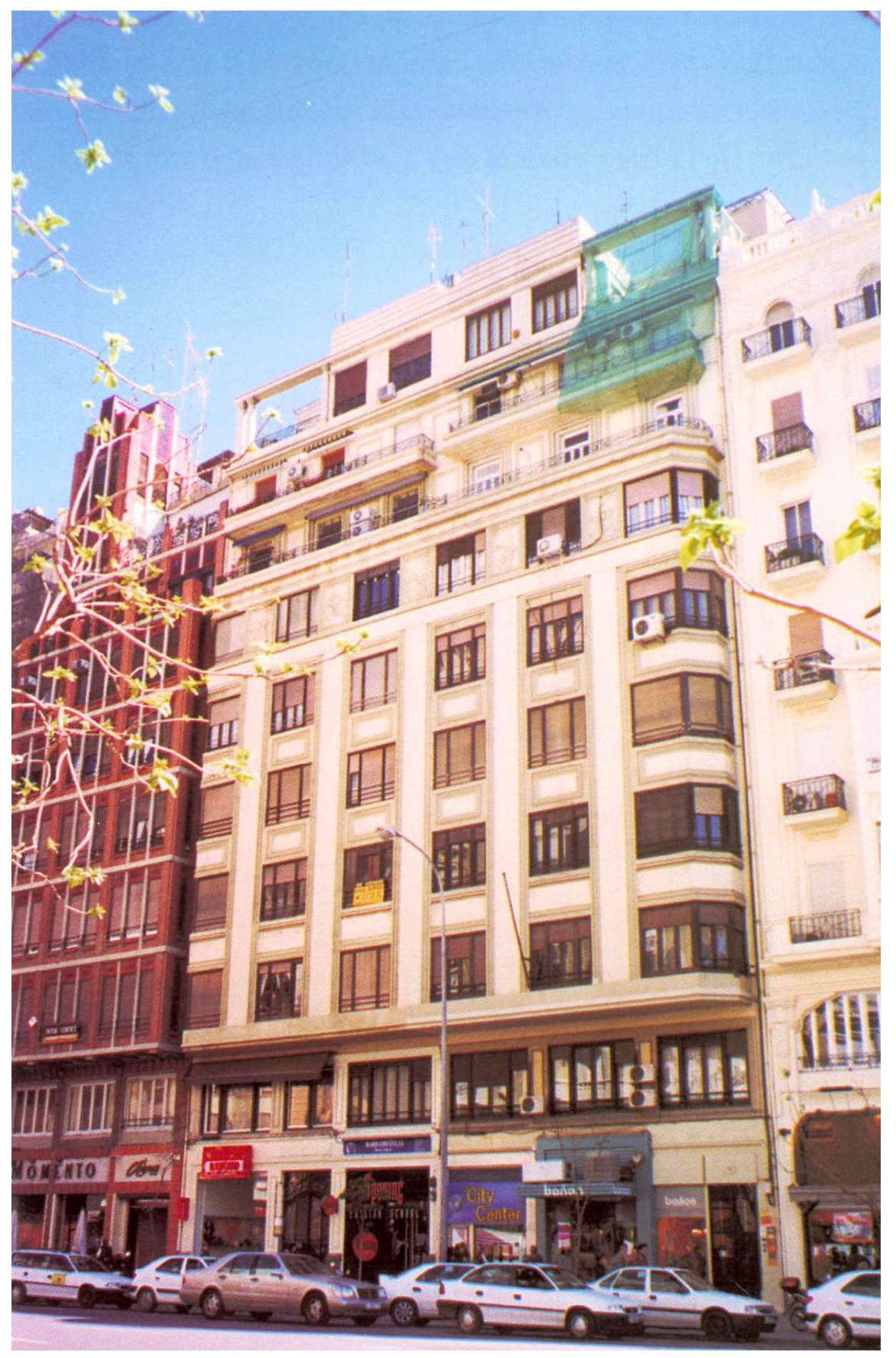


1930. Caja 05; Expediente 00008

EMPLAZAMIENTO: Blasco lbáñez, avenida (actual plaza del Ayuntamiento) PROMOTOR: Sánchez, Tomás

1930. Caja 05; Expediente 00011

EMPLAZAMIENTO: Blasco lbáñez n 13, avenida

PROMOTOR: García, Rufino

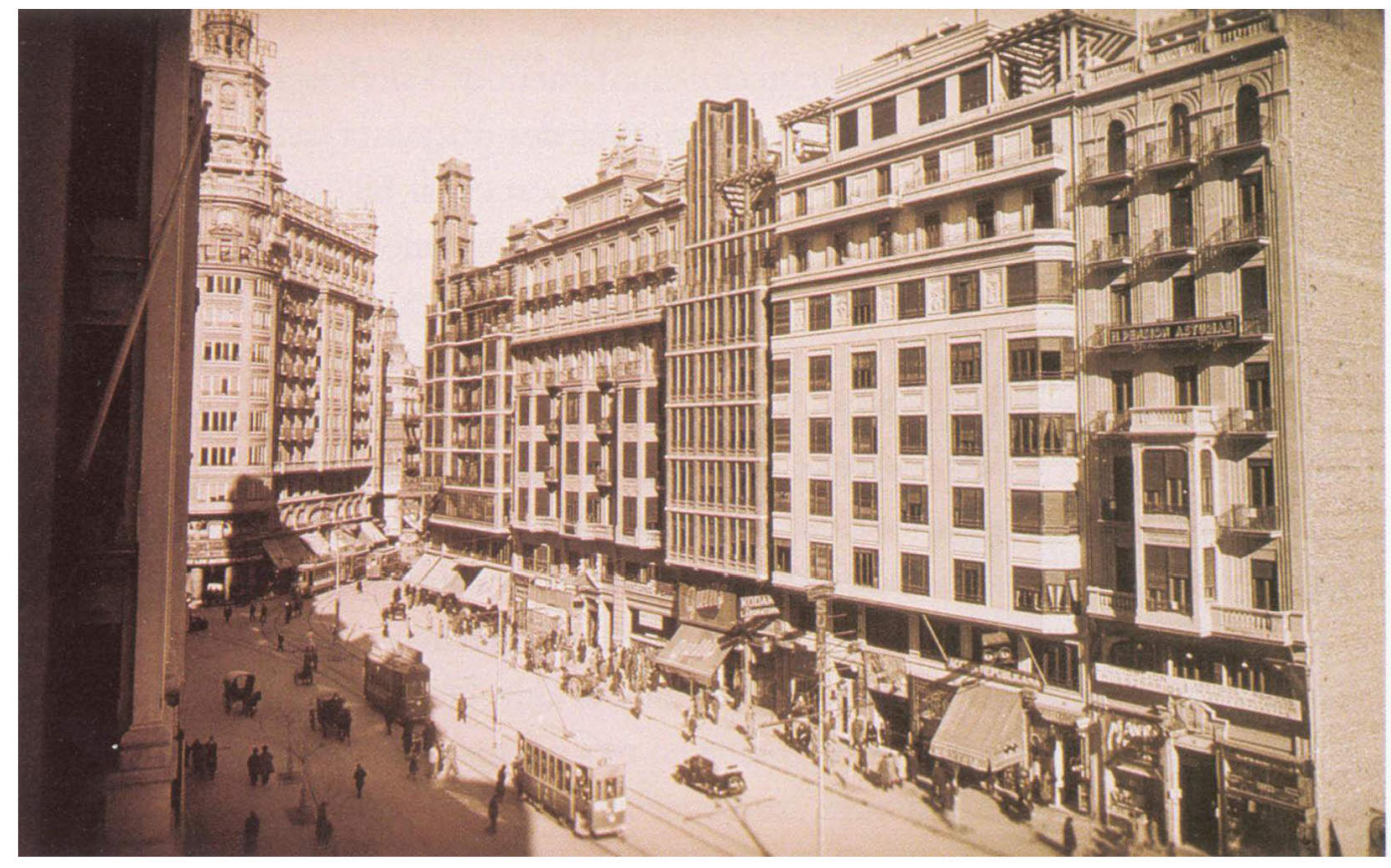




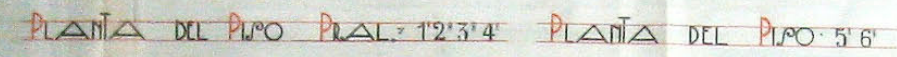
Pl $\triangle$ NTIA de ATICOO
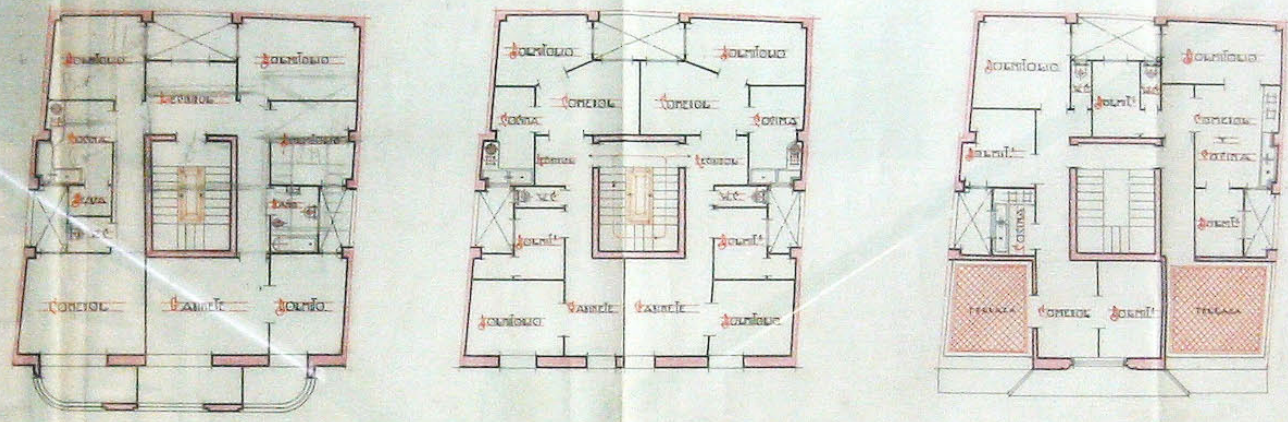

PLAMTA DE JOTAMO
PANTA BAIA

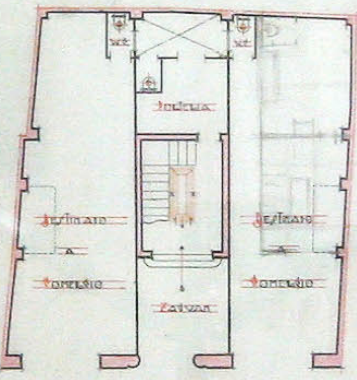

PLANTA de ENTRLVELO

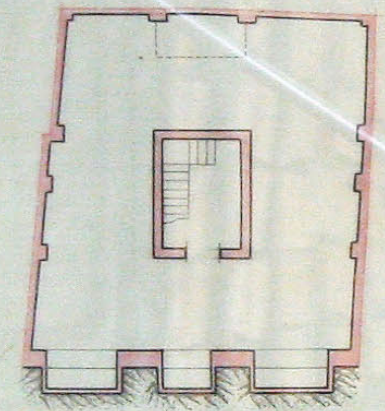

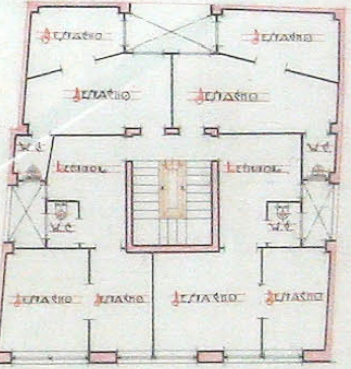




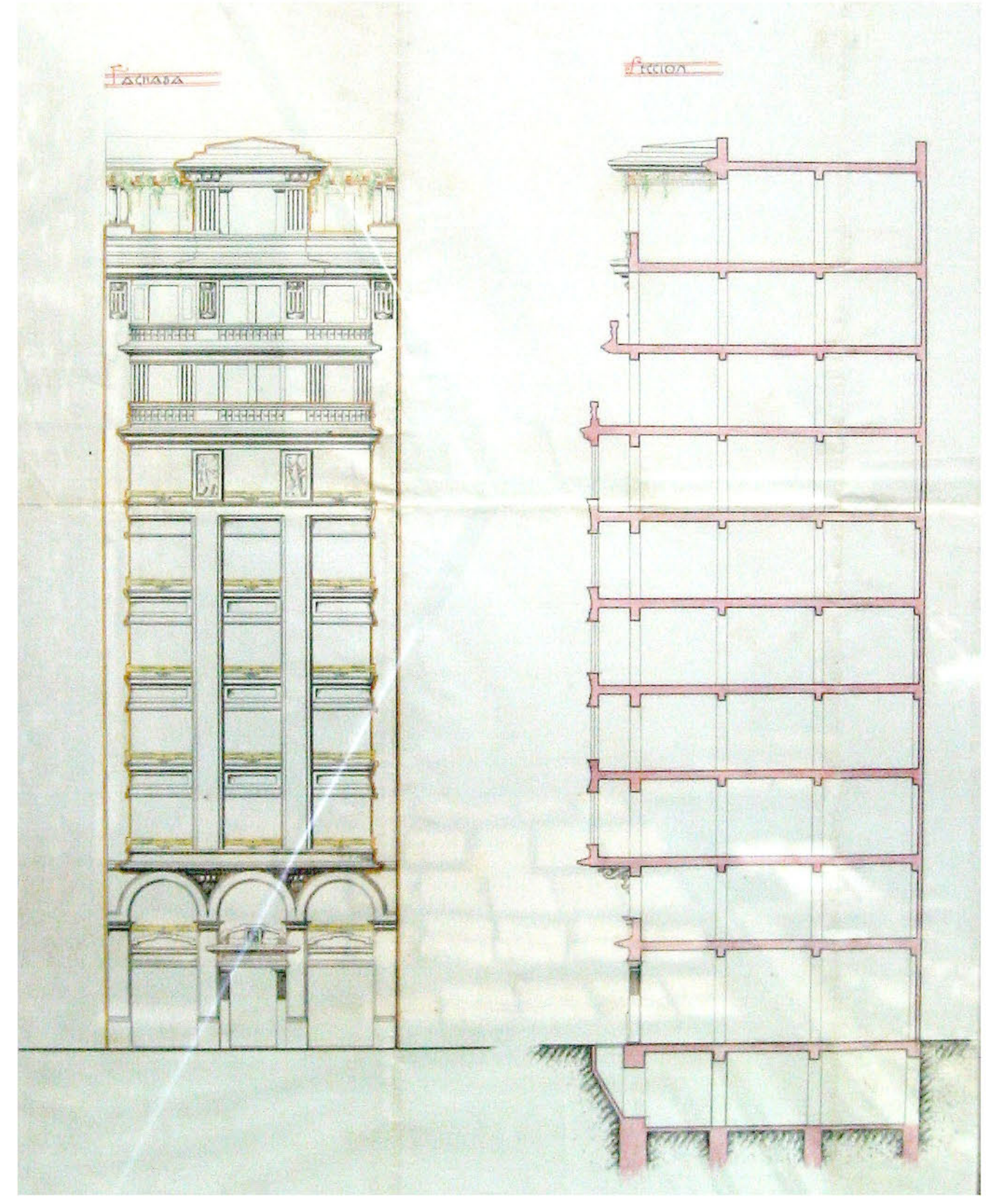



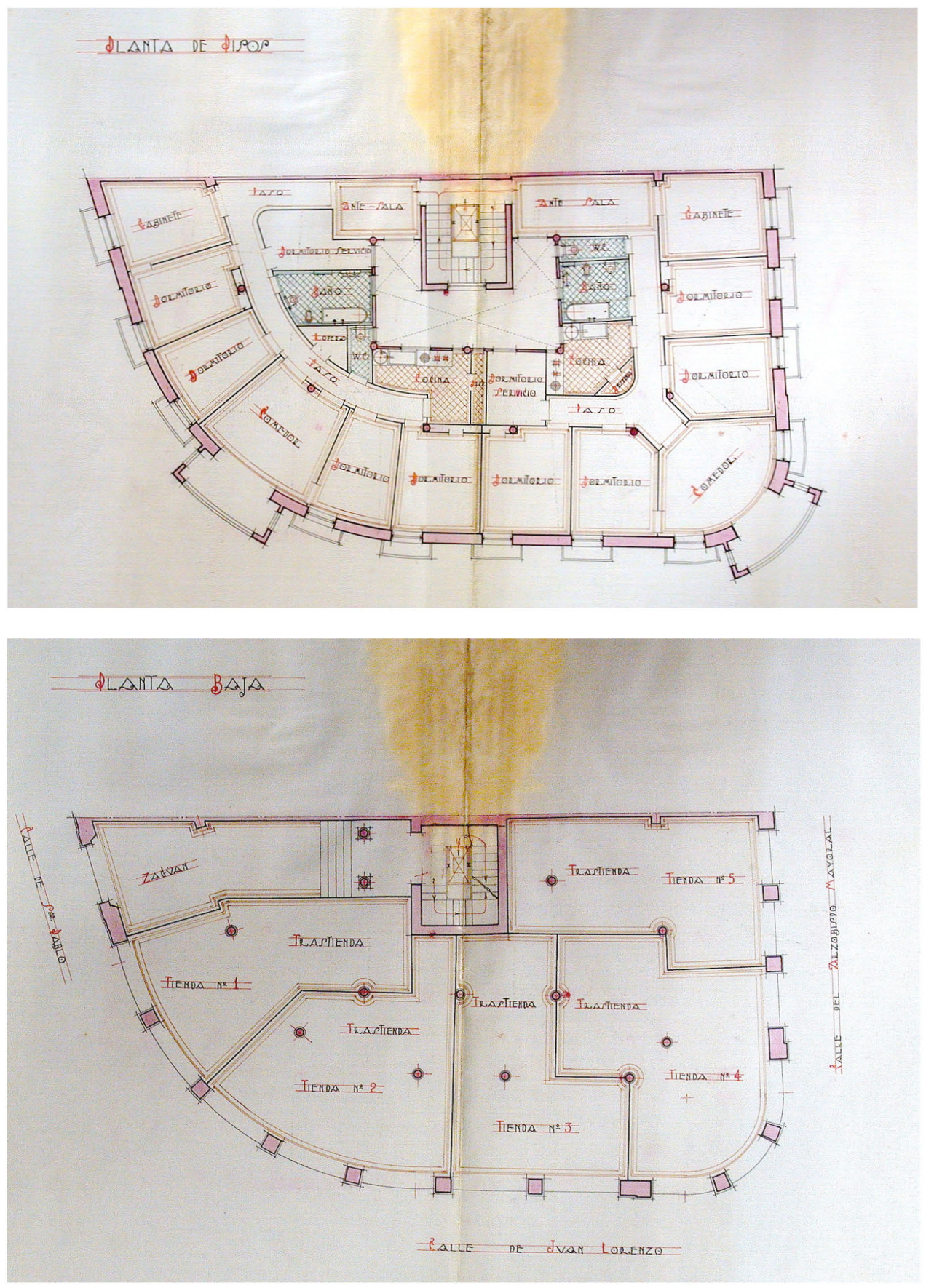
1930. Caja 13; Expediente 00050

EMPLAZAMIENTO: Juan Lorenzo, San Pablo y Arzobispo Mayoral PROMOTOR: Momparler, Manuel

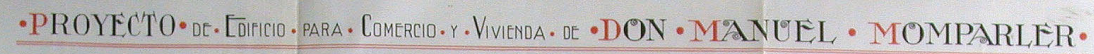

A 4

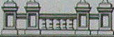

A 4 A $A$ A

$\underline{0.000909}$

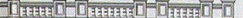

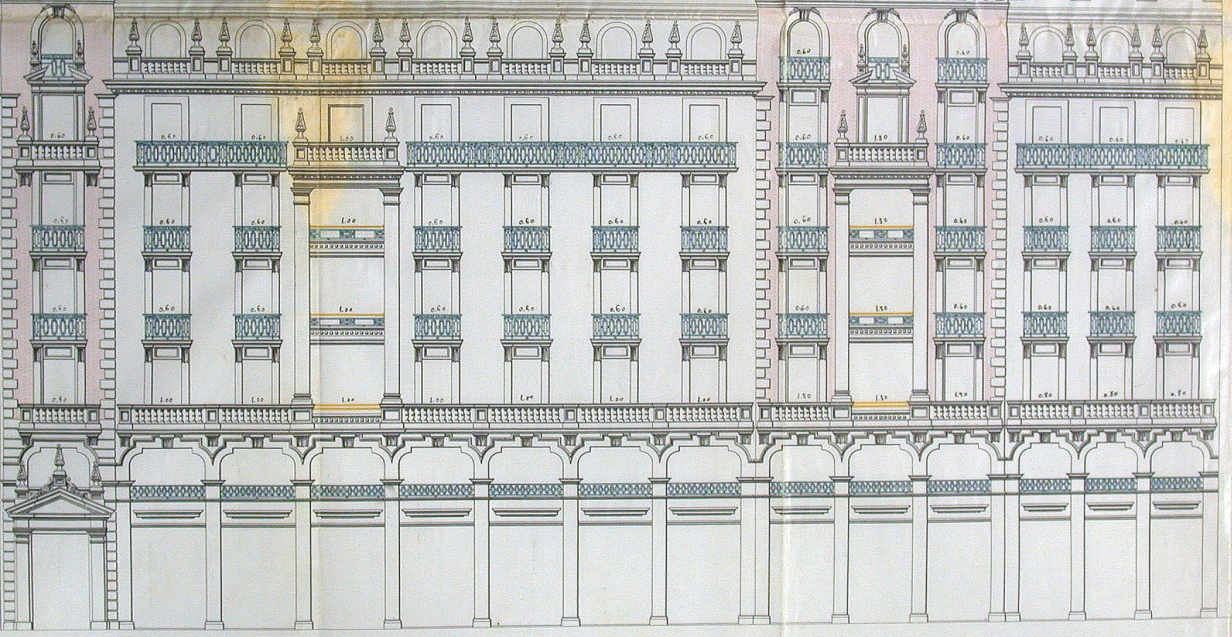




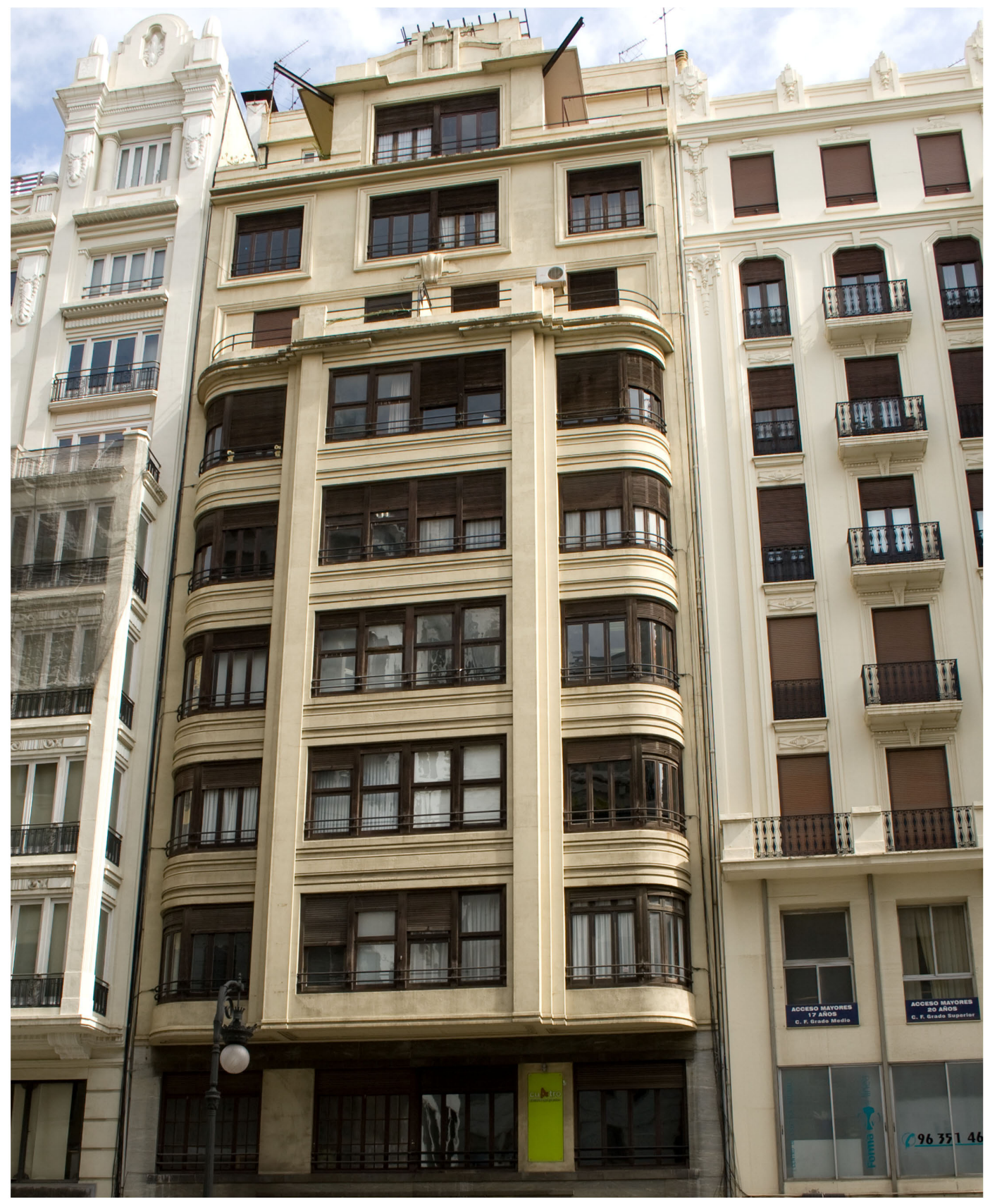


1930. Caja 27: Expediente 00021

EMPLAZAMIENTO: San Vicente

PROMOTOR: Mompó, Juan Antonio
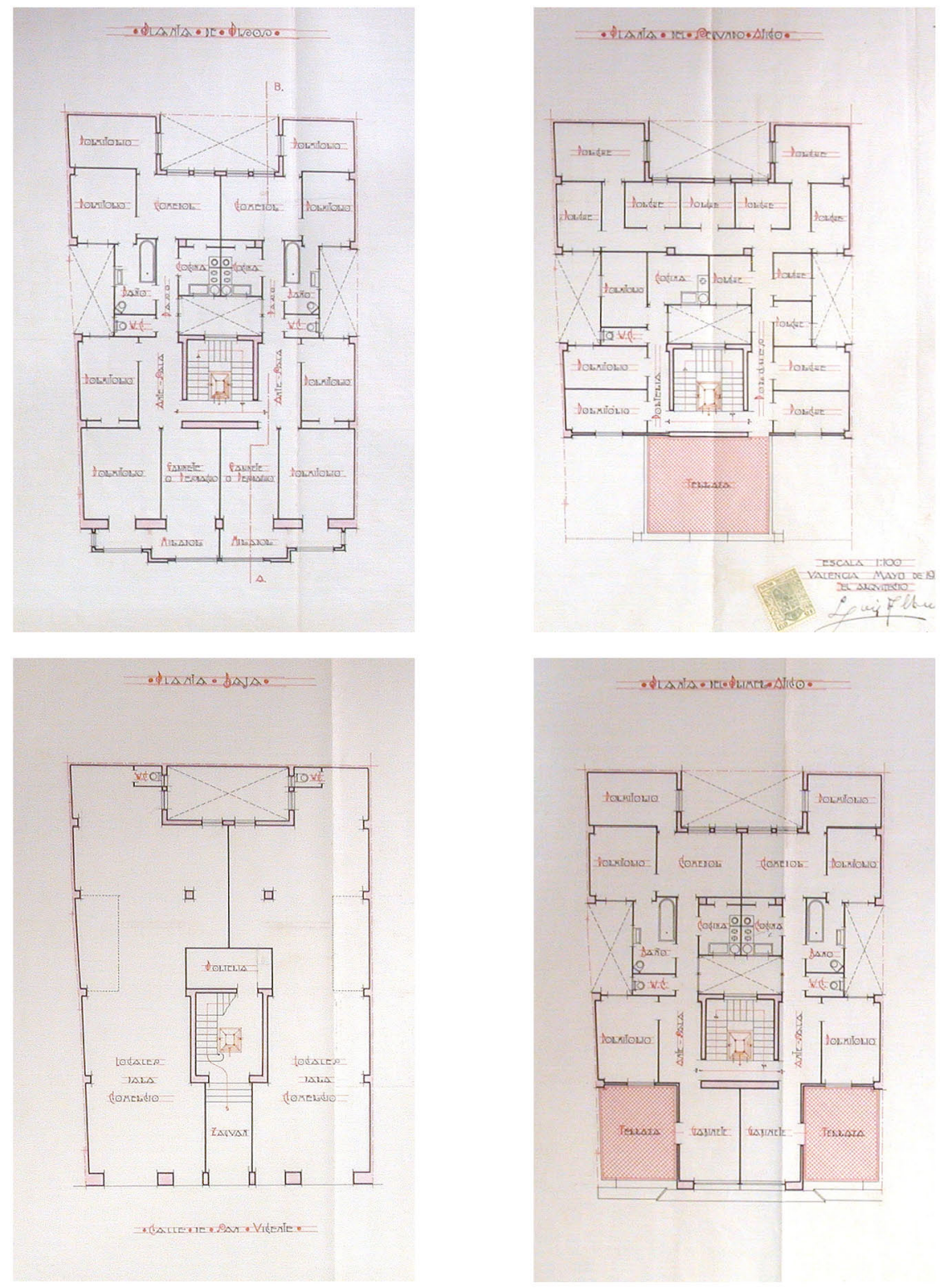


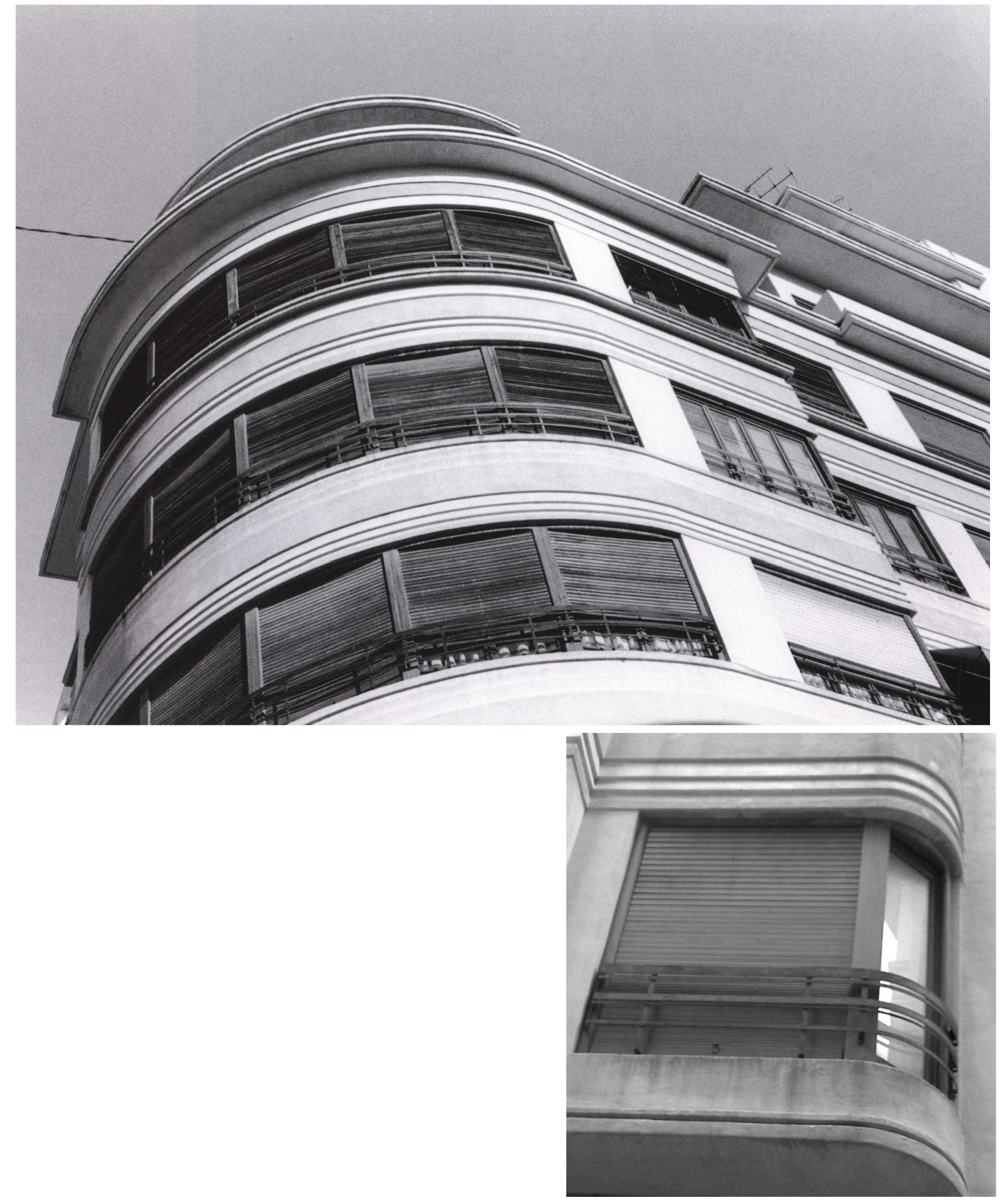


1931. Caja 08; Expediente 00006

EMPLAZAMIENTO: de la Nave, Comedias y Barcelona PROMOTOR: TortOsa, Pilar
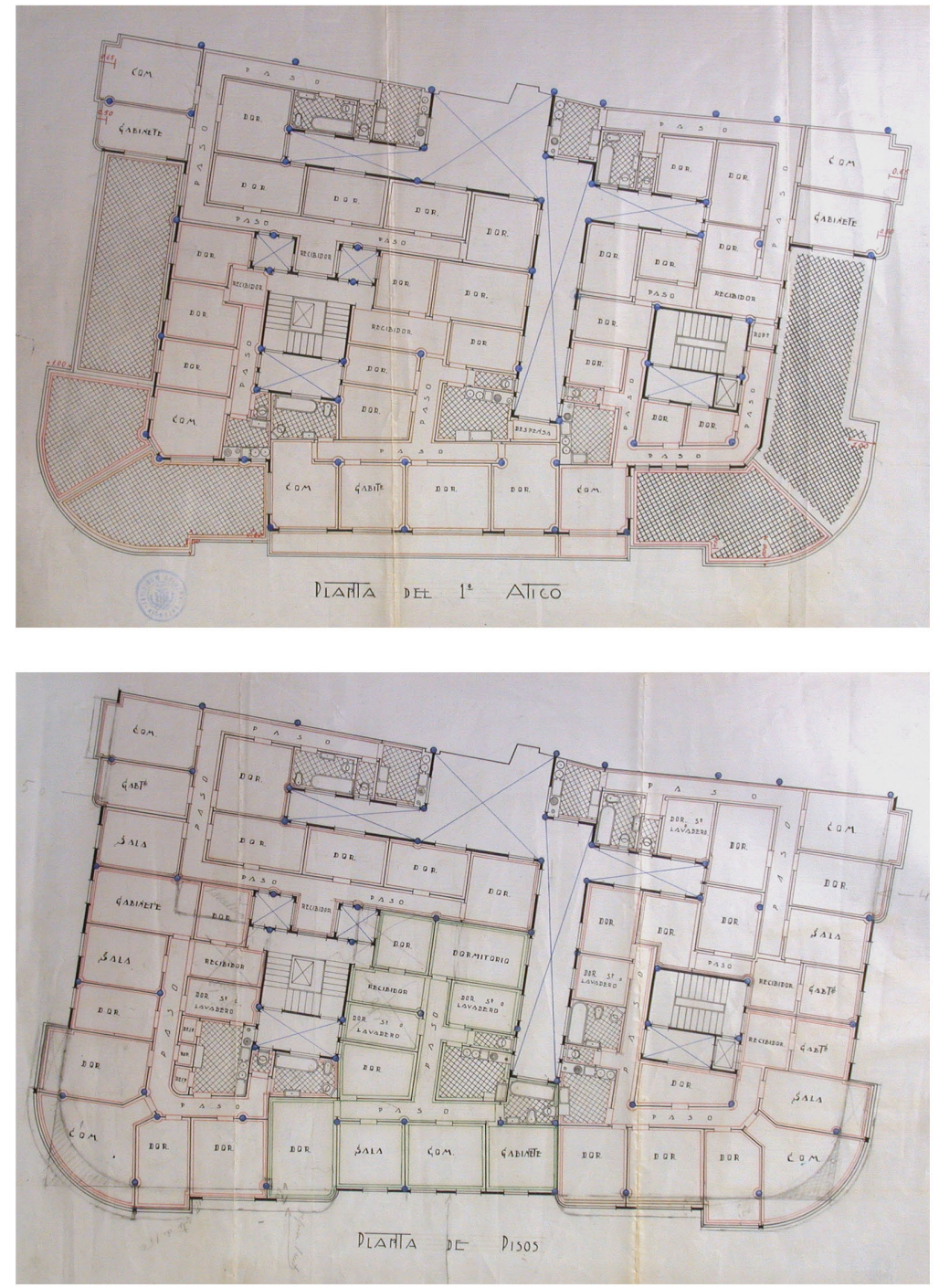

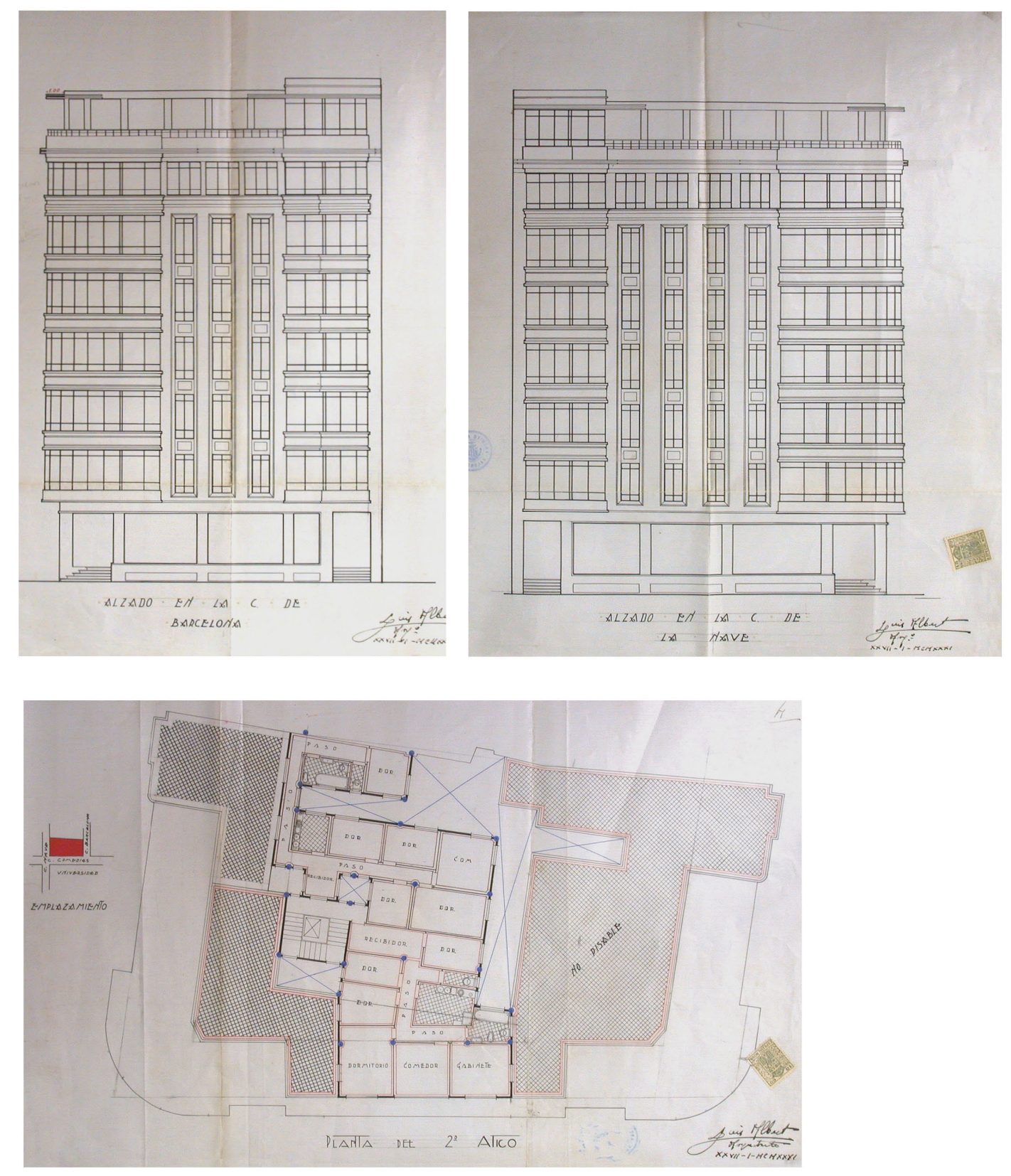

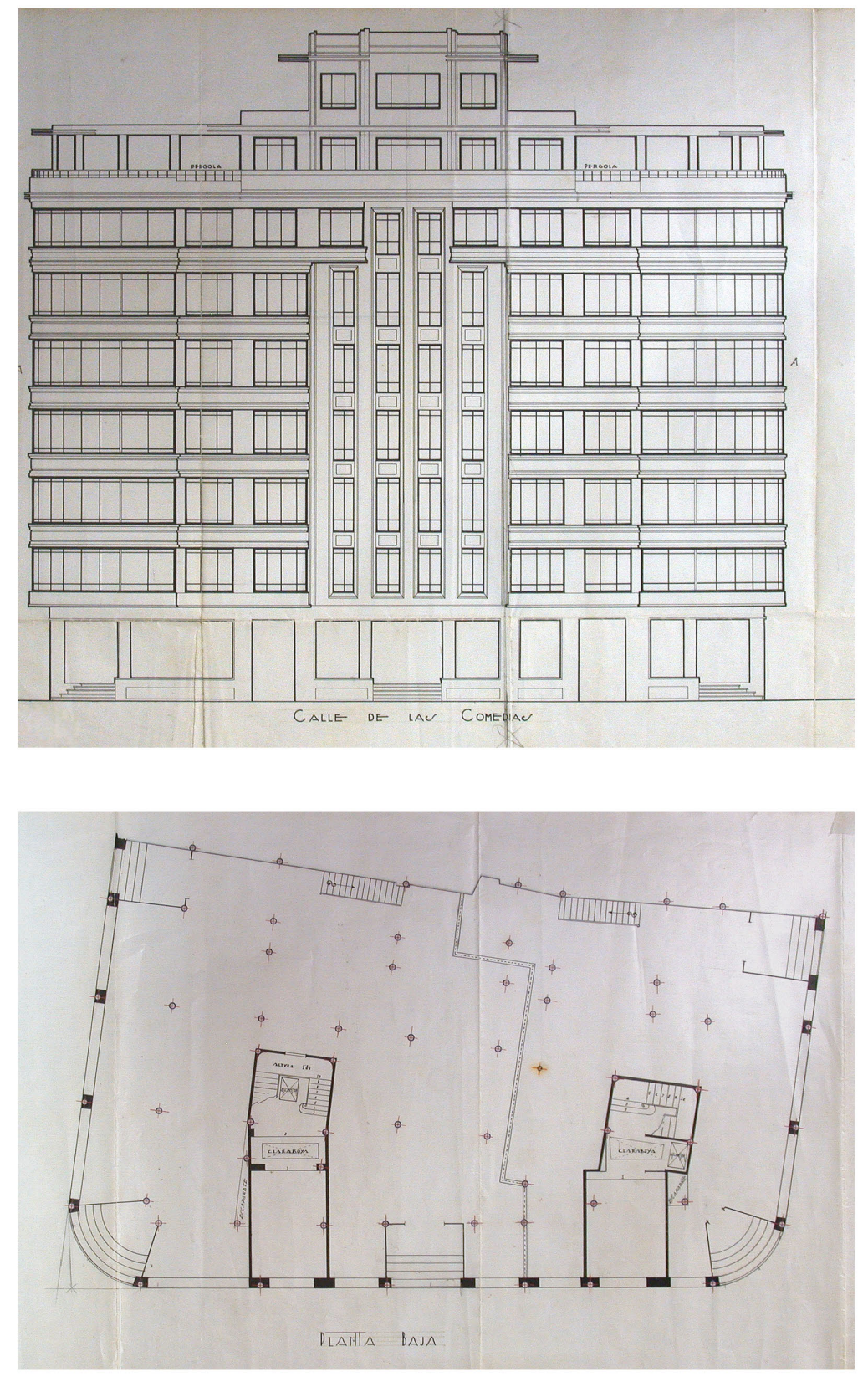


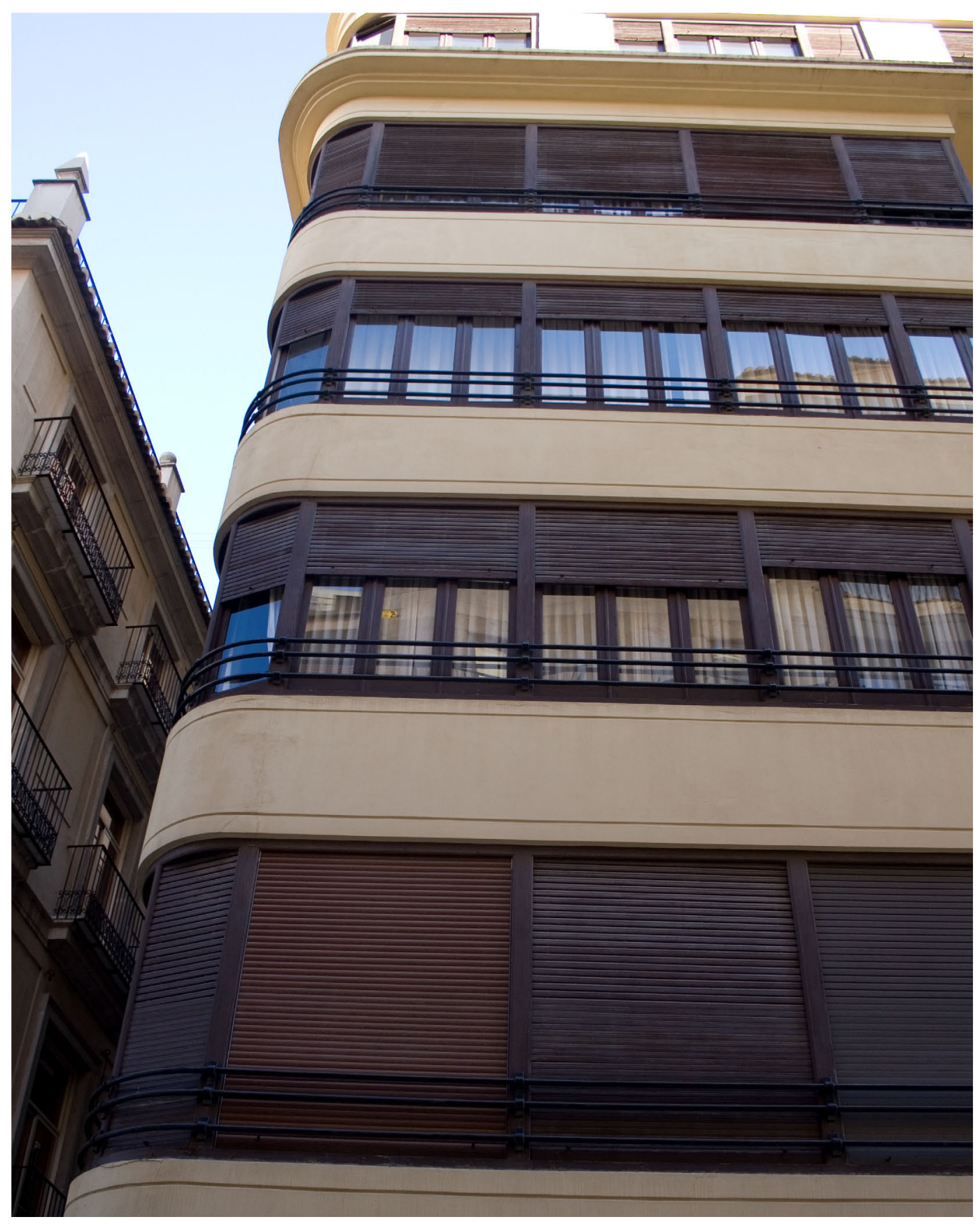


1932. Caja 13; Expediente 0033B

EMPLAZAMIENTO: Navellos, Micer Tarazona y Yerba PROMOTOR: Cánovas, Manuel
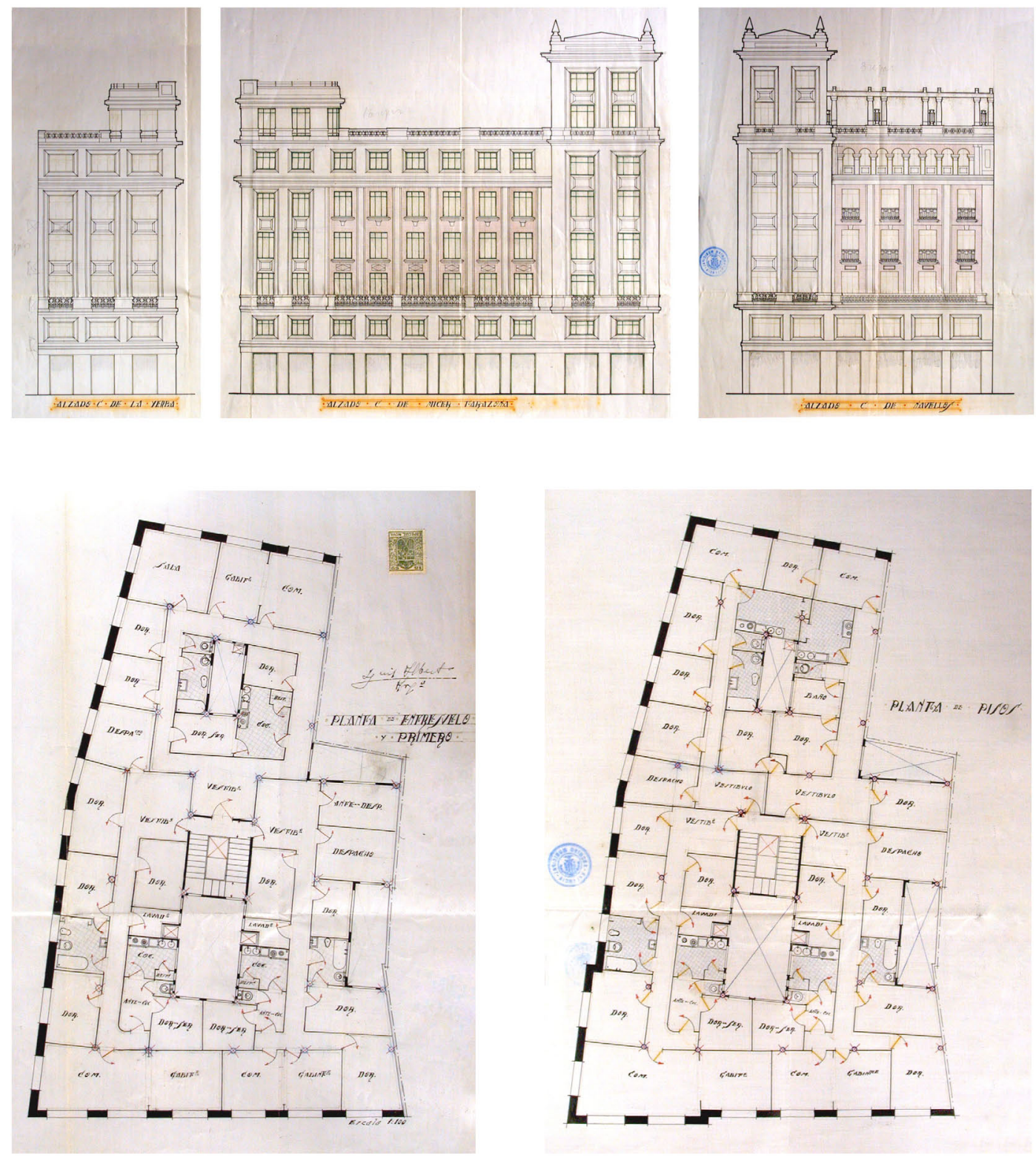


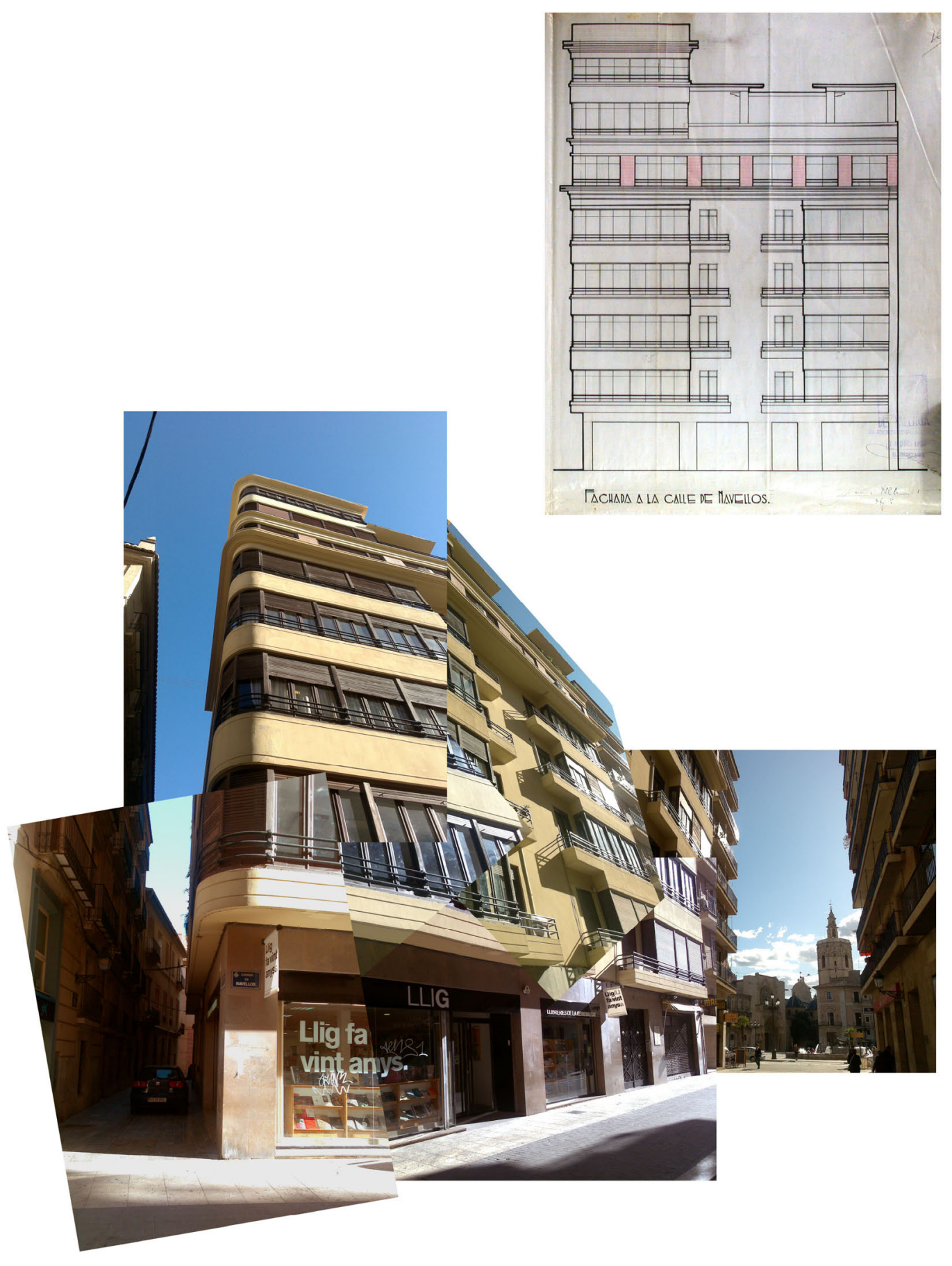



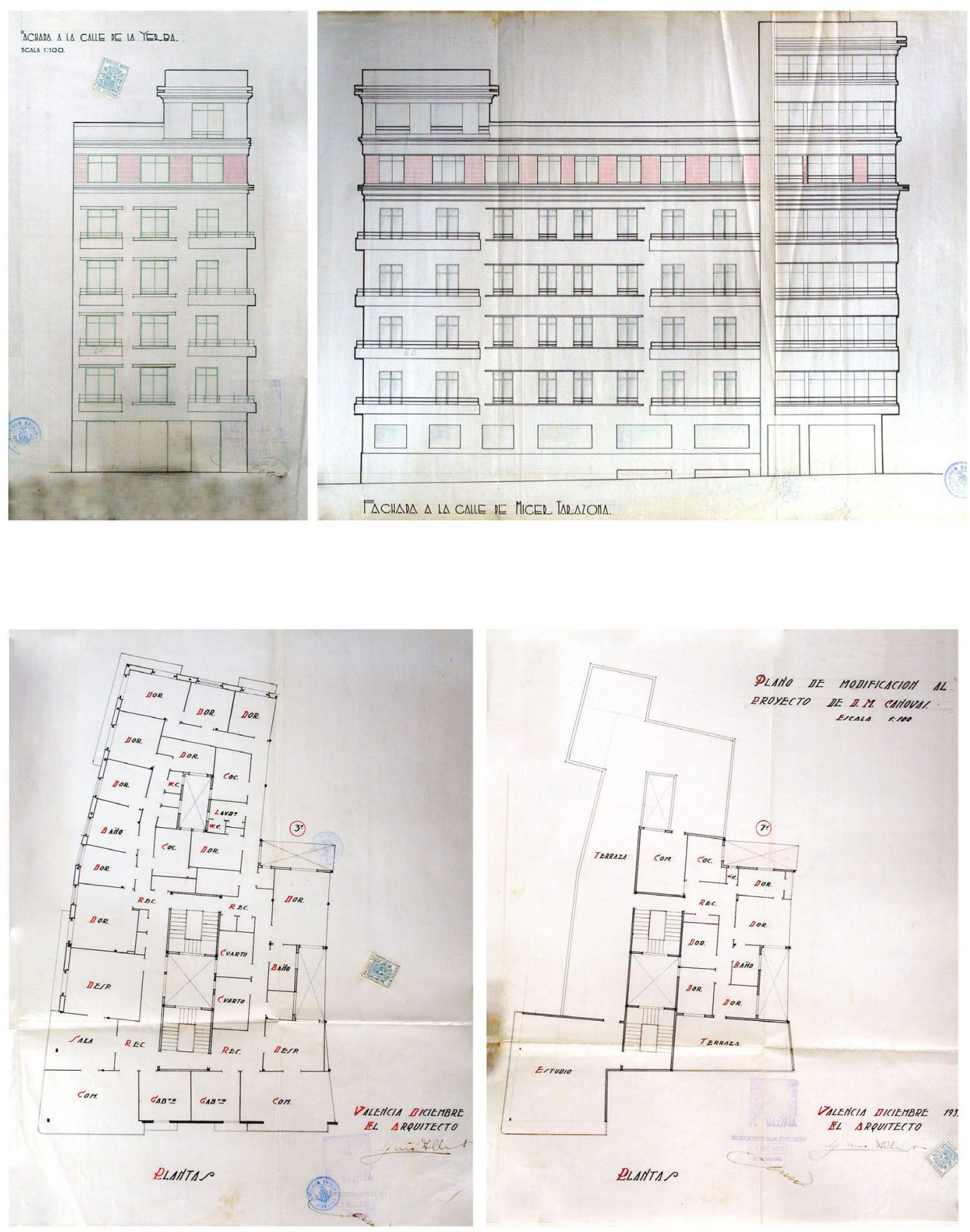

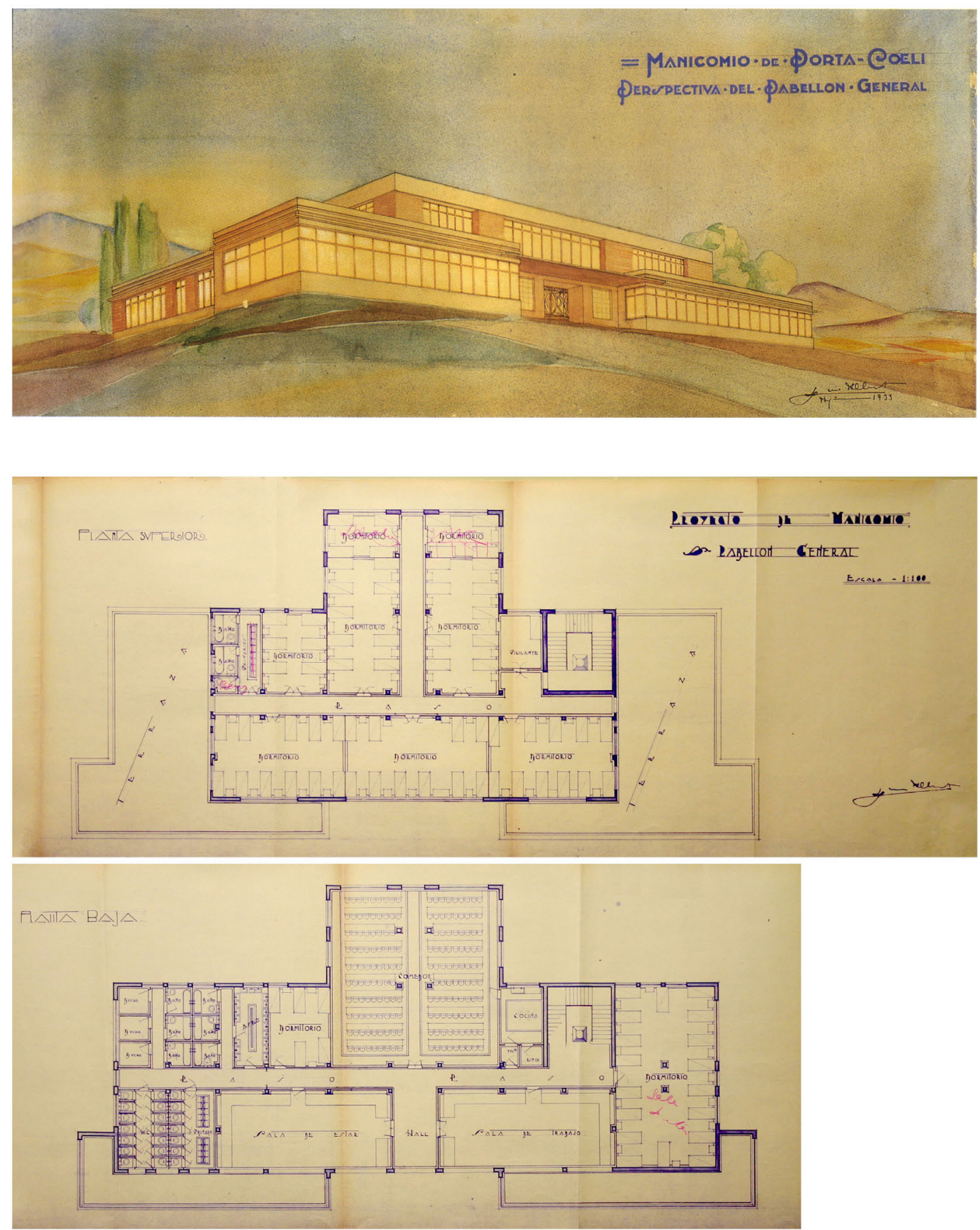
EMPLAZAMIENTO: Manicomio Porta Coelli

PROMOTOR: Diputación Provincial de Valencia (proyecto)
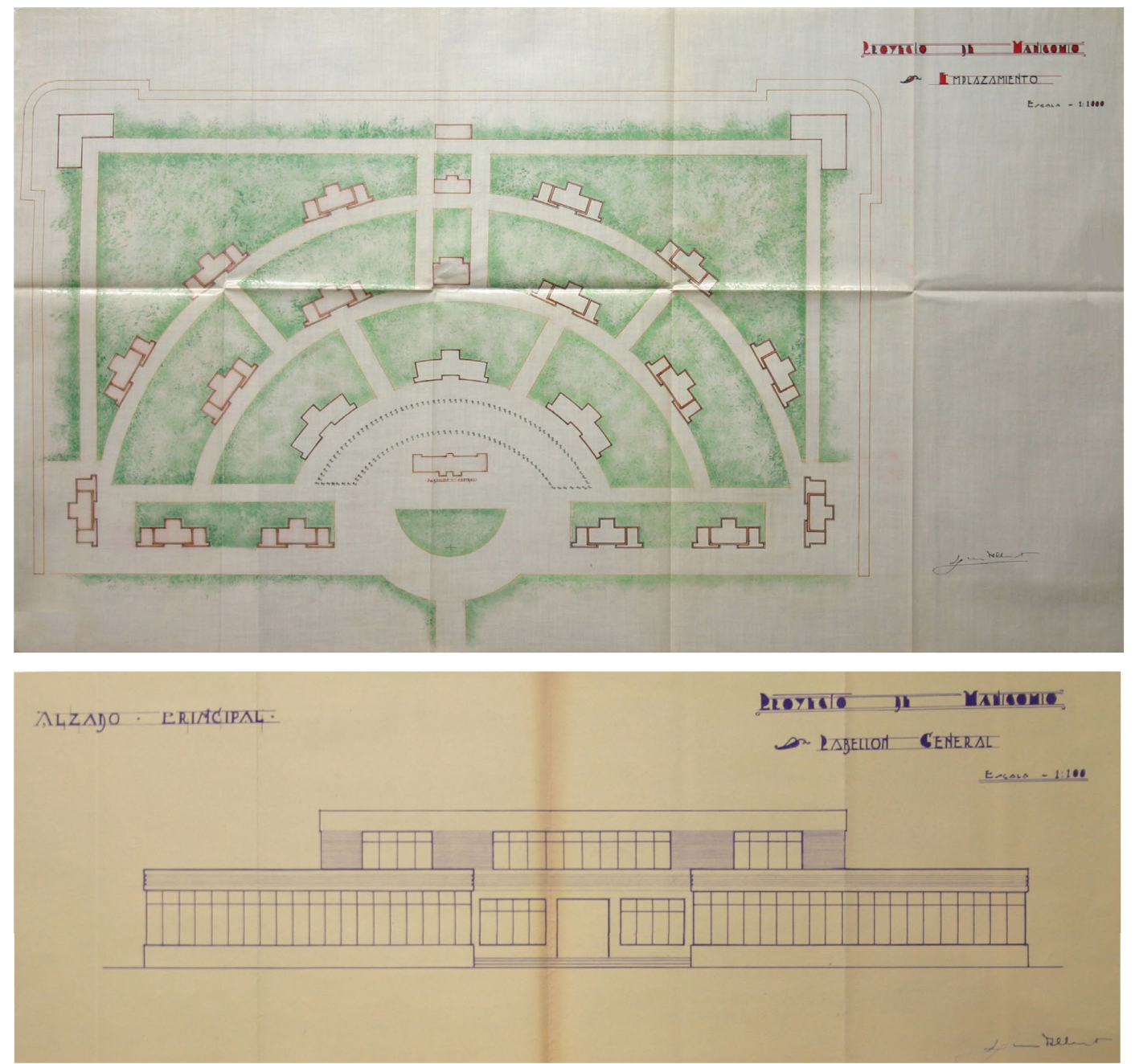


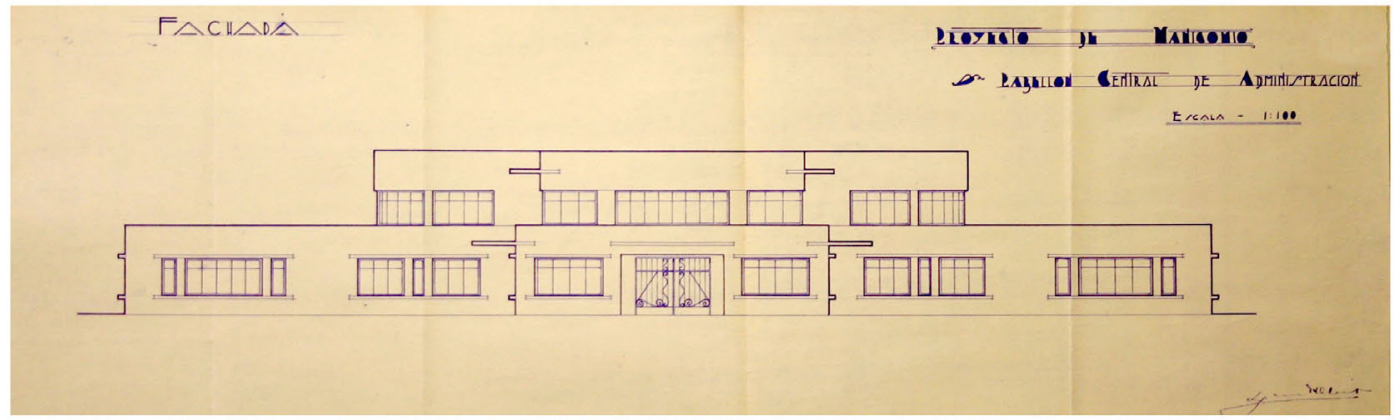

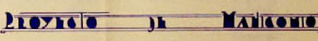

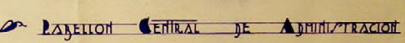

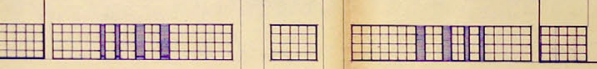

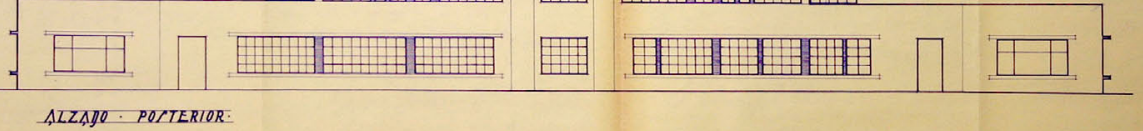

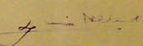
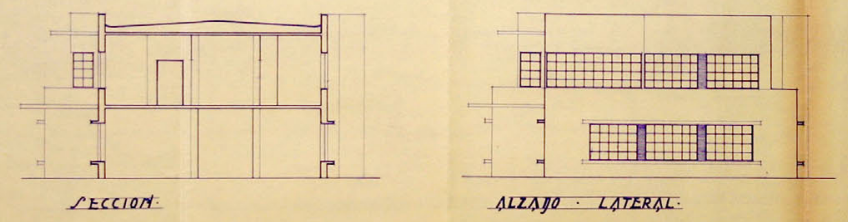


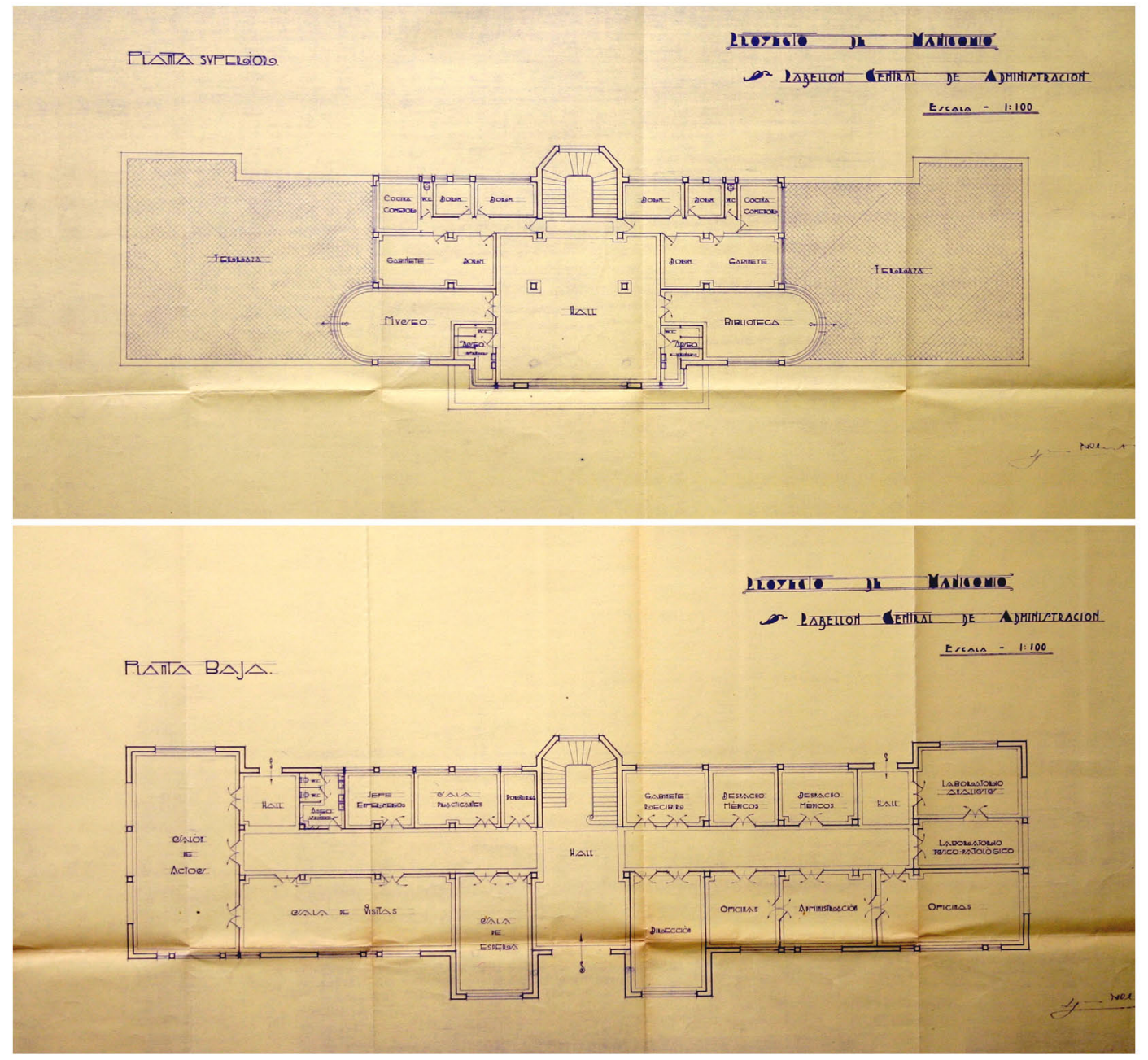



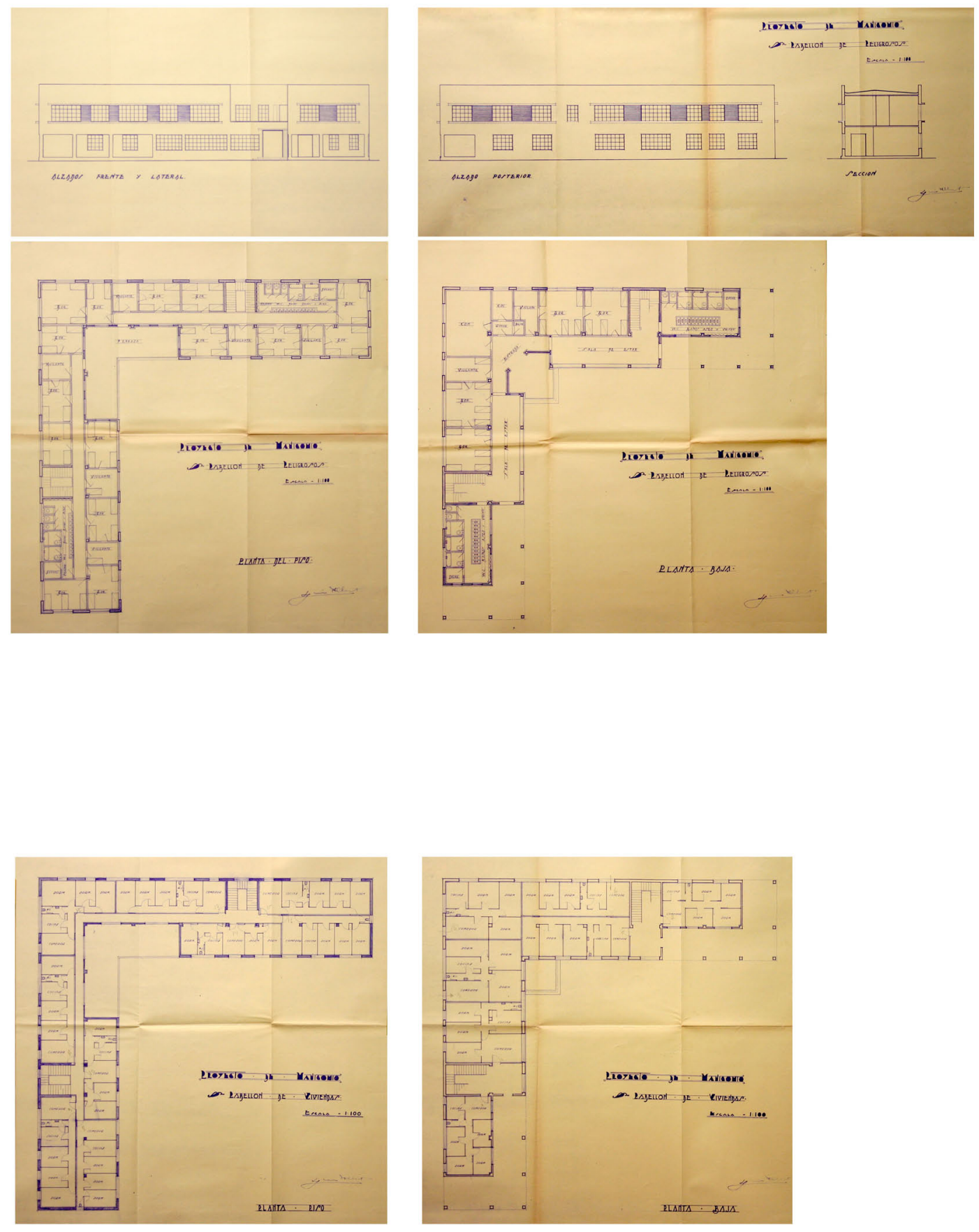

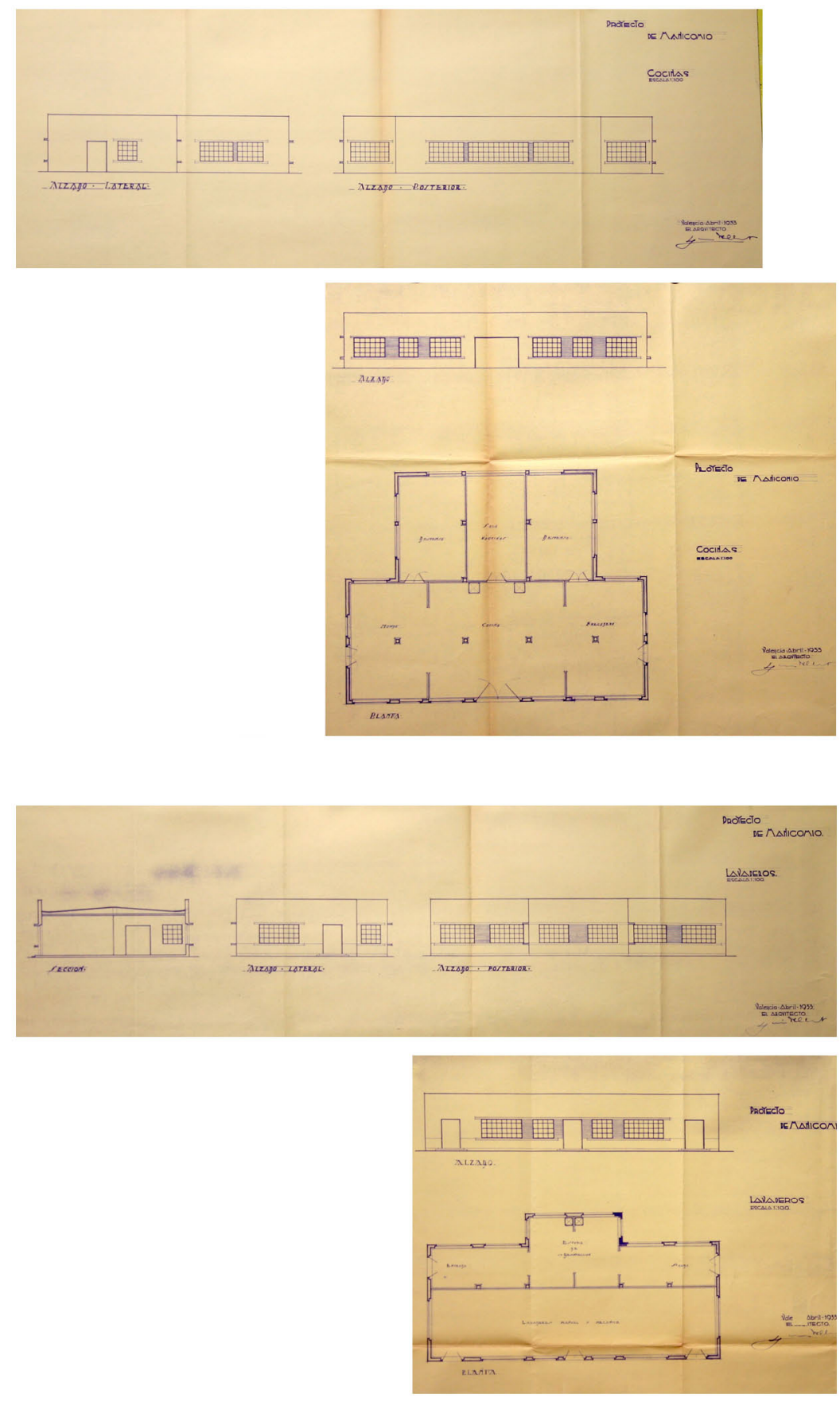


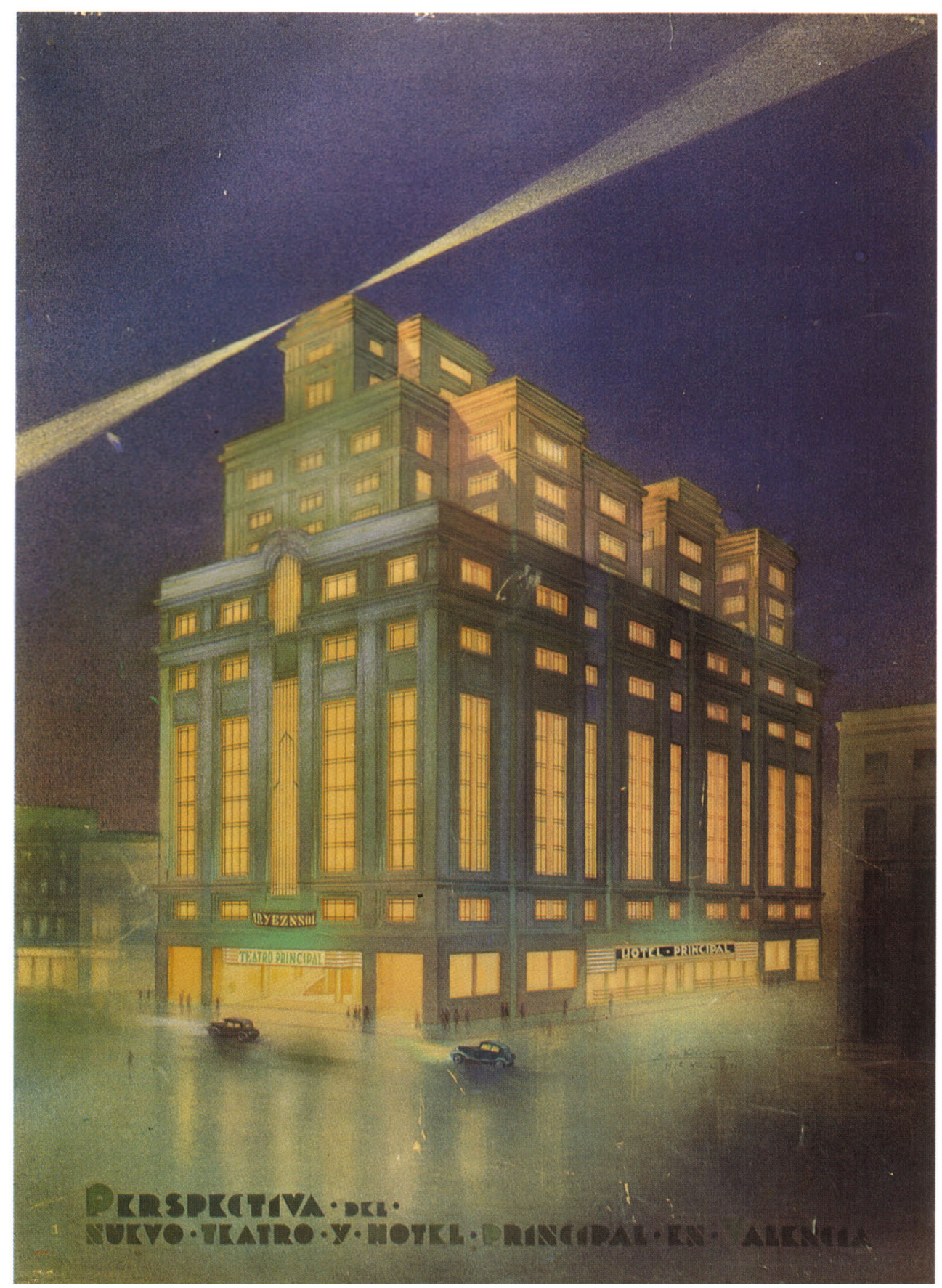


EMPLAZAMIENTO: de las Barcas y Poeta Querol PROMOTOR: Teatro Principal y Hotel (proyecto)
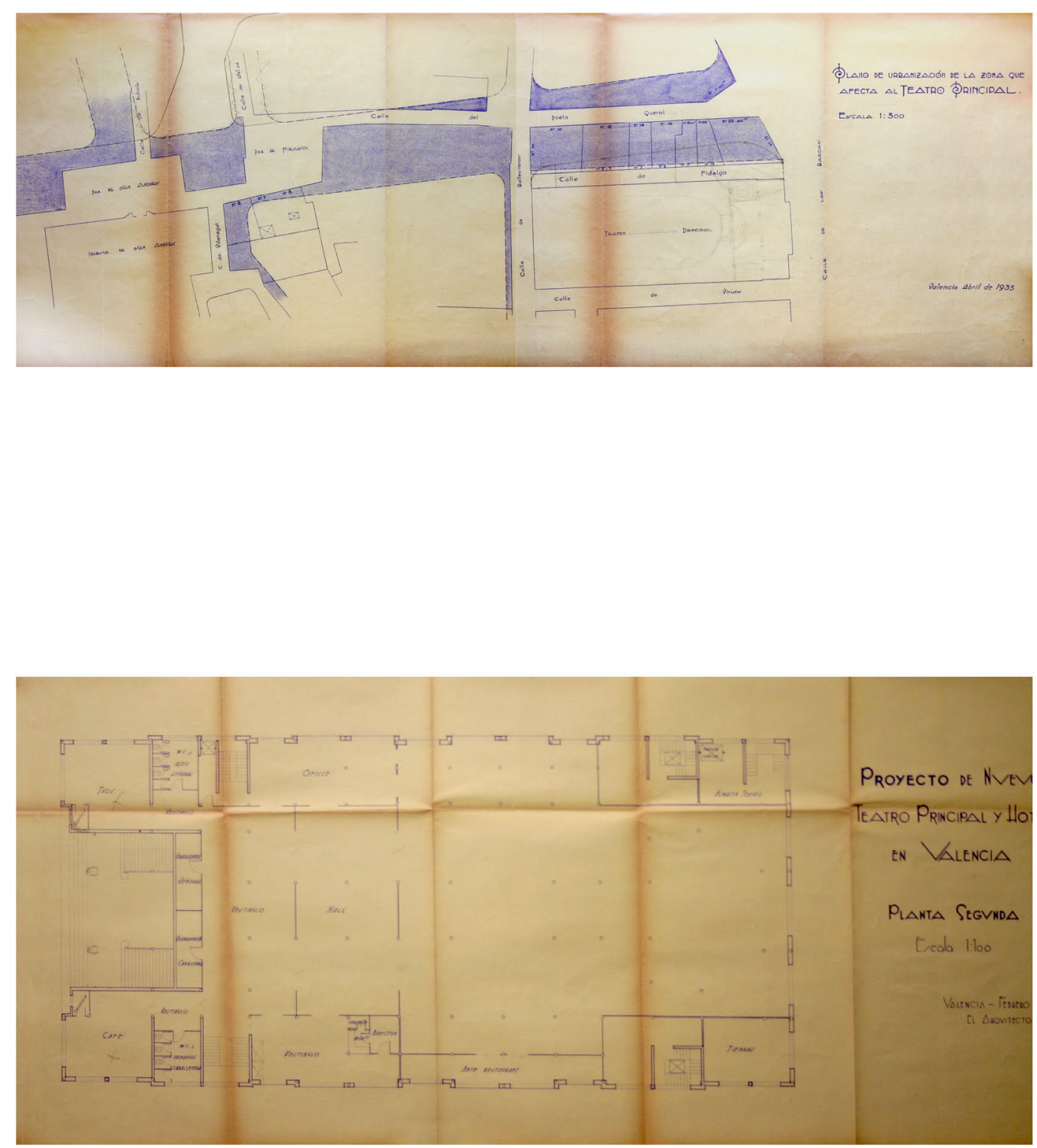

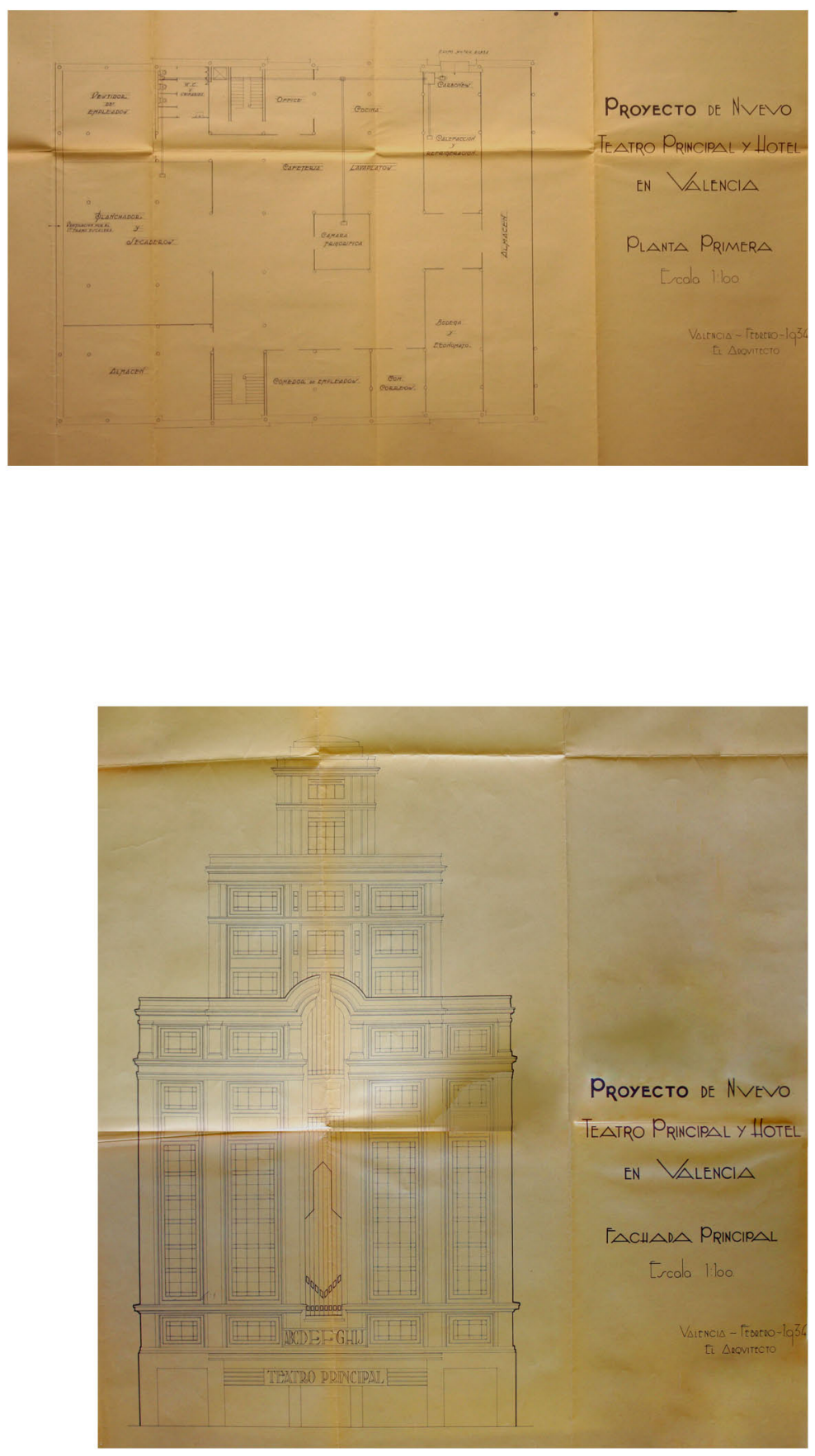

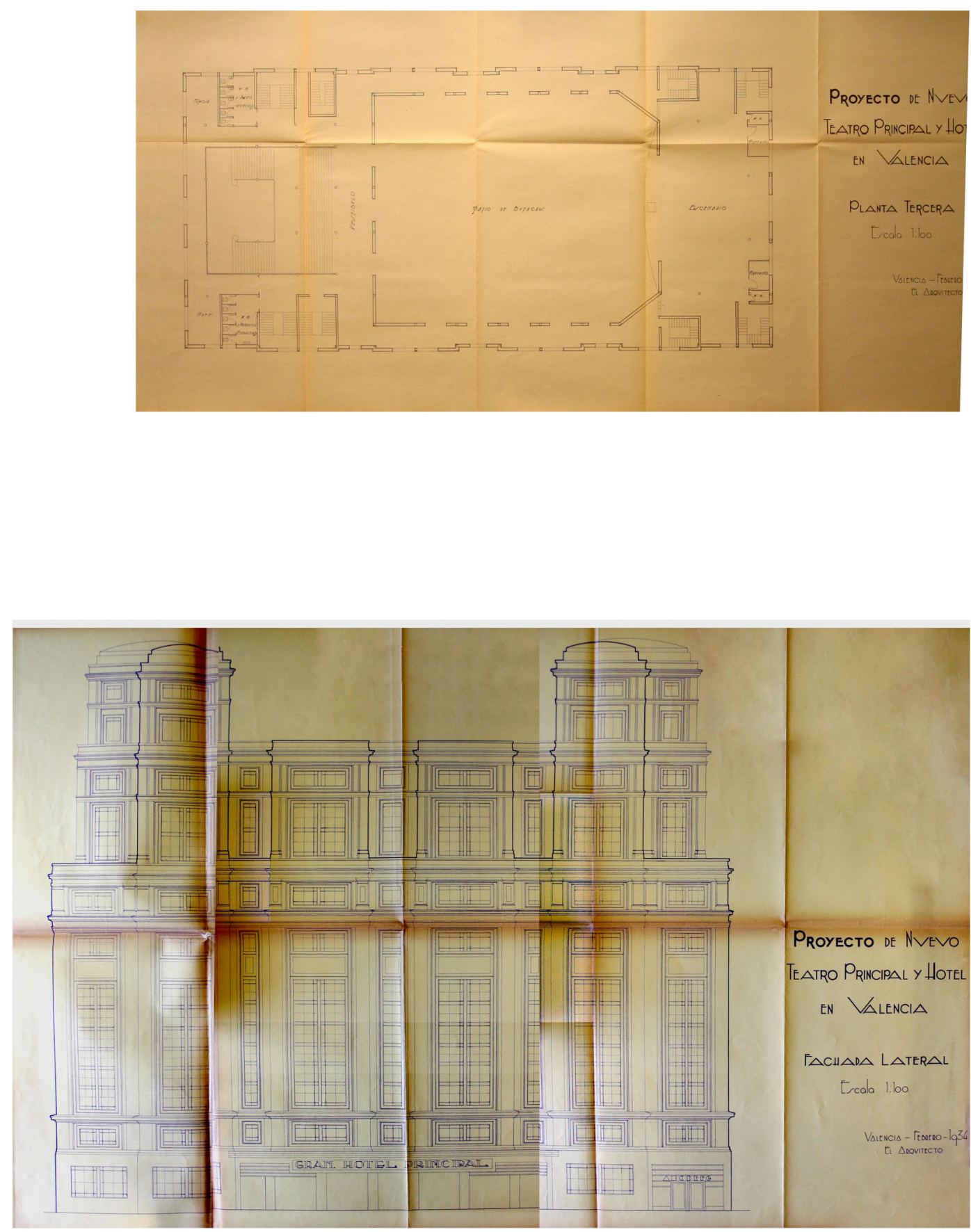


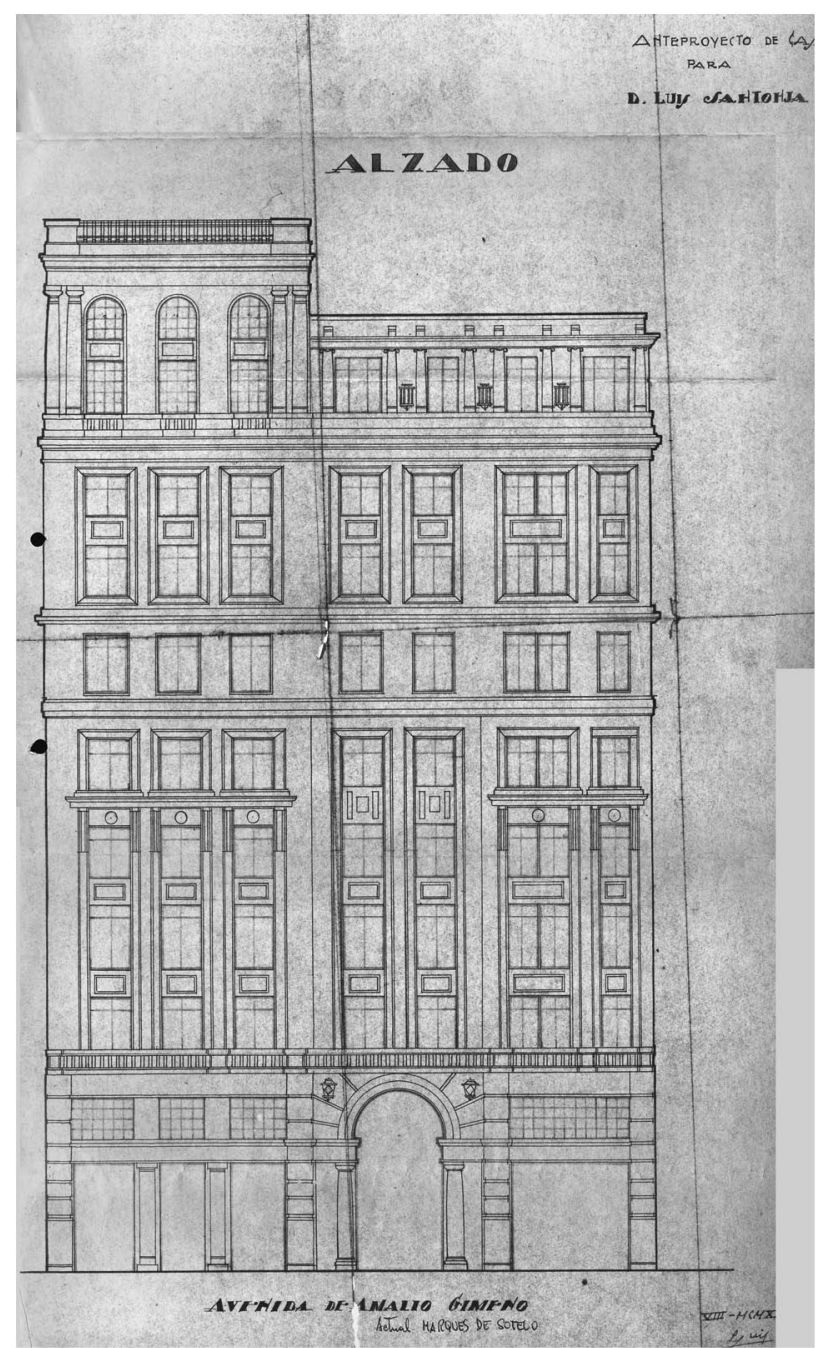


1934. Caja 12; Expediente 12827

EMPLAZAMIENTO: Nicolás Salmerón (avenida Marqués de Sotelo) PROMOTOR: Santonja, Luis
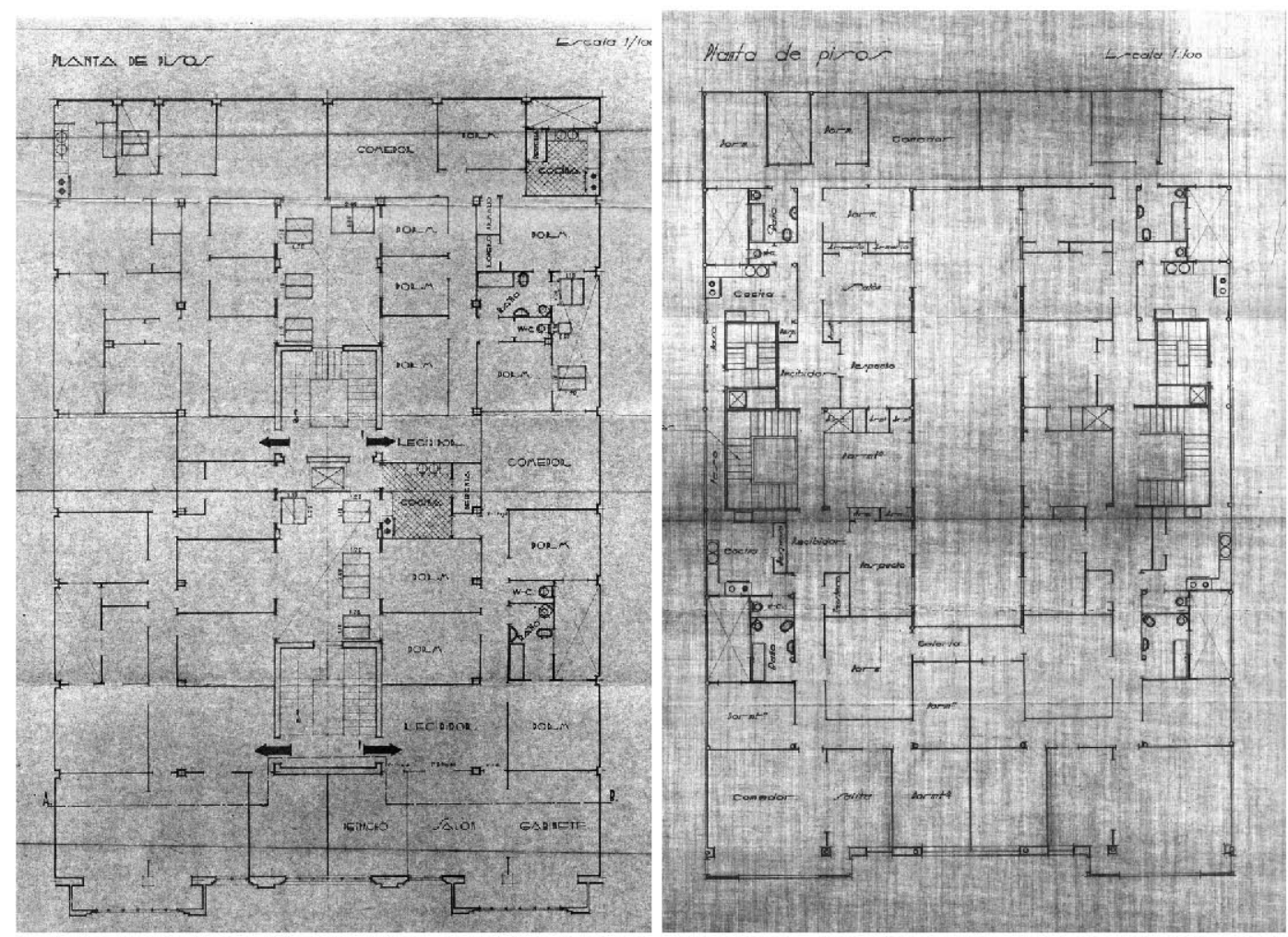


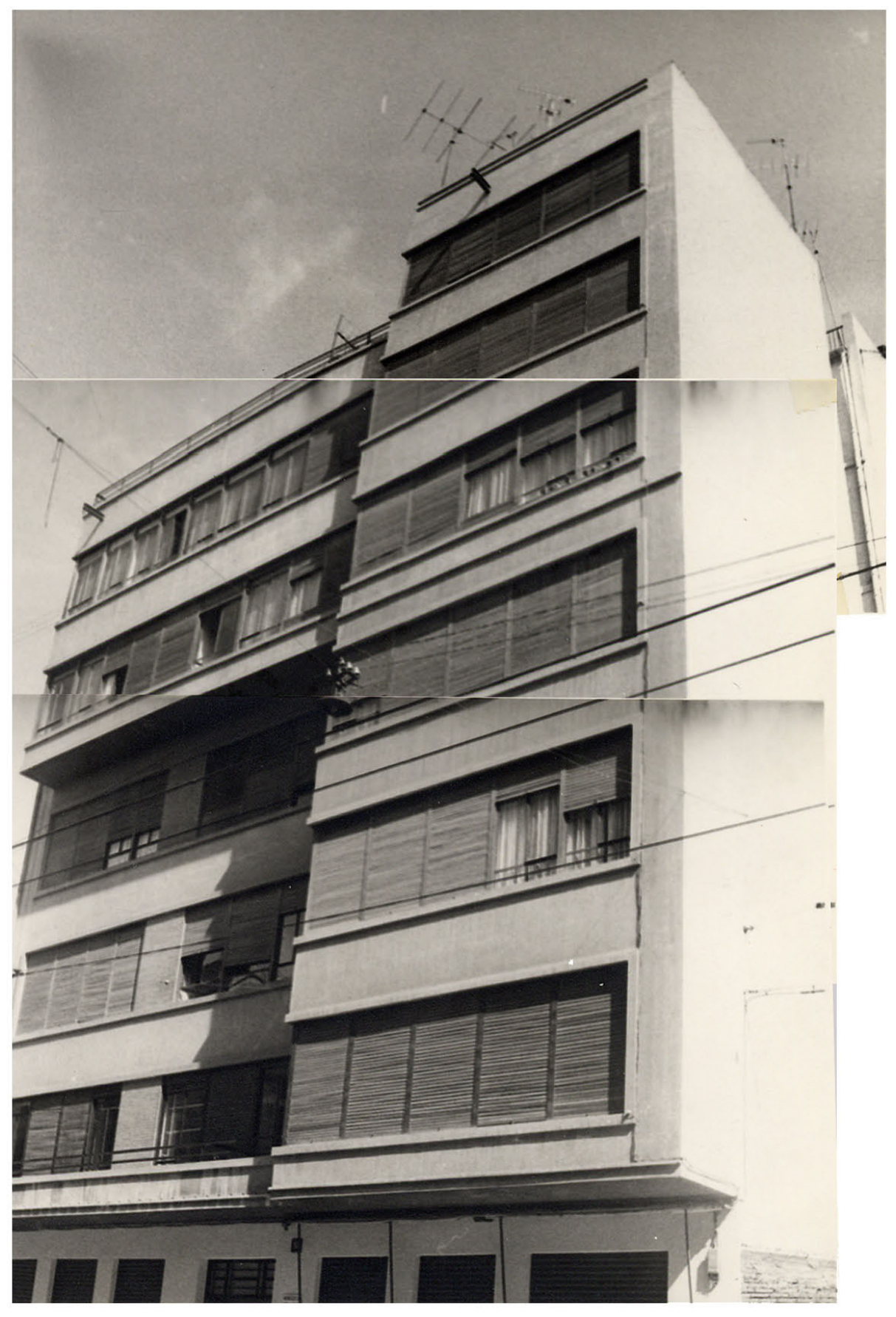


1935. Caja E03; Expediente 25001

EMPLAZAMIENTO: Cuarte $n^{\circ} 114$ y San Jacinto $n^{\circ} 3$

PROMOTOR: Buch, Máximo

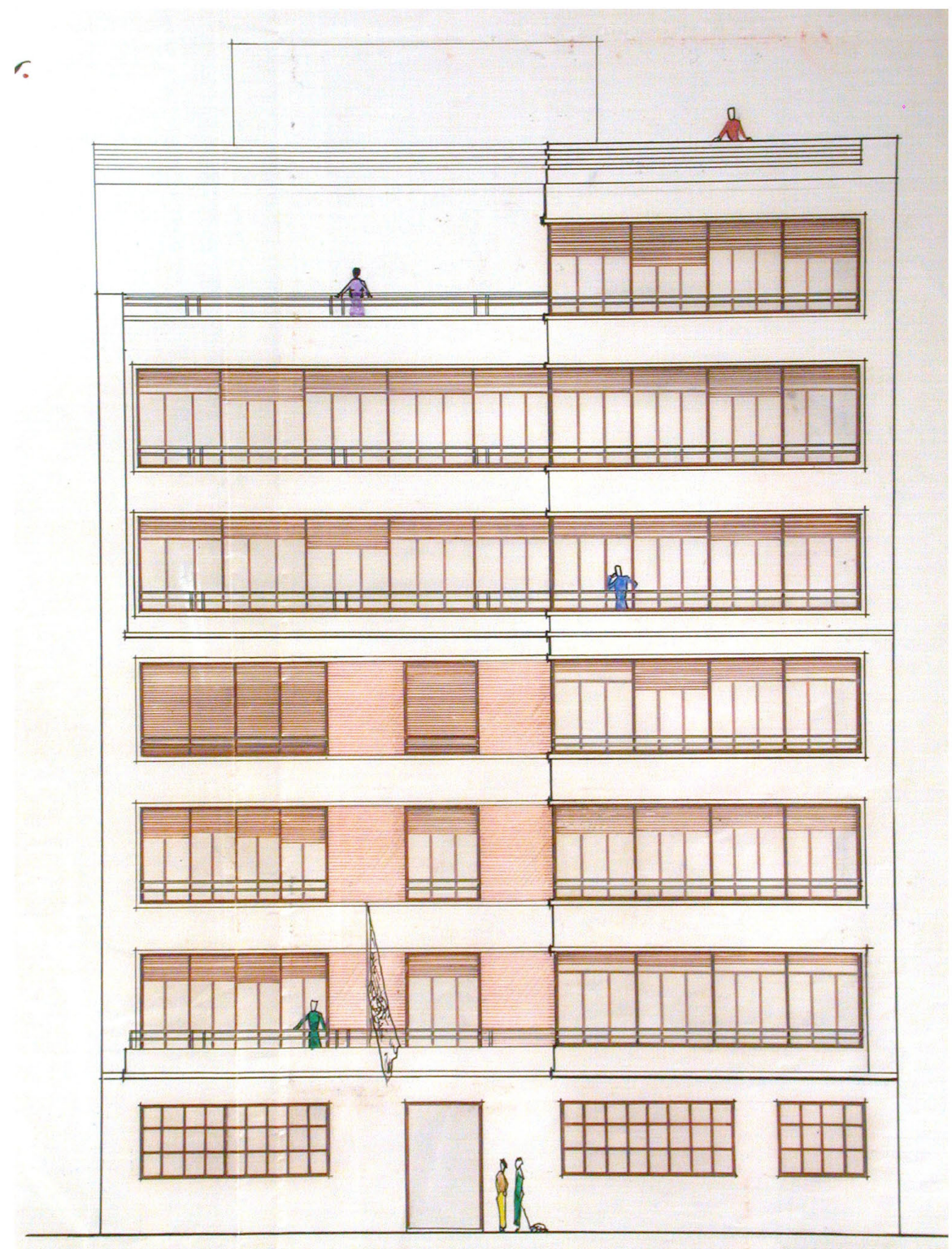




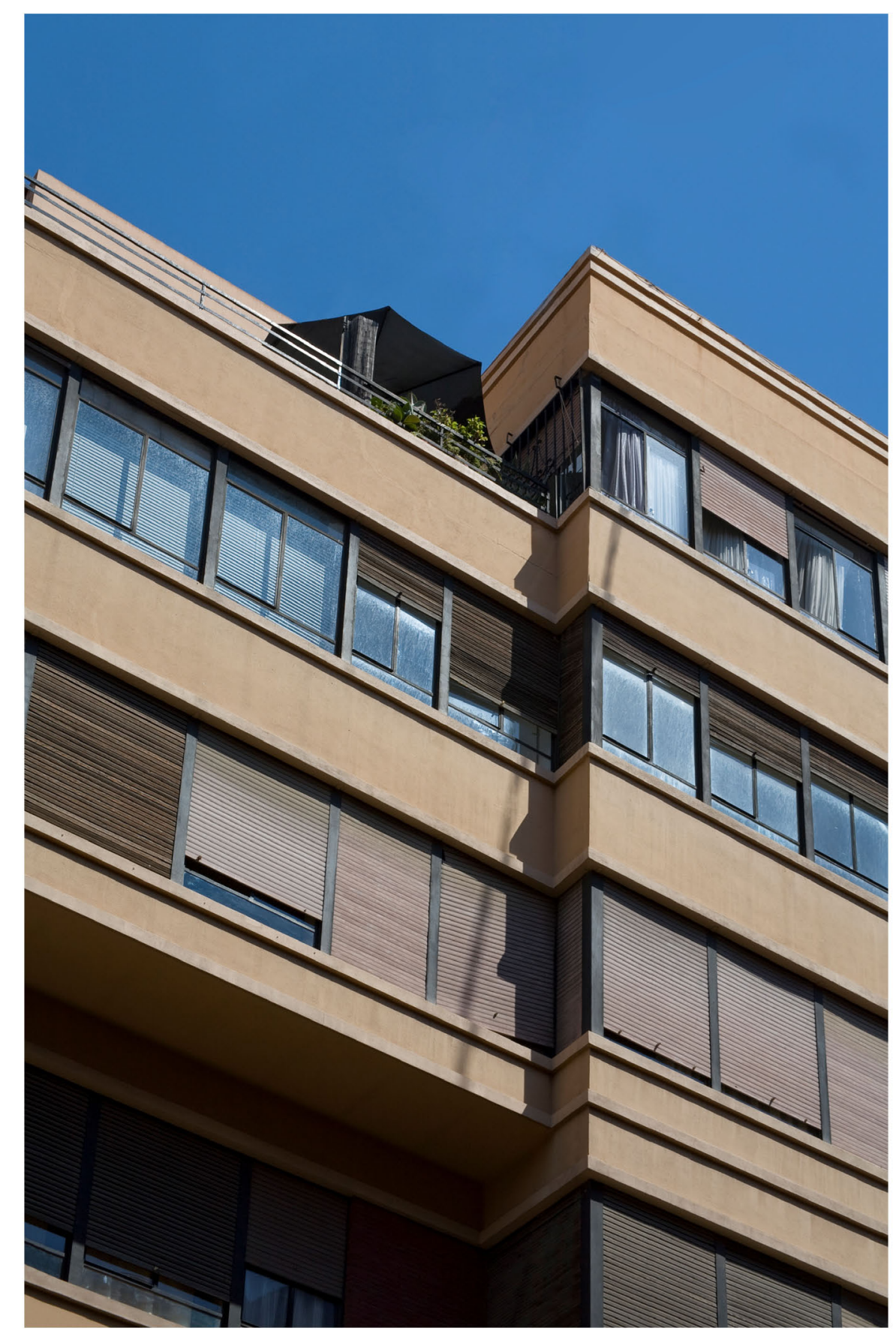



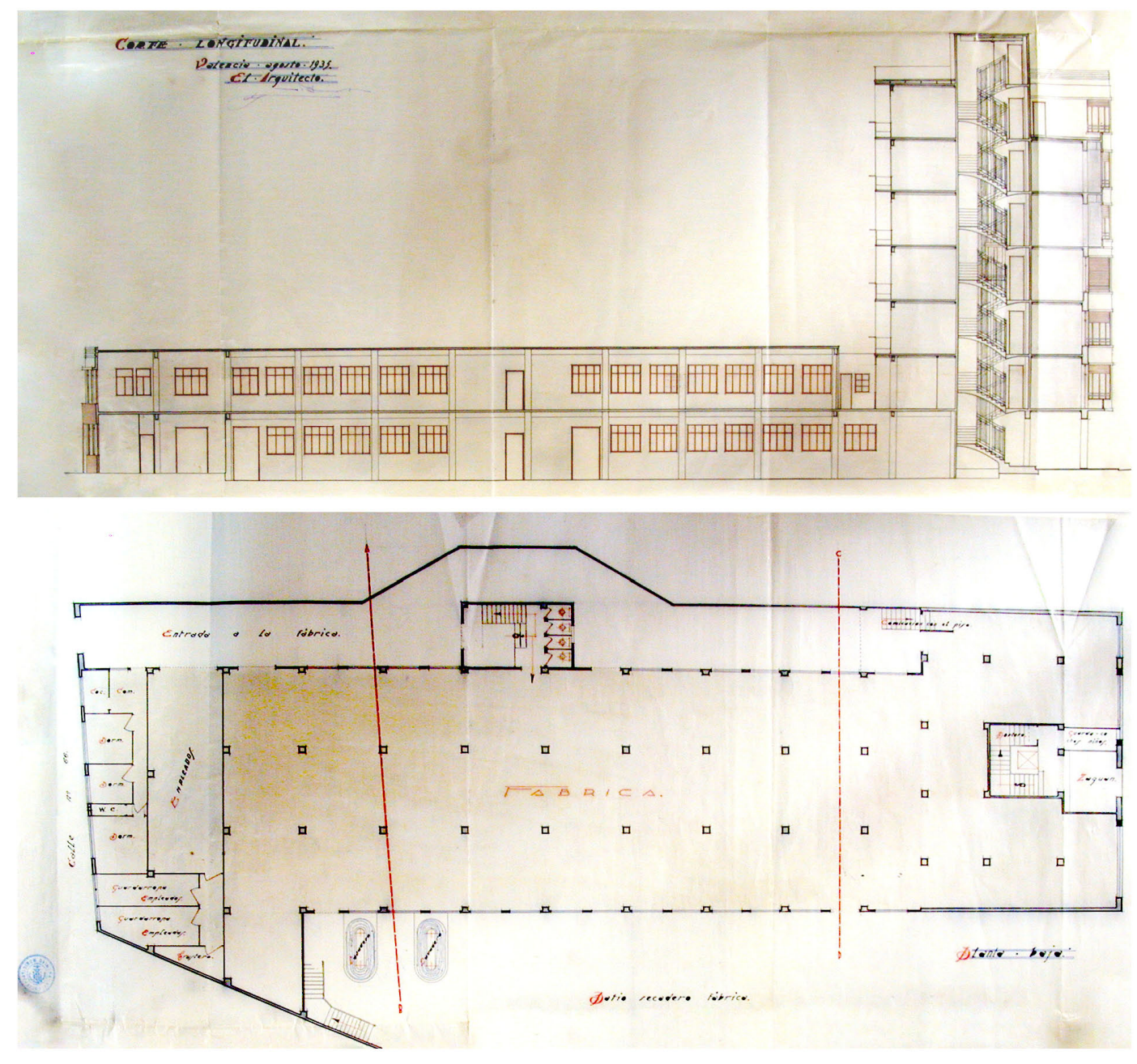


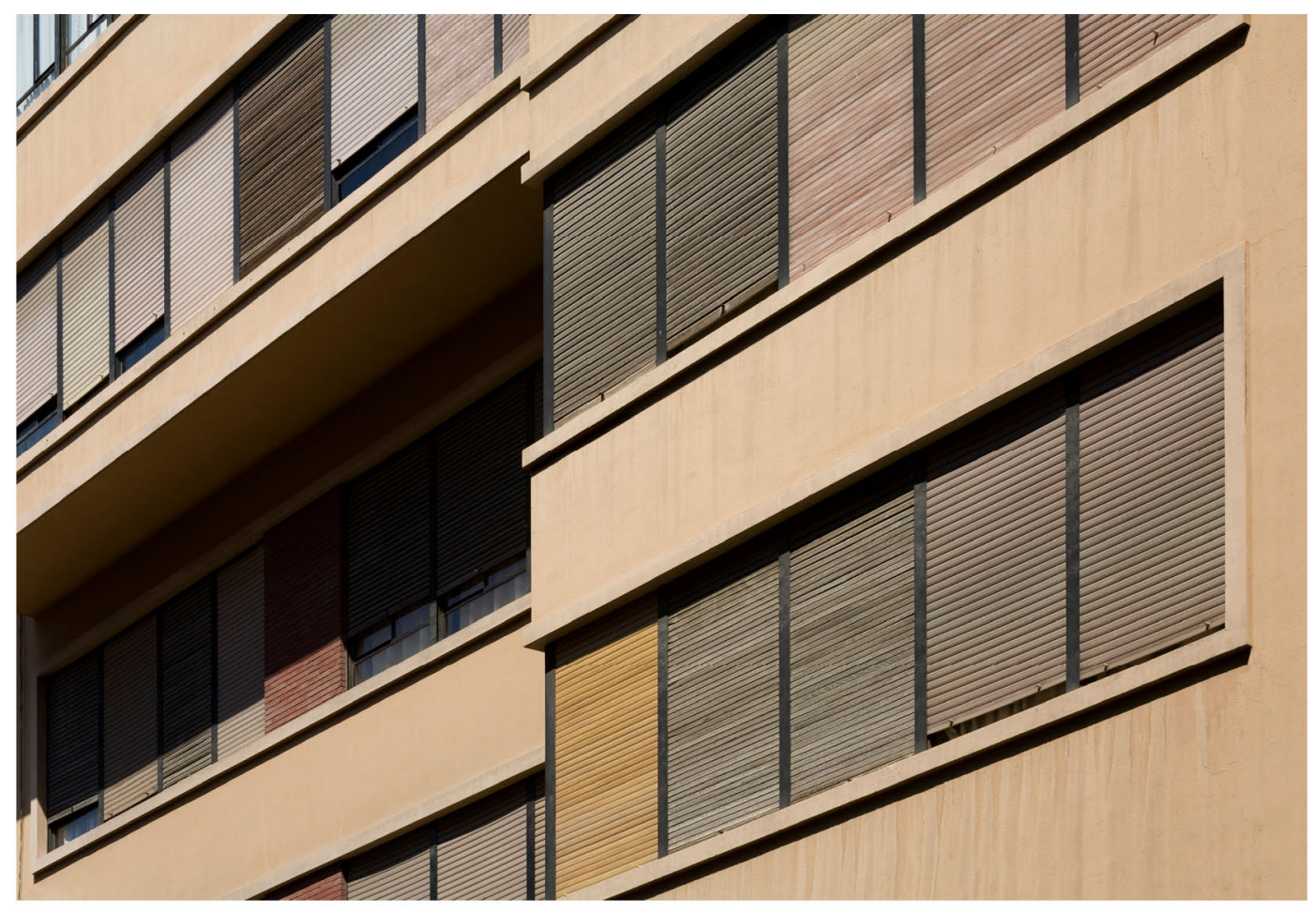



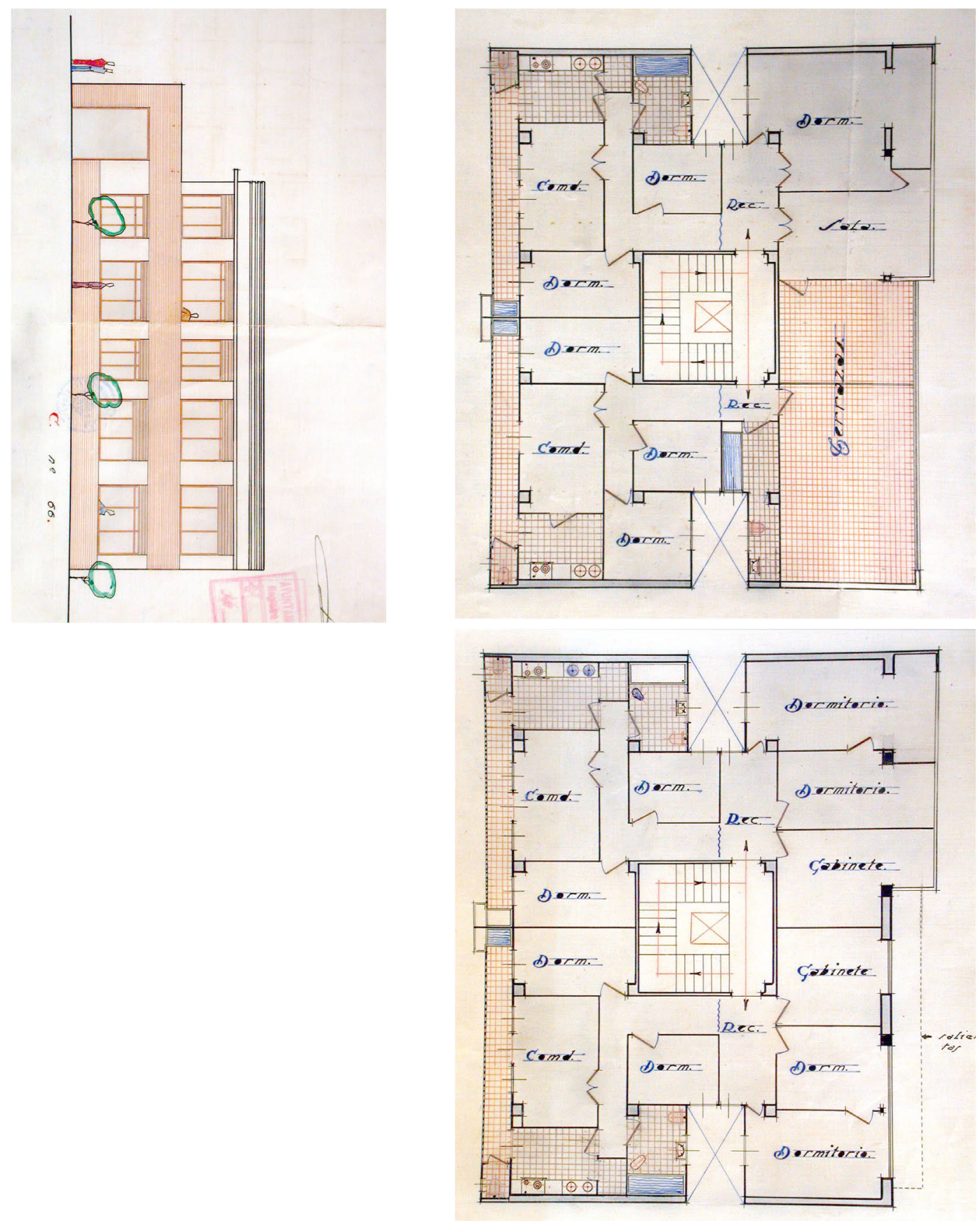


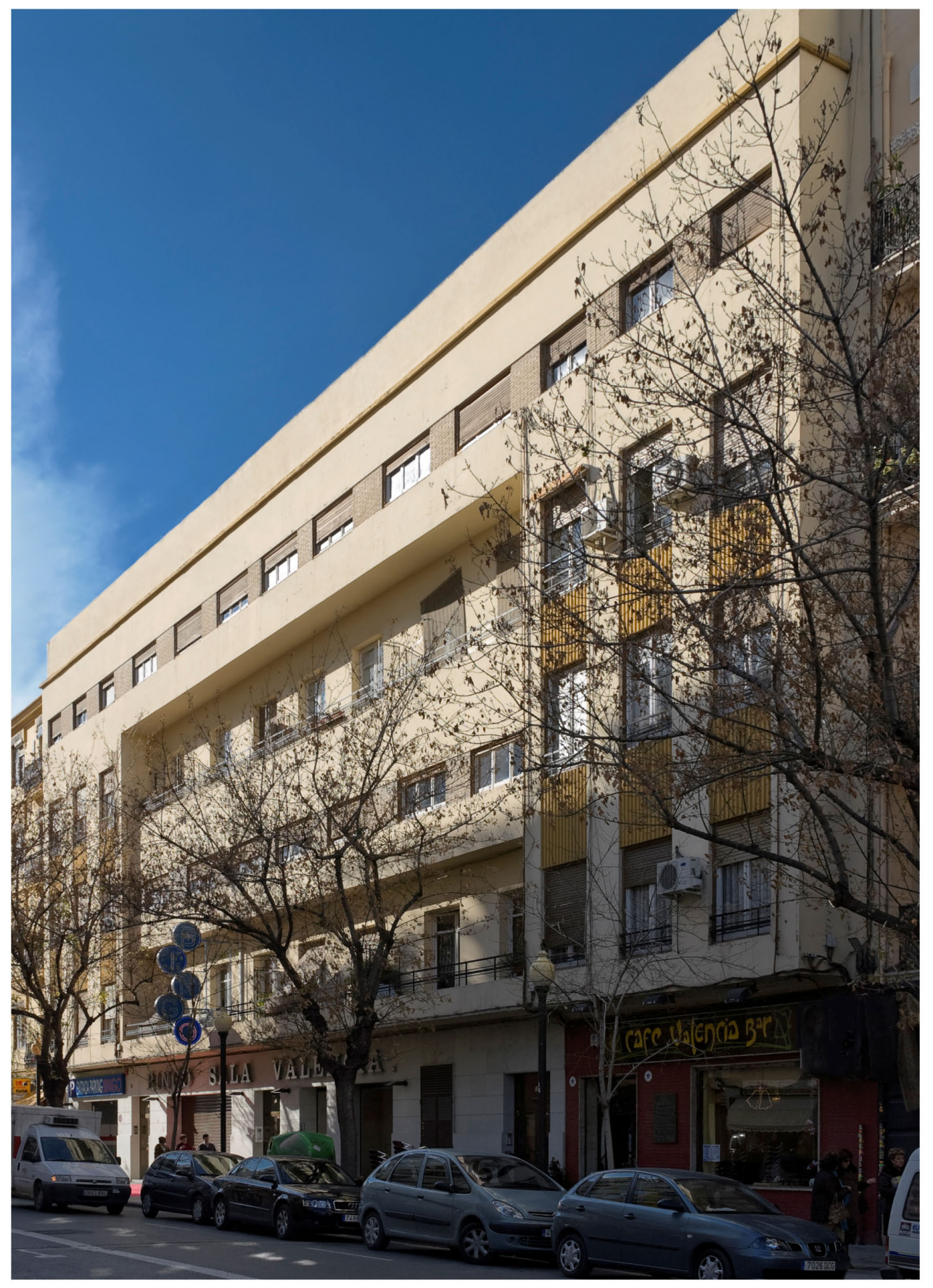


1935. Caja E03: Expediente 43257

EMPLAZAMIENTO: Cuenca $n^{\circ} 16$

PROMOTOR: Zabala, José Manuel

\section{PROYECTO}

ale

cansan viviemala

en Ia calle des Cuencan 16
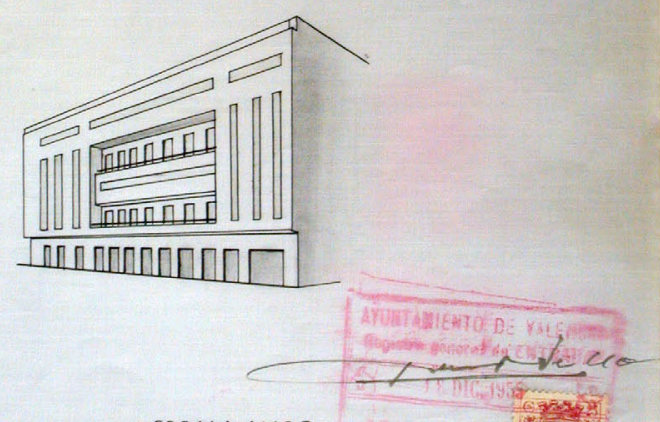

ESCALA 1:100

Valencia diciembre 1935

EL ARQUITECTO.
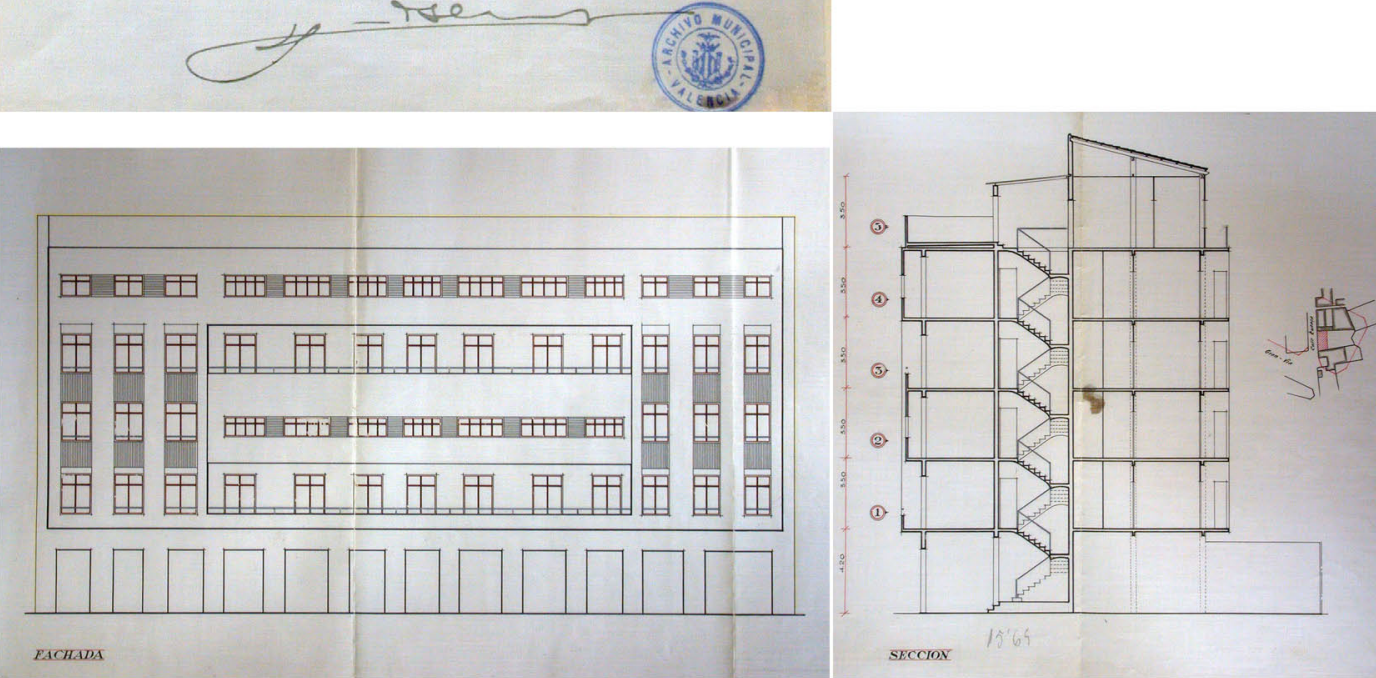

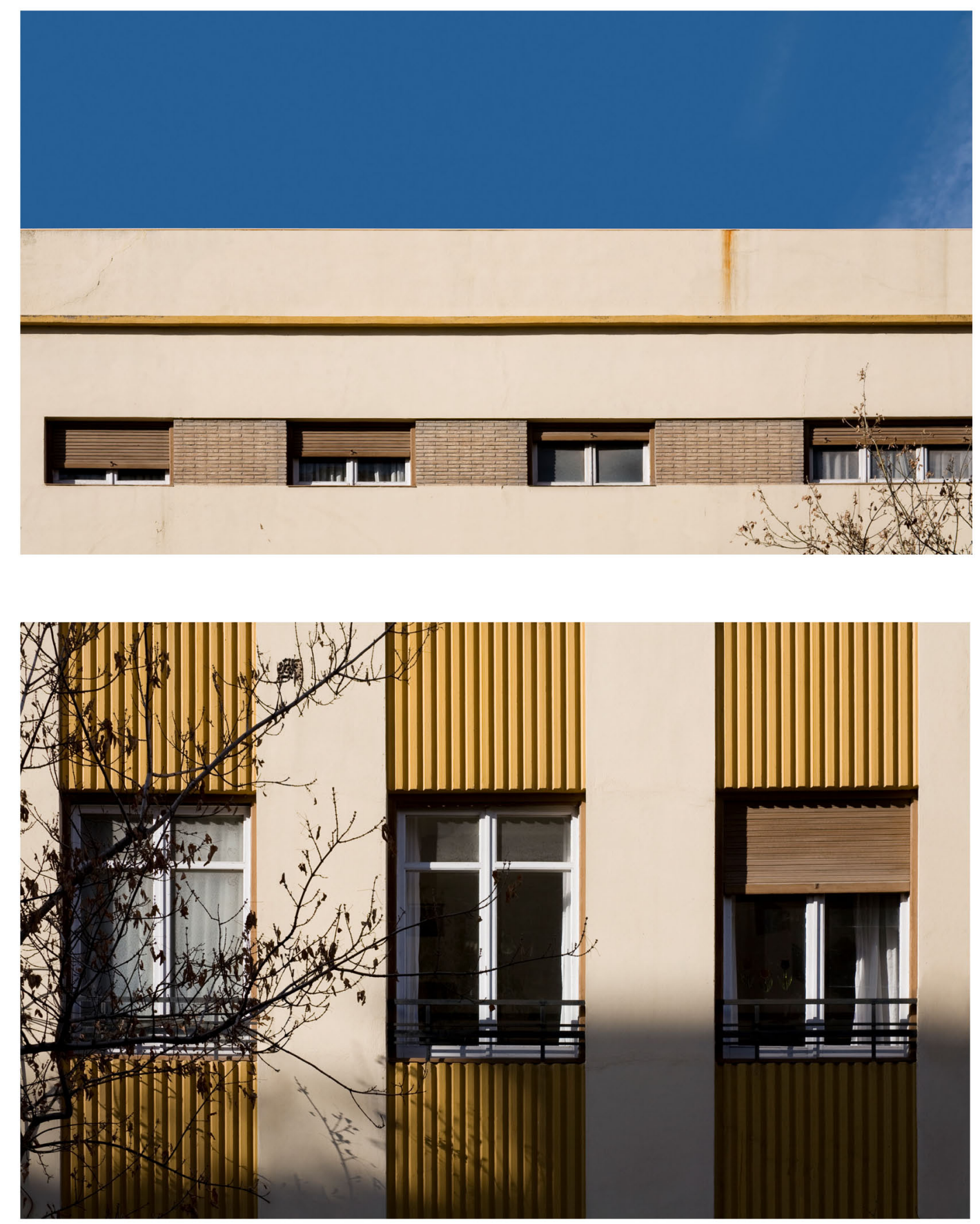

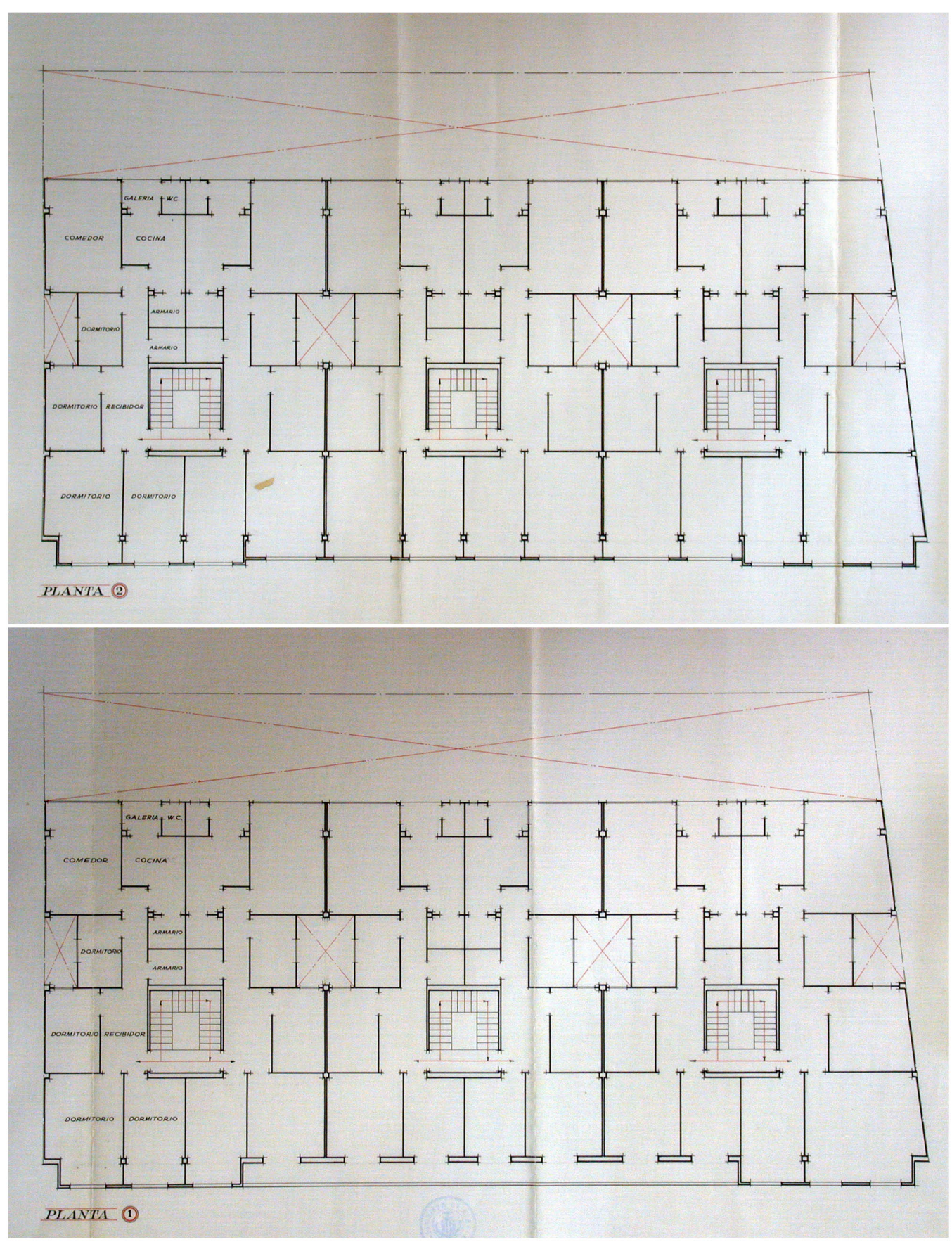


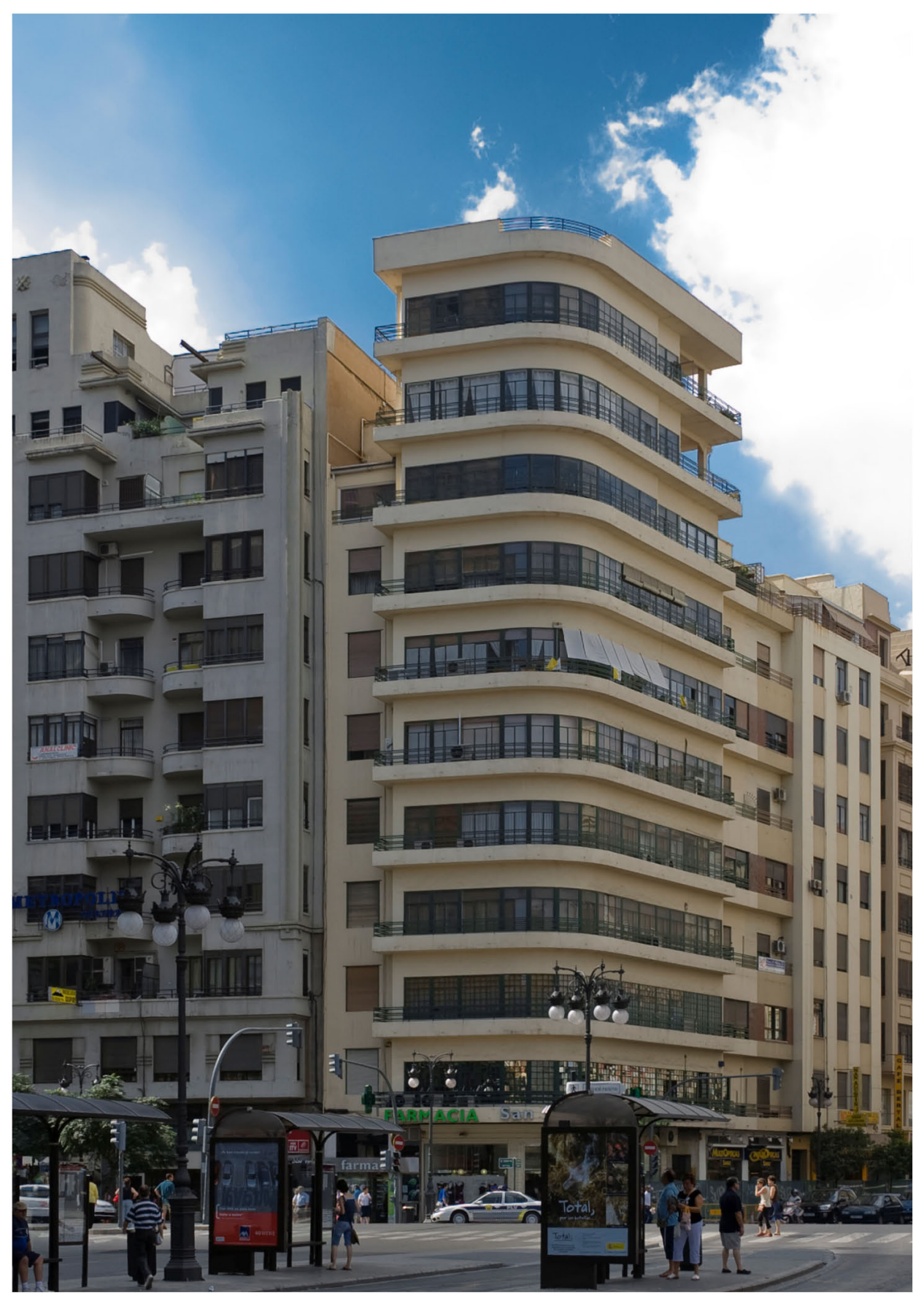


1935. Caja E04; Expediente 45662

EMPLAZAMIENTO: Játiva, esquina San Vicente

PROMOTOR: Alonso, Carmen

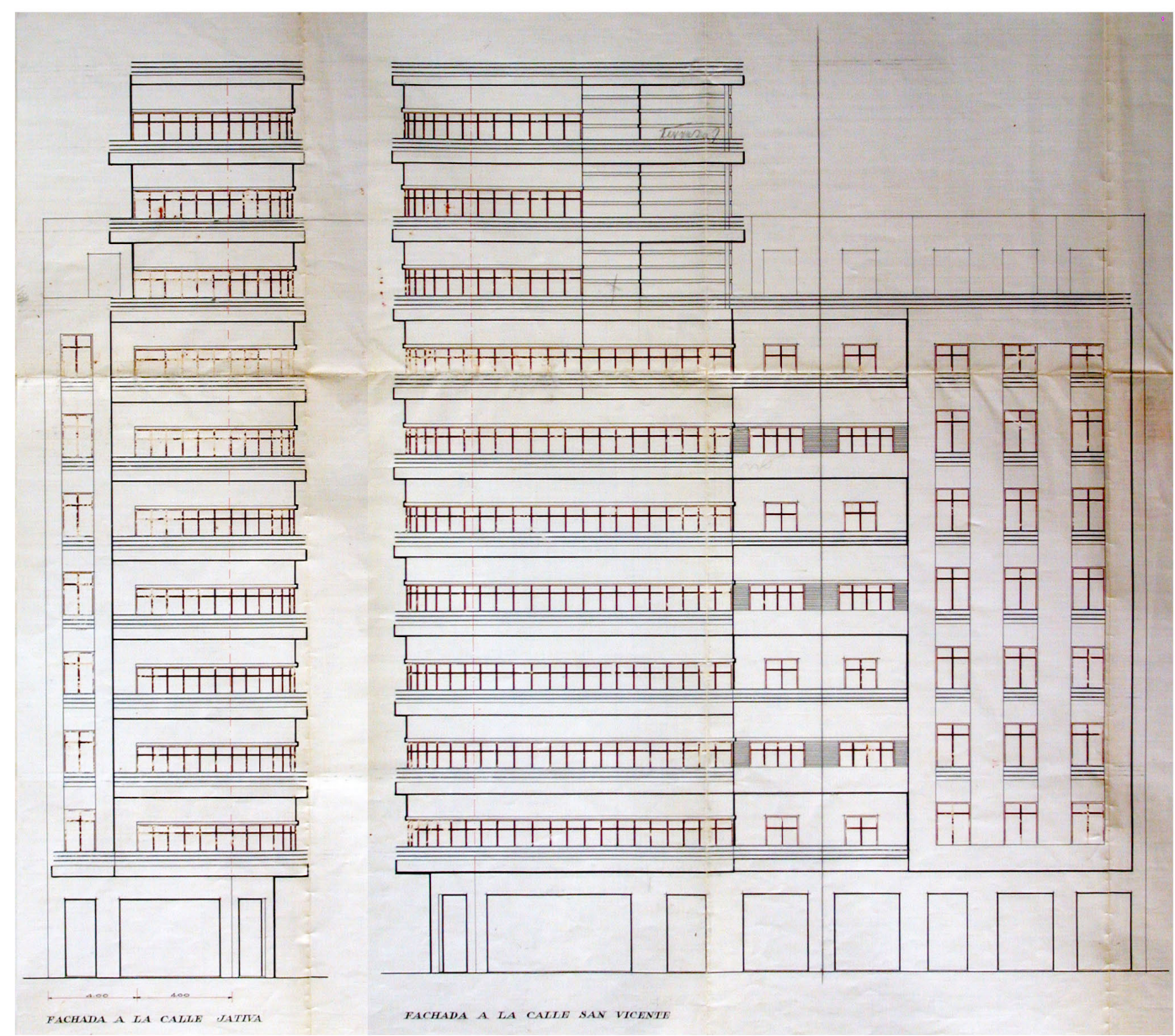




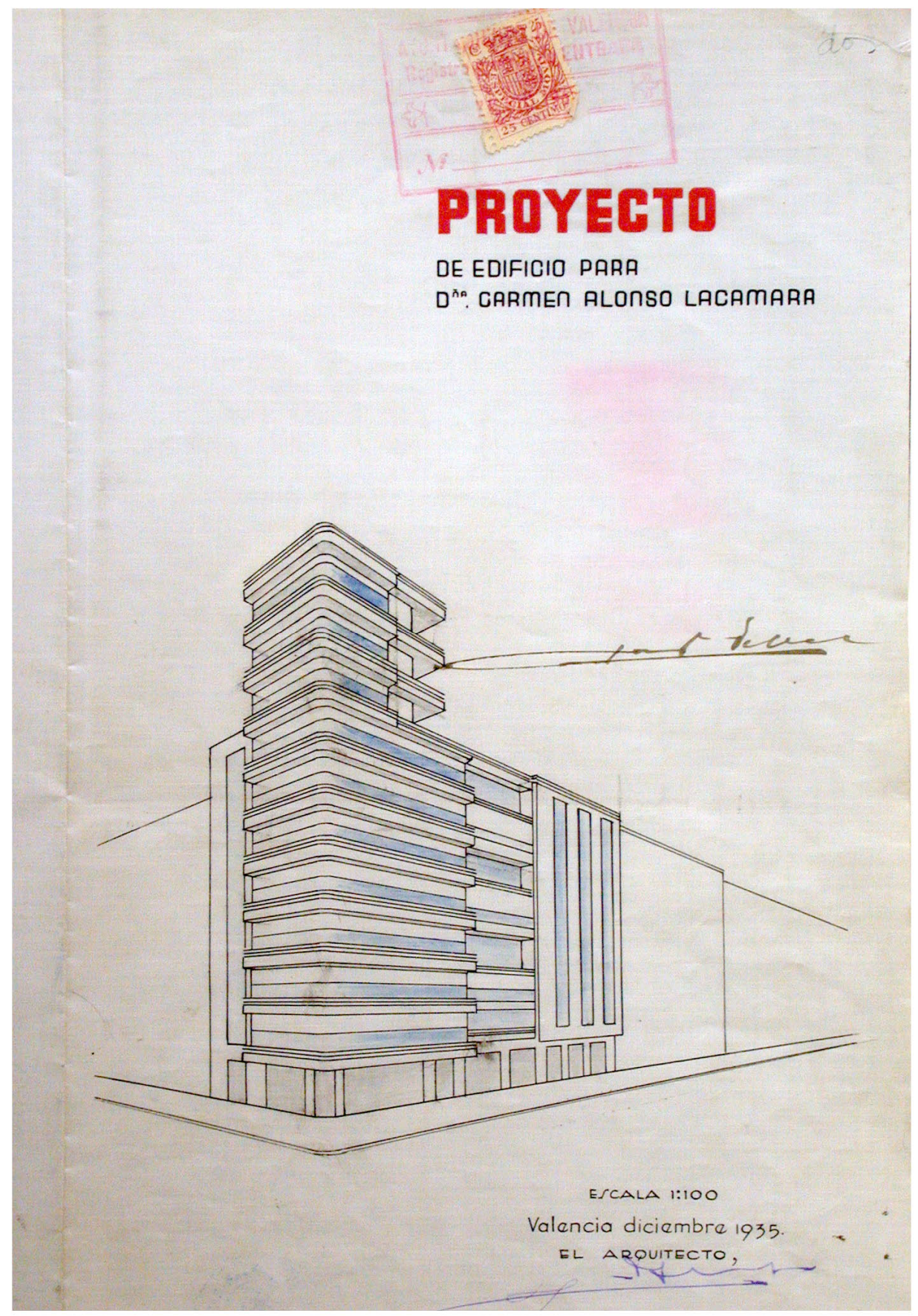



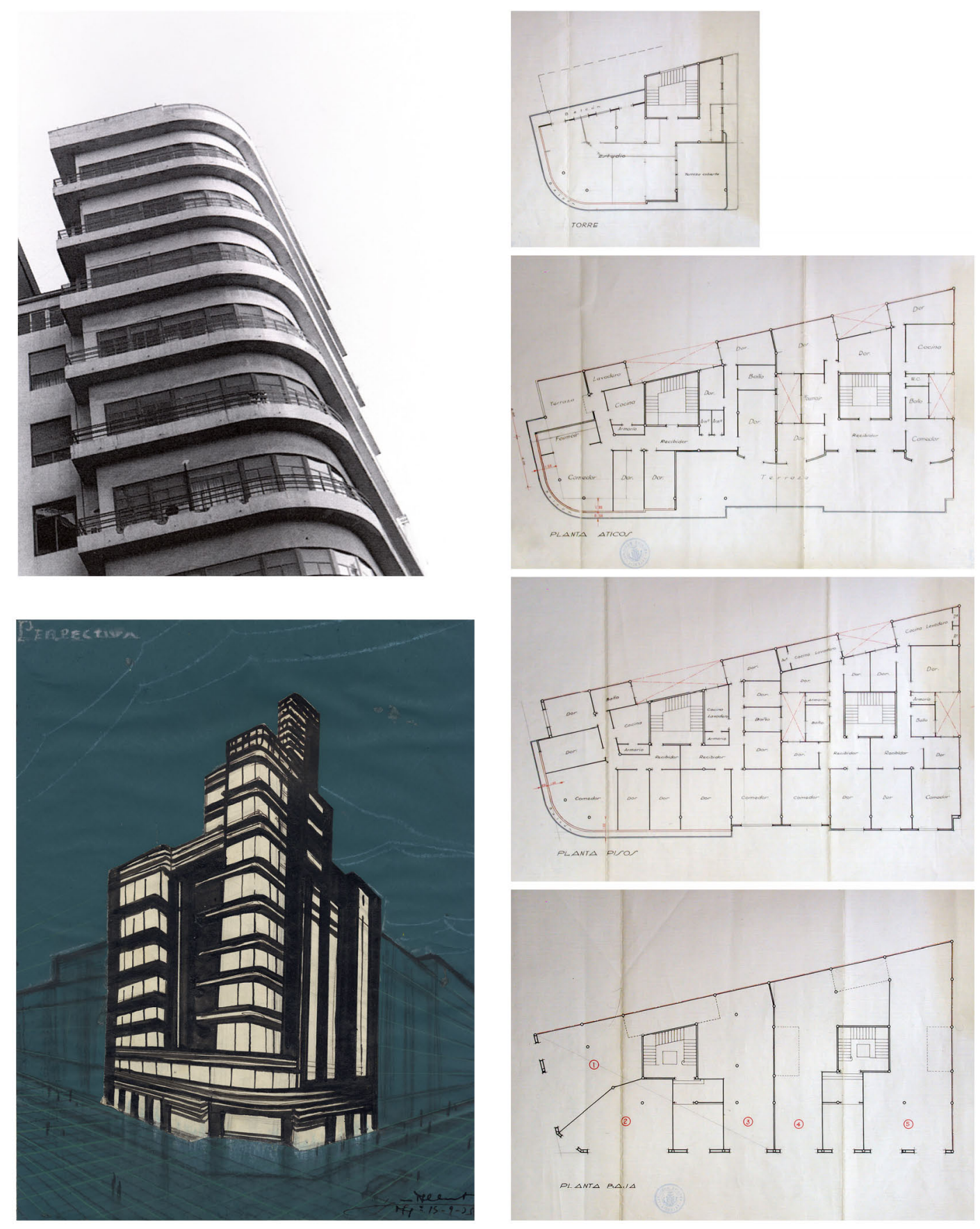

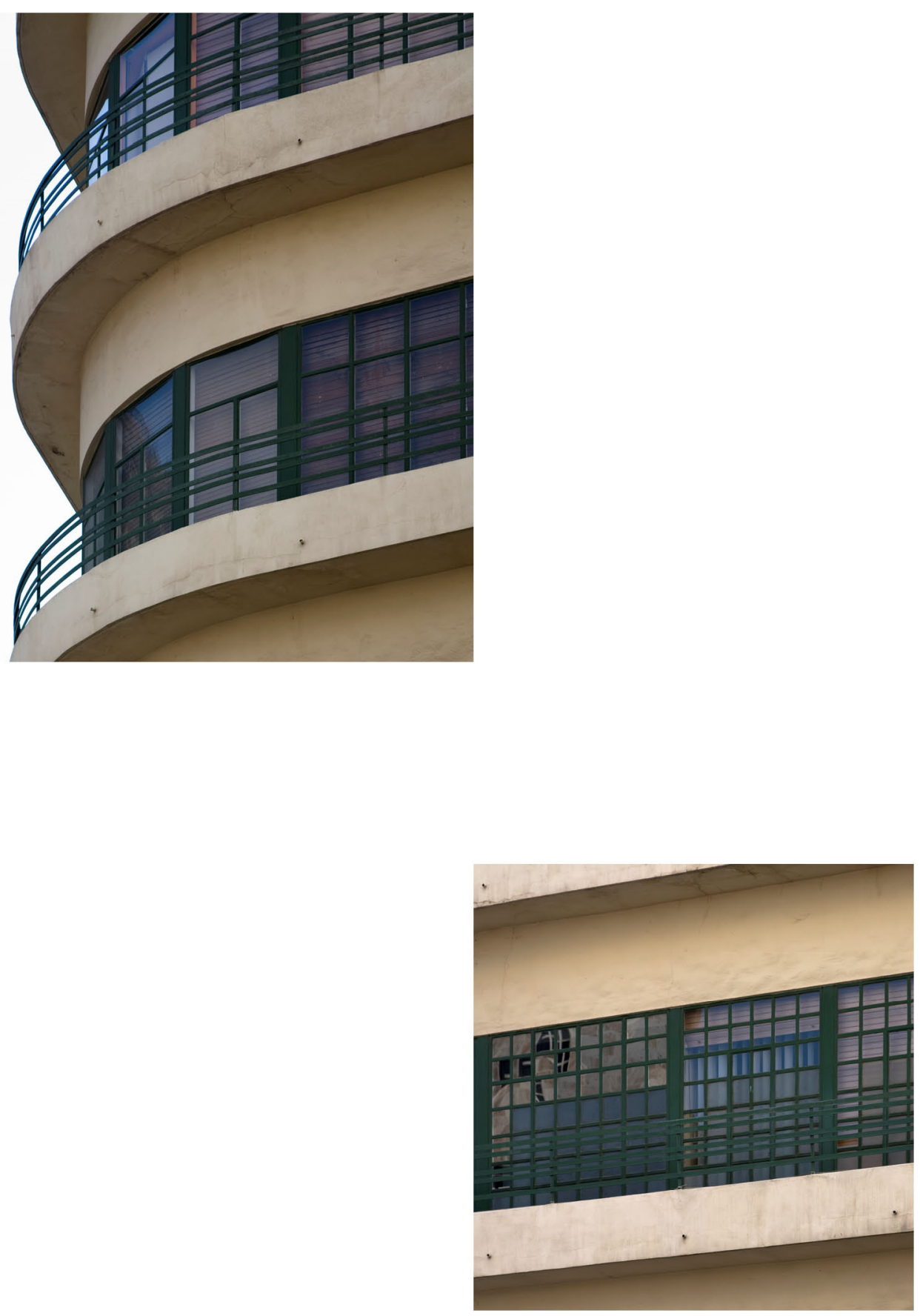

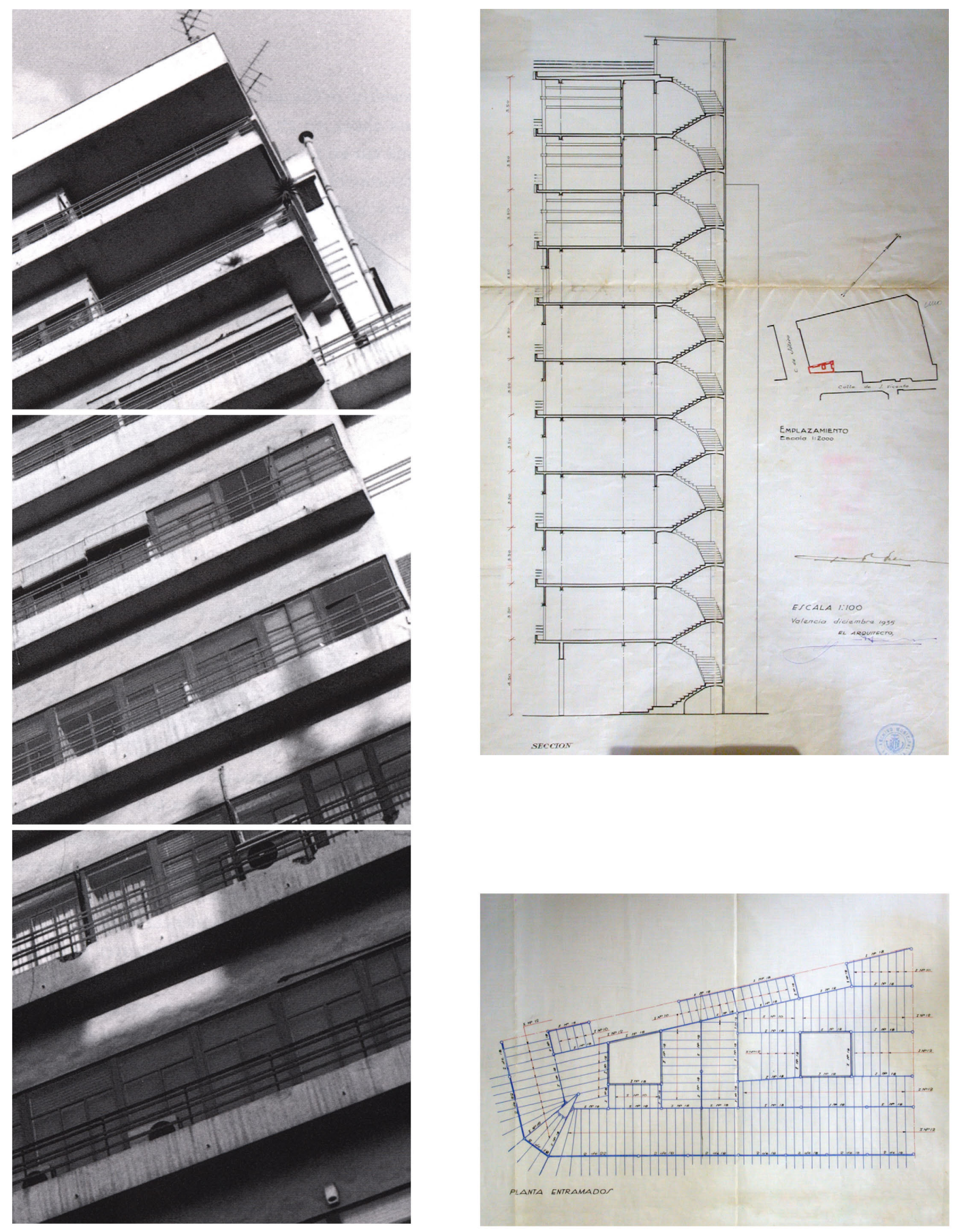

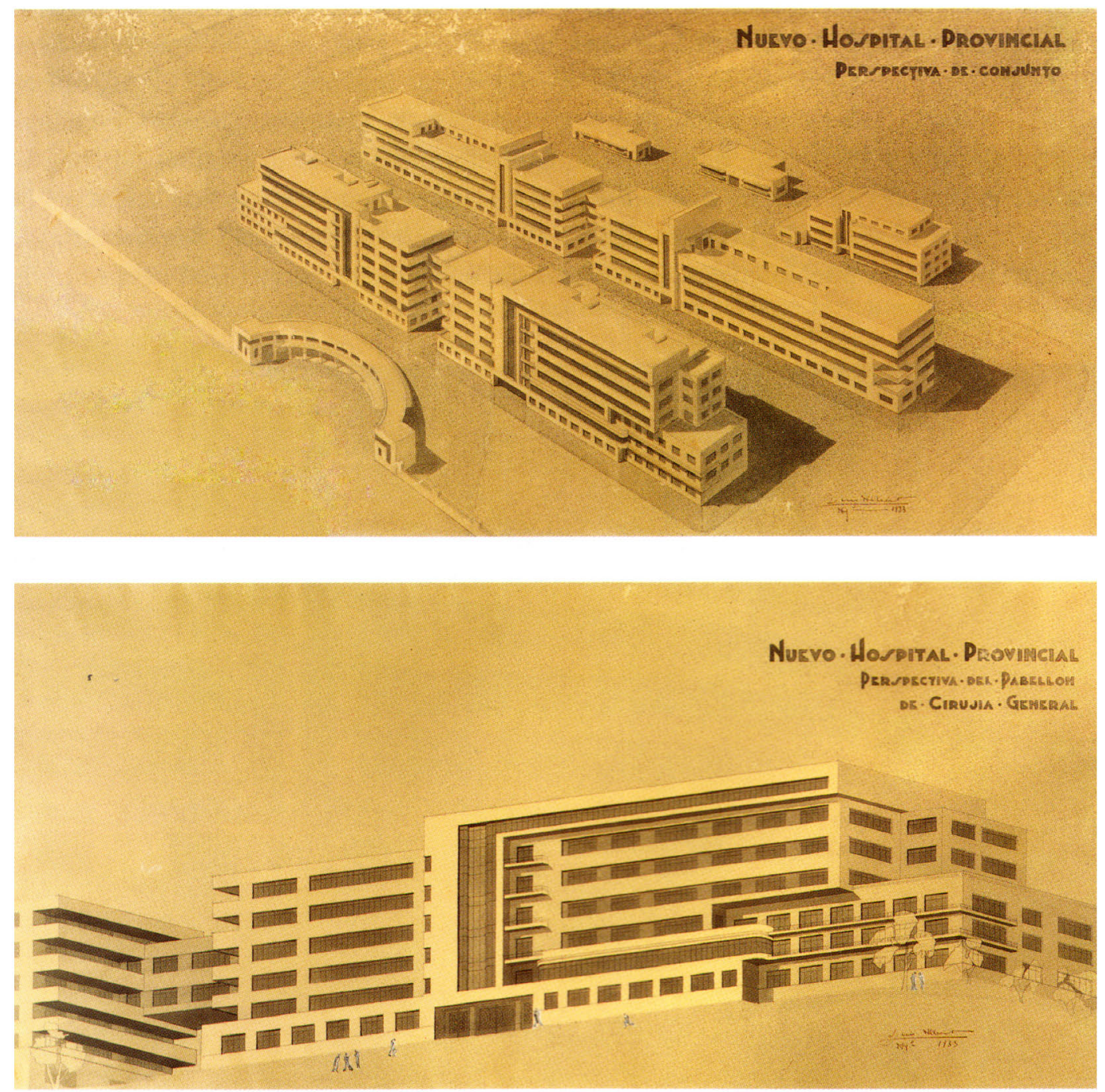
1935

EMPLAZAMIENTO: Hospital Provincial

PROMOTOR: Diputación Provincial de Valencia (proyecto)

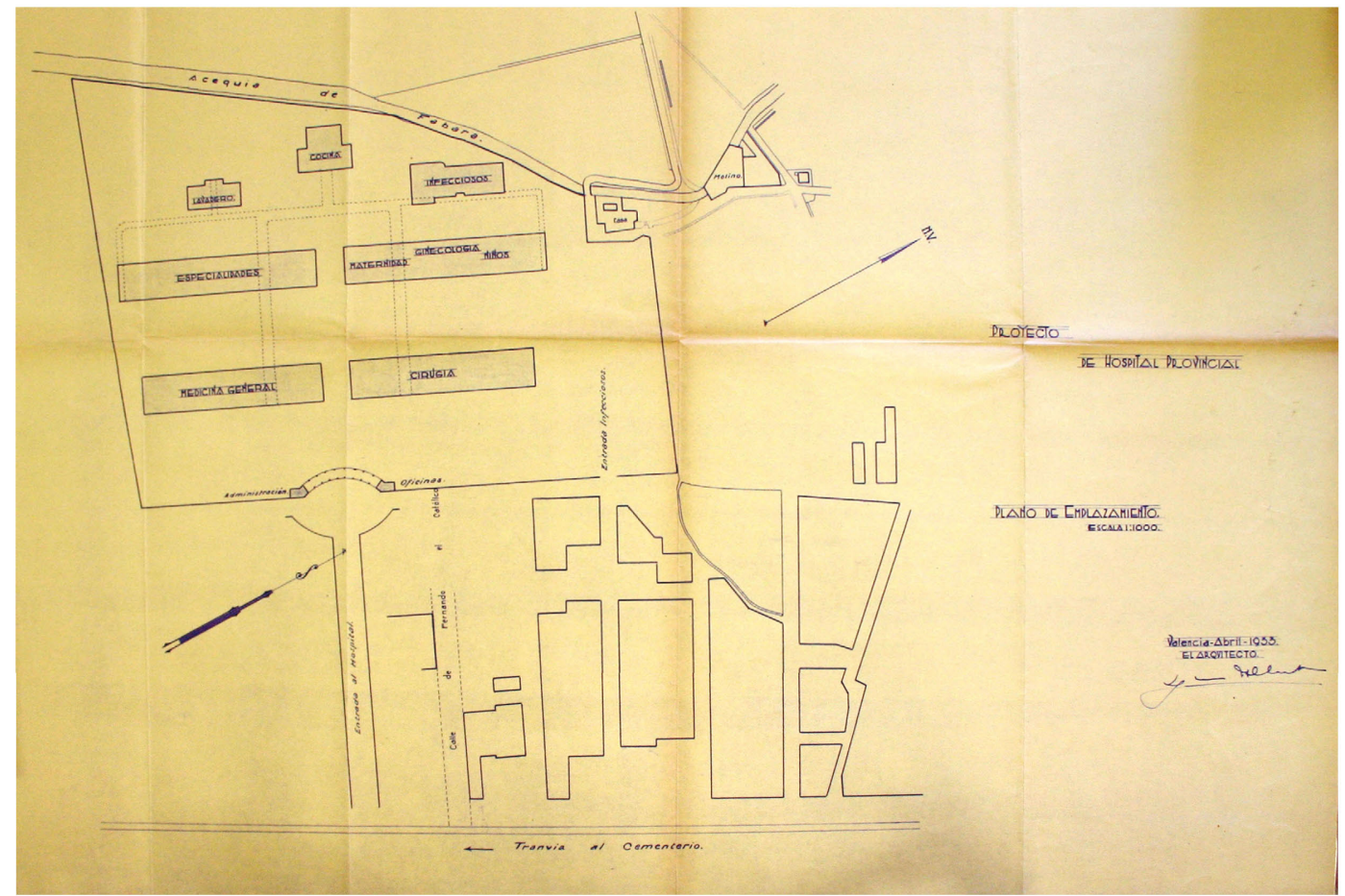



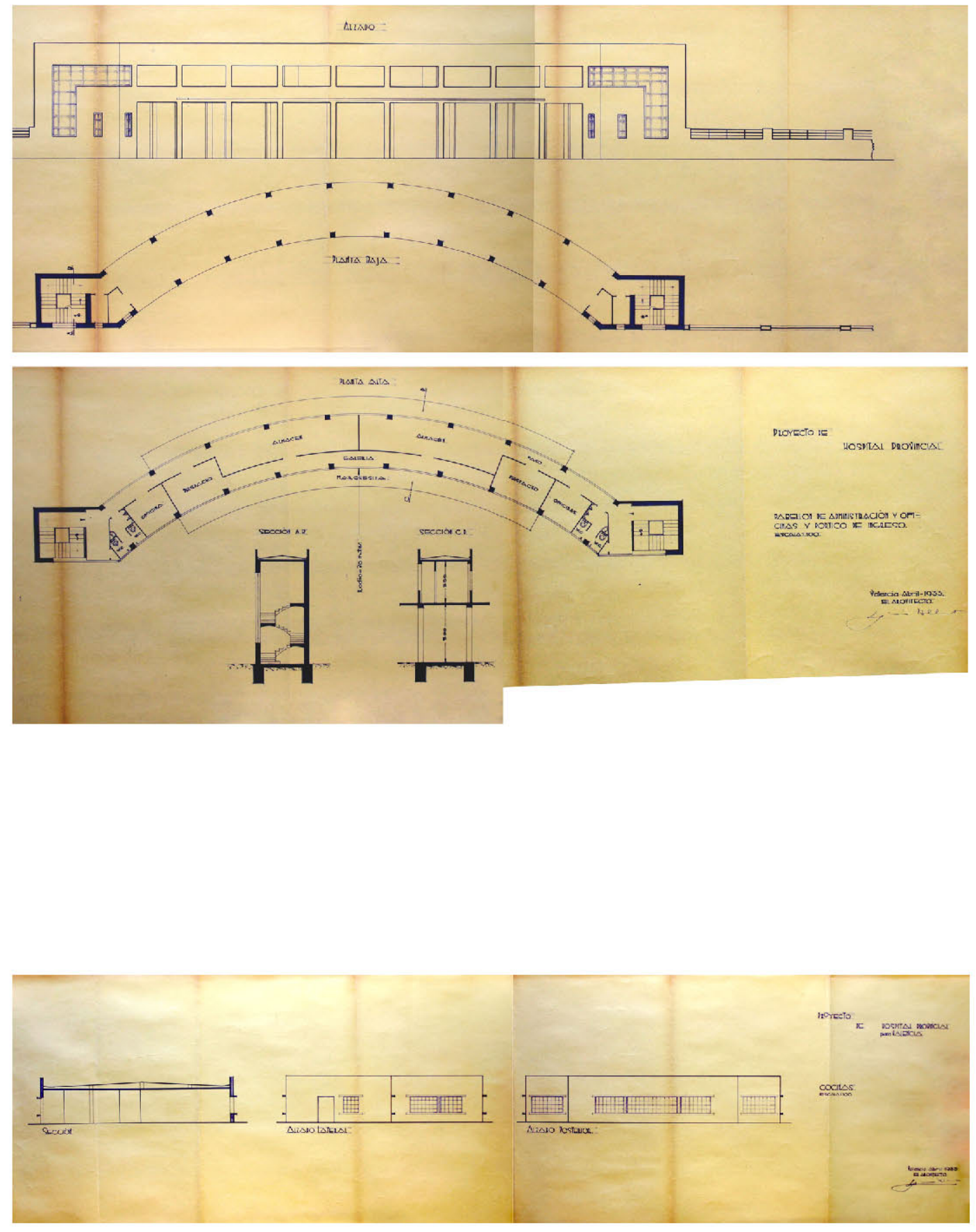

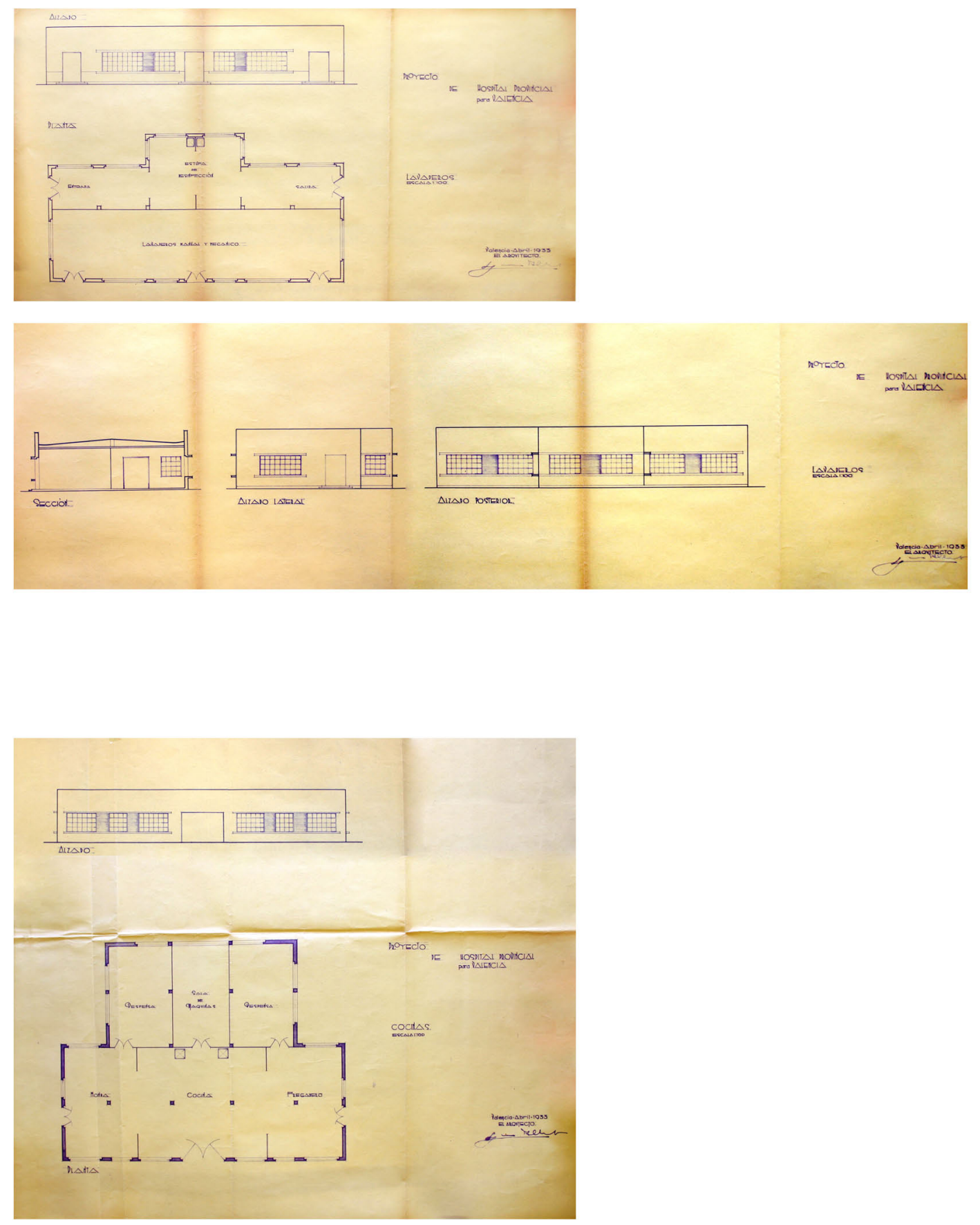

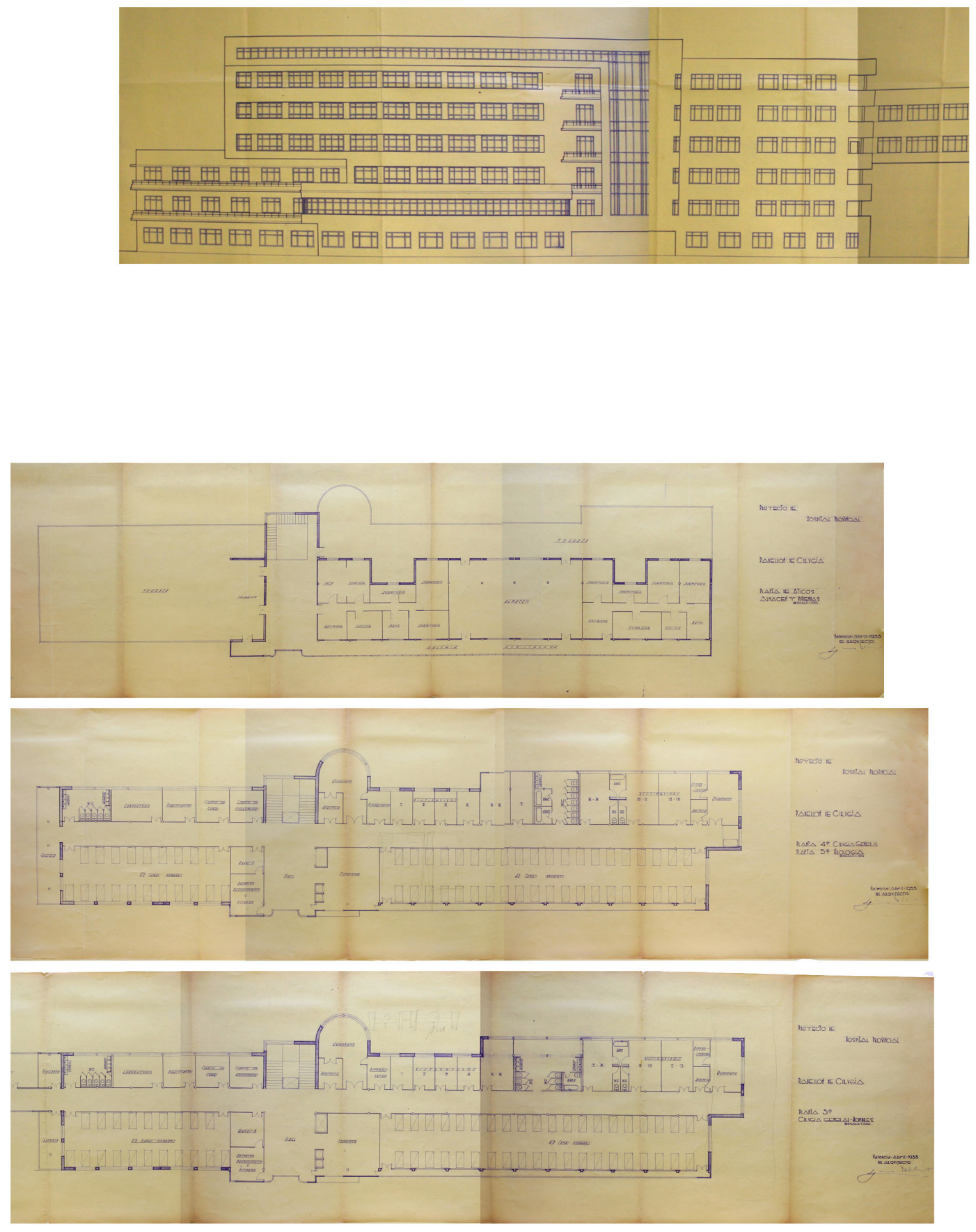

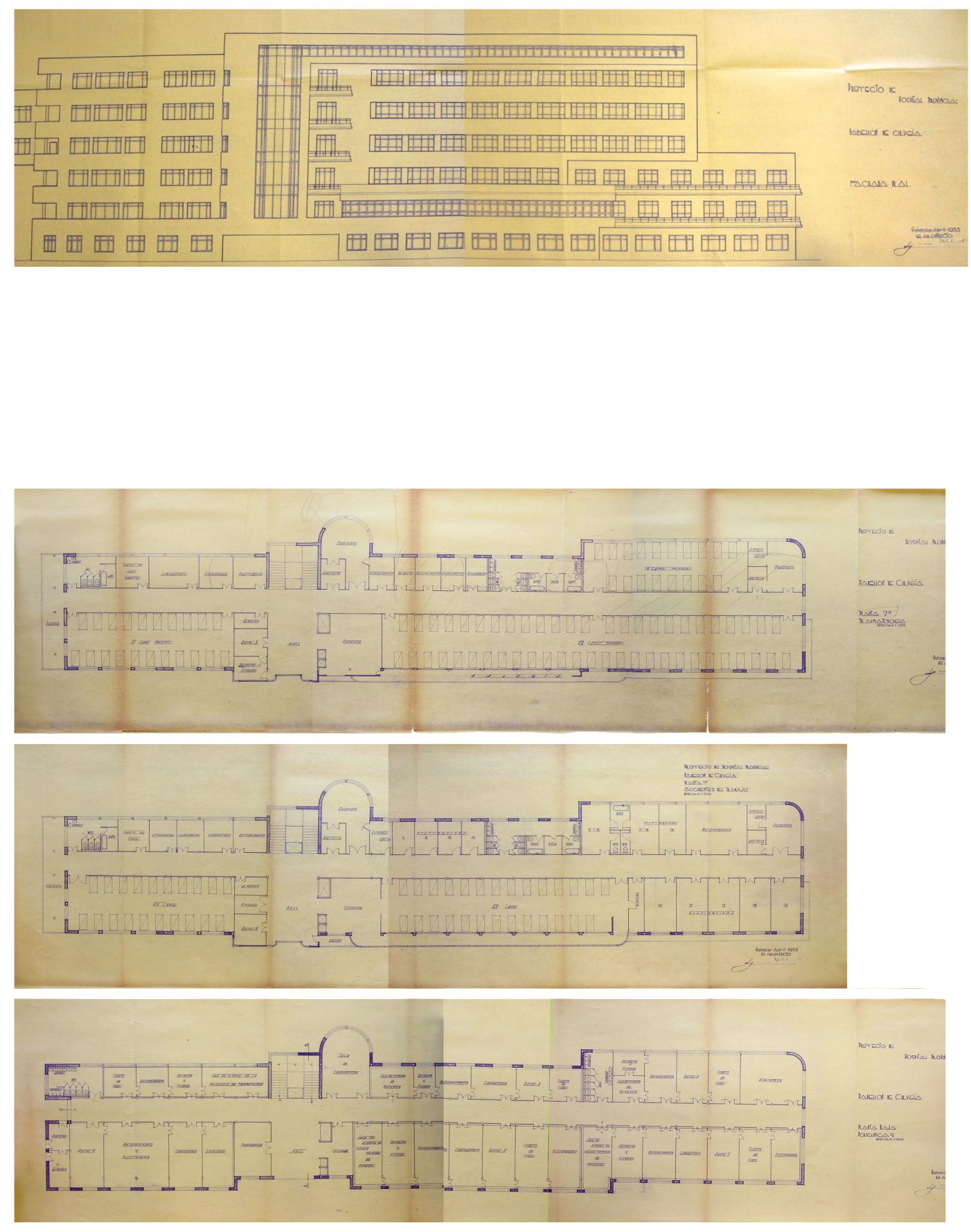

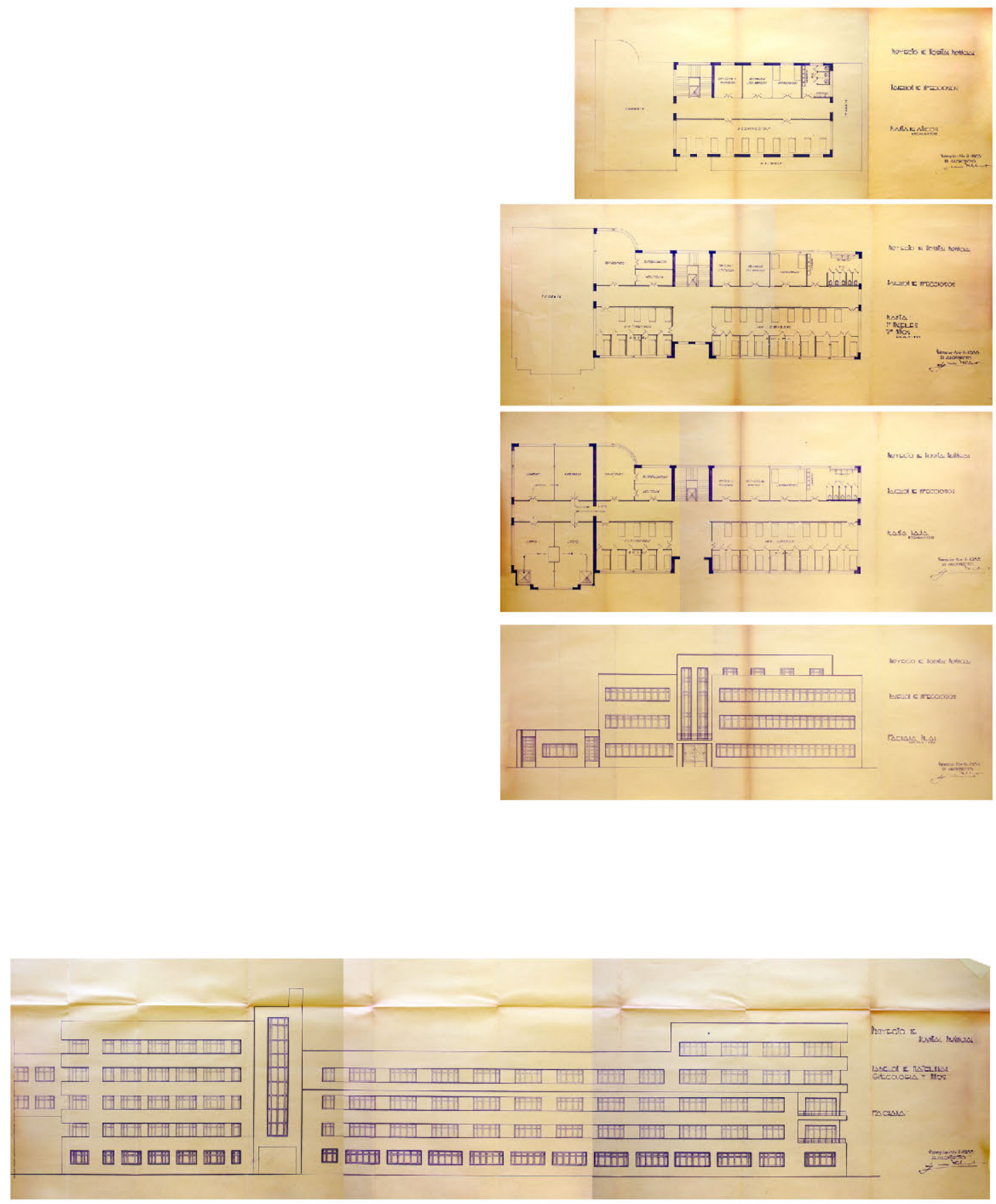


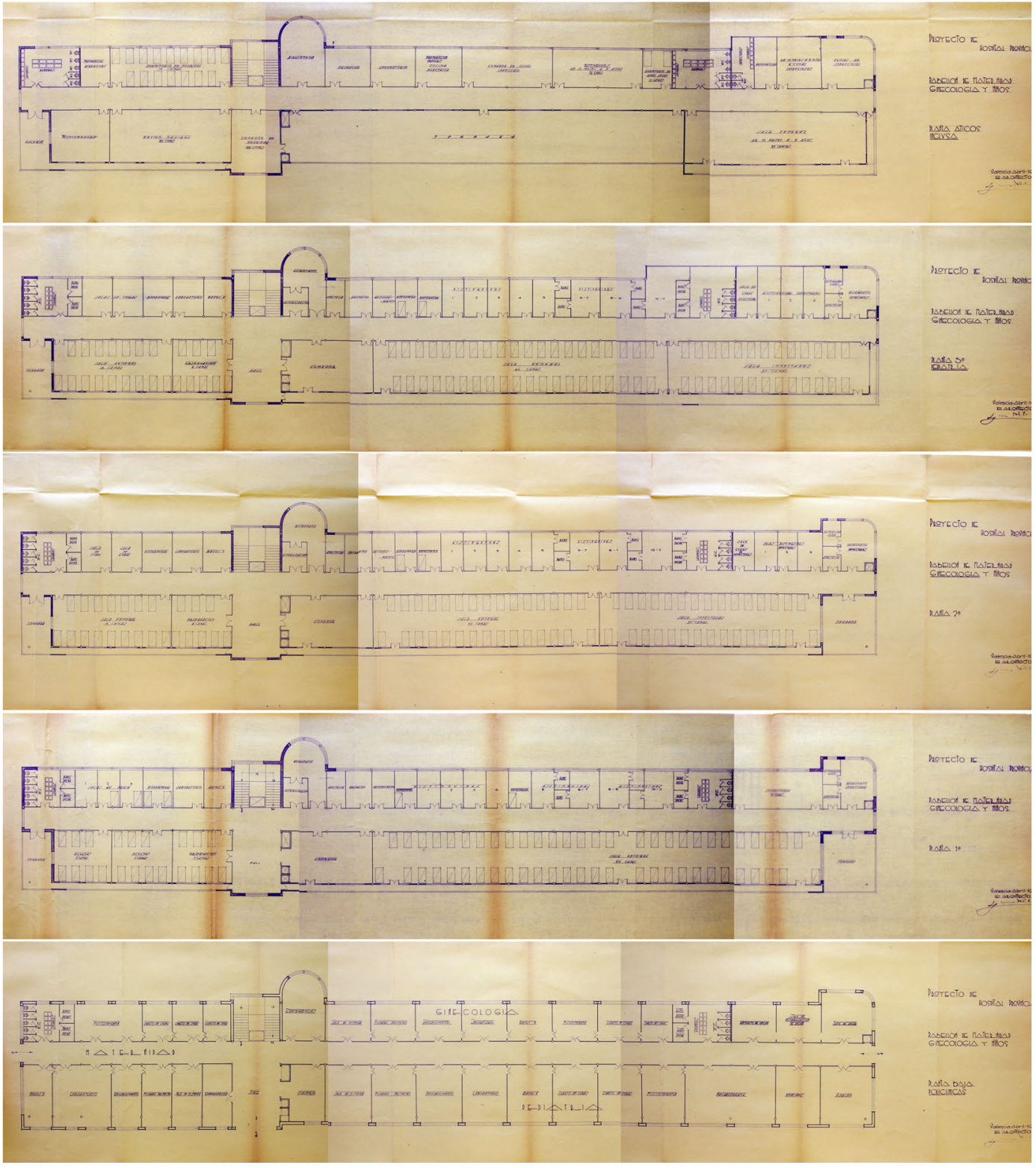



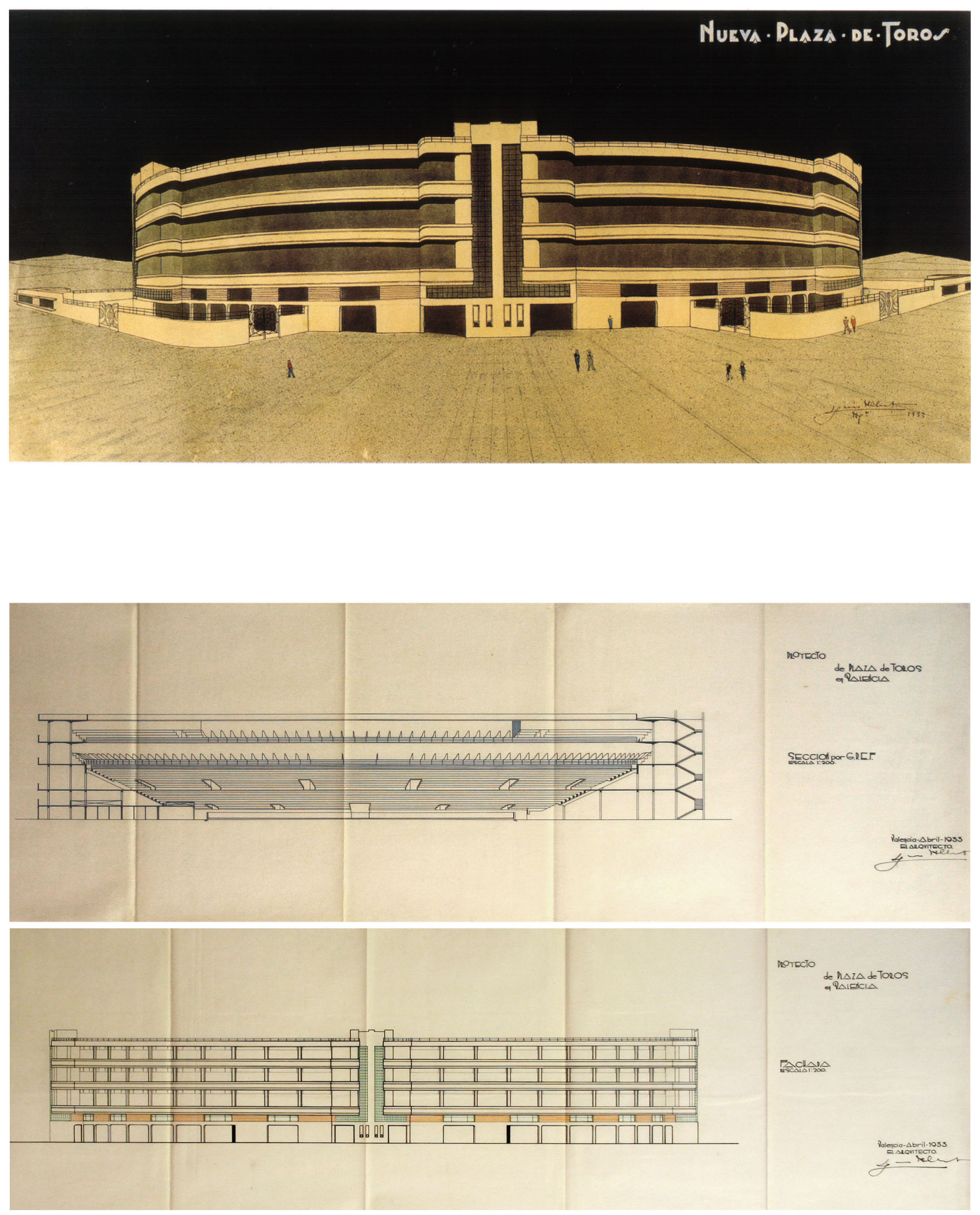
PROMOTOR: Diputación Provincial de Valencia (proyecto)

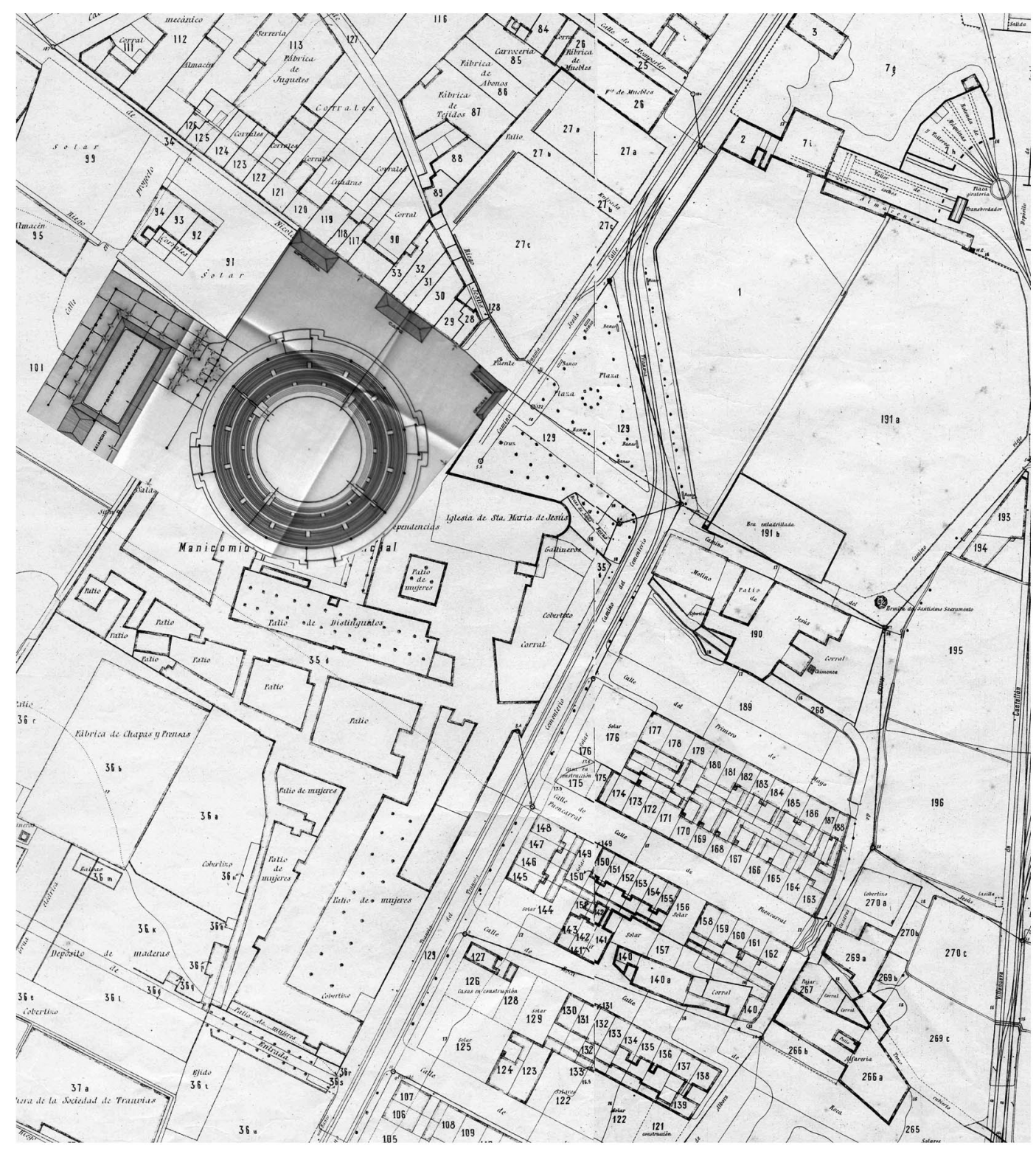




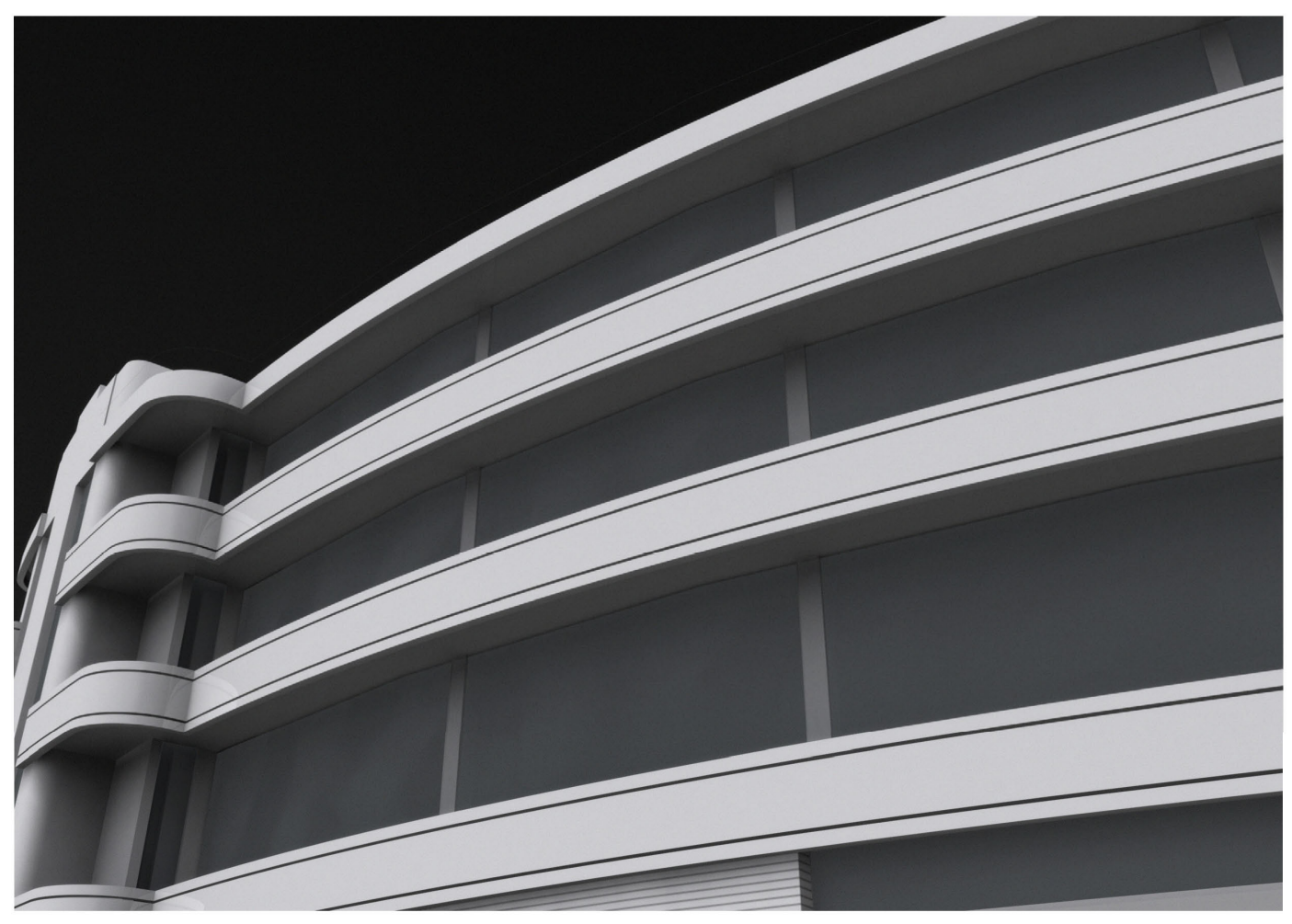



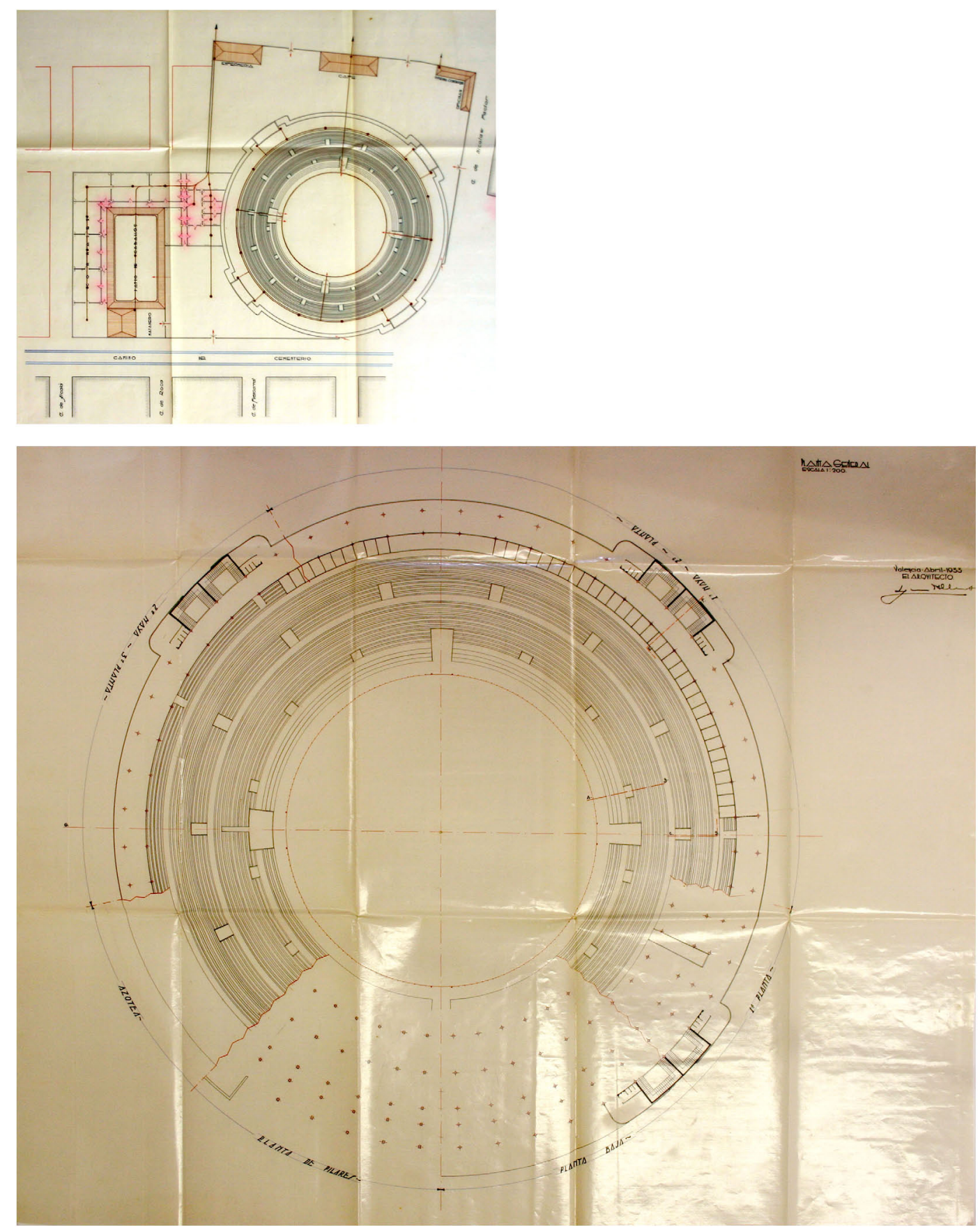

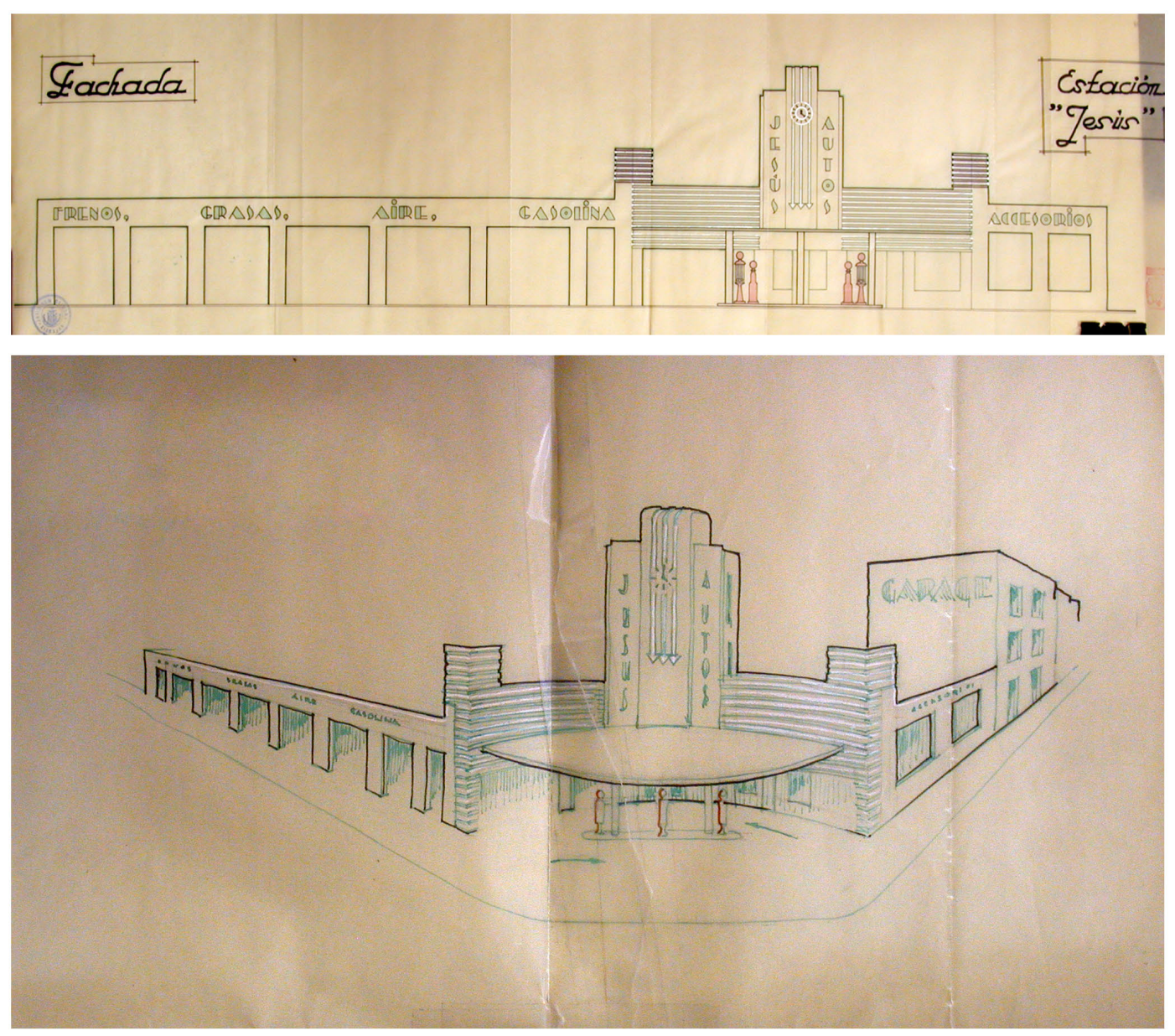
1939. Caja E03; Expediente 44227

EMPLAZAMIENTO: Jesús, Alcira

PROMOTOR: Enriquez, Jesús (Estación para engrase de automóviles)
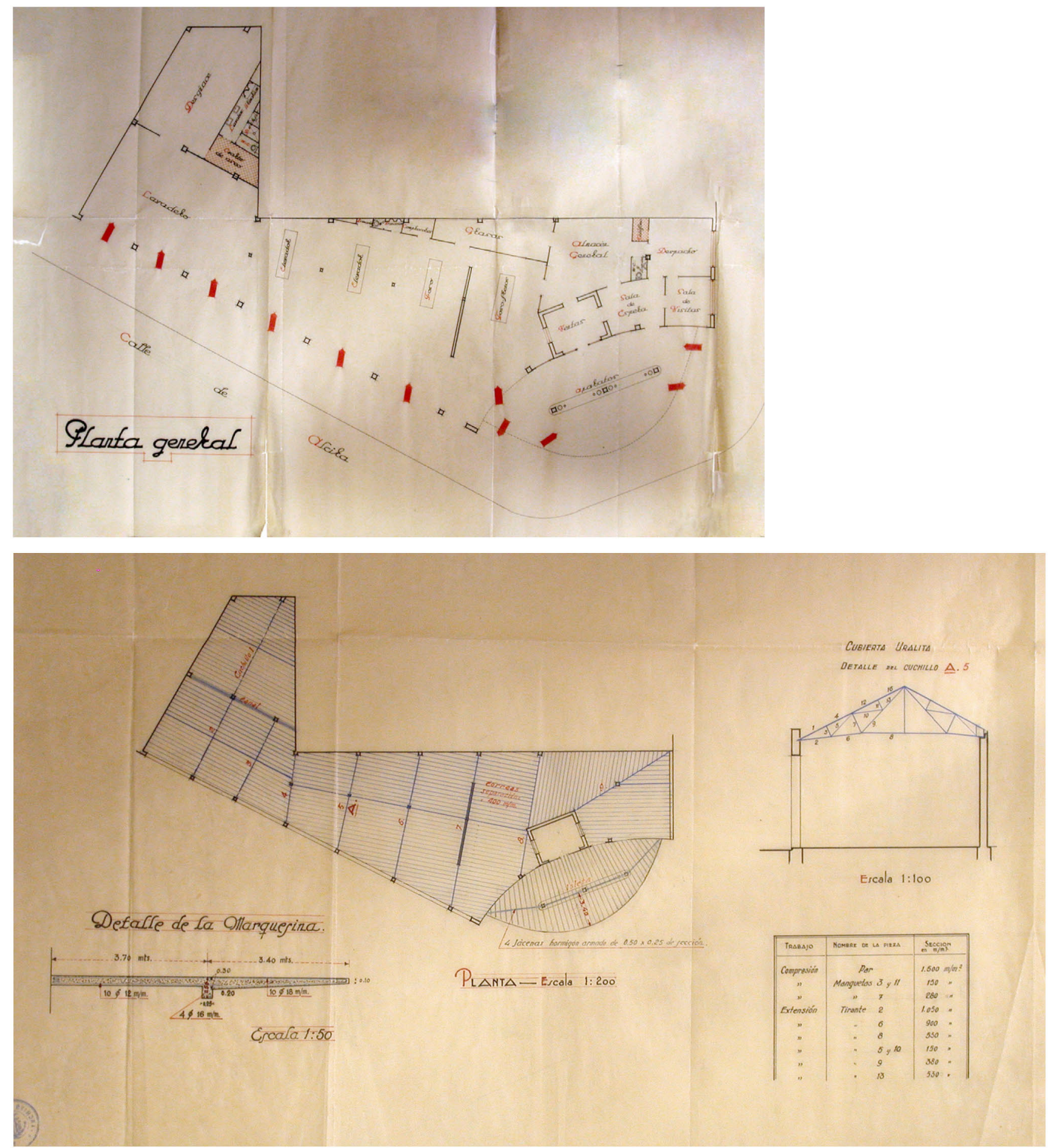


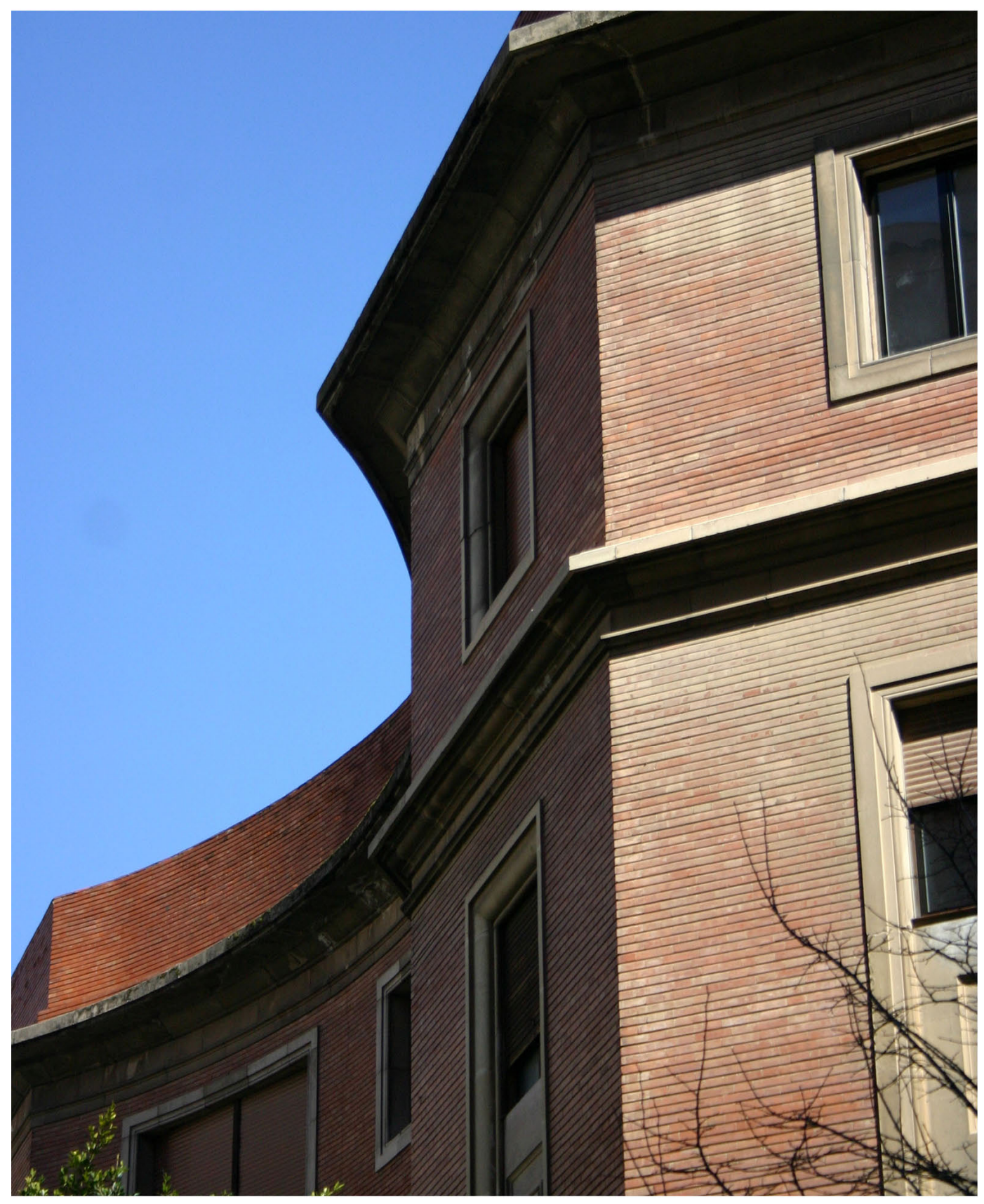


1939. Caja E0 4; Expediente

EMPLAZAMIENTO: Jacinto Benavente, Peris y Valero, Salamanca PROMOTOR: Rodríguez, Isabel (Colegio LORETO)

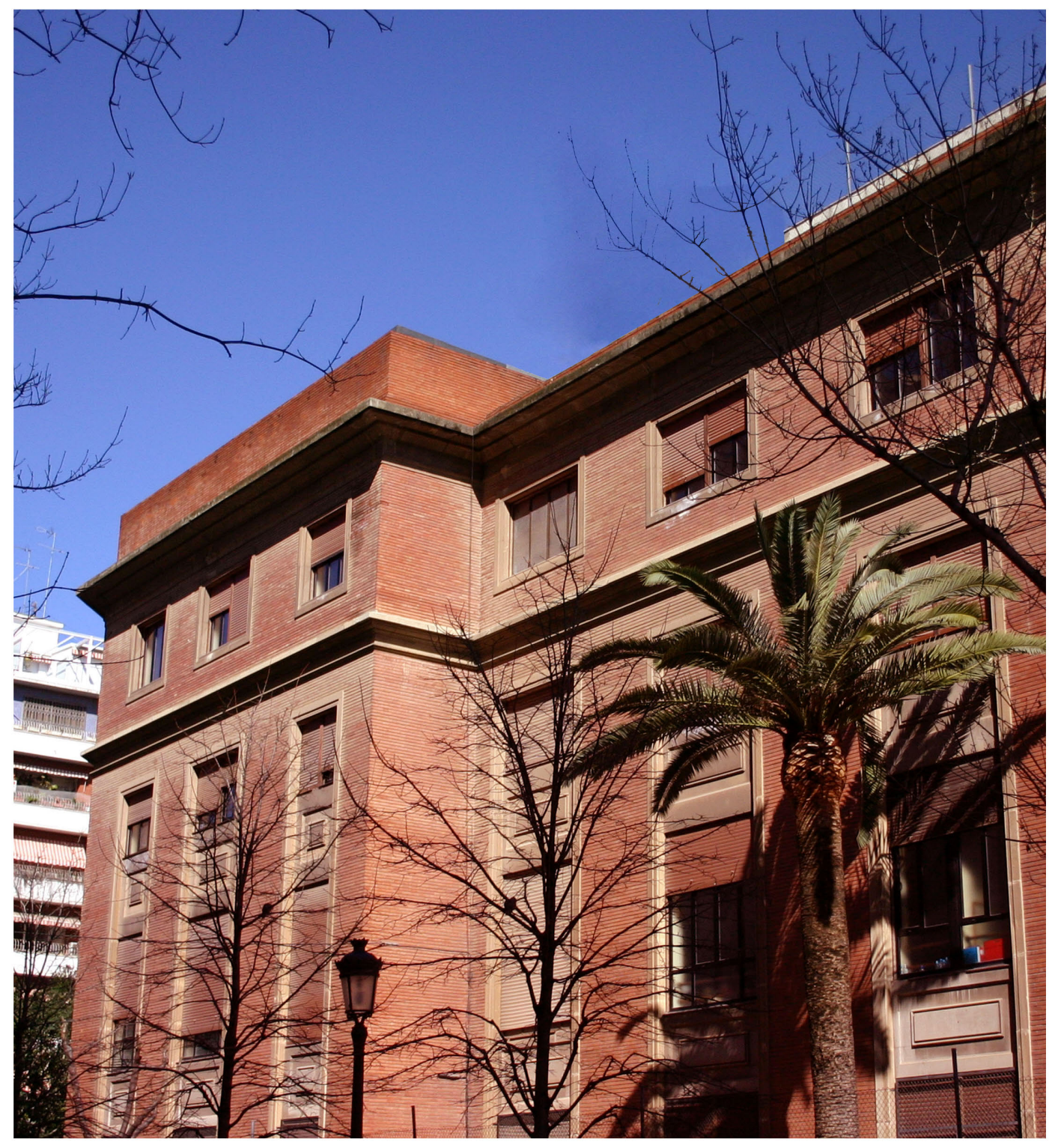




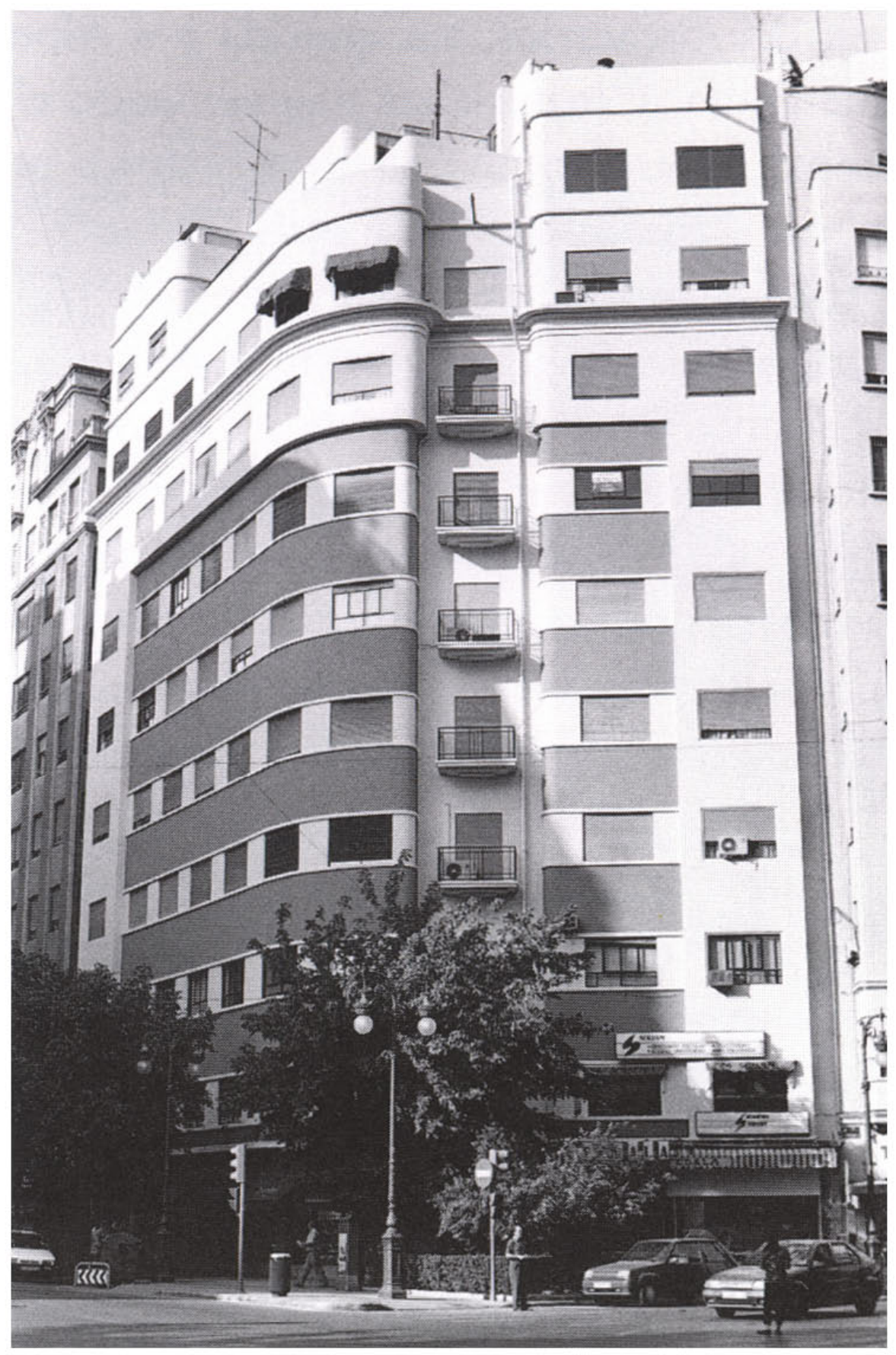


1941. Caja 09; Expediente 11643

EMPLAZAMIENTO: Oeste, avenida (actual Barón de Carcer) PROMOTOR: Albert Ballester, Luis (promoción propia)

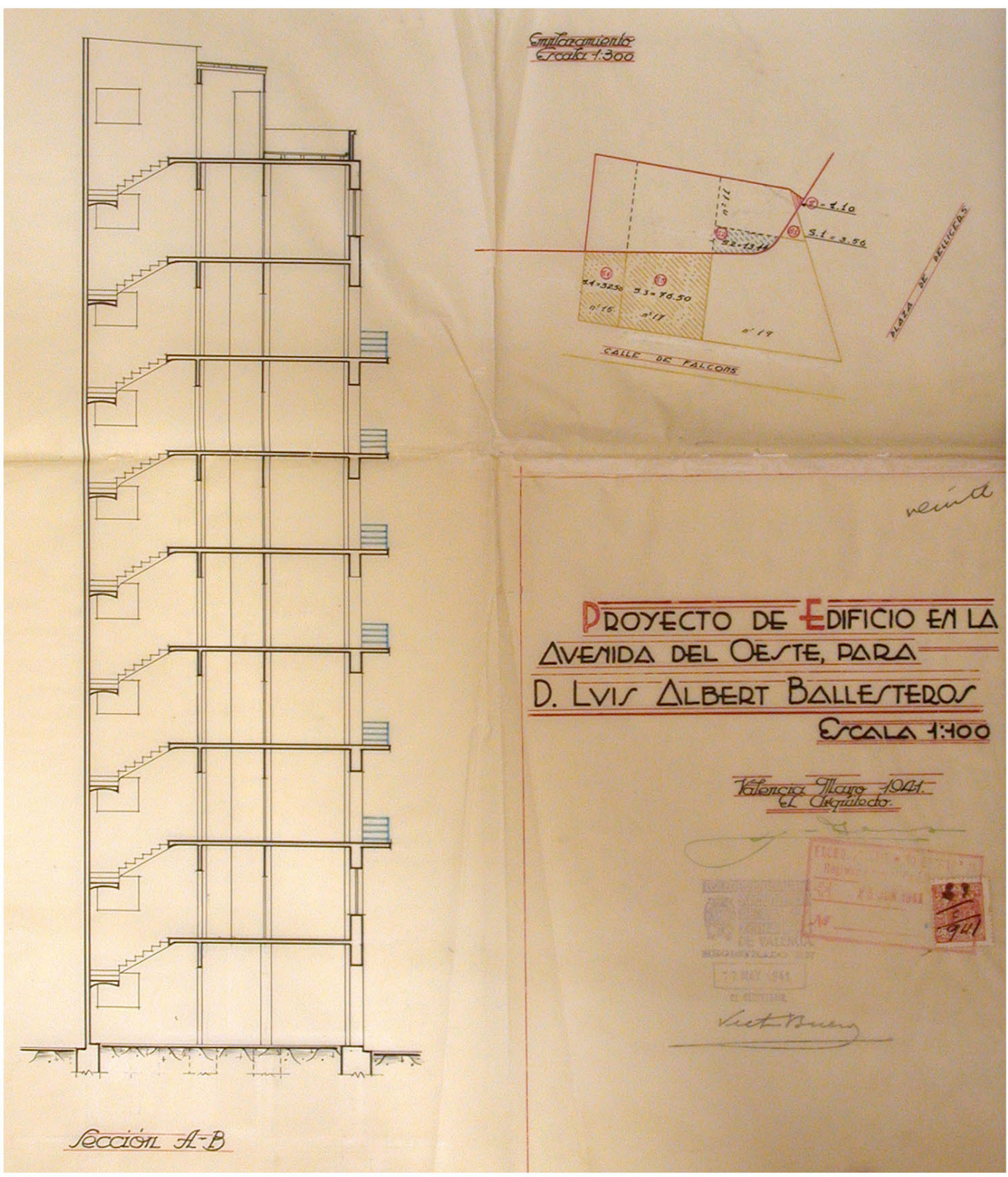




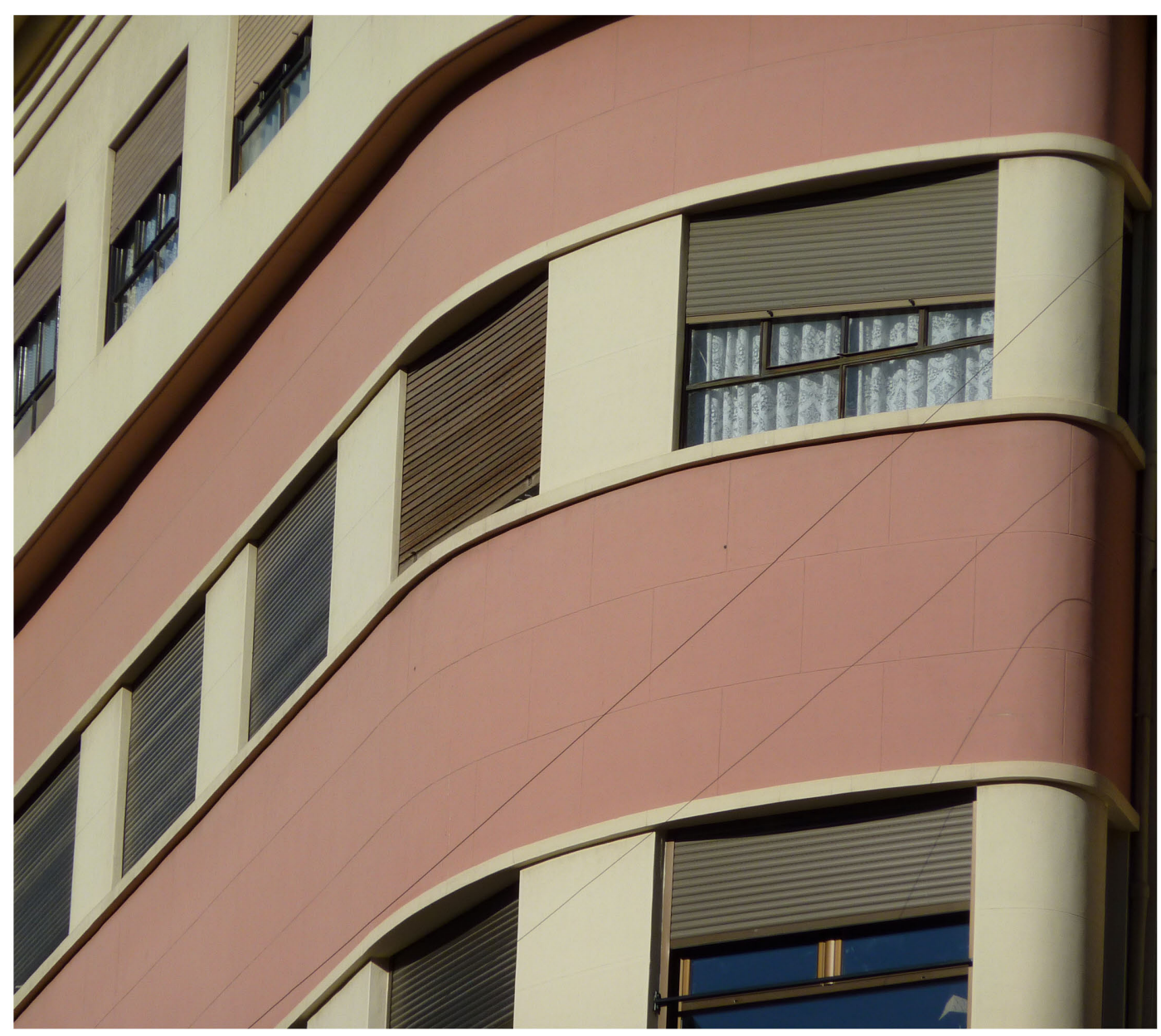



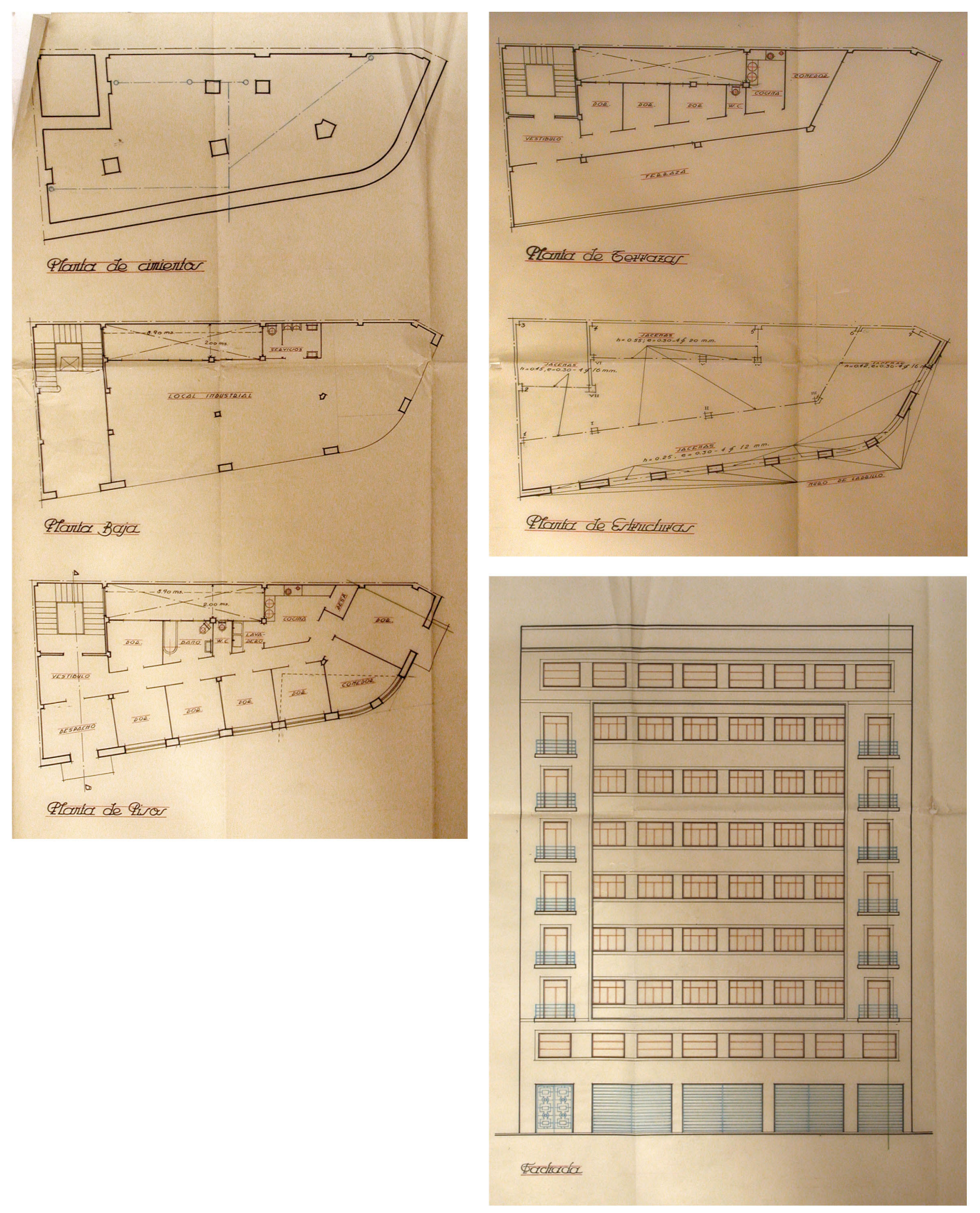

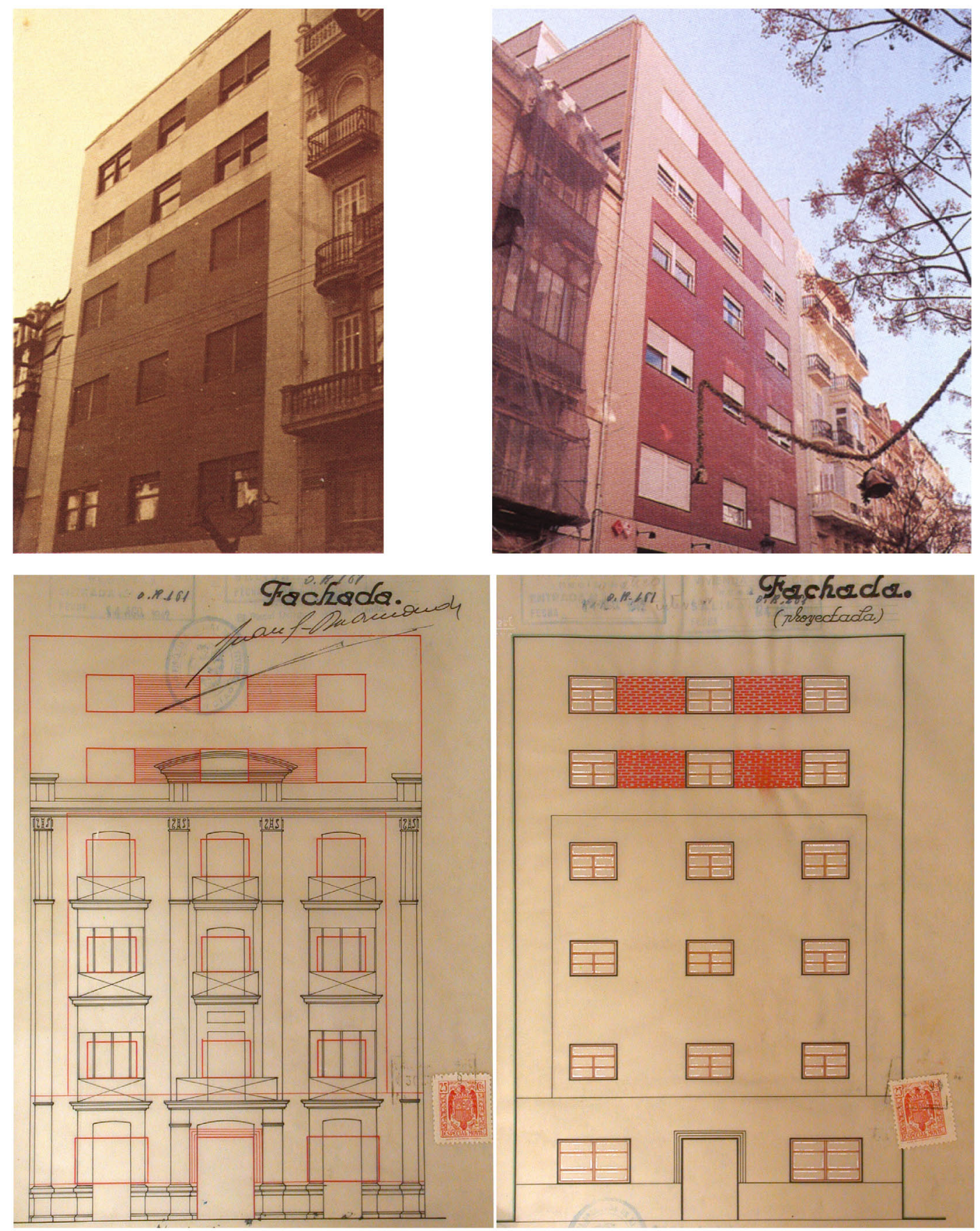
1941. Caja E09: Expediente 01473

EMPLAZAMIENTO: Sorní, $n^{\circ} 24$

PROMOTOR: Martínez, Lorenzo
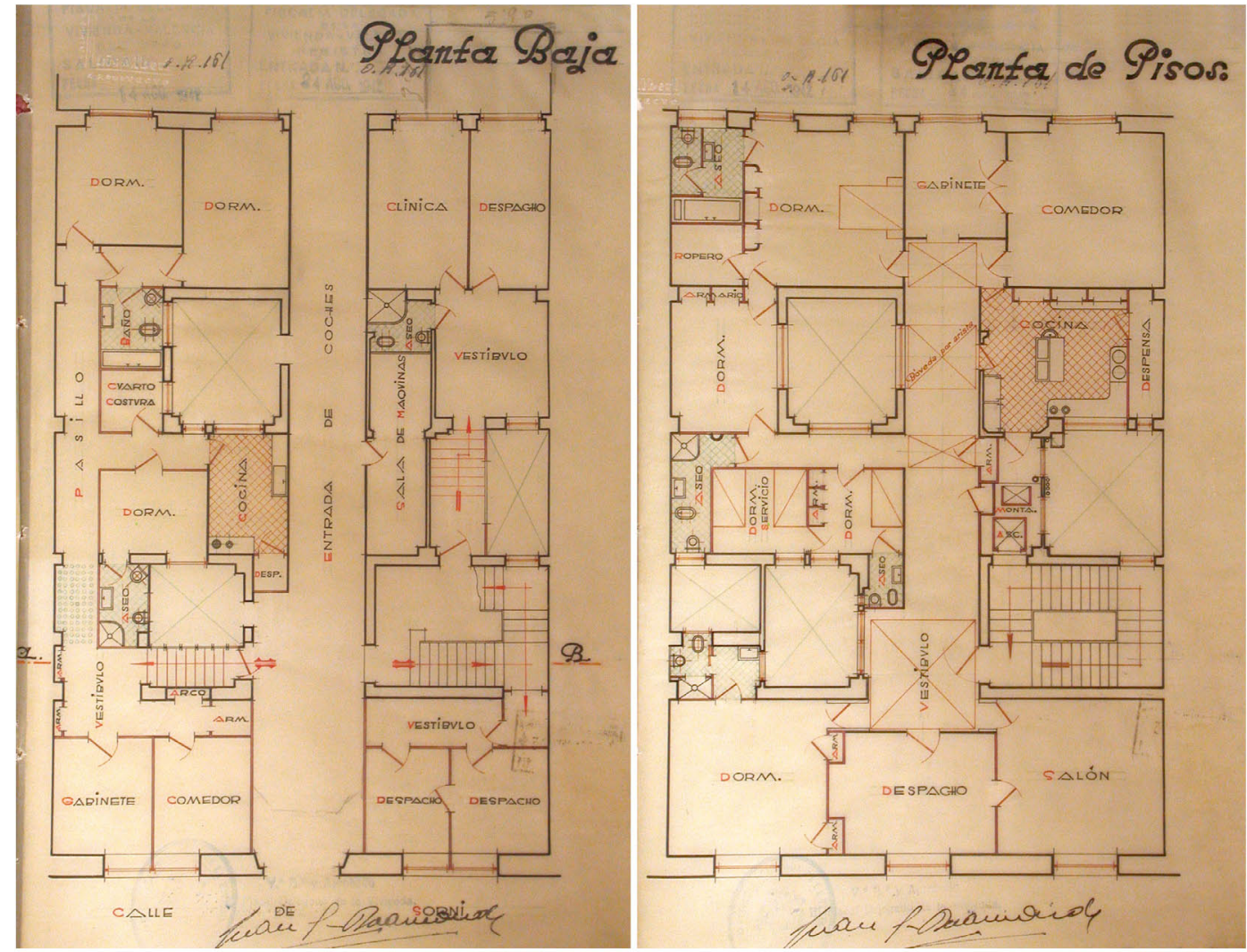


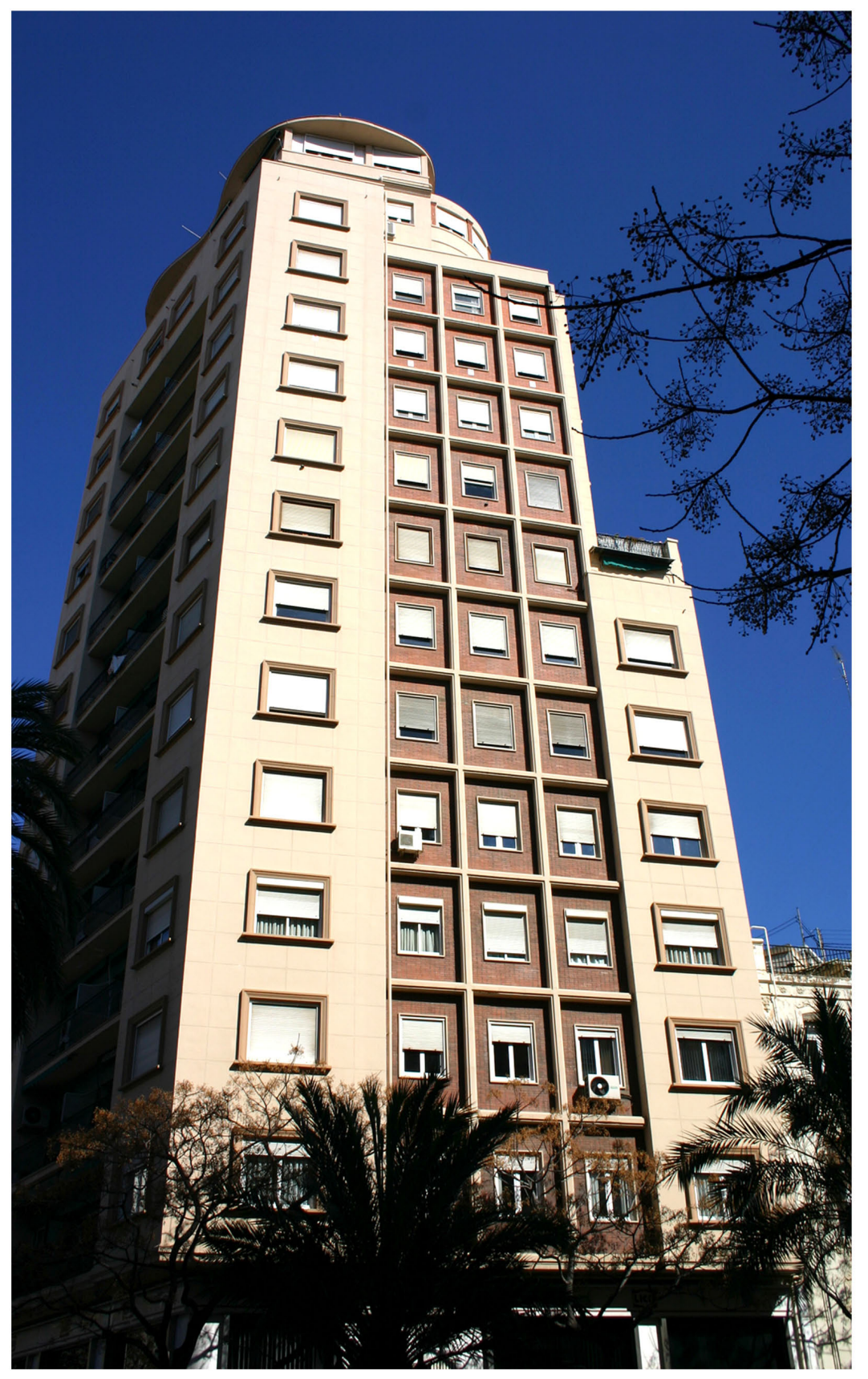


1944. Caja E0; Expediente

EMPLAZAMIENTO: Marques del Turia

PROMOTOR: Illueca, Gastón

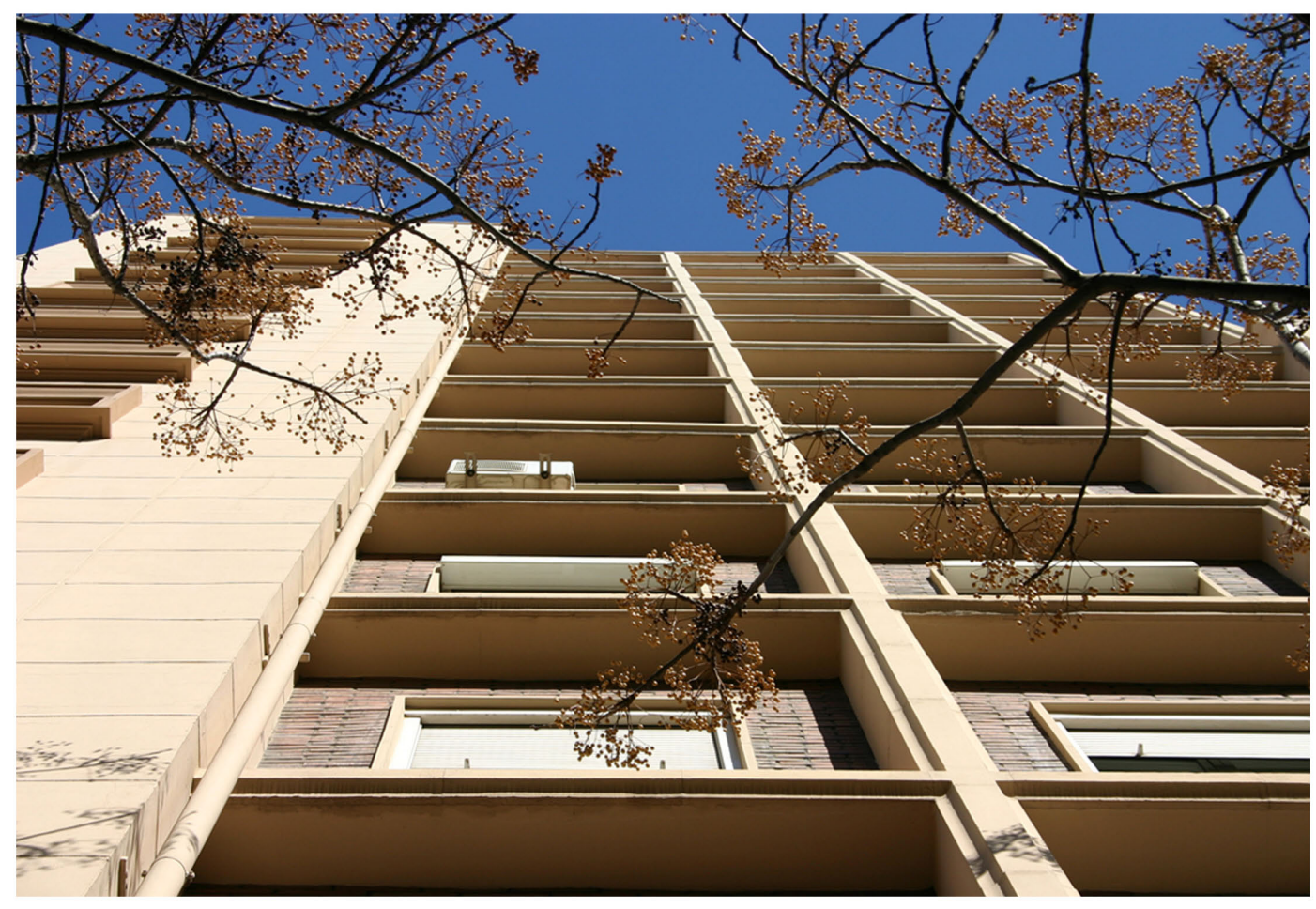




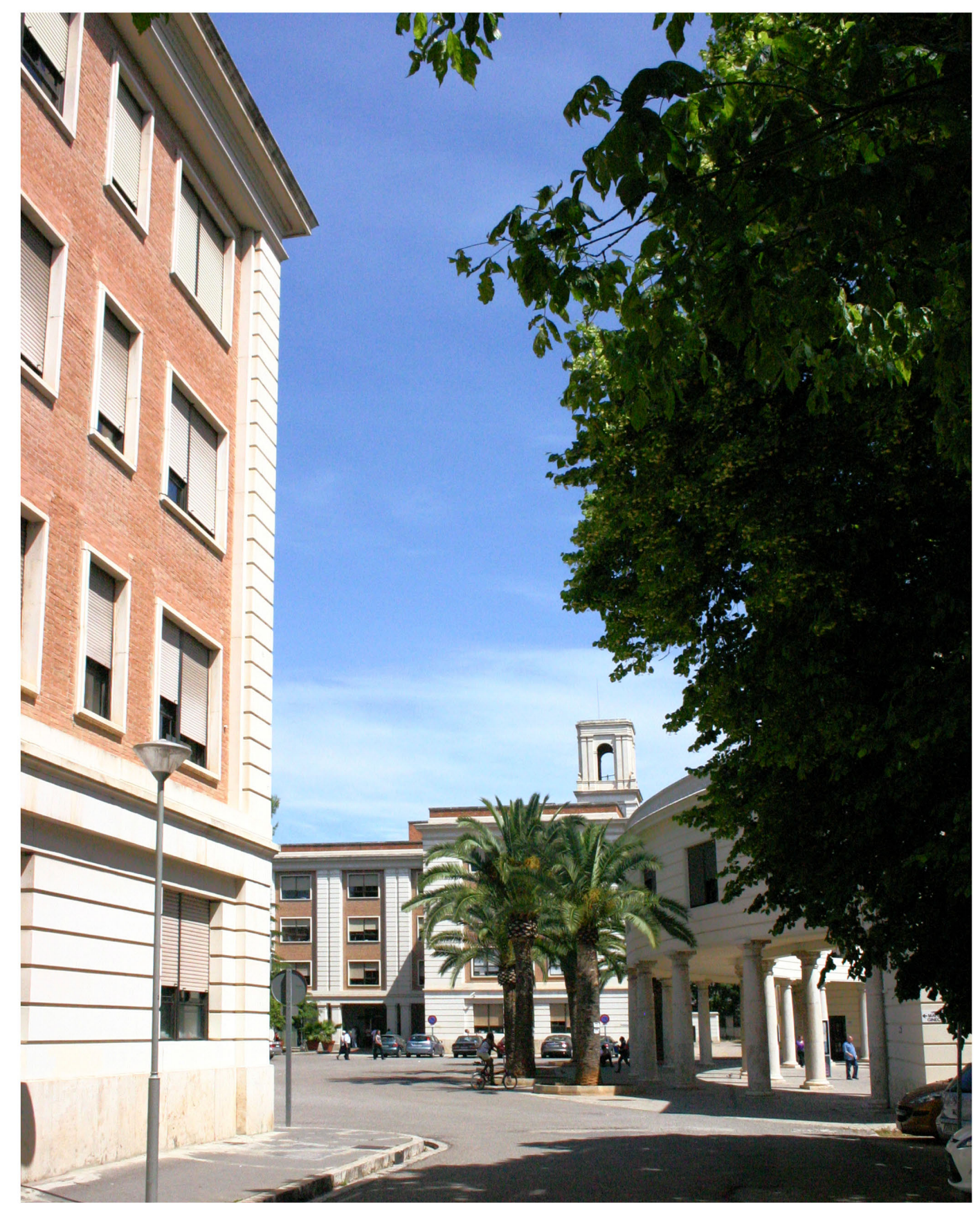


1948. Caja E0; Expediente

EMPLAZAMIENTO: Castilla, avenida y Tres Cruces

PROMOTOR: Diputación Provincial de Valencia (Hospital Provincial)

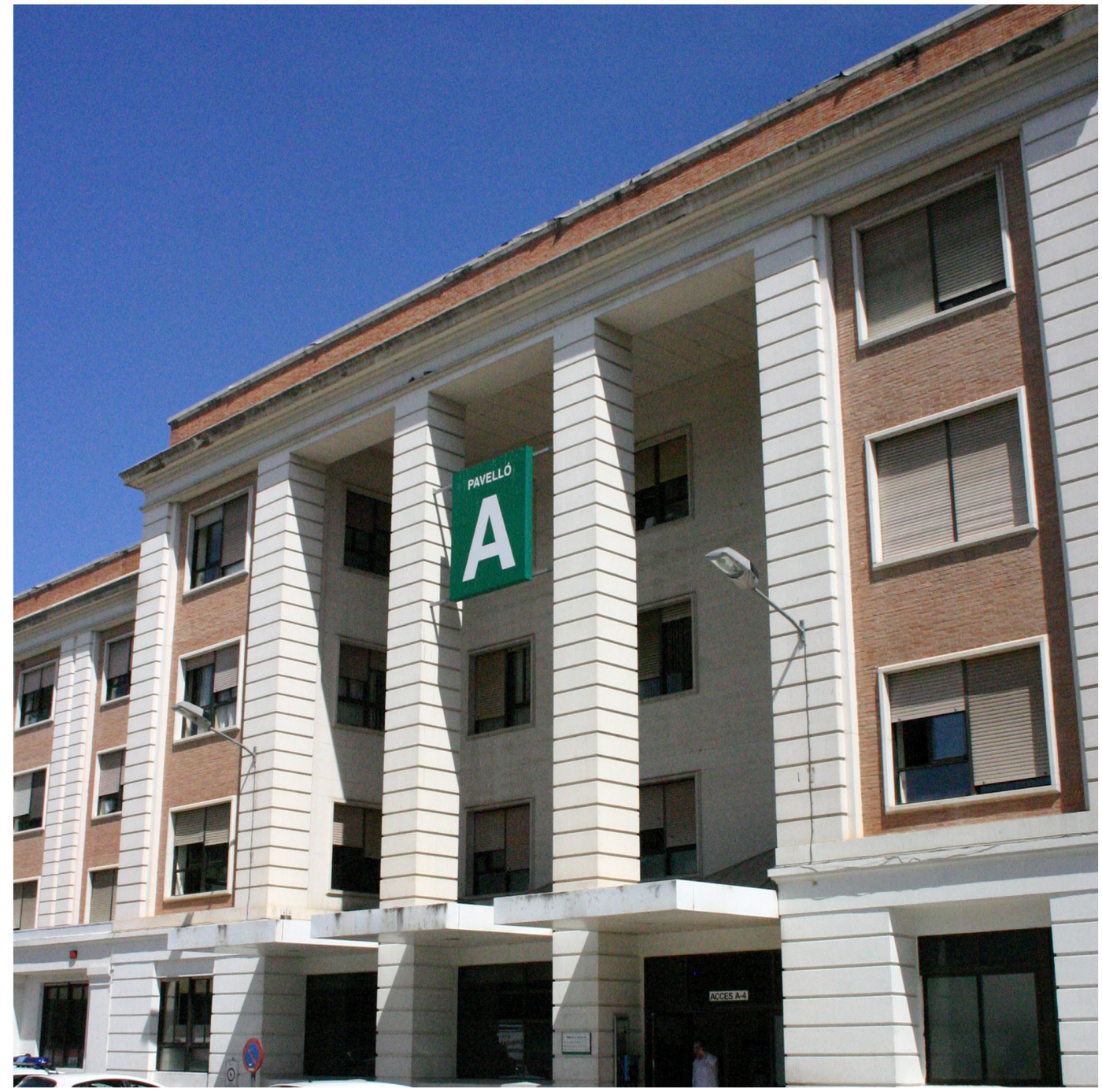




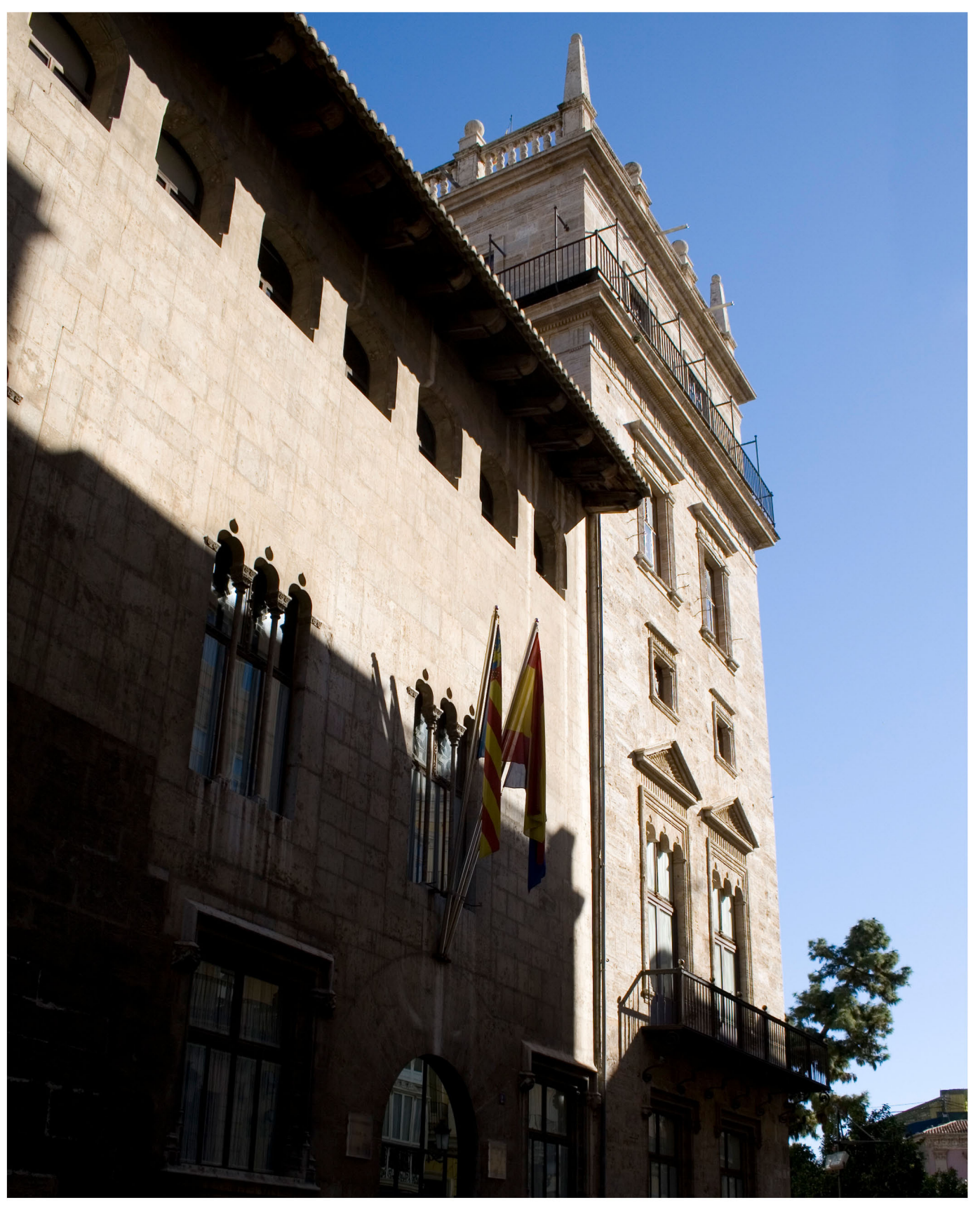


1951

EMPLAZAMIENTO: Caballeros y La Virgen

PROMOTOR: Excelentísima Diputación Provincial de Valencia

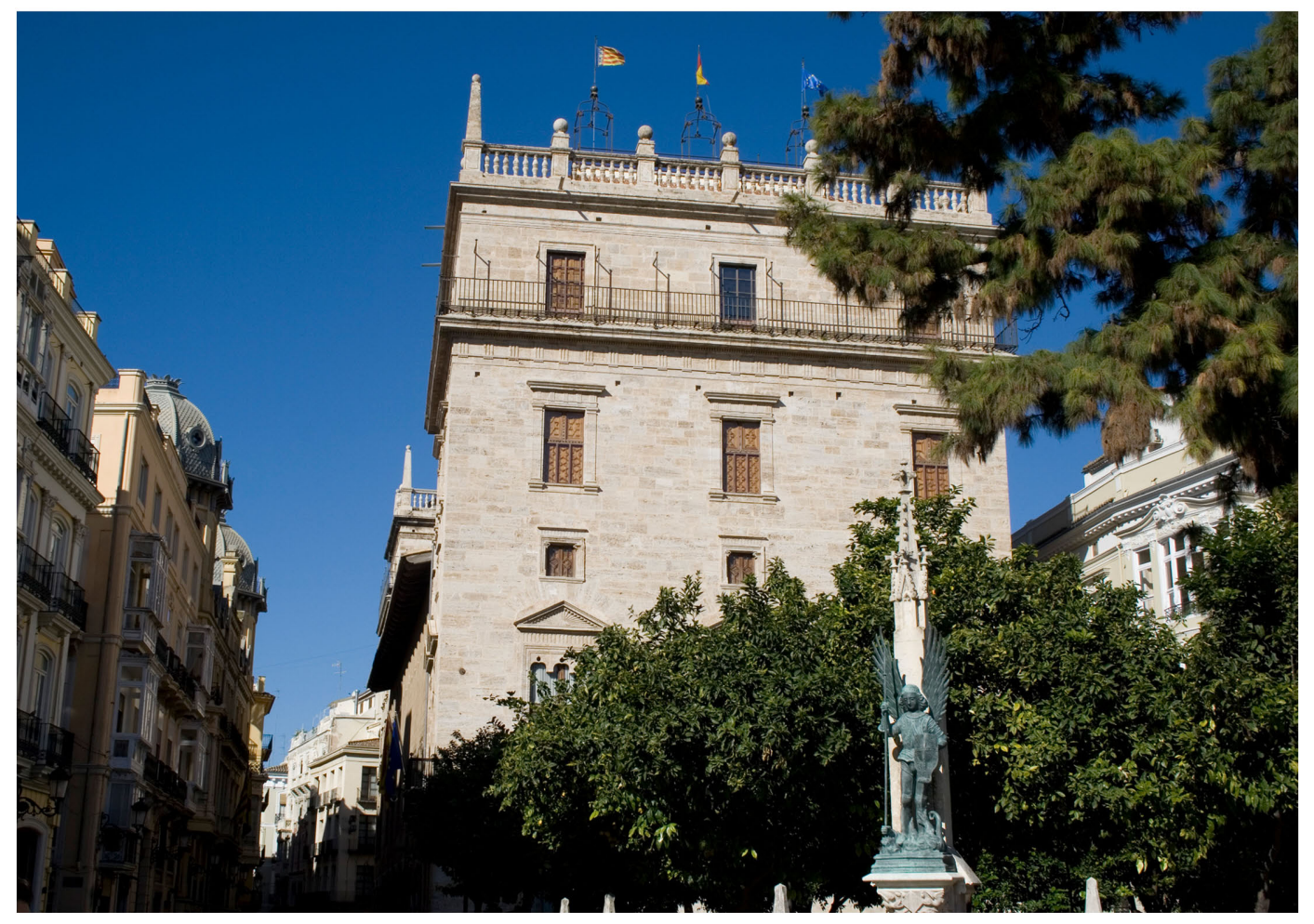



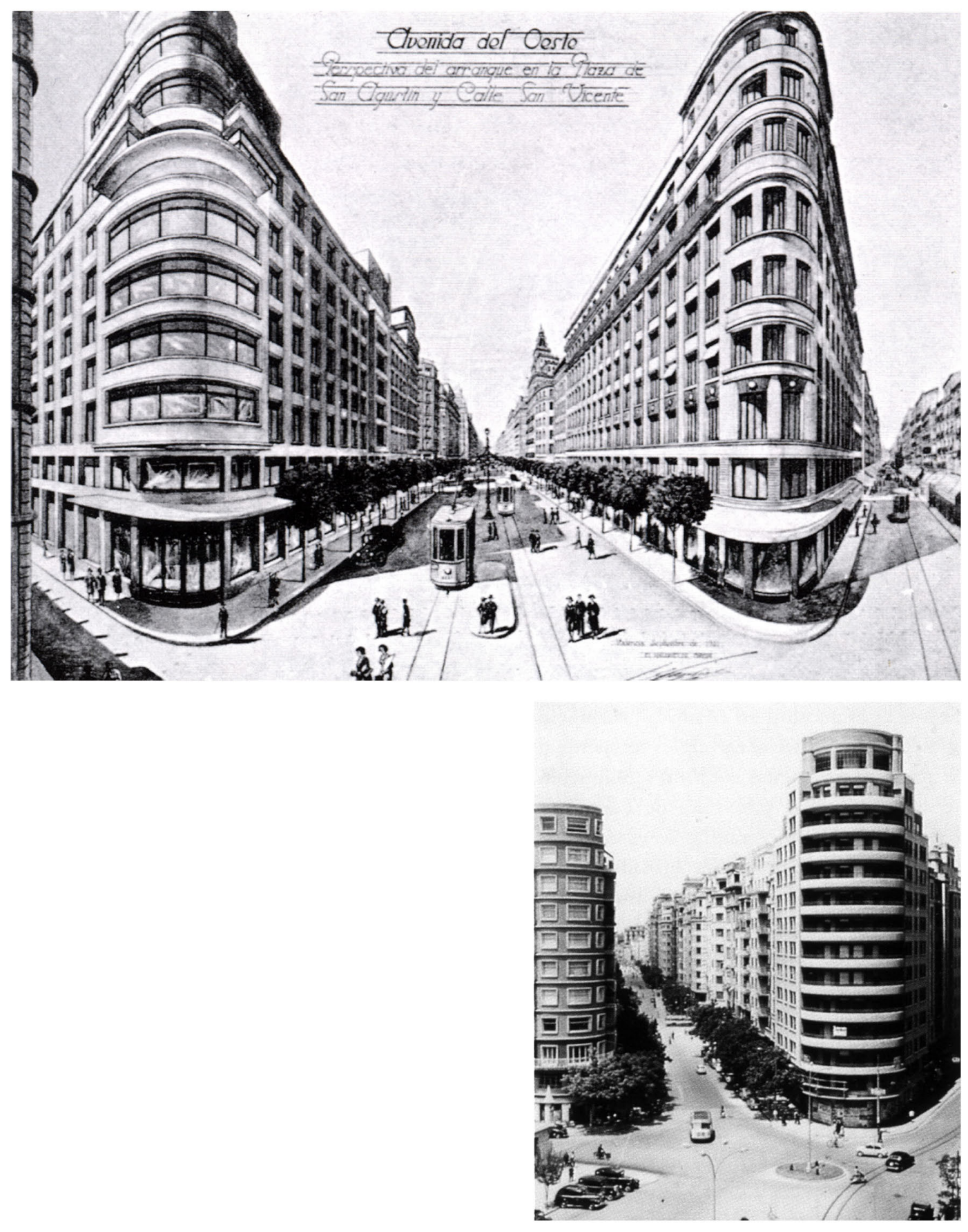
1953. Caja 08; Expediente 16162

EMPLAZAMIENTO: Oeste, San Agustín y Gracia

PROMOTOR: Gil, Francisco

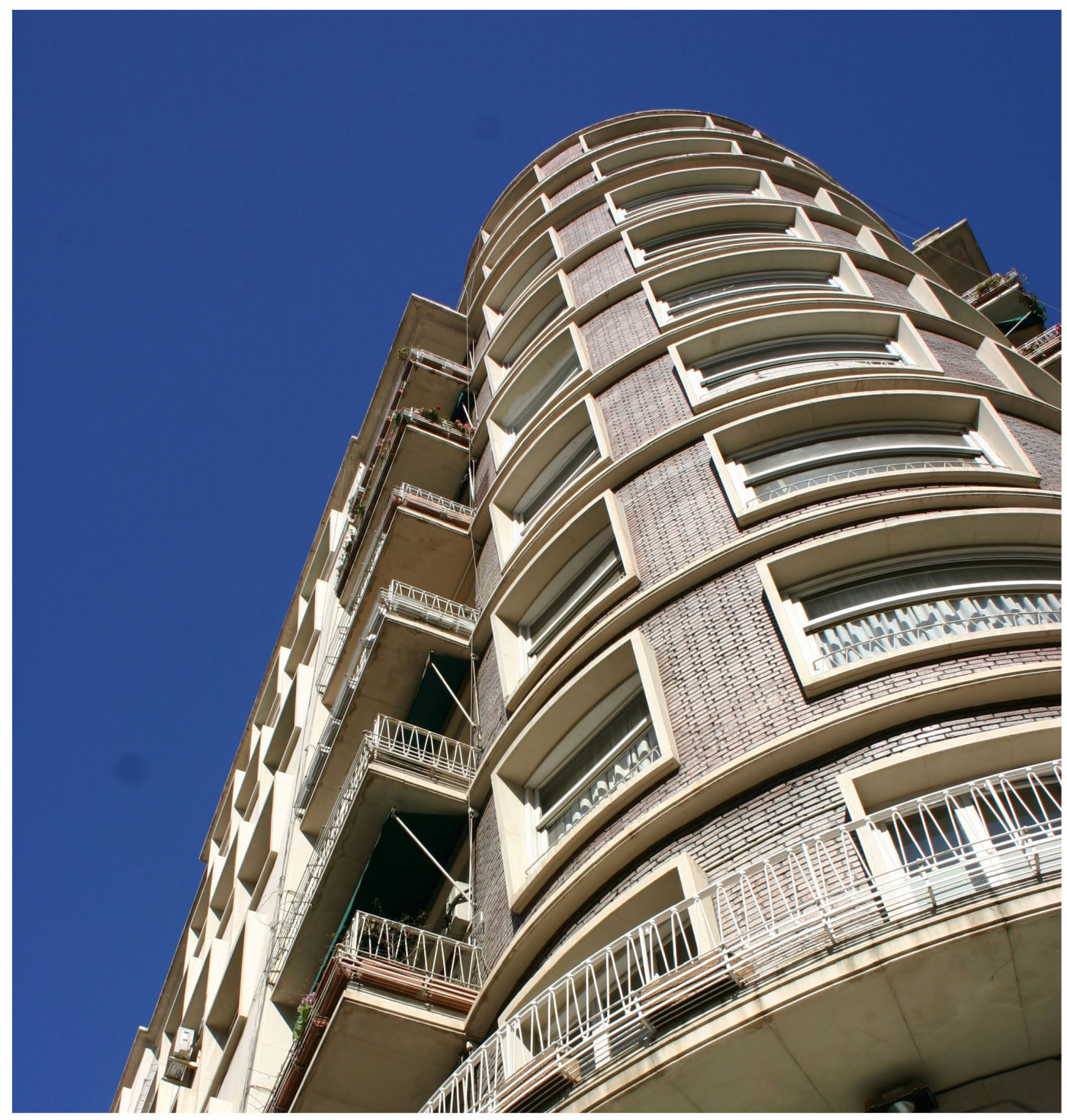




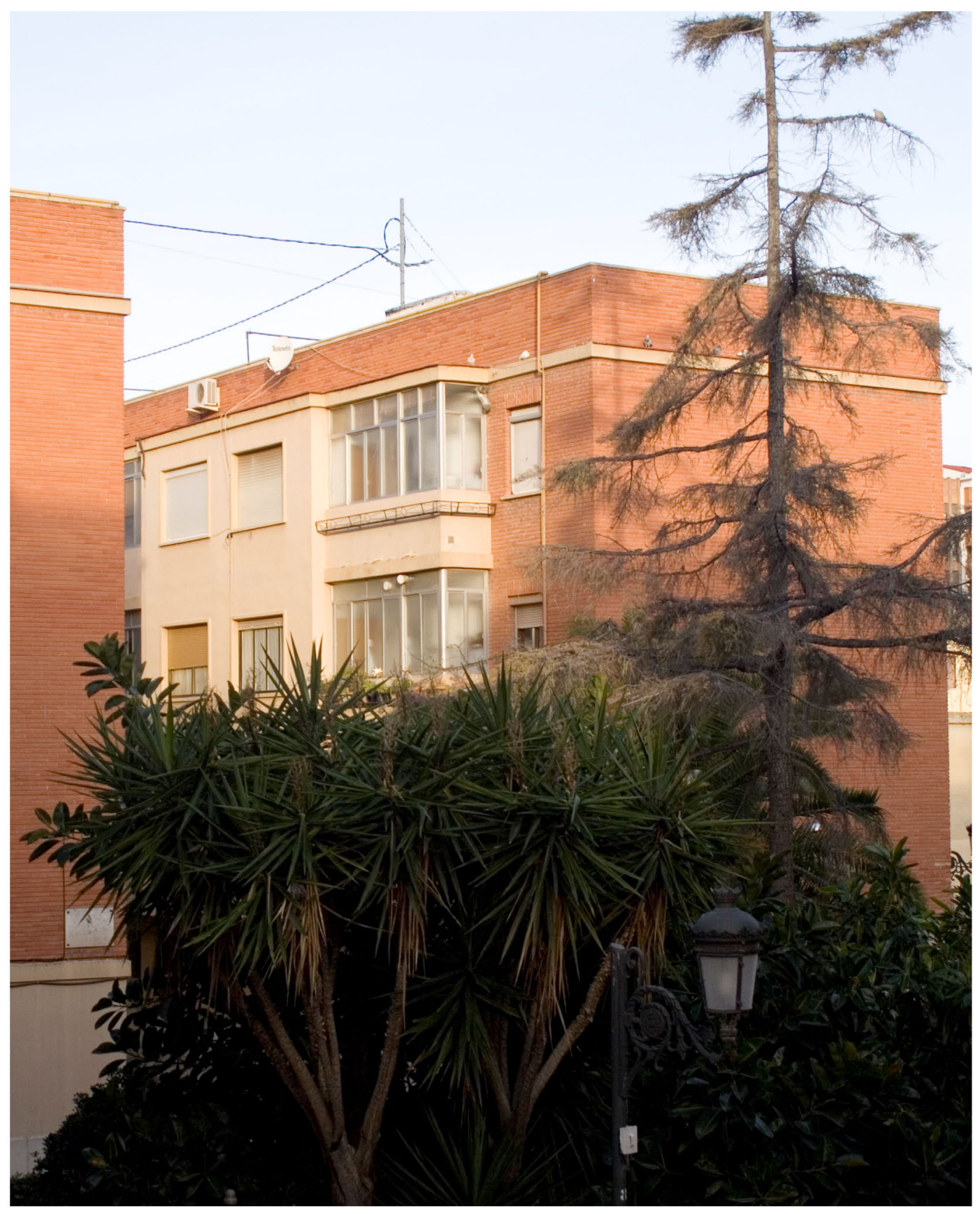


1957

EMPLAZAMIENTO: La Bocha y Camarón

PROMOTOR: Bloque residencial para funcionarios

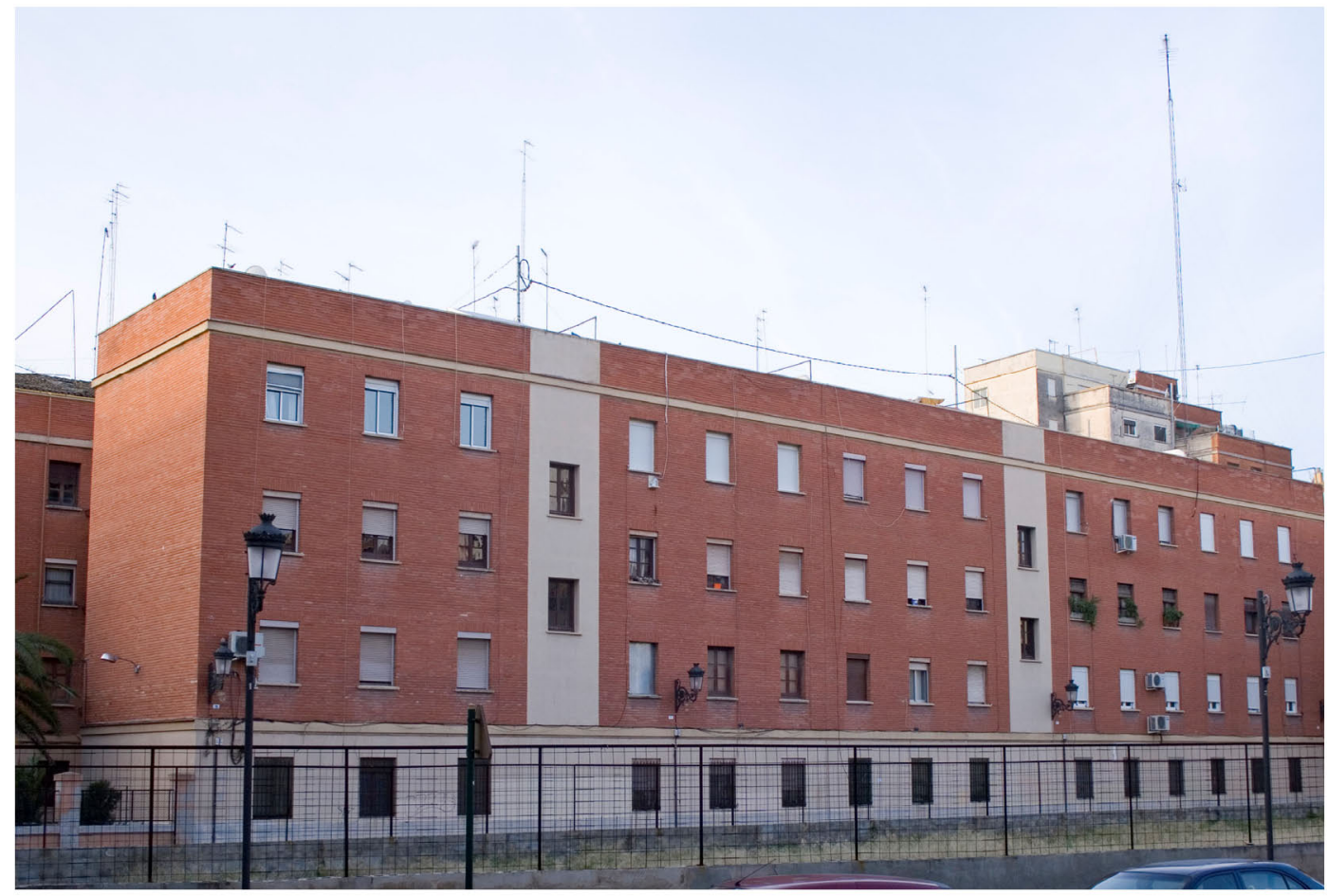




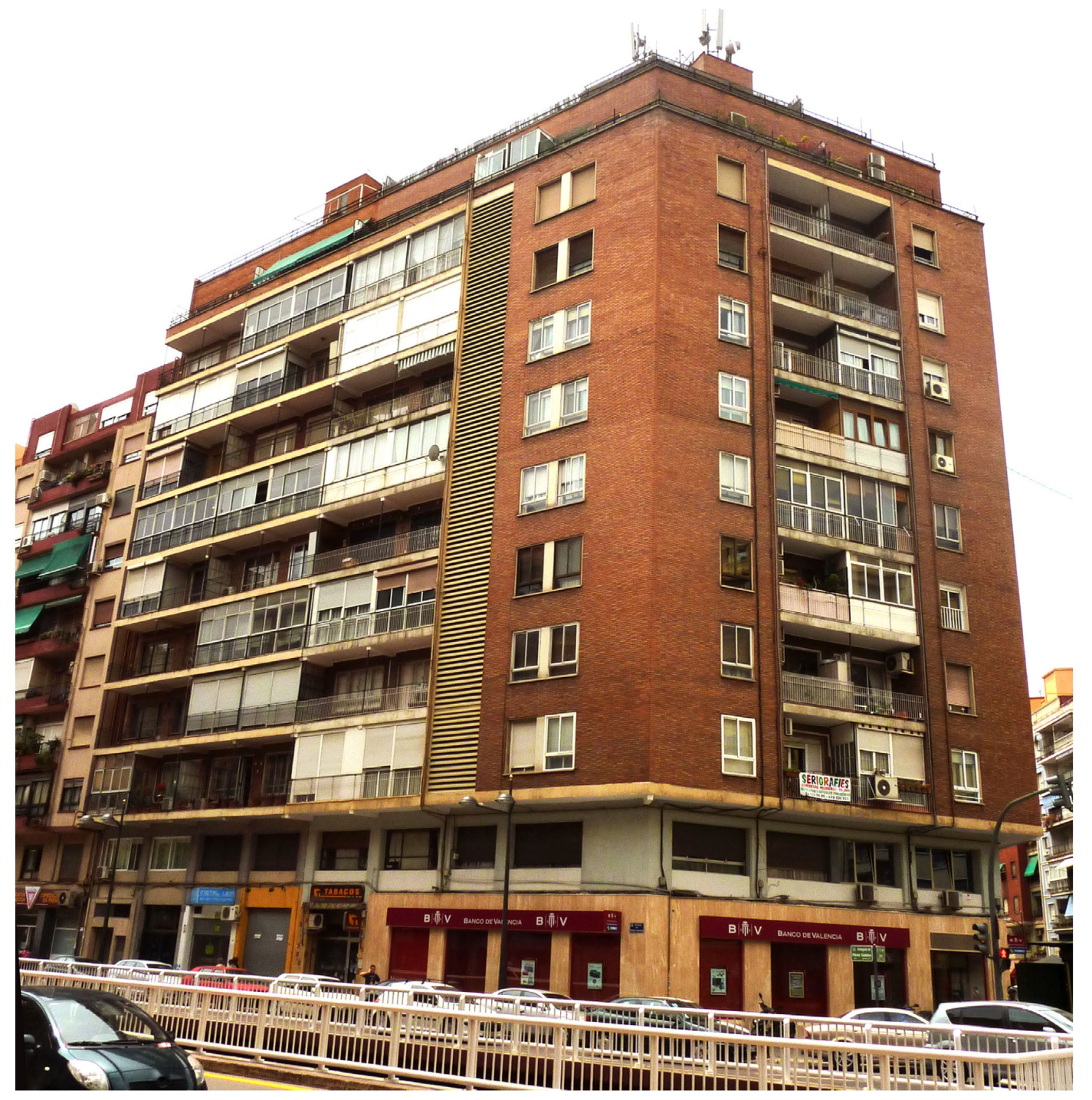


EMPLAZAMIENTO: Lorca, Pérez Galdós

PROMOTOR: Viviendas Protegidas

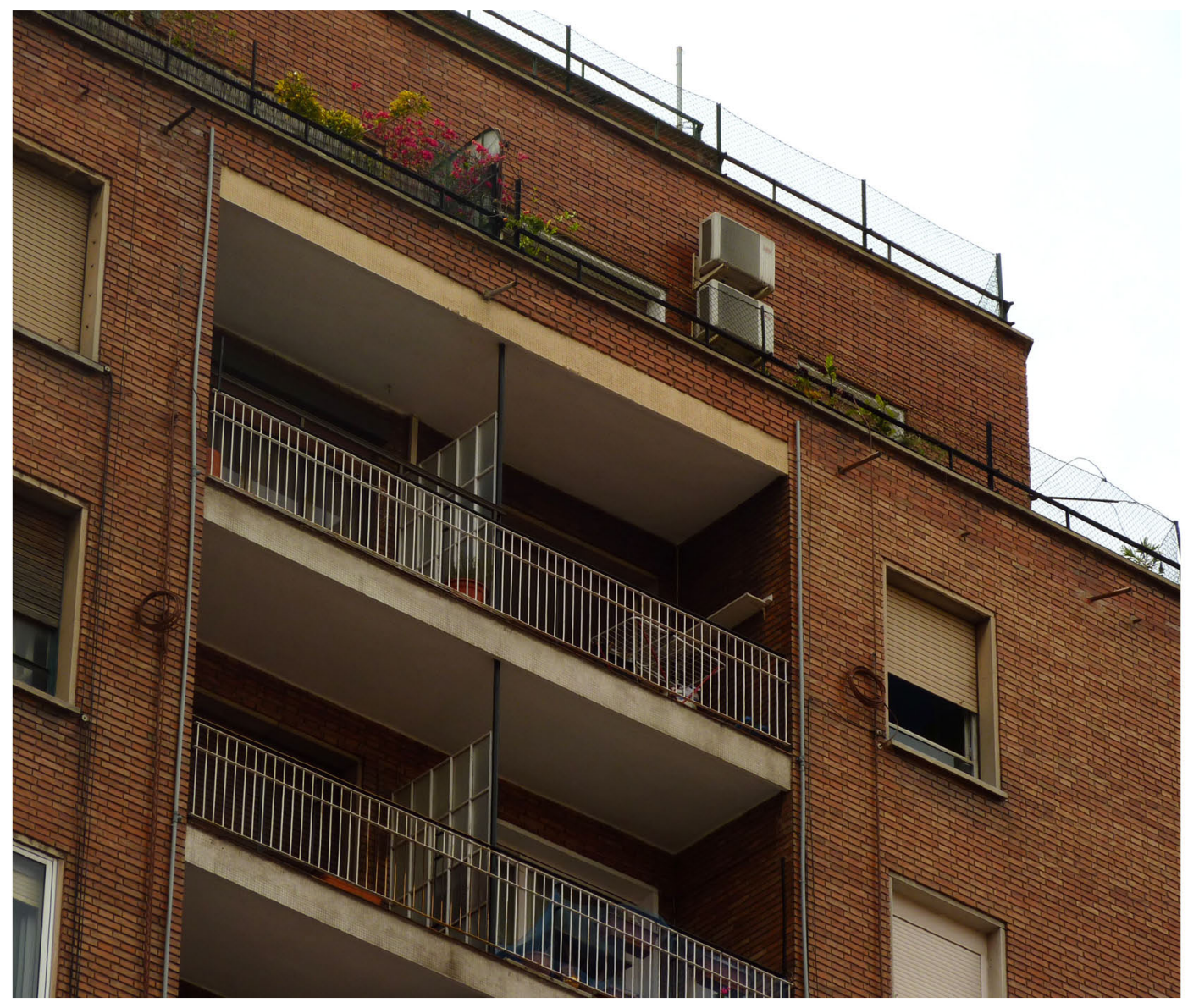




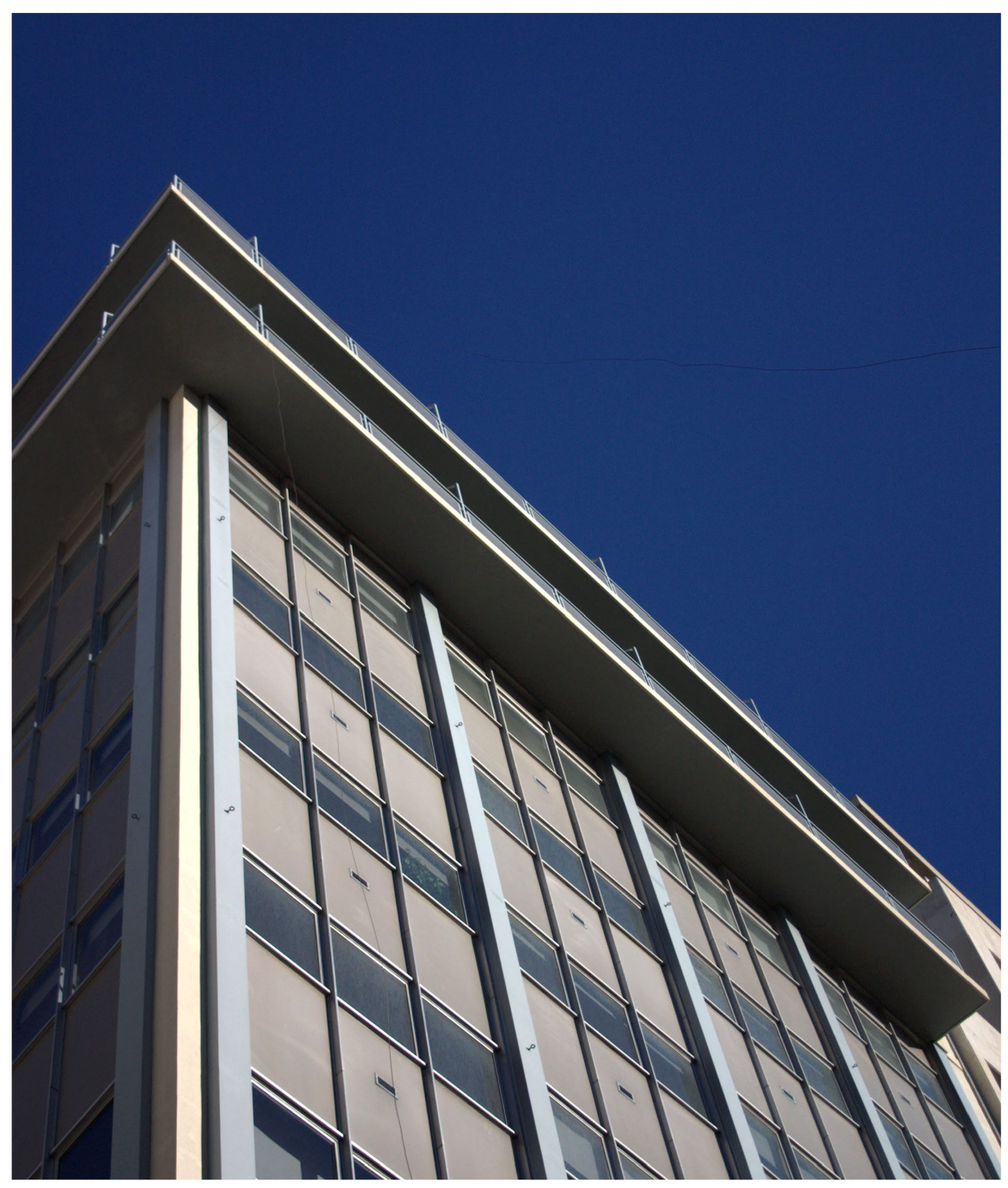


1966

EMPLAZAMIENTO: Poeta Querol

PROMOTOR: Cámara de Comercio

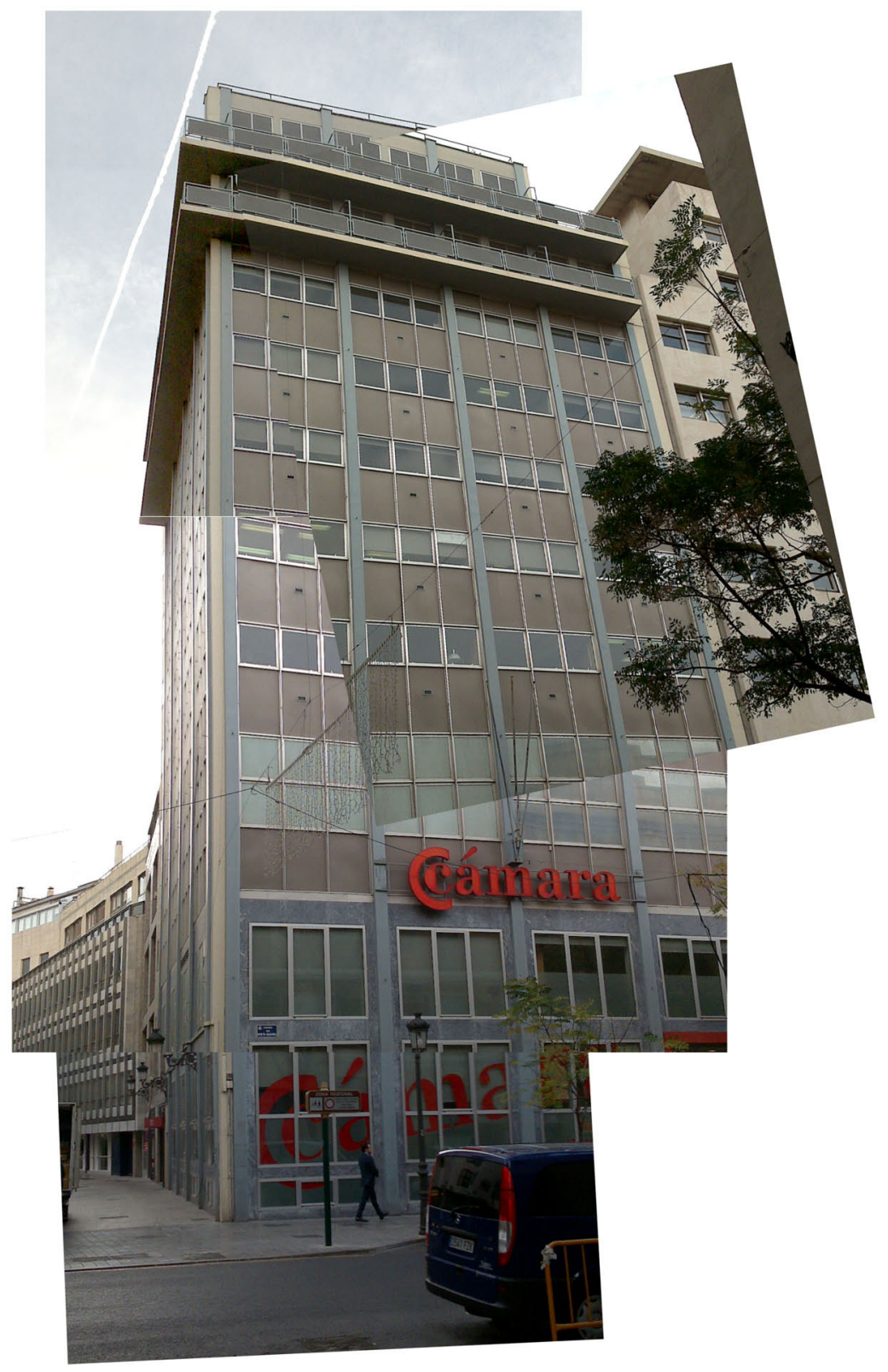


EMPLAzAMIENTO: Emilio Castelar, plaza (actual plaza del Ayuntamiento) PROMOTOR: SOCIEdAd ATENEO MERCANTIL VALENCIANO

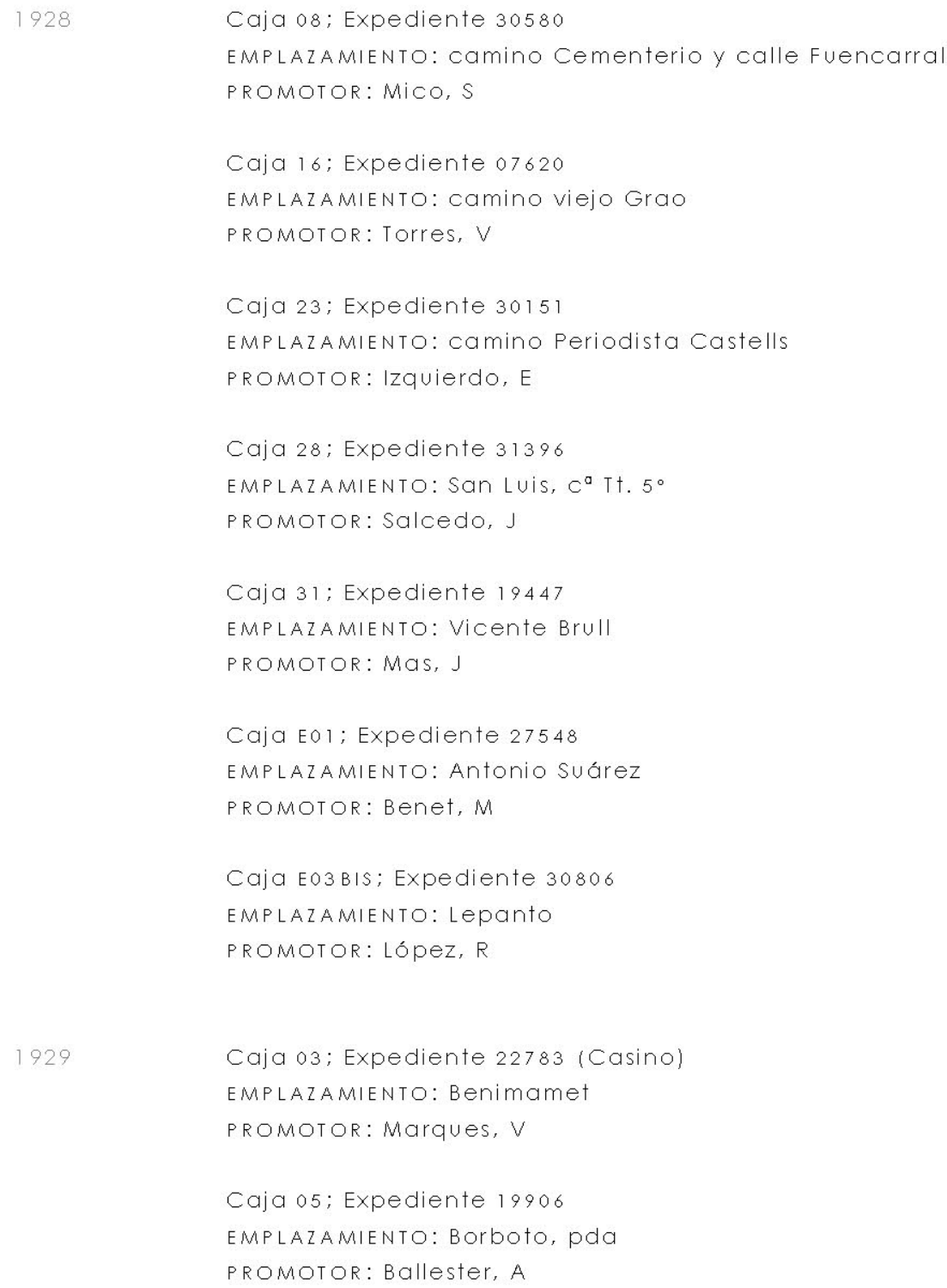


Caja 10; Expediente 15985

EMPLAZAMIENTO: Cementerio, $\mathrm{C}^{\circ}$

PROMOTOR: MICO, S

Caja 14: Expediente 19413

EMPLAZAMIENTO: Escalante, $n^{\circ} 266$ (Cabanyal)

PROMOTOR: DAS, J

Caja 17; Expediente 01181

EMPLAZAMIENTO: José Benlliure, $n^{\circ} 68$ (Cabanyal)

PROMOTOR: FOnt, A

Caja 17; Expediente 03388

EMPLAZAMIENTO: Játiva, $n^{0} 13$ (actual 21) y Ribera

PROMOTOR: CARBAJOSA, FrancisCO

Caja 17; Expediente 27847

EMPLAZAMIENTO: José Benlliure, $n^{\circ} 215$ (Cabanyal)

PROMOTOR: ValerO,

Caja 34; Expediente 21352

EMPLAZAMIENTO: Vicente Brull

PROMOTOR: BONOVA, J

Caja E0 1; Expediente 00779

EMPLAZAMIENTO: Algirós

PROMOTOR: PEITÓ, J

Caja E01; Expediente 04124

EMPLAZAMIENTO: Algirós

PROMOTOR: Cerdá, C

Caja EO1BIS; Expediente 09299

EMPLAZAMIENTO: Burjasót, $C^{\circ}$ viejo

PROMOTOR: Montesinos, M

PROMOTOR: CRESPO, J M 
Caja 05; Expediente 00008

EMPLAzAMIENTO: Blasco Ibáñez, avenida (actual plaza del Ayuntamiento) PROMOTOR: sánchez, Tomás

Caja 05; Expediente 00011

EMPLAZAMIENTO: Blasco Ibáñez no 13 , avenida

PROMOTOR: García, Rufino

Caja 06; Expediente 00028

EMPLAZAMIENTO: Capdepont $n^{\circ} 226$ (actual calle Barraca) (Cabanyal)

PROMOTOR: Safont, P

Caja 12; Expediente 00004

EMPLAZAMIENTO: Florida

PROMOTOR: Burguete, E

Caja 13; Expediente 00050

EMPLAZAMIENTO: Juan Lorenzo, San Pablo y Arzobispo Mayoral

PROMOTOR: MOMparler, Manuel

Caja 15; Expediente 00008

EMPLAZAMIENTO: LIamosí

PROMOTOR: PARdO, A

Caja 15; Expediente 00008

EMPLAZAMIENTO: Llamosí

PROMOTOR: Correcher, J

Caja 20: Expediente 00036

EMPLAZAMIENTO: Planes, $n^{\circ} 31$

PROMOTOR: BEnEyto, R

Caja 21; Expediente 00008

EMPLAZAMIENTO: Progreso, $n^{0} 399$ (Cabanyal)

PROMOTOR: NOguera, J

Caja 21 ; Expediente 00009

EMPLAZAMIENTO: Progreso, $n^{0} 262$ (Cabanyal)

PROMOTOR: Belenguer, J 
Caja 27; Expediente 00021 EMPLAZAMIENTO: San Vicente PROMOTOR: MOMPó, Juan Antonio

Caja 29; Expediente 00014 EMPLAZAMIENTO: Vicente Ballester, $n^{\circ} 28$ y 30 (Cabanyal) PROMOTOR: POrtero, Francisco

Caja E02; Expediente 24516 EMPLAZAMIENTO: Cádiz

PROMOTOR: Villaba, Alberto

Caja EO2: Expediente 29532 EMPLAZAMIENTO: Campanar PROMOTOR: LIOPIS, Vicente

Caja E04; Expediente 01293 EMPLAZAMIENTO: Lepanto, $n^{\circ} 27$ PROMOTOR: LÓPEZ, R

Caja E04; Expediente 27819 EMPLAZAMIENTO: José María Orense PROMOTOR: Laguarda, A

Caja 10; Expediente 00034 EMPLAZAMIENTO: José Benlliure, $n^{\circ} 272$ (Cabanyal) PROMOTOR: Casañ. Vicente

Caja 12; Expediente 00014 EMPLAZAMIENTO: José Benlliure, $n^{\circ} 336$ (Cabanyal) PROMOTOR: Simó, Vicenta 
Caja 12; Expediente 00044 EMPLAZAMIENTO: Malvarrosa

PROMOTOR: Gay, JOSé

Caja 18; Expediente 00022

EMPLAZAMIENTO: Pilar, $n^{\circ} 61$ (Cabanyal)

PROMOTOR: Tadeo, Pascual

Caja 18; Expediente 00023

EMPLAZAMIENTO: Pilar, $n^{\circ} 45$ (Cabanyal)

PROMOTOR: Pascual, Manuel

Caja 24; Expediente 00005

EMPLAZAMIENTO: San Ramón (Cabanyal)

PROMOTOR: Navarro, Vicente

Caja 24; Expediente 00006

EMPLAZAMIENTO: San Roque (Pueblo Nuevo del Mar)

PROMOTOR: Alcañiz, Manuel

Caja 01; Expediente 00005

EMPLAZAMIENTO: Actor Llorens (prolongación)

PROMOTOR: Marco, Ramón

Caja 01; Expediente 00015

EMPLAZAMIENTO: Algirós (junto al Instituto Candela)

PROMOTOR: Giner, Miguel

Caja 06; Expediente 00001

EMPLAZAMIENTO: Capdepont, $n^{\circ} 232$ Y234 (actual Barraca) (Cabanyal)

PROMOTOR: Gallart, Angela

Caja 08; Expediente 00015

EMPLAZAMIENTO: Escalante, $n^{\circ} 323$ (Cabanyal)

PROMOTOR: Jimeno, Juan Bautista

Caja 08; Expediente 00017

EMPLAZAMIENTO: Escalante, $n^{\circ} 226$ (Cabanyal)

PROMOTOR: Cerveró, Manuel 
Caja 10; Expediente 00016 EMPLAZAMIENTO: José Benlliure, n³41 (Cabanyal) PROMOTOR: Martí, JOSé M

Caja 13: Expediente 00011 EMPLAZAMIENTO: Micer Rabasa PROMOTOR: Micó, Salvador

Caja 13: Expediente 0033B EMPLAZAMIENTO: Navellos, Micer Tarazona y Yerba PROMOTOR: CÁNOVAS, MaNUEl

Caja 15; Expediente 00013 EMPLAZAMIENTO: Pilar, $n^{\circ} 26$ (Cabanyal) PROMOTOR: Merlé, Francisco

Caja E03; Expediente 36128 EMPLAZAMIENTO: José María Orense PROMOTOR: Pascual, Carmelo

Caja E04: Expediente 21445 EMPLAZAMIENTO: calle $n^{0} 158$ y 162 PE (Plan Ensanche). Polo y Peyrolón PROMOTOR: Alvarez, Félix

Caja E05: Expediente 00045

EMPLAZAMIENTO: Vuelta del Ruiseñor

PROMOTOR: ROMERO, JOSé

Caja 07; Expediente 00008 (cimentación y estructura) EMPLAZAMIENTO: GOYA PROMOTOR: ROdríguez, JOSé

Caja 07; Expediente 26BIS EMPLAZAMIENTO: Guillem de Castro PROMOTOR: Extrems, Vicente

Caja 08; Expediente 01141 EMPLAZAMIENTO: José Benlliure, $n^{\circ} 336$ (Cabanyal) PROMOTOR: Noguera, Joqquín 
Caja 09; Expediente 08988

EMPLAZAMIENTO: $c^{\circ}$ Malvarrosa

PROMOTOR: Granell, Conrado

Caja 09; Expediente 10465

EMPLAZAMIENTO: $C^{\circ}$ Real de Madrid

PROMOTOR: BIASCO, Miguel

Caja 09; Expediente 11571

EMPLAZAMIENTO: $c^{\circ}$ Malvarrosa

PROMOTOR: BUENO, JOSÉ

Caja E06; Expediente 15807 (cimentación y estructura)

EMPLAZAMIENTO: Vicente Sancho Tello

PROMOTOR: Navarro, Jesús

EMPLAZAMIENTO: Manicomio Porta Coelli

PROMOTOR: DIPUTACIÓN PROVINCIAL de Valencia (proyecto)

1934

EMPLAZAMIENTO: de las Barcas y Poeta Querol

PROMOTOR: TEATRO PRINCIPAL Y HOTEL (proYECTO)

Caja 05; Expediente 13729

EMPLAZAMIENTO: Doctor LIuch (Cabanyal)

PROMOTOR: Núñez, José

Caja 06BIS; Expediente 09535

EMPLAZAMIENTO: Escalante, $n^{\circ} 225$ (Cabanyal)

PROMOTOR: Trillo, Vicente

Caja 07; Expediente 32562

EMPLAZAMIENTO: Horno (Malvarrosa)

PROMOTOR: Montañana, Ramón

Caja 08; Expediente 07170

EMPLAZAMIENTO: José Benlliure, $n^{0} 335$ (Cabanyal)

PROMOTOR: ValerO, salvador 
Caja 08; Expediente 35196

EMPLAZAMIENTO: José Benlliure, $n^{\circ} 353$ (Cabanyal)

PROMOTOR: NOguera, José

Caja 08; Expediente 35487

EMPLAZAMIENTO: Juan de Garay

PROMOTOR: DÍaz, José

Caja 09; Expediente 14560

EMPLAZAMIENTO: Libertad, $n^{\circ} 303$

PROMOTOR: Pérez, JOSÉ

Caja 12; Expediente 12827

EMPLAZAMIENTO: Nicolás Salmerón (avenida Marqués de sotelo)

PROMOTOR: Santonja, Luis

Caja 12; Expediente 15196

EMPLAZAMIENTO: Salvador García, $n^{\circ} 33$ (Natzaret)

PROMOTOR: Beltrán, Manuel

Caja E01; Expediente 34418

EMPLAZAMIENTO: $C^{\circ}$ Algirós

PROMOTOR: Giner, Miguel

Caja E03; Expediente 14698

EMPLAZAMIENTO: calle $n^{0} 18$ PE (Plan Ensanche)

PROMOTOR: Navarro, Jesús

Caja E05; Expediente 11035

EMPLAZAMIENTO: calle $n^{0} 162$ PE (Plan Ensanche)

PROMOTOR: Bonet, Irene

Caja 02; Expediente 13927

EMPLAZAMIENTO: Beatriz Tortosa

PROMOTOR: MORa, Vicente

Caja 06; Expediente 14081

EMPLAZAMIENTO: Eugenia Viñes (Malvarrosa)

PROMOTOR: Montañana, Ramón 
Caja 06: Expediente 30259

EMPLAZAMIENTO: Escrivá

PROMOTOR: Zanón, Vicente

Caja 07; Expediente 09030

EMPLAZAMIENTO: Horno (Cabanyal)

PROMOTOR: Galiana, José María

Caja 07; Expediente 21540

EMPLAZAMIENTO: Horno (Cabanyal)

PROMOTOR: Vicente, Carles

Caja 08; Expediente 30252

EMPLAZAMIENTO: José Benlliure, $n^{\circ} 41$ (Cabanyal)

PROMOTOR: Zapatero, Galo

Caja 09; Expediente 31182

EMPLAZAMIENTO: Libertad, $n^{\circ} 300$

PROMOTOR: Meliá, Vicente

Caja 10; Expediente 07093

EMPLAZAMIENTO: Malvarrosa, $C^{\circ}$ (Cabanyal)

PROMOTOR: Navella, Manuel

Caja 10; Expediente 09029

EMPLAZAMIENTO: Malvarrosa, $C^{\circ}$ (Cabanyal)

PROMOTOR: Vila, JUan

Caja 12; Expediente 45995

EMPLAZAMIENTO: Padre Luis Navarro, $n^{\circ} 385$ (Cabanyal)

PROMOTOR: LIOHIS, JOSÉ

Caja 19; Expediente 42385

EMPLAZAMIENTO: Vicente Ballester, $n^{\circ} 28$ (Cabanyal)

PROMOTOR: PORCal, Vicente

Caja E02; Expediente 35514

EMPLAZAMIENTO: Campanar

PROMOTOR: CampOS, Ernesto 
Caja E03; Expediente 25001

EMPLAZAMIENTO: Cuarte $n^{\circ} 114$ y San Jacinto $n^{\circ} 3$

PROMOTOR: BUCH, MáXImo

Caja E03; Expediente 43257

EMPLAZAMIENTO: Cuenca $n^{\circ} 16$

PROMOTOR: ZABALA, JOSÉ Manvel

Caja E0 4; Expediente 45662

EMPLAZAMIENTO: Játiva, esquina san Vicente

PROMOTOR: ALONSO, Carmen

Caja E08; Expediente 40494

EMPLAZAMIENTO: Vicente Sancho Tello

PROMOTOR: Pascual, carmelo

EMPLAZAMIENTO: HOSpital Provincial

PROMOTOR: DIPUTACIÓN PROVINCIAL de Valencia (proyecto)

EMPLAZAMIENTO: Plaza de TorOS

PROMOTOR: DIPUTACIÓN PROVINCIAL de Valencia (proyecto)

Caja 01: Expediente 04376

EMPLAZAMIENTO: de los Ángeles, $n^{\circ} 83$ (Cabanyal)

PROMOTOR: DUpla, Francisco

Caja 01; Expediente 22486

EMPLAZAMIENTO: Libertad, $n^{\circ} 13$

PROMOTOR: Vila, Dolores

Caja 04; Expediente 06818

EMPLAZAMIENTO: José Benlliure, $n^{\circ} 206$ (Cabanyal)

PROMOTOR: Sarrió, A

PROMOTOR: Alhambra, JOSé 
Caja E03; Expediente 44227

EMPLAZAMIENTO: Jesús y Alcira

PROMOTOR: ENRIQUEz, Jesús (Estación para engrase de automóviles)

Caja E04; Expediente 44228

EMPLAZAMIENTO: Salamanca, Peris y Valero

PROMOTOR: Rodríguez, Isabel (Colegio del LORETO)

Caja 02; Expediente 52909

EMPLAzAMIENTO: Escalante, $n^{\circ} 223$ (Tr. Progreso)

PROMOTOR: Jarques, Agustín

Caja 06; Expediente 29003

EMPLAZAMIENTO: Vicente Ballester, $n^{\circ} 25$ (Cabanyal)

PROMOTOR: March, JOSÉ

Caja 06: Expediente 55436

EMPLAZAMIENTO: Serranos, $n^{\circ} 41$ (Cabanyal)

PROMOTOR: Fornás, Ezequiel

Caja E05; Expediente 21769

EMPLAZAMIENTO: San Bernardo

PROMOTOR: LIOPIS, JOSÉ

PROMOTOR: García, Miguel

Caja 09; Expediente 11643

EMPLAZAMIENTO: Oeste, avenida (actual Barón de Carcer)

PROMOTOR: Albert Ballester, Luis (promoción propia)

Caja 09; Expediente 11676

EMPLAZAMIENTO: Juan Verdaguer, $s / n$

PROMOTOR: Más, José y Vicente

Caja 10; Expediente 06289

EMPLAZAMIENTO: Reina, $n^{\circ} 285$ (Cabanyal)

PROMOTOR: Fós, Francisco 
Caja E03; Expediente 48181

EMPLAZAMIENTO: Doctor Sumsi $n^{\circ} 38$

PROMOTOR: Giner, Miguel

Caja E05; Expediente 44583

EMPLAZAMIENTO: Maestro Gozalvo, esquina conde Altea

PROMOTOR: Illueca, Gastón

Caja E08; Expediente 18767

EMPLAZAMIENTO: TURIa $n^{\circ} 55$

PROMOTOR: Sevilla, Fernando

Caja E09; Expediente 01473

EMPLAZAMIENTO: SORní, $n^{\circ} 24$

PROMOTOR: Martínez, Lorenzo

Caja 01; Expediente 25150

EMPLAzAmiento: de los Ángeles, nº 80 (Cabanyal)

PROMOTOR: DOmingo, Rafael

Caja 02; Expediente 30927

EMPLAZAMIENTO: Alegret, $C^{\circ}$ Alboraya (Benimaclet)

PROMOTOR: Cuenca, Francisco

Caja 10; Expediente 28387

EMPLAZAMIENTO: Padre Luis Navarro, $n^{\circ} 28$ (Cabanyal)

PROMOTOR: Aragonés, Antonio

Caja 11; Expediente 36114

EMPLAZAMIENTO: del Progreso, $n^{\circ} 41$ (Cabanyal)

PROMOTOR: Angel, Juana

Caja 06; Expediente 08375

EMPLAZAMIENTO: Martí Grajales, $n^{\circ} 14$

PROMOTOR: BuENO, CrUZ

Caja 06; Expediente 22406

EMPLAZAMIENTO: Manolo Taberner, $s / n$

PROMOTOR: Sáez, Antonio 
Caja 06; Expediente 23540

EMPLAZAMIENTO: José Benlliure, $n^{\circ} 186$ (Cabanyal)

PROMOTOR: Carabal, Carmelo

Caja 06: Expediente 29457

EMPLAZAMIENTO: Martí Grajales, $n^{\circ} 12$

PROMOTOR: ROcafull, Juan Bautista

Caja 08; Expediente 32119

EMPLAZAMIENTO: Padre Luis Navarro, n² 27 (Cabanyal)

PROMOTOR: Gallart, Francisco

Caja 08; Expediente 33769

EMPLAZAMIENTO: Pedro Masa, $n^{\circ} 32$ (Cabanyal)

PROMOTOR: Gómez, Ponciano

Caja 09; Expediente 30322

EMPLAZAMIENTO: del Rosario, $n^{\circ} 27$ y Amparo, $n^{\circ} 20$ (Cabanyal)

PROMOTOR: SANz, Elías

Caja 10; Expediente 43874

EMPLAZAMIENTO: $C^{0}$ Tránsitos, $n^{0} 141$ (junto senda Carrasca)

PROMOTOR: Giner, Vicente

PROMOTOR: Darder, JOSEfa

Caja 02; Expediente 30874

EMPLAZAMIENTO: Barraca, $n^{\circ} 13$ y 15 , Padre Luis Navarro (Cabanyal) PROMOTOR: Montañana, Fidel

Caja 08; Expediente 13148

EMPLAZAMIENTO: José Benlliure, $n^{\circ} 34$ (Cabanyal)

PROMOTOR: Furió, IsmaEl

Caja 09; Expediente 41914

EMPLAZAMIENTO: Manolo Taberner, $s / n$

PROMOTOR: Sanz, Braulio 
Caja 12B; Expediente 14947

EMPLAZAMIENTO: Reina, $n^{\circ} 60$ y Doctor Lluch, $n^{\circ} 57$ (Cabanyal)

PROMOTOR: Giner, JOSÉ

Caja 12B; Expediente 34410

EMPLAZAMIENTO: Reina, $n^{\circ} 45$ y Capdepont (actual Barraca)

PROMOTOR: POrtero, Francisco

Caja 12B; Expediente 38473

EMPLAZAMIENTO: del Rosario, $n^{\circ} 132$ (Cabanyal)

PROMOTOR: Parada, Ramón

Caja 14; Expediente 45408

EMPLAZAMIENTO: San Pedro, $n^{\circ} 98$ (Cabanyal)

PROMOTOR: Vallcanera, JOsé

Caja 03B; Expediente 14485

EMPLAZAMIENTO: José Antonio, avda (actual Reino de Valencia), Matías perelló

PROMOTOR: Albert BallesterOs, Luis

Caja E0 4; Expediente 15133

EMPLAZAMIENTO: Marqués del Turia, gran vía $n^{\circ} 53$

PROMOTOR: Illueca, Gastón

Caja 02; Expediente 45329

EMPLAZAMIENTO: Barraca, $n^{0} 75$ (Cabanyal)

PROMOTOR: García, Eduarda

Caja 02: Expediente 47355

EMPLAZAMIENTO: Recreo (Benimaclet)

PROMOTOR: Sanchís, Francisca

Caja 05; Expediente 14203

EMPLAZAMIENTO: Doctor LIuch, $n^{\circ} 253$ y Pintor Ferrandis (Cabanyal)

PROMOTOR: Martí, Tadeo

Caja 05; Expediente 31468

EMPLAZAMIENTO: Doctor Lluch, $n^{0} 137$ y TV. de la Iglesia (Cabanyal)

PROMOTOR: Montañana, Fidel 
Caja 05; Expediente 40349

EMPLAZAMIENTO: Doctor Lluch, $s / n$ y Reina, $n^{0} 74$ (Cabanyal)

PROMOTOR: Hernández, B. y otros

Caja 06; Expediente 33407

EMPLAZAMIENTO: Eugenia Viñes, $n^{\circ} 205$ (Malvarrosa)

PROMOTOR: DOL, María

Caja 09; Expediente 22288

EMPLAZAMIENTO: José Benlliure, $n^{\circ} 292$ (Cabanyal)

PROMOTOR: Martínez, Ricardo

Caja 11; Expediente 15542

EMPLAZAMIENTO: $c^{\circ}$ Malvarrosa, $n^{\circ} 82$ (Cabanyal)

PROMOTOR: Ferrer, Francisco

Caja 11; Expediente 35342

EMPLAZAMIENTO: $C^{\circ}$ Malvarrosa (Cabanyal)

PROMOTOR: Andrés, Francisco

Caja 11; Expediente 46561

EMPLAZAMIENTO: $0^{\circ}$ Malvarrosa (Cabanyal)

PROMOTOR: Macián, Pedro

Caja 14; Expediente 15542

EMPLAZAMIENTO: Nicolás Estébanez, $n^{\circ} 4$

PROMOTOR: Garrigós, Antonio

Caja 15; Expediente 08078

EMPLAZAMIENTO: Padre Luis Navarro, $n^{\circ} 15$ (Cabanyal)

PROMOTOR: Pérez, Amadeo

Caja 15; Expediente 12284

EMPLAZAMIENTO: Padre Luis Navarro, $n^{\circ} 176$ y Barraca (Cabanyal)

PROMOTOR: Brú, Ana y Dolores

Caja 15; Expediente 29834

EMPLAZAMIENTO: Padre Luis Navarro, $n^{\circ} 275$ (Cabanyal)

PROMOTOR: FOrt, JOSÉ 
Caja 17; Expediente 17999

EMPLAZAMIENTO: Progreso, $n^{\circ} 307$

PROMOTOR: Villagrasa, concepción

Caja 20: Expediente 37479

EMPLAZAMIENTO: Vicente Ballester, $n^{\circ} 14$ (Cabanyal)

PROMOTOR: Quintero, José

Caja E06; Expediente 44172

EMPLAZAMIENTO: Norte y San Jacinto

PROMOTOR: Villalba, Juan Bautista

Caja 02; Expediente 03675

EMPLAZAMIENTO: casas de Bárcena, $n^{\circ} 5$ y $\mathrm{C}^{\circ}$ Barcelona

PROMOTOR: Orts, Manuel

Caja 02; Expediente 40327

EMPLAZAMIENTO: $c^{a}$ Barcelona y casas de Bárcena

PROMOTOR: Laguardia, Daniel

Caja 03; Expediente 36766

EMPLAZAMIENTO: Alegret, $n^{\circ} 10$ y Michagalta (Benimaclet)

PROMOTOR: ARASO, José

Caja 07; Expediente 16381

EMPLAZAMIENTO: Doctor LIuch, $n^{0} 68$ (Cabanyal)

PROMOTOR: García, Eduardo

Caja 08: Expediente 40514

EMPLAZAMIENTO: Eugenia Viñes, $n^{0} 110$

PROMOTOR: Benedito, Vicente

Caja 10; Expediente 01641

EMPLAZAMIENTO: Isabel de Villena, $n^{\circ} 55$ (Cabanyal)

PROMOTOR: Sampedro, Luis

Caja 12; Expediente 43740

EMPLAZAMIENTO: Mare Nostrum, $n^{\circ} 10$ y José Benlliure (Cabanyal)

PROMOTOR: Montañana, Fidel 
Caja 14; Expediente 13292

EMPLAZAMIENTO: Mayor (Natzaret)

PROMOTOR: Montañana, Ramón

Caja 16; Expediente 53625

EMPLAZAMIENTO: Progreso, $n^{\circ} 107$ (Cabanyal)

PROMOTOR: Montañana y Chiralt

Caja 17; Expediente

EMPLAZAMIENTO: Reina, $n^{\circ} 28$ y Doctor Lluch (Cabanyal)

PROMOTOR: Montañana, Fidel

Caja E03 B; Expediente 00260

EMPLAZAMIENTO: Erudito Orellana, $s / n$

PROMOTOR: Parroquia del Buen Pastor

Caja E10; Expediente 17470

EMPLAZAMIENTO: Pintor Gisbert y Filipinas

PROMOTOR: LIOPIS, LUIS

Caja 02B; Expediente 11240

EMPLAZAMIENTO: Alegret (Benimaclet)

PROMOTOR: San Martín, JOSÉ

Caja 05; Expediente 35127

EMPLAZAMIENTO: Cardenal Benlloch, no 197 (antes no 149)

PROMOTOR: Berenguer, Francisco

Caja 08; Expediente 12542

EMPLAZAMIENTO: Doctor Lluch, $n^{\circ} 30$ y TV. de la Iglesia (Cabanyal)

PROMOTOR: Montañana, Fidel

Caja 09; Expediente 12542

EMPLAZAMIENTO: Escalante, $n^{\circ} 30$ y José Benlliure, $n^{\circ} 51$ (Cabanyal)

PROMOTOR: Gavino y Montañana

Caja 11; Expediente 28737

EMPLAZAMIENTO: José Benlliure, $n^{\circ} 220$ y Escalante, $n^{\circ} 226$ (Cabanyal)

PROMOTOR: Cerveró, Manuel 
Caja 13: Expediente 07732

EMPLAZAMIENTO: $C^{\circ}$ Malvarrosa (Cabanyal)

PROMOTOR: Cervera, Isidro

Caja 15; Expediente 34167

EMPLAZAMIENTO: $2^{\circ}$ TV. Mar (Natzaret)

PROMOTOR: Péris, María

Caja 16; Expediente 20237

EMPLAZAMIENTO: TV. Pinedo al Mar (Pinedo)

PROMOTOR: Palomino, Miguel

Caja 17; Expediente 12347

EMPLAZAMIENTO: TV. Progreso, $n^{0} 14$ al 18 (Cabanyal)

PROMOTOR: MOreno, josé

Caja 19; Expediente 24712

EMPLAZAMIENTO: San ROque, $n^{\circ} 55$ y Pilar, $n^{\circ} 58$ (Cabanyal)

PROMOTOR: Beneyto, Roberto

Caja 02; Expediente 45189

EMPLAZAMIENTO: San Roque, $n^{\circ} 50$ (Cabanyal)

PROMOTOR: Burdens, Antonio

Caja 07; Expediente 16379

EMPLAZAMIENTO: MaYor (Natzaret)

PROMOTOR: Vinaixa, DOmingo

Caja 10; Expediente 37647

EMPLAZAMIENTO: San ROque (Cabanyal)

PROMOTOR: Estrela, Felix

Caja 10; Expediente 39626

EMPLAZAMIENTO: Vidal de Canells, $n^{\circ} 48$

PROMOTOR: Estudillo, Doroteo

Caja E02; Expediente 02693

EMPLAZAMIENTO: Castilla, avenida y Tres Cruces

PROMOTOR: DIPUTACIÓN PROVINCIAL de Valencia (HOspital Provincial) 
Caja E02; Expediente 06639 (con Salvador Pascual Gimeno, arquitecto) EMPLAZAMIENTO: Colón, $n^{\circ} 28$

PROMOTOR: Ugarte. Andrés

Caja 02; Expediente 08167

EMPLAZAMIENTO: $c^{a}$ Barcelona y casas de Bárcena

PROMOTOR: Romero, Vicente

Caja 02; Expediente 11909

EMPLAZAMIENTO: San José, $n^{\circ} 4$ (Benimaclet)

PROMOTOR: Cuenca, Francisco

Caja 02; Expediente 13262 (industria y vivienda)

EMPLAZAMIENTO: Mistral, $n^{\circ} 20$ (Benimaclet)

PROMOTOR: Alcodori, Benito

Caja 02: Expediente 49347 (proyecto definitivo 1955)

EMPLAZAMIENTO: casas de Bárcena

PROMOTOR: Romero, Vicente

Caja 05; Expediente 01039

EMPLAZAMIENTO: Eugenia Viñes, s/n (Cabanyal)

PROMOTOR: Montañana, Fidel

Caja 05; Expediente 21882

EMPLAZAMIENTO: Doctor Lluch, $n^{\circ} 257$ y Padre Ferrandis (Cabanyal)

PROMOTOR: Garzando, Francisco

Caja 05; Expediente 30998

EMPLAZAMIENTO: Escalante, $n^{\circ} 342$ (Cabanyal)

PROMOTOR: Garzando, Francisco

Caja 05; Expediente 36609

EMPLAZAMIENTO: Escalante, $n^{\circ} 348$ y José Benlliure (Cabanyal)

PROMOTOR: Montes, Constantino

Caja 06; Expediente 02833

EMPLAZAMIENTO: Francisco Eximenis, $n^{\circ} 60$ (Cabanyal)

PROMOTOR: Catalá, Emiliano 
Caja 08: Expediente 13512

EMPLAZAMIENTO: Isabel de Villena, $n^{\circ} 57$ (Cabanyal)

PROMOTOR: VIVES, Jaime

Caja 08; Expediente 13514

EMPLAZAMIENTO: Isabel de Villena, $n^{\circ} 59$ (Cabanyal)

PROMOTOR: Juliana, José

Caja 08: Expediente 44310

EMPLAZAMIENTO: Juan Mercader (Cabanyal)

PROMOTOR: Estrela, Vicente

Caja 10; Expediente 18714

EMPLAZAMIENTO: avda. Mare Nostrum, $n^{\circ} 10$ y José Benlliure (Cabanyal)

PROMOTOR: Ballester, Ignacio

Caja 02B; Expediente 11729

EMPLAZAMIENTO: Maestro Caballero, $n^{\circ} 10$ (Benimaclet)

PROMOTOR: Castro, Francisco

Caja 02 B; Expediente 36188

EMPLAZAMIENTO: Mistral, $s / n$ (Benimaclet)

PROMOTOR: Navarro, Ramón

Caja 12; Expediente 29361

EMPLAZAMIENTO: Mayor, $n^{0} 127$ (Natzaret)

PROMOTOR: COSCOlla, JOSé

Caja 16; Expediente 24295

EMPLAZAMIENTO: Pilar (Cabanyal)

PROMOTOR: Cerveró, JOSé

Caja EO2B; Expediente 13511

EMPLAZAMIENTO: Cardenal Benlloch, $n^{\circ} 55$

PROMOTOR: Belenguer, Antonio

Caja 02: Expediente 33857

EMPLAZAMIENTO: Valencia, $n^{\circ} 28$ (Benimaclet)

PROMOTOR: Albert, DOlores 
Caja 11; Expediente 26016

EMPLAZAMIENTO: Rosario, $n^{\circ} 134$ (Cabanyal)

PROMOTOR: Martí, Encarnación

Caja 02; Expediente 45058

EMPLAZAMIENTO: Rafael Tramoyeres, $n^{\circ} 4$ y 6 (Benimaclet)

PROMOTOR: Liern, Vicente

Caja 03; Expediente 47900 (industria Seda)

EMPLAZAMIENTO: pza. San Miguel (Benimaclet)

PROMOTOR: Prats, Andrés (hermanos)

Caja 05; Expediente 43650

EMPLAZAMIENTO: Escalante, $n^{\circ} 30$ (Cabanyal)

PROMOTOR: Montañana, Ramón

Caja 10; Expediente 11406

EMPLAZAMIENTO: Reverendo José Martí, nº 10 (Benimaclet)

PROMOTOR: Marqués, Alfredo

Caja 12; Expediente 41833

EMPLAZAMIENTO: Cronista Felipe Garisa (Cabanyal)

PROMOTOR: Luján, Miguel

Caja EO1; Expediente 08199

EMPLAZAMIENTO: $\mathrm{C}^{\circ}$ Alboraya, $s / n$ y Martí

PROMOTOR: San Martín, Joqquín

EMPLAZAMIENTO: Claustro y sala Capitular de los Dominicos PROMOTOR: DIPUTACIÓN PROVINCIAL de Valencia (restauración)

EMPLAZAMIENTO: Palau de la Generalitat Valenciana PROMOTOR: Diputación Provincial de Valencia (restauración) 
Caja 02; Expediente 03642 (Teatro de verano)

EMPLAZAMIENTO: pza. Luis Cano, $n^{\circ} 3$ (Benimamet)

PROMOTOR: SOciedad Cultural Deportiva

Caja 02: Expediente 16435

EMPLAZAMIENTO: Enrique Navarro (Benimaclet)

PROMOTOR: Genovés, Antonio

Caja 08; Expediente 16162

EMPLAZAMIENTO: avda. Oeste, San Agustín y Gracia

PROMOTOR: Gil, Francisco

Caja 01B; Expediente 30073

EMPLAZAMIENTO: $C^{\circ}$ Alboraya (Benimaclet)

PROMOTOR: Cuenca, Francisco

Caja 03; Expediente 39137

EMPLAZAMIENTO: José Benlliure, $n^{\circ} 242$ y del Progreso (Cabanyal)

PROMOTOR: García, Amparo

Caja 06; Expediente 23156

EMPLAZAMIENTO: Toneleros, $n^{\circ} 13$ y Liñan

PROMOTOR: Montañana. María Luisa

Caja 02B; Expediente 14479

EMPLAZAMIENTO: DOctor Lluch, $s / n$ (Cabanyal)

PROMOTOR: Pérez, Higinio y Giner, J

Caja $02 \mathrm{~B}$; Expediente 29177

EMPLAZAMIENTO: Doctor LIuch, s/n y Borrasca (Cabanyal)

PROMOTOR: Pérez, Higinio

Caja 03: Expediente 4996

EMPLAZAMIENTO: Juan Verdeguer, $n^{\circ} 12$

PROMOTOR: Montañana, Fidel

Caja E01: Expediente 50915

EMPLAZAMIENTO: Beltrán Bigorra, $n^{\circ} 1$ y Pinzón

PROMOTOR: Inmobiliaria Alcacer 
Caja EO1; Expediente 50916

EMPLAZAMIENTO: Guillem de Castro y en proyecto (solares Casa Misericordia) PROMOTOR: Inmobiliaria Alcacer

EMPLAZAMIENTO: Camarón y plaza de la Bocha

PROMOTOR: GRUPO LASSALA (viviendas para funcionarios)

EMPLAZAMIENTO: avenida Pérez Galdós, esquina Lorca

PROMOTOR: 86 Viviendas protegidas

EMPLAZAMIENTO: Palacio del Temple

PROMOTOR: DIPUTACIÓN PROVINCIAL de Valencia (restauración) 